Department of the INTERTon

Hubert Work, Secretary

ข. \$. GEOLOGICAL GURVET

George Otis Smith, Director

Water-Supply Paper 576

\title{
THE GROUND-WATER RESOURCES OF MISSISSIPPI
}

BY

LLOYD W. STEPHENSON, WILLIAM N. LOGAN

AND GERALD A. WARING

WITH DISCUSSIONS OF

THE CHEMICAL CHARACTER OF THE WATERS

BY C. S. HOWARD

Prepared in cooperation with the

Mississippi State Geological Survey

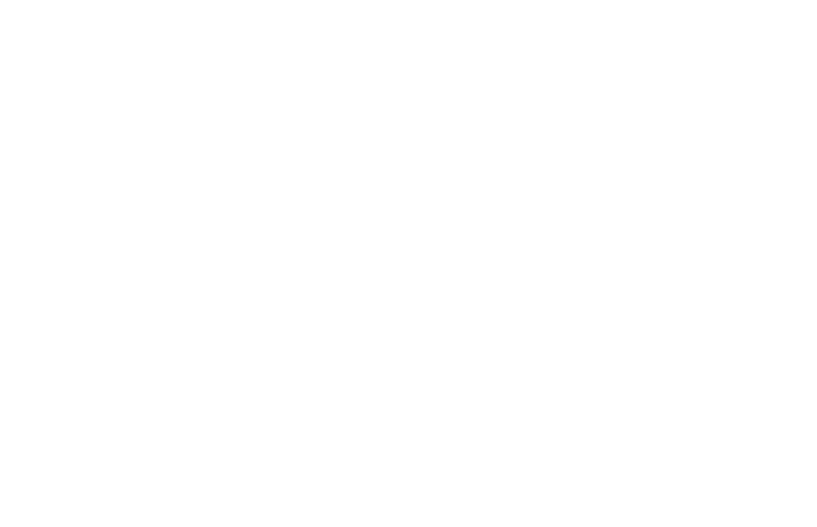

UNITED STATES

GOVERNMENT PRINTING OFTICE

WASHINGTON

1928 
ADDITIONAL COPIES

OF THIS PUBLICATION MAY BE PROCURED TROMA THE SUPERINTENDENT OF DOCंUM ENTS U.S.GOVERNM ENTPRINTING,OFFICE

WASHINGTON, D. C.

AT

90 CENTS PER COPY 


\section{CONTENTS}

Thtrothetion Page

Introduction.........

Physiagraphy

General features.............. 2

Tombigbee and Tennessee River Hills._.

Black Prairie belt.

Pontotoc Hills.

Flatwoods_...

North Central Hills . . . 6

Jackson Prairie belt $\ldots \ldots \ldots$

Long-leaf Pine Hills 7

Coastal Pine Meadows... 7

Loess or Bluff Hills....

Mississippi alluvial plain...... 9

Precipitation.

Surface waters.. _. 10

Streams

Lakes and ponds.

Swamps....

Quality of water.

Ground waters... 14

Source..

Disposal . . . .

Quantity...

Springs_.

Nonartesian waters... 16

Artesian waters. . . . .

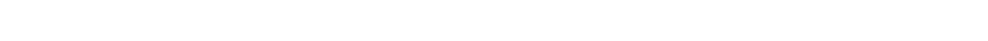

Artesian conditions in Mississippi

Areas of flowing wells determined by topography _... . .

Causes of decrease in static level and in yield

Blowing wells......... 19

Quality of water. 20

Sources of data. . .

Methods of analysis

Constituents determined. 21

Calculation of sodium

Classification of waters.

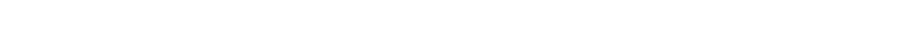

Sanitary considerations

Hardness.............. 23

Iron

Boiler use.

Scale

Water softening

Relations of chemical composition of ground waters to waterbearing formations. . 26 
Character and age of the rocks ...................... 27

The geologic formations and their contained water............. 29

Paleozoic rocks_.

Cretaceous system.

Upper Cretaceous series_...

Tuscaloosa formation........................ 29

Eutaw formation................................ 31

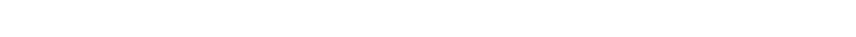

Ripley formation......... 39

Tertiary system

Eocene series.............. 43

Midway group............. 43

Clayton formation.

Porters Creek clay .......................... 44

Wilcox group................................... 45

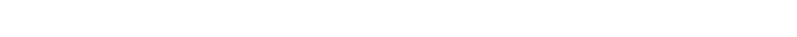

Holly Springs sand._.

Bashi ("Woods Bluff") formation................ 48

Grenada formation. ............ 48

Hatchetigbee formation............. 48

Undifferentiated Wilcox deposits............... 49

Claiborne group. ...

Tallahatta formation . .

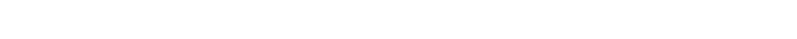

Yegua formation...

Jackson formation. . . . . . . . .

Oligocene series........

Vicksburg group. . .

Miocene series_............. 55

Catahoula sandstone........

Hattiesburg clay ......

Pascagoula clay...

Pliocene series _._.

Citronelle formation .

Pliocene terrace deposits of undetermined relations.... $\quad 60$

Quaternary system................................... 61

Pleistocene series. . . . . .

Terrace deposits along the Gulf coast.............. 61

Natchez formation. .................................. 61

Alluvial terrace deposits ("second bottoms") .......... 61

Loess. . . . . . . . .

Port Hudson formation . . . . . . 63

Recent series

Alluvium of Mississippi River...... 63

Ground-water resources by counties.

Adams County

Alcorn County . .

Amite County

Attala County

Benton County..... 86

Bolivar County

Calhoun County

Carroll County

Chickasaw County 
Ground-water resources by counties-Continued. . . Page

Choctaw County ...

Claiborne County _...

Clarke County......

Clay County ............ 125

Coahoma County

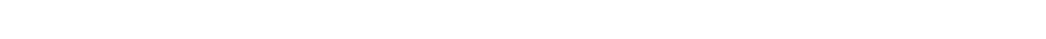

Covington County

De Soto County ... . .

Forrest County ..... 155

Franklin County

George County _........... 169

Greene County

Grenada County

Hancock County ....... 181

Harrison County................. 189

Hinds County

Holmes County .......

Humphreys County ........

Issaquena County

Itawamba County

Jackson County _..._._._._.

Jasper County

Jefferson County

Jefferson Davis County . .

Jones County ........_.

Kemper County

Lafayette County

Lamar County _................ 266

Lauderdale County ............ 272

Lawrence County

Leake County

Lee County ........

Leflore County

Lineoln County ............ 303

Lowndes County . . . . 307

Madison County

Marion County ... 323

Marshall County....... 328

Monroe County

Montgomery County .....

Neshoba County..... 348

Newton County

Noxube County . . . .

Oktibbeha County .

Panola County

Pearl River County

Perry County

Pike County

Pontotoc County

Prentiss County. . .

Quitman County

Rankin County

Scott County..... 412

Sharkey County 
Ground-water resources by counties-Continued. Page

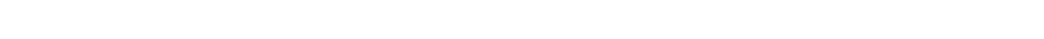

Smith Gounty . .

Stone County . . .

Sunflower County.........

Tallahatchie County . . .

Tate County . . . . 443

Tippah County .............. 448

Tishomingo County

Tunica County .... 460

Union County

Walthall County... 468

Warren County..... 470

Washington County

Wayne County

Webster County

Wilkinson County . .

Winston County ....

Yalobusha County ................... 493

Yazoo County .

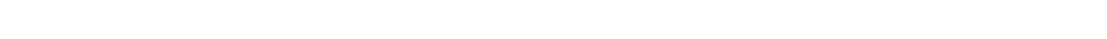

\section{ILLUSTRATIONS}

Plate 1. $A$, The Loess or Bluff Hills looking north from observation tower near the National Cemetery, Vicksburg; $B$, Chautauqua Lake, an artificial lake $11 / 4$ miles north by west of Crystal Springs, Copiah County, formed by damming one of the headwater branches of Turkey Creek

2. Geologic map of Mississippi. . . . . . . . . . . . . . . In pocket.

3. Sketch map showing shapes of drainage basins of Mississippi_

4. A, Pearl River below the wagon bridge at Monticello, Lawrence County; $B$, Dry bed of an intermittent creek which heads in the Black Prairie belt (Selma chalk area), half a mile west of Okolona, Chickasaw County

5. A, Spring having its source in gravel of the Tuscaloosa formation, in a cut of the Southern Railway 3 miles east of Iuka, Tishomingo County; $B$, The Minnie Portis Spring, a mineral spring having its source in the Porters Creek clay at Wahalak, Kemper County

6. A, Flowing well 295 feet deep at the residence of C. E. Watts, Monticello, Lawrence County; $B$, Four of the mineral wells at Brown's Wells, 10 miles southwest of Hazlehurst, Copiah County .

7. Flowing wells in Mississippi: $A$, Well of Long Beach Water Co., 840 feet deep, at Long Beach, Harrison County; $B$, Flowing well, 396 feet deep, used for public drinking water at Batesville, Panola County; $C$, Flowing well, 642 feet deep, of Love Wagon Co., Durant, Holmes County; $D$, Flowing well of G. S. Mitchell, only 35 feet deep, 3 miles south of New Albany, Union County .................. 
Puate 8. Map of Mississippi showing areas of flowing wells and location and depths of typical wells................ In pocket.

9. Map of northeastern Mississippi showing ground-water conditions in Cretaceous formations, including areas of flowing wells, and location and depths of typical wells......... In pocket.

10. A, Steel distributing tank near the waterworks at Houston, Chickasaw County; $B$, Steel distributing tank at the waterworks at Gloster, Amite County

11. $A$, Wooden tank for distributing water at the lumber plant of the Long-Bell Co., Quitman, Clarke County; B, The waterworks at. Grenada, Grenada County, including the pumping plant, operated by steam, and a brick ground reservoir. . . .

12. $A$, The waterworks at Sumrall, Lamar County, including the pumping plant and a concrete ground reservoir; $B$, Steel distributing tank at the waterworks at Columbia, Marion County

Figure 1. Physiographic districts of Mississippi

2. Section illustrating the conditions that chiefly control artesian pressure in Mississippi

3. Diagrammatic north-south section showing the relations of the subdivisions of the Upper Cretaceous deposits in Mississipp

\section{INSERT}

Generalized section of the geologic formations of Mississippi 



\title{
THE GROUND-WATER RESOURCES OF MISSISBPPI
}

\author{
By Lhord W. Stephexson, Wruliam N. Logan, and \\ Gmato A. Waming
}

\section{INTRODUCTYON}

Preparation of report.-This repert on the ground-water resources of Mississippi has been prepared in accordance with a cooperative arrangement with the Mississippi State Geological Survey, under E. N. Lowe, State geologist.

The section on the ground waters of the Cretaceous area was prepared by L. W. Stephenson, of the Federal Survey; data on the Eocene area were collected and assembled by E. N. Lowe and W. N. Logan, of the State Survey, and by G. A. Waring and L. W. Stephenson, of the Federal Survey; the preliminary data on the part of the State south of the Eocene area were collected by G. C. Matson, of the Federal Survey, and supplementary data were collected by L. W. Stephenson, who also wrote the section of the report on that area. Data on the quality of the waters were first assembled by R. B. Dole (deceased), of the Federal Survey; the work was continued by A. A. Chambers and C. H. Kidwell, of the Federal Surtey, and the parts relating to quality were written by C. S. Howard, of the Federal Survey. T. Wayland Vaughan, geologist in charge of Coastal Plain investigations, supervised the preparation of the entire report.

Acknowledgments. - The authors desire to acknowledge their indebtedness to the following persons for cooperation and assistance in assembling the data:

To E. W. Shaw, who cooperated in the compilation of data relating to the physiography of the area and who offered valuable suggestions bearing on the structure of the deposits and the geologic history recorded by them.

To well drillers of Mississippi, who gave detailed information in regard to individual wells and descriptions of the general groundwater conditions existing in the communities in which they operated.

To postmasters, municipal authorities, and owners of wolls and springs, who courteously and generously cooperated in supplying a large part of the data on which the report is based.

Free use was made of published reports on the geology and ground waters of the State.

Previous pubtications. - The following are the principal eatlier roports treating of the ground waters of Mississippi: 
HrLGARD, E. W., Report on the geology and agriculture of the State of Mississippi : Published by order of the Legislature in 1860.

Ground waters of the Cretaceous, Tertiary, and Quaternary formations are discussed on pages 104-106, 187-193, 196-197, 267-272, 283-288, 310312, 327-330, 345-347, 362-365, and 384-386.

Logan, W. N., and Perkins, W. R., A preliminary report on the underground waters of Mississippi: Mississippi Agr. Exper. Sta. Bull. 89, 112 pp., 1915.

Jornson, L. C. [Underground waters of] Mississippi: U. S. Geol. Survey WaterSupply Paper 114, pp. 171-178, 1905.

Crider, A. F., and Johnson, L. C., summary of the underground water resources of Mississippi: U. S. Geol. Survey Water-Supply Paper 159, 86 pp. 6 pls., 1906.

Lowe, E. N., Mississippi; its geology, geography, soils, and mineral resources: Mississippi Geol. Survey Bull. 12, 1915. (Second edition, Bull. 14, pp. 107-120, 1919.) (Underground waters, pp. 100-113.)

\section{PHYSIOGRAPHY}

\section{GENERAL FEATURES}

The State of Mississippi lies within the Gulf Coastal Plain but is by no means the low swampy country pictured by some people who are not familiar with the conditions of its surface. Although the State is a lowland as compared with a mountainous district, it presents a diversity of minor surface features and is separable into at least 10 distinct physiographic districts. (See fig. 1.) The relative altitudes and the land forms exhibited by all but two of these districts have resulted from the differing effects of erosion on the materials that immediately underlie the surface. Formations composed predominantly of sand or sandstone resist erosion more effectively than do formations composed of chalk or clay. The areas in which the sandy formations crop out therefore stand as hilly uplands, whereas the areas underlain by clay and chalk are reduced to gently undulating or moderately rolling plains between the hilly districts. The two districts whose main features are not primarily determined by erosion are the Yazoo Delta and the Coastal Pine Meadows. These are constructional plains which have not yet been strongly modified by destructive processes. The relation of these districts to the occurrence and recovery of waters is discussed on pages 7-8, 9 .

\section{TOMBIGBEE AND TENNESBEE RIVER HILLS}

In northeastern Mississippi, in the area underlain by the predominantly sandy strata of the Tuscaloosa and Eutaw formations (see pl. 2), including also the small areas underlain by the Paleozoic rocks (see p. 29), the surface is generally hilly and ranges from low smoothly rounded hills of 40 or 50 feet relief, with broad intervening valleys, to hills and ridges of 200 feet relief, with steep slopes, narrow. crests, and narrow separating valleys. These hills form the physiographic district to which the name Tombigbee Hills is here applied; 


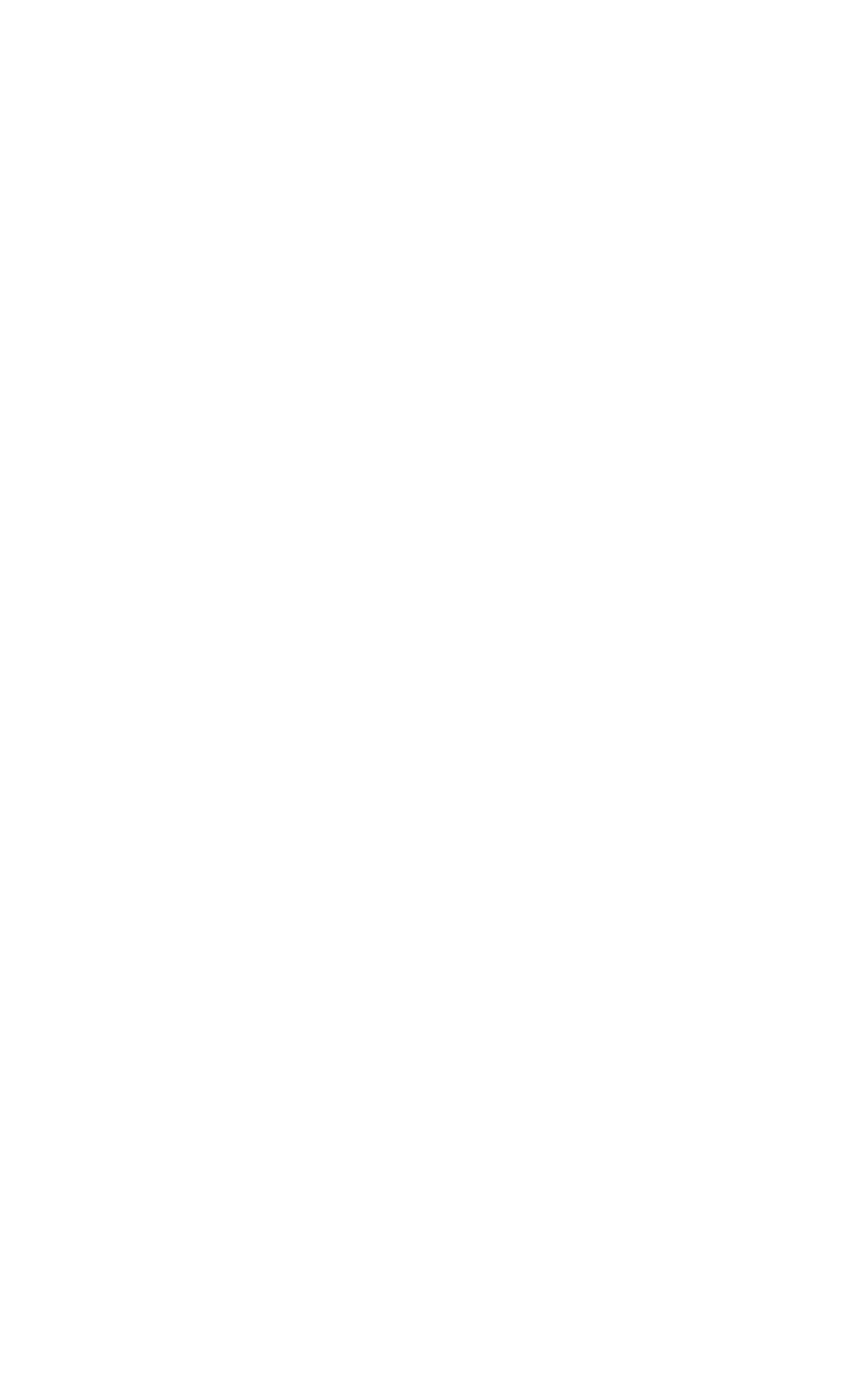

FigURE 1.-Physiographic districts of Mississippi 
they lie chiefly within the Tombigbee River drainage basin but in part in the Tennessee River drainage basin. Crider and Lowe have applied the name Tennessee River Hills to this district, but the name is not strictly appropriate, as only a relatively small part of the area lies within the drainage basin of Tennessee River.

The tops of the hills and ridges range in altitude above sea level from 400 feet in the south, in Lowndes and Monroe Counties, to 680 feet in the northeast, in Tishomingo, County, and there are two isolated hills in Tishomingo County that reach altitudes respectively of 720 and 780 feet. The roughest and highest part of the area is along the Alabama line in Tishomingo, Itawamba, and Monroe Counties.

The topographic aspect of this hilly district has been materially modified by terrace-forming processes, which have operated in the valley of Tombigbee River from Lowndes County far upstream into the valleys of the headwater creeks. The terraced lowland that borders the river is 5 to 7 miles wide in Lowndes County and stands 150 to 200 feet above sea level; the lowland gradually becomes narrower up the valley of the main and the tributary streams.

The Tombigbee Hills in Mississippi, together with their eastward extension into Alabama, form the catchment area of the waters found in the Tuscaloosa and Eutaw formations. These formations lie high enough in the hills in the eastern and northeastern parts of the district to develop sufficient hydrostatic pressure in the waters that they contain to produce flowing wells in the valley of Tombigbee River and its headwater branches as far north as the southern part of Prentiss County. (See pl. 9.) Most of the streams that head in this area are fed by perennial springs and contain flowing water throughout the year.

\section{BLACK PRAIRIE BELT}

The Black Prairie belt corresponds in geographic extent to the outcrop of the Selma chalk. (See geologic map, pl. 2 and fig. 1.) The surface is characterized by low relief, ranging from nearly level plains to hills which rise only 10 to 15 feet above the valley bottoms and which present long, gentle, smoothly covered slopes. The altitude of the belt ranges from 250 feet in the south in Noxubee County, to over 500 feet in the north in Prentiss and Alcorn Counties. In general the surface is lower than that of the Tombigbee Hills on the east and the Pontotoc Hills on the west.

In small areas bordering the larger streams the prevailing rolling topography of the Selma belt is modified to nearly flat plains by terracing processes that have operated during Pleistocene and Recent times. Perhaps the most notable example of this kind of topography is in the valley of Tibbee River in Clay County, where the terraced 
area extends from the western part of the county to Tombigbee River valley and has a maximum width of 6 or 7 miles. The town of West Point is situated on the principal and highest terrace. These plains are underlain by terrace loams, sands, and clays which produce thinner and lighter soils than those derived from the chalk.

The Selma chalk is compact and does not readily absorb water, so that the rain water runs off quickly. Streams that head in the Black Prairie belt are intermittent in their flow and contain running water only during rains and for short periods following them.

Hundreds of wells in the Black Prairie belthave been drilled through the Selma chalk into the water-bearing beds in the underlying Eutaw and Tuscaloosa formations. The fact that the belt lies lower than that of the hilly district to the east, which forms the catchment area of these waters, has considerable bearing on the recovery of the waters, for throughout the belt the static level of the waters is near enough to the surface to render feasible the use of ordinary suction and force pumps, and in some of the valleys, including the Noxubee, Tibbee, and Tuscumbia, flowing artesian wells are obtainable.

\section{PONTOTOC HILIS}

The Pontotoc Hills coincide in their geographic distribution with the outcrop of the Ripley and Clayton formations. (See pl. 2 and fig. 1.) The altitude of the surface ranges from hills of 40 or 50 feet relief, with gentle slopes and broadly rounded crests, which prevail along the western side of the area, to those of sharp outline and a relief of as much as 250 feet, with steep slopes, narrow ridges, and narrow intervening valleys, which prevail along the eastern side of the area. The hills range in altitude above sea level from 350 feet in the south, in Oktibbeha County, to over 650 feet in the north, in the western end of Alcorn County.

From northern Union County to southern Chickasaw County the hills form the divide between the Tombigbee drainage system on the east and the streams that flow to Mississippi River on the west. In Tippah and Alcorn Counties the hills are drained by the headwater streams of Hatchie River, a tributary of Mississippi River in Tennessee, and the southern end of the area in Clay and Oktibbeha Counties is drained by tributaries of Tombigbee River.

The more porous sands of the Ripley formation are water bearing, and the catchment area is among the Pontotoc Hills, where these beds crop out. The middle and lower water-bearing strata crop out toward the eastern border of the hilly area, and their buried westward extensions afford water to wells along the western side of the area and in the Flatwoods, which border the Pontotoc Fills on the west. 


\section{FIATWOODS}

The Flatwoods form a long, narrow belt of low relief which marks the outcrop of the Porters Creek clay. (See geologic map, pl. 2 and fig. 1.) The surface ranges in altitude above sea level from 200 feet or less in the south, in Noxubee County, to 500 feet in the north, in Tippah County. In general the area is a gently undulating to somewhat rolling wooded plain underlain by the dense, impervious clays of the Porters Creek. Springs are rare and small, and the streams that head in the area contain no running water except during and immediately following rains.

In the Flatwoods from Chickasaw County northward water is obtained from the Ripley formation, which underlies the Porters Creek clay, and on account of the relatively low altitude of the area as compared with that of the catchment area in the Pontotoc Hills the waters rise in the wells so near the surface that they can be obtained by means of hand suction or force pump, and in many of the valleys the wells overflow. (See pl. 9.)

In the Flatwoods southeast of Oktibbeha County good supplies of water can be obtained only by drilling through the Porters Creek clay and the Selma chalk into the water-bearing beds of the Eutaw formation. Although this water rises near enough to the surface to be reached by ordinary pumps no flowing wells have been reported in the Flatwoods.

\section{NORTH CHNTRAL HILIS}

Throughout the area immediately underlain by the Wilcox and Claiborne groups of the Eocene (see pl. 2 and fig. 1) the surface is hilly and at many places is decidedly broken and rough. The district has been called the North Central Hills (or "plateau"). The area is bounded on the east by the Flatwoods, on the south by the Jackson Prairie belt, and on the west by the Loess Hills. This extensive district is an upland that has been cut into hills and $\mathrm{v}$ alleys by stream erosion. The hills range in altitude above sea level from 400 feet in the south to over 600 feet in the north, and the valleys lie 50 to 250 feet below the hilltops.

This district is the catchment area of all the more valuable waterbearing sands in the Eocene series, and as many of the valleys lie lower than the outcrop of the sands among the hills, the hydrostatic conditions are favorable for obtaining flowing wells.

\section{JACKSON PRAIRIE BELT}

The Jackson Prairie belt is a relatively narrow strip of gently rolling country, including numerous small prairie-like tracts, which lie 300 to more than 500 feet above sea level. The belt marks the outcrop of the Jackson and Yegua formations (see pl. 2 and fig. 1), 
and the smooth topography is the result of the weathering of the clays that predominantly compose these formations. The clays yield water only sparingly, and many cisterns for storing rain water are in use throughout the district. Good water can be obtained in the formations that underlie the Jackson, but throughout most of the area the surface is higher than the static level of the water in the wells; and flows are not obtained. Flowing wells are obtained in Wayne County in the valley of Chickasawhay River, where the surface is lower than the static level of the waters of the Claiborne group.

\section{LONG-LFAF PINE HIILS}

All of southern Mississippi south of the Jackson Prairie belt, except a strip a fow miles wide along the Gulf coast (the Coastal Pine Meadows) and a narrow strip in the west (the Bluff Hills), forms a region of rolling to moderately rugged hills to which the name Long-leaf Pine Hills has been given. This region is underlain by the Vicksburg group, the Catahoula, Hattiesburg, Paseagoula, and Citronelle formations, and in the extreme south by certain unclassified Pleistocene deposits (see pl. 2, and fig. 1), but the topographic characters of the area are chiefly determined by the sandy beds of the Citronelle formation, which overlaps the older formations on all the divides. The hills range in altitude above sea level from 100 feet or less in the southeast to 500 feet or more in the north and northwest. This region was once covered with a nearly unbroken virgin forest of long-leaf pine, but a large part of it has been cut over, and the remaining tracts of virgin pine are rapidly disappearing before the saw and ax of the lumberman.

The Long-leaf Pine Hills form the catchment area of all the waterbearing beds in the formations just named. Hundreds of wells, most of them less than 100 feet deep, have been dug or bored throughout the area, and afford adequate supplies of good water for domestic and farm uses. The buried southward extensions of the waterbearing beds afford flowing wells in many of the valleys in central and southern Mississippi. The same waters can be obtained on the higher lands between the streams, but the static level is not high enough to afford flows, and pumps have to be installed to raise the water to the surface.

\section{CoAstaL PINE meadows}

South of the Long-leaf Pine Hills in the southeastern part of the State is a low-lying district 7 to 20 miles wide (see fig. 1), which borders the Gulf of Mexico and supports an open growth of long-leaf and Cuban pine. This area is called the Coastal Pine Meadows. No part of it is more than 100 feet and most of it is less than 50 feet above sea level. The topographic features of the area: have 
mot.been studied in detail, but the surface ranges from gently rolling to level and toward the coast presents broad expanses of flat land and considerable tracts of swamp and marsh. Near the coast the monatony of the surface is broken here and there by ridges of sand that rise 10 or 15 feet above the general plain. These are former sand dunes that have become fixed by a covering of vegetation.

Throughout this area the water table lies within a few feet of the surface, and in the swamps and marshes it rises above the surface. The streams are sluggish and flow in tortuous sendy channels. The water of streams and fresh-water swamps is clear, but its contact with peaty matter has given to it a distinctly amber tint.

The water-bearing beds of the Citronelle, Pascagoula, and Hattiesburg formations (see pl. 2) all dip to the south at low angles and pass beneath the Coastal Pine Meadows. As the eatchment areas of these beds are at higher levels among the Long-leaf Pine Hills, hydrostatic pressure is developed sufficient to raise the water above the surface throughout the Coastal Pine Meadows, and in some of the deeper beds the pressure is adequate to raise the water to a height of 100 feet above sea level if confined in a pipe. The inhabitants have taken advantage of the favorable artesian conditions, and scores of flowing wells that range in depth from 150 to 1,300 feet are in use throughout the area. (See pl. 8.)

\section{LOESS OR BLUFF HILLS}

The western border of the upland portion of Mississippi is covered with a thick deposit of calcareous loess, as described on page 62 which forms a belt 5 to 15 miles wide that parallels the eastern margin of the bottom lands of Mississippi River from the Tennessee State line to the Louisiana State line. (See pl. 1, $A$, and fig. 1.) Throughout this strip the surface is characterized by pronounced hills with steep slopes, narrow ridges, and narrow intervening valleys. The Loess or Bluff Hills, as they are called, are bounded on the west by an abrupt escarpment, which leads down to the level bottom lands of Mississippi River. North of Vicksburg these bottom lands are collectively known as the Yazoo Delta. The tops of the Bluff Hills stand 150 to 250 feet higher than the bottom lands and 300 to 500 feet above sea level.

On account of the thick covering of non-water-bearing loess the inhabitants find difficulty at many places in obtaining water by means of the ordinary shallow wells, and many cisterns for storing rain water are in use throughout the area. Water is present, however, in sands and gravels which at most places underlie the loess, even where the cover is 100 feet or more in thiekness. Flowing wells can be obtained in many of the deeper valleys by drilling to the water-bearing beds of the deeply buried older formations. 


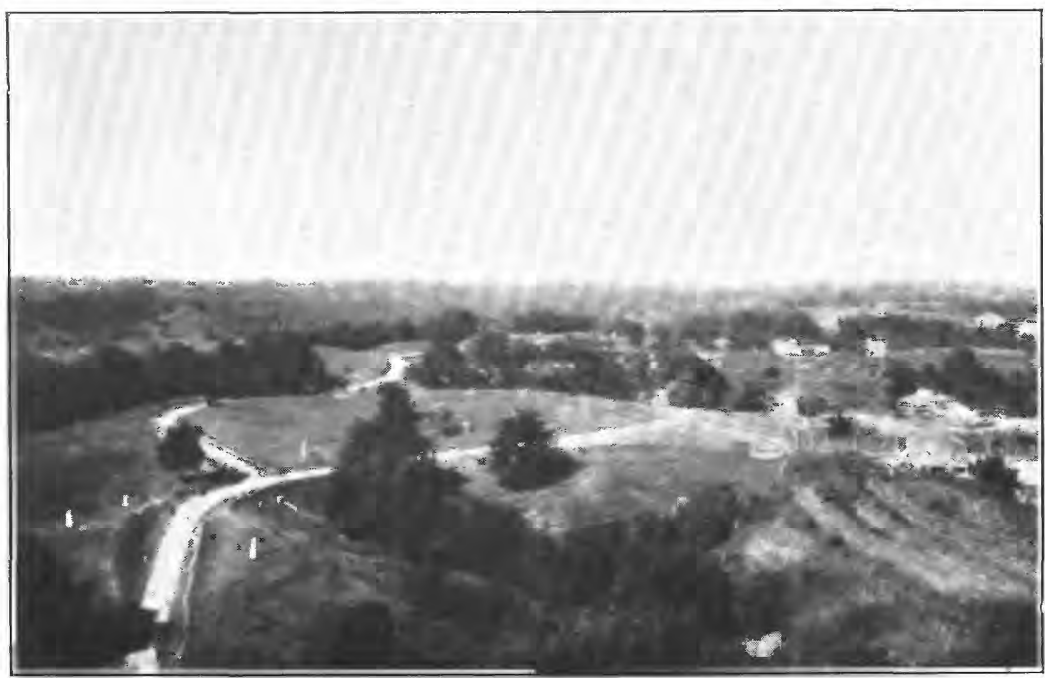

A. THE LOESS OR BLUFF HILLS, LOOKING NORTH FROM OBSERVATION TOWER NEAR THE NATIONAL CEMETERY, VICKSBURG

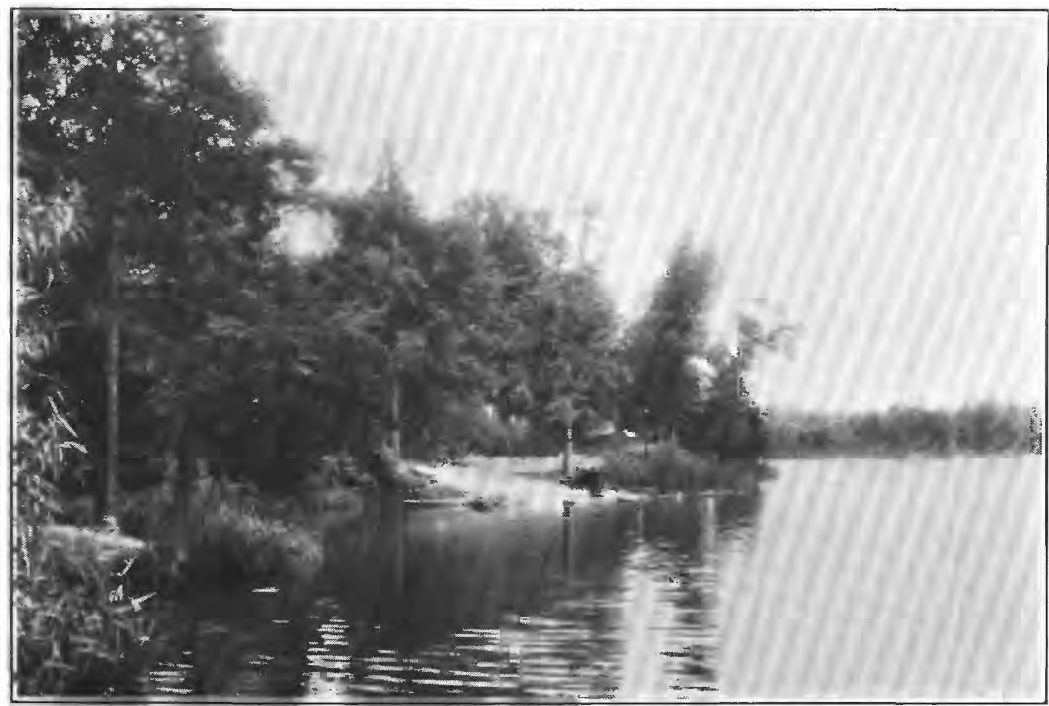

B. CHAUTAUQUA LAKE, AN ARTIFICIAL LAKE 11/4 MILES NORTH BY WEST OF CRYSTAL SPRINGS, COPIAH COUNTY

Formed by damming one of the headwater branches of Turkey Creek 



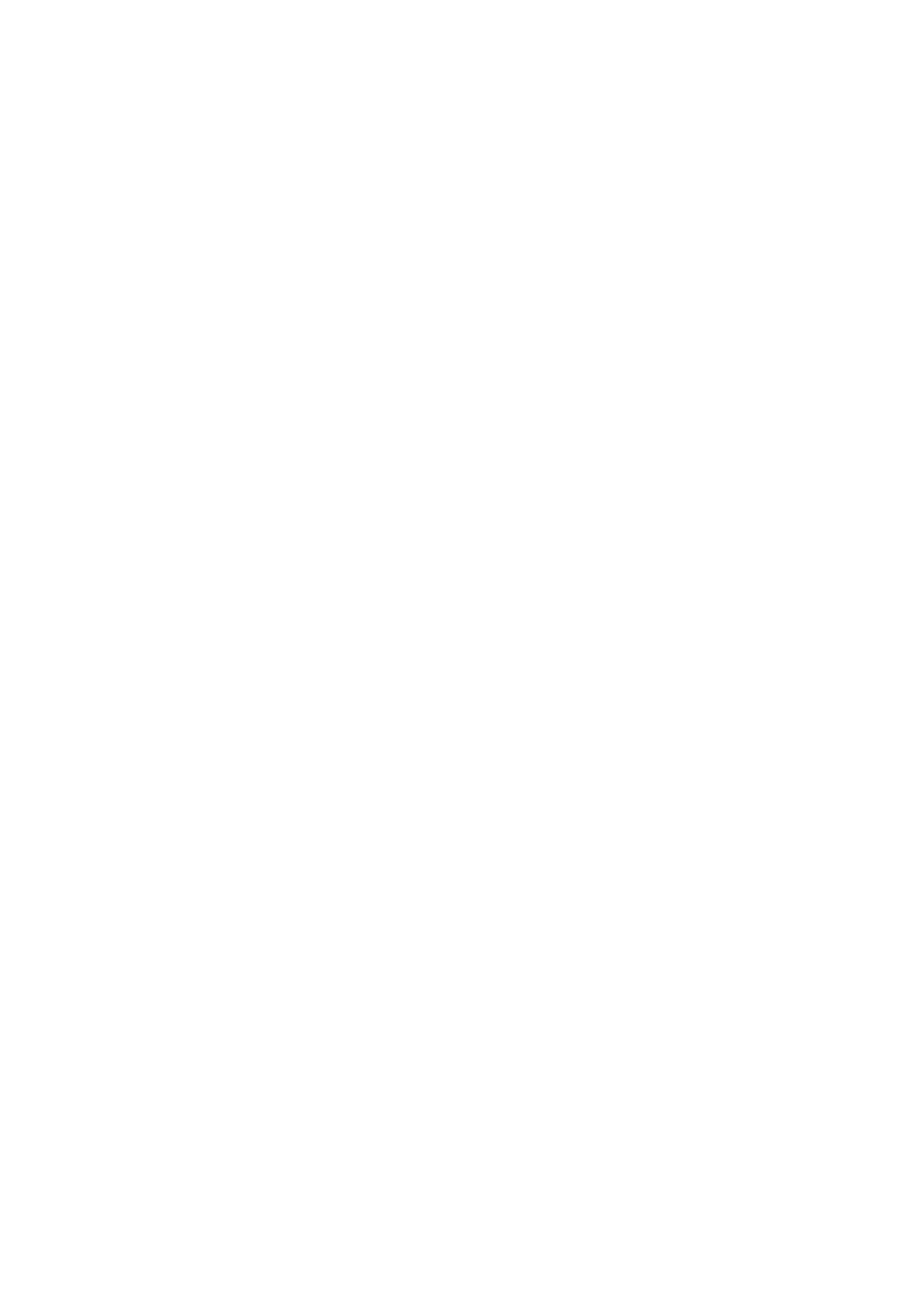

$10 \quad 0 \quad 10 \quad 20 \quad 30 \quad 40 \quad 50$ Miles 


\section{MISEISGIPRI AITUVIAL PIAIN}

The Mississippi alluvial plain includes all the land between Mississippi River and the Bluff or Loess Hills. (See fig. 1.) South of Vicksburg only a few relatively small tracts of bottom land lie east of the river in Mississippi, and in places the river touches the foot of the bluffs. North of Vicksburg the bottom lands spread out into a broad expanse of level plain that has a maximum widith from east to west of 65 miles and a length from north to south of 190 miles. This vast plain, to which the name Yazoo Delta has been given, slopes from an altitude above sea level of 210 feet in the north to 90 feet in the south, or at the rate of about $7 \frac{1}{2}$ inches to the mile. There is also a slope of 4 or 5 inches to the mile from the so-called natural levees along the main river toward the eastern edge of the "delta." Because of this slight eastward inclination the plain is drained chiefly by Yazoo River, which flows southward near the eastern edge of the "delta" throughout the greater part of its length and joins the Mississippi near Vicksburg. The two largest tributaries of the Yazoo are Sunflower River and Deer Creek.

The drainage channels, including both the main streams and numerous tributary bayous and creeks, are extremely sinuous, widely meandering, and sluggish, and in many places they take the form of interconnecting distributaries. Numerous small lakes scattered over the plain represent either original undrained depressions or abandoned stream channels only partly filled with sediments. Many of the old water-filled channels still retain the oxbow or horseshoe form characteristic of meandering streams. A luxuriant forest originally covered the "delta," but a system of protecting levees was completed in 1886, since which time large tracts have been cleared and the fertile soils put in cultivation.

The alluvial deposits of Mississippi River, which underlie the Yazoo Delta to a depth of 125 to 200 feet, contain very large quantities of water, but this water is under little or no artesian pressure. The deeply buried water-bearing sands of the Eocene series, the catchment areas of which lie at higher levels in the hills of central and northern Mississippi, give rise to flowing artesian wells that yield water in abundance throughout the "delta." (See pl. 8.)

\section{PRECIPITATION}

The mean annual precipitation in Mississippi ranges from approximately 50 inches in the north to slightly over 60 inches in the southeast near the Gulf of Mexico. The precipitation occurs chiefly in the form of rain. The following table gives the average monthly and annual precipitation at several stations in or near Mississippi. 
Average monthly and annual precipitation, in inches, at several stations in or near Mississippi

[U. S. Weather Bureau]

\begin{tabular}{|c|c|c|c|c|c|c|c|c|c|c|c|c|c|}
\hline Station & Jan. & Feb. & Mar. & Apr. & May & June & July & Aug. & Sept. & Oct. & Nov. & Dec. & Year \\
\hline $\begin{array}{l}\text { Columbus } \\
\text { Oorinth } \\
\text { Jackson } \\
\text { Meridian } \\
\text { Vicksburg } \\
\text { Memphis } \\
\text { Mobile } \\
\text { New Orieans }\end{array}$ & $\begin{array}{l}\mathbf{5 . 0 7} \\
4.75 \\
4.84 \\
5.54 \\
5.67 \\
5.21 \\
4.85 \\
4.63\end{array}$ & $\begin{array}{l}5.53 \\
4.07 \\
5.12 \\
4.90 \\
4.61 \\
4.35 \\
5.36 \\
4.47\end{array}$ & $\begin{array}{l}\text { 6.17 } \\
\text { 5. } 69 \\
\text { 5. } 66 \\
\text { 5. } 61 \\
\text { 6. } 25 \\
\text { 5. } 77 \\
\text { 7. } 17 \\
\text { 5. 30 }\end{array}$ & $\begin{array}{l}5.34 \\
5.12 \\
5.45 \\
5.04 \\
5.16 \\
4.83 \\
4.35 \\
4.91\end{array}$ & $\begin{array}{l}6.94 \\
\text { 4. } 08 \\
\text { 4. } 06 \\
\text { 3. } 92 \\
4.26 \\
4.34 \\
4.00 \\
\text { 3. } 88\end{array}$ & $\begin{array}{l}4.12 \\
4.00 \\
4.26 \\
4.62 \\
4.49 \\
4.37 \\
5.95 \\
6.16\end{array}$ & $\begin{array}{l}4.71 \\
4.92 \\
4.40 \\
4.50 \\
4.42 \\
3.51 \\
7.04 \\
6.47\end{array}$ & $\begin{array}{l}4.44 \\
\text { 3.78 } \\
4.26 \\
\text { 3. } 55 \\
\text { 3. } 53 \\
\text { 3. } 20 \\
6.81 \\
\text { 5. } 61\end{array}$ & $\begin{array}{l}\text { 3.09 } \\
\text { 2. } 94 \\
2.99 \\
\text { 3.47 } \\
\text { 3. 34 } \\
\text { 3. } 05 \\
\text { 5.02 } \\
\text { 4. } 81\end{array}$ & $\begin{array}{l}2.36 \\
2.56 \\
2.17 \\
2.70 \\
2.80 \\
2.74 \\
\text { 3. } 18 \\
2.93\end{array}$ & $\begin{array}{l}4.19 \\
3.62 \\
4.36 \\
4.14 \\
4.19 \\
4.59 \\
3.74 \\
3.79\end{array}$ & $\begin{array}{l}5.12 \\
5.62 \\
4.84 \\
5.21 \\
5.02 \\
4.38 \\
4.57 \\
4.46\end{array}$ & $\begin{array}{l}56.98 \\
51.15 \\
51.51 \\
53.20 \\
53.74 \\
50.34 \\
62.04 \\
57.42\end{array}$ \\
\hline
\end{tabular}

\section{SURFACE WATERS}

\section{STREAMS}

All the drainage of Mississippi is received by the Gulf of Mexico. The surface waters of the northern, north-central, and western parts of the State reach the Gulf by way of Mississippi River. Those of the eastern, south-central, and southern parts of the State flow to the Gulf by way of three principal streams-Tombigbee, Pascagoula, and Pearl Rivers. (See pl. 3.)

The principal streams included in the Mississippi River drainage basin are Tennessee River, which drains a few townships in the extreme northeast; Hatchie and Tuscumbia Rivers, which flow northward into Tennessee, where they unite to form Wolfe River; Yazoo River, a long sinuous stream whose tributaries drain practically all of the Yazoo Delta and a large tract of upland in the northwest; Big Black River, which drains a long, narrow strip of upland in the central and southwestern parts of the State; and Bayou Pierre, Coles Creek, and Homochitto River, which drain several of the southwestern counties.

Tombigbee River heads in northeastern Mississippi and drains 10 or more counties, including most of the Black Prairie belt; the main stream leaves the State in Lowndes County and thence flows through Alabama for the remainder of its course to the Gulf. Pascagoula River drains an extensive area in the southeastern part of Mississippi and reaches the Gulf in Jackson County. Pearl River drains a large though relatively narrow area in central and southern Mississippi and flows into the Gulf about 55 miles west of the mouth of Pascagoula River.

The gradients of all the main streams are low and in few places, if anywhere, exceed a fall of a foot to the mile; some gradients are flatter than others, as, for example, those of the sluggish, widely meandering streams of the Yazoo Delta, which have a fall of only a few inches to the mile.

The streams that drain the upland belong to the ordinary or normal class of streams that are characteristic of most of the wellwatered portions of the earth's surface. In drainage of this class 
the smaller branches flow in separate valleys until they join larger streams, and these in turn flow in separate valleys until they join still larger streams, and so on until the main or parent stream is reached. There are no interconnecting channels between the branches. The streams of this class are treelike in plan, and the term "dendritic drainage" is applied to them. The drainage in the Yazoo Delta differs from that in the hilly upland in that the currents are sluggish, the channels are widely meandering, and networks of channels or bayous connect the tributary branches with each other and with the numerous lakes and ponds of the area.

Most of the streams of the State are fed by ever-flowing springs and contain flowing water throughout the year; they are called perennial streams. However, streams which head in areas where, springs are rare or absent, as in the Black Prairie belt, the Flatwoods, and the Jackson Prairie belt, contain running water only during and for short periods following rains, and these are known as intermittent streams.

The following table gives the maximum, minimum, and average discharge in second-feet of streams in Mississippi that have been gaged by the United States Geological Survey. Gage heights only are recorded for Sunflower River and Homochitto River; hence they are omitted in the table.

Maximum, minimum, and average discharge of streams in Mississippi that have been gaged by the United States Geological Survey

\begin{tabular}{|c|c|c|c|c|c|c|}
\hline \multirow{2}{*}{ Stream } & \multirow{2}{*}{ Station } & \multirow{2}{*}{$\begin{array}{l}\text { Iength } \\
\text { of record } \\
\text { (years) }\end{array}$} & \multirow{2}{*}{ Dates } & \multicolumn{3}{|c|}{ Discharge, second-feet } \\
\hline & & & & Maximum & Minimum & Average \\
\hline $\begin{array}{l}\text { Tombigbee River } \\
\text { Pearl River } \\
\text { Tallahatchie River. } \\
\text { Tallahatchie River. } \\
\text { Yazoo River. } \\
\text { Yazoo River } \\
\text { Coldwater River. }\end{array}$ & $\begin{array}{l}\text { Columbus. } \\
\text { Jackson } \\
\text { Batesville... } \\
\text { Philipp } \\
\text { Greenwood. } \\
\text { Yazoo City } \\
\text { Savage }\end{array}$ & $\begin{array}{r}13 \\
10 \\
7 \\
5 \\
6 \\
4 \\
5\end{array}$ & $\begin{array}{l}1900-1912 \\
1903-1912 \\
1906-1912 \\
1908-1912 \\
1908-1913 \\
1901-1904 \\
1908-1912\end{array}$ & $\begin{array}{l}50,420 \\
36,500 \\
14,200 \\
28,600 \\
39,000 \\
27,700 \\
14,500\end{array}$ & $\begin{array}{r}195 \\
80 \\
260 \\
910 \\
900 \\
1,730 \\
20\end{array}$ & $\begin{array}{r}5,631 \\
3,351 \\
b 2,365 \\
\cdot 6,550 \\
9,996 \\
d 9,314 \\
\cdot 1,547\end{array}$ \\
\hline Yalobusha River. & Grenada............ & 6 & $\left\{\begin{array}{c}1906 \\
1908-1912\end{array}\right.$ & 17,000 & 35 & $f 2,400$ \\
\hline
\end{tabular}

- 1905 omitted because data are incomplete.

- 1906 omitted because data are incomplete.

- 1908 omitted because data are incomplete.

- 1904 omitted because data are incomplete.

- 1908 and 1912 omitted because data are incomplete.

f 1906, 1908, 1910, and 1912 omitted because data are incomplete.

The following publications of the United States Geological Survey contain the records of stream measurements at the stations listed in the table: Water-Supply Papers 48, 65, 75, 83, 98, 127, 128, 168, 169, 204, 205, 242, 247, 261, 267, 282, 287, 302, 307, 322, 327, 352, 357.

\section{LAKES AND PONDS}

Natural lakes and ponds are rare in the upland portions of Mississippi, except in the flood plains of the larger streams, where they occur in some places, chiefly in the form of abandoned channels only 
pairtly filled with sediments. A fow small lakes occur in the broad battom lands that border the lower course of Pascagoula River and in the flat, low-lying lands that border the Gulf of Mexico.

Lakes and ponds are numerous throughout the Yazoo Delta. They are either more or less completely abandoned stream channels or original shallow undrained depressions in the plain. Many of the lakes are obviously abandoned and only partly filled oxbow loops of streams. Some of these bodies of water are connected with each other and with the larger creeks and rivers by an intricate system of smaller creeks and bayous.

\section{SWAMPS}

Swamps are rare in the upland portion of Mississippi away from the streams. In the narrow flood plains of the rivers and larger creeks tree-grown swamps in irregular tracts of greater or less extent are common. Many of these swamps have been artificially drained. Extensive tracts of salt marsh and fresh-water swamp occur in the belt of flat low-lying land along the Gulf of Mexico in the southeastern part of the State. The Yazoo Delta was formerly subject to the overflow of Mississippi River, and it then included large tracts of treegrown swamp. Since 1886, when a system of protecting levees was completed, many poorly drained, more or less swampy tracts have been artificially drained by canals and have been reclaimed for cultivation. Swampy tracts still exist, however, and in the southern part of the delta, where backwater in Yazoo River from the floods of Mississippi River renders drainage more difficult, some large tracts still remain in a swampy condition.

\section{QUALTTY OF WATER}

Although ground water of excellent quality can be obtained almost anywhere in Mississippi, there are localities where surface waters furnish a more satisfactory supply on account either of the chemical composition of the water or the quantity available. As population increases the surface waters will be more extensively utilized. Surface waters have the disadvantage of being turbid and exposed to pollution so that they require purification, which is not necessary for deep well waters. In most places the dissolved mineral matter in the surface waters is not very different in quantity or quality from that in ground water in the neighborhood. The analyses in the accompanying table show the chemical character of some surface waters in Mississippi. Luxapalila River, which furnishes the municipal supply for Columbus, and the reservoir that furnishes the supply for Meridian are each represented by an analysis of a single sample (Nos. 1 and 2). The other results are averages of analyses of composite samples taken during a period of a year. At each station small samples were collected daily and united to make composite samples for analysis. The New Orleans composite samples contained 7 daily samples, the others 
contained 10 each. The turbidity and suspended matter of the samples from Luxapalila River and the Meridian Reservoir were not determined. The other determinations on all samples represent the filtered water.

Analyses of surface waters in Mississippi

[Parts per, million]

\begin{tabular}{|c|c|c|c|c|c|c|}
\hline & 1 & 2 & 3 & 4 & 5 & 6 \\
\hline 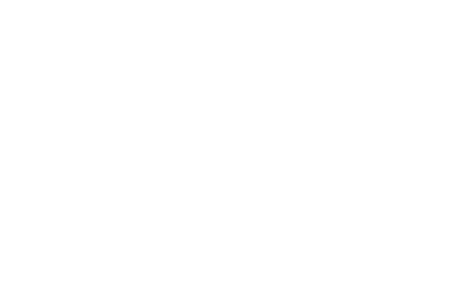 & $\begin{array}{r}25 \\
1.0 \\
1.4 \\
1.0 \\
7.2 \\
17.0 \\
3.0 \\
\text { Trace. } \\
61 \\
8\end{array}$ & $\begin{array}{l}29 \\
1.6 \\
6.8 \\
15 \\
8.0 \\
3.4 \\
\text { Trace. } \\
56 \\
6\end{array}$ & $\begin{array}{l}56 \\
46 \\
18 \\
7.37 \\
7.1 \\
1.1 \\
8.9 \\
32.0 \\
6.4 \\
3.4 \\
59 \\
20\end{array}$ & $\begin{array}{c}126 \\
100 \\
25 \\
18.63 \\
1.8 \\
10 \\
.0 \\
67.0 \\
6.8 \\
3.0 \\
94^{.6} \\
52\end{array}$ & $\begin{array}{c}556 \\
519 \\
24 \\
36 \\
36 \\
12 \\
19 \\
129 \\
129 \\
43 \\
8.6 \\
1.7 \\
202 \\
139\end{array}$ & $\begin{array}{c}11 \\
32.13 \\
8.4 \\
13 \\
111 \\
24 \\
9.7 \\
2.5 \\
166 \\
114\end{array}$ \\
\hline
\end{tabular}

- Na, 4.2; K, 3.0 parts per million.

b Computed.

1. Luxapalila River at Columbus, Miss. Sample collected Aug. 25, 1919. Analyzed by C. H. Kidwell and Margaret D. Foster, U. S. Geological Survey.

2. Reservoir at Meridian, Miss. Sample collected Aug. 27, 1919. Analyzed by Margaret D. Faster,

J. S. Geological Survey. to Oct. 19,1907 .

4. Tombigbee River near Epes, Ala. Average of analyses of composites of daily samples from Oct. 24, 1906, to Oct. 24, 1907.

5. Mississippi River at Memphis, Tenn. Average of analyses of composites of daily samples from Jan. 10,1907 , to Jan. 1,1908 .

6. Mississippi River at New Orleans, La. Average of analyses of composites of daily samples from Apr. 29,1905 , to A pr. 28,1906 .

Analyses 3, 4, 5, and 6 from U. S. Geological Survey Water-Supply Paper 236, 1909.

Luxapalila River drains an area where the Tuscaloosa formation predominates, and its water is particularly low in calcium. The Meridian Reservoir is fed by springs and small streams which have not been long in contact with the rock materials. The composition of the water is practically the same as that of Luxapalila River.

Other surface waters may be equally soft, but the analysis of water from Pearl River at Jackson is probably representative of the greater number of the streams of the State. Nearer their sources the streams carry less dissolved mineral matter.

The analysis of water from Tombigbee River at Epes, Ala., represents in part water coming from Mississippi. The Selma chalk occurs in the area drained by this river, so there is more calcium in solution than is found in most surface waters in the State. The water is, however, fairly soft, and on the basis of the dissolved mineral matter would be classed as excellent for all ordinary uses.

The chemical character of the water of Mississippi River along the border of the State is shown by the analyses of the water at Memphis, Tenn., and New Orleans, La. This water is much harder than most surface waters in the State, and in addition to the larger quantity of dissolved mineral matter it carries much suspended material, which decreases its. value as a source of supply. Filtered river water furnishes the municipal supply at Vicksburg. 


\section{GROUND WATERS}

\section{SOURCE}

The strata which underlie the surface of Mississippi are saturated with water below a level known as the water table, which ranges from the surface to a depth of 100 feet or more. The water table lies deepest in some of the higher parts of the upland and shallowest. in the lowlands; in the swamps it lies continuously or intermittently above the surface of the ground. The water table does not occupy a fixed position at any given place but continually fluctuates, being highest at the end of a long period of precipitation and lowest at the end of a long drought.

Although the beds are saturated to the level of the water table they do not yield their water to : wells with equal readiness. The waters in the more compact layers are so completely locked within. the fine interstices as to be practically unobtainable. Only the more porous sands and gravels yield their waters readily and in large quantities, and the term water-bearing beds is commonly applied to beds composed of these materials, which are the beds that the well driller seeks to reach with the drill.

The location and depth of typical wells are indicated in Plates 8 and 9.

The greater part of the ground water of Mississippi is derived: from rainfall within the borders of the State. However, the Tuscaloosa formation obtains most of its supply in the hills of northwestern Alabama, and sea water probably still exists in large quantities in some of the deeply buried formations in the southern partof the State. As some of the geologic formations that underlie the surface in Mississippi are composed of dense clay, chalk, limestone, or sandstone, and as other intervening formations are composed of porous sand or gravel, it follows that rain water which falls on the surface will be more readily absorbed by the sandy formations where they crop out and will pass by gravity down the gently inclined, buried beds of sand and gravel between the other denser and relatively impervious beds. In this way vast quantities of water have become stored in the formations and constitute a natural resource of incalculable value.

\section{DISPOSAL}

Van Hise ${ }^{1}$ has estimated that at least 99 per cent of the meteoric waters that enter the earth return to the surface sooner or later and the remaining 1 per cent or less enters into chemical combination with minerals. A large part of the ground water gradually returns to the surface by capillary attraction and is evaporated; a large part is taken up by the roots of plants and is eventually evaporated; and a

1 Van Hise, C. R., Treatise on metamorphism: U. S. Geol. Survey. Mon. 47, p. 156, 1904. 
large part emerges at the surface as springs and flows away in streams: In an area underlain by beds that are inclined slightly toward the: ocean, as in the Atlantic and Gulf Coastal Plain, there is probably a constant though extremely slow movement of the ground waters in the direction of the coast, so that a large proportion of these waters may reach the ocean by this course.

\section{QUANTITY}

The quantity of water obtainable from the ground in Mississippi by means of wells differs greatly from place to place and at different depths, depending upon the local geologic and hydrologic conditions. At most places it is practicable to obtain from wells the relatively small amounts needed for domestic and ordinary farm uses, and most of the towns and smaller cities have found it possible to obtain enough water from wells to meet both their domestic and industrial needs.

In places the quantity of water available is very large, as shown by the following examples: At Hattiesburg, in Forrest County, approximately $1,000,000$ gallons of water is furnished daily to the city by the water works from five wells, and large additional quantities are independently obtained from wells by several lumber companies; at Greenwood, in Leflore County, an average daily consumption of 2,225,000 gallons is furnished by six flowing wells; and at Greenville, in Washington County, an average daily consumption of approximately 2,500,000 gallons is furnished by four nonflowing wells. The alluvial deposits that underlie the Yazoo Delta to depths of 125 to 200 feet contain vast quantities of water, which may be regarded as practically inexhaustible even locally; a well of large diameter would probably yield from these déposits as high as 3,000 or 4,000 gallons a: minute without seriously lowering the water level.

In some parts of the State where the yield of the earlier wells was. large, subsequent heavy draft has demonstrated that the quantity of water available from the beds now being drawn upon is limited and that at the present rate of removal the supply will eventually become seriously depleted. A good example of depletion is afforded by wells: in Tupelo and vicinity, in some of which the static level of the water is now as much as 70 feet below the surface, whereas originally wells at. the same locality overflowed.

\section{SPRINGS}

Most of the springs of Mississippi emerge at the outcropping contacts between relatively impervious strata, such as clay, chalk, or dense sandstone, and overlying water-bearing sands. The springs. occur at the heads of small branch valleys, on valley slopes, or in 
valley bottoms, and, with certain exceptions, are small, the yield ranging from less than a gallon to 20 or 25 gallons a minute. Where conveniently located and of adequate yield the springs are utilized for domestic, farm, and school supplies. A fow of the small or moderate-sized towns obtain their municipal supplies from single springs or groups of springs. Health resorts have been established at several springs whose waters are reputed to possess therapeutic properties, and the waters of several similar springs are bottled and sold for therapeutic use.

\section{NONARTESIAN WATERS}

The term "nonartesian" is in this report applied to ground waters that are not under sufficient hydrostatic pressure to force them to any appreciable height above the containing beds when they are tapped by wells or other excavations. Nonartesian waters occur, as a rule, at shallow depths in materials that do not possess the structural conditions necessary for an artesian system. The waters contained in most of the Pleistocene and Recent alluvial deposits in the valleys and low plains belong to this class, for the reason that the deposits are nearly horizontal and do not contain persistent impervious layers of clay or other dense material. Most of the waters obtained from shallow wells throughout the upland are also nonartesian, because they form the uppermost layer of the ground waters and are therefore not under hydrostatic pressure.

The nonartesian waters are obtained by means of dug, bored, and driven wells and are raised by rope and bucket, hand pumps, windmills, and various types of more powerful steam, gasoline, or oildriven pumps. The type of well, its depth and diameter, and the kind of lifting machinery are determined by the use to which the waters are to be put and the amount of water required. Wells that supply municipalities, large factories, and irrigated lands are equipped with powerful machinery, steam-driven force pumps, centrifugal pumps, and air compressors being most generally used.

The waters of numerous shallow wells of the nonartesian class are locally, or more or less widely, reputed to possess therapeutic properties, and health resorts are conducted at several of them. The waters of some such wells are bottled and sold for medicinal use.

\section{ARTESIAN WATERS}

\section{DEFINITION}

The term "artesian" is applied in this report to ground waters that are under sufficient hydrostatic pressure to force them to an appreciable height above the level of the containing beds when they are penetrated by wells or other excavations. Artesian water does 
not necessarily rise to the surface, and an artesian well may be either flowing or nonflowing. Frequently the topographic position of a well determines whether or not it will flow. Thus a well located low in a valley may be a flowing artesian well because the hydrostatic pressure there is sufficient to raise the water above the surface, whereas a well located on a near-by hill is a nonflowing artesian well because the hydrostatic level of the water at that point is not as high as the upland surface. (See pl. 7.) The significance of the term "artesian" has been discussed by Fuller."

\section{ARTESIAN CONDITIONS IN MISSISSIPPI}

The conditions that govern the occurrence of artesian water in Mississippi may be summarized as follows: (1) The principal source of the water in the artesian systems is the rain that falls upon the surface within the borders of the State or in closely adjacent areas; (2) the retaining agents are chiefly layers of dense clay, chalk, marl, sandstone, claystone or limestone, which dip gently to the west, southwest, or south; (3) the water as a rule is contained in layers of sand or sandy marl of greater or less porosity, interbedded with the denser layers that serve as retaining agents; (4) the artesian pressure in any part of a water-filled sand is afforded chiefly by the weight of the water in the same layer at higher levels; (5) with perhaps a few local exceptions conditions favorable to the occurrence of artesian water are present throughout the State, but the surface of most of the upland is too high to permit the wells to overflow at the surface. (See pl. 8.)

Some of the more important artesian conditions in the State are illustrated in Figure 2.

Another set of conditions (not shown in fig. 2), which produce artesian pressure but the effectiveness of which is not generally appreciated, is dependent upon the higher position of the water table in a hill or upland, as compared with that of an adjacent valley or lowland. Although the water-bearing bed may be overlain by one or more impervious beds the pressure of the water in the higher land, where the water table is high, is transmitted vertically downward and may so affect the water-bearing bed as to raise the water above the mouths of wells located in the lower land that tap this source of supply. Many flowing wells in Mississippi are probably produced in this manner.

\section{AREAS OF FLOWING WELLS DETERMINED BY TOPOGRAPHY}

A glance at the map (pl. 8), on which is indicated the areas of artesian flow of Mississippi shows that these areas are largely determined by topography; they are the low-lying parts of the State.

- Fuller, M. L., Underground-water papers: U. S. Geol. Survey Water-Supply Paper 160, pp. 9-15, 1906. 


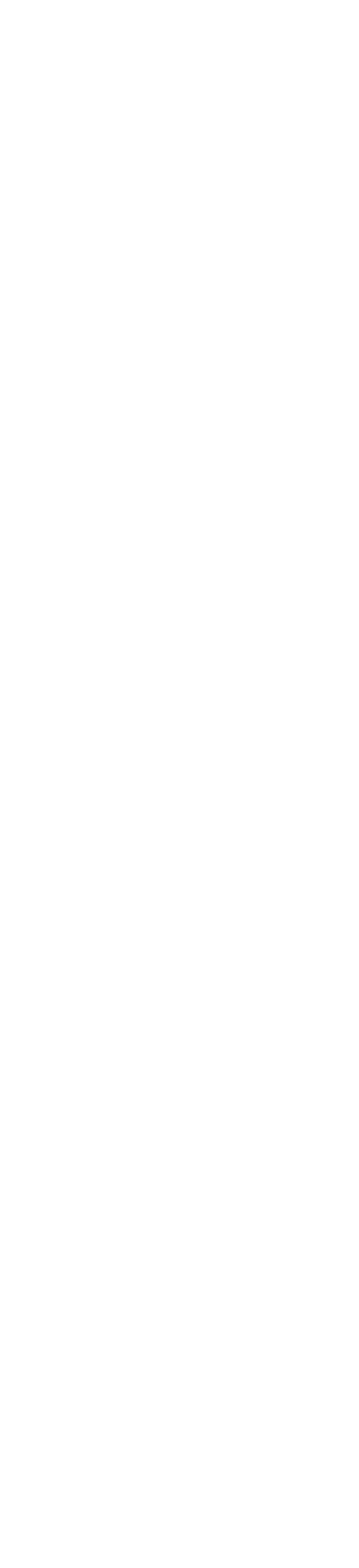

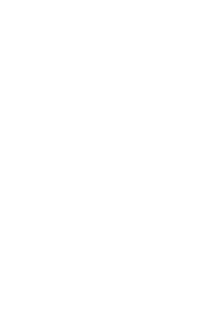

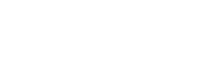

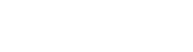

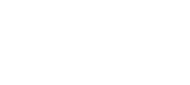

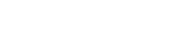

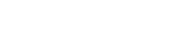

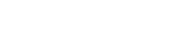

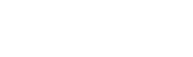

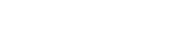

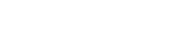

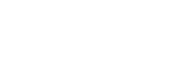

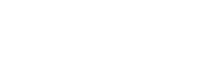

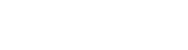

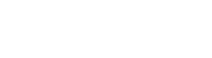

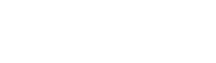
啊 穿 \$ \$

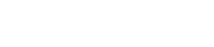

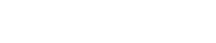
8 영요영

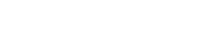

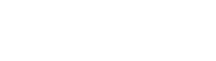

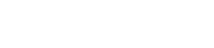

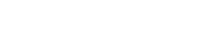

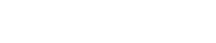

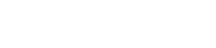

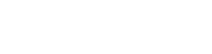

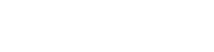

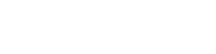
क व क

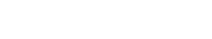

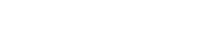

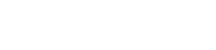
영응 家家

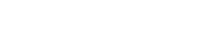

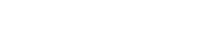
1 速

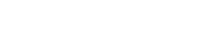
约 : 
The most extensive area is the Yazoo Delta, which lies 200 to 300 feet lower than the upland to the east. Next in extent is the belt of low-lying plains that borders the Gulf of Mexico, where flowing wells of large yield are numerous. Flowing wells also occur in the lowlands that border all the larger rivers and many of their tributaries: The static level of the water in "wells is high"enough to produce flows in these low-lying areas but is too low to produce flows in the adjacent upland districts.

\section{CAUSES OF DECREASE IN STATIC LEVEL AND IN YIELD}

In certain districts, as at Tupelo, in Lee County (see p. 287), and at Columbus, in Lowndes County (see p. 308), there has been a material lowering of the static level of the water in wells since the original wells were drilled. The explanation appears to be that the water is being removed from the containing beds faster than it can be renewed by the passage of water down the dip from the intake area to the points where the beds are tapped by the wells. In such districts conservation of the water supply becomes necessary unless a supplementary source of supply can be found, as for example a deeper waterbearing stratum and one perhaps that bears water more abundantly.

A decrease in the yield of artesian wells may be due to any one of several causes. A lowering of the static level by overdraft results in a decrease in the amount of water forced into the well opening. The lower part of an uncased well may become clogged with clay or fine sand which prevents a maximum amount of water from entering the well opening. In a cased well the screen or the perforations in the casing that serve as a strainer may become clogged with sand or clay and interfere with the free flow of water into the casing. Old casings and strainers become weakened by corrosion and eventually collapse, permitting the well to become choked with sand or clay or permitting the ascending artesian water to escape before it reaches the surface.

\section{BLOWING WELIS}

In certain parts of Mississippi, particularly in the western half of the upland, some of the shallow wells exhibit peculiar phenomena which are locally described as "blowing," "breathing," or "sucking," and some wells in which air currents are not noticed become muddy, milky, or irony at certain times. These manifestations are in all places correlated with certain weather conditions, and with the exception of the inward breathing or sucking they are generally observed just before storms or rains.

The phenomenon of blowing wells is not uncommon, for many such wells have been reported in certain parts of the United States. In- 
vestigators have generally agreed that the blowing or breathing is due to changes in atmospheric pressure. ${ }^{3}$

The following explanation is offered to accaunt for the effect of the weather on wells in Mississippi: In many parts of the upland the water table is low and the water occurs in the basal parts of the porous sands and gravels of the Citronelle and other surficial formations, whereas the upper parts of the formations are "dry" or unsaturated. During a period of high barometer-that is, during fair weatherair is driven down into the wells by the increased atmospheric pressure and passes into the unsaturated pore spaces in sand and gravel that. intervene between the water table and an overlying impervious layer of clay or compact sand. On the other hand, during a period of low barometer, which is generally accompanied by cloudy or stormy weather, the atmospheric pressure becomes lower and permits the escape of some of the imprisoned air. Under favorable conditions. the release of pressure is sufficient to cause the air to rush out through the relatively small well opening, agitating and roiling the water as it. goes and producing the hissing and roaring sounds manifested by some of the wells. In some wells the outgoing current of air, though strong enough to agitate the water is not strong enough to produce a noticeable sound.

More wells affected by weather conditions in the manner described have been reported in Amite than in any other county in the State. (See p. 76.) One rather extreme example, in which mud and water were blown from the well, has been reported near Carrollton, in Carroll County. (See p. 100.)

\section{QUALITY OF WATER}

The quality of ground waters in Mississippi is shown by analyses given in tables under the county descriptions. These analyses show the quantities of the dissolved mineral constituents, reported as radicles and in parts of the determined radicles in 1,000,000 parts of water. Analyses not made specially for this report and expressed in other forms have been recalculated to the adopted form.' Computations and classifications in the tables follow the usage of earlier publications. ${ }^{4}$

\footnotetext{
8 Some notes on blowing wells and related phenomena are eontained in the following papers: Hay, Robert. Water resounces of a portion of the Great Plains: U.S. Geol. Survey Sixteenth Ann. Rept., pt. 2, pp. 567-568, 1895. Barbour, W. H., Wells and windmills in Nebraska: U. S. Geol. Survey Water.Supply Paper 29; pp. 78-82, 1899. McCallie, S. W., Blowing springs and wells of Georgia: Georgia Geol. Survey Bull. 15, pp. 296-305, 1908. Fuller, M. L., The freezing of wells and related phenomena: U. S. Geol. Survey WaterSupply Paper 258, pp. 23-31, 1911.

4 Stabler, Herman, Some streams of the western United States, with chapters on sediment carried by the Rio Grande and the industrial application of Water analyses: U.S. Geol. Survey Water-Supply Paper 274, 1911. Mendenhall, W. C., Dole, R. B., Stabler, Herman, Ground water in San Joaquin Valley, Calif.: U. \$. Geol. Survey Water-Supply Paper 398, 1916.
} 


\section{SOURCES OF DATA}

Over 200 of the analyses given in this report represent samples collected by. C. H. Kidwell and by L. W. Stephenson during the final field work in 1919. A few samples were obtained later from owners of springs, and 12 were collected in 1921 by E. N. Lowe. Some analyses were made for this report at the University of Mississippi and at the Mississippi State Chemical Laboratory; others have been obtained from published reports and from records of the Mississippi State Chemical Laboratory.

The greater part of the published analyses are from "The underground waters of Mississippi," a few are taken from "Summary of the underground-water resources of Mississippi." 8 Nearly all these analyses represent samples collected 10 or 20 years ago and may possibly not be representative of water now obtained from the sources indicated. Some which were available were made by methods which did not insure accuracy, and possibly some were made by analysts without much experience. The analyses were examined with care to discover indications of possible inaccuracy, both from internal evidence and by comparison with other analyses of waters from the same formations. A number were rejected on account of lack of confidence in their accuracy or from doubt of the representative character of the samples.

\section{METHODS OF ANALYSIS}

Constituents determined. - In general all the analyses were made by methods described in well-known works. ${ }^{7}$ In the analyses made by the United States Geological Survey the following constituents were regularly determined: Total dissolved solids at $180^{\circ} \mathrm{C}$., silica ( $\mathrm{SiO}_{3}$ ), iron $(\mathrm{Fe})$, calcium $(\mathrm{Ca})$, magnesium $(\mathrm{Mg})$, carbonate radicle $\left(\mathrm{CO}_{3}\right)$, bicarbonate radicle $\left(\mathrm{HCO}_{3}\right)$, sulphate radicle ( $\left.\mathrm{SO}_{4}\right)$; chloride radicle (Cl), nitrate radicle $\left(\mathrm{NO}_{3}\right)$. Sodium $(\mathrm{Na})$ and potassium $(\mathrm{K})$ were determined separately in a few samples; in some their chlorides were weighed together and the quantity of sodium corresponding to this weight was reported as sodium and potassium. In many analyses sodium was calculated.

Calculation of sodium.-The substances in solution in water may be considered as forming a system in which basic and acid radicles balance one another. The calcium, magnesium, sodium, and potassium taken together balance or are chemically equivalent to the carbonate, bicarbonate, sulphate, chloride, and nitrate taken together. If, then, all but the sodium and potassium are determined the quan-

Missistppi Agt. Exper. Sta. Ball. 89, 112 pp., 1915.

- U. 8. Geol. Burvey Wothosupply Peper 169, 86 pp. 6 pls., 1906.

'American Public Health Association, Standard methods of water analysis, 1917. Mason, W: $\mathbb{R}_{\text {, }}$ Examination of water, 1917. 
tity of sodium equivalent to the sodium and potassium present must be the quantity which is needed to make the sum of the basic radicles equivalent to the sum of the acid radicles. The following table gives the quantities of the different radicles which are equivalent to one another in chemical reactions.

Approximate unit quantities in which acid and basic radicles take part in reactions

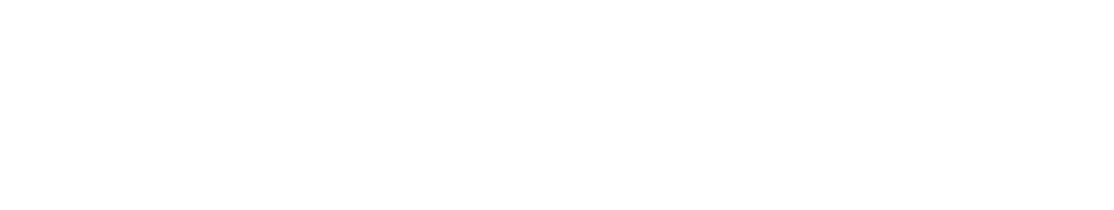

Only a comparatively small number of the constituents of the earth's crust are found in significant quantities in natural waters. In most waters the substances that are dissolved in largest quantities and that most influence the character of the water are compounds of calcium and of magnesium, which are obtained chiefly from limestone, dolomite, and gy.psum and to some extent from nearly all rocks. Limestone and dolomite, which are carbonates, do not dissolve readily without the aid of carbon dioxide or some other acid. In the presence of carbon dioxide these carbonates go into solution, forming bicarbonates.

Sodium and potassium are present in small quantities in many minerals. Most natural waters take up only small quantities of these elements from the ground. Where brines or deposits of salt (sodium chloride) occur the natural waters carry large quantities of sodium and more potassium than fresh waters. The ratio of sodium to potassium usually increases with increasing quantities of salt in the water.

In most waters the sodium and potassium correspond in quantity to the chloride and part of the sulphate present, and the calcium and magnesium correspond to the bicarbonate and the remainder of the sulphate. A large number of ground waters in Mississippi, however, do not contain the basic radicles in the usual proportions. Calcium and magnesium are present in very small quantities as compared with the sodium, and the sodium is therefore equivalent to nearly all the bicarbonate as well as to the chloride and sulphate. These waters, which may contain several hundred parts per million of dissolved mineral matter, have less calcium and magnesium than waters which have taken up as little as 20 parts per million of dissolved solids from insoluble rocks like granite. Some clays and other materials have the power to take calcium and magnesium from water with which they are in contact and give up equivalent quantities of sodium or potassium, and probably such an exchange accounts for the large proportion of sodium in many of the ground waters of Mississippi. 
QUAINT OI WATER

rom many kinds of rock. Only a small quantity On in water exposed to the air unless the water is is not found in appreciable quant in this F. Sn not generally given in the ante acid radicles

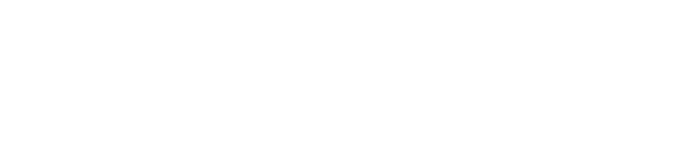
F 5 is lost some of its natural excess of carbon F donate may appear as carbonate. When dioxide a sulphur of certain sulphides in the rock Some rocks contain large quantities of oxidized by air and moisture to form sulphuric

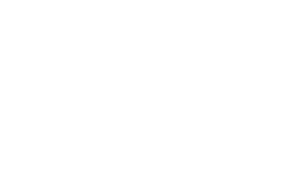

carries into solution much iron and aluminum not found in Mississippi. forms of organic matte rite quantities of this radicle.

CLASSIFICATION ONE

Sanitary considerations. The analyses given in this report fum no basis for opinions as to the sanitary quality of the waters exam and statements in the dissolved ming refer to use as affected by possible pollution constituents and do take into account pollution can bease-producing bact The possibility of surface sate rs be determined by insp of the surroundings. shallow wells, and

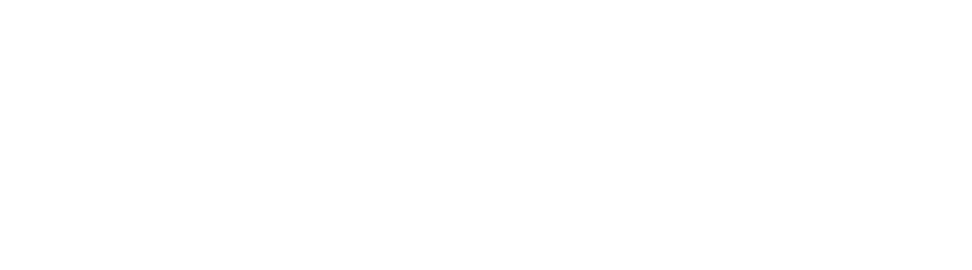
surface water that mas of through defective casing Hardness. - Hardin ce lather and recognized by

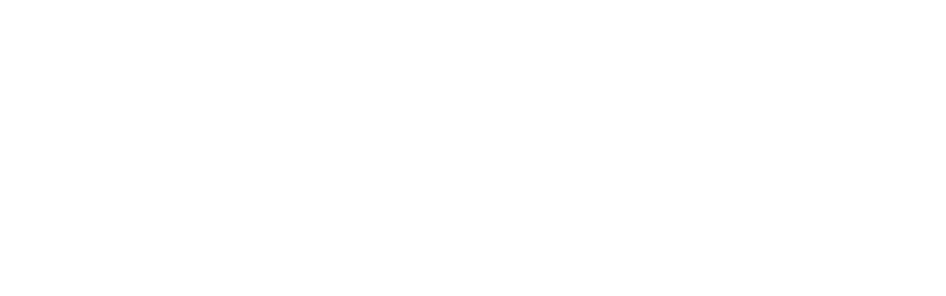
nesium soaps. The hardness depends on the quentin and magnesium in the water. In order to have a unities for hardness it is customary to report it as calcium uniform 
equivalent to the calcium and mated OF. MISE

nesium by 4.1 lying the quantity of esium.

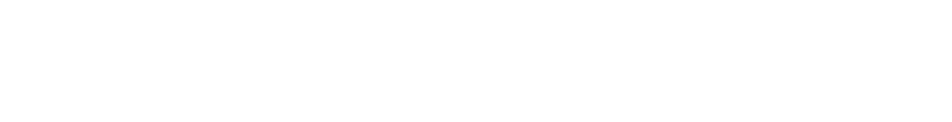
respectively. million of this equation by the for If the bar of total hardness, $\mathrm{TH}, \mathrm{Ca}$, and noticed, and ness is less than does not produrdness from 50 parts per mill, and 200 parts per mee serious in 50 to 150 parts, million it is us rain water for million is comconvenience. parts, although not Iron.- The use in laundry comon many. Where water wot domestic use. A smce of much and wherever are built to present in collodial stall quantity will is objectionabl is used. the air. is likely to separthout becomin in solution in water fol settles to the water becomes out when the noticeable. If bicarbonate are present, bottom of the turbid at first water stands If much is will be left the iron will stain vessel. If first but clears exposed to plumbing on enamel-wain articles wash several parts as the iron objectionable to Ex. Excessive vessels and on in the water per million "upposed to to some users, quantitios cause a ther or enameled
cf iron. by reason of their waters are steam The most comm BOILR USE on suspended in formation of due to water in the for the 6 char the water is water deposits. Mineral matter operation "' and to of the deposit and concen the shell and in solue. cium and on the design the composition eration. the ins the which in additio the active ingredion 9 water. silica, iron oxide, these elements The amount the water is said to are equivalent to the When waterbonate equicium and magne carbonate ibo calcium ar with only carbonts is the nosium exceed ly blown out and magnesium carbonate hardness noncarbonete If a hard and the scale that precipitated is beated in clphate it water contains littlo does form is so as a sludge a hard scale. 
Water softening.-Many waters can be much improved for boiler and other uses by softening, which consists in removing calcium and magnesium from the water.

Two general types of softening systems are in use-the lime soda system, which has been in use many years, and the exchange silicate system, which is a recent development.

The lime-soda system comprises two sets of reactions. Lime is added to the water to take care of the free carbon dioxide and the bicarbonate and an extra quantity corresponding to the magnesium. In general this addition may be said to reverse the process by which the calcium carbonate of the rocks was dissolved by the water. This solution took place by reason of the carbon dioxide in the water. If the right quantity of lime is added it unites with the carbon dioxide, thus releasing the calcium carbonate taken up by the carbon dioxide and at the same time settling out as a precipitate. This much softening is clear gain; the added calcium separates out with that which was in the water. This treatment removes only carbonate hardness.

To convert noncarbonate to carbonate hardness soda (sodium carbonate) is added to the water. Calcium sulphate is changed to calcium carbonate and the sodium carbonate to sulphate. The calcium carbonate settles out, but sodium sulphate remains in solution. This treatment softens the water but leaves in solution about the same total quantity of mineral matter. Some natural waters contain so much noncarbonate hardness that they can not be treated successfully by this method. After the scale-forming constituents are removed these waters contain such a quantity of sodium salts that they are not fit for boiler use on account of foaming.

The lime-soda process is carried out either intermittently or continuously and either with cold or hot water.

A large proportion of the waters analyzed for this report are so soft that they would not be improved by lime-soda or other treatment. The softening by the lime-soda method is limited by the solubility of the calcium carbonate and magnesium hydroxide which are precipitated, and the softened water therefore contains some calcium and magnesium. In a plant operating properly this residual hardness has no appreciable effect on boiler operation.

The exchange silicate softening systems make use of alkaline aluminum silicate composed of different natural or manufactured raw materials. When hard water flows through a bed of grains of one of these exchange silicates the calcium and magnesium in the water are replaced by sodium, leaving the water practically free from hardness. When the silicate no longer softens water completely it is regenerated by use of a strong salt solution, which causes a reversal of the softening reaction and gives back to the silicate sodium in exchange for the calcium and magnesium removed from the water. 
After washing, the material is ready for use again. This treatment does not appreciably reduce the total quantity of dissolved mineral matter in a water, but it usually removes hardness more completely than the lime-soda treatment,.

RELATIONS OF CHEMICAL COMPOSITION OF GROUND WATERS TO WATER-BEARING FORMATIONS

For the study of the influence of the geologic formations on the chemical character of the ground waters all analyses of waters from certain formations have been brought together under the description of the formations (pp. 29-63). Several factors, however, limit the accuracy of conclusions that may be drawn from such a study. It is impossible to tell the exact formation from which some of the samples come on account of the incompleteness of the well records. It often happens in drilling a well several water-bearing strata are encountered, and sometimes no attempt is made to case off completely the water from the upper level or levels; any sample taken from such a well would not be representative of any particular formation. Often the casing deteriorates, and waters from higher levels seep through and mix with the water within the casing. The draft on a well often affects the mineral content of the water. . Water commonly shows a higher mineral content when a well is new than after it has been used for some time. However, excessive pumping may increase the mineral content of the water owing to the local lowering of the water table and the consequent drawing from other beds. This increase is especially noticeable near the coast, where contamination from sea water may take place. Shallow wells may be contaminated from the surface as well as diluted from rains. Wells of different depths in the same formation differ in the character of the water, as is shown in the Tuscaloosa, where the deeper wells usually have water with the most dissolved solids. The water-bearing formations and their lithologic characteristics are described on pages 29-63. The formations for which there are sufficient analyses to draw conclusions are the Tuscaloosa, Eutaw, and Ripley formations of the Upper Cretaceous; the Ackerman formation and Holly Springs sand of the Wilcox group, in addition to some undifferentiated Wilcox deposits; the Tallahatta and Lisbon formations of the Claiborne group; the Catahoula sandstone and the Hattiesburg and Pascagoula clays of the Miocene; and the Citronelle formation of the Pliocene.

In this study analyses that showed waters of unusual composition were omitted in obtaining the tables of average, minimum, and maximum values for the constituents. The results in the tables can not show the actual composition of waters from the given formations because of the several factors that influence the solution of materials. These results should, however, help in the prediction of the quality of water one would expect to get from a well that tapped any of the formations mentioned above. 


\section{GENERAL GEOLOGY}

\section{CHARACTER AND AGE OF THE ROCKS}

Southern Mississippi forms a part of the main Gulf Coastal Plain of the southern United States, whereas the northern part of the State extends into the lesser physiographic division of the Coastal Plain to which the name Mississippi embayment is commonly applied. The Gulf Coastal Plain is in general an extensive lowland that ranges in altitude from sea level to about 1,000 feet above sea level and in width from 130 to more than 550 miles. The plain is underlain by a series of sedimentary formations which range in age from Cretaceous to Recent and which increase in thickness from a featheredge along the inner border of the plain to an unknown maximum (perhaps as much as 25,000 feet) at the coast in the vicinity of the mouth of Mississippi River. These deposits rest upon a basement of ancient rocks, in part of Paleozoic age and in part of pre-Paleozoic age.

The Mississippi embayment is a broad arm of the Gulf Coastal Plain that extends about 250 miles up the valley of Mississippi River: to the southern extremity of Illinois. The area is bordered on the west, north, and east by a territory underlain by consolidated. sedimentary rocks of Paleozoic age. Structurally the embayment is a down-warped trough or geosyncline of Paleozoic rocks filled to the: level of the present surface with deposits, mostly unconsolidated, ranging in age from Cretaceous to Recent. The axis of the trough: trends slightly west of south, and the maximum depth to the Paleozoic floor, though not determined, is known to exceed 4,000 feet. The depth at Memphis, Tenn., has been shown by wells to be more than 2,500 feet, and a well at Winona, Montgomery County, Miss., had. not reached the basement rocks at a depth of 4,075 feet. This down-warped trough probably extends from the Mississippi embay-: ment toward the south out under the main Gulf Coastal Plain to and beyond the present Gulf coast.

Deposits of Cretaceous age occupy the bottom of the trough of the Mississippi embayment and probably reach a maximum thickness of 3,000 feet or more. They crop out in a relatively narrow belt along the eastern limb of the trough in Alabama, Mississippi, Tennessee, and southern Illinois, and along the western limb of the trough in the vicinity of Newark, Independence County, Ark.; they are also present at a relatively shallow depth along the border of the Ozark province from Little Rock, Pulaski County, northeastward to Beebe, White County, Ark.

The Cretaceous deposits are overlain by Eocene deposits, including, in ascending order, the Midway, Wilcox, and Claiborne groups and the Jackson formation, 2,000 feet or more in aggregate thickness. These formations crop out east of Mississippi River in Mississippi, Tennessee, Kentucky, and southern Illinois; they form 
the core of Crowleys Ridge in Missouri and Arkansas and crop out in the Coastal Plain uplands of south-central Arkansas and in small areas along the western margin of the embayment from Little Rock northeastward to the southern part of Independence County, Ark.

In the broad belt of outcrop east of Mississippi River the Eocene deposits are partly overlain by terrace gravels and sands believed to be of Pliocene age, and these terrace deposits are in turn largely overlain by deposits of loess of Pleistocene age. The same succession of surficial deposits occurs above the Eocene in Crowleys Ridge in Arkansas. On the crests of the Paleozoic hills that border the embayment on the west in Misssouri and Arkansas lie scattered deposits of gravel, sand, and loam, which probably represent, respectively, the Pliocene gravels and sands and the loess.

The Cretaceous and Eocene deposits and the overlying Pliocene and Pleistocene deposits have been partly removed by the erosive action of Mississippi and Ohio Rivers to depths of 100 to 225 feet below the present surface of the lowlands, and the valleys have been partly refilled by material brought in by the same streams. In this manner the Mississippi bottom (Yazoo "delta") of western Mississippi was formed.

In Mississippi the Paleozoic basement rocks crop out in small areas in the northeastern part of the State. These rocks are overlain by a series of Upper Cretaceous formations the outcrop of which includes the area of seven whole counties and parts of eight others. These formations strike toward the south but swing around toward the southeast as they approach the Alabama line in east-central Mississippi. They dip gently toward the west and southwest and pass under the overlapping Eocene deposits.

The Eocene formations crop out in a belt 60 to 120 miles wide in north-central Mississippi, where they strike toward the south and dip gently toward the west; toward the south the strike swings around toward the southeast and the dip to the southwest and in the eastcentral part of the State the belt passes into Alabama.

Over the northwestern part of the State the Eocene formations are covered by the recent alluvial deposits of Mississippi River, but in the central part of the State, where the dip is to the southwest, the Eocene formations pass under those of Oligocene age.

Southern Mississippi is underlain by formations that range in age from Oligocene to Recent. In general they strike west by north and dip south by west, the older formations passing beneath the younger.

Surficial alluvial deposits of Pleistocene and Recent age have been laid down on the older deposits in the valleys of all the larger streams, and along the western border of the Coastal Plain upland lie extensive wind-blown deposits to which the name loess is applied.

A generalized section of the geologic formations of Mississippi is given in the accompanying table. 
Generalized section of the geologic formations of Mississippi

\begin{tabular}{|c|c|c|c|c|c|c|c|c|}
\hline Era & System & \multicolumn{2}{|c|}{ Series and group } & \multicolumn{2}{|c|}{ Formation and member } & Thickness (feet) & Physical character & Water-bearing capacity and kind of water \\
\hline \multirow{24}{*}{ Cenozoic. } & \multirow{3}{*}{ Quaternary. } & \multicolumn{2}{|c|}{ Recent. } & \multicolumn{2}{|l|}{ Alluvial deposits. } & $125-200$. & Loam, clay, sand, and gravel. & $\begin{array}{l}\text { A bundantly water bearing in the Yazoo Delta; yields hard } \\
\text { water of moderately high mineral content. }\end{array}$ \\
\hline & & \multirow{2}{*}{\multicolumn{2}{|c|}{ Pleistocene. }} & \multicolumn{2}{|c|}{$\begin{array}{l}\text { Alluvial terrace deposits ("second bottoms"), Port Hud- } \\
\text { son formation, and loess. }\end{array}$} & 200 (maximum) (?). & Sands, clays, and limy silt (loess). & Some water. \\
\hline & & & & \multicolumn{2}{|c|}{$\begin{array}{l}\text { Terrace deposits that border the Gulf Coast and Natchez } \\
\text { formation. }\end{array}$} & 200 (maximum) (?). & Sand, loam, clay, and gravel. & Water bearing. \\
\hline & \multirow{21}{*}{ Tertiary. } & \multicolumn{2}{|c|}{ Pliocene. } & \multicolumn{2}{|c|}{ Citronelle formation. } & $1-450$ & Sand, gravel, and clay, of fluviatile, estuarine, and shallow marine origin. & $\begin{array}{l}\text { Abundantly water bearing; yields soft water, low in min- } \\
\text { eral content. }\end{array}$ \\
\hline & & \multirow{3}{*}{\multicolumn{2}{|c|}{ Miocene. }} & \multicolumn{2}{|l|}{ Pascagoula clay. } & $250-400$ & Clay, sandy clay, and sand. & $\begin{array}{l}\text { Water bearing, abundantly in places; soft water of moderate } \\
\text { mineral content. }\end{array}$ \\
\hline & & & & \multicolumn{2}{|l|}{ Hattiesburg clay. } & $325-450$. & Blue and gray clay, some claystone, lignite, and sand. & $\begin{array}{l}\text { Some water; locally abundantly water bearing; yields soft } \\
\text { water of moderately low mineral content. }\end{array}$ \\
\hline & & & & \multicolumn{2}{|c|}{ Catahoula sandstone. } & $300-500$ (?) & Irregularly bedded sand, sandstone, and clay. & $\begin{array}{l}\text { Abundantly water bearing, yields soft water of moder- } \\
\text { ately low mineral content. }\end{array}$ \\
\hline & & \multirow{4}{*}{ 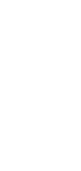 } & \multirow{4}{*}{ Vicksburg group. } & \multicolumn{2}{|l|}{ Byram marl. } & \multirow{4}{*}{$145-185(?)$} & \multirow{4}{*}{ Limestone, marl, clay, and sand. } & \multirow{4}{*}{ Water bearing, especially the Forest Hill sand. } \\
\hline & & & & Glendon limestone. & & & & \\
\hline & & & & \multicolumn{2}{|c|}{ Marianna limestone (chiefly Mint Spring marl member). } & & & \\
\hline & & & & Forest Hill sand. & Red Bluff clay. & & & \\
\hline & & \multirow{13}{*}{ 密 } & & \multirow{2}{*}{ Jackson formation. } & Yazoo clay member. & $70-600$ & Clay, more or less calcareous, with some sand and marl. & \multirow[b]{2}{*}{ Some water in lower part. } \\
\hline & & & & & Moodys marl member. & $35-90$. & Shells inclosed in quartz sand and glauconite. & \\
\hline & & & \multirow{5}{*}{ Claiborne group. } & \multicolumn{2}{|l|}{ Yegua formation. } & $30-400(?)$ & Irregularly bedded, more or less laminated lignitic clay, sand, and lignite. & Some water; quality varies considerably. \\
\hline & & & & & & 50. & $\begin{array}{l}\text { Highly calcareous, more or less glauconitic marl, and red and yellow sand con- } \\
\text { taining characteristic Lisbon launa. }\end{array}$ & Some water, chiefly hard, of high mineral content. \\
\hline & & & & Lisbon formation. & Kosciusko sandstone member. & 50. & Saccharoidal to quartzitic sandstone and unconsolidated sand. & Soft water of moderate mineral content. \\
\hline & & & & & Winona sand member. & $45-300 \pm$ & Highly glauconitic sand, more or less clayey. & $\begin{array}{l}\text { Abundantly water bearing; yields soft water of moderate } \\
\text { mineral content. }\end{array}$ \\
\hline & & & & Tallahatta formatio & & $15-240$. & Diatomaceous claystone, quartzite, soft sandstone, and sand. & Water bearing in sandy beds; quality of water variable. \\
\hline & & & & $\begin{array}{l}\text { Hatchetigbee and G } \\
\text { temporaneous). }\end{array}$ & ada formations (approximately con- & $60-250$ (?). & Lignitic clay, lignite, and sand. & Some water. \\
\hline & & & Willear aroun 20 & Bashi (" Woods Blt & 1) formation. & 30 or 35. & Glauconitic calcareous sandy marl, with large calcareous concretions. & Little water. \\
\hline & & & & Holly Springs sand & & $160-600$. & Strongly cross-bedded, more or less micaceous sand with lenses of clay. & $\begin{array}{l}\text { Abundantly water bearing; yields soft water of moderately } \\
\text { low mineral content. }\end{array}$ \\
\hline & & & & Ackerman formatio & & $300-550$. & Gray, more or less lignitic clay, lignite, and sand. & Some water; locally abundantly water bearing. \\
\hline & & & Midway group. & $\begin{array}{l}\text { Naheola formation. } \\
\text { Porters Croek clay. }\end{array}$ & & 75-200. & $\begin{array}{l}\text { Naheola formation (from Alabama line to the area beyond DeKalb) consists } \\
\text { or red or yellow micaceous sands that rest on Porters Creek clay. Tippah } \\
\text { sandstone member of Porters Creek clay, in northeastere Mississippip pon- } \\
\text { sists of } 75 \text { to } 100 \text { feet of yellow and red, somewhat glauconitic sand. } \\
\text { Dark-gray clay. }\end{array}$ & Little water. \\
\hline & & & & Clayton formation. & & 60 (maximum). & $\begin{array}{l}\text { Hard yellowish limestone, } 15 \text { to } 25 \text { feet thick, overlain by } 20 \text { to } 40 \text { feet of greenish- } \\
\text { gray glauconitic sandy marl in places weathered to red sand. }\end{array}$ & Some water-bearing beds. \\
\hline & & & & Ripley formation. & McNairy sand member. & 100-400. & $\begin{array}{l}\text { Compact to loose sand, sandstone, sandy limestone, and shell marl, with } \\
\text { extensive beds of calcareous and noncalcareous clay. }\end{array}$ & $\begin{array}{l}\text { A bundantly water bearing in sandy beds; yields hard and } \\
\text { soft water of moderate mineral content. }\end{array}$ \\
\hline & & & & Selma chalk. & & $250-900$. & More or less argillaceous or sandy chalk. & Little water. \\
\hline Mesordic. & Cretaceous. & Gulf (t & Upper Cretaceous). & (n) & Coffee sand member. & $950-550(9)$ & Cross-bedded and massive, more or less glauconitic fine to medium sand, with & Abundantly water bearing in sandy beds; quality of water \\
\hline & & & & Eutaw tormation. & Tombigbee sand member. & $260-550(?)$. & subordinate laminated clay. & varies considerably. \\
\hline & & & & Tuscaloosa formatic & & $200-300$ & Irregularly bedded sand, clay, gravel, and lignite. & $\begin{array}{l}\text { Abundantly water bearing; yields soft water of low mineral } \\
\text { content. }\end{array}$ \\
\hline & & Penns & ylvanian. & Pottsville formation & & Unknown. & $\begin{array}{l}\text { Is known to be present in Monroe and Lowndes Counties beneath the Tuscer- } \\
\text { loosa formation but probably does not crop out. }\end{array}$ & \\
\hline Paleozoic. & Carboniferous. & Missis & ssippian. & $\begin{array}{l}\text { Bangor limestone. } \\
\text { Hartselle sandstone } \\
\text { Gasper formation. } \\
\text { Bethel sandstone. } \\
\text { Ste. Cenevileve forn } \\
\text { Warsaw limestone. } \\
\text { Fort Payne chert. }\end{array}$ & & $900 \pm$ & $\begin{array}{l}\text { Sandstones, chert, and cherty, shaly, and volitic limestones. Encountered in } \\
\text { wells in eastern part of State but exposed in northeast corner only. }\end{array}$ & $\begin{array}{l}\text { Unknown except Fort Payne chert, which is water bearing } \\
\text { at Corlnth, Alcorn County. }\end{array}$ \\
\hline & Devonian. & Lower & Devonian. & & & & & \\
\hline
\end{tabular}





\section{PALEOZOIC ROCKS}

The oldest rocks that come to the surface in Mississippi are of Paleozoic age and are found in relatively small narrow areas in Tishomingo and Itawamba Counties. (See pl. 2.) These strata are divisible, in the ascending order of their geologic occurrence, into (1) rocks of Devonian age that have been called "Yellow Creek beds"; (2) rocks of Mississippian age which include the Fort Payne or "Lauderdale" chert, the Warsaw limestone, the Ste. Genevieve formation, the Bethel sandstone, the Gasper formation, the Hartselle sandstone, and the Bangor limestone; and (3) rocks of Pennsylvanian age that belong to the Pottsville formation. These rocks include sandstones, cherts, cherty limestones, and shaly limestones whose water-bearing capacities are imperfectly known, with the exception of the Fort Payne chert, which is abundantly water bearing at Corinth in Alcorn County. Little is known concerning the quality of water from the Paleozoic rocks.

\section{CRETACEOUS SYSTEM \\ UPPER CRETACEOUS SERIES \\ TUSCALOOSA FORMATION}

General features.-The Tuscaloosa formation crops out in a relatively small area in northeastern Mississippi. (See geologic map, pl. 2.) It is composed of sand, clay, gravel, and lignite and is characterized by great irregularity of bedding, which indicates that these materials were laid down in part in the shallow marginal waters of the sea that in early Upper Cretaceous time occupied the down-warping trough of the Mississippi embayment and in part in bordering bays, lagoons, and márshes and on the deltas of debouching streams. The maximum measured thickness of the formation in Mississippi is in a well at Gattman, Monroe County (see log, p. 339), which penetrated 18 feet of surficial sandy clay, 283 feet of sand, clay, and gravel of the Tuscaloosa formation, and 312 feet of basement sandstone of Paleozoic age. As the well did not start at the extreme top of the Tuscaloosa the thickness of the formation at Gattman probably slightly exceeds 300 feet.

The gravel, which occurs chiefly in the basal 175 feet or less of the formation, is composed largely of angular to subangular coarse chert derived from the Fort Payne chert and the Warsaw limestone, both of Paleozoic (Mississippian) age, which forms in part the basement on which the deposits of the Coastal Plain rest and which crop out in the upland east of the Coastal Plain in Alabama and Tennessee. There are also a few small, smoothly rounded quartz pebbles. 
In northeastern Mississippi the formation rests with unconformable relations upon Paleozoic basement rocks of Devonian and Mississippian age. Farther south in Mississippi the basement rocks are of Pennsylvanian age, but these have not been reported in surface outcrops.

The Tuscaloosa formation is overlain by the Eutaw formation. The transition from the Tuscaloosa to the Eutaw type of deposits is marked by a band of more or less lignitic and carbonaceous clay which is traceable from northern Mississippi to Hale County, Ala., and which is probably approximately of the same age throughout this distance. As the Tuscaloosa deposits were laid down in a sea which transgressed from west-central Alabama northwestward through Mississippi, the formation has its maximum thickness (1,000 feet) in Alabama, from whence it gradually diminishes until in northern Mississippi the thickness is 200 feet or less; and as the deposits in northern Mississippi were probably laid down toward the close of Tuscaloosa time they represent only the upper 200 feet of the 1,000 feet of deposits in Alabama. In small areas along Bear Creek, in Tishomingo County, the formation is unconformably overlain by terrace loams, sands, and gravels of Pleistocene age.

The strata of the Tuscaloosa formation exhibit simple monoclinal structure. The strike of the strata is approximately south in Mississippi, but as the formation swings around into Alabama the strike turns more and more to the east and finally becomes nearly due east.

In Mississippi the strata dip to the west and southwest, as a rule at the rate of 30 to 32 feet to the mile, but in places the dip appears to be as low as 20 feet to the mile. The direction of dip ranges from west by north in Tishomingo County, to west in the latitude of Fulton, to west by south in Monroe County, and finally to due south in east-central Alabama.

The hills in the eastern part of the Tombigbee Hills district described on pages 2-4 are the topographic expression of the formation.

Water-bearing capacity. - The medium to coarse sands that predominantly compose the formation as a whole and the heavy beds of coarse gravel that compose the basal 175 feet or less of the formation are admirably adapted to serve as reservoirs for ground waters.

Quality of water.-The Tuscaloosa formation is the source of abundant water, which is good for both domestic and boiler uses. The following table gives results based on analyses of 12 waters that have their source in this formation. The mineral matter is low; in 10 of the waters the total dissolved solids is less than 100 parts per million. Lowndes No. 2 and Noxubee No. 4 have 133 and 227 parts per million for the total dissolved solids. Both of these wells are over 1,100 feet deep. Noxubee No. 4 has considerably more sulphate than any of 
the others. The quantities of sodium plus potassium and of alkalinity are higher in these 2 samples than in the other 10 . The calcium, magnesium, sodium, and potassium, chloride, and nitrate are quite consistent except as noted for sodium and potassium. The average quantity for silica is higher than was found in 10 of the samples, but it is not excessively high.

Average, minimum, and maximum quantities of mineral constituents in waters from Tuscaloosa formation a

[Parts per million]

\begin{tabular}{|c|c|c|c|}
\hline & Average & Minimum & Maximum \\
\hline 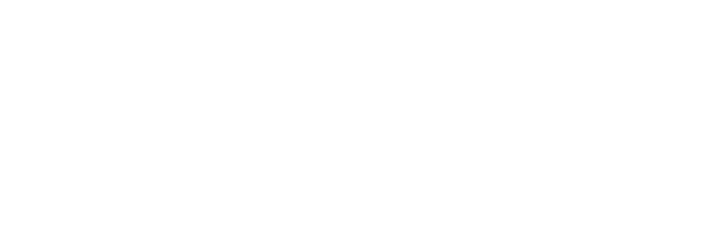 & $\begin{array}{r}18 \\
4.9 \\
7.8 \\
2.8 \\
18 \\
73 \\
5.0 \\
4.5 \\
92 \\
91\end{array}$ & $\begin{array}{l}9.4 \\
.08 \\
1.4 \\
3.7 \\
1.2 \\
1.4 \\
1.0 \\
30 \\
6\end{array}$ & $\begin{array}{l}35 \\
20 \\
13 \\
4.8 \\
67 \\
197 \\
16 \\
8.0 \\
227 \\
47\end{array}$ \\
\hline
\end{tabular}

- Based on results of 12 analyses, as follows: Lowndes County, Nos. 2, 6, 8, 9, 10, 25; Monroe County, Nos. 1, 6, 7, 12; Noxubee County, No. 4; Tishomingo County, No. 4. For complete analyses see county descriptions.

- Based on 10 determinations.

\section{BUTAW FORMATION}

General features.-The Eutaw formation crops out in Mississippi or is locally covered only by relatively thin terrace deposits, in a belt 15 to 30 miles wide, west of the area of outcrop of the Tuscaloosa formation and east of that of the Selma chalk. (See geologic map, pl. 2.)

The formation is predominantly composed of massive and crossbedded, more or less glauconitic, fine to medium grained, more or less micaceous sand. Many fine examples of various types of marine cross-bedding are exhibited by the strata. Throughout much of the formation the sand is interstratified with clay in the form of subordinate thin laminae, laminated layers, and some more massive layers. The clays are commonly dark gray to nearly black, though lighter colored clays occur in places. Most of the clays contain comminuted plant fragments, and small pieces of lignite are common or even abundant in some parts of the terrain. The surficial weathered facies are universally deep reddish to brownish, chiefly through the oxidation of the iron contained in the glauconite.

In general the materials of the Eutaw are fine to medium in texture, but small lenses and stringers of small pebbles occur in the lower part of the formation in Itawamba and Tishomingo Counties; where the present inner margin of the formation is nearer the ancient shore line of the Eutaw sea than it is farther south in Mississippi and Alabama. The rain waters absorbed by the sands have dissolved 
the iron liberated by the decay of glauconite in the zone of humic acids, and as the waters have percolated downward they have redeposited the iron in the lower parts of the zone of weathering, producing sandy, oxidized concretions and platy layers. In places conspicuous masses of ferruginous sandstone have thus been formed.

For convenience of treatment the Eutaw formation has been differentiated into (1) the lower or typical part, which has a thickness of 200 or 250 feet and is characterized by irregularity of bedding and by the presence of thin clay laminae and thicker laminated clay layers; (2) the massive Tombigbee sand member, described below; and (3) the Coffee sand member, also described below.

In Alabama and in east-central Mississippi approximately the upper 150 feet of the formation is composed chiefly of massive glauconitic, more or less calcareous sand, with indurated layers and concretionary masses at intervals, which are immediately overlain by the Selma chalk. This part of the formation is the Tombigbee sand member. The change from the typical Eutaw strata below to massive sand above is not abrupt but is marked by a band of more or less cross-bedded sand and laminated clay. Marine invertebrate fossils occur in certain layers, particularly within the upper 50 feet, but a large part of the member is nonfossiliferous. This massive band of sand has been traced northward through Mississippi nearly to the Tennessee State line, but, as shown in Figure 3, the member is overlain in northern Mississippi not by chalk but by the Coffee sand member of the Eutaw, which corresponds in age to the basal portion of the typical Selma. Here the upper limits of the member are not as easily determined as farther south, because parts of the overlying Coffee sand are also of massive character. The relation of the subdivisions of the Eutaw and other Upper Cretaceous formations are shown in Figure 3.

The Coffee sand member at its type locality at Coffee Landing, Hardin County, Tenn., ${ }^{8}$ is lithologically similar to the typical Eutaw deposits in Alabama, although it occupies a stratigraphically higher position. The member is characterized by its content of glauconite, by the presence of thin laminae and laminated layers of clay, by the finely cross-bedded structure of the sands, and by its content of comminuted lignite. From the vicinity of its type locality northward to Kentucky the Coffee sand includes all the deposits between the Paleozoic basement rocks and the overlying Selma chalk and has an estimated thickness of over 200 feet.

The deposits extend southward from Hardin County into northern Mississippi where, however, they are underlain by the Tombigbee sand member of the formation, as shown in Figure 3 . They are in general like the typical materials of the Eutaw except

\footnotetext{
'Safford, J. M., Geology of Tennessee, pp. 411-414, 1869.
} 


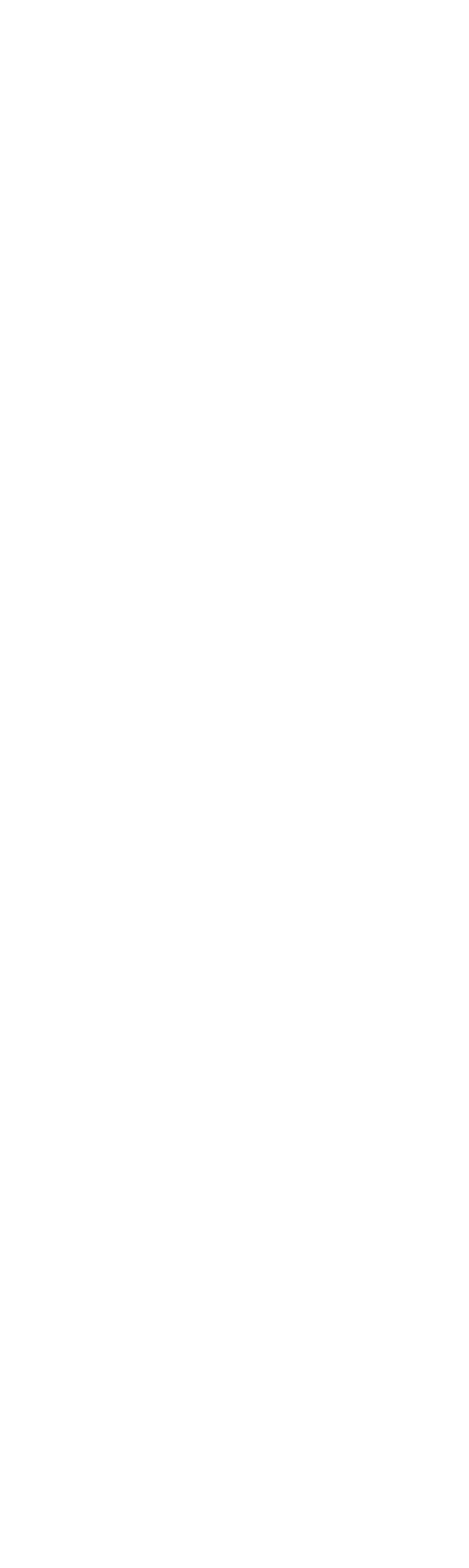


that from the Tennessee line southward the bedding in parts of the member becomes more massive, until in the valley of Old Town Creek in Lee County the Tupelo tongue of the Coffee sand member (see fig. 3), described below, presents massive uniform structure similar to that of the Tombigbee sand. These more massive facies were deposited in deeper waters than the typical deposits, and in places yield marine fossils.

The Tupelo tongue ${ }^{9}$ of the Coffee sand member of the Eutaw is a body of dark gray, chiefly massive, calcareous, glauconitic sand, which extends southward from the Coffee sand of northern Lee County into the main body of the Selma chalk and is underlain by a corresponding tongue of chalk, the Mooreville tongue (see p. 37 and fig. 3), which extends northward from the basal part of the Selma. The Mooreville tongue loses its identify by mergence into or minor intertonguing with the chalk in southern Lee County.

Throughout its occurrence in Mississippi the Eutaw formation rests upon the Tuscaloosa formation, the relation being that of conformity so far as can be determined from present available evidence. The transition from the Tuscaloosa to the Eutaw is marked by a nearly continuous, more or less carbonaceous and lignitic clay band 15 or 20 feet thick, with interbedded thin layers of glauconitic sand, immediately above which lie marine sands that are characterized by their content of glauconite and that form the base of the Eutaw.

From Itawamba County southward through Mississippi and eastward through Alabama to the western part of Russell County the formation is conformably overlain by the Selma chalk, and throughout this distance the Eutaw maintains a nearly uniform thickness and is an approximately synchronous band of deposits. North of Itawamba County conditions favorable to the formation of deposits, chiefly glauconitic sands of the Eutaw type, persisted to a later time than they did farther to the south, so that the lower 250 feet or more of the chalk of east-central Mississippi and Alabama is here represented by deposits of glauconitic sand of the same age. The Tupelo tongue (see fig. 3) represents a southward spread of sand-forming conditions across a similar northward-extending body of chalk, the Mooreville tongue, which had previously been accumulating. At a later time chalk-forming conditions spread far to the north through Mississippi into Tennessee, so that from Tupelo to the Tennessee line and beyond the Eutaw is overlain by chalk which represents the middle third or half of the Selma as developed farther to the south. (See fig. 3.)

In an area 5 to 7 miles wide, which borders Tombigbee River in Lowndes and Monroe Counties and which extends with decreasing

\footnotetext{
- Stephenson, L. W., Tongue, a new stratigraphic term, with illustrations from the Mississippi Cretaceous: Washington Acad. Sci. Jour., vol. 7, No. 9, pp. 243-250, 1917.
} 
width up the valleys of the principal tributaries of the Tombigbee in Lee, Itawamba, and Prentiss Counties, the Eutaw is unconformably overlain by loams, sands, and gravels that were laid down on terrace plains cut in the Eutaw deposits by the meandering of the streams during Pleistocene and Recent times.

The Cretaceous strata of Mississippi form a gentle monocline. In the north the Eutaw beds strike approximately south; to the south the strike swings gradually around to the east until in east-central Alabama it is approximately east. In Mississippi the beds have a nearly uniform slope of 30 or 31 feet to the mile, the direction of dip ranging from west by slightly north in northern Mississippi to west in the latitude of Tupelo, to southwest in Lowndes County, and finally to the south in eastern Alabama. (See pl. 2.)

The Tombigbee Hills, described on page 2, are in the main the topographic expression of the Eutaw formation.

Water-bearing capacity.-The medium to fine sands which largely compose the formation, and especially the more irregularly bedded sands of the lower member (below the Tombigbee sand) and of the Coffee sand member, including the Tupelo tongue, are well adapt ${ }^{\wedge}$ to serve as reservoirs for ground water.

Quality of water.-Waters from the Eutaw formation vary col:siderably in the amount and character of the dissolved materials. There are not enough analyses from the individual members to draw any conclusions as to the quality of the waters found in each of them. The results in the following table are based on analyses of 35 waters which have total dissolved solids of less than 340 parts per million, 8 with total solids from 400 to 1,000 parts per million, and 5 with over 1,000 parts per million. In 23 of the waters with less than 400 parts per million of solids the calcium is greater than 10 parts per million, although in only 7 is the figure for scale-forming constituents greater than 90 parts per million. In 9 waters the total solids are less than 100 parts per million; in these the average for calcium is 7 parts per million. In 11 waters the total solids are between 100 and 200 parts per million, and the average for calcium in these is 26 parts per million. In 15 waters the total solids are between 200 and 324 parts per million, and the average for calcium is 17 parts per million. The sulphate radicle is higher in several waters of this group, but the increase is proportional to the increase in total solids. The average value for the chloride radicle is higher in each group than in the preceding group, and this is further shown in the waters whose total solids are greater than the limits considered. Some waters from the Eutaw formation are not suitable for domestic or boiler use, as is shown by the fact that the average results from 13 analyses given in the second and third columns of the table represent waters in which the total solids are greater than 400 parts per million and the 
chloride radicle constitutes a large proportion of the dissolved mineral matter. In 8 of these waters the chloride ranges between 160 and 236 parts per million and the total solids are less than 1,000 parts per million. The other 5 waters are classified as sodium chloride waters and came from Noxubee and Kemper Counties, which are both on the Mississippi-Alabama boundary line. In Alabama brines have been found in the Eutaw formation. ${ }^{10}$

Averages of mineral constituents of waters from Eutaw formation

[Parts per million]

\begin{tabular}{|c|c|c|c|}
\hline & $\begin{array}{l}\text { Total dis- } \\
\text { solved sol- } \\
\text { fds less } \\
\text { than } 400^{a}\end{array}$ & $\begin{array}{c}\text { Total dis- } \\
\text { solved sol- } \\
\text { ids } 400^{\circ} \\
1,000^{\circ}\end{array}$ & $\begin{array}{l}\text { Total dis- } \\
\text { solved sol- } \\
\text { ids greater } \\
\text { than } 1,000^{-}\end{array}$ \\
\hline 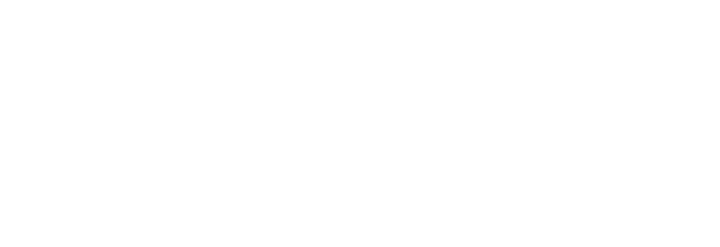 & $\begin{array}{l}21 \\
2.9 \\
21 \\
4.1 \\
39 \\
135 \\
13 \\
22 \\
192 \\
70\end{array}$ & $\begin{array}{l}14 \\
1.7 \\
10 \\
2.8 \\
235 \\
446 \\
6.3 \\
120 \\
620^{6 .} \\
36\end{array}$ & $\begin{array}{c}20 \\
70 \\
7.4 \\
2.9 \\
546 \\
508 \\
3.1 \\
558 \\
1.4 \\
1,427 \\
31\end{array}$ \\
\hline
\end{tabular}

a Based on the following 35 analyses: Alcorn County, Nos. 3, 4, 12, 16, 18; Chickasaw County, Nos. 2, 7, 18; Clay County, Nos. 11, 15; Lee County, Nos. 2, 3, 4, 11, 19, 20, 24, 31, 35; Lowndes County, Nos. 26, 27; Monroe County, Nos. 13, 19, 24; Prentiss County, Nos. 2, 3, composite of 8 and 9, 10, 13, 15, 16, 17; Tishomingo County, Nos. 1, 3; Union County, No. 1.

b Based on the following 8 analyses: Clay County, No. 13; Lowndes County, Nos. 1, 14, 16; Oktibbeha County, Nos. $4,23,24,27$.

Based on the following 5 analyses: Kemper County, Nos. 5, 9; Noxubee County, Nos. 17, $23,31$.

\section{SELMA CHALK}

General features.-The Selma chalk extends into Mississippi from Alabama in a belt about 20 miles wide in northeastern Kemper and in Noxubee Counties, from whence it trends northward, extending to and beyond the Tennessee State line. (See geologic map, pl. 2.)

The chalk consists of soft, more or less argillaceous or sandy limestone of very fine earthy or chalky texture, including a few more or less local interbedded layers of nearly pure hard limestone. In fresh exposures the rock is dark gray to bluish-gray but dries to light gray and white and produces the glaring bald spots of the prairies and the white bluffs that border the streams. The content of calcium carbonate ranges in different forms from 85 per cent or more to impure chalky clays and sands of low lime content. Small concretionary nodules of marcasite, most of them approximately spherical and not more than 1 or $1 \frac{1}{4}$ inches in diameter, are common, though somewhat widely scattered in the chalk. In general no difficulty is experienced in distinguishing the chalk from either the underlying Eutaw sands or the overlying Ripley sands and clays. The chalk weathers

10 Fuller, M. L., Underground waters of eastern United States: U. S. Geol. Survey Water-Supply Paper 114, p. 186,1905 . 
to rich clay soils, that are grayish-brown to nearly black-the Black Prairies-or to thinner brownish or reddish-brown silty clay soilsthe "post oak lands."

The structure of the chalk is typically massive, but the more argillaceous and sandy facies usually exhibit distinct bedding plains, and even the purer facies, where subjected to weathering in the bluffs, clearly show stratification lines that indicate slight uniform differences in lithologic character and in hardness. The chalk was deposited in marine waters less than 100 fathoms deep, probably for the most part less than 50 fathoms deep, as indicated by the presence in many layers, particularly in the less pure facies, of great numbers of large shells of the oyster family.

In western Alabama the formation has a measured thickness of 930 feet in a well at Livingston, Sumter County. The thickness in Mississippi immediately adjacent to Alabama is comparable to that at Livingston, but at all points to the north in Mississippi the thickness is less than that amount. At Shuqualak, Noxubee County, the formation is 760 feet thick; at Starkville, Oktibbeha County, the main body of the chalk is about 580 feet thick; at Longview, Oktibbeha County, it is $\mathbf{7 4 4}$ feet thick; in western Clay County it is about $\mathbf{5 7 0}$ feet thick; at Houlka, Chickasaw County, about 570 feet thick; at Sherman, Pontotoc County, where only the middle third or half of the formation, as developed farther to the south, is represented by chalk, the thickness is 280 feet; at Kossuth, Alcorn County, the thickness is 250 feet.

The basal part of the Selma chalk of east-central Mississippi is represented in northern Mississippi by nonchalky strata, chiefly sands with subordinate amounts of clay, which belong to the Coffee sand member of the Eutaw formation. The passage from chalk to sand takes place in western Itawamba and eastern Lee Counties and is accomplished by intertonguing of chalk and sand and by mergence of the one type of deposit into the other. Two conspicuous tongues are developed, one of impure chalk, known as the Mooreville tongue, which projects from the basal part of the chalk northward into the Eutaw type of deposit, and another of sand (the Tupelo tongue, see p. 34), which extends southward from the Coffee sand member of the Eutaw into the chalk, the Mooreville tongue below interlocking with the Tupelo tongue above. ${ }^{11}$ (See fig. 3.)

The Mooreville tongue is composed chiefly of impure argillaceous chalk and shaly, chalky clay. Its thickness, as shown by the log of a well near Tupelo (p. 288), is 215 feet.

A long, thin tongue of chalk called the Oktibbeha tongue, projects from the extreme top of the Selma in northwestern Noxubee County northward through Oktibbeha, Clay, and Chickasaw Counties, con-

u Stephenson, L. W., Washington Acad. Sci. Jour. vol. 7, No. 9, pp. 243-250, 1917 
formably above the southward-extending nonchalky sands and clays of the Ripley formation as shown in Figure 3. This chalk forms the uppermost part of the Upper Cretaceous series and is unconformably overlain by strata of Midway age (Eocene). The chalk is typically exposed in gullies on the campus of the Agricultural and Mechanical College near Starkville, Oktibbeha County. The thickness of the tongue has not been determined but probably does not exceed 60 feet.

In east-central Mississippi and in western Alabama, where the Selma is most fully developed, it is more than 900 feet thick and is conformably underlain by the Eutaw formation (Tombigbee sand member) and overlain by the Midway group of the Eocene, from which it is separated by an unconformity that represents a long period of geologic time. In other words, the chalk includes all the Upper Cretaceous sediments between the Eutaw and the Eocene that have been preserved in this area. The Tombigbee sand is the underlying formation from Itawamba County, Miss., through Alabama to western Georgia, and the Midway group overlies the chalk from Chickasaw County, Miss., to Wilcox County, Ala.

In northern Mississippi the chalk as developed farther to the south is represented by the following divisions, named in ascending order: Coffee sand member of the Eutaw; chalk representing the middle third or half of the Selma; and Ripley formation. Between eastcentral and northern Mississippi the basal and upper portions of the Selma therefore merge and intertongue into nonchalky representatives as shown in Figure 3. The Coffee sand member of the Eutaw was laid down contemporaneously with the basal 250 feet of the Selma. The passage from chalk to sand takes place in western Itawamba and in Lee Counties and is accomplished by an intertonguing of chalk and sand, the principal bodies of which are the northward-extending Mooreville tongue of the Selma and the overlying southward-extending Tupelo tongue of the Coffee sand member of the Eutaw. The Ripley formation of northern Mississippi was laid down contemporaneously with the upper 125 or 150 feet of the Selma. The Ripley extends southward through Chickasaw, Clay, Oktibbeha, and northwestern Noxubee Counties into the Selma chalk, being underlain by the main body of the chalk and overlain by the Oktibbeha tongue of the chalk. (See fig. 3.) The final passage of the sand into chalk is probably accomplished by merging. The Oktibbeha tongue probably loses its identity to the north by merging into the Ripley type of materials, for its fauna is apparently of the same age as that of the type Ripley in Tippah County.

Along some of the streams tributary to Tombigbee River on the west, which flow eastward and southeastward, notably along Tibbee River in Clay County and along Noxubee River in Noxubee County, the chalk is unconformably overlain by terrace loams, clays, and sands 
of Pleistocene and Recent age. The largest area of this sort is along the Tibbee and its tributaries, where the terraced belt has a maximum width of 6 or 7 miles and extends from the western part of Clay County to the Tombigbee.

The chalk is a notable part of the series of Upper Cretaceous formations in the eastern Gulf region, which, as a whole, form a gentle monocline that dips toward the embayment and the Gulf. The strike of the chalk in northern Mississippi is nearly due south, but to the south the strike gradually swings around to the east until in central Alabama it becomes due east. In Mississippi the beds have a nearly uniform slope of 30 to 32 feet to the mile, and the direction of dip ranges from west by slightly north in northern Mississippi to west in the latitude of Tupelo and finally to south in central Alabama. (See pl. 2.)

The relatively low altitude of the Black Prairie country is due not to structural down-warping but to the fact that the materials which compose the Selma have lent themselves more readily to the processes of erosion than have the sands which predominantly compose the Eutaw formation to the east.

Water-bearing capacity.-The Selma, like all the other formations of the Coastal Plain, is saturated with water to the level of the ground water table, but owing to the compactness of the chalk the water is so securely locked within the interstices that separate the fine particles that it can not be obtained for use, and the formation is commonly regarded as not water bearing. Hundreds of wells have been drilled through the Selma into the underlying sands of the Eutaw formation, but rarely is water reported from beds that compose any part of the chalk. However, the formation is an essential part of the principal artesian system of the region, for it serves as a confining stratum for the waters of the underlying Eutaw sands and thus makes possible the development of artesian pressure sufficient to raise the water in wells within easy reach of suction or force pumps.

RIPLEY FORMATION

General features.-The Ripley formation crops out in Mississippi in a belt that extends from the Tennessee State line, where the width is nearly 20 miles, southward with continued lessening width to the northwestern part of Noxubee County. (See geologic map, pl. 2.)

The Ripley formation is predominantly composed of marine sands and sandstones, though thick beds of clay, more or less local in extent, are common. The maximum thickness of the formation in northern Tippah County, though not accurately determined by well borings, is estimated to be approximately 400 feet. The formation gradually becomes thinner to the south until at its southern extremity in Noxubee County the thickness is probably 100 feet or less. 
The sands and sandstones are fine to coarse, more or less micaceous, glauconitic, argillaceous, and calcareous and range from loose sands through compact, partly indurated sands to hard sandstones, most of which are calcareous in greater or less degree. In fresh exposures the colors range from white or light gray to dark greenish or bluish-gray. The stratification ranges from thinly laminated to heavy bedded and the structure from finely cross-bedded to massive. The calcareous sands and sandstones are strongly developed in Chickasaw, Pontotoc, and Union Counties, where they probably compose the bulk of the formation.

The clays are commonly laminated and are interbedded with partings and thin layers of micaceous sand. In fresh condition they range from light gray or drab through dark greenish or bluish-gray to nearly black. The laminated clays with their associated thin partings and laminae of fine micaceous sand have their greatest development in the base of the formation, where their outcrops may be seen in the lower $\mathbf{4 0}$ or $\mathbf{5 0}$ feet of the eastern slope of the Pontotoc Hills. They appear to form a transition zone between the Selma chalk and the more typical Ripley sand and sandstone.

In northeastern Tippah and in Alcorn Counties the formation is partly represented by a great tongue of sand of shallow-water origin, the southern extremity of the McNairy sand member of the formation described below and shown in Figure 3 (p. 33), which thickens to the north in Tennessee and finally replaces the more typical, deeperwater marine beds, both above and below it.

In general, the Ripley strata weather reddish, brownish, and yellowish, the colors resulting chiefly from the oxidation of the iron, which partly composes the mineral glauconite. Some of the iron that was dissolved in the zone of humic acids has been redeposited at lower levels within the limits of weathering, and forms ferruginous concretions and platy ferruginous sandstones. These sandstones, however, are not as conspicuously developed in the typical beds of the Ripley as they are in the Eutaw formation, but they are extensively developed in the McNairy sand member.

Marine fossils are common and in places very abundant in the typical beds of the formation but are rare in the McNairy sand member.

The McNairy member has its fullest development north of Mississippi in Tennessee, where the type section is exhibited in the deep cut of the Southern Railway at the "Big Hill," 11/4 miles west of Cypress, McNairy County. ${ }^{12}$ The member typically consists of irregularly bedded noncalcareous, nonglauconitic sand and subordinate clay, probably deposited chiefly in shallow marine waters

\footnotetext{
1s Stephenson, L. W., Cretaceous deposits of the eastern Gulf region, and Species of Exogyra from the eastern Gulf region and the Carolinas: U. S. Geol. Survey Prof. Paper 81, pp. 17, 18, 22, 1914.
} 
within the range of strong waves and currents, though some of the materials were formed in marginal swamps and some may have been formed on low alluvial plains that border the coast. The maximum thickness in Mississippi, in northern Tippah County, is estimated to be 225 or 250 feet.

The sands are coarse to fine, gray to varicolored, more or less micaceous, and range from finely to coarsely current-bedded. They are unconsolidated with the exception of more or less local ferruginous, corrugated, tubular, and platy sandstones, which occur at irregular intervals but which constitute a diagnostic character of the member in northern Mississippi and in McNairy County, Tenn. The locally developed lenses of clay are light or varicolored or are dark gray to black from their content of lignite or other carbonaceous matter.

In Mississippi the McNairy member forms a great wedge-shaped mass, the southern extremity of which tongues into the main body of the typical Ripley deposits in Tippah and Alcorn Counties, where it is both underlain and overlain by northward-extending tongues of deeper marine invertebrate-bearing sands, clays, and marls. The lower tongue extends northward through Tennessee nearly to the Kentucky line; the upper tongue thins to the north and either loses its identity by merging into the McNairy sand or is overlapped by the Eocene, probably in Chester County, Tenn.

The Ripley formation in Mississippi and Tennessee rests with conformable relations on the Selma chalk. At most places in Mississippi where observations have been made the passage from the chalk to the overlying predominantly sandy deposits of the Ripley is marked by 40 or 50 feet of more or less sandy and calcareous laminated clay. The age of this transition band is nearly the same throughout the horizon of its occurrence in the State, though there is probably, a slight upward transgression of the band across the geologic column from the northern to the southern part of the area.

From Chickasaw County, Miss., northward to the head of the embayment in southern Illinois the Ripley is unconformably overlain by Eocene strata, which in Mississippi and southern Tennessee are referable to the Midway group. The unconformity represents a long period of geologic time, the greatest hiatus in fact in the geologic record of Mississippi, or of the Gulf region in general, between the beginning of Upper Cretaceous time and the Recent. The unconformity is, however, not a conspicuous physical feature because the surface on which the Eocene deposits were laid down was an approximate peneplain, in places scarcely distinguishable from a bedding plane, and the materials that form the base of the Eocene were in part derived by reworking from the-underlying Cretaceous deposits, which in places they closely resemble.

$54134-28-4$ 
South of Chickasaw County the Ripley tongues into the Selma chalk, ${ }^{13}$ the upper 125 or 150 feet of which it represents, and maintains its sandy and argillaceous character through Clay and Oktibbeha Counties, but finally in northwestern Noxubee County it passes probably by merging or by minor intertonguing into chalk. From Chickasaw County to this point the Ripley is therefore overlain by chalk to which the name Oktibbeha tongue has been given. (Seo fig. 3 and p. 37.)

The structure of the Ripley formation in the Mississippi embayment is gently monoclinal, the strike being nearly south and the dip to the west at the nearly uniform rate of 30 to 32 feet to the mile. The direction of dip and strike varies slightly from place to place along the area of outcrop; the strike is south by slightly east in the southern part of the area and north by slightly east near the Mississippi-Tennessee boundary, and the dip deviates slightly from due west in accordance with the change in strike. (See pl. 2.)

The predominantly sandy strata of the Ripley formation are topographically expressed in the Pontotoc Hills, described on page 5.

Water-bearing capacity. -The sandy beds that largely compose the Ripley formation are all water bearing, but some of them on account of their greater porosity and looseness yield their contained waters much more freely than others, and these are the beds that are commonly regarded as water bearing. Beds that carry water in quantities sufficient for domestic and farm use are likely to be encountered in any part of the formation; but the larger supplies, such as are required to meet the needs of the towns and villages, most of which are situated along the western border of the Pontotoc Hills, are obtained from beds of loose sand in the middle or a little below the middle of the formation.

Quality of water.-The waters of the Ripley formation for which analyses are available show a marked uniformity in quantities of total dissolved solids. In 19 out of 21 samples the total dissolved solids range from 167 to 280 parts per million. Two waters from Houston, Chickasaw County, have total solids of 445 and 450 parts per million. In these two waters the results for the sulphate radicle are 82 and 97 parts per million, in contrast to an average of 20 parts per million for the other 19 waters.

In the subjoined table the analyses have been arranged in order of increasing calcium. It will be noticed that as the calcium increases the sodium plus potassium decreases. When this fact is considered in connection with the uniformity of the total solids it seems likely that a natural water-softening deposit has caused an exchange of the bases as the waters percolated through the earth. 
The Ripley formation is composed of marine sands and sandstones that are more or less calcareous and beds of clay laminated with layers of sand. The clay is probably the material that is causing the exchange. An interesting example of this process is shown in the table by samples designated Tippah Nos. 10 and 11, which come from the same township but from different depths, 461 and 155 feet, respectively.

A report on the ground waters of Georgia ${ }^{14}$ gives 28 analyses of waters from the Ripley formation. The 21 analyses from Mississippi given in the table below have an average value of 235 parts per million for total dissolved solids, whereas 27 analyses from Georgia give an average of 150 parts per million. In general the analyses of waters from the formation in the two States differ very little.

Certain constituents of waters from the Ripley formation a

[Parts per million]

\begin{tabular}{|c|c|c|c|c|c|}
\hline County & $\begin{array}{c}\text { Analysis } \\
\text { No. }\end{array}$ & $\begin{array}{l}\text { Calcium } \\
\text { (Ca) }\end{array}$ & $\underset{(\mathbf{M g})}{\text { Magnesium }}$ & $\begin{array}{l}\text { Sodium } \\
\text { and potas- } \\
\text { sium } \\
(\mathrm{Na}+\mathrm{K})\end{array}$ & $\begin{array}{l}\text { Total } \\
\text { dissolved } \\
\text { solids }\end{array}$ \\
\hline $\begin{array}{l}\text { Tunica } \\
\text { Tunica } \\
\text { Tippah } \\
\text { Marshall } \\
\text { Tippah } \\
\text { Onion } \\
\text { Union } \\
\text { Union } \\
\text { Union } \\
\text { Tippah } \\
\text { Chickasaw } \\
\text { Chickasaw } \\
\text { Benton } \\
\text { Union } \\
\text { Union } \\
\text { Tippah } \\
\text { Tippah } \\
\text { Tippah } \\
\text { Tippah } \\
\text { Pontotoc } \\
\text { Tippah }\end{array}$ & $\begin{array}{r}1 \\
4 \\
10 \\
11 \\
2 \\
12 \\
10 \\
9 \\
17 \\
5 \\
16 \\
15 \\
3 \\
21 \\
8 \\
6 \\
26 \\
32 \\
21 \\
10 \\
11\end{array}$ & $\begin{array}{c}1.4 \\
1.5 \\
6.1 \\
7.2 \\
8.0 \\
11 \\
14 \\
14 \\
17 \\
21 \\
21 \\
22 \\
33 \\
42 \\
45 \\
46 \\
48 \\
55 \\
56 \\
57 \\
67\end{array}$ & $\begin{array}{r}0.7 \\
.8 \\
2.4 \\
2.8 \\
5.2 \\
2.9 \\
5.2 \\
5.5 \\
4.6 \\
1.3 \\
8.3 \\
9.6 \\
11 \\
1.8 \\
4.1 \\
9.6 \\
7.8 \\
6.4 \\
8.7 \\
5.4 \\
13\end{array}$ & $\begin{array}{r}b 64 \\
b 99 \\
60 \\
60 \\
54 \\
59 \\
47 \\
62 \\
30 \\
25 \\
133 \\
134 \\
628 \\
11 \\
6.3 \\
14 \\
10 \\
19 \\
23 \\
17 \\
17\end{array}$ & $\begin{array}{l}175 \\
280 \\
187 \\
205 \\
188 \\
185 \\
184 \\
248 \\
167 \\
182 \\
445 \\
450 \\
245 \\
186 \\
202 \\
195 \\
201 \\
264 \\
252 \\
224 \\
274\end{array}$ \\
\hline Average. .......... &...- & 28 & 6.1 & 46 & 285 \\
\hline
\end{tabular}

- For complete analyses see corresponding numbers under county descriptions. $\quad{ }^{b}$ Computed.

\section{TERTIARY SYSTEM \\ EOCENE SERIES 16 \\ MIDWAY GROUP \\ CLAYTON FORMATION}

General features. - The area of outcrop of the Clayton formation, the oldest Tertiary formation present in Mississippi, lies west of that of the Ripley formation. (See pl. 2.)

\footnotetext{
4 Stephenson, L. W., Veatch, J. O., and Dole, R. B., underground waters of the Coastal Plain of Georgia: U. S. Geol. Survey Water-Supply Paper 341, p. 512, 1915.

18 The descriptions of the formations of the Eocene series, with the exception of the Jackson formation, are based in part on an unpublished manuscript by Dr. E. N. Lowe, State geologist of Mississippi, and in part on field work conducted by W ythe Cooke of the U. S. Geological Survey, subsequent to the transmission 0. Doctor Lowe's manuscript. The description of the Jackson formation is based on published reports by Mr. Cooke.
} 
The formation consists of 15 to 25 feet of hard limestone containing numerous marine fossils, overlain by 20 to 40 feet of greenish-gray glauconitic sandy marl, which weathers to yellowish-red sand. Exposed ledges of the limestone weather to rough surfaces, owing in part to differential erosion around hard fossils. The maximum thickness of the formation is probably about 60 feet.

The Clayton formation rests with unconformable relations in part on the Ripley formation and in part on the Oktibbeha tongue of the Selma chalk. (See fig. 3 and p. 37.) This unconformity represents a very long period of geologic time. The formation is conformably overlain along its western margin by the Porters Creek clay, the next younger formation, which is also part of the Midway group. The beds strike approximately northward and dip westward beneath the Porters Creek clay at the rate of 20 or 25 feet to the mile.

The rolling or moderately hilly surface along the western border of the Pontotoc Hills is determined by the outcrop of the Clayton formation.

Water-bearing capacity.-The sandy marls that form the main body of the formation above the basal limestone include water-bearing beds, the value of which, however, has not been fully determined. A few wells in the western part of Tippah, Union, Pontotoc, and Chickasaw Counties are believed to have their source in these beds.

PORTERS CREEK CLAY

General features.-The Porters Creek clay appears in a long, narrow belt 4 to 12 miles wide, which enters Mississippi from Alabama in Kemper County and extends northwestward and northward to the Tennessee State line. (See pl. 2.)

The formation typically consists of about 150 feet of dark-gray clay, which as a rule is not distinctly stratified. The clay weathers light gray to nearly white and on drying breaks into small masses that shell off in successive thin conchoidal layers. Toward the north the upper part of the clay becomes sandy, and in Tippah County it is replaced by 75 to 100 feet of yellow and red, somewhat glauconitic sand, overlain by a few feet of hard fossiliferous glauconitic sandstone. For these sandy beds Lowe has proposed the name Tippah sandstone member. Red or yellow micaceous sands, apparently the continuation of the Naheola formation of Alabama, which overlie the Porters Creek clay from the Mississippi line to the region beyond De Kalb, have been mapped with the Porters Creek.

The Porters Creek clay rests conformably on the Clayton formation and where the Naheola formation is absent is overlain unconformably by the Ackerman formation of the Wilcox group. The clay dips to the west and southwest at the rate of 20 or 25 feet to the mile and passes beneath the Ackerman. 
The clay does not resist erosion as effectively as the more sandy strata of the Ripley and Clayton formations on the east and the Ackerman formation on the west, and its surface has been reduced to a somewhat lower, gently undulating to moderately rolling plain, known as the Flatwoods. (See p. 6.)

Water-bearing capacity. - The clay is too compact to serve as a valuable aquifer, but a few shallow wells and springs that have their source in it yield small quantities of water, which is, as a rule, rather highly mineralized. The Tippah sandstone member probably carries water in sufficient quantity and of suitable quality to serve as domestic and farm supplies, though its importance has not been definitely ascertained.

\section{WILCOX GROUP}

\section{ACKERMAN FORMATION}

General features.-The belt of outcrop of the Ackerman formation is 3 to 15 miles wide and lies immediately west of that of the Porters Creek clay. (See pl. 2.)

The formation consists of 300 to 550 feet of stratified gray, more or less lignitic clay, with many interbedded layers of lignite, some of which are of good quality and of considerable thickness. Many of the clay layers are more or less sandy, and some beds of sand are interstratified with the clay. Associated with the clays in some places are thin layers of carbonate of iron. Although the clays in the basal portion of the Ackerman formation resemble the underlying Porters Creek clay, the two formations are believed to be separated by an unconformity. The Ackerman formation is overlain by the Holly Springs sand, and the relation between these two formations is also believed to be that of unconformity. The strata dip to the west at the rate of 25 or 30 feet to the mile and pass beneath the Holly Springs sand.

The outcrop of the Ackerman formation is marked by hills which contrast strongly with the lower, smoother surface of the Porters Creek clay on the east. The hills are in general less pronounced than those produced by the Holly Springs sand on the west. The upland surface in the Ackerman belt ranges in altitude above sea level from 400 to 600 feet.

Water-bearing capacity.-Although the Ackerman formation is composed predominantly of clay it contains interbedded layers of sand that have more or less capacity for water; in some places moderately large supplies are obtained from the formation, as at the municipal waterworks at Louisville in Winston County (see p. 491); elsewhere wells have passed through the formation without obtaining water. Small springs are common throughout the area.

Quality of water.-Results based upon analyses of 13 waters which have their source in this formation are tabulated below. The total 
solids for this group range from 53 to 319 parts per million, but in 11 of the waters the quantity of total solids is less than 200 parts per million. Although 9 of the waters contain less iron than the average, layers of iron earbonate have been found in the clay, and waters from this formation probably contain considerable iron. The two analyses which have total solids greater than 200 parts per million-Grenada County No. 4 and Tallahatchie County No. 24have slightly higher chlorides. The greatest increases, however, were in the amounts of sodium plus potassium and in bicarbonate, these increases being proportional to the increase in total solids. The other constituents are consistent for all the waters considered.

Average, minimum, and maximum quantities of mineral constituents in waters from the Ackerman formation a

[Parts per million]

\begin{tabular}{|c|c|c|c|}
\hline & Average & Minimum & Maximum \\
\hline 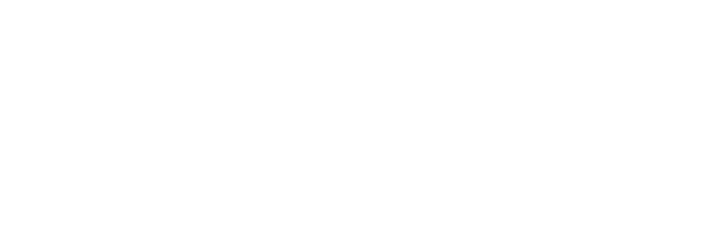 & $\begin{array}{r}29 \\
1.6 \\
8.8 \\
2.8 \\
42 \\
127 \\
7.4 \\
6.3 \\
1.5 \\
161 \\
34\end{array}$ & 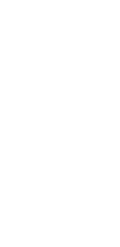 & $\begin{array}{c}49 \\
8.8 \\
18 \\
7.6 \\
120 \\
283 \\
21 \\
12 \\
4.0 \\
319 \\
63\end{array}$ \\
\hline
\end{tabular}

- Based on results of 11 analyses, as follows: Benton County, No. 1; Choctaw County, No. 1; Grenada County, No. 4; Lafayette County, Nos. 9, 13, 17; Tallahatchie County, No. 24; Tippah County, No. 33; Tunica County, No. 2; and Yalobusha County, Nos. 1, 8. For complete analyses see county descriptions.

HOLLY SPRINGS SAND

General features.-The belt of outcrop of the Holly Springs sand ranges in width from 3 to 20 miles and lies immediately west of that of the Ackerman formation. (See pl. 2.)

The formation is predominantly composed of irregularly and highly cross-bedded, more or less micaceous sand of white, light gray, or bluish and greenish gray color, which weathers on exposure to red, yellow, and purple and carries subordinate interbedded lenses of clay, generally of light color. Very fine gray laminated sand is common in the eastern counties. The formation ranges in thickness from about 160 feet near the Alabama line in Lauderdale County to a maximum of perhaps 600 feet in northern Mississippi. About midway of the formation in northern Mississippi is a zone of pink or white clay lenses, which more or less completely separates the lower from the upper half of the formation.

The Holly Springs sand rests, probably with unconformity, on the Ackerman formation. From Grenada County northward the formation is unconformably overlain by the Grenada, the uppermost formation of the Wilcox group. In Lauderdale County the Bashi ("Woods Bluff") and Hatchetigbee formations of the Wilcox group 
rest unconformably upon the Holly Springs. The Hatchetigbee is probably contemporaneous with the Grenada. The strata that compose the Holly Springs dip to the west at the rate of 15 to 20 feet to the mile, and the formation disappears beneath the overlying younger Eocene formations.

The Holly Springs area is one of pronounced hills and valleys. (See p. 6.)

Water-bearing capacity.-The physical constitution of the Holly Springs sand admirably suits it to serve as an aquifer, and it is the source of the water of hundreds of springs and shallow wells in its area of outcrop. Toward the west and southwest, where the formation passes out under the overlying younger formations, its waterbearing sands are tapped by hundreds of deep wells, both flowing and nonflowing.

Quality of water.-Waters from this formation show considerable variation in the quantity and character of dissolved mineral matter. The following table gives results based upon analyses of 30 waters from this formation. None of the 30 waters has over 300 parts per million of total solids. Six have total solids less than 100 parts per million; 16 have between 100 and 200 parts per million; 8 have between 200 and 300 parts per million. The group of 30 is quite consistent in the quantities of the constituents present. Coahoma No. 20, Holmes No. 24, and Tallahatchie No. 11 have total solids greater than 300 parts per million and have not been included in the analyses mentioned above. These three analyses have low sulphate and calcium and in the first and last of these the chloride is higher than the average for the others from the formation. A few analyses not included in the table had much larger quantities of calcium than the average given. These analyses indicate that some waters of the Holly Springs sand may have considerable dissolved material, of which calcium is a large part.

Average, minimum, and maximum quantities of mineral constituents in waters from Holly Springs sand ${ }^{*}$

[Parts per million]

\begin{tabular}{|c|c|c|c|}
\hline & A verage & Minimum & Maximum \\
\hline 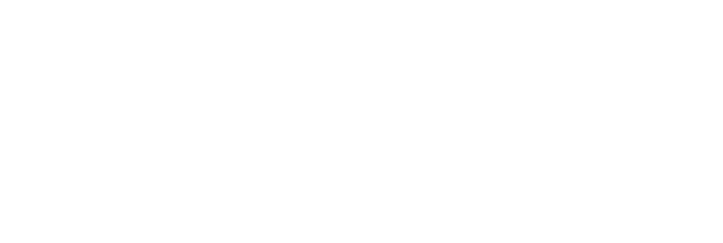 & $\begin{array}{l}29 \\
2.6 \\
12 \\
3.6 \\
36 \\
126 \\
8.9 \\
7.3 \\
1.7 \\
163 \\
44\end{array}$ & $\begin{array}{l}8.4 \\
1.3 \\
1.7 \\
5.3 \\
16 \\
1.7 \\
1.00 \\
35\end{array}$ & $\begin{array}{c}56 \\
17 \\
45 \\
8.8 \\
95 \\
295 \\
25 \\
24 \\
12 \\
296 \\
149\end{array}$ \\
\hline
\end{tabular}

- Based on results of 27 analyses, as follows: Grenada County, Nos. 6, 9, 20; Holmes County, No. 11; Lafayette County, No. 12; Lauderdale County, Nos. 9, 13, Marshall County, Nos. 3, 4; Neshoba Oounty Nos. 1, 2, 3, 4; Newton County, No. 19; Panola County, Nos. 3, 13; Quitman County, Nos. 1, 3, 4, 6; Tajlahatchie County, Nos. 17, 19, 22; Tate County, No. 11; Yalobusha County, Nos. 13, 18, 19. For complete analyses see county descriptions.

- Based on 26 determinations. 


\section{BASHI ("WOODS BLUFF") FORMATION}

General features.-The Bashi formation of Alabama has been recognized in Mississippi at two Jocalities near Meridian, Lauderdale County-one in a cut of the Memphis \& Meridian Railroad south of Meridian and the other in a public road cutting at Bonita, east of Meridian. (See pl. 2.) The outcrop of the Bashi is not shown separately on the geologic map but is included with the Hatchetigbee.

The materials near Meridian consist of 30 or 35 feet of glauconitic calcareous sand or sandy marl containing large gray calcareous fossiliferous concretions that weather out in mushroom-like forms. The contact of the Bashi formation with the underlying Holly Springs sand has not been observed but is doubtless unconformable. The marine marl of the Bashi is overlain by fresh-water clay of the Hatchetigbee formation.

Water-bearing capacity.-The Bashi is not a valuable water-bearing formation in Mississippi.

\section{GRENADA FORMATION}

General features.-In the valley of Yalobusha River in the vicinity of Grenada, Grenada County, occur outcrops of lignitic clay and lignite interbedded with more or less sand, which has been named the Grenada formation and which corresponds in age to the Hatchetigbee formation. Outcrops of similar lignitic clay occur in the lower slopes of the bluffs that overlook the Yazoo Delta in Grenada, Tallahatchie, Panola, Tate, and De Soto Counties. These clays, including interbedded sands, probably underlie a belt 20 to 35 miles in width east of the bluffs and extend from Yallobusha Valley northward to the Tennessee line. In this area the beds are in part concealed by Pliocene terrace gravels and by loess. (See pl. 2.)

The Grenada formation is estimated to be 150 or 200 feet thick in Grenada County. It rests unconformably on the Holly Springs sand and is unconformably overlain by the Tallahatta formation.

Water-bearing capacity.-Little is definitely known about the waterbearing capacity of the Grenada formation, but some of the beds of sand interbedded with the clay doubtless contain water, and some wells west of the outcrop of the formation probably have their source in the formation.

\section{HATCHETIGBEE FORMATION}

General features.-The Hatchetigbee formation extends from Alabama across the greater part of Lauderdale County. It appears to overlap the Bashi formation and to rest unconformably upon the Holly Springs sand. The hills near Meridian are composed chiefly of the Hatchetigbee, but some of them are capped by the harder Tallahatta "buhrstone." The Hatchetigbee formation is predomi- 
nantly clayey but contains also considerable sand and some lignite. (See pl. 2.) The clays are brown or chocolate-colored and break with hackly fracture, a characteristic which distinguishes the Hatchetigbee from the laminated or platy clays in the Holly Springs sand. The exact thickness of the formation is unknown, but 75 feet may be assumed as a conservative estimate.

The Hatchetigbee formation has been correlated with the Grenada formation (see p. 28) by means of its fossil plants, and this correlation is confirmed by its stratigraphic position. Both formations lie between the Holly Springs sand and the Tallahatta formation.

Water-bearing capacity. - The formation probably contains lenses and layers of water-bearing sand, although little is definitely known about their capacity and extent.

\section{UNDIFFERENTIATED WILCOX DEPOSITS}

In some areas it was impossible to determine to what formation of the Wilcox group the water-bearing sand belonged. The results in the following table are based upon analyses of 14 such waters. Most of these waters are much more concentrated than the waters of either the Ackerman formation or the Holly Springs sand. Chloride is greater than 10 parts per million in 11 of the waters; calcium is less than 5 parts per million in 11 waters, and the sulphate less than 10 parts per million in 14 waters. There are not sufficient data at hand to identify the particular formations of the Wilcox group from which these 14 waters came. As a rule the waters from the Wilcox group have moderate quantities of dissolved mineral matter, the quantities of calcium vary considerably, but only few really soft waters are reported from this group.

Minimum and maximum quantities of mineral constituents in waters from Wilcox group ${ }^{a}$

[Parts per million]

\begin{tabular}{|c|c|c|c|c|c|}
\hline & $\begin{array}{l}\text { Mini- } \\
\text { mum }\end{array}$ & $\begin{array}{l}\text { Maxi- } \\
\text { mum }\end{array}$ & , & $\begin{array}{l}\text { Mini- } \\
\text { mum }\end{array}$ & $\begin{array}{l}\text { Maxi- } \\
\text { mum }\end{array}$ \\
\hline $\begin{array}{l}\text { Silica }\left(\mathrm{SiO}_{2}\right) \\
\text { Iron }(\mathrm{F \theta}) \\
\text { Oalcium }(\mathrm{Ca}) \\
\text { Magnesium }(\mathrm{Mg}) \\
\text { Sodium and potassium }(\mathrm{Na}+\mathrm{K}) \\
\text { Bicarbonate radicle }(\mathrm{HCO}\end{array}$ & $\begin{array}{c}14 \\
.04 \\
.6 \\
92^{.1} \\
146\end{array}$ & $\begin{array}{r}78 \\
65.9 \\
45 \\
30 \\
850 \\
1,939\end{array}$ & $\begin{array}{l}\text { Sulphate radicle }\left(\mathrm{SO}_{4}\right) \\
\text { Chloride radicle }(\mathrm{Cl}) \\
\text { Nitrate radicle }\left(\mathrm{NO},{ }_{3}\right) \\
\text { Total dissolved solids } \\
\text { Total hardness as CaCo } \\
\end{array}$ & $\begin{array}{r}0.9 \\
5.0 \\
180^{.00} \\
3\end{array}$ & $\begin{array}{c}29 \\
185 \\
5.0 \\
2,079 \\
236\end{array}$ \\
\hline
\end{tabular}

Ta Based on results of 16 analyses, as follows: Bolivar County, Nos. 19, 20; Coahoma County, Nos. 1, 4, 5, 6, 8, 18; Hinds County, Nos. 15, 16; Sunflower County, Nos. 8, 12; Washington County, Nos. 2, 12,15, 21. For complete analyses see county descriptions.

b Iron and aluminum oxides, $\left(\mathrm{Fe}_{2} \mathrm{O}_{3}+\mathrm{Al}_{3} \mathrm{O}_{3}\right)$.

- Based on 13 determinations. 
TALLAHATTA FORMATION

General features.-The Tallahatta formation comes to the surface in a belt that extends from northern Clarke County to Grenada County. The belt is widest and most irregular in Clarke, Lauderdale, and Newton Counties, where it is in places as much as 6 miles wide and where the formation appears to be about 240 feet thick. The formation thins toward the northwest to little more than 15 feet near Duck Hill, and the belt of outcrop becomes correspondingly narrower. (See pl. 2.)

The prevailing rocks of the Tallahatta formation are white, gray, or cream-colored brittle claystone or diatomaceous earth, interbedded with hard gray sandstone or quartzite. A peculiar breccia-like rock composed of patches of claystone inclosed in coarse sandstone is not uncommon. These hard rocks are sometines called "buhrstone." The claystone is light in weight and porous and is composed chiefly of the siliceous remains of diatoms (tiny marine plants) and radiolarians (tiny marine animals).

The outcrop of the Tallahatta formation has the form of a cuesta; that is, its eastern or northeastern side is steep or even precipitous, but the opposite side slopes very gently toward the west or southwest. The bluff thus formed is inconspicuous in the northwest, where the formation is thin, but at the other extremity a steep escarpment upheld by the hard rocks of the Tallahatta formation forms a serious obstacle to travel. The line of outcrop in this southern region is very crooked because it is cut across by several streams. Outliers of the Tallahatta rocks cap the "mountains" near Meridian.

The Tallahatta formation lies between the Grenada or the Hatchetigbee formation below and the Lisbon formation above. It is unconformable with the Grenada formation and is also probably separated from the Hatchetigbee by an unconformity, but it appears to be conformable with the overlying Lisbon. In Lauderdale County it dips southwestward at the rate of 25 feet or more to the mile.

Water-bearing capacity.-The formation probably does not carry large quantities of water, although some of its more porous parts may be water bearing.

LISBON FORMATION

General features.-The Lisbon formation occupies a wedge-shaped area that extends from the Mississippi line at Clarke County to the edge of the Yazoo Delta, but the formation is concealed at the west end by a covering of loess and gravel. The width of the area ranges from 10 miles or less at the east end to about 60 miles in Holmes, Carroll, and Grenada Counties. 
In Clarke County the Lisbon formation is more than 200 feet thick and dips southward or southwestward at an estimated rate of 20 or 25 feet to the mile. The formation probably thickens toward the west, and the dip becomes somewhat more gentle, but no reliable data regarding thickness are at hand.

The basal part of the Lisbon, now known as the Winona sand member, consists of highly ferruginous bright-red sand, which appears to rest conformably upon the Tallahatta formation. In Clarke County the Winona sand member is $\mathbf{4 5}$ feet thick and includes at the base a 10-foot bed loaded with "Scutella" mississippiensis. To the northwest it increases in thickness to possibly 300 feet. ${ }^{16}$ Where the beds are unweathered the sands are green. The red color is due to the presence of limonite (iron rust) formed by the oxidation of greensand. The red beds extend northwestward from Clarke County to Montgomery and Carroll Counties.

The Winona member is overlain by cross-bedded white or ironstained sands at least 50 feet thick in Clarke County, which were called "Decatur sand" by Lowe." In Attala and adjacent counties much of this sand is consolidated into hard quartzitic sandstone, which, because of its hardness, was regarded by both Crider ${ }^{18}$ and Lowe ${ }^{19}$ as of Tallahatta age. This part of the Lisbon formation has recently been named the Kosciusko sandstone member by Cooke, ${ }^{20}$ because the name Decatur is preoccupied.

In Clarke, Jasper, and Newton Counties the white sand is overlain by 50 feet or more of glauconitic marl and red and yellow sand which contains a large fauna characteristic of the Lisbon formation of Alabama. This typical part of the Lisbon formation has been called the "Wautubbee marls" by Lowe. ${ }^{21}$ It is overlain by lignitic sands that are referred to the Yegua formation.

The Lisbon formation rests conformably on the underlying Tallahatta formation and appears to be conformably overlain by the Yegua formation. The average dip of the Lisbon strata is 20 to 25 feet to the mile. The hills in the area occupied by the Lisbon are less pronounced than those formed by the outcrop of the quartzitic rocks of the Tallahatta formation and in places in the northwest are gently undulating and prairie-like.

Water-bearing capacity. - The typical marl of the Lisbon is not a notable aquifer, though it contains some water-bearing beds. The Winona sand member, on account of its porous character is a valua-

\footnotetext{
10 Cooke, O. W., Correlations of Eocene formations of Mississippi and Alabama: U. S. Geol. Survey Prof. Paper 140, pp. 138-136, 1925.

17 Lowe, E. N., Mississippi, its geology, geography, soil and mineral resources: Mississippi Geol. Burvey Bull. 14, p. 78, 1919.

10 Crider, A. F., Geology and mineral resources of Mississippi: U. S. Geol. Survey Bull. 283, pl. 1, 1906.

13 Lowe, E. N., op. cit., pp. 75-76, 1919.

20 Op. cit.

${ }^{1}$ Lowe, E. N., op. cit., p. 78, 1919.
} 
ble aquifer and is the source of the water obtained in hundreds of shallow wells in its area of outcrop and also of the water of many deep wells toward the southwest in central and west-central Mississippi.

Quality of water.-Analyses of waters from the Lisbon formation, including the Kosciusko sandstone and Winona sand members, were used in the preparation of the following table. In 11 of the 18 analyses available the total solids are between 400 and 970 parts per million. One water has total solids of 109 and another has 1,214 parts per million. This latter analysis, Covington No.5, is from a well 1,487 feet deep. This water contains very little more sodium and bicarbonate. Seven of the analyses have calcium greater than 20 parts per million, but the remaining 11 have calcium less than 10 parts per million. Chloride in several of the waters is higher than would be expected. From these data it appears that the concentrations of waters from members of the Lisbon formation are high and that calcium may be present in large quantities, but the predominating characteristic is the large proportion of sodium and bicarbonate. A number of waters from this formation have a brown or red color which is probably due to colloidal organic matter. In general the color is more marked in the waters which contain the larger quantities of sodium and bicarbonate.

Minimum and maximum quantities of mineral constituents in waters from Lisbon formation a

[Parts per million]

\begin{tabular}{|c|c|c|c|c|c|}
\hline & $\underset{\text { mumi- }}{\text { Mini- }}$ & $\underset{\text { muxi }}{\text { Maxi- }}$ & & $\begin{array}{l}\text { Mini- } \\
\text { mum }\end{array}$ & $\underset{\text { muxi- }}{\text { Maxi- }}$ \\
\hline $\begin{array}{l}\text { Silica }\left(\mathrm{SiO}_{2}\right) \\
\text { Iron }(\mathrm{Fe}) \\
\text { Calcium }(\mathrm{Ca}) \\
\text { Magnesium }(\mathrm{Mg}) \\
\text { Sodium and potassium }\left(\mathrm{Na}^{2} \mathrm{+K}\right) \\
\text { Bicarbonate radicle }\left(\mathrm{HCO}_{3}\right)\end{array}$ & $\begin{array}{l}11.20 \\
1.4 \\
13^{.4} \\
63\end{array}$ & $\begin{array}{c}60 \\
4,3 \\
68 \\
22 \\
513 \\
1,235\end{array}$ & $\begin{array}{l}\text { Sulphate radicle }\left(\mathrm{SO}_{4}\right) \\
\text { Chloride radicle (CI) } \\
\text { Nitrate radicle (NO})_{3} \\
\text { Total dissolved solids } \\
\text { Total hardness as } \mathrm{Ca}_{3} \mathrm{CO}_{3}\end{array}$ & $\begin{array}{c}0.0 \\
4.5 \\
109^{.00} \\
5\end{array}$ & $\begin{array}{c}130 \\
72 \\
4.0 \\
1,214 \\
230\end{array}$ \\
\hline
\end{tabular}

a Based on results of 18 analyses, as follows: Clarke County, Nos. 21, 22; Covington County, No. 5, Holmes County, Nos. 12, 16, 32, 33, 37; Humphreys County, No. 9; Jasper County, Nos. 2, 3; Jones County, Nos. 9, 10; Newton County No. 20; Sharkey County, Nos. 2, 3, 5; Smith County, No. 1. For complete analyses see county descriptions.

$b$ Based on 15 determinations.

YEGUA FORMATION

General features.-The Yegua formation appears at the surface in a belt 1 to 8 miles wide that lies immediately southwest of that of the Lisbon formation. (See pl. 2.)

The formation consists of irregularly bedded, more or less laminated lignitic clay, sand, and lignite and ranges in thickness from 30 to 40 feet in the southeast to 300 or perhaps as much as 400 feet in Madison and Yazoo Counties. The formation lies between the Lisbon formation below and the Jackson formation above, both of which contain marine fossils. Its lithology indicates an estuarine or fresh- 
water origin. The beds dip to the southwest at rates which probably range from 20 to 35 feet to the mile in different parts of the outcrop, and the formation passes beneath the Jackson formation. The topography produced by the Yegua is gently undulating to moderately hilly. (See p. 6.)

Water-bearing capacity.-The formation is sufficiently sandy to render it of some value as an aquifer, and doubtless shallow wells in the area of outcrop and some deeper wells southwest of the outcrop draw water from it.

Quality of water.-Analyses Clarke Nos. 13 and 14 and Madison Nos. 5, 13, and 15 are from this formation. No table was made for these analyses because of the great variation in the determined quantities. The total solids are from 211 to 1,388 parts per million, and the calcium from 26 to 216 parts per million. The water containing the most dissolved mineral matter is classified as a calcium sulphate water and may have percolated through a bed of gypsum. These five analyses indicate that waters from the Yegua formation may be high in total solids and calcium.

\section{JACKSON FORMATION}

General features.-The Jackson formation crops out in an irregular belt that ranges in width from a few miles near the Alabama line in Clarke County to a maximum of 25 or 30 miles in the valley of Pear] River north of Jackson. (See pl. 2.)

The formation consists chiefly of clay, as a rule more or less calcareous, and less prominent beds of sand and marl. The basal portion, however, consists of beds of shells inclosed in quartz sand and glauconite. This lower portion ranges in thickness from 35 or 40 feet in the west to 90 feet in the east and is now known as the Moodys marl member. The upper or typical portion of the formation ranges in thickness from about 70 feet in the east to 600 feet in the west and is now known as the Yazoo clay member. The total thickness of the formation therefore increases from about 150 feet in the east, in Clarke County, to over 600 feet in the west, in Yazoo County.

The Jackson formation overlies, probably unconformably, the Yegua formation of the Claiborne group and is in turn conformably overlain by the Vicksburg group of the Oligocene. In places the Jackson is concealed by overlapping deposits that belong to the Citronelle formation. Such deposits occur in Jasper, Smith, Rankin, and Scott Counties. The strata of the Jackson dip south by west at the average rate of 20 or 25 feet to the mile, but owing to the folding of the strata the dip is in places less than indicated by these figures.

The surface of the country underlain by the Yazoo clay, where not protected by more resistant surficial deposits, has been reduced by erosion to flat or rolling, poorly drained plains. (See p. 6.) 
Water-bearing capacity.-So far as known the Yazoo clay contains no extensive water-bearing beds, but in places it yields small quantities of rather highly mineralized water. The Moodys marl is more porous and is probably more productive, although little is known of the value of its water content:

\section{OHIGOCENE SERIES}

VICKSBURG GROUP

General features.-The Vicksburg group ${ }^{22}$ appears in outcrops in a narrow strip of country just south of and parallel to the outcrop of the Jackson formation. (See pl. 2.) It consists of a series of sands, clays, marls, and limestones that have a thickness of about 185 feet in the east near the Alabama State line and probably decrease to about 145 feet in the west, in the vicinity of Vicksburg. These beds have been subdivided, from the base upward, into the Forest Hill sand (in the east) and the Red Bluff clay (in the west); the Marianna limestone, represented chiefly by the Mint Spring marl member; the Glendon limestone; and the Byram marl.

The Vicksburg group is believed to rest conformably on the Jackson formation. The stratigraphic relation of the group to the overlying Catahoula sandstone has not been determined. In places the Vicksburg appears to pass by gradual transition into the Catahoula, whereas elsewhere there appears to be an abrupt line of contact between the two divisions. In places the Vicksburg strata are overlapped and concealed by younger sands and gravels, which probably belong to the Citronelle formation of the Pliocene; overlaps and outliers of these deposits occur in Jasper, Smith, and Rankin Counties.

The strata of the Vicksburg group dip south by west at a rate that probably does not average over 20 feet to the mile, although locally, as around the Jackson anticline, ${ }^{23}$ dips as high as 70 feet to the mile have been recorded.

On account of the varied character of the Vicksburg deposits the surface features that result from their erosion range from smoothly rolling plains, such as the prairies which characterize the area of the Red Bluff clay in Wayne County, to the rather pronounced hills which here and there mark the outcrop of the Marianna limestone.

Water-bearing capacity.-All the subdivisions of the Vicksburg group contain more or less water, but the one that affords the largest yield is the Forest Hill sand, which is composed of about 70 feet of sand and subordinate amounts of clay. This sand is the source of springs and shallow wells in the area of outcrop, and it has been tapped by a considerable number of wells south of the outcrop. 
MIOCRNE SERIOS

\section{CATAFOULA SANDSTONE 24}

General features.-Outcrops of the Catahoula sandstone occur in a broad belt that trends west by south across south-central Mississippi, south of the outcrop of the Vicksburg group. (See pl. 2.)

The formation is composed of many alternations of sand, sandstone, and clay; the sandy sediments predominate, and the clays are distributed through the sands and sandstones in the form of lenses of small or large size. The thickness of the formation increases from 300 feet or less in eastern Mississippi to 500 feet or more adjacent to Mississippi River.

The Catahoula formation is underlain by the Vicksburg group, but whether the relation is one of conformity or of unconformity has not been ascertained. The Catahoula is overlain by the Hattiesburg clay, and apparently the relation between the two is that of conformity. On the divides the Catahoula is at many places overlapped and concealed by deposits of sand and gravel that belong to the Citronelle formation of the Pliocene. The strata that compose the Catahoula formation dip to the south at the rate of approximately 20 feet to the mile and pass beneath the Hattiesburg clay.

The area underlain by the Catahoula sandstone is typically one of moderate to pronounced topographic relief. Locally the outcropping ledges of sandstone produce a rough and relatively rugged topography. In places the valley bottoms lie 250 to 300 feet below the crests of the adjacent ridges.

Water-bearing capacity. - The Catahoula is a highly valuable waterbearing formation. The beds of medium to coarse sand that largely compose the formation are porous and are admirably suited to serve as aquifers. Throughout the belt of outcrop numerous shallow wells enter these sands and afford abundant supplies of water suitable for both domestic and industrial uses. South of the outcrop for distances of 30 to 50 miles many deeper wells have been sunk through the overlying younger formations into the water-bearing sands of the Catahoula.

Quality of water.-The results in the following table are based on the analyses of 27 waters which have their source in the Catahoula formation. These analyses are quite consistent. The range for total dissolved solids is quite large, but 21 of the waters have total solids less than 200 parts per million. Calcium is less than 10 parts per million in 19 of the waters, and in only 2 is the amount of scaleforming constituents greater than 90 parts per million. In 2 waters sulphate is greater than 20 parts per million, and in 5 the chloride is greater than 15 parts per million. Jasper Nos. 4 and 5 have 102 and 63 parts per million, respectively, of calcium. These quantities are so

2 Matson, G. C. The Catahoula sandstone: U. S. Geol. Survey Prof. Paper 98, pp. 209-226, 1016. 
much higher than those in most of the other waters of the formation that they have been omitted from the tabulated results. As a rule the waters from the Catahoula formation have moderately high total solids and one may expect to find calcium in moderate quantities.

Average, minimum, and maximum quantities of mineral constituents in waters from Catahoula sandstone ${ }^{a}$

[Parts per million]

\begin{tabular}{|c|c|c|c|}
\hline & Average & Minimum & Maximum \\
\hline 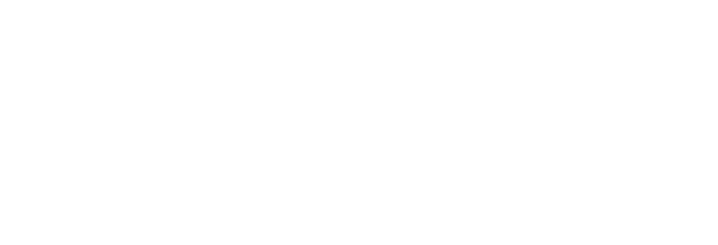 & \begin{tabular}{c|c}
32 \\
1.1 \\
6.2 \\
2.4 \\
49 \\
119 \\
13 \\
14 \\
$177^{-36}$ \\
26
\end{tabular} & $\begin{array}{l}9 \\
.00 \\
.4 \\
.5 \\
2.8 \\
7.3 \\
1.6 \\
1.0 \\
24^{.00} \\
4\end{array}$ & $\begin{array}{c}69 \\
4.5 \\
17 \\
6.2 \\
225 \\
486 \\
93 \\
54 \\
4.8 \\
578 \\
68\end{array}$ \\
\hline
\end{tabular}

- Based on results of 27 analyses, as follows: Claiborne County, Nos. 1, 2; Copiah County, Nos, 1, 3, 10, 15; Covington County, Nos. 4, 10, 1.1; Forrest County, composite of Nos. 9, 10, and 11, Nos. 12, 24; Hinds County, No. 27; Jefferson Davis County No. 1; Jones County, Nos. 4, 7, 8, 11, 15, 19; Lamar County, Nos. 6, 10; Lawrence County, Nos. 6, 8; Perry County, Nos. 4, 5; Simpson County, No. 1. For complete analyses see county descriptions.

\section{HATTIESBURG CLAY}

General features.-The area in which occur outcrops of the Hattiesburg clay ${ }^{25}$ forms a belt of country 15 to 30 miles wide that lies immediately south of that in which occur outcrops of the Catahoula sandstone. (See pl. 2.)

The formation increases from an estimated thickness of 325 feet in the east to 450 feet in the west. It is composed chiefly of marine blue and gray clay that weathers to mottled red or yellow and finally to deep red or yellow when exposed at the surface. Some layers are indurated to "claystone" or "mudstone." Some lignite and a few fossil leaves occur in the clay.

The Hattiesburg clay rests apparently with conformable relations upon the Catahoula sandstone; the strata dip to the south at the rate of 15 to 20 feet to the mile and pass beneath the overlying Pasce goula clay. The contact between the Hattiesburg and Pascagoula believed to be one of unconformity. On all the divides through the area of its occurrence the Hattiesburg is thickly blanketed with a deposit of sand, gravel, and clay that belongs to the Citronelle formation of the Pliocene. In the terraced lowlands of all the rivers and larger creeks the formation is overlain by Pleistocene terrace deposits. Outcrops of the Hattiesburg are therefore confined to the lower slopes of the valleys and to the banks of streams.

Most of the area underlain by the Hattiesburg is hilly, but the clay has in reality influenced the topography only slightly, for the con-

25 Based on unpublished manuscript of G. C. Matson. 
trolling factor in determining the character of the surface is the resistance to erosion offered by sands and gravels of the overlying Citronelle formation.

Water-bearing capacity.-Although the formation is chiefly composed of clay, layers of porous water-bearing sand, some of which are capable of yielding large quantities of water, are interbedded with the clay in the southward buried extension of the formation, even as far as the coast counties, as at Camp Shelby, Forrest County. (See p.159.) The formation must indeed be classed as one of the valuable waterbearing formations of southern Mississippi.

Quality of water.-The results in the following table are based upon analyses of 11 waters which had their source in this formation. The analyses used for the tabulation are quite consistent. Chloride is less than 6.0 parts per million in 10 of the waters. Calcium is not very high in any of the analyses which were used for the table. Most waters from the Hattiesburg clay should be good for all purposes.

Average, minimum, and maximum quantities of mineral constituents in waters from Hattiesburg clay ${ }^{a}$

[Parts per million]

\begin{tabular}{|c|c|c|c|}
\hline , & Average & Minimum & Marimum \\
\hline 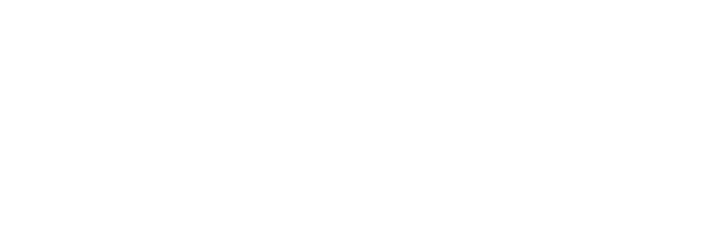 & $\begin{array}{l}29 \\
2.70 \\
1.5 \\
43 \\
107 \\
12.2 \\
5.2 \\
144^{.12} \\
12\end{array}$ & $\begin{array}{l}16 \\
.07 \\
.6 \\
.4 \\
4.6 \\
9.8 \\
6.5 \\
3.0 \\
29 \\
4\end{array}$ & $\begin{array}{l}50 \\
1.5 \\
5.2 \\
3.2 \\
90 \\
208 \\
16 \\
12 \\
1.0 \\
230 \\
24\end{array}$ \\
\hline
\end{tabular}

- Based on results of 11 analyses, as follows: Forrest County, Nos. 1, 4; Green County, No. 2; Marion County, No. 2; Pearl River County, Nos. 6, 9, 10, 15, 16; Pike County, No. 14; Walthall County, No. 1. For complete analyses see county descriptions.

Based on 10 determinations.

\section{PASCAgOUTLA CraT}

General features. - Outcrops of the Pascagoula clay ${ }^{20}$ are found in belt of country 15 to 30 miles wide that trends west by north across ,he southern part of the State, south of the outcrop of the Hattiesburg lay. (See pl. 2.)

The Pascagoula formation is composed chiefly of clay, including many beds of sandy clay, and interbedded with the clay are many beds of fine sand and silty sand. Some layers of sand and clay have been indurated to sandstone and claystone. The formation is estimated to be about 250 feet thick in the east, and it increases to about 400 feet in the west.

The Pascagoula clay is believed to rest unconformably on the Hattiesburg and is unconformably overlain by the Citronelle forma-

3 Based on unpublished manusaript of G. C. Matson.

$54134-28-5$ 
tion, which overlaps to the north and forms a thick covering over the Pascagoula on all the divides. Along the terraced river and creek valleys the formation is overlain by relatively thin alluvial deposits. Like the Hattiesburg clay, therefore, the Pascagoula crops out only on the lower valley slopes and in stream banks and bluffs.

The strata are inclined in a direction slightly west of south at an estimated rate of approximately 15 feet to the mile in the east in the vicinity of the Alabama line, but the rate increases toward the west until near Mississippi River it is about 30 feet to the mile.

The formation has only slightly influenced the topography in the area in which it appears at the surface, owing to the fact that the Citronelle formation so generally covers it except in the lower parts of the valleys.

Water-bearing capacity.-The more porous beds of sand interstratified with the Pascagoula clay are water bearing, and in places, particularly in the coast counties, these sands yield large quantities of flowing water suitable for domestic and industrial uses.

Quality of water.-The results in the following table are based on analyses of 33 waters from this formation. There is a large range in the quantities of total dissolved solids, sodium plus potassium, bicarbonate, and chloride. Seventeen of the waters have total solids less than 300 parts per million. Calcium is less than 3.1 parts in 28 of these waters. Chloride is greater than 100 parts per million in 9 of these waters, which come from Jackson County. The high chloride is probably due to embedded sea water. The calcium is lower than would be expected from water mixed with sea water, which may be due to an exchange of bases that possibly took place as the waters percolated through the earth. Sulphate is less than 15 parts per million in all the waters considered, and in 23 of them is less than 10 parts per million. Waters from the Pascagoula formation probably contain considerable quantities of total dissolved solids, without much calcium. The chloride will probably be high in waters drawn from wells near the Gulf, but that is not a characteristic of the formation.

Average, minimum, and maximum quantities of mineral constituents in waters from Pascagoula clay ${ }^{a}$

[Parts per million]

\begin{tabular}{|c|c|c|c|}
\hline & Average & Minimum & Maximu \\
\hline 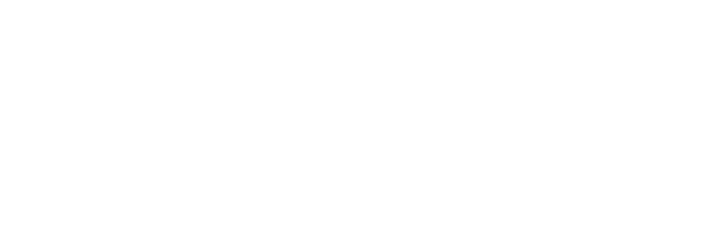 & $\begin{array}{l}33 \\
2.22 \\
2.4 \\
122 \\
232 \\
6.7 \\
55^{.9} \\
338^{.25}\end{array}$ & $\begin{array}{l}11 \\
.00 \\
.5 \\
10 \\
30 \\
.1 \\
.7 \\
49^{.00} \\
2\end{array}$ & $\begin{array}{r}53 \\
1 \\
11 \\
2 . \\
381 \\
531 \\
15 \\
284 \\
1 . \\
979 \\
36\end{array}$ \\
\hline
\end{tabular}

- Based on results of 33 analyses, as follows: George County, No. 2; Hancock County, Nos. 4, 7, 8, 24, 26, 27; Harrison County, Nos. 4, 7, 13, 16, 18, 20, 22, 23, 28, 30, 32, 34; Jackson County, Nos. 8, 9, 10, 13, 15, 17, 18, 19, 20, 24, 25; Marion County, No. 15; Pike County, No. 11; Stone County, No. 9. For complete analyses see county descriptions.

B Based on 26 determinations. 
PLIOCENE SERIES

CITRONELLE FORMATION

General features.- The Citronelle formation ${ }^{27}$ is the most widespread surficial formation in Mississippi. It covers more or less continuously the greater part of the State south of the latitude of Vicksburg and Jackson in the west and of the latitude of Quitman in the east. (See pl. 2.) The formation differs in composition from place to place but consists predominantly of sand or in many parts of the area of sand and gravel, though subordinate amounts of clay occur in the form of thin layers and lenses. These materials are of fluviatile, estuarine, and shallow marine origin. Most of the materials available for study have been weathered to orange, red, and yellow.

The Citronelle formation has its greatest thickness in Jackson County (350 to 450 feet). In Stone County it is 200 to 300 feet or more thick, in Pearl River County 150 to 200 feet, and in George County 100 to 200 feet. It includes all the materials that compose the uplands from the tops of the ridges down to and below the water level of the streams. In the southernmost tier of counties it rests unconformably on the Pascagoula clay, and the beds are slightly inclined toward the south at a rate that probably does not exceed 5 or 6 feet to the mile. In the southern part of Pearl River County and in the northern part of Hancock, Harrison, and Jackson Counties the formation passes beneath sands, clays, and loams of Pleistocene age that border the Gulf coast.

From southern Mississippi the formation spreads away to the north, overlapping and partly concealing the Pascagoula, Hattiesburg, Catahoula, Vicksburg, and Jackson formations. In the southern part of Lamar, Marion, Walthall, Pike, Amite, and Wilkinson Counties the base of the Citronelle formation rises above the water level of the streams, and thence northward it continues to rise at a very low angle, so that toward the north the formation gradually grows thinner, until it finally feathers out and disappears, mostly in the belt of outcrop of the Catahoula sandstone, though a few outliers occur on the hills in the area of outcrop of the Vicksburg group and the Jackson formation. Included in the Citronelle formation are superficial contemporaneous terrace deposits, which were laid down on plains that rise 250 to 500 feet above sea level, named, in the order of their age from the oldest to the youngest, the Brookhaven, Sardis, Canton, and Loxley terraces. Throughout a large part of southern Mississippi the older Catahoula, Hattiesburg, and Pascagoula formations appear in surface outcrops only beneath the Citronelle formation in the lower slopes of the valleys and in the banks of streams.

\footnotetext{
${ }^{27}$ Matson, G. C., The Pliocene Citronelle formation of the Gulf Coastal Plain: U. S. Geol. Survey Prof. Paper 98, pp. 167-192, 1916.
} 
Throughout that part of southern Mississippi in which the Citronelle is the principal outcropping formation the surface is carved into the hills that are described on page 7 as the Long-leaf Pine Hills.

Water-bearing capacity.-The sand and gravel of the Citronelle formation are water bearing, particularly toward the basal part of the deposits, and in places they yield large quantities of "freestone" water of excellent quality for domestic and industrial uses. Thousands of dug and bored wells have been sunk to these water-bearing beds. Where the formation passes beneath the Pleistocene deposits in Hancock, Harrison, and Jackson Counties, it is the source of flowing wells of small to moderately large yield.

Quality of water.-The following table is based on analyses of 19 waters from the Citronelle formation. In 14 of these waters the total solids are less than 100 parts per million. Calcium is low in all the waters studied, and in none does the amount of scale-forming constituents exceed 52 parts per million. Sulphate is less than 8.1 parts per million in 7 waters, but most of these are from shallow wells and have considerable nitrate present. Waters from the Citronelle formation should contain small or moderate amounts of dissolved material and should be good for most uses.

Average, minimum, and maximum quantities of mineral constitibents in waters from Citronelle formation a

[Parts per million]

\begin{tabular}{|c|c|c|c|}
\hline & A verage & Minimum & Marimum \\
\hline $\begin{array}{l}\text { Siliea ( }\left(\mathrm{SiO}_{2}\right) \\
\text { Iron }\end{array}$ & $\begin{array}{r}19 \\
.47 \\
2.3 \\
1.2 \\
31 \\
69 \\
4.9 \\
9.5 \\
20.7 \\
105 \\
16\end{array}$ & $\begin{array}{r}7.4 \\
\text { Trace. } \\
.4 \\
.3 \\
7.7 \\
7.3 \\
4.8 \\
2.0 \\
2.0 \\
2.0\end{array}$ & $\begin{array}{r}36 \\
3.0 \\
4.1 \\
3.1 \\
92 \\
228 \\
15 \\
15 \\
19 \\
270 \\
20\end{array}$ \\
\hline
\end{tabular}

a Based on results of 19 analyses, as follows: Amite County, Nos. 8, 10; George County, Nos. 1, 3; Hancock County, Nos. 5, 14; Harrison County Nos. 5, 27, 31; Lamar County, No. 8; Lincoln County, No. 7; Pearl River County, No. 20; Pike County, Nos. 7, 9, 15; Simpson County, No. 2; Stone County, Nos. 11, 12; Wilkinson County, No.2. For complete analyses see county descriptions.

PLIOCENE TERRACE DEPOSITS OF UNDETERMINED RELATIONS

General features.-Along the western border of the upland of Mississippi in the area underlain by the thicker portions of the loess (see pl. 2) and in places extending somewhat to the east of the main loess belt, occur relatively thin deposits of sand and gravel which rest on formations of Eocene, Oligocene, and Miocene age and are largely overlain by the loess. These sands and gravels are believed to have been deposited by ancient streams, which during the Pliocene epoch flowed at much higher levels than the present streams. The 
deposits are probably contemporaneous with the Citronelle formation but their relation to that formation has not been accurately determined.

Water-bearing capacity.-The sands and gravels are generally coarse and porous and therefore contain much water, which is drawn upon by many shallow wells and which emerges as springs along the foot of the bluffs that overlook the Yazoo Delta and along the lower slopes of the valleys among the loess hills. Water from these deposits is commonly hard.

\section{QUATERNARY SYSTEM}

\section{PLEISTOCENE SERIES}

TERRACE DEPOSITS ALONG TEE GULF COAST

General features.-The broad, flat terrace plains that border the Gulf coast in Jackson, Harrison, and Hancock Counties are underlain by deposits of loam, sand, and clay of Pleistocene age that increase in thickness from only 20 or 30 feet along their northern border to 200 feet or more in the immediate vicinity of the coast. (See pl. 2.) These are believed to rest unconformably on the Citronelle formation. The surface of the deposits is probably separable into several plains, which differ slightly in altitude above sea level, but these plains have not been differentiated in detail.

Water-bearing capacity.-Some of the sand beds in these formations carry abundant water, but these waters are not under a strong artesian head and are generally cased off by the drillers, who prefer to sink the wells to the waters at deeper horizons which yield flows.

NATCEEZ FORMATION

General features.-As described by Shaw in an unpublished manuscript, the Natchez formation is a very early Pleistocene stream deposit that consists of 150 to 175 feet of gravels, sands, and clays. The only good exposure of this formation that is known is at Natchez, the type locality, where it lies considerably above the position reached by the highest floods of the present day and is well exposed in the bluff. It appears to be much older than the loess.

Water-bearing capacity.-Little is known in regard to the waterbearing capacity of this formation.

\section{ALLUVIAL TERRACE DEPOSITS ("SECOND BOTTOMS")}

General features.-Most of the rivers and larger creeks of the State flow in level terraced lowlands which range in width from half a mile or less to 7 or 8 miles. In most of these valleys the lowlands are separable into two or three plains, which lie at different altitudes above the present stream channels and which represent old abandoned 
flood plains formed during different stages of the development of the valleys during Pleistocene time. All these plains are covered with deposits of loam, clay, sand, and gravel, which range in thickness from a few feet to 40 feet or more and which were laid down by the streams during these former stages at the same time that the plains were being cut and in the same manner that flood-plain deposits are being formed at the present time.

Water-bearing capacity.-The basal portions of most of these old alluvial deposits are composed of coarse sand, or porous sand and gravel, and as the underlying older formations are generally compact and thus hinder downward drainage the sand and gravel are water bearing at most places. Hundreds of dug, bored, and driven wells have their source in deposits of this kind, and many springs emerge along the contact between these deposits and the older formations in the lower slopes of the valleys that have been cut in the terrace plains. These deposits commonly yield hard water.

LOESS

General features.-In Mississippi the materials classed as loess form a thick mantle on the older formations in the upland bluffs that overlook the Mississippi River bottom, from the Tennessee State line in De Soto County in the north to the Louisiana State line in Wilkinson County in the south. Throughout this distance the loess near the bluffs ranges in thickness from 50 to 100 feet or more. Toward the east it gradually becomes thinner and eventually disappears, though loesslike loams coat the uplands for a distance of 40 to 60 miles east of the bluffs.

The typical loess is a grayish to yellowish to brown, massive, calcareous (limy) silt, the fine particles of which consist chiefly of quartz, with subordinate amounts of calcite, dolomite, feldspar, and magnetite. The material is relatively light and porous and permits water to percolate down through it readily. Shells of snails are scattered through the loess and in places are abundant. Toward the east, where the loess becomes thinner, it loses its limy character, probably through leaching by percolating water, and the thin noncalcareous facies east of the main body of the loess are generally classed as yellow, brown, or red loam. The main body of the loess - that is, the typical calcareous loess-which is regarded as of Iowan or earlyPeorian age, occurs in a belt of hilly country known as the Bluff or Loess Hills, which is 5 to 20 miles in width and which forms the western border of the üpland portion of the State from Tennessee to Louisiana. It is this typical portion of the loess that is shown on the geologic map (pl. 2).

The loess rests from place to place on formations of all ages from middle Eocene to Pleistocene, but at many places, perhaps at most 
places, the typical loess lies upon deposits of terrace sand and gravel of Pliocene age, which intervene between the loess and the underlying older formations.

Water-bearing capacity.-The loess, though porous and capable of absorbing large quantities of water, is generally non water bearing, for the reason that the water that enters it percolates readily down through it into the coarser sand and gravel that underlie it at most places.

PORT HUDSON FORMATION

General features.-As described by Shaw in an unpublished manuscript, the Port Hudson formation consists chiefly of clay and sand of late Pleistocene age and is apparently largely a brackish-water deposit, though a part was laid down by fresh waters at the lower end, near the mouths of rivers, and a part is a marine deposit offshore. Its areal distribution indicates that a large part of the deposit was laid down in estuaries, the principal one of which extended up Mississippi River to southern Mississippi and perhaps farther north. Where best developed the Port Hudson bears only a scant deposit of loess. This loess is probably of later age than the main body of loess, which is regarded as of Iowan or early Peorian age.

Water-bearing capacity.-The water-bearing capacity of this formation has not been ascertained.

\section{RECENT SERIES}

\section{ALLUVIUM OF MISSISSIPPI RIVER}

General features.-The bottom lands of Mississippi River which intervene between the river channel and the foot of the Loess or Bluff Hills is underlain to depths of 125 to 200 feet by alluvial loams, clay, sand, and gravel which have been deposited by the river as it has meandered back and forth across its flood plain during the Recent epoch. (See pl. 2.)

Water-bearing capacity.-These materials are saturated with water to a level within 15 feet or less of the surface, and the porous sands and gravels, which largely compose the lower half of the deposits, contain vast quantities of water that can readily be procured by means of properly constructed wells and pumps. Generally this water is cased off and the wells are sunk into the deeper Eocene formations, the waters of which are at most places under a sufficiently high head to cause flows at the surface. Some use, however, is made of the water, as, for example, at Shaw in Bolivar County (p. 92), where it furnishes the municipal water supply, and on a plantation near Ben Lomond, Issaquena County (p. 226), where it is used both for domestic supplies and for irrigation. Water from the alluvial deposits is commonly hard and moderately high in mineral content. 


\section{GROUND-WATER RESOURCES BY COUNTIES}

\section{ADAMS COUNTY}

GENERAL FEATURES

Area, 426 square miles. Population, 22,183 (census of 1920)

Adams County includes parts of two physiographic districts-the hilly loess-covered upland and the Mississippi Alluvial Plain. The topographic aspect and the soils of the upland portion of the county are determined chiefly by the loess, which forms a covering that ranges in thickness from 50 to 60 feet in the west, where the bluffs overlook the Mississippi lowland, to only a few feet on the hills in the eastern part of the county. The loess is underlain, in descending order, by the Natchez (very early Pleistocene), Citronelle (Pliocone), Pascagoula (Miocene), Hattiesburg (Miocene), and Catahoula (Miocene) formations. Of these the Natchez formation is well exposed in the bluff at Natchez, and the Citronelle, Pascagoula, and Hattiesburg crop out beneath the loess along the escarpment that overlooks the Mississippi lowland and at a few places in the eastern part of the county, whereas the Catahoula is completely buried beneath the younger formations. These formations are described on pages 55-61, and their distribution is shown on the geologie map (pl. 2). The Mississippi lowland is underlain by alluvial loam, cls,y, sand, and gravel, estimated to be 150 to 200 feet thick, which rest in part upon the Catahoula sandstone and in part upon the Hattiosburg clay.

\section{GROUND-WATER CONDITIONS}

The shallow ground-water conditions in the upland are largely determined by the loess, which forms a covering over the older Citronelle formation. The loess is calcareous and pervious, so that the surface water readily drains down through it, dissolving lime as it goes, and passes into the sands and gravels of the underlying Citronelle formation. Most of the shallow wells of the uplandthat is, wells less than 100 feet deep-derive their supply from the Citronelle. The degree of hardness of the water, which is due to the dissolved lime, varies greatly and in places is higher than is desirable for domestic uses. This fact, together with the excessive thickness of the loess in the western part of the upland, has led to the construction of cisterns, which have come into common use for storing rain water.

Springs that have their source in the sands and gravels of the Citronelle formation are numerous along the line of outcrop of the Citronelle, in the escarpment that faces the Mississippi lowland, and in the slopes of the deeper creek valleys that trench the upland. 
The Pascagoula clay extends into approximately the southeastern two-thirds of the county and intervenes between the Citronelle formation above and the Hattiesburg clay below. The maximum thickness of the Pascagoula in the southeastern part of the county is probably about 200 feet. Little is known in regard to the importance of the formation as an aquifer within the county, but some of the interbedded layers of sand are probably water bearing.

The Hattiesburg clay underlies the Pascagoula, and some of its interbedded sand layers are valuable water bearers, as shown by the records of wells at Natchez, most of which derive their supplies from this source at depths of 100 to about 450 feet (Nos. 3-12). In the log of the Natchez Ice Co.'s well a coarse water-bearing sand is indicated at a depth of 252 to 272 feet. The formation may be regarded as a possible source of water throughout the county. The beds dip slightly toward the south, perhaps at the rate of 10 or 15 feet to the mile, so that north of the latitude of Natchez, where the base of the formation lies about 420 feet below sea level, the waterbearing beds lie at somewhat shallower depths than they do south of that latitude.

A deeper and probably a very abundant, though largely undeveloped, source of water is the Catahoula sandstone, the water of which is contained in the coarser layers of sand. In the well of the Natchez Ice Co. (see $\log$ ), the principal water-bearing sand at a depth of 493 to 509 feet is believed to be at the top of the Catahoula.

The sand and coarser basal sand and gravel of the alluvial deposits which underlie the Mississippi lowland to an estimated depth of 150 to 200 feet are water bearing and are utilized in the inhabited parts of the area, where waters are obtained chiefly by means of driven wells. Wells at Arnot (No. 1), Kienstra, and elsewhere in the lowland are equipped with windmills for raising the water.

\section{LOCAL SUPPLIES}

Natchez.-The principal source of water supply at Natchez is the Hattiesburg clay, the water-bearing beds of which are reached by wells 100 to about 450 feet deep. The waterworks is supplied by five wells (including Nos. 3-5) 275 to 300 feet deep, situated at the river front, about 70 feet above sea level. Two wells of the Natchez Ice Co. at Natchez (Nos. 7 and 8), 534 and 509 feet deep, are believed to tap a water-bearing bed in the top of the Catahoula formation. The log of the 534-foot well follows: 
Log of well of Natchez Ice Co., Natchez

[Altitude at mouth of well, about 75 feet above sea level. Authority, A. B. Learned, of Natchez]

\begin{tabular}{|c|c|c|c|c|c|}
\hline & $\begin{array}{c}\text { Thick- } \\
\text { ness }\end{array}$ & Depth & . & $\underset{\text { ness }}{\text { Thiok }}$ & Depth \\
\hline $\begin{array}{l}\text { Citronelle formation (?): Gravel } \\
\text { and sand. } \\
\text { Hattiesburg clay: } \\
\text { Hard clay } \\
\text { Coarse white sand; water } \\
\text { bearing } \\
\text { Clay } \\
\text { Sand } \\
\text { Clay } \\
\text { Sand }\end{array}$ & $\begin{array}{r}\text { Feet } \\
49 \\
203 \\
20 \\
28 \\
3 \\
27 \\
5\end{array}$ & $\begin{array}{r}\text { Feet } \\
49 \\
252 \\
272 \\
300 \\
303 \\
330 \\
335\end{array}$ & $\begin{array}{l}\text { Hattiesburg clay-Continued. } \\
\text { Clay } \\
\text { Soft clay } \\
\text { Clay } \\
\text { Catahoula sandstone: } \\
\text { Fine sand; water bearing... } \\
\text { Clay } \\
\text { Sandstone } \\
\text { Clay } \\
\text { Sandstone }\end{array}$ & $\begin{array}{r}\text { Feet } \\
65 \\
10 \\
83 \\
16 \\
8 \\
6 \\
3 \\
8\end{array}$ & $\begin{array}{r}\text { Feet } \\
400 \\
410 \\
493 \\
509 \\
517 \\
523 \\
526 \\
534\end{array}$ \\
\hline
\end{tabular}

Washington.-The Jefferson Military Academy obtains its water supply in part from Ellcots Spring, which probably has its source in the Citronelle formation, and in part from a large cistern in which rain water is stored. The daily yield of the spring is said to be between 2,000 and 3,000 gallons. The spring water is described as rather limy and hard.

Walker Springs.-A group of seven springs, known as Walker Springs, emerges in a valley $11 / 2$ miles south of Fenwick, in sec. 32, T. 7 N., R. $1 \mathrm{~W}$. These springs flow from either the Pascagoula formation or the terrace sands and gravels that intervene between the Pascagoula and the overlying loess. The water of spring No. 7 is bottled and sold to local consumers. (See analysis 16.) 


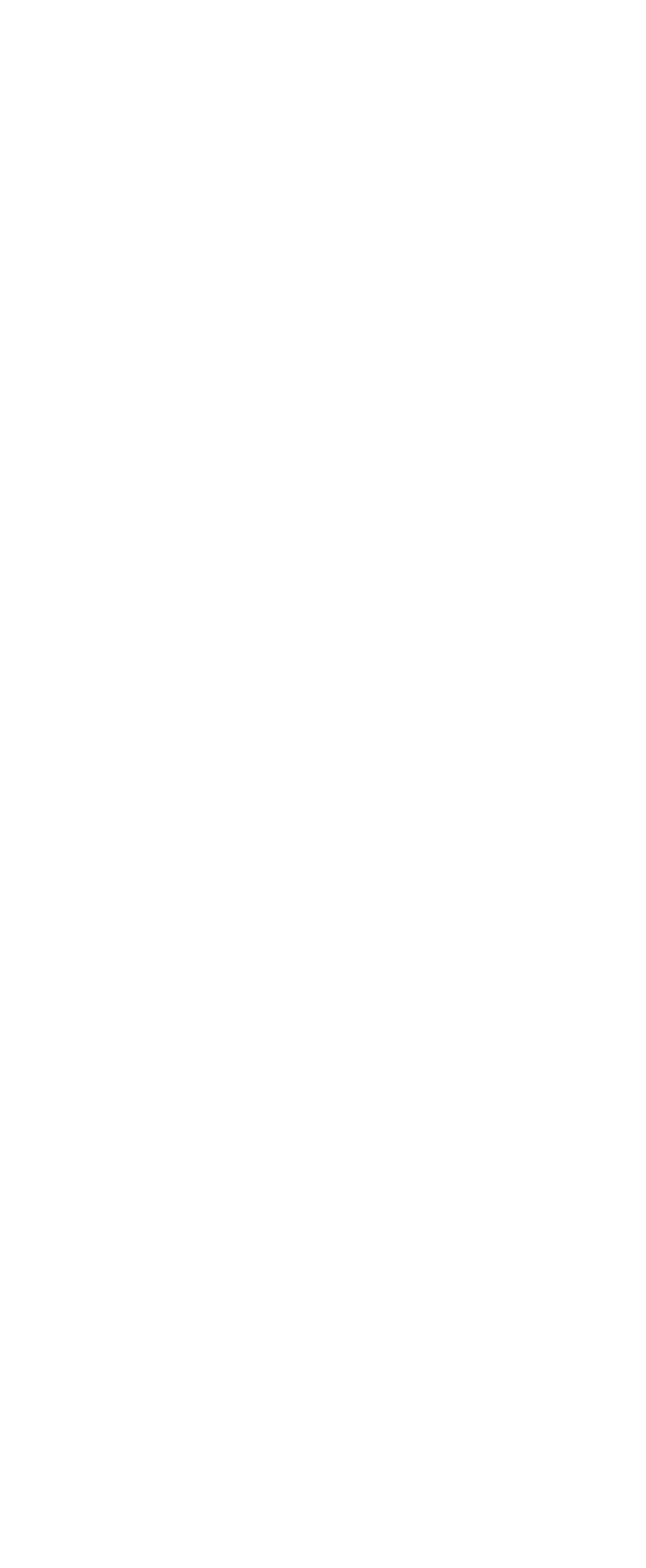




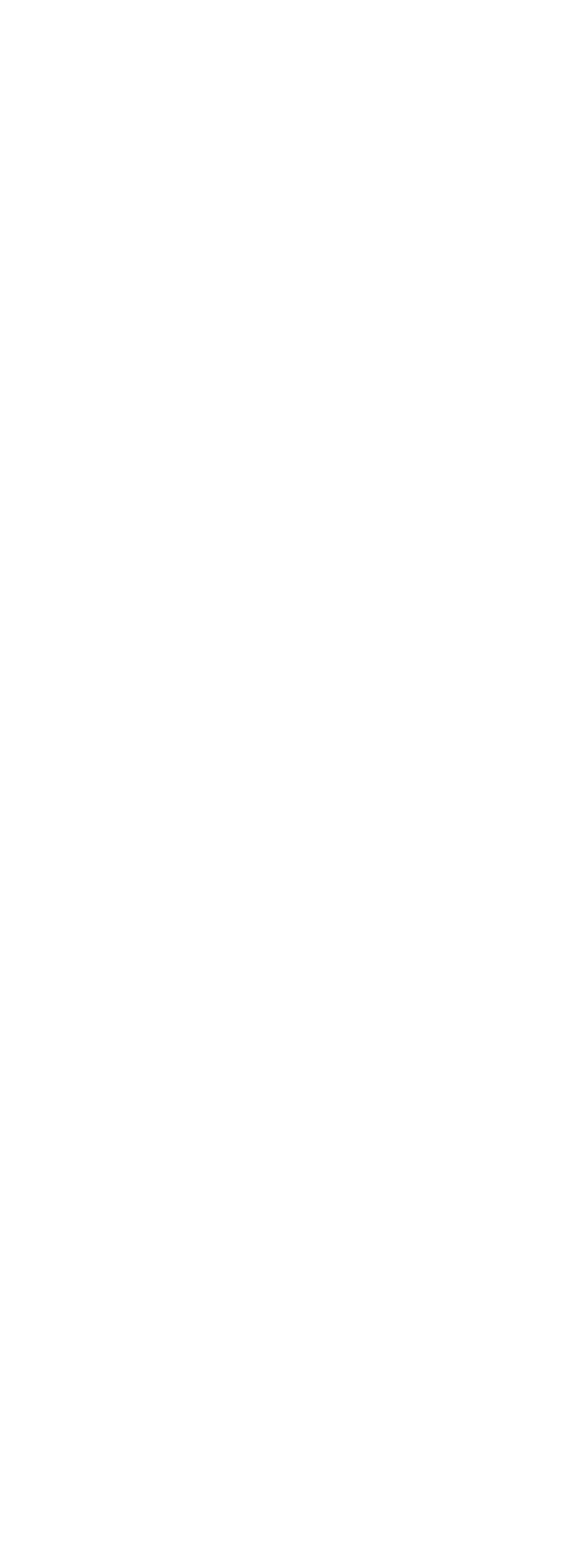


Mineral analyses of ground waters from Adams County

[Parts per mallion. Nambers at heads of columns refer to corresponding well and spring numbers in preceding table]

\begin{tabular}{|c|c|c|c|c|c|c|c|}
\hline & 3 & 4 & 5 & 8 & 18 & 14 & -16 \\
\hline 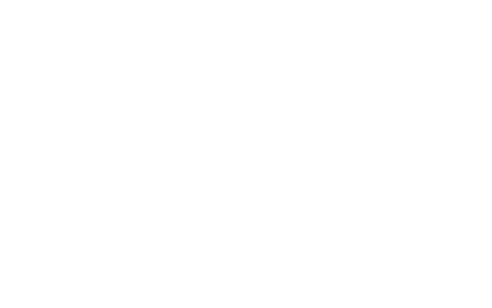 & $\begin{array}{c}55 \\
2.1 \\
34 \\
11 \\
83 \\
{ }^{5} .0 \\
840 \\
16 \\
5 . \theta \\
\text { Trace. } \\
364 \\
130 \\
\text { Sept., } \\
1910\end{array}$ & $\begin{array}{c}57 \\
2.2 \\
34 \\
11 \\
77 \\
.0 \\
326^{\circ} \\
16 \\
6.0 \\
2.3 \\
360 \\
130 \\
\text { Sept., } \\
1910\end{array}$ & $\begin{array}{l}47 \\
42^{.60} \\
15 \\
.0 \\
817^{\circ} \\
24 \\
26 \\
362.38 \\
166 \\
\text { Sept., } \\
1910^{\circ}\end{array}$ & $\begin{array}{c}58 \\
\text { Trace. } \\
85 \\
15 \\
70 \\
{ }^{2} 0 \\
848 \\
17 \\
6.0 \\
2.5 \\
873 \\
149 \\
\text { Sept., } \\
1019\end{array}$ & $\begin{array}{l}40 \\
.13 \\
35 \\
31 \\
.0 \\
630 \\
6.4 \\
22 \\
9.0 \\
434 \\
346 \\
\text { Sept., } \\
1919\end{array}$ & $\begin{array}{c}60 \\
1.4 \\
203 \\
11 \\
32 \\
{ }^{2} 0 \\
739 \\
1.2 \\
17 \\
702.00 \\
553 \\
\text { Jtne, } \\
1944\end{array}$ & $\begin{array}{r}24 \\
21.62 \\
8.9 \\
8.9 \\
98.0 \\
6.8 \\
7.5 \\
9.0 \\
128 \\
89 \\
194\end{array}$ \\
\hline
\end{tabular}

a Analyeos of 6 other Walker spring show tetal dissol vedsolids 106, 110,94, 112, 124, 130 parts per million, and are similar in composition to No. 16

Analysts: 3, 4, 5, 8, 13, H. B. Riffenburg, U. S. Geological Survey; 14, Mississippi State Chemical Laboratory; 16, W. F. Ttand, Misaissippi State'Chomieal Labomatory.

\section{ALCORN COUNTY}

GENERAL FEATURES

Area, 386 square miles. Population, 21,369 (census of 1920)

Alcorn County, in the upland of northern Mississippi, embraces parts of three physiographic districts-the Tombigee or Tennessee River Hills in the east, the Black Prairies in the center, and the Pontotoc Hills in the west.

The geologic formations that underlie the county are of Upper Cretaceous age and are separable, in ascending orden into the Tuscaloosa formation, the Eutaw formation (Coffee sand member), the Selma chalk, and the Ripley formation. These formations are described on pages 29-39 and shown on the geologic map (pl. 2).

\section{GROUND-WATER CONDITIONS}

The Coffee sand member of the Eutaw formation is a valuable waterbearing terrane, and in the area of its outcrop, which embraces the hills in approximately the eastern third of the county, it is the principal source of domestic supply. In these hills springs of small to moderate yield are numerous, and where convenient are utilized; but dag bored wells, which range in depth from few feet to 100 feet or more, are the chief means employed to obtain the water from the sands. No deep wells have been reported from this area.

The Selma chalk, which crops out in the gently undulating to roll.ing belt 4 to 8 miles wide that trendslnorthward through the central part of the county, is so fine grained and compaet that it does not readily yield its water to wells, but the chalk serves as a confining stratum for the water of the underlying Eutaw and Tuscaloosa formations, which is thus kept under sufficient hydrostatic pressure to raise it within easy reach of pumps and to produce flows in the valley of Tuscumbia River westfoffCorinth. Many wells have been drilled through the chalk into the Eutaw sands, and in the vicinity of Corinth some have been sunk deep enough to tap the water- 
bearing sands of the still more deeply buried Tuscaloosa formation. The water-bearing strata of the Eutaw lie at shallower depths along the eastern border of the chalk belt than along the western border where, as at Kossuth, it is necessary to drill at least 250 feet to reach them. Cisterns and artificially constructed pools for storing rainwater are in common use by those inhabitants of the Selma belt who have not provided themselves with artesian wells.

The ground-water conditions in the hilly to rugged area in the western part of the county, which is underlain by the Ripley formation, are similar to those of the Eutaw area in the east. Springs, which are numerous, and shallow wells afford an abundance of water for the needs of the comparatively few inhabitants of the area.

The upper surface of the Paleozoic rocks, which form the basement on which the Cretaceous deposits rest, lies at a depth of about 200 feet in the eastern part of the county and is encountered at a depth of more than 300 feet at the waterworks at Corinth. These rocks also contain water-bearing beds, as shown by the record of the deeper wells at the Corinth waterworks.

Analyses of eight of the ground waters are given on page 75.

\section{LOCAL SUPPLIES}

Corinth.-The municipal waterworks at Corinth is owned by the town and is located about half a mile south of the Mobile \& Ohio Railroad station, west of the track. The water supply is obtained from six wells (Nos. 5-10). The two deeper wells enter the Paleozoic basement rocks and obtain water from so-called gravel, which is either true gravel or badly shattered novaculite that occurs at the Fort Payne horizon. The water is raised from all these wells by vertical force pumps operated by steam. Logs of the $4631 / 2$-foot well and an abandoned 551-foot well are given below. Analyses of samples of water from the $4631 / 2$ and $264(?)$ foot wells are given in the table. Several other wells have been drilled within the corporate limits of Corinth (Nos. 1, 3, and 4).

Log of well No. 5 at the waterworks, Corinth (No. 7)

[Authority, Southern Mill \& Contracting Co., Memphis; copy of $\log$ on file at the waterworks]

\begin{tabular}{|c|c|c|c|c|c|}
\hline & $\begin{array}{c}\text { Thick- } \\
\text { ness }\end{array}$ & Depth & & $\underset{\text { ness }}{\text { Thick }}$ & Depth \\
\hline $\begin{array}{l}\text { Selma chalk: } \\
\text { Red clay } \\
\text { White clay. } \\
\text { Blue clay and shale } \\
\text { Eutaw and Tuscaloosa formations: } \\
\text { Sandrock. } \\
\text { Blue clay. } \\
\text { Loose sand; water bearing. } \\
\text { Blue clay. } \\
\text { Sandrock. } \\
\text { Blue clay } \\
\text { Loose sand } \\
\text { Sandrock. } \\
\text { Loose gray sand; water bearing } \\
\text { Blue clay. } \\
\text { Loose sand and a iittle clay; } \\
\text { water bearing }\end{array}$ & $\begin{array}{r}\text { Feet } \\
10 \\
10 \\
15 \\
11 \\
10 \\
54 \\
28 \\
4 \\
11 \\
31 \\
2 \\
20 \\
10 \\
84\end{array}$ & $\begin{array}{r}\text { Feet } \\
30 \\
20 \\
35 \\
46 \\
56 \\
110 \\
138 \\
142 \\
153 \\
184 \\
186 \\
206 \\
216 \\
300\end{array}$ & $\begin{array}{l}\text { Paleozoic (?): } \\
\text { Very hard limerock. } \\
\text { Loose sand and a little shale. } \\
\text { Hard limerock } \\
\text { Loose sand and a little clay } \\
\text { Clay } \\
\text { Very hard black rock } \\
\text { Clay } \\
\text { Paleozoic: "Gravel" (Fort Payne } \\
\text { chert) with streaks of clay at the } \\
\text { tcp and two little streaks of sand; } \\
\text { water bearing. }\end{array}$ & $\begin{array}{c}\text { Feet } \\
5 \\
66 \\
2 \\
32 \\
3 \\
1 \\
1\end{array}$ & $\begin{array}{l}\text { Feet } \\
305 \\
371 \\
373 \\
405 \\
408 \\
4081 / 3 \\
4091 / 3\end{array}$ \\
\hline
\end{tabular}


The accuracy of this $\log$ is questioned by the engineer at the plant, who is of the opinion that not only this well but the 470 (?)-foot woll is at least 600 feet deep and that this well is 10 inches in diameter.

Log of an abandoned well at the waterworks, Corinth

[Altitude of mouth of well about $\mathbf{4 3 0}$ feet above sea level. Adapted from description by Crider and Johnson a]

Soil and residuum from Selma chalk

Selma chalk: Blue clay.

Eutaw formation in the apper part, Tuscaloosa formation in the basal part:

Sand; water bearing

Hard rock.

Sand; water bearing

Paleozoic:

Sandstone, limestone, and shale.

Siliceous rock ("flint rock"), (Fort Payne chert)

\begin{tabular}{|c|c|}
\hline Thickness & Depth \\
\hline Feet $\begin{aligned} 15 \\
\\
20\end{aligned}$ & Feet 18 \\
\hline $\begin{array}{r}30 \\
1 \\
35 \\
200\end{array}$ & $\begin{array}{r}6 \\
66 \\
101 \\
\mathbf{3 0 1}\end{array}$ \\
\hline $\begin{array}{l}135 \\
115\end{array}$ & $\begin{array}{l}44 \\
55\end{array}$ \\
\hline
\end{tabular}

- Crider, A. F., and Johnson, L. C., Summary of the underground-water resources of Mississippi: U. S, Geol. Survey Water-Supply Paper 169, p. 60, 1906.

The $\log$ of T. F. Burnett's well (No. 11) is as follows:

Log of well of T. F. Burnett, $31 / 2$ miles west of Corinth

[Altitude 10 feet above-Tuscumbia River]

Surficial deposit: Red clay

Selma chalk:

White limestone

Eutaw formation: Sand, clay, and rock; water bearing

\begin{tabular}{|r|r}
\hline Thickness & \multicolumn{1}{|l}{ Depth } \\
\hline Feet & \multicolumn{1}{|c}{ Feet } \\
20 & 20 \\
20 & 40 \\
70 & 110 \\
10 & 120 \\
\hline
\end{tabular}

East of Corinth.-No deep wells have been reported from the eastern part of the county, where water in sufficient quantity for ordinary domestic purposes is easily obtained from the Eutaw formation by means of shallow dug or bored wells. Logs of two such wells are given below:

Log of well of W.T. Wilson, 3 miles south by east of Glen, in sec. 12,T. $3 S ., R .8 E$.

\begin{tabular}{|c|c|c|}
\hline & Thickness & Depth \\
\hline $\begin{array}{l}\text { Eutaw formation: } \\
\text { Red clay... } \\
\text { Sand }\end{array}$ & & \\
\hline
\end{tabular}

Log of well of John Hathcock, a quarter of a mile west of Kendrick in sec. 32, T. 1 S., R. $9 \mathrm{E}$.

[Adapted from description by T. T. Watson]

Soil and residuum

Eutaw formation:

Red sand.

Whack loam

\begin{tabular}{|c|c|}
\hline Thickness & Depth \\
\hline Feet $_{10}$ & Feet ${ }_{10}$ \\
\hline $\begin{array}{r}15 \\
8 \\
12\end{array}$ & $\begin{array}{l}25 \\
33 \\
45\end{array}$ \\
\hline
\end{tabular}


Taylor Spring, owned by a corporation, emerges on a hill slope 5 miles east of Corinth; it flows 60 gallons a minute and supplies an artificial lake 40 acres in extent. The water is regarded as possessing certain therapeutic properties and in addition to supplying the lake is used chiefly for drinking. The spring is of historic interest, as according to report it was dug by Federal cavalry who were encamped at this locality during the Civil War. (See analysis 18.)

Kossuth.-Wells which tap a water-bearing stratum in the Eutaw formation at depths of 250 to 350 feet are numerous in the vicinity of Kossuth, a village about 8 miles southwest of Corinth, near the western border of the Selma chalk belt (Nos. 13-16). The following additional information on the ground-water conditions is summarized from a statement furnished by Mr. H. B. Priddy, a well driller who lives at Kossuth. Many wells which range in depth from 270 to 350 feet have been drilled in the Selma chalk belt east of the Pontotoc Hills in Alcorn County. The water-bearing stratum of sand and gravel is 20 to 30 feet thick, and the depth at which it is encountered in any well depends in part upon the altitude of the surface at the well and, as the stratum dips to the west at about 30 feet to the mile, in part upon the distance of the well from the eastern margin of the Selma chalk. A $41 / 2$-inch casing is sunk to a depth of 20 or 30 feet, where it rests securely on a firm chalk foundation; below this depth casing is not needed. The water rises within 70 to 90 feet of the surface on the upland, but in the valley of Tuscumbia River, 4 or 5 miles to the northeast, the artesian pressure is sufficient to cause the water to overflow at a maximum height of about 20 feet above the surface. Force pumps are therefore necessary to lift the water to the surface on the upland, the capacity of the pumps commonly in use being 12 gallons a minute. A log showing the nature and thickness of the materials encountered at Kossuth is given below:

\begin{tabular}{|c|c|c|}
\hline & Thickness & Depth \\
\hline $\begin{array}{l}\text { Sand and clay (residual from the Selma) } \\
\text { Selma chalk: Blue marl } \\
\text { Eutaw formation (Coffee sand member): }\end{array}$ & $\begin{array}{r}\text { Feet } \\
20 \\
230\end{array}$ & $\begin{aligned} & \text { Feet } \\
& 20 \\
& 250\end{aligned}$ \\
\hline $\begin{array}{l}\text { Sand } \\
\text { Fine sand; yields a small quantity of water } \\
\text { Sandstone-y and gravel; water bearing } \\
\text { Coarse sand }\end{array}$ & $\begin{array}{r}2 \\
5 \\
3 \\
30 \\
(?)\end{array}$ & $\begin{array}{l}252 \\
257 \\
260 \\
290 \\
(?)\end{array}$ \\
\hline
\end{tabular}

Wenasoga.-Wells 200 to 300 feet deep, in which the water rises within 20 to 75 feet of the surface, have been drilled in the vicinity of Wenasoga. Although no detailed information has been obtained in regard to these wells, the conditions are essentially the same as at Kossuth, where the water is found beneath the Selma chalk in a bed of sand that belongs to the Eutaw formation. 


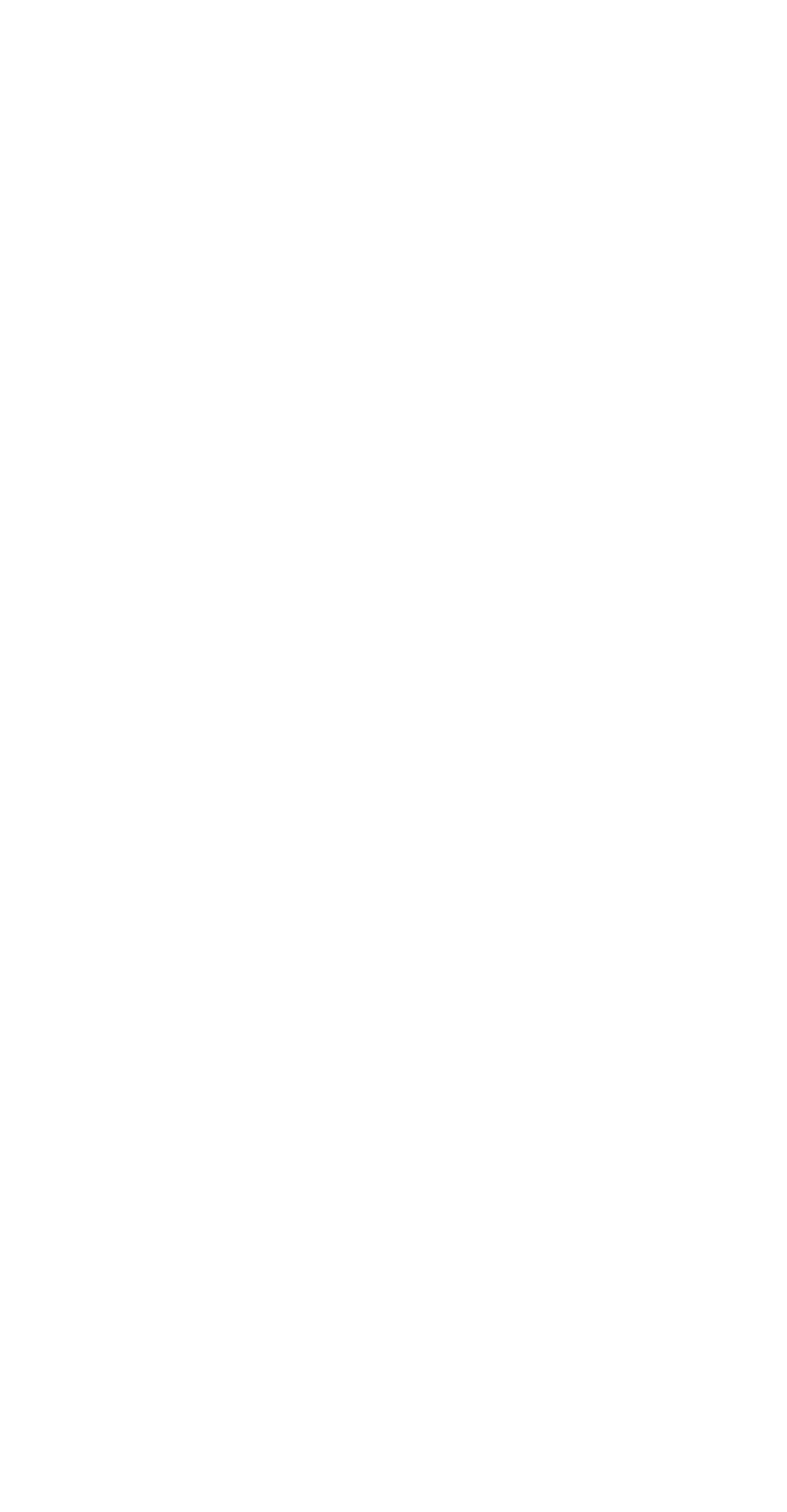




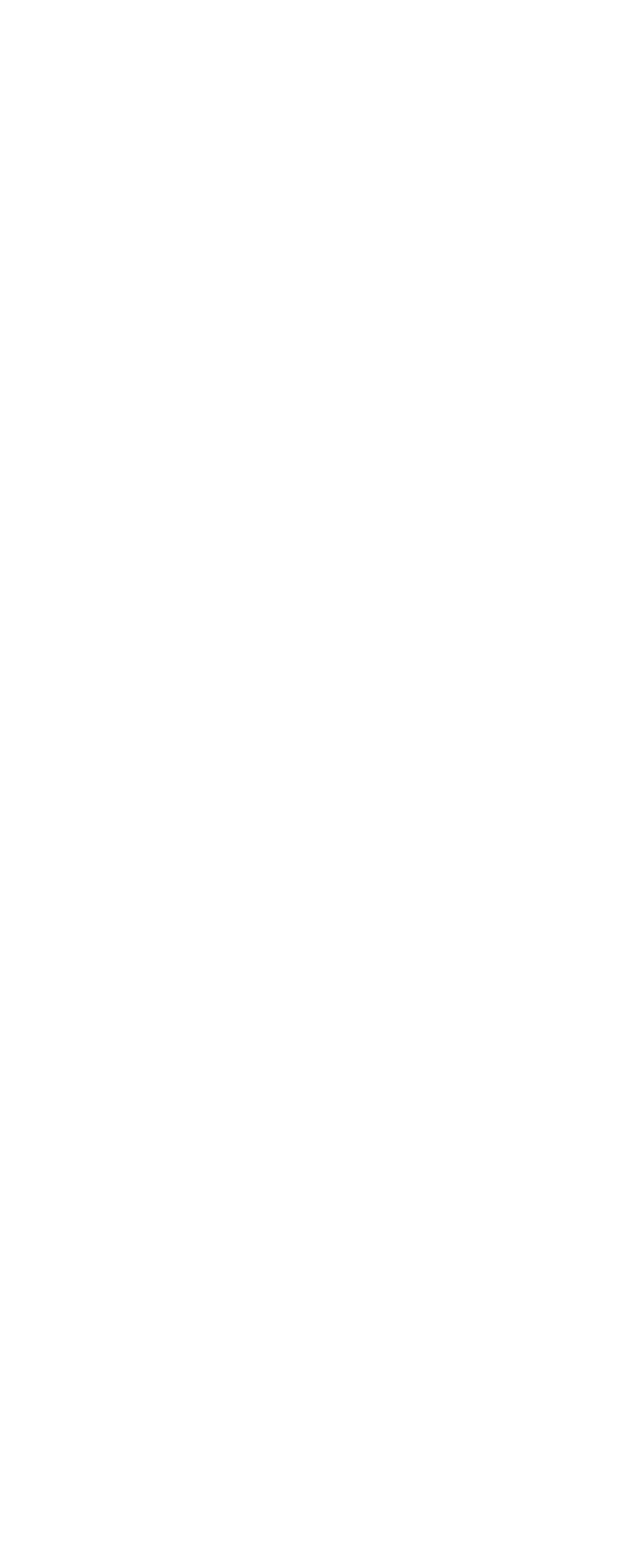


Mineral analyses of ground waters from Alcorn County

[Parts per million. Numbers at head of columns refer to corresponding numbers in preceding table]

\begin{tabular}{|c|c|c|c|c|c|c|c|c|}
\hline & 3 & 4 & 7 & 9 & 12 & 16 & 17 & 18 \\
\hline 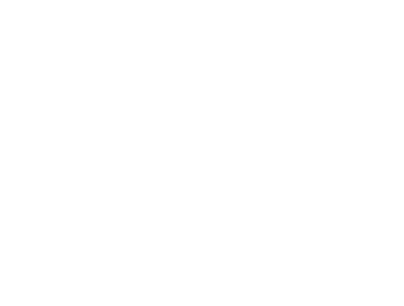 & $\begin{array}{l}20 \\
.62 \\
9.0 \\
2.1 \\
9.1 \\
38.0 \\
8.2 \\
6.0 \\
67.00 \\
31 \\
1914\end{array}$ & $\begin{array}{c}33 \\
3.3 \\
71 \\
4.7 \\
12 \\
165 \\
165 \\
30 \\
35 \\
10 \\
287 \\
197 \\
\text { Apr. } \\
1914\end{array}$ & $\begin{array}{l}28 \\
14.32 \\
9.5 \\
98 \\
13 \\
92 \\
11 \\
117 \\
\text { Trace. } \\
334 \\
74 \\
\text { Sept., } \\
1919\end{array}$ & $\begin{array}{l}31 \\
10 \\
14 \\
3.0 \\
22.0 \\
93.0 \\
7.6 \\
6.1 \\
\text { Trace. } \\
135 \\
47 \\
\text { Sept., } \\
1919\end{array}$ & $\begin{array}{l}18 \\
2.0 \\
12 \\
2.4 \\
12.4 \\
63^{.0} \\
7.6 \\
4.8 \\
92^{\circ} .00 \\
40 \\
\text { May, } \\
1913\end{array}$ & $\begin{array}{l}22 \\
3.1 \\
43 \\
7.6 \\
13 \\
12.0 \\
25 \\
7.5 \\
191^{\circ} \\
139 \\
\text { June } \\
1914\end{array}$ & $\begin{array}{c}11 \\
2.1 \\
2.9 \\
2.8 \\
20 \\
12.0 \\
12 \\
3.9 \\
23 \\
20 \\
107 \\
19 \\
\text { Sept., } \\
1919\end{array}$ & $\begin{array}{c}11 \\
.41 \\
3.3 \\
.8 \\
3.0 \\
12.0 \\
3.0 \\
3.0 \\
31.50 \\
12 \\
\text { Nov.; } \\
1914\end{array}$ \\
\hline
\end{tabular}

- Calculated.

Analysts: 3, 4, 16, W. F. Hand, Mississippi State Chemical Laboratory; 7, 9, 17, Margaret D. Foster, U. S. Geological Survey; 12, 18, Mississippi State Chemical Laboratory.

\section{AMITE COUNTY}

\section{General FeAtures}

Area, 714 square miles. Population, 18,960 (Census of 1920)

Amite County is included in the Long-leaf Pine Hills and lies chiefly within the upper drainage basin of Amite River, whose waters flow into Lake Maurepas, La. The two principal geologic formations that appear at the surface in the county are the Pascagoula clay (Miocene), which is seen only in small outcrops low on the valley - slopes in the north, and the Citronelle formation (Pliocene), which overlies the Pascagoula and which determines the principal topographic and soil characters of the area. These formations are described on pages $57-60$, and their distribution is shown on the geologic map (pl. 2).

\section{GROUND-WATER CONDITIONS}

The developed ground-water supplies of the county, so far as reported, are, with two exceptions (Nos. 4 and 22), derived from the sand and gravel, which, together with subordinate amounts of clay, compose the Citronelle, the formation that immediately underlies practically the whole area. Dug and bored wells, chiefly the latter, which range in depth from 15 to 150 feet, are numerous, and with local exceptions furnish abundant supplies of water that is soft and of a satisfactory quality for domestic and farm uses. Some typical wells are described in the table of well data.

In general the static head of the waters of the Citronelle is low, and in few places does the water rise more than a foot or two higher than the containing stratum. Commonly the wells are bored, and square wooden cribbing is inserted as deep as the top, middle, or bottom of the water-bearing stratum. Such wells are quickly and cheaply constructed, the cost ranging from $\$ 10$ to $\$ 40$ a well. 
An unusual number of wells are reported from this county as showing certain effects produced by varying weather conditions. Some wells are described as "blowing" or "breathing" during times of storm, whereas in others the water becomes milky, muddy, or .irony during unsettled weather. The following table lists the wells reported.

\section{Wells affected by atmospheric conditions in Amite County}

[Based on descriptions given by the owners]

\begin{tabular}{|c|c|c|c|c|}
\hline Location and owner & Depth & $\begin{array}{c}\text { Static } \\
\text { heaci }\end{array}$ & $\begin{array}{l}\text { Lithologic char- } \\
\text { acter of water- } \\
\text { bearing bod }\end{array}$ & Phenomena \\
\hline $\begin{array}{l}\text { Well of Natalbany Lumber Co. } \\
1 / 4 \text { mile north-northwest of Coles } \\
\text { (No. } 4 \text { in table). }\end{array}$ & 136 & -132 & & $\begin{array}{l}\text { During storms water tastes of gas and } \\
\text { is unfit to use until well is cleaned }\end{array}$ \\
\hline $\begin{array}{l}\text { Well of J. T. Leake, } 1 / 2 \text { mile south- } \\
\text { west of Coles. }\end{array}$ & 32 & -28 & & $\begin{array}{l}\text { Becomes muddy during rainy weath- } \\
\text { er. }\end{array}$ \\
\hline $\begin{array}{l}\text { Well of J. N. MeDowell near } \\
\text { Coles, in SW. 1/4 sec. 32, T. } 4 \text { N., } \\
\text { R. } 2 \text { E. (No. 5). }\end{array}$ & 80 & -62 & Gravel... & $\begin{array}{l}\text { Becomes irony at times when wind } \\
\text { is rough. }\end{array}$ \\
\hline $\begin{array}{l}\text { Well of W.J. Little, } 6 \text { miles south } \\
\text { of Liberty (No. 12). }\end{array}$ & 50 & & $\begin{array}{l}\text { Aravel composed } \\
\text { of black peb- } \\
\text { bles. }\end{array}$ & $\begin{array}{l}\text { Beeomes milky. "We have had } \\
\text { about one week of cloudy weather } \\
\text { and we can hear the well roaring at } \\
\text { a distance of about } 35 \text { feet." (Nov., } \\
\text { 1911.) }\end{array}$ \\
\hline $\begin{array}{l}\text { Well of J. A. White, } 12 \text { miles } \\
\text { north of Liberty (No. 13): } \\
\text { abandoned. }\end{array}$ & & & $\begin{array}{l}\text { Quicksand and } \\
\text { gravel. }\end{array}$ & $\begin{array}{l}\text { During rains or stormy weather well } \\
\text { would roar and blow mud } 2 \text { or } 3 \text { feet } \\
\text { above its mouth. }\end{array}$ \\
\hline $\begin{array}{l}\text { Well of J. E. Felder, } 1 / 4 \text { mile north } \\
\text { of Peoria (No. 19). }\end{array}$ & 33 & -29 & Gravel.......... & $\begin{array}{l}\text { Beeomes muddy during rain or wind } \\
\text { storms. }\end{array}$ \\
\hline $\begin{array}{l}\text { Well of E. J. Gerald, } 2 \text { miles west } \\
\text { of Smithdale (No. 21). }\end{array}$ & 70 & -58 & Yellow grevel.... & $\begin{array}{l}\text { Blows considersbly and becomes } \\
\text { milky during rainy weather. }\end{array}$ \\
\hline
\end{tabular}

Two blowing wells have been reported from Pike, the adjoining county on the east. (See p. 387.) The cause of blowing wells and. related phenomena in Mississippi is discussed on pages 19-20.

Springs of small to moderate yield, generally not exceeding 10 gallons a minute, which have their source in the sands and gravels of the Citronelle formation, occur particularly in the more hilly areas in the central and western parts of the county. The springs occur chiefly near the base of the slopes of the deeper branch and creek valleys, which have been cut slightly below the level of the water table: According to the reports, the waters of the springs are generally soft and of good quality, though a fow are described as irony, sulphurous, or hard.

With the exception of two wells (Nos. 4 and 22 in the table), none of the wells reported from the county have been drilled through the Citronelle formation into any of the underlying older formations, which include, in descending order, the Pascagoula clay (Miocene), the Hattiesburg clay (Miocene), and the Catahoula sandstone (Miocene). Of these the Pascagoula and Hattiesburg contain some interbedded layers of water-bearing sand. The Catahoula sandstone, which is a valuable aquifer in some of the counties to the north, is estimated to lie at depths of 900 to 1,500 feet in the northern part of Amite County, and several hundred feet deeper in the southern part of the county. The more porous sands of the formation may be 
regarded as a possible, through as yet untested source of water supply. The static level of the Catahoula waters may be high enough to produce flows at the surface, in wells that are low in the valleys of some of the larger headwater tributaries of Amite River.

\section{LOCAL SUPPLIES}

Gloster.-The town of Gloster has constructed a waterworks in a shallow branch valley half a block west of the Yazoo \& Mississippi Valley Railroad station and obtains water from a 78-foot well (No. 8) that has its source in the Citronelle formation. A 100-foot well, 18 inches in diameter (No. 9), is kept in condition as a reserve supply.

Liberty.-On the low ridge on which the town of Liberty is built water is obtained chiefly by means of bored wells about 70 feet deep (No. 10). Analysis 11 represents a sample of water from J. L. Jacobs's well. The water-bearing strabum tapped by the wells in the town crops out along the base of the westward-facing slope of Tan Yard Creek west of town and is marked by a line of seeps and springs.

Coles.-Two wells near Coles are described in the table (Nos. 4, 5) and the logs of two typical wells are given below.

Log of well of J. N. McDowell, at Coles, in SW. 1/4 sec. 32, T. 4 N., R. Z E.

[Authority, the owner]

\begin{tabular}{l|r|r}
\hline & Thickness & Depth \\
\hline $\begin{array}{l}\text { Oitronelle formation: } \\
\text { Clay }\end{array}$ & Feet & Feet \\
Gravel & 4 \\
Band and gravel & & 1 \\
Blue clay; well stopped on water-bearing gravel & 16 \\
\end{tabular}

Log of well of J.T. Leake, one-half mile southwest of Coles

[Authority, the owner]

\begin{tabular}{|c|c|c|}
\hline & Thickness & Depth \\
\hline $\begin{array}{l}\text { Oitronelle formation: } \\
\text { Red clay- }\end{array}$ & & \\
\hline $\begin{array}{l}\text { Pipe clay } \\
\text { Gravel } \\
\text { Quicksand; water bearing }\end{array}$ & $\begin{array}{r}4 \\
18 \\
4\end{array}$ & $\begin{array}{l}\mathbf{1 0} \\
\mathbf{2 8} \\
\mathbf{3 2}\end{array}$ \\
\hline
\end{tabular}

Stephenson.-The inhabitants at Stephenson, a lumber-mill community 2 miles west of Coles, are supplied with water for domestic use from a well 280 feet deep (No. 22) that is owned by the Foster Creek Lumber \& Manufacturing Co.

Bewelcome.-Wells in the vicinity of Bewelcome range in depth from 60 to more than 100 feet. One of the deeper wells is described in the table of well data (No. 3), and a log of the well is given below. 
Log of well of T. F. Randall, 5 miles north of Bewelcome, in NE. 1/4 NW. 1/4 sec. 34, T. 4 N., R. 3 E.

[Authority, the owner]

\begin{tabular}{l|r|r}
\hline & Thickness & Depth \\
\hline $\begin{array}{l}\text { Citronelle formation: } \\
\text { Clay and sand, mixed..... Feet }\end{array}$ & Feet \\
$\quad \begin{aligned} 52 \\
\text { Quicksand, with small pebbles ai base; water bearing }\end{aligned}$ \\
\hline
\end{tabular}

Woodmen Springs.-Among the hills 3 miles north of Gloster, in sec: 9 , T. 3 N., R. 2 E., lies a group of springs known as Woodmen Springs. Some of the springs are reputed to possess therapeutic qualities. The place was formerly conducted as a health and pleasure resort under the auspices of the Order of the Woodmen of the World. There are reported to be more than 50 small springs at the foot of the slopes within a radius of one-half mile of the hotel. A sample of water from a spring at the base of the slope east of the hotel and about 75 feet below the crest of the hill on which the hotel stands was analyzed (No. 24). 


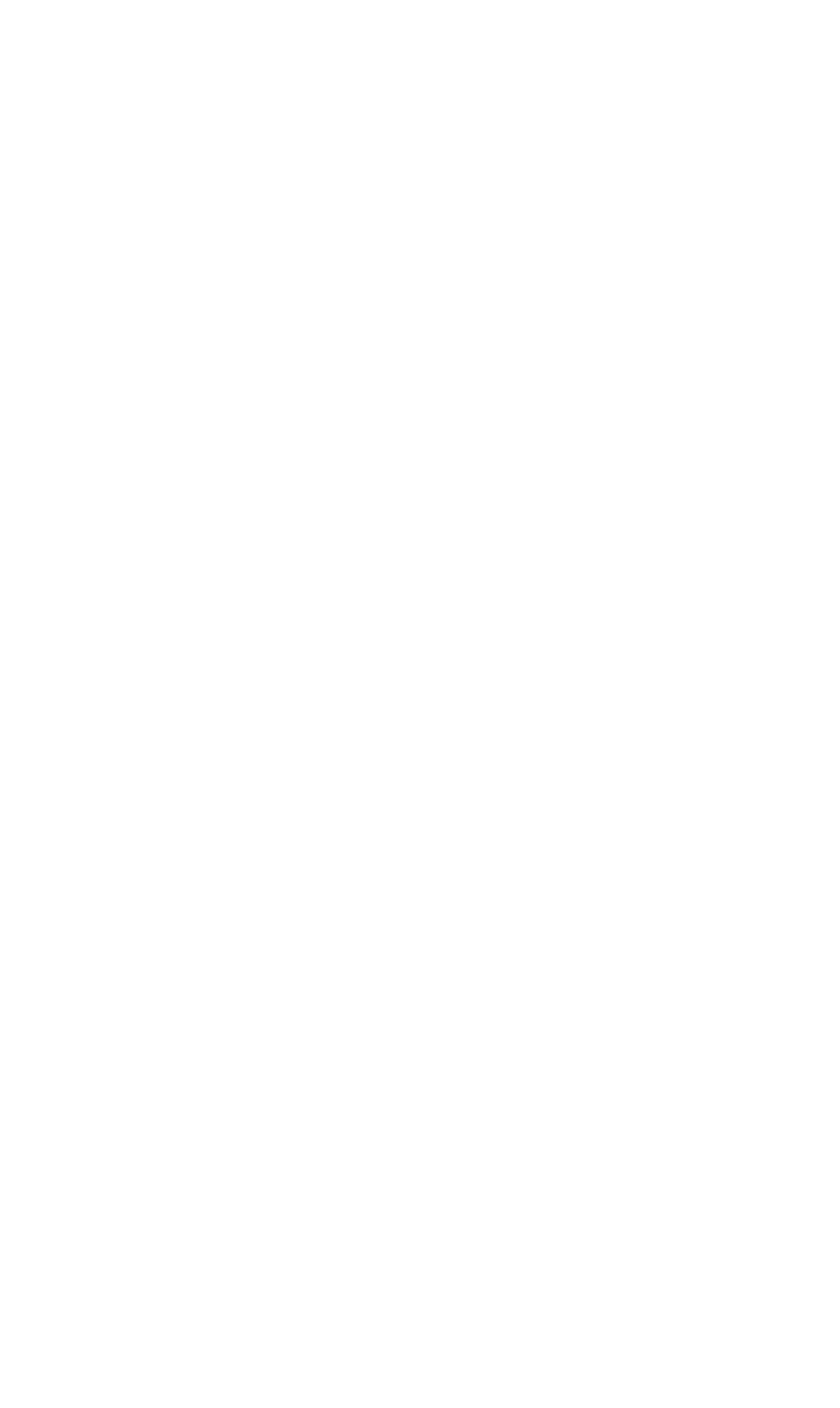




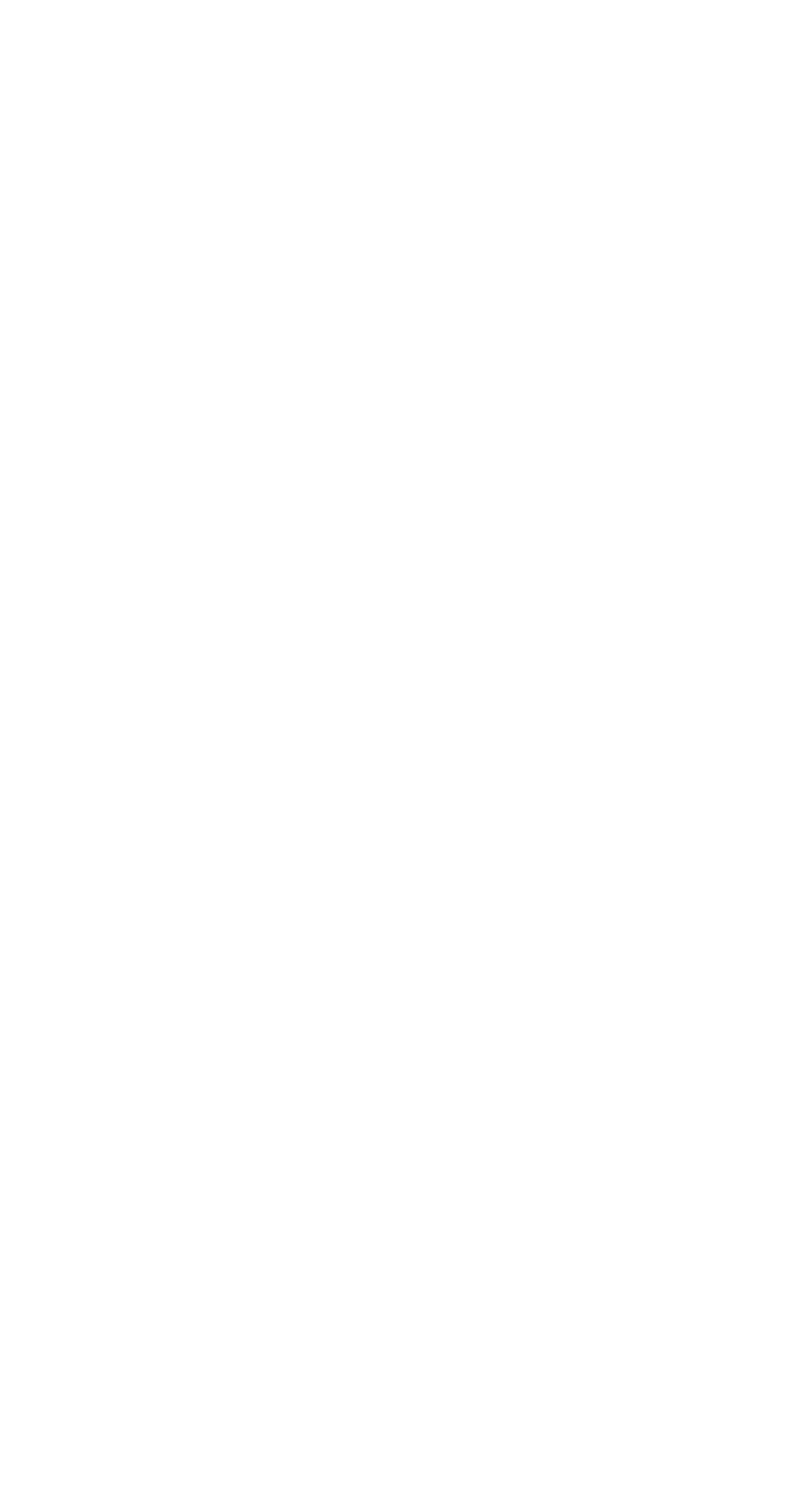




\section{Mineral analyses of ground waters from Amite County}

[Parts per million. Samples collected July 5, 1919. Numbers at heads of columns refer to corresponding well and spring numbers in precoding table]

\begin{tabular}{|c|c|c|c|}
\hline & 8 & 10 & 24 \\
\hline 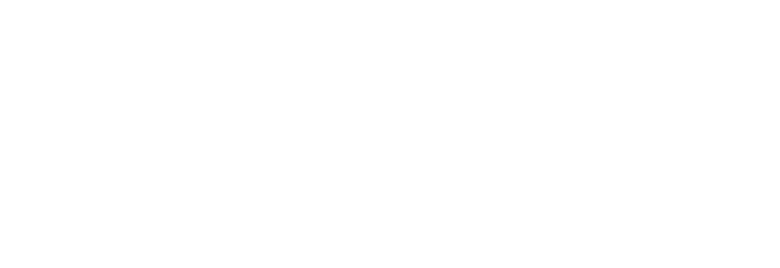 & $\begin{array}{l}16 \\
2.04 \\
1.5 \\
20.4 \\
.0 \\
32.0 \\
2.9 \\
9.8 \\
64.0 \\
74 \\
12\end{array}$ & $\begin{array}{r}12 \\
1.78 \\
1.8 \\
.6 \\
6.9 \\
15.0 \\
1.6 \\
4.9 \\
1.3 \\
38 \\
7\end{array}$ & $\begin{array}{r}16 \\
2.08 \\
-11^{.7} \\
2.0 \\
28 \\
3.4 \\
.4 .5 \\
1.6 \\
63 \\
10\end{array}$ \\
\hline
\end{tabular}

- Calculated.

Analysts: 8, Margaret D. Foster, U. S. Geclogical Survey; 10, 24, Addie T. Geiger, U. S. Geological. Survey.

\section{ATTALA COUNTT \\ GENERAL FEATURES}

Area, 715 square miles. Population, 24,831 (census of 1920)

Attala County is included within the physiographic division known as the North Central Hills. Most of the surface of the county is underlain by sedimentary materials belonging to the Tallahatta formation and the overlying Lisbon formation (including the Winona sand and Kosciusko sandstone member), both of which belong to the Claiborne group. In a small area in the northeast the Holly Springs sand of the Wilcox group forms the surficial covering. The principal streams are bordered by lowlands 1 to 2 miles in width, and here alluvium covers the older, more consolidated deposits. Descriptions of these formations are given on pages 46-50, and their distribution is shown on the geologic map (pl. 2).

\section{GROUND-WATER CONDITIONS}

All the formations contain sandy water-bearing beds, but the Holly Springs and Winona sands are the principal water-bearing formations. The water-bearing strata dip to the southwest at the rate of 20 or 25 feet to the mile.

The Wilcox group, which underlies the Tallahatta formation and is thought to be 1,000 feet thick, contains numerous water-bearing sands. It crops out in a relatively small area in the extreme northe ast and dips gently to the southwest. This group is therefore a promising source of water supply throughout the area, though it is most accessible and most used in the northeast, where it comes to or near the surface.

Springs issue at several places along the base of the Winona sand, and the spring 4 miles northwest of $\mathrm{McCool}$ is typical. This spring yields slightly sulphureted water of good quality at the rate of 2 gallons a minute.

On the higher lands, between the streams, water is obtained from shallow wells, driven or dug in the surficial portions of the several 
formations. The 18-foot well of Jeff Sills (No. 12), 4 miles northwest of Kosciusko, is typical of this class of wells, except that it yields a more highly mineralized water than most of the shallow wells; this water has been sold locally as a mineral water. Drilled wells on the upland generally yield water of better quality than that of the shallow wells.

On the hills along the southern border of the county water is commonly obtained by means of drilled wells about 100 feet deep. In a 120-foot well, which taps the upper or typical beds of the Lisbon formation (No. 19), on a slope 3 miles west of McVille, water stands at a depth of 108 feet. Near McVille W. E. Rickets has a similar but shallower well, and farther east, near Center, wells (Nos. 1 and 2) penetrate the Winona sand member of the Lisbon formation to depths of somewhat less than 100 feet.

In the northwest, along Big Black River, shallow water of only fair quality is obtained from wells sunk in the alluvium. Deeper drilled wells draw chiefly from the Lisbon formation, but well 21 struck solid rock, probably a hard layer in the Winona sand member of the Lisbon, beneath which an artesian flow was obtained.

\section{LOCAL SUPPLIES}

Kosciusko.-At Kosciusko, good supplies of water are obtained, at depths of 200 to 325 feet, in part in the Winona sand, and in part in the upper portion of the Holly Springs sand. One well (No. 9) has been sunk much deeper into the Holly Springs sand. The character of the strata penetrated is shown by the logs of this well and one of the wells at the water-works (No.4), below. The municipal waterworks is half a block west of the courthouse square, and water is obtained from two wells, each 307 feet deep (Nos. 4, 5), at the plant on ground about 15 feet lower than the top of the hill at the courthouse. (See analysis 4.)

Log of well of Kosciusko Cotton Mill (No. 9)

\begin{tabular}{|c|c|c|c|c|c|}
\hline & $\begin{array}{c}\text { Thick- } \\
\text { ness }\end{array}$ & $\begin{array}{l}\text { Ap- } \\
\text { proxi- } \\
\text { mate } \\
\text { depth }\end{array}$ & & $\underset{\text { ness }}{\text { Thick }}$ & $\begin{array}{c}\text { Ap- } \\
\text { proxi- } \\
\text { mate } \\
\text { depth }\end{array}$ \\
\hline 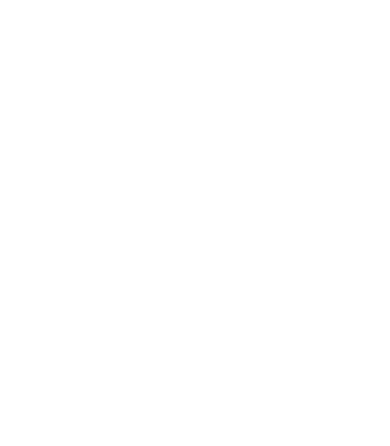 & $\begin{array}{c}\text { Feet } \\
50 \\
8 \\
10 \\
10 \\
1 / 4 \\
25 \\
1 \\
1 \\
50 \\
1 / 4 \\
1 \\
82 \\
20 \\
7 \\
3 \\
3 \\
17 \\
10\end{array}$ & $\begin{array}{r}\text { Feet } \\
50 \\
58 \\
68 \\
78 \\
78 \\
103 \\
104 \\
105 \\
155 \\
155 \\
156 \\
238 \\
258 \\
265 \\
266 \\
269 \\
286 \\
296\end{array}$ & 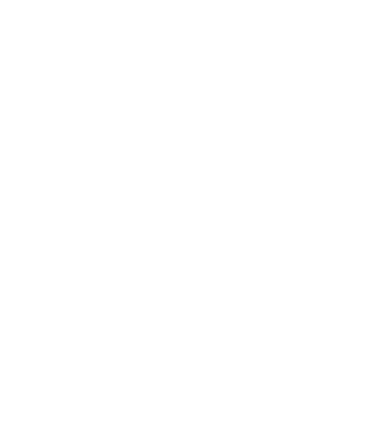 & $\begin{array}{r}\text { Feet } \\
4 \\
7 \\
4 \\
4 \\
83 \\
20 \\
20 \\
56 \\
45 \\
1 \\
12 \\
76 \\
4 \\
24 \\
68 \\
3 \\
16 \\
25\end{array}$ & $\begin{array}{c}\text { Feet } \\
300 \\
307 \\
311 \\
320 \\
320 \\
403 \\
423 \\
479 \\
524 \\
525 \\
537 \\
613 \\
617 \\
641 \\
709 \\
712 \\
722 \\
755\end{array}$ \\
\hline
\end{tabular}


Log of well at waterworks, Kosciusko (No. 4)

\begin{tabular}{|c|c|c|c|c|c|}
\hline & $\begin{array}{l}\text { Thick- } \\
\text { ness }\end{array}$ & Depth & & $\underset{\text { Thicks }}{\text { Thick }}$ & Depth \\
\hline 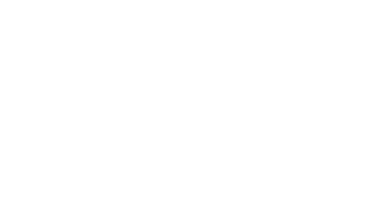 & $\begin{array}{r}\text { Feet } \\
\\
30 \\
10 \\
25 \\
25 \\
60 \\
5\end{array}$ & $\begin{array}{r}\text { Feet } \\
\\
30 \\
40 \\
65 \\
90 \\
150 \\
155\end{array}$ & 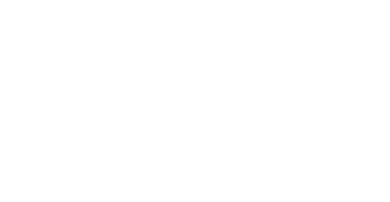 & \begin{tabular}{r|} 
Feet \\
\\
40 \\
50 \\
30
\end{tabular} & $\begin{array}{r}\text { Feet } \\
\\
\quad \begin{array}{l}195 \\
245 \\
275\end{array}\end{array}$ \\
\hline
\end{tabular}

The character of the water obtained at Kosciusko is shown by analyses 4 and 6 . The waters from the deeper wells (see table, pp. 84-85) probably come from the Holly Springs sand, whereas those from the shallower wells come from the lisbon formation, chiefly the Winona sand member. A good supply is furnished by a well 191 feet deep, drilled on the Gilliland place, 2 miles north of Kosciusko, in the bottom of an abandoned quarry, where road metal has been obtained from hard ledges of the Kosciusko sand member of the Lisbon formation. The following $\log$ of this well is available:

Log of well on Gilliland place, 2 miles north of Kosciusko (No. 11)

\begin{tabular}{|c|c|c|}
\hline & Thickness & Depth \\
\hline $\begin{array}{l}\text { Lisbon formation: } \\
\text { Red clay (started drilling below the outcropping ledge of rock in the quarry) } \\
\text { Gray coarse-grained sandstone, slightly glauconitic } \\
\text { Clay and red sand with numerous rock layers } \\
\text { Gray sand. } \\
\text { Black "muck" (lignitic clay?) } \\
\text { Coarse white sand (Winona sand member), water bearing. }\end{array}$ & Feet $\begin{array}{r}24 \\
4 \\
60 \\
20 \\
39 \\
44\end{array}$ & $\begin{array}{r}\text { Feet } \\
24 \\
28 \\
88 \\
108 \\
147 \\
191\end{array}$ \\
\hline
\end{tabular}

McCool--At McCool wells are sunk below the river alluvium into the Holly Springs formation, in which good supplies of water are obtained in sands at depths of 60 to 200 feet or more. The B. L. Black, Fancher, Turnipseed, and M. L. Black wells (Nos. 14 to 18 ) are typical.

Ethel.-The town of Ethel, in the valley of Yokahockany River in the eastern part of the county, owns a public well (No. 3) 105 feet deep, which probably enters a water-bearing bed in the upper part of the Holly Springs sand. Hard rock was encountered at a depth of 50 to 58 feet, and good water was found at a depth of 100 feet in white sand. Water was also encountered in this well in alluvium bordering the river at depths of 18 and 35 feet. Three other drilled wells, each about 100 feet deep, and several dug or driven wells, 20 feet or less in depth, have been reported.

Sallis.-At Sallis, near the western border of the county, on a tributary of Big Black River, the town supply is furnished by a flowing well (No. 22), 235 feet deep, which probably taps a waterbearing bed in the Winona sand. Six other flowing wells, each about 200 feet deep, have been reported, and several other flowing wells are said to have been obtained along the stream valley within a distance of 5 miles to the east and to the west. 


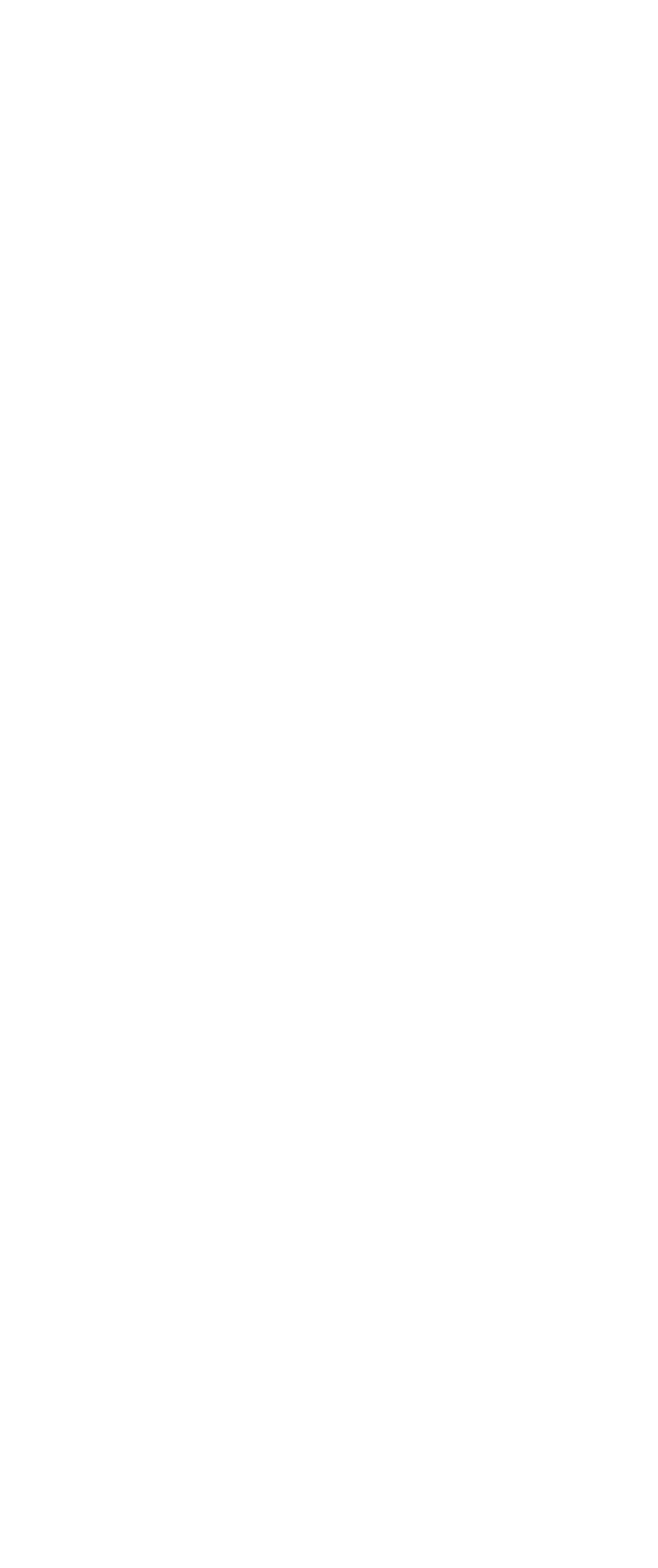




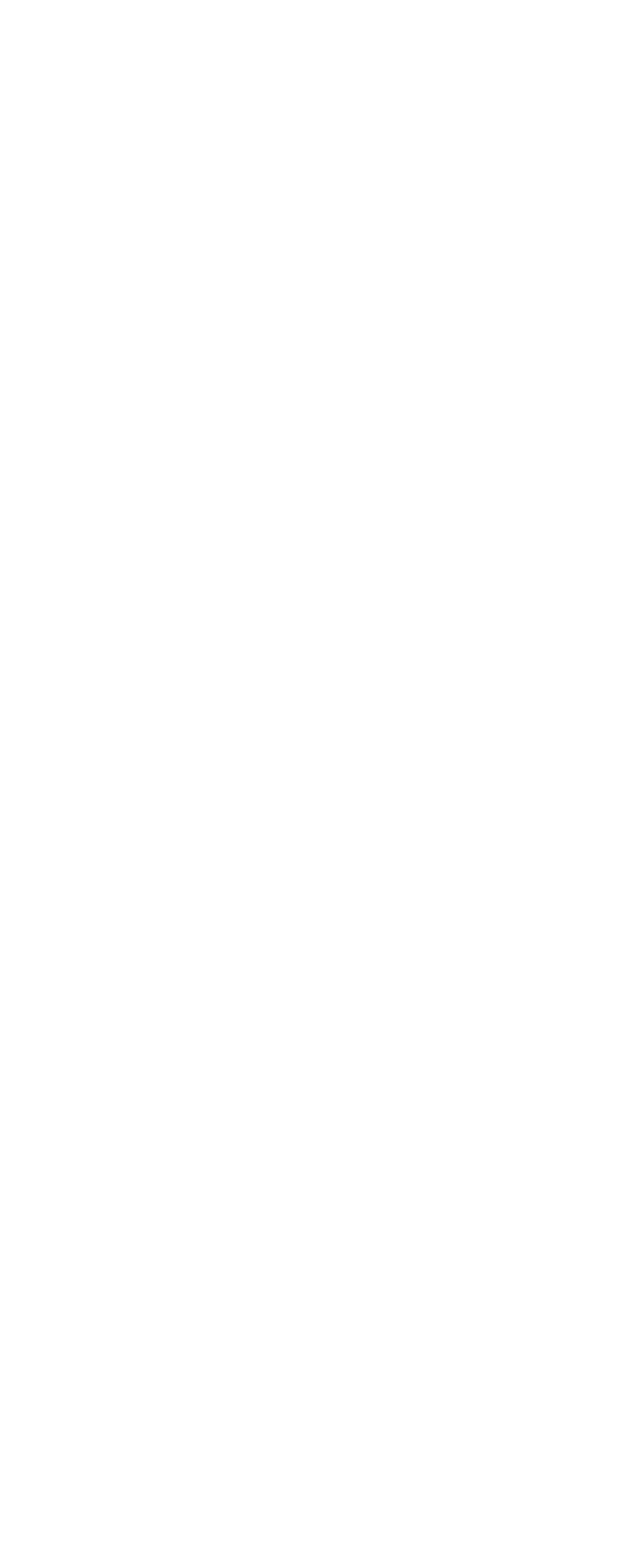




\section{Mineral analyses of ground waters from Attala County}

[Parts per million. Samples collected Feb. 7, 1921; analyzed by C. S. Howard, U. S. Geological Surveg* Numbers at heads of columns refer to corresponding well numbers in preceding table]

\begin{tabular}{|c|c|c|}
\hline . & 4 & 6 \\
\hline 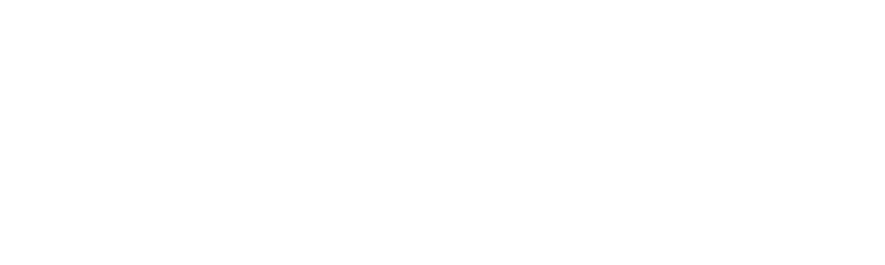 & $\begin{array}{l}57 \\
2.3 \\
21 \\
5.8 \\
9.2 \\
.0 \\
87 \\
15 \\
5.0 \\
\text { Trace. } \\
161 \\
76\end{array}$ & $\begin{array}{c}42 \\
13.17 \\
13 \\
5.6 \\
9.8 \\
.0 \\
71 \\
12 \\
2.0 \\
\text { Trace. } \\
114 \\
55\end{array}$ \\
\hline
\end{tabular}

\section{BENTON COUNTY}

GENERAL FEATURES

Area, 396 square miles. Population, 9,851 (census of 1920)

Benton County lies in the northern part of the North Central Hills district. The county is underlain chiefly by the Ackerman formation and the Holly Springs sand - the two lowermost formations of the Wilcox group of the Eocene. These formations are described on pages $45-47$, and their distribution is shown on the geologic map (pl. 2). The Porters Creek clay, the uppermost formation of the Midway group of the Eocene, closely underlies the Ackerman formation in the east; the main belt of outcrop of the Porters Creek is in western Tippah County, but a narrow strip in southeastern Benton County appears to be included in this belt.

\section{GROUND-WATER CONDITIONS}

The strata that compose the Eocene formations mentioned above dip to the west at the rate of 20 or 25 feet to the mile and afford conditions favorable to the development of artesian pressure in the waters contained in their westward buried extensions. However, both the Porters Creek formation and the lower part of the Ackerman formation are dominantly composed of clay, and it is doubtful if they contain sandy beds suitable to serve as reservoirs for large or perhaps even for moderately large quantities of water. Flowing wells are therefore scarcely to be expected from them.

The upper part of the Ackerman formation contains sandy beds, which are probably water bearing, and the coarse sands which largely compose the Holly Springs formation carry abundant quantities of water. Both these formations probably lie too high in the hills to afford flowing wells in Benton County, but they are the sources of the domestic and farm supplies obtained by means of shallow dug and bored wells throughout the greater part of the area. Many springs also flow from the sands of these formations where they crop out on the slopes. 
The sandy beds of the Clayton, the 'lowermost formation of the Midway group of the Eocene, and similar sands which in part compose the Ripley, the uppermost formation of the Upper Cretaceous are possible sources of flowing artesian water in the valleys of Wolf River and Tippah Creek in Benton County. These formations crop out in Tippah County (see geologic map, pl. 2), where they dip to the west at a low angle and pass out under Benton County. The water-bearing sands of the Ripley formation are estimated to lie at depths of 500 to 800 feet in the valley of Tippah Creek in Benton County. A 600-foot well at Hickory Flat, in Benton County, and a 718-foot well at Potts Camp, just across the line in Marshall County, both in the valley of Ocklimetah Creek, probably reach the Ripley. At Michigan City the Ripley would probably be entered at a depth of 600 to 800 feet. The sands of the Clayton formation would be reached at a shallower depth than those of the Ripley. A flowing well 160 feet deep, owned by H. A. Stubbs, in the valley of Tippah Creek, 8 miles southeast of Ashland, probably has its source in the Clayton formation.

\section{LOCAL SUPPLIES}

Michigan City.-At Michigan City domestic supplies are obtained chiefly from the Holly Springs sand by means of wells 30 to 60 feet deep. The Illinois Central Railroad owns a small plant at this place, which pumps water from Wolf River for use in the boilers of locomotives.

Lamar.-At Lamar bored wells 75 or 80 feet deep enter the Holly Springs sand and yield satisfactory domestic supplies. A dug well only 20 feet deep, owned by Steve Dowdy, in a small stream valley 3 miles west of Lamar, is said to emit a small stream at times, though the static head may be as much as 3 feet below the surface at other times. The well probably taps a westward-dipping water-bearing sand whose intake is at a higher level on the hills within a few miles to the east.

Maxwell.-The 100-foot well of J. S. Maxwell, 30 yards west of the post office at Maxwell, penetrated water-bearing sands in the Holly Springs formation at several levels between depths of 50 and 100 feet. The largest quantities come from the deeper sands.

Canaan.-At Canaan the domestic water supplies are obtained from wells 50 to 125 feet deep. In the shallower wells the source of the water is the sands of the Holly Springs formation, but the deeper wells probably pass through the Holly Springs formation into the underlying Ackerman formation. A 55-foot well owned by L. Benton, a mile east of Canaan, is typical. There are several springs in this vicinity, of which one, owned by J. C. Hicks, half a mile east of Canaan, is typical. These springs yield small quantities of good water. 
Ashland.-At Ashland water is obtained chiefly from shallow wells that have their source in the Holly Springs sand. The 160 -foot well at the courthouse at Ashland probably has its source in the Ackerman formation, as has also the 150 -foot well of A. J. Simpson, 100 yards east of the post office, in the SW. 1/4 sec. $11, T: 3 \mathrm{~S}$, R. $1 \mathrm{E}$. Water from the courthouse well is soft, as is shown by analysis.

Hickory Flat.-In the narrow lowland of Ocklimetah Creek at Hickory Flat dug or driven wells, 40 to 70 feet deep, yield fair supplies. A well owned by the town, 100 feet north of the St. Louis \& San Francisco Railroad, dug in 1893, is 30 feet deep and is cribbed with terra-cotta pipe. The water is raised by hand and is used for public drinking. (See analysis 2.) Other somewhat deeper wells have been drilled here, but apparently they enter the clay that forms the base of the Ackerman formation and the underlying Porters Creek clay, and do not yield satisfactory supplies. However, one 600-foot well drilled in 1900 on the property of J. T. Crawford, in the SW.1/4 sec. 27 , T. 5 S., R. 1 E., penetrates a water-bearing sand, probably in the Ripley formation of the Cretaceous, at a depth of 490 to 500 feet and yields by pumping 60 gallons a minute. In this well 4 -inch casing extends to a depth of 200 feet, and 2-inch casing extends to the waterbearing sand. The static head is 15 feet below the surface. The well cost $\$ 600$, and the water is rather hard but is used for domestic supplies, for stock, and for boilers. (See analysis 3.)

Mineral analyses of ground waters from Benton County

[Parts per million. For further data regarding these wells see text]

\begin{tabular}{|c|c|c|c|}
\hline & 1 & 2 & 3 \\
\hline 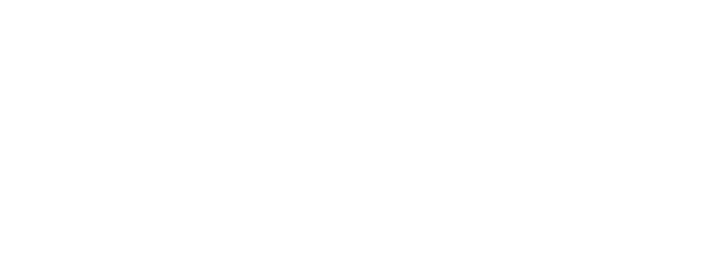 & \begin{tabular}{c|}
13 \\
2.41 \\
2.7 \\
1.6 \\
9.5 \\
30.0 \\
6.6 \\
2.7 \\
53 \\
13 \\
June, 1914
\end{tabular} & $\begin{array}{l}26 \\
.05 \\
3.3 \\
32.7 \\
68^{.0} \\
3.7 \\
31.0 \\
4.0 \\
159 \\
28 \\
\text { Sept., } 1919\end{array}$ & $\begin{array}{l}38 \\
33 \\
11 \\
28 \\
209 \\
15 \\
2.0 \\
6.0 \\
245 \\
128 \\
\text { Nov., } 1911\end{array}$ \\
\hline
\end{tabular}

- Includes iron and aluminum ( $\mathrm{Fe}+\mathrm{Al})$.

- Calculated.

Analysts: 1, W. F. Hand, Mississippi State Chemical Laboratory; 2, C. S. Howard, U. S. Geological Survey; 3, W. L. Perdue, University of Mississippi.

1. Courthouse well, 160 feet deep, at Ashland.

2. Dug town well, 30 feet deep, at Hickory Flat.

3. Drilled well, 600 feet deep, of J. T. Crawford, at Hickory Flat.

\section{BOLIVAR COUNTY}

GENERAL FEATURES

Area, 879 square miles. Population, 57,669 (census of 1920)

Bolivar County lies in the Yazoo Delta. The surface is underlain by alluvial deposits that have an estimated thickness of 150 or 200 feet and the alluvium is underlain by a thick series of interbedded 
clays and sands which belong in deocending succession to the Claibone, Wiloox, and Midway groups of the Eocene.

\section{GROUND-WATER COIDITIONS}

Water in great quantity but under little or no artesian head is contained in the more porous sands and gravels of the alluvitum that underlies the county to a depth of 150 or 200 feet. This water is easily obtainable by means of bored and driven wells that are equipped with ropes and buckets or with pumps. At most places the water table lies within easy reach of suction pumps. Locally the shallow water has been rendered more or less objectionable for domestic use by coloring matter derived from buried vegetation.

The thick series of Eocene sands and clays that underlies the alluvium includes porous sands, the waters of which are under sufficient artesian head to yield flows anywhere in the county. The highest static head recorded is that of the 1,250-foot well owned by the town of Duncan, the water of which, if confined, will rise to a height of 70 feet above the surface. The flowing wells of the county range in depth from 300 to 1,700 feet. They have their source in the Claiborne and Wilcox groups of the Eocene, but it is not possible by means of the available data to determine with exactness the positions of the boumdaries that separate the different formations of these groups. In the table on pages 93-94 a rough attempt has been made to determine the formations from which the wells draw their water, but these correlations must be regarded as only tentative.

\section{LOCAL SUPPLIES}

Round Lake and vicinity. - The character of the water of shallow wells in the northwest is shown by the analyses of samples from driven wells (Nos. 16 and 10) at Round Lake and at the village of Francis, 2 miles north of Round Lake.

Duncan.-The town of Duean owns a strongly flowing artesian well 1,250 feet deep (No. 9), which probably completely penetrates the Claiborne group and enters the upper part of the Wilcox group. On the Boughman plantation, near Duncan, water is obtained from sandy layers in the alluvium by means of 32 driven wells 20 to 60 foet deop, equipped with pitcher pumps, and 3 drilled wells 84 to 86 foet deep.

Gunnison.-The principal part of the municipal water supply at Guninison is furnished by a 1,750-foot flowing well three and a half blocks southenst of the Yazoo \& Mississippi Valley Railroad station (No. 12). A well owned by J. J. McGowan, depth not.stated, supplies manufacturing needs and also the household requirements of about, 400 people.

$54134-28-7$ 
Shelby.-The town of Shelby owns a waterworks a quarter of a mile southwest of the Yazoo \& Mississippi Valley Railroad station: The water supply is obtained from two wells (Nos. 20 and 21), one of which is 1,565 feet deep and flows 250 gallons a minute and the other is a nonflowing well that is reported to be approximately 800 feet deep. A 1,582-foot well that was formerly used as a municipal supply has been abandoned. Analyses of samples of water from this well and the two wells now in use are given in the tables (Nos. 20, 21, 22). In a 1,045-foot flowing well (No. 22), about 3 miles east of Shelby, the principal water-bearing sand is reported to have been encountered at a depth of 915 feet. (See analysis 22.)

Rosedale.-The waterworks at Rosedale is owned by the town and is two blocks west of the courthouse. The water supply is obtained from a nonflowing well 316 feet deep (No. 15), which is equipped for pumping either with a deep-well pump or with an air compressor.

Beulah and vicinity.-The town of Beulah owns a flowing well 1,760 feet deep (No. 4), which provides the municipal supply. The static head of the well is 40 feet above the surface, and when flowing freely it yields at the rate of 80 gallons a minute. There are several wells at Beulah that range in depth from 350 to 530 feet, but detailed information is wanting. Bellisle, 4 miles southwest of Beulah, and Lobdell, 6 miles south of Beulah, obtain their domestic water supplies. chiefly from the alluvium by means of driven and dug wells.

Mound City.-At Mound City, 5 miles southeast of Beulah, the dug well of V.R. Young (No. 14) is 40 feet deep, and the water stands within about 35 feet of the surface.

Mound Bayou.-A public well at Mound Bayou (No. 13) is 1,150 feet deep and yields a moderate flow of water, which probably comes from the upper part of the Wilcox group at a depth of 1,030 to 1,050 feet. (See analysis 13.)

Cleveland. - The principal part of the water supply at Cleveland is furnished by a flowing well that is reported somewhat questionably to be about 1,500 feet deep (No. 8). It is at the waterworks about 400 feet north of the Yazoo \& Mississippi Valley Railroad station. An old well, said to be about 1,000 feet deep (No. 7), furnishes only a subordinate part of the supply. (See analysis 7.)

Merigold.-At Merigold domestic water supplies are afforded by three flowing wells the depths of which are not recorded. The source of the water may be the lower part of the Claiborne group. The wells are directly connected with mains that have a total length of $11 / 2$ miles, by which the artesian pressure is utilized in distributing the water to the consumers.

Boyle.-The municipal water supply at Boyle is afforded by a well 1,555 feet deep (No. 5 ), which is estimated to yield about 225 gallons a minute when allowed to flow freely. The water is under a strong 
artesian head ind is distributed through a system of mains and pipes by means of the natural pressuré. The source of the water is believed ' to be the Wilcox group. The well of L. C. Taylor at Boyle (No. 6) is 1,000 feet deep and yields a strong artesian flow which questionably has its source in the lower part of the Claiborne group.

Benoit.-A description of an abandoned 686 -foot well drilled at. Benoit in 1904 under the auspices of the town is given in the table of well data (No. 1), and a log of the well is given below. Another public well (No. 2) drilled in 1910 is probably 353 feet deep and taps a water-bearing bed in the Lisbon formation. The well does not flow, but the artesian pressure is sufficient to bring the water withim 13 feet of the surface. The present municipal water supply is afforded by a 1,702-foot flowing well (No. 3), which yields 130 gallons a minute. This well has its source in the Wilcox group.

\section{Log of town well on land of Allen Gray at Benoit}

[Authority, O. L. Aldrich]

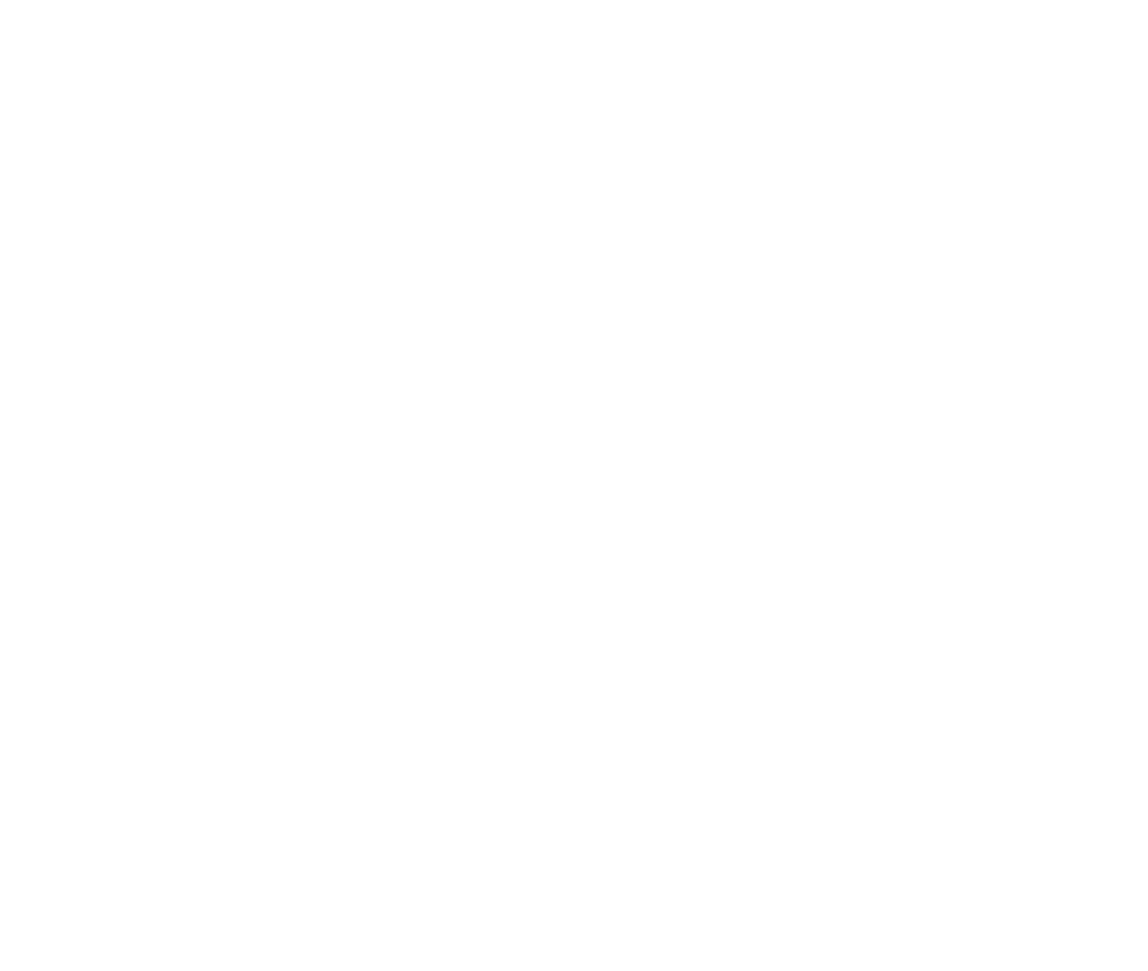


Scott.-The following log pertains to a dug woll 7 soileatheast of Seott, near the southern border of the county:

Log of well 7. miles southexst of Scott

\begin{tabular}{l|r|r|r|r|}
\hline | & Thiekness & Depth \\
\hline Alluvium: \\
Surface loam \\
Sand, resembling sand freshiy deposited by Mississippi River \\
Black buckshot clay \\
Red clay (and sand?); water bearing.
\end{tabular}

When the red water-bearing clay (or sand?) was reached in this well the water rose so rapidly that the man engaged in digging was obliged to abandon the work precipitately. The water rose within 15 feet of the surface. The log is of interest as showing the presence here of buckshot clay, which in places characterizes the delta deposits.

Shaw.-The town of Shaw owns a municipal waterworks about one and a half blocks south of the Yazoo \& Mississippi Valley Railroad station. The water supply is obtained from one well 160 feet deep (No. 17), which has its. source in the coarse sand and gravel that forms the basal portion of the Mississippi River alluvium. The water is very hard, as is shown by analysis 17 . Two other wells have been drilled for the purpose of supplying the town with water. The depth of the older of these wells was 436 feet, but it has been abandoned; the other is a flowing well of small yield, 1,360 feet deep (No. 18), which supplies a fountain in front of the waterworks.

Log of the 486-foot well owned by the town of Shaw (No. 18)

\begin{tabular}{|c|c|c|c|c|c|}
\hline & $\begin{array}{l}\text { Thick- } \\
\text { ness }\end{array}$ & Depth & & Thiok- & Depth \\
\hline $\begin{array}{l}\text { Alluwium: } \\
\text { Souland anday__. } \\
\text { Sand } \\
\text { Gravel }\end{array}$ & $\begin{array}{r}\text { Feet } \\
28 \\
114 \\
6\end{array}$ & $\begin{array}{r}28 \\
28 \\
148 \\
148\end{array}$ & $\begin{array}{l}\text { Lisbon formation (?): } \\
\text { Clay. } \\
\text { Fime sand- } \\
\text {. Coanse saad; water bearing. }\end{array}$ & $\begin{array}{r}\text { Feet } \\
250 \\
80 \\
88\end{array}$ & $\begin{array}{r}\text { Pret } \\
298 \\
378 \\
\mathbf{4 3 6}\end{array}$ \\
\hline
\end{tabular}

The coarse sand described in the portion of the log referrad questionably to the Lisbon formation has led Dr. E. N. Lowe to infer that coarse sandy beds, unlike the outcropping beds of the Lisbon in Mississippi, may dovetail from the west into the finer-grained Eocene beds that are buried beneath the delta deposits. 


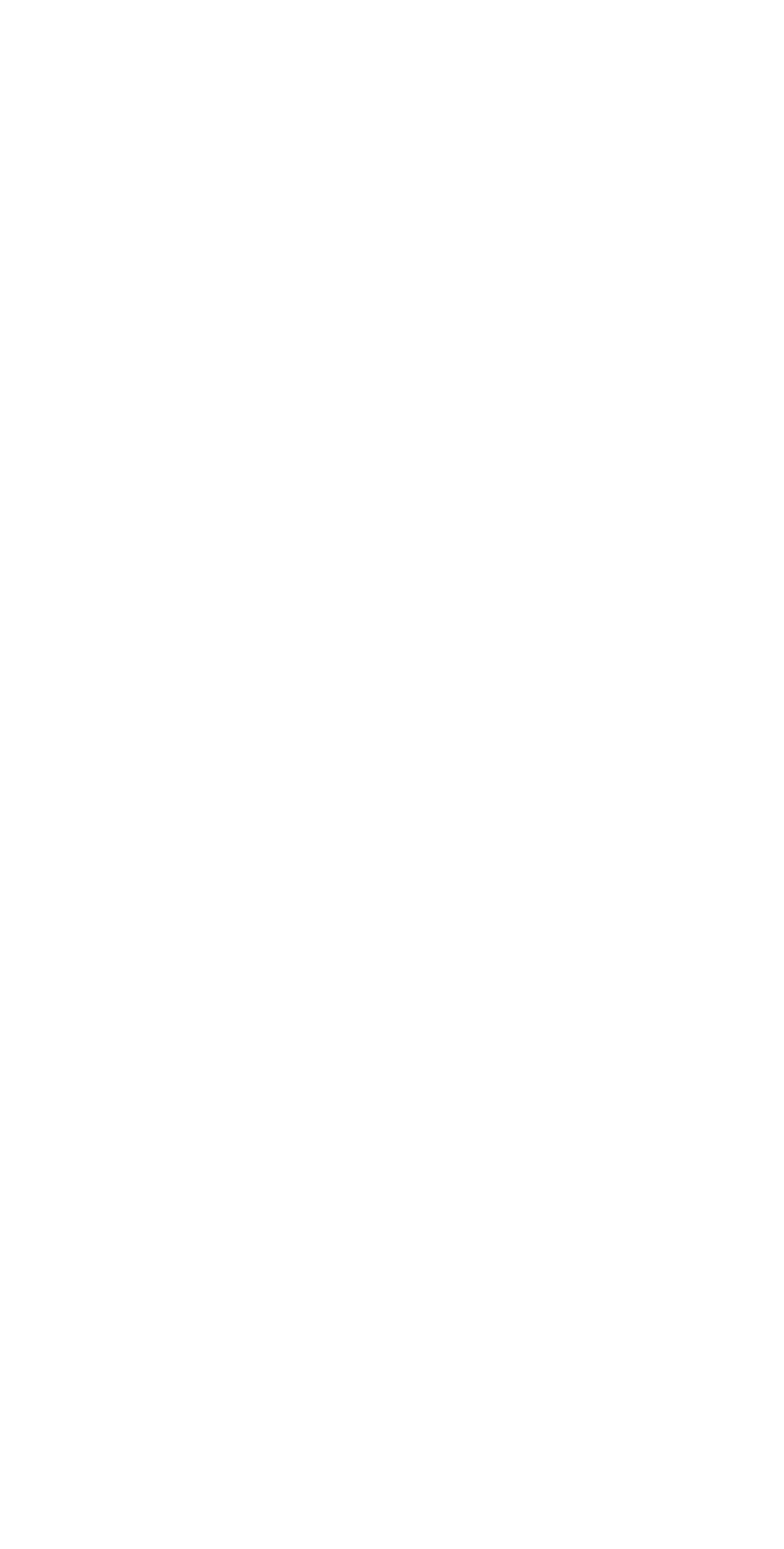




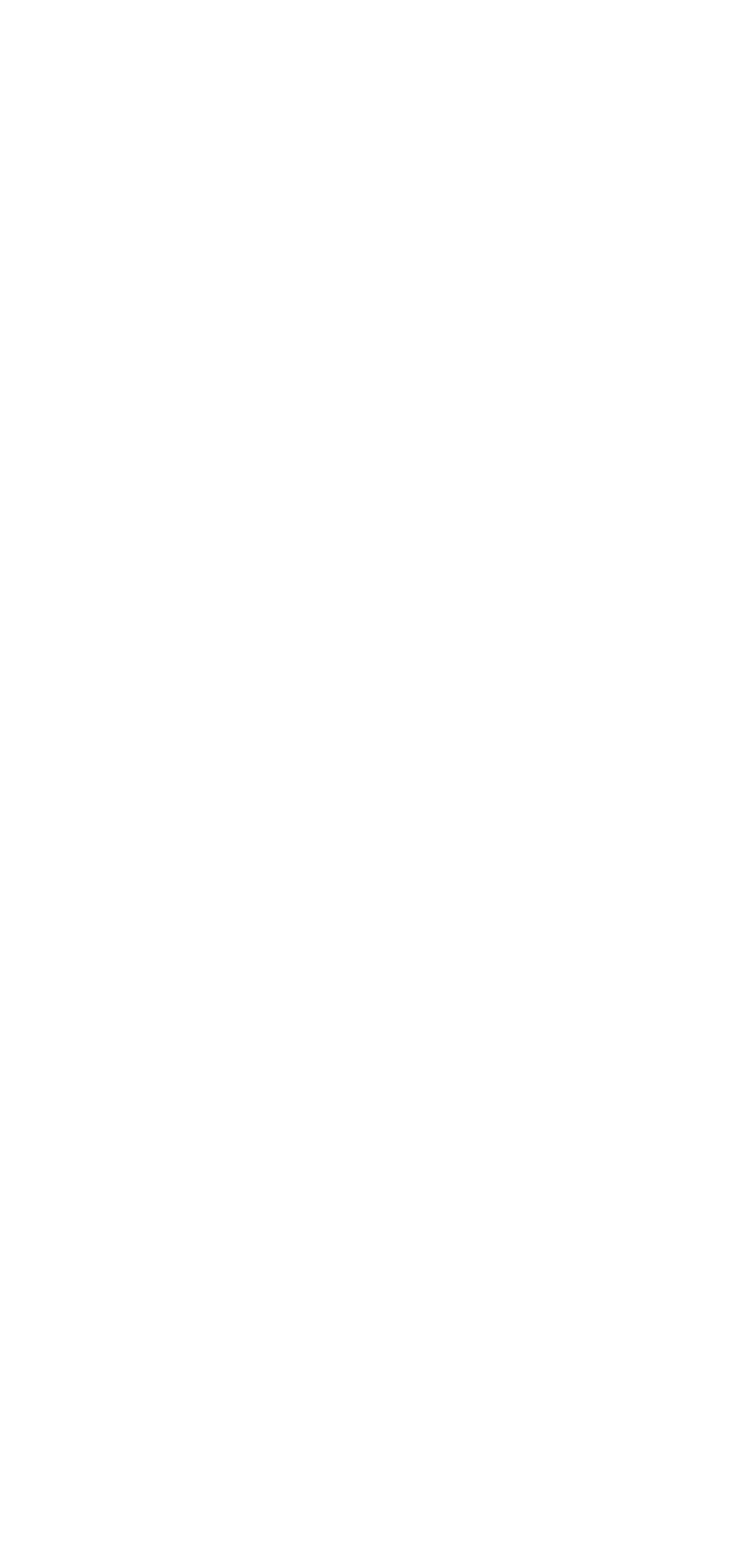


Mineral analyses of ground waters from Bolivar County:

[ [Parts per million. Numbers at heads of columns refer to corresponding well thumbers in preceding table]

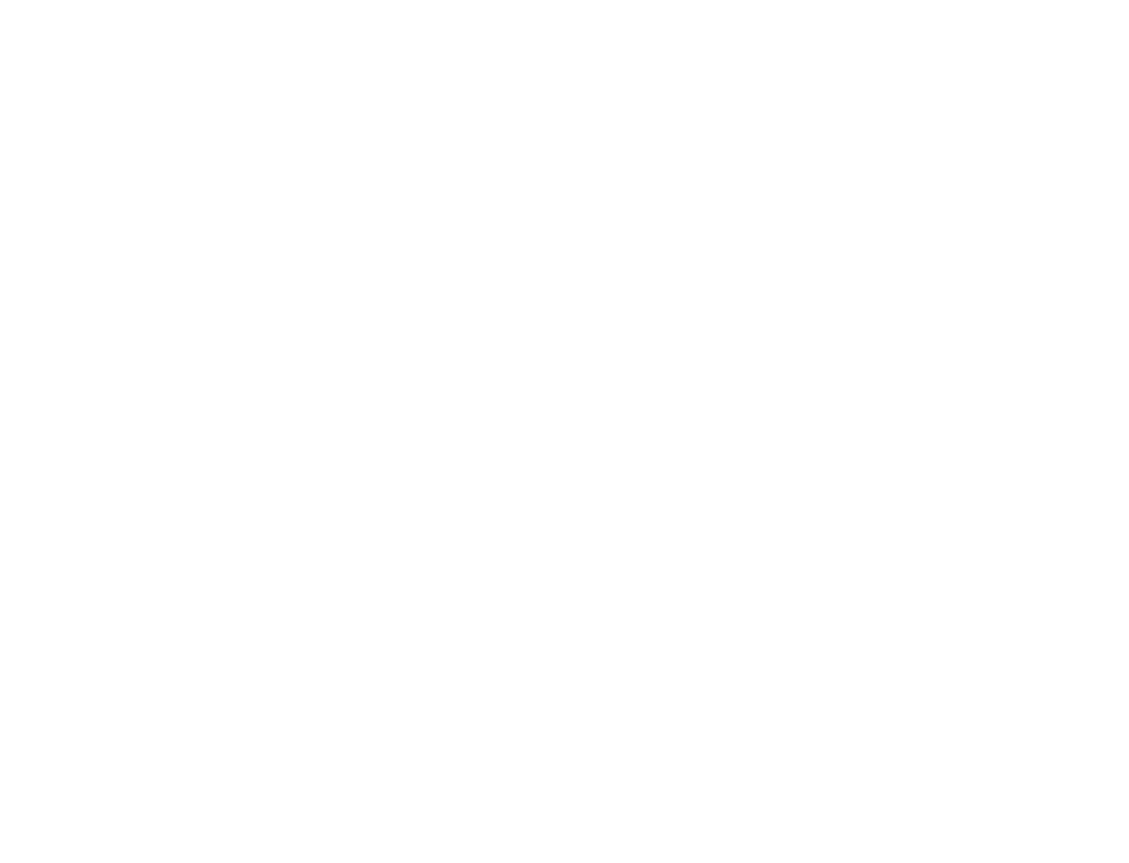

a Iron and aluminum oxides $\left(\mathrm{Fe}_{2} \mathrm{O}_{3}+\mathrm{Al}_{2} \mathrm{O}_{2}\right)$. ' Includes iron and aluminum (Fe+Al). C Calculated.

Analysts: 7, W. R. Perkins (Mississippi Agr. Exper. Sta. Bull. 89, p. 84, 1905); 10, 11, 16, 19, W. L. Kennop, - University of Mississippi; 13, 15, W. L. Perdue, University of Mississippi; 17, 21, Margaret D. Foster and Clara M. Forman, Ư. S. Geological Survey; 20, 22, Mississippi State Chemical Laboratory.

\section{CALHOUN COUNTY}

\section{GENERAL FEATURES}

Area, 579 square miles. Population, 16,823 (census of 1920)

Calhoun County lies within the North Central Hills district and chiefly within the belt of outcrop of the Ackerman formation of the Wilcox group (Eocene). (See geologic map, pl. 2.)

\section{GROUND-WATER CONDITIONS}

The Ackerman formation consists of an estimated thickness between 500 and 600 feet of strata, including massive clays at the base which pass above into interbedded sands and sandy clays and some interbedded layers of lignite and lignitic clay. The more sandy layers carry water in moderate quantities, sufficient, however, for ordinary domestic and farm needs, and throughout the county domestic supplies are obtained chiefly from this source by means of dug or bored wells less than 100 feet deep. Springs of small yield are also fairly common, and some of them are utilized. 
The Ackerman formation is underlain by the Porters Creek clay of the Midway group, which lies at a shallow depth along the eastern boundary and dips to the west beneath the Ackerman at an estimated rate of about 25 feet to the mile. The thickness of the Porters Creek is 100 feet or more. On account of the predominance of clay the formation is not an important aquifer, although it contains some water, which is as a rule rather highly mineralized. The Clayton, the basal formation of the midway group, and the underlying Ripley formation of the Upper Cretaceous both contain sandy strata that would doubtless prove productive of water in Calhoun County, especially in the eastern part. One well at Calhoun City probably reached the water-bearing sands of the Ripley at a depth of 600 feet.

In the eastern part of the county the deeply buried sands of the Eutaw formation (Upper Cretaceous) may possibly be a source of nonflowing water. The 1,200-foot well at Vardaman is believed to have reached these sands, and it is roughly estimated that the well passed through 450 feet of clay, sand, and limestone belonging to the Midway group, 100 feet of sand of the Ripley formation (Upper Cretaceous), 550 or 600 feet of Selma chalk (Upper Cretaceous), and 50 or 100 feet of Eutaw sand. The formations of the Midway group and the Upper Cretaceous are described on pages 29-45.

\section{LOCAL SUPPLIES}

Pittsboro.-In the vicinity of Pittsboro springs are fairly common and have their source in sandy beds of the Ackerman formation. One on the property of C. D. Davis 2 miles southeast of Pittsboro yields clear orange-colored, strongly chalybeate water that is used locally for medicinal purposes. A well on the Provine farm, 3 miles southwest of Pittsboro, was drilled through the Ackerman formation in to the Porters Creek clay to a total depth not stated by the informant. A fair supply of water was obtained in the Ackerman formation at a depth of 210 feet, but the Porters Creek clay yielded no water. In the 150-foot well of J. I. Aston, 8 miles west by south of Pittsboro (4 miles northwest of Bounds), the water derived from sand in the Ackerman formation rises to a level within 10 feet of the surface.

Coles Creek.-Coles Creek is a small village near the western border of the county. In $1900 \mathrm{~L}$. S. Provine drilled a well in the valley of Yalobusha River, 3 miles south of Coles Creek, where he hoped to obtain flowing water. Water was struck in white sand at a depth of 40 to 110 feet and rose within 2 feet of the surface. Below this sand only non water-bearing clay was penetrated, and the well was abandoned at a depth of 565 feet. The well probably penetrated nearly to the base of the Porters Creek clay. The following is the $\log$ of the well: 
Log of well of L. S. Proutne, mat south of Coles Creek

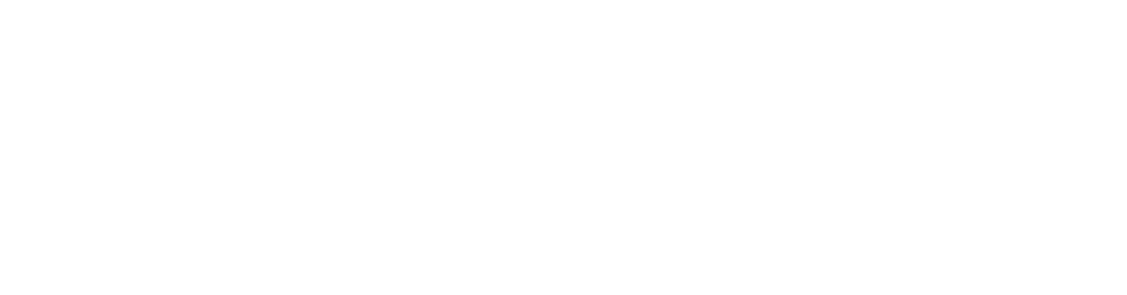

Calhoun City.-At Calhoun City water is abtained from both deep drilled wells and shallow wells. The Bursur wein 600 feet deep, was drilled in an attempt to get flowing waber but wegative results. The well probably penetrated the Ackerman formation, and the Midway group and entered the Ripley formation.

L. Y. Mallory owns a well at Calhoun City, drilled in 1914, which is 400 feet deep and 6 inches in diameter and yields an adoquate supply of water for domestic use. The source of the water is probably a sand stratum in the Clayton formation of the Midway group. The water rises within 30 feet of the surface and is raised by maans of a hand force pump. The mouth of the well is reported to be about 50 feet higher than the level of the track at the Mobile \& Ohio Railroad station. For an analysis of water from this well see No. 1 in the table. The water supply of the Calhoun City Hotel is obtained from a 35-foot well sunk about the year 1910 and cribbed with 10-inch wooden casing. The water is derived from sand in the Ackerman formation and the static head is 20 feet below the surface; the water is raised by hand. (See analysis 2.) The dug well of J. W. Seale, located in a valley on Washington Street one-fourth of a mile northeast of the post office, is 24 feet deep and yields a fair supply of water from sand in the Ackerman formation.

Vardaman.-Vardaman (formerly called Timberville), a village on the Mobile \& Ohio Railroad, 8 miles east of Calhoun, owhs 1,195-foot well, drilled in 1912. The well taps a water-bearing sand in the Eutaw formation of the Upper Cretaceous at a depth of 1,170 to 1,195 feet, and the static head of the water is 30 feet below the surface. From incomplete data it is estimeted that the surface at the mouth of this well is about 325 feet above sea level. According to the log given below the base of the Selma chalk was reached at a depth of 964 feet, or 639 feet below sea level. 
Log of town well at Vardaman

\begin{tabular}{|c|c|c|}
\hline & Thickness & Depth \\
\hline $\begin{array}{l}\text { Earth } \\
\text { Soft black rock } \\
\text { White chalk (Selma) } \\
\text { Hard rock } \\
\text { Soft formation. } \\
\text { Hard rock } \\
\text { Soft black formation } \\
\text { Sand; water bearing }\end{array}$ & $\begin{array}{r}\text { Feet } \\
40 \\
300 \\
624 \\
2 \\
3 \\
1 \\
200 \\
25\end{array}$ & $\begin{array}{r}\text { Feet } \\
\quad 40 \\
\quad 340 \\
964 \\
966 \\
969 \\
970 \\
1,170 \\
1,195\end{array}$ \\
\hline
\end{tabular}

Mineral analyses of ground waters from Calhoun County

[Parts per million. Samples collected Dec. 4, 1920; analyzed by C. S. Howard. For further data regarding these wells see text]

\begin{tabular}{|c|c|c|}
\hline & 1 & 2 \\
\hline 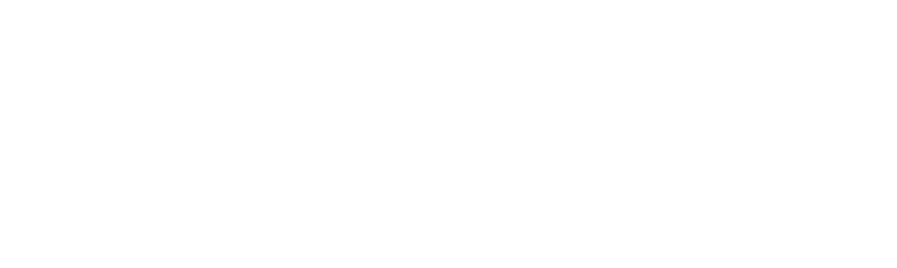 & $\begin{array}{l}30 \\
6.41 \\
3.9 \\
90 \\
20.0 \\
205 \\
13 \\
24 \\
\text { Trace. } \\
267 \\
33\end{array}$ & $\begin{array}{r}29 \\
4.72 \\
3.0 \\
49 \\
1.0 \\
32 \\
3.7 \\
80 \\
\text { Trace. } \\
179 \\
23\end{array}$ \\
\hline
\end{tabular}

1. Drilled well, 400 feet deep, of L. Y. Mallory, at Calhoun City.

2. Bored well, 35 feet deep, of Calhoun City Hotel, at Calhoun City.

\section{CARROLL COUNTY}

\section{GENERAL FEATURES}

Area, 624 square miles. Population, 20,324 (census of 1920)

Carroll County lies mostly within the Loess or Bluff Hills district but a small portion on the west slopes into the Yazoo Delta and an area on the east merges into the North Central Hills district.

The county is underlain by the Tallahatta and Lisbon formations of the Claiborne group (Eocene.) A surficial mantle of loess, which ranges in thickness from 40 to 50 feet in the west to only a few feet in the east, covers the Eocene beds throughout most of the county. Outcrops of the Eocene beds appear only in the lower slopes of the valleys and of the escarpment that bounds the Loess Hills on the west. In places several feet of terrace sand and gravel, probably of Pliocene age, intervene between the Tallahatta formation below and the loess above. The Tallahatta formation, the Lisbon formation (including the Winona sand member), and the loess are described on pages 50-52, and the distribution of the formations is shown on the geologic map (pl. 2).

\section{GROUND-WATER CONDITIONS}

The beds that compose the Tallahatta and Lisbon formations, together with the still older deeply buried Eocene beds that underlie the 
Tallahatta, all dip west by south at an estimated rate of about 25 feet to the mile. . The conditions are therefore fivorable for the devels. opment of artesian pressure, and flowing wells have been obtained in different parts of the county.

The oldest water-bearing formation reached by wells in Carroll County is the Holly Springs sand of the Wilcox group, which does not come to the surface within the county but whose topmost beds lie at depths that range from 200 to 250 feet in the east to perhaps 600 feet in the west. The coarse sands that largely compose the formation carry an abundance of water, which is under a strong artesian head, probably sufficient to produce flows in the lowlands, particularly in the lowland that borders Big Black Creek in the east and in the Yazoo Delta, the eastern edge of which forms a narrow belt along the western part of the county.

The Tallahatta formation is relatively thin and overlies the Holly Springs sand. It crops out in a small area in the southeast and extends to the northeast through Montgomery County, butits westward buried extension probably underlies all of Carroll County beneath the Winona sand. The Tallahatta probably does not contain abundant supplies of water.

The Winona sand member of the Lisbon formation overlies the. Tallahatta formation and appears in surface outcrops in a narrow strip along the eastern part of the county and in adjacent parts of Montgomery County. The Winona is probably 200 or 300 feet thick and is the source of the water obtained in shallow wells in its belt of outcrop and in deeper wells farther to the west, where it passes under the younger parts of the Claiborne group. Some of the flowing wells in the vicinity of McCarley and Vaiden probably tap the Winona water-bearing sands.

The typical beds of the Lisbon formation, which here overlie the Winone sand member, are the source of the water obtained in some of the nonflowing wells in the central part of the county. The Lisbon is . concealed by the loess and the gravels, which underlie the loess. throughout the central and western parts of the county.

The terrace sands and gravels, which in places intervene between. the Tallahatta formation below and the overlying loess, are waterbearing and produce springs along the lower slopes. On the loesscovered upland wells are also sunk through the loess to these sands and gravels.

\section{LOCAL SUPPLIES}

Carrollton.-The town of Carrollton owns a waterworks which is located near the bridge over Sandy Creek at the line between Carroll-: ton and North Carrollton. Water is obtained from two flowing wells, 408 and 260 feet deep (Nos. 1, 2). A well drilled at the waterworks im 1900 'but apparently' no longer in use was 1,250 feet deep' 
(No. 3). J. E. Trummell's well (No. 5,), about 11/2 miles southodet of Carrollton, penetrates water-bearing sand in the Lisbon formation at a dopth of 68 feet; the water riges within 40 fee of the surfece. An analysis of water from one of the waterworks welle ( $\mathrm{Na} .1$ ) is iven below.

Afineral analysis of water from town well 408 feet deep at Carrollton, Carroll County

[Sample collected Sept. 29, 1919; analyzed by Margaret D. Foster, vł. S. Ceological Survey]

\begin{tabular}{|c|c|}
\hline Silica $\left(\mathrm{SiO}_{2}\right)_{-}$ & $\begin{array}{c}\text { Parts per } \\
\text { milision } \\
36\end{array}$ \\
\hline Iron $(\mathrm{Fe}) \ldots$ & .64 \\
\hline Calcium $\left(\mathrm{Ca}_{1}\right)$ & 16 \\
\hline Magnesium $(\mathrm{Mg})$ & 6. 5 \\
\hline Sodium and potassium $(\mathrm{Na}+\mathrm{K})$ (caloulated) & 33 \\
\hline Carbonate radicle $\left(\mathrm{CO}_{3}\right)$ & .0 \\
\hline Bicarbonate radicle $\left(\mathrm{HCO}_{3}\right)$ & 149 \\
\hline Sulphate radicle $\left(\mathrm{SO}_{4}\right)$ & 10 \\
\hline Chloride radicle $(\mathrm{Cl})$ & 2.7 \\
\hline Nitrate radicle $\left(\mathrm{NO}_{3}\right)$ & 2.9 \\
\hline Total dissolved sqlids at $180^{\circ} \mathrm{C} \ldots \ldots . .$. & 184 \\
\hline Total hardness as $\mathrm{CaCO}_{3}$ (calculated) & 67 \\
\hline
\end{tabular}

In unpublished notes Dr. E. N. Lowe, the State geologist, describes a "blowing well" in Carroll County that was brought to his attention. in March, 1913. He responded to an urgent request to examine an old well at the residence of John Mabrey, 10 miles north of Carrollton, which was said to be spouting mud and water in an alarming manner. The well was of the bored type, about 8 inches in diameter, and said to be about 70 feet deep. It had been abandoned and was partly clogged with earth. On a certain night during a protracted storm of heavy rain and wind strange noises came from the well; and in the morning water and mud were spurting from it. When Dr. Lowe reached the well, on March 31, the weather had cleared and instead of "blowing" the well was "sucking" or drawing a strong current of air into it. The cause of these phenomena is discussed on pages 19-20. According to Mr. Mabrey, the well penetrated a thick bed of clay and entered porous sand, which was doubtless not saturated with water. During the stormy weather, which constituted a period of unusually low atmospheric pressure, air escaped forcibly from the unsaturated porous sand and blew the obstructions from the well, and later, when clear weather and high atmospheric pressure prevailed, air was driven back into the sand.

McCarley.-McCarley is a village 5 miles east of Carrollton. A well owned by C. C. Felts (No. 9), one-fourth of a mile west of McCarley, at a point about 15 feet above the bottom lands along Sandy: Creek, is 200 feet 'deep, and 'flows a small stream, whioh is suffieient; however, for domestic and stock uses. The source of this water is the Winona sand. At MeCarley two wells (Nos. 7 and 8), 175 and 100 
feet deep, also have their source in the Winona. In each well the water is under artesian head, but only the 160 -foot well, the mouth of which is topographically lower than that of the 175-foot well, yields a flow. The water of the 175-foot well is said to come from green glauconitic sand, such as is characteristic of the Winona sand.

Coila.-In the vicinity of Coila water is commonly obtained from shallow wells and from springs, both of which have their source in terrace gravels that underlie the loess deposits. A few deeper wells have been sunk, however, of which that of N. H. Hughs (No. 6) is probably typical; it yields a fair supply of water from the Lisbon formation at a depth of about 100 feet. Four springs, which are used for domestic and stock supply, are reported to the east and southeast of Coila. Those of W. E. Collier and Mr. Reeve are each about 2 miles east of Coila; those of Henry Burnley and W. A. Catron are each about $31 / 2$ miles southeast of Coila. The following record of a dug well 9 miles east of Coila shows the general character of the strata that compose the Winona sand.

Log of dug well 9 miles east of Coila

\begin{tabular}{|c|c|c|}
\hline & Thickness & Depth \\
\hline $\begin{array}{l}\text { Winona sand member: } \\
\text { Variegated clay }\end{array}$ & & Feet \\
\hline Indurated ferruginous sand, with seams of crystalline selonite alternating with & (2) & 20 \\
\hline Greensand. & $\begin{array}{l}\mathbf{4} \\
\mathbf{9}\end{array}$ & 20 \\
\hline Indurated ferruginous sand with layers of greensand. & $\begin{array}{l}4 \\
3\end{array}$ & 33 \\
\hline Siliceous, indurated sandstone with shelis & 6 & 42 \\
\hline $\begin{array}{l}\text { Light-yellow sand; water bearing; includes ledges of indurated sand that carry } \\
\text { concretions of sandstone and nodules of clay }\end{array}$ & 6 & 48 \\
\hline
\end{tabular}

Water that was too strongly mineralized for domestic use was found in this well at a depth of 44 feet.

Blackhawk.-In the vicinity of Blackhawk water is obtained at depths of 25 to 100 feet, principally at a depth of about 65 feet, in a stratum of white sand in the Lisbon formation.

Blackmonton.-At Blackmonton water is obtained by means of wells 40 to 150 feet deep, which penetrate the Lisbon formation, the deeper ones probably reaching the Winona sand member; they encounter water which rises within about 30 feet of the surface.

Vaiden:-At Vaiden a 230-foot well (No. 11), owned by R. A. Peacock, located in the lowland near Hays Creek, yields a moderate artesian flow from the Holly Springs sand. About 21/2 miles south of Vaiden, in the same valley, the well of R. E. Meyers, of Beatty, Miss., on the old Doctor Fullilove place (No. 12), yields a small artesian flow from the Winona sand at a depth of 110 feet; the water is used for domestic and farm supply. 


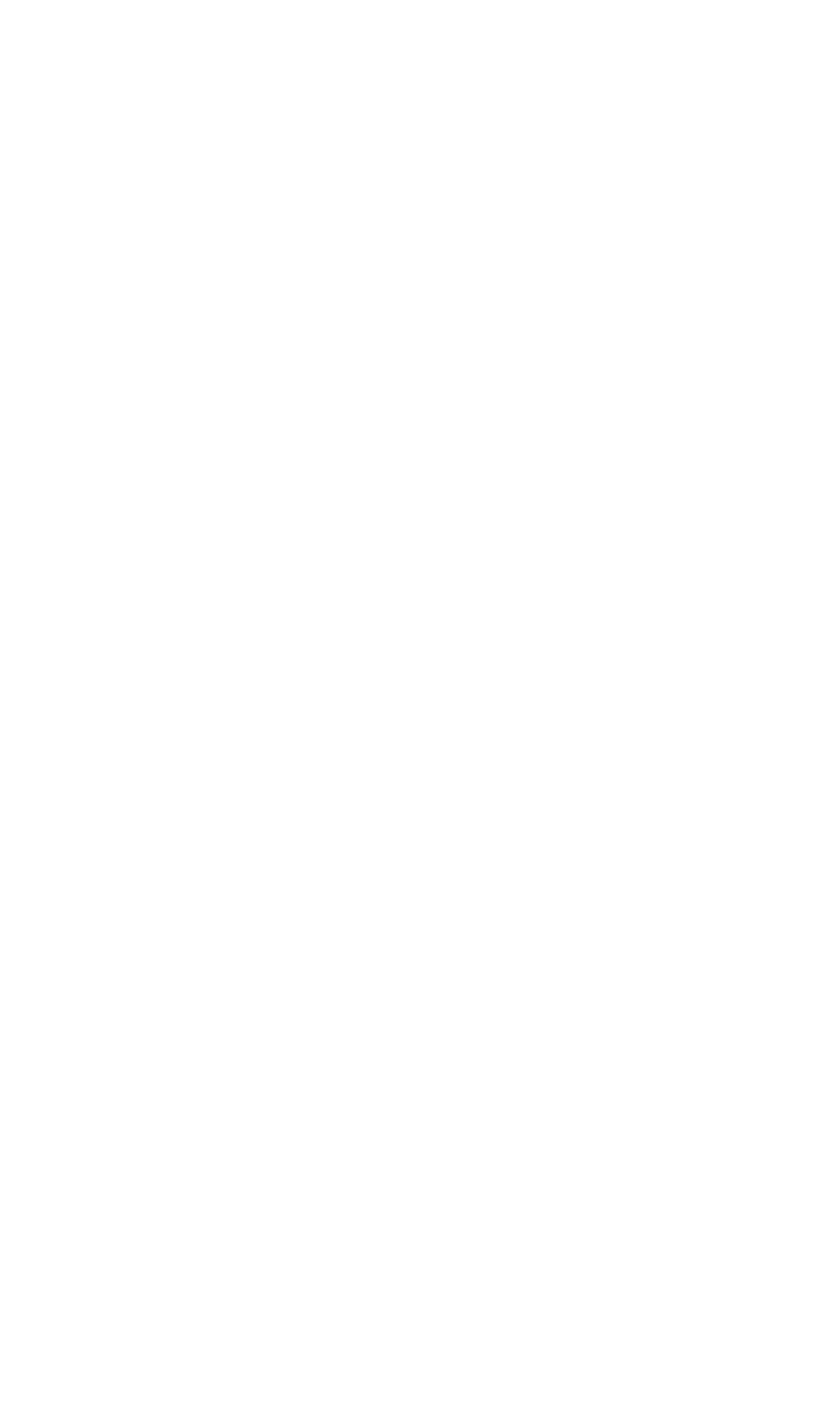




\section{CHIOKABAW GOUNTT:}

\section{GENERAL FEATURES}

Area, 501 square miles. Population, 22,212 (census of 1920)

Chickasaw County is divisible into three distinct physiographic parts - the Black Prairie belt, the Pontotoc Hills district, and the Flatwoods district. Two upper Cretaceous formations-the Selma chalk and the Ripley formation-and three Eocene formations-the Clayton formation, the Porters Creek clay, and the Ackerman formation-appear at the surface within the county. These formations are described on pages 36-46, and their distribution is shown on the geologic map (pl. 2). They all dip west 25 or 30 feet to the mile.

\section{GROUND-WATER CONDITIONS}

The Black Prairie belt, which occupies the eastern part of the county, is underlain by the Selma chalk. Owing to its compact, impervious character, the Selma is not a water bearer of economic importance, but it șerves as a confining agent for the underlying abundantly water-bearing Eutaw and still deeper Tuscaloosa formations and is therefore one of the chief factors determining the artesian pressure which causes the water to rise in wells from these two lower formations to a level within easy reach of pumps. Previous to the advent of the artesian well, cisterns and artificially constructed pools for storing rain water were the principal means of providing domestic water supplies.

The Eutaw formation is encountered at a depth of 300 to 350 feet along the eastern border of the county. Owing to the westward dip of the strata at the rate of about 30 feet to the mile the formation lies at successively greater depths from east to west, being 650 to 750 feet below the surface along the western border of the Black Prairie belt. The uppermost important water-bearing stratum of the Eutaw, which lies about 100 to 150 feet below the top of the formation, is tapped by many wells in the Black Prairie belt (see. table), and this source of supply is rapidly replacing that of cisterns: and surface pools.

Owing to the abundance of water obtainable from the upper part, of the Eutaw formation few wells have been sunk to the water-bearing beds of the lower part of the formation, and few, if any, are deep enough to draw upon the still more deeply buried Tuscaloosa waters, which may prove to be better suited for general domestic and industrial uses than those of the Eutaw. Nos. 2, 7, and 18 are high in chloride. (See analyses and local descriptions.)

The Pontotoc Hills, in the central part of the county, are underlain by the sands and clays of the Ripley formation. In the longitude of Houston the Ripley is 200 to 250 feet thick, but on account of the westward dip of the strata the successively lower beds of the forman 
tion come to the surface from west to east, and the formation finally feathers out 5 or 6 miles east of Houston. The inhabitants of this hilly area obtain their water supplies chiefly from water-bearing beds in the Ripley; in the eastern part of the belt, where the formation is thin, the water is mostly taken from shallow dug and bored wells, whereas farther to the west, as at Houston and Houlks, dug, drilled; and bored wells 100 to 160 feet deep are in general use.

At about the longitude of Houston the westward-dipping beds of the Ripley pass beneath overtapping beds of Eocene age, which immediately underlie the surface throughout the western two-fifths of the county. The Eocene is represented chiefly by the Porters Creek clay, whiph does not contain large supplies of water. In the belt of outcrop of the Porters Creek the Ripley waters lie at depths from east to west of 100 to 400 feet or more and are therefore valuable water supplies. A few wells in the Pontotoc Hills have been drilled to the water-bearing beds of the Eutaw formation, which lie at depths of 700 to 1,000 feet (Nos. 11, 21-23). Analyses of five waters are given on page 110.

\section{LOCAI SUPPLIES}

Okolona.-Okolona and the surrounding country depend for water supplies chiefly on the water-bearing sands of the Eutaw formation, which are first encountered at a depth of 423 feet (Nos. 18-20). As the base of the Selma chalk lies at a depth of 320 feet the waterbearing stratum, which is 50 feet thick, is 103 to 153 feet below the top of the Eutaw. As shown by the following quotation, ${ }^{28}$ the arailability of the waters of the Eutaw formation was discovered prior to 1854:

In Okolona a boring has been made to the depth of 470 feet, which supplies a well sunk to the depth of 90 feet, the water rising to within 75 feet of the surfaee.

The waterworks is owned by the town and is located about a block northwest of the Mobile \& Ohio Railroad station; "on ground about level with the track at the station. Two other deep wells at Okolona are described in the table (Nos. 19, 20), and a $\log$ of the beds penetrated in the well of the Mobile \& Ohio Railroad is given below:

Log of well of Mobile \& Ohio Railroad, Okolona ${ }^{a}$

[Altitude of mouth of well about 304 feet above sea level. Adapted from description by Logan and Perkins]

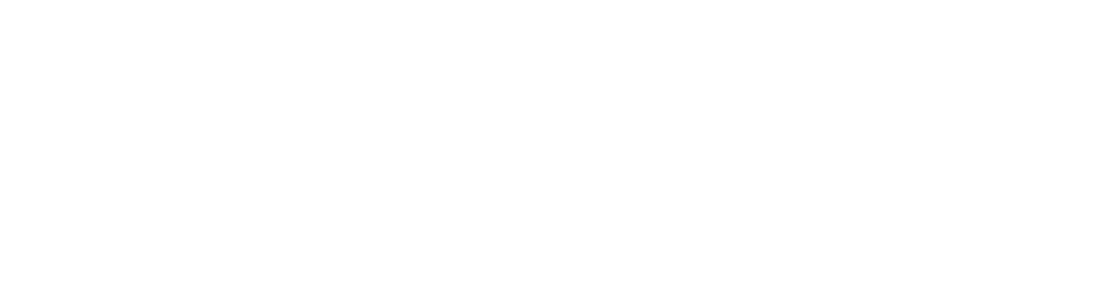

- Logan, W. N., and Parkins, W. R., Mississippi Agr. Exper. Sta. Bull. 89, p. 29, 1905.

W Walles, B. T. Q., report op the geology and agriculture of Mississippl (published by order of the legis10tarti); D. 250, 1254 


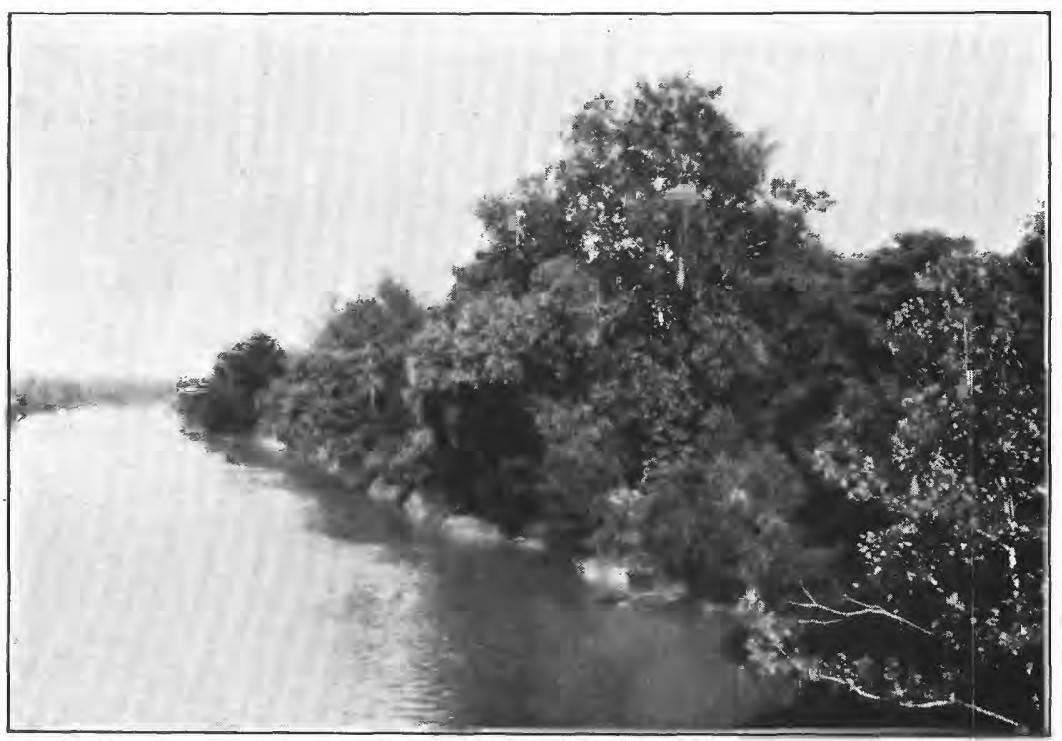

A. PEARL RIVER BELOW THE WAGON BRIDGE AT MONTICELLO, LAWRENCE COUNTY

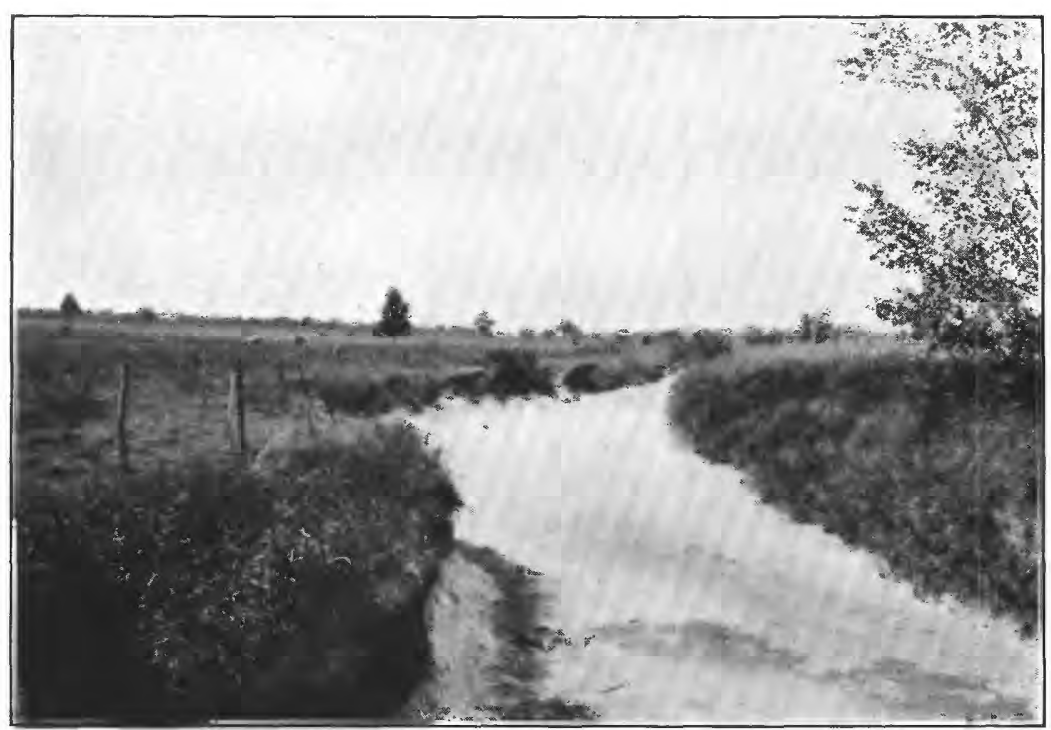

B. DRY BED OF AN INTERMITTENT CREEK WHICH HEADS IN THE BLACK PRAIRIE BELT (SELMA CHALK AREA), HALF A MILE WEST OF OKOLONA, CHICKASAW COUNTY 


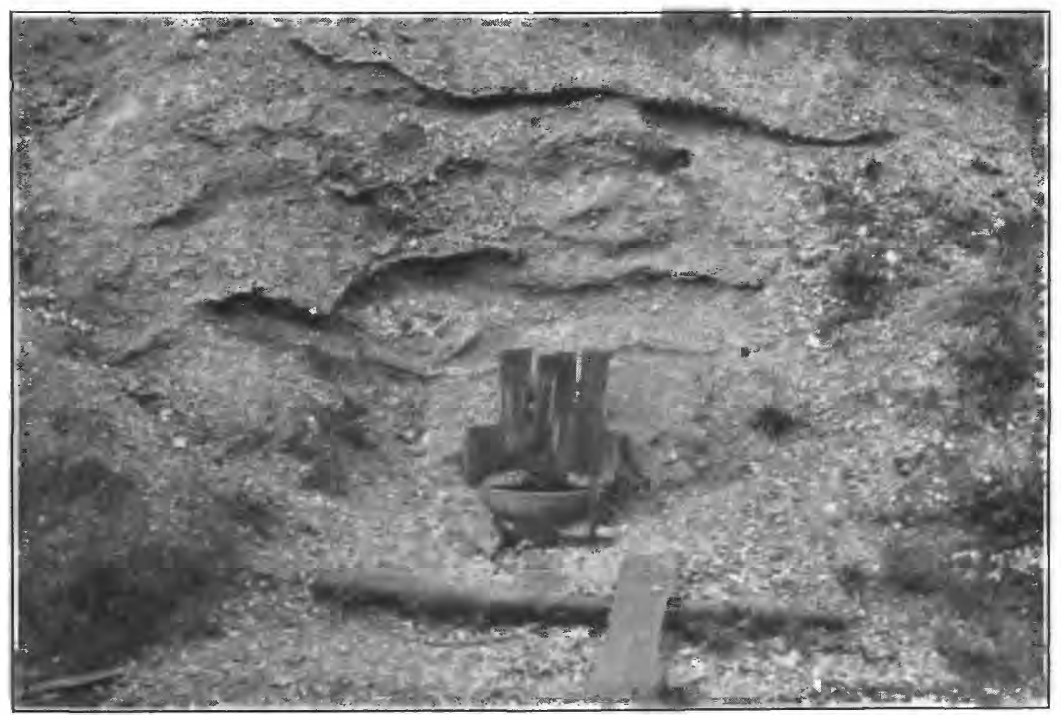

A. SPRING HAVING ITS SOURCE IN GRAVEL OF THE TUSCALOOSA FORMATION, IN A CUT OF THE SOUTHERN RAILWAY 3 MILES EAST OF IUKA, TISHOMINGO COUNTY

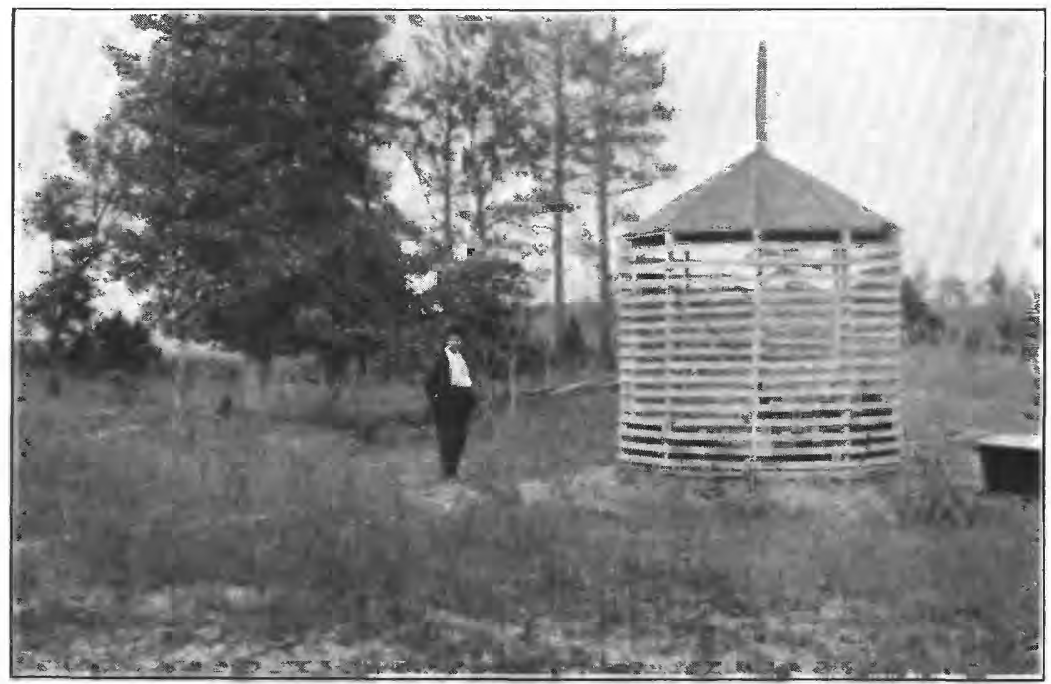

B. THE MINNIE PORTIS SPRING, A MINERAL SPRING HAVING ITS SOURCE IN THE PORTERS CREEK CLAY AT WAHALAK, KEMPER COUNTY 


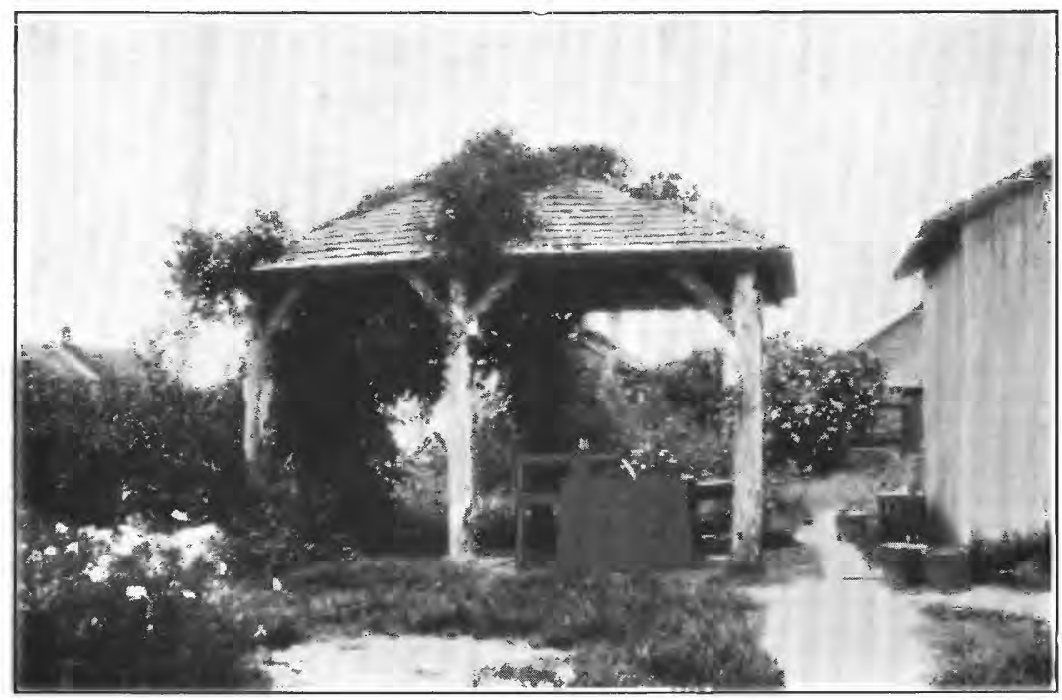

A. FLOWING WELL 295 FEET DEEP AT THE RESIDENCE OF C. E. WATTS, MONTICELLO, LAWRENCE COUNTY

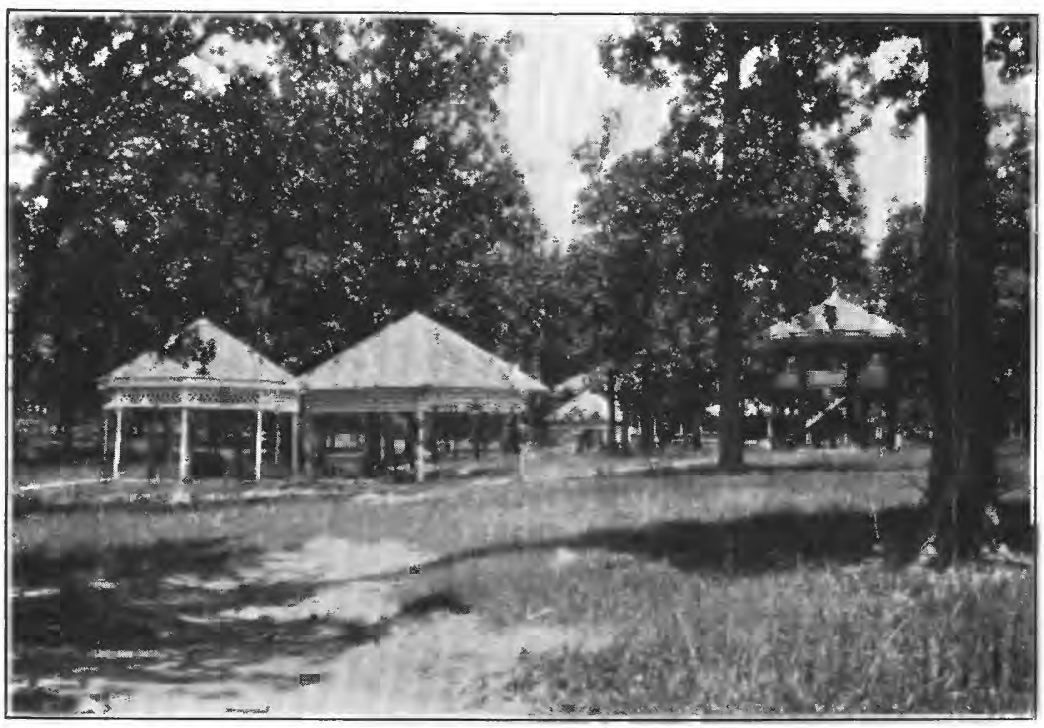

B. FOUR OF THE MINERAL WELLS AT BROWN WELLS, 10 MILES SOUTHWFST OF HAZLEHURST, COPIAH COUNTY 

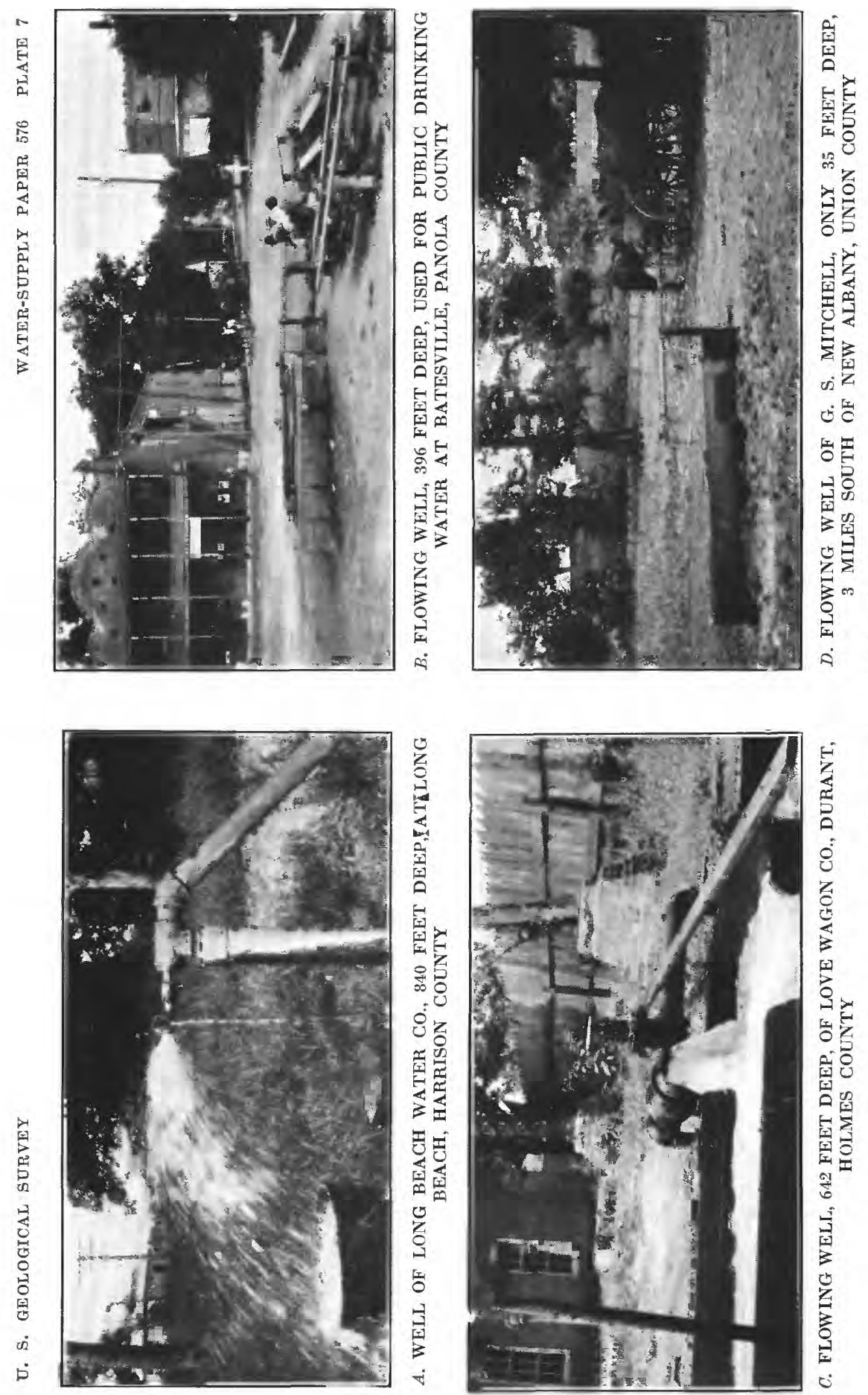


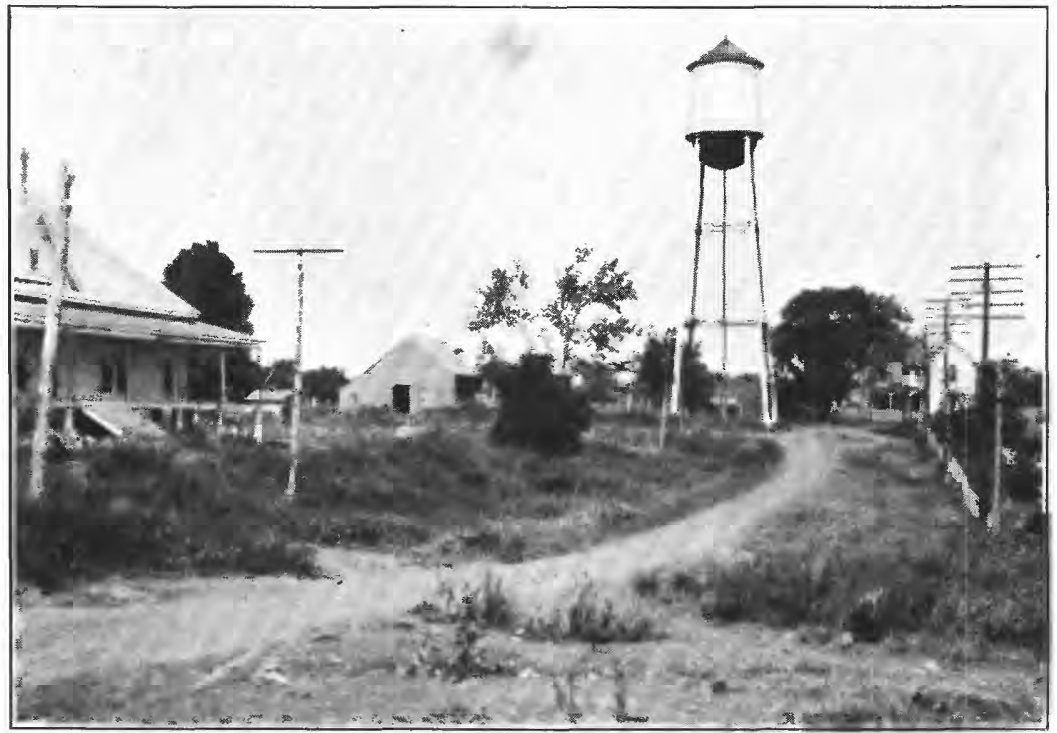

A. STEELDI STRIBUTING TANK NEAR THE WATERWORKS AT HOUSTON, CHICKASAW COUNTY

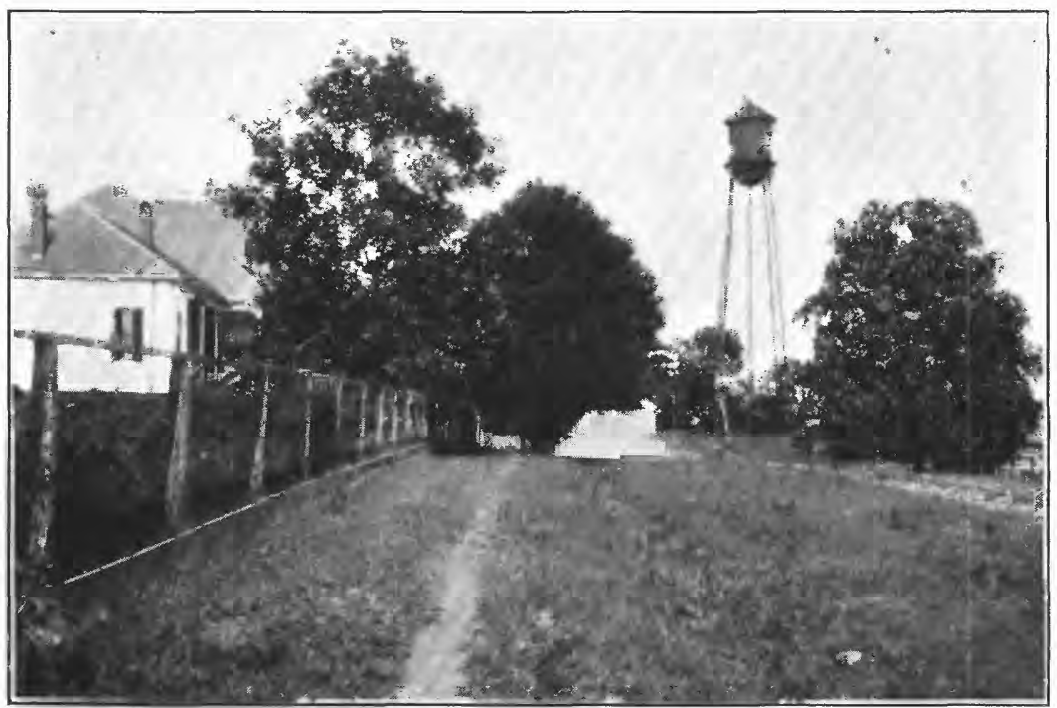

B. STEEL DISTRIBUTING TANK AT THE WATERWORKS AT GLOSTER, AMITE COUNTY 


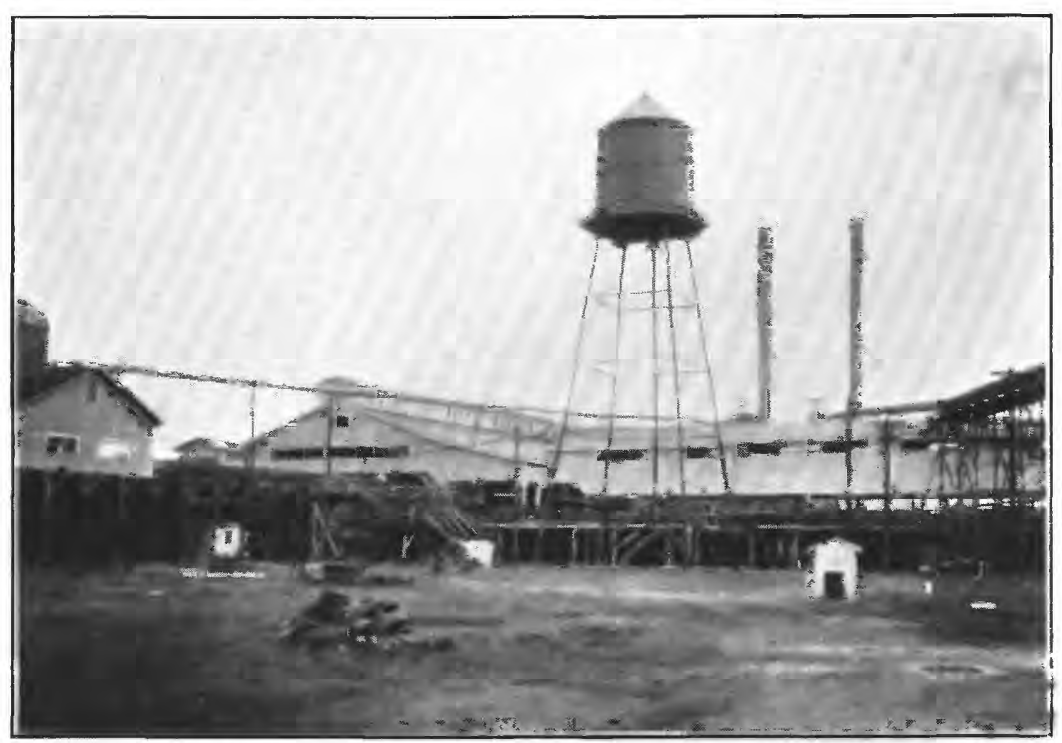

A. WOODEN TANK FOR DISTRIBUTING WATER AT THE LUMBER PLANT OF THE LONG-BELL CO., QUITMAN, CLARKE COUNTY

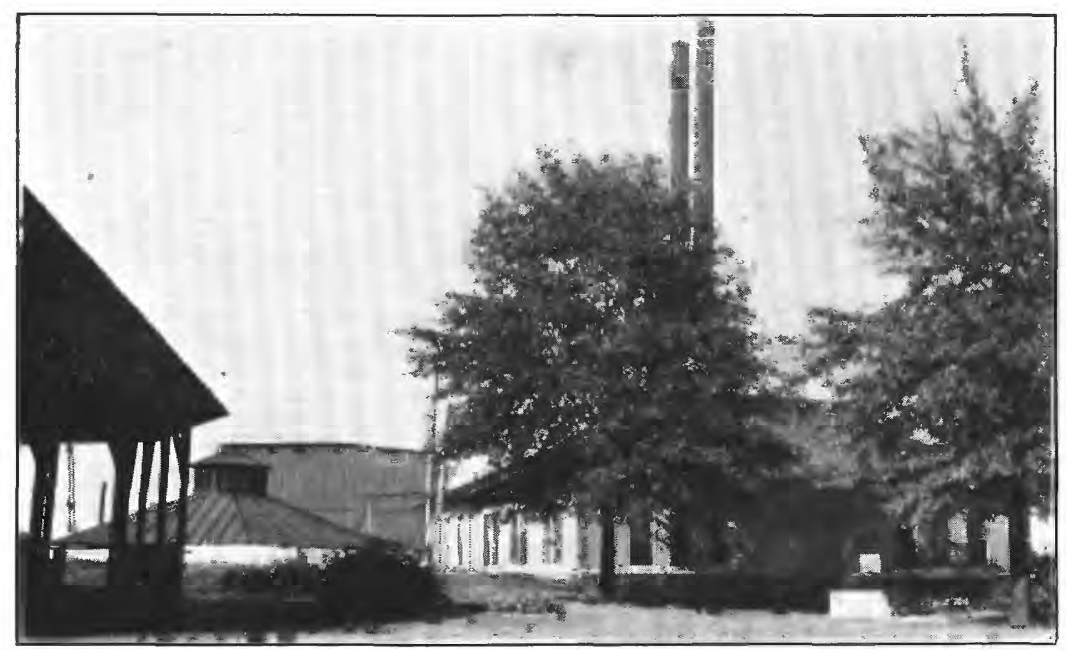

B. THE WATERWORKS AT GRENADA, GRENADA COUNTY

Including the pumping plant, operated by steam, and a brick ground reservoir 


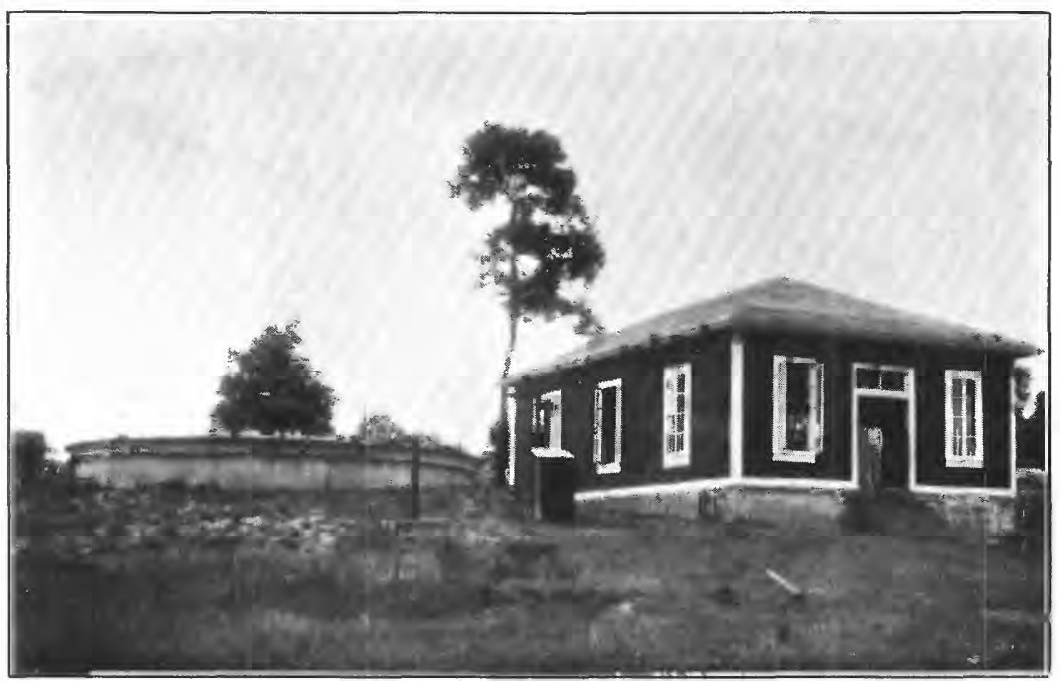

A. THE WATERWORKS AT..SUMRALL, LAMAR ${ }^{-}$.COUNTY . :

- Including the pumping plant and a concrete ground reservoir

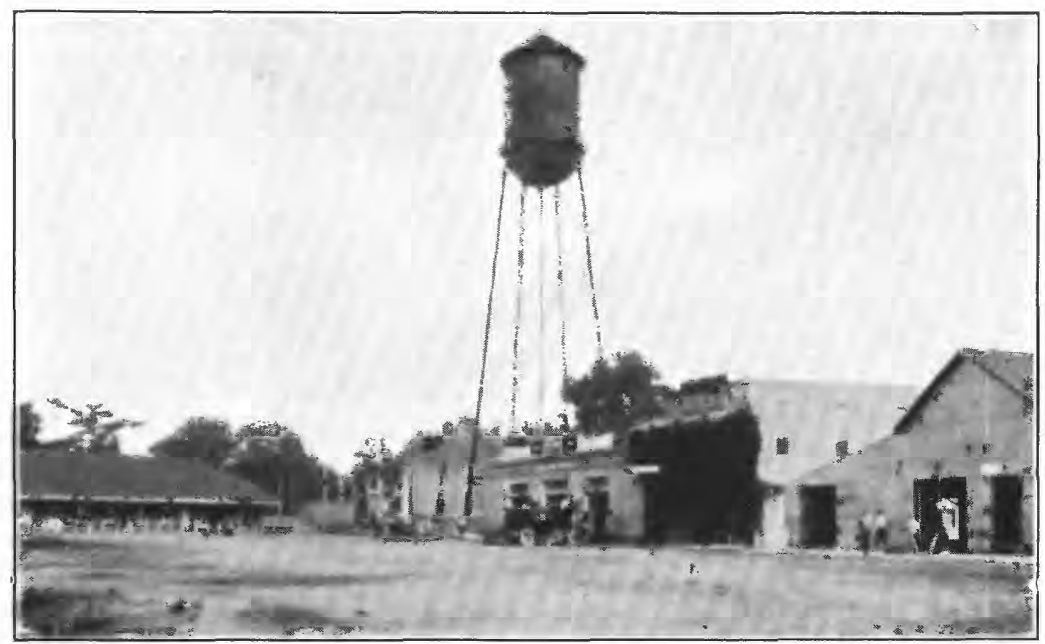

B. STEEL DisTRIBUTING TANK AT THE WATERWORKS AT COLUMBIA, MARION COUNTY 

Egypt.-The ground-water conditions at Egypt are essentially like those at Okolona except that, owing to geographic position, the uppermost valuable water-bearing stratum of the Eutaw lies at a shallower depth at Egypt-only 300 feet. Many wells that range in depth from 360 to 460 feet, four of which are described in detail in the table (Nos. 7-10), have been drilled at and near Egypt.

Buena Vista.-The numerous wells at and near the village of Buena Vista, owing to the westward dip of the water-bearing strata, reach the water-bearing sands of the Eutaw formation at depths of 600 to 700 feet. Six wells (Nos. 1-6), are described in the table.

McCondy.-The ground-water conditions at McCondy are essentially the same as those at Buena Vista, except that according to the rather meager available information the depth to the first valuable water-bearing stratum is not so. great. The wells within a radius of several miles of the village range in depth from 300 to 700 feet, depending on their geographic positions. One privately owned well at McCondy is described in the table (No. 17).

Vanvleet.-The village of Vanvleet is close to the boundary between the Black Prairie belt and the Pontotoc Hills, and wells must be sunk through practically the full thickness of the Selma chalk to reach the water-bearing beds of the Eutaw formation. The wells range in depth from about 690 to 800 feet; three of them are described in detail in the table (Nos. 21-23). Shallow wells (15 to 30 feet deep) are used by some of the people of the vicinity, especially by those living in the area to the west underlain by the sands of the Ripley formation.

Houston.-Houston stands near the boundary which separates the area underlain by the Cretaceous deposits on the east from that underlain by the Eocene on the west. The municipal water supply is derived from a water-bearing stratum in the Ripley formation by means of two wells, each 115 feet deep. (See No. 15.) A log of one of the wells is given below. The waterworks is owned by the town and is located about three blocks north of the courthouse. The waterbearing stratum from which the municipal water supply is drawn is tapped by other wells at and near Houston at depths of 100 to 160 feet.

Log of one of the wells at the municipal waterworks, Houston

[Mouth of well is 2 or 3 feet lower than the level of the Mobile \& Ohio R. R. track, which pases near the pumping station]

\begin{tabular}{|c|c|c|}
\hline . & Thickness & Depth \\
\hline $\begin{array}{l}\text { Surface soll (residual) } \\
\text { Ripley formation: } \\
\text { Blue rodk (sand and clayr) } \\
\text { Oray findy micaceous sand; water bearing }\end{array}$ & Feet $\begin{array}{r}20 \\
5 \\
5\end{array}$ & $\begin{array}{r}\text { Feet } \\
20 \\
110 \\
116\end{array}$ \\
\hline
\end{tabular}

Houlka.-The people living at and in the immediate vieinity of Houlka obtain water for general domestic and farm uses chiefly from a water-bearing stratum in the Ripley formation, which probably corresponds to the stratum that affords the municipal water supply $54134-28-8$ 
at Houston. The wells range in depth from 100 to 250 feet. A few wells less than 100 feet deep are in use. A well (No. 13) $41 / 2$ miles southwest of Houlka taps a water-bearing stratum near the base of the Ripley formation at a depth of 380 feet. Two wells at Houlka, one owned by the Ferguson \& Palmer Co. (No. 11), the other by the New Orleans, Mobile \& Chicago Railroad, penetrate the Ripley formation and the Selma chalk and enter the underlying Eutaw formation, the well of the Ferguson \& Palmer Co. at a depth of $8701 / 2$ feet. An abundant supply of water was obtained from the Eutaw in the well of the Ferguson \& Palmer Co., and as the 4-inch casing was inserted to the bottom of the well the water was probably obtained from sand below the lowermost layer of hard rock described in the $\log$ (given below) - that is, at a depth of about 1,087 feet, or 217 feet below the top of the Eutaw.

Log of well of Ferguson \& Palmer Co., one-fourth of a mile west of Houlka

[Altitude of mouth of well, more than 350 feet above sea level. Adapted from $\log$ furnished by E. N. Lowe, State geologist; drilled by Layne \& Bowler Co.]

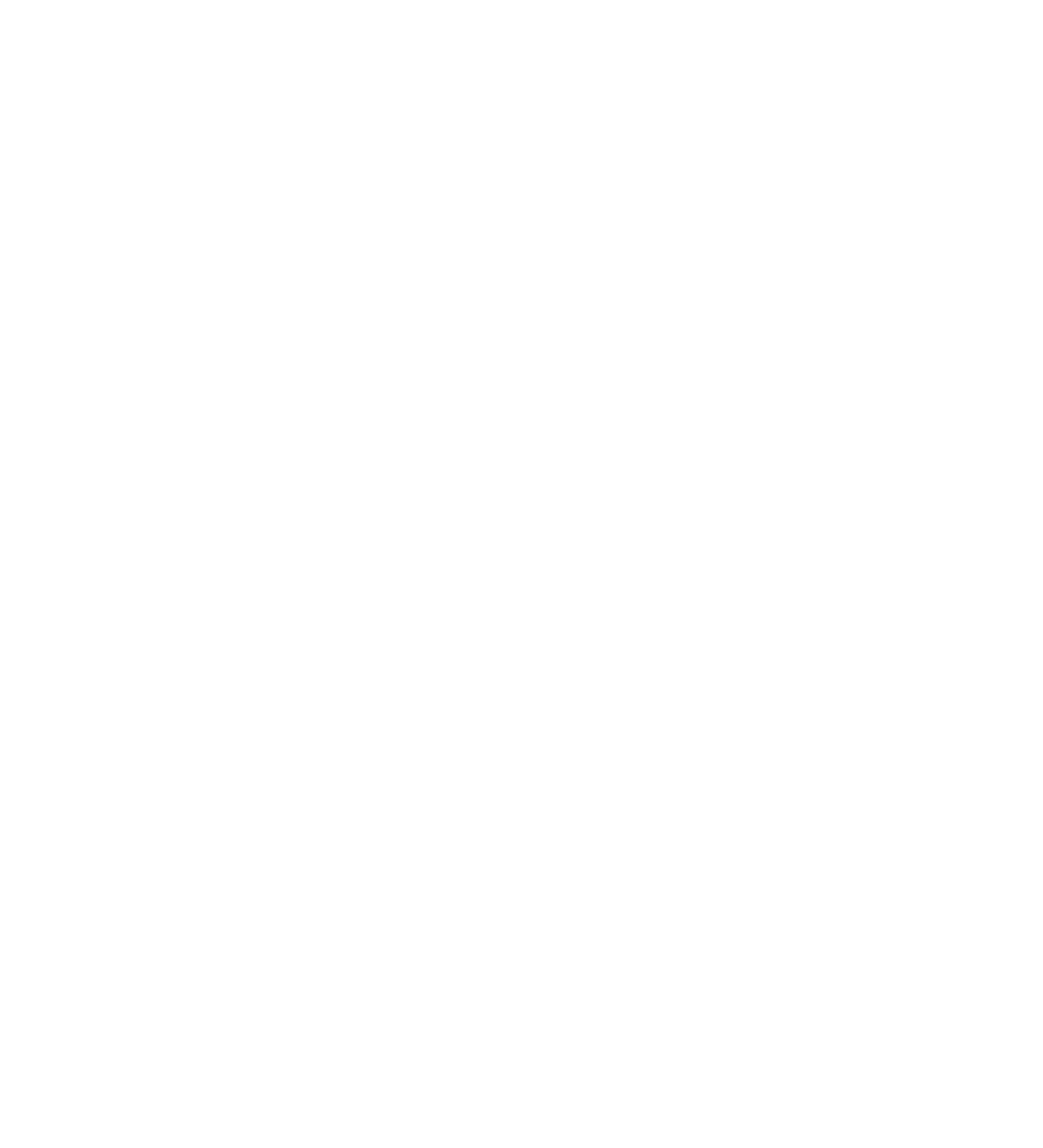


This $\log$, though accurately recorded, is not easily interpreted owing to the terms used in describing the materials. Obviously the terms "soft rock," "clay," "shale," "gumbo," "rock," and "sa nd" are used for different facies of the chalk, and as the same terms are used for parts of the section both above and below the chalk it is difficult to determine the limits of this formation. However, as the chalk formation is so well known to drillers who are operating in the northeastern part of the State it is perhaps reasonable to assume that the Selma was encountered at 300 feet, as indicated by the first appearance of the term "chalk" in the log, though this assumption may involve some error. The thickness of Selma chalk thus obtained (570 feet) is the same as that shown by the log of a well $51 / 2$ miles southeast of Montpelier. (See p. 129.)

Another well 2 miles east of Houlka (No. 12), owned by I. W. Cole, penetrated a water-bearing sand at a depth of 720 feet. If the correlation indicated in the preceding log is correct the water-bearing sand in the Cole well would, on the assumption of the usual dip of 30 feet to the mile, seem to be stratigraphically too high to belong to the Eutaw formation, and it may be a sandy facies of the Selma chalk.

Woodland.-Two deep wells (Nos. 24 and 26) at Woodland tap the water-bearing sands of the Eutaw formation (Upper Cretaceous) at depths of 955 and 1,014 feet. One well (No. 25), only 170 feet deep, yields water too highly mineralized for ordinary uses; this water is probably from the Ripley formation. A well known as the Lewis Mineral well, 4 miles southwest of Woodland, is especially interesting because of the shallow depth (14 feet) at which flowing water was obtained and the highly mineralized character of the water; the source of this water is apparently the base of the Ackerman formation of the Wilcox group, near the contact of the formation with the underlying Porters Creek clay. The following is a partial log of one of the deep wells at Woodland:

Log of well of Mrs. Van E. Abernathy, half a mile west of the railroad station at Woodland

[Altitude of mouth of well, 322 feet above sea level. Authority, W. N. Logan]

\begin{tabular}{|c|c|c|c|c|c|}
\hline & $\begin{array}{c}\text { Thick- } \\
\text { ness }\end{array}$ & Depth & & $\begin{array}{c}\text { Thick- } \\
\text { ness }\end{array}$ & Depth \\
\hline 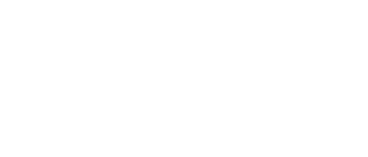 & $\begin{array}{r}\text { Feet } \\
25 \\
475 \\
200 \\
100 \\
1 \\
3\end{array}$ & $\begin{array}{l}\text { Feet } \\
25 \\
500 \\
700 \\
800 \\
801 \\
804\end{array}$ & $\begin{array}{l}\text { Hard white rock } \\
\text { Not reported. } \\
\text { Sandrock } \\
\text { Not reported } \\
\text { White sand; water bearing }\end{array}$ & $\begin{array}{r}\text { Feet } \\
3 \\
128 \\
5 \\
60 \\
14\end{array}$ & $\begin{array}{r}\text { Feet } \\
807 \\
935 \\
940 \\
1,000 \\
1,014\end{array}$ \\
\hline
\end{tabular}

From above downward this well passed through an undetermined thickness of the Porters Creek clay, the Clayton formation, and the Ripley formation, the full thickness of the Selma chalk, and entered the Eutaw formation, from which the water was obtained. 


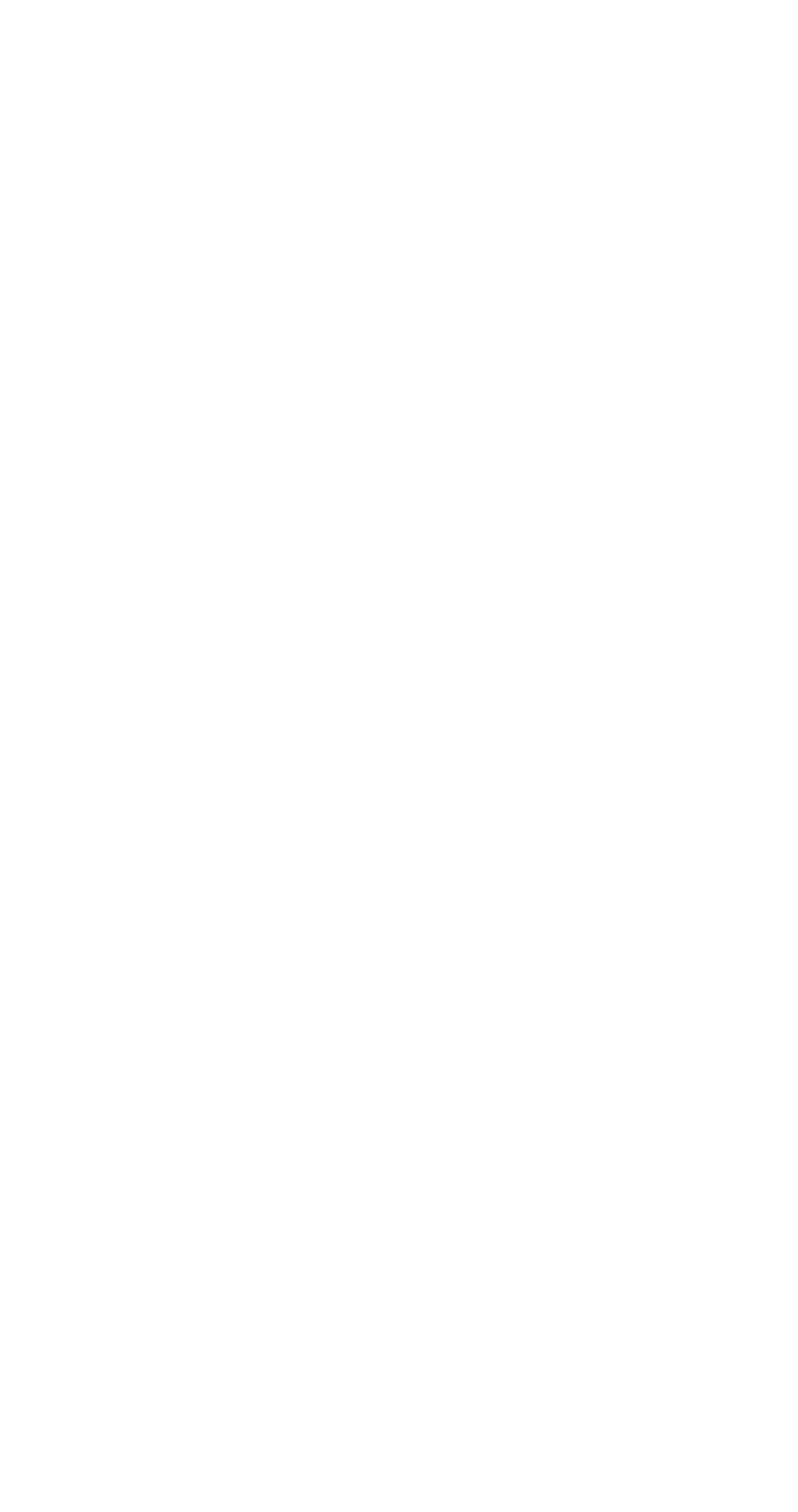




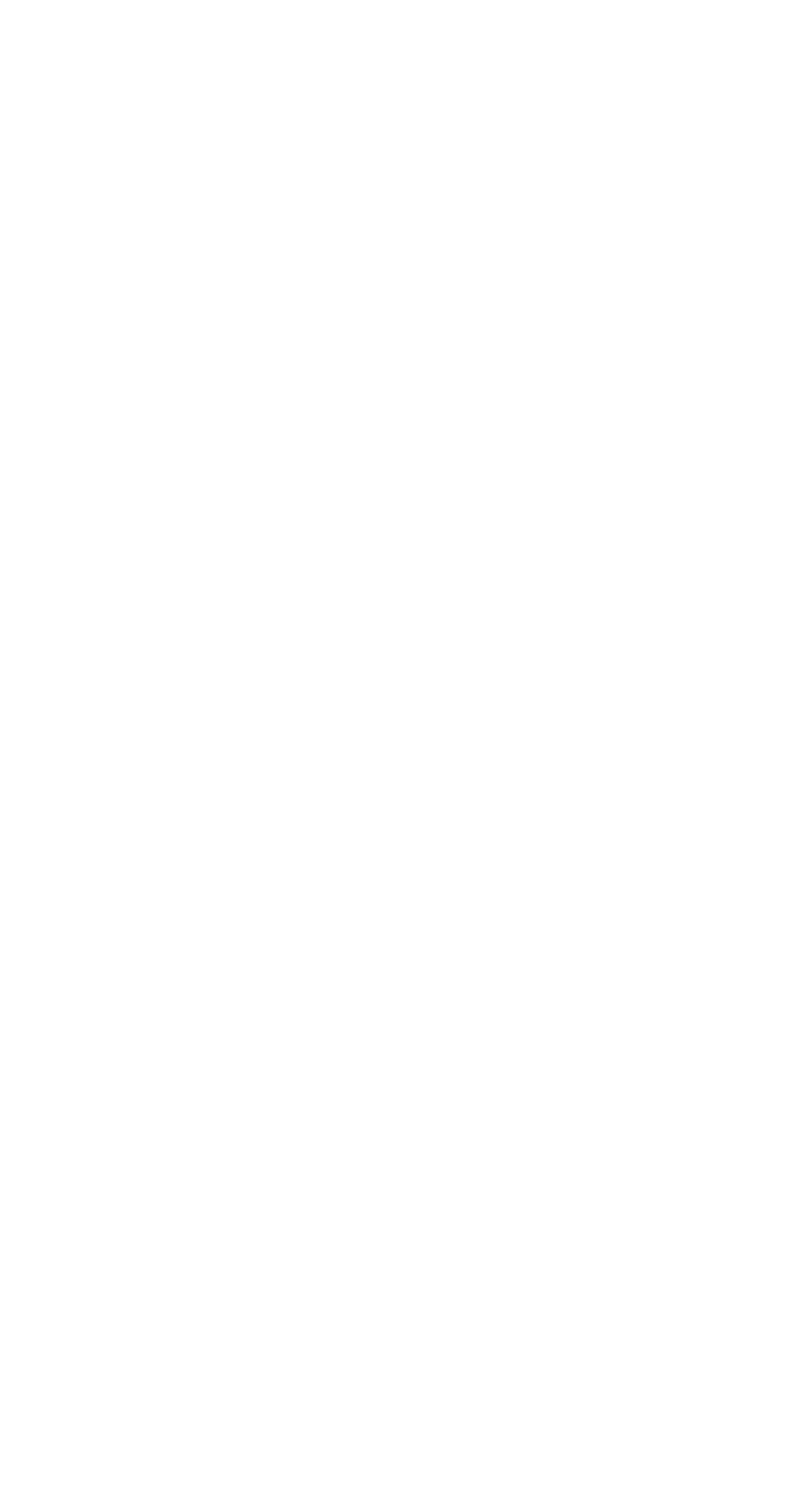


Mineral analyses of ground waters from Chickasaw County

[Parts per million. Numbers at heads of columns refer to corresponding well numbers in preceding table]

\begin{tabular}{|c|c|c|c|c|c|}
\hline & 2 & $\mathbf{7}^{\prime}$ & 15 & 16 & 18 \\
\hline 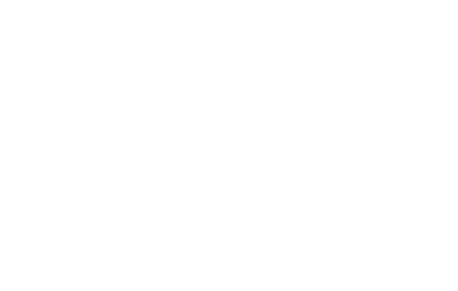 & $\begin{array}{c}12 \\
8.41 \\
8.1 \\
105 \\
173^{.0} \\
5.6 \\
76.00 \\
298 \\
28 \\
\text { Sept., } 1914\end{array}$ & $\begin{array}{c}9.4 \\
18^{.50} \\
2.8 \\
88.0 \\
190^{.0} \\
10 . \\
70^{1.0} \\
1.0 \\
287^{56} \\
\text { Nov., } 1911\end{array}$ & \begin{tabular}{|c|}
18 \\
22.11 \\
9.6 \\
134.0 \\
326 \\
97 \\
8.1 \\
3.0 \\
450 \\
94 \\
Apr., 1920
\end{tabular} & \begin{tabular}{|c|}
16 \\
1.9 \\
21 \\
8.3 \\
133 \\
$337^{\circ}$ \\
82 \\
10 \\
1.2 \\
445 \\
86 \\
June, 1914
\end{tabular} & \begin{tabular}{|c|c|}
25 \\
.05 \\
8.1 \\
2.8 \\
0106 \\
38 \\
92 \\
3.6 \\
84 \\
1.5 \\
317 \\
32 \\
Sept., 1919
\end{tabular} \\
\hline
\end{tabular}

alculated.

Analysts: 2, 7, 16, W. F. Hand, Mississippi State Chemical Laboratory; 15, Margaret D. Foster, U. S. Geological Survey; 18, Margaret D. Foster and Clara M. Forman, U. S. Geological Survey.

\section{CHOCTAW COUNTY}

\section{GENERAL FEATURES}

Area, 414 square miles. Population, 12,491 (census of 1920)

Choctaw County lies within the North Central Hills district. The county is underlain chiefly by the Ackerman formation and the Holly Springs sand, both of which belong to the Wilcox group of the Eocene. These formations are described on pages $45-47$, and their distribution is shown on the geologic map (pl. 2).

\section{GROUND-WATER CONDITIONS}

The strata that compose the Ackerman and Holly Springs formations dip west by south at a rate between 20 and 30 feet to the mile, so that their attitude is favorable for the development of artesian pressure. On account of the predominance of clay the Ackerman formation appears to carry only a little water, but the Holly Springs sand contains an abundance of water of excellent quality for general uses. Supplies of water adequate for domestic and farm use are obtained throughout practically the entire county, even in the belt underlain by the Ackerman, by means of dug and bored wells, most of them less than 100 feet deep. No flowing wells have been reported but the conditions appear to be favorable for obtaining flows in the northwestern part of the county, in the valleys of Big Black River and its larger tributary creeks, at depths of 120 to 600 feet. Springs of small and moderate yield are more or less common but are especially numerous in the area underlain by the Holly Springs sand.

\section{LOCAL SUPPLIES}

Reform.-A spring located in a valley near "Williams Hill" on T. L. Griffin's place, 3 miles north of Reform, yields 2 gallons a minute, and the water is used locally for medicinal purposes. ". The water has its source in the Ackerman formation. (See analysis 1.) 
Bankston.-The Bramlette well, 5 miles northwest of Bankston, in the NE. $1 / 4$ sec. 22, T. 18 N., R: $8 \mathrm{E}$., is 73 feet deep and 10 inches in diameter and yields water that is used for domestic and stock supplies; it has its source in the Holly Springs sands. Red Springs, 4 miles northwest of Bankston, on the farm of J. L. Williams, has been developed as a local resort, including a small hotel, Red Springs mineral water has been bottled and sold to local consumers. The springs flow from the Holly Springs sand. About 3 miles northeast of Bankston J. W. Ramage has a spring, also from the Holly Springs formation, whose water is used for domestic supply.

Chester.-In the vicinity of Chester good water, as a rule, is obtained by means of wells 50 to 75 feet deep. A typical well is the 50 -foot well of J. L. Ray, three-fourths of a mile southwest of town, in which water was obtained in gray sand. However, the 73-foot well of B. G. McGarrity, 300 yards north of the post office, yields a strongly mineralized water that comes from beneath a bed of lignitic clay. Domestic water supplies are also afforded by springs. A typical spring is one owned by I. W. Lowery a mile north of Chester which yields a constant flow of clear, soft water at the rate of 4 gallons a minute. This water comes from the base of light-colored sands that lie above a sandstone ledge; these beds belong to the Holly Springs sand.

French Camp.-At French Camp domestic supplies are obtained from wells 10 to 100 feet deep. In the 70-foot well of Z. T. Irving, 200 yards west of the post office, a good supply of water was encountered near the bottom, and it rose within 50 feet of the surface.

Ackerman.-The source of the municipal water supply at Ackerman is a group of springs, owned by the town, located at the head of a small branch, about a mile south of the courthouse. The average daily consumption is about 25,000 gallons. The present supply is scarcely adequate, and the addition of other springs is contemplated. (See analysis 2.) Two attempts have been made to obtain the muncipal water supply at Ackerman from deep wells. The first well was 300 or 400 feet deep and yielded apparently an insufficient quantity of water, probably from the Midway group. In 1910 a second attempt was made apparently with the intention of sinking the well to the deeply buried sands of the Eutaw formation, which underlie the Selma chalk. The following log shows the charaater of the beds penetrated in this well. 
Log of well at the municipal waterworka, Ackemnan

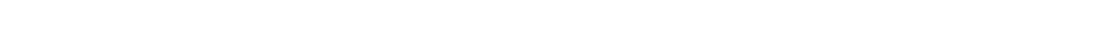

\begin{tabular}{|c|c|c|}
\hline & Thidkness & Depth \\
\hline 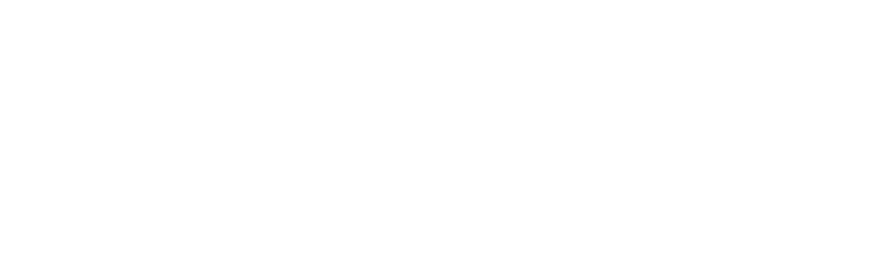 & $\begin{array}{rr}\text { Itt. } & \text { in. } \\
19 & 9 \\
14 & 9 \\
8 & 0 \\
80 & 2 \\
20 & 0 \\
81 & 3 \\
18 & 4 \\
19 & 0 \\
18 & 4 \\
77 & 11 \\
38 & 2\end{array}$ & $\begin{array}{r}74 \\
19 \\
38 \\
41 \\
61 \\
81 \\
109 \\
121 \\
141 \\
159 \\
217 \\
250\end{array}$ \\
\hline 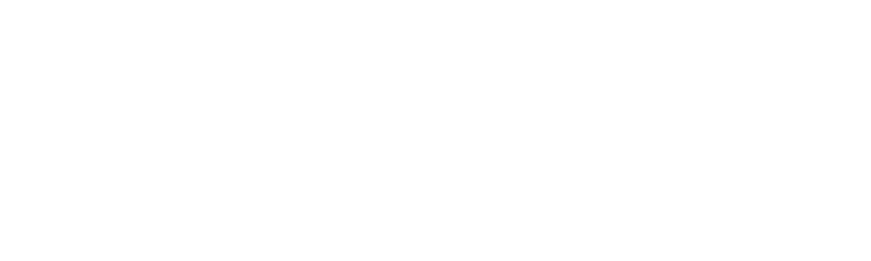 & $\begin{array}{rl}60 & 2 \\
20 & 9 \\
19 & 8 \\
20 & 5 \\
20 & 0 \\
30 & 6 \\
19 & 1 \\
22 & 6 \\
22 & 0 \\
88 & 9 \\
517 & 9\end{array}$ & $\begin{array}{r}315 \\
336 \\
356 \\
376 \\
396 \\
436 \\
455 \\
477 \\
499 \\
888 \\
1,106\end{array}$ \\
\hline
\end{tabular}

This well probably completely penetrates the Eocene and several hundred feet of the underlying Upper Cretaceous strata. The materials as described in the log suggest that the 517 feet of "black mud" at the base should be correlated with the Selma chalk. It is estimated that in order to reach the Eutaw sand at Ackerman it would be necessary to drill a well to a depth of 1,600 to 1,800 feet. One other well at Ackerman, three blocks east of the post office, owned by W. F. Burney, was drilled to a depth of 375 feet, and water rose to a level within 12 feet of the surface, or to an altitude of about 540 feet above sea level. The well was abandoned. This water probably had its source in the Midway group. The character of the water is shown by analysis 3 in the table below.

Mineral analyses of ground waters from Chactaw County

[Parts per million. For further data regarding the wells and springs see pp. 110-112]

\begin{tabular}{|c|c|c|c|}
\hline & 1 & $\boldsymbol{z}$ & 3 \\
\hline $\begin{array}{l}\text { Silica }\left(\mathrm{SlO}_{2}\right) \\
\text { Iron }(\mathrm{Fe}) \\
\text { Calciun }(\mathrm{Ca}) \mathrm{Mg} \\
\text { Magnesitum }(\mathrm{Mg})\end{array}$ & $\begin{array}{c}38 \\
3.8 \\
13 \\
5.2\end{array}$ & $\begin{array}{c}11 \\
.85 \\
5.2 \\
.9\end{array}$ & $\begin{array}{r}29 \\
14 \\
11 \\
81\end{array}$ \\
\hline Bodium and potassitum $(\mathrm{Na}+\mathrm{K})$ & 14 & 4.5 & \\
\hline 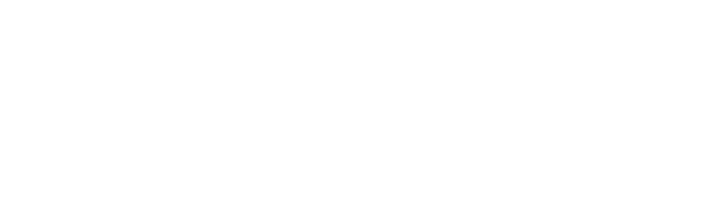 & \begin{tabular}{|c|c|c|}
$62^{2}$ \\
21.0 \\
7.70 \\
129 \\
54 \\
April, 1914
\end{tabular} & $\begin{array}{l}20 \\
3.1 \\
6.0 \\
.00 \\
39 \\
17 \\
\text { May, } 1914\end{array}$ & 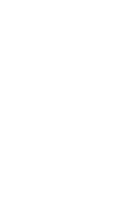 \\
\hline
\end{tabular}

- Iron and aluminum oxides $\left(\mathrm{Fe}_{\mathrm{g}} \mathrm{O}_{3}+\mathrm{Al}_{3} \mathrm{O}_{3}\right)$.

- Oalculated.

Analysts: 1, Mississippi State Chemical Laboratory; 2, W. F. Hand, Missísisippi "State "OhemicaI Laboratory; 3, W. R. Perkins, Mississippi State Chemical Laboratory.

1. Spring owned by $\mathrm{T}$. L. Grifin at Reform.

2. One of the springs that furnish the.municipal supply at Ackerman.

3. Abandoned well, 375 foet deep, of W. F. Burney, Ackerman. 


\section{CLATBRAR CODATY}

\section{GENERAL FEATURES}

Area, 489 square miles. Population, 13,019 (census of 1920)

The greater part of Claiborne County lies in the Loess Fills district, but a relatively small part lies in the Mississippi allavial Plain, and an enstward extension lies in the Iong-leaf Pine district. The two principal geologic formations that underlie the uplend part of the county are the Catahoula sandstone and the Hattiesburg clay (both of Miocene age). These formations are overlain by a discontinuous sheet of sand and gravel, generally 80 foet or less in thickness, which belongs to the Citronelle formation (Pliocene), the distribution of which has not been determined in detail. Over all these formations lies a coating of loess and loesslike loam; whichduring the Pleistocene epoch was carried by the winds in the form of dust from mud flats in the bottom lands of Mississippi River upward over the higher lands to the east, where it accumulated to depths that range from a few feet to 75 feet or more. The Mississippi lowland and the narrow bottom lands bordering Big Black River and Bayou Pierre are underlain by alluvial deposits of loam, clay, and gravel, which in places in the Mississippi bottom probably exceed 150 feet in thickness. (See pp. 55-63 and geologic map, pl. 2.)

\section{GROUND-WATER CONDITIONS}

The loess that covers the upland to depths of a few feet to 75 feet or more is a fine calcareous permeable material, which allows the surface water to drain down through it into the sand and gravel of the underlying Citronelle formation. The loess is therefore not a valuable aquifer. The water of the Citronelle formation, because it has been in contact with the overlying calcareous loess, is more or less hard, and at some places the degree of hardness is such that the water is unsuited for domestic use. Many springs have their source in the sands and gravels of the Citronelle and the water of some of the springs is utilized for domestic or farm supplies and for public drinking places along the roads.

The water of some shallow wells (less than 100 feet deep) at Port Gibson, Martin, Brandywine (southwest corner of county), and elsewhere, are reported to be hard, irony, and sulphurous and more or less unsatisfactory for ordinary uses. These qualities, together with the excessive hardness that in places characterizes the water from the sand and gravel of the Citronelle formation, have led to the construction of many cisterns for storing rain water. However, water of satisfactory quality is found at many places at depths that range from a few feet to 100 feet. 
In the bottom lands of the Mississippi lowland in the western part of the county water for domestic use is obtainable from the sands and gravels of the alluvial deposits at depths that range from a few feet to 150 feet or more, though the shallower waters of these deposits (less than 50 feet deep) can searcely be regarded as a satisfactory source of water supply owing to the danger of pollution from the surface.

The Catahoula sandstone underlies the northern part of the county beneath the loess and the Citronelle formation and dips southward at the rate of 15 or 20 feet to the mile, so that it passes beneath the next younger formation, the Hattiesburg clay. The Catahoula also underlies the alluvial deposits of Mississippi River. Many of the sand beds of this formation are water bearing and constitute the principal, though largely undeveloped, source of potable, nonflowing artesian water in the county. Deep wells at Alcorn and Port Gibson have their source in the Catahoula.

The Hattiesburg clay, which overlaps the Catahoula formation in approximately the southeastern third of the county, contains some beds of sand that may be water bearing, but definite information in regard to this possible source of water is lacking. The data afforded by the 1,760-foot well at Port Gibson indicate that the water contained in the deeply buried Tertiary formations is too salty for either domestic or industrial uses.

\section{LOCAL SUPPLIES}

Port Gibson.-The waterworks at Port Gibson is owned by the town and is located on Market Street about 1,000 feet southwest of the Yazoo \& Mississippi Valley Railroad station. The water supply is obtained from a bed of sand about 10 feet thick, in the Catahoula sandstone, by means of two wells at the plant, one 250 and the other 260 feet deep. The surface at the waterworks is about 120 feet above sea level. The 250 -foot well is 10 inches in diameter and yields by pumping with air 300 gallons a minute. The 260 -foot well is 8 inches in diameter and yields 200 gallons a minute; in both wells the static head of the water is 55 feet below the surface. An abandoned well at the waterworks, drilled in 1909 , is 1,760 feet deep. The log given below shows the position of several water-bearing beds. Salty water was encountered at three levels between depths of 1,405 and 1,760 feet, as indicated in the log. Analyses of water from the 250-foot and 260 -foot wells are given in the table. 
[Altititade of monthi of well, 116 feet above sea level. Authority, William Young, driller, and H. D. Bronjee, supt,

\begin{tabular}{|c|c|c|}
\hline & Thickness & Depth \\
\hline $\begin{array}{l}\text { Loess } \\
\text { Terrace sand; water bearing }\end{array}$ & $\begin{array}{r}\text { Feet } \\
55 \\
12\end{array}$ & $\begin{array}{r}\text { Feet } \\
\mathbf{5 5} \\
\mathbf{6 7}\end{array}$ \\
\hline Catahoula sandstone: & & \\
\hline Medium to hard rock & 13 & 80 \\
\hline Clay & 8 & 9312 \\
\hline Shale and gravel & 34 & 12713 \\
\hline $\begin{array}{l}\text { Sand; water bearing- } \\
\text { Blue gumbo }\end{array}$ & $\begin{array}{l}60 \\
17\end{array}$ & $2013 / 2$ \\
\hline Hard rock & $11 / 2$ & 2067 \\
\hline Blue gumbo & 14 & 220 \\
\hline $\begin{array}{l}\text { Hard rock } \\
\text { Clay }\end{array}$ & $\frac{1}{14}$ & 2221 \\
\hline Hard rock & $\begin{array}{r}14 \\
6\end{array}$ & 241 \\
\hline Sand; water bearing........ & 10 & \\
\hline $\begin{array}{l}\text { Hard rock } \\
\text { Gumbo }\end{array}$ & $\begin{array}{r}18 \\
6\end{array}$ & $\stackrel{269}{275}$ \\
\hline Rock-1- & 15 & 290 \\
\hline $\begin{array}{l}\text { Black sand and lignite. } \\
\text { Rock }\end{array}$ & 8 & 298 \\
\hline Shale & 10 & 310 \\
\hline Rock-k & 4 & 314 \\
\hline \multicolumn{3}{|l|}{$\begin{array}{l}\text { Older Tertiary formations (probably including vicksburg group, Jackson forma- } \\
\text { tion, and Claiborne group): }\end{array}$} \\
\hline Gumbo & 186 & 500 \\
\hline Gumbo.......... & 570 & 1,230 \\
\hline Shale & 170 & 1,400 \\
\hline $\begin{array}{l}\text { Lignite... } \\
\text { Sand; water bearing (salty water) }\end{array}$ & $\begin{array}{r}5 \\
32\end{array}$ & $\begin{array}{l}1,405 \\
1,437\end{array}$ \\
\hline 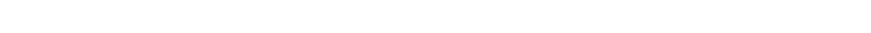 & 1 & 1,438 \\
\hline Sand; water bearing (salty water) - & 40 & 1,478 \\
\hline 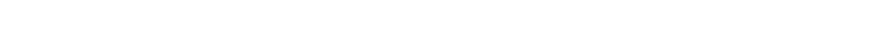 & $\begin{array}{r}22 \\
6\end{array}$ & $\begin{array}{l}1,500 \\
1,506\end{array}$ \\
\hline Blue shale.............. & 30 & 1,536 \\
\hline Very hard rock & 7 & $1,548^{i}$ \\
\hline $\begin{array}{l}\text { Shale and gumbo } \\
\text { Sand and streaks of shale; water bearing (salty water); temperature, } 92^{\circ} \mathbf{F}\end{array}$ & $\cdot 147$ & $\begin{array}{l}1,629 \\
1,760\end{array}$ \\
\hline & & \\
\hline
\end{tabular}

A well at the Chamberlain-Hunt Boys' Academy, a mile south of the courthouse at Port Gibson, is 50 feet deep and 6 inches in diameter and obtains water from Pliocene terrace sand and gravel in the lower 5 feet of the well. The static head of the water is 41 feet below the surface, and the well is kept as a reserve supply. (See analysis 3.)

Alcorn.-Alcorn, the site of the Alcorn Agricultural and Mechanical College, is on the upland 7 miles west of Russum, near the Jefferson County line. The college community obtains its water supply from a 6-inch well 375 feet deep, which taps a water-bearing sand in the Catahoula formation in the lower 40 feet. The well also penetrated 40 feet of water-bearing gravel between depths of 237 and 277 feet. The static head of the water is 214 feet below the surface, and the yield by pumping is 75 gallons a minute.

Barland.-In the vicinity of Barland, in the southeastern part of the county, water is obtained from sand or gravel, probably in part in the Citronelle formation and in part in the Hattiesburg clay, by means of bored wells of moderate depth 10 or 12 inches in diameter, in which the water is under practically no artesian head. The 60foot well of W. E. Marling, 2 miles east of Barland, in the SW. 1/4 
SW. $1 / 4$ sec. 24 , T. 11 N., R. 4 E., and the 60 -foot well of D. B. Westrope, 3 miles southeast of the town, in the NE. 1/4 NE. $1 / 4$ sec. 2, T. 10 N., R. 4 E., are typical.

\section{Mineral analyses of ground waters from Claiborne County}

[Parts per million. Samples collected Sept. 13, 1919]

\begin{tabular}{|c|c|c|c|}
\hline . & 1 & 2 & 8 \\
\hline 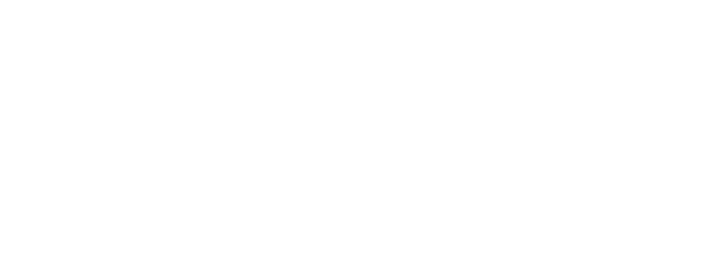 & $\begin{array}{c}58 \\
4: 0 \\
11 \\
4.2 \\
120 \\
331.0 \\
8.7 \\
15 \\
\text { Trace. } \\
392 \\
45\end{array}$ & $\begin{array}{c}69 \\
1.2 \\
136 \\
4.8 \\
317 \\
2.7 \\
35 \\
\underset{440}{\operatorname{Trace}} \\
6\end{array}$ & $\begin{array}{l}45 \\
4.5 \\
55 \\
27 \\
26 \\
382 \\
2.0 \\
3.0 \\
\text { Trace. } \\
355 \\
248\end{array}$ \\
\hline
\end{tabular}

Analysts: 1, H. B. Riffenburg, U. S. Geological Survey; 2, 3, C. S. Howard, U. S. Geological Survey. 1. 250-foot town well at Port Gibson.

2. 260-foot town well at Part Gibson.

3. 50-foot well of Chamberlain-Hunt Boys' Academy at Port Gibson.

\section{CLAREF COUNTY}

\section{GENERAL FEATURES}

Area, 675 square miles. Population, 17,927 (census of 1920)

Clarke County is in the southern part of the North Central Hills district but has a western extension into the Jackson Prairie belt. The geologic divisions are exposed in zones that trend in northwesterly direction across the county. In succession from the northeast to the southwest these divisions include: (1) Eocene, the Hatchetigbee formation of the Wilcox group; the Tallahatta formation, Lisbon formation (including the Winona sand and Kosciusko sandstone members), and Yegua formation of the Claiborne group; and the Jackson formation. (2) Oligocene, the Vicksburg group. (3) Miocene, Catahoula sandstone. (4) Pliocene, the Citronelle formation. These formations are described on pages $48-60$, and their distribution is shown on the geologic map (pl. 2).

\section{GROUND-WATER CONDITIONS}

With the exception of the Jackson formation, which is composed chiefly of relatively impervious clay, all these géologic divisions appear to contain water-bearing beds of more or less economic value, but probably the most abundant supplies occur in the relatively more porous Hatchetigbee formation and the Winona and Kasciusko members of the Lisbon formation. The formations all dip to the south-southwest at rates between 20 and 40 feet to the mile, so that artesian pressure is developed and flowing wells can be obtained from one or another of the water-bearing formations in the deeper valleys of the area. (See table of well data.) Except in areas immediately underlain by the clays of the Jackson formation, water for domestic 
use can be obtained almost anywhere in the county by means of shallow wells-that is, wells less than 100 feet deep. In the beld in which the Jackson formation crops out cisterns for storing rain water are in common use.

In addition to the geologic divisions just described the alluwial deposits of Pleistocene and Recent age in the lowlands that border the streams contain nonartesian water that is obtained by means of shallow wells.

Springs of small yield, which have their source in the outcropping sand beds of the Eocene, Oligocene and Miocene formations, are common in the hilly interstream areas, and springs of small to moderately large yield flow from the alluvial deposits at many places in the lowlands.

\section{LOCAL SUPPLIES}

Basic.-At Basic, in the well of J. L. Bullard (No. 3), flowing water was struck in the Hatchetigbee formation at a depth of 200 feet. In the MeRae well (No. 4), about 300 yards northeast of the Bullard well, a good supply of water was obtrined at a depth of 108 feet, probably in the Tallahatta formation, and rose within 8 feet of the surface. Drilling was continued to a depth of 400 feet without developing a flow.

Enterprise.-In the vicinity of Enterprise water is abtained in part from shallow wells, but abundant supplies of water of excellent quality are also afforded by deper wells (Nos. 7-10). There are three public flowing wells on Front Street, whioh range in depth from 156 to 239 feet and yield water from the Tallahatta formation. (See analysis 7.) The nature of the beds penetrated by the wells at Enterprise is shown by the following logs.

Log of publac well at Enterprise (No. 7)

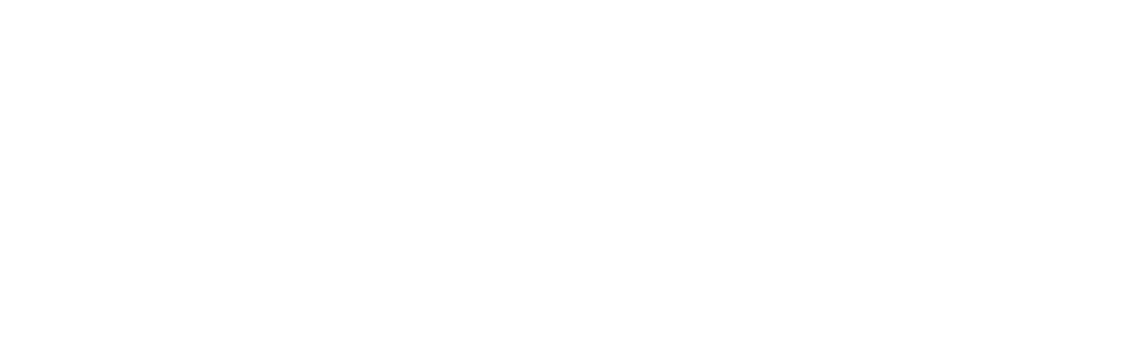

Log of well of John Kamper, Enterprise

\begin{tabular}{|c|c|c|}
\hline & Thickness & Depth \\
\hline 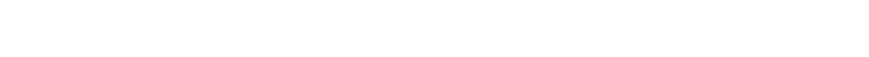 & Feet 35 & Feet 35 \\
\hline $\begin{array}{l}\text { Tallahatta formation: } \\
\text { Soapstone (clay) } \\
\text { Shell rock- (clay) } \\
\text { Soapstone } \\
\text { Sand, water bearing }\end{array}$ & $\begin{array}{r}20 \\
100 \\
15 \\
2\end{array}$ & $\begin{array}{r}55 \\
165 \\
170 \\
172\end{array}$ \\
\hline
\end{tabular}


In 1903 a boring was made for oil at Enterprise under the auspices of a local company. A partial log of the well follows:

Partial log of first oil-prospecting well of 'Alabama-Mississippi Investment \& Development Co., a quarter of a mile east of Mobile \& Ohio Railroad station at ${ }^{*}$ Enterprise

[Lowe, E. N., Mississippi Geol. Survey Bull. 15, pp. 34-35, 1919. The log of this well is based on an incomplete set of samples furnished by Judge John L. Buckley and examined by Dr. E. N. Lowe, State geologist]

Lisbon formation (Winona sand, member): Glauconitic

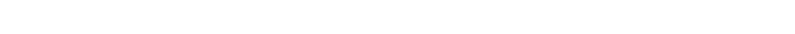

Tallahatta formation:

Light-gray sandy clay, noncalcareous, at...........

Light-gray siliceous claystone, at...................

Hatchetigbee formation: Light-gray clayey sand with particles of lignitic clay, at.

Depth (feet)

Holly Springs sand:

Dark-gray lignitic sandy clay, at............... 500-620

A good oil sand reported (no cuttings, character not

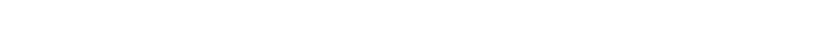

Gray sandy clay, fossiliferous, at............... 1, 065

Gray fossiliferous clay, with coarse sand intermixed, at ............. 1, 085

Light siliceous sand, grains coarse and rounded, at.... 1,390

Subangular grit and fine gravel of quartz of various colors, at_.................. 1, 400

Coarse subangular quartz grains, lignitic grains, lignitic clay, lignite and shell fragments, at ............ 1, 450

(A small fragment of dark-brown fine-grained sandstone from this horizon has the appearance of being saturated with oil but gives no hydrocarbon odor.)

Gray, fine-grained siliceous sand, at_........... 1, 530 Ackerman formation (?):

Dark-gray sandy clay, slightly micaceous, at_....... 1,621

Black lignitic clay, with large proportion of lignite, at_.- 1, 675

Gray lignitic clay, at _...................... 1, 680

Dark-gray lignitic clay, with fragments of light-gray

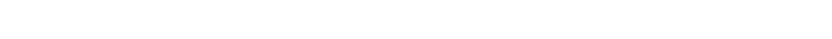

Very light gray, soft chalky limestone, no recognizable fossils, at ....................... 1,806

Dark-gray soft limestone cuttings, at............... 1,812

Lignite and marcasitic lignitic clay ........... 1,806-1, 812

Dark brownish-gray lignitic clay, noncalcareous, at..... 1, 822

Lignite, marcasite, and hard brown glauconitic sandstone, slightly calcareous, at................ 1, 842

Hard black sandstone, bituminous (?), at _.......... 1, 8421/3

Undifferentiated:

Gray sand.

Very fine gray sand.

Glauconitic sand. 
Lowe ${ }^{29}$ says:

The company reorganized in 1904 under the name of the Mississippi Crude Oil Co. and sank a 6-inch well on the west side of Chickasawhay River below Enterprise. At 400 feet a gushing artesian well was struck, and further drilling was abandoned.

LaVesia Spring, on the J. L. Buckley place, a mile southwest of Enterprise, issues at the base of the alluvium at its contact with an underlying marl of the Lisbon formation. The spring is on the west side of the river, only a few rods from the stream and about 10 feet above it and is sometimes covered by high water; it yields 7 gallons a minute. The water is clear but yellow and is used as a domestic supply; it is regarded as possessing certain therapeutic qualities. The spring of $\dot{W}$. D. Singleton, also about a mile southwest of Fnterprise, is 4 feet deep and issues through a 2-inch pipe. The water is hard but is used for domestic supplies. (See analysis 28.) The Dexter and Hall wells (see No. 10) in the river valley, 1 and 2 miles south of Enterprise, yield artesian flows from depths of about 200 feet. The character of the beds penetrated is shown by the following log:

Log of Hall well, near Enterprise (No. 10)

\begin{tabular}{|c|c|c|}
\hline & Thickness & Depth \\
\hline Pleistocene alluvium: Surface sand . . . & Feet 48 & ${ }_{48}$ \\
\hline $\begin{array}{l}\text { Soapstone (clay) } \\
\text { Shell rock } \\
\text { Soapstone (clay) and sand; water bearing }\end{array}$ & $\begin{array}{r}23 \\
118 \\
B 0\end{array}$ & $\begin{array}{r}71 \\
189 \\
239\end{array}$ \\
\hline
\end{tabular}

A well on the Buckley place, a mile east of Enterprise, passed through 22 feet of loose surficial material, below which it was continued in the Winona sand and the Tallahatta formation to a total depth of 198 feet. Water under artesian pressure was encountered and rose within 2 feet of the surface.

Hurricane Creek.-At Hurricane Creek the Hatchetigbee formation immediately underlies the surface, and fair supplies areobtained from it at depths of 30 to 50 feet.

Stonewall.-The Wainwright well (No. 25), a mile northeast of Stonewall, in the area of the Lisbon formation east of Big Black River, was drilled 300 feet deep and obtained a strong artesian flow at a depth of 250 feet, probably from a bed in the Hatchetigbee formation. The 340-foot well of F. F. Kamper (No. 26), 3 miles south of Stonewall, yields a flow from sand penetrated at a depth of a little more than 300 feet, and the J. Kamper well (No. 27), a mile farther south, obtains a fair supply of nonflowing water at a depth of 125 feet. The following records show the strata passed through in each of these wells: 
Log of well of F. F. Kamper, 3 miles south of Stonewall (No. 26)

\begin{tabular}{|c|c|c|}
\hline & Thickness & Depth \\
\hline $\begin{array}{l}\text { Pleistocene alluvium: Clay } \\
\text { Lisbon formation (Kosciusko sandstone and winona sand members): sand. } \\
\text { Tallahatte and Hatchetigbee formations: } \\
\text { Shell rock. } \\
\text { Boapstone and sand; water bearing }\end{array}$ & $\begin{array}{r}\text { Feet } \\
16 \\
102 \\
140 \\
82\end{array}$ & $\begin{array}{r}\text { Feet } \\
10 \\
118 \\
\\
268 \\
340\end{array}$ \\
\hline
\end{tabular}

Log of well of J. Kamper, 4 miles south of Stonewall (No. 27)

\begin{tabular}{|c|c|c|}
\hline & Thickness & Depth \\
\hline 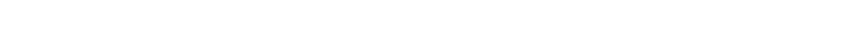 & Feet ${ }_{18}$ & Feet ${ }_{18}$ \\
\hline $\begin{array}{l}\text { Lisbon formation: Shell rock and sand (Kosciusko sandstone member); water } \\
\text { beaning }\end{array}$ & 107 & 125 \\
\hline
\end{tabular}

Pachuta.-Pachuta is near the western border of the county, close to the northern edge of the belt in which the Jackson formation: crops out. Water is obtained at depths of 100 to 140 feet, probably in the Yegua formation of the Claiborne group. The log of the well of M. F. Berry (No. 13) is as follows:

Log of well of M. F. Berry, Pachuta (No. 13)

\begin{tabular}{|c|c|c|}
\hline & Thickness & Depth \\
\hline $\begin{array}{l}\text { Alluvium: Sandy loam and clay } \\
\text { Jackson formation: "Prairie" clay } \\
\text { Yegua formation: Sand; water bearing }\end{array}$ & $\begin{array}{r}\text { Feet } \\
20 \\
80 \\
40\end{array}$ & $\begin{array}{r}\text { Feet } \\
20 \\
100 \\
140\end{array}$ \\
\hline
\end{tabular}

The public well at Pachuta (No. 15) is reported to be about as deep as the Berry well and has its source in the same water-bearing bed. P. E. Lewis's well (No. 14) is 100 feet deep. Analyses of water from the last two wells are given in the table.

Barnett.-Near Barnett water is obtained chiefly from relatively shallow wells in the Jackson formation. Attempts have been made to develop better supplies by deep drilling, but in two wells (Nos. 1,2) of which records are available the water that was encountered in each at depths of 65 and 125 feet in sandy layers of the Jackson was lost in sands of the Lisbon formation at a depth of 350 feet, and a suitable supply was not obtained by deeper drilling.

Quitman.-The lumber plant of the Long-Bell Co. at Quitman is. provided with an efficient waterworks. Water is obtained mainly from a 204-foot well at the plant (No. 16), but there is another 200-foot well, about 75 feet distant from the first, which is kept in condition for use as a reserve supply. Wells at the lumber plant. 170 to 200 feet deep originally flowed, but heavy pumping with air has lowered the head to about 4 foet below the surface. Elsowhere 
in the town there are several privately owned flowing wells on lower ground, and these tap the same stratum as the one tapped by the waterworks wells. A typical well is described in the table of well data (No. 17). Several of the older wells at Quitman, the original static head of which ranged fron 15 to 20 feet above the surface, have ceased to flow, probably because of the heavy pumping on the waterworks wells of the Long-Bell Co. Marked interference has been observed on the 200 -foot reserve well at the waterworks, which is about 75 feet from the 204-foot well. An analysis of the water from a 170(?)-foot well at the courthouse is given elsewhere (No. 18). The following logs of several of the older wells at Quitman show the character of the beds penetrated:

Log of well of John Kamper, 4 miles northwest of Quitman (No. 20)

\begin{tabular}{|c|c|c|}
\hline & Thickness & Depth \\
\hline Pleistocene alluvium: Sand. & & \\
\hline $\begin{array}{l}\text { Lisbon formation: } \\
\text { Shell rock } \\
\text { Sospstone (clay) and sand (Kosciusko sandstone member); water bearing.... }\end{array}$ & 92 & $\begin{array}{l}110 \\
170\end{array}$ \\
\hline
\end{tabular}

Log of well at courthouse, Quitman (No. 18)

\begin{tabular}{|c|c|c|}
\hline & Thickness & Depth \\
\hline $\begin{array}{l}\text { Pleistocene alluvium: } \\
\text { Surface soil........ } \\
\text { Sand. }\end{array}$ & Feet $\begin{array}{r}6 \\
41\end{array}$ & Feet 6 \\
\hline $\begin{array}{l}\text { Lisbon formation: } \\
\text { Shell rock } \\
\text { Sospstone (clay) and sand (Koscinsko sandstone member); water bearing... }\end{array}$ & $23(?)$ & $170(9)$ \\
\hline
\end{tabular}

Log of well of J. W. McGee, 11/4 miles southeast of Quitman

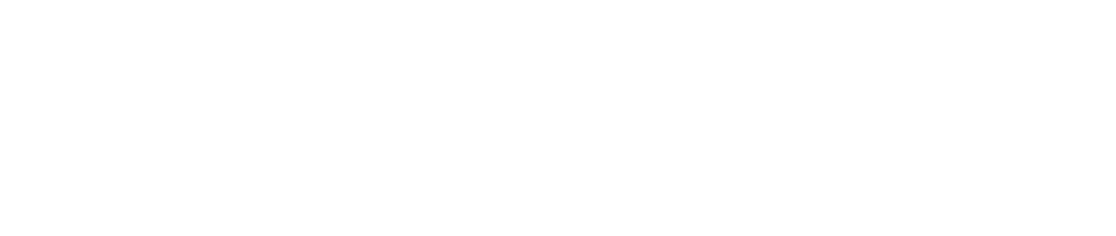

Springs on the property of S. H. Terrell near Quitman issue from alluvium near the border of the river valley.

Archusa Springs.-Archusa Springs (No. 29), owned by Samuel Terrell, rise in a small branch that enters Archusa Creek, about a mile south of the courthouse at Quitman; the place is a local picnic and camping ground. There are two springs of moderate yield, one of which emerges 40 or 50 feet from the creek bank about 1 foot above water level and is walled with brick; this water has a decided reddish color and probably has its source in the Lisbon formation. The other spring emerges about 180 feet farther up the branch, 5 or 6 feet above water level and about 27 feet below the terrace plain which borders the creek. This water lacks the reddish color and is known as "white 54134-28-9 
water"; it probably has its source in sand at the base of a terrace deposit which rests on the Lisbon formation.

Linton.-At Linton, in the belt in which the Lisbon formation, crops out, about 10 miles east of Quitman, water is said to be obtained from wells 16 to 50 feet deep.

De Soto.-At De Soto a public well 485 feet deep (No. 5) penetrates the Lisbon formation, the Tallahatta formation, and finally the water-bearing beds of the Hatchetigbee formation. There are one Jr two other similar wells at this place. Domestic supplies are also obtained from shallow wells, which probably do not extend deeper than the base of the Pleistocene alluvium that borders Chickasawhay River. In the well of M. V. Carlisle (No. 6), which is only 20 feet deep, a good supply of water for domestic use is encountered at a depth of 15 feet. A few springs near De Soto also furnish domestic supplies of water, and a typical one is that of N. J. Cris, which issues from a sandy bed that overlies a clay stratum of the Lisbon formation. Mr. James Knight's spring, 3 miles southeast of De Soto, is another whose yield, though small, is sufficient for a household supply.

Goodwater.-At Goodwater water is obtained chiefly from shallow wells, the dug well of W.S. Rowell (No. 12) being only 15 feet deep. Springs in this vicinity also furnish a considerable portion of the domestic needs, though the water of some of them is not of good quality. Sanders Mineral Spring, 2 miles southwest of Goodwater, owned by S. M. Sanders, yields a moderate flow of water. Eucutta Spring, on the property of Albert Lowery, 7 miles southwest of Goodwater, probably issues from the Vicksburg group and yields a calcareous water.

Shubuta.-At Shubuta, in the Chickasawhay River valley near the south-central border of the county, flowing water is obtained from the Kosciusko sandstone member of the Lisbon formation by means of wells 400 to 450 feet deep; this water has a decidedly reddist. color. The character of the strata passed through at Shubuta is shown by the following log of the Weems well.

Log of Weems well, Shubuta (No. 22)

\begin{tabular}{|c|c|c|}
\hline & Thickness & Depth \\
\hline $\begin{array}{l}\text { Pleistocene alluvium: Sand and clay } \\
\text { Jackson and Lisbon formations: }\end{array}$ & Feet ${ }_{25}$ & ${ }^{\text {Feet }}{ }_{25}$ \\
\hline $\begin{array}{l}\text { Marl, clay, and sand (Kosciusko sandstone member); water bearing in lower } \\
\text { portion. }\end{array}$ & 272 & $\begin{array}{l}15 ? \\
422\end{array}$ \\
\hline
\end{tabular}

Flowing wells are also obtained on the lower slopes in the area between Chickasawhay River and Bucatunna Creek, as is exemplified by the well of A. Johnson (No. 24), 280 feet deep, 6 miles northeast: of Shubuta, which struck flowing water at a depth of 260 feet, in the Kosciusko sandstone member of the Lisbon formation. 


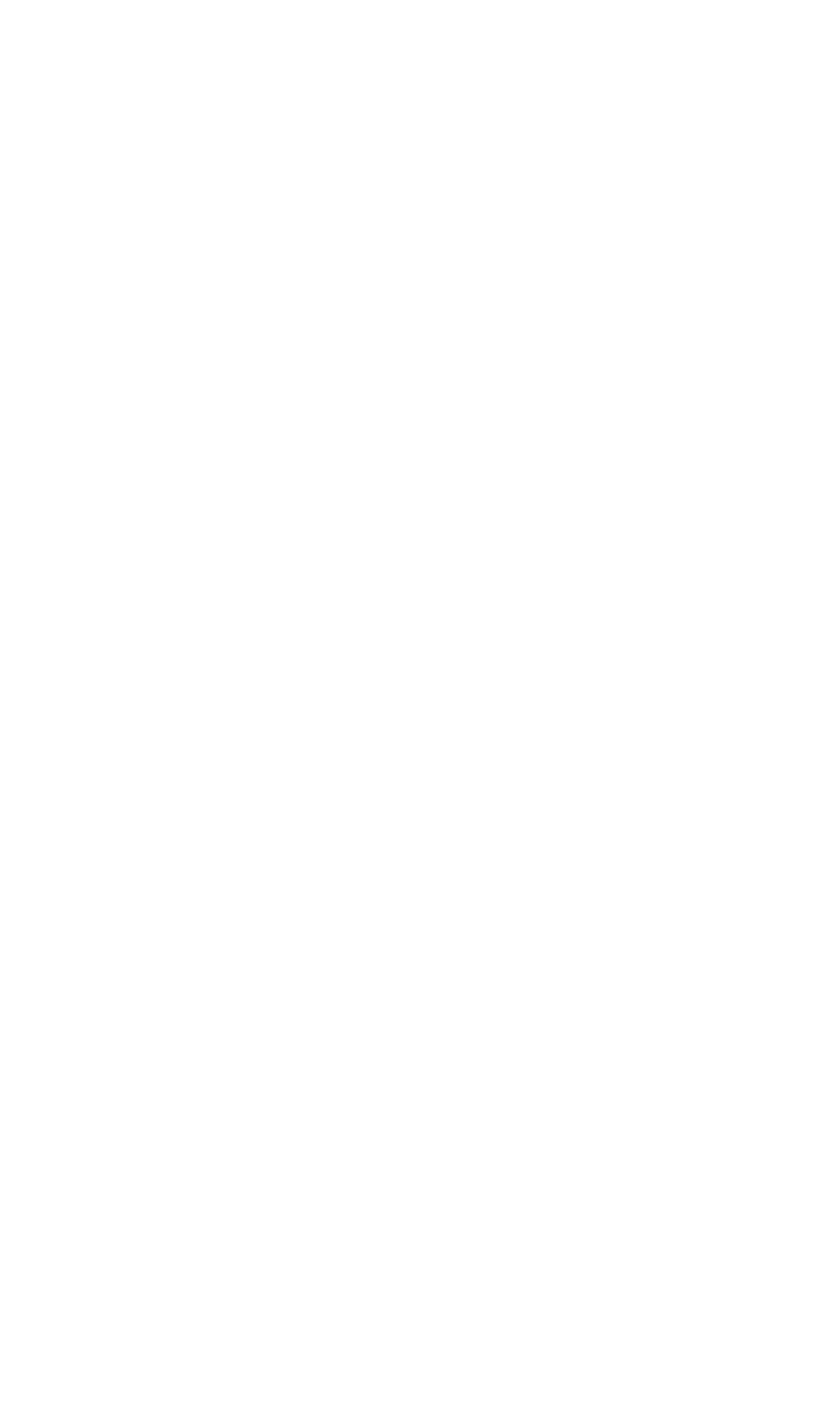




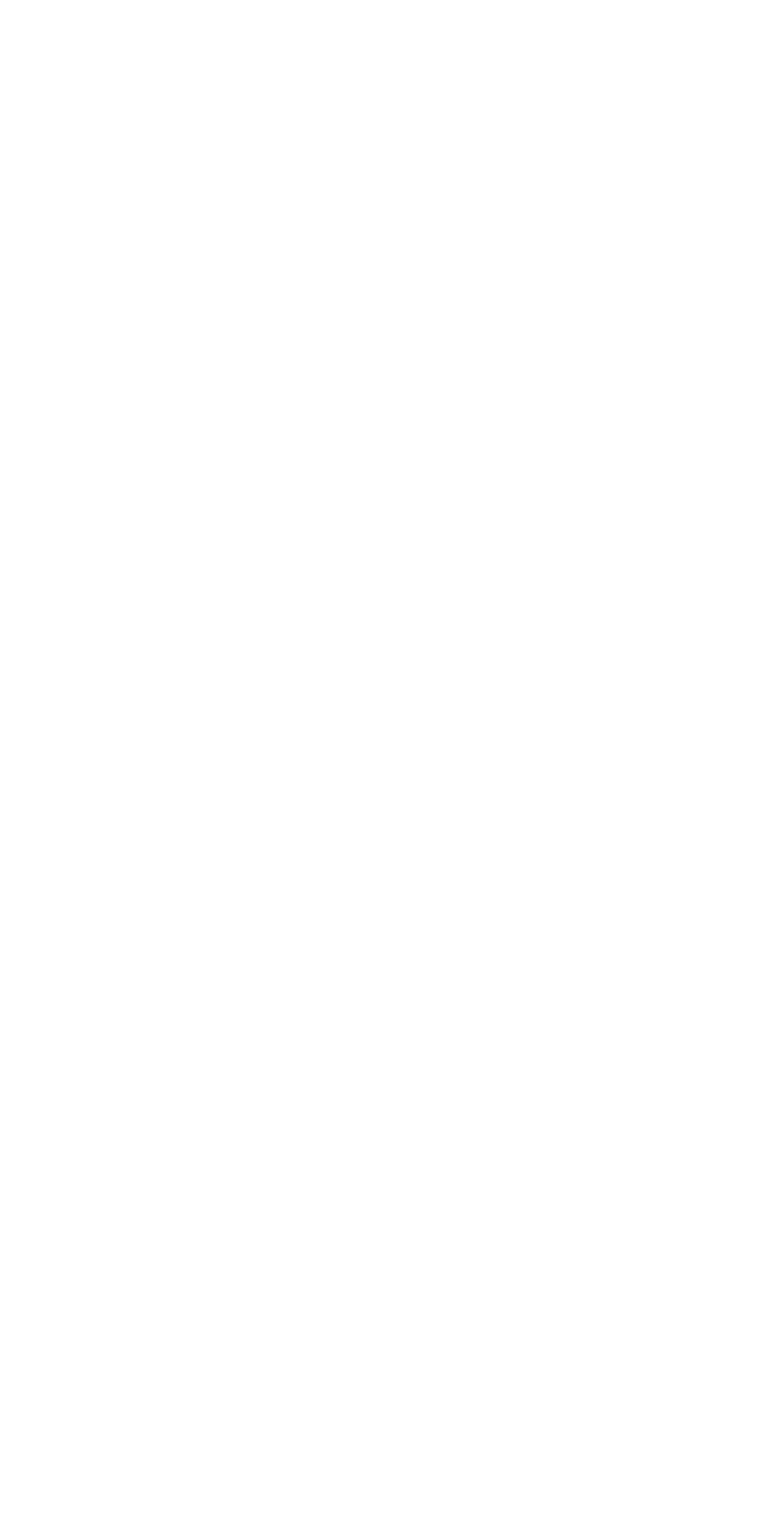


Mineral analyses of ground waters from Clarke County:

[Parts per million. Numbers at heads of columns zefer to corresponding well numbers in preeading table]

\begin{tabular}{|c|c|c|c|c|c|c|c|}
\hline & 3 & 4 & 7 & 8 & 9 & 11 & 13 \\
\hline $\begin{array}{l}\text { Silica }(\mathrm{BiO}) \\
\text { Iron }(\mathrm{Fe}) \\
\text { Calcium }\left(\mathrm{Cg}_{2}\right) \\
\text { Magnesium }(\overline{\mathrm{M}} \mathrm{g})\end{array}$ & $\begin{array}{c}38 \\
21 \\
7.2\end{array}$ & $20^{25}$ & \begin{tabular}{l|r}
14 & 14 \\
4 & 3.7
\end{tabular} & $\begin{array}{r}25 \\
2 . \\
1 .\end{array}$ & $\begin{array}{r}7.2 \\
.83 \\
6.8 \\
.1\end{array}$ & $\begin{array}{l}26 \\
.05 \\
3.6 \\
1.0\end{array}$ & $\begin{array}{r}42 \\
3.4 \\
4.6\end{array}$ \\
\hline Sodium and potassium $(\mathrm{N} a+\mathrm{K})$ & 20 & 38 & $\begin{cases}\mathrm{Na} & 107 \\
\mathrm{~K} & 13\end{cases}$ & \} & 14 & $b 118$ & 14 \\
\hline 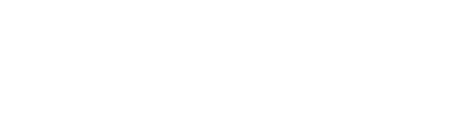 & $\begin{array}{c}129^{.0} \\
23 \\
5.0 \\
.5\end{array}$ & $\begin{array}{c}129^{\circ} \\
25 \\
5.0 \\
1.0\end{array}$ & $\begin{array}{r}302 \\
4.8 \\
4.8 \\
-.8\end{array}$ & $\begin{array}{r}16 \\
244 \\
9.8 \\
5 . \\
1 .\end{array}$ & $26^{2.3}$ & \begin{tabular}{|r|}
12 \\
284 \\
7.1 \\
5.0 \\
.88
\end{tabular} & $\begin{array}{c}176^{.0} \\
24 \\
0.0 \\
.00\end{array}$ \\
\hline $\begin{array}{l}\text { Total dissolved solids at } 180^{\circ} \mathrm{C} \\
\text { Total hardness as } \mathrm{CaCO}_{3} \text { (calculated) } \\
\text { Date of collection. }\end{array}$ & $\begin{array}{c}180^{-} \\
82 \\
1911\end{array}$ & $\begin{array}{c}179 \\
52 \\
1911\end{array}$ & $\begin{array}{r}297^{\circ} \\
10 \\
-10\end{array}$ & $\begin{array}{c}291 \\
11 \\
D \in C \\
1920\end{array}$ & c. $\begin{array}{c}49 \\
17 \\
\text { Sept., } \\
1913\end{array}$ & $\begin{array}{c}328 \\
13 \\
\text { Dec. } \\
1920\end{array}$ & $\begin{array}{l}245 \\
144 \\
\text { May, }\end{array}$ \\
\hline & & 14 & 18 & 21 & 22 & 28 & 29 \\
\hline $\begin{array}{l}\text { Silica }\left(\mathrm{SiO}_{2}\right) \\
\text { Iron }(\mathrm{Fe}) \\
\text { Calcinm }(\mathrm{Ca}) \\
\text { Magnesium }(\overline{\mathrm{Mg}})\end{array}$ & & $\begin{array}{c}41 \\
50^{.48} \\
7.5\end{array}$ & $\begin{array}{c}37.60 \\
30 \\
7.1\end{array}$ & $\begin{array}{r}25 \\
7.6 \\
4.4\end{array}$ & $\begin{array}{r}21 \\
21.1 \\
3.0 \\
1.4\end{array}$ & ${ }_{27}^{40} .68$ & $\begin{array}{l}27 \\
3.10 \\
1.6\end{array}$ \\
\hline Sodium and potassium $(\mathrm{Na}+\mathrm{K})$ & & 30 & $\begin{cases}\mathrm{Na} & 37 \\
\mathrm{~K} & 5.7\end{cases}$ & 258 & $\begin{cases}\mathrm{Na} & 290 \\
\mathrm{~K} & 6.0\end{cases}$ & 20 & 127 \\
\hline $\begin{array}{l}\text { Carbonate radicle }\left(\mathrm{CO}_{3}\right) \\
\text { Bicarbonate radicle }(\mathrm{HCO}) \\
\text { Sulphate radicle }\left(\mathrm{SO}_{4}\right) \\
\text { Chloride radicle }(\mathrm{C} 1) \\
\text { Nitrate radicle }\left(\mathrm{NO}_{3}\right)\end{array}$ & & $\begin{array}{c}199^{\circ} \\
40 \\
9.0 \\
.00\end{array}$ & $\begin{array}{r}221.0 \\
3.6 \\
4.6\end{array}$ & $\begin{array}{c}19 \\
639 \\
14 \\
4.5 \\
.00\end{array}$ & $\begin{array}{r}782^{\circ} \\
2.0 \\
4.7\end{array}$ & $\begin{array}{c}59^{.0} \\
116 \\
10 \\
.00\end{array}$ & $\begin{array}{c}16 \\
301 \\
17 \\
3.0 \\
.78\end{array}$ \\
\hline $\begin{array}{l}\text { Total dissolved solids at } 180^{\circ} \mathrm{C} \\
\text { Total hardness as CaCOj (calculated) } \\
\text { Date of collection. }\end{array}$ & & $\begin{array}{l}273 \\
156 \\
\text { June, } \\
1914\end{array}$ & $\begin{array}{l}236 \\
104\end{array}$ & $\begin{array}{c}650 \\
37 \\
1911\end{array}$ & $\begin{array}{r}8714 \\
18 \\
-9-9\end{array}$ & $\begin{array}{c}261 \\
\text { June, } \\
\text { Jine } \\
1015\end{array}$ & $\begin{array}{c}358 \\
16 \\
D e c \\
1926\end{array}$ \\
\hline
\end{tabular}

a Iron and aluminum oxides $\left(\mathrm{Fe}_{3} \mathrm{O}_{3}+\mathrm{Al}_{2} \mathrm{O}_{3}\right)$

- Calculated.

Analysts: 3, 4, 21, E. S. Wallace, Uंniversity of Mississippi; 7, 18, 22, W. R. Perking (Missisgippi Agr. Exper. Sta. Bull. 89, p. 55, 1905); 8, 11, 29, C. S. Howard, U. S. Geological Survey; 9, Mississippi State Chemical Laboratory; 13, 14, 28, W. F. Hand, Mississippi State Chemical Laboratory.

\section{CLAY COUNTY}

\section{GENERAI FEATURES}

Area, 408 square miles. Population, 17,490 (census of 1920)

Clay County includes parts of three physiographic divisions-the Black Prairie belt, the Pontotoc Hills, and the Flatwoods. Three Upper Cretaceous formations-the Eutaw formation (the uppermost or Tombigbee sand member only is exposed), the Selma chalk, and the Ripley formation-appear at the surface within the county. The Cretaceous is overlain by the Porters Creek clay, a formation of Eocene age. The character, structure, and physiographic expression of these terranes are discussed on pages 31-45, and their distribution is shown on the geologic map (pl. 2).

\section{GROUND-WATER CONDITIONS}

The Tuscaloosa, the lowermost of the Upper Cretaceous formations of Mississippi, is several hundred feet thick. It does not crop out within the county, but from its outcrop in Lamar 
County, Ala., where it rests upon a basement of Paleozoic rocks, and in the valley of Buttahatchie River, in Monroe and Lowndes Counties, it dips to the west at the rate of about 30 feet to the mile and extends out under all of Clay County, its upper surface lying at a depth of about 250 feet in the east, in Tombigbee Valley, and at depths of 1,200 to 1,500 feet in the west. The Tuscaloosa is overlain by the Eutaw formation, which is about 400 feet thick and which also dips to the west at the rate of approximately 30 feet to the mile. The Eutaw crops out in Monroe County and in the extreme eastern part of Clay County, and its upper surface lies at depths of 700 to 1,200 feet in the western part of Clay County. Both the Eutaw and. Tuscaloosa are predominantly composed of sand, and the Tuscaloosa includes beds of gravel in its base, so that both are admirably suited to serve as water bearers. The Eutaw is overlain by the Selma chalk, which underlies the Black Prairie belt in the eastern and central parts of the county and which, on account of its compact nature, serves as a confining bed for the waters in the Eutaw and Tuscaloosa sands. The Selma is therefore one of the chief factors in producing the hydrostatic pressure to which these waters are constantly subjected, a pressure which is sufficient to raise the water to or near the surface in the eastern part of the county, so that flows are obtained in the valleys as far west as the vicinity of Abbott and Cedar Bluff and the water is easily obtained by means of pumps in the central and western parts of the county.

The whole county is therefore fortunate in possessing an excellent, practically inexhaustible and easily accessible supply of ground water, which is being utilized by hundreds of wells, most numerous in the east but also generally distributed throughout the remainder of the county. In the east the wells range in depth from 300 to 700 feet; westward the depth of the wells increases, owing to the westward inclination of the water-bearing beds, until in the longitude of Montpelier the depths range from 700 to 1,000 feet.

In the early history of this region, before the deeper ground-water resources became known, the principal source of water for general domestic and farm use in the Black Prairie belt-was cisterns and surface pools in which rain water was stored, and these are still in use by people who have not provided themselves with artesian supplies.

The sandy beds of the Ripley formation, which is estimated to be 150. to 200 feet thick, crop out in a hilly area, known as the Pontotoc Hills, a few miles wide west of Cedar Bluff and Abbott and east of Pheba and Montpelier. The formation dips to the west beneath the Oktibbeha tongue of the Selma chalk, which there forms the uppermost part of the Cretaceous. The Oktibbeha tongue inclines to the west beneath the overlapping Eocene strata, which appear at 
the surface throughout the remainder of the county in the west. The Ripley sands carry moderate quantities of water, which comes to the surface in numerous small springs in the Pontotoc Hills, or is tapped by shallow dug and bored wells. For some reason, perhaps because of insufficient yield, this source of supply has apparently not proved satisfactory, as shown. by the numerous deep wells that have been drilled to the water-bearing sands of the Eutaw in this section.

\section{LOCAL SUPPLIES}

West Point.-West Point is located on a Pleistocene terrace plain bordering Tibbee River in the eastern part of the county, about 7 miles due west of Tombigbee River. This terrace is the flood plain of an ancient Pleistocene river and now stands at an altitude of a little over 250 feet above sea level and somewhat more than 50 feet above the present flood plain of Tibbee River. The material that immediately underlies the plain to a depth of 10 to 30 feet is chiefly alluvial argillaceous sand, which locally yields water to shallow dug and driven wells. Below this terrace deposit is the Selma chalk, which at West Point is reported to be 180 feet thick. Beneath the Selma, between depths of 200 and 600 feet, lie the water-bearing sands and interbedded clays of the Eutaw formation, and below the Eutaw lie several hundred feet of water-bearing sands, gravels, and interbedded clays of the Tuscaloosa formation. The exact depth to the Paleozoic basement rocks on which the Tuscaloosa formation rests has not been determined, but it is estimated to be about 900 feet.

The town is therefore fortunately situated with respect to supplies of ground water, and hundreds of wells, which range in depth from 300 to 750 feet, tap the water-bearing sands of the Eutaw and Tus-. caloosa formations within the limits of the town and in the surrounding country. Many of the wells overflow at the surface; the static head depends on the elevation of the ground above sea level at the mouths of the wells and on the depth of the wells. Wells 500 feet or more in depth will overflow on the terrace plain on which the town stands, the elevation of which is a little more than 250 feet; many wells less than 500 feet deep will overflow on the lower slopes or in the valley bottoms. Detailed information in regard to 11 wells at and near West Point is given in the table (Nos. 15-25).

The waterworks at West Point is owned by the town and is located on Washington Street near the Illinois Central Railroad. Water is obtained from three wells, two of them 390 feet and one of them 790 feet deep. A $\log$ of the 600 -foot well owned by the town (No.15) and a $\log$ of a well owned by C. T. White, a mile northeast of the post office, are given on the following page. 


\section{Log of well at municipal waterworks, West Point a}

[Aititude of mouth of well, 240 feet above sea level. Adapted from description of Logan and Perkins]

\begin{tabular}{|c|c|c|}
\hline & Thieknese & Depth \\
\hline $\begin{array}{l}\text { Pleistocene terrace deposit: Soil and loam } \\
\text { Selma chalk: Limestone } \\
\text { Eutaw formation: Sand and clay; water bearing }\end{array}$ & $\begin{array}{r}\text { Feet } \\
20 \\
180 \\
400\end{array}$ & 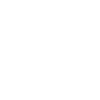 \\
\hline
\end{tabular}

- Logan, W. N., and Perkins, W. R., The underground waters of Mississippi; Mississippi Agr. Exper . Sta. Bull. 89, p. 33, 1905 .

Log of well of C. T. White, 1 mile northeast of post office at West Point (No. 19)

[Adapted from owner's description]

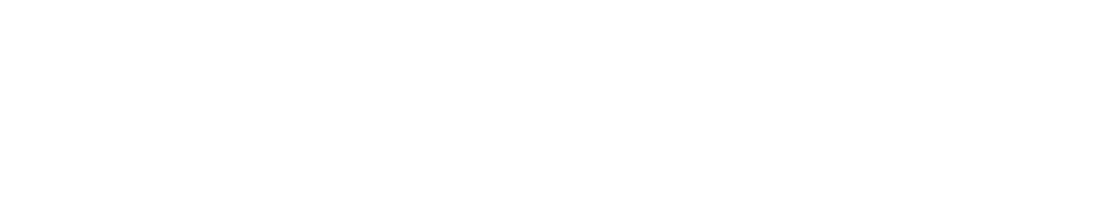

Payne Aviation Field.-The water supply at Payne Aviation Field, $41 / 2$ miles north of New Albany, was obtained from two wells, 550 and 500 feet deep, located 200 feet apart east of the pump house near the center of the camp; the source of the water is the Eutaw formation, and each well yields by pumping with air 114 gallons a minute. (See analysis of composite sample from these wells, No. 11.)

Abbott.-The ground-water conditions at Abbott are similar to those at West Point, except that owing to the westward dip of the strata the depth to the water-bearing sands of the Eutaw is greater. Between 35 and 40 wells, 3 of which are described in the table (Nos. 1-3), are in use in this vicinity; the wells are 500 to over 800 feet deep. Most of the wells are nonflowing, but a few of the deeper ones (depth 750 feet or more), located on the lower slopes or in the creek bottoms, penetrate to the water-bearing beds in the lower part of the Eutaw formation or in the still deeper Tuscaloosa formation and yield flows. The log of a well near Abbott is given below:

Log of well of R. L. Calvert, 200 yards northeast of the post office at Abbott [Altitude of mouth of well, 30 (?) feet above creek bottom. Adepted from description by Gordon Gates. driller]

\begin{tabular}{|c|c|c|}
\hline . & Thictress & Depth \\
\hline $\begin{array}{l}\text { Soil (residual from the Selma) } \\
\text { Selma chalk: } \\
\text { Rotten Jimerock. } \\
\text { Hard, firm blue rock or limerock } \\
\text { "Soapstone" (argillaceous facies of the Selma chalk?) } \\
\text { Eutaw formation: } \\
\text { Sand, water bearing; small yield. } \\
\text { Clay } \\
\text { Flint rock or hardpan (sandstone) } \\
\text { Pure sand, water bearing; principal supply }\end{array}$ & Feot $\begin{array}{r}2 \\
6 \\
120 \\
240 \\
62 \\
8 \\
2 \\
60\end{array}$ & $\begin{array}{r}\text { Feet } \\
2 \\
8 \\
128 \\
868 \\
430 \\
498 \\
440 \\
500\end{array}$ \\
\hline
\end{tabular}


Cedar Bluff.-The ground-water conditions at Cedar Bluff, a village at the western border of the Black Prairie belt, are essentially like those at Abbott. Six or more wells 600 to 700 feet deep, which tap water-bearing beds in the upper part of the Eutaw formation, have been drilled at and near the village; the water rises within 30 feet of the surface. East and south of the village, on the bottom lands of Line Creek and other tributaries of Tibbee River, flowing wells can be obtained. The nearest flowing well reported is 2 miles south of the post office. Descriptions of the public well and of the well of H. A. Noblin are given in the table (Nos. 4, 5), and a log of the public well follows:

\section{Log of public well, Cedar Bluff a}

[Adapted from description by Logan and Perkins]

\begin{tabular}{|c|c|c|}
\hline & Thickniess & Depth \\
\hline $\begin{array}{l}\text { Pleistocene terrace deposit (?): Soil and loam } \\
\text { Selma chalk: Limestone }\end{array}$ & Feet $\begin{array}{r}10 \\
450\end{array}$ & Feet ${ }_{10}$ \\
\hline $\begin{array}{l}\text { Sutaw formation: } \\
\text { Hard rock } \\
\text { Sand; water bearing }\end{array}$ & $\begin{array}{r}2 \\
188\end{array}$ & $\begin{array}{l}462 \\
650\end{array}$ \\
\hline
\end{tabular}

- Logan, W. N., and Perkins, W. R., Mississippi Agr. Exper. Sta. Bull. 89, p. 34, 1905.

Montpelier.-Montpelier is a small village near the boundary between the Cretaceous and Eocene formations. Formerly shallow wells 10 to 50 feet deep, which tapped the rather meagerly waterbearing beds of the Ripley formation, afforded the principal water supply of the region. During the last 15 or 20 years, however, many wells have been drilled to the water-bearing beds of the Eutaw formation at a depth of 700 to 900 feet (Nos. 6-10). No flowing wells have been reported, but the water rises within 28 to 70 feet of the surface in the wells listed in the table. The log of one well (No. 10), 51/2 miles southeast of Montpelier, is given below:

Log of well of George W. Gullett, 51/2 miles southeast of Montpelier (NE. 1/4 sec. 29, T. 16 S., R. 4 E.)

[Altitude of mouth of well, 25 feet (?) above creak bottom. Adapted from owner's description]

\begin{tabular}{|c|c|c|}
\hline & Thickness & Depth \\
\hline $\begin{array}{l}\text { Ripley formation: } \\
\text { Band and clay } \\
\text { Material not adequately described }\end{array}$ & Feet $\begin{array}{r}20 \\
\pm 80\end{array}$ & $\begin{array}{l}\text { Feet } \\
\quad 20 \\
\pm 100\end{array}$ \\
\hline $\begin{array}{l}\text { Selma chalk: } \\
\text { White limerock } \\
\text { Blue limestone }\end{array}$ & $\begin{array}{l} \pm 500 \\
\pm 70\end{array}$ & $\begin{array}{r} \pm 600 \\
670\end{array}$ \\
\hline $\begin{array}{l}\text { Eutaw formation: Very fine sand mixed with black grains (glauconito); water } \\
\text { bearing. }\end{array}$ & 42 & 712 \\
\hline
\end{tabular}

Pheba.-A public well (No. 12) at the village of Pheba, is reported to be about 1,000 feet deep and doubtless taps a water-bearing bed in the Eutaw formation... An 880-foot well owned by W. T. Terry is also described in the table (No. 13). 


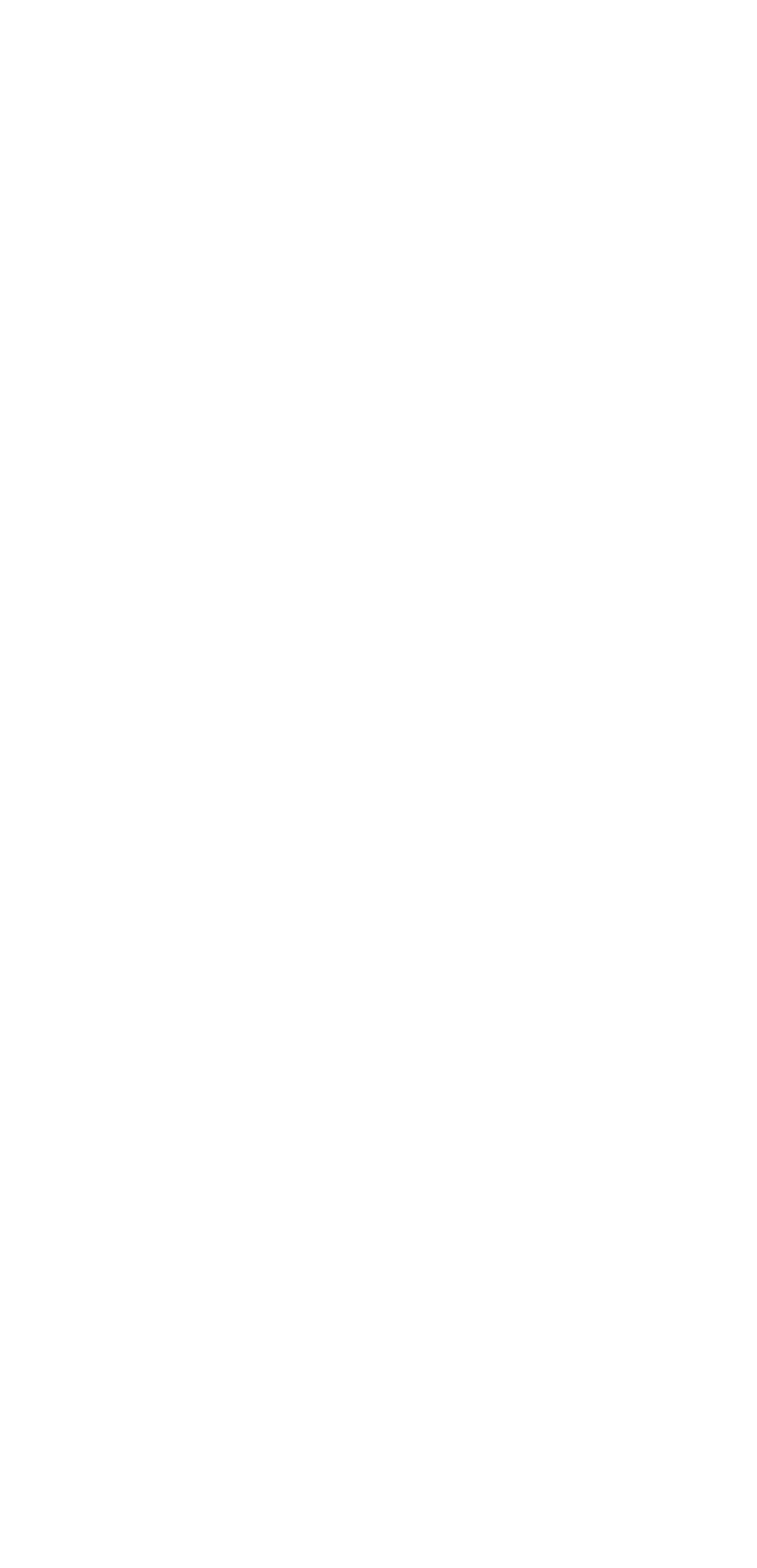




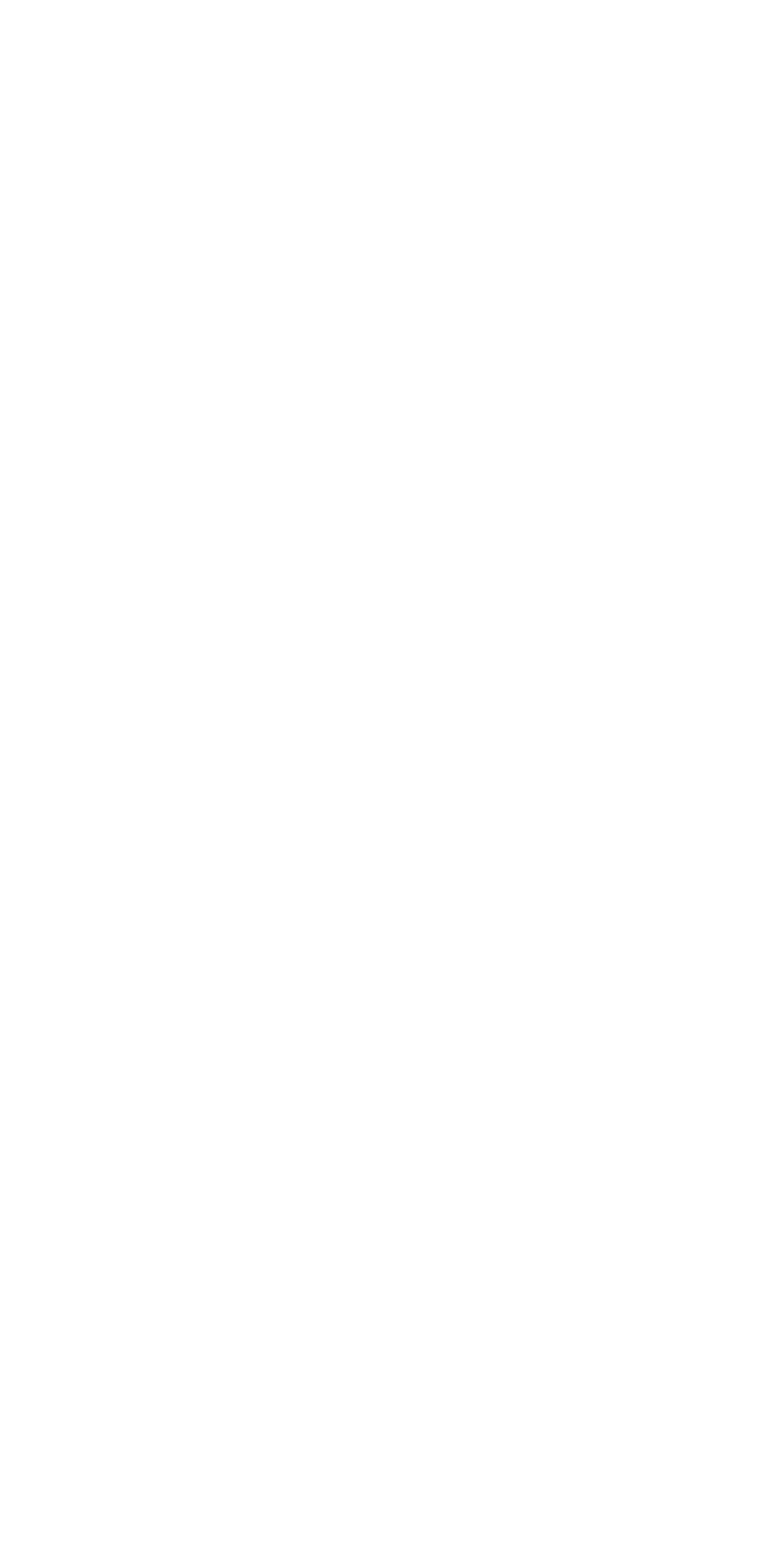




\section{Mineral analyses of ground waters from Clay County}

[Parts per million. Numbers at heads of columns refer to corresponding well numbers in preceding table]

\begin{tabular}{|c|c|c|c|}
\hline & - 11 & 13 & 15 \\
\hline $\begin{array}{l}\text { Silica }\left(\mathrm{SiO}_{2}\right) \\
\text { Iron }(\mathrm{F} \theta) \\
\text { Calcium }(\mathrm{Ca}) \\
\text { Magnesium }(\overline{\mathrm{Mg}})\end{array}$ & $\stackrel{19}{14.18}$ & $\begin{array}{r}16 \\
1.7 \\
5.5 \\
1.8\end{array}$ & $\begin{array}{r}9.8 \\
2.2 \\
9.1 \\
2.2\end{array}$ \\
\hline Sodium and potassium $(\mathrm{Na}+\mathrm{K})$ & - 92 & 269 & $\left\{\begin{array}{l}\mathrm{Na} \\
\mathrm{K}\end{array}\right.$ \\
\hline 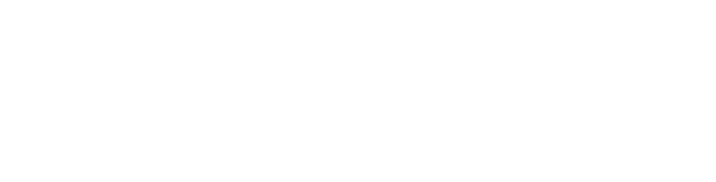 & $\begin{array}{c}224^{4.1} \\
1.9 \\
40^{295} \\
50 \\
\text { Sept. } \\
1919\end{array}$ & $\begin{array}{c}14 \\
466 \\
2.4 \\
142 \\
692 \\
21 \\
\text { Apr., } 1914\end{array}$ & 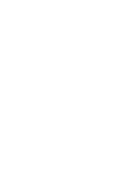 \\
\hline
\end{tabular}

- Composite of waters from well No. 11 and a similar well 550 feet deep.

6 Iron and aluminum oxides $\left(\mathrm{Fe}_{2} \mathrm{O}_{3}+\mathrm{Al}_{9} \mathrm{O}_{3}\right)$.

- Calculated.

Analysts: 11, Margaret D. Foster, U. S. Geological Survey; 13, W. F. Hand, Mississippi State Chemical Laboratory; 15, W. R. Perkins (Mississippi Agr. Exper. Sta. Bull. 89, p. 33, 1905,

\section{COAHOMA COUNTY}

\section{GENERAL FEATURES}

Area, 530 square miles. Population, 41,511 (census of 1920)

Coahoma County lies in the Yazoo Delta. The "delta" is underlain to an estimated depth of 150 or 200 feet by the alluvial deposits of Mississippi River, beneath which lies a great thickness of sedimentary deposits that belong to the Eocene series of the Tertiary, including the Wilcox group and the Midway group.

\section{GROUND-WATER CONDITIONS}

The alluvial deposits, which underlie the entire county, consist of loam, clay, sand, and gravel, the more porous parts of which contain great quantities of water that is under little or no artesian head. This water is easily obtained by bored wells, equipped with rope and bucket, or by driven wells, equipped with either suction or force pumps, as determined by the depth to the water table. Locally this water is stained with vegetable matter buried in the alluvium.

The Eocene deposits that underlie the alluvium include interbedded layers of more or less porous sand, the waters of which are under artesian pressure. The formations that are of especial interest in connection with supplies of ground water are, in descending order, the Grenada, Holly Springs, and Ackerman formations of the Wilcox group, the aggregate thickness of which is estimated to be 1,200 or 1,400 feet. So little is known of the character and thickness of the individual formations, where they extend out under the alluvium, that no attempt is made to correlate the water-bearing sands with the different formations of the group. All the wells 800 feet or more in depth yield flows, and the highest recorded static head is that of two wells near Farrell, owned by R. N. McWilliams, the water of which will rise 40 feet above the surface. 


\section{LOCAL SUPPLTES}

Lula.-In the vicinity of Lula water supplies are obtained in part from the alluvial deposits by means of driven wells 50 to 100 feet. deep. As the water table lies only 10 to 15 feet below the surface, suction pumps can be used to raise the water; this water is reported to be hard. The town well (No. 18) is 1,030 feet deep and yields a strong artesian flow from sands that are correlated with the Wilcox group. (See analysis 18.)

Friar Point.-The waterworks at Friar Point, which is owned by the town, is located 300 feet southwest of the Yazoo \& Mississippi Valley Railroad station. The water is afforded by a 1,500-foot flowing well (No. 16), which yields 125 gallons a minute and discharges in part into a 40,000-gallon concrete ground reservoir. An earlier public well at Friar Point was 1,140 feet deep (No. 15) and yielded 10 gallons a minute.

Coahoma.-The town of Coahoma owns a public flowing well (No. 9), which taps a water-bearing sand in the Wilcox group at a depth of about 1,330 feet and yields 100 gallons a minute. An older public well was 1,120 feet deep and flowed 10 gallons a minute. (See analysis 8.)

Dickerson.-A flowing well at Dickerson, owned by King \& Dickerson, yields 15 gallons a minute, and the water is utilized as a domestic and farm supply. The depth of the well is not stated in the record, but it probably has its source in the Wilcox group.

Farrell.-The inhabitants of Farrell are supplied with water from a 1,300-foot well (No. 14) one-eighth mile south of the $\mathrm{Y}_{\mathrm{azoo}}$ \& Mississippi Valley Railroad station. The well yields 60 gallons a minute when flowing freely, and the water is distributed to the consumers' through a system of small pipes by means of the artesian pressure afforded by the well. Two deep flowing wells near Farrell, owned by R. N. McWilliams, are described in the table of well data (Nos. 12,13). The 65-foot driven well (No. 11) at Farrell is typical of the shallower wells that enter only the alluvium. In this well the water stands witbin 10 feet of the surface and is raised by a pitcher pump.

Jonestown.-An 800-foot flowing well at Jonestown (No. 17) has its source in the Wilcox group and yields 8 gallons a minute.

Eaglesnest.-An 825-foot flowing well (No. 10) on the Alcorn estate at Eaglesnest yields 8 gallons a minute from a water-bearing sand in the Wilcox group.

Cloverhill.-In the vicinity of Cloverhill some water is obtained from the alluvium by means of driven wells about 40 feet deep, but several deep flowing wells have their saurce in the Wilcox group and yield water of more satisfactory character. One well (No. 7) is 1,100 feet deep and flows 15 gallons a minute. There are three deep 
flowing wells on the plantation of R. B. Lowles, but their depths are not recorded. They each yield 35 to 45 gallons a minute.

Sherard.-At Sherard shallow wells are in common use. J. H. Sherard owns a 25-foot well (No. 21) which obtains its water from the alluvium.

Clarksdale.-The waterworks at Clarksdale, which is owned by the town, is located at Third and Sharkey Streets. The source of the water supply is four wells (Nos. 1, 2, table; column of remarks). One well was originally 1,502 feet deep, but the casing was part withdrawn, and its lower end now stands at a depth of 1,380 feet; the second and third wells are reported to be each about 1,300 feet deep and 6 inches in diameter; and the fourth well is 1,000 feet deep and 10 inches in diameter. Analyses of water from the wells now in use and also from several wells no longer used are given on page 138 . The $\log$ of the 1,502-foot well is given below:

Log of the town well at the waterworks at Clarksdale (No. 1)

.[Furnished by E. N. Lowe, State geologist; Layne \& Bowler, drillers]

\begin{tabular}{|c|c|c|c|c|c|}
\hline & $\begin{array}{c}\text { Thick- } \\
\text { ness }\end{array}$ & Depth & & $\begin{array}{c}\text { Thick- } \\
\text { ness }\end{array}$ & Depth \\
\hline 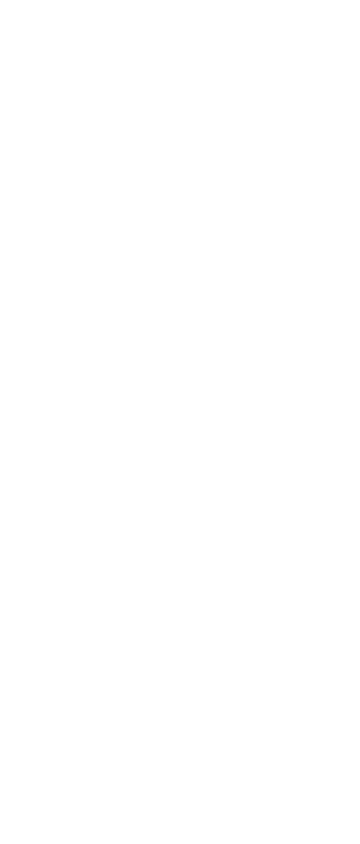 & $\begin{array}{r}\text { Feet } \\
3 \\
27 \\
55 \\
1 \\
67 \\
58 \\
5 \\
5 \\
5 \\
35 \\
7 \\
75 \\
3 \\
11 \\
78 \\
4 \\
63 \\
32 \\
6 \\
24 \\
62 \\
9 \\
18 \\
25 \\
12 \\
11 \\
10 \\
5 \\
40 \\
8 \\
1 / 2 \\
39 \\
3 \\
1 / 2 \\
6 \\
11 \\
3 \\
1\end{array}$ & $\begin{array}{r}\text { Feet } \\
3 \\
30 \\
85 \\
86 \\
153 \\
211 \\
\\
216 \\
221 \\
226 \\
261 \\
268 \\
343 \\
346 \\
357 \\
435 \\
439 \\
502 \\
534 \\
540 \\
564 \\
626 \\
635 \\
653 \\
678 \\
690 \\
701 \\
711 \\
716 \\
756 \\
764 \\
7641 / 2 \\
8031 / 2 \\
8061 / 2 \\
807 \\
813 \\
8141 / 2 \\
8171 / 2 \\
8181 / 2\end{array}$ & 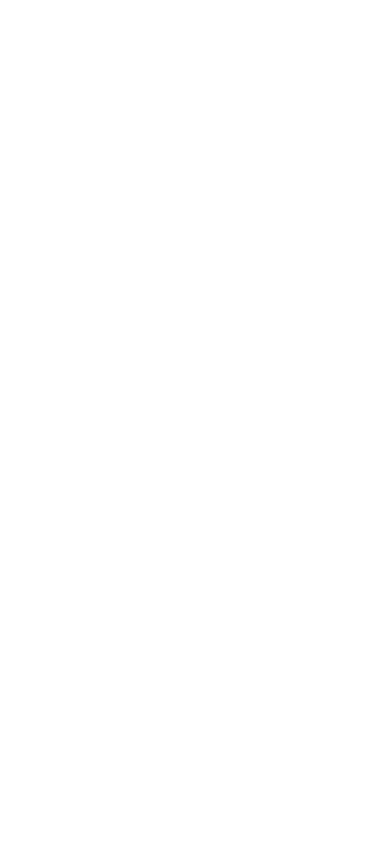 & $\begin{array}{c}\text { Feet } \\
11 \\
3 / 2 \\
3 \\
2 \\
6 \\
10 \\
1 / 2 \\
2 \\
7 \\
7 \\
2 \\
8 \\
45 \\
3 \\
9 \\
2 \\
44 \\
1 \\
10 \\
15 \\
46 \\
8 \\
2 \\
40 \\
10 \\
30 \\
5 \\
30 \\
50 \\
20 \\
60 \\
5 \\
30 \\
9 \\
21 \\
1 \\
47 \\
12 \\
76\end{array}$ & $\begin{array}{c}F e e t \\
8291 / 2 \\
830 \\
833 \\
835 \\
841 \\
851 \\
8511 / 2 \\
8531 / 2 \\
854 \\
861 \\
863 \\
871 \\
916 \\
919 \\
928 \\
930 \\
974 \\
975 \\
985 \\
1,000 \\
1,046 \\
1,054 \\
1,056 \\
1,096 \\
1,106 \\
1,136 \\
1,141 \\
1,171 \\
1,221 \\
1,241 \\
1,301 \\
1,306 \\
1,336 \\
1,345 \\
1,366 \\
1,367 \\
1,414 \\
1,426 \\
1,502\end{array}$ \\
\hline
\end{tabular}

Detailed information in regard to the two wells owned by J. W. Cutrer is lacking, but the accompanying analyses of samples of water from them seem to indicate that they have their source in the Wilcox group. 
Lyon.-The town of Lyon owns a municipal waterworks and obtains water from a 975-foot flowing well (No. 19). A partial log of the well is given below. The static head is about 31 feet above the surface and is utilized to force the water through the mains to the consumers.

Partial log of well owned by Lamar Fontaine at Lyon (No. 19)

[Authority, the owner, through Dr. E. N. Lowe, State geologist]

\begin{tabular}{|c|c|c|}
\hline & Thickness & Depth \\
\hline $\begin{array}{l}\text { Pleistocene alluvium (in part): } \\
\text { Rich alluvium }\end{array}$ & $\begin{array}{c}\text { Feet } \\
108\end{array}$ & Feet 108 \\
\hline $\begin{array}{l}\text { Coarse gravel with pieces of wood or lignite and "charred bones at depth of } 128 \\
\text { feet; some of the pebbles contained imprints of Paleozoc fossils. [Part of this } \\
\text { is probably Eocene sand or clay] }\end{array}$ & \multirow{5}{*}{$\begin{array}{l}289 \\
111 \\
38 \\
10(?) \\
106 \\
117\end{array}$} & \multirow{5}{*}{$\begin{array}{l}397 \\
508 \\
546 \\
556 \\
662 \\
779\end{array}$} \\
\hline $\begin{array}{l}\text { Eocene; Holly Springs sand in lower part: } \\
\text { Fine clean white sand. }\end{array}$ & & \\
\hline 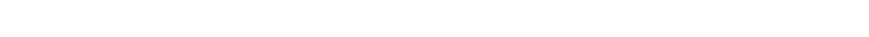 & & \\
\hline Lignite & & \\
\hline Coarse sand with fossil sheils and corals & & \\
\hline $\begin{array}{l}\text { Colnpact elay and fine black sand; water bearing at base; static head } 21 \text { feet } \\
\text { above surface; water tasted strongly of iron; } 21 / 2-\text { neh casing set on clay inside }\end{array}$ & \multirow{3}{*}{$\begin{array}{r}87 \\
104 \\
5\end{array}$} & \multirow{3}{*}{$\begin{array}{l}668 \\
970 \\
975\end{array}$} \\
\hline of 4 inch casing at depth of 866 feet & & \\
\hline Clean white sand; water bearing; static head 31 feet above surface.... & & \\
\hline
\end{tabular}

In the preceding log gravel is described as composing the section from a depth of 108 feet to a depth of 397 feet. As the Pleistocene alluvial gravel is generally not found deeper than about 200 feet below the level of the bottom lands, it seems probable that the lower part of this material is in reality sand and clay of Eocene age. The W. T. Allen well (No. 20) at Lyon yields a strong artesian flow from a depth of 950 to 975 feet. (See analysis.) E. J. Mullen owns a flowing well, depth not recorded, three-fourths of a mile southwest of Lyon; the static head is 20 feet above the surface. 


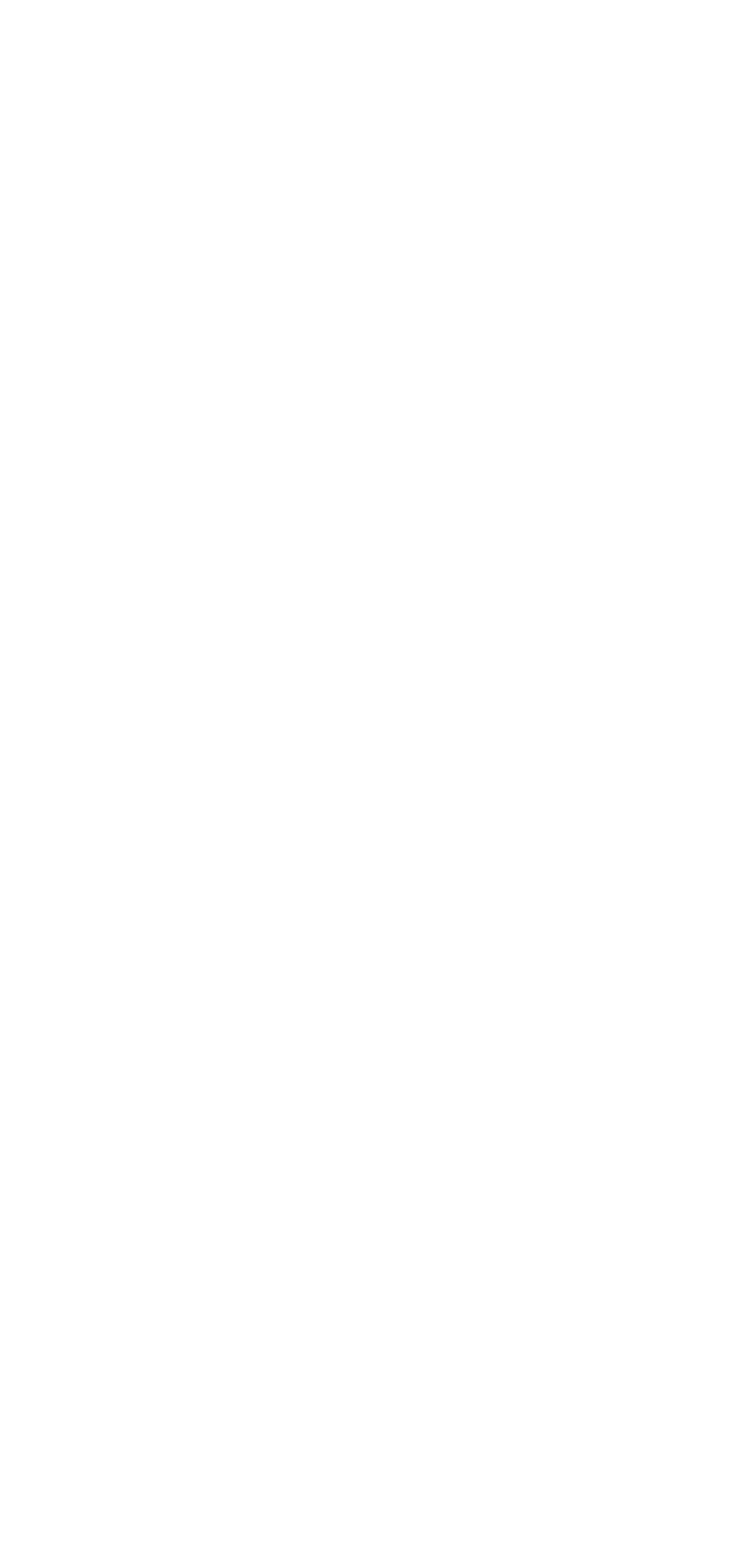




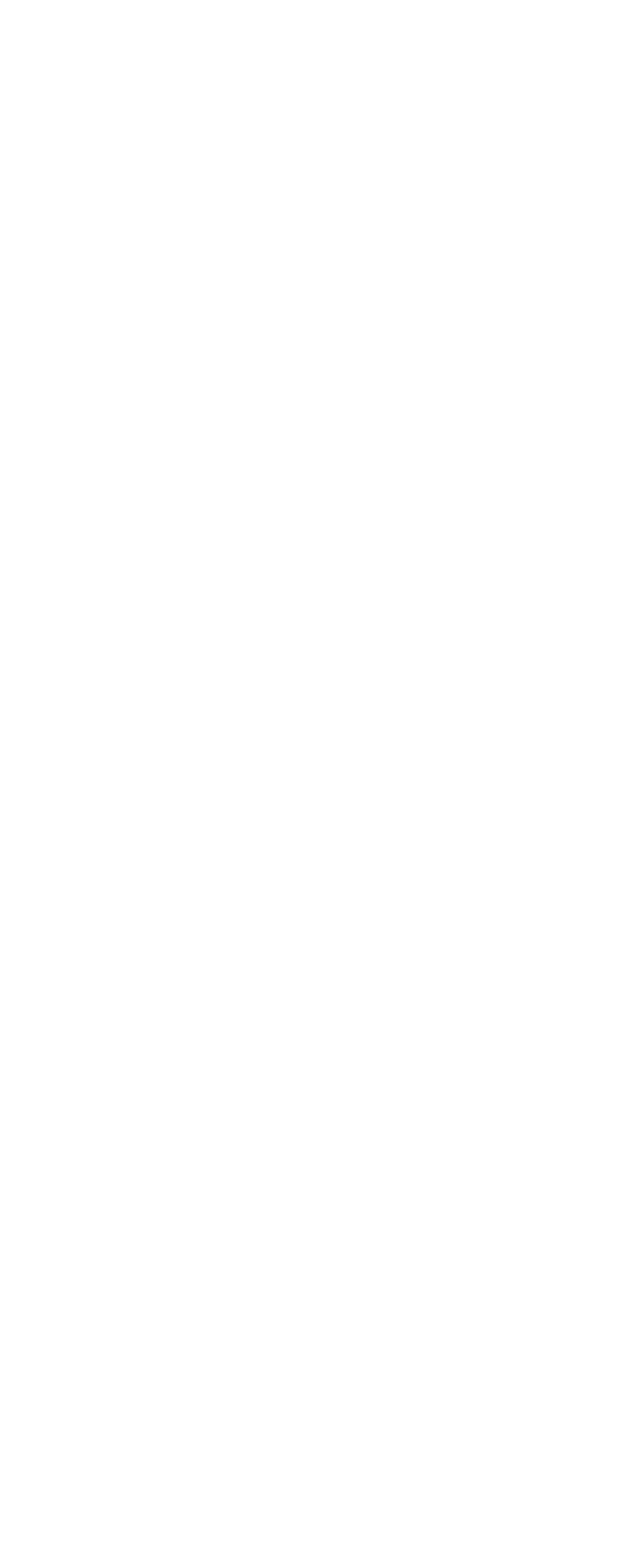


Mineral analyses of ground waters of Coahoma County

[Parts per million. Numbers at heads of columns refer to corresponding well numbers in preceding table]

\begin{tabular}{|c|c|c|c|c|c|c|c|}
\hline & 1 & 4 & 5 & 6 & 8 & 18 & 20 \\
\hline $\begin{array}{l}\text { Silica }\left(\mathrm{SiO}_{2}\right) \\
\text { Iron }(\mathrm{Fe}) \\
\text { Calcium }(\mathrm{Cg}) \\
\text { Magnesium }(\mathrm{Mg})\end{array}$ & $\begin{array}{r}78 \\
2.6 \\
.6 \\
.6\end{array}$ & $\begin{array}{l}17 \\
41.6 \\
18\end{array}$ & $\begin{array}{r}39 \\
\mathbf{1} .3 \\
.9 \\
.3\end{array}$ & $\begin{array}{l}31 \\
a 5.9 \\
45 \\
30\end{array}$ & $\begin{array}{c}36 \\
2.5 \\
10 \\
8.6\end{array}$ & $\begin{array}{l}34 \\
7.90 \\
7.1 \\
2.1\end{array}$ & $\begin{array}{r}38 \\
1.3 \\
1.1 \\
.2\end{array}$ \\
\hline Sodium and potassium $(\mathrm{Na}+\mathrm{K})$ & 168 & $\left\{\begin{array}{l}\mathrm{Na} 112 \\
\mathrm{~K} 4.1\end{array}\right.$ & $\begin{array}{l}\mathrm{Na} .160 \\
\mathbf{K} 3.0\end{array}$ & $\begin{array}{r}\mathrm{Na} 9.0 \\
\mathbf{K} \\
2.7\end{array}$ & 92 & b 50 & $\begin{cases}\mathrm{Na}_{\mathrm{a}} 142 \\
\mathrm{~K}\end{cases}$ \\
\hline $\begin{array}{l}\text { Carbonate radicle }\left(\mathrm{CO}_{3}\right) \\
\text { Bicarbonate radicle }\left(\mathrm{H}^{2} \mathrm{CO}_{3}\right) \\
\text { Snlphate radicle }\left(\mathrm{SO}_{4}\right) \\
\text { Chloride radicle }(\mathrm{Cl}) \\
\text { Nitrate radicle }\left(\mathrm{NO}_{3}\right)\end{array}$ & $\begin{array}{r}354^{.0} \\
2.5 \\
52.00\end{array}$ & $\begin{array}{c}48 i^{\circ} \\
1.1 \\
20\end{array}$ & $\begin{array}{c}357^{.0} \\
1.1\end{array}$ & $\begin{array}{r}300^{.0} \\
2.2 \\
6.8\end{array}$ & $\begin{array}{c}242^{\circ} \\
28 \\
30 \\
1.5\end{array}$ & $\begin{array}{r}146 \\
9.1 \\
5.0 \\
.20\end{array}$ & $\begin{array}{c}315^{.0} \\
4.2 \\
41^{2}\end{array}$ \\
\hline $\begin{array}{l}\text { Phosphate radicle (POA) } \\
\text { Total dissolved solids at } 180^{\circ} \mathrm{C} \\
\text { Total hardness as } \mathrm{CaCO}_{3} \text { (calculated) } \\
\text { Date of collection. }\end{array}$ & $\begin{array}{c}474^{4} \\
\text { Jan., }\end{array}$ & $\begin{array}{c}6453^{-09} \\
179\end{array}$ & $\begin{array}{c}2.0 \\
3428 \\
3\end{array}$ & $\begin{array}{c}6281^{.92} \\
236\end{array}$ & $\begin{array}{c}335 \\
60 \\
\text { Aug., }\end{array}$ & $\begin{array}{c}180 \\
26 \\
\text { Aug., }\end{array}$ & $\begin{array}{c}1.9 \\
385 \\
4\end{array}$ \\
\hline
\end{tabular}

a Iron and aluminum oxides $\left(\mathrm{Fe}_{2} \mathrm{O}_{3}+\mathrm{Al}_{2} \mathrm{O}_{3}\right)$.

- Calculated.

Analysts: 1, Mississippi State Chemical Laboratory; 4, 5, 6, 20, W. R. Perkins (Mississippi Agr. Exper. Sta. Bull. 89, p. 82, 1905); 8, 18, W. L. Kennon, University of Mississippi.

\section{COPIAH COUNTY}

\section{GENERAL FEATURES}

Area, 769 square miles. Population, 28,672 (census of 1920)

Copiah County lies wholly within the Long-leaf Pine Hills district. The three principal formations that crop out in the county are, in the order of age from the oldest to the youngest, the Catahoula sandstone (Miocene), the Hattiesburg clay (Miocene), and the Citronelle formation (Pliocene). Above these older formations on the divides lies a surficial deposit of yellow loam that ranges in thickness from a few inches to a maximum of perhaps 10 or 15 feet. This loam is a wind-blown deposit and is in fact the eastern featheredge of the loess, which has its maximum development farther west, in Warren, Claiborne, and Jefferson Counties. Thin alluvial terrace deposits of gravel, sand, clay, and loam underlie the lowlands that border Pearl River, Bayou Pierre, and the larger creeks tributary to these streams. A general description of the geologic formations that occur in the county is given on pages 55-62, and their approximate distribution is shown on the geologic map (pl. 2).

\section{GROUND-WATER CONDITIONS}

The topmost beds of the Cataboula formation crop out in a narrow strip in the northern part of the county, where, however, they are overlain in places on the ridges by thin outliers of sand and gravel of the Citronelle formation or by a thin surficial covering of yellow loam or loess. The Catahoula is here estimated to be about 400 feet thick. The more porous sands are water bearing and constitute an abundant, though largely undeveloped, source of water supply. The formation 
dips slightly to the south, its top lying at an estimated depth of 500 feet along the southern boundary of the county. The formation may therefore be regarded as a possible source of water at depths that range from a few feet to 400 feet in the north and from 500 to 900 feet in the south. Wells that tap this source of supply are described in the table of well data (p. 144-145). Doubtless many shallow dug and bored wells in the northern part of the county yield water from the Catahoula.

The Catahoula formation is overlain by the Hattiesburg clay, which increases in thickness from a featheredge in the north to a maximum estimated thickness of 400 to 450 feet in the south. In the main the formation is too impervious to serve as an efficient aquifer, though doubtless some of the subordinate sand layers are water bearing. Several wells near Wesson (see No. 17) are thought to obtain water from the Hattiesburg.

Immediately above the Hattiesburg clay in the southern and central parts of the county and lapping over onto the Catahoula sandstone in the northern part of the county lie the sands and gravels of the Citronelle formation. The Citronelle differs in thickness from place to place, but in general it increases in thickness from 30 feet or less in the north to a maximum of probably somewhat more than 100 feet in the south. Though essentially a surficial formation it is water bearing and is in fact the principal source of water supplies for domestic and farm use throughout the hilly parts of the county, where the water is obtained by shallow dug and bored wells. The formation is also the source of many small to medium-sized springs that yield waters of excellent quality for domestic and farm use, and some of them are utilized.

The alluvial terrace deposits that underlie the lowlands along Pearl River, Bayou Pierre, and the larger creeks are water bearing and water is obtained from them by means of driven, dug, and bored wells, generally less than 40 feet deep.

\section{LOCAL SUPPLIES}

Hazelhurst.-The municipal waterworks at Hazelhurst is located 600 feet south of the Illinois Central Railroad station on ground about 8 feet lower than the track at the station. The water supply is obtained from the Citronelle formation by means of three wells, each 48 feet deep (see No, 13), one 10 and two 8 inches in diameter. The log of an abandoned well 284 feet deep, at the waterworks, is given below. 
Log of well at municipal waterworks at Hazelhurst (No. 14)

[Altitude of mouth of well about 470 feet above ses level. Authority, 0 . L. Aldrich, in charge of drilling]

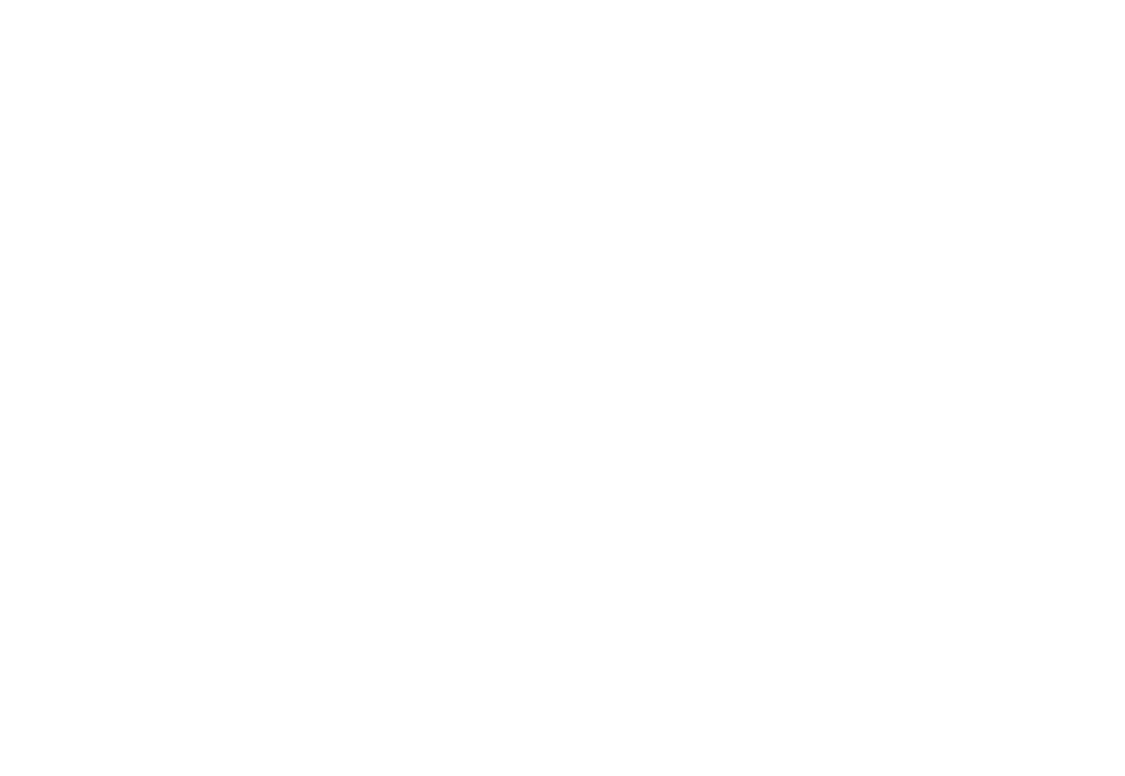

Brown's Wells.-Brown's Wells, a health resort owned by the Brown's Wells Co., is located in a grove on rolling hills 10 miles southwest of Hazelhurst and 2 miles south of Glancy. The altitude of the ridge on which the hotel stands is 355 or 360 feet above sea level, as determined by an aneroid barometer set at the tracks at the Illinois Central Railroad station at Hazelhurst. The seven mineral wells range in depth from $741 / 2$ to 98 feet. (See No. 2.) They are located on rolling ground a short distance south of the hotel within a radius of 600 feet of each other, and their mouths range in altitude from 340 to 353 feet above sea level (aneroid determination). (See pl. 6, B.) The waters of the different wells are reported to differ in chemical character and therapeutic properties. The resort is equipped to entertain 300 guests. A small waterworks near the hotel obtains water for general domestic use and fire protection from two wells 148 and 165 feet deep (No. 1). (See analysis 1.)

Wesson.-A waterworks was installed at Wesson in 1915, but as yet (July, 1919) all attempts to obtain an adequate supply of water have failed. A well at the plant originally drilled to a depth of about 300 feet has become filled with sand until it is now only about 150 feet deep (No. 18). Although the water is of satisfactory quality the well will yield only about 5 gallons a minute and at that rate becomes exhausted after one to two days of pumping. Analyses of samples of water from the waterworks well (No. 18) and the $371 / 2$-foot dug well of Mrs. L. D. Moody at the Richardson House (No. 19) are given in the table. 
Crystal Springs.-Numerous wells that range in depth from 70 to 200 feet have been sunk into the water-bearing sands of the Catahoula formation in the vicinity of Crystal Springs (Nos. 3-6). The municipal water supply is obtained from two of five wells leased from the Illinois Central Railroad, located about 600 feet south of the station on the west side of the track and about 300 feet north of the waterworks on the east side of the track. The five wells (see No. 5) are each 110 feet deep (below the surface) and are located in the bottom of a concrete pit 70 feet deep and about 12 feet in diameter. Two of the group of five wells yield an adequate municipal supply. These wells are not used by the railroad. The water is apparently of satisfactory quality for domestic use. A 114-foot well (No.3,p.145) at the waterworks, 900 feet south of the Illinois Central Railroad station, is no longer used to furnish a municipal supply but is kept in condition for a reserve supply. The $\log$ of an abandoned 195foot well, known as No. 3, at the plant is given below. Several other wells have been drilled and abandoned on account of failure of strainers.

Log of abandoned well at municipal waterworks, Crystal Springs

[Altitude at mouth of well, about 457 feet above sea level. Authority, W. N. Logan]

\begin{tabular}{|c|c|c|}
\hline & Thidkness & Depth \\
\hline $\begin{array}{l}\text { Soil and clay } \\
\text { Gravel, clay, and sand } \\
\text { Sand and gravel; water bearing } \\
\text { Pipe clay } \\
\text { Sand and gravel; water bearing } \\
\text { Hard conglomerate and ironstone } \\
\text { Sand, rock, and clay } \\
\text { Gray clay } \\
\text { gand, rock, and clay } \\
\text { Greenish-blue clay }\end{array}$ & Feet $\begin{array}{r}15 \\
50 \\
18 \\
4 \\
18 \\
1 \\
3 \\
20 \\
14 \\
52\end{array}$ & $\begin{array}{r}\text { Feet } \\
15 \\
65 \\
83 \\
87 \\
105 \\
106 \\
109 \\
129 \\
143 \\
195\end{array}$ \\
\hline
\end{tabular}

The soil and clay that form the upper 15 feet of this section is probably loess; an undetermined portion of the gravel, sand, and clay that form the second layer from the top probably belongs to the Citronelle formation; the remainder of the section, including both the water-bearing beds, is referable to the Catahoula sandstone. The $\log$ of the well of the Crystal Springs Manufacturing Co. (No. 6, p. 145) is given below.

Log of well of Crystal Springs Manufacturing Co., Crystal Springs

[Altitude at mouth of well, about 453 feet above sea level. Authority, A. J. Wallace, president of the company]

\begin{tabular}{|c|c|c|}
\hline & Thickness & Depth \\
\hline $\begin{array}{l}\text { Clay } \\
\text { Gravel } \\
\text { Sand; water bearing- } \\
\text { Gravel; water bearing in part } \\
\text { Sand; water bearing }\end{array}$ & $\begin{array}{l}\text { Feet } \\
10 \\
30 \\
5 \\
20 \\
7 \frac{7}{12}\end{array}$ & $\begin{array}{l}\text { Feet } \\
10 \\
40 \\
45 \\
65 \\
72 \frac{7}{12}\end{array}$ \\
\hline
\end{tabular}


Georgetown.-At Georgetown domestic water supplies are obtained chiefly from bored wells, 15 to 20 feet in depth, which have their source in the terrace deposits that underlie the lowland that borders Pearl River. Three deeper wells are described in the table of well data (Nos. 8-10). The 100-foot well of the Pioneer Boxing Co. (No. 10) was originally sunk to a depth of about 200 feet and yielded a small flow, but the supply was inadequate for the boiler at the factory. To increase the yield the 6 -inch casing was pulled back until the lower end was at a depth of about 80 feet, and a 20 -foot strainer was set opposite a water-bearing sand that extended from a depth of 80 to 100 feet. When the well was pumped sand came up from the uncased part of the well below the strainer, and to prevent this a lead plug was inserted at the bottom of the strainer. Analysis 10 represents water from the beds at 80 to 100 feet. The 210-foot well of W. S. Catchings (No. 8), half a mile west of Georgetown, yielded a small stream for a year after it was completed, but on account of improper construction the walls caved and the well became of little use. Some water is obtained from it, however, by means of a hand suction pump.

Chautauqua Lake.-The water supply for the boilers of the locomotives of the Illinois Central Railroad is obtained from an artificial lake, known as Chautauqua Lake (pl. $1, B$ ), formed by damming one of the headwater branches of Turkey Creek, in the N. $1 / 2$ sec. 24, T. 2 N., R. 2 W., $11 / 4$ miles north by west of Crystal Springs. The lake is owned in fee by the railroad company, but a tract of 40 acres adjacent to the lake on the north is owned by the Hennington Camp Meeting Association. The lake is fed by numerous springs, many of which are now submerged. The surface of the lake lies 60 or 70 feet below the general upland level and probably about 400 feet above sea level. The lake water does not form a scale and is of satisfactory quality for boiler use. An arrangement has been made with the railroad company whereby this water is also used in the boilers at the municipal waterworks. The camp-meeting grounds are leased by the Chautauqua Association, the meetings of which are held each year. A spring, sometimes called the Chautauqua Association Spring, in a small branch which enters the main branch below the dam of the lake, flows into a covered basin 16 feet long, 8 feet wide, and 8 feet deep, constructed in 1908. The spring is 55 feet below the adjacent hill on the north and about 10 feet below the level of the lake. It is said to yield at the rate of 8 gallons a minute. The water is pumped to an elevated tank on the grounds and is used at the cottages for the general needs of the Chautauqua meetings. 
Gallman.-The log of one well at Gallman (No. 7), the water of which is believed to come from the Citronelle formation, is given below:

Log of well of J. E. Lilley at Gallman

[Authority, W. N. Logan]

\begin{tabular}{|c|c|c|}
\hline • & $\begin{array}{l}\text { Approxi- } \\
\text { mate } \\
\text { thickness }\end{array}$ & $\begin{array}{c}\text { Approx- } \\
\text { mate } \\
\text { depth }\end{array}$ \\
\hline $\begin{array}{l}\text { Loess (?): Soil and clay } \\
\text { Citronello formation (?): } \\
\text { Sand and gravel } \\
\text { Pipe clay } \\
\text { Gravel and sand; water bearing }\end{array}$ & $\begin{array}{r}\text { Feet } \\
7 \\
30 \\
9 \\
14\end{array}$ & $\begin{array}{c}\text { Feet } \\
\quad 7 \\
\quad 37 \\
46 \\
\quad 60 ?\end{array}$ \\
\hline
\end{tabular}




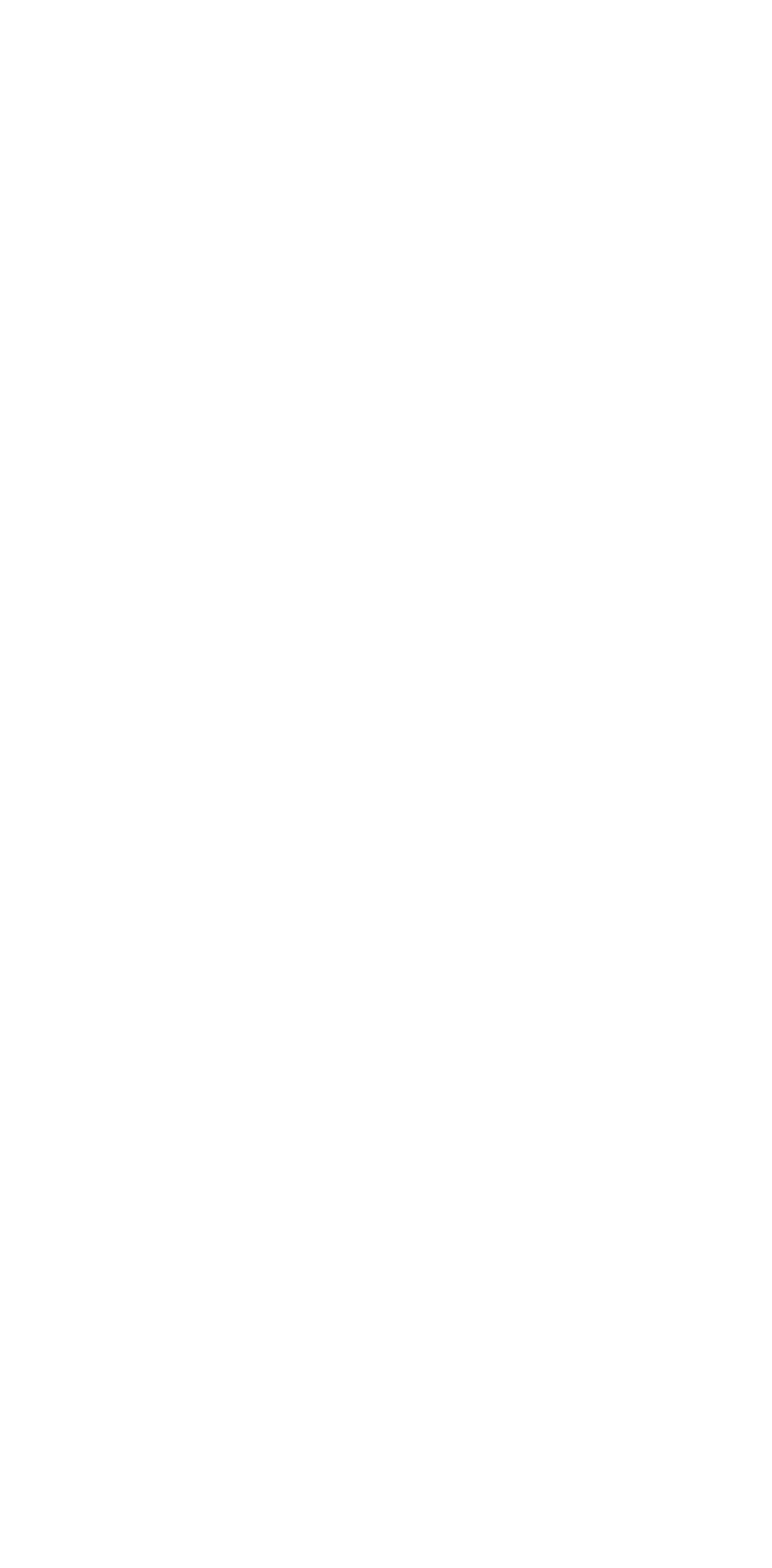




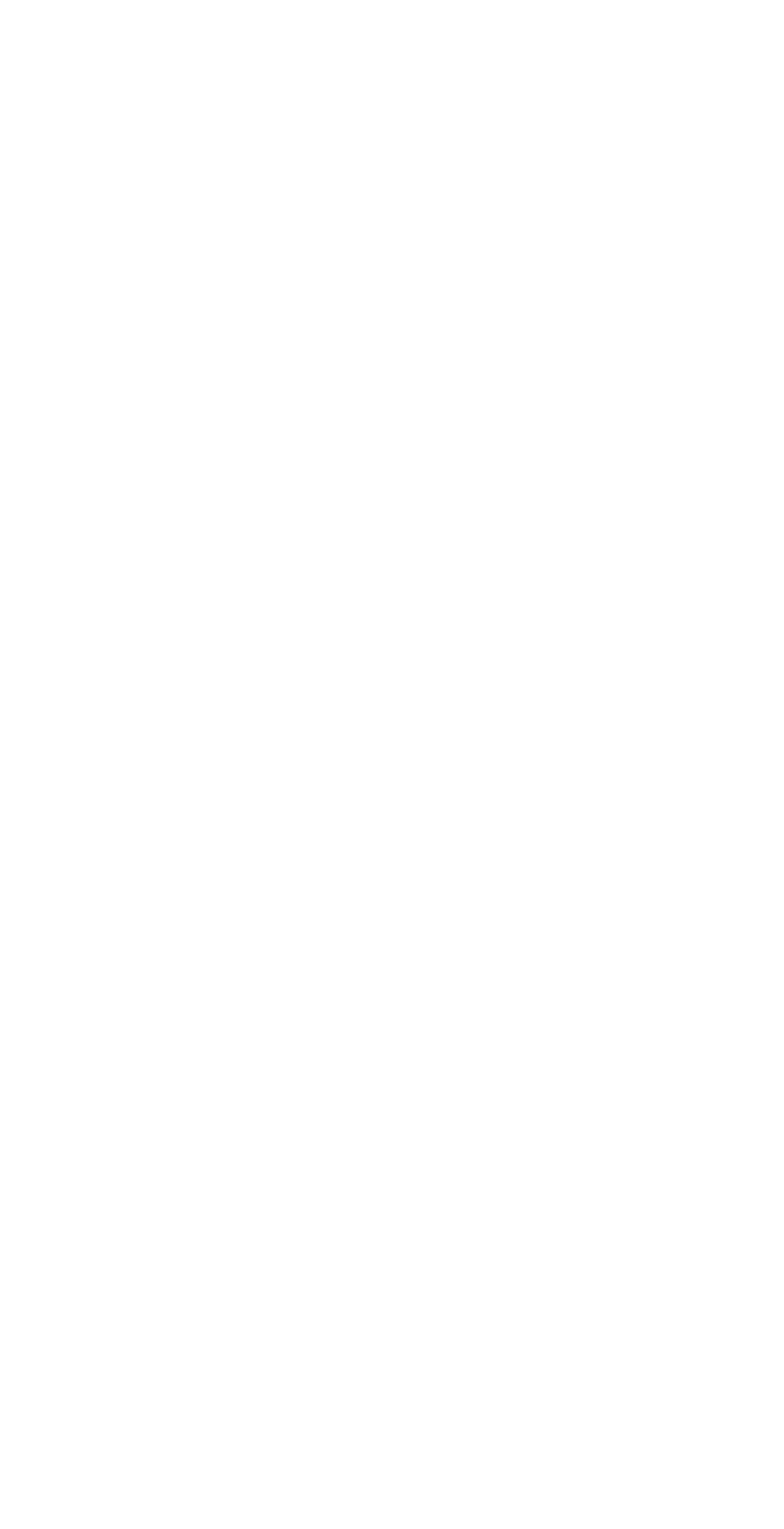




\section{Mineral analyses of ground waters from Copiah County}

[Parts per million. Numbers at heads of columns refer to corresponding well numbers in preceding table]

\begin{tabular}{|c|c|c|c|c|c|c|c|c|}
\hline & - 1 & ${ }^{6} 3$ & 5 & 10 & - 13 & 15 & 18 & 19 \\
\hline 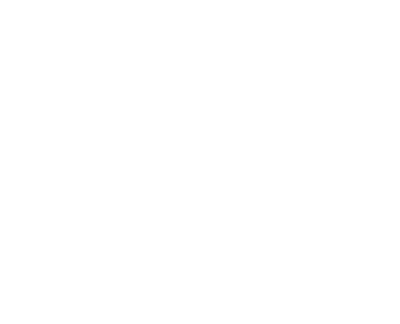 & $\begin{array}{r}22 \\
1.7 \\
3.3 \\
1.0 \\
87.7 \\
18.0 \\
18 \\
4.3 \\
7.0 \\
\text { Trace. } \\
58 \\
12 \\
\text { Jan., } \\
1921\end{array}$ & $\begin{array}{c}19 \\
1.8 \\
17 \\
6.2 \\
31 \\
{ }_{24}^{24} .0 \\
49 \\
40 \\
{ }_{176^{6}}^{.65} \\
{ }^{68} \\
\text { June, } \\
1914\end{array}$ & $\begin{array}{c}22 \\
13 \\
5.48 \\
5.4 \\
{ }^{2} 34 \\
{ }^{51} \cdot 0 \\
20 \\
38 \\
15 \\
170 \\
\\
55 \\
\text { July } \\
1919\end{array}$ & $\begin{array}{c}23 \\
.13 \\
2.3 \\
1.7 \\
31 \\
.0 \\
56 \\
4.4 \\
14.0 \\
103 \\
108 \\
13 \\
\text { July } \\
1919\end{array}$ & $\begin{array}{l}16 \\
26 \\
{ }^{.05} \\
13 \\
55 \\
{ }_{32}^{0} \\
57 \\
74 \\
74 \\
36 \\
309 \\
118 \\
\text { Sept., } \\
1919\end{array}$ & $\begin{array}{c}38 \\
10^{\circ} \\
3.1 \\
14 \\
.^{\circ} 0 \\
46^{\circ} \\
8.5 \\
12 \\
4.8 \\
110^{-8} \\
38 \\
\text { Sept., } \\
1919\end{array}$ & $\begin{array}{r}15 \\
1.7 \\
7.6 \\
5.0 \\
837 \\
3.0 \\
37 \\
2.7 \\
41 \\
37 \\
178 \\
40 \\
\text { July, } \\
1919\end{array}$ & 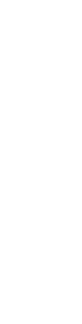 \\
\hline
\end{tabular}

- Composite sample of 2 wells (148 and 165 feet deep), of the Brown's Wells Co.

b Composite sample of 3 wells 114 feet deep.

- Composite sample of 3 city wells (48 feet deep).

¿ Calculated.

Analysts: 1, C. S. Howard, U. S. Geological Survey; 3, W. F. Hand, Mississippi State Chemfeal Laboratory; 5, 18, 19, Addie T. Geiger, U. S. Geological Survey; 10, Margaret D. Foster, U. S. Geological Survey; 13, 15, H. B. Riffenburg, U. S. Geological Survey.

\section{COVINGTON COUNTY}

\section{GENERAL FEATURES}

Area, 410 square miles. Population, 14,869 (census of 1920)

Covington County lies wholly within the Long-leaf Pine Hills district. Three geologic formations- the Catahoula sandstone (Miocene), the Hattiesburg clay (Miocene), and the Citronelle formation (Pliocene)-appear at the surface in the county. They are described on pages 55-60, and their distribution is shown on the geologic map (pl. 2).

\section{GROUND-WATER CONDITIONS}

The Catahoula sandstone underlies the northern half of the county, where, however, it is covered by 100 feet or less of sands, clays, and gravels of the Citronelle formation, except in the lower slopes of the deeper valleys. The exact thickness of the Catahoula is not known, but in this area it is estimated to be 350 or 400 feet. Water is obtained from the middle and lower parts of the formation at Collins and Arbo at depths of 180 to 360 feet (wells Nos. 1-7). One of the wells at Arbo (No. 1) affords a natural flow. The southward inclination of the formation carries it to estimated depths of 200 to 700 feet in the southern part of the county. The formation may therefore be said to be the most productive source of the deeper class of ground waters in the county. The static head appears to be such that flowing artesian wells can be obtained from the Catahoula formation low in the valleys of Okatoma and Bowie Creeks in the southeastern townships. 
The Hattiesburg clay, which overlies the Catahoula sandstone in the southern half of the county, does not carry large quantities of water, but the clay probably contains some interbedded sandy layers which carry moderate amounts of water that would be adequate for domestic supplies.

Most of the hills of the county, to depths of 50 to 100 feet or more, are composed of the Citronelle formation, the basal beds of which are nearly everywhere more or less water bearing and are the source of the water obtained in most of the shallow wells commonly in use for domestic and farm supplies. Some of the deeper dug and bored wells, however, probably completely penetrate the Citronelle formation and tap water-bearing beds in the underlying Hattiesburg clay and Catahoula sandstone. Small springs, most of which have their source in the Citronelle formation, are more or less common throughout the county.

Partial logs of two oil-prospecting wells, one at Seminary $(3,100$ feet deep) and one at Sanford (4,029 feet deep), both of which penetrated the buried Tertiary formations down to and including part of the Claiborne group, are given below. The deeper well may reach almost to the top of the Wilcox group, which underlies the Claiborne.

\section{LOCAL SUPPLIES}

Collins.-The municipal waterworks at Collins, the county seat, is located about a block south of the Gulf \& Ship Island Railroad station. Water is obtained chiefly from a well (No. 4), reported to be 220 feet deep, which taps a water-bearing sand in the Catahoula formation. (See analysis 4.) Another well 190 feet deep is held to furnish a reserve supply.

Mount Olive.-The municipal waterworks at Mount Olive is located about 100 yards east of the Gulf \& Ship Island Railroad station. The water supply is obtained from the Catahoula formation by means of two flowing wells (see No. 9), one reported to be 140 feet and the other 200 feet deep. Analysis 10 represents water from the 140foot well.

Seminary.-In G. C. Matson's notebook (Coastal Plain No. 3, p. 32) the statement is made that in a well at Seminary thin rock, sand, and water were encountered between the depths of 100 and 400 feet; an abundance of water was found between the depths of 150 and 155 feet, and it rose within 14 feet of the surface. These abundantly water-bearing beds are doubtless in the Catahoula formation. The head was lowered when the well was drilled deeper. The following is a partial log of an oil-prospecting well drilled by the Seminary Oil \& Gas Co., a quarter of a mile southeast of Seminary, in 1914. 
Partial log of oil-prospecting well of Seminary Oil \& Gas Co. on land of $0 . W$. Conner in $S W .1 / 4 N E$. 1/4 sec. $22, T .7 N ., R .15 W$. near Seminary

[A]titude of mouth of woll, 244 foet above ses level. fog neade by O. B. Fopkins from samples: fossils identifled by $\mathrm{C}$. W. Cooke]

\begin{tabular}{|c|c|c|}
\hline & Thiekness & Depth \\
\hline 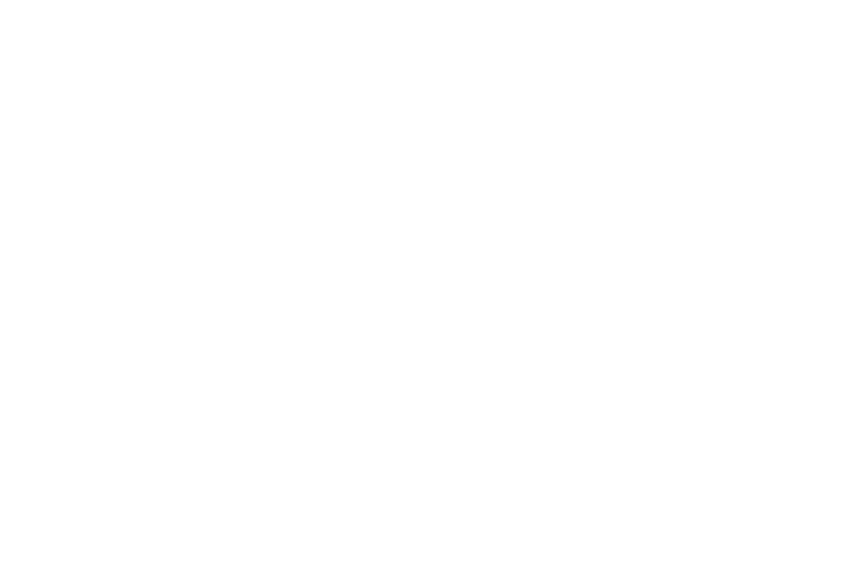 & $\begin{array}{r}20 \\
13 \\
7 \\
75 \\
70 \\
30 \\
109 \\
20\end{array}$ & $\begin{array}{l}\text { Feet } \\
2,725 \\
\\
2,745 \\
2,758 \\
\\
2,765 \\
2,840 \\
2,870 \\
2,900 \\
3,000 \\
3,020\end{array}$ \\
\hline
\end{tabular}

C. W. Cooke, who identified the fossils from this well, states that all the fossils found between depths of 2,758 and 3,100 feet appear to be of Claiborne (Eocene) age. Hopkins, who examined the samples between depths of 2,725 and 3,100 feet, states that in addition to the fossils identified by Cooke there were many other small gastropods and foraminifers.

Sanford.-The log of an oil-prospecting well near Sanford, drilled several years ago by W. O. Tatum, lessor, is given on page 149. 


\section{Partial log of oil-prospecting well near Sanford}

[Altitude of mouth of well about 216 feet above sea level. Authority, W. O. Tatum, lessor, and his son, W. S. F. Tatum, who prepared the written descriptions of the materials]

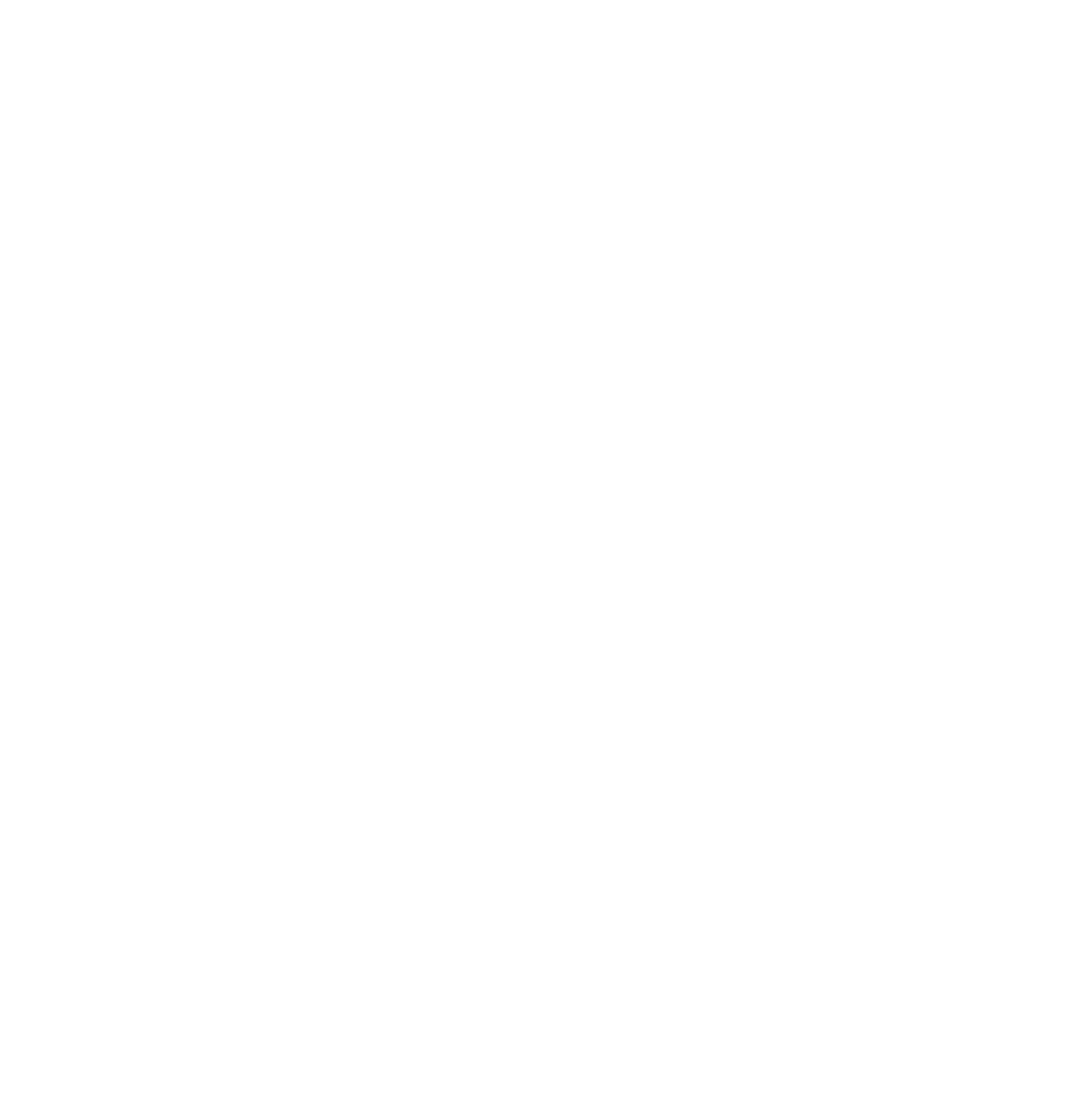




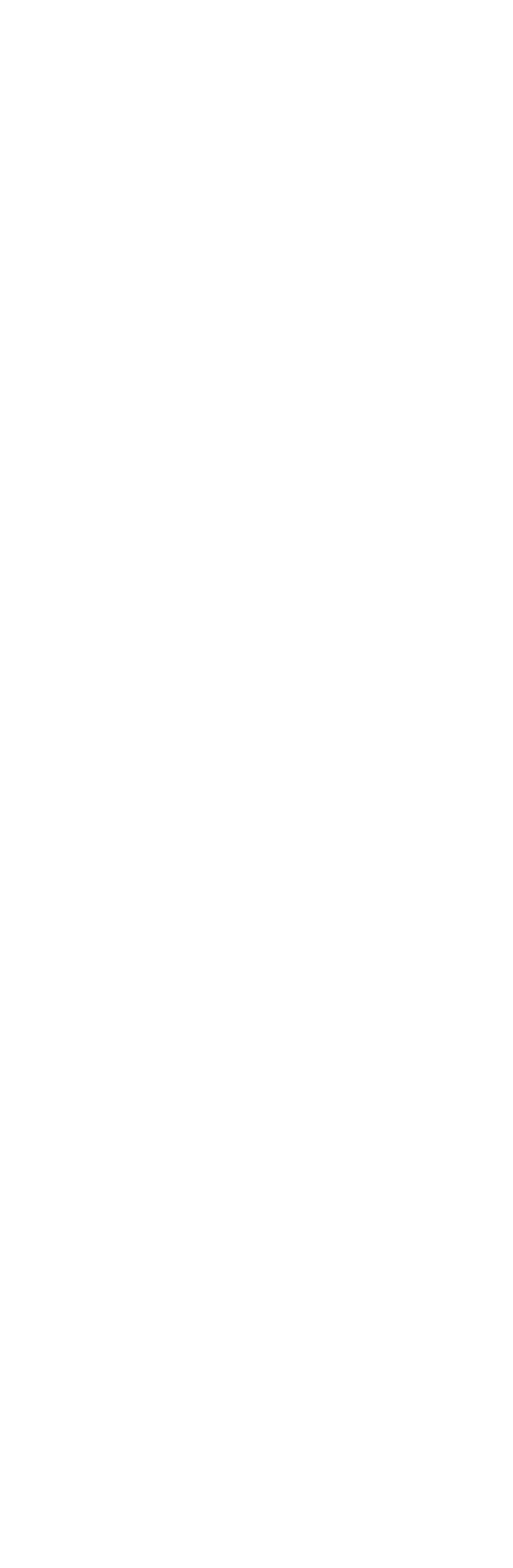




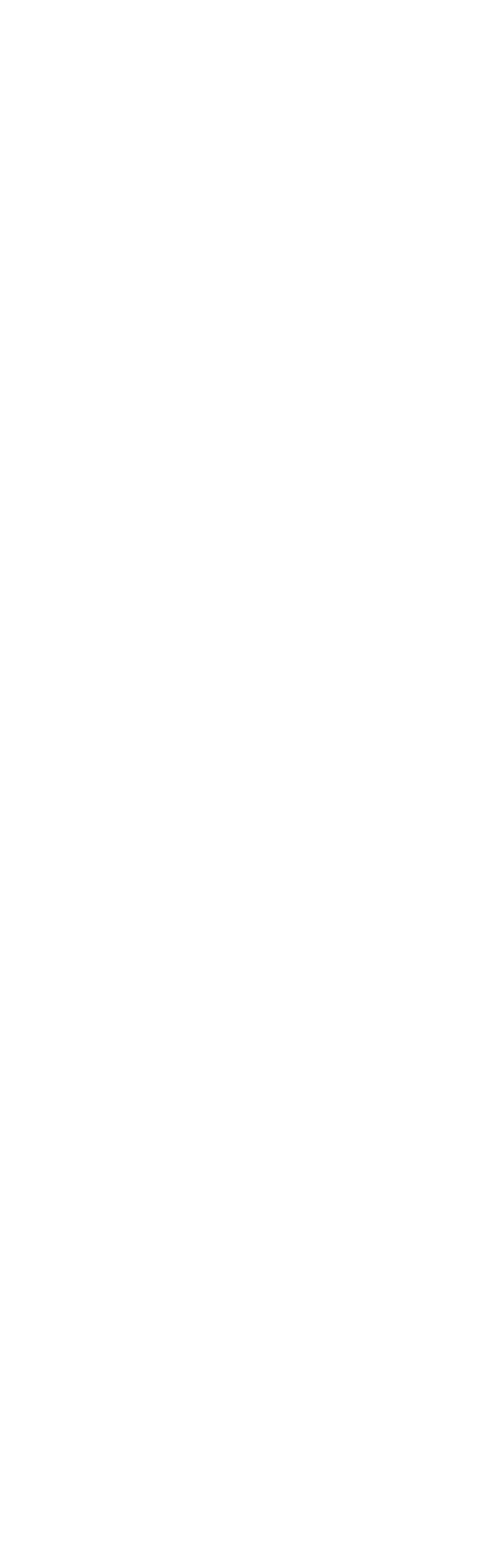




\section{Mineral analyses of ground waters from Covington County}

[Parts per million. Numbers at heads of columns refer to corresponding well numbers in preceding table]

\begin{tabular}{|c|c|c|c|c|}
\hline . & 4 & 5 & 10 & 11 \\
\hline 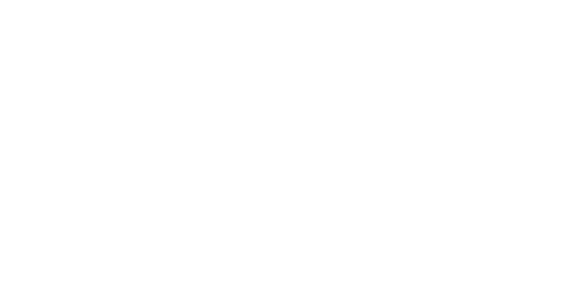 & \begin{tabular}{|c|c|c|}
26 \\
2.04 \\
2.5 \\
1.0 \\
17 \\
17 \\
10 \\
3.2 \\
4.3 \\
Trace. \\
70 \\
10 \\
Aug., 1919
\end{tabular} & $\begin{array}{c}13 \\
2.0 \\
4.4 \\
513.4 \\
1,235^{.0} \\
7.7 \\
48.7 \\
2.6 \\
1,214 \\
13 \\
\text { Juno, } 1912\end{array}$ & $\begin{array}{c}17 \\
4.5 \\
15 \\
5.7 \\
220 \\
106 \\
13 \\
3.3 \\
\text { Trace. } \\
128 \\
61 \\
\text { Aug., } 1919\end{array}$ & 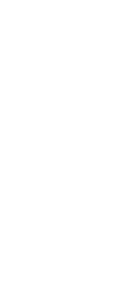 \\
\hline
\end{tabular}

- Calculated.

Analysts: 4, 10 Margaret D. Foster. U. S. Geological Survey; 5, Mississipp iState Chemical Laboratory; 11, W. F. Hand, Mississippi State Chemical Laboratory.

\section{DE SOTO COUNTY}

\section{GENERAL FEATURES}

Area, 475 square miles. Population, 24,359 (census of 1920)

The eastern two-thirds of De Soto County lies within the North Central Hills district, and the remainder, with the exception of a small area in the Yazoo Delta in the northwest corner, lies within the Bluff Hills district. The upland portion of the county is underlain by the Grenada, the uppermost formation of the Wilcox group of the Eocene. The other formations of the group, the Holly Springs sand and the Ackerman formation, lie in succession below the Grenada, but they do not appear in outcrops. In areas of undetermined extent in the west the Grenada is overlain by terrace sands and gravels of Pliocene age. Upon these terrace deposits or, where they are absent, the Grenada formation, lies a nearly coutinuous covering of loess (Pleistocene), which in the vicinity of the bluffs is 40 to 75 feet thick but which decreases to a thickness of only a few feet in the east. The Yazoo Delta is underlain by alluvial deposits of loam, clay, sand, and gravel, which have an aggregate thickness of 150 feet or more. These formations are described on pages $48-63$, and their distribution is shown on the geologic map (pl. 2); only the thicker portions of the loess are represented on the map.

\section{GROUND-WATER CONDITIONS}

The principal developed sources of water supply in De Soto County are the Grenada formation, the Pliocene terrace sand and gravel where they are present, and the thick alluvium that underlies the Yazoo Delta.

The Grenada formation includes some layers of water-bearing sand. Most of the shallow wells in the eastern part of the county and most 
of the wells 100 feet or more in depth throughout the upland area have their source in the Grenada. At Memphis, in Shelby County, Tenn., the municipal water supply, which amounts to $14,000,000$ gallons daily, is obtained from fine sand, probably in the Grenada formation, at depths of 275 to 500 feet. As the western part of $\mathrm{De}$ Soto County is due south of Memphis, directly on the strike of the formations, similar abundant supplies of water could undoubtedly be developed at comparable depths from the southward extension of the same water-bearing beds. The static head of these waters may be high enough to produce flows in the Yazoo Delta and in the valley of Coldwater River.

Where the terrace sand and gravel that intervene between the Grenada formation and the overlying loess are present they are water bearing and many shallow wells are sunk through the loess into them. The sand and gravel that in part compose the thick alluvial deposits in the Yazoo Delta contain an abundance of nonflowing water that is easily procured by means of bored or driven wells, which range in depth from a few feet to 150 or 175 feet.

\section{LOCAL SUPPLIES}

Lakeview.-At Lakeview, on the Yazoo \& Mississippi Valley Railroad, near the northwest corner of the county, domestic supplies are obtained from the alluvium by means of wells about 30 feet deep. Small springs that issue from the base of the bluff to the east also supply a few families.

Horn Lake.-In the vicinity of Horn Lake not all the shallow wells yield satisfactory supplies, and a few wells have been drilled into the Grenada formation. On the Gayoso farm, $1 \frac{1}{2}$ miles east of town, a well 240 feet deep and 4 inches in diameter taps a good water-bearing sand in the Grenada formation, and the water rises within about 140 feet of the surface. The well is cased with 6-inch casing to a depth of 110 feet and below that depth with 4 -inch casing and strainer to the bottom.

Mineral Wells.-In the vicinity of Mineral Wells, on the northern border of the county, water is obtained from the Grenada formation at depths of 20 to 150 feet. The 150-foot well of J. S. Hudnall, three-quarters of a mile northwest of town, and the 75 -foot dug well of W. A. Acre, 11/4 miles southwest of town, are typical and furnish ample supplies of soft water for domestic and farm use.

Olive Branch.-A well at the De Soto gravel pit; a mile south of Olive Branch, at the base of the quarry hill, is 140 feet deep and 3 inches in diameter. It yields excellent water for domestic and boiler use from a layer of white sand in the Grenada formation. The quarry

$$
54134-28-11
$$


here exposes 70 feet of terrace gravel overlain by a thin bed of darkbrown clay, which is in turn overlain by 20 feet of brown loess.

Lake Cormorant.- In the vicinity of Lake Cormorant, water is obtained chiefly from dug and driven wells 15 to 25 feet deep. One flowing $4 \frac{1}{2} 2^{-i n c h}$ well, owned by J. C. Brantley, was drilled to a depth of 2,150 feet and yielded a small flow, which had a static head 23 feet above the surface. The well completely penetrated the Eocene and entered sand of the Upper Cretaceous. The water is used for domestic and stock supply, and as it is a soft water it is locally considered to be of satisfactory quality (see analysis), although it is highly mineralized.

Mineral analysis of water from 2,150-foot well of J. C. Brantley, near Lake, Cormorant, De Soto County

[Sample collected July 7, 1914; analyzed by Mississippi State Chemical Laboratory]

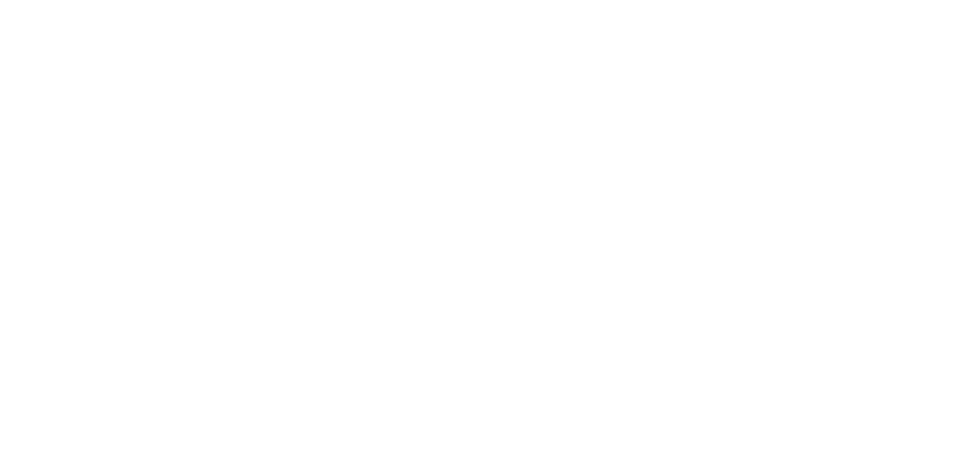

Glover.-At Glover, 4 miles northeast of Lake Cormorant, the water supply is reported to be obtained wholly from driven wells 15 to 30 feet deep, which enter only the alluvial deposits. This shallow water is rather hard but is locally considered to be of good quality for domestic use.

Cedarview.-At Cedarview, in the eastern part of the county, abundant supplies of water suitable for domestic and farm uses are obtained from the Grenada formation at depths of 70 to 150 feet.

Lewisburg.-The H.H. Collins well at Lewisburg is 106 feet deep and yields a large supply from sand, probably in the Grenada formation. The 48-foot dug well of H. M. Johnson, at the same place, yields a rather hard water from sand in the lower 8 feet, probably in the same formation.

Cub Lake.-A well at Cub Lake, 10 miles west by south of Hernando, owned by Dockery \& Emerson, is 200 feet deep and yields water under artesian pressure sufficient to cause it to rise within 12 feet of the surface. The source is the water-bearing sands of the Grenada formation.

Hernando.-At Hernando water is obtained both from wells less than 50 feet deep, which penetrate only to the Pliocene terrace 
gravels beneath the loess, and from somewhat deeper wells that enter the water-bearing sands of the Grenada formation. Three dug wells, 40 or 45 feet deep, in the street, at the southeast, northeast, and southwest corners, respectively, of the public square, are used for public drinking. A dug well at the courthouse, reported to be 75 feet deep, probably reaches a bed of sand in the Grenada formation. A 4-inch well 100 yards south of the Illinois Central Railroad station at Hernando is reported to be 348 feet deep; water was struck in fine white sand, probably the Holly Springs sand, and rose within 60 feet of the surface. It yields by pumping 200 gallons a minute and is used in boilers.

Bright.-Near Bright, 4 miles northeast of Hernando, good water under some artesian head is commonly obtained at depths of 30 to 110 feet. The 4-inch well of E. E. Vaiden, 98 feet deep; the 2 -inch well of J. O. Louderdale, 90 feet deep; and the 12-inch bored well of W. C. Glenn, 40 feet deep, all of which enter clean white sand of the Grenada formation, are typical of the wells of this locality.

Cockrum.-At Cockrum, 12 miles east by south of Hernando, domestic water supplies are obtained from wells 60 to 125 feet deep, more commonly 75 to 100 feet deep, which enter white sand of the Grenada formation.

\section{FORREST COUNTY}

\section{GENERAL FEATURES}

Area, 462 square miles. Population, 21,238 (census of 1920)

Forrest Gounty lies within the southern portion of the Long-leaf Pine Hills district. The geologic formations found in surface outcrops in the county include the Hattiesburg clay (Miocene), the Pascagoula clay (Miocene), and the Citronelle formation (Pliocene), which overlaps and largely conceals the two first-named formations. These formations are described on pages $56-60$, and their distribution is shown on the geologic map (pl. 2).

\section{GROUND-WATER CONDITIONS}

The Citronelle formation makes up the body of the hills to depths of 50 to 100 feet in the northern part of the county and increases in thickness to perhaps 200 feet along the southern boundary. Throughout the upland portion of the area these beds are the chief source of water for domestic use. The water is obtained by means of bored and dug wells that range in depth from 15 to 125 feet, or from numerous small springs, which flow out from the sands and grasels of the Citronelle formation, where they are exposed in the hill slopes. Several typical wells are described in the table of well data.

Water of shallow occurrence is also found in the sands and gravels that compose the basal portions of Pleistocene terrace deposits which 
border Leaf River and Bowie, Black, and Red Creeks. Springs from this source are numerous along the edges of the terraces. Mammoth Spring and Rawles Spring, respectively 51/4 and 6 miles northwest of Hattiesburg, and McInnis Spring, 3 miles south of Hattiesburg, are bold springs which appear to flow either from the terrace deposits that border Bowie Creek (pp. 159-160) or from layers of sand in the Hattiesburg clay, which immediately underlies the terrace deposits.

In the southern half of the county the Pascagoula clay, which intervenes between the Hattiesburg clay beneath and the Citronelle formation above, increases in thickness from a featheredge along its northern margin to perhaps 300 or 350 feet along the southern boundary; so far as known the Pascagoula is economically not water bearing, although elsewhere in southern Mississippi it is known to contain some water-bearing sands interbedded with the clay.

The Hattiesburg clay, which underlies the Pascagoula clay and is between 300 and 400 feet thick, consists predominantly of massive blue and gray clays but also contains interbedded layers of sand, some of which carry abundant water. (See log, p. 159.) The clays are exposed in the banks of Leaf River and Bowie Creek and in places in the lower slopes of the valleys of these streams and their tributaries. The name of the formation is derived from the city of Hattiesburg, near which typical outcrops of the clays occur. The formation dips to the south at an estimated rate of 15 to 18 feet to the mile and passes beneath the Pascagoula clay.

The principal water-bearing sands of the Hattiesburg appear to lie in the upper half or two-thirds of its thickness, and the constitute an abundant though largely undeveloped source of water supply in the central and southern parts of the county. The wells at the main waterworks plant at Camp Shelby (Nos. 1-3 in the table) are believed to tap one of these beds. Wells low in the valley of Black Creek, as for example at Brooklyn, ought to encounter the same bed or some other water-bearing bed in the Hattiesburg at depths estimated to be between 375 and 500 feet, and the static head of the water would probably be high enough to produce flowing wells.

The Hattiesburg clay is underlain by the Catahoula sandstone (Miocene), which consists of 400 to 500 feet of irregularly bedded sandstone, sand, and clay, including extensive beds of porous, more or less pebbly, water-bearing sand. The Catahoula does not crop out in Forrest County but is easily reached by wells. At the municipal waterworks at Hattiesburg the top of the formation is encountered at a depth between 220 and 240 feet, and the sands that furnish most of the municipal water supply are penetrated between the depths 
of 230 and 450 feet (see $\log$, p. 157, and wells $9-12$ in table). The deepest well at the waterworks, 649 feet (No. 13), penetrates a thick, water-bearing sand between depths of 589 and 694 feet, which is probably near the base of the Catahoula formation, though the available data are too meager to admit of the positive identification of the sand. A log of this well is given on page 158 .

\section{LOCAL SUPPLIES}

Hattiesburg.-Many flowing wells, which range in depth from 300 to 700 feet and furnish abundant supplies of water, have been drilled in the lowland of Leaf River in the vicinity of Hattiesburg. A maximum static head of 30 feet above the surface has been reported. Detailed information concerning 14 such wells is given in the table of well data (Nos. 12-21, 24, 25, 27, 28). As interpreted, the source of the water is sands and pebbly sands or gravels in the Catahoula formation. The logs show two principal water-bearing sands, which at the waterworks lie at depths of about 230 to 320 feet and 340 to 445 feet; elsewhere in the vicinity of the town the depth to these sands varies a few feet from the figures given, depending upon the topographic and geographic position of the wells. In the 694-foot well at the waterworks a still deeper water-bearing sand was penetrated at a depth of 589 to 694 feet, and a few other wells have been sunk to this stratum. The municiapl water supply is obtained from five wells, 300 to 694 feet deep, owned by the city (Nos. 9-13). The wells tap water-bearing beds in the Catahoula formation, and they afford a combined yield of at least 1,500 gallons a minute. The average daily consumption is about $1,000,000$ gallons.

Log of 453.5-foot well at waterworks, Hattiesburg, drilled in 1919

LAItitude above sea level, about 143 feet. Authority, Layne \& Bowler Co.; log furnished by Burke Jones, superintendent of water department]

\begin{tabular}{|c|c|c|}
\hline & Thickness & Depth \\
\hline $\begin{array}{l}\text { Ploistocene alluvium(?): } \\
\text { Red sandy clay } \\
\text { Coarse yellow sand; water bearing }\end{array}$ & $\begin{array}{c}\text { Feet } \\
27 \\
16\end{array}$ & $\begin{array}{r}\text { Feet } \\
27 \\
43\end{array}$ \\
\hline $\begin{array}{l}\text { Hattiosburg clay: } \\
\text { Tough yellow clay, } \\
\text { Hard "soapstone" }\end{array}$ & $\begin{array}{r}157 \\
4 \\
14\end{array}$ & $\begin{array}{l}200 \\
204 \\
218\end{array}$ \\
\hline $\begin{array}{l}\text { Oatahoula sandstone: } \\
\text { Dry gravel } \\
\text { Fine sand } \\
\text { Olay } \\
\text { Fine white sand; water bearing(p) } \\
\text { Coarse sand and gravel; water bearing } \\
\text { Tough clay, or blue gumbo } \\
\text { Sand mixed with medium-sized pebbles; water bearing } \\
\text { Blue gumbo } \\
\text { Gravel }\end{array}$ & $\begin{array}{r}2 \\
7 \\
4 \\
40 \\
49 \\
20 \\
107 \\
4 \\
2.5\end{array}$ & $\begin{array}{l}220 \\
227 \\
231 \\
271 \\
320 \\
340 \\
447 \\
251 \\
468.5\end{array}$ \\
\hline
\end{tabular}


Log of 694-foot well at waterworks at Hattiesburg, drilled in 1917

[Altitude above sea level, about 143 feet. Authority, John A. Sutter, contractor]

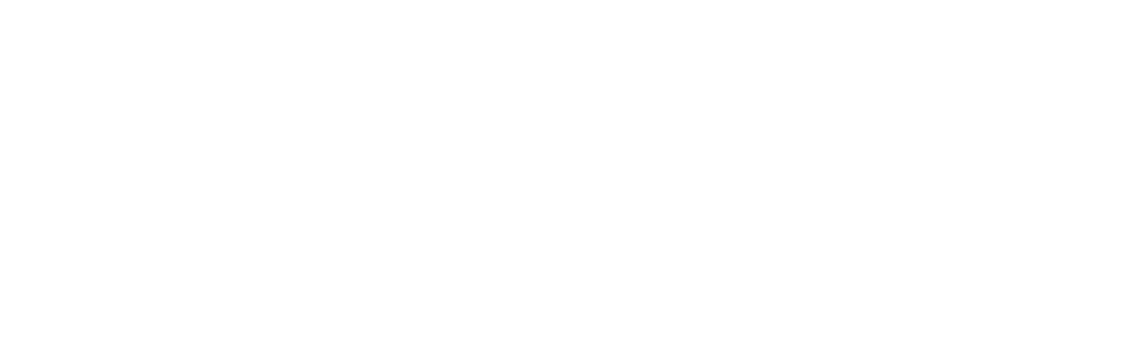

This $\log$ and the one that precedes it contradict each other in that according to the former, the massive clay of the Hattiesburg is first reached at a depth of 43 feet, whereas, according to the latter, it is reached at a depth of 100 feet. In other respects the logs are in essential agreement. The 694-foot well probably penetrated nearly to the base of the Catahoula formation, which, if the log is correctly interpreted, indicates that the Catahoula is here more than 450 feet thick.

The following are the logs of the 445-foot well of the Firm Lumber Co. and the 6011/6-foot well of the State Normal College, at Hattiesburg:

\section{Log of well of Firm Lumber Co., Hattiesburg}

[Authority, John A. Sutter, driller]

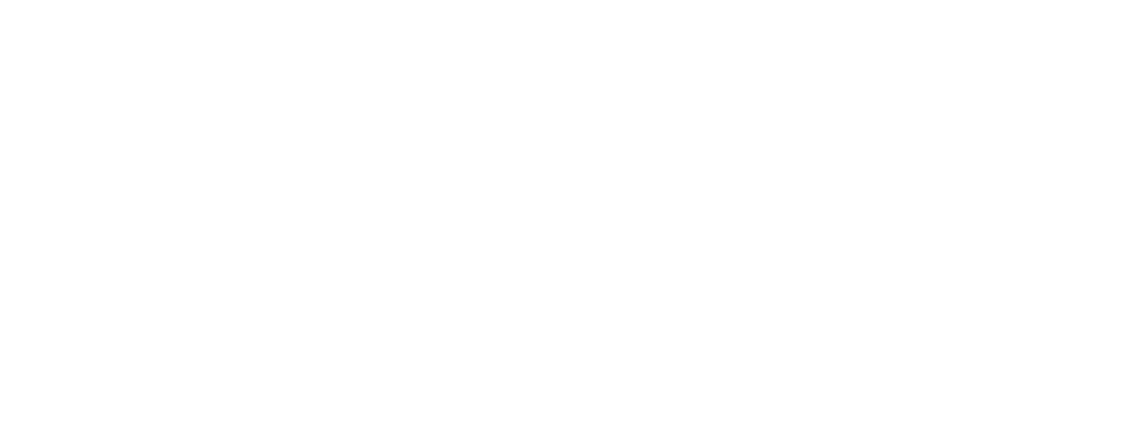

Log of well of State Normal College, Hattiesburg

[Authority, Gray Artesian Well Co.]

\begin{tabular}{|c|c|c|}
\hline . & Thickness & Depth \\
\hline $\begin{array}{l}\text { Hattiesburg clay (chiefiy): } \\
\text { White clay.............. }\end{array}$ & \multirow{5}{*}{$\begin{array}{c}\text { Feet } \\
75 \\
187 \\
60 \\
1831 \% \\
42 \\
40 \\
14\end{array}$} & \multirow{5}{*}{$\begin{array}{r}\text { Feet } \\
75 \\
262 \\
\\
322 \\
5051 \\
5471 \\
5871 \\
6011 \%\end{array}$} \\
\hline Catahoula sandstone: & & \\
\hline $\begin{array}{l}\text { Catanoula sandstone: } \\
\text { Hard soapstone........ }\end{array}$ & & \\
\hline Sand and gravel & & \\
\hline $\begin{array}{l}\text { Light gravel and sand } \\
\text { Gumbo }\end{array}$ & & \\
\hline
\end{tabular}


Camp Shelby.-Camp Shelby was located on the rolling upland hills along the McLaurin road, about 10 miles southeast of Hattiesburg and 1 to 2 miles south of McCallum station on the Bonhomie \& Hattiesburg Southern Railroad. Some of the hills within the limits of the camp rise to a maximum height of 365 feet above sea level. The following information was obtained from Maj. F. I. Wheeler, construction quartermaster, on April 8, 1918. The water supply for the main camp was then being obtained from three wolls, respectively $3431 / 6,3592 / 3$, and $3632 / 3$ feet deep (Nos. 1-3); 375 feet apart at the corners of a triangular area, near the head of a small branch valley. The altitude of the ground at the wells was.225 or 230 feet above sea level. The static head of the water was about 30 feet below the surface. The bed tapped by these wells is believed to be water-bearing sand interbedded in the Hattiesburg claý. A log of the deepest well is given below. Several other wells were subsequently drilled at the pumping plant, but no detailed information in regard to them has been obtained. At Rifle Range A, north of Leaf River, 101/2 miles southeast of Hattiesburg, water was being procured from the Hattiesburg formation by means of two wells of comparable depth, one of which was $811 / 6$ feet deep (No. 4). The static head was below the surface, and the water was being raised by means of gas-driven pumps. At Rifle Range $B$ water was being obtained from a well $81 \frac{1}{6}$ feet deep (No. 5). .

Log of well No. 3 at waterworks plant at Camp Shelby

[Altitude above ses level at mouth of well, about 230 feet. Authority, Twombly \& Hemphill, engineers, C. H. Hanna, driller in charge]

\begin{tabular}{|c|c|c|}
\hline & Thickness & Depth \\
\hline $\begin{array}{l}\text { Citronelle formation: } \\
\text { Surface clay } \\
\text { Sand and gravel; water beering }\end{array}$ & \begin{tabular}{r|r} 
Feet \\
8 \\
48
\end{tabular} & $\begin{array}{r}\text { Feet } \\
86\end{array}$ \\
\hline $\begin{array}{l}\text { Hattiesburg clay: } \\
\text { Black dirt or shale. } \\
\text { Sand } \\
\text { Black dirt or shsie. } \\
\text { Sand } \\
\text { Gumbo } \\
\text { Bluish sharp sand and gravel (?); water bearing } \\
\text { Shale. }\end{array}$ & $\begin{array}{l}84 \\
15 \\
80 \\
15 \\
20 \\
80 \\
13 \%\end{array}$ & $\begin{array}{l}140 \\
155 \\
235 \\
250 \\
270 \\
350 \\
363 \%\end{array}$ \\
\hline
\end{tabular}

Mammoth Spring.-Mammoth Spring is 51/4 miles northwest of Hattiesburg in a small branch valley that cuts a Pleistocene terrace plain which borders Bowie River, one-eighth of a mile east of the Gulf \& Ship Island Railroad station. The main spring flows from a boring about 10 feet deep, cased with terra-cotta pipe, and has its source either in sand and gravel at the base of a terrace deposit or in a bed of sand in the Hattiesburg clay, which immediately underlies the terrace deposit. The fact that the water exhibits enough hydrostatic pressure to cause it to rise in the pipe and overflow a 
foot or more above the surface of the ground suggests that it comes from the Hattiesburg formation. The spring yields about 21 gallons a minute. Upon exposure to the air a flocculent precipitate forms in the water. The water is reputed to possess therapeutic properties and has been made the basis for the establishment of a health resort. (See analysis 35.)

Rawles Spring.-Rawles Spring is 6 miles northwest of Hatties; burg, in a small branch valley that cuts a Pleistocene terrace plain which borders Bowie River. The water appears to flow from a bed. of gravel that forms the base of a terrace deposit 12 or 14 feet thick: The source may, however, be a layer of sand in the Hattiesburg clay, which immediately underlies the gravel. The water flows into a brick-lined excavation about 9 feet long, 8 feet whe; and 2 to 3 feet deep. A bed of compact clay of the Hattiesburg formation appears at the bottom of the excavation. The yield of the spring is about 15 gallons a minute.

McInnis Spring.-McInnis Spring, owned by Conn Bros., of Hattiesburg, is about 3 miles south of Hattiesburg in the bottom of a branch valley which cuts 20 to 25 feet below the level of a Pleistocene terrace plain. The source of the water could not be definitely ascertained, but it appears to come from sand and gravel that forms the base of a terrace deposit. The spring yields about 5 gallons a minute, and the water is bottled and sold for drinking, chiefly in Hattiesburg. 


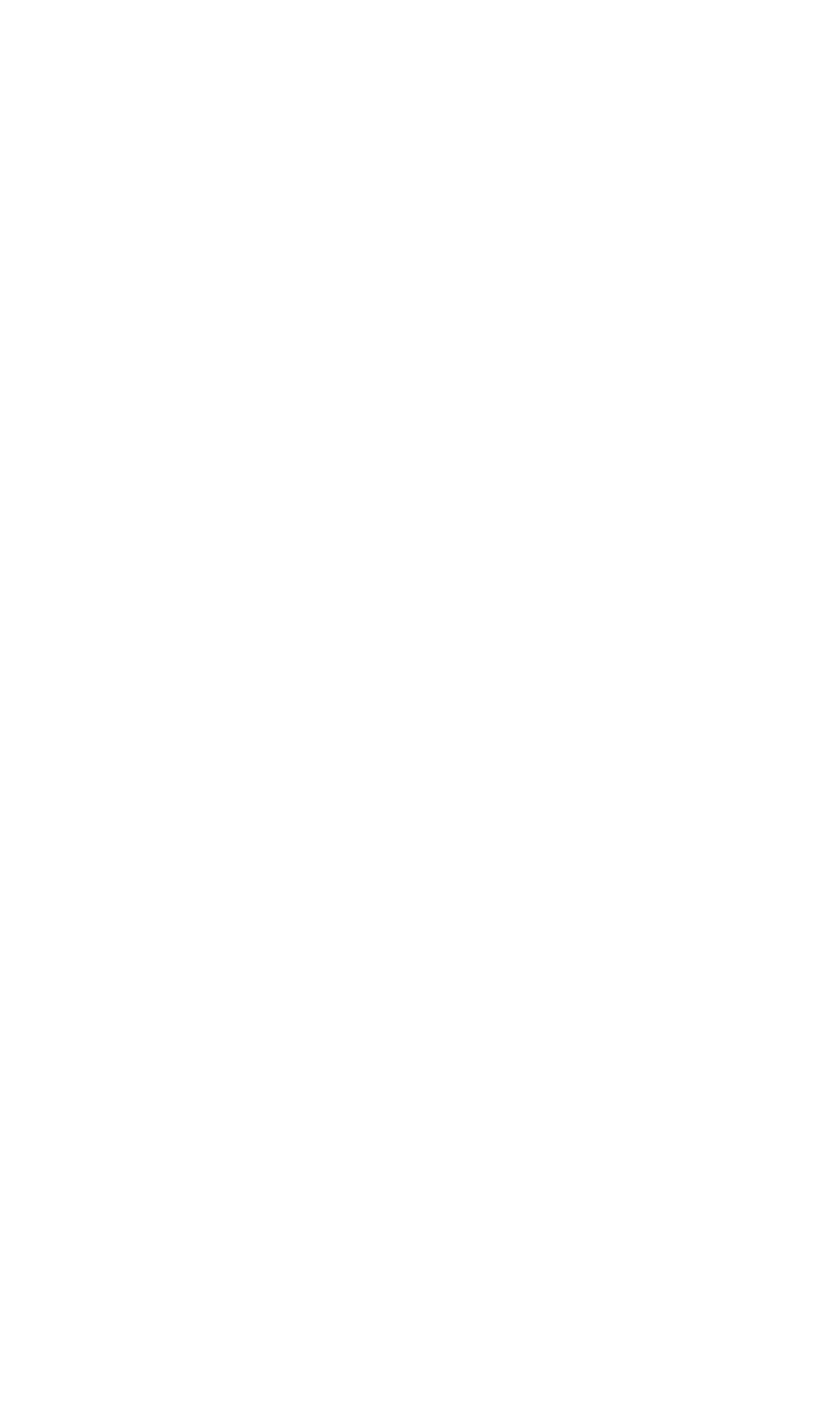




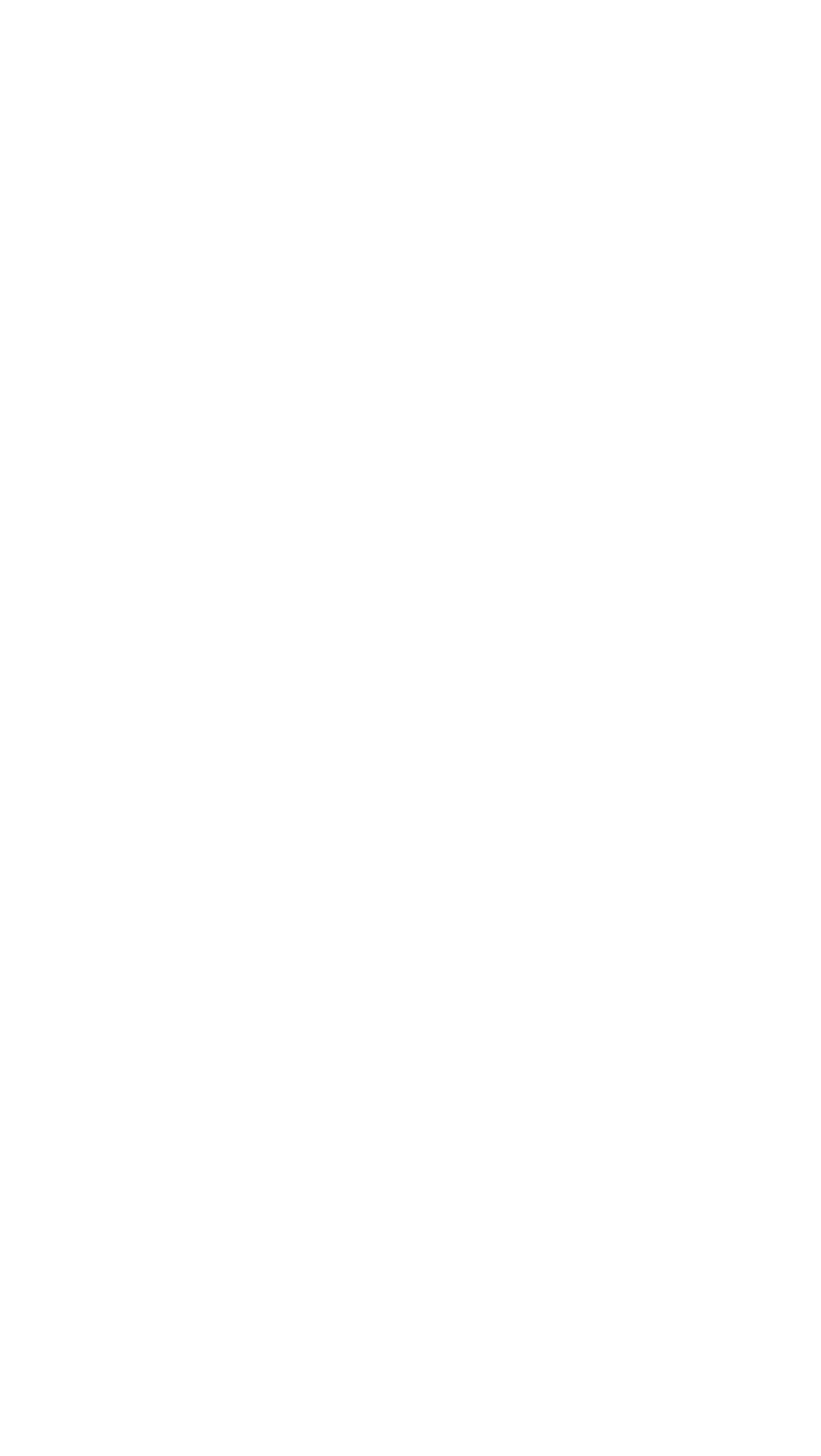




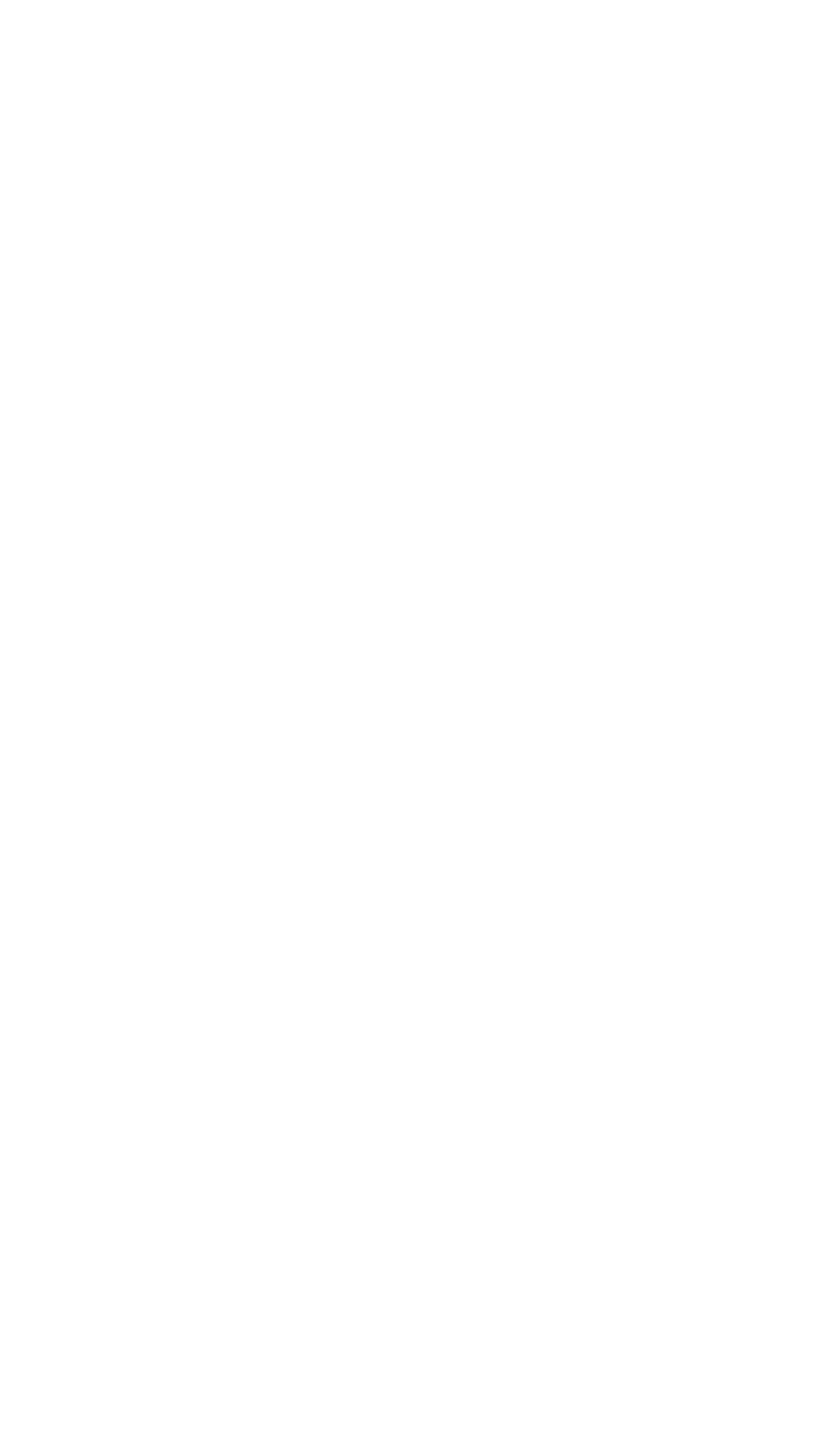




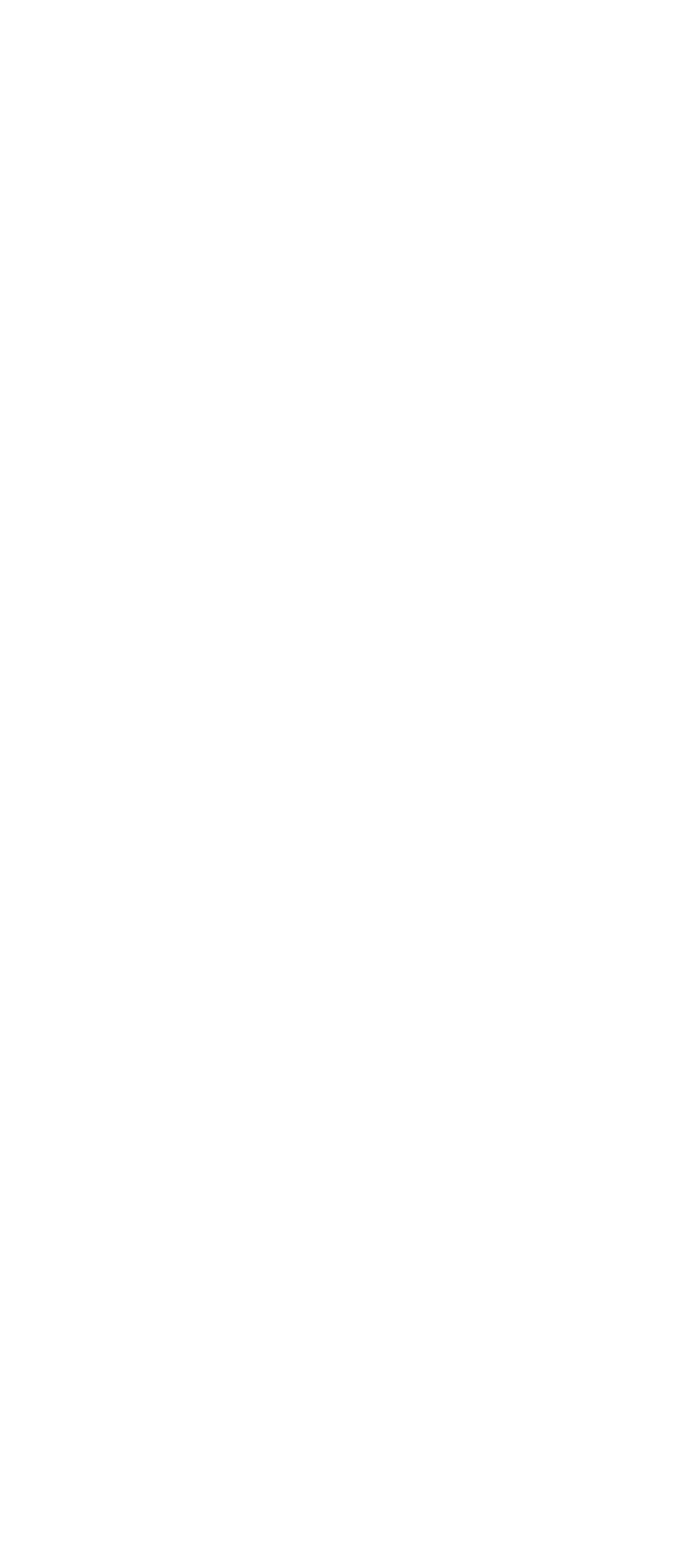


Mineral analyses of ground waters from Forrest County

[Parts per million. Numbers at heads of columns refer to cortesponding well numbers in preceding table.

\begin{tabular}{|c|c|c|c|c|c|c|c|c|c|}
\hline & 1 & 4 & 8 & $\bullet 9$ & 12 & 13 & 24 & 34 & 35 \\
\hline 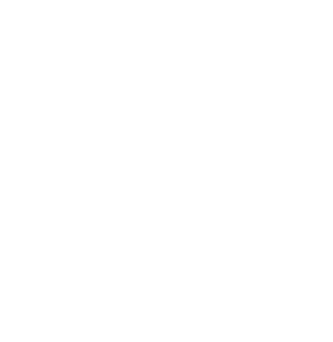 & \begin{tabular}{|l|}
50 \\
.07 \\
3.0 \\
2.5 \\
10 \\
.0 \\
$29 \cdot 0$ \\
8.2 \\
5.9 \\
Trace. \\
91 \\
18 \\
Apr. \\
1918
\end{tabular} & $\begin{array}{l}16 \\
.13 \\
.6 \\
2.0 \\
4.6 \\
.0 \\
9.8 \\
7.1 \\
3.0 \\
29^{.00} \\
10 \\
\text { Apr., } \\
1918\end{array}$ & $\begin{array}{l}7.4 \\
2.4 \\
10 \\
.1 \\
9.2 \\
.0 \\
44^{\circ} \\
7.8 \\
61^{.00} \\
25 \\
\text { Sept., } \\
1913\end{array}$ & $\begin{array}{l}34 \\
1.7 \\
6.3 \\
2.7 \\
18 \\
48^{.0} \\
11 \\
6.0 \\
98^{.00} \\
27 \\
\text { Feb.; } \\
1915\end{array}$ & $\begin{array}{l}25 \\
7.29 \\
8.9 \\
9.8 \\
49^{.0} \\
11 \\
6.0 \\
88 \\
8.00 \\
33 \\
\text { May, } \\
1916\end{array}$ & $\begin{array}{c}20 \\
1.1 \\
8.2 \\
3.6 \\
31 \\
107^{\circ} \\
10 \\
3.5 \\
129 \\
.45 \\
35 \\
\text { July, } \\
1919\end{array}$ & $\begin{array}{c}27 \\
1.2 \\
8.8 \\
1.8 \\
13 \\
52^{.0} \\
11 \\
5.5 \\
80^{.00} \\
29 \\
\text { Dec., } \\
1918\end{array}$ & $\begin{array}{c}33 \\
.31 \\
1.9 \\
.7 \\
19 \\
.0 \\
50 \\
21 \\
4.8 \\
\text { Trace. } \\
82 \\
8 \\
\text { Ang., } \\
1919\end{array}$ & $\begin{array}{r}19 \\
12 \\
2.4 \\
\mathrm{Na} 6.0 \\
7.7 \\
40^{\circ} \\
2.2 \\
7.8 \\
40 \\
40\end{array}$ \\
\hline
\end{tabular}

- Composite sample of wells Nos. 9, 10, and 11.

- Calculated.

Analysts: 1, 4, A. A. Chambers and C. H. Kidwell, U. S. Geological Survey; 8. 9, 24, Mississippl State Chemical Laboratory; 12, W. F. Hand, Mississippi state Chemical Laboratory; 13, N. Fuchs, U. S. Geological Survey; 34, Margaret D. Foster, U. S. Geological Survey; 35, W. L. Hutchison, Agrlcultural and Mechanical College of Mississippi (U. S. Geol. Survey Water-Supply Paper 159, p. 79, 1906.

\section{FRANKIIN COUNTY}

\section{GENERAL FEATURES}

Area, 547 square miles. Population, 14,156 (census of 1920)

Franklin County lies entirely within the Long-leaf Pine Hills region. The three principal geologic formations that appear at the surface in the county, named in descending order of age and stratigraphic position, are the Citronelle formation (Pliocene), the Pascagoula clay (Miocene), and the Hattiesburg clay (Miocene). A few feet of yellowish or reddish loam, which is probably the eastern featheredge of the wind-blown loess of Adams County on the west, blankets most of the higher hills and determines the character of the soil over much of the upland. The geologic formations just named are described on pages 56-60, and their distribution is shown on the geologic map (pl. 2).

\section{GROUND-WATER CONDITIONS}

The domestic water supplies of the county are obtained chiefly from dug or bored wells, generally less than 100 feet deep and many of them less than 50 feet deep. A few exceed 100 feet in depth. In the southern two-thirds of the county the source of the water is either the sands and gravels of the Citronelle formation, whiek constitute the upper 50 to 100 feet or more of the beds that make up most of the hills, or the Pascagoula formation, which underlies the Citronelle: and contains layers of water-bearing sand interbedded with the clay that predominantly composes the formation. In the northern tier of counties the source of the water is either the Citronelle 
formation or sands interbedded with the clays of the Hattiesburg formation, which here immediately underlies the Citronelle. Springs that have their source in either the Citronelle, Pascagoula, or Hattiesburg formations are common throughout the county. Most of the springs are small, but a few yield copious flows.

So far as reported, no wells more than 160 feet deep have been drilled in the county, and the more deeply buried ground-water resources appear therefore to be totally unexplored. The Pascagoula clay, whose estimated thickness in the southern part of the county is about 200 feet, the Hattiesburg clay, probably about 450 feet thick, and the Catahoula sandstone (Miocene), also about 450 feet thick, form a series of sands and clays which has an aggregate thickness of 1,000 to 1,100 feet, and which dips slightly toward the south. The two uppermost formations, the Pascagoula and Hattiesburg, though composed chiefly of clay, also contain layers of water-bearing sand, which in places, as at Natchez, constitute an abundant source of water supply, whereas the lowermost formation, the Catahoula, is in general an abundant source of ground water from its belt of outcrop across the State (see pl. 2), southward for a distance of 40 or 50 miles.

Over most of the area the static head of the waters of these formations is too low to produce flowing wells, except perhaps low in the valley of Homochitto River, where future drilling may demonstrate the feasibility of obtaining flows.

\section{LOCAL SUPPLIES}

Bude.-Near Bude, 3 miles east of Meadville, in sec. 30, T. 6 N., R. 4 E., the Homochitto Lumber Co. obtains water for its boilers and for the domestic use of its employees by means of a well, 140 feet deep, located on a slope. Ten-inch casing, including 40 feet of strainer, extends to the bottom of the well, and the water is under sufficient pressure to bring it within 16 feet of the surface. The yield by pumping is 100 gallons a minute. The log of the well is given below.

Log of well of Homochitto Lumber Co, at Bude, in NE. 1/4 sec. 30, T. 6 N., R. \& E.

[Authority, Nicholas Green, superintendent]

\begin{tabular}{|c|c|c|}
\hline & Thickness & Depth \\
\hline $\begin{array}{l}\text { Red clay } \\
\text { Send; water bearing } \\
\text { Blue clay } \\
\text { Yellow clay } \\
\text { Red clay } \\
\text { Rock } \\
\text { Coarse sand (Hattiesburg); water bearing }\end{array}$ & $\begin{array}{l}\text { Feet } \\
6 \\
10 \\
90.5 \\
1 \\
1.5 \\
1 \\
30\end{array}$ & $\begin{array}{l}\text { Feet } \\
6 \\
16 \\
106.5 \\
107.5 \\
109 \\
110 \\
140\end{array}$ \\
\hline
\end{tabular}

The red clay at the top of this section probably represents the eastern featheredge of the loess, the water-bearing sand just below 
the red clay probably belongs to the Citronelle formatipn, and the rest of the section may be classed as undifferentiated Pascagoula clay and Hattiesburg clay, the Pascagoula, composing the upper and the: Hattiesburg the lower part of the section.

Bunckley.-Two typical bored wells in the vicinity of Bunckley are those of T. E. Edwards, jr., and A. G. Jacobs. The Edwards well is a 12-inch bored well, 80 feet deep, and is located on the upland a mile north of the town, in the SE. $1 / 4$ NW. $1 / 4$ sec. 29, T. 5 N., R. 2 E. The water is obtained from a bed of white quicksand in the Pascagoula clay at a depth of 65 to 80 feet, is under little or no artesian pressure, and is pumped by hand. Mr. Jacobs's well is a 10 -inch bored well, 91 feet deep, located 6 miles east of Bunckley, in the NE. 1/4 sec. 33(?), T. 5 N., R. $3 \mathrm{E}$. The water is under no appreciable artesian pressure. A log of the well is given below.

Log of well of A. G. Jacobs, 6 miles east of Bunckley

[Authority, the owner]

\begin{tabular}{|c|c|c|}
\hline . & Thickness & Depth \\
\hline $\begin{array}{l}\text { Citronelle formation (chiefly): } \\
\text { Red and yellow clay } \\
\text { Fire clay } \\
\text { Clay and sand, interstratified in layers } 6 \text { to } 10 \text { inches thick } \\
\text { Sand; abundantly water bearing }\end{array}$ & Feet $\begin{array}{r}31 \\
30 \\
20 \\
10\end{array}$ & $\begin{array}{l}\text { Feet } \\
31 \\
61 \\
81 \\
91\end{array}$ \\
\hline
\end{tabular}

Ganden City.-Shallow bored wells of moderate depth are the source of domestic supplies at Garden City. A. A. Mosher owns a typical bored well, 38 feet deep, located on a slope, a log of which is given below.

Log of well of A. A. Mosher, Garden City

Altitude at mouth of well, 5 feet higher than track at station of Yazoo \& Mississippi Valley Railroad. Authority, the owner]

\begin{tabular}{|c|c|c|}
\hline & Thickness & Depth \\
\hline 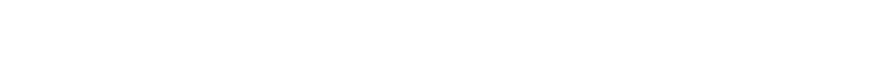 & Feet 8 & \\
\hline $\begin{array}{l}\text { Red and wite sand } \\
\text { White sand; water bearing } \\
\text { Blue pipe elay }\end{array}$ & $\begin{array}{r}15 \\
\pm 1 \\
\pm 14\end{array}$ & $\begin{array}{r}23 \\
\pm 24 \\
38\end{array}$ \\
\hline
\end{tabular}

The white water-bearing sand probably belongs to the Pascagoula formation. Another 7-inch bored well on the upland, owned by S. J. Primm, is 60 feet deep and obtains water under no artesian pressure in sand and clay of the Citronelle formation at 40 to 60 feet.

Dick.-J. Q. Tew owns a 10-inch bored well, 160 feet deep, located on a hill a mile east of Dick, in the S. $1 / 2$ NW. $1 / 4$ sec. $21, T .5$ N., R. $4 \mathrm{E}$. Water under' no artesian pressure is obtained by hand pump from gravel of the Citronelle formation at a depth of 140 to 160 feet. 
Suffolk.-Henson D. Hunt owris a 14-inch bored 'well; 114"feet deep, on a hill a mile south of Suffolk, in the $\$$ W. $1 / 4$ sec. $34,1,6 \mathrm{~N}$, R. $2 \mathrm{E}$. Water is obtained by hand pump from gravel of the Citron. elle formation. An 8-inch bored well only 60 feet deep, owned by T. C. Cloy, 3 miles east of Suffolk, in sec. 32, T. 6 N., R. 3 E. (?) has its source in sand of the Citronelle formation.

Whiteapple.-The 12-inch bored well of C. E. MeMillan, sr., 21/2 miles southwest of Whiteapple, in the SE. $1 / 4$ sec. 43, T. 6 N., R. 1 E., is 53 feet deep and obtains water from sand of the Citronelle formation in the lower 8 feet of the well. This water rises within 30 feet of the surface and is raised by hand pump.

Wildwood Springs.-Wildwood Springs are near the head of one of the headwater branches of Wells Creek, 11/2 miles south of Hamburg, east of the Yazoo \& Mississippi Valley Railroad; on land owned by L. W. Lyle, of Utica, Miss. The main spring is described as a large strong "boil" in the middle of the branch swamp, at a place now overgrown with brush. A sample of water for analysis was obtained from a small spring that yielded only 1 or 2 gallons a minute, of apparently clear, good water, which is said to issue from sand that in its present unimproved condition is covered with gray mud. The springs are about 85 feet lower than the Yazoo \& Mississippi Valley Railroad track at Hamburg station and probably have their source in a layer of sand in the Pascagoula formation. An analysis of the water is given below.

Mineral analysis of water from one of the Wildwood Springs, near Hamburg;. Franklin County

[Sample collected July 15, 1919; analyzed by N. Fuohs and $\mathrm{C}_{;}$H. Kidwell]

\begin{tabular}{|c|c|}
\hline & $\begin{array}{c}\text { Parts per } \\
\text { millton }\end{array}$ \\
\hline Silica $\left(\mathrm{SiO}_{2}\right) \ldots$ & 26 \\
\hline Iron $(\mathbf{F e})$ & .89 \\
\hline Calcium (Ca) & 3. 3 \\
\hline Magnesium (Mg) & 1. 6 \\
\hline Sodium and potassium $(\mathrm{Na}+\mathrm{K})$ (calculated) $\ldots$ & 1. 3 \\
\hline Carbonate radicle $\left(\mathrm{CO}_{3}\right)_{2}$ & .0 \\
\hline Bicarbonate radicle $\left(\mathrm{HCO}_{3}\right)$ & Trace. \\
\hline Sulphate radicle $\left(\mathrm{SO}_{4}\right) \ldots$ & 2. 0 \\
\hline Chloride radicle $(\mathrm{Cl})$ & 11 \\
\hline Nitrate radicle $\left(\mathrm{NO}_{3}\right)$ & Trace. \\
\hline Total dissolved solids at $180^{\circ} \mathrm{C}$ & 65 \\
\hline Total hardness as $\mathrm{CaCO}_{3}$ (calculated) & 15 \\
\hline
\end{tabular}

Deerfield plantation.-Several springs of somewhat more note than the common small springs of the county have been reported on Deerfield plantation, owned by F. B. Hull, 4 miles southeast of Garden City. The Big Blue Spring, at the foot of a slope leading down to Wells Creek bottom, 2;100 feet from Mr. Hull's residence, emits bold-flowing deep-blue water, which forms a pool 16 feet in 
diameter at the point of emergence. Neither the depth of the pool nor the amount of the How are stated. Plumb Spring, another bold spring, is 2,100 feet from Mr. Hull's residence, and not far distant in a small valley there are eight closely associated free-flowing. springs known as the Crescent Cluster of Springs.

Hamburg.-Hamburg is situated in a hilly district, the highest. ridges of which rise 450 or 500 feet above sea level. Domestic water supplies are obtained in part from wells which range in depth from 80 to 120 feet, depending upon topographic position, and in part from cisterns in which rain water is stored. The wells probably have their source in a stratum of sand in the Paseagoula formation, corresponding in position to the water-bearing sand fram which the Wildwood Springs issue. (See p. 168.)

\section{GHORGE COUNTY}

\section{GENERAL FeATURES}

Area, 475 square miles. Population, 5,564 (census of 1920)

George County lies entirely within the Long-leaf Pine Hills region, in the Pascagoula River drainage basin. The Citronelle formation (Pliocene) is the principal geologic formation appearing at the surface, but the Pascagoula clay (Miocene) crops out on the lower slopes beneath the Citronelle in the central and northern parts of the county, and thin terrace deposits of Pleistocene age overlie both the Pascagoula and Citronelle formations in the lowlands that border Pascagoula River and its larger tributaries. These formations are described on pages $/ 57-60$, and their distribution is shown on the geologic map (pl. 2).

\section{GROUND-WATER CONDITIONS}

The Citronelle, the principal surface formation of the county, is also the principal developed source of domestic water supply. The formation has a thickness of 100 feet or more in the north and increases to 150 to 200 feet on the upland in the south. The more porous sand and gravel layers are water bearing, and the water is obtained by means of bored and dug wells that range in depth from 150 to 200 feet or more. Springs that have their source in the Citronelle are numerous, and some of them are utilized. One spring near Lucedale is the source of the municipal water supply of that town, and another near Merrill is utilized for boiler supply by the Gulf, Mobile \& Northern 'Railroad.

The Citronelle formation is underlain by the Pascagoula clay, which has an estimated thickness of 400 or 500 feet and appears in outcrops in the lower slopes of the valleys in the central and northern townships. Although the Pascagoula is composed principally of 54134-28-12 
non water-bearing clay, it appears to contain some interbedded layers of water-bearing sand, which yield moderate quantities of water. One flowing well at Merrill and another 3 miles northeast of Clarence. probably have their source in this formation.

The Pascagoula clay is underlain in descending succession by the Hattiesburg clay (Miocene), which is estimated to be 350 or 400 feet thick, and by the Catahoula sandstone (Miocene), which is estimated to be 400 or 500 feet thick. Neither of these formations appears at the surface in George County. In Greene County, on the north, the Hattiesburg contains some interbedded layers of water-bearing sand, and probably similar beds would be encountered in the buried extension of the formation under George County. The Catahoula formation is abundantly water bearing in other counties to the north, both in Alabama and Mississippi, and it is perhaps the most promising, though as yet undeveloped, artesian aquifer in George County. It is estimated that the Catahoula would be penetrated at depths of about 600 to 1,000 feet in the north, and several hundred feet deeper in the south. The formation would probably yield strong flows in the valleys of Pascagoula River and its larger tributaries.

\section{LOCAL SUPPLIES}

Lucedale.-The municipal water supply at Lucedale is obtained from a spring located at the head of a small branch three-fourths of a mile northeast of the post office. The spring emerges 65 or 70 feet below the level of the ridge on which the town is built, and probably has its source in a layer of sand in the Citronelle formation. As improved, the spring consists of a shallow wood-lined pool about 40 feet long and 20 feet wide, in the sandy bottom of which the water emerges from many small openings; the yield is estimated to be 60 to 70 gallons a minute, more than half of which is overflow water not needed for the town supply. (See analysis 3.) An attempt to obtain the municipal water supply by drilling a well to a depth of 300 feet resulted in failure to secure an adequate quantity. A similar attempt at the ice plant at Lucedale, where a well was sunk to a depth of 500 feet, likewise failed. These wells were not sunk deep enough to reach the water-bearing beds of the Catahoula formation. A well owned by M. H. Allman, on a hill 10 miles west by south of Lucedale, in the SE. $1 / 4$ sec. 5, T. 2 S., R. 7 W., is 203 feet deep and 3 inches in diameter. The water rises within 63 feet of the surface and yields by hand pump 3 gallons a minute. A log of the well is given on page 171 . 
Log of well of M. H. Allman, 10 miles west by south of Lucedale

[Authority, the owner]

\begin{tabular}{|c|c|c|}
\hline & Thickness & Depth \\
\hline $\begin{array}{l}\text { Citronelle and Pascagoula formations: } \\
\text { Sandy clay } \\
\text { Blue clay } \\
\text { Red mud and sand. } \\
\text { Red sandy slush } \\
\text { Blue mud; slight] w water bearing } \\
\text { Material resembling. hair (peat? } \\
\text { Wood or low grade of coal (lignite?) } \\
\text { Black sand; water bearing }\end{array}$ & $\begin{array}{r}\text { Feet } \\
10 \\
90 \\
20 \\
25 \\
10 \\
15 \\
20 \\
13\end{array}$ & $\begin{array}{r}\text { Feet } \\
10 \\
100 \\
120 \\
145 \\
155 \\
170 \\
190 \\
203\end{array}$ \\
\hline
\end{tabular}

The Big Creek Lumber Co. owns an 80-foot well in a valley 2 miles northwest of Lucedale. The water is derived from sand in the Citronelle formation and is raised by hand pump through a 2-inch casing. (See analysis 1.)

Merrill.-At Merrill the Gulf, Mobile \& Northern Railroad Co. obtains water for boiler use from a spring half a mile south of the post office, in the NE. $1 / 4$ sec. $8, T .1 \mathrm{~S} .$, R. $7 \mathrm{~W}$. The daily yield of the spring is reported to be 50,000 gallons. A 260-foot flowing well at Merrill, 200 yards northwest of the post office, owned by J. C. Dorsett, is used chiefly for public drinking; the water is derived from sand and gravel in the Pascagoula clay 200 to 260 feet below the surface, rises 12 feet above the surface, and flows 3 gallons a minute from a 2-inch casing. (See analysis 2.)

Clarence.-A well on the property of Walter J. Green, 3 miles northeast of Clarence, a village 13 miles southwest of Lucedale, is 93 feet deep and flows 65 gallons a minute from a 2-inch casing, which extends to a depth of 30 feet. The log of the well is given below:

Log of well of Walter J. Green, in S. 1/2 SW. 1/4 sec. 12, T. 9 S., R. 8 W., 9 miles northeast of Clarence

[Authority, the owner]

\begin{tabular}{|c|c|c|}
\hline$\cdot$ & Thickness & Depth \\
\hline Alluvium (?): Sand; water bearing..... & ${ }^{\text {Feet }}{ }_{30}$ & \\
\hline $\begin{array}{l}\text { Pascagoula clay: } \\
\text { Blue clay with thin layer of rock at base } \\
\text { Sand; water bearing. }\end{array}$ & $\begin{array}{r}60 \\
3\end{array}$ & $\begin{array}{l}90 \\
93\end{array}$ \\
\hline
\end{tabular}

Evanston.-In the vicinity of Evanston, about 3 miles southeast of Lucedale, water for domestic purposes is obtained from sand and gravel of the Citronelle formation by means of bored wells 50 to 75 feet deep. The water is under little or no artesian pressure and is raised by means of hand pumps. The wells of J. W. Herndon, 53 deep; Henry Fryer, 62 feet deep; an d Charles Griffen, 65 feet deep, all within a mile and a half of the town, are typical. 
Agricola-At Agricola the Citronelle formation also furnishes the domestic water supplies. The 70 -foot bored well of J. T. Vise, a quarter of a mile southeast of town is typical.

Mineral analyses of ground waters from George County

6. [Parts per million!

\begin{tabular}{|c|c|c|c|}
\hline & 1 & 2 & 3 \\
\hline 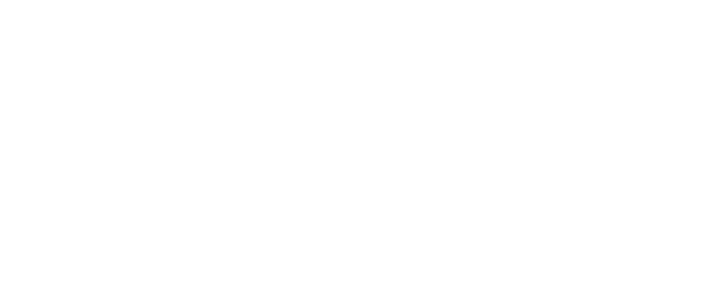 & $\begin{array}{c}16 \\
2.0 \\
3.4 \\
1.1 \\
6.8 \\
18.0 \\
.0 .8 \\
6.5 \\
.00 \\
13 \\
\text { May, } 1914\end{array}$ & $\begin{array}{c}16 \\
.00 \\
2.2 \\
130 \\
12 \\
229 \\
12 \\
69 \\
{ }_{\text {May, }}^{379} \\
23 \\
.00 \\
1915\end{array}$ & $\begin{array}{c}13 \\
.05 \\
.6 \\
1.6 \\
18 \\
13 \\
17 \\
1.8 \\
4.5 \\
\text { Track } \\
58 \\
4.6 \\
\text { Aug., } 1919\end{array}$ \\
\hline
\end{tabular}

- Calculated.

Analysts: 1, W. F. Hand, Mississippi State Chemical Laboratory; 2, E. 8. Wallace, University of Míssissippi; 3 , C. H. Kidwell and Margaret D. Foster, U. S. Geological Survey.

1. 80-foot well of Big Creek Lumber Co., at Lucedale.

2. 260-foot well of J. C. Dorsett, at Merrill.

3. Spring owned by $G$. M. Luce, at Lucedale.

\section{GREENE COUNTT}

\section{GENERAL FEATURES}

Area, 710 square miles. Population, 10,430 (census of 1920)

Greene County is entirely within the Long-leaf Pine Hills district. The principal geologic formations that appear in surface outcrops in the county include in the ascending order of their age the Catahoula sandstone (Miocene), the Hattiesburg clay (Miocene), the Pascagoula clay (Miocene), and the Citronelle formation (Pliocene). In addition relatively thin alluvial terrace deposits of loam, clay, sand, and gravel (Pleistocene) rest upon the older formations in the lowlands of Chickasawhay and Leaf Rivers. The several formations are described on pages 55-61, and their distribution is shown on the geologic map (pl. 2).

\section{GROUND-WATER CONDITIONS}

The source of most of the domestic water supplies in the upland portions of Greene County, as well as in the uplands of the neighboring counties of both Mississippi and Alabama, is the Citronelle formation, which has a thickness of 100 feet or more in the south and thins to perhaps 50 feet or less in the north. The water is obtained from bored and dug wells that range in depth from a few feet to 100 feet or more and from small springs.

In the lowlands the sands and gravels that form the lower part of the terrace deposits have in the past afforded the main water supply, 
which was obtained by wells generally less than 50 feet deep; but in recent years the number of artesian wells has increased, and this source is gradually replacing the former shallow source.

In the southern part of the county the Citronelle formation is underlain by the Pascagoula clay, which has an estimated maximum thickness of 200 to 300 feet along the southern boundary but which thing to the north and comes to a featheredge at about the middle of the county. So far as known no water-bearing beds have been found in this formation in Greene County.

In the northern part of the county the Citronelle formation is underlain by the Hattiesburg clay, which is estimated to be 350 or 400 feet thick, and which, though composed mainly of clay, also includes interbedded layers of water-bearing sand. The Hattiesburg dips slightly to the south, and about midway of the county passes beneath the Pascagoula elay. Several flowing wells at McLain, a 260-foot nonflowing well at Neely, and a 400-foot flowing well at Leaf, are believed to tap water-bearing beds in the Hattiesburg. This formation may be regarded as the most feasible source of artesian warer in the valleys of both the Leaf and the Chickasawhay in the two southern tiers of townships.

The Catahoula sandstone, which has an aggregate thickness of 400 or 500 feet, underlies the Hattiesburg clay and appears at the surface in the valley of Chickasawhay River for a few miles south of the northern boundary of Greene County. It dips to the south and passes beneath the Hattiesburg. The more porous sands constitute an important, though largely undeveloped, source of artesian water beneath the entire county. Along the northern boundary all the water-bearing beds in the formation ought to be reached at depths of less than 500 feet. Along the southern boundary the top of the formation is estimated to lie at a depth of 600 or 700 feet, and the bottom perhaps 1,000 or 1,100 feet. Here the formation would probably afford strong flows in the valleys of Leaf and Chickasawhay Rivers.

\section{IOCAL SUPPLIES}

Leakesvitle.-Flowing wells that have their source in sand of the Catahoula sandstone are obtainable in Chickasawhay Valley at Leakesville at depths of 400 to 450 feet. The 3-inch.well of J. E. Miller is $\mathbf{5 5 0}$ feet deep, and the water-bearing sand is in the lower 70 feet. The static head is 30 feet above the surface, and the yield is 30 gallons a minute. A 6 -inch public well, owned by the county, is more than 440 feet deep and yields 20 gallons a minute. 
A log of the courthouse well is given below:

Log of courthouse well, Leakesville

\begin{tabular}{|c|c|c|}
\hline - & Thickness & Depth \\
\hline $\begin{array}{l}\text { Pleistocene alluvium: Sandy yellow clay } \\
\text { Hattiesburg clay: } \\
\text { Blue pipe clay } \\
\text { Greenish clay } \\
\text { Catahoula sandstone (?): } \\
\text { Sand; water bearing } \\
\text { Blue clay } \\
\text { Sand; water bearing }\end{array}$ & $\begin{array}{r}\text { Feet } \\
6 \\
24 \\
350 \\
10 \\
50\end{array}$ & $\begin{array}{r}\text { Feet . } 6 \\
30 \\
880 \\
390 \\
440\end{array}$ \\
\hline
\end{tabular}

McLain.-Ten or more privately owned flowing wells, 150 to 180 feet deep, are in use at McLain in the valley of Leaf River; they have their source in sand of the Hattiesburg formation. A 2-inch well, owned by the town, is 155 feet deep and yields 75 gallons a minute; its static head is 18 feet above the surface. The well supplies water to about 100 buildings and 350 people. A log of the well is given below.

Log of well at McLain, owned by the town

[Authority, Joseph E. Green]

\begin{tabular}{|c|c|c|}
\hline & Thickness & Depth \\
\hline $\begin{array}{l}\text { Pascagoula and Hattiesburg clays: } \\
\text { Sand; water bearing at base. } \\
\text { Clay, passing into water-bearing gravel at base } \\
\text { Bluo sand; water bearing in lower } 5 \text { feet }\end{array}$ & $\begin{array}{r}\text { Feet } \\
15 \\
75 \\
65\end{array}$ & $\begin{array}{l}\text { Feet: } \\
15 \\
i, 150 \\
150\end{array}$ \\
\hline
\end{tabular}

The 2-inch well of R. H. Coleman, 200 yards east of the post office, is 155 feet deep and flows 60 gallons a minute. The following partial $\log$ of the well shows the character of the beds penetrated.

Partial log of well of R. H. Coleman, McLain

[Altitude of mouth of well, about 76 feet above sea level]

\begin{tabular}{|c|c|c|}
\hline & Thickness & Depth \\
\hline $\begin{array}{l}\text { Pascagoula and Hattiesburg clays: } \\
\text { Not reported } \\
\text { Pipe clay } \\
\text { Blue mari. } \\
\text { Character of material not stated, but yielded flowing water at } 4 \text { gallons a } \\
\text { minute } \\
\text { Chard, brittle chalk (clay) } \\
\text { minuter of material not stated but yielded flowing water at } 11 \text { gallons a } \\
\text { Blue marl. } \\
\text { Gravel; water bearing; fows } 60 \text { galions a minute }\end{array}$ & $\begin{array}{r}\text { Feet } \\
33 \\
15 \\
37 \\
30 \\
8 \\
15 \\
27\end{array}$ & $\begin{array}{r}\text { Feet } \\
\quad 33 \\
.48 \\
85 \\
115 \\
123 \\
138 \\
1.55\end{array}$ \\
\hline
\end{tabular}

The well of B. E. Green, 400 feet southeast of the post office, is 155 feet deep, has a static head of 25 feet above the surface, and yields 35 gallons a minute. (See analysis 2.) Two flowing wells 
of the Howze Lumber Co., a quarter of a mile south of the post office, are 175 and 180 feet deep.

Avera.-The flowing well of the Griffin Lumber Co. at Avera, in the valley of Chickasawhay River, is 490 feet deep. Water is obtained from white sand of the Catahoula sandstone. A log of the well is given below:

Log of well of Griffin Lumber Co. at Avera

[Authority, Gray Artesian Well Co.]

\begin{tabular}{|c|c|c|c|c|c|}
\hline & $\begin{array}{c}\text { Thick- } \\
\text { ness }\end{array}$ & Depth & $\because$ & $\begin{array}{c}\text { Thick- } \\
\text { ness }\end{array}$ & Depth \\
\hline $\begin{array}{l}\text { Sand } \\
\text { Brown sand. } \\
\text { Clay } \\
\text { Sand } \\
\text { Clay } \\
\text { Soapstone } \\
\text { Fine sand } \\
\text { Blue clay } \\
\text { Rook sand } \\
\text { Gumbo }\end{array}$ & \begin{tabular}{r|} 
Feet \\
22 \\
5 \\
40 \\
8 \\
19 \\
13 \\
12 \\
37 \\
9 \\
35
\end{tabular} & $\begin{array}{r}\text { Feet } \\
22 \\
27 \\
67 \\
75 \\
94 \\
107 \\
119 \\
156 \\
165 \\
200\end{array}$ & 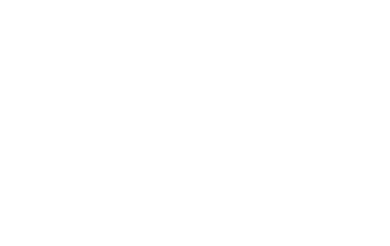 & $\begin{array}{r}\text { Feet } \\
4 \\
49 \\
40 \\
14 \\
8 \\
55 \\
114 \\
6\end{array}$ & $\begin{array}{r}\text { Feet } \\
204 \\
263 \\
293 \\
307 \\
315 \\
370 \\
484 \\
490\end{array}$ \\
\hline
\end{tabular}

The flowing well of L. D. Clark, 4 miles south of Avera, is 207(?) feet deep and also has its source in sand in the Catahoula sandstone.

Neely.-At Neely, on the upland 7 miles east of McLain, C. J. Neely owns a nonflowing well 260 feet deep, in which the water is derived from a bed of sand in the Hattiesburg clay; the static head is 90 feet below the surface, and the water is raised by hand.

Mineral analyses of ground waters from Greene County

[Parts per million]

\begin{tabular}{|c|c|c|}
\hline & 1 & 2 \\
\hline 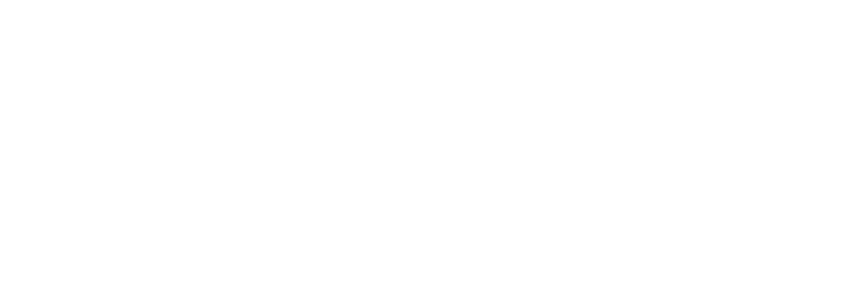 & 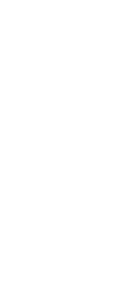 & $\begin{array}{l}21 \\
4.4 \\
3.2 \\
51.0 \\
139^{\circ} \\
13 \\
12.00 \\
180^{2 .} \\
24 .\end{array}$ \\
\hline
\end{tabular}

1. 400-foot well of J. C. Daughdrill, at Leaf.

2. 155-foot well of B. E. Green, at McLain.

Analysts: 1, Mississippi State Chemical Laboratory; 2, E. S. Wallace, University of Mississippi.

\section{GRENADA COUNTT}

\section{GENERAL FEATURES}

Area, 442 square miles. Population, 13,607 (census of 1920)

Grenada County lies mostly within the North Central Hills district but extends westward through the Loess Hills district into the Yazoo Delta: The geologic formations that crop out in Grenada County 
include the Eocene Holly Springs sand and Grenada formation of the Wilcox group and the Tallahatta and Lisbon formations of the Claiborne group (the Lisbon represented only by the Winona sand member and the Kosciusko sandstone member); Pliocene terrace sands and gravels, which intervene between the Eocene formations and the overlying loess, and probably also some of the higher terrace sands and gravels that flank the Yalobusha Valley; Pleistocene and Recent loess deposits which blanket the western border of the upland and which range in thickness from 30 to 40 feet along their western margin to only a few feet in the eastern part of the county; the thick alluvium that underlies the Yazoo Delta; and the alluvium that underlies the flood plain and lower second bottoms of Yalobusha River. The geologic divisions are described on pages 46-63, and their distribution is shown on the geologic map (pl. 2).

\section{GROUND-WATER CONDITIONS}

The beds that compose the Eocene formations enumerated above dip west by south at an estimated rate of 20 or 25 feet to the mile and are therefore in a favorable structural attitude for the development of artesian pressure in the waters which they contain. Numerous flowing wells have been obtained in the valley of Yalobusha River.

The Ackerman formation of the Wilcox group, which crops out in Calhoun County just east of Grenada County, aggregates between 500 and 600 feet in thickness and is overlain by 400 or 500 feet of the Holly Springs sand. All of the deeper wells of the county have their source in either the more sandy portions of the Ackerman or the Holly Springs sand, which contain abundant water.

The Grenada formation, here of undetermined thickness, overlies the Holly Springs sand. Outcrops occur in the lower slopes in the vicinity of Grenada, but the distribution of the formation has not been determined in detail.

The Tallahatta formation is thin and underlies less than the western half of the county.

The Winona and Kosciusko members of the Lisbon formation underlie the upland in the central and western parts of the county, and they probably are the source of the waters obtained in many shallow wells.

The terrace sands and gravels that intervene between the Eocene formations and the surficial covering of loess are water bearing and yield water to shallow wells; many small springs flow from these materials where they crop out on the slopes. Shallow wells also penetrate the water-bearing sands and gravels which in part compose the alluvial deposits that border Yalobusha River, and the alluvial deposits that underlie the Yazoo Delta to an estimated depth of about 150 feet contain an abundance of nonflowing water that is easily procured by bored and driven wells. 


\section{LOCAL SUPPLIES}

Hardy station.-At Hardy station water is obtained chiefly from: wells 20 to 25 feet deep; the static head is about 10 feet below the surface. One well (No. 16), is 400 feet deep and yields a good supply of soft water from the Holly Springs sand. Another well 80 feet deep. (No. 15), yields an abundant supply of water.

Graysport.-At Graysport there are seven or eight flowing wells. which range in depth from 275 to 350 feet and probably have their source in the Ackerman formation. Most of them yield less than a gallon a minute. Two of the wells (Nos. 3,4) are described in thetable of well data. (See analysis 4.)

Holcomb. - Three flowing wells at Holcomb are described in the table of well data (Nos. 17, 18, and 19). They are 210,355, and 380 feet deep and probably penetrate to the water-bearing beds of the Holly Springs sand. Water from well No. 19 is very hard. (Seeanalysis 19.)

Dubard.-Two flowing wells at Dubard, a village $61 / 2$ miles west of Grenada, are respectively $2101 / 2$ and 280 feet deep (Nos. 1, 2). They probably have their source in the Holly Springs sand. The following: log of well No. 1 shows the character of strata encountered at this place:

Log of well at Dubard (No. 1)

\begin{tabular}{|c|c|c|}
\hline & Thickness & Depth \\
\hline $\begin{array}{l}\text { Alluvium: } \\
\text { Clay } \\
\text { Quicksand }\end{array}$ & $\begin{array}{r}\text { Feet } \\
10 \\
20\end{array}$ & $\begin{array}{r}\text { Feet } \\
10 \\
30\end{array}$ \\
\hline $\begin{array}{l}\text { Grenada and Holly Springs formations: } \\
\text { Soapstono } \\
\text { Sandstone } \\
\text { Sand; water bearing }\end{array}$ & $85^{\circ}$ & $\begin{array}{l}125 \\
125.5 \\
210.5\end{array}$ \\
\hline
\end{tabular}

Bew Springs.-In places along Yalobusha River springs issue atthe base of the slopes that border the valley. One spring of this kind, owned by J. F. Singleton, three-quarters of a mile southeast. of Bew Springs post office (51/4 miles west of Grenada) issues with. strong upward current at. the base of a steep hillside.

Grenada.-The municipal waterworks at Grenada is 300 yards: south of the Illinois Central Railroad station on ground about 3 feet higher than the track-at the station. (See pl. 11, B.) The water supply is obtained chiefly from two 10 -inch wells 169 and 168 feet deep (Nos. 6, 7). A third well, 620 feet deep (No. 5), flows into the reservoir at 20 gallons a minute, and a fourth well, also 620 feet deep (No. 8), flows 10 gallons a minute and its water is used chiefly for drinking. (See analyses 5, 6.) The following logs show the character of the beds penetrated by deep wells at Grenada: 
Log of well at waterworks, Grenada (No. 8)

\begin{tabular}{|c|c|c|}
\hline & Thickness & Depth \\
\hline $\begin{array}{l}\text { Pleistocene alluvium (?): } \\
\text { Surface loam } \\
\text { Sand } \\
\text { Grenada formation; Soapstone (clay) } \\
\text { Holly Springs sand and Ackerman formation: } \\
\text { Sand and soft clay } \\
\text { Boapstone (clay) and sand; water bearing } \\
\text { Blue sand } \\
\text { Soapstone (clay?) } \\
\text { Blue sandy rock, very fine grained } \\
\text { Soft clay } \\
\text { Sand; water bearing } \\
\text { Soft blue sandstone } \\
\text { Rock }\end{array}$ & $\begin{array}{r}\text { Feet } \\
60 \\
30 \\
30 \\
40 \\
90 \\
30 \\
30 \\
140 \\
10 \\
30 \\
110 \\
20\end{array}$ & $\begin{array}{r}\text { Feet } \\
90 \\
120 \\
160 \\
250 \\
280 \\
310 \\
450 \\
460 \\
490 \\
600 \\
620\end{array}$ \\
\hline
\end{tabular}

Log of Bledsoe well at Grenada (No. 14)

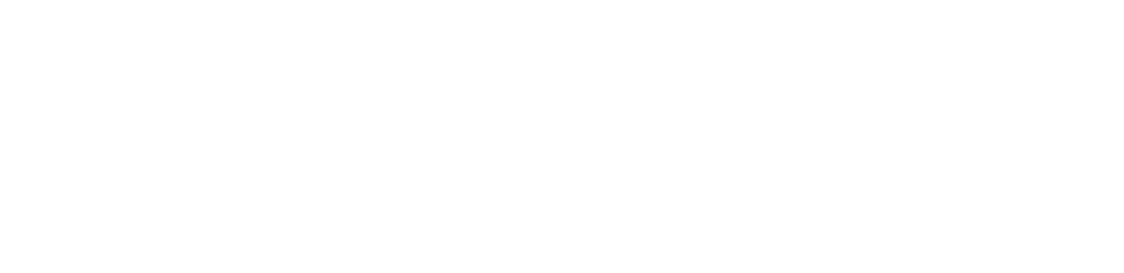

Well No. 12, owner not named, 721 feet deep, 3 miles south of Grenada, on a terrace or second bottom somewhat higher than that at Grenada, flows a small stream. The following log indicates that the well penetrated a series of beds similar to that encountered in the wells at Grenada.

Log of well 3 miles south of Grenada (No. 12)

\begin{tabular}{|c|c|c|c|c|c|}
\hline & $\begin{array}{c}\text { Thick- } \\
\text { ness }\end{array}$ & Depth & & $\underset{\text { Thick- }}{\text { ness }}$ & Depth \\
\hline $\begin{array}{l}\text { Pleistocene alluvium: } \\
\text { Clay } \\
\text { Sand } \\
\text { Grenada formation: } \\
\text { Soapstone } \\
\text { Band } \\
\text { Soapstone (clay) } \\
\text { Mud } \\
\text { Soapstone (clay) }\end{array}$ & $\begin{array}{l}30 \\
10 \\
10 \\
20 \\
10\end{array}$ & $\begin{array}{r}\text { Feet } \\
10 \\
40 \\
70 \\
80 \\
90 \\
110 \\
120\end{array}$ & $\begin{array}{l}\text { Holly Springs sand and Ackerman } \\
\text { formation: } \\
\text { Very coarse sand. } \\
\text { Hard rock. } \\
\text { Sand } \\
\text { Soapstone (clay) } \\
\text { Two thin rock layers } \\
\text { Soapstone (clay) } \\
\text { Not reported }\end{array}$ & $\begin{array}{c}\text { Feet } \\
95 \\
1 / 4 \\
10^{1 / 4} \\
335 \\
40^{8 / 4} \\
120\end{array}$ & $\begin{array}{l}\text { Feet } \\
215 \\
2151 \\
225 \% \\
5603 \\
561 \\
601 \\
721\end{array}$ \\
\hline
\end{tabular}

Leflore.-Leflore is a village on the edge of the Yazoo Delta on the Yazoo \& Mississippi Valley Railroad near the southwest corner of the county. M. L. Pollard's well (No. 20) at this place is 450 feet deep and yields flowing water. The well is believed to have its source in the Holly Springs sand. (See analysis 20.) 


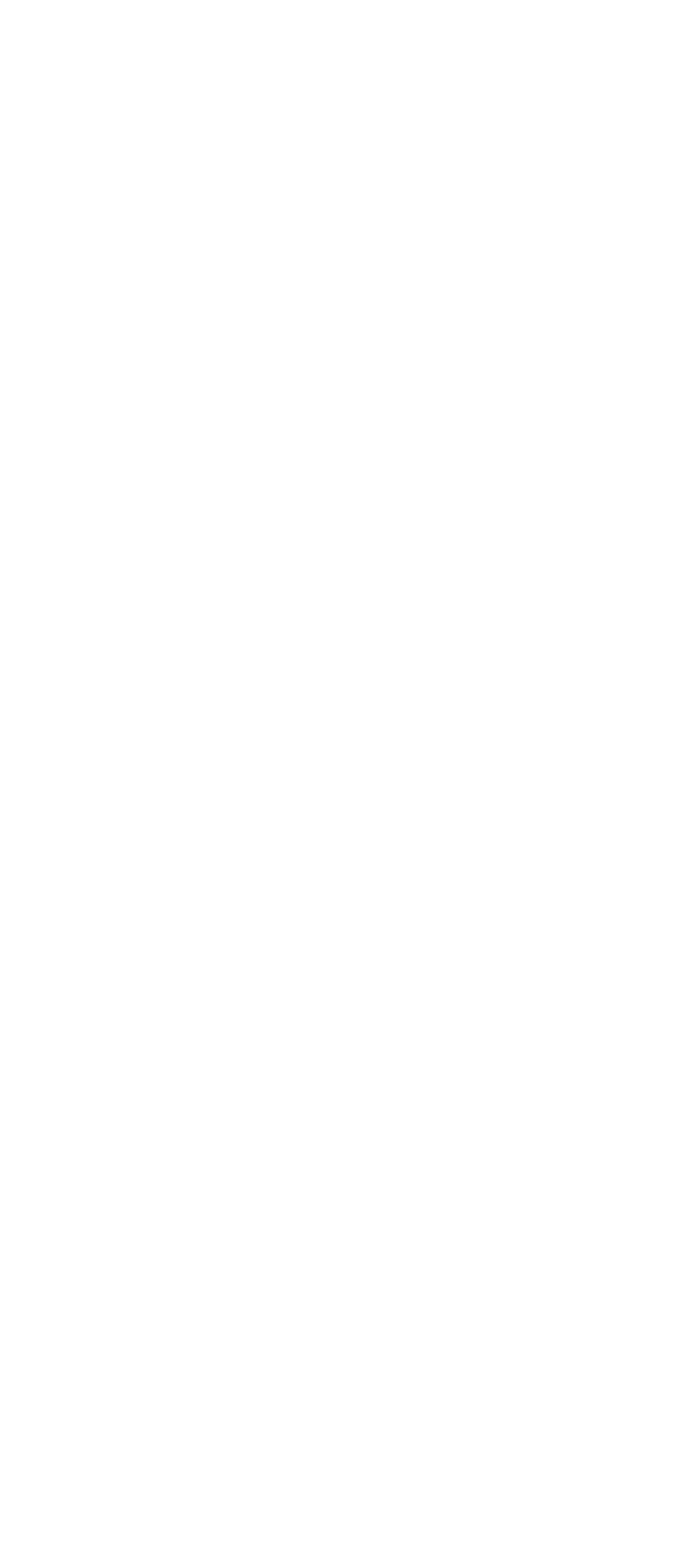




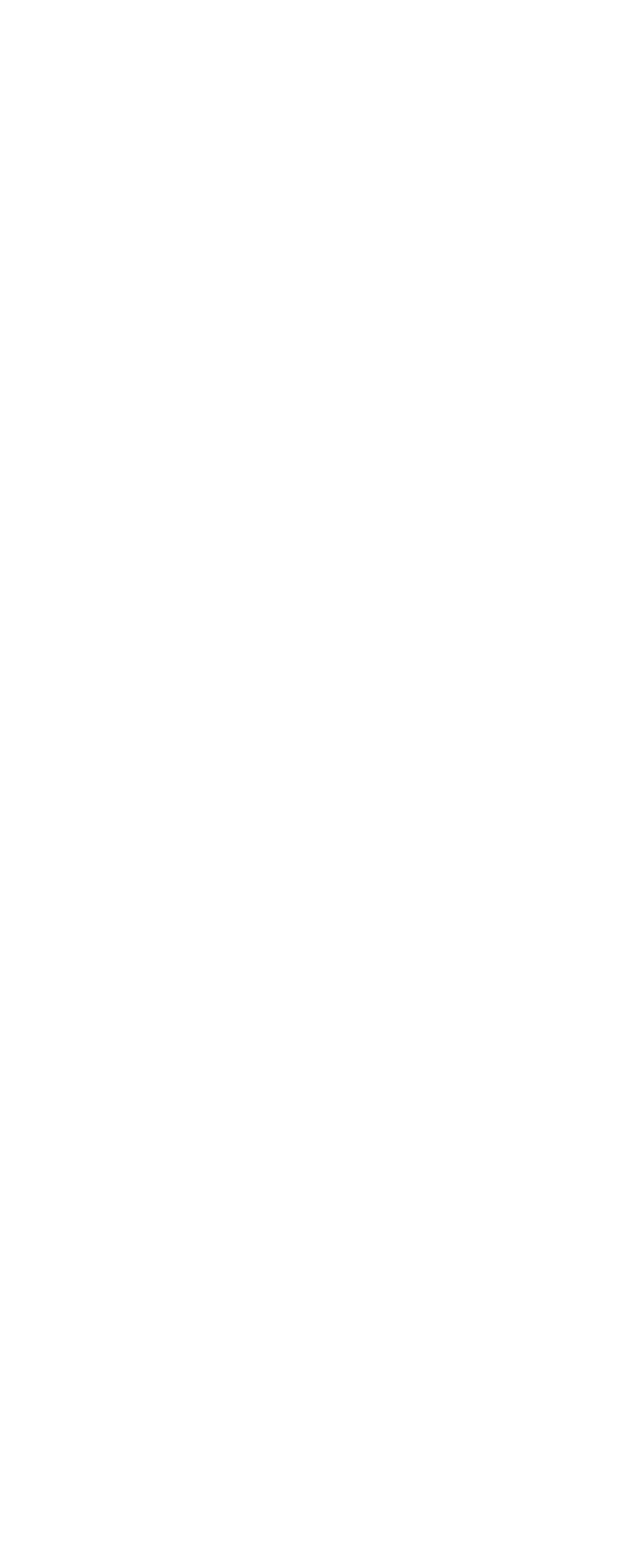




\section{Mineral analyses of ground waters from Grenada Caunty}

Parts per million. Numbers at heeds of columns refor to corresponding well numbers in preceding table]

\begin{tabular}{|c|c|c|c|c|c|c|c|c|}
\hline & 4 & 5 & 6 & 8 & $\theta$ & 1 & 19 & 20 \\
\hline $\begin{array}{l}\text { Silica }\left(\mathrm{SiO}_{2}\right) \\
\text { Iron }(\mathrm{F} \theta) \\
\text { Oalcium }(\mathrm{C} \mathrm{a}) \\
\text { Magnesium }(\mathrm{Mg})\end{array}$ & $\begin{array}{l}19 \\
\mathbf{3} .7 \\
1.7\end{array}$ & $\begin{array}{l}11 \\
5.20 \\
1.2\end{array}$ & $\begin{array}{l}26 \\
10 \\
10 \\
2.2\end{array}$ & $\begin{array}{r}11 \\
1.0 \\
3.4 \\
1.6\end{array}$ & $\begin{array}{l}19 \\
.32 \\
6.4 \\
3.1\end{array}$ & $\begin{array}{l}15 \\
4.43 \\
1.0\end{array}$ & $\frac{64}{81}$ & $\begin{array}{l}33 \\
9.2 .1 \\
12 . \\
5.8\end{array}$ \\
\hline Sodium and potassium $(\mathrm{N} s+\mathrm{K}) \ldots$ & 111 & & 82 & & 95 & $\$ 218$ & 12 & \\
\hline 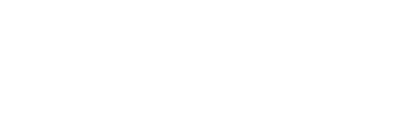 & $\begin{array}{c}24 \\
281 \\
3.1 \\
11 \\
1.2\end{array}$ & $\begin{array}{c}9.6 \\
278 \\
1.3 \\
75 \\
.30\end{array}$ & $\begin{array}{l}232^{\circ} \\
7.0 \\
24.0 \\
.00\end{array}$ & $304^{.0}$ & $\begin{array}{c}251^{.0} \\
3.8 \\
18 \\
\text { Trace. }\end{array}$ & $\begin{array}{l}7.2 \\
334 \\
3.3 \\
140 \\
\text { Trace. }\end{array}$ & 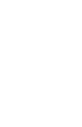 & $\begin{array}{r}173^{.0} \\
6.7 \\
6.7\end{array}$ \\
\hline $\begin{array}{l}\text { Total dissolved solids at } 180^{\circ} \\
\text { Total hardness as CaCOs (cslculated) } \\
\text { Date of collection.... }\end{array}$ & $\begin{array}{l}200 \\
16 \\
\text { Aug., } \\
1919\end{array}$ & $\begin{array}{l}400 \\
18 \\
\text { June, } \\
1911\end{array}$ & $\begin{array}{l}27 \overline{5} \\
34 \\
\text { Sept., } \\
1915\end{array}$ & $\begin{array}{c}430^{2.2} \\
15\end{array}$ & $\begin{array}{l}203 \\
29 \\
\text { Jan., } \\
1921\end{array}$ & $\begin{array}{l}\text { Aug. } \\
1919 \\
\text { Aug. }\end{array}$ & $\begin{array}{l}398 \\
1911\end{array}$ & 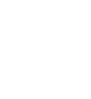 \\
\hline
\end{tabular}

- Iron and aluminum oxides $\left(\mathrm{Fe}_{2} \mathrm{O}_{3}+\mathrm{Al}_{2} \mathrm{O}_{3}\right)$.

o Calculated.

Analysts: 4, 10, Margaret D. Foster, U. S. Geological Survey; 5, W. L: Kennon, University of Míssis: sippi; 6, W. F. Hand, Mississippi State Chemical Laboratory; 8, 20, W. R. Perkins (Mississippi Ast. Exper. Sta. Bull. 89, p. 107, 1905); 9, C. S. Howard, U. S. Geological Survey; 19, E. S. Wallace, University o tMississippi.

\section{HANCOCK COUNTY}

\section{GENERAL FEATURES}

Area, 469 square miles. Population, 10,380 (census of 1920)

Hancock is the westernmost of the tier of counties that borders the Gulf of Mexico in southeastern Mississippi, in the Coastal Pine Meadows area. The county is underlain by loam, clay, and sand, which were deposited chiefly during the Pleistocene epoch in the shallow marginal waters of the Gulf of Mexico. These deposits together with the sand, clay, and marl, of the Citronelle formation (Pliocene), Pascagoula clay (Miocene), and Hattiesburg clay. (Miocene), which underlie the Pleistocene deposits in the order named, are more fully described on pages 48-61. (See also geologic map, pl. 2.)

\section{GROUND-WATER CONDITIONS}

The loam, clay, and sand of Pleistocene age that underlie the broad, flat plains or terraces which compose the surface of the county have not been studied in detail, but they probably increase in thickness from only 20 or 30 feet in the north to perhaps 200 feet or more in the extreme south. The porous sandy layers are water bearing; and the water is obtainable by relatively shallow dug, bored, or driven wells. This water is the common source of domestic water supply in the northern part of the county and to a less extent also in thesouth, where the deeper artesian wells have come into more general use. Small springs, which have their source in the Pleistocene deposits, secur in places in the county, especially in the higher land in the north.

The Pleistocene deposits are underlain by a series of interbedded clays, sands, marls, and some gravels, which have been penetrated by 
wells to a maximum depth of about 1,040 feet within the county. Certain of the beds of sand and gravel carry abundant water and are the source of the many flowing artesian wells in the southern half of the county; some of these wells are described in the table of well data. This series of beds belongs in descending order to the Citronelle, Pascagoula, and Hattiesburg formations, but exact information on which to base a determination of the thickness of the different formations is meager.

The Citronelle formation, which immediately underlies the Pleistocene, is estimated to be between 400 and 500 feet thigk. In the northern part of the county some of the creeks may have cut through the relatively thin Pleistocene deposits into the upper part of the Citronelle, but toward the south the formation passes to greater depths, until along the coast its uppermost stratum is buried beneath a thickness of 150 to 200 feet or more of Pleistocene deposits. At Kiln a bed of sand and gravel, at a depth of 495 to 560 feet (see log; p. 185), may mark the base of the Citronelle. By consulting the table of well data it will be seen that the flowing water of many wells that range in depth from 100 feet to a questionable maximum of 750 feet comes from beds that are regarded as belonging to the Citronelle formation. The hydraulic head of the water of some of these wells is as much as 50 feet above the surface, and the yield ranges from 20 to 600 gallons or more a minute.

The deeper wells of the county, the deepest of which so far as reported is about 1,040 feet, penetrate water-bearing sands that are believed to be in the Pascagoula formation. All these wells exhibit strong artesian pressure, and in some of them the head is as much as 75 feet above the surface (about 85 feet above sea level) and the yield amounts to as much as 600 gallons a minute.

Most of the older wells in this area have decreased both in head and in the amount of yield, and the causes of this decrease are discussed on page 19 of this report.

Flowing wells can be obtained wherever the altitude of the surface of the ground is lower than the maximum height above sea level to which the hydrostatic pressure will raise the ground waters at that locality. As stated above, a maximum head of 85 feet above sea level has been recorded. Flows can not be obtained on the uplands that lie much more than 80 or 85 feet above sea level; flows probably can be obtained in all the valleys whose bottom lands lie less than 70 or 80 feet above sea level.

\section{LOCAL SUPPLIES}

Bay St. Louis.-Many flowing artesian wells, which range in depth from 150 to over 1,000 feet, have been drilled at and in the vicinity of Bay St. Louis. A fow typical wells are described in the table of well 
data, (wells Nos. 1-10)..$^{30}$ The town is supplied with water from three artesian wells (Nos. 1-3), two of which are about 1, 000 feet and the third 840 feet deep. When flowing freely the combined yield of the three wells is 850 gallons a minute. The logs or partial logs of five wells at and near Bay St. Louis are given below. These logs indicate several important water-bearing beds in the Citronelle and Pascagoula formations between depths of 300 and 1,000 feet.

Log of well drilled in 1904 a mile north of Bay St. Louis (No. 10)a

[Diameter, 3 inches. Authority, John L. Ford, driller]

\begin{tabular}{|c|c|c|}
\hline & Thickness & Depth \\
\hline $\begin{array}{l}\text { Undifferentiated Pleistocene, Pliocene (Citronelle formation), and Miocene (Pas- } \\
\text { cagonla clay): } \\
\text { Blue sandy clay } \\
\text { White sand } \\
\text { Yellow sand } \\
\text { White sand and gravel } \\
\text { Green clay } \\
\text { Gray sand } \\
\text { Green clay sand } \\
\text { Green clay } \\
\text { Sand; water bearing; flows } 50 \text { gallons a minute } \\
\text { Blue clay } \\
\text { Sand; water bearing; flows } 225 \text { galions a minute }\end{array}$ & $\begin{array}{r}\text { Feet } \\
10 \\
50 \\
35 \\
50 \\
15 \\
60 \\
130 \\
20 \\
280 \\
40 \\
128 \\
79\end{array}$ & $\begin{array}{r}\text { Feet } \\
10 \\
60 \\
95 \\
1.45 \\
160 \\
220 \\
350 \\
370 \\
650 \\
690 \\
818 \\
897\end{array}$ \\
\hline
\end{tabular}

- U. S. Geol. Survey Bull. 264, p. 62, 1904.

Log of well of Louisville \& Nashville Railroad, at Bay St. Louis (No. 8) •

[Altitude of mouth of well a few feet above sea level. Authority, Frank Sutter, driller]

\begin{tabular}{|c|c|c|}
\hline & Thickness & Depth \\
\hline $\begin{array}{l}\text { Ondifferentiated Pleistocene, Pliocene (Citronelle formation), and Miocene (Pas- } \\
\text { cagoula clay): } \\
\text { Yellow clay } \\
\text { Deep orange clay } \\
\text { Blue clay } \\
\text { Sand; water bearing } \\
\text { Blue clay } \\
\text { Shell rock } \\
\text { Blue clay } \\
\text { Sand; water bearing }\end{array}$ & $\begin{array}{r}\text { Feet } \\
200 \\
30 \\
220 \\
40 \\
260 \\
1 \\
49 \\
60\end{array}$ & $\begin{array}{r}\text { Feet } \\
200 \\
230 \\
450 \\
490 \\
750 \\
751 \\
800 \\
860\end{array}$ \\
\hline
\end{tabular}

- Mississippi Agr. Exper. Sta. Bull. 89, p. 69, 1905.

Partial log of well of F. Loeber, one-half mile west of the post office at Bay St. Louis

[Authority, Charles Sanger, driller]

\begin{tabular}{|c|c|c|}
\hline & Thiekness & Depth \\
\hline 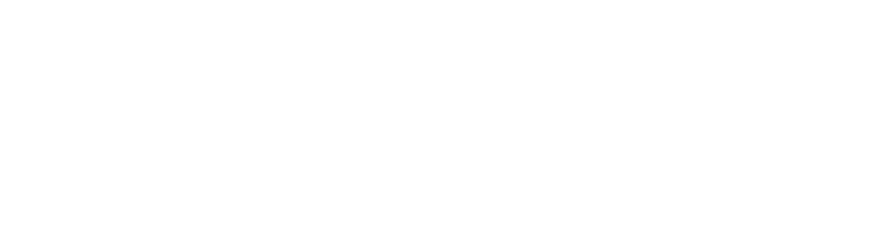 & $\begin{array}{r}\text { Feet } \\
117 \\
56 \\
89 \\
1 \\
117 \\
1 \\
149 \\
8 \\
118 \\
13\end{array}$ & $\begin{array}{r}\text { Feet } \\
117 \\
173 \\
262 \\
263 \\
380 \\
381 \\
530 \\
538 \\
656 \\
669\end{array}$ \\
\hline
\end{tabular}

* Some of the older wells at Bay St. Louis are described in U. S. Geol. Survey Water-supply Paper 159, pp. 42-46, 1906. 
Partial log of well of Charles Sanger, one-fourth mile west of the post office at Bay St. Louis

[Authority, the owner]

\begin{tabular}{|c|c|c|}
\hline & Thickness & Depth \\
\hline $\begin{array}{l}\text { Undifferentiated Pleistocene deposits and Citronelle formation (Pliocene): } \\
\text { Not reported. } \\
\text { Blue clay } \\
\text { Sand } \\
\text { Blue clay } \\
\text { Green sand } \\
\text { Blue clay } \\
\text { Gray sand; water bearing }\end{array}$ & $\begin{array}{r}279 \\
23 \\
9 \\
23 \\
19 \\
8 \\
23\end{array}$ & $\begin{array}{r}\text { Feet } \\
279 \\
302 \\
311 \\
334 \\
353 \\
\mathbf{3 6 1} \\
\mathbf{3 8 4}\end{array}$ \\
\hline
\end{tabular}

Waveland.-The town of Waveland is provided with a water-supply system known as the Waveland Waterworks. The water is obtained from two flowing wells, 950 (?) and 1,040 (?) feet deep (Nos. 24, 25), which have a maximum combined yield of about 775 gallons a minute. Analysis 24 represents water from the 950foot well. Many flowing artesian wells, which range in depth from 350 to 1,000 feet, have been drilled at and near Waveland. ${ }^{31}$ Several beds of water-bearing sand yielding moderate to large flows are encountered between these depths. Most of the wells are less than 500 feet deep, and the source of the water is in sands that are regarded as belonging to the Citronelle formation. A few of the wells extend to greater depths and penetrate beds that are probably referable to the Pascagoula formation. Partial logs of two privately owned wells, drilled by Charles Sanger, are given below.

Partial $\log$ of well of $A$. Metranger, 1,500 feet west of the post office at Waveland (No. 28)

[Authority, Charles Sanger, driller]

\begin{tabular}{|c|c|c|}
\hline & Thickness & Depth \\
\hline $\begin{array}{l}\text { Undifferentiated Pleistocene deposits and Citronelle formation (Pliocene): } \\
\text { Not reported } \\
\text { Sand } \\
\text { Not reported. } \\
\text { Sand } \\
\text { Not reported } \\
\text { Clay (?) } \\
\text { Sand } \\
\text { Cand; water bearing }\end{array}$ & $\begin{array}{r}\text { Feet } \\
245 \\
1 \\
17 \\
1 \\
6 \\
08 \\
16 \\
40 \\
19 .\end{array}$ & $\begin{array}{r}\text { Feet } \\
245 \\
246 \\
263 \\
264 \\
270 \\
363 \\
379 \\
419 \\
438\end{array}$ \\
\hline
\end{tabular}

" Some of the older wells at Waveland are described in U. S. Geol. Survey Water-Supply Paper 159, pp. 44-45, 1906. 
Partial log of well of Paul Conrad, 11/2 miles west of the post offes at Weveland (No. 28)

[Authority, Charles Sanger, driller]

\begin{tabular}{|c|c|c|}
\hline & Thicknoss & Depth \\
\hline 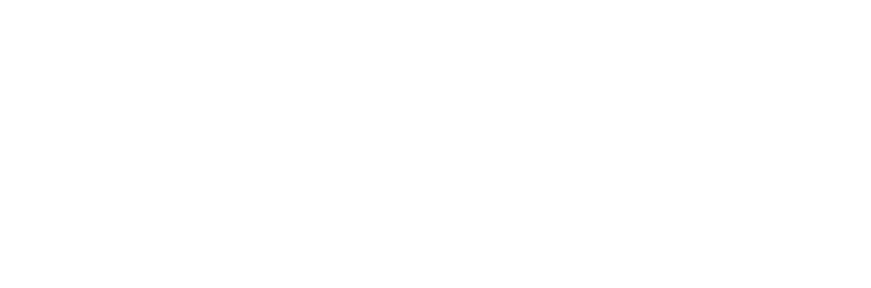 & $\begin{array}{r}75 \\
27 \\
33 \\
127 \\
29 \\
5 \\
2 \\
27 \\
47 \\
14 \\
26 \\
20\end{array}$ & $\begin{array}{r}75 \\
109 \\
135 \\
262 \\
291 \\
296 \\
298 \\
325 \\
372 \\
386 \\
412 \\
432\end{array}$ \\
\hline
\end{tabular}

Kiln.-Several flowing wells which range in depth from 140 to 560 feet have been reported from Kiln (Nos. 13-17). The log of one well, owned by the Jordan River Lumber Co., is given below and indicates nine water-bearing sands between depths of 104 and 560 feet. Eight other deep wells are in use at the lumber plant of this company, but no records of their depths have been kept. The company owns a waterworks supplied by three of the nine wells, including the 560-foot well mentioned above.

Log of well of Jordan Ruver Lumber Co., at the lumber plant at Kiln in sec. 29, T. 7 S., R. 14 W. (No. 14)

[Authority, J. A. Sutter, contractor]

\begin{tabular}{|c|c|c|}
\hline & Thickness & Depth \\
\hline 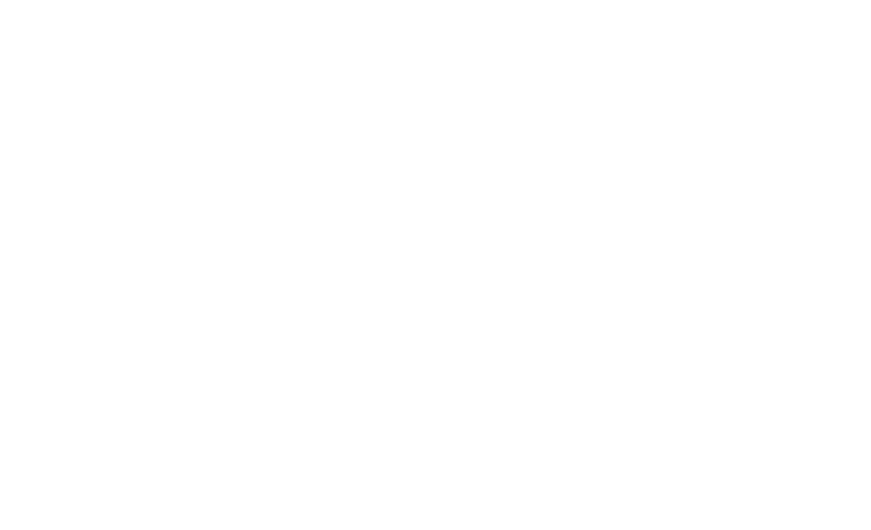 & $\begin{array}{r}65 \\
6 \\
24 \\
10 \\
9 \\
26 \\
5 \\
15 \\
10 \\
30 \\
10 \\
40 \\
25 \\
39 \\
21 \\
26 \\
10 \\
10 \\
16 \\
30 \\
24 \\
30 \\
25 \\
65\end{array}$ & $\begin{array}{r}\text { Feet } \\
\mathbf{5 6} \\
61 \\
85 \\
85 \\
95 \\
104 \\
130 \\
136 \\
150 \\
160 \\
190 \\
200 \\
240 \\
265 \\
304 \\
325 \\
350 \\
360 \\
370 \\
386 \\
416 \\
440 \\
470 \\
495 \\
560\end{array}$ \\
\hline
\end{tabular}

$54134-28-13$ 
Logtown.-The records of three artesian wells at Logtown are given in the table of well data (Nos. 18-20). There are many other wells in the vicinity. The wells range in depth from 300 to 750 feet and yield 3 to 200 gallons a minute. The highest recorded head is 30 feet above the surface.

Standard.-The following log of a bored well at Standard, a village about 18 miles north of Bay St. Louis, may be regarded as typical of the shallow wells commonly in use in the northern part of the county:

Log of well of Ephraim Cuevas, one-fourth mile southeast of post office at Standard (No. 2B)

[Authority, the owner]

\begin{tabular}{l|r|r|}
\hline & Thickness & Depth \\
\hline Pleistocene terrace deposit: & Freet & Feet \\
Red sand. & 10 & 10 \\
White sand day & \\
Blue pipe clay \\
Gravel; water bearing
\end{tabular}

Clermont Harbor.-The following $\log$ of an oil-prospecting well drilled some years ago at Clermont Harbor, $2 \frac{1}{2}$ miles southwest of Waveland, shows the character of the beds penetrated in that locality. The log appears to be either the original or a carefully made copy of the original, but neither the date nor the authority is recorded.

Log of oil-prospecting well at Clermont Harbor

\begin{tabular}{|c|c|c|c|c|c|}
\hline & $\begin{array}{c}\text { Thick- } \\
\text { ness }\end{array}$ & Depth & & $\begin{array}{c}\text { Thick- } \\
\text { ness }\end{array}$ & Depth \\
\hline $\begin{array}{l}\text { Undifferentiated Pleistocene de- } \\
\text { posits and Citronelle formation } \\
\text { (Pliocene): } \\
\text { White and red clay } \\
\text { Black sand } \\
\text { Oil(?) sand } \\
\text { Blue clay } \\
\text { White clay } \\
\text { White sand } \\
\text { Blue clay } \\
\text { Green clay } \\
\text { White sand } \\
\text { Clay (?) } \\
\text { White sand. }\end{array}$ & $\begin{array}{rr}F t . & \text { in. } \\
17 & 5 \\
19 & 7 \\
20 & 0 \\
19 & 11 \\
18 & 2 \\
19 & 8 \\
56 & 10 \\
20 & 3 \\
56 & 8 \\
20 & 0 \\
59 & 0\end{array}$ & $\begin{array}{rr}F t . & i n . \\
17 & 5 \\
37 & 0 \\
57 & 0 \\
76 & 11 \\
95 & 1 \\
114 & 9 \\
171 & 7 \\
191 & 10 \\
248 & 6 \\
268 & 6 \\
327 & 6\end{array}$ & $\begin{array}{l}\text { Undifferentiated Pleistocene de- } \\
\text { posits and Citronelle formation } \\
\text { (Pliocene)-Continued. } \\
\text { Fine gravel. } \\
\text { White clay and sand } \\
\text { Clay } \\
\text { Sand } \\
\text { Sand; water bearing } \\
\text { Hard clay } \\
\text { Joint clay } \\
\text { White clay } \\
\text { Green clay } \\
\text { Hard clay }\end{array}$ & $\begin{array}{lr}F t . & \text { in. } \\
18 & 5 \\
19 & 7 \\
20 & 0 \\
19 & 10 \\
19 & 5 \\
39 & 0 \\
20 & 0 \\
26 & 0 \\
28 & 0 \\
18 & 0\end{array}$ & $\begin{array}{lr}F t .1 & \text { in } \\
345 & 11 \\
365 & 6 \\
385 & 6 \\
405 & 4 \\
424 & 8 \\
463 & \\
483 & 9 \\
509 & 9 \\
537 & 9 \\
555 & 9\end{array}$ \\
\hline
\end{tabular}




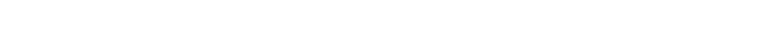

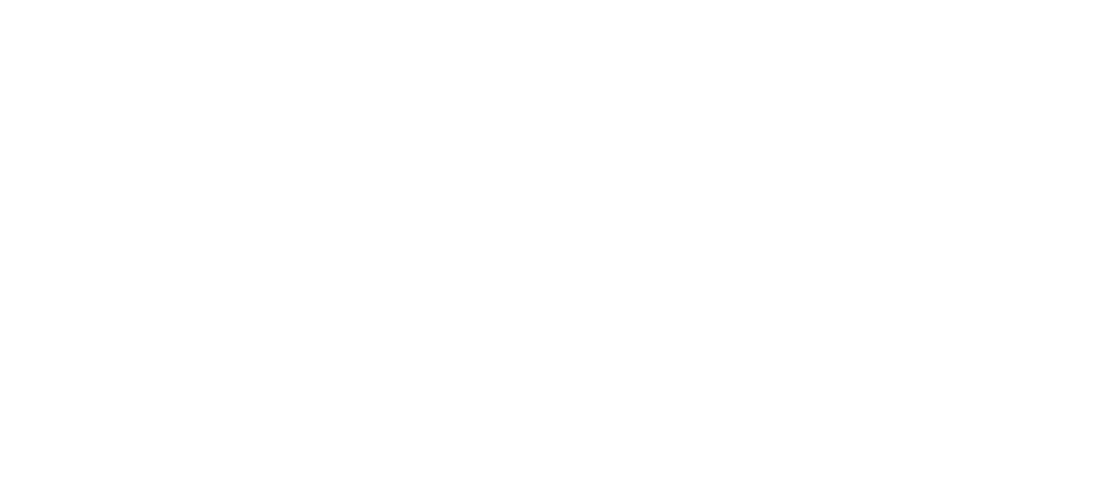

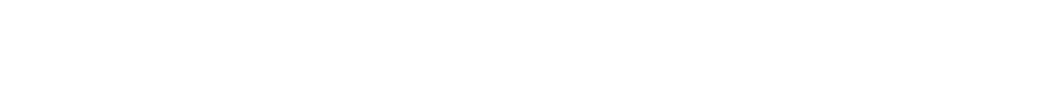

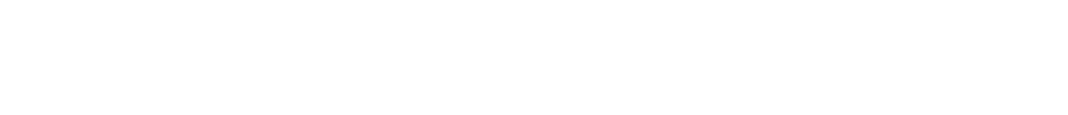
竞部兽

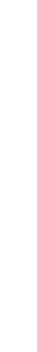

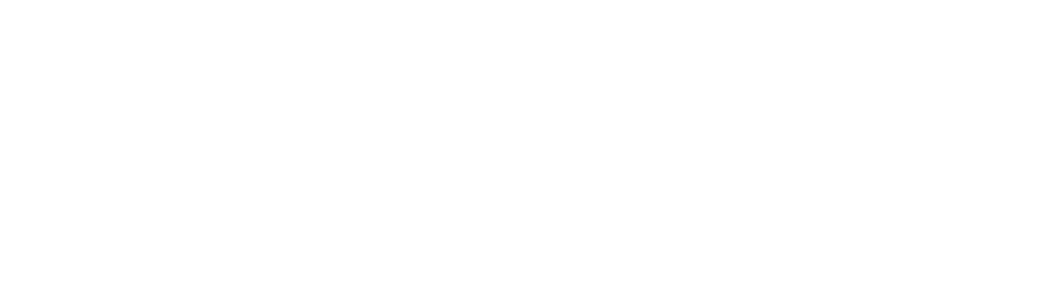
㭻

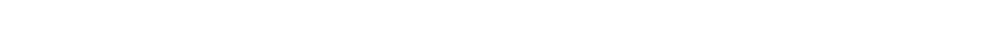
E

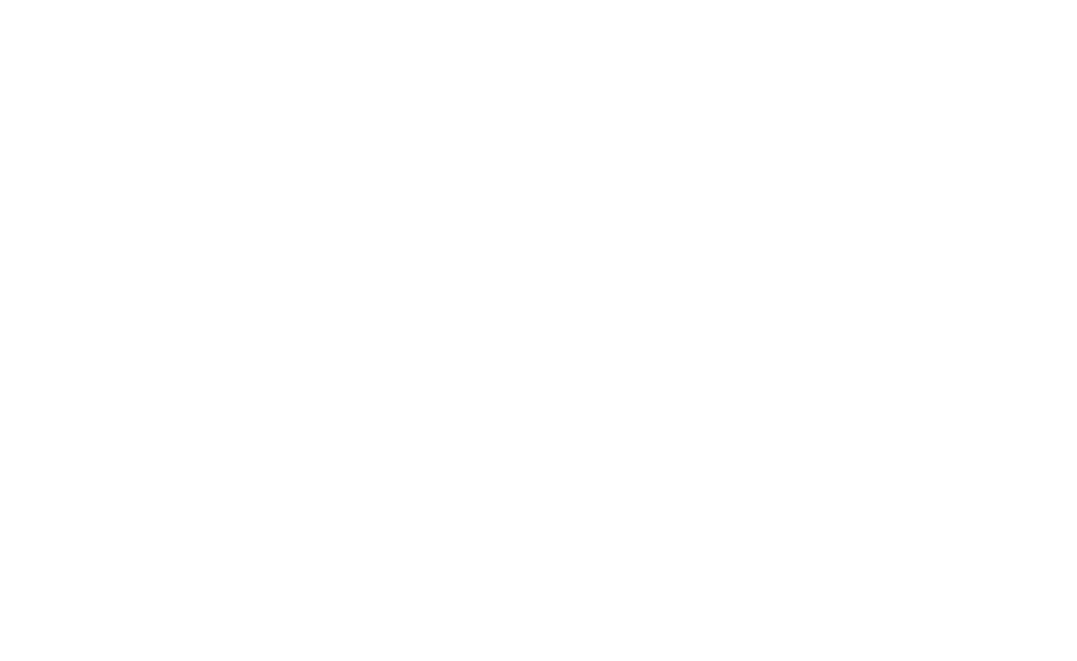

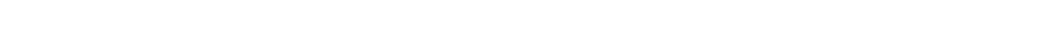




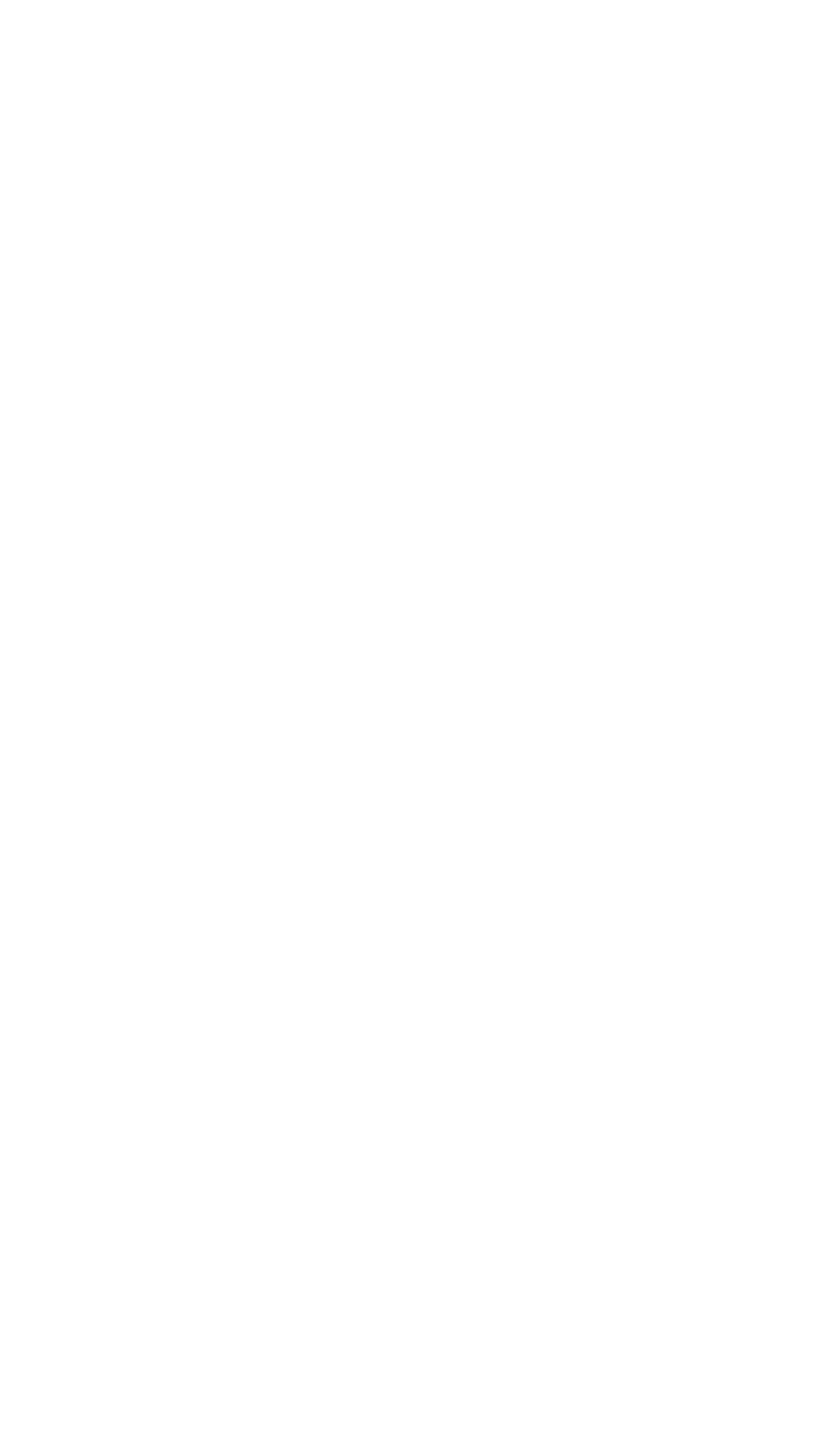




\section{Mineral analyses of ground waters from Hancock County}

[Parts per million. Numbers at heads of columns refer to corresponding well numbers in preceding table]

\begin{tabular}{|c|c|c|c|c|c|c|c|}
\hline & 1 & 2 & 3 & 4 & $\delta$ & 6 & 7 \\
\hline \multirow[t]{2}{*}{ 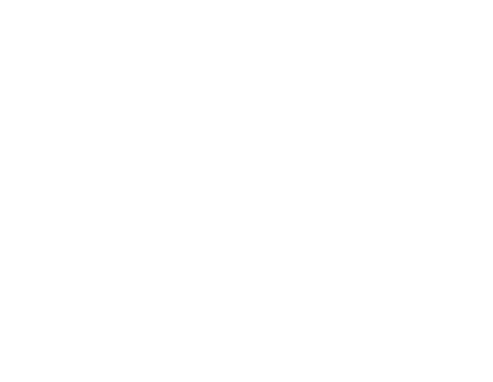 } & $\begin{array}{l}54 \\
2.17 \\
1.0 \\
1.2 \\
162 \\
19 \\
290 \\
8.5 \\
38 \\
\text { Trace. } \\
480 \\
10 \\
\text { Sept. } \\
1919\end{array}$ & $\begin{array}{r}24 \\
1.09 \\
.8 \\
.92 \\
2.0 \\
222.0 \\
8.2 \\
11 \\
\text { Trace. } \\
2247 \\
7 \\
\text { Sept. } \\
1919\end{array}$ & $\begin{array}{c}34 \\
1.3 \\
2.1 \\
132.9 \\
7.2 \\
268 \\
3.1 \\
36.1 \\
348^{-.00} \\
9 \\
1914\end{array}$ & 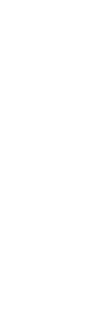 & $\begin{array}{c}30 \\
.07 \\
8.1 \\
90.7 \\
9.6 \\
208 \\
6.5 \\
21.7 \\
2270^{.75} \\
11 \\
\text { Sept.. } \\
1919\end{array}$ & $\begin{array}{c}28 \\
1.2 \\
1.6 \\
13.8 \\
7.2 \\
708 \\
3.4 \\
3.4 \\
34.90 \\
7 \\
790 \\
1914\end{array}$ & 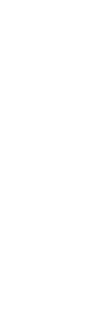 \\
\hline & & 8 & 9 & 14 & 24 & 26 & 27 \\
\hline 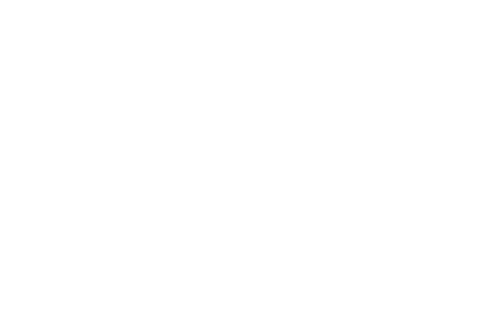 & & $\begin{array}{c}38 \\
.04 \\
3.6 \\
. .9 \\
139^{-9} \\
54 \\
215 \\
5.8 \\
27 \\
\text { Trace. } \\
368 \\
13 \\
\text { 8ept., } \\
1919\end{array}$ & $\begin{array}{c}22 \\
.50 \\
4.4 \\
4.8 \\
114 \\
283.0 \\
2.0 \\
24.0 \\
{ }^{2} .25 \\
331 \\
31 \\
\text { Nov. } \\
1911\end{array}$ & $\begin{array}{c}34 \\
2.04 \\
2.1 \\
592 \\
33 \\
33 \\
159 \\
12 \\
6.5 \\
\text { Trace. } \\
257 \\
7 \\
\text { Aug. } \\
1919\end{array}$ & $\begin{array}{c}32 \\
.03 \\
.9 \\
.9 \\
099 \\
36 \\
168 \\
8.0 \\
9.4 \\
\text { Trace. } \\
263 \\
4 \\
\text { Aug. } \\
1919\end{array}$ & $\begin{array}{c}23 \\
1.12 \\
1.6 \\
1.0 \\
\times 68 \\
6.0 \\
152 \\
10 \\
7.1 \\
100 \\
8 \\
8.38 \\
\text { Sept. } \\
1919\end{array}$ & $\begin{array}{c}44 \\
.08 \\
2.0 \\
72^{-7} \\
14 \\
132 \\
4.8 \\
9.1 \\
226^{.50} \\
8 \\
8 \\
\text { sept., } \\
1919\end{array}$ \\
\hline
\end{tabular}

\section{- Calculated.}

Analysts: 1, 4, 5, 26, 27, H. B. Riffenburg, U. S. Geological Survey; 2, 7, 8, C. S. Howard, U. S. Geological Survey; 3, 6, 9, W. F. Hend, Mississippi State Chemical Leboratory; 14, 24, Margaret D. Foster, U. 8. Geological Survey.

\section{HARRISON COUNTY}

\section{GENERAI FEATURES}

Area, 570 square miles. Population, 32,855 (census of 1920)

Harrison is the middle one of the three counties that border the Gulf of Mexico. With the exception of a narrow strip of the Longleaf Pine Hills district in the north, it lies within the Coastal Pine Meadow region. The mainland is separated from the open Gulf by the broad, shallow waters of Mississippi Sound, but Cat and Ship Islands, which lie along the outer border of the sound, respectively 8 and 10 miles from the mainland, are included in Harrison County. Sands, loams, and clays of Pleistocene age underlie the surface throughout the county, with the exception of small areas in the north, where the underlying Citronelle formation (Pliocene) comes to the surface. These deposits, together with the Pascagoula clay (Miocene), Hattiesburg clay (Miocene), and Catahoula sandstone (Miocene), which successively underlie the Pleistocene, are described on pages 55-61. (See also geologic map, pl. 2.) 


\section{GROUND-WATER CONDITIONS}

The loams, sands, and clays of the Pleistocene, which immediately underlie the surface throughout the greater part of the county, have not been studied in detail. In the north they are probably not more than 20 or 30 feet thick, but toward the south they appear to thicken until immediately along fthe lcoast they are 150 to 200 feet or more in thickness. The sands of the Pleistocene are water bearing and are the source of the water obtained in many dug, bored, and driven wells that range in depth from 10 to 100 feet. Throughout the upland portion of the county shallow wells of this type are still the principal source of domestic water supply, though a few deep wells have been drilled. At many places in the coastal lowland gray to black fetid clay, full of vegetable matter, is struck a few feet below the surface, and water obtained in this clay is undesirable. Small springs which have their source in the Pleistocene deposits are common in the upland, and some occur in the lowlands.

The Citronelle, Pascagoula, Hattiesburg, and Catahoula formations, which underlie the Pleistocene deposits (see pp. 55-58), include many water-bearing beds. Information in regard to the thickness of the formations enumerated, in their buried coastward extension beneath Harrison and the adjoining counties to the east and west, is very meager, and the attempted reference of the water-bearing beds to the different formations in the table of well data (pp. 195-198) must be regarded as tentative and subject to revision when more of the facts are known.

The Citronelle, the first of the formations beneath the Pleistocene, is believed to be several hundred feet thick along the coast. The formation rises toward the north, and the uppermost beds probably come to the surface along the northern edge of the county. In a well at Lyman a 50-foot bed of sand and gravel between the depths of 375 and 425 feet (see log, p. 193) is tentatively regarded as the base of the Citronelle formation. A similar 60-foot bed of sand and gravel between the depths of 460 and 520 feet in a well at Ocean Springs, in Jackson County, is regarded as the base of the Citronelle at that locality. On this assumption many of the flowing wells in the southern part of Harrison County have their source in the Citronelle.

The Pascagoula clay, which underlies the Citronelle formation, is also believed to be 400 or 500 feet thick. The formation includes several extensive water-bearing beds, and more of the recorded artesian wells appear to have their source in this than in any other formation.

Some of the deeper wells (900 feet and more) probably penetrate the upper part of the Hattiesburg clay, which also contains productive water-bearing beds under strong artesian"head. 
The deepest recorded well in the county is the 1,480-foot well of the Howison Lumber Co. at Howison, which probably completely penetrates the Citronelle, Pascagoula, and Hattiesburg formations and enters the Catahoula sandstone, in which the principal waterbearing sand occurs. This well is located on the upland at too high an altitude above sea level (178? feet) to permit it to flow at the surface, the static head being 35 feet below the surface.

Although the static head of the ground waters is not high enough to produce flows on the higher parts of the upland in the central and northern parts of the county, the same water-bearing beds that yield flows from wells located on low ground can be drawn upon anywhere on the upland by means of wells equipped with pumps, and the quantity thus obtainable is just as great.

All the formations penetrated by the deep wells of Harrison County dip toward the south, or perhaps slightly west of south, at a rate estimated to be between 15 and 20 feet to the mile. Up the dip they approach nearer to the surface and eventually come to the surface farther north in Mississippi in belts of outcrop that trend east and west. ${ }^{32}$ (See geologic map, pl. 2.)

\section{LOCAL SUPPLIES}

Biloxi.-Many flowing artesian wells, which range in depth from 400 to 960 feet, are in use at Biloxi and in the surrounding district; a few of these wells are described in the table of well data. A maximum head of 90 feet above the surface or over 100 feet above sea level, and a maximum yield of 1,000 gallons a minute at the ground level, have been reported. The waterworks is owned by the city, and water is obtained from four flowing wells, respectively 928, 960, 930, and 960 feet deep. Records of two of the wells (Nos. 1 and 2) are given in the table of well data. Analyses of water from two of the wells at the waterworks and from several other wells in Biloxi are given in the table of analyses. Logs of two wells near Biloxi are given below:

Log of well half a mile east of the Louisville \& Nashville Railroad station at Biloxi a

[Authority, Mr. Brown]

\begin{tabular}{|c|c|c|}
\hline & Thickness & Depth \\
\hline $\begin{array}{l}\text { Undifferentiated Ploistocene deposits and Citronelle, Pascagoula, and Hattiesburg } \\
\text { formations: } \\
\text { Soil and clay } \\
\text { Sand; water bearing } \\
\text { Whitish clay } \\
\text { Greenish clay } \\
\text { Sand, fine above, becoming coarser, to coarse gravel at base; water bearing }\end{array}$ & $\begin{array}{r}\text { Feet } \\
61 \\
35 \\
390 \\
428\end{array}$ & $\begin{array}{r}\text { Feet } \\
65 \\
100 \\
490 \\
918\end{array}$ \\
\hline
\end{tabular}

- Ionisiana Geol. Survey Bull. 1 (Rept. for 1905), p. 25, 1925.

a Information concerning many of the older wolls in the county is given in a table of well data in $U$. 8 . Geol: Eurvey Water-Supply Paper 159, pp. 44-49, 1906. 
Partial log of well of E. C. Emanuel, near Biloxi

[Altitude of mouth of well above sea level, $15 \pm$ teet. Anthority, F. B. Castenaza, driller]

\begin{tabular}{|c|c|c|}
\hline & Thickness & Depth \\
\hline $\begin{array}{l}\text { Not reported, except day at a depth of } 60 \text { feet } \\
\text { Gravel } \\
\text { Not reported } \\
\text { Sand; water bearing } \\
\text { Not reported } \\
\text { Sand; water bearing } \\
\text { Not reported } \\
\text { Sand; water bearing }\end{array}$ & Feet $\begin{array}{r}80 \\
12 \\
88 \\
26 \\
244 \\
38 \\
32 \\
38\end{array}$ & $\begin{array}{r}\text { Feet } \\
80 \\
92 \\
180 \\
206 \\
450 \\
488 \\
520 \\
558\end{array}$ \\
\hline
\end{tabular}

Gulfport.-Flowing artesian wells at Gulfport are numerous and range in depth from 500 to nearly 1,300 feet. A maximum head of 80 feet above the surface and a maximum yield of 450 gallons a minute are recorded. The municipal water supply is furnished by five flowing wells located in different parts of the city, two of which (Nos. 9, 10) are described in the table. They range in depth from 600 to 1,173 feet and afford a combined yield of about 1,400 gallons a minute. A log of the 1,173-foot city well is given below, and analyses 9 and 10 represent water from this well and an 862-foot city well. Analyses of water from several other wells are also given in the table.

Log of the deepest well owned by the city of Gulfport (No. 9)

[Furnished by H. D. Shaw, city engineer]

\begin{tabular}{|c|c|c|c|c|c|}
\hline & $\begin{array}{l}\text { Thick- } \\
\text { ness }\end{array}$ & Depth & & $\begin{array}{c}\text { Thick- } \\
\text { ness }\end{array}$ & Depth \\
\hline $\begin{array}{l}\text { Undifferentiated Pleistocene de- } \\
\text { posits and the Citronelle, Pasca- } \\
\text { goula, and Hattiesburg forma- } \\
\text { tions: } \\
\text { Yollow sand.... } \\
\text { Blue clay } \\
\text { White sand. } \\
\text { White clay } \\
\text { Gray sand } \\
\text { Blue clay } \\
\text { Gray sand } \\
\text { Wumbo" clay } \\
\text { White sand. } \\
\text { Wray sand } \\
\text { White clay } \\
\text { Fine sand } \\
\text { Blue clay }\end{array}$ & $\begin{array}{r}\text { Feet } \\
59 \\
6 \\
50 \\
27 \\
72 \\
45 \\
100 \\
125 \\
12 \\
104 \\
21 \\
83 \\
25 \\
3\end{array}$ & $\begin{array}{r}\text { Feet } \\
59 \\
65 \\
115 \\
142 \\
210 \\
255 \\
355 \\
480 \\
492 \\
598 \\
617 \\
700 \\
725 \\
728\end{array}$ & 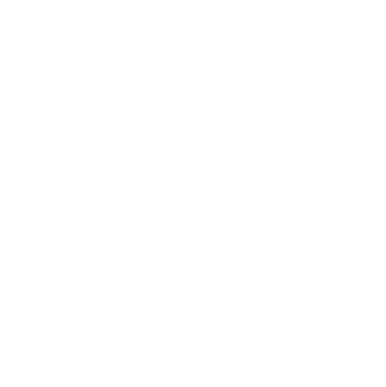 & $\begin{array}{r}\text { Feet } \\
7 \\
5 \\
25 \\
7 \\
7 \\
28 \\
10 \\
35 \\
10 \\
15 \\
74 \\
3 \\
226\end{array}$ & $\begin{array}{r}\text { Feet } \\
735 \\
740 \\
765 \\
772 \\
800 \\
810 \\
845 \\
855 \\
870 \\
944 \\
947 \\
1,173\end{array}$ \\
\hline
\end{tabular}

Pass Christian.-Many artesian wells have been drilled at Pass Christian; they range in depth from 400 to more than 1,000 feet and yield at rates that range from 25 to 400 gallons a minute. A maximum static head of nearly 100 feet above sea level has been recorded. A few typical wells are described in the table of well data (Nos. 28 to 32 ). The town owns 10 scattered wells, but only meager data in regard to them have been obtained. Two of the wells (Nos. 28, 29), 700 and 900 feet deep, are described in the table of well data. (See 
analyses 28,29 .) The other eight wells are probably comparable in depth to these. Distribution is effected by means of the artesian pressure.

Long Beach.-A dozen or more privately owned flowing wells, which range in depth from 500 to 900 feet and yield from 50 to 500 gallons a minute, have been drilled at Long Beach. Two wells are described in the table of well data (Nos. 22, 23).

Handsboro.-Two deep flowing wells at Handsboro are described in the table of well data (Nos. 19, 20). The town is provided with a waterworks, owned by the Handsboro Water Works Co., and the water is obtained from a flowing artesian well, the reported depth of which is 900 feet, and the yield of which is 150 gallons a minute. Timbuctoo Spring, three-fourths of a mile west of the post office at Handsboro, as improved, is 4 feet square and 10 feet deep and flows 3 gallons a minute. The water is used as a domestic supply and is, regarded by the owner as possessing certain therapeutic qualities.

Mississippi City.-The water supply at Mississippi City is provided by the Mississippi City Water Co., which owns a well 915 feet deep (No. 24, p. 195). The well yields 475 gallons a minute when flowing freely, and the water is distributed to the consumers under artesian pressure through 3 miles of mains. (See analysis 24.)

Lyman.-The employees of the Ingram Day Lumber Co. at Lyman are supplied with water for domestic use by a small waterworks owned by the company. The water is obtained from a flowing well about 940 feet deep. The log of a 480 -foot well at Lyman owned by the Gulf Coast Lumber Co., predecessors of the Ingram Day Lumber Co., is given below:

Log of well of Gulf Coast Lumber Co. at Lymana

[Altitude, about 96 feet above sea level. Authority, W. N. Logan and W. R. Perkins]

\begin{tabular}{|c|c|c|}
\hline & Thickness & Depth \\
\hline $\begin{array}{l}\text { Undifferentiated Pleistocene deposits and Citronelle formation (Pliocene): } \\
\text { Yellow clay } \\
\text { Red clay } \\
\text { Blue clay } \\
\text { Sand; water bearing } \\
\text { Blue clay - gravel (Citronelle); water bearing } \\
\text { Sand and } \\
\text { Clay }\end{array}$ & Feet $\begin{array}{r}40 \\
20 \\
240 \\
30 \\
45 \\
50 \\
55\end{array}$ & $\begin{array}{r}\text { Feet } \\
40 \\
60 \\
300 \\
330 \\
375 \\
425 \\
480\end{array}$ \\
\hline
\end{tabular}

- Mississippi Agr. Exper. Sta. Bull. 89, p. 76, 1905.

Wortham.-The following log of the well of the Gulf \& Ship Island Railroad at Wortham shows the character of the beds penetrated. 
Log of well of Gulf \& Ship Island Railroad at Wortham (No. s7)

Altitude above sea level of mouth of well, about 35 feet. Prepared from samples, U. S. Geol. Survey, well No. 188, and driller's record; John A. Sutter, driller]

\begin{tabular}{|c|c|c|}
\hline & Thickness & Depth \\
\hline $\begin{array}{l}\text { Pleistocene deposits and Citronelle formation: } \\
\text { Yellow compact silty sand, with mixture of very fine to medium coarse quartz } \\
\text { grains } \\
\text { Loose white medium-grained sand } \\
\text { Soft yellowish, very fine sand or with a mixture of medium coarse grains } \\
\text { Loose gray fine sand; water bearing; fows } \\
\text { Very fine gray sand or silt with an admixture of medium coarse grains; slightiy } \\
\text { indurated. } \\
\text { Loose gray fine sand; water bearing; fiows } \\
\text { Compact greenish-gray argillaceous, very fine sand or silt } \\
\text { Loose gray medium-grained sand with scattered black grains, fragments of } \\
\text { brown lignite; gray and black pebbles of subangular chert up to one-half } \\
\text { inch in length and several smaller pebbles of quartz } \\
\text { Pascagoula clay: } \\
\text { Compact greenish-gray clay containing fine sand } \\
\text { Loose gray sand with scattered black grains; water bearing; flows. }\end{array}$ & $\begin{array}{r}\text { Feet } \\
20 \\
10 \\
80 \\
10 \\
10 \\
25 \\
90 \\
\\
30 \\
275 \\
90\end{array}$ & $\begin{aligned} & \text { Feet } \\
& 20 \\
& 30 \\
& 110 \\
& 120 \\
& 130 \\
& 155 \\
& 245 \\
& \\
& \\
& 275\end{aligned}$ \\
\hline
\end{tabular}

Howison.-At Howison there is a small water-works plant owned by the Native Lumber Co. Water is obtained from a 1,340-foot nonflowing well, which yields by pumping with air 50 or 55 gallons a minute. The water is used for drinking, boiler supply, and fire protection. The Howison Lumber Co. at Howison owns the deepest well (1,480 feet) reported from the county, a log of which is given below:

Log of well of Howison Lumber Co. at Howison (No. 21)a

[Altitude of mouth of well about 178 feet above sea level. Authority, W. N. Logan and W. R. Perkins]

\begin{tabular}{|c|c|c|}
\hline & Thickness & Depth \\
\hline $\begin{array}{l}\text { Citronelle formation: } \\
\text { Red clay } \\
\text { White sand }\end{array}$ & Feet ${ }_{100}$ & Feet \\
\hline $\begin{array}{l}\text { Paseagoula, Hattiesburg, and Catahoula formations: } \\
\text { Blue clay } \\
\text { Sand; water bearing }\end{array}$ & $\begin{array}{r}1,200 \\
80\end{array}$ & 1,400 \\
\hline
\end{tabular}

- Mississippi Agr. Exper. Sta. Bull. 89, p. 77, 1805.

Ship Island.-Two flowing wells, one owned by the United States Government and the other by A. Murdock, have been reported from Ship Island. These are described in the table of well data (Nos. $33,34)$. The following is the $\log$ of the well at the Government quarantine station:

Log of U. S. Government well at the quarantine station, Ship Island (No. BS)a

[Altitude of mouth of well, about 10 feet above sea level. Authority, P. C. Kallock]

\begin{tabular}{|c|c|c|}
\hline & Thickness & Depth \\
\hline $\begin{array}{l}\text { Undifferentiated Recent and Pleistocene deposits and Citronelle and Pascagoula(?) } \\
\text { formations: } \\
\text { White sand } \\
\text { Soft clay and mud } \\
\text { Hard blue clay } \\
\text { White sand } \\
\text { Blue clay } \\
\text { Bandstone } \\
\text { Blue clay } \\
\text { Sand; water bearing }\end{array}$ & $\begin{array}{c}\text { Feet } \\
45 \\
155 \\
100 \\
5 \\
260 \\
0.5 \\
156 \\
9\end{array}$ & $\begin{array}{l}\text { Feet } \\
45 \\
200 \\
300 \\
305 \\
565 \\
865.5 \\
721 . \\
790 .\end{array}$ \\
\hline
\end{tabular}

- Louisiana Geol. Survey pt. 6 (Rept. for 1902), p. 220, 1902. 


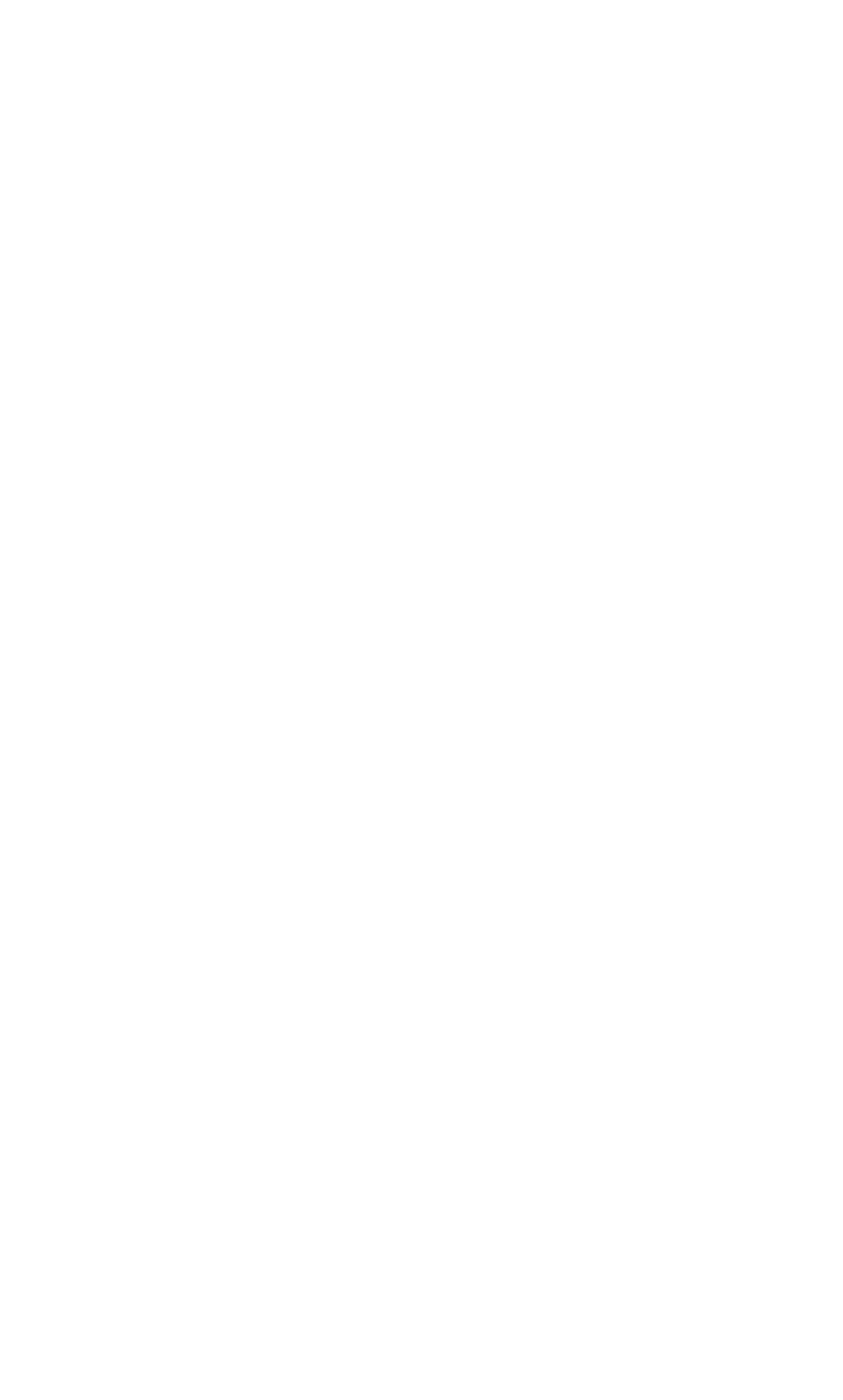




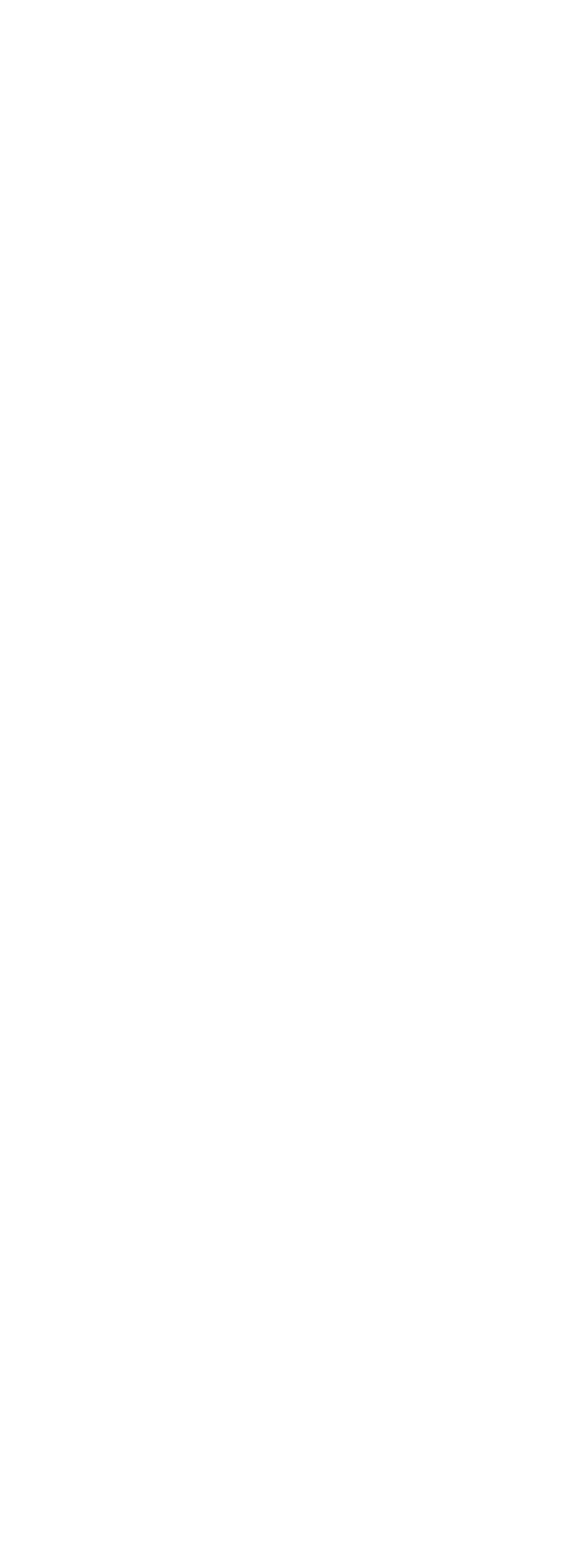




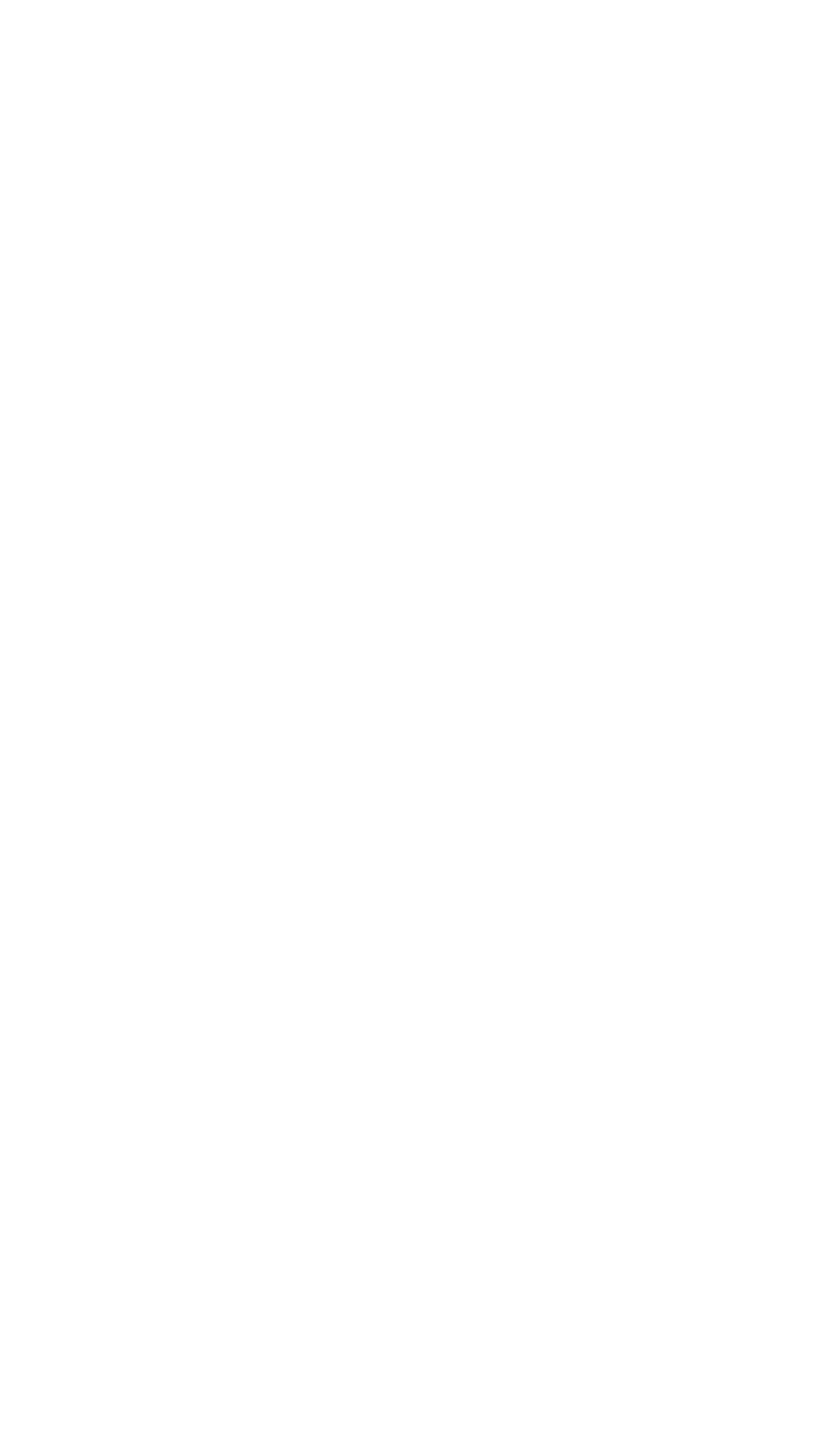




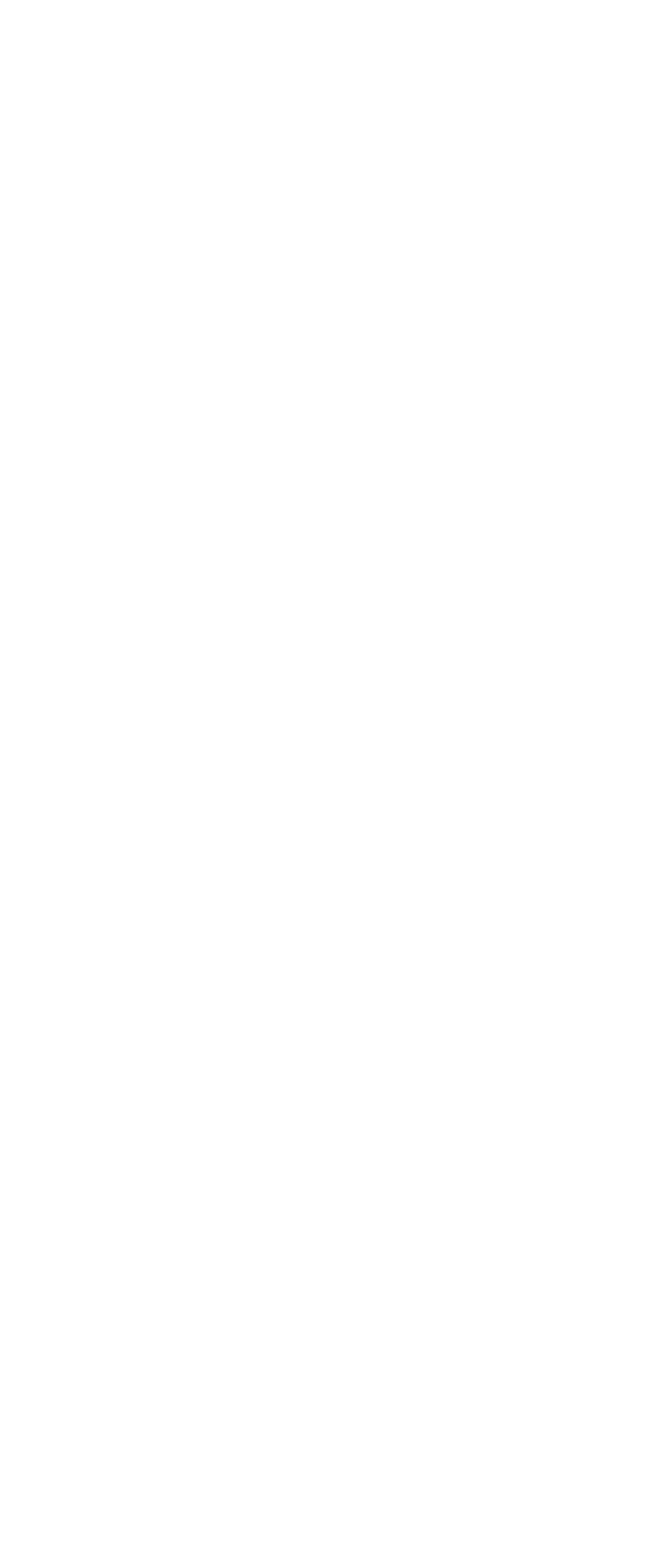




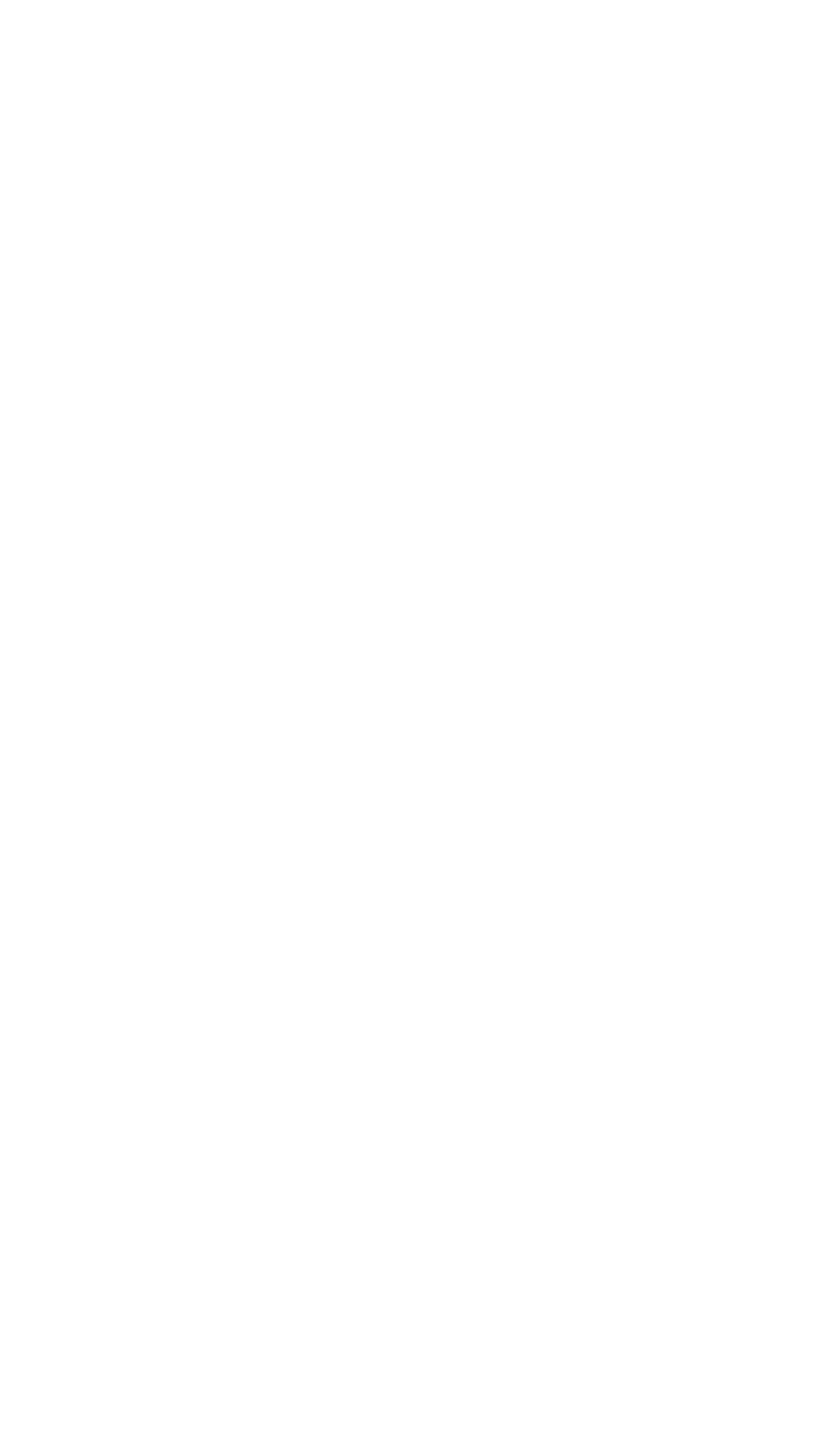




\section{HINDS COUNTY}

\section{GENERAL FEATURES}

Area, 858 square miles. Population, 57,110 (census of 1920)

Hinds County lies mostly within the Long-leaf Pine Hills district. but extends into the Jackson Prairie Belt on the east and into the Bluff Hills district on the west. The principal geologic formations that crop out in the county are the Jackson formation (Eocene), the Vicksburg group (Oligocene), and the Catahoula sandstone (Miocene). The character and physiographic expression of these formations is discussed on pages 53-56, and their distribution is approximately shown on Plate 2. In addition to these formations there are many outliers, or remnants, of weathered sand and gravel, generally less than 30 feet thick, on the hills throughout the southern and central parts of the county, which belong to the Citronelle formation (Pliocene). All these formations are more or less completely covered with a surficial covering of loess and brown loam. In narrow areas along the streams there are also surficial terrace deposits of loam, sand, and gravel.

\section{GROUND-WATER CONDITIONS}

The deepest water well reported in the county, at the Edwards House in Jackson, is 1,446 feet deep and yields a strong flow of salty water and a small showing of gas. ${ }^{33}$ This water is believed to be derived from a sand stratum in the upper part of the Wilcox group, whose nearest outcrop lies about 65 miles to the northeast in Neshoba County. Although this water is more highly mineralized than is generally desired for domestic and industrial uses (see analysis 15), this well does not necessarily condemn the water from the Wilcox in other parts of the county for Jackson has been shown to be located on an anticline in which there may have been a local concentration of briny water. ${ }^{34}$

The occurrence of abundant supplies of potable water in the Lisbon formation of the Claiborne group, which overlies the Wilcox group, is proved by a dozen or more wells 600 to 1,200 feet deep in the vicinity of Jackson. (See wells Nos. 6-14, 17, 19-22, and logs on pp. 202-204.) The main belt of outcrop of the Claiborne group lies outside of Hinds County, the nearest points being on Pearl River about 25 miles to the northeast and on Big Black River about 24 miles to the north. However, according to Wythe Cooke, the top of the Claiborne is brought to the surface by the uplift that produced the Jackson anticline at two localities within 3 miles northeast of Jackson-one along Moodys Branch, in the S. $1 / 2$ sec. 35, T. 6 N., R. 1 E., and the other along

\footnotetext{
as Hopkins, O. B., Structure of the Vicksburg-Jackson area, Miss., with special referenee to oil and gas: ర. S. Geol. Survey Bull. 6t1, p. 116, 1916.

" Idem, pp. 109, 110, pl. 8.
} 
another small branch in the SW. $1 / 4$ sec. 25 of the same township. In the northeastern part of Hinds County the strata of both the Claiborne and Jackson formations lie in a nearly horizontal position, so that the top of the Claiborne is probably nowhere more than 100 feet below the surface. The water-bearing beds of the Claiborne can therefore be reached at depths of 600 to 1,000 feet throughout the northeastern part of the county. As the general dip of the beds, where they are not affected by the Jackson anticline, is to the southwest at an estimated rate of 20 to 30 feet to the mile, the depth to water increases in that direction, so that in the extreme southwest these beds probably lie 2,000 feet or more below the surface.

The Yegua, the uppermost formation of the Claiborne group, is composed in part of beds of sand, some of which may be water bearing, though this has apparently not been demonstrated.

So far as known the Jackson formation, which is composed chiefly of clay and marl and which underlies several townships in the northeastern part of the county, contains no water-bearing beds worthy of note.

The Forest Hill sand, the basal formation of the Vicksburg group whose belt of outcrop extends in a northwesterly direction across the northern part of the county, may be a water-bearing bed, though nothing definite is known of its character in this respect.

In the area of outcrop of the more or less impervious clays and marls of the Jackson formation and Vicksburg group, north of the Alabama \& Vicksburg Railroad, shallow well water is not so easily obtained as in the more sandy country south of the railroad, and cisterns for storing rain water are in common use.

The central and southern parts of the county south of the belt of outcrop of the Vicksburg group are underlain by the Catahoula sandstone. Many of the sand layers are water bearing and are the source of the water obtained in numerous dug, bored, and drilled wells, 15 to 100 feet or more in depth. These wells, together with springs, which also derive water from the Catahoula formation, afford the principal domestic and farm water supplies throughout this section.

The coarse sands and gravels of the Citronelle formation, which occur as remnants or outliers on many of the hills in the central and southern parts of the county, are, where thick enough, the source of the water of shallow wells and of some springs.

\section{LOCAL SUPPLIES}

Jackson.-The waterworks at Jackson is owned by the municipality and is located in the northeastern outskirts of the city, in sec. 36, T. 6 N., R. 1 E., about 2,000 feet west of Pearl River, from which the water supply is obtained. Several years ago three wells (No.6-8) 54134-28- 14 
were drilled by the city for the purpose of procuring the municipal water supply from an underground source. They were $776^{5} \%$, $1,2071 / 3$, and $7463 / 4$ feet deep. Water of satisfactory quality was found in the Lisbon formation of the Claiborne group, but the wells failed to yield the large quantity of water necessary to meet the needs of the city. The log of the deepest well is given below.

Log of deep city well, Jackson (No. 7)

[Furnished by E. N. Lowe, state geologist; Layne \& Bowler Co., drillers]

\begin{tabular}{|c|c|c|c|c|c|}
\hline & $\underset{\text { ness }}{\text { Thick- }}$ & Depth & & $\begin{array}{l}\text { Thick- } \\
\text { ness }\end{array}$ & Depth \\
\hline $\begin{array}{l}\text { Jackson formation: } \\
\text { Clay } \\
\text { Red sandand and sheil } \\
\text { Black sand } \\
\text { Yegua formation: } \\
\text { Gumbo. } \\
\text { Hard packed sand } \\
\text { Undifferentiated Claiborne: } \\
\text { Gumbo } \\
\text { Goapstone } \\
\text { Rock } \\
\text { Gumbo } \\
\text { Hard rock } \\
\text { Chocolate gumbo } \\
\text { Hard packed sand }\end{array}$ & \begin{tabular}{rr}
\multicolumn{2}{c}{ Ft.in. } \\
40 & 2 \\
35 & 1 \\
& 1 \\
57 & 6 \\
133 & 0 \\
76 & 4 \\
56 & 8 \\
3 & 3 \\
16 & 0 \\
4 & 0 \\
72 & 7 \\
38 & 5
\end{tabular} & $\begin{array}{rr}\text { Ft.in. } \\
40 & 2 \\
3 & 3 \\
78 & 4 \\
135 & 10 \\
268 & 10 \\
& \\
345 & 2 \\
401 & 10 \\
405 & 1 \\
421 & 1 \\
425 & 1 \\
497 & 8 \\
536 & 1\end{array}$ & $\begin{array}{l}\text { Undifferentiated Claiborne-Con. } \\
\text { Ohocolate gumbo } \\
\text { Gumbo with sand in pockets.- } \\
\text { Coarse sand; water bearing } \\
\text { (Lisbon)... } \\
\text { Chocolate gumbo } \\
\text { Do } \\
\text { Medium hard rock } \\
\text { Chocolate gumbo } \\
\text { Soft blue gumbo mixed with } \\
\text { some fime sand } \\
\text { Fine soft black sand } \\
\text { Fine sand, pepper and sait color } \\
\text { Hard packed sand, same color. }\end{array}$ & $\begin{array}{rr}\text { Ft.in. } \\
114 & 2 \\
38 & 5 \\
76 & 8 \\
19 & 1 \\
96 & 10 \\
2 & 0 \\
212 & 0 \\
18 & 6 \\
19 & 6 \\
63 & 5 \\
20 & 8\end{array}$ & \begin{tabular}{rr}
\multicolumn{2}{c}{$F t . i n}$. \\
650 & 3 \\
688 & 8 \\
765 & 4 \\
784 & 5 \\
881 & 3 \\
883 & 3 \\
1,095 & 3 \\
1,103 & 9 \\
1,123 & 3 \\
1,186 & 8 \\
1,207 & 4
\end{tabular} \\
\hline
\end{tabular}

The logs of three other water wells at and near Jackson, all of which penetrate the water-bearing beds of the Lisbon formation, are given below. Analysis 17 represents water from the 750-foot well of the Jackson Steam Laundry, which also has its source in the Lisbon, and analysis 15 represents a sample from the 1,446-foot well at the Edwards Hotel which is believed to enter the Wilcox group.

Logs of two oil-prospecting wells drilled near Jackson have been recently published. ${ }^{35}$ One, drilled by the Atlas Oil Co., is 3,079 feet deep and is in the southwest corner of the SE. $1 / 4 \mathrm{SW} .1 / 4$ sec. 18, T. 6 N., R. 1 E.; the other, drilled by the Arkansas Natural Gas Co., known as the Benedick-Treese, Swearengen, or Big Ben well, is 3,043 feet deep and is in the NE. $1 / 4$ SE. 1/4 sec. 14, T. 6 N., R. 1 E. Both are on the Jackson anticline, and both probably completely penetrated the Eocene formations and entered the Selma chalk of the Upper Cretaceous, when drilling was discontinued.

s Lowe, E. N., Oil and gas prospecting in Mississippi: Mississippi Geol. Survey Bull. 15, pp. 38-47, 1919. 
Log of well of Gulf \& Ship Island Railroad Co., Jackson (No. 13)

[Furnished by E. N. Lowe, State geologist; Layne \& Bowler Co., drillers]

\begin{tabular}{|c|c|c|c|c|c|c|c|}
\hline & $\begin{array}{c}\text { Thic } \\
\text { ness }\end{array}$ & & Dept & & & $\begin{array}{c}\text { Thick- } \\
\text { ness }\end{array}$ & Depth \\
\hline 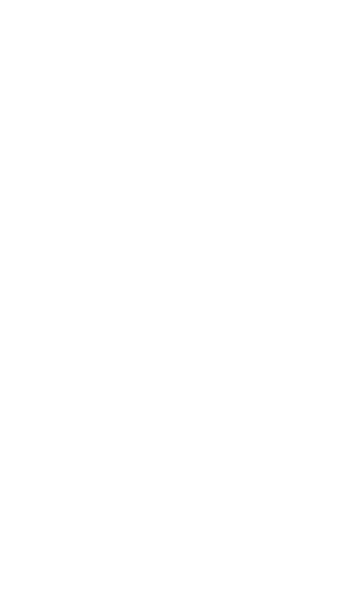 & $\begin{array}{r}F t . \\
27 \\
23 \\
22 \\
20 \\
64 \\
15 \\
4 \\
10 \\
6 \\
5 \\
36 \\
37 \\
17 \\
17 \\
11 \\
3 \\
19 \\
9 \\
18 \\
4 \\
3 \\
6 \\
13\end{array}$ & $\begin{array}{l}\text { in. } \\
0 \\
0 \\
0 \\
0 \\
0 \\
0 \\
0 \\
0 \\
0 \\
0 \\
0 \\
9 \\
0 \\
0 \\
0 \\
4 \\
6 \\
0 \\
0 \\
0 \\
0 \\
0 \\
0 \\
0 \\
8\end{array}$ & $\begin{array}{r}F t . \\
\mathbf{2 7} \\
\mathbf{5 0} \\
\mathbf{7 2} \\
\\
\mathbf{9 2} \\
\mathbf{1 5 6} \\
\mathbf{1 7 1} \\
\mathbf{1 7 5} \\
\mathbf{1 8 5} \\
\\
\mathbf{1 9 1} \\
196 \\
\mathbf{2 3 2} \\
\mathbf{2 6 9} \\
\mathbf{2 8 6} \\
\mathbf{3 0 3} \\
\mathbf{3 1 4} \\
\mathbf{3 1 5} \\
\mathbf{3 1 8} \\
\mathbf{3 3 7} \\
\mathbf{3 4 6} \\
\mathbf{3 6 4} \\
\mathbf{3 6 8} \\
\mathbf{3 7 1} \\
\mathbf{3 7 7} \\
\mathbf{3 9 0} \\
\mathbf{3 9 1}\end{array}$ & $\begin{array}{l}0 \\
0 \\
0 \\
0 \\
0 \\
0 \\
9 \\
9 \\
1 \\
7 \\
7 \\
7 \\
7 \\
7 \\
7 \\
7 \\
7 \\
3\end{array}$ & 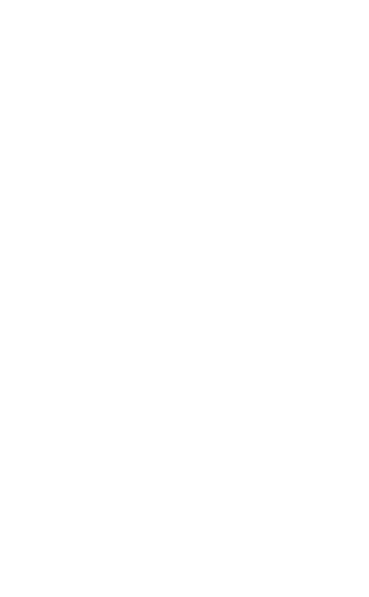 & $\begin{array}{rr}F t . i n \\
2 & 10 \\
1 & 6 \\
11 & 0 \\
3 & 0 \\
5 & 0 \\
2 & 0 \\
8 & 0 \\
96 & 4 \\
4 & 0 \\
14 & 0 \\
3 & 0 \\
3 & 0 \\
10 & 0 \\
27 & 0 \\
2 & 0 \\
6 & 0 \\
8 & 0 \\
3 & 0 \\
11 & 0 \\
2 & 0 \\
57 & 3 \\
2 & 0 \\
7 & 0 \\
& \\
55 & 1 \\
9 & 1\end{array}$ & 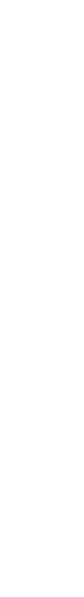 \\
\hline
\end{tabular}

Water level, 72 feet.

Log of well of J. L. Enochs, 3 miles north of Jackson (No. 20)

[Furnished by E. N. Lowe, State geologist; Layne \& Bowler Co., drillers]

\begin{tabular}{|c|c|c|c|c|c|}
\hline & $\begin{array}{c}\text { Thick- } \\
\text { ness }\end{array}$ & Depth & & $\underset{\text { ness }}{\text { Thick- }}$ & Depth \\
\hline $\begin{array}{l}\text { Jackson foundation: } \\
\text { Yellow clay } \\
\text { Blue clay. } \\
\text { Claiborne group: } \\
\text { Shale. } \\
\text { Gumbo } \\
\text { Shale. } \\
\text { Soapstone } \\
\text { Packed sand } \\
\text { Chocolate gumbo } \\
\text { Soapstone } \\
\text { Hard shale } \\
\text { Gumbo. } \\
\text { Hard shale } \\
\text { Soapstone } \\
\text { Gumbo } \\
\text { Rock } \\
\text { Gumbo } \\
\text { Rock } \\
\text { Gumbo. }\end{array}$ & $\begin{array}{rr}F_{t} t & \text { in. } \\
\mathbf{4 0} & 0 \\
50 & 0 \\
91 & 6 \\
9 & 0 \\
30 & 0 \\
9 & 0 \\
104 & 0 \\
10 & 0 \\
8 & 0 \\
39 & 0 \\
4 & 0 \\
31 & 6 \\
25 & 0 \\
32 & 0 \\
1 & 0 \\
8 & 0 \\
\mathbf{2} & 3 \\
9 & 0\end{array}$ & $\begin{array}{rr}\text { Ft. } & \text { in. } \\
40 & 0 \\
00 & 0 \\
& \\
181 & 6 \\
190 & 6 \\
220 & 6 \\
229 & 6 \\
333 & 6 \\
343 & 6 \\
351 & 6 \\
390 & 6 \\
394 & 6 \\
426 & 0 \\
451 & 0 \\
483 & 0 \\
484 & 0 \\
492 & 0 \\
494 & 3 \\
503 & 3\end{array}$ & 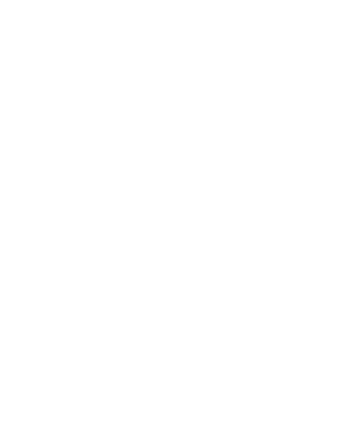 & $\begin{array}{rr}r t . i n \\
6 & 0 \\
20 & 0 \\
4 & 0 \\
44 & 0 \\
4 & 0 \\
2 & 0 \\
2 & 0 \\
10 & 0 \\
4 & 0 \\
16 & 0 \\
6 & 0 \\
10 & 0 \\
12 & 0 \\
16 & 0 \\
165 & 0 \\
5 & 0 \\
12 & 2 \\
2 & 2\end{array}$ & 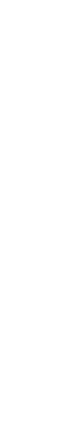 \\
\hline
\end{tabular}


Log of well at Country Club, 4 miles west of Jackson (No. 21)

[Furnished by E. N. Lowe, State geologist; Layne \& Bowler Co., drillers]

\begin{tabular}{|c|c|c|c|c|c|}
\hline & $\begin{array}{c}\text { Thick- } \\
\text { ness }\end{array}$ & Depth & & $\begin{array}{c}\text { Thick- } \\
\text { ness }\end{array}$ & Depth \\
\hline $\begin{array}{l}\text { Clay } \\
\text { Boapstone } \\
\text { Gumbo } \\
\text { Hard clay } \\
\text { Glay } \\
\text { Graveliy clay. } \\
\text { Sandrock. } \\
\text { Muddy sand } \\
\text { Gumbo } \\
\text { Rock } \\
\text { Gumbo } \\
\text { Soapstone } \\
\text { Rock } \\
\text { Boapstone }\end{array}$ & \begin{tabular}{rr}
\multicolumn{1}{r}{ Ft. } & in \\
64 & 0 \\
80 & 0 \\
44 & 0 \\
15 & 0 \\
179 & 0 \\
17 & 0 \\
5 & 0 \\
25 & 0 \\
58 & 0 \\
& 6 \\
18 & 6 \\
32 & 0 \\
1 & 0 \\
37 & 0
\end{tabular} & $\begin{array}{rr}\boldsymbol{F t} \text {. } & \text { in. } \\
\mathbf{6 4} & 0 \\
144 & 0 \\
188 & 0 \\
203 & 0 \\
382 & 0 \\
399 & 0 \\
\mathbf{4 0 4} & 0 \\
429 & 0 \\
\mathbf{4 8 7} & 0 \\
\mathbf{4 8 7} & 6 \\
\mathbf{5 0 6} & 0 \\
\mathbf{5 3 8} & 0 \\
\mathbf{5 3 9} & 0 \\
576 & 0\end{array}$ & $\begin{array}{l}\text { Rock } \\
\text { Soapstone } \\
\text { Rock } \\
\text { Coapstone } \\
\text { Rock } \\
\text { Gumbo } \\
\text { Sand; water bearing (?) (İsbon) } \\
\text { Gumbo. } \\
\text { Shale } \\
\text { Sand } \\
\text { Clay } \\
\text { Sand; water bearing (Lisbon) } \\
\text { Gumbo }\end{array}$ & \begin{tabular}{rr}
\multicolumn{2}{c}{ Ft.in. } \\
2 & 3 \\
8 & 9 \\
3 & 0 \\
6 & 0 \\
46 & 7 \\
& 11 \\
33 & 0 \\
50 & 0 \\
33 & 0 \\
13 & 6 \\
27 & 0 \\
2 & 0 \\
50 & 0 \\
10 & 0
\end{tabular} & \begin{tabular}{cc}
\multicolumn{2}{c}{$F t . t n^{2}$} \\
578 & 3 \\
587 & 0 \\
590 & 0 \\
506 & 0 \\
642 & 7 \\
643 & 6 \\
676 & 6 \\
726 & 6 \\
759 & 6 \\
773 & 0 \\
800 & 0 \\
802 & 0 \\
852 & 0 \\
862 & 0
\end{tabular} \\
\hline
\end{tabular}

Clinton.-The town of Clinton is provided with a small waterworks and obtains its water supply from two so-called springs located in the bottom of a branch about half a mile south of the post office. A well recently drilled at Mississippi College, Clinton (No. 2), is reported to be 1,125 feet deep and when tested yielded 175 gallons a minute.

Bolton.-A well 1,517 feet deep furnishes the municipal water supply at Bolton (No. 1). The principal water-bearing sand, penetrated at a depth of 1,000 to 1,060 feet, is believed to be in the Lisbon formation of the Claiborne group. The static head of the water is 70 feet below the surface. No other water-bearing beds were encountered with the exception of beds containing some water at a depth of 30 or 40 feet. Mr. Mason Birdsong, the superintendent of the waterworks, states that blue clay or gumbo was penetrated from a depth of $\mathbf{4 0}$ feet to the top of the water-bearing sand at a depth of 1,000 feet.

Edwards.-The municipal water supply at Edwards is obtained from a well $1,183 \% 4$ feet deep (No. 5), which penetrates water-bearing beds in the Claiborne group as indicated in the log given below. Analysis 5 represents the water from a 1,210-foot city well. In places on the hills in the vicinity of Edwards water for domestic use can be obtained in sandy materials beneath the loess at depths of 30 to 40 feet. Cisterns for storing rain water are also in use in the community. 
Log of well at waterworks at Edwards a

[Altitude of mouth of well 229 feet aboze sea level. Layne \& Bowler Co., contractors and drillers]

\begin{tabular}{|c|c|c|c|c|c|c|c|c|}
\hline & $\begin{array}{c}\text { Thick- } \\
\text { ness }\end{array}$ & Depth & & & $\begin{array}{r}\text { Thic } \\
\text { nes }\end{array}$ & & Dept & \\
\hline 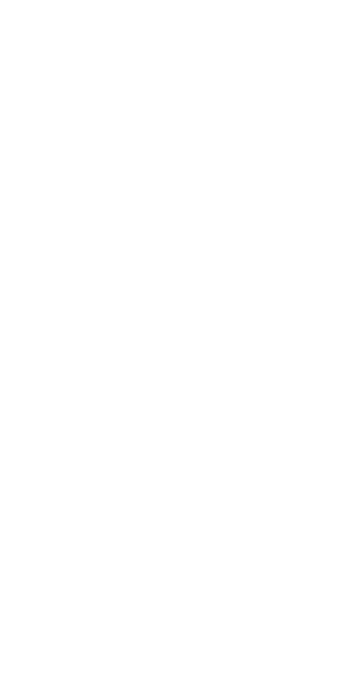 & 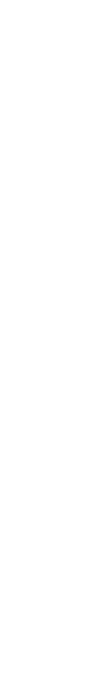 & $\begin{array}{l}F t . \\
58 \\
114 \\
114 \\
119 \\
121 \\
123 \\
126 \\
128 \\
131 \\
132 \\
139 \\
146 \\
147 \\
149 \\
181 \\
\\
220 \\
247 \\
251 \\
292 \\
307 \\
331 \\
351 \\
366 \\
370 \\
379 \\
719\end{array}$ & $\begin{array}{r}i n . \\
11 \\
5 \\
1 \\
1 \\
1 \\
9 \\
1 \\
1 \\
11 \\
1 \\
6 \\
6 \\
0 \\
1\end{array}$ & 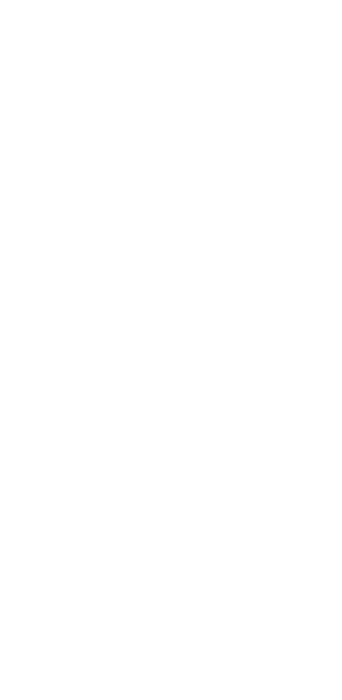 & $\begin{array}{r}4 \\
79 \\
4 \\
2 \\
3 \\
27 \\
33 \\
18 \\
1 \\
10 \\
15 \\
47 \\
23 \\
15 \\
16 \\
16 \\
46 \\
3 \\
\\
13 \\
19 \\
9 \\
9 \\
15 \\
3\end{array}$ & $\begin{array}{r}0 \\
8 \\
0 \\
0 \\
0 \\
10 \\
6 \\
6 \\
0 \\
0 \\
5 \\
10 \\
5 \\
0 \\
6 \\
8 \\
4 \\
8 \\
7 \\
7 \\
9 \\
0 \\
0 \\
0 \\
5\end{array}$ & $\begin{array}{r}749 \\
829 \\
833 \\
835 \\
838 \\
866 \\
899 \\
918 \\
919 \\
929 \\
944 \\
992 \\
1,015 \\
1,030 \\
1,047 \\
1,084 \\
1,110 \\
1,114 \\
1,127 \\
1,147 \\
1,156 \\
1,165 \\
1,180 \\
1,183\end{array}$ & $\begin{array}{r}8 \\
4 \\
4 \\
4 \\
4 \\
2 \\
8 \\
8 \\
2 \\
2 \\
2 \\
7 \\
5 \\
10 \\
10 \\
4 \\
0 \\
4 \\
0 \\
7 \\
7 \\
4 \\
4 \\
4 \\
4 \\
9\end{array}$ \\
\hline
\end{tabular}

- Hopkins, O. B., Structure of the Vicksburg-Jackson area, Miss., with special reference to oil and gas: U. S. Geol. Survey Bull. 641, p. 120, 1916 .

Raymond.-The town of Raymond is provided with a waterworks and obtains its supply from a well the depth of which is not stated.

Utica.-The municipal water supply at Utica is obtained from a well (No. 27) which, according to the driller's $\log$, is $2211 / 2$ feet deep, although $O$. L. Aldrich, the superintendent of the waterworks, questions the accuracy of the log and states that the well is only 207 or 208 feet deep. The water has its source in two beds of sand in the Catahoula formation, one at a depth of approximately 145 to 156 feet and the other at a depth of about 190 to $2081 / 2$ feet. Strainers are set opposite each of these beds. The lower water-bearing sand is so fine that a large amount of it passes through the fine copper strainer and is pumped out with the water. The driller's log is given below. (See analysis 2.7 .) 
Log of well at the waterworks, Utica (No. 27)

[Altitude at mouth of well, 295 feet above sea level. Authority, M. C. Hanna, driller]

\begin{tabular}{|c|c|c|}
\hline & $\begin{array}{c}\text { Approxi- } \\
\text { mate } \\
\text { thick- } \\
\text { ness }\end{array}$ & $\begin{array}{l}\text { Approxi. } \\
\text { mate } \\
\text { depth }\end{array}$ \\
\hline 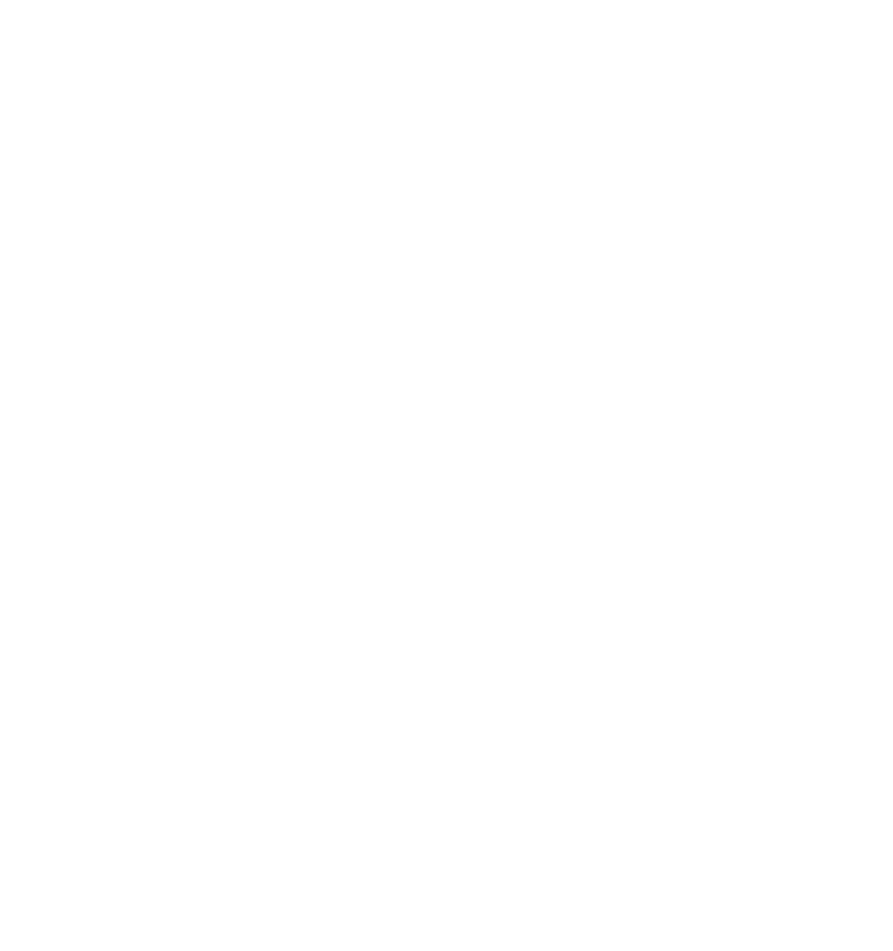 & $\begin{array}{r}\text { Feet } \\
32 \\
2 \\
5 \\
4 \\
4 \\
2 \\
3 \\
5 \\
2 \\
4 \\
2 \\
10 \\
1 \\
6 \\
1 \\
8 \\
6 \\
3 \\
10 \\
1 \\
3 \\
2 \\
5 \\
3 \\
2 \\
3 \\
6 \\
1 \\
1 \\
2 \\
6 \\
4 \\
1 \\
6 \\
8 \\
12 \\
3 \\
6 \\
4 \\
1 \\
181 / 2 \\
413 \\
812\end{array}$ & $\begin{array}{r}F e e t \\
32 \\
34 \\
39 \\
43 \\
47 \\
47 \\
49 \\
52 \\
57 \\
59 \\
63 \\
65 \\
75 \\
76 \\
82 \\
83 \\
91 \\
97 \\
100 \\
110 \\
111 \\
114 \\
116 \\
121 \\
124 \\
126 \\
129 \\
135 \\
136 \\
137 \\
139 \\
145 \\
149 \\
150 \\
156 \\
164 \\
176 \\
179 \\
185 \\
189 \\
190 \\
\\
20814 \\
213 \\
22136\end{array}$ \\
\hline
\end{tabular}

In June, 1919, O. L. Aldrich, the superintendent of the waterworks, submitted to Dr. E. N. Lowe, the State geologist, a sample of fine, clean, sharp quartz sand, which entered the well through the screen set opposite the lowest water-bearing stratum described in the log just given, and Mr. Aldrich commented on the sand in substance as follows:

This sand is composed of only the finest grains that are small enough to passthrough the screen. Sand of this character accompanies the water with every stroke of the pump. The quantity of sand is such that it has been necessary to remove it from the settling tank four times in the past 5 years, and at the present time there is a thickness of $31 / 2$ to 4 feet of sand in the tank. This waterbearing stratum is capable of yielding 80 to 100 gallons of water a minute, with present pumping facilities.

Terry.-A well (No. 26) originally drilled to a depth of 1,400 feet, in which, however, the principal water-bearing stratum is the Forest Hill sand at a depth of only 240 feet, affords the public water supply at Terry. (See analysis 26.) 
Coopers Mineral Well.-Coopers Well Hotel, owned by A. D. Spengler, is a health resort located about 4 miles east of Raymond. The merits of the place as a resort are based on the quality of the water obtained from a dug well, 97 feet deep (No. 3), the mineral character of whose water is shown in analysis 3 . The well was dug about the year 1841, under the direction of Preston Cooper, owner of the land, about 70 feet below the top of the hill on which the present hotel stands. The water supply at the hotel is furnished by a 1,062-foot well (No. 4) in a branch valley a few hundred yards southwest of the hotel at an altitude about 90 feet lower than the top of the hill at the hotel.

Robinson Spring.-A mineral spring near Madison station, known as Robinson Spring, yields water which is reputed to possess certain therapeutic properties.

Oakley. - The log of a well at the State penitentiary farm at Oakley is given below. This well penetrated part of the Catahoula sandstone, the Vicksburg group, the Jackson formation, and entered the water-bearing beds of the Claiborne group (Lisbon formation ?).

Log of well of State penitentiary farm, Oalley (No. 24)

[Furnished by E. N. Lowe, State geologist, Layne \& Bowler Co., drillers]

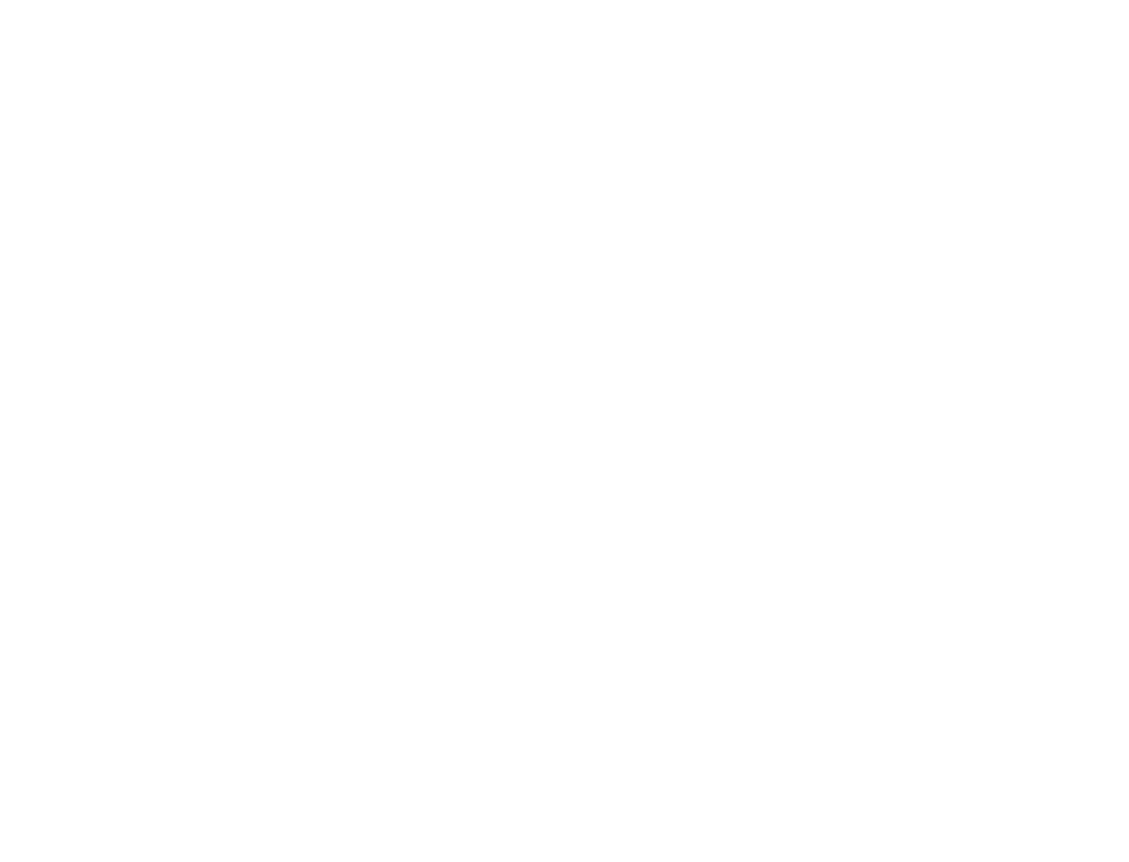




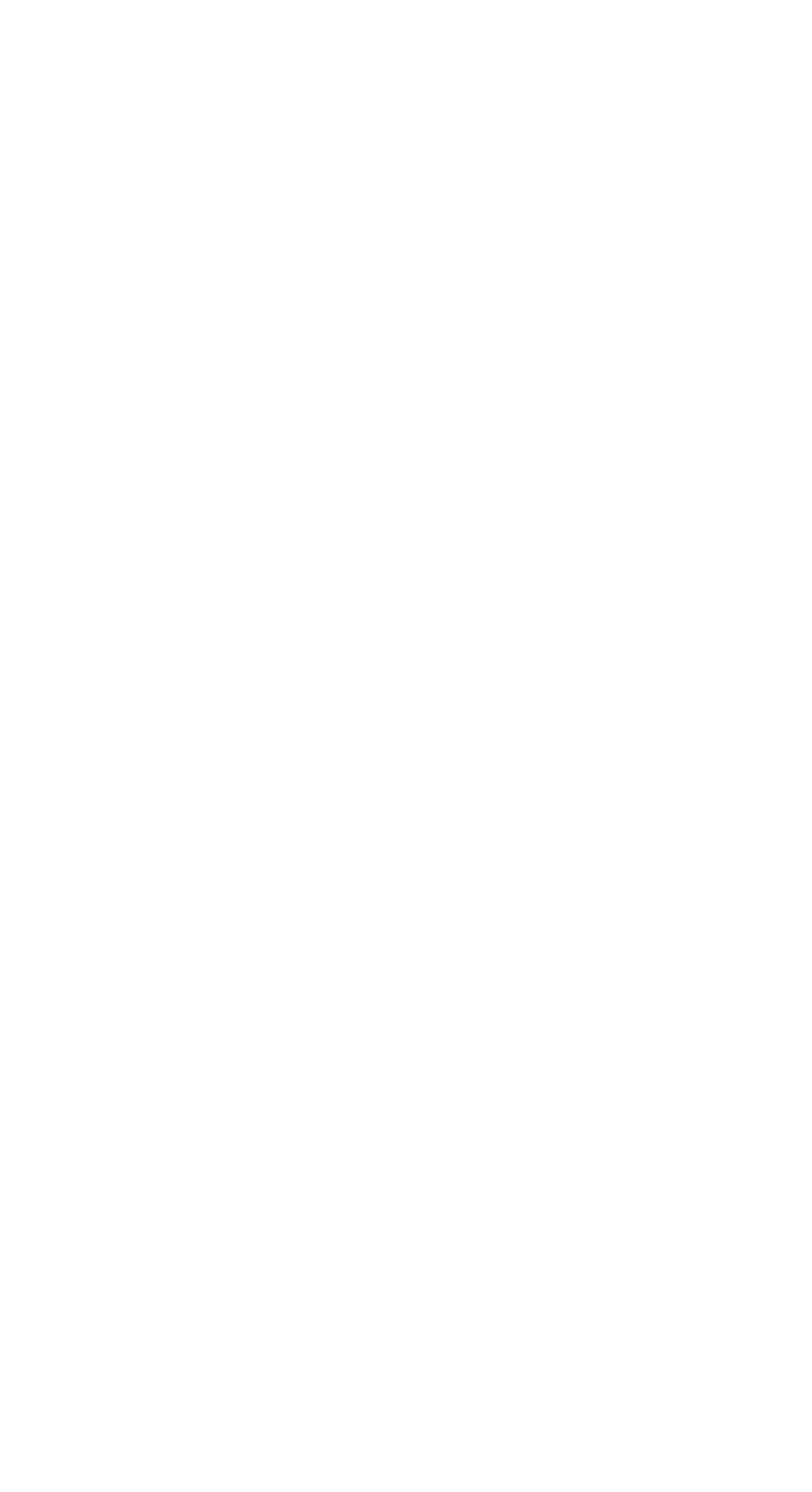




\begin{tabular}{|c|c|c|c|c|c|c|c|c|}
\hline \multicolumn{2}{|c|}{ 悉 } & 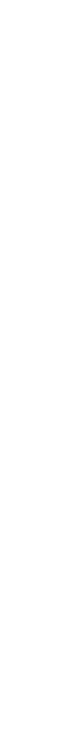 & 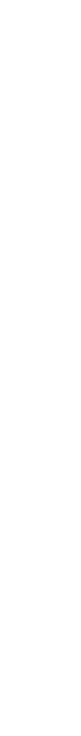 & 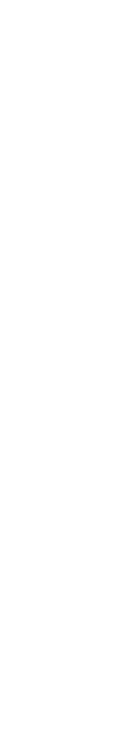 & 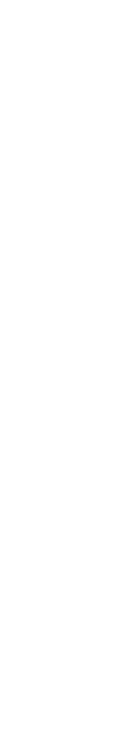 & 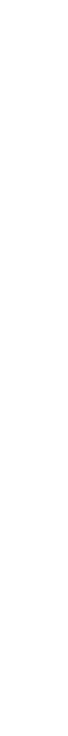 & 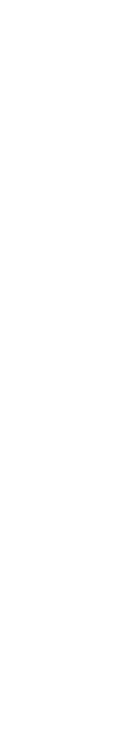 & 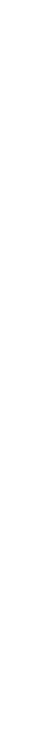 \\
\hline \multirow{2}{*}{\multicolumn{2}{|c|}{ 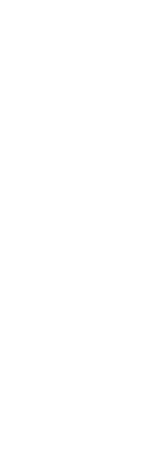 }} & 密 & 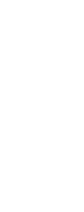 & & & 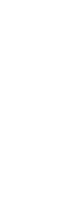 & 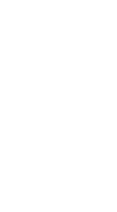 & 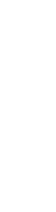 \\
\hline & & 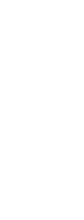 & 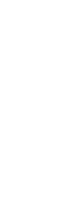 & 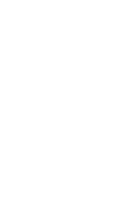 & 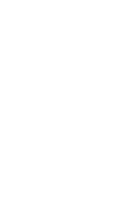 & 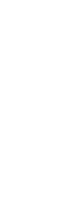 & 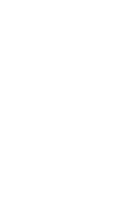 & $\begin{array}{l:l}5 \\
0 \\
0 \\
0\end{array}$ \\
\hline \multicolumn{2}{|l|}{ 兽 } & 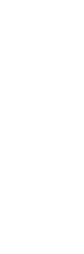 & 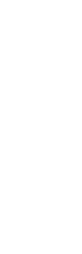 & 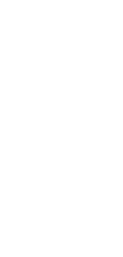 & 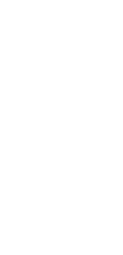 & 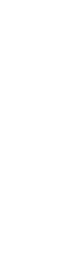 & 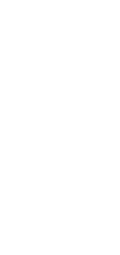 & 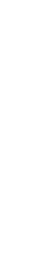 \\
\hline \multicolumn{2}{|c|}{ 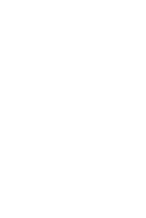 } & 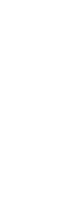 & 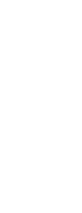 & 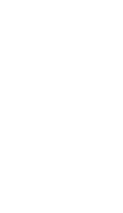 & 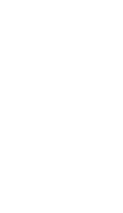 & 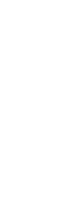 & 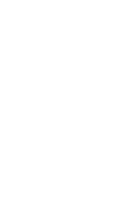 & : \\
\hline \multirow{2}{*}{ 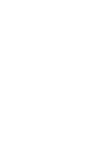 } & 息 & $\$$ & : & :ব্নিম & : & 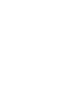 & 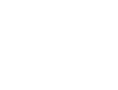 & is \\
\hline & 客 & 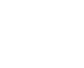 & & 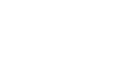 & 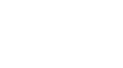 & 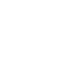 & $1: 111$ & \\
\hline
\end{tabular}




\section{Mineral analyses of ground waters from Hinds County}

[Parts per million. Numbers at heads of columns refer to corresponding well numbers in preceding table]

\begin{tabular}{|c|c|c|c|c|c|}
\hline & 1 & 3 & 50 & 10 & 15 \\
\hline 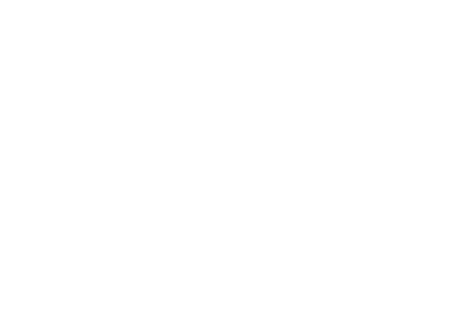 & $\begin{array}{l}28 \\
.15 \\
.8 \\
162 \\
35 \\
265 \\
41 \\
25 \\
426 \\
6 \\
6 \\
\text { July, } 1919\end{array}$ & $\begin{array}{c}74 \\
6.7 \\
447 \\
175 \\
\circ 89 \\
.0 \\
34 \\
1,662 \\
192 \\
\text { Trace. } \\
.2,663 \\
1,840 \\
\text { Nov., } 1920\end{array}$ & $\begin{array}{c}15 \\
1.7 \\
15 \\
7.2 \\
164 \\
22 \\
417 \\
15 \\
20 \\
2.0 \\
476 \\
67 \\
\text { July, } 1911\end{array}$ & 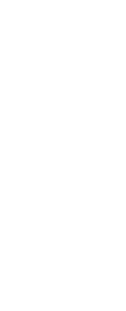 & 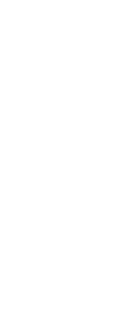 \\
\hline & & . 16 & 17 & 26 & 27 \\
\hline $\begin{array}{l}\left.\text { Silica }(\mathrm{SiO})_{2}\right) \\
\text { Iron }(\mathrm{Fe}) \\
\text { Calcium }(\mathrm{Ca}) \\
\text { Magnesium }(\mathrm{Mg})\end{array}$ & & $\begin{array}{r}14 \\
\quad 30 \\
2.4 \\
3.2 \\
\text { Sa } 571\end{array}$ & $\begin{array}{l}18 \\
3.5 \\
5.0 \\
.9 \\
0.9\end{array}$ & $\begin{array}{r}16 \\
1.2 \\
2.3 \\
.3\end{array}$ & ${ }_{11}^{69} .98$ \\
\hline 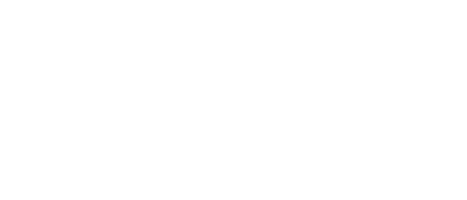 & & 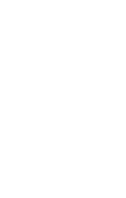 & $\begin{array}{l}95 \\
9.6 \\
224 \\
14.0 \\
7.0 \\
265^{.00} \\
16 \\
\text { Oct., } 1915\end{array}$ & $\begin{array}{c}153 \\
9.6 \\
366 \\
29 \\
9.0 \\
2.0 \\
409 \\
7 \\
\text { Aug., } 1916\end{array}$ & $\begin{array}{l}335^{\circ} \\
93 \\
54 \\
578^{51} \\
46 \\
\text { July, } 1919\end{array}$ \\
\hline
\end{tabular}

- Water from old 1,210-foot well owned by city of Edwards.

Iron and aluminum oxides $\left(\mathrm{Fe}_{2} \mathrm{O}_{3}+\mathrm{Al}_{2} \mathrm{O}_{3}\right)$.

- Calculated.

Analysts: 1, 15, 27, Margaret D. Foster, U. S. Geological Survey; 3, O. S. Howard, U. S. Geological Survey; 5, 16, W. L. Kennon, University of Mississippi; 10, W. R. Perkins (Mississippi Agr. Exper. Sta. Bull. 89, p. 112, 1905); 17, 26, W. F. Hand, Mississippi State Chemical Laboratory.

\section{HOTMES COUNTY}

\section{GENERAL FEATURES}

Area, 751 square miles. Population, 34,513 (census of 1920)

Holmes County is separable into three almost equal physiographic parts-the Yazoo Delta, which embraces approximately the western third; the Loess or Bluff Hills; and the North Central Hills district in the east. The land between Tchula Lake and Yazoo River, part of which is in Holmes County, is locally known as Honey Island. Scattered over the lowland, both east and west of Tchula Lake, are numerous smaller lakes, most of which are abandoned stream channels and many of which still retain the characteristic oxbow or horseshoe form. Conspicuous examples are Horseshoe Lake, Horseshoe Brake, and Bee Lake. The lowland was originally covered with a heavy growth of timber, but much of this land is now cleared and in cultivation. 
The Lisbon formation of the Claiborne group of the Eocene underlies the upland portion of the county, but on account of the nearly universal covering of loess, described below, exposures are small and are limited to the lower slopes of the valleys and of the escarpment that leads down to the Yazoo Delta. The distribution of the Lisbon formation is shown on the geologic map (pl. 2). Only the thicker part of the loess mantle is shown on the map. The Lisbon formation is underlain in descending order by the Tallahatta formation of the Claiborne group, the Holly Springs sand and Ackerman formations of the Wilcox group, and by still older formations, but these lie deeply buried and do not come to the surface within the county.

The loess consists of an accumulation of fine gray silty material which during the Pleistocene epoch was carried by the wind from mud flats in the bottom lands of Mississippi River and dropped on the adjacent upland. The loess covers the upland to a maximum thickness of 50 feet or more along the western border of the upland nearest the original source of the material and decreases to only a few feet in thickness in the eastern part of the county.

In places several feet of gravel and sand that are probably of alluvial terrace origin intervene between the Lisbon formation below and the overlying loess; these materials are probably of Pliocene age. Alluvial deposits also underlie the lowland of Big Black River, along the eastern edge of the county.

The Yazoo Delta is underlain by alluvial deposits that probably have an aggregate thickness of not less than 150 feet. These alluvial deposits rest upon a basement of older deposits which represent the westward buried extension of the formations of the Claiborne group.

\section{GROUND-WATER CONDITIONS}

The Lisbon formation, together with the still older deeply buried Eocene formations that underlie them, all dip south by west at a gentle inclination, estimated to be about 25 feet to the mile. The conditions are therefore favorable for the development of artesian pressure, and many flowing wells have been abtained in different parts of the county.

The oldest water-bearing formation that is utilized in Holmes County is the Holly Springs sand of the Wilcox group, whose topmost beds lie at depths that range from 300 feet in the extreme northeast to 800 feet or more in the south and southwest. The coarse sands which largely compose the formation carry an abundance of water, which is under a strong head and yields large flows in the deeper valleys and in the Yazoo Delta.

The Tallahatta formation overlies the Holly Springs sand but is believed to be very thin in Holmes County and is probably not a notable water bearer. 
The Winona sand member of the Lisbon formation cansists of glauconitic sand, more or less clayey, and carries an abundance of soft water and water of only moderate mineral content.

The Kosciusko sandstone member of the Lisbon formation is thinprobably less than 25 feet in thickness-and overlies the Winona sand member of the Lisbon. The Kosciusko member consists of white to gray stratified sand with clay partings and is apparently of favorable lithologic character to carry water. However, the sand has not been differentiated in well sections from the underlying Winona sand and the overlying typical strata of the Lisbon formation.

The typical strata of the Lisbon formation overlie the Kosciusko member. These bed's come to the surface in the southeastern part of the county and extend to the west under the surficial coverings of loess. The sand beds contain water that is apparently not under sufficient head to produce flows.

The Pliocene sands and gravels, which in places on the upland intervene between the Eocene formations below and the loess above are the source of springs and of the water obtained in many shallow wells. The alluvial sands in the lowland of Big Black River also yield water to shallow wells. The alluvial deposits that make up the Yazoo Delta to a depth of perhaps 150 feet include many beds of sand and gravel that are abundantly water bearing, but the water is not under an appreciable hydrostatic head. This water is easily obtained by means of bored and driven wells equipped with pumps or buckets.

\section{LOCAL SUPPLIES}

Marksvitle.-Several flowing wells have been obtained at Marksville, a village in the Yazoo Delta in the northwest.

Cruger.-At Cruger some flowing wells of large yield (Nos. 7-9) that range in depth from 680 to 826 feet probably tap water-bearing beds in the top of the Holly Springs sand. Analysis 9 represents a sample of hard water from the 826-foot well of C. A. Pitchford.

Acona.-Near Acona water is obtained chiefly from the Kosciusko sandstone member of the Lisbon formation at depths of 120 to 180 feet. Wells Nos. 1-3, at and near Acona, are typical. In the Diggs well (No. 3) water was struck in white sand at a depth of 170 feet, and it rose within 100 feet of the surface. The log of this well follows:

Log of well of K. H. Diggs, $11 / 2$ miles northwest of Acona (No. B)

\begin{tabular}{|c|c|c|}
\hline & Thickness & Depth \\
\hline & Feet ${ }_{40}$ & Feet ${ }_{\mathbf{4 0}}$ \\
\hline $\begin{array}{l}\text { Lisbon formation (Kosciusko sandstone member): } \\
\text { Alternate layers of sand and clay } \\
\text { Sand }\end{array}$ & $\begin{array}{l}30 \\
94\end{array}$ & $\begin{array}{r}764 \\
180\end{array}$ \\
\hline
\end{tabular}


In the McRae well (No. 1) and also in the Steele well (No. 2) water was encountered at a depth of 120 feet, in a sandy layer several feet thick.

Emory.-In the well of W. C. Moss (No. 19), 21/4 miles west of Emory and 4 miles east of Acona, water was struck at a depth of 165 feet and rose within 63 feet of the surface.

Tchula.-The town of Tchula, near the east border of the Yazoo Delta, owns two flowing wells (Nos. 29, 30), which are 1,130 and 987 feet deep. The largest yield is afforded by sand penetrated at a depth somewhat less than 987 feet. The water is distributed to the consumers by direct artesian pressure. In the deepest well hard quartzitic sandstone was encountered at a depth of 985 to 1,010 feet, below which dense sand or soft sandstone was penetrated. Similar conditions were encountered in the 1,100 -foot well of J. M. Howard (No. 31). Analysis 29 represents water from the 1,130foot town well.

Lexington.-At Lexington, in the valley of Black Creek, water is obtained both from shallow dug or driven wells and from deep drilled wells. A town well (No. 23) and a well owned by G. A. Wilson (No. 24) are respectively 900 and 800 feet deep, and both yield flowing water, probably from the upper part of the Holly Springs sand. (See analysis 24.) The town is provided with a municipally owned waterworks which is located about 400 yards southwest of the post office, and the water supply is obtained from the 200 -foot well (No. 23) already mentioned. The Patrick McDade well (No. 25) and a well owned by the Lexington Oil Mill are shallow and probably have their source in the terrace gravels that underlie the loess. On the H. A. Rosenthal place, about 2 miles southeast of Lexington, there is a small spring that furnishes a domestic water supply. It is situated in a small valley tributary to Black.Creek, and the water probably issues from the terrace gravels that underlie the loess.

Bowling Green.-At Bowling Green, in the valley of Black Creek 8 miles northeast of Lexington, water is obtained from shallow wells sunk in the alluvium that borders the stream. Two wells (Nos. 5 and 6) are respectively 18 and 12 feet deep and furnish ample supplies for domestic use.

West.-In the valley of Big Black River, in the northeast corner of the county, water is obtained in part from shallow wells, but better supplies of flowing water have been obtained from deeper wells, some of which probably penetrate to the upperpart of the Holly Springs sand and some only to the Winona sand member of the Lisbon formation. These wells range in depth from 180 to 475 feet. The following $\log$ of the deepest well shows the general character of the formations encountered. 
Log of well at West (No. 36)

\begin{tabular}{l|r|r|r}
\hline & Thickness & Depth \\
\hline Alluvium, Winona sand member of Lisbon formation, Tallahatta formation, and & & Feet & Feet \\
Holly Springs sand: & & 245 \\
Sand and clay . & 5 & 250 \\
Sandstone & 150 & 400 \\
Sand; water bearing
\end{tabular}

Analysis 38 represents water from the 180 -foot well of $\mathrm{L}$. S. Rodgers, and a log of the 315 -foot well is given below.

Log of well of L. S. Rodgers at his creamery at West (No. 38)

[Authority, the owner]

\begin{tabular}{|c|c|c|}
\hline & Thickness & Depth \\
\hline Red clay & Feet ${ }_{18}$ & \\
\hline $\begin{array}{l}\text { Sand and some water } \\
\text { Black lignitic clay } \\
\text { Succossive beds of glaraconitic sheil mal }\end{array}$ & $\begin{array}{r}12 \\
30 \\
60\end{array}$ & $\begin{array}{r}30 \\
60\end{array}$ \\
\hline $\begin{array}{l}\text { Successive beds of glauconitic shell marl. } \\
\text { Not reported }\end{array}$ & 130 & \\
\hline $\begin{array}{l}\text { Hard rock (Tallahatta?) } \\
\text { Not reported }\end{array}$ & (?) & \\
\hline Blue sand; water bearing (Holly Bprings) & & 315 \\
\hline
\end{tabular}

Hoffman.-At Hoffman switch (Illinois Central Railroad), 4 miles south of West, there is a 425-foot flowing well (No. 22). (See analysis 22.)

Thornton.-In the vicinity of Thornton flowing water is obtained by means of wells 650 to 730 feet deep, which penetrate the alluvial deposits of the Yazoo Delta and the underlying Lisbon formation. Wells Nos. 32-34 are typical. Analysis 33 represents water from the well of R. L. Peaster.

Owens.-In the vicinity of Owens, 5 miles east of Lexington, water is obtained in part from shallow wells and in part from deep drilled wells. One well at Owens (No. 26), reported to be 740 feet deep, probably penetrates to the upper part of the Holly Springs sand, from which a strong artesian flow issues. A dug well, known as Owens Mineral Well (No. 27) is reported to be about 50 feet deep and has its source in a sand bed in the Lisbon formation. For an analysis of this highly mineralized water see No. 27.

Durant.-At Durant water is supplied chiefly by deep wells, some of which have their source in the Winona sand member of the Lisbon formation and some in the Holly Springs sand. There are said to be eight deep wells in the town, and detailed information in regard to five of them is given in the table of well data (Nos, 10-14). The municipal water supply is obtained in part from a well 850 feet deep (No. 10), near the Baptist Church, four blocks southwest of the post office, and in part from a well 642 feet deep (No. 11), about three 
blocks south of the post office. (See pl. 7, C.) The following log of this well shows the character of the materials encountered to a depth of 642 feet.

Log of well of Love Wagon Co., Durant (No. 11)

\begin{tabular}{|c|c|c|c|c|c|}
\hline & $\begin{array}{c}\text { Thick- } \\
\text { ness }\end{array}$ & Depth & & Thick- & Depth \\
\hline $\begin{array}{l}\text { Alluvium, Lisbon formation, and } \\
\text { Holly Springs sand: } \\
\text { Clay } \\
\text { Clay and sand sandstone } \\
\text { Soft sandstones. } \\
\text { Clay, with stones } \\
\text { Shale. } \\
\text { Greensand, } \\
\text { Shale. } \\
\text { Sand } \\
\text { Shale and sand } \\
\text { Sandstone } \\
\text { Shale, sand, and clay } \\
\text { Sandstone. }\end{array}$ & \begin{tabular}{r|} 
Feet \\
40 \\
252 \\
6 \\
14 \\
24 \\
16 \\
14 \\
4 \\
13 \\
2 \\
12 \\
3
\end{tabular} & \begin{tabular}{r|} 
Feet \\
40 \\
292 \\
298 \\
312 \\
336 \\
352 \\
366 \\
370 \\
383 \\
385 \\
397 \\
400
\end{tabular} & $\begin{array}{l}\text { Alluvium, Lisbon formation, and } \\
\text { Holly Springs sand-Continued. } \\
\text { Shale.. } \\
\text { Sand and sandstone } \\
\text { Shale and sandstone. } \\
\text { Sandstone and shale } \\
\text { Sand, shale, and boulders. } \\
\text { Sandstone and shale... } \\
\text { Sand and shale } \\
\text { Gravel, shale, and boulders... } \\
\text { Sand } \\
\text { Shale, clay, and boulders } \\
\text { Sand } \\
\text { Shale. }\end{array}$ & $\begin{array}{r}\text { Feet } \\
31 \\
20 \\
11 \\
32 \\
7 \\
6 \\
13 \\
22 \\
20 \\
21 \\
24 \\
35\end{array}$ & $\begin{array}{r}\text { Feet } \\
431 \\
451 \\
462 \\
494 \\
501 \\
507 \\
520 \\
542 \\
562 \\
583 \\
607 \\
642\end{array}$ \\
\hline
\end{tabular}

Analyses of water from wells 11 and 12 are given in the table. Castalian Springs, about 4 miles west of Durant, was formerly a health and pleasure resort. The water of the springs apparently issued from the Lisbon formation.

Ebenezer.-In the vicinity of Ebenezer water is obtained both from shallow wells, which enter the terrace gravel at the base of the loess, and from deeper wells, which penetrate to the water-bearing sands of the Lisbon formation. Water is said to be encountered in the terrace gravel mainly at depths of 60 to 80 feet, though in the 36-foot well of W. H. Faulconer (No. 15) an ample supply of soft water is obtained at a depth of about 30 feet. The three other wells described in the table (Nos. 16-18) are 114, 133, and 135 feet deep, and all yield plentiful supplies of water from the sands of the Lisbon formation. For an analysis of water from the W. B. Burwell well see No. 16 (p. 219).

Goodman.-The municipal waterworks at Goodman is about 150 yards southwest of the Illinois Central Railroad station, on ground about 2 feet lower than the track at the station. The water supply is afforded by one flowing well 785 feet deep (No. 21) which discharges into a 25,000-gallon ground reservoir at the rate of about 100 gallons a minute. (See analysis 21.) In addition to the water provided by the municipal plant, domestic supplies are obtained in part from shallow wells which have their source in the alluvium that borders Big Black River.

Pickens.-The town of Pickens owns a municipal waterworks, which is about 200 yards south of the Illinois Central Railroad station, on ground about level with the track at the station. The water supply is obtained from two wells that are reported somewhat questionably to be about 300 feet deep (No. 28). 


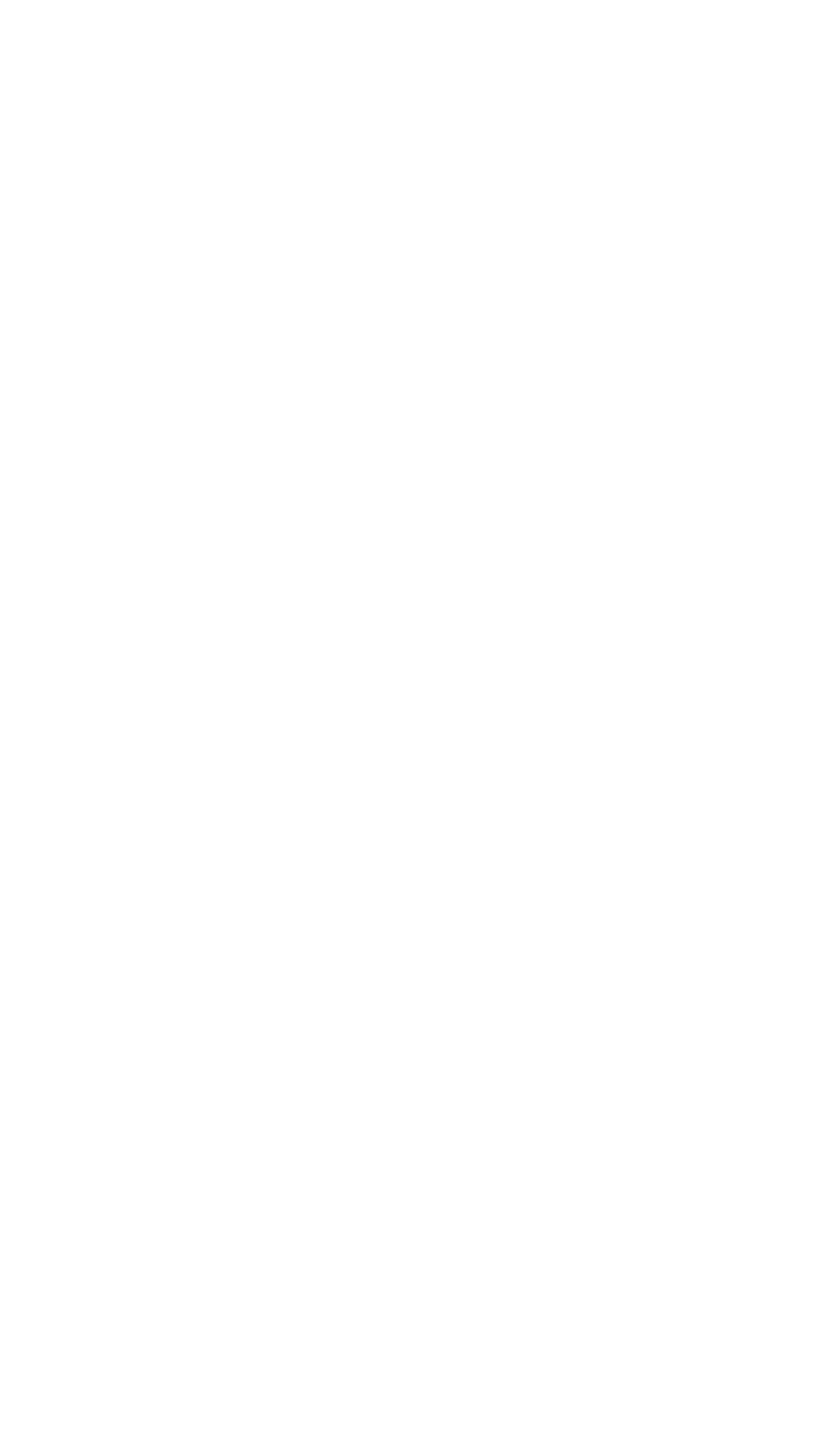




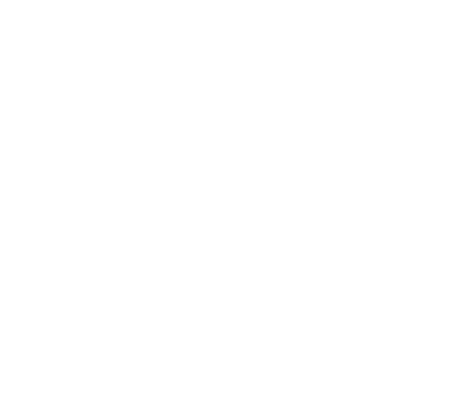

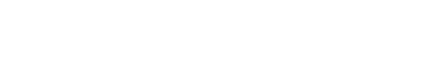

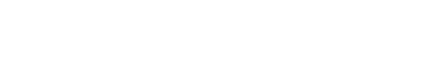

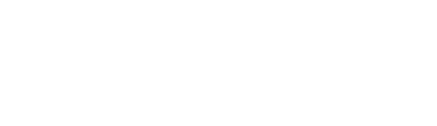

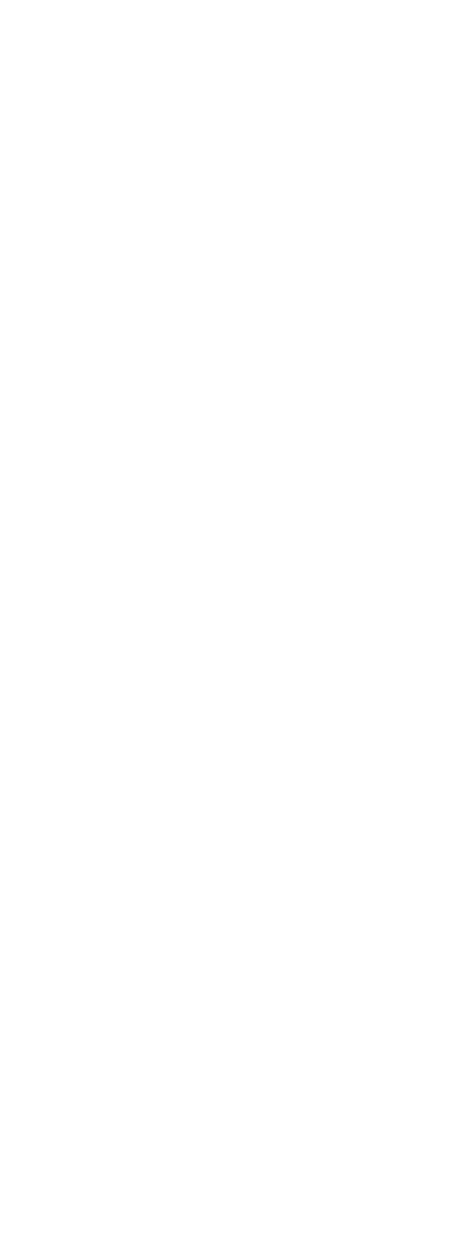
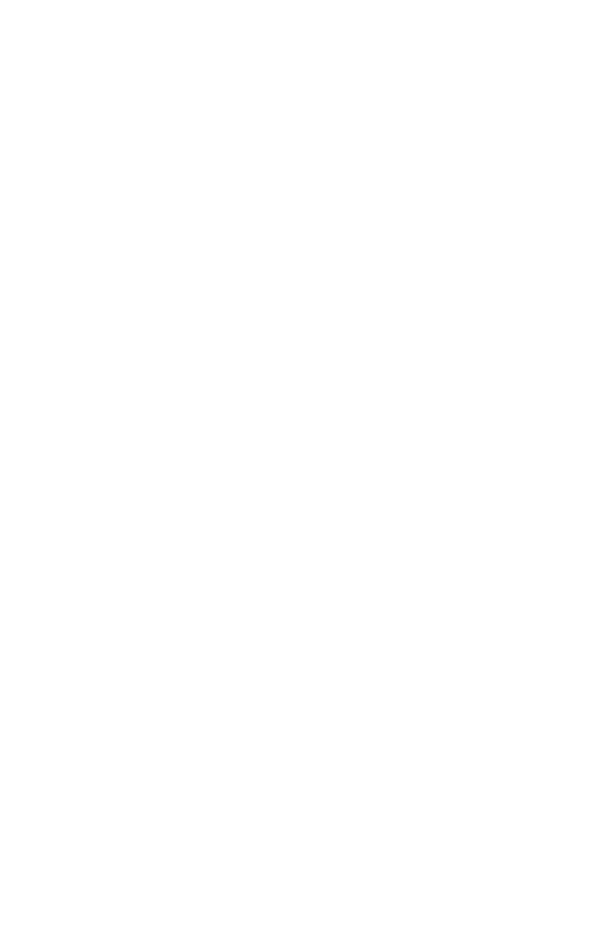

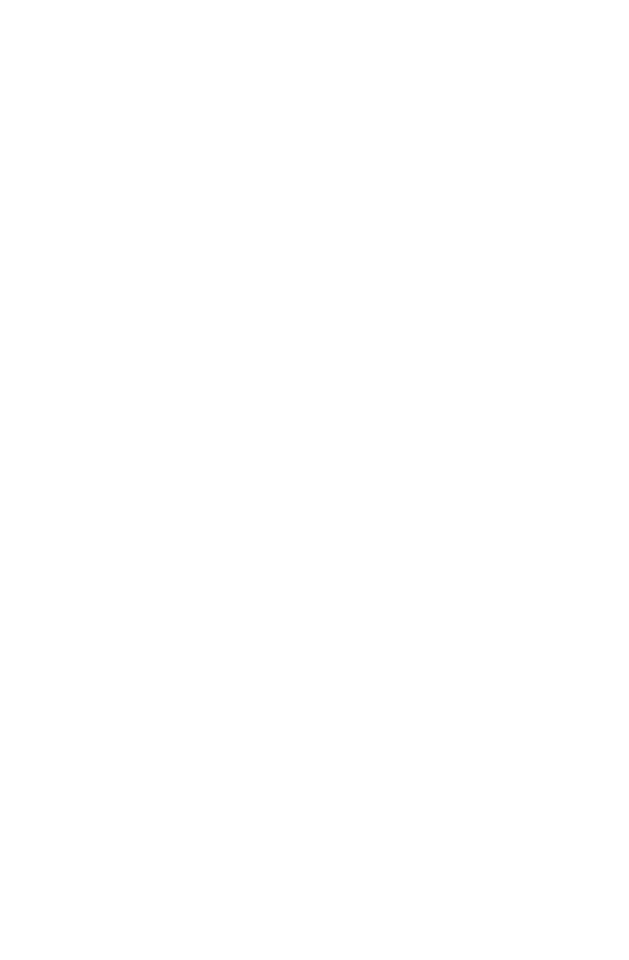




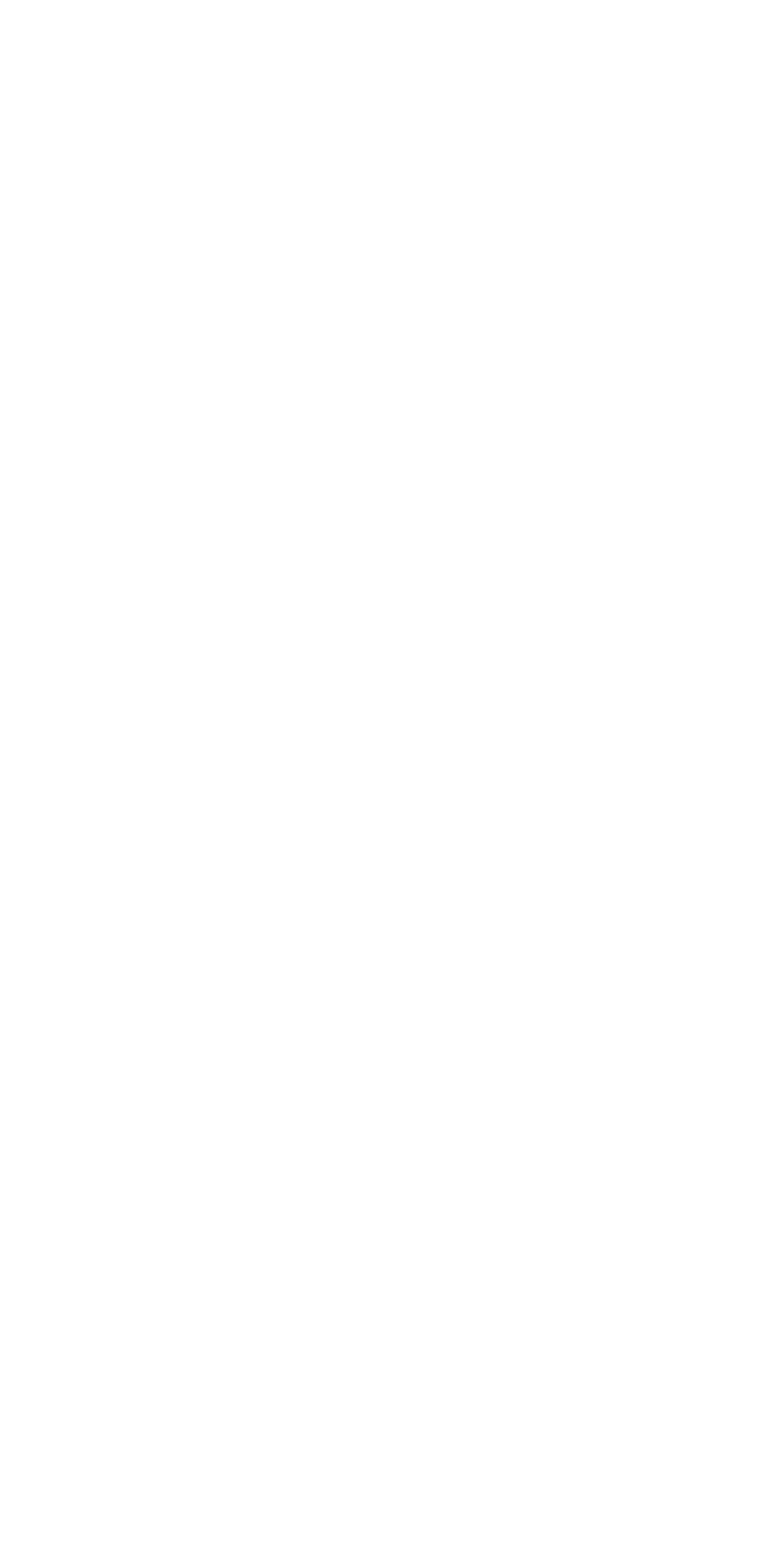




\section{Mineral analyses of ground waters from Holmes County}

[Parts per million. Numbers at heads of columns refer to corresponding well numbers in preceding table]

\begin{tabular}{|c|c|c|c|c|c|c|}
\hline & 9 & 11 & 12 & 16 & 21 。 & 22 \\
\hline \multirow{3}{*}{ 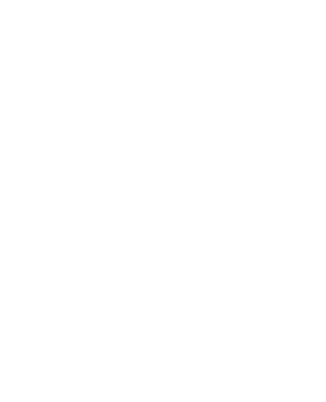 } & $\begin{array}{l}26 \\
6.40 \\
64 \\
1.8 \\
.89 \\
29 \\
353 \\
16 \\
4.5 \\
.10\end{array}$ & 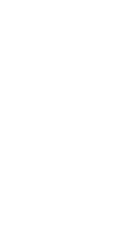 & \begin{tabular}{cc} 
& 26 \\
& 6.60 \\
& 4.9 \\
& 7.9 \\
$\mathrm{Na}$ & 74 \\
$\mathrm{~K}$ & 12 \\
& \multicolumn{1}{c}{.0} \\
& 21.5 \\
& 26 \\
& 12
\end{tabular} & $\begin{array}{l}32 \\
2.2 \\
9.2 \\
2.7 \\
16 \\
.0 \\
63.0 \\
1.6 \\
9.0 \\
.00\end{array}$ & $\begin{array}{r}50 \\
3.09 \\
1.6 \\
132 \\
12 \\
322 \\
14 \\
3.5 \\
\text { Trace. }\end{array}$ & $\begin{array}{l}40 \\
21^{4.1} \\
7.1 \\
41 \\
166^{.0} \\
19 \\
3.0 \\
2.4\end{array}$ \\
\hline & $\begin{array}{c}406 \\
167 \\
\text { Nov., } 1911\end{array}$ & $\begin{array}{c}165 \\
44 \\
\text { June, } 1911\end{array}$ & $\cdot 270^{.25}$ & $\begin{array}{c}109 \\
34 \\
\text { Apr., } 1913\end{array}$ & $\begin{array}{c}372 \\
16 \\
\text { Aug., } 1919\end{array}$ & $\begin{array}{c}216 \\
82 \\
\text { June, } 1912\end{array}$ \\
\hline & 24 & 27 & 29 & 32 & 38 & 37 \\
\hline 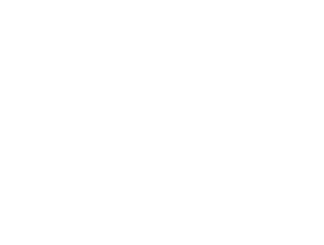 & 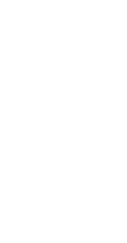 & $\begin{array}{l}77 \\
1.2 \\
103 \\
42 \\
106 \\
37^{.0} \\
502 \\
47 \\
1.2\end{array}$ & 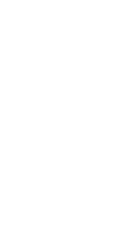 & $\begin{array}{c}60 \\
1.1 \\
8.8 \\
.5 \\
46 \\
.0 \\
120.0 \\
7.6 \\
3.0 \\
.00\end{array}$ & $\begin{array}{l}56 \\
4.3 \\
6.6 \\
2.2 \\
46 \\
.194 .0 \\
11.5 \\
5.00\end{array}$ & $\begin{array}{l}20 \\
20 \\
14 \\
13 \\
114 \\
32 \\
4.5 \\
4.0\end{array}$ \\
\hline $\begin{array}{l}\text { Phosphate radicle ( } \mathrm{PO}_{4} \text { ) } \\
\text { Total dissolved solids at } 180^{\circ} \mathrm{C} \text {. } \\
\text { Total hardness as } \mathrm{CaCO}_{3} \text { (cal- } \\
\text { culated) } \\
\text { Date of collection }\end{array}$ & $\begin{array}{r}510 \\
6\end{array}$ & $\begin{array}{c}923 \\
430 \\
\text { Oct., } 1912\end{array}$ & $\frac{.68}{6}$ & $\begin{array}{r}185 \\
24 \\
1914\end{array}$ & $\begin{array}{c}191 \\
26 \\
\text { Aug., } 1914\end{array}$ & $\begin{array}{c}160 \\
107 \\
\text { Nov., } 1911\end{array}$ \\
\hline
\end{tabular}

- Includes ỉron and aluminum ( $\mathrm{Fe}+\mathrm{Al})$.

- Iron and aluminum oxides $\left(\mathrm{Fe}_{2} \mathrm{O}_{3}+\mathrm{Al}_{2} \mathrm{O}_{3}\right)$.

- Calculated.

Analysts: 9, 37, W. L. Perdue, University of Mississippi; 11; W. L. Kennon, University of Missiasippi; 12. 24, 29, W. R. Perkins (Mississippi Agr., Exper. Bta. Bull. 89, p. 102, 1905); 16, 22, 27, 33, Miesissippi State Chemical Laboratory; 21, M. D. Foster, U. S. Geological Survey; 22, E. B. Wallace, University of Mississippi.

\section{HUMPHREYS COUNTY}

\section{GENERAL FEATURES}

Area, about 400 square miles. Population, 19,192 (census of 1920) "

Humphreys is a recently organized county, in the southeastern part of the Yazoo Delta, formed from parts of the adjoining counties of Washington, Sunflower, Holmes, Yazoo, and Sharkey.

\section{GROUND-WATER CONDITIONS}

The alluvial deposits, which underlie the county to a depth of 150 or $\mathbf{2 0 0}$ feet, include beds of sand and gravel that contain great quantities of water, which is under little or no artesian head but which is readily obtainable by means of bored or driven wells equipped with ropes and buckets or with pumps, and at most places the water table is so near the surface that suction pumps can be used.

Water under artesian head is contained in many of the layers of sand that in part compose the series of Eocene beds beneath the 
alluvial deposits, and flowing wells 300 to nearly 1,400 feet deep, which derive their supplies from these sands, have been drilled at or near Isola, Belzoni, Midnight, Louise, Silver City, and Craig.

Detailed information in regard to the dip, strike, and thickness of the several formations that compose the series of buried Eocene beds is lacking, but a rough attempt has been made to determine the formations or groups to which the principal water-bearing beds penetrated in the wells belong; the basis for these determinations is an assumed uniformity of the dip and thickness of formations from their area of outcrop, westward beneath the alluvium.

\section{LOCAL SUPPLIES}

Belzoni.-The town of Belzoni is provided with a municipal waterworks which is located about 300 yards south of the Yazoo \& Mississippi Valley Railroad station, east of the track. Water is obtained from two flowing wells (Nos. 1, 2) at the plant, one reported to be 630 feet and the other 7711/4 feet deep. The following log shows the character of the beds penetrated by the waterworks well that was drilled in 1914:

Log of well at the waterworks at Belzoni (No. Z)

[Furnished by J. J. Sisloff, superintendent of waterworks; Layne \& Bowler Co, drillers]

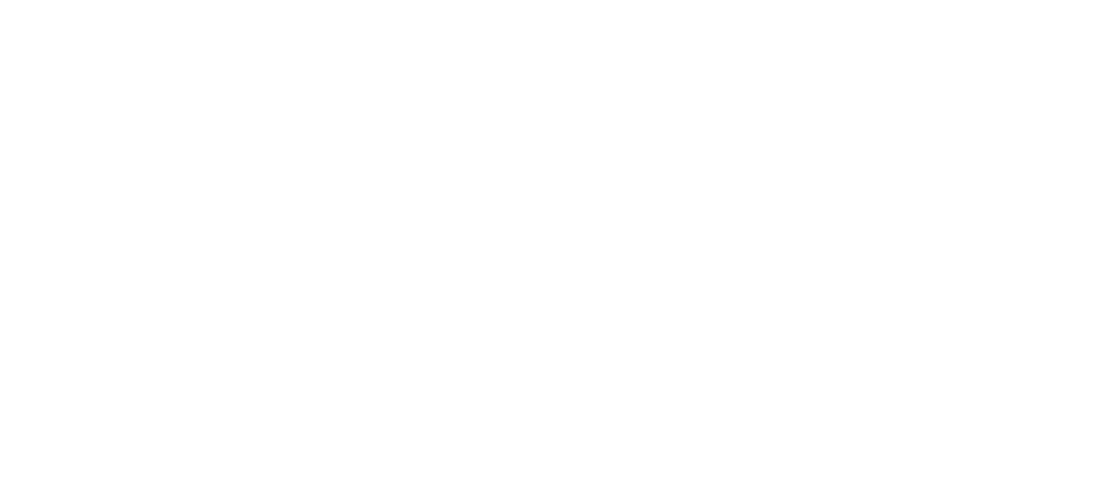

The principal water-bearing bed in this well is the coarse sand that was penetrated between depths of 670 and 764 feet. About 80 feet of 6-inch strainer was set opposite this sand, which probably belongs to the Lisbon formation. Several other artesian wells at Belzoni are described in the table of well data. Analysis 1 represents a rather hard water from the 630-foot waterworks well.

Sitor City.-Mast of the inhabitants of Silver City are supplied with water for domestio use from an 820-foot artesian wall (No. 14), which is about 900 feet west of the past office. The source of this water is believed to be a sand in the Lisbon formation of the Claiborne group. Several other artesian wells at and near Silver City, which 
range in depth from 734 to 908 feet, are described in the table of well data (Nos. 15-18). These wells were all drilled by W. F. Linsenmeyer, of Silver City, from whom the information recorded in the table was obtained. The $\log$ of a 908-foot well, which was completed in July, 1919, is given below.

Log of well of S. H. Lusk, one-fourth mile southeast of Yazoo \& Mississippi Valley Railroad station, Silver City

[Authority, W. F. Linsenmeyer, driller; given from memory]

\begin{tabular}{|c|c|c|}
\hline & Thickness & Depth \\
\hline $\begin{array}{l}\text { Alluvium: } \\
\text { Clay } \\
\text { Blue sanding } \\
\text { Blue clay } \\
\text { Sand and gravel; water bearing }\end{array}$ & $\begin{array}{r}\text { Feet } \\
18 \\
20 \\
40 \\
57\end{array}$ & $\begin{array}{r}\text { Feet } \\
18 \\
38 \\
78 \\
135\end{array}$ \\
\hline $\begin{array}{l}\text { Eocene: } \\
\text { Clay } \\
\text { Sand } \\
\text { Alternating layers of clay, shale, and sand } \\
\text { White clay } \\
\text { Rock and shale in alternating layers } \\
\text { Sand (Lisbon); water bearing }\end{array}$ & $\begin{array}{r}20 \\
60 \\
385 \\
60 \\
20 \\
208\end{array}$ & $\begin{array}{l}155 \\
215 \\
600 \\
660 \\
680 \\
908\end{array}$ \\
\hline
\end{tabular}

Isola.-A public flowing well at Isola (No. 7) is 807 feet deep, and another flowing well (No. 8) is 1,356 feet deep. Analysis 7 represents water from the 807-foot well.

Lotus.-At Lotus, near the southeast corner of the county, domestic water supplies are obtained from wells that enter the alluvium to depths of 18 to 80 feet.

Midnight.-Most of the people at Midnight obtain their domestic water supplies from a 500-foot well (No. 10). Several other deep flowing wells have been drilled at and near Midnight. One of these wells (No. 11) is 645 feet deep and flows 300 gallons a minute. Another well (No. 12) is 550 feet deep and flows 260 gallons a minute. A $\log$ of this well is given below:

Log of well of C. B. Box at Midnight

[Authority, W. F. Linsenmeyer, driller]

\begin{tabular}{|c|c|c|}
\hline & Thickness & Depth \\
\hline $\begin{array}{l}\text { Alluvium: } \\
\text { Clay } \\
\text { Sand and gravel; water bearing }\end{array}$ & Feet 20 & Feet 20 \\
\hline $\begin{array}{l}\text { Eocene: } \\
\text { Sand. } \\
\text { Clay } \\
\text { Iimerock } \\
\text { Sand } \\
\text { Brown clay } \\
\text { Sand; water bearing; overflows } \\
\text { Shale rock } \\
\text { Limerock } \\
\text { Hard brown rock } \\
\text { White sand (Lisbon); water bearing; strong flow }\end{array}$ & $\begin{array}{r}200 \\
60 \\
5 \\
\mathbf{5 5} \\
10 \\
\mathbf{4 0} \\
\mathbf{5} \\
\mathbf{3} \\
\mathbf{2} \\
\mathbf{7 0}\end{array}$ & $\begin{array}{r}\mathbf{3 2 0} \\
\mathbf{3 8 0} \\
\mathbf{3 8 5} \\
\mathbf{4 2 0} \\
\mathbf{4 3 0} \\
\mathbf{4 7 0} \\
\mathbf{4 7 5} \\
\mathbf{4 7 8} \\
\mathbf{4 8 0} \\
\mathbf{5 5 0}\end{array}$ \\
\hline
\end{tabular}


A shallow dug well (No. 13) at this place exhibits the succession of strata described in the following log:

Log of dug well at Midnight

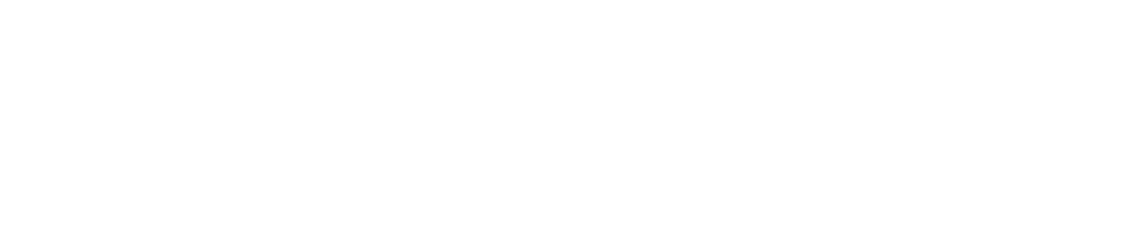

Louise.-The 920-foot well near Louise (No. 9) yields an artesian flow from a bed penetrated at a depth of 840 feet that appears to belong to the Lisbon formation. Other water-bearing beds were penetrated at depths of 350 feet (nonflowing) and at 700 feet (flowing). About 500 people obtain their domestic water supplies from this well; the water is distributed through a system of small pipes by means of the artesian pressure.

Craig.-The 1,1031/2-foot well (No. 6), on the Anchor Plantation near Craig, penetrated a thick consolidated sand or soft sandstone between depths of 1,073 and 1,103 feet, from which comes a strong flow of water. This bed is in the Lisbon formation. (See analysis 6.) 


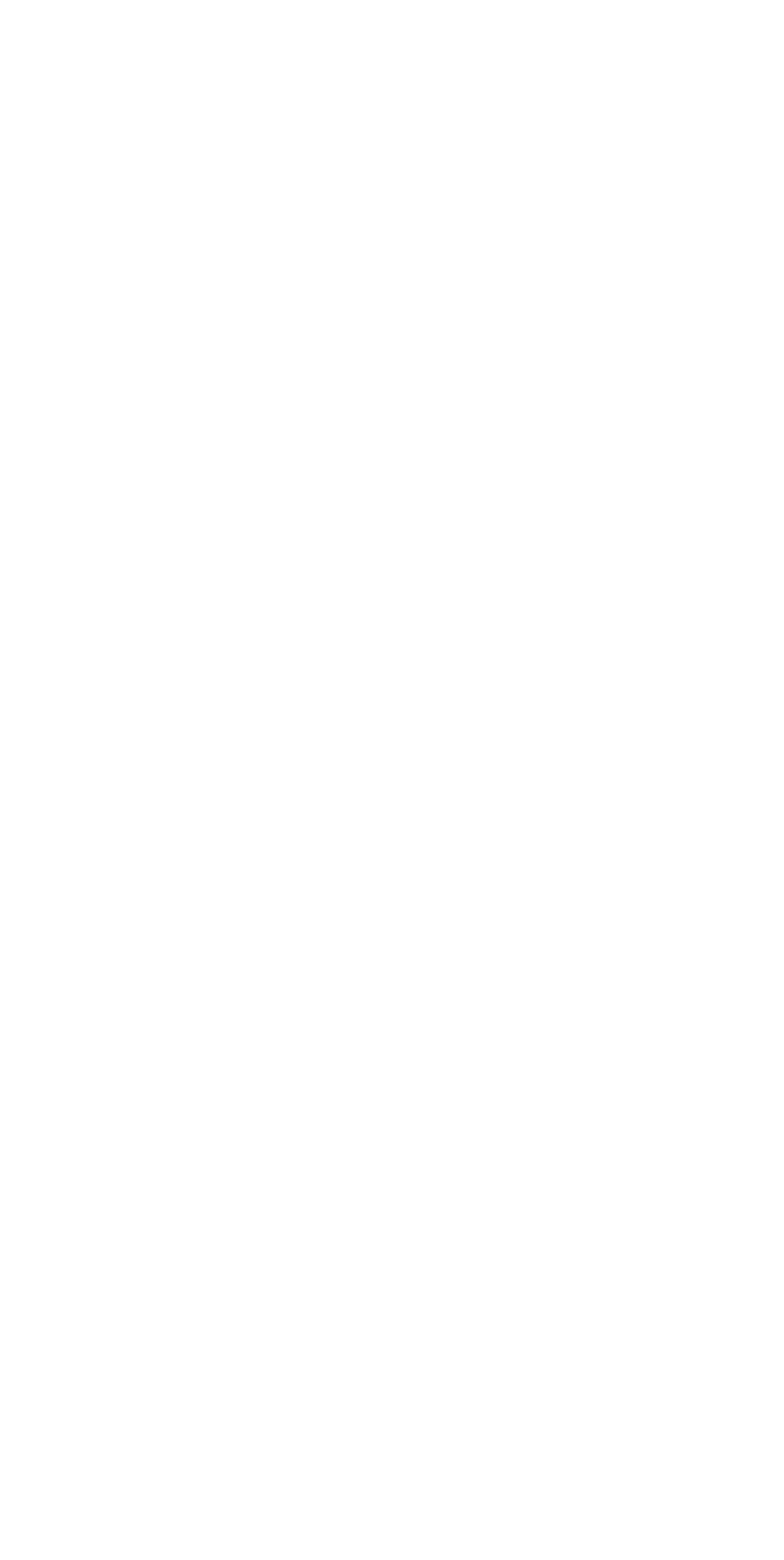




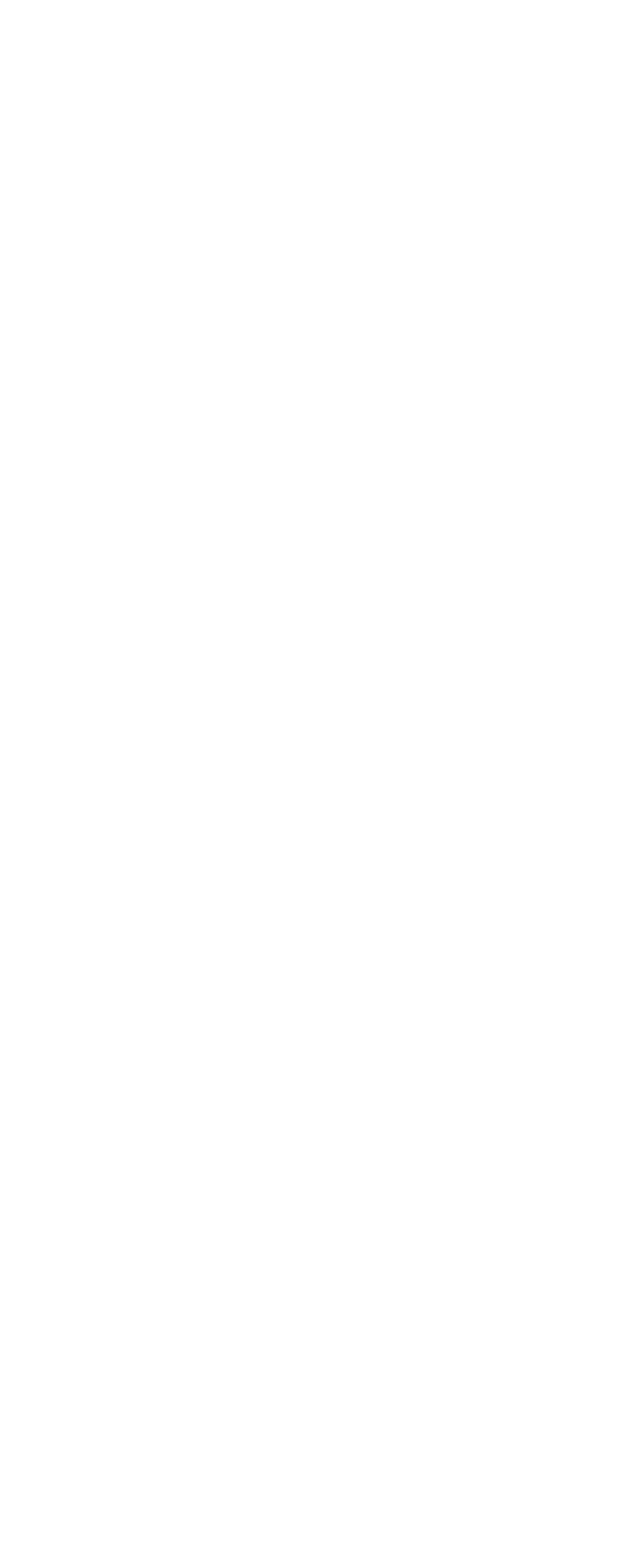


Mineral analyses of ground waters from Humphreys County

[Parts per million. Numbers at heads of columns refer to corresponding well numbers in preceding table]

\begin{tabular}{|c|c|c|c|c|c|}
\hline & 1 & 6 & 7 & 9 & 18 \\
\hline 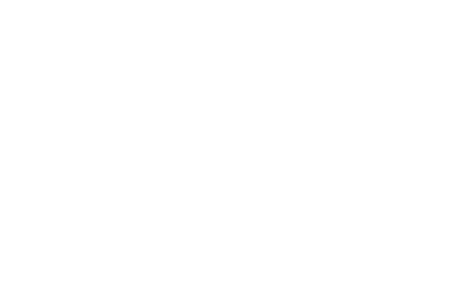 & \begin{tabular}{|c|}
25 \\
38.50 \\
9.0 \\
24.8 \\
4.8 \\
203 \\
4.1 \\
3.5 \\
248 \\
132 \\
Nov., 1911
\end{tabular} & $\begin{array}{c}12 \\
3.50 \\
3.1 \\
3.1 \\
9.6 \\
240 \\
8.3 \\
2.0 \\
1.6 \\
240 \\
108 \\
\text { Nov., } 1911\end{array}$ & $\begin{array}{c}17 \\
1.4 \\
21 \\
3.1 \\
58 \\
12 \\
195 \\
2.0 \\
7.0 \\
1.0 \\
222 \\
65 \\
\text { Aug., } 1911\end{array}$ & $\begin{array}{c}17 \\
.76 \\
2.6 \\
87^{-9} \\
7.2 \\
200 \\
15 \\
6.0 \\
298 \\
10 \\
1914\end{array}$ & $\begin{array}{c}58 \\
3.18 \\
1.3 \\
689^{57} \\
155 \\
13 \\
2.8 \\
277^{-40} \\
14 \\
\text { July, } 1919\end{array}$ \\
\hline
\end{tabular}

- Includes iron and aluminum ( $\mathrm{Fe}+\mathrm{Al})$.

- Calculated.

Analysts: 1, 6, W. L. Perdue, University of Mississippi; 7, W. L. Kennon, University of Mississippi; 9, Mississippi State Chemical Laboratory; 18, Margaret D. Foster, U. S. Geological Survey.

\section{ISSAQUENA COUNTY}

\section{GENERAI FEATURES}

Area, 4U6 square miles. Population, 7,618 (census of 1920)

Issaquena County is in the southern part of the Yazoo Deltu. The surface is underlain by the alluvial deposits of Mississippi River, which have an estimated aggregate thickness of 150 to 200 feet. Beneath the alluvium is a great series of interbedded sands, clays, and marls that probably include representatives of all the Eocene formations of central and northern Mississippi. These, named in descending order, include the Jackson formation; the Yegua, Lisbon, and Tallahatta formations of the Claiborne group; the Grenada, Holly Springs, and Ackerman formations of the Wilcox group; and the Porters Creek and Clayton formations of the Midway group. (See pp. 43-54.)

\section{GROUND-WATER CONDITIONS}

The more porous sands and gravels of the alluvium, which underlies the Yazoo Delta to estimated depths of 150 or 200 feet, contain an abundance of water under little or no artesian head that can be easily obtained by driven or bored wells equipped with ropes and buckets or with pumps. The use of suction pumps is feasible at most places, as the water table generally lies less than 25 feet below the surface.

The Eocene deposits, which underlie the alluvium, include interbedded layers of sand, the waters in which are under a strong artesian head. Although the records of only a few wells are available, it is probable that flowing wells can be obtained anywhere in the county at depths of 700 to 1,500 feet or more. The source of these artesian waters would be the Claiborne group, and chiefly the Lisbon and Tallahatta formations of that group. 


\section{LOCAL SUPPLIES}

Duncansby.-At Duncansby domestic supplies are obtained from the alluvium at depths of 35 to 65 feet.

Grace.-Numerous driven wells 25 to 75 feet deep, which enter the water-bearing beds of the alluvium, are in use at the village of Grace. An 816-foot flowing well, drilled in 1910, which is 3 inches in diameter, yields 70 gallons a minute; the water-bearing stratum is questionably referred to the Lisbon formation. (See analysis 1.)

Ben Lomond.-A well 186 feet deep, a mile east of Ben Lomond, drilled in 1910, yields water that is used for domestic supplies and for the irrigation of a small acreage of rice. The well is 24 inches in diameter at the top and 12 inches in diameter at the bottom and yields large quantities of water by pumping; it probably derives its water from sand or gravel near the base of the alluvium.

Snave.-At.Snave, 7 miles northwest of Valley Park, water for domestic use is obtained chiefly from the alluvium by means of nonflowing driven wells of small diameter. A highly mineralized water from one well 62 feet deep and $11 / 2$ inches in diameter, which was sunk in 1915, is bottled and sold under the trade name "Evans Mineral Water." (See analysis 2.)

Mineral qnalyses of ground waters from Issaquena County

[Parts per million. For further data regarding these wells see text]

\begin{tabular}{|c|c|c|}
\hline & 1 & 2 \\
\hline 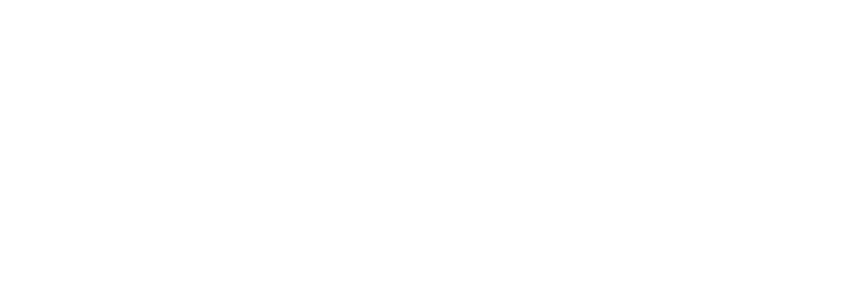 & $\begin{array}{l}25^{\circ} \\
20 \\
193 \\
488^{\circ} \\
12 \\
32 \\
4.0 \\
537^{\circ} \\
71 \\
\text { Aug., } 1911\end{array}$ & $\begin{array}{c}51 \\
188^{\circ} .56 \\
85 \\
102 \\
{ }^{620^{\circ}}{ }^{\circ} \\
448 \\
46 \\
{ }_{1,225}{ }^{\circ} .00 \\
818 \\
\text { June, } 1916\end{array}$ \\
\hline
\end{tabular}

Analysts: 1, W. L. Kennon, University of Mississippi; 2, W. F. Hand, Mississippi State Chemical Laboratory.

1. Drilled well, 816 feet deep, of L. C. Dulaney, at Grace.

2. Well, 62 feet deep, owned by A. M. Evans, at Snave.

\section{ITAWAMBA COUNTY}

\section{GENERAL FEATURES}

Area, 529 square miles. Population, 15,647 (census of 1920)

Itawamba County lies wholly within the Tombigbee Hills district. Two Upper Cretaceous formations, the Tuscaloosa and Eutaw, and the eastern edge of the Mooreville tongue of the Selma chalk appear at the surface within the county. These formations are described on pages $29-38$, and their distribution is shown on the geologic map (pl. 2). 


\section{GROUND-WATER CONDITIONS}

The strata that immediately underlie the surface throughout the greater part of the county are composed predominantly of sand which belongs to the Eutaw formation. However, sands, clays, and thin beds of impure lignite, which belong to the Tuscaloosa formation, appear in the lower slopes of Reeds, Bull Mountain, and Splunge Creeks and their tributaries. The sands of both the Eutaw and Tuscaloosa formations carry abundant water, and owing to the numerous springs of small to moderate yield and the accessibility of the water-bearing beds by means of shallow dug and bored wells few deep wells have been drilled in the area.

Artesian flows can probably be obtained in the bottom lands of the East Fork of Tombigbee River and its tributaries in the western part of the county by means of wells sunk to the water-bearing beds of the Tuscaloosa formation at depths of 200 to 400 feet.

\section{LOCAL SUPPLIES}

Fulton.-Domestic water supplies at Fulton, the county seat, are obtained chiefly by means of privately owned shallow wells, most of which are not more than 40 or 50 feet deep.

Ratcliff.-A well near the post office in the village of Ratcliff, owned by W. C. Cummings \& Bro., drilled in 1905, is 222 feet deep and $41 / 2$ inches in diameter and taps a water-bearing sand in the Eutaw formation at a depth of 100 feet. The well is located in a valley, and the water, which rises to a level within 35 feet of the surface, is raised by means of a hand force pump with a capacity of 5 gallons a minute. Another well, owned by James E. Cunningham, one-fourth of a mile north of the post office at Ratcliff, drilled in 1908, is 200 feet deep and $31 / 2$ inches in diameter, and derives its principal supply of water from sand in the Eutaw at a depth of 175 feet. The well is located on a hill 50 feet higher than the other well at Ratcliff, just described, and the water, which rises only to a level within 85 feet of the surface, is raised by means of a rope and bucket.

\section{JACKSON COUNTY}

GENERAL FEATURES

Area, 710 square miles. Population, 19,208 (census of 1920)

Jackson County lies mostly in the Coastal Pine Meadows district but extends northward into the Long-leaf Pine Hills district. The southern two-thirds of the county is underlain chiefly by loams, clays, and sands of Pleistocene age. Beneath the Pleistocene deposits is the Citronelle formation (Pliocene), the uppermost beds of which come to the surface in the northern part of the county, and under 
the Citronelle in succession lie the Pascagoula clay (Miocene), the Hattiesburg clay (Miocene), the Catahoula sandstone (Miocene), and the Vicksburg group (Oligocene). These formations are described on pages 54-61, and their distribution is shown on the geologic map (pl.2).

\section{GROUND-WATER CONDITIONS}

The Pleistocene loams, sands, and clays, which underlie the surface in the southern part of the county, and the similar materials of the Citronelle, which underlies the surface in the northern part, contain water-bearing beds that constitute an abundant source of domestic supply. The water is obtained by means of dug, bored, and driven wells 10 to 100 feet in depth. Several typical shallow wells are described in the table of well data (Nos. 4-7, 16). Small springs which have their source in these same deposits, occur at many places throughout the area. In places in the coastal lowland gray to black fetid clay that contains much vegetable matter is encountered within a few feet of the surface and the water of shallow wells, obtained from sands associated with these clays, is likely to be of undesirable quality. Artesian wells are gradually being substituted for the shallow wells throughout the coastal lowland.

The Pleistocene deposits are thinnest along the northern border of their occurrence in the county (see geologic map, pl. 2), where they are probably only 20 or 30 feet thick and are thickest along the coast, where they are estimated to extend to a depth of 200 feet or more. In an oil-prospecting well at Laine (p. 233), sandy beds penetrated to a depth of 153 feet are correlated with the Pleistocene.

The thickness of the Citronelle formation is estimated to be between 400 and 500 feet. A gravel bed encountered in the oil-prospecting well at Laine, at a depth of 608 to 616 feet, is regarded as forming the base of the formation. If this correlation is correct many flowing wells between 500 and 600 feet deep, in the southern part of the county, have their source in beds of sand in the lower part of the Citronelle. The beds that compose the Citronelle rise gradually toward the north and come to the surface in the northern part of Jackson and the southern part of George County.

The Pascagoula clay, which underlies the Citronelle but does not come to the surface in the county, is at least 500 feet thick, and it may reach a thickness of 1,000 feet or more. All the wells that exceed 600 feet in depth are believed to tap water-bearing sands in this formation. By reference to the table of well data it will be seen that many of the artesian wells derive supplies from this source.

So far as known none of the water wells of the county have their source in the Hattiesburg clay, which underlies the Pascagoula, but the 3,010-foot oil-prospecting well at Laine (see p. 233) is believed to 
have completely penetrated the Hattiesburg and to have entered still deeper and older Tertiary formations. (See table of formations on p. 28.)

\section{LOCAL SUPPLIES}

Pascagoula.-The waterworks at Pascagoula was owned by the Pascagoula Street Railway \& Power Co. but is now owned by the city and is located a block west of the Louisville \& Nashville Railroad station. Water is obtained from an 875-foot well (No. 24), which yields 300 gallons a minute when flowing freely. A log of an abandoned well at the waterworks is given below. The logs of a water well at Bellevue and of the oil-prospecting well of the Bellevue Oil Co. at Pascagoula were published in 1919. ${ }^{36}$

Log of abandoned well of Pascagoula Street Railway \& Power Co., Scranton, near Pascagoula (No. 35) a

[Altitude of mouth of well, 9 feet above sea level. Authority, W. H. Logan and W. R. Perkins]

\begin{tabular}{|c|c|c|}
\hline . & Thicknoss & Depth \\
\hline $\begin{array}{l}\text { Sand and gravel } \\
\text { Blue clay, } \\
\text { "Clam" sheilss } \\
\text { Blue clay, } \\
\text { Sand; water bearing- }\end{array}$ & $\begin{array}{r}\text { Feet } \\
350 \\
400 \\
5 \\
25 \\
20\end{array}$ & $\begin{array}{r}\text { Feet } \\
350 \\
750 \\
755 \\
780 \\
800\end{array}$ \\
\hline
\end{tabular}

a Mississippi Agr. Exper. Sta. Bull. 89, p. 78, 1905.

The following list shows the fossil organisms identified by W. C. Mansfield in samples submitted in September, 1920, from an oilprospecting well of the Sea Coast Oil Co. 4 miles north of Pascagoula, in sec. 22 , T. 7 S., R. 6 W. Mr. Mansfield states that the fossils indicate the Miocene age of the containing strata, which probably belong to the Pascagoula formation.

At depth of 1,266 to 1,287 feet (U. S. G. S. station 9093a):

Rangia johnsoni Dall.

At depth of 1,284 to 1,360 feet (U. S. G. S. station $9093 b$ ):

Arca? (fragment).

Ostrea? (fragment).

Rangia johnsoni Dall.

At depth of 1,360 to 1,424 feet (U. S. G. S. station 9093 c):

Terebra? (fragment).

Arca near A. buccula Conrad.

Ostrea? (fragment).

Rangia johnsoni Dall.

at depth of 1,424 to 1,467 feet (U. S. G. S. station $9093 d$ ):

Ostrea? (fragment).

Rangia johnsoni Dall.

At depth of 1,467 to 1,508 feet (U. S. G. S. station 9093e):

Anachis sp. (fragment).

Arca? (fragment).

Rangia johnsoni Dall.

36 Lowe, E. N., Oil and gas prospecting in Mississippl: Mississippi Creol. Survey Bull. 15, pp. 47-49, 1919. 
At depth of 1,508 to 1,552 feet (U. S. G. S. station 9093f):

Area? (fragment).

Ostrea? (fragment).

Rangia jobnsoni Dall.

Mr. Mansfield has also identified some imperfect shells from a depth of 2,257 to 2,361 feet in the same well, which were submitted by R. F. Baker, of the Texas Co., as Cerithium or Potamides, and he compares them with Cerithium whitfieldi (Heilprin), from the Claiborne group of the Eocene. Julia A. Gardner has also identified fossils from a depth of 2,100 to 2,150 feet in the same well as follows:

Oliva? sp.

Cerithium sp.?, group of C. whitfieldi (Heilprin).

Cerithium? sp.

Natica? sp.

Rangia johnsoni Dall.

Crab claw.

Moss Point.-Domestic water supplies at Moss Point are afforded chiefly by three wells, each of which supplies a 'group of families. The water is distributed through systems of pipes by means of the artesian pressure, and neither pumps nor elevated tanks are provided to increase the pressure for fire protection. One of these wells (No. 8) is 1,110 (?) feet deep and supplies numerous families. A second well (No. 15) is 806 (?) feet deep and supplies 30 families. The third well, depth not reported, is owned by a local company. The following are logs of two artesian wells at Moss Point:

Log of well at Moss Point a

[Owner not stated. Authority John L. Ford, drillex]

\begin{tabular}{|c|c|c|c|c|c|}
\hline & $\begin{array}{c}\text { Thick- } \\
\text { ness }\end{array}$ & Depth & & $\begin{array}{c}\text { Thick- } \\
\text { ness }\end{array}$ & Depth \\
\hline $\begin{array}{l}\text { Hard yellow clay, sandy } \\
\text { Yellow sand } \\
\text { Clay, sandy, variegated } \\
\text { Sand, fine, white } \\
\text { Sand, coarse, white....... } \\
\text { Clay, sandy ..... }\end{array}$ & $\begin{array}{r}\text { Feet } \\
20 \\
15 \\
15 \\
50 \\
40 \\
70\end{array}$ & $\begin{array}{r}\text { Feet } \\
20 \\
35 \\
50 \\
100 \\
140 \\
210\end{array}$ & $\begin{array}{l}\text { Sand, fine white } \\
\text { Clay, fine, white- } \\
\text { Sand } \\
\text { Sayd, fine, gray; water bearing } \\
\text { Clay. }\end{array}$ & $\begin{array}{r}\text { Feet } \\
10 \\
150 \\
20 \\
320 \\
80 \\
(?)\end{array}$ & $\begin{array}{l}\text { Feet } \\
220 \\
370 \\
390 \\
710 \\
790 \\
(?)\end{array}$ \\
\hline
\end{tabular}

¿ U. s. Geol. Survey Bull. 264, p. 87, 1905.

Log of well of F. H. Lewis at Moss Point (No. 12) a

[Authority, W. H. Logan and W. R. Perkins]

\begin{tabular}{|c|c|c|c|c|c|}
\hline & $\begin{array}{l}\text { Thick- } \\
\text { ness }\end{array}$ & Depth & & $\begin{array}{c}\text { Thick- } \\
\text { ness }\end{array}$ & Depth \\
\hline $\begin{array}{l}\text { Sand } \\
\text { Clay and mud. } \\
\text { Hard clay } \\
\text { Sand; water bearing } \\
\text { Hard clay }\end{array}$ & $\begin{array}{r}\text { Feet } \\
100 \\
150 \\
150 \\
20 \\
200\end{array}$ & $\begin{array}{r}\text { Feet } \\
100 \\
250 \\
400 \\
420 \\
620\end{array}$ & $\begin{array}{l}\text { Sand; water bearing. } \\
\text { Sand and clay } \\
\text { Sand; water bearing } \\
\text { Hard rock, sand, mud, and wood.. }\end{array}$ & $\begin{array}{r}\text { Feet } \\
40 \\
110 \\
44 \\
736\end{array}$ & $\begin{array}{r}\text { Feet } \\
660 \\
770 \\
814 \\
1,550\end{array}$ \\
\hline
\end{tabular}

aississippi Agr. Exper. Sta. Bull. 89, p. 64, 1905. 
Ocean Springs.-Many flowing artesian wells, which range in depth from 500 to 1,200 feet, have been drilled at and in the ticinity of Ocean Springs. Typical wells are described in the table of well data (Nos. 17-23). Water-bearing sands are found in both the Citronelle and Pascagoula formations. A maximum head of 90 feet above the surface (about 100 feet above sea level) and a maximum yield of 250 gallons a minute are recorded.

The municipal water supply is obtained from three artesian wells, 965,875 , and 880 feet deep (Nos. 17, 18), owned by the Ocean Springs Water Co. When flowing freely the combined yield of the wells is 650 gallons a minute. The wells are attached directly to the mains and maintain an artesian pressure therein of 10 to 15 pounds to the square inch. A log of the well at Ocean Springs is given below:

\section{Log of well at Ocean Springs *}

[Altitude of mouth of well about 25 feet above sea level. Authority, W. H. Logan and W. R. Perkins]

\begin{tabular}{|c|c|c|}
\hline & Thickness & Depth \\
\hline $\begin{array}{l}\text { Sand and gravel. } \\
\text { Clay } \\
\text { Sand } \\
\text { Clay } \\
\text { Sand and gravel- } \\
\text { Clay } \\
\text { Sand; water bearing- }\end{array}$ & $\begin{array}{r}\text { Feet } \\
150 \\
250 \\
20 \\
40 \\
60 \\
400 \\
30\end{array}$ & $\begin{array}{r}\text { Feet } \\
150 \\
400 \\
420 \\
460 \\
520 \\
920 \\
950\end{array}$ \\
\hline
\end{tabular}

- Mississippi Agr. Exper. Sta. Bull. 89, p. 77, 1905.

Deer Island.-A partial log of a well owned by the Deer Island Improvement Co., on Deer Island, off the southwest shore of the mainland of Jackson County, is given below.

Partial log of well of Deer Island Improvement Co., on north shore of Deer Island a mile west of the east end (No. 1)

[Authority, F. B. Costanera, driller]

\begin{tabular}{|c|c|c|}
\hline & Thickness & Depth \\
\hline $\begin{array}{l}\text { Undifferentiated Recent and Pleistocene deposits and Citronelle and Pascagoula } \\
\text { formations: } \\
\text { Not reported. } \\
\text { Sand } \\
\text { Clay (i) } \\
\text { Sand } \\
\text { Clay (i) } \\
\text { Sand (i) } \\
\text { Sand } \\
\text { Hard shale } \\
\text { Sandstone and sand } \\
\text { Soft mud and } \\
\text { Sand; water bearing; strainer placed opposite the lower } 40 \text { feet of sand (Pasca- } \\
\text { goula) }\end{array}$ & $\begin{array}{c}\text { Feet } \\
350 \\
36 \\
50 \\
52 \\
185 \\
27 \\
141 / 2 \\
191 / 2 \\
20 \\
1 / 3 \\
113 / 2 \\
80\end{array}$ & $\begin{array}{c}\text { Feet } \\
350 \\
386 \\
436 \\
488 \\
673 \\
700 \\
7141 / 2 \\
734 \\
754 \\
75413 \\
7661 / 4 \\
8461 / 4\end{array}$ \\
\hline
\end{tabular}

Harleston.-At Harleston and vicinity the principal source of domestic water supply is driven wells, which range in depth from 15 to 
35 feet. An abundance of water of satisfactory quality can apparently be obtained in this way. The log of one shallow well is given below.

Log of well of P. G. Galloway, \& miles west of Harleston (No. 4)

[Authority, the owner]

\begin{tabular}{|c|c|c|}
\hline & Thickness & Depth \\
\hline $\begin{array}{l}\text { Pleistocene: } \\
\text { Loamy sand_... } \\
\text { Red clay }\end{array}$ & Fivet $\begin{array}{l} \\
1 \\
10\end{array}$ & Feet ${ }_{11}^{1}$ \\
\hline $\begin{array}{l}\text { Red sand; water bearing (water is red) } \\
\text { White sand; water bearing at base }\end{array}$ & $\begin{array}{r}3 \\
3 \\
18\end{array}$ & $\begin{array}{l}14 \\
\mathbf{3 2}\end{array}$ \\
\hline
\end{tabular}

Hurley.-In the vicinity of Hurley most of the domestic water supplies are obtained at shallow depths in deposits of Pleistocene age. The log of a typical well is given below.

Log of well of J.K. Monteith, 3 miles northwest of Hurley (No. 7)

[Authority, the owner]

\begin{tabular}{|c|c|c|}
\hline & Thickness & Depth \\
\hline $\begin{array}{l}\text { Pleistocene: } \\
\text { Sandy loam } \\
\text { Stiff bandy clay } \\
\text { Hard, stiff yellow clay } \\
\text { Yellow sandy clay } \\
\text { Sand; water bearing }\end{array}$ & Feet $\begin{array}{l} \\
1 \\
3 \\
6 \\
4 \\
4 \\
6\end{array}$ & $\begin{array}{r}\text { Feet } \\
1 \\
4 \\
10 \\
14 \\
20\end{array}$ \\
\hline
\end{tabular}

Nutbank.-At Nutbank, a village on the Alabama \& Mississippi Railroad, 14 miles north of Pascagoula, domestic water supplies are obtained from very shallow wells, which are said to range in depth from 5 to 30 feet. These afford an abundance of good water. The log of Frank E. Hurd's well is given below:

Log of well of Frank $\boldsymbol{E}$. Hurd, at Nutbank (No. 16)

[Authority, the owner]

\begin{tabular}{|c|c|c|}
\hline . & Thickness & Depth \\
\hline $\begin{array}{l}\text { Black sandy soil } \\
\text { Pleistocene: } \\
\text { Yellow sandy subsoil } \\
\text { Yellow sandy clay } \\
\text { Red clay } \\
\text { Quicksand; water bearing }\end{array}$ & Feet $\begin{array}{r}2 \\
2 \\
4 \\
7 \\
4 \\
3\end{array}$ & Feet $\begin{array}{r}2 \\
6 \\
13 \\
17 \\
20\end{array}$ \\
\hline
\end{tabular}

Helena.-The following log shows the character of the beds penetrated in a shallow well near Helena, a small village on the Alabama \& Mississippi Railroad, 12 miles north of Pascagoula: 
Log of well of Charles Alexander, $11 / 2$ miles north of Helena (No. 5)

[Authority, the owner]

\begin{tabular}{|c|c|c|}
\hline - & Thickness & Depth \\
\hline $\begin{array}{l}\text { Pleistocene: } \\
\text { Black sand. } \\
\text { Yellow sand mixed with clay } \\
\text { Stiff hard clay } \\
\text { Fine white sand; water bearing }\end{array}$ & Feet $\begin{array}{r} \\
1 \\
5 \\
21 / 2 \\
111 / 2\end{array}$ & $\begin{array}{l}\text { Feet } \\
\quad 1 \\
\quad 6 \\
81 / 2 \\
20\end{array}$ \\
\hline
\end{tabular}

Laine.-An oil-prospecting well 3,010 feet deep, which, though unsuccessful as an oil producer, afforded scientific information of value, was drilled at Laine, a village 5 miles northeast of Pascagoula, in 1911 by the Pascagoula Development Co. The log of this well has been published. ${ }^{37}$ A second well, 700 feet west of the first one, was drilled by the same company to a depth of 2,240 feet shortly after the first one was abandoned. The fossils from this well were identified by C. W. Cooke, with the exception of Arca plicatura Conrad, from a depth of 1,700 feet, which was identified by T. W. Vaughan. Cooke states that Rangia johnsoni Dall is generally regarded as characteristic of the Pascagoula clay. Therefore, if the gravel bed whose base is at a depth of 616 feet and 8 inches is taken as the base of the Citronelle formation, the occurrence of Rangia johnsoni Dall at depths of $1,300,1,400,1,500$, and 1,700 feet would seem to indicate that the Pascagoula formation is 1,100 feet thick. However, as the 10-inch casing was set at a depth of 881 feet, it must be regarded as possible that the specimens of this species fell from a higher level than that at which they were taken. Venus and Arca, which are found at a depth of 1,700 feet, are marine forms. Arca plicatura Conrad has been reported by Dall from the Duplin (Miocene) and Waccamaw (Pliocene) formations of the Carolinas, and the bed containing it in this well probably belongs to the Pascagoula formation.

Vancleave.-The records of three artesian wells at Vancleave are given in the table of well data (Nos. 26-28); the logs of two oilprospecting wells drilled by the Atlas Oil Co. southeast of Vancleave were published in $1919 .^{38}$

${ }^{37}$ Lowe, E. N., Oil and gas prospecting in Mississippi: Mississippi Geol. Survey Bull. 15, pp. 49-52, 1919.

${ }^{38}$ Idem, pp. 54-61.

$$
54134-28-16
$$




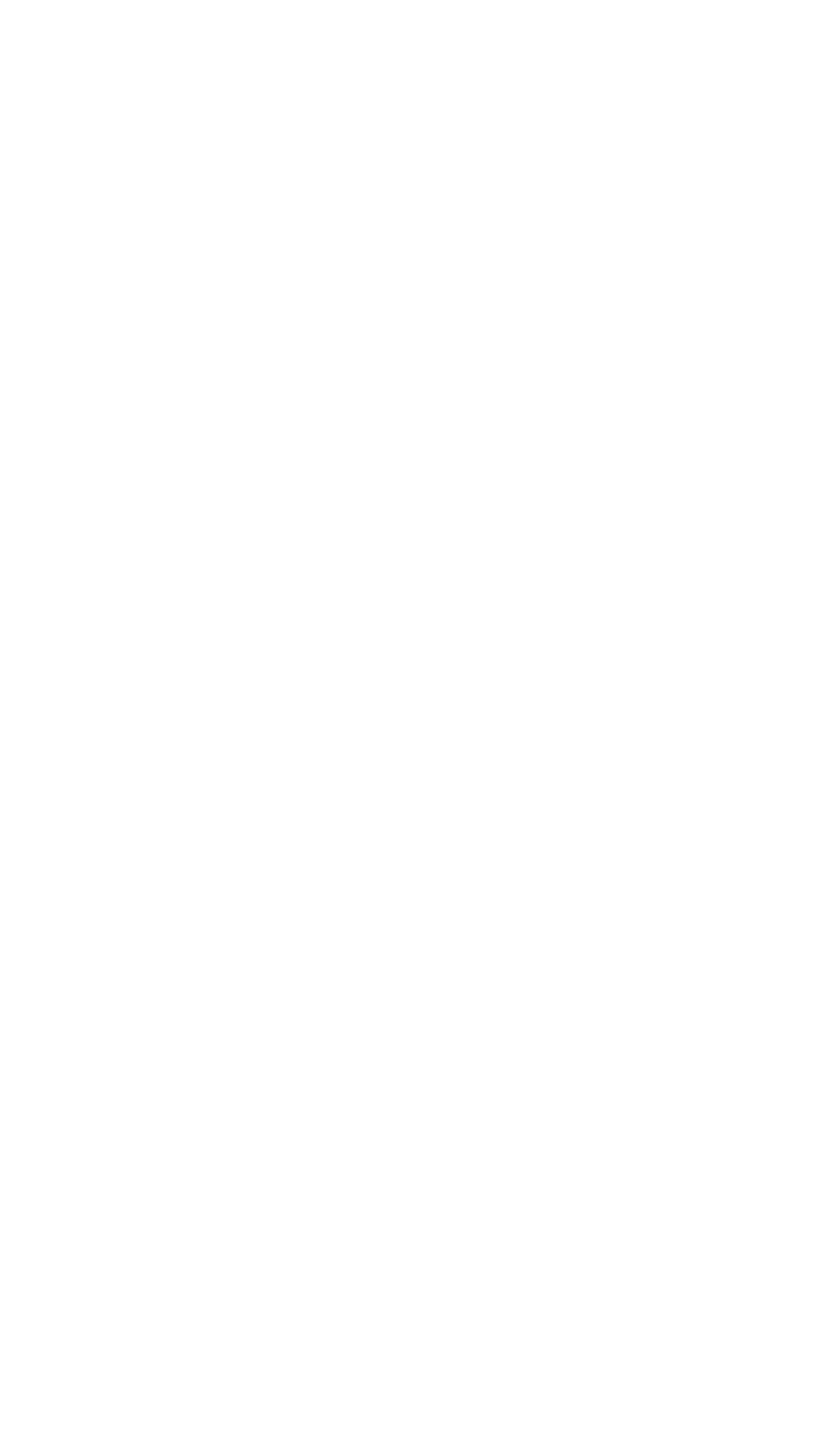




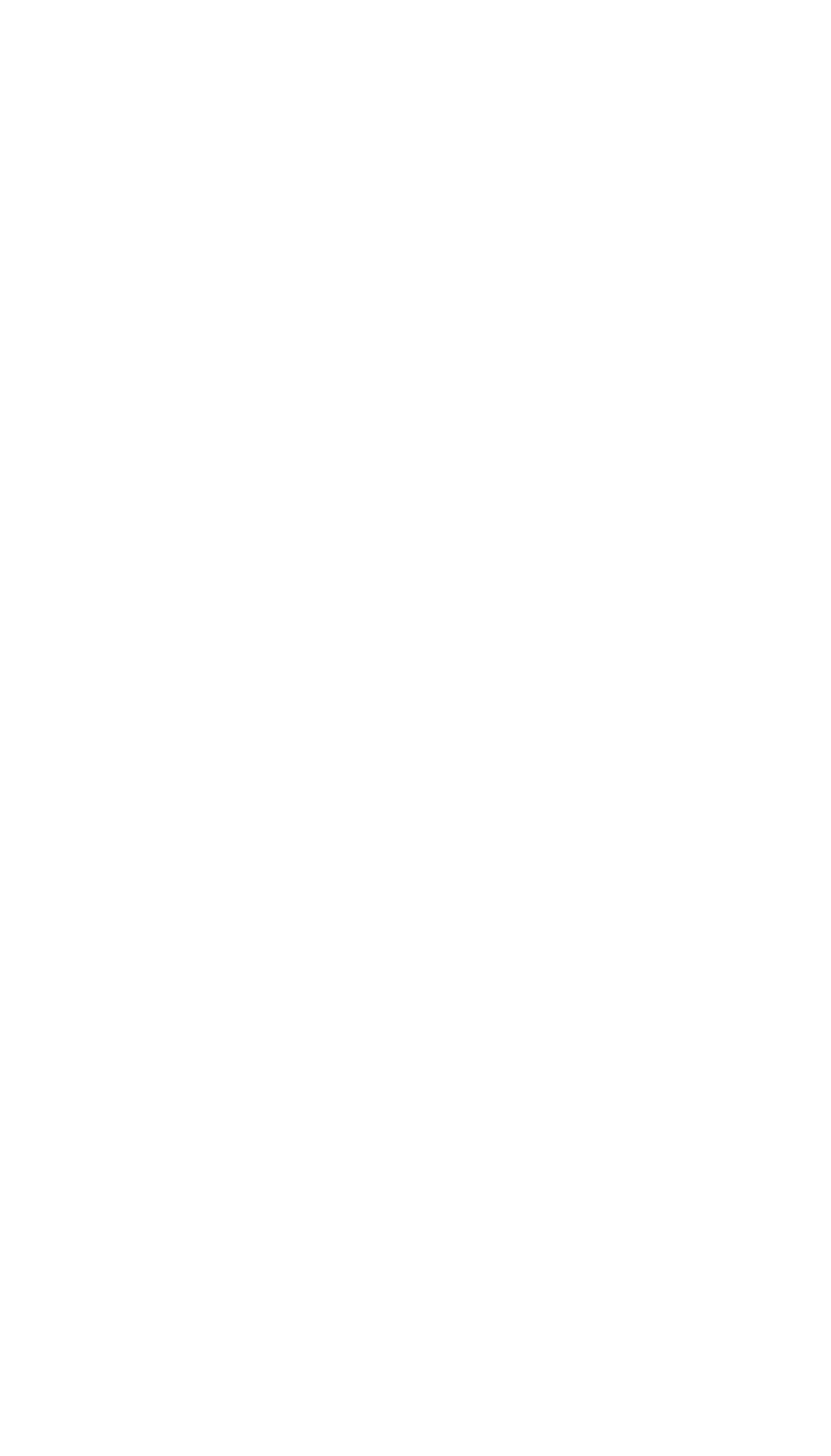




\section{Mineral analyses of ground waters from Jackson County}

[Parts per million. Numbers at heads of columns refer to corresponding well numbers in preceding table]

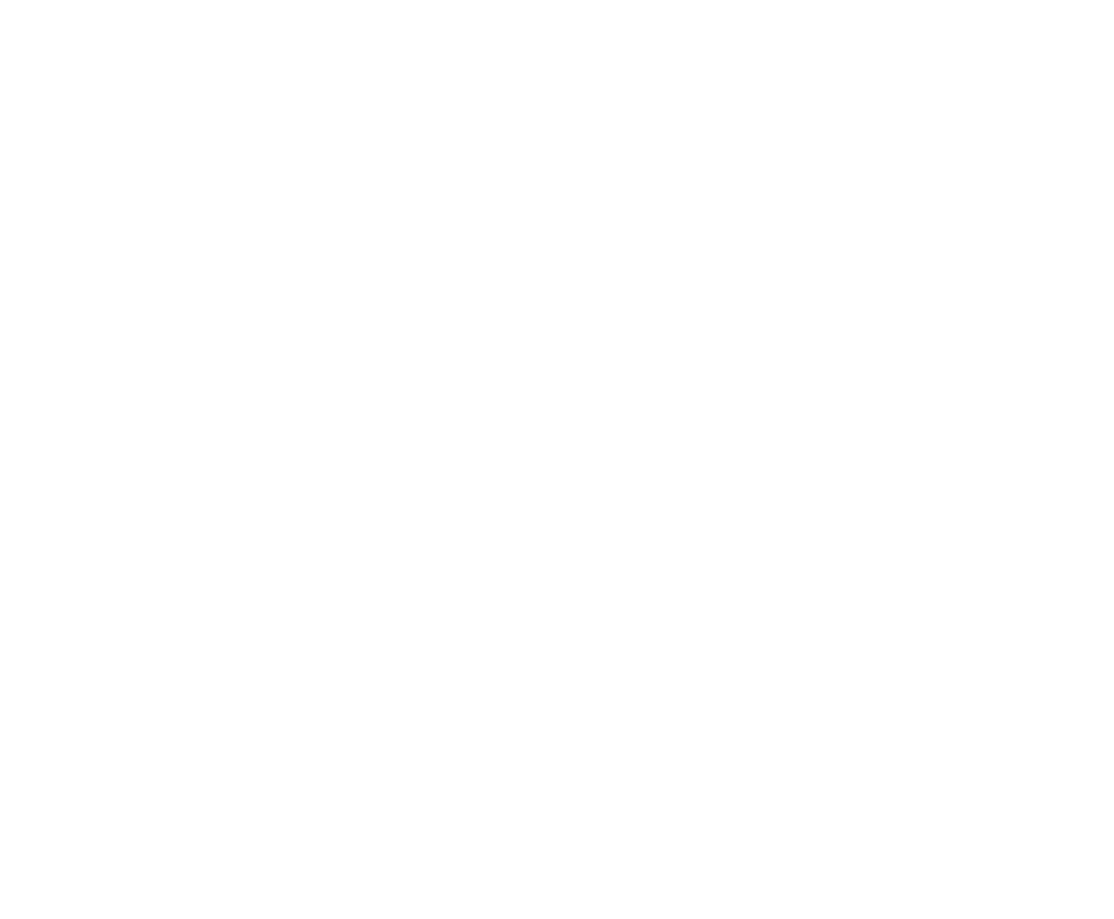

- Iron and aluminum oxides $\left(\mathrm{Fe}_{2} \mathrm{O}_{3}+\mathrm{Al}_{2} \mathrm{O}_{3}\right)$.

Calculated.

Analysts: 8, 10, 15, Margaret D. Foster, U. S. Geological Survey; 9, 18, 19, 20, 21, 22, 23, 24, C. S. Howard, U. S. Geological Survey; 13, 17, 25, W. R. Perkins (Mississippi Agr. Exper. Sta. Bull. 89, p. 77, 1905).

\section{JASPER COUNTY}

\section{GENERAI FEATURES}

Area, 667 square miles. Population, 18,508 (census of 1920)

Jasper County is in part in the Jackson Prairie Belt, in part in the Long-leaf Pine Hills district. The geologic formations that occur at the surface within the county include, in the order of age from the oldest to the youngest, the Lisbon and Yegua formations of the Claiborne group, the Jackson formation, the Marianna and Glendon limestones and the Byram marl of the Vicksburg group, the Catahoula sandstone, and the Citronelle formation. With the exception of the Citronelle formation, which occurs as overlapping remnants on the other formations, the formations crop out in the order just given from northeast to southwest. Their character and physiographic expression are discussed on pages 50-60, and their approximate distribution is shown on the geologic map (pl. 2). 


\section{GROUND-WATER CONDITIONS}

The deepest water-bearing beds that could be practically utilized in the county are those of the Wilcox group. So far as reported no wells have been drilled to these beds, but they would probably be reached at depths of 1,000 to 1,500 feet in the northeastern part of the county, whence they dip to the southwest at an estimated rate of 25 to 40 feet to the mile. Nothing definite is known in regard to either the quantity or the quality of the water that could be obtained from this source.

The Claiborne group, the upper part of which appears at the surface in the northeastern part of the county, is a valuable aquifer. One well 7 miles east of Paulding is believed to have reached a waterbearing bed in the Lisbon formation of this group, at a depth of 497 feet. Likewise a coarse water-bearing sand, which probably belongs to the Lisbon, was reached in a well 7 miles southeast of Louin, at a depth of 613.5 feet. The deep wells at Louin and Montrose tap water-bearing sands in the Lisbon. This formation is a notable source of artesian water and is believed to be accessible by drilling throughout the county. At Montrose a water-bearing sand is penetrated at a depth of about 300 to 380 feet in the Lisbon formation. As the formation dips to the southwest this sand would lie at depths less than 300 feet east and northeast of Montrose. At Louin a waterbearing sand, probably the same as that at Montrose, is reached at a depth of about 510 feet. To the south of Louin the sand continues to increase in depth and probably lies 1,100 to 1,200 feet below the surface in the southwest corner of the county. The 1,135-foot flowing well at Taylorsville, Smith County, is believed to obtain its supply from this source.

So far as known, the Jackson formation, which is composed chiefly of clay and calcareous marl, does not contain valuable water-bearing beds in Jasper County. The belt of outcrop of the formation is 12 to 15 miles wide and trends to the northwest through the central part of the county.

Above the Jackson lies the Vicksburg group, the basal formation of which, the Forest Hill sand, may be a source of water in this county, though exact information in regard to it is wanting. The Vicksburg group comes to the surface in a narrow strip that trends to the northwest just south of the belt of outcrop of the Jackson formation.

The Vicksburg group is overlain by the Catahoula sandstone, the main body of which crops out in the southern part of the county and overlapping remnants of which cap many of the hills in the belt of outcrop of the Vicksburg group and of the Jackson formation, in the central and northern parts of the county. The formation consists of many alternations of sandstone, sand, and clay, and the more porous sands are water bearing. Although the conditions appear to be 
unfavorable to the occurrence of large quantities of water in the formation, it is, nevertheless, the principal source of domestic and farm supply in several townships in the southern part of the county. Small springs are numerous in this region and are utilized where conveniently located. Probably the most common means of obtaining the water, however, consists of dug, bored, and drilled wells which range in depth from 20 to 75 feet.

\section{LOCAL SUPPLIES}

Bay Springs.-The town of Bay Springs has grown up around the spring of the same name in the SE. $1 / 4$ SE. $1 / 4 \mathrm{sec} .29$, T. 2 N., R. 10 E., 400 feet west of the post office. The spring is at the head of a small branch valley, at an altitude somewhat less than 400 feet above sea level, and probably originates in a bed of porous sand near the base of the Catahoula formation. The yield of the spring is reported to be $171 / 2$ gallons a minute, with only slight seasonal variation. No analysis of the water is available, but the water is described as ferruginous and sulphurous and has been bottled and sold for a mineral water.

Louin.-The Gulf, Mobile \& Northern Railroad owns a 6-inch well, at. Louin, 525 feet deep. The well yields 75 gallons a minute by pumping. The water rises within 188 feet of the surface and is used in locomotive boilers. A log of the well is given below.

Log of well of Gulf, Mobile \& Northern Railroad at Louin, Jasper County

[Altitude at mouth of well about 427 feet above sea level. Authority, W. N. Logan]

\begin{tabular}{|c|c|c|}
\hline . & $\begin{array}{l}\text { Approxi- } \\
\text { mate } \\
\text { thickness }\end{array}$ & $\begin{array}{l}\text { Approxi- } \\
\text { mate } \\
\text { depth }\end{array}$ \\
\hline $\begin{array}{l}\text { Sand and pebbly loam } \\
\text { Loose dry marl mud } \\
\text { Blue marl and mud } \\
\text { Sand (Lisbon); water bearing }\end{array}$ & $\begin{array}{r}\text { Feet } \\
20 \\
95 \\
395 \\
1,5\end{array}$ & $\begin{array}{r}20 \\
115 \\
510 \\
525\end{array}$ \\
\hline
\end{tabular}

The sand forming the upper 20 feet of this section may belong to the Citronelle formation. Below this sand the well is believed to have completely penetrated the Jackson formation and to have tapped a water-bearing sand in the still deeper Lisbon formation of the Claiborne group. The following is the log of a 6 -inch well 636.5 feet deep, owned by the Gilchrist-Fordney Co., on a hill 7 miles southeast of Louin, in the NE. $1 / 4$ sec. 9, T. 2 N., R. 11 E. The water rises within 75 feet of the surface and yields by pumping 60 gallons a minute. 
Log of well of Gilchrist-Fordney Co., 7 miles southeast of Louin

[Authority, Layne \& Bowler Co., drillers; $\log$ furnished by F. R. Gilchrist]

\begin{tabular}{|c|c|c|c|c|c|}
\hline & $\begin{array}{c}\text { Thick- } \\
\text { ness }\end{array}$ & Depth & & $\begin{array}{c}\text { Thick- } \\
\text { ness }\end{array}$ & Depth \\
\hline $\begin{array}{l}\text { Sandy clay } \\
\text { Gumbo } \\
\text { Soapstone } \\
\text { Gumbo } \\
\text { Shale } \\
\text { Sand } \\
\text { Shale } \\
\text { Gumbo } \\
\text { Sand and shells } \\
\text { Gumbo } \\
\text { Fine sand } \\
\text { Chocolate gumbo }\end{array}$ & $\begin{array}{c}\text { Feet } \\
22 \\
268 \\
35 \\
9.5 \\
8 \\
4 \\
6 \\
30 \\
44 \\
46 \\
8 \\
49\end{array}$ & $\begin{array}{c}\text { Feet } \\
22 \\
290 \\
325 \\
334.5 \\
342.5 \\
346.5 \\
352.5 \\
382.5 \\
426.5 \\
472.5 \\
480.5 \\
529.5\end{array}$ & $\begin{array}{l}\text { Clay and dry gravel } \\
\text { Clay and dry boulders. } \\
\text { Rock } \\
\text { Gumbo and dry boulders } \\
\text { Gumbo } \\
\text { Rock } \\
\text { Gumbo } \\
\text { Rock } \\
\text { Clay } \\
\text { Coarse sand (Lisbon); water bear- } \\
\text { Gug } \\
\text { Gumbo }\end{array}$ & $\begin{array}{c}\text { Feet } \\
12 \\
14 \\
2 \\
12 \\
11 \\
2.5 \\
15.5 \\
1 \\
14 \\
19 \\
4\end{array}$ & $\begin{array}{l}\text { Feet } \\
541.5 \\
555.5 \\
557.5 \\
569.5 \\
580.5 \\
583 \\
598.5 \\
599.5 \\
613.5\end{array}$ \\
\hline
\end{tabular}

This well passed through the Jackson formation and reached a water-bearing sand at a depth of 613.5 to 632.5 feet, which is probably in the Lisbon formation of the Clajborne group. The shallow dug well of J. D. Leake at Louin questionably enters the Jackson formation. (See analysis 1.)

Montrose.-Two deep wells have been drilled at Montrose. One owned by the Home Lumber Co. is 680 feet deep and 6 inches in diameter; the water rises to a level within 80 feet of the surface and is pumped at the rate of 60 gallons a minute. A strainer is placed in the well at a depth of about 370 to 380 feet, where the principal supply is obtained, and the water is used in boilers. A log of the well is given below. (See analysis 2.)

Log of well of Home Lumber Co., Montrose

[Altitude at mouth of well about 418 feet above sea level. Authority, W. N. Logan]

\begin{tabular}{|c|c|c|}
\hline & Thickness & Depth \\
\hline $\begin{array}{l}\text { Jackson formation: } \\
\text { Yellow and blue mud } \\
\text { Soapstone (clay) } \\
\text { Soapstone and white alay }\end{array}$ & $\begin{array}{r}\text { Feet } \\
60 \\
140 \\
100\end{array}$ & $\begin{array}{r}\text { Feet } \\
60 \\
200 \\
300\end{array}$ \\
\hline $\begin{array}{l}\text { Lisbon formation (of Claiborne group): } \\
\text { Fine sand; water bearing } \\
\text { Coarse sand; water bearing } \\
\text { Hard stone and rock } \\
\text { Hard soapstone (clay), with lignite }\end{array}$ & $\begin{array}{r}760 \\
10 \\
100 \\
200\end{array}$ & $\begin{array}{l}370 \\
380 \\
480 \\
680\end{array}$ \\
\hline
\end{tabular}

The other well is owned by the Tallahatta Lumber Co. and is 900 feet deep and 6 inches in diameter. The well is cased with 6 -inch casing to a depth of only 400 feet and just below that depth the principal supply is obtained from sand in the Lisbon formation. The water rises within 40 feet of the surface and is pumped at the rate of 50 gallons a minute. The water is hard but is used for domestic supplies and for boilers. (See analysis 3.) Hard rock is reported to have been penetrated at a depth of 600 feet. 
Well of J. E. Green.-One well, owned by J. E. Green, 7 miles east of Paulding, is believed to have reached a water-bearing sand in the Lisbon formation of the Claiborne group at a depth of 497 feet.

Springs near Weems.-Near Weems, a village $11 / 2$ miles west of Vosburg, there are two springs, one known as Mineral Spring No. 1 and the other as Donald Spring No. 2, which probably originate in sands of the Catahoula formation just above the Glendon limestone (of the Vicksburg group). (See analyses 4, 5.)

Stafford Mineral Springs.-Stafford Mineral Springs is a health resort located among the hills, 11/2 miles south of Vosburg. The spring (for there is only one) is described as an ordinary hillside spring that yields a slightly ferruginous water at the rate of 17 gallons a minute, with little variation. The water probably has its source in sand (Catahoula or Citronelle) that closely overlies the Glendon limestone and in this respect resembles the springs near Weems just described.

Spring of J. M. Welborne-A spring near Stringer, in T. 10 N., R. $13 \mathrm{~W}$., owned by J. M. Welborne, is believed to originate in sand of the Catahoula formation. The yield is 3 gallons a minute.

Mineral analyses of ground waters from Jasper County

[Parts per million]

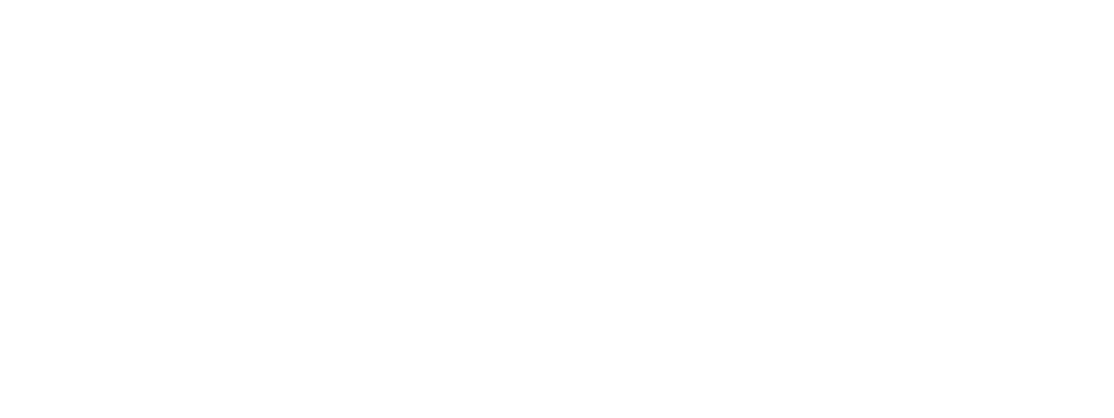

a Calculated.

Analysts: 1, 2, W. F. Hand, Mississippi State Chemical Laboratory; 3, R. S. Wallace, University of Mississippi; 4, 5, R. W. Jones, University of Mississippi (U. S. Geological Survey Water-supply Paper 159 , p. 79,1906$)$

1. 40-foot well of J. D. Leeke, at Louin

2. 680-foot well of Home Lumber Co., at Montrose.

3. 900-foot well of Tallahatta Lumber Co., at Montrose.

4. Mineral Spring No. 1, at Weems.

5. Donald Spring No. 2, at Weems.

\section{JEFFERSON COUNTY}

GINERAL FEATURES

Area, 507 square miles. Population, 15,946 (census of 1920)

Jefferson County lies chiefly in the loess-covered belt that forms the western border of the upland portion of Mississippi, but a small area is included in the Mississippi Alluvial Plain. The geologic formation which chiefly determined the topography and the soil 
conditions is the loess, which forms a mantle a few feet to 60 feet or more in depth over practically all the upland portion of the county. (See pp. 62-63.) The greatest thickness of the loess is in the west, where the upland overlooks the lowland, and the material gradually thins out to only a few feet in thickness in the extreme east. Beneath the loess lies a more or less continuous sheet of sand and gravel that ranges in thickness from a few feet to approximately 100 feet, which belongs to the Citronelle formation (Pliocene), and beneath the Citronelle lie, in succession, the Hattiesburg clay (Miocene) and the Catahoula sandstone (Miocene). The Catahoula is not exposed in the county, except questionably in the bluffs in the extreme northwest near Rodney. Descriptions of the several formations named will be found on pages 55-60. (See pl. 2.) The Mississippi lowland is underlain by 150 to 200 feet of alluvial loam, clay, sand, and gravel, which probably rest upon the Catahoula formation.

\section{GROUND-WATER CONDITIONS}

The ground-water supplies of the county, as at present developed, are derived from relatively shallow sources, and there are only a few wells more than 100 feet deep. The mantle of loess that covers practically all of the upland portion of the county does not carry water in sufficient quantities for economic use, but the sands and gravels of the underlying Citronelle formation are water bearing at most places. The loess is strongly calcareous, and the water that percolates through it from the surface dissolves the lime and carries it downward, thus imparting the quality of hardness to the waters of the underlying Citronelle formation. The degree of hardness varies greatly, however, from place to place and is by no means generally excessive. In fact, the waters of many wells and springs that furnish domestic supplies have their source in this formation. Where the loess is thick and the water of the underlying Citronelle formation is so hard as to render it unsatisfactory for domestic use, the problem of providing a suitable water supply is generally solved by constructing cisterns for storing rain water. The records show that many cisterns are in use throughout the county.

In the east, where the surficial covering of loess is only a few feet thick and the underlying Citronelle formation is not more than 50 or 60 feet thick, many of the dug and bored wells penetrate both the loess and Citronelle and tap water-bearing sands interstratified with the underlying Hattiesburg clay. The water-bearing material in this formation, according to some of the well owners, is "pipe" clay, but as clay is generally impervious the water probably comes from thin layers of sand interbedded with the clay.

A very promising undeveloped source of water in this county is the Catahoula sandstone, which underlies the Hattiesburg clay. The 
Catahoula consists of several hundred feet of irregularly bedded sandstone, sand, and clay, and the more porous lenses and layers of sand are water bearing. At Port Gibson, in Claiborne County, where the municipal water supply is obtained from the Catahoula, the base of the formation lies at a depth of 314 feet, or approximately 200 feet below sea level. The southward dip of the Catahoula is estimated to be between 15 and 20 feet to the mile. If 20 feet is assumed to be the rate the base of the formation in the northern part of Jefferson County would be 320 feet below sea level, or 400 to 650 feet below the surface of the ground. If the Catahoula is 500 feet thick water could be obtained from it here at depths of 100 feet or less to 650 feet, the depth depending upon the location and the altitude of the surface. The assumed southward dip would carry the base of the Catahoula to a depth of about 700 feet below sea level, or 800 to 1,100 feet below the surface of the ground, along the southern border of the county. Here the water should be obtained from the formation at depths of 300 to 1,100 feet. It is doubtful if the static head of the water of the Catahoula would be high enough to afford flows anywhere in the county.

In the Mississippi lowland, in the western part of the county, an abundance of water can be obtained from the sands and gravels of the alluvial deposits at depths of a few feet to 150 or 200 feet. Water from depths of 50 feet or less, however, is subject to pollution from surface sources and should be used with caution.

\section{LOCAL SUPPLIES}

Fayette.-Fayette, the county seat, is provided with a public waterworks located about 450 feet west of the post office, and obtains water from a nonflowing well 265 feet deep (No. 1). The log of a typical well used for domestic and farm supply in the vicinity of Fayette is given below.

Log of well of M. P. McGarry, 6 miles southeast of Fayette (No. 2)

[Authority, the owner]

\begin{tabular}{|c|c|c|}
\hline & Thickness & Depth \\
\hline Loess: Clay & Feet ${ }_{20}$ & \\
\hline $\begin{array}{l}\text { Oitronelle formation: } \\
\text { Red sand } \\
\text { White sand and gravej; water bearing. }\end{array}$ & $\begin{array}{l}40 \\
30\end{array}$ & 80 \\
\hline
\end{tabular}

Analysis 4 represents a sample of water from a 46-foot dug well owned by Mrs. Kate M. Doyle, 1,000 feet northeast of the Yazoo \& Mississippi Valley Railroad station. So far as reported, the deepest well that has been drilled in the county is the 2,575-foot oil-prospecting well of the Lake Truly Oil Co., at Lake Truly, in the Mississippi lowland, 16 miles west of Fayette. The $\log$ of this well was published 
in $1919 .^{39}$ The water-bearing beds were not indicated in this log. The well penetrated first an undetermined thickness, probably 150 or 200 feet, of river alluvium, below which followed in succession the Tertiary Catahoula sandstone (Miocene), Vicksburg group (Oligocene), Jackson formation (Eocene), and Claiborne group (Eocene). Of these only the Lisbon formation of the Claiborne group has been discriminated with certainty. Fossils obtained between depths of 2,181 and 2,205 feet were identified by C. W. Cooke, who referred them to the Lisbon. The well probably did not penetrate to the base of the Claiborne group.

Eastern part of the county.-The eastern part of the county is well supplied with ground water for domestic and farm use, which is obtained by dug and bored wells that range in depth from a few feet to 100 feet or more. A few typical wells at Loedo, $\mathrm{McBride}, \mathrm{McNair}$, and Union Church, are described in the table of well data (Nos. 5-18). The source of these waters is the Citronelle formation and sandy layers interbedded in the underlying Hattiesburg clay. The logs of two wells near Leedo and one at Union Church are given below.

Log of well of N.H. Buie, 2 miles southeast of Leedo, in the SE. 1/4 NE. 1/4 sec. 34, T. 8 N., R. 4 E. (No. 5)

[Authority, the owner]

\begin{tabular}{|c|c|c|}
\hline & Thickness & Depth \\
\hline (190. & Feet 6 & Feat \\
\hline $\begin{array}{l}\text { litronelle formation (?): Sand } \\
\text { Hattiesburg clay (?): Quicksand; water bearing }\end{array}$ & $\begin{array}{r}54 \\
24\end{array}$ & $\begin{array}{l}60 \\
84\end{array}$ \\
\hline
\end{tabular}

Log of well of J. E. McCaa, 3 miles southwest of Leedo, in sec. $31, T .8$ N., R. 4 E., (No.8)

[Authority, the owner]

\begin{tabular}{|c|c|c|}
\hline & Thickness & Depth \\
\hline Loess: Clay & ${ }_{10}$ & \\
\hline $\begin{array}{l}\text { Citronelle formation: } \\
\text { Sand }\end{array}$ & 59 & 69 \\
\hline $\begin{array}{l}\text { Rocks (gravel?) } \\
\text { Hattiesburg clay: Pipe clay (interbedded with sand?); water bearing }\end{array}$ & 20 & $\begin{array}{l}70 \\
90\end{array}$ \\
\hline
\end{tabular}

Log of well of L. A. Cato, Union Church, in NW. 1/4 NW. 1/4 sec. 10, T. 8 N., R. 4 E. (No. 16)

[Authority, the owner]

\begin{tabular}{|c|c|c|}
\hline & Thickness & Depth \\
\hline $\begin{array}{l}\text { Loess(?): Red clay } \\
\text { Citronelie formation: Sand and gravel; water bearing in lower io foet..... }\end{array}$ & Feet ${ }_{45}{ }_{45}$ & Feet ${ }_{150}$ \\
\hline
\end{tabular}

${ }^{90}$ Lowe, E. N., Oil and gas prospecting in Mississippi: Mississippi Geol. Survey Bull. 15, pp. 61-64, 1919, 


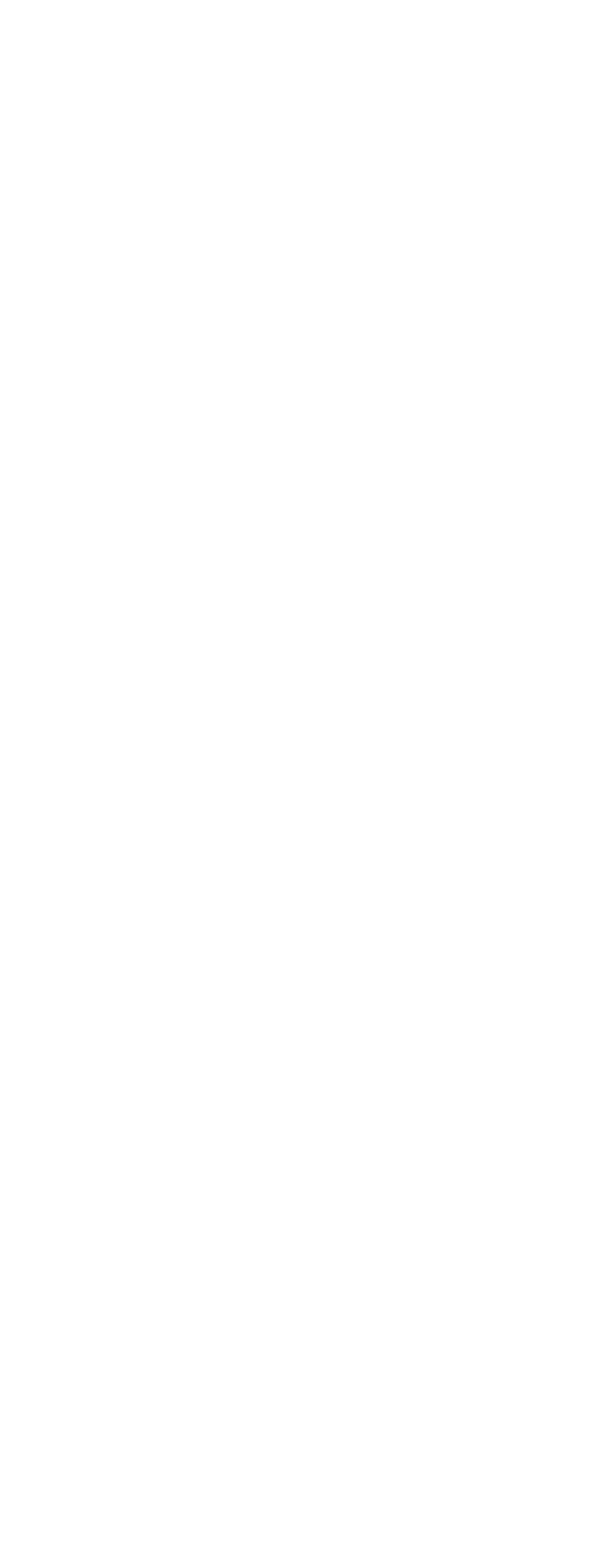




\begin{tabular}{|c|c|c|c|}
\hline 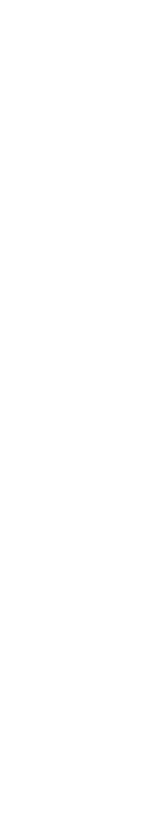 & 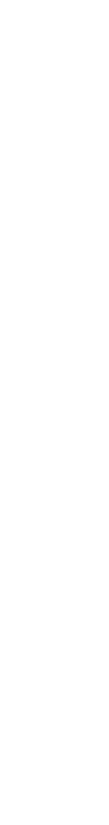 & 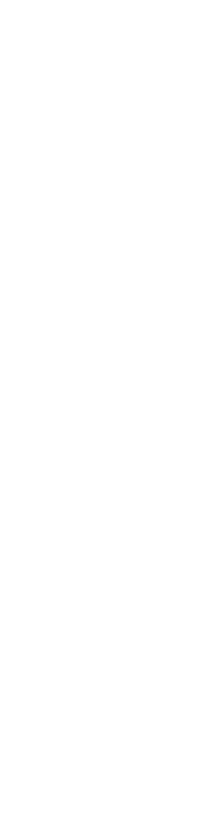 & 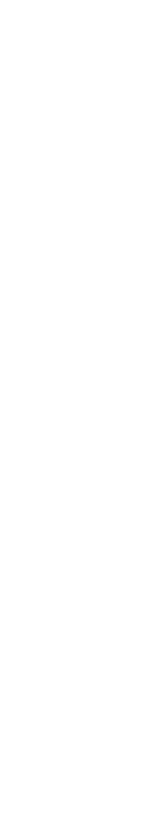 \\
\hline 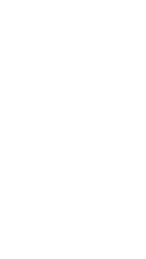 & 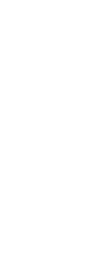 & 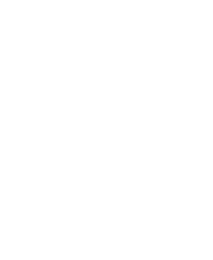 & 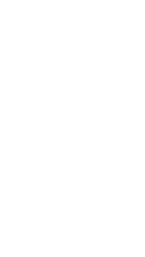 \\
\hline 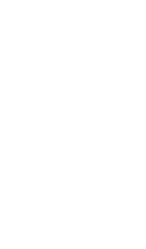 & 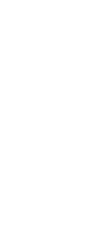 & 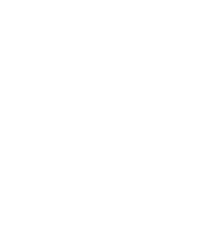 & 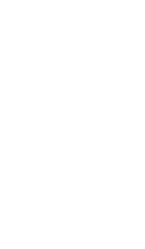 \\
\hline$\stackrel{\mathscr{D}}{\circ}$ & 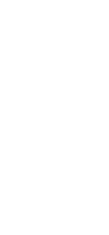 & 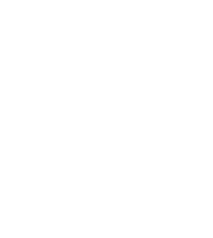 & 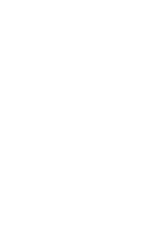 \\
\hline 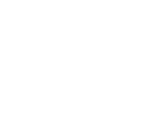 & 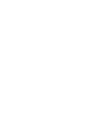 & 氙: & 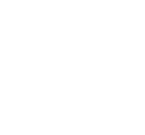 \\
\hline 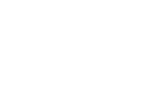 & $\cong$ & & \\
\hline ì & -1 & 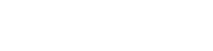 & 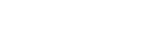 \\
\hline
\end{tabular}


Mineral analyses of ground waters from Jefferson County

[Parts per million. Samples collected July 7, 1919; analyzed by Margaret D. Foster, U. S. Geologica] Survey. Numbers at heads of columns refer to corresponding well numbers in preceding table]

\begin{tabular}{|c|c|c|}
\hline & 1 & 4 \\
\hline 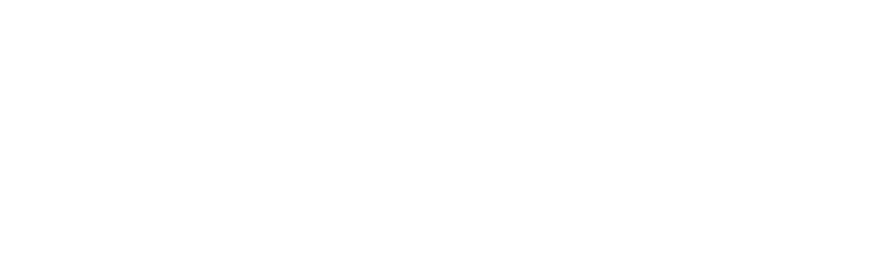 & $\begin{array}{c}47 \\
1.6 \\
18 \\
7.2 \\
30 \\
\text { Trace. } \\
146 \\
9.9 \\
6.6 \\
189^{\circ} \\
71\end{array}$ & $\begin{array}{r}59 \\
2.0 \\
18 \\
8.0 \\
36 \\
140^{.0} \\
4.3 \\
26 \\
224^{-78} \\
78\end{array}$ \\
\hline
\end{tabular}

\section{JEFFERSON DAVIS COUNTY}

GENERAL FEATURES

\section{Area, 404 acres. Population, 12,755 (census of 1920)}

Jefferson Davis County lies between the valleys of Pearl and Leaf Rivers in south-central Mississippi, in the Long-leaf Pine Hills district. The three principal formations that crop out in the county are the Catahoula sandstone (Miocene), the Hattiesburg clay (Miocene), which overlies the Catahoula, and the Citronelle formation (Pliocene), which overlaps both the older formations. These formations are described on pages 55-60, and their distribution is shown on the geologic map (pl. 2).

\section{GROUND-WATER, CONDITIONS}

The Citronelle formation makes up the upper 50 to 100 feet or more of the hills throughout the county. The more porous beds of sand and gravel are water bearing and constitute the principal source of domestic water supply, which is obtained by digging or boring wells to depths of 20 to 150 feet or more. Quantities adequate to. satisfy the demands of the house and farm are easily obtainable at most places in this way. Small springs, which also have their source in the sands and gravels of the Citronelle formation, are common, and some of them are used.

Throughout all but the extreme northeastern part of the county the Citronelle formation is immediately underlain by the Hattiesburg clay, a formation that is about 400 feet thick where it is fully developed. Though it is composed chiefly of clay, the Hattiesburg clay also contains interbedded layers of sand, some of which may be water bearing. A few of the deeper wells, as, for example, wells at Bassfield, which are reported to be 160 to 170 feet deep, may tap water-bearing beds in the Hattiesburg.

The Hattiesburg clay is underlain by the Catahoula sandstone, a formation which consists of approximately 400 feet of irregularly bedded sandstone, sand, and clay, including beds of porous water- 
bearing sand. In the northeast the Catahoula formation immediately underlies the Citronelle formation and crops out on the lower slopes of the valleys, but within a few miles to the southwest it passes beneath the Hattiesburg clay at a rate of dip sufficient to carry its uppermost bed to a depth of 400 or 500 feet below the surface in the valley of Pearl River, in the extreme southwestern part of the county. The Catahoula sandstone may therefore be regarded as a promising source of deep well water throughout the area. In the extreme northeastern part of the county wells, after passing through as much of the surficial Citronelle formation as happened to be locally present, would penetrate the Catahoula formation to depths of perhaps 400 or 500 feet. To the southwest the depth of the formation increases, until in the lowland of Pearl River wells, after passing through 400 to 500 feet of Hattiesburg clay, would penetrate the Catahoula to a depth of 800 or 900 feet. The static head of the waters in this formation is probably high enough to produce flowing wells in the lowland of Pearl River, and perhaps also low in the valleys of some of the larger creeks, such as White Sand, Greene, and Bowie. Elsewhere the water would have to be raised to the surface by means of buckets or pumps, and on most of the upland deep-well pumps would have to be used. The well at the municipal waterworks at Prentiss probably derives its supply from the upper part of the Catahoula.

\section{LOCAL SUPPLIES}

Prentiss.-Prentiss, the county seat, is provided with a waterworks, in a valley 350 feet west of the Mississippi Central Railroad station, which obtains water from an 8 -inch nonflowing well $1461 / 3$ feet deep. The source of the water is gravel and sand of the Catahoula sandstone, which is penetrated in the lower 14 feet of the well; the water rises within 18 feet of the surface and is pumped at the rate of 75 gallons a minute. An 8-inch casing, including the strainer extends to the bottom of the well. An analysis of the water is given below:

Mineral analysis of water from 146-foot well of the town of Prentiss, Jefferson Davis County

[Sample collected Dec. 9, 1920; analyzed by C. S. Howard, U. S. Geological Survey]

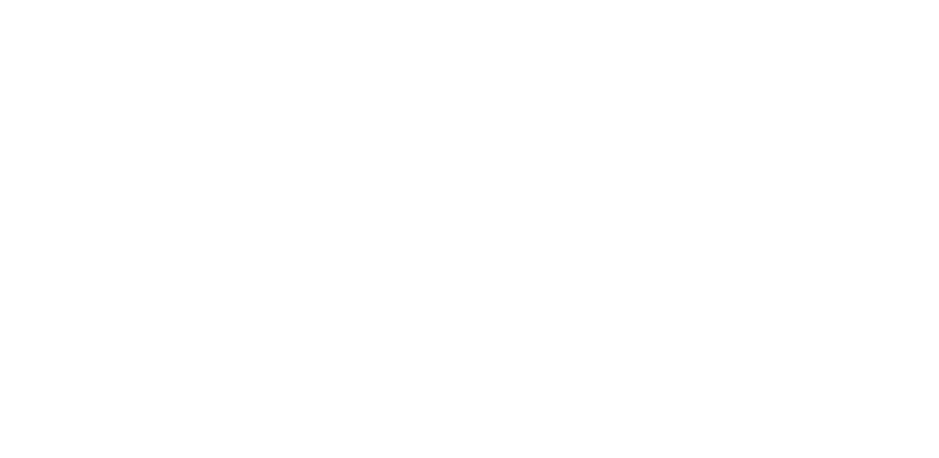


The log of the well of W. M. Hathorn, a typical bored well, located on the upland about 14 miles south of Prentiss, in the SE. 1/4 sec. 10, T. 5 N., R. 19 W., is given below. The well is 10 inches in diameter. The water is derived from sand and gravel in the Citronelle formation at a depth of 77 to 83 feet and is under little or no artesian pressure.

Log of well of W. M. Hathorn, 14 miles south of Prentiss, $21 / 2$ miles northeast of Hathorn

[Authority, the owner]

\begin{tabular}{|c|c|c|}
\hline & $\begin{array}{c}\text { Thick- } \\
\text { ness }\end{array}$ & Depth \\
\hline $\begin{array}{l}\text { Citronelle formation: } \\
\text { Sand and clay } \\
\text { Ore rock, sand, and chaik (clay) } \\
\text { Chalk (clay) and sand. } \\
\text { Sand and gravel with white pebbles; water bearing }\end{array}$ & $\begin{array}{r}F e e t \\
20 \\
53 \\
4 \\
6\end{array}$ & $\begin{array}{r}\text { Feet } \\
20 \\
73 \\
77 \\
83\end{array}$ \\
\hline
\end{tabular}

A similar well, owned by J. C. Hathorn, located on a slope in the NW. $1 / 4$ sec. 10 , is 85 feet deep and obtains water from a bed of black gravel with small pebbles in the Citronelle formation.

\section{JONTES COUNTY}

\section{GENERAL FEATURES}

Area, 696 square miles. Population, 32,919 (census of 1920)

Jones County lies in the Long-leaf Pine Hills district. One geologic formation, the Catahoula sandstome (Miocene), underlies practieally the entire county, though it is overlapped in the south by the next younger formation, the Hattiesburg clay (Miocene), and thin remnants of still younger sand and gravel of the Citronelle formation (Pliocene), which occur on many of the hills, rest on the Hattiesburg clay in the south and on the Catahoula formation throughout the remainder of the area to the north. Relatively thin surficial deposits of gravel, sand, clay, and loam are present on the narrow terraces and flood plains that border the larger streams. Beneath the Catahoula sandstone, but not appearing at the surface within the county lies a thick succession of marl, limestone, clay, and sandstone, which compose the part of the Tertiary system that is older than the Catahoula. These beds include in deseending order the Vicksburg group, the Jackson formation, and the Claiborne, Wilcox, and Midway groups. At still greater depths beneath the Tertiary deposits lie the rocks of the Cretaceous system, but these are too far below the surface to require consideration here. The character and thickness of the geologic formations mentioned in this paragraph are described on pages 29-63, and their approximate distribution in the county may be ascertained from the geologic map (pl. 2). 


\section{GROUND-WATER CONDITIONS}

The Catahoula sandstone, which increases in thickness from less than 100 feet in the northeast to perhaps 500 feet in the south, is the principal developed source of ground water. Large quantities of water are obtainable in places in the formation, as shown by the records in the table. Many of these wells tap water-bearing sands in the Catahoula. The static level of the waters of the Catahoula is high enough in the southern part of the county to produce flowing wells in the lowlands that border some of the larger streams, such as Leaf River and Bogue Homo (Nos. 6, 22-24). Throughout the area of its outcrop the Catahoula is the source of small to medium-sized springs, most of which yield water of excellent quality for ordinary uses.

The Hattiesburg clay, which overlaps the Catahoula in the south, is not regarded as a probable source of large quantities of water because of the impervious nature of the clay of which it is chiefly composed; but the formation contains some sandy layers and may be the source of some domestic water supplies in the area of its outcrop.

The sand and gravel deposits that cap many of the hills of the area, and likewise the coarser sand and gravel that form the base of the terrace deposits which border the streams, are doubtless the source of springs and of the water obtained in some of the shallow dug and bored wells.

The 1,000-foot and 1,316-foot wells at the waterworks at Laurel probably tap water-bearing beds in the Lisbon, the middle formation of the Claiborne group. The waters from the last-mentioned wells are reddish in color, and in this respect resemble the water from the Lisbon in Clarke and Wayne Counties. (See pp. 121, 484.) The water-bearing sands of the Lisbon are tapped by wells 500 feet deep at Waynesboro in Wayne County, on the east; by wells 525 feet deep at Louin, in Jasper County, on the north; and by one well 1,135 feet deep at Taylorsville, in Smith County, on the northwest. In Jones County the Lisbon is estimated to lie at depths of 500 to 600 feet in the northeast to 1,500 or 2,000 feet in the south and southwest.

\section{LOCAL SUPPLIES}

Laurel.-Many wells, which range in depth from 50 to 412 feet, have been bored and drilled at and in the vicinity of Laurel. The source of the water in all of them is probably the Catahoula formation. Most of these wells are capable of furnishing moderate to large quantities of water. The logs of two wells (Nos. 13, 14) given below show the character of the materials that compose the Catahoula formation. The waterworks at Laurel is owned by the town and is half a mile 
west of the post office. Water is obtained from three wells at the plant, two of which are 400 feet deep and the third 412 feet deep. (See Nos. 7, 8.) Two wells at the waterworks (Nos. 9, 10) 1,000 and 1,316 feet deep, yield water which on account of its reddish color is not used as a part of the city supply. The log of the deeper of these wells is given below.

Log of deep well at the waterworks at Laurel

[Authority, J. H. Miller, chief engineer]

\begin{tabular}{|c|c|c|c|c|c|}
\hline . & $\begin{array}{c}\text { Thick- } \\
\text { ness }\end{array}$ & Depth & & $\begin{array}{c}\text { Thick- } \\
\text { ness }\end{array}$ & Depth \\
\hline $\begin{array}{l}\text { Sand and clay } \\
\text { Tough gumbo } \\
\text { Sandrock } \\
\text { Sand } \\
\text { Gumbo } \\
\text { Hard sand } \\
\text { Water sand. } \\
\text { Soapstone. } \\
\text { Humbord sand } \\
\text { Water sand } \\
\text { Gumbo } \\
\text { Sande } \\
\text { Gumbo } \\
\text { Hard sand } \\
\text { Rock } \\
\text { Gumbo } \\
\text { Soapstone } \\
\text { Gumbó. } \\
\text { Shale } \\
\text { Gumbo. } \\
\text { Rock } \\
\text { Gumbo. } \\
\text { Rock } \\
\text { Shale. } \\
\text { Rock } \\
\text { Shale. } \\
\text { Soft rock } \\
\text { Shale } \\
\text { Gumbo } \\
\text { Sand }\end{array}$ & $\begin{array}{r}\text { F'eet } \\
35 \\
7 \\
1 \\
18 \\
74 \\
12 \\
15 \\
8 \\
20 \\
10 \\
10 \\
102 \\
79 \\
7 \\
14 \\
7 \\
31 \\
141 \\
21 \\
12 \\
9 \\
23 \\
3 \\
13 \\
1 \\
2 \\
3 \\
11 \\
2 \\
32 \\
21 \\
6\end{array}$ & $\begin{array}{c}\text { Feet } \\
35 \\
42 \\
43 \\
61 \\
135 \\
147 \\
162 \\
170 \\
190 \\
200 \\
210 \\
312 \\
391 \\
398 \\
412 \\
419 \\
4221 \\
437 \\
458 \\
470 \\
479 \\
502 \\
505 \\
518 \\
519 \\
521 \\
524 \\
535 \\
537 \\
569 \\
590 \\
596\end{array}$ & 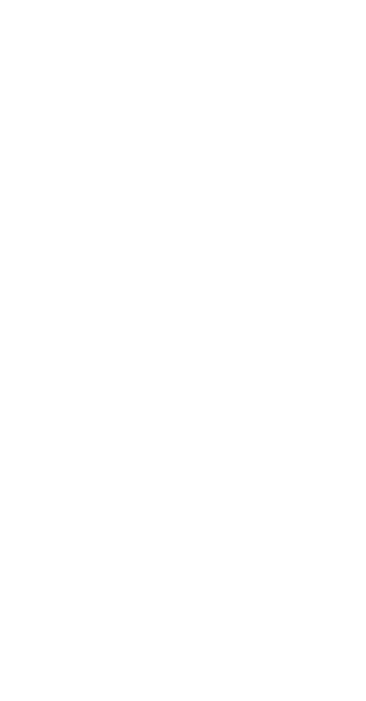 & $\begin{array}{r}\text { Feet } \\
25 \\
37 \\
10 \\
79 \\
30 \\
28 \\
55 \\
34 \\
25 \\
15 \\
5 \\
38 \\
17 \\
7 \\
10 \\
29 \\
4 \\
29 \\
2 \\
29 \\
2 \\
12 \\
51 \\
3 \\
3 \\
5 \\
14 \\
12 \\
100 \\
10\end{array}$ & $\begin{array}{r}\text { Feet } \\
621 \\
658 \\
668 \\
747 \\
777 \\
805 \\
860 \\
894 \\
919 \\
934 \\
939 \\
977 \\
994 \\
1,001 \\
1,011 \\
1,040 \\
1,044 \\
1,073 \\
1,075 \\
1,104 \\
1,106 \\
1,118 \\
1,169 \\
1,172 \\
1,175 \\
1,180 \\
1,194 \\
1,206 \\
1,306 \\
1,316\end{array}$ \\
\hline
\end{tabular}

Logs of two wells of the Wausau Southern Lumber Co. (Nos. 13 and 14) are given below.

Log of well of Wausau Southern Lumber Co., a mile south of Laurel, in sec. 8, T. $8 \mathrm{~N} ., R .11 \mathrm{~W}$.

[Altitude of mouth of well 243 feet above sea level. Authority, Layne \& Bowler Co., B. H. Putnam, driller in charge; log furnished by the Wausau Southern Lumber Co.]

\begin{tabular}{|c|c|c|c|c|c|}
\hline & $\begin{array}{c}\text { Thick- } \\
\text { ness }\end{array}$ & Depth & & $\begin{array}{l}\text { Thick- } \\
\text { ness }\end{array}$ & Depth \\
\hline $\begin{array}{l}\text { Catahoula sandstone: } \\
\text { Red clay } \\
\text { Very fine white sand } \\
\text { Blue clay } \\
\text { Coarse sand........ }\end{array}$ & $\begin{array}{rr}\text { Ft. } \\
4 & \text { in. } \\
54 & 0 \\
8 & 0 \\
16 & 0\end{array}$ & $\begin{array}{cc}\text { Ft. in. } \\
4 \\
58 & 0 \\
66 & 0 \\
82 & 0\end{array}$ & $\begin{array}{l}\text { Catahoula sandstone-Contd. } \\
\text { White gumbo } \\
\text { Fine floating sand } \\
\text { Coarse sand; water bearing } \\
\text { Gumbo }\end{array}$ & $\begin{array}{cc}\text { Ft. } & \text { in. } \\
47 & 5 \\
30 & 6 \\
93 & 0 \\
19 & 6\end{array}$ & $\begin{array}{lr}F t . & i n . \\
129 & 5 \\
159 & 11 \\
252 & 11 \\
272 & 5\end{array}$ \\
\hline
\end{tabular}


Log of well of Wausau Lumber Co., at Laurel

\begin{tabular}{|c|c|c|c|c|c|}
\hline & $\begin{array}{c}\text { Thick- } \\
\text { ness }\end{array}$ & Depth & & $\begin{array}{c}\text { Thick- } \\
\text { ness }\end{array}$ & Depth \\
\hline $\begin{array}{l}\text { Catahoula sandstone: } \\
\text { Red clay } \\
\text { White kaolin } \\
\text { Sandy gray clay } \\
\text { Hard blue clay } \\
\text { Gray sandy clay } \\
\text { Soft yellow clay } \\
\text { Olive-green clay }\end{array}$ & $\begin{array}{r}\text { Feet } \\
12 \\
8 \\
40 \\
27 \\
44 \\
29 \\
14\end{array}$ & $\begin{array}{r}\text { Feet } \\
12 \\
20 \\
60 \\
87 \\
131 \\
160 \\
174\end{array}$ & $\begin{array}{l}\text { Catahoula sandstone-Contd. } \\
\text { Clay and sand pockets. } \\
\text { Blue clay } \\
\text { Gray sand. } \\
\text { Clay, pand pockets and clay } \\
\text { Sand; water bearing } \\
\text { Clay.... }\end{array}$ & $\begin{array}{r}\text { Feet } \\
30 \\
17 \\
8 \\
7 \\
20 \\
42 \\
1\end{array}$ & $\begin{array}{r}\text { Feet } \\
204 \\
221 \\
229 \\
236 \\
256 \\
298 \\
299\end{array}$ \\
\hline
\end{tabular}

Analysis 26 represents water from a spring on the farm of $\mathrm{B}$. F. Stoltzfus, $13 / 4$ miles east of the post office at Laurel, 380 feet north of Mr. Stoltzfus's house. The spring emerges from sand and clay probably belonging to the Citronelle formation, exposed on a hill slope. Analysis 27 represents water from the spring of T. G. McCallum, a mile west of Laurel, which probably has its source in the Citronelle formation.

Ellisville.-The waterworks at Ellisville is half a mile southwest of the post office and east of the New Orleans \& Northeastern Railroad, and the water supply is obtained from a flowing well at the plant (No. 4), the reported depth of which is 540 feet. (See analysis 4.) Prior to the drilling of the 540-foot well a public well was drilled to a depth of 1,400 feet without obtaining an adequate supply of water, and the well was abandoned. The log of this well is given below.

Log of the old well owned by the town of Ellisville a

[Altitude of mouth of well about 243 feet above sea level. Authority, W. N. Logan and W. R. Perkins]

\begin{tabular}{|c|c|c|c|c|c|}
\hline & $\begin{array}{c}\text { Thick- } \\
\text { ness }\end{array}$ & Depth & & $\begin{array}{l}\text { Thick- } \\
\text { ness }\end{array}$ & Depth \\
\hline $\begin{array}{l}\text { Sand and gravel } \\
\text { Green clay..... } \\
\text { Sand; water bearing }(?) \\
\text { Green clay } \\
\text { Sandrock }\end{array}$ & $\begin{array}{r}\text { Feet } \\
80 \\
280 \\
10 \\
230 \\
12\end{array}$ & $\begin{array}{r}\text { Feet } \\
80 \\
360 \\
370 \\
600 \\
612\end{array}$ & $\begin{array}{l}\text { Greenish marl } \\
\text { Shell rock } \\
\text { Green marl } \\
\text { Shells } \\
\text { Green marl }\end{array}$ & $\begin{array}{r}\text { Feet } \\
288 \\
5 \\
195 \\
5 \\
295\end{array}$ & $\begin{array}{l}\text { Feet } \\
900 \\
905 \\
1,100 \\
1,105 \\
1,400\end{array}$ \\
\hline
\end{tabular}

- Mississippi Agr. Exper. Sta. Bull. 89, p. 62, 1905.

Ovett.- Flowing water has been obtained from the Catahoula formation at Ovett in the valley of Bogue Homo and for several miles both above and below the town, at depths of 150 and 300 feet. Three wells at Ovett are described in the table (Nos. 22-24).

Moselle.-A well seven-eighths of a mile south of Moselle, at Albeison (No. 19), owned by P. M. Ikeler, is 525 feet deep and yields an adequate supply of nonflowing water for domestic use. (See analysis 19.)

Estabuchie.-A semipublic drinking place at Estabuchie is afforded by a flowing well, 360 feet deep (No. 6), which is owned jointly by the town and Mrs. Jennie Baylis. The log of a privately owned nonflowing well, 5 miles northeast of Moselle, is given below. 
Log of well of Margaret Overland, 5 miles northeast of Moselle, in the NW. 1/4 sec. 30, T. Y N., R. 12W. (No. 20)

[Authority, the owner]

\begin{tabular}{|c|c|c|}
\hline & Thickness & Depth \\
\hline $\begin{array}{l}\text { Hard yellow clay } \\
\text { Soft red sand. } \\
\text { Chalk (white clay) } \\
\text { Red quicksand; water bearing }\end{array}$ & $\begin{array}{r}\text { Beet } \\
12 \\
20 \\
10 \\
16\end{array}$ & $\begin{array}{r}\text { Feet } \\
12 \\
32 \\
42 \\
58\end{array}$ \\
\hline
\end{tabular}

The water-bearing sand indicated in this $\log$ is probably near the top of the Catahoula formation.

Blodgett.-The log of a well (No. 2) owned by the Griffin Lumber Co., at Blodgett, 3 miles southeast of Orett, is given below.

Log of well of Griffin Lumber Co., at Blodgett

\begin{tabular}{|c|c|c|c|c|c|}
\hline & Thick- & Depth & & $\begin{array}{c}\text { Thick- } \\
\text { ness }\end{array}$ & Depth \\
\hline $\begin{array}{l}\text { Hattiesburg clay: Chalk (clay) } \\
\text { Catahoula sandstone(?): } \\
\text { Fine sand. } \\
\text { Blue marl } \\
\text { Fine sand. }\end{array}$ & $\begin{array}{r}\text { Feet } \\
63 \\
10 \\
20 \\
10\end{array}$ & $\begin{array}{r}\text { Feet } \\
63 \\
73 \\
93 \\
103\end{array}$ & $\begin{array}{l}\text { Catahoula sandstone(?)-Contd. } \\
\text { Blue marl } \\
\text { Fine sand } \\
\text { Blue gumbo } \\
\text { Fine sand.-.joaring } \\
\text { Sand; water bearing }\end{array}$ & \begin{tabular}{r|} 
Feet \\
47 \\
10 \\
22 \\
34 \\
15916
\end{tabular} & $\begin{array}{l}\text { Feet } \\
150 \\
160 \\
182 \\
216 \\
37516\end{array}$ \\
\hline
\end{tabular}




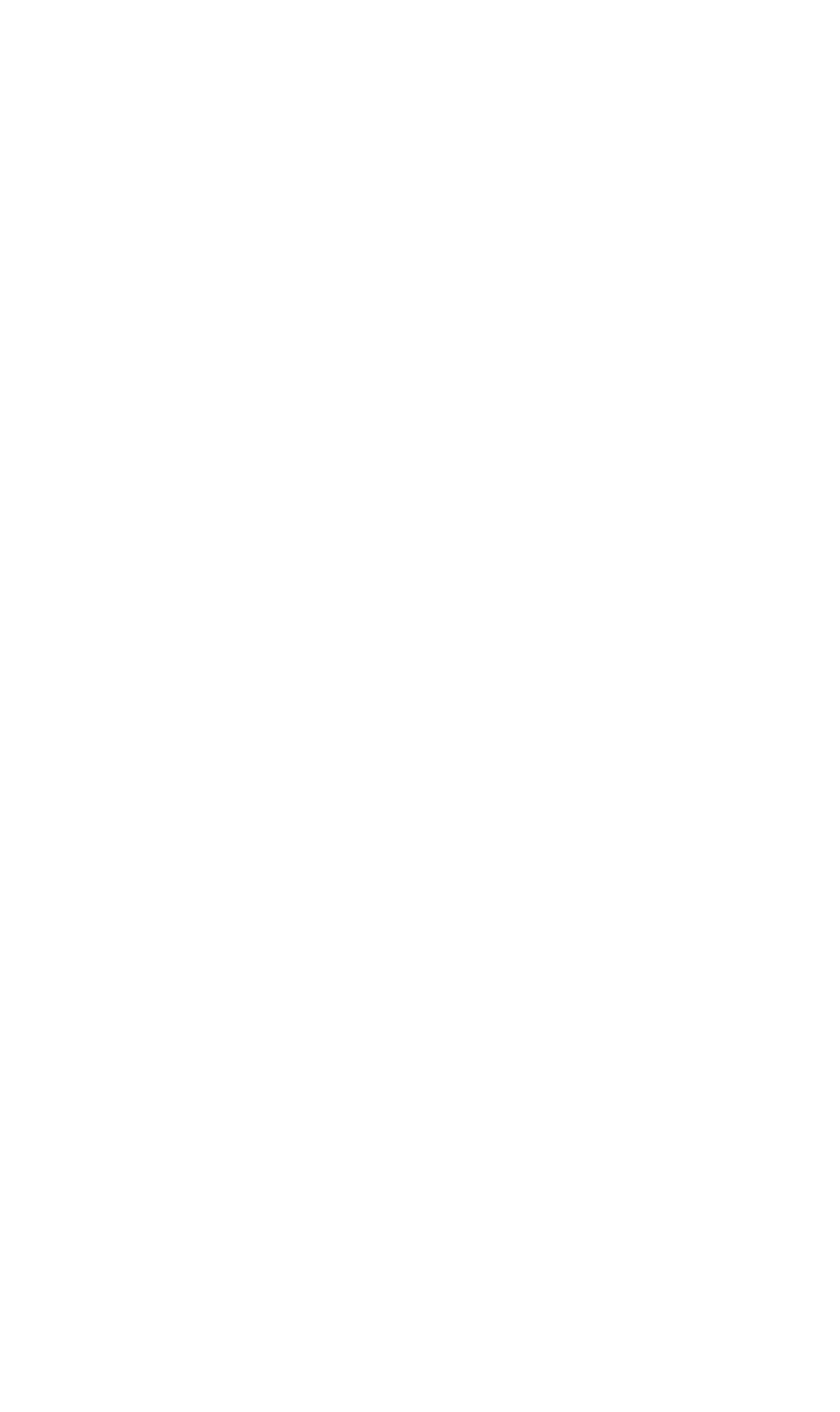




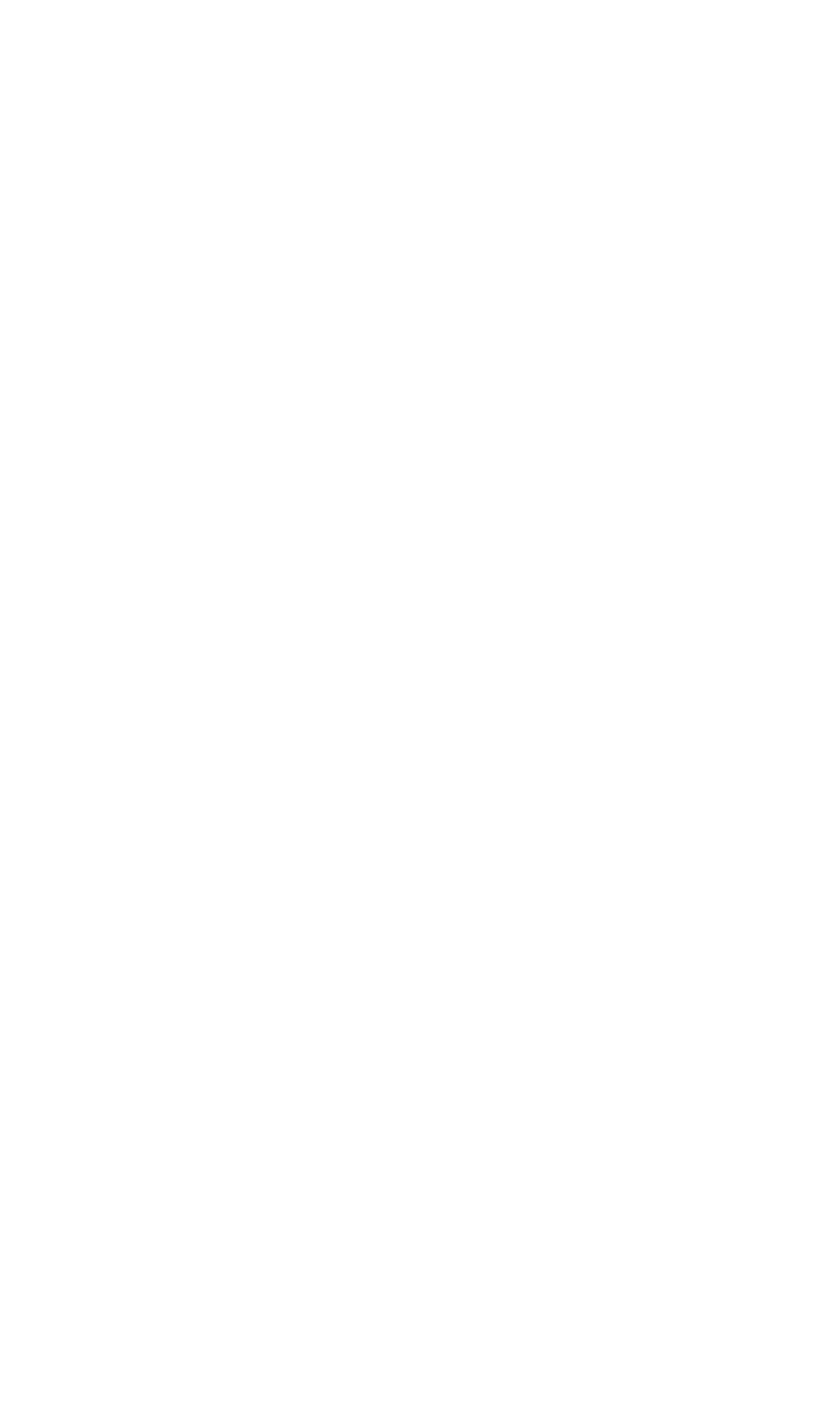


Mineral analyses of ground waters from Jones County

[Parts per million. Numbers at heads of columns refer to corresponding well numbers in preceding table]

\begin{tabular}{|c|c|c|c|c|c|}
\hline & 4 & 7 & 8 & 9 & 10 \\
\hline \multirow[t]{2}{*}{ 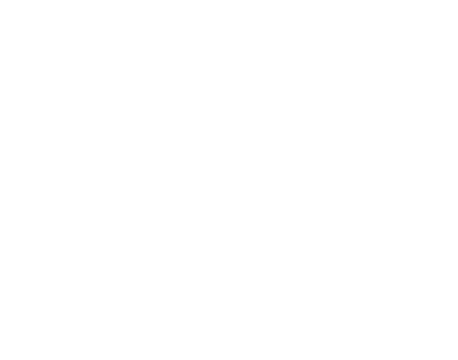 } & $\begin{array}{c}58 \\
.05 \\
3.5 \\
51^{-6} \\
\text { Trace. } \\
124 \\
12 \\
3.0 \\
\text { Trace. } \\
181 \\
11 \\
\text { Feb., } 1921\end{array}$ & 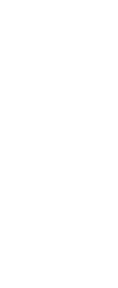 & $\begin{array}{l}20 \\
2.0 \\
11 \\
3.2 \\
18 \\
49^{\circ} .0 \\
16 \\
12 \\
97^{.60} \\
41 \\
\text { Feb., } 1912\end{array}$ & 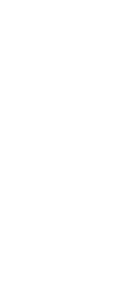 & $\begin{array}{c}17 \\
.22 \\
2.0 \\
1.6 \\
0348 \\
58 \\
800 \\
4.8 \\
7.0 \\
\text { Trace. } \\
862 \\
12 \\
\text { Dec., } 1920\end{array}$ \\
\hline & 11 & 15 & 19 & 26 & 27 \\
\hline 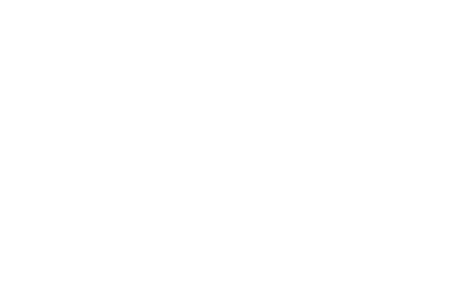 & $\begin{array}{c}13 \\
.24 \\
3.6 \\
2.7 \\
12.0 \\
34 \\
13 \\
3.0 \\
\text { Trace. } \\
\text { a } 64 \\
20 \\
\text { Aug., } 1919\end{array}$ & $\begin{array}{r}34 \\
1.7 \\
2.8 \\
1.9 \\
13 \\
37^{-0} \\
6.3 \\
4.1 \\
\text { Trace. } \\
79 \\
15 \\
\text { Aug., } 1919\end{array}$ & $\begin{array}{c}20 \\
4.3 \\
11 \\
3.6 \\
47^{2} \\
13 \\
129 \\
12 \\
3.5 \\
179^{-21} \\
42 \\
\text { Aug., } 1919\end{array}$ & $\begin{array}{c}17 \\
.94 \\
1.6 \\
1.0 \\
7.2 \\
13.0 \\
13.9 \\
2.9 \\
4.5 \\
4.5 \\
46 \\
8 \\
\text { Aug., } 1919\end{array}$ & $\begin{array}{c}10 \\
1.0 \\
1.3 \\
1.2 \\
10.0 \\
9.8 \\
4.5 \\
8.0 \\
.00 \\
34^{8} \\
\text { June, } 1915\end{array}$ \\
\hline
\end{tabular}

a Calculated.

Analysts: 4, 10, C. S. Howard, U. S. Geological Survey; 7, 8, 9, Mississippi State Chemical Laboratory; $11,15,19,26$, Margaret D. Foster, U. S. Geological Survey; 27, W. F. Hand, Mississippi State Chemical Laboratory.

\section{KEMPER COUNTY}

\section{GENERAL FEATURES}

Area, 752 square miles. Population, 19,619 (census of 1920)

More than half of Kemper County lies in the North Central Hills district, but the eastern part lies within the Flatwoods district and the Black Prairie belt. The upland part of the county is underlain by the Ackerman and Holly Springs formations of the Wilcox group; the Black Prairie belt by the Selma chalk; and the Flatwoods area by the Porters Creek clay. These formations are more fully described on pages 36-46, and their distribution is shown on the geologic map (pl. 2).

\section{GROUND-WATER CONDITIONS}

The Selma chalk (maximum thickness 800 to 900 feet) and the overlying Porters Creek clay (probably about 100 feet thick) are not water bearing, with the exception of certain layers, which afford only small amounts of mineralized water, but the Selma serves to confine the waters that are contained in the deeply buried Eutaw formation and the still deeper Tuscaloosa formation. In both the Black Prairie and the Flatwoods water is therefore obtained by drilling through the Selma, or, through the Porters Creek and the Selma, 
where both formations are present, to the water-bearing beds of the underlying Eutaw and Tuscaloosa formations. In the extreme northeast, where the upper part of the Selma has been removed by erosion, the water-bearing beds of the Eutaw formation, about 400 feet thick, lie at depths of 650 to 750 feet, but the southwestward dip carries them to a depth of about 1,206 feet at Scooba and 1,319 feet at Electric Mills, 4 miles south of Scooba, on the Mobile \& Ohio Railroad, at which place wells have been drilled to them.

No wells deep enough to reach the water-bearing sands of the Tuscaloosa, which at Scooba and.Wahalak are estimated to lie at depths of 1,200 to 2,000 feet, have been reported.

Along the eastern border of the Flatwoods a few springs of very small yield appear to derive their supplies from the basal beds of the Porters Creek clay. Their waters as a rule are rather highly mineralized.

The remainder of the county southwest of the Flatwoods is underlain by the Wilcox group, including the Ackerman formation and the Holly Springs sand, both of which carry water in greater or less abundance. In this hilly district springs are common, and abundant supplies of water for domestic use can also be obtained by means of dug or bored wells, usually at depths of less than 100 feet.

\section{LOCAL SUPPLIES}

Binnsville.-At Binnsville and vicinity water is obtained from cisterns, ponds, and deep wells. Records of four wells are given in the table (Nos. 1-4). The wells range in depth from 800 to 868 feet, and all are drilled through the Selma chalk into the waterbearing sands of the Eutaw formation; the head is sufficient to bring the water close to the surface. In well No. 1 water was struck at depths of 340 and 500 feet, respectively, probably in sandy layers near the bottom of the Selma chalk, but the principal supply comes from sand beds in the Eutaw formation at depths of 650 and 750 feet. At a depth of 800 feet well No. 3 struck water which rose within 3 feet of the surface.

Wahalak.-The Minnie Portis spring (No. 11), one-fourth mile from the post office at Wahalak, owned by D. V. Portis, is a spring of small yield or in reality a well only 3 feet deep, which yields a mineralized water. (See pl. 5, B.) The spring has its source in the basal beds of the Porters Creek clay. The water is reputed to possess therapeutic properties and has been sold in small quantities. There is a public well 840 feet deep at Wahalak, which completely penetrates the Selma chalk, 800 feet thick, and enters a sandy water-bearing stratum at the top of the Eutaw formation. The water rises within 15 inches of the surface. 
Scooba.-The old town well at Scooba is 1,206 feet deep (No. 7); it was sunk through the basal beds of the Porters Creek clay and through the entire thickness of the Selma chalk into the Eutaw sands. Analysis 8 represents highly mineralized water from a shallow well known as the Mineral Well, which probably obtains its water from a sandy lens in the Porters Creek clay. The present municipal water supply at Scooba is obtained from a well (No. 9) that is reported to be about 1,238 feet deep. This well is owned by the Kemper Agricultural High School and is located near the school buildings, which are on a broad ridge about 53 feet, according to aneroid reading, above the Mobile \& Ohio Railroad track at the station. The water is highly mineralized, as is shown by analysis 9. A recently completed well (No. 10), owned by Gilbert \& Mooney, about 250 yards south of the Mobile \& Ohio Railroad station on ground about 3 feet lower than the track, flows a small stream at ground level. This water is to be used in the manufacture of ice.

Electric Mitls.-Electric Mills is a small lumber mill town on the Mobile \& Ohio Railroad, 4 miles south of Scooba. The town is supplied with water for domestic use and fire protection by a waterworks owned and operated by the Sumter Lumber Co. The source of the water is a well, $1,3781 / 2$ feet deep (No. 5), which taps a waterbearing sand in the Eutaw formation. This water is highly mineralized, as shown by analysis 5 .

Log of well of Sumter Lumber Co., Electric Mills (No. 5)

[Adapted from description furnished by Layne \& Bowler Co.; permission to publish dated Dec. 18, 1916]

\begin{tabular}{|c|c|c|c|c|c|}
\hline & $\begin{array}{c}\text { Thick- } \\
\text { ness }\end{array}$ & Depth & & $\underset{\text { ness }}{\text { Thick- }}$ & Depth \\
\hline $\begin{array}{l}\text { Eocene (weathered Porters } \\
\text { Creek clay): Red clay } \\
\text { Selma chalk: Soapstone. } \\
\text { Eutaw formation: } \\
\text { Very fine sand.............. } \\
\text { Hard rock } \\
\text { Hard gumbo } \\
\text { Shale } \\
\text { Gumbo and rock forma- } \\
\text { tion. }\end{array}$ & $\begin{array}{rr}\text { Ft. } & \text { in. } \\
39 & 5 \\
959 & 0 \\
& \\
5 & 0 \\
2 & 0 \\
67 & 11 \\
87 & 1 \\
58 & 0\end{array}$ & \begin{tabular}{rr}
\multicolumn{1}{l}{ It. } & in. \\
39 & 5 \\
998 & 5 \\
& \\
1,003 & 5 \\
1,005 & 5 \\
1,073 & 4 \\
1,160 & 5 \\
1,218 & 5
\end{tabular} & $\begin{array}{l}\text { Eutaw formation-Contd. } \\
\text { Hard shale } \\
\text { Gumbo } \\
\text { Very hard shale } \\
\text { Fine white sand; water } \\
\text { bearing } \\
\text { Hard gumbo. }\end{array}$ & $\begin{array}{rr}\text { Ft. } & \text { in. } \\
40 & 10 \\
40 & 4 \\
19 & 8 \\
50 & 3 \\
9 & 0\end{array}$ & $\begin{array}{ll}\text { Ft. } & \text { in. } \\
1,259 & 3 \\
1,299 & 7 \\
1,319 & 3 \\
1,369 & 6 \\
1,378 & 6\end{array}$ \\
\hline
\end{tabular}

Enondale.-At Enondale water is obtained chiefly from dug wells, 10 to 30 feet deep, in the sands of the Wilcox group. The dug well of J. A. Simmons (No. 6), on a small hill a quarter of a mile southwest of the post office, is 27 feet deep and yields soft water, locally called "freestone water," as contrasted with the hatd or calcareous water of the lime-bearing formations. 


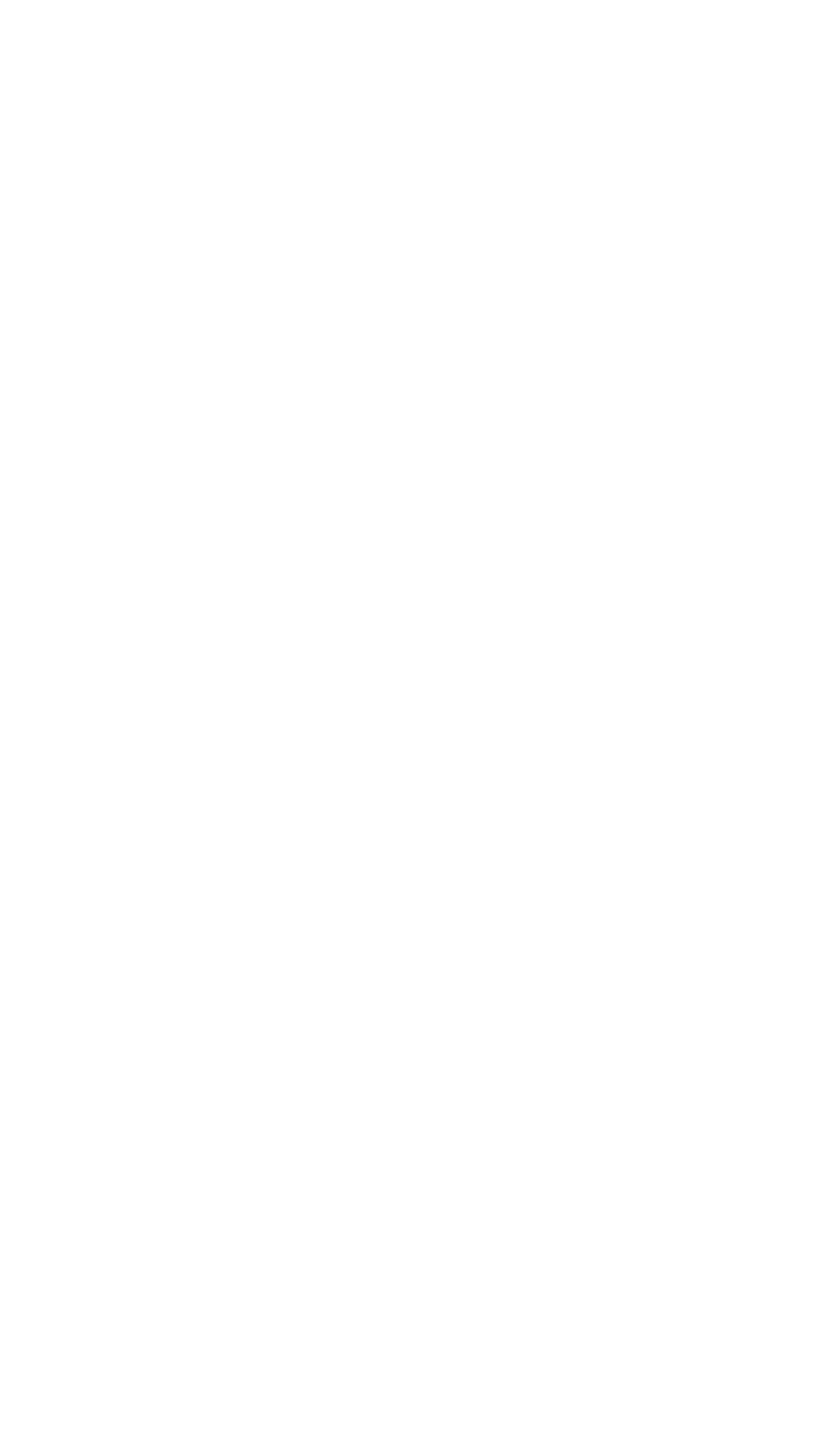


Mineral analyses of ground waters from Kemper County

[Parts per million. Numbers at heads of columns refer to corresponding well numbers in preceding table]

\begin{tabular}{|c|c|c|c|}
\hline & 5 & 8 & $\theta$ \\
\hline $\begin{array}{l}\text { Silica }\left(\mathrm{SiO}_{2}\right) \\
\text { Iron }(\mathrm{Fe}) \\
\text { Calcium } \\
\text { Magnesium }(\mathrm{M})\end{array}$ & $\begin{array}{c}28 \\
.20 \\
3.7 \\
1.6\end{array}$ & $\begin{array}{l}25 \\
25.1 \\
510 \\
238\end{array}$ & $\begin{array}{l}19 \\
.28 \\
8.1 \\
4.1\end{array}$ \\
\hline Sodium and potassium $(\mathrm{Na}+\mathrm{K})$ & 443 & $\begin{array}{l}\mathrm{Na} \\
\mathrm{K}\end{array}$ & \\
\hline 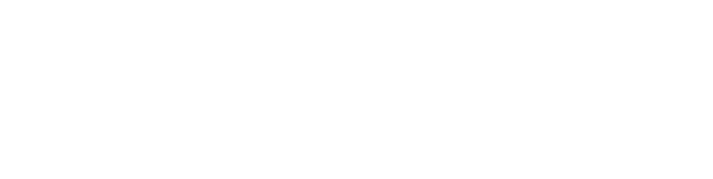 & $\begin{array}{c}30 \\
414 \\
3.4 \\
397 \\
1.1 \\
1,114 \\
16 \\
\text { Aug., } 1919\end{array}$ & $\begin{array}{c}983^{\circ} \\
774 \\
934 \\
23,287 \\
2,250\end{array}$ & \begin{tabular}{|c|c|c|}
21 \\
434 \\
5.9 \\
713 \\
1.6 \\
1,651 \\
37 \\
Aug., 1919
\end{tabular} \\
\hline
\end{tabular}

a Iron and aluminum oxides $\left(\mathrm{Fe}_{2} \mathrm{O}_{3}+\mathrm{Al}_{2} \mathrm{O}_{3}\right)$.

Calculated.

Analysts: 5, C. H. Kidwell and Margaret D. Foster, U. S. Geological Survey; 8, W. R. Perkins (Mississippi Agr. Exper. Sta. Bull. 89, p. 51, 1905); 9, Margaret D. Foster, U. S. Geological Survey.

\section{IAFAYETTE COUNTY}

\section{GENERAL FEATURES}

Area, 664 square miles. Population, 19,243 (census of 1920)

Lafayette County is in the North Central Hills district. Two Eocene formations, the Ackerman formation and the Holly Springs sand, both of which belong to the Wilcox group, occur in surface outcrops in the county. These formations are described on pages 45-47, and their distribution is shown on the geologic map (pl. 2). On the upland the Eocene formations are covered with a blanket of surficial loam, only a few feet thick, which represents the eastern attenuated extension of the loess of western Mississippi. (See pp. 62-63.) The lowlands of Tallahatchie and Yocona Rivers are underlain by relatively thin alluvial deposits of loam, clay, and sand, in part of Recent and in part of Pleistocene age.

\section{GROUND-WATER CONDITIONS}

The beds that compose the Eocene formations in Lafayette County dip to the west at the rate of 20 or 25 feet to the mile and afford conditions favorable to the development of artesian pressure in their contained waters. Most of the deep wells about which information has been obtained are located on the higher lands, above the upper limit of the static head of the ground waters and do not flow. Generally, however, the water rises near enough to the surface to be within easy reach of suction or force pumps. Flowing wells have been obtained in the valley of Yocona River near De Lay, and apparently the conditions are favorable for obtaining flows anywhere in the lowlands of both Yocona and Tallahatchie Rivers.

The Ackerman formation crops out in a northward-trending belt 10 to 15 miles wide in the eastern part of the county. The more 
sandy portions, chiefly in the upper half of the formation, are water bearing and are the source of the domestic water supplies obtained by means of shallow wells. The westward-dipping sands are also reached by some of the deeper wells, as for example at Market and in the vicinity of De Lay. .

The Holly Springs sand overlies the Ackerman formation and appears in outcrops throughout the western half or more of the county, where it probably attains an aggregate thickness of 400 or 450 feet. The sands are abundantly water bearing and are tapped by hundreds of dug and bored wells and by a lesser number of deeper drilled wells. Most of the wells in the vicinity of Oxford and along the line of the Illinois Central Railroad south of Oxford have their source in this formation.

The alluvial deposits of Recent and Pleistocene age, which underlie the lowlands of Tallahatchie and Yocona Rivers and their larger tributary creeks, are in part composed of water-bearing sands that as a rule lie at depths of less than 40 feet.

Springs of small to moderately large yield are common throughout the county, and those that are near dwellings are utilized for domestic supplies.

\section{LOCAL SUPPLIES}

Abbeville.-At Abbeville wells in the higher (eastern) part of the town are about 40 feet deep and penetrate strata such as are described below:

Generalized section of strata penetrated by wells in eastern part of Abbeville

\begin{tabular}{|c|c|c|}
\hline & Thickness & Depth \\
\hline Surficial loam: Brown loam & & \\
\hline $\begin{array}{l}\text { Holly Springs sand: } \\
\text { Red clayey sand } \\
\text { White clay and sand; water be aring }\end{array}$ & $\frac{16}{20}$ & $\frac{20}{40}$ \\
\hline
\end{tabular}

The yield from these shallow wells is small but is sufficient for domestic needs. A well in the lower part of the town is reported to be 400 feet deep. A layer of hard rock was encountered at a depth of about 55 to 57 feet, below which were penetrated clay and sandy clay that did not yield a satisfactory water supply.

College Hill station.-A well at the plant of the Oxford Brick Co., at College Hill station, 3 miles north of Oxford, is 140 feet deep. Water-bearing sand was penetrated between depths of 95 and 110 feet, and the water rose within 70 feet of the surface. The following log shows the character of the beds penetrated by the well: 
Log of well of Oxford Brick Co., at College Hill station (No. 1)

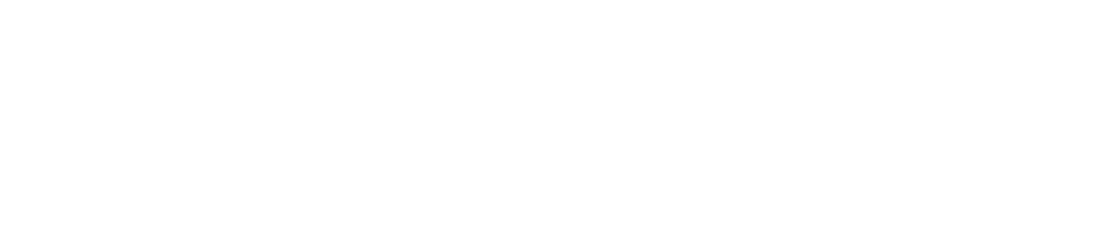

Oxford.-The waterworks at Oxford is owned by the town, and the water supply is afforded by three wells (Nos. 10, 11, 12), 250, 825, and 144 feet deep. The 144-foot and 250-foot wells are 200 feet east of the public square, on ground about 500 feet above sea level, and the 825 -foot well is half a mile west of the public square, near the Illinois Central Railroad station, at an altitude of approximately 450 feet above sea level. The principal water-bearing sand in the 825foot well lies at a depth of only 340 to 350 feet. Logs of an abandoned (?) 370-foot well and of the 825 -foot well are given below. Analysis 13 represents water from the 370 -foot well.

Log of abandoned(?) city well at Oxford (No. 13)

\begin{tabular}{|c|c|c|}
\hline & Thiokness & Depth \\
\hline $\begin{array}{l}\text { Holly Springs sand: } \\
\text { Clay and sand } \\
\text { Dry sand } \\
\text { Clay }\end{array}$ & Feet $\begin{array}{r}90 \\
15 \\
67\end{array}$ & $\begin{array}{r}\text { Feet } \\
90 \\
105 \\
172\end{array}$ \\
\hline $\begin{array}{l}\text { Ackerman formation(?): } \\
\text { Boapstone (clay) } \\
\text { Hard sandstone } \\
\text { Lignitic clay, barren of water }\end{array}$ & $\begin{array}{l}78 \\
50 \\
70\end{array}$ & $\begin{array}{l}250 \\
300 \\
370\end{array}$ \\
\hline
\end{tabular}

Log of new city well at Oxford (No. 11)

\begin{tabular}{|c|c|c|}
\hline & Thicknoss & Depth \\
\hline $\begin{array}{l}\text { Holly Springs sand: } \\
\text { Band and clay, red above to white below:.... } \\
\text { Sand with thin layers of sandstone }\end{array}$ & \multirow{2}{*}{$\begin{array}{r}\text { Feet } \\
90 \\
150 \\
2 \\
8\end{array}$} & \multirow{2}{*}{$\begin{array}{rl}\text { Feet } & 90 \\
& 90 \\
240 & 242 \\
250\end{array}$} \\
\hline 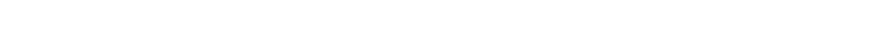 & & \\
\hline Ackerman formation (?):- & & \\
\hline $\begin{array}{l}\text { Sand and lignite- } \\
\text { Sand; water bearing. }\end{array}$ & 10 & 340 \\
\hline 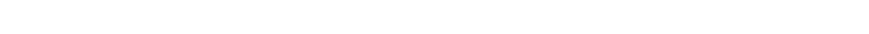 & 475 & \\
\hline
\end{tabular}

At the State university, near Oxford, two wells have been drilled for boiler supply at the power plant. One well at the power house (No. 15), which is 187 feet deep, penetrated 30 feet of red sand, below which, to the bottom of the well, came white and light-colored sand with a little clay. The well was finished on a layer of hard rock. Two water-bearing beds were found, one at a depth of about 100 feet and the other at a depth of 175 feet. The other well (No. 16) is 100 yards southeast of the power house and is 125 feet deep. It yields water from sandy beds that overlie lignitic clay, which was penetrated between depths of 100 and 125 feet. 
Butler Springs.-Butler Springs, formerly known as Howell Springs, 2 miles east of Oxford, yields a moderately mineralized water that has a local sale as a table water. The water probably issues from the Holly Springs sand.

Altus.-Near Altus, 7 or 8 miles in an air line east of Oxford, water is supplied by springs and by shallow wells, the common depth of which is 30 to 40 feet.

Chandler Spring.-Several small springs in the valley of Yocona River, in the southwestern part of the county, are utilized for domestic supplies. One of them, known as Chandler Spring, 21/2 miles southeast of Taylor, yields about 10 gallons a minute. The spring is near the base of a 35-foot bluff and issues from the base of laminated yellow sand of the Holly Springs formation, which rests upon a 6-inch layer of iron carbonate ore at the top of a bed of clay. The water is strongly chalybeate, and the springs were formerly developed as a local resort.

Markette.-At Markette, 3 miles northeast of Taylor, B. F. Markette owns two wells (Nos. 8, 9)-one 30 feet deep and the other 438 feet deep. The shallow well yields a fair supply of soft water suitable for domestic use. The principal domestic supply, however, is furnished by the deep well, which penetrates a water-bearing sand at a depth of about 300 feet. The water is raised by means of a pump operated by a gasoline engine.

Lafayette Springs.-At Lafayette Springs, a village and watering place on the east border of the county, water is supplied by shallow wells and by springs. The village takes its name from a group of small springs, owned by A. F. Taylor, 300 yards east of the post office. This place has been developed as a local resort and has hotel accommodations for 50 guests. There are two principal springs known as Nos. 1 and 2, which flow about 3 gallons a minute each, and four smaller springs issue a short distance from the larger ones. The surface of the pool is coated with a film of iron oxide. (See analysis 17.) The analysis of a sample of water from a 30-foot well owned by E. P. Sneed is given on page 266 (No. 7). The E. W. Sneed spring, 4 miles north of Lafayette Springs, yields an abundance of clear water that is used for domestic and stock supply.

De Lay.-Flowing wells have been obtained in the Yocona River bottom, in the vicinity of De Lay; although detailed information is lacking they are reported to range in depth from 125 to 170 feet. Nonflowing wells are obtained on the higher lands in the vicinity of De Lay, three of which are described in the table of well data (Nos. $2-4)$. The logs of the wells are given below. 
Log of well at Eskridge's sawmill at De Lay (No. 2)

\begin{tabular}{l|r|r}
\hline & Thickness & Depth \\
\hline Ackerman formation: & Feet & Feet \\
Yellow sand and clay & 20 & 20 \\
Gray sand; water bearing & 33 \\
Black, lignitic clay & \\
Blue clay & 30 \\
Sand; water bearing. & 130 \\
160 \\
\end{tabular}

Log of well of N. P. Eskridge, on hill at store at De Lay (No. S)

\begin{tabular}{|c|c|c|}
\hline & Thickness & Depth \\
\hline $\begin{array}{l}\text { Ackerman formation: } \\
\text { Red sticky clay } \\
\text { Coarse blue-gray sand } \\
\text { Gray, brown, and black clay } \\
\text { White clean sand; water bearing } \\
\text { Gray, brown, and black clay }\end{array}$ & $\begin{array}{c}\text { Eeet } \\
20 \\
20 \\
160 \\
8(?) \\
120\end{array}$ & Feet $\begin{array}{r}20 \\
40 \\
200 \\
208 \\
\quad 328\end{array}$ \\
\hline
\end{tabular}

Log of well on Thweatt place, 5 miles southwest of De Lay (No. 4)

\begin{tabular}{|c|c|c|}
\hline & Thickness & Depth \\
\hline $\begin{array}{l}\text { Ackermen formation: } \\
\text { Red clay } \\
\text { Coarse yeliow sand } \\
\text { Hard gray sandstone } \\
\text { White sand; water bearing } \\
\text { Blue and gray clay } \\
\text { Fine quicksand; water bearing. }\end{array}$ & \begin{tabular}{r|r} 
Feet \\
9 \\
34 \\
2 \\
2 \\
121 \\
4
\end{tabular} & $\begin{array}{r}\text { Feet } \\
9 \\
43 \\
45 \\
47 \\
168 \\
172\end{array}$ \\
\hline
\end{tabular}




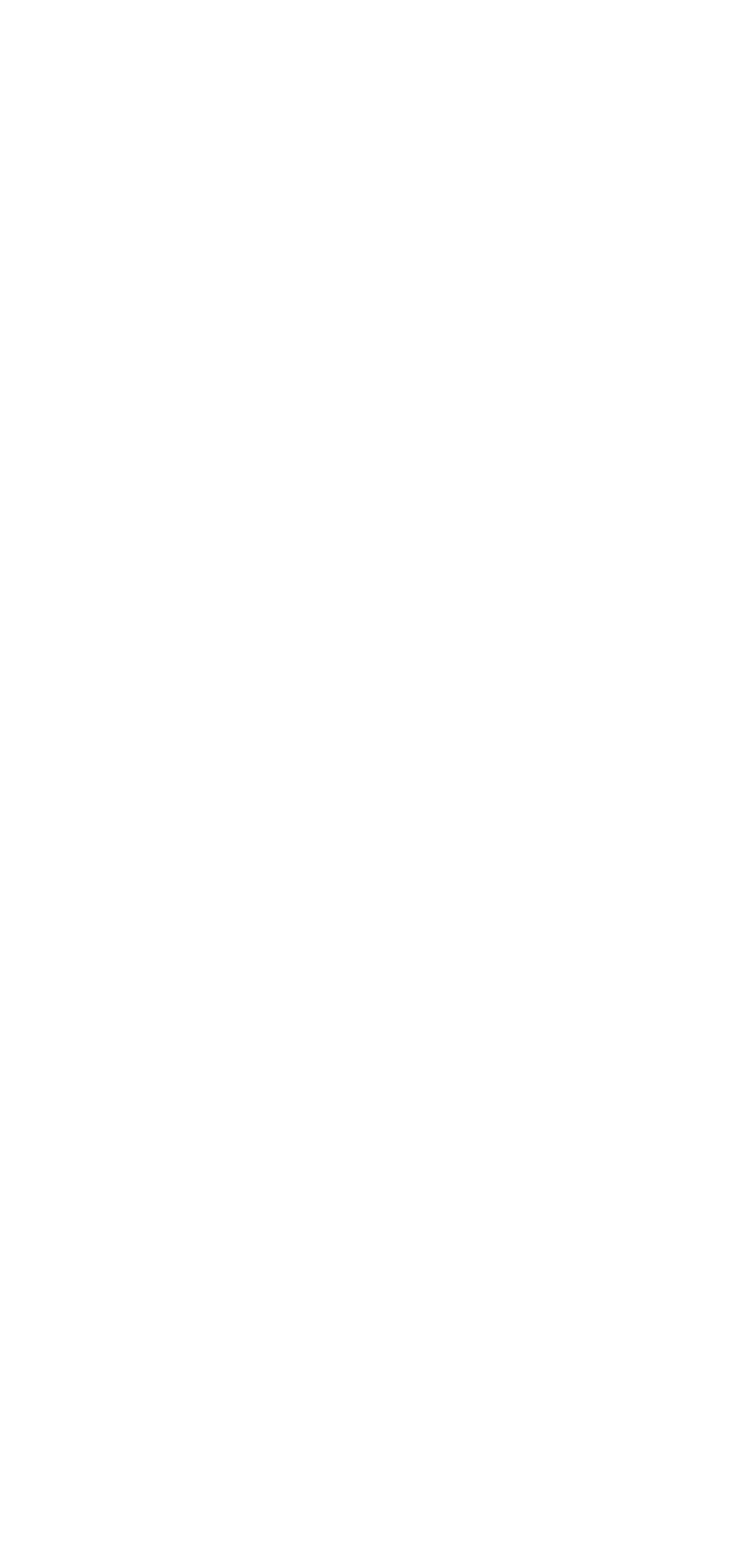




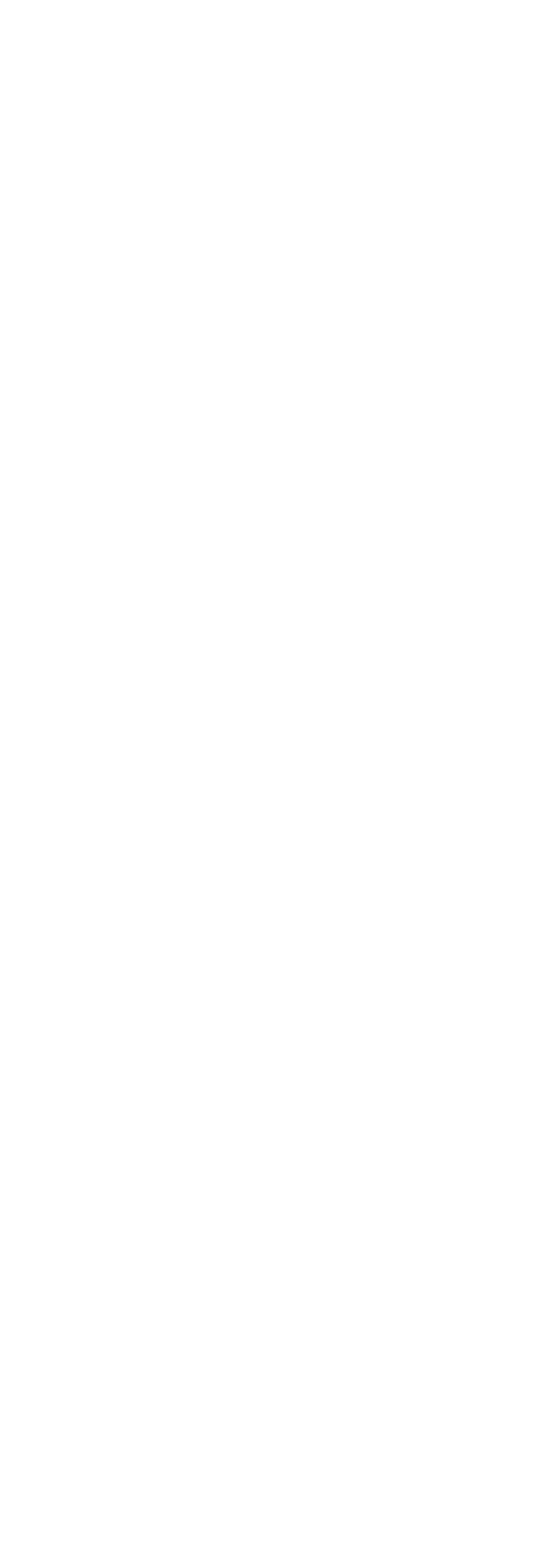




\section{Mineral analyses of ground waters from Lafayette County}

[Parts per million. Numbers at heads of columns refer to corresponding well and spring numbers in pre. ceding table]

\begin{tabular}{|c|c|c|c|c|c|}
\hline & 7 & 9 & 12 & 13 & 17 \\
\hline 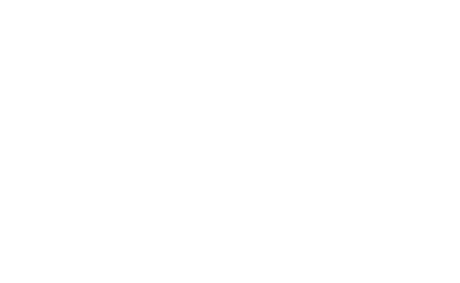 & $\begin{array}{c}38 \\
34.0 \\
6.6 \\
39.0 \\
181.0 \\
29.0 \\
241.20 \\
112 \\
\text { Nov., } 1911\end{array}$ & $\begin{array}{l}17^{-20} \\
7.6 \\
22^{.0} \\
98^{.0} \\
18^{7.5} \\
148^{.00} \\
74 \\
1911^{-00}\end{array}$ & $\begin{array}{c}19 \\
4.16 \\
2.5 \\
24 \\
12 \\
38 \\
3.5 \\
9.0 \\
4.6 \\
98 \\
21 \\
\text { Sept., } 1919\end{array}$ & $\begin{array}{r}35 \\
4.2 \\
18 \\
4.4 \\
9.8 \\
95 \\
95 \\
7.2 \\
4.5 \\
6.0 \\
138 \\
63 \\
\text { July, } 1911\end{array}$ & $\begin{array}{r}49 \\
9.2 \\
4.6 \\
18 \\
{ }^{81} .0 \\
4.9 \\
5.0 \\
.00 \\
124 \\
42 \\
\text { June, } 1912\end{array}$ \\
\hline
\end{tabular}

2 Iron and aluminum ( $\mathrm{Fe}+\mathrm{Al})$.

b Calculated.

Analysts: 7, W. L. Perdue, University of Mississippi; 9, E. S. Wallace, University of Mississippi; 12, C. S. Howard, U.S. Geological Survey; 13, W. L. Kennon, University of Mississippi; 17, Mississippi State Chemical Laboratory.

\section{LAMAR COUNTY}

\section{GENERAL FEATURES}

Area, 495 square miles. Population, 12,869 (census of 1920)

Lamar County is within the Long-leaf Pine Hills district. The three principal geologic formations that appear at the surface in the county, named in the order of their age from the oldest to the youngest, are the Hattiesburg clay, the Pascagoula clay, and the Citronelle formation. These formations are described on pages 56-60, and their distribution is shown on Plate 2.

\section{GROUND-WATER CONDITIONS}

Here, as in the other upland counties of south-central Mississippi, the inhabitants obtain most of their domestic water supplies from dug and bored wells, chiefly bored wells, which range in depth from 15 to 100 feet, and from small springs. The main source of the water of both the wells and springs is the Citronelle formation, the clays; sands, and gravels of which compose the body of the hills to depths ranging from 50 feet or less in places in the north to perhaps 150 feet in the south. Several typical wells are described in the table of well data (Nos. 1-3,8). In most wells of this kind the water does not rise more than a foot or two above the containing bed and may therefore be classed as essentially nonartesian.

Some of the deeper wells of the county (for example No. 7) have been drilled through the Citronelle formation and the underlying Pascagoula formation into the still deeper Hattiesburg clay, a formation, which, though composed chiefly of clay, also contains interbedded layers of water-bearing sand. The Hattiesburg is roughly estimated to be about 375 feet thick and dips west by south at a rate 
estimated to be about 17 feet to the mile. It appears in small outcrops in the north beneath the Citronelle formation, but within a few miles to the south it passes beneath the Pascagoula clay. The waters of the Hattiesburg are under considerable hydrostatic pressure, but so far as reported the head is insufficient to bring the water to the surface and produce flows.

The Pascagoula clay, which over most of the county intervenes between the Hattiesburg clay below and the Citronelle formation above, is roughly estimated to be 300 feet thick in the south, but it thins to a featheredge in the north. So far as at present known, the Pascagoula is practically not water bearing in Lamar County, though the log of the 1,800-foot well of the Camp Hinton Lumber Co., at Lumberton, seems to indicate that it contains some sandy waterbearing layers. This well is believed to have penetrated the following geologic divisions, named from the top downward: Citronelle formation (Pliocene), Pascagoula clay (Miocene), Hattiesburg clay (Miocene), Catahoula sandstone (Miocene), Vicksburg group (Oligocene), Jackson formation (Eocene), and a part of the Claiborne group (Eocene). No water is indicated in that part of the section referred to the Catahoula sandstone. The water obtained below the deepest casing (860 feet) in this well probably comes from the Claiborne group.

To the north and northeast in Covington and Jones Counties the Catahoula formation contains an abundance of water, and one well at Epley (No. 4), 494 feet deep, probably taps this source.

\section{LOCAL SUPPLIES}

Lumberton.-The municipal waterworks at Lumberton is located at the lumber plant of the Edward Hines Yellow Pine Trustees. The well, ground reservoir, elevated tank, and mains are owned by the town, but the pumping plant is owned and operated by the lumber company. The source of the water is an 810 -foot well (No. 6), which probably taps a water-bearing sand in the Catahoula formation. The $\log$ of an 1,800-foot well owned by the CampHinton Lumber Co. (No. 5), as given by Logan and Perkins ${ }^{40}$ in 1905, is incomplete and is difficult to interpret. It is not certain whether the descriptions in the part of the log furnished by Mr. J. M. Jenkins pertain to the materials at the exact depth stated for each bed or to the materials extending from one depth to the next. In the version of the log given below, which is adapted in part from the data furnished by Logan and Perkins and in part from Matson's columnar section, ${ }^{41}$ the former alternative is assumed. 
Incomplete log of well of Camp-Hinton Lumber Co., at Lumberton

[Altitude of mouth of well, about 260 feet above sea level. Authority in part, J. M. Jenkins]

Citronelle formation(?):

Feet

Sand and clay

1-40

Sand and gravel; water bearing

$40-45$

Pascagoula clay:

Fine sand

$85-90$

Fine sand and white clay, at.......

103

Soft fine sand, at......

180

Hard white clay, at ........

200

Hard white clay, at . . . . .

110

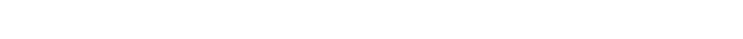

180

Hard white clay, at. . . . ............................

200

Hard and soft layers; water bearing, at..........

210

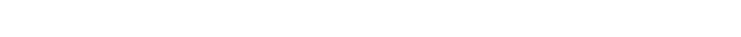

277

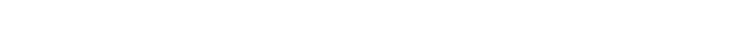

314

Hattiesburg clay:

Blue mud

512-528

Blue mud, at................ 560

Hard clay; water bearing at(?), ............ 620

Very soft rock (sand?) ... . . . . . . . . . . . . . . . . 650-670

Very soft white clay._...

Catahoula sandstone:

Hard clay, at. ............................ 720

Blue clay, at . .

Hard rock, at............ $\quad 770$

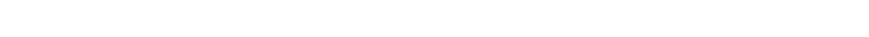

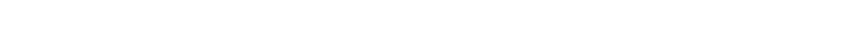

Hard rock, at........ 850

Sand at ........................... 860

Undifferentiated, probably including lower part of Catahoula sandstone, all of Vicksburg group, all of Jackson formation, and part of Claiborne group: Blue and green clay and sand; water bearing in part... 860-1,800

Sumrall.-The town of Sumrall is provided with a municipal waterworks, which was put in operation in 1918. The pumping plant is about 700 feet northeast of the Mississippi Central Railroad station (see pl. 12, A), and water is obtained from a 409-foot nonflowing well at the plant (No. 10). The town mains are connected with the mains and with pumps of large capacity, which are used for fire protection at the plant of the J. J. Newman Lumber Co., and by this arrangement the two waterworks systems can supplement each other in an unusually critical fire emergency. The lumber company uses impounded water for fire protection. The log of an abandoned well (No. 9) is given below. This well, owned by the J. J. Newman Lumber Co., was formerly used as a municipal water supply and for fire protection both at the lumber plant and in the town. 
Log of abandoned well of J.J. Newman Lumber Co., one-habl mile west of Sumrall, in sec. $12, T .5$ N., R. $16 \mathrm{~W}$.

[Altitude at mouth of well about 275 feet above sea level. Authority, W. J. Haynen, assistant genera] manager]

\begin{tabular}{|c|c|c|}
\hline & Thickness & Depth \\
\hline $\begin{array}{l}\text { Mud and clay } \\
\text { Soft gravel; water bearing; stopped in upper part of red clay. }\end{array}$ & $\begin{array}{l}\text { Feet } \\
200 \\
170(?)\end{array}$ & $\begin{array}{l}\text { Feet } \\
200 \\
370(?)\end{array}$ \\
\hline
\end{tabular}

Purvis.-Domestic water supplies at Purvis are obtained by means of privately owned bored wells 50 to 100 feet deep. Some windmills are in use for raising the water. One well, 640(?) feet deep (No. 7), has been drilled on the courthouse grounds.

Baxterville.-Several wells typical of those in use in the vicinity of Baxterville are described in the table of well data (Nos. 1-3). The $\log$ of one such well is given below:

Log of well of D. L. Davis, 41/2 miles west of Baxterville, in NW. 1/4 sec. 30, T. 2 N., R. $16 \mathrm{~W}$.

[Authority, the owner]

\begin{tabular}{|c|c|c|}
\hline & $\begin{array}{c}\text { Thickness } \\
\text { (approx- } \\
\text { imate) }\end{array}$ & Depth \\
\hline $\begin{array}{l}\text { Citronelle formation: } \\
\text { Soil, clay, and sand } \\
\text { Hard clay. } \\
\text { Sand } \\
\text { Gravel; water bearing at base }\end{array}$ & $\begin{array}{r}\text { Feet } \\
7 \\
60 \\
25 \\
8\end{array}$ & Feet $\begin{array}{r}7 \\
67 \\
92 \\
92 \\
100\end{array}$ \\
\hline
\end{tabular}

Epley.-The log of a 494-foot well owned by the Major-Sowers Sawmill Co. at Epley is given below:

Log of well of Major-Sowers Sawmill Co., one-half mile northwest of Epley (No. 4)

[Authority, W. J. Sowers]

\begin{tabular}{|c|c|c|c|c|c|}
\hline & $\begin{array}{c}\text { Thick- } \\
\text { ness }\end{array}$ & Depth & & $\begin{array}{l}\text { Thick- } \\
\text { ness }\end{array}$ & Depth \\
\hline $\begin{array}{l}\text { Citronelle formation(?): } \\
\text { Yellow clay } \\
\text { Red sand and mud } \\
\text { Hattiesburg clay: } \\
\text { Hard blue clay } \\
\text { Bluish-gray sand } \\
\text { Soft blue clay }\end{array}$ & $\begin{array}{r}\text { Feet } \\
20 \\
70 \\
160 \\
15 \\
3\end{array}$ & $\begin{array}{r}\text { Feet } \\
20 \\
90 \\
\\
250 \\
265 \\
268\end{array}$ & $\begin{array}{l}\text { Hattiesburg clay-Continued. } \\
\text { Sand; water bearing } \\
\text { Tough blue clay } \\
\text { Sand and clay mixed... } \\
\text { Hard clay } \\
\text { Catahoula sandstone: Hard-packed } \\
\text { sand; water bearing.............. }\end{array}$ & $\begin{array}{r}\text { Feet } \\
32 \\
5 \\
42 \\
78 \\
69\end{array}$ & $\begin{array}{r}\text { Freet } \\
300 \\
305 \\
347 \\
425 \\
494\end{array}$ \\
\hline
\end{tabular}




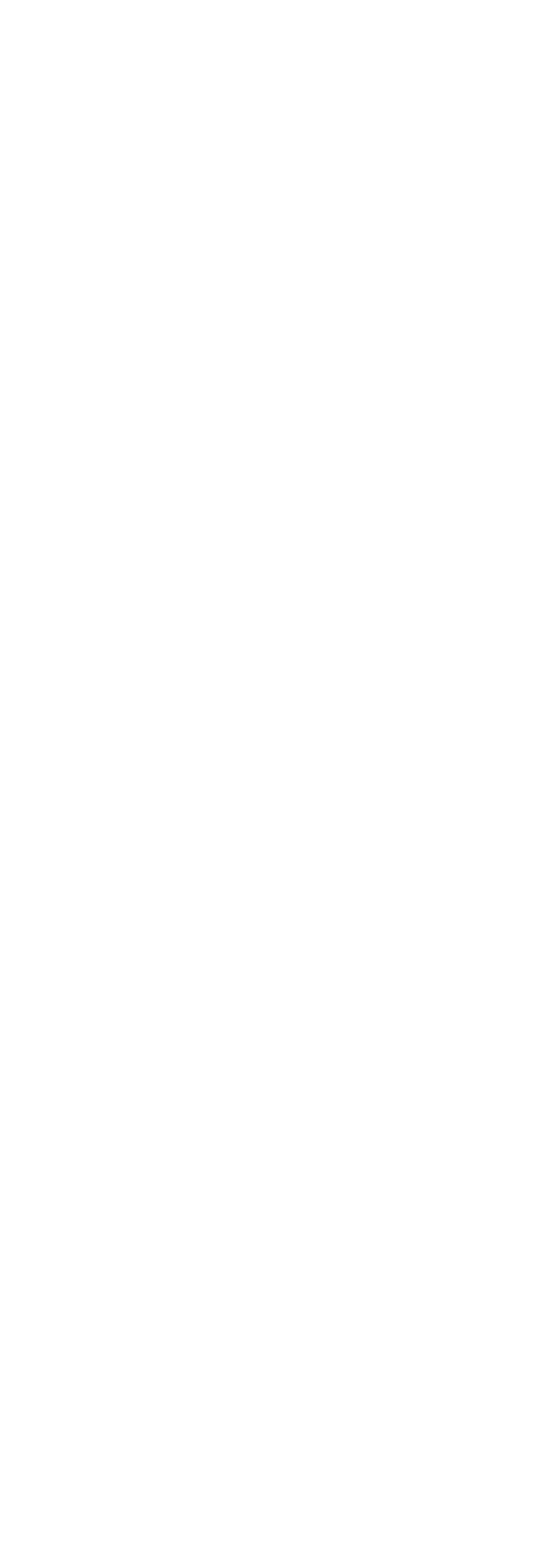




\begin{tabular}{|c|c|c|c|}
\hline 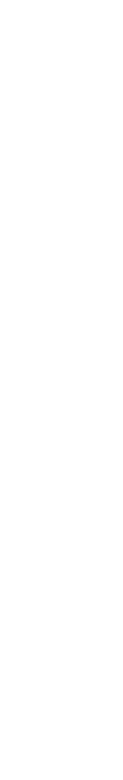 & 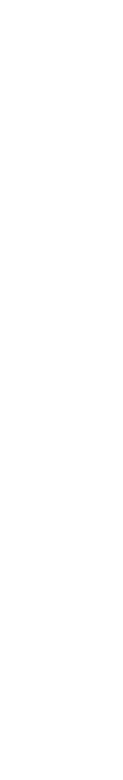 & 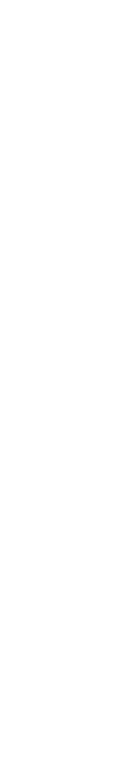 & 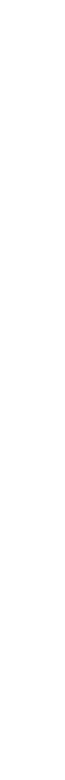 \\
\hline 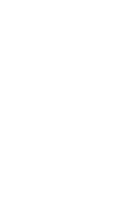 & 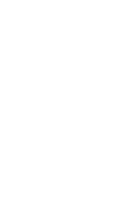 & 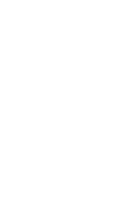 & 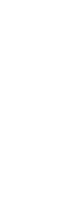 \\
\hline 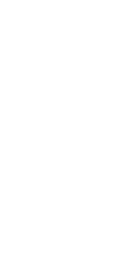 & 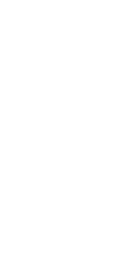 & 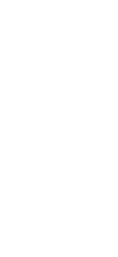 & 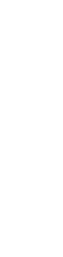 \\
\hline 密 & 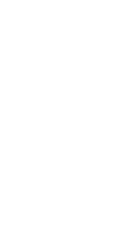 & 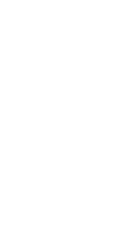 & 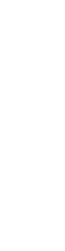 \\
\hline 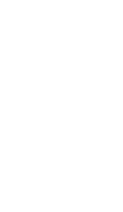 & 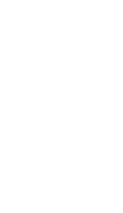 & 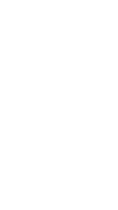 & 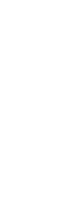 \\
\hline 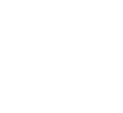 & • $\begin{array}{c:c}\infty \\
\vdots \\
4\end{array}$ & 유" & 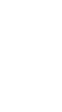 \\
\hline$\dot{z}$ & TNकA & $0+\infty \infty$ & 익 \\
\hline
\end{tabular}




\section{Mineral analyses of ground waters from Lamar County}

[Parts per million. Numbers at heads of columns refer to corresponding well numbers in preceding table]

\begin{tabular}{|c|c|c|c|c|}
\hline & 6 & 7 & 8 & 10 \\
\hline 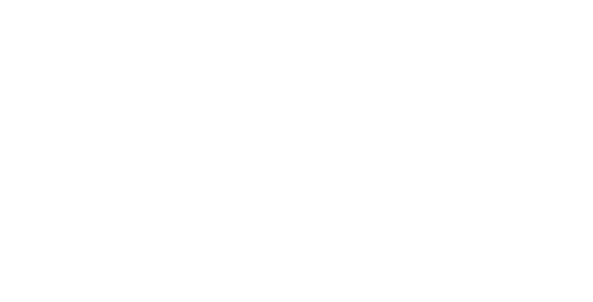 & $\begin{array}{l}44 \\
.05 \\
.6 \\
58 \\
133^{.5} \\
10 \\
8.0 \\
\text { Trace. } \\
174 \\
4 \\
\text { Feb., } \\
1921\end{array}$ & $\begin{array}{l}27.80 \\
2.0 \\
12.5 \\
29.0 \\
1.7 \\
7.5 \\
70^{.00} \\
7 \\
\text { Apr., } \\
1914\end{array}$ & 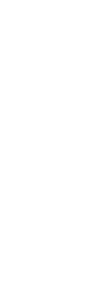 & $\begin{array}{r}28 \\
.39 \\
3.4 \\
1.5 \\
16 \\
7.2 \\
33 \\
3.5 \\
5.1 \\
77 \\
77 \\
15 \\
\text { July, } \\
1919\end{array}$ \\
\hline
\end{tabular}

- Calculated.

Analysts: 6, C. S. Howard, U. S. Geological Survey; 7, W. F. Hand, Mississippi State Chemical Laboratory; 8, Mississippi State Chemical Laboratory; 10, N. Fuchs, U. S. Geological Survey.

\section{LAUDERDALE COUNTY}

\section{GENERAL FEATURES}

Area, 700 square miles. Population, 45,897 (census of 1920)

Lauderdale County lies in the southern part of the North Central Hills district. The county is underlain by formations of Eocene age, which, named in order from the oldest to the youngest, include the Naheola formation of the Midway group, the Ackerman, Holly Springs, Bashi, and Hatchetigbee formations of the Wilcox group, and the Tallahatta and Lisbon formations of the Claiborne group. These formations are described on pages $28,45-52$, and their distribution is shown on the geologic map (pl. 2). They all dip toward the southwest at an average rate of about 25 feet to the mile, though locally the Tallahatta dips at the rate of 35 or 40 feet to the mile.

Within this county the most notable water-bearing formation is the Holly Springs sand. This formation affords abundant supplies of excellent water, which is obtained by both shallow and deep wells throughout that part of the county in which the sands crop out and also for several miles to the southwest, where the sands pass from view beneath overlying younger formations. This source of water has been extensively developed at and in the vicinity of Meridian, where wells over 200 feet deep are believed to reach it. Lesser supplies of water are obtained from each of the other formations, particularly from the Ackerman formation and the Hatchetigbee, and questionably from the Bashi formation. Springs of small to moderate yikld are common throughout the county and are utilized to some ext int for domestic supplies. 


\section{LOCAL SUPPLIES}

Meridian.-Numerous water wells have been drilled at Meridian. Those concerning which information is available (Nos. 7-21) range in depth from 140 to 900 feet and tap water-bearing beds in different parts of the Wilcox group nearly to its base, and the deepest one (900 feet) may reach the Midway group. The record of one well (No. 14), which is given below, shows an alternation of clay and sand and lignitic layers; the well probably completely penetrates the Hatchetigbee and Bashi formations and ends in the Holly Springs sand. The waterworks at Meridian is owned by the city and is located about four blocks southeast of the union station. The water supply is obtained from a reservoir which is formed by damming a small branch valley that enters Siwashee Creek from the southeast, at a point about 2 miles east by south of the business part of the city. This reservoir covers 90 acres and is divided into two parts by an earthen dam.

Log of well of Meridian Cotton Mills, Meridian (No. 14)

\begin{tabular}{|c|c|c|c|c|c|}
\hline & $\begin{array}{c}\text { Thick- } \\
\text { ness }\end{array}$ & Depth & & $\begin{array}{c}\text { Thick- } \\
\text { ness }\end{array}$ & Depth \\
\hline 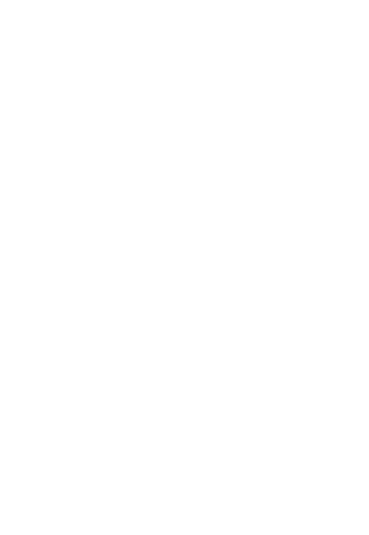 & $\begin{array}{r}\text { Feet } \\
14 \\
16 \\
6 \\
14 \\
1 \\
2 \\
3 \\
2 \\
19 \\
6 \\
7 \\
2 \\
3 \\
4 \\
22 \\
5 \\
5 \\
5 \\
4 \\
1 \\
18 \\
9 \\
5 \\
2\end{array}$ & $\begin{array}{r}\text { Feet } \\
14 \\
30 \\
36 \\
50 \\
51 \\
53 \\
56 \\
58 \\
77 \\
83 \\
90 \\
92 \\
95 \\
99 \\
121 \\
126 \\
131 \\
136 \\
140 \\
141 \\
159 \\
168 \\
173 \\
175\end{array}$ & $\begin{array}{l}\text { Wilcox group-Continued. } \\
\text { Lignite } \\
\text { Sandstone } \\
\text { Clay } \\
\text { Sand } \\
\text { Lignite } \\
\text { Clay } \\
\text { Sand } \\
\text { Lignite } \\
\text { Sand } \\
\text { Clay } \\
\text { Lignite } \\
\text { Clay } \\
\text { Sand } \\
\text { Clay } \\
\text { Sand } \\
\text { Clay } \\
\text { Pyritic sandstone } \\
\text { Sand } \\
\text { Clay } \\
\text { Lignite- } \\
\text { Clay } \\
\text { Sand (Holly springs?); water } \\
\text { bearing }\end{array}$ & $\begin{array}{r}\text { Feet } \\
4 \\
1 \\
7 \\
27 \\
8 \\
8 \\
2 \\
2 \\
2 \\
27 \\
12 \\
4 \\
27 \\
4 \\
4 \\
6 \\
5 \\
1 \\
3 \\
7 \\
2 \\
15 \\
43\end{array}$ & $\begin{array}{r}\text { Feet } \\
179 \\
180 \\
187 \\
\mathbf{1 8 7} \\
214 \\
222 \\
224 \\
226 \\
228 \\
255 \\
267 \\
271 \\
298 \\
302 \\
306 \\
312 \\
317 \\
318 \\
321 \\
328 \\
330 \\
345\end{array}$ \\
\hline
\end{tabular}

The following log shows the general character of the materials penetrated in a well in the valley of Okatibbee Creek, which yields a flow from a depth of 200 to 230 feet.

Log of well of J. M. McBeath, 21/2 miles west of Meridian (No. 20)

\begin{tabular}{|c|c|c|}
\hline & Thickness & Depth \\
\hline $\begin{array}{l}\text { Wilcox group (Hatchetigbee formation?): } \\
\text { Gray sand }\end{array}$ & \multirow{3}{*}{$\begin{array}{r}\text { Feet } \\
100 \\
50 \\
2 \\
78\end{array}$} & \multirow{3}{*}{$\begin{array}{l}\text { Feet } \\
\quad 100 \\
\quad 150 \\
\\
\quad 230\end{array}$} \\
\hline $\begin{array}{l}\text { Black earth or soapstone } \\
\text { Lignite }\end{array}$ & & \\
\hline 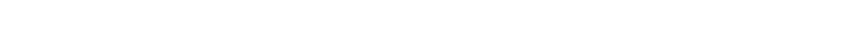 & & \\
\hline
\end{tabular}


Analyses of waters from several wells at and near Meridian are given in the table.

Jackson Spring.-Jackson Spring, owned by F. M. Jackson, is $61 / 2$ miles north of Meridian, in the SE. $1 / 4$ SW. $1 / 4$ sec. 17 , T. 7 N., R. 16 E. The spring issues from light-gray sand in the Hatchetigbee formation at the base of a hill and yields 20 gallons a minute. (See analysis 23.)

Lucile.-Analysis 21 represents water from the 188 -foot well of J. H. Muir near Lucile, about 3 miles north of Meridian.

Barachel Springs.-The water of Barachel Springs, in a grove near. Meridian, which is owned by the Barachel Mineral Springs Water Co., has within recent years been developed commercially as a mineral water. The water probably has its source in the Hatchetigbee formation.

Bonita.-The well of J. L. McLemore (No. 1), at Bonita, 2 miles east of Meridian is 29 feet deep and yields water from a hard blue sandstone, which is probably the Bashi formation of the Wilcox group. The C. F. Blanks well (No. 2), 160 feet deep, yields a good supply from looser, sandy beds that probably belong to the Holly Springs sand.

Arundel Spring.-Arundel Spring, three-quarters of a mile west of Arundel station, which is about 5 miles southwest of Meridian, is in the zone of the Tallahatta formation and issues from the base of a sandy layer that overlies a quartzitic bed.

Daleville.-A spring on the property of W. D. Harbous a quarter of a mile west of Daleville yields 5 gallons a minute of clear, soft water from the Holly Springs sand. At Daleville water is obtained by means of numerous shallow wells 30 to 65 feet deep, the most common depth being about 40 feet.

Lockhart.-At Lockhart shallow wells, which range in depth from 20 to 100 feet, are reported to be the source of domestic water supplies. Soft water is obtained in most wells, but a few wells are said to yield water that is distinctly mineralized, probably from lignitic clay beds.

Lauderdale.-At Lauderdale, in the valley of Possum Creek, water is obtained in part by means of shallow dug wells, but supplies can also be procured in the Holly Springs sand and the Ackerman formation of the Wilcox group at depths of 100 to 220 feet. This deeper water is under considerable artesian head, and in one well, now abandoned, a small artesian flow was obtained. Only one of the three or four deeper wells that have been drilled in the town, that of the Mobile \& Ohio Railroad (No. 4), is now in use. (See analysis 4.) Lauderdale Springs, 1 mile east of Lauderdale, owned by I. N. Hollingsworth, includes one group of three springs and another group of four springs. The yield from each spring is small, 
and the water is slightly mineralized, presumably as a result of having passed through lignitic clay beds that contain marcasite. The property was conducted as a health resort until about the year 1916, when the resort was discontinued.

Marion.-The spring of C. F. Stone 4 miles west of Marion issues from a soft sandstone bed near the base of a slope, and yields at the rate of 4 to 6 gallons a minute. (See analysis 24.) A mile east of Marion another spring issues as a stream that has an estimated flow of 150 gallons a minute from the contact zone of sands with lignitic clays below (Hatchetigbee formation.) The water power afforded by this spring is used in operating Kinard's corn mill, also known as the Old Meadow Mill.

Kewanee.-At Kewanee, near the eastern border of the county, the two Shamburgher springs, owned by J. M. Shamburgher, yield water for domestic use at the rate of 20 gallons a minute from the Holly Springs sand. A well (No. 3) at Kewanee reaches coarse sand in the Holly Springs formation at a depth of 187 feet and yields an abundant supply of slightly hard water.

Meehan Junction.-In the southwest part of the county, in the vicinity of Meehan Junction, flowing water is obtained from wells that probably reach the Holly Springs sand. Wells 5 and 6, 324 and 175 feet deep, are believed to obtain their water from this source. Analysis 6 represents water from the 175 -foot well. 


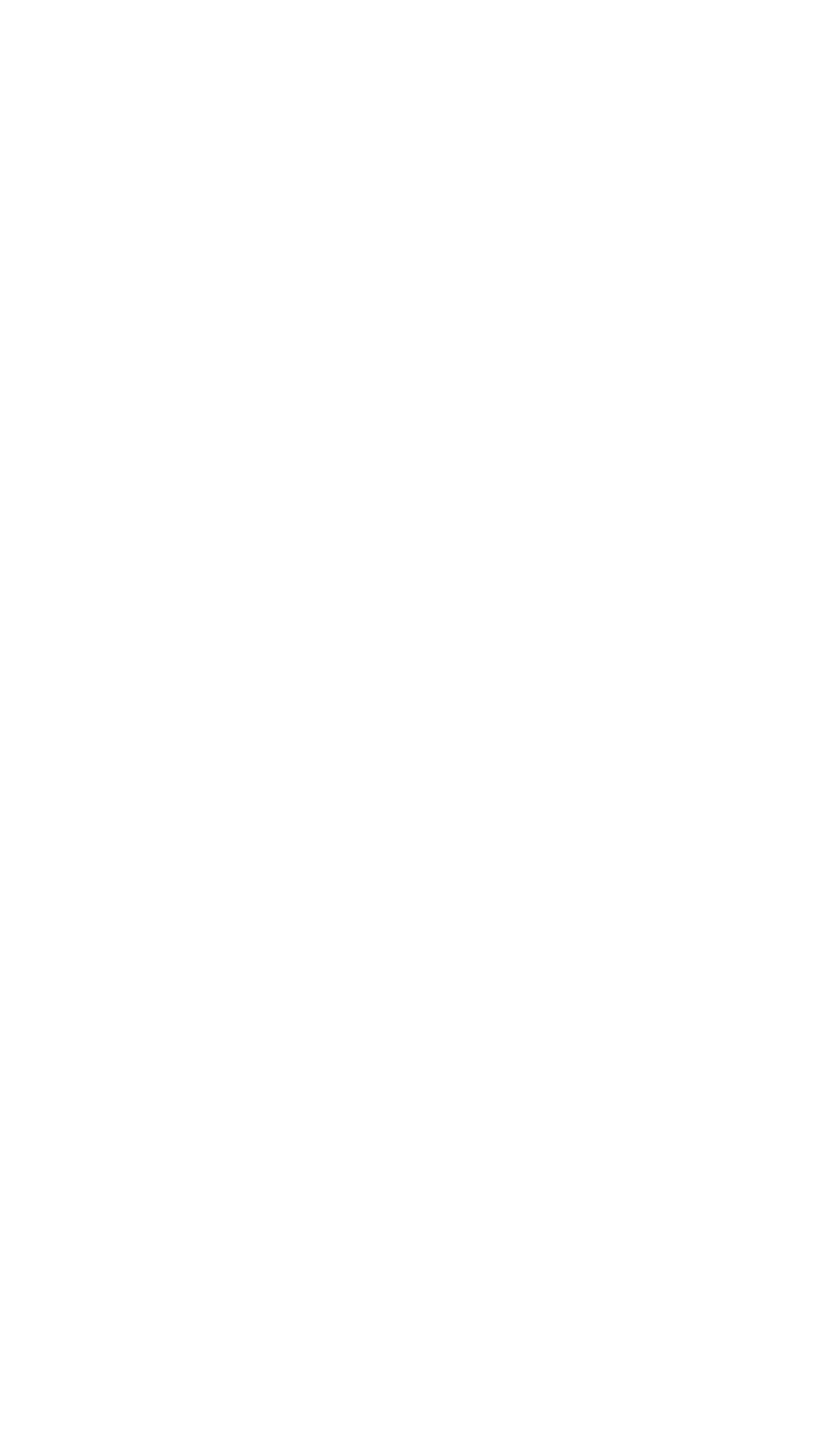




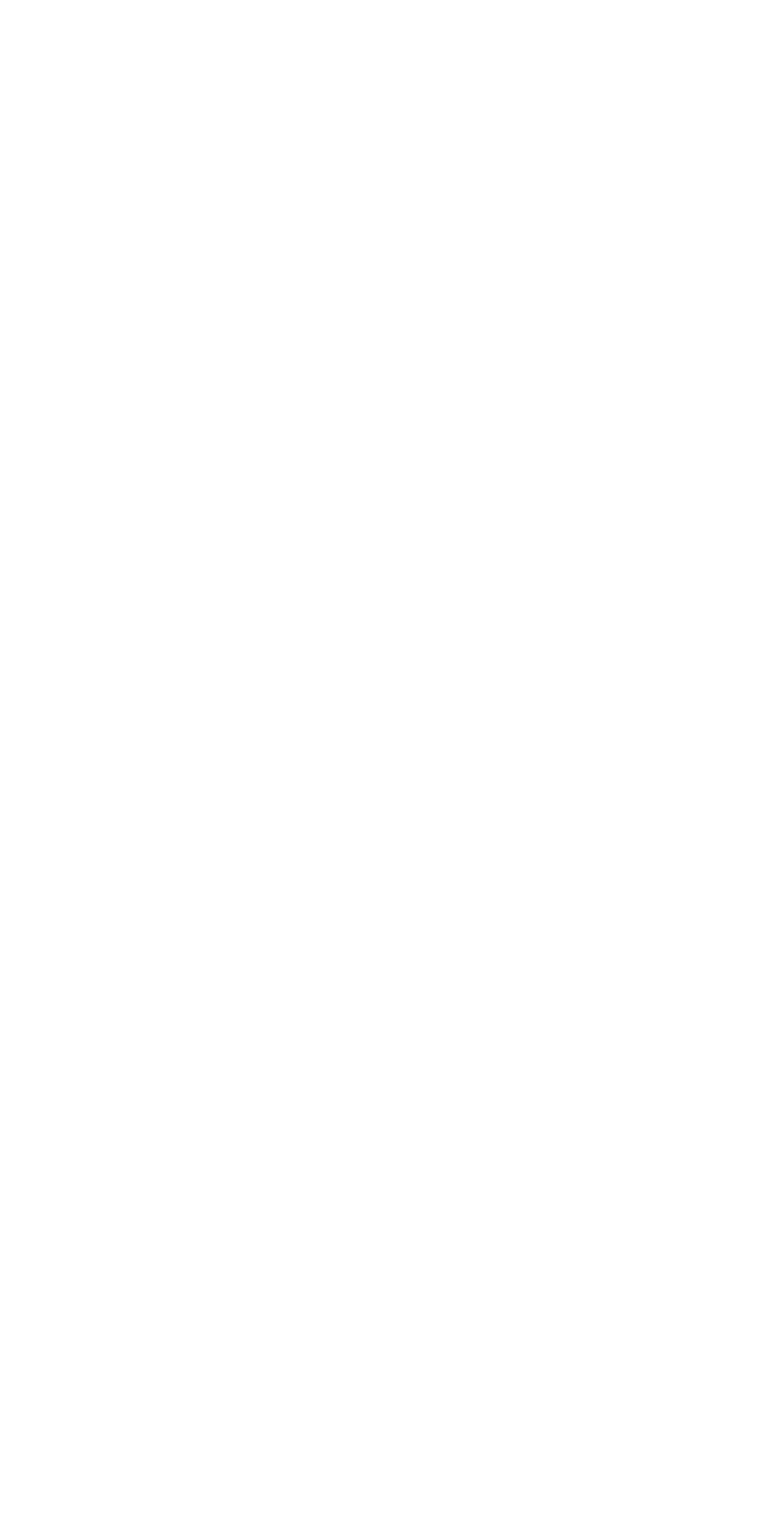




\section{Mineral analyses of ground waters from Lauderdale County}

[Parts per million. Numbers at heads of columns refer to corresponding well numbers in preceding table]

\begin{tabular}{|c|c|c|c|c|c|c|c|}
\hline & 3 & 4 & 6 & 7 & 8 & 9 & 13 \\
\hline 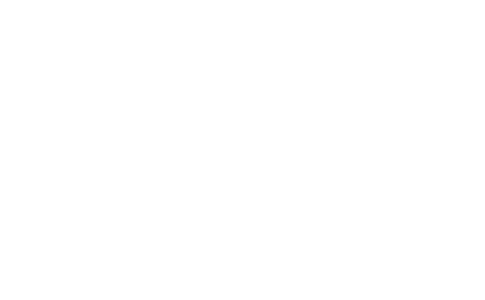 & $\begin{array}{c}36 \\
a 11 \\
35 \\
10 \\
12 \\
.0 \\
154 \\
22 \\
3.5 \\
.00 \\
201 \\
128 \\
1911\end{array}$ & $\begin{array}{c}28 \\
1.6 \\
5.3 \\
1.7 \\
634 \\
.0 \\
79 \\
14 \\
9.6 \\
.33 \\
133 \\
20 \\
\text { Aug., } \\
1919\end{array}$ & $\begin{array}{c}61 \\
2.9 \\
31 \\
8.6 \\
20 \\
{ }^{8} .0 \\
76 \\
8.0 \\
237 \\
113 \\
\text { Sept., } \\
1914\end{array}$ & $\begin{array}{c}44 \\
1.8 \\
34 \\
4.1 \\
11 \\
131 \\
12 \\
12 \\
4.7 \\
\text { Trace. } \\
191 \\
102 \\
\text { Ang., } \\
1919\end{array}$ & $\begin{array}{c}30 \\
.06 \\
9.7 \\
2.1 \\
57 \\
.0 \\
173 \\
8.0 \\
4.5 \\
197.87 \\
33 \\
\text { Aug., } \\
1919\end{array}$ & $\begin{array}{c}42 \\
3.6 \\
19 \\
3.5 \\
67.2 \\
.0 \\
77^{\circ} \\
9.2 \\
3.4 \\
.00 \\
126 \\
62 \\
\text { Aug. } \\
1919\end{array}$ & $\begin{array}{c}38 \\
9.2 \\
18 \\
3.6 \\
13 \\
{ }^{\circ} .0 \\
88^{\circ} \\
9.0 \\
4.1 \\
.00 \\
138 \\
60 \\
\text { Aug., } \\
1919\end{array}$ \\
\hline & & 18 & 19 & 20 & 21 & 23 & 24 \\
\hline 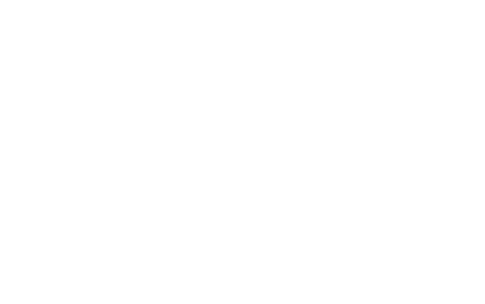 & $\begin{array}{c} \\
\end{array}$ & $\begin{array}{l}24 \\
45^{.49} \\
8.9 \\
15 \\
192^{0} \\
11 \\
5.0 \\
193.00 \\
149 \\
\text { Nov., } \\
1914\end{array}$ & $\begin{array}{l}29 \\
6.0 \\
13 \\
5.2 \\
13.0 \\
34 \\
42 \\
5.0 \\
134 \\
54 \\
\text { Oct. } \\
1913\end{array}$ & \begin{tabular}{|c}
30 \\
.06 \\
25 \\
2.0 \\
632 \\
4.8 \\
144 \\
7.8 \\
3.7 \\
1.4 \\
178 \\
71 \\
Aug., \\
1919
\end{tabular} & $\begin{array}{c}43 \\
2.0 \\
23 \\
6.5 \\
24.0 \\
143 \\
10 \\
5.0 \\
.00 \\
185 \\
84 \\
\text { Dec., } \\
1914\end{array}$ & $\begin{array}{c}8.4 \\
.03 \\
.8 \\
1.2 \\
7.1 \\
.0 \\
4.9 \\
3.0 \\
5.0 \\
5.0 \\
38 \\
7 \\
\text { Sept. } \\
1914\end{array}$ & $\begin{array}{c}9.0 \\
.24 \\
.4 \\
.7 \\
6.1 \\
.0 \\
6.1 \\
2.8 \\
5.0 \\
.00 \\
24 \\
4 \\
\text { June, } \\
\text { 1915 }\end{array}$ \\
\hline
\end{tabular}

a Iron and aluminum oxides $\left(\mathrm{Fe}_{2} \mathrm{O}_{3}+\mathrm{Al}_{2} \mathrm{O}_{3}\right)$.

b Calculated.

Analysts: 3, E. S. Wallace, University of Mississippi; 4, C. H. Kidwell and Margaret D. Foster, U. S. Geological Survey; $6,18,19,21,23$, Mississippi State Chemical Laboratory; 7, 8, 9, 13, 20, Margaret D. Foster; 24 , W. F. Hand, Mississippi State Chemical Laboratory.

\section{LAWRENCE COUNTY}

\section{GENERAL FEATURES}

Area, 418 square miles. Population, 12,663 (census of 1920)

Lawrence County lies wholly within the Long-leaf Pine Hills district. The principal geologic formations that appear at the surface within the county include, in ascending order of age, the Hattiesburg clay (Miocene) (see pl. 4, $A$ ), the Pascagoula clay (Miocene), and the Citronelle formation (Pliocene). Descriptions of these formations are given on pages 56-60, and their distribution is shown on the geologic map (pl. 2). Surficial terrace deposits of loam, clay, sand, and gravel, of Pleistocene and Recent age, underlie the lowland bordering Pearl River. 


\section{GROUND-WATER CONDITIONS}

The principal developed source of ground water in the upland part of the county is the Citronelle formation, which forms the body of the hills to depths of 50 to 150 feet or more. The formation is generally water bearing. The water is obtained by dug and bored wells that range in depth from a few feet to 100 feet or more. These wells are easily and cheaply constructed and are generally cribbed with wooden casing. Several typical wells are described in the table of well data. (Nos. 11-15). Small springs that have their source in the sands and gravels of the Citronelle formation are common throughout the county, and some of the larger and better ones are used for domestic water supplies. Shallow wells can doubtless obtain water from the alluvial terrace deposits that border Pearl River.

The Hattiesburg clay, which consists of 400 or 450 feet of massive blue and gray clay and subordinate amounts of sand and sandstone, immediately underlies the Citronelle formation throughout all except the southwestern part of the county, where a thickness of 150 or 200 feet of the Pascagoula clay overlaps onto the Hattiesburg clay and is overlain in turn by the Citronelle formation. Both the Hattiesburg and Pascagoula formations consist chiefly of non-water-bearing clay, but some of the subordinate beds of sand that are interbedded with the clay are doubtless water bearing. Two of the wells reported in the table of well data (Nos. 3, 9) appear to derive water from the Hattiesburg.

The source of the water of most of the numerous flowing wells that have been obtained in the lowland that borders Pearl River during the last decade is believed to be the upper part of the Catahoula sandstone, which underlies the Hattiesburg clay and consists of 400 or 500 feet of irregularly bedded sandstone, sand, and clay. The more porous beds of sand are water bearing and constitute one of the most valuble sources of ground water in southern Mississippi. Several wells at Monticello, where water-bearing beds of the Catahoula are tapped at depths of 280 to 330 feet, are described in the table of well data (Nos. 1, 5-8). The static head of the water in these wells ranges from 1 to 15 feet above the level of the lowland in the vicinity of Monticello.

The Catahoula formation (Miocene) underlies the entire county, but it does not appear anywhere at the surface. The nearest outcrop of the formation is in the valley of Pearl River, about 25 miles north of the northern boundary of Lawrence County. The formation dips to the south at the rate of about 20 feet to the mile, so that along the southern boundary, if the dip is uniform, the top of the formation lies 450 or 500 feet below the surface of Pearl River lowland, or 650 to 700 feet below the surface of the highest parts of the upland. 
The static head of the Catahoula waters is sufficient to cause them to rise 5 to 20 feet above the surface of the Pearl River lowland. Flowing wells can therefore be obtained only in this lowland and in the lowlands that border some of the larger tributary creeks. The same waters can, however, be obtained anywhere in the county, but to reach them the wells would have to be drilled as much deeper as the difference in altitude between the ground at any given locality and the nearest adjacent part of the Pearl River lowland, and deepwell pumps or air-lifts would have to be installed to raise the water to the surface.

\section{LOCAL SUPPLIES}

Monticello.-Monticello is built on a Pleistocene terrace plain which lies 35 to 40 feet above low-water level of Pearl River. At least 16 flowing wells have been drilled in the vicinity of the town, and eight of them are described in the table of well data. The log of one well (No. 5) is given below. Most of the wells range in depth from 285 to 330 feet, and they tap a water-bearing sand in the Catahoula formation. The wells had initial yields ranging from 3 to 60 gallons a minute, but the yield of some of them has shown a marked decrease. Several of the wells are 190 to 200 feet deep and have their source in a shallower sand than the others; the yield from this stratum is not so large as that from the deeper stratum. One well owned by the county (No. 2), located at the courthouse, is 926 (?) feet deep and flows 3 gallons a minute. It probably has its source in the Forest Hill sand of the Vicksburg group. Shallow wells 15 to 25 feet deep are still in use. Analyses of samples from a 22-foot well (No. 4), a 295foot well (No. 8; pl. 6, A), a 330-foot well (No. 6), and the 926-foot well (No. 2) at the courthouse, are given in the table.

Log of well of G. Wood Magee, at Monticello (No. 5)

[Altitude of mouth of well about 200 feet above sea level. Authority, the owner]

\begin{tabular}{l|r|r}
\hline & $\begin{array}{c}\text { Approxi- } \\
\text { mate } \\
\text { thickness }\end{array}$ & $\begin{array}{c}\text { Approxi- } \\
\text { mate } \\
\text { depth }\end{array}$ \\
\hline $\begin{array}{r}\text { Terrace deposit(?): } \\
\text { Red clay } \quad\end{array}$ & Feet & Feet \\
Coarse sand; water bearing & 5 \\
Hattiesburg clay: Close gummy marl (clay) & $\begin{array}{r}5 \\
40\end{array}$ \\
\hline
\end{tabular}

Oakvale.-A $\log$ of Phil R. Polk's nonflowing 200-foot well at Oakvale is given below: 
Log of well of Phil R. Polk, Oakvale (No. 10)

[Authority, the owner, from memory]

Citronelle formation(?): Clay and gravel.

Hattiesburg clay:

Firm blue clay without sand or grit

Soft white clay with red streaks.

Catahoula sandstone:

Sandstone.

Coarse sand

Coarso si

Gravel and sand; water bearing.

\begin{tabular}{|c|c|c|}
\hline . & $\begin{array}{c}\text { Approxi- } \\
\text { mate } \\
\text { thickness }\end{array}$ & $\begin{array}{c}\text { Approxi- } \\
\text { mato } \\
\text { depth }\end{array}$ \\
\hline el. & $\underset{20}{\text { Feet }}$ & Feet $_{20}$ \\
\hline 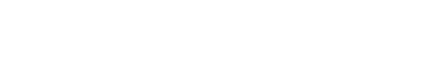 & $\begin{array}{r}140 \\
20\end{array}$ & $\begin{array}{l}160 \\
180\end{array}$ \\
\hline - & $\begin{array}{c}1 \\
11 \\
0.5 \\
7.5\end{array}$ & $\begin{array}{l}181 \\
192 \\
192.5 \\
200\end{array}$ \\
\hline
\end{tabular}

\section{$54134-28-19$}




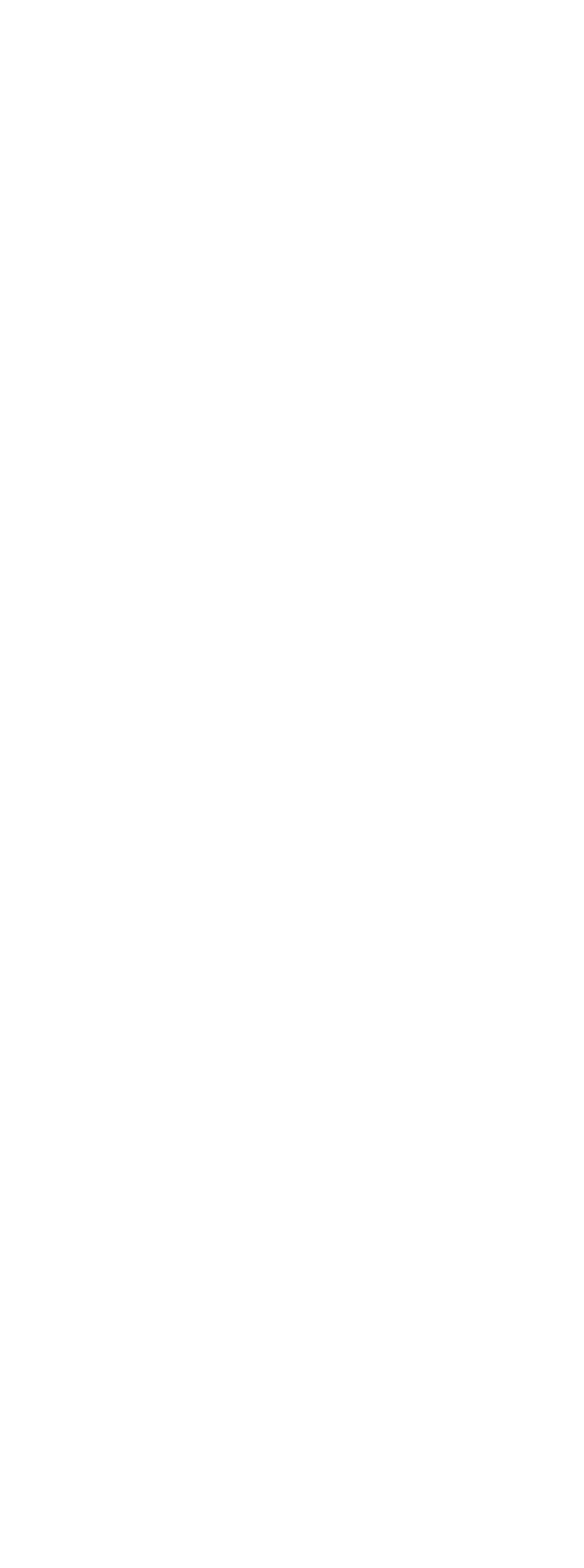




\begin{tabular}{|c|c|c|c|c|c|c|c|}
\hline \multicolumn{2}{|c|}{ 逜 } & 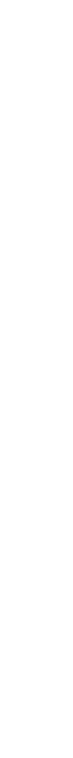 & 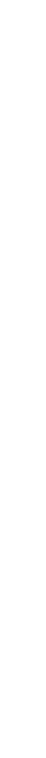 & 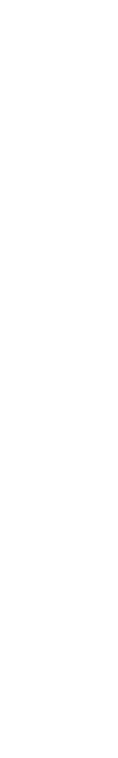 & 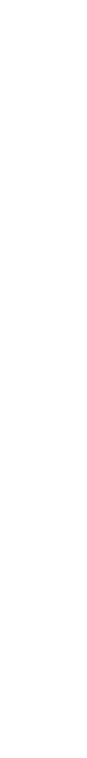 & 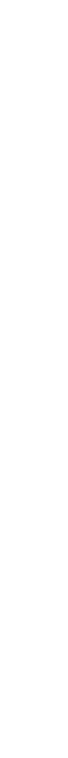 & 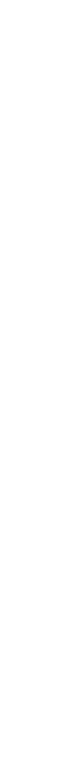 \\
\hline 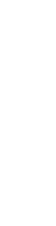 & 象 & $\begin{array}{l}0 \\
0 \\
0 \\
0 \\
0\end{array}$ & 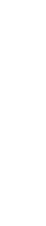 & 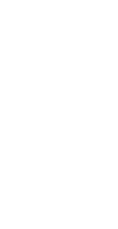 & 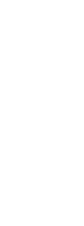 & 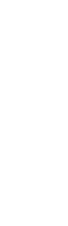 & 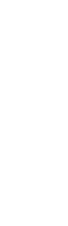 \\
\hline \multicolumn{2}{|c|}{ 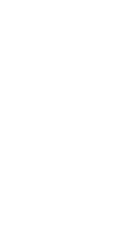 } & 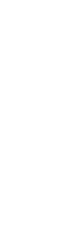 & 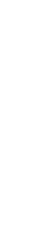 & 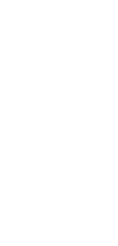 & 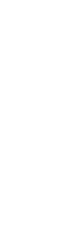 & 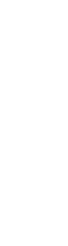 & 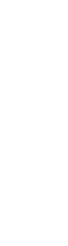 \\
\hline \multicolumn{2}{|c|}{$\stackrel{8}{0}$} & 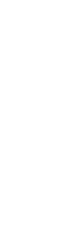 & :ִ & 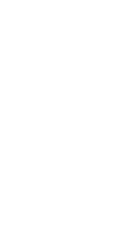 & 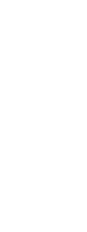 & :1 & 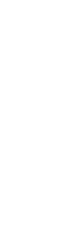 \\
\hline \multicolumn{2}{|c|}{ 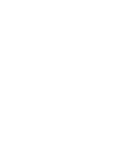 } & 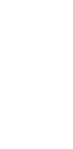 & 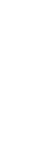 & 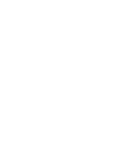 & : & की & 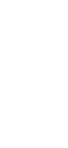 \\
\hline \multirow{2}{*}{ 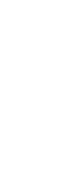 } & 을 & & & & $*$ & & \\
\hline & $\frac{\mathrm{E}}{\mathrm{E}}$ & 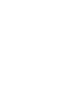 & & \begin{tabular}{|l|l|l}
8000 \\
\end{tabular} & $\infty !$ & & $\infty$ \\
\hline \multicolumn{2}{|c|}{ 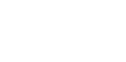 } & नतN & $*$ & $\infty \infty-\infty$ & $\infty$ & ing & $\stackrel{9}{=}$ \\
\hline
\end{tabular}


Mineral analyses of ground waters from Lawrence County

[Parts per million. Numbers at heads of columns refer to corresponding well numbers in preceding table]

\begin{tabular}{|c|c|c|c|c|c|}
\hline & 2 & 4 & 6 & 8 & 13 \\
\hline 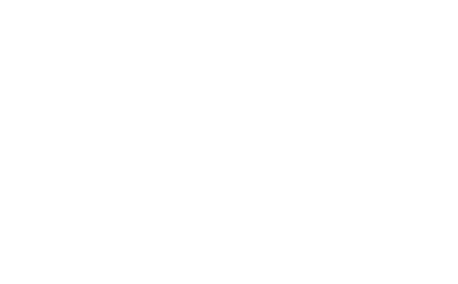 & 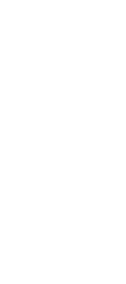 & 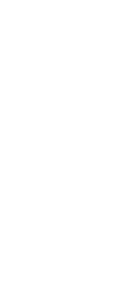 & $\begin{array}{c}26 \\
3.00 \\
1.6 \\
23.6 \\
61.0 \\
8.9 \\
3.2 \\
\text { Trace. } \\
93 \\
14 \\
\text { July, } 1919\end{array}$ & $\begin{array}{c}27 \\
.79 \\
3.2 \\
1.7 \\
27.7 \\
71.0 \\
9.3 \\
3.7 \\
\text { Trace. } \\
104 \\
15 \\
\text { July, } 1919\end{array}$ & $\begin{array}{c}35 \\
21 \\
33 \\
18 \\
116 \\
149^{\circ} \\
26 \\
148 \\
32 \\
493 \\
156 \\
\text { Dec., } 1914\end{array}$ \\
\hline
\end{tabular}

- Computed.

Analysts: 2, 4, 8, Margaret D. Foster, U. S. Geological Survey; 6, N. Fuchs, U. S. Geological Survey; 13 , Mississippi State Chemical Laboratory.

\section{IFAKE COUNTY}

\section{GENERAL FEATURES}

Area, 576 square miles. Population, 16,972 (census of 1920)

Leake County is in the North Central Hills district. The entire county is underlain by formations that belong to the Claiborne group of the Eocene. The Tallahatta formation touches the eastern edge; the Winona sand member of the Lisbon formation crosses the northeast corner, and the remainder of the county is underlain by the Kosciusko sandstone member and undifferentiated beds of the Lisbon. Descriptions of these formations are given on pages 50-52 and their distribution is shown on the geologic map (pl. 2).

\section{GROUND-WATER CONDITIONS}

The beds that comprise these formations dip to the southwest at a rate estimated to be between 20 and 30 feet to the mile, though the inclination is probably more than $\mathbf{3 0}$ feet to the mile in some places and perhaps less than 20 feet in others. As all the formations contain water-bearing sands of greater or less capacity, it is possible throughout practically the whole area to obtain supplies of water adequate for domestic and farm use from wells less than 100 feet deep. Springs are common.

The southwestward dip of the water-bearing beds renders the conditions favorable for the production of artesian pressure. Although no flowing wells have been reported, they could probably be obtained at points low in the valleys of Pearl River and all of its larger tributaries. The most abundant prospective source of artesian water sup- 
plies, however, is not the formations that appear at the surface within the limits of the county, but the water-bearing beds of the Holly Springs sand, which crop out in Winston County on the northeast and dip to the southwest beneath the Tallahatta formation. These beds doubtless extend out under all of Leake County. In the valleys of Pearl River and Labutchie Creek, where these streams enter the county on the northeast, the depth to the topmost beds of the Holly Springs sand is probably less than 250 feet.

\section{LOCAL SUPPLIES}

Dossville.-A well at Dossville, drilled in 1908, is 150 feet deep and yields nonflowing water from fine white sand which probably is the Winona sand member of the Lisbon formation. The following log shows the character of the strata penetrated:

Record of R. T. Lovorn well at Dossville

\begin{tabular}{|c|c|c|}
\hline & Thickness & Depth \\
\hline Surface material.... & \multirow{6}{*}{$\begin{array}{c}\text { Feet } \\
20 \\
32 \\
.5 \\
7.5 \\
10 \\
18 \\
12.5 \\
49.5\end{array}$} & \multirow{6}{*}{$\begin{array}{c}\text { Feet } \\
20 \\
52 \\
52 \\
52.5 \\
60 \\
70 \\
88 \\
88.5 \\
10.5 \\
150\end{array}$} \\
\hline $\begin{array}{l}\text { Lisbon formation: } \\
\text { Black clay }\end{array}$ & & \\
\hline $\begin{array}{l}\text { Kosciusko sandstone member- } \\
\text { Hard gray sandstone.......... }\end{array}$ & & \\
\hline $\begin{array}{l}\text { Sand } \\
\text { Sandstone }\end{array}$ & & \\
\hline $\begin{array}{l}\text { Black muck } \\
\text { Sandstone }\end{array}$ & & \\
\hline $\begin{array}{l}\text { Gravel with small shills and shark's teeth } \\
\text { winona sand member(?)-sand, white at bottom. }\end{array}$ & & \\
\hline
\end{tabular}

Conway.-At Conway water is obtained both from dug and from drilled wells. The dug wells range in depth from 15 to 60 feet; the drilled wells are about 150 feet deep and afford soft water under artesian pressure that brings it within 10 to 35 feet of the surface; the source is probably the Kosciusko sandstone member of the Lisbon formation.

St. Anns.-At St. Anns, in the valley of Yokahockany River, 7 miles north of Ofahoma, water is obtained chiefly from shallow wells, probably in the river alluvium. The 35-foot dug well of T. G. Gamble is typical.

Carthage.-A 55-foot well at the southwest corner of the courthouse square at Carthage, drilled in 1910, is 2 inches in diameter and yields nonflowing water from the Kosciusko sandstone member of the Lisbon formation. An analysis of the water is given below. 
The principal source of ground water in this county is the Eutaw formation, the main body of which lies at depths of 600 to 1,000 feet in the west and rises at the rate of about 30 feet to the mile until it comes to the surface east of Lee County and forms the hills of Itawamba County. The Tuscaloosa formation underlies the Eutaw and appears at the surface in eastern Itawamba County, Miss., and in Marion and Franklin Counties; Ala. Hundreds of wells have been drilled to the Eutaw, but only a few wells are deep enough to reach the Tuscaloosa formation, the waters of which are under a stronger head than those of the Eutaw and probably constitute an extensive undeveloped source of supply.

In addition to the main water-bearing beds of the Eutaw, the stratigraphically higher Tupelo tongue (see pp. 33-34) is a notable source of supply in the west-central part of the county. At Belden water is obtained from this source by means of wells 135 to 310 feet deep (Nos. 2-8).

The Coffee sand member of the Eutaw formation, the outcropping beds of which form the hills in the northeastern portion of the county, is composed in part of water-bearing sands which dip to the west and are tapped in the northwestern portion of the county, as in the vicinity of Bethany, by wells located on the Selma chalk (No. 9):

Many of the deeper wells in Lee County were dirilled subsequent to 1890. A few date back to 1870 . Originally many of the wells located in the valleys of Old Town Creek and its tributaries overflowed, but owing to the heavy draft on the main water-bearing beds of the Eutaw the static head has been lowered, and many of the wells now have to be pumped. At Tupelo, where the heaviest draft has been made, there are now no flowing wells.

In the early history of the county cisterns and artificiallyconstructed pools for storing rain water were in general use throughout the Black Prairie belt, but wells are rapidly replacing this unsatisfactory means of providing water supplies. In the areas immediately underlain by the Coffee sand member and the Tupelo tongue shallow dug and bored wells are still the most common means of obtaining supplies for domestic use.

\section{LOCAL SUPPLIES}

Tupelo.-The wells first drilled at and near Tupelo, with the exception of those located on the higher parts of the upland west of Old Town Creek, overflowed, and the amount of yield ranged from a few gallons to many gallons a minute. Most of them tapped waterbearing sands in the Eutaw formation at depths of 300 to $\mathbf{4 5 0}$ feet. The heavy draft on this reservoir occasioned by the wells at the hatcheries of the United States Bureau of Fisheries south of town, 
the five wells that supply the water of Park Lake north of town, the numerous privately owned wells, and the wells that furnish the municipal water supply, has so greatly reduced the static head that the wells no longer flow, and the water now stands from 5 to 70 feet below the surface in different parts of the town. The greatest decrease in hydrostatic pressure took place when the large 8 and 10inch wells at the waterworks plant were put in operation. The suggestion is offered that if wells drilled in the future should be sunk to the water-bearing beds of the Tuscaloosa, which at Tupelo lie at estimated depths of 700 to 1,000 feet, and if wells now in use should be deepened to the same formation, not only might waters under stronger hydrostatic pressure be obtained but the lessening of the draft on the old source might result in a gradual strengthening of the static head.

Detailed information concerning six wells at and near Tupelo, which range in depth from 325 to 456 feet, is given in the table (Nos. 24-29). A few wells deeper than those listed, some reaching depths as great as 1,000 feet, have been drilled at Tupelo, but detailed information concerning them is lacking. The waterworks at Tupelo, which is owned by the town, is on Court Street east of Spring Street, near the Mobile \& Ohio Railroad. Water is obtained from six $\cdot$ wells, which range in depth from 380 to 456 feet. Two wells (Nos. 25 and 26) are described in the table of well data. Two logs of wells at Tupelo are given below:

\section{Log of well of W. J. Paulk, a mile west of Tupelo (No. 29)}

[Altitude of mouth of well 310 feet above sea level (estimated). Adapted from description by J. W. Webb, driller]

\begin{tabular}{|c|c|c|}
\hline & Thickness & Depth \\
\hline $\begin{array}{l}\text { Pleistocene or residual Selma: } \\
\text { Soil and clay } \\
\text { Not reported } \\
\text { Eutaw formation (Tupelo tongue of Coffee sand member): Sand } \\
\text { Selma chalk (Mooreville tongue): Blue marl and soapstone } \\
\text { Eutaw formation: Sand; water bearing }\end{array}$ & $\begin{array}{r}\text { Feet } \\
15 \\
10 \\
100 \\
215 \\
60\end{array}$ & $\begin{array}{r}\text { Feet } \\
15 \\
25 \\
125 \\
340 \\
400\end{array}$ \\
\hline
\end{tabular}

Log of average well at Tupelo a

[Altitude of mouth of well 270 feet above sea level at crossing of Mobile \& Ohio and Frisco railroads. Adapted from description by Crider]

\begin{tabular}{|c|c|c|}
\hline & Thickness & Depth \\
\hline 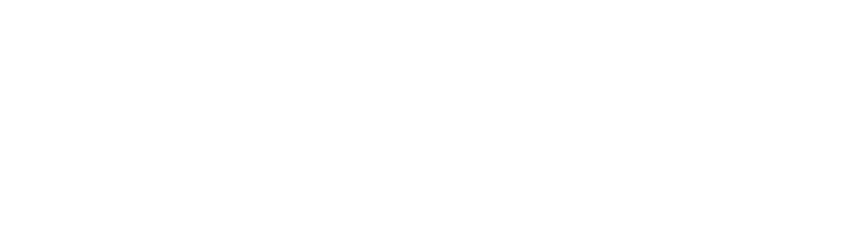 & $\begin{array}{rr}\text { Feet } & \\
20 \\
100 \\
130 \\
10 \\
4 \\
4 \\
10 \\
\\
\text { (?) }\end{array}$ & $\begin{array}{r}\text { Feet } \\
20 \\
120 \\
250 \\
260 \\
260 \\
274 \\
294 \\
\text { (?) }\end{array}$ \\
\hline
\end{tabular}

- Crider, A. F., Mississippl Geol. Survey Bull. 1, p. 46, 1907. 
Of the two preceding logs the log of the Paulk well, which was prepared by an experienced driller, is probably the more reliable as regards the thickness and the character of the beds penetrated, and it harmonizes with the facts shown by outcrops of the beds, as recently determined. Crider's section is interesting as showing 100 feet of sand at a depth of 20 to 120 feet, which puzzled him because of his preconceived belief that the Tupelo was immediately underlain by typical Selma chalk. This sand is the southward extension of the body of sand in the Eutaw formation described on pages 32-34, which tongues into the Selma and to which the name Tupelo tongue has been given. The thickness of 130 feet which Crider gives for the "blue limestone," or the northward-extending Mooreville tongue of the Selma that underlies the sand, is less than that indicated by the other log and also than that determined by calculations based on surface outcrops and by other logs.

Mooreville.-The principal source of ground water at Mooreville is the Eutaw formation, the uppermost beds of which lie beneath the Mooreville tongue of the Selma chalk at a depth of 155 feet. The section here is shown by the following well log:

Log of well at Mooreville (No. 13) a

[Altitude of mouth of well, about 395 feet above sea level. Adapted from description by Crider and Johnson]

\begin{tabular}{|c|c|c|}
\hline & Thickness & Depth \\
\hline $\begin{array}{l}\text { Selma chalk (Mooreville tongue): Calcareous clay } \\
\text { Eutaw formation: Sand; water bearing }\end{array}$ & $\begin{array}{r}\text { Feet } \\
155 \\
20\end{array}$ & $\begin{array}{r}\text { Feet } \\
155 \\
175\end{array}$ \\
\hline
\end{tabular}

- Crider, A. F., and Johnson, L. C., U. S. Geol. Survey Water-Supply Paper 159, p. 67, 1906.

City Point.-City Point is a station on the St. Louis \& San Francisco Railroad, 3 miles south by east of Plantersville. The following log shows the character of the beds penetrated in a well on the bottom lands of Old Tom Creek, west of the railroad (No. 10).

Log of well near City Point

[Altitude of mouth of well, 245 feet above sea level. Adapted from data furnished by W. N. Logan]

\begin{tabular}{l|r|r}
\hline & Thickness & Depth \\
\hline Silt, fine sand, and clay & Feet & Feet \\
Blue marl with layers of hard sandstone & 40 \\
Sand; water bearing (Eutaw formation) & 80 & 120 \\
230
\end{tabular}

Nettleton.-Ground waters at Nettleton are obtained chiefly from the Eutaw formation at depths of 100 to more than 550 feet. Three wells are described in the table (Nos. 14-16). Flowing wells are common on the low, flat terrace plains that border Old Tom Creek in the vicinity of the town. A public well ( $\mathrm{No.} \mathrm{14)} \mathrm{that} \mathrm{is} \mathrm{located} \mathrm{in}$ 
the street originally overflowed, but in 1910 the flow ceased from some undetermined cause.

Plantersville.-The numerous wells in the Ivicinity of Plantersville range in depth from 140 to 300 feet and tap water-bearing beds in the Eutaw formation. (Nos. 17, 18.) Some of the wells on the level lands adjacent to Old Tom Creek overflow, but the yield as a rule is only a few gallons a minute. A few wells that are only 140 to 150 feet deep probably do not reach the Eutaw but draw their supplies from a water-bearing sand in the Mooreville tongue of the Selma chalk.

Shannon.-Many wells 300 to 400 feet deep have been drilled at the village of Shannon and on the $\mathbf{T}$ near-by farms. (Nos. 22, 23.) The source of the water is the Eutaw formation. The wells on the upland do not flow but some wells on the bottom lands of the creeks give rise to small streams. The town owns a public well about 350 feet deep (No. 23), the purpose of which is to provide water for sprinkling the streets and for fire protection. Another public well near the first one is also about 350 feet deep, and the water is used chiefly for drinking.

Verona.-Deep wells were in use at Verona as early as 1870. Since then many wells, which range in depth from 250 to 425 feet, have been drilled in the vicinity. (Nos. 31-34.) The source of the water is the sands of the Eutaw formation. The static head of wells on the upland ranges from 25 to 80 feet below the surface, depending in any given well on the altitude of its mouth and on the hydrostatic pressure of the water in the particular bed or beds drawn upon. Windmills for raising the water have been installed at some of the wells. One well 250 feet deep, located in a creek bottom three-fourths of a mile west of town. is reported to have originally overflowed at the rate of 8 gallons a minute, but it has since ceased to flow. Other wells in the vicinity, also on low ground, yield flows, but detailed information regarding them is lacking. Analysis 31 represents water from R. S. Gibson's well. A public well in the street at Verona is reported to be about 400 feet deep. Logs of two wells near Verona are given below:

Log of well at Verona, located in the lowest part of the town near the station *

[Altitude of mouth of well, about $300 \pm$ feet above sea level. Adapted from description by Crider]

\begin{tabular}{|c|c|c|}
\hline .. & Thickness & Depth \\
\hline Surface soil (residual from the Selma) .. & Feet ${ }_{21}$ & Feet 21 \\
\hline $\begin{array}{l}\text { Selma chalk: } \\
\text { Chalk of light color } \\
\text { Blue limestone (chalik) }\end{array}$ & $\begin{array}{r}80 \\
160\end{array}$ & 101 \\
\hline Eutaw formation: & & 771 \\
\hline $\begin{array}{l}\text { Gray sand; water bearing } \\
\text { Compact sticky sand }\end{array}$ & $\begin{array}{l}10 \\
30 \\
15\end{array}$ & \\
\hline $\begin{array}{l}\text { Black clay - } \\
\text { Fine gray sand; water bearing }\end{array}$ & $(9)^{20}$ & $(9)^{336}$ \\
\hline
\end{tabular}

- Crider, A. F., Mississippi Geol. Survey Bull. 1, p. 48, 1907. 
Log of well of J.E. MeShaw (W.S. Johnson well) an eighth of a mile northwest of the post office, Verona (No. \$2)

[Altitude of mouth of well, about 298 feet above sea level. Adapted from description by W. W. Johnson]

\begin{tabular}{l|r|r|r}
\hline & Thickness & Depth \\
\hline Olay (residual from the Selma) & Feet & Feet \\
18 & 18 \\
Selma ohalk: Lime rock (chall) \\
Eutaw formation (Tombigbeo sand member): Sand; water bearing
\end{tabular}

Saltillo.-Saltillo is located near the western border of the area of outcrop of the Coffee sand member of the Eutaw formation. Shallow dug and bored wells 25 to 80 feet deep are used by many of the inhabitants; the source of the water of these wells is the Coffee sand. A few wells 300 to 350 feet deep, which pass through the Coffee sand and Tombigbee sand members and tap water-bearing beds in the typical Eutaw deposits, are also used; those located on low ground give rise to small streams. (See wells 19-21.) The log of W. E. Milam's well, 200 yards east of the Mobile \& Ohio Railroad station, is given below. (See analysis 19.)

\section{Log of vell of W. E. Milam at Saltillo (No. 19)}

[Altitude of mouth of well, about 310 feet above sea level. Adapted from owner's description]

\begin{tabular}{|c|c|c|}
\hline & Thickness & Depth \\
\hline $\begin{array}{l}\text { Eutaw formation: } \\
\text { Sand } \\
\text { Soft bilue rock- } \\
\text { Hard rock } \\
\text { Sand; water bearing } \\
\text { Hard blue rock } \\
\text { Band; water bearing }\end{array}$ & $\begin{array}{l}\text { Feet } \\
45 \\
84(?) \\
1(?) \\
1(?) \\
109(?) \\
25\end{array}$ & $\begin{array}{l}\text { Feet } \\
40 \\
124(?) \\
125(?) \\
126(?) \\
325 \\
350\end{array}$ \\
\hline
\end{tabular}

Guntown.-Guntown is situated on the eastern edge of the Selma chalk; the basal beds of which appear in the cut just north of the station. The inhabitants of the town and the adjacent country on the north, east, and south depend for domestic water supplies chiefly on dug and bored wells, 25 to 40 feet deep, which tap water-bearing sands in the upper part of the Coffee sand member of the Eutaw formation. West of the town, in the Black Prairie belt, cisterns and pools provide the principal water supply. A fow nonflowing wells 400 to 500 feet deep, which reach the water-bearing beds in the main part of the Eutaw formation below the Tombigbee sand member, are in use. Analyses 11 and 12 represent hard water from the public well and from N. H. Crenshaw's well.

Baldwyn.-The main part of Baldwyn is situated on the outcrop of the uppermost beds of the Coffee sand. A thin isolated patch of Selma chalk caps the hill in the western part of the town. Shallow dug and bored wells are used by many of the inhabitants, but wells 
250 to 500 feet deep, which tap water-bearing beds near the base of the Coffee sand and in the main part of the Eutaw below the Tombigbee sand, are coming into more general use. Those located on lower ground in the creek and branch valleys east of town overflow, and some yield 20 gallons or more a minute. As the northern part of the town extends across the line into Prentiss County other data, including a description of the municipal waterworks, are given in the section on the ground waters of that county (pp. 402-404). A spring of small yield on the Mobile \& Ohio Railroad's right of way, 500 feet south of the station and east of the track, has its source in the Coffee sand; it has practically ceased to flow and is no longer in use. (See analysis 35 .)

Belden.-The people living at Belden, a village about midway between the east and west borders of the area underlain by the main belt of the Selma chalk, depend for domestic water supplies chiefly on nonflowing wells 135 to 180 feet deep (Nos. 2-8), which penetrate a water-bearing stratum in the Tupelo tongue of the Coffee sand. Good supplies might also be obtained here by drilling to the main water-bearing beds of the Eutaw at depths of 550 to 800 feet. Logs of three wells near Belden are given below. (See analyses 2,3.)

Log of well of G. W. Ritter, on the upland half a mile south of Belden (No. 8)

[Adapted from description by driller]

\begin{tabular}{|c|c|c|}
\hline & Thickness & Depth \\
\hline $\begin{array}{l}\text { Selma chalk: } \\
\text { Chalk }\end{array}$ & Feet $\begin{array}{r}80 \\
30\end{array}$ & Feet 80 \\
\hline $\begin{array}{l}\text { Eutaw formation (Tupelo tongue of Coffee sand member): } \\
\text { Hard sandstone }\end{array}$ & 2 & 112 \\
\hline $\begin{array}{l}\text { White sand, feebly water bearing, followed by interstratified layers of roek and } \\
\text { water-bearing sand }\end{array}$ & & 140 \\
\hline
\end{tabular}

Log of well of L. F. Ritter, three-quarters of a mile east of Belden (No. 5)

[Altitude of mouth of well about 300 feet above sea level. Adapted from owner's description]

\begin{tabular}{|c|c|c|}
\hline & Thickness & Depth \\
\hline $\begin{array}{l}\text { Selma chalk: } \\
\text { Not reported. } \\
\text { White limerock } \\
\text { Blue limerock } \\
\text { Sandrock } \\
\text { Aray limerock } \\
\text { Eutaw formation (Tupelo tongue of cofiee sand member) } \\
\text { Sandrock } \\
\text { Sand; water bearing }\end{array}$ & $\begin{array}{r}\text { Feet } \\
16 \\
2 \\
100 \\
\pm 1 \\
\pm 22 \\
2 \\
3\end{array}$ & $\begin{array}{r}\text { Feet } \\
16 \\
18 \\
118 \\
\pm 119 \\
141 \\
143 \\
146\end{array}$ \\
\hline
\end{tabular}


Log of well of C. N. Ritter, on the upland an eighth of a mile north of Belden (No.6) [Altitude of mouth of well 40 teet above Town Creek. Adapted from desaription by J. W. Webb, driller]

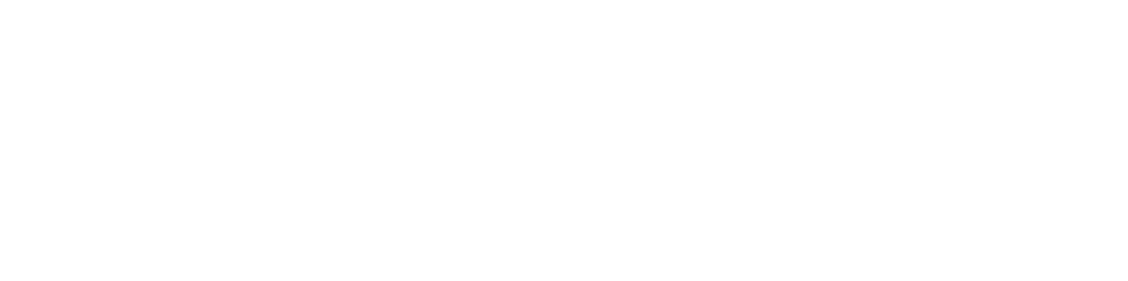

Bethany.-Wells in the vicinity of Bethany, a village in the northwestern part of the county about 6 miles west of Baldwyn, are drilled to the water-bearing beds of the Coffee sand at depths of 200 to 400 feet. (See well 9.) No flowing wells have been reported, and the static head ranges from 50 to 100 feet below the surface. 


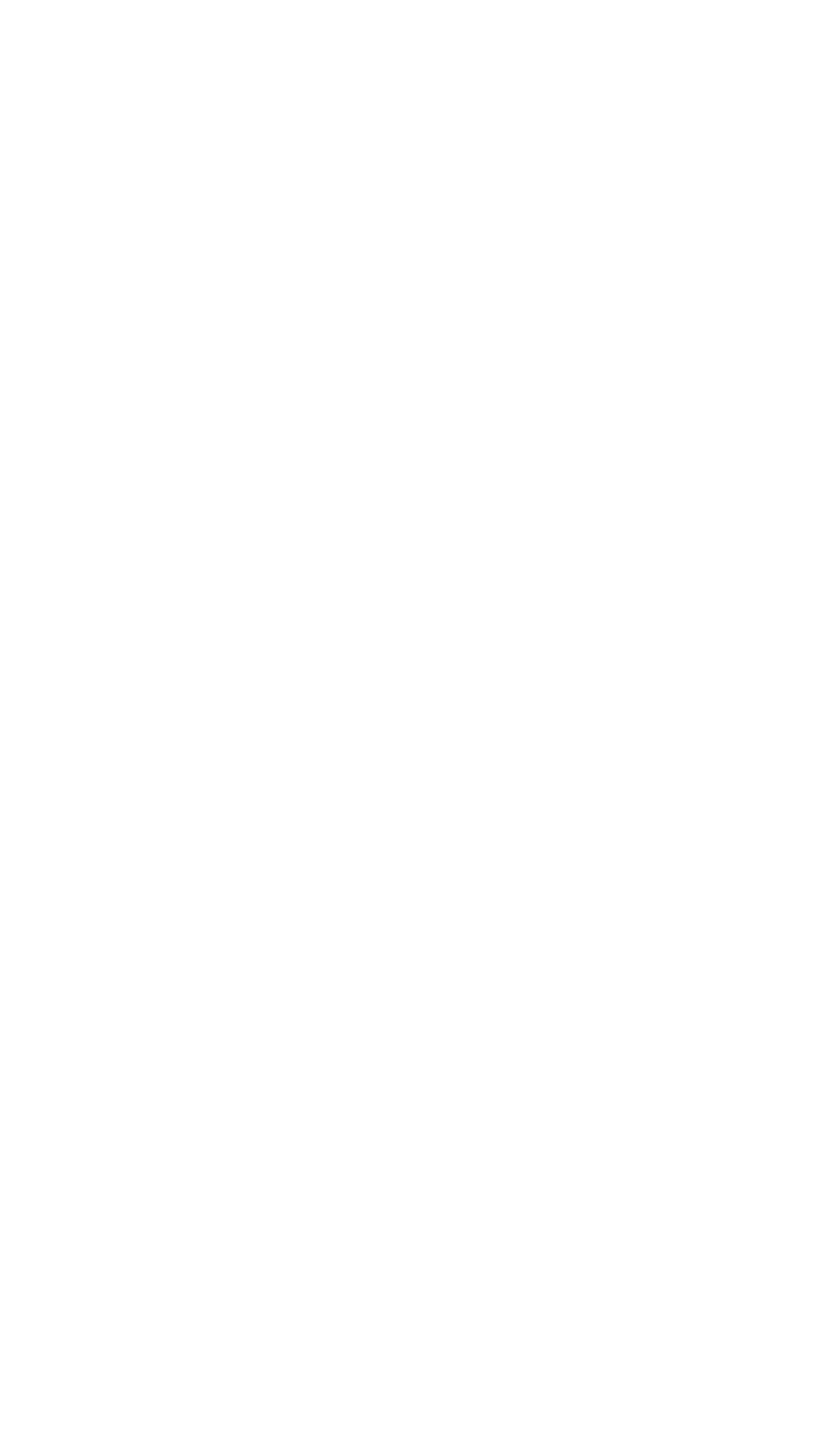




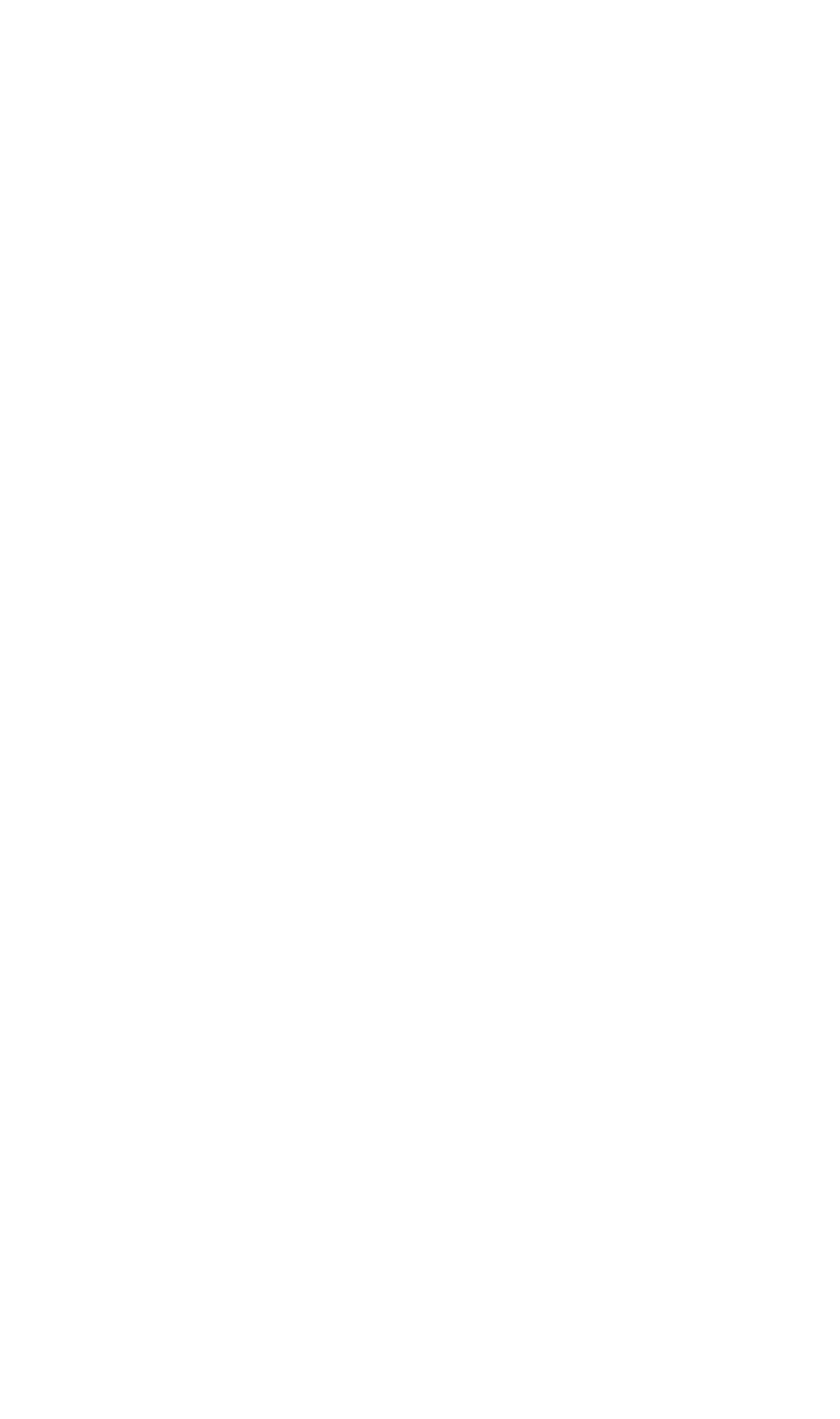




\begin{tabular}{|c|c|c|c|c|c|c|c|c|c|c|c|c|c|c|c|}
\hline$!$ & & 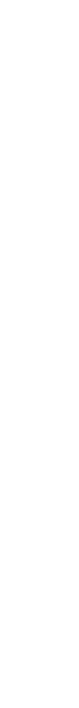 & 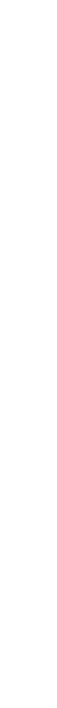 & 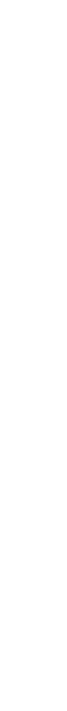 & 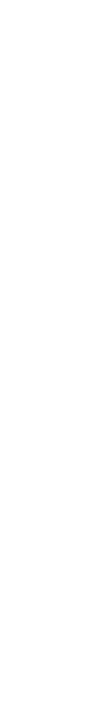 & 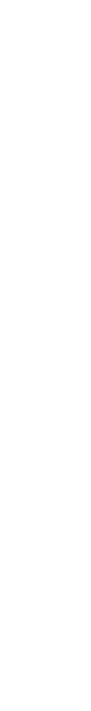 & 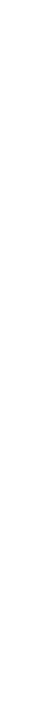 & 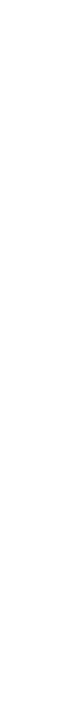 & 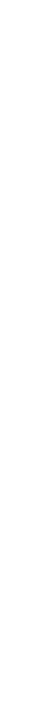 & 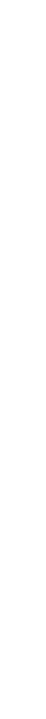 & 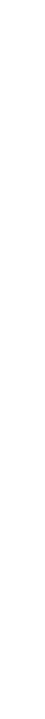 & 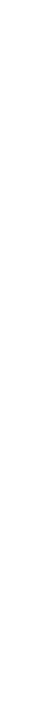 & 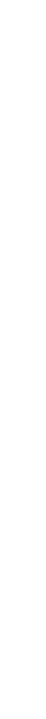 & 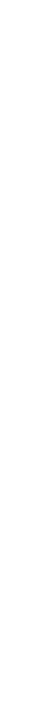 & \\
\hline 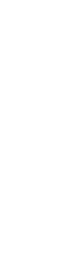 & & 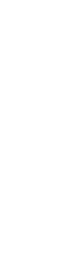 & ' & 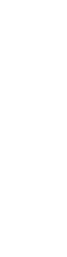 & 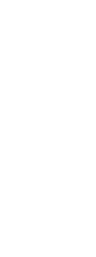 & 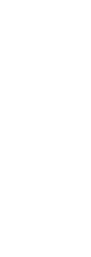 & & ' & ¿̊̊ & 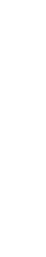 & & 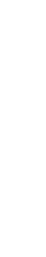 & & & \\
\hline 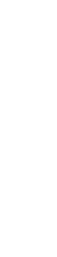 & & 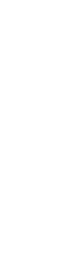 & : & 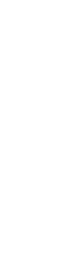 & वे & ชి & ه્ּْ & '̊ & ఫิ่ & هั่ & ชิ่ & वें & هُ & & 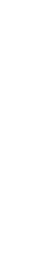 \\
\hline \multicolumn{2}{|c|}{ 总 } & 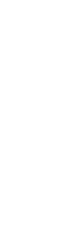 & 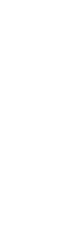 & 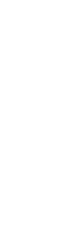 & 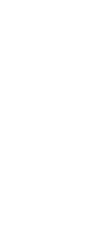 & 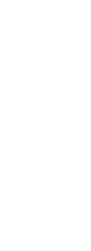 & & 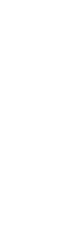 & 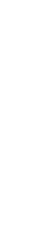 & 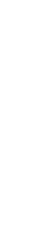 & 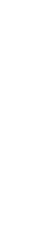 & $g$ & 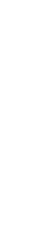 & & 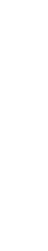 \\
\hline \multicolumn{2}{|c|}{ 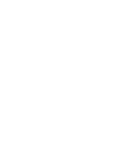 } & 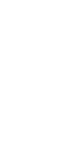 & वُّ & 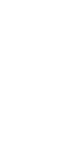 & 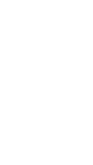 & $\frac{5}{4}$ & & 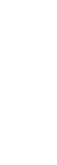 & 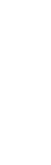 & 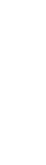 & $\begin{array}{c}\vdots \\
\vdots \\
\vdots \\
\square\end{array}$ & : & 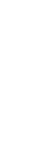 & 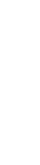 & \\
\hline \multirow{2}{*}{ 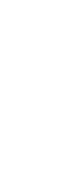 } & 息 & 0 & & & & \& & & (8) & $H$ & $H$ & & & 을 & & \\
\hline & 总 & & 20 & $\infty$ & 19 & & & & & & & & & & \\
\hline
\end{tabular}


Mineral analyses of ground waters from Lee County

[Parts per million. Numbers at heads of columns refer to corresponding well numbers in proceding table]

\begin{tabular}{|c|c|c|c|c|c|c|c|}
\hline & 2 & 3 & 4 & 11 & 12 & 15 & 19 \\
\hline \multirow[t]{2}{*}{ 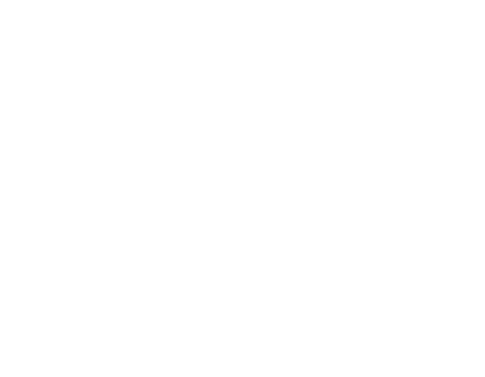 } & $\begin{array}{l}25 \\
.23 \\
9.4 \\
5.6 \\
101 \\
25 \\
202 \\
38 \\
13 \\
324 \\
46 \\
\text { Sept., } \\
1919\end{array}$ & $\begin{array}{l}17 \\
16^{.05} \\
5.7 \\
60 \\
240^{\circ} .0 \\
39 \\
13 \\
1.2 \\
297 \\
63 \\
\text { Sept., } \\
1919\end{array}$ & $\begin{array}{l}24 \\
11.06 \\
3.8 \\
95 \\
8.9 \\
243 \\
19 \\
11 \\
1.0 \\
280 \\
43 \\
\text { Sept., } \\
1919\end{array}$ & $\begin{array}{l}22 \\
2.6 \\
51 \\
11 \\
28 \\
254 \\
19 \\
6.0 \\
8.0 \\
272 \\
173 \\
\text { July, } \\
1914\end{array}$ & $\begin{array}{l}39 \\
123 \\
8.65 \\
20 \\
20 \\
375^{\circ} \\
69 \\
4.7 \\
482^{\circ} \\
343 \\
\text { Sept. } \\
1919\end{array}$ & $\begin{array}{c}18 \\
27^{\circ} .97 \\
4.2 \\
23 \\
{ }^{\circ} .0 \\
124 \\
8.5 \\
10 \\
149^{\circ} \\
85 \\
\text { June, } \\
1914\end{array}$ & $\begin{array}{c}25 \\
.12 \\
8.0 \\
2.8 \\
47 \\
31 \\
54 \\
7.2 \\
20 \\
173 \\
170 \\
32 \\
\text { Sept., } \\
1919\end{array}$ \\
\hline & & 20 & 24 & -25 & 26 & 31 & 35 \\
\hline $\begin{array}{l}\text { Silica }\left(\mathrm{SiO}_{2}\right. \\
\text { Iron }(\mathrm{Fe}) \\
\text { Calcium }(\mathrm{Ca}) \\
\text { Magnesium }(\mathrm{Mg})\end{array}$ & & ${ }_{20}^{15} .85$ & ${ }_{4 .}^{27} .05$ & ${ }_{4.8}^{30} .04$ & $\stackrel{42}{43^{.05}}$ & ${ }_{2.3}^{35}$ & $\begin{array}{r}18 \\
6.0 \\
3.4 \\
1.4\end{array}$ \\
\hline Sodium and potassium $(\mathrm{Na}+\mathrm{K})$ & & 32 & b 44 & 645 & b 53 & b 67 & \\
\hline $\begin{array}{l}\text { Carbonate radicle }\left(\mathrm{CO}_{3}\right) \\
\text { Bicarbonate radicle }\left(\mathrm{HCO}_{3}\right) \\
\text { Sulphate radicle }\left(\mathrm{SO}_{4}\right) \\
\text { Chloride radicle }(\mathrm{Cl}) \\
\left.\text { Nitrate radicle ( } \mathrm{NO} \mathrm{O}_{3}\right) \\
\text { Total dissolved solids at } 180^{\circ} \mathrm{C} \\
\text { Total hardness as } \mathrm{CaCO}_{3} \text { (calculated) } \\
\text { Date of collection }\end{array}$ & & $\begin{array}{l}116^{\circ} \\
8.9 \\
19 \\
153 \\
62 \\
\text { Apr. } \\
1914\end{array}$ & $\begin{array}{c}6.7 \\
107 \\
6.7 \\
60 \\
243 \\
95 \\
95 \\
\text { Sept. } \\
1919\end{array}$ & $\begin{array}{l}121^{\circ} \\
6.7 \\
61 \\
240^{-18} \\
95 \\
\text { Apr.; } \\
1920\end{array}$ & $\begin{array}{c}5.8 \\
125 \\
5.0 \\
96 \\
339^{\circ} \\
138 \\
\text { Apr. } \\
1920\end{array}$ & $\begin{array}{l}41 \\
69 \\
7.6 \\
35 \\
249^{.89} \\
37 \\
\text { Sept., } \\
1919\end{array}$ & $\begin{array}{r}20^{.0} \\
7.8 \\
2.5 \\
\hdashline 58 \\
14 \\
\hdashline\end{array}$ \\
\hline
\end{tabular}

a Composite sample from 5 similar wells.

b Calculated.

Analysts: 2, 12, 19, 31, Margaret D. Foster and Clara M. Forman, U. S. Geological Survey; 3, 4, 24, 25, 26, Margaret D. Foster; 11, 15, 20, W. F. Hand, Mississippi State Chemical Laboratory; 35, W. $\mathbf{R}$. Perkins (Mississippi Agr. Exper. Sta. Buli. 89, p. 24, 1905).

\section{LEFLORE COUNTY}

\section{GENERAL FEATURES}

Area, 572 square miles. Population, 37,256 (census of 1920)

Leflore County lies wholly within the Yazoo Delta. The county is underlain to an estimated depth of 150 or 200 feet by alluvium of Mississippi River, below which lies a thick series of sedimentary deposits of Tertiary (Eocene) age that belong in their upper part chiefly to the Lisbon and Tallahatta formations of the Claiborne group and in their lower part to the Wilcox group, which includes in descending order the Grenada, Holly Springs, and Ackerman formations. Descriptions of these formations are given on pages 45-63.

\section{GROUND-WATER CONDITIONG}

The alluvial deposits which underlie the "delta" to estimated depths of 150 to 200 feet are saturated with water at most places within 20 feet or less of the surface. The more porous sands and gravels will yield abundant supplies to bored or driven wells equipped 
with buckets or pumps, and generally suetion pumps can be used. Vegetable matter in the alluvium has colored the water locally and rendered it more or less objectionable for domestic use.

The thick series of Eocene deposits that underlies the alluvium consists chiefly of interbedded sands and clays, and the more porous sands carry commercial quantities of water under strong artesian head. Although this series is known to include, in descending order, the Lisbon and Tallahatta formations of the Claiborne group, and the Grenada, Holly Springs, and Ackerman formations of the Wilcox group, it is not possible with the available well logs to discriminate accurately the separate formations. The correlations indicated in the table of well data are tentative rough estimates that are based on an assumed west by southwest dip of the formations at the rate of about 25 feet to the mile. All the wells described in the table yield flows. The wells range in depth from 300 to 900 feet, and most of them are believed to have their source in the Lisbon formation; a few are correlated with the Grenada formation and a few with the Holly Springs sand of the Wilcox group.

\section{LOCAL SUPPLIES}

Minter City.-The well of C. E. Feigler, 2 miles northeast of Minter City, is 437 feet deep, and penetrated the strata described in the following log:

Log of well of C. E. Feigler, near Minter City (No. 14)

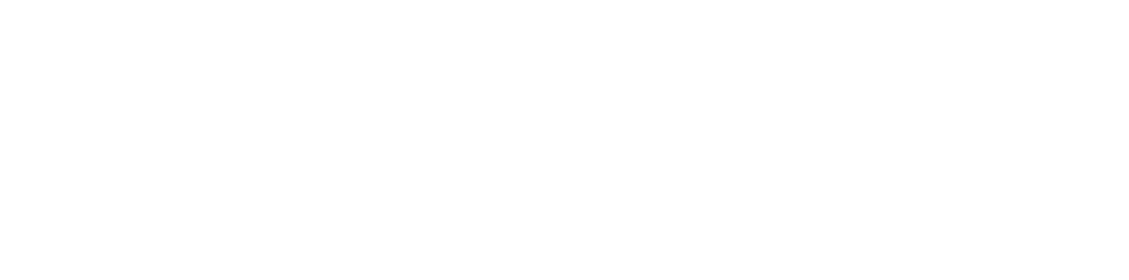

The 550-foot flowing well of F. F. Streeter at Minter City (No. 13), formerly owned by P. C. White, provides the domestic water supplies of several families. For an analysis of the water see No. 13 (p. 303).

Sunnyside.-At Sunnyside Mr. J. K. Towns owns a flowing, well that is reported to be about 400 feet deep; other flowing wells of approximately the same depth in the vicinity yield ample supplies for domestic and farm uses.

Highlandale.-A well owned by B. L. Jones (No. 10), near Highlandale, 2 miles south of Sunnyside, is 720 feet deep and yields a strong artesian flow from sand penetrated near the bottom of the well. A small flow was also struck at a depth of about 500 feet:

Schlater.-Numerous artesian wells have been drilled at and near Schlater. Two wells are described in the table of well data (Nos. 
19,20 ), and analyses of samples of water from these wells are given in the table of analyses.

Ittabena.-The town of Ittabena is provided with a waterworks located about 400 feet west of the Southern Railway station. The supply is obtained from three wells. One of the wells is reported to be 605 feet deep (No. 12), but the depths of the other two are not known exactly, though they are reported to be probably between $\mathbf{9 0 0}$ and 1,000 feet deep. At Ittabena a well 597 feet deep (No. 11) flows 60 gallons a minute. This well and the 605 -foot well at the waterworks have their source in the Lisbon formation of the Eocene.

Geren.-A 900-foot well (No. 2) at Geren, 5 miles south of Philipp, completely penetrates the Lisbon, Tallahatta, and Grenada formations, and probably enters the Holly Springs sand.

Money.-Two strongly flowing wells at Money (Nos. 15, 16), are 420 and 350 feet deep and have their source in the Lisbon formation. The 350-foot well supplies seven residences with running water. Analysis 15 represents the water from the 420-foot well. Two other flowing wells (Nos. 17, 18) near Money are 380 and 300 feet deep and yield strong flows from the Lisbon formation.

Shellmound.-At Shellmound a 426-foot well on the Bledsoe place (No. 21) is reported to flow 300 gallons a minute.

Greenwood.-The waterworks at Greenwood is owned by the city and water is obtained from six flowing wells, which discharge into a 130,000-gallon circular brick ground reservoir. One of the wells is 600 feet deep and yields 100 gallons a minute (No. 3); another is 835 feet doep and yields 1,000 gallons a minute (No. 4); the remaining four are reported to be each about 800 feet deep. Information concerning five other wells in the vicinity of Greenwood, which are owned by individuals and by business concerns, is given in the table of well data (Nos. 5-9), and the logs of two wells are given below. The two deepest of the wells noted in the table (Nos. 5, 7) are each 650 feet deep, and it is estimated that they penetrate to the Grenada, the uppermost formation of the Wilcox group.

Log of well of T. B. Minyard, at Greenwood (No. 6)

\begin{tabular}{|c|c|c|}
\hline & Thickness & Depth \\
\hline $\begin{array}{l}\text { Alluvium: } \\
\text { Soil and clay }\end{array}$ & Feet ${ }_{15}$ & Feet 15 \\
\hline $\begin{array}{l}\text { Mud and silt } \\
\text { Lisbon formation: }\end{array}$ & 140 & 155 \\
\hline Goapstone (clay) theensand with thin strata of hard rock... & $\begin{array}{r}200 \\
20\end{array}$ & $\begin{array}{l}355 \\
375\end{array}$ \\
\hline
\end{tabular}




\begin{tabular}{|c|c|c|}
\hline & Thickness & Depth \\
\hline $\begin{array}{l}\text { Alluvium: } \\
\text { Soil and blue mud.. }\end{array}$ & \multirow{3}{*}{$\begin{array}{r}\text { Feet } \\
\quad 50 \\
78 \\
\\
50 \\
5 \\
57 \\
37\end{array}$} & \multirow{3}{*}{$\begin{array}{r}\text { Feet } \\
\quad 50 \\
128 \\
178 \\
183 \\
220\end{array}$} \\
\hline $\begin{array}{l}\text { Lisbon formation: } \\
\text { Soapstone (clay) }\end{array}$ & & \\
\hline $\begin{array}{l}\text { Shell rock } \\
\text { Sand; water bearing. }\end{array}$ & & \\
\hline
\end{tabular}

Browning.-At Browning, 4 miles east of Greenwood, domestic water supplies are obtained, chiefly from the alluvium, by dug or driven wells 50 feet or less in depth. A well (No. 1) 4 miles south of Browning is 266 feet deep and is reported to yield 200 gallons a minute. The following log shows the beds penetrated in this well:

Log of well of T. B. Minyard, 4 miles south of Browning (No. 1)

\begin{tabular}{|c|c|c|}
\hline & Thickness & Depth \\
\hline $\begin{array}{l}\text { Alluvium: } \\
\text { Soil and clay } \\
\text { Sand } \\
\text { Blue mud. } \\
\text { Sand. }\end{array}$ & Feet $\begin{array}{r}10 \\
5 \\
25 \\
72\end{array}$ & $\begin{array}{r}\text { Feet } \\
10 \\
15 \\
40 \\
112\end{array}$ \\
\hline $\begin{array}{l}\text { Lisbon formation: } \\
\text { Soapstone (clay) } \\
\text { Shell rock } \\
\text { Sand; water bearing }\end{array}$ & $\begin{array}{r}80 \\
2 \\
72\end{array}$ & $\begin{array}{l}192 \\
194 \\
266\end{array}$ \\
\hline
\end{tabular}

Sidon.-The town of Sidon owns a small waterworks and derives its water supply from a public flowing well, the depth of which is not recorded. The water is distributed to the consumers by direct artesian pressure through about a mile of mains. A flowing well (No. 22) owned by J. Aaron, 3 miles north of Sidon, is about 510 feet deep and probably penetrates to the uppermost beds of the Grenada formation. (See analysis 22.) 


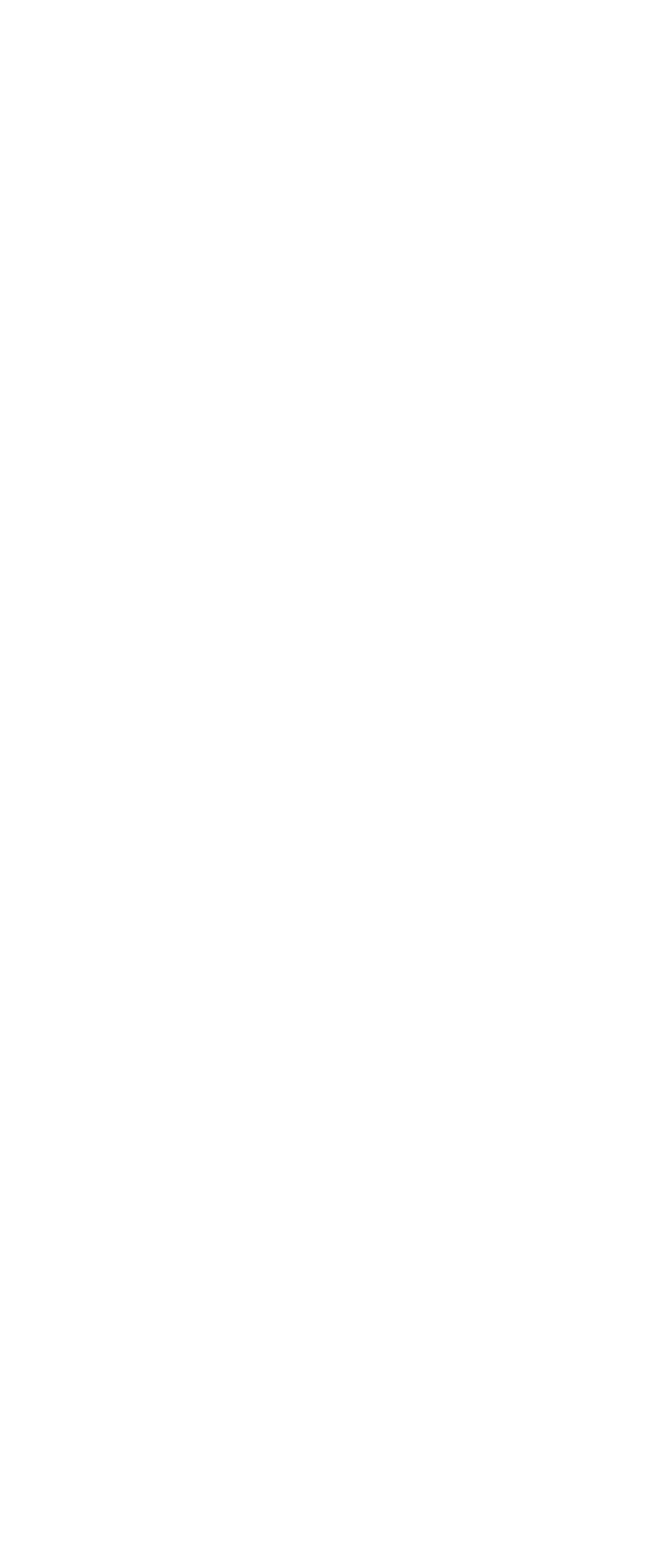




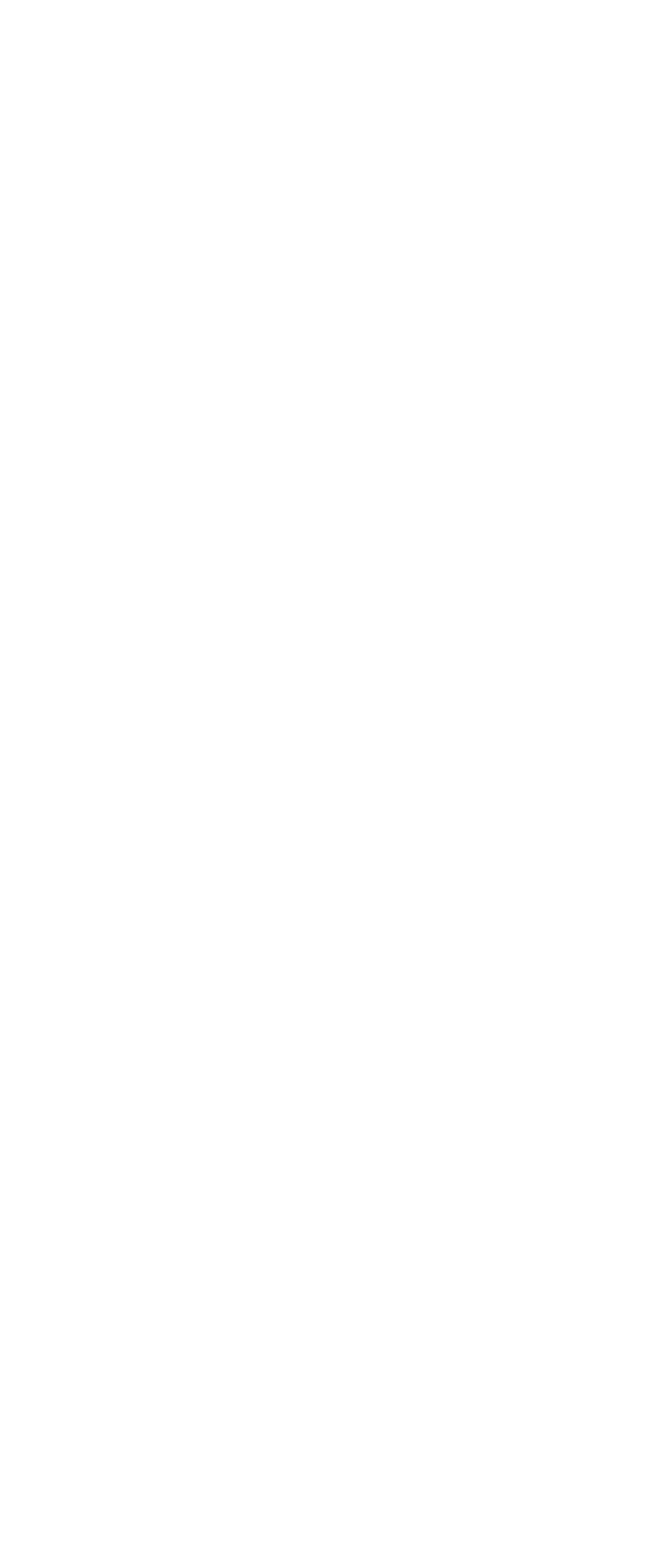




\section{Mineral analyses of ground waters from Leflore County}

[Parts per million. Numbers at heads of columns refer to corresponding well numbers in preceding table]

\begin{tabular}{|c|c|c|c|c|c|}
\hline & 13 & 15 & , 19 & 20 & 22 \\
\hline 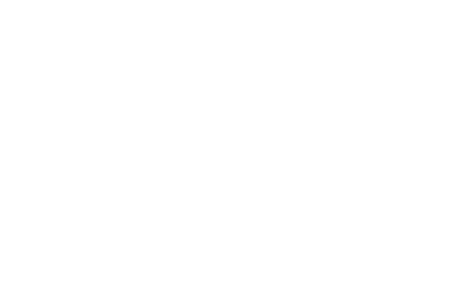 & \begin{tabular}{|c|}
39 \\
3.50 \\
3.2 \\
4.2 \\
94 \\
14 \\
228 \\
3.4 \\
8.0 \\
$275^{.60}$ \\
25 \\
Aug., 1911
\end{tabular} & 4.40 & 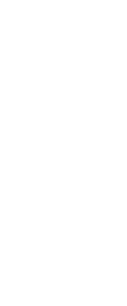 & $\begin{array}{l}51 \\
.15 \\
1.0 \\
.8 \\
108 \\
35 \\
209 \\
2.8 \\
5.1 \\
\text { Trace. } \\
308 \\
6 \\
\text { Sept., } \\
1019\end{array}$ & $\begin{array}{l}26 \\
9.00 \\
1.0^{\circ} \\
100^{\circ} \\
1.4 \\
4.0 \\
201^{.0} \\
28 \\
\text { March, } \\
1913\end{array}$ \\
\hline
\end{tabular}

- Includes iron and aluminum ( $\left.\mathrm{F}_{\mathrm{\theta}}+\mathrm{Al}\right)$.

- Caiculated.

Analysts: 13, 19, W. L. Kennon, University of Mississippi; 15, W. L. Perdue, University of Mississippi 20, Margaret D. Foster and Clara M. Forman, U. S. Geological Survey; 22, Mississippi State Chemical Laboratory.

\section{IINCOIN COUNTY}

\section{GENERAL FEATURES}

Area, 578 square miles. Population, 24,652 (census of 1920)

Lincoln County is in the Long-leaf Pine Hills district. The three principal geologic formations that crop out in the county, named in the order of age, beginning with the oldest, are the Hattiesburg clay (Miocene), the Pascagoula clay (Miocene), and the Citronelle formation (Pliocene). These formations are described on pages 56-60, and their distribution is shown on the geologic map (pl. 2). The soil conditions throughout the western part of the county and on the divides throughout much of the eastern part are largely determined by a few inches to 10 feet of red, yellow, and brown loam, which represents the eastern featheredge of the wind-blown loess, whose extensive development on the western border of the upland portion of Mississippi is described on pages 62-63 of this report.

\section{GROUND-WATER CONDITIONS}

The principal formation below the surficial loam is the Citronelle formation, which makes up the body of all the hills to depths of 50 to 200 feet. The more sandy and gravelly beds of the formation are water bearing and constitute the principal source of domestic supply. The water is obtained by wells that range in depth from 25 to 200 feet and from springs, which are numerous in some parts of the area. A few wells are described in the table of well data.

The formations which underlie the Citronelle formation, named in descending order, are the Pascagoula clay, which overlaps about halfway across the county from the south and is estimated to be about 200 feet thick near the southern boundary, and the Hattiesburg clay, about 450 feet thick, which underlies the Citronelle formation 
in the northern half of the county and dips gently to the south beneath the Pascagoula. So far as known these formations are not important aquifers, though they may contain beds of water-bearing sand of more or less capacity.

Beneath the Hattiesburg clay, the base of which at Brookhaven is estimated to lie at a depth of approximately 800 feet, lies the Catahoula sandstone (Miocene), which is 400 or 450 feet thick. In the belt of outcrop which crosses Mississippi from east to west, 20 to 50 miles north of Lincoln County, and for 40 or 50 miles south of that belt, the more porous sands of the Catahoula contain water in rather large quantities. As Lincoln County falls within these limits, the formation may be regarded as a prospective source of water supply. The 950-foot well of the Southern Gravel \& Development Co. at Brookhaven, probably penetrated the uppermost 150 or 200 feet of the Catahoula but apparently encountered only non-waterbearing clay. In order to thoroughly test the formation the well should have been drilled to a depth of not less than 1,300 feet.

\section{LOCAL SUPPLIES}

Brookhaven.-Supplies of water are obtained from the Citronelle formation at and in the vicinity of Brookhaven by wells 50 to 200 feet in depth. (See wells 2-14.) The municipal waterworks at Brookhaven is five blocks north of the union station and is owned by the town. The water supply is furnished by four wells, two of which are 160 feet deep, and the other two 170 feet deep. A log of one of the city wells is given below. (See analyses 4,5 .)

Log of well at the waterworks plant, Brookhaven

[Altitude of mouth of well, about 487 feet above sea level. Authority, W. N. Logan]

\begin{tabular}{|c|c|c|}
\hline & Thickness & Depth \\
\hline $\begin{array}{l}\text { Citronelle formation: } \\
\text { Red sand } \\
\text { Gravel; water bearing } \\
\text { Citronelle formatjon(?): Fine white sand; water bearing }\end{array}$ & $\begin{array}{r}\text { Feet } \\
100 \\
40 \\
30\end{array}$ & $\begin{array}{r}\text { Beet } \\
100 \\
140 \\
170\end{array}$ \\
\hline
\end{tabular}

The deepest well reported in the county is that of the Southern Gravel \& Development Co., at Brookhaven, the log of which follows:

Log of well of Southern Gravel \& Development Co., Brookhaven (No. g) a

[Altitude of mouth of well, about 460 feet above sea level]

\begin{tabular}{|c|c|c|}
\hline & Thickness & Depth \\
\hline $\begin{array}{l}\text { Citronelle formation: } \\
\text { Gravel }\end{array}$ & \multirow{3}{*}{$\begin{array}{r}\text { Feet } \\
30 \\
100 \\
170 \\
600 \\
50\end{array}$} & \multirow{3}{*}{$\begin{array}{r}\text { Feet } \\
30 \\
130 \\
300 \\
900 \\
950\end{array}$} \\
\hline $\begin{array}{l}\text { Red sand with a few layers of white sand } \\
\text { Pascagoula, Hattiesburg, and Catahoula (?) formations: }\end{array}$ & & \\
\hline $\begin{array}{l}\text { White clay, alternating with blue clay } \\
\text { Blue and white clay } \\
\text { Very hard blue gummy clay }\end{array}$ & & \\
\hline
\end{tabular}

a Adapted from U. S. Geol. Survey Prof. Paper 98, pl. 43 (columnar section No. 7), 1916. 


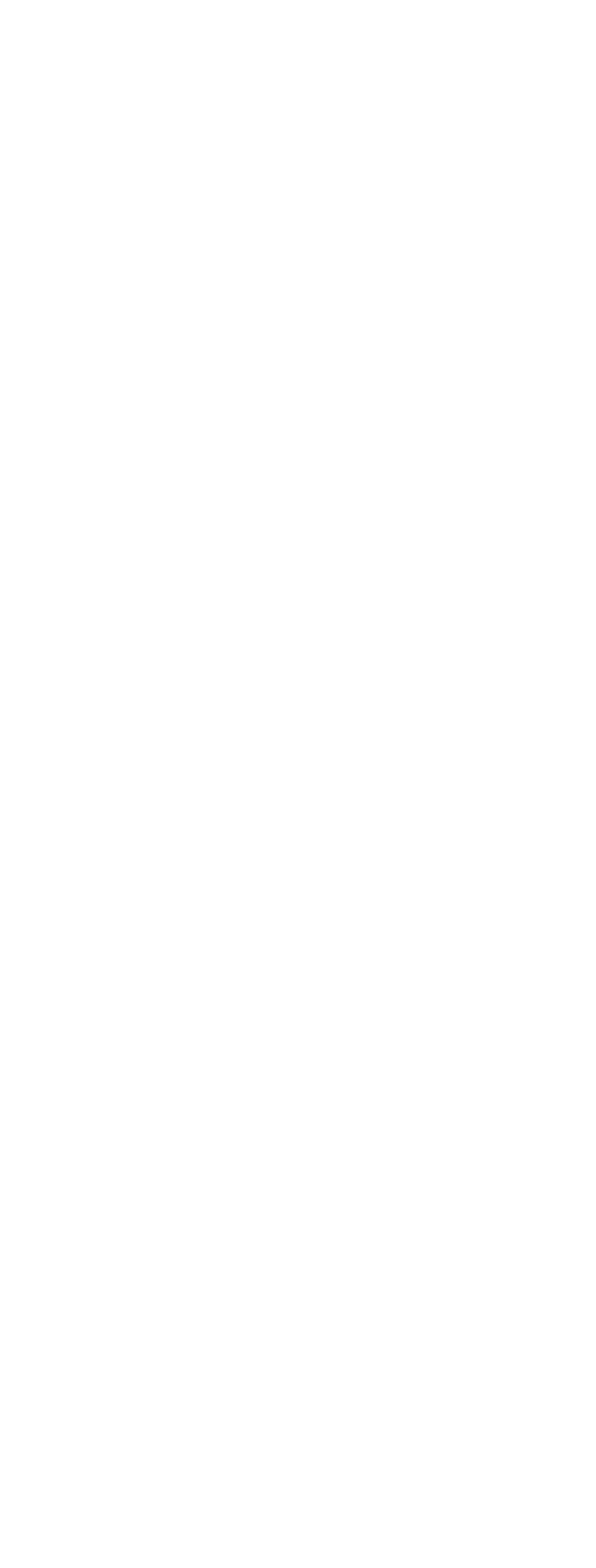




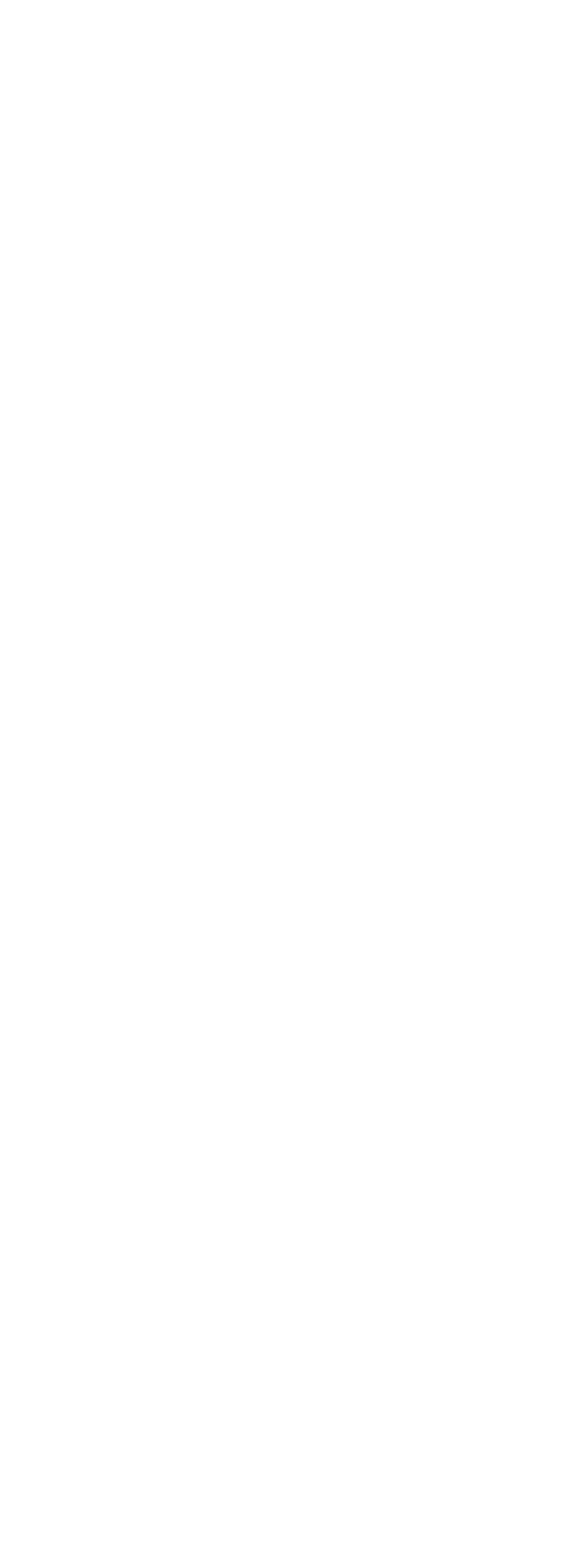




\section{Mineral analyses of ground waters from Lincoln County}

[Parts per million. Samples collected Bept. 10, 1919. Numbers at heads of columns, prto corra , inding well numbers in preceding table]

\begin{tabular}{|c|c|c|c|c|c|}
\hline - & 4 & 5 & 6 & 7 & 14 \\
\hline 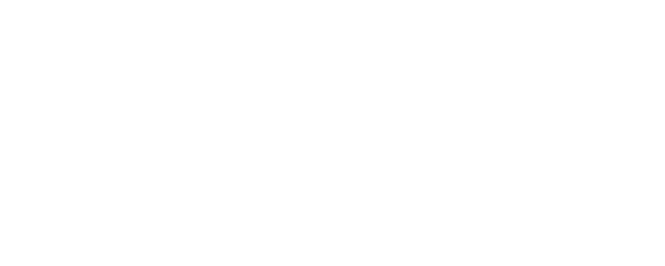 & \begin{tabular}{|c|c|}
59 \\
4.01 \\
28.6 \\
6.0 \\
11 \\
3.1 \\
31 \\
5.2 \\
162 \\
13
\end{tabular} & $\begin{array}{l}37.08 \\
4.0 \\
20^{.6} \\
20^{.0} \\
3.6 \\
38^{1.2} \\
134 \\
12\end{array}$ & $\begin{array}{l}28 \\
1.20 \\
1.1 \\
9.3 \\
20.0 \\
2.1 \\
8.1 \\
60^{.50}\end{array}$ & $\begin{array}{l}20 \\
1.2 \\
2.2 \\
2.0 \\
18 \\
24.0 \\
20.7 \\
4.0 \\
14\end{array}$ & $\begin{array}{r}20 \\
.04 \\
2.2 \\
.8 .3 \\
.8 .0 \\
16.0 \\
4.4 \\
6.0 \\
\text { Traco. } \\
650 \\
7\end{array}$ \\
\hline
\end{tabular}

- Calculated.

Analysts: 4, 5, 14, O. S. Howard, U. S. Geological Survey; 6, 7, H. B. Riffenburg, U. S. Geological Survey.

\section{LOWNDES COUNTY}

\section{GENERAL FEATURES}

Area, 499 square miles. Population, 27,632 (census of 1920)

Mest of Lowndes County west of the Tombigbee River lowland is included in the Black Prairie belt, but the eastern half lies within the Tombigbee Hills district. Two Upper Cretaceous, formations, the Eutaw formation and the Selma chalk, appear at the surface within the county. The Tuscaloosa, the basal formation of the Upper Cretaceous, underlies the Eutaw and crops out to the northeast in Alabama. The physical characters of these formations are described on pages $29-39$, and their distribution is shown on the geologic map (pl. 2). Alluvial terrace deposits of Pleistocene and Recent age underlie the broad plains that compose the lowland of Tombigbee River.

\section{GROUND-WATER CONDITIONS}

The Eutaw and Tuscaloosa formations, both of which are predominantly composed of sand, are the principal sources of domestic and industrial water supplies. Crider and Johnson ${ }^{42}$ stated in 1906 that 140 deep wells were then in use in the county, and many wells have subsequently been drilled. East of Tombigbee River, in the area immediately underlain by the Eutaw formation, the wells range in depth from 100 to 700 feet, and nearly all of them are deep onough to reach the Tuscaloosa water-bearing sands, though some, especially those located on the terrace plains that border Tombigbee River, doubtless draw upon the waters contained in the vusai veas of the Eutaw. Most of the wells located in the valleys of Tombigbee River, Floating Turtle Creek, and Buttahatchie River overflow at

1 Crider, A. F., and Johnson, L. C., Summary of the underground-water resources of Mississippi: U. S. Geol. Survey Water-Supply Paper 159, p. 34, 1906. 
the surface, and the yield of some of them is large. In the Black Prairie belt west of Tombigbee River the numerous wells range in depth from 300 to 1,300 feet and pass through the non water-bearing beds of the Selma chalk and enter the underlying Eutaw formation. Most of the wells do not completely penetrate the Eutaw as it is composed in part of abundantly water-bearing sands, but a few have been drilled to the still more abundantly water-bearing sands of the Tuscaloosa formation. Flowing wells are obtained in many of the creek valleys in the Black Prairie belt.

Shallow dug and bored wells are still used by many of the people who live in the hilly area east of Tombigbee River valley. In the Black Prairie belt west of Tombigbee River cisterns dug in the compact Selma chalk, which require no retaining wall, and surface pools, are in use to a small extent; prior to the discovery of the artesian waters of the Eutaw and Tuscaloosa these cisterns and pools were the chief source of water supply.

\section{LOCAL SUPPLIES}

Columbus.-Tombigbee River valley, in the vicinity of Columbus, was one of the first districts in the United States to utilize artesian waters. Wailes ${ }^{43}$ in 1854 gave an interesting account of the early artesian developments in Lowndes County. The wells originally drilled within the city limits flowed, but in recent years the static head has been so lowered by local draft that wells on the terrace on which the main part of the town is situated have ceased to flow. This terrace is about 70 or 75 feet above low-water level of the river. Detailed information in regard to a few wells in the vicinity of Columbus is given in the table (Nos. 6-13), and analyses of water from several of the wells are given on page 315 . The log of a well owned by the Mobile \& Ohio Railroad is given below:

Log of well of Mobile \& Ohio Railroad, Columbus (No. 11)a

[Altitude of mouth of well about 190 feet above sea level. Adapted from description by Logan and Perkins

\begin{tabular}{|c|c|c|}
\hline & Thickness & Depth \\
\hline 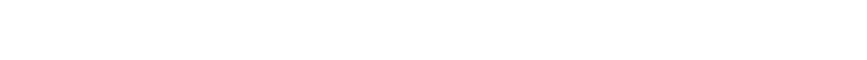 & Feet 25 & ${ }_{25}$ \\
\hline $\begin{array}{l}\text { Eutaw and Tuscaloosa formations: } \\
\text { Sandstone (compact glauconitic sand) } \\
\text { Greensand and clay; water bearing }\end{array}$ & $\begin{array}{r}300 \\
95\end{array}$ & $\begin{array}{l}325 \\
420\end{array}$ \\
\hline
\end{tabular}

- Logan, W. N., and Perkins. W. R., Mississippi Agr. Exper. Sta. Bull. 89, p. 35, 1905.

4a Wailes, B. L. C., Report on the agriculture and geology of Mississippi (published by order of the legislature), pp. 262-264, 268, 1854. 
Many flowing wells have been drilled on the terrace plains that border Tombigbee River within 10 miles of Columbus. The municipal waterworks at Columbus, which is owned by the city, is 2 miles northeast of the business section, on the west bank of Luxapallila or Floating Turtle Creek. (See analysis 1, p. 315.)

Steens.-Several wells in the vicinity of Steens, a village 9 miles northeast of Columbus, yield flows from water-bearing sands in the Tuscaloosa formation at depths of 100 to 220 feet. (Nos. 24, 25.) A $\log$ of R. G. Harris's well is given below. Analysis 25 represents water from C. O. Gore's well.

Log of well of R. G. Harris, at Steens (No. 24)

[Altitude of mouth of well 220 feet above sea level. Adapted from owner's description]

\begin{tabular}{|c|c|c|}
\hline & Thickness & Depth \\
\hline Pleistocene terrace deposit: Clay, sand, and gravel... & ${ }_{18}^{\text {Feet }}$ & Feet ${ }_{18}$ \\
\hline $\begin{array}{l}\text { Eutaw and Tuscaloosa formations: } \\
\text { Blue rock. }\end{array}$ & 70 & 88 \\
\hline $\begin{array}{l}\text { Blue rock } \\
\text { Sand and gravel; water bearing }\end{array}$ & $\begin{array}{l}20 \\
13\end{array}$ & 112 \\
\hline
\end{tabular}

Bentoak.-Wells in the immediate vicinity of Bentoak, which is situated on the Selma chalk, range in depth from 400 to 800 feet; those more than 500 feet deep probably enter the water-bearing beds of the Tuscaloosa formation, whereas those of less depth draw on the water-bearing sands of the overlying Eutaw formation. (Nos. 4, 5.)

Mayhew.-Many wells that range in depth from 350 to 815 feet have been drilled in the vicinity of Mayhew (Nos. 18-21). Most of them are nonflowing, but on the upland the static head is generally within 20 feet of the surface, and a few wells in the valley of Catalpa Creek and its tributaries overflow at the surface. Most of the wells tap water-bearing sands in the Eutaw formation, and the principal supply comes from a bed of sand below a 11/2 to $21 / 2$ foot layer of hard rock at a depth of 300 to 350 feet. The few wells that exceed depths of 450 or 500 feet reach the sands of the Tuscaloosa formation, the waters of which are under greater hydrostatic pressure than those of the Eutaw. and the yield of which is larger. (See well 20.) Logs of four wells near Mayhew are given on page 310. 
Partial log of oil-prospecting well of Anderson Drilling Co., near Billups station, 5 miles southeast of Mayhew in SW. 1/4 sec. $12, T .18$ N., R. 16 E., Lowndes County

[Authority, Anderson Drilling Co., through E. N. Lowe, State geologist. At the time of writing this well was still in process of drilling]

\begin{tabular}{|c|c|c|c|c|c|}
\hline & $\begin{array}{l}\text { Thick- } \\
\text { ness }\end{array}$ & Depth & & $\begin{array}{l}\text { Thick- } \\
\text { ness }\end{array}$ & Depth \\
\hline 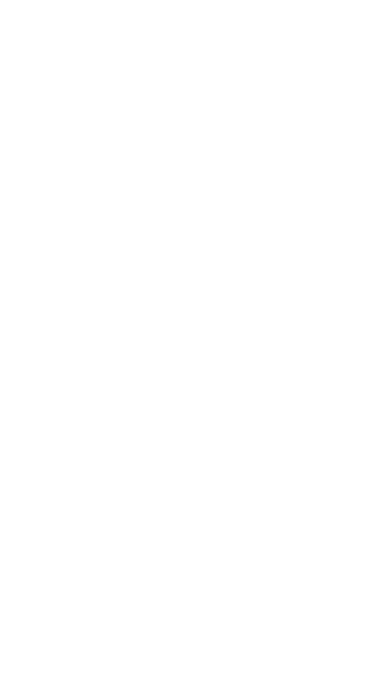 & $\begin{array}{r}\text { Feet } \\
-8 \\
40 \\
16 \\
54 \\
150 \\
50 \\
20 \\
100 \\
10 \\
20 \\
15 \\
35 \\
50 \\
29 \\
71 \\
40 \\
1 \\
10 \\
15 \\
14 \\
20 \\
20 \\
46 \\
34 \\
20 \\
22 \\
28 \\
15\end{array}$ & $\begin{array}{r}\text { Feet } \\
232 \\
240 \\
280 \\
296 \\
350 \\
500 \\
550 \\
570 \\
670 \\
680 \\
700 \\
715 \\
750 \\
800 \\
829 \\
900 \\
940 \\
941 \\
951 \\
966 \\
980 \\
1,000 \\
1,020 \\
1,066 \\
1,100 \\
1,120 \\
1,142 \\
1,170 \\
1,185\end{array}$ & 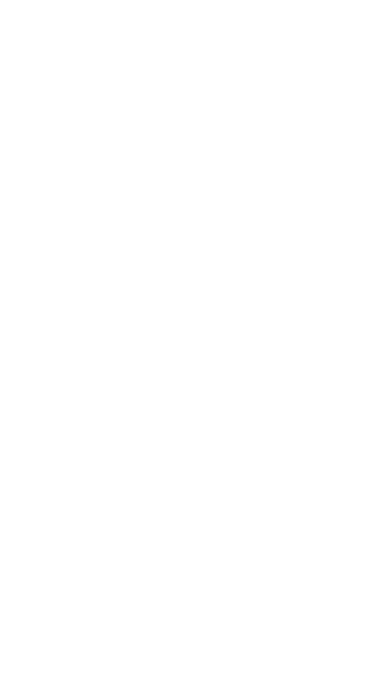 & $\begin{array}{r}\text { Feet } \\
10 \\
25 \\
10 \\
63 \\
10 \\
13 \\
20 \\
\\
20 \\
12 \\
10 \\
38 \\
14 \\
4 \\
2 \\
18 \\
18 \\
2 \\
6 \\
20 \\
22 \\
10 \\
14 \\
14 \\
22 \\
5 \\
18 \\
12 \\
138\end{array}$ & 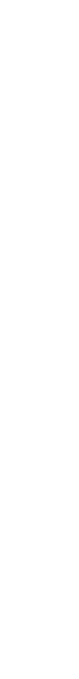 \\
\hline
\end{tabular}

\section{Log of well on the Billups estate, 3 miles south of Mayhew (No. 20)}

[Altitude of mouth of well about 206 feet above sea level. Adapted from description by W. F. Little, driller]

Recent alluvium: Black loam and clay

Selma chalk: Rotten limestone or shale

Eutaw formation:

Sand; water bearing in three parts, which are set off from each other by layers of hard roek 6 to 16 inches in thickness.

Muck and dry black clay with a few interbed ded streaks of sand and red clay.

Hard rock

Tuscaloosa formation (at least in part); Gray sand in part, but not fuily described.-

\begin{tabular}{|c|c}
\hline Thickness & Depth \\
\hline Feet & Feet \\
20 & 20 \\
300 & 320 \\
& \\
130 & 450 \\
250 & 700 \\
$2 / 3$ & $700 \% 3$ \\
$1143 / 3$ & 815 \\
\end{tabular}

Log of well of Mrs. N. A. Golden, a quarter of a mile southwest of Mayhew (No. 21) [A ltitude of mouth of well about 211 feet above sea level. Adapted from description by J. H. Pilkinton]

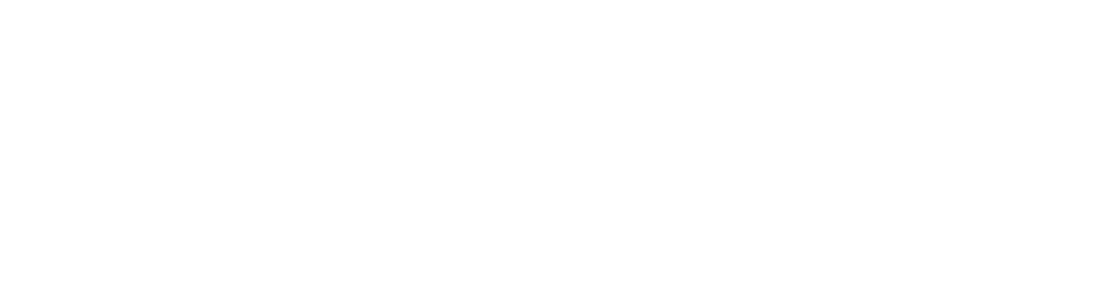


Mr. Pilkinton, the driller, states that the water-bearing sand which was entered in the lower part of Mrs. Golden's well extends to a depth of at least 550 feet, the greatest depth to which he has drilled near Mayhew.

Artesia.-The ground-water.conditions at Artesia are like those at Mayhew except that a greater thickness of the Selma chalk must be penetrated before the well reaches the water-bearing beds of the Eutaw, which in this vicinity lie at a depth of 450 feet or more. Here also the principal supply is obtained from sand beneath a layer of hard rock about 1 foot thick. The 1,300-foot well of the Mobile \& Ohio Railroad (No. 2) is deep enough to reach the water-bearing sands of the Tuscaloosa formation. The following log shows the character of the beds penetrated in a well at Artesia:

Log of well of J.V. Mitchell, located in a valley 30 yards southwest of the post office at Artesia (No. B)

[Adapted from owner's description]

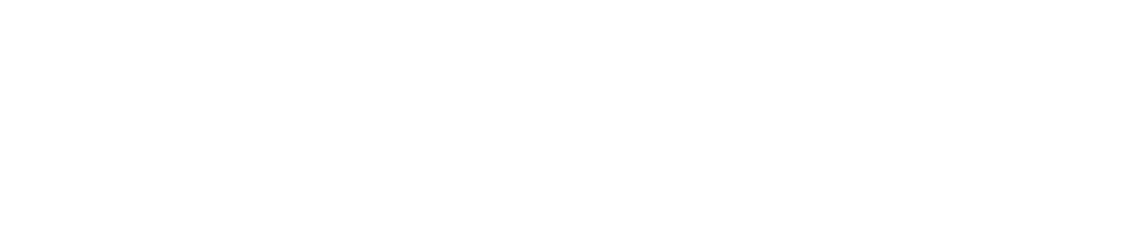

Penn.-The ground-water conditions at Penn and in the immediate vicinity are not essentially different from those at Artesia. The wells range in depth from 400 to 750 feet, but most of them are more than 600 feet deep; the static head is 40 to 100 feet below the surface. The Selma chalk, as shown by the log given below, is about 400 feet thick, so that here the principal source of water appears to be in the lower half of the Eutaw formation. Waterbearing beds at as shallow a depth as 450 feet, howerer, have been reported. The village is provided with a small waterworks, which is owned by the Penn Co. and designed to supply water for the boilers of a gin and mill, for fire protection, and for the household use of some of the inhabitants. The water is obtained from a 732-foot well (No. 22) and is stored in a tank of 100,000 gallons capacity; the average daily consumption is 1,000 gallons.

Log of well of Buck Cook, located on the upland half a mile novth by east of Penn (No. 23 )

[Adapted from description by J. C. Reeder, driller]

\begin{tabular}{|c|c|c|}
\hline & Thickness & Depth \\
\hline $\begin{array}{l}\text { Soll and red clay (residual from the Selma) } \\
\text { Qelma chalk: Chalk. } \\
\text { Eutaw formation: } \\
\text { Sand with layers of sandstone at top and bottom, each } 10 \text { inches thick } \\
\text { Pipe clay } \\
\text { Sand and shells. } \\
\text { Sand; water bearing }\end{array}$ & $\begin{array}{c}\text { Feet } \\
71 / 2 \\
400 \\
31 / 2 \\
249 \\
10 \\
50\end{array}$ & $\begin{array}{c}\text { Freet } \\
71 / 4 \\
40716 \\
411 \\
660 \\
670 \\
720\end{array}$ \\
\hline
\end{tabular}


Crawford.-Wells at Crawford range in depth from 500 to 700 feet (Nos. 14-16) and derive their principal supplies from waterbearing beds in the middle and upper portions of the Eutaw formation. The static head of the water in wells in the immediate vicinity of the town is 100 to 110 feet below the surface. The log of one well follows:

Log of well of G. W. Hairston, 300 yards west of the post office at Crawford (No. 15)

[Altitude of mouth of well about 310 feet above sea level. Adapted from owner's description]

\begin{tabular}{|c|c|c|}
\hline & Thickness & Depth \\
\hline Red clay (residual from the Selma) & Feet 2 & Feet 2 \\
\hline $\begin{array}{l}\text { Selma chalk: } \\
\text { White rock }\end{array}$ & 10 & 12 \\
\hline Blue rock & 550 & 562 \\
\hline Eutaw formation: Blue and black sand with layers of ironstone 2 to 3 inches thick & 138 & 700 \\
\hline
\end{tabular}

Kolola Springs.-Kolola Springs is a village near Buttahatchie River in the northern part of the county, 13 or 14 miles north of Columbus (sec. 14, T. 16 S., R. 18 W.). The springs from which the village is named probably have their source in a low terrace deposit that borders the river. (See analyses 26, 27.) 


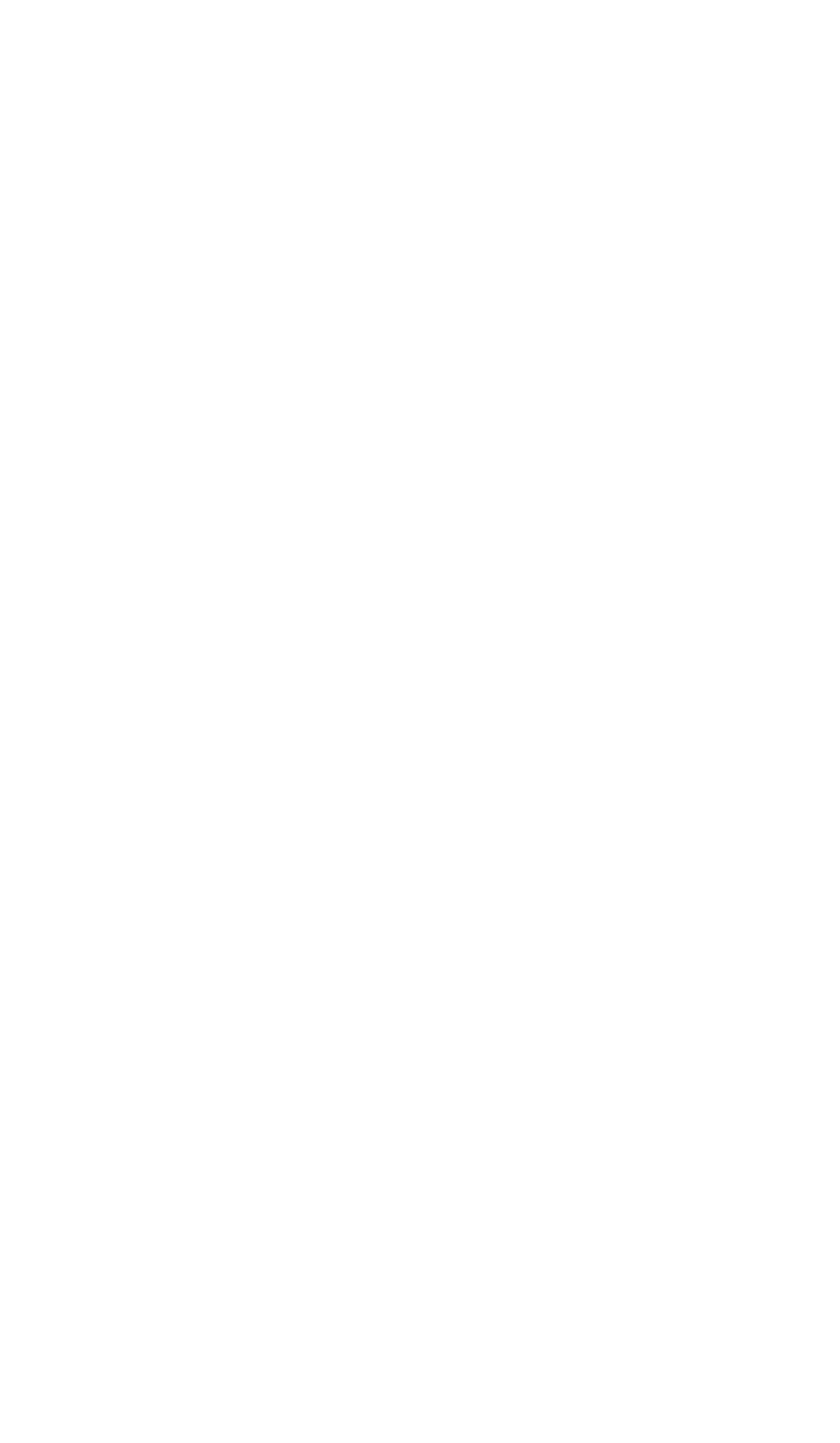




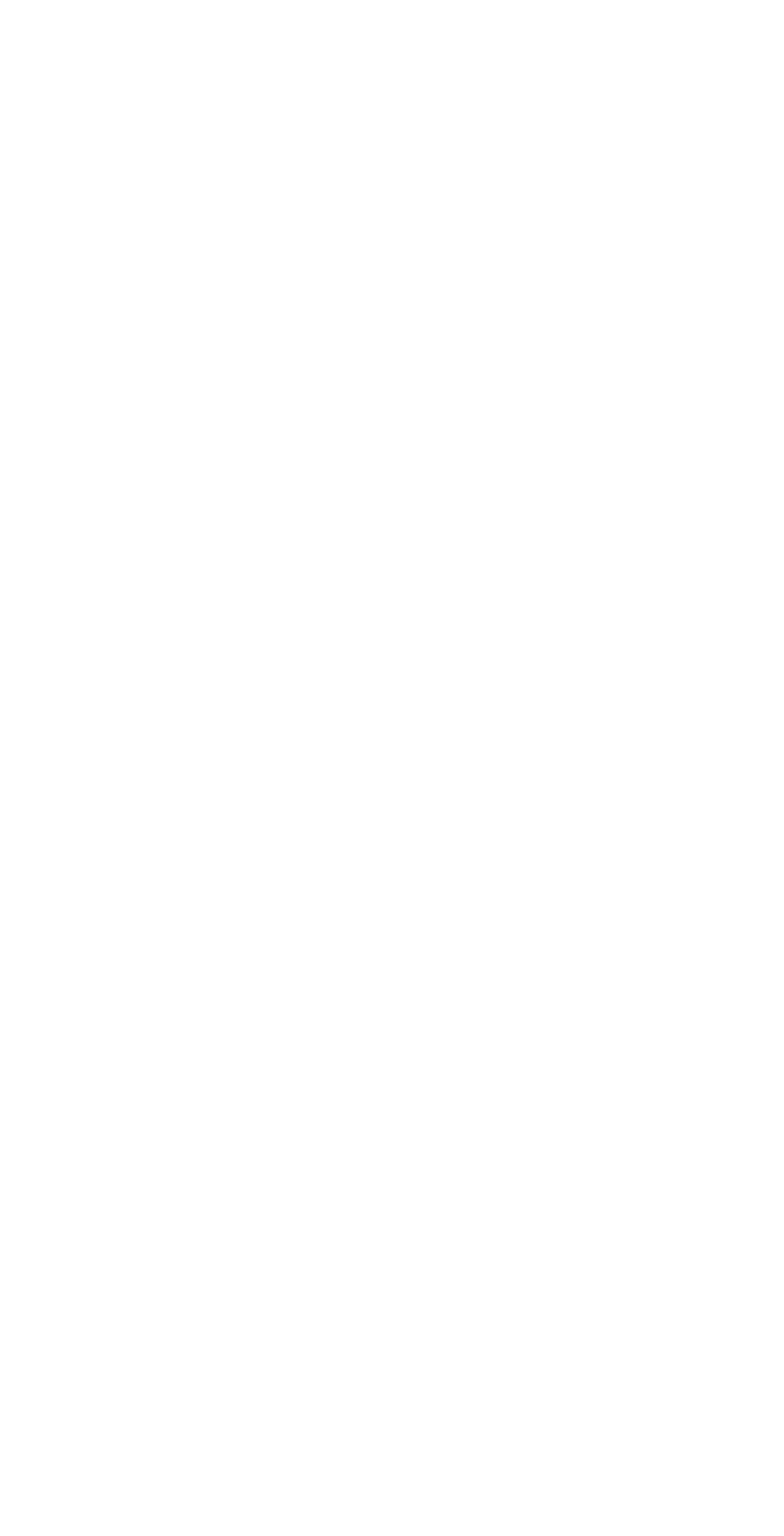




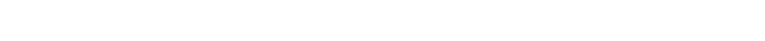

[Parts per million. Numbers at heads of columns refer to corrispanding well numbers in prepadins table]

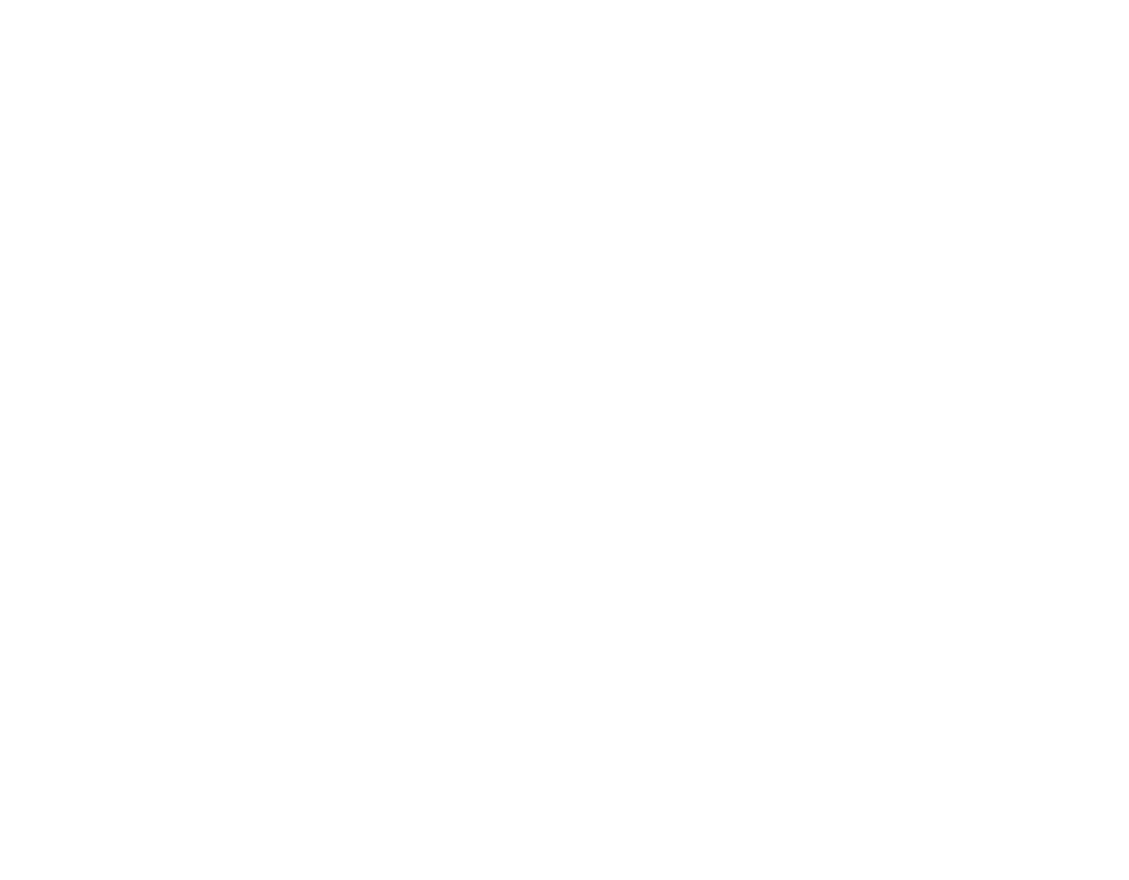

- Iron and aluminum oxides $\left(\mathrm{Fe}_{2} \mathrm{O}_{3}+\mathrm{Al}_{2} \mathrm{O}_{3}\right)$.

- Calculated.

Analysts: 1, 9, 10, 12, 14, 26, 27, W. R. Perkins (Mississippi Agr. Exper. Sta. Bull. 89, pp. 34-35, 1905); 2, 8, Margaret D. Foster, U. S. Geological Survey; 6, 16, Mississippi State Chemical Laboratory; 25, W' $\mathbf{F}$. Hand, Mississippi State Chemical Laboratory.

\section{MADISON COUNTY}

\section{GENERAL FEATURES}

Area, 725 square miles. Population, 29,292 (census of 1920)

Madison, a county of irregular shape, lies a little to the southwest of the center of the State, partly within the Jackson Prairie Belt and partly within the North Central Hills district. The principal geologic formations that crop out in the county are of Eocene age and include the Lisbon and Yegua formations of the Claiborne group and the Jackson formation. In addition to the Eocene formations, overlapping strata belonging to the Vicksburg group (Oligocene) occur on the tops of the hills in small areas in the south and southwest; surficial sands and gravels that belong to the Citronelle formation (Pliocene) cover parts of the upland; much of the surface is covered by a blanket of loam that represents the thin, eastward extension of the loess (Pleistocene), which is more fully developed in the west in Yazoo County; and alluvial terrace loams, clays, sands, and gravels underlie the narrow lowlands that border Pearl and Big Black Rivers. 


\section{GHOUND-WATER CONDIMONS}

As indicated on the geologic map (pl. 2), the Lisbon formation crops out in a broad belt in the northeastern part of the county and is roughly estimated to be about 200 feet or more in thickness. The formation dips to the southwest and passes under the Yegua formation at a low angle. The typical beds that compose the upper part of this formation do not appear to have yielded large quantities of water in their southwestward buried extension in this county, but they doubtless include some water-bearing beds of small yield; the Kosciusko sandstone and Winona sand members, which underlie the typical beds but are not exposed in the county, are notable water bearers.

The belt of outcrop of the Yegua formation lies southwest of that of the Lisbon. The formation appears to thicken in its buried extension toward the south, for, as shown by well logs, it is probably not less than 300 feet thick at Canton (see log, p. 317) and is probably 400 feet thick at Jackson. Some of the sands are evidently water bearing, for, as interpreted, several wells (Nos. 4-6, 13-15), have their source in the formation.

The belt of outcrop of the Jackson formation includes approximately the southwestern half of the county. At Jackson, in Hinds County, the total thickness of the formation is about 230 feet, but the thickness rapidly increases toward the northwest and in the extreme westtern part of Madison County probably reaches 450 feet or more. On accornt of the predominance of clay the formation is in the main physically unsuited to serve as an aquifer, and where the clay immediately underlies the surface shallow water is in many places not obtainable; at such places cisterns are constructed for storing water.

On some of the higher hills in the southwestern part of the county the Jackson formation is overlain by strata that belong to the Vicksburg group, the basal formation of which, the Forest Hill sand, is water bearing and is the source of the water of springs and shallow wells. The Jackson formation is also covered in part by surficial loams, sands, and gravels that belong to the Citronelle formation (Pliocene), from which emerge small springs and in which water in sufficient quantities for domestic and farm uses can be obtained by means of shallow wells.

The relatively thin alluvial terrace deposits in the lowlands that border Pearl and Big Black Rivers are also water bearing and afford domestic and farm supplies.

Valuable water-bearing beds, which do not appear at the surface in the county but which are reached by deep wells (see table of well data), are the Kosciusko sandstone and Winona sand members of the Lisbon formation, and the Holly Springs sand of the Wilcox group. These formations are described on pages 46-52. 


\section{LOCAL GUPPLIMS}

Camden.-At Camden water is obtained chiefly from shallow wells, which penetrate only to the ground-water level in the Lisbon formation or in the terrace gravels at the base of the Citronelle formation, which in places mantle the Lisbon. In the 38-foot well of C. S. Terry (No. 2) at Camden the water rises within 16 feet of the surface.

Way.-At Way, in the valley of Big Black River, on the Illinois Central Railroad, 9 miles north of Canton, water is obtained chiefly from wells in alluvial deposits.

Allison's Wells.-Allison's Wells is a health resort located on rolling hills about 1 mile east of Way. Strongly mineralized waters are obtained from two wells about 500 feet apart, which probably have their source in the Yegua formation, one known as the "iron" well, 52 feet deep, and the other as the "sulphur" well, 38 feet deep (Nos. 23, 24). The sulphur well is on ground about 7 feet lower than the iron well. Water for domestic use at the hotel is obtained from a well 390 feet deep. A deep-well force pump, operated by a gasoline engine, raises the water from the well and forces it to an elevated wooden distributing tank.

Canton.-The municipal waterworks at Canton is about threequarters of a mile northwest of the public square, west of the Illinois Central Railroad track, on ground about 8 feet below the level of the track at the station. The water supply is obtained from three wells (Nos. 3-5), 1,050, 379, and 3731/4 feet deep. The static head of the water in the 1,050-foot well is about 10 feet above the surface, whereas that of the water in the two shallower wells is about 9 feet below the surface. A fourth well at the plant, 375 feet.deep (No. 6), is not ordinarily used but is kept in condition as a reserve supply. Analyses 3 and 5 represent water from the 1,050-foot and 3731/4foot wells. Logs of three wells at the waterworks are given below:

Log of well (known as No. 8) at Canton waterworks (No. 5)

[Altitude at mouth of well, about 216 foet above sea level. Authority, John T. Sharp, jr., superintendent of waterworks, and driller]

\begin{tabular}{|c|c|c|}
\hline & Thickness & Depth \\
\hline 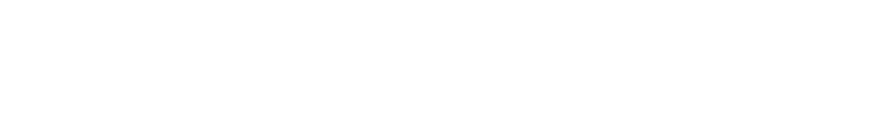 & \multirow{6}{*}{$\begin{array}{r}\text { Feet } \\
18 \\
1 \\
1 \\
40 \\
15 \\
19 \\
8 \\
48 \\
20 \\
124 \\
1 \\
78 \\
74\end{array}$} & $\begin{array}{r}\text { Feat } \\
18 \\
19 \\
20 \\
60\end{array}$ \\
\hline $\begin{array}{l}\text { Yegua formation: } \\
\text { Greensand with traces of lignite. }\end{array}$ & & 75 \\
\hline $\begin{array}{l}\text { White sand } \\
\text { Hard ahocolate-oolored ciny........ }\end{array}$ & & $\begin{array}{r}94 \\
102\end{array}$ \\
\hline $\begin{array}{l}\text { Chocolate-brown elay ... } \\
\text { Boft brown clay and very fine sand. }\end{array}$ & & $\begin{array}{l}150 \\
170\end{array}$ \\
\hline 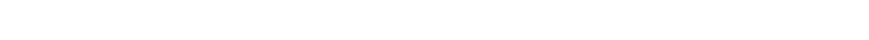 & & ${ }_{296}^{294}$ \\
\hline 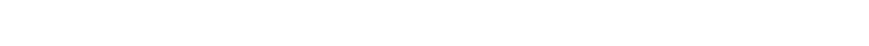 & & $\begin{array}{l}373 \\
a 731 / 4\end{array}$ \\
\hline
\end{tabular}




\section{Log of 1,064-foot well at Canton waterworks}

\begin{tabular}{|c|c|c|}
\hline & Thickness & Depth \\
\hline Jackson formation: Surface olay with smail stones & Feet ${ }_{80}$ & Feet ${ }_{80}$ \\
\hline $\begin{array}{l}\text { Jackson tormation: Surrace dagy with smail stones. } \\
\text { Yegua and Lisbon formations: } \\
\text { Clay and fine sand }\end{array}$ & $\begin{array}{r}80 \\
380\end{array}$ & \\
\hline Blue shale & 430 & \\
\hline $\begin{array}{l}\text { Hard blue sandstone } \\
\text { Blue shale }\end{array}$ & 74 & $\begin{array}{l}896 \\
970\end{array}$ \\
\hline $\begin{array}{l}\text { Coarse Sand; water bearing (Lisbon) } \\
\text { Hard gumbo. }\end{array}$ & $\begin{array}{l}23 \\
25\end{array}$ & $\begin{array}{r}993 \\
1,018\end{array}$ \\
\hline Sand; water bearing (Lisbon) & 10 & 1,028 \\
\hline Coarso sand; water bearing (Lisbon) & 20 & $\begin{array}{l}1,034 \\
1,054\end{array}$ \\
\hline Gumbo ................................... & & 1,064 \\
\hline
\end{tabular}

$\log$ of 1,281-foot well at Canton waterworks

\begin{tabular}{|c|c|c|}
\hline & Thickness & Depth \\
\hline nation: Surface clay w & Feet ${ }_{80}$ & \\
\hline $\begin{array}{l}\text { Yegua and Lisbon formations: } \\
\text { Clay and fine sand............... }\end{array}$ & 383 & \\
\hline Bue clay & 290 & $\begin{array}{l}758 \\
75\end{array}$ \\
\hline $\begin{array}{l}\text { White limestone. . } \\
\text { Blue shale ... }\end{array}$ & $\begin{array}{r}2 \\
188\end{array}$ & $\begin{array}{l}75: \\
94:\end{array}$ \\
\hline $\begin{array}{l}\text { Fine sand } \\
\text { Black, very lignitic clay }\end{array}$ & $\begin{array}{r}45 \\
293\end{array}$ & \\
\hline
\end{tabular}

Other deep wells at Canton are listed in the table of well data (Nos. 7-9, 11, 12), and the log of one of them follows:

\section{Log of well of Elk Lumber Co., Canton (No. 11)}

[Adapted from unpublished manuscript of E. N. Lowe; drilled by Layne \& Bowler Co.]

\begin{tabular}{|c|c|c|c|c|c|}
\hline & $\begin{array}{c}\text { Thick- } \\
\text { ness }\end{array}$ & Depth & & $\begin{array}{c}\text { Thick- } \\
\text { ness }\end{array}$ & Depth \\
\hline $\begin{array}{l}\text { Jackson formation: Clay } \\
\text { Yegua and Lisbon formations: } \\
\text { Lignite and sand. } \\
\text { Gray sand } \\
\text { Gumbo } \\
\text { Olay and gravel, mixed. }\end{array}$ & $\begin{array}{r}\text { Feet } \\
28 \\
\\
18 \\
25 \\
34 \\
38\end{array}$ & $\begin{array}{r}\text { Feet } \\
28 \\
46 \\
71 \\
105 \\
143\end{array}$ & $\begin{array}{l}\text { Yegua and Lisbon formations-Con. } \\
\text { Sand } \\
\text { Gumbo clay } \\
\text { Yellow cland } \\
\text { Sand } \\
\text { Yellow sand. }\end{array}$ & $\begin{array}{r}\text { Feet } \\
10 \\
8 \\
70 \\
184 \\
10\end{array}$ & $\begin{array}{r}\text { Feet } \\
153 \\
161 \\
231 \\
415 \\
434\end{array}$ \\
\hline
\end{tabular}

The 40-foot well of I. Edwards, at Canton, probably has its source in the Yegua formation. The William Goff well (No. 14), 7 miles northeast of Canton, is 30 feet deep and penetrates the Yegua formation. The Catlett well (No. 15), $31 / 2$ miles east of Canton, penetrates the Yegua formation to a depth of 62 feet, and water is found in blue or gray sand and gravel. (See analysis 15).

Adelle.-At Adelle, near the southwest corner of the county, wells 35 to 60 feet deep are reported. The water is questionably obtained from the terrace gravels, which at this place overlie the Jackson formation, but some of the wells may enter the Forest Hill sand, the basal formation of the Vicksburg group. 
Flora.-The old town well at Flora, now abandoned, was 640 feet deep and probably penetrated the Yegua formation. The new well, from which the present municipal supply is obtained, is 1,304 feet deep (No. 16) and probably taps a sand in the Lisbon formation. Water under artesian pressure was found in both wells and in the new well stands 45 feet below the surface. The 400 -foot well of $R$. C. Chandler (No. 1), about 5 miles east of Flora and 2 miles east of Anderson, struck a good supply of soft water at a depth of 380 feet in sands that probably belong to the Yegua formation. The water rose to a level within 60 feet of the surface.

Mannsdale.-A well (No. 21) at Mannsdale, 7 or 8 miles southeast of Flora, is $1,1343 / 4$ feet deep and is believed to have reached the Winona sand member of the Lisbon formation.

\section{Log of well of Mann \& Son at Mannsdale}

[Log furnished by E. N. Lowe, State geologist; well drilled by Layne \& Bowler Co.]

\begin{tabular}{|c|c|c|c|c|c|}
\hline & $\begin{array}{l}\text { Thick- } \\
\text { ness }\end{array}$ & Depth & & $\begin{array}{c}\text { Thick- } \\
\text { ness }\end{array}$ & Depth \\
\hline $\begin{array}{l}\text { ackson, Yegua, and Lisbon } \\
\text { formations: } \\
\text { Blue clay } \\
\text { Gumbo } \\
\text { Blue clay } \\
\text { Gumbo... } \\
\text { Sand } \\
\text { Gumbo } \\
\text { Packed sand } \\
\text { Gumbo } \\
\text { Packed sand } \\
\text { Gumbo } \\
\text { Packed sand } \\
\text { Soapstone... } \\
\text { Packed sand } \\
\text { Sospstone........ }\end{array}$ & $\begin{array}{rr}\text { Ft. } & \text { in. } \\
212 & 3 \\
39 & 11 \\
37 & 6 \\
87 & 1 \\
8 & 11 \\
73 & 6 \\
21 & 4 \\
19 & 6 \\
5 & 8 \\
29 & 6 \\
48 & 10 \\
37 & 6 \\
100 & 4 \\
42 & 11\end{array}$ & $\begin{array}{cr}\text { Fit. } & \text { in. } \\
212 & 3 \\
252 & 2 \\
289 & 8 \\
376 & 9 \\
385 & 8 \\
459 & 2 \\
480 & 6 \\
500 & 0 \\
505 & 8 \\
535 & 2 \\
584 & 0 \\
621 & 6 \\
721 & 10 \\
764 & 9\end{array}$ & $\begin{array}{l}\text { Jackson, Yegua, and Lisbon } \\
\text { formations-Continued. } \\
\text { Rock formation } \\
\text { Soapstone. } \\
\text { Gumbo } \\
\text { Soapstone- } \\
\text { Packed sand. } \\
\text { Soapstone. } \\
\text { Sand } \\
\text { Gumbo } \\
\text { Soapstone } \\
\text { Gumbo } \\
\text { Soapstone. } \\
\text { Packed sand; water bear- } \\
\text { ing (Lisbon) }\end{array}$ & $\begin{array}{rr}F_{.} & \text {in. } \\
4 & 0 \\
29 & 3 \\
56 & 7 \\
84 & 5 \\
12 & 0 \\
6 & 0 \\
41 & 1 \\
6 & 0 \\
8 & 0 \\
7 & 9 \\
9 & 0 \\
105 & 11\end{array}$ & $\begin{array}{rr}F t . & i m \\
768 & 9 \\
798 & 0 \\
854 & 7 \\
939 & 0 \\
951 & 0 \\
957 & 0 \\
998 & 1 \\
1,004 & 1 \\
1,012 & 1 \\
1,019 & 10 \\
1,028 & 10 \\
1,134 & 9\end{array}$ \\
\hline
\end{tabular}

On the Goodloe plantation, about 2 miles southwest of Mannsdale, a spring of clear, soft water furnishes part of the supply for the plantation; the water is probably derived from the Forest Hill sand of the Vicksburg group. A number of other smaller springs issue at different places on the plantation.

Madison station.-A well at Madison station (No. 17), owned by the Illinois Central Railroad, is 25 feet deep and 8 feet in diameter and draws its water from a bed of sand in the Jackson formation. This water is highly mineralized, as shown by analysis 17 .

The following log shows the character of the beds penetrated in a drilled well (No. 20) near the border of the lowland along Pearl River about 3 miles east of Madison. This well seems to have reached nearly to the base of the Yegua formation, at a depth of 415 feet. 
Log of well 3 miles edst of Madieen (No. 20)

\begin{tabular}{|c|c|c|}
\hline . & Thickness & Depth \\
\hline 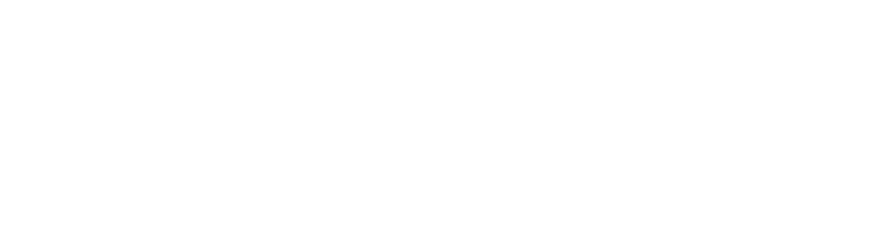 & Feet & $\begin{array}{r}\text { Feet } \\
80 \\
80 \\
275 \\
275 \\
290 \\
875 \\
375 \\
418\end{array}$ \\
\hline
\end{tabular}

Ridgeland.-On the W. H. Atkinson place, $41 / 2$ miles west of Ridgeland, a spring yields a small flow of clear but mildly sulphurotos water, which is used as a domestic supply. Two other smaller springs near by also yield mineralized water. 


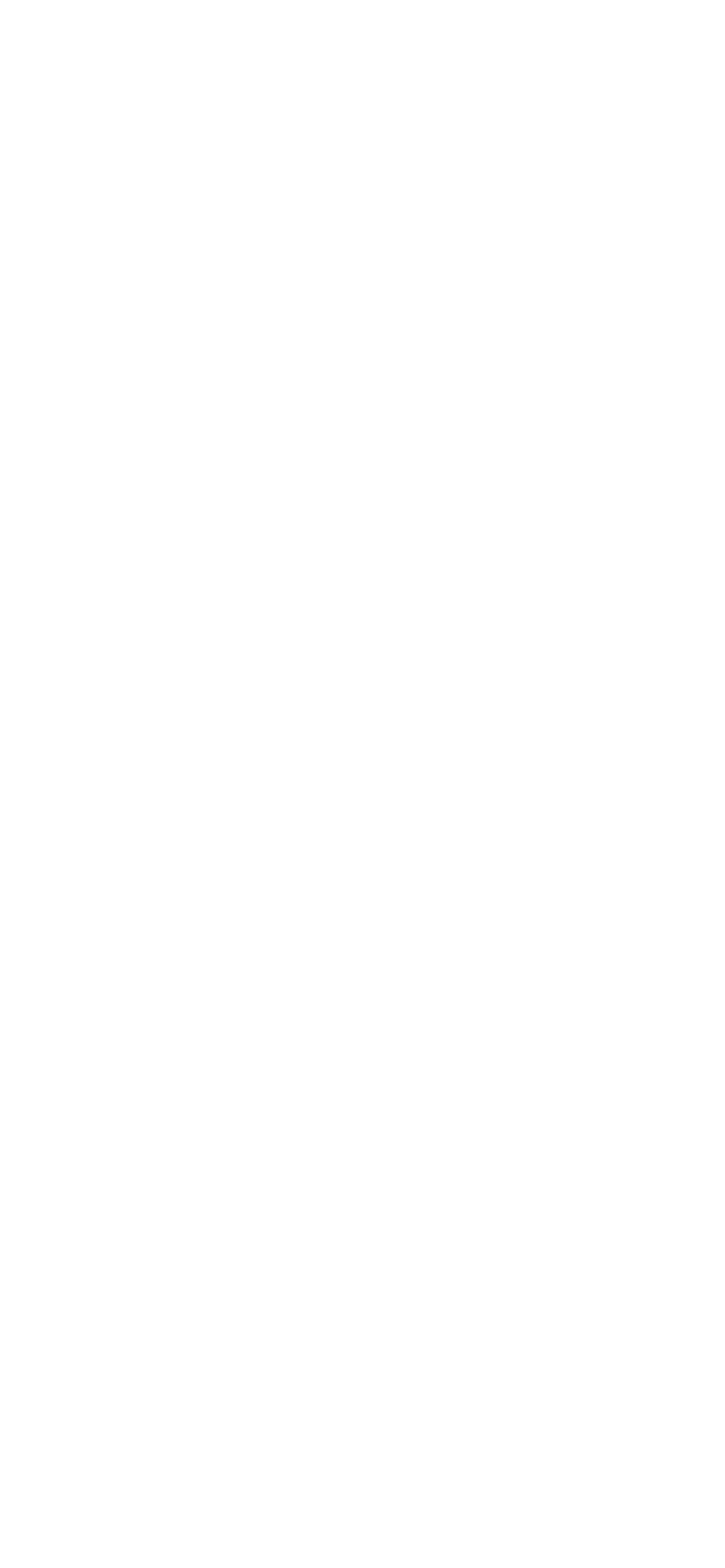




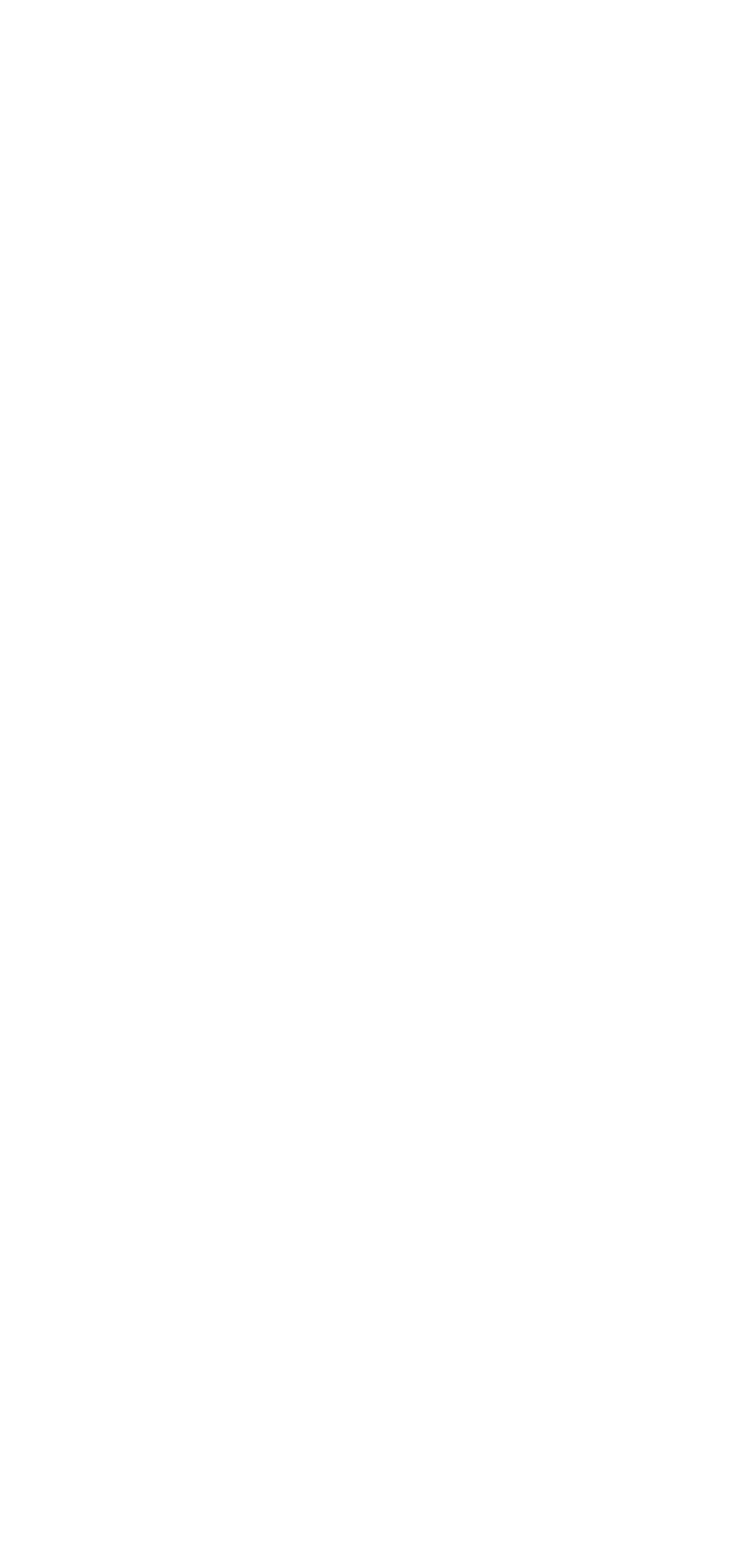


Mineral analyses of ground waters from Madison County

| Parts per million. Numbers at heads of eolumns refer to corresponding well numbers in preceding tabla]

\begin{tabular}{|c|c|c|c|c|c|c|}
\hline & 3 & 5 & 13 & 15 & 17 & 18 \\
\hline $\begin{array}{l}\text { Silica }\left(\mathrm{SiO}_{2}\right) \\
\text { Iron }(\mathrm{Fe}) \\
\text { Oalcium }(\overline{\mathrm{C}} \mathrm{a}) \\
\text { Magnesium }(\mathrm{M} \mathrm{g})\end{array}$ & $\begin{array}{c}40 \\
.10 \\
1.2 \\
1.5\end{array}$ & $\begin{array}{l}38 \\
1.0 \\
26 \\
5.3\end{array}$ & ${ }_{28}^{20} .97$ & $\begin{array}{c}10 \\
216 \\
21\end{array}$ & $\begin{array}{c}33 \\
3.6 \\
144 \\
48\end{array}$ & $\begin{array}{l}26 \\
2.8 \\
19 \\
3.3\end{array}$ \\
\hline Sodium and potassium $(\mathrm{Na}+\mathrm{K})$ & & 35 & 65 & 165 & 399 & 34 \\
\hline 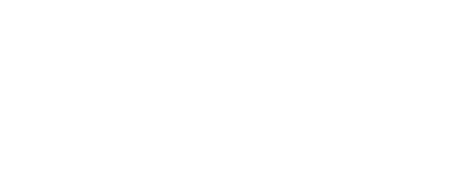 & $\begin{array}{c}137^{\circ} \\
15 \\
7.5 \\
198^{.60} \\
9 \\
\text { June, } 1911\end{array}$ & \begin{tabular}{|}
$\frac{127^{-0}}{44}$ \\
6.0 \\
Trace. \\
211 \\
87 \\
Feb., 1921
\end{tabular} & $\begin{array}{l}455^{.0} \\
46 \\
56 \\
{ }_{329}^{-00} \\
\text { 337 }^{-00} \\
\text { Aug., } 1914\end{array}$ & \begin{tabular}{|l|}
$494^{\circ}$ \\
477 \\
166 \\
$1,388^{\circ}$ \\
733 \\
June, 1912
\end{tabular} & $\begin{array}{l}505^{\circ} \\
126 \\
626 \\
2.5 \\
1,669 \\
557 \\
1914\end{array}$ & 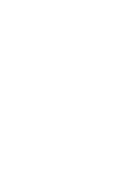 \\
\hline
\end{tabular}

Analysts: 8, W. L. Kennon, University of Mississippi; 5, C. S. Howard, U. S. Geological Survey; 13, 15, Mississippi State Chemical Laboratory; 17, 18, W. F. Hand, Mississippi State Chemical Laboratory،

\section{MARION COUNTY}

\section{GENERAL FEATURES}

Area, 535 square miles. Population, 17,144 (census of 1920)

Marion County lies in the Long-leaf Pine Hills district. The principal geologic formations that appear in surface outcrops in the county include, in the ascending order of their stratigraphic occurrence, the Hattiesburg clay (Miocene), the Pascagoula clay (Miocene), and the Citronelle formation (Pliocene). These formations are described on pages $56-60$, and their distribution is shown on the geologic map (pl. 2).

\section{GROUND-WATER CONDITIONS}

Most of the ground-water supplies of Marion County fall roughly into two classes-the ordinary shallow or "surface" waters, obtained chiefly from springs and by bored wells less than 100 feet deep, and the artesian waters, obtained by deep drilled wells. Shallow wells are common throughout the county and as a rule are sunk deep enough to reach a point a few feet below the level of the water table in dry weather; the water in these wells is under little or no hydrostatic pressure and does not rise appreciably above the containing bed. In the upland the water occurs chiefly in the porous water-bearing sands and gravels of the Citronelle formation, which makes up the upper 50 to 150 feet or more of the body of the hills; in the lowland the water occurs in the coarser sands and gravels of the alluvial deposits that immediately underlie the terrace plains to depths of 15 to 40 feet.

Artesian wells have been drilled chiefly in the lower levels in the valleys, especially in the lowland that borders Pearl River; they are sunk to the deeper sands and gravels whose waters are under sufficient hydrostatic pressure to flow at the surface. These same waters 
can, of course, be obtained by drilled wells at higher levels on the hills of the upland, but there the pressure would not be adequate to cause flows, and the wells, though as truly artesian as the flowing wells, would have to be pumped. The source of most of the artesian waters now being used in the county is believed to be the Hattiesburg formation, which is about 400 feet thick and which, though composed chiefly of clay, contains extensive interbedded layers of water-bearing sand. On the upland in the northeast the base of this formation is estimated to lie at a depth of about 400 feet, or about at sea level, whereas in the south, owing to the southward dip of the strata, the base probably lies 600 to 700 feet below sea level, or 700 to 1,000 feet below the surface. Most of the flowing wells at Columbia have their source in the Hattiesburg formation at depths of 300 to 500 feet. Some of the shallower wells probably tap water-bearing sands in the Pascagoula formation, which overlies the Hattiesburg.

The Catahoula sandstone (Miocene), which underlies the Hattiesburg formation but does not come to the surface in Marion County, is water bearing. On the upland in the northeast the beds of this formation would probably be reached at depths of 400 to 800 feet, but their slight southward dip would carry them several hundred feet deeper along the southern border of the county. The 600-foot flowing well at the plant of the Columbia Ice \& Power Co. at Columbia (No. 8) probably has its source in the Catahoula, as has the 852-foot well at Sandy Hook (No. 21).

The 1,310-foot well (No. 14) $41 / 2$ miles northeast of Columbia, the deepest well reported in the county, is estimated to have reached the Forest Hill sand, the basal formation of the Vicksburg group, though owing to the meagerness of the data on which the estimate is based this correlation is little better than a conjecture.

\section{LOCAL SUPPLIES}

Columbia.-Flowing artesian wells, some of large yield, are common in the valley of Pearl River at and in the vicinity of Columbia. Typical wells are described in the table of well data (Nos. 2-14). The municipal water supply is obtained in part from two wells, each reported to be about 470 feet deep (Nos. 2, 3). The natural flow from these two wells is more than adequate to meet the needs of the consumers. (See analysis 2.) The lumber mill of J. J. White \& Co. is located on the south edge of town, about half a mile south of the post office. Two wells of large yield have been drilled at this mill. One well is 495 feet deep (No. 4) and flows into a ground reservoir at an estimated rate of 800 gallons a minute. The other well at the lumber mill (No. 5) is 500 feet deep and is estimated to yield 600 gallons a minute; it supplies a large log pond. 
Foxworth.-A well (No. 15) $21 / 2$ miles north of Foxworth, a village $21 / 2$ miles west of Columbia, is of interest chiefly because of the shallow depth at which flowing water was obtained. The well is only 41 feet deep and flows a small stream slightly above the surface. (See analysis 15:

Pinebur.-A 525-foot flowing well at Pinebur (No. 18) affords water for the boilers of loeomotives. The bead is high enough to raise the water to the tank without pumping. Another well (No. 19), 1,700 feet northwest of the post office at Pinebur, is 4 inches in diameter and flows a strong stream. The record of the depth of the well is lost, but it is probably at least as deep as the 525-foot well.

Hathorn.-The $\log$ of a driven well which taps a water-bearing sand in Pleistocene alluvium at Hathorn is given below.

Log of well of H. S. Hathorn, at Hathorn (No. 17)

[Authority, the owner]

\begin{tabular}{|c|c|c|}
\hline & Thickness & Depth \\
\hline $\begin{array}{l}\text { Pleistocene alluvium: } \\
\text { Hard clay } \\
\text { Blue sand with a pecutiar odor white sand with pebbles; water bearing } \\
\text { Whit }\end{array}$ & $\begin{array}{r}18 \\
2 \\
5\end{array}$ & Feet $\begin{array}{r}18 \\
20 \\
200\end{array}$ \\
\hline
\end{tabular}

Jamestown.-At Jamestown teveral flowing wells, which range in depth from 240 to 300 feet, yield 3 to $17 \mathrm{gallons}$ a minute. 


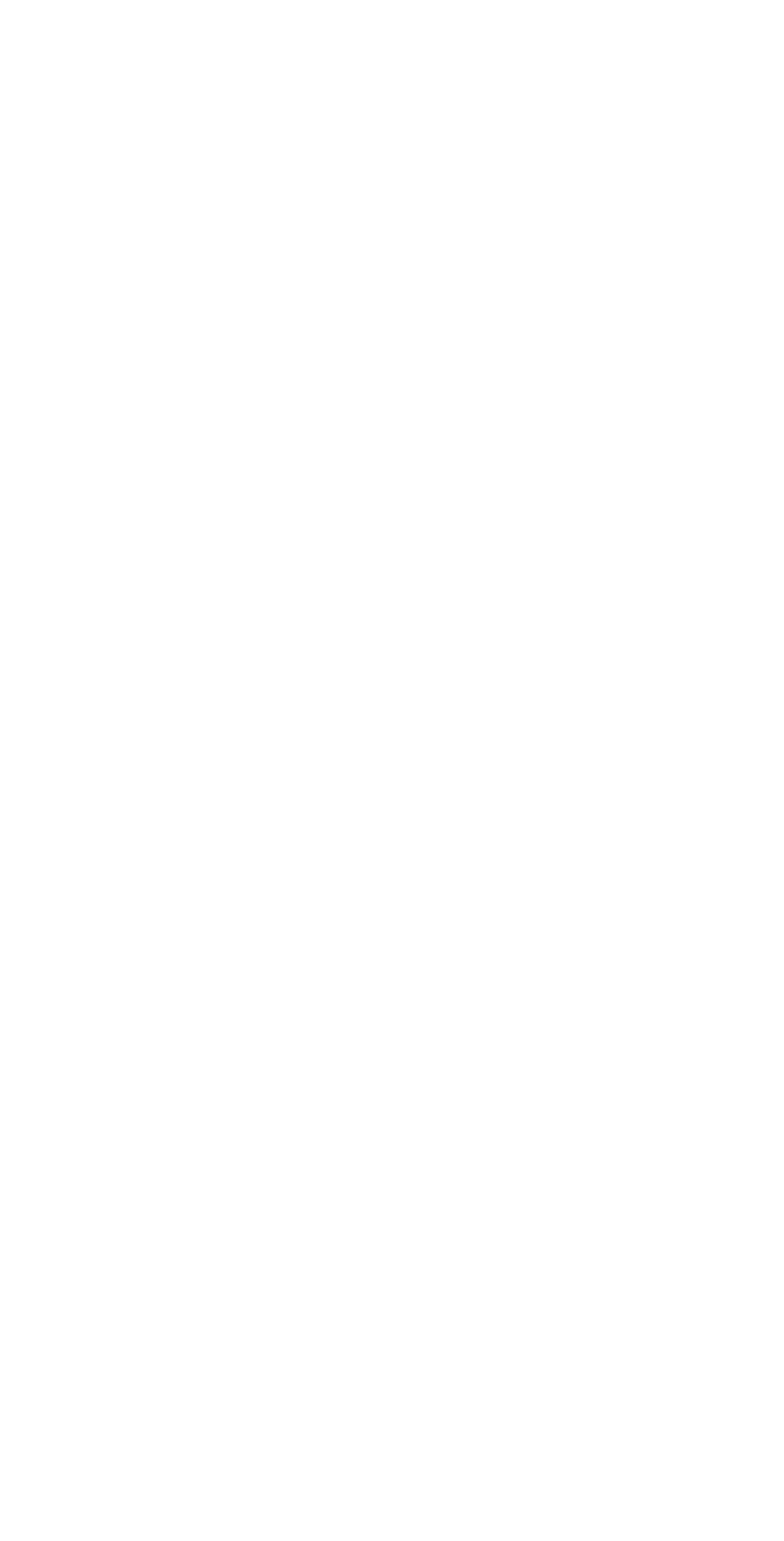




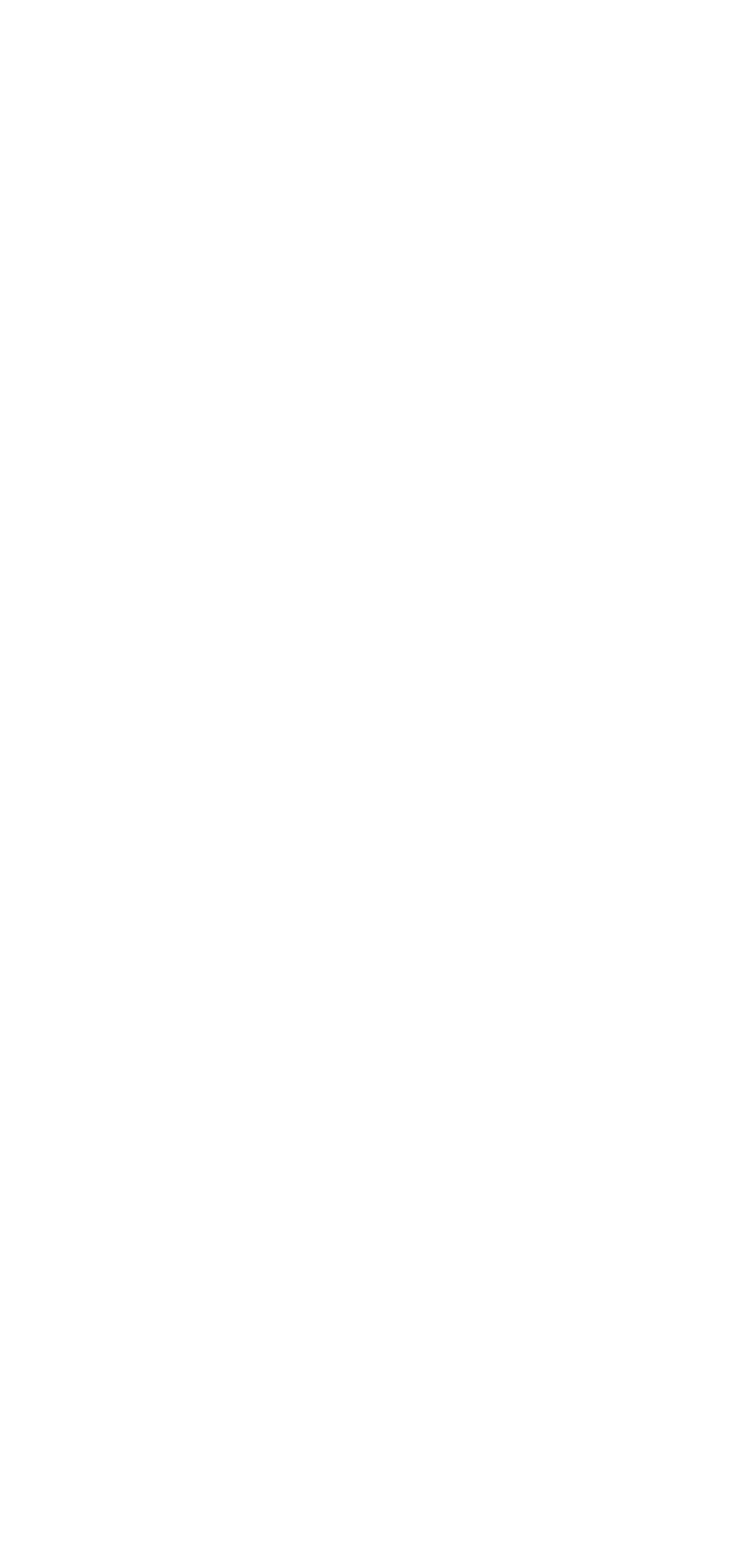




\section{Mineral analyses of ground waters from Marion County}

[Parts per million. Bamples colleted July 16, 1919; anslyzed by N. Fuchs, U. 8. Geological Survey. Numbers at heads of columns fefer to corresponding well yumbers in precedin: table]

\begin{tabular}{|c|c|c|c|c|c|}
\hline & 2 & 15 & & 2 & 15 \\
\hline $\begin{array}{l}\text { Silica }(\mathrm{SIO}) \\
\text { Iron }(\mathrm{Fe}) \\
\text { Calcium }(\mathrm{Ca}) \\
\text { Magnesium }(\mathrm{Mg}) \\
\text { Sodium and potassium }(\mathrm{Na}+\mathrm{K}) \\
\quad \text { (calculated) } \\
\left.\text { Carbonate radicle ( } \mathrm{CO}_{3}\right)\end{array}$ & $\begin{array}{l}48 \\
8.67 \\
1.2 \\
22 \\
.0\end{array}$ & $\begin{array}{l}22.55 \\
7.2 \\
2.5 \\
40 \\
.0\end{array}$ & 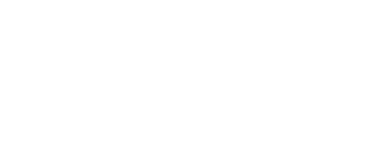 & $\begin{array}{c}51 \\
12 \\
3.2 \\
108^{.23} \\
11\end{array}$ & $\begin{array}{r}49 \\
5.2 \\
3.7 \\
\text { Trace. } \\
75 \\
28\end{array}$ \\
\hline
\end{tabular}

\section{MARSEALt COUNTY}

\section{Gentaral maturits}

Area, 689 square milles. Poptalation, 26,105 (census of 1920)

Marshall County is in the northere extremity of the North Central Hills district. The county is underlain by three geologic formations, all of which belong to the Wilcox group of the Fecene. In ascending order of age these are the Ackerman formation, the Holly Springs sand, and the Grenada formation; the Holly Springs and the Grenada have not been accurately discriminated in northern Mississippi. Descriptions of these formations are given on pages $45-48$, and their distribution is approximately shown on the geologic map (pl. 2).

\section{GROUND-WATER CONDITIONS}

The beds that compose the Wilcox group dip to the west at the rate of 20 or 25 feet to the mile and afford conditions favorable to the development of artesian pressure in their contained ters. However, no flowing wells have their source in these formations, so far as known, and in fact the static head is not high enough to produce flows, except perhaps in some of the deeper valleys to the west.

The Ackerman formation has an aggregate thickness of 400 or 500 feet, and the beds dip to the west and pass beneath the Holly Springs sand. The sands in the upper part of the formation are probably water bearing.

The Holly Springs sand is abundantly water and would probably yield flows in the valleys of Coldwater River and its tributary creeks in the western part of the county.

The Grenada formation crops out in the northwestern part of the county, but neither its character nor distribution have been determined in detail. However, it doubtless includes some water-bearing beds.

With perhops local exceptions water supplies can be sobtained throughout the upland portion of the county from one or another of

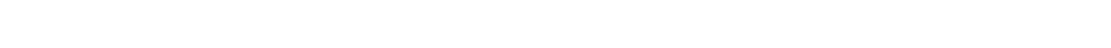
than 100 feet theep; in fact, most of the domestic and farm supplies are obtained from these sources. 
Springs that have their-source in the same formations are also common, and some of them are atilized. The relatively thin alluvial deposits that underlie the lowlands along the larger streams carry water that can be obtained by shallow dug, bored, or driven wells.

The only flowing well described in the table of well data is the 718-foot town well (No. 11) at Potts Camp. This well probably completely penetrates the Eocene strata and enters a water-bearing sand in the Ripley formation of the Upper Cretaceous, whict lies deeply buried beneath the surface in Marshall County. (See discussion under head of Benton County, p. 87.)

\section{LOCAL SUPPLIES}

Mount Pleasant.-A 100-foot well (No. 10) a mile south of Mount Pleasant yields an ample supply of water, which is reported to be rather hard, from the Holly Springs sand.

Byhalia.-The town well at Byhalia (No. 1) is 85 feet deep and probably taps a water-bearing sand in the Grenada formation. (See analysis 1.)

Hudsonville.-The 168-foot well of E. C. Mahon (No. 7), 2 miles northwest of Hudsonville, struck water at a depth of about 165 feet; the water stands about 12 feet deep in the well. On the J. M. Lambkin place, $11 / 2$ miles southwest of Hudsonville, a spring issues from the Holly Springs sand on a fairly steep hillside and yields a bold stream of clear soft water that is of good quality for domestic and general farma use.

Makon:-Near Mahon a 100-foot well and a 113-foot well (Nos. 8, 9) struck good supplies of water at depths of 90 and 98 feet, respectively. In the 100-foot well the water stands about 10 feet deep, and in the 113-foot well about 3 feet deep. The 100-foot well is reported to have penetrated 10 feet of sand and 90 feet of material that is chriefly clay; the water comes from a sandy layer in the clay. The M. L. Patterson spring, a mile southerst of Mahon, is typical of springs in this vicinity; it issues from the base of a low bluff and yields a small quantity of clear soft water.

Holly Springs.-The municipal waterworks at Holly Springs is located on North Market Street, 150 yards northeast of the courthouse. The water supply is obtained from four wells, one of which is 400 (?) feet deep and the others each about 350 feet deep (Nos. 2-5). Analyses 3 and 4 represent water from two of the city wells, and-logs of two of the wells are given below.

$54134-28-22$ 
Logs of public vells at Holly Springs

Well 2

\begin{tabular}{|c|c|c|c|c|c|}
\hline & Thick- & Depth & & $\begin{array}{c}\text { Thick } \\
\text { ness }\end{array}$ & Depth \\
\hline $\begin{array}{l}\text { Holly Springs sand: } \\
\text { Reddish clay } \\
\text { Red sand } \\
\text { Sandstone } \\
\text { Clay }{ }^{\bullet} \\
\text { Hard sandstone. }\end{array}$ & $\begin{array}{c}\text { Beet } \\
20 \\
87 \\
1 \\
52 \\
1 / 2\end{array}$ & $\begin{array}{r}\text { Feet } \\
20 \\
107 \\
108 \\
160 \\
1601 / 2\end{array}$ & $\begin{array}{l}\text { Holly Springs sand-Continued. } \\
\text { Clay and sandstone... } \\
\text { Fine sand; water bearing } \\
\text { Pipe elay } \\
\text { Coarse sand } \\
\text { Ackerman formation(?): Sticky clay. }\end{array}$ & $\begin{array}{c}\text { Beat } \\
1391 / 2 \\
40 \\
13 \\
4 \\
43(1)\end{array}$ & $\begin{array}{l}\text { Feet } \\
300 \\
340 \\
353 \\
357 \\
400(?)\end{array}$ \\
\hline
\end{tabular}

Well 5

\begin{tabular}{|c|c|c|c|c|c|}
\hline $\begin{array}{l}\text { Holly Springs sand: } \\
\text { Sand } \\
\text { Sandstone } \\
\text { Variegated clay } \\
\text { Sandstone }\end{array}$ & $\begin{array}{r}110 \\
1 \\
49 \\
1 / 2\end{array}$ & $\begin{array}{l}110 \\
111 \\
160 \\
1601 / 2\end{array}$ & $\begin{array}{l}\text { Holly Springs sand-Continued. } \\
\text { Quicksand; water bearing } \\
\text { Blue clay } \\
\text { Sand; water bearing }\end{array}$ & $\begin{array}{r}100 \\
60 \\
30\end{array}$ & $\begin{array}{l}2601 / 2 \\
3201 / 2 \\
3501 / 2\end{array}$ \\
\hline
\end{tabular}

- This thick clay parting in the Holly Springs formation is very persistent in extent.

- This clay is a very persistent bed in the Holly Springs formation.

In 1898 a well at the waterworks, 20 feet northeast of the present site of the $3501 / 2$-foot well, was drilled to a depth of 750 feet, where a 4-foot stratum of water of small yield was encountered. The well was abandoned. In 1899 a well 25 feet southwest of the abandoned well was drilled to a depth of 1,500 feet, but no water was found below the 750-foot stratum. The 20-foot well of Lynch Cochran (No. 6), near Holly Springs, contains water that stands within 6 feet of the surface. A spring on the place of Judge H. K. Mahon, 300 yards north of the waterworks at Holly Springs, yields about 2 gallons a minute of slightly hard water, which is used for a domestic supply. (See analysis 12.)

Waterford.-At Waterford domestic water supplies are obtained from wells 12 to 90 feet deep dug or drilled into the Holly Springs sand.

Potts Camp.-The town of Potts Camp owns a waterworks, 10cated 100 yards northwest of the St. Louis \& San Francisco Railroad station, and obtains water from a 718-foot flowing well (No.11). A log of the well is given below. (See analysis 11.) 


\section{Log of public well at Potts Camp (No. 11)}

[Authority, A. B. Roach, driller]

\begin{tabular}{|c|c|c|}
\hline & Thick & Depth \\
\hline $\begin{array}{l}\text { Alluvinm(?): } \\
\text { Soil and subsoll } \\
\text { Red sand }\end{array}$ & Feet 10 & Feet ${ }_{25}$ \\
\hline 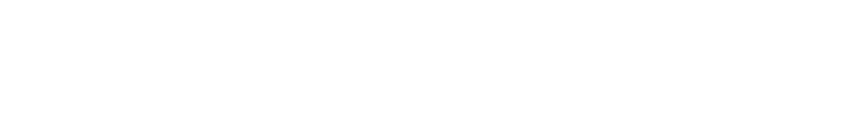 & $\begin{array}{r}25 \\
2 \\
593 \\
5\end{array}$ & $\begin{array}{r}50 \\
52 \\
645 \\
650\end{array}$ \\
\hline $\begin{array}{l}\text { Ripley formation: } \\
\text { Sand; water bearing } \\
\text { Black clay }\end{array}$ & $\begin{array}{l}50 \\
18\end{array}$ & $\begin{array}{l}700 \\
718\end{array}$ \\
\hline
\end{tabular}

- This material is a carbonate of iron which resembles lithographte stone.

Eagle Springs, half a mile from Potts Camp, yield water that is said to be highly mineralized. The springs are believed to issue from the Ackerman formation, which at many places yields strongly chalybeate and calcareous waters. 


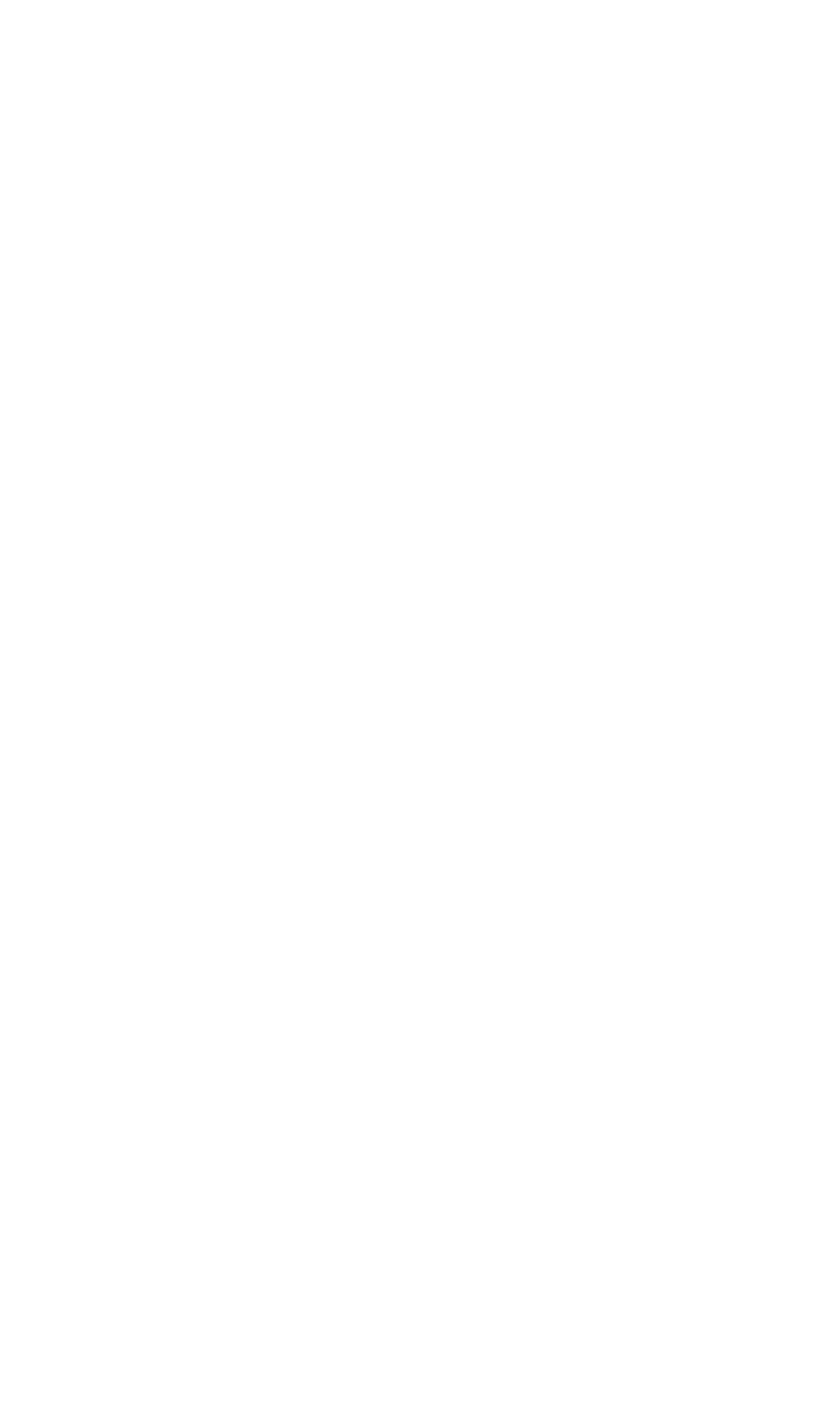




\section{Mfineral analyse of ground waters from Marshall County}

[Parts per mifilon. Numbors at heads of columing refor to corresponding weil and spring ntmbers in peo: ceding table]

\begin{tabular}{|c|c|c|c|c|c|}
\hline & 1. & 3 & 4 & 11 & 12 \\
\hline 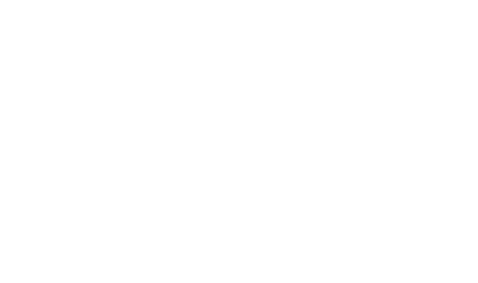 & \begin{tabular}{|c|c|c|c|c|}
25 \\
16 \\
9.6 \\
2.2 \\
.0 \\
31 \\
30 \\
2.2 \\
10 \\
125 \\
79 \\
Nov. 1011
\end{tabular} & 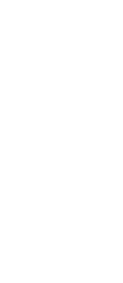 & 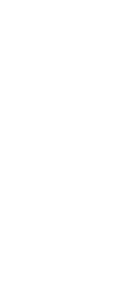 & $\begin{array}{c}8.0 \\
2.0 \\
7.2 \\
2.8 \\
60 \\
176^{.0} \\
25 \\
1.3 \\
205^{.00} \\
30 \\
1011\end{array}$ & $\begin{array}{c}28^{\circ} \\
11 \\
31 \\
62^{\circ} \\
60 \\
31 \\
35 \\
245 \\
118 \\
\text { Bept } 1910\end{array}$ \\
\hline
\end{tabular}

- Includes iron and aluminum $(\mathrm{F} \theta+\mathrm{Al})$.

- Calculated.

Analysts: 1, W. L. Perdue, University of Mississippl; 3, 4, C. s. Howard, U. S. Geological Survey; 11 , T. S. Wallace, University of Mississippi; 12, Margaret D, Foster and Clara M. Forman, U. S. Geologica Burvey.

\section{MONROE COUNTY}

\section{GENERAL FEATURES}

Area, 770 square milles. Population, 32,613 (census of 1920)

Monroe County, one of the tier of counties that borders Alabama, lies in the Tombigbee Hills district on the east and in the Black Prairie belt on the west. The principal facts relating to the three Upper Cretaceous terrains-the Tuscaloosa and Eutaw formations and the Selma chalk-which crop out within the county are discussed on pages 29-39, and their distribution is shown on the geologic map (pl. 2). Formations of minor importance in the area are the series of thin alluvial terrace deposits which were laid down on the river flood plains of Pleistocene time in a belt 6 to 10 miles wide along the present Tombigbee River. (See p. 61.)

\section{GROUND-WATER CONDITIONS}

The Tuscaloosa, the basal formation of the Upper Cretaceous, appears at the surface only in a narrow area in the lower slopes of Buttahatchie River and its principal tributaries Sipsey and Splunge Creeks, in the eastern part of the county. The formation, however, underlies the whole county, and the 200 feet or more of strata, principally sand, which compose it, constitute an abundant source of artesian water of good quality. The Tuscaloosa beds dip to the west at the rate of about 30 feet to the mile, so that along the western boundary of the county they lie at estimated depths of 700 to 1,000 feet. The catchment area of this aquifer is in Lamar, Marion, and Fayette Counties, Ala., at elevations considerably above that of the formation even in eastern Monroe County, so that a strong artesian head is developed as is shown by the many flowing wells which derive their supply from this source in the valleys of Tombigbee River and its 
tributaries. Wells that yield as much as 200 gallons a minute have been reported. The surface of the uplands in both the eastern and western parts of the county lies above the upper limit of the hydrostatic pressure developed in the Tuscaloosa, so that in these areas no flowing wells have been obtained, but at all points in the county the water of the Tuscaloosa sands will rise within comparatively easy. reach of pumps.

The Eutaw formation, which consists of an estimated thickness of 400 feet of sand, in part water bearing, and subordinate layers of clay, overlies the Tuscaloosa formation and crops out or lies at relatively shallow depths beneath surficial deposits throughout approximately the eastern two-thirds of the county. The formation dips to the west and passes beneath the non-water-bearing beds of the Selma chalk, which immediately underlies the Black Prairie belt for approximately the western third of the county. Along the western border of the county the Eutaw is first reached at a depth of about 300 feet. The Eutaw is the source of many of the flowing wells in Tombigbee River valley that are 200 feet or less in depth and of the majority of the many wells in the Black Prairie belt in the western part of the county, only a few of which are deep enough to reach the water-bearing sands of the Tuscaloosa. The hydrostatic pressure manifested by the water of the Eutaw is in general not quite so great as that of the water of the Tuscaloosa.

Two wells deep enough to reach the Paleozoic basement rocks have been reported. One well at Gattman, the log of which is given on page 339 , reached the basement at a depth of 311 feet; the total depth is 623 feet, and the principal supply of water is obtained from Paleozoic sandstone. The other well at Amory (see log, p. 337), reached the basement rocks at a depth of 373 feet but apparently obtained no water below the base of the Tuscaloosa.

In the hilly area east of Tombigbee River valley many of the inhabitants derive their domestic water supplies from shallow wells dug or bored into the sands of the Eutaw formation. Springs of small to moderate yield are common among these hills; they have their source in sandy strata of the Tuscaloosa and Eutaw formations. Some of the springs are utilized for domestic supplies, but many that are not conveniently located with respect to dwellings are undeveloped. Greenwood Springs, a local resort, is described on page 338. In the wide belt of nearly level terraced land that borders Tombigbee River, chiefly on the east side (see p. 4), springs are common, and many of them are bold and strong. They occur at the contact between the relatively thin unconsolidated terrace deposits and the underlying more compact sands and clays of the Eutaw formation. On account of the accessibility of flowing artesian water these springs are not extensively used for domestic supplies. 
In the Black Prairie belt west of Tombigbee River many people still depend on cisterns and artificially construoted pools, but artesian wells are rapidly replacing these unsatisfactory means of providing water supplies.

\section{LOCAL SUPPLIES}

Aberdeen.-Flowing artesian wells have been in use at Aberdeen for 70 years or more. ${ }^{44}$ Water is obtained both from the Eutaw formation, the base of which lies at a depth of 200 to 220 feet, and from the underlying Tuscaloosa formation, the base of which, where it rests upon the Paleozoic basement rocks, is estimated to be 500 to 550 feet below the surface. The hydrostatic pressure to which the waters of the Eutaw formation are subjected is not great enough to cause flows on the terrace plain on which the main part of Aberdeen is situated, the static head being 20 to 40 feet below the surface, but the static head of the waters of the Tuscaloosa formation from depths of 260 feet or more is 10 to 15 feet above the surface, so that these waters when tapped by wells flow at the surface. Many wells have been drilled in and near the town, several of which are described in the tables (Nos. 1-5). The waterworks at Aberdeen is owned by the town and is located near the intersection of Orange and Fulton Streets. Water is afforded by five wells 140 to 185 feet deep, from which it is raised by two steam-driven air compressors. One of the wells is described in the table of well data (No. 3). The average daily consumption is 200,000 gallons. The five wells are near the pump house and are not over 50 feet apart. The following $\log$, which was furnished by the superintendent of the waterworks, shows that the wells have their source in a water-bearing sand in the Eutaw formation:

Log of well at the waterworks, Aberdeen

[Altitude of mouth of well 200 feet above sea level]

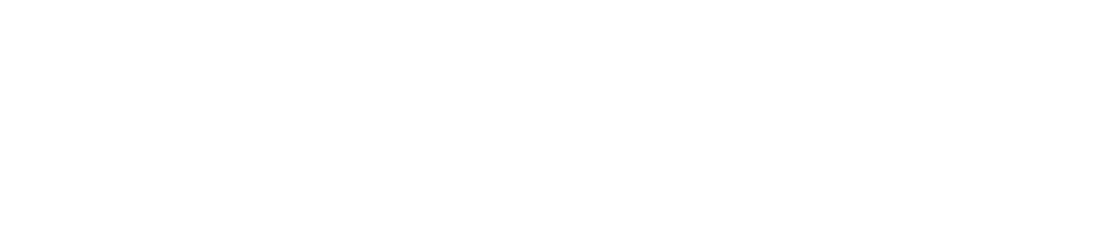

4 Wailee, B. L. O., Report on the agriculture and geology of Mississippi, p. 264, 1854. 
The following $\log$ of a well at Aberdeen known as the Compress well shows the oharacter of the deoper lying beds:

Log of the Compress well, Aberdeen *

[Altitude of month of well 210 foet above sea lewel. Adapteq from description by Logan and Perkins

\begin{tabular}{|c|c|c|}
\hline & Thicknes & Denth \\
\hline $\begin{array}{l}\text { Olay and sand } \\
\text { Sandrock, hard in places } \\
\text { Samdrock and olay; water bearing }\end{array}$ & $\begin{array}{r}\text { Peet } \\
300 \\
126\end{array}$ & Feet $\begin{array}{c}25 \\
325 \\
410\end{array}$ \\
\hline
\end{tabular}

- Logan, W. N., and Perkins, W. R., The underground waters of Mississippl: Missiqsippi Agr. Exper; Bta. Bull. 89, p. 3a, 1005 .

This well penetrates 25 foet of clay and sand, which probably is a Pleistacene terrace depasit, an estimated thickness of 175 feat of Eutaw strata, and 250 feet of the Tuscaloosa formation. Lee Lantz, a driller, describes from memory the materials penetrated by wells at Aberdeen to a depth of 350 feet, as follows:

Materials penetrated in wolls at Aberdeon

[Adapted from deseription by Lee Lankz, driller]

\begin{tabular}{|c|c|c|}
\hline & Thiokness & Depth \\
\hline Not reported, but in part Pleistocene terrace depasits.... & & \\
\hline $\begin{array}{l}\text { Eutaw formation: } \\
\text { Soft sandroek (compact glauconttic sand); passes into blue water-bearing sand } \\
\text { Clay (thin) } \\
\text { Blue sand; water bearing }\end{array}$ & $\begin{array}{r}65 \\
\pm 10 \\
+115\end{array}$ & $\begin{array}{r}95 \\
\pm 105 \\
\pm 200\end{array}$ \\
\hline $\begin{array}{l}\text { Tuscaloosa formation: } \\
\text { Clay, with thin layers of soft rack and lignite at intervals } \\
\text { White sand; water bearing }\end{array}$ & $\begin{array}{r}100 \\
30\end{array}$ & $\underset{350}{320}$ \\
\hline
\end{tabular}

Amory.-Amory is situated on a terrace plain in the valley of Tombigbee River that lies at an altitude of 235 to 240 feet above sea level. Many flowing wells 150 to $\mathbf{4 7 0}$ feet deep have been drilled in the town and on lower terrace plains, which stretch away to the north, west, and south and 2 or 3 miles to the east. The wells have their source in part in the Eutaw and in part in the deeper Tuscaloosa formation. A few years ago there were six or more public flowing wells in the center of the main street, but three of them have ceased to flow. When the street was paved the water of these three wells was piped to or near the curb, where it flows continuously and is used chiefly for public drinking. In addition to the wells in the center of the main street there were many semipublic wells at street corners which, though owned by individuals, were paid for in part from the town treasury. Many of these wells have ceased to flow. The failure of flows may be due in part to the lowering of the static head by heavy local draft but is doubtless also due in part to the corrosion and collapse of the casings and the consequent 
choking with sand. Several wells are described in detail in the tables (Nos. 6-13); the logs of three welly at and near the town are given below; and analyses of waters from several wells are given in the table of analyses. The town is provided with a municipally owned waterworks which is located near the intersection of Chestnut and Front Streets. Water is obtained from four wells, one 467 feet deep and three each about 260 feet deep. Two of the wells are described in the table of well data (Nos. 6,7).

\section{Log of well at municipal water plant, Amory (No. 7)}

[Altitude of mouth of well 237士 feet above sea level. Adapted from description by A. B. Roach, driller]

\begin{tabular}{|c|c|c|}
\hline & Thichness & Depth \\
\hline 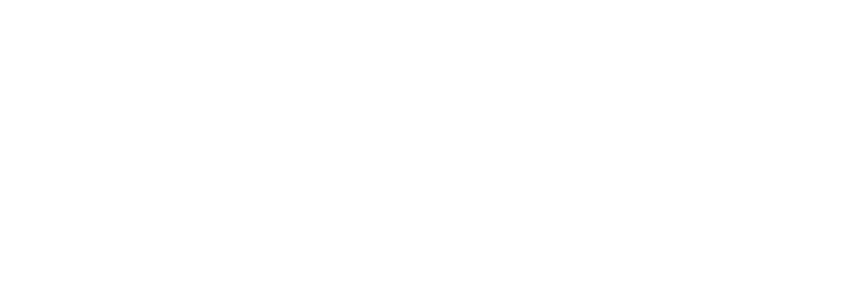 & $\begin{array}{c}140 \\
10 \\
20 \\
50 \\
138 \\
72 \\
21 / 3 \\
21\end{array}$ & $\begin{array}{l}160 \\
170 \\
190 \\
240 \\
373 \\
445 \\
445 \% \\
467\end{array}$ \\
\hline
\end{tabular}

Log of well (ononer untenowon) at Amory

[Authority, R. B. Laird, driller, through E. N. Lowe]

\begin{tabular}{|c|c|c|c|c|c|}
\hline & $\begin{array}{c}\text { Thitek } \\
\text { ness }\end{array}$ & Dopth & & $\begin{array}{c}\text { Thick- } \\
\text { ness }\end{array}$ & Depth \\
\hline 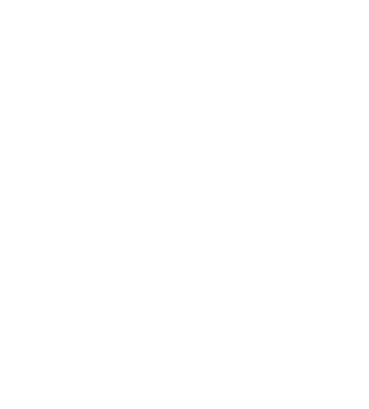 & $\begin{array}{rr}\text { Ft. in. } \\
12 & 0 \\
10 & 0 \\
7 & 0 \\
0 & 0 \\
4 & 0 \\
6 & 0 \\
25 & 0 \\
& \\
128 & 6 \\
3 & 0 \\
4 & 0 \\
2 & 0 \\
9 & 0 \\
1 & 0 \\
0 & 6 \\
0 & 0\end{array}$ & $\begin{array}{ll}F t . & \text { in } \\
12 & 0 \\
22 & 0 \\
27 & 0 \\
78 & 0 \\
37 & 0 \\
43 & 0 \\
68 & 0 \\
& \\
196 & 6 \\
199 & 6 \\
203 & 6 \\
205 & 6 \\
214 & 6 \\
215 & 6 \\
216 & 0 \\
245 & 0\end{array}$ & 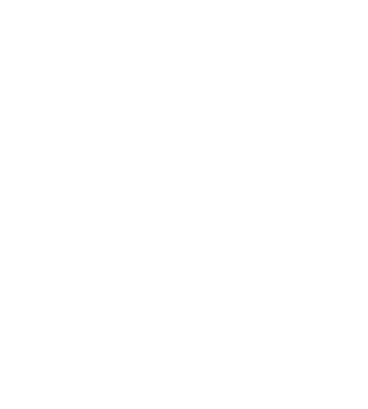 & $\begin{array}{rr} & \\
& 10 \\
10 & 0 \\
21 & 0 \\
6 & 0 \\
4 & 0 \\
12 & 6 \\
12 & 0 \\
2 & 6 \\
2 & 6 \\
10 & 0 \\
12 & 0 \\
19 & 0 \\
9 & 0 \\
69 & 0 \\
1 & 0\end{array}$ & $\begin{array}{ll}\text { Ft. } & \text { in. } \\
225 & 1 \\
235 & 1 \\
256 & 1 \\
262 & 1 \\
286 & 1 \\
287 & \\
279 & 1 \\
279 & 1 \\
282 & \\
292 & \\
304 & 323 \\
331 & \\
400 & 4 \\
401 & \end{array}$ \\
\hline
\end{tabular}

Log of Stookton well, 416 miles north of A mary

[Altitude of mouth of well about 250 feet above sea level. Adapted from deacription by Logan and Perkins]

\begin{tabular}{|c|c|c|}
\hline & Thickness & Depth \\
\hline Plojistocene terrace deposit: Surface 1 & Feet ${ }_{16}$ & Feat 10 \\
\hline $\begin{array}{l}\text { Blue sand and clay } \\
\text { Band and gravel; water igöring }\end{array}$ & $\begin{array}{r}130 \\
10\end{array}$ & $\frac{146}{160}$ \\
\hline
\end{tabular}

- Logan, W. N., and Perikins, W. R., The underground waters of Mississippi: Mississippi Agr. Exper. 8ta., Bull. 89, p. 29, 1005. 
Landis Faulkner owns a spring 11 miles east of Amory, in the SW. $1 / 4$ SE. $1 / 4$ sec. 23 , T. 12 S., R. $17 \mathrm{~W}$. The water emerges from white sand interbedded with some clay, which probably belongs to the Tuscaloosa formation. In A. E. Dalrymple's well (No. 11) the Pleistocene terrace deposit, the base of which is a bed of gravel, was found to be $\mathbf{4 0}$ feet thick. Most of the materials encountered below the gravel and above the water-bearing sand that lies at a depth of 300 feet are stated to be "soapstone" (clay), although a water-bearing sand was struck at a depth of about 160 feet.

Hamilton.-The village of Hamilton is situated near the eastern edge of the terraced area that borders Tombigbee River and is probably on the Pleistocene terrace plain, the altitude of which is 60 to 70 feet above low-water level of the river. About 12 wells have been drilled within a radius of half a mile of the post office, of which four overflowed at the surface in 1916. (See wells 16-17.) Most of the wells originally flowed, but the static head has become lowered until it is now at or a little below the surface. The source of the water is the Tuscaloosa formation. Flows are obtained in adjacent creek valleys, which are cut 15 or 20 feet below the terrace level, and strong flows are obtained on a terrace plain a few miles to the west, which lies about 20 feet lower than the surface at the village. (See well 18.) A partial description of the ground-water conditions is given below:

Ground-water conditions at Hamilton

[Authority, J. W. Basham]

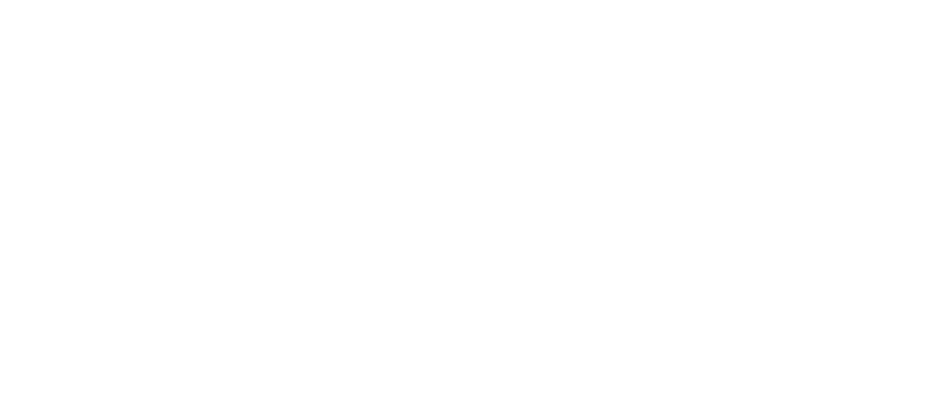

Greenwood Springs.-A spring owned by H. F. Bryles, located near the St. Louis \& San Francisco Railroad, 10 miles southeast of Amory, is known as Greenwood Springs. The source of the water is either the basal part of the Eutaw formation or the upper part of the Tuscaloosa formation.

Gattman.-A well at Gattman (No. 15), which reached the Paleozoic basement rocks at a depth of 311 feet yields flowing water from soft sandstone at a depth of 620 feet. At the base of the Tuscaloosa formation, at a depth of 308 to 311 feet, 3 feet of water-bearing sand was encountered. The $\log$ of this well is as follows: 


\section{Log of well at Gattman a}

[Altitude of mouth of well 280 foet above sea level. Adapted from log by Crider and Johnson]

\begin{tabular}{|c|c|c|}
\hline & Thickness & Depth \\
\hline $\begin{array}{l}\text { Pleistocene terrace deposit: Sandy yellow clay } \\
\text { Tuscaloosa formation: } \\
\text { Fine sand (quicksand) } \\
\text { Gravel and sand. } \\
\text { Yellow sand. } \\
\text { Gray sand } \\
\text { Deep-red clay. } \\
\text { Lignitic clay } \\
\text { Sand } \\
\text { Hard grayish sandrock } \\
\text { Fine sand or opening from which water rose to surface, furnishes about } 2 \text { galions } \\
\text { a minute. } \\
\text { Small, round gravel, about the size of large shot } \\
\text { Peleonoic: Hard gray sandstone (hard as millstone); becomes softer and darker in } \\
\text { in color below; water rose to surface from this soft sandstone }\end{array}$ & $\begin{array}{r}\text { Feet } \\
18 \\
65 \\
4\end{array}$ & $\begin{array}{r}\text { Heet } \\
18 \\
83 \\
87\end{array}$ \\
\hline
\end{tabular}

- Crider, A. F., and Johnson, L. C., U. S. Geol. Survey Water-Supply Paper 159, p. 69, 1906.

Water flows above surface at the rate of 15 gallons a minute; is full of gas bubbles and has a taste of borax and soda.

Prairie.-Many wells have been drilled in the vicinity of Prairie, and the majority of them range in depth from 350 to 450 feet. They tap water-bearing sands in the Eutaw formation. Several wells are described in the table (Nos. 23-26). The base of the Selma chalk lies at a depth of 200 to 250 feet, and the most abundant supplies are found between 260 and 400 feet; the static head of the water is 50 to 100 feet below the surface. The log of one well near Prairie is given below, and analysis 24 represents water from another well.

Log of we of W. H. Henderson, located on a level prairie a mile east of Prairie (No. 25)

[Adapted from description by Lee Lanz, driller]

\begin{tabular}{|c|c|c|}
\hline . & Thickness & Depth \\
\hline $\begin{array}{l}\text { Topsoil (residual from the Selma) } \\
\text { Belma chalk: Limerock (chalk) }\end{array}$ & $\begin{array}{r}\text { Feet } \\
20 \\
220\end{array}$ & Feet 20 \\
\hline $\begin{array}{l}\text { Eutaw lormation: } \\
\text { Sandrock } \\
\text { Sand; water bearing }\end{array}$ & $\begin{array}{r}1 \\
170\end{array}$ & $\begin{array}{l}241 \\
411\end{array}$ \\
\hline
\end{tabular}

Muldon.-The ground-water conditions at Muldon are essentially like those at Prairie. In general the wells range in depth from 350 to 500 feet, and the static head of the water, which comes chiefly from the Eutaw formation, is 50 to 85 feet below the surface. Data concerning several wells are given in the table (Nos. 19-22). The 620foot well of the Mobile \& Ohio Railroad (No. 20) is probably deep enough to reach the uppermost strata of the Tuscaloosa formation.

Strongs.-As indicated by the log of Moses Williams's well (No. 28) given below, the ground-water conditions in the vicinity of Strongs are similar in essential respects to those at Prairie and Muldon. 
Log of well of Moses Williams, three-fourth a mile northwest of Strongs

[Alttude of mouth of well about 232 bet bbove 808 level. Adapted from owner's description]

\begin{tabular}{|c|c|c|}
\hline & Thickness & Depth \\
\hline $\begin{array}{l}\text { Clay (residual from the Selma) } \\
\text { Selma chalk: Limerock. } \\
\text { Eutaw formation: } \\
\text { White pepper sand, with thin layers of rock at intervals; water beering in the } \\
\text { upper few feet and at the base } \\
\text { Sand with interbedded layers of biue muek or mud (elay), whieh eaves bediy } \\
\text { In lower part. }\end{array}$ & $\begin{array}{r}\text { Feet } \\
30 \\
178 \\
05 \\
290\end{array}$ & $\begin{array}{r}\text { Feet } \\
30 \\
200 \\
\\
300 \\
620\end{array}$ \\
\hline
\end{tabular}




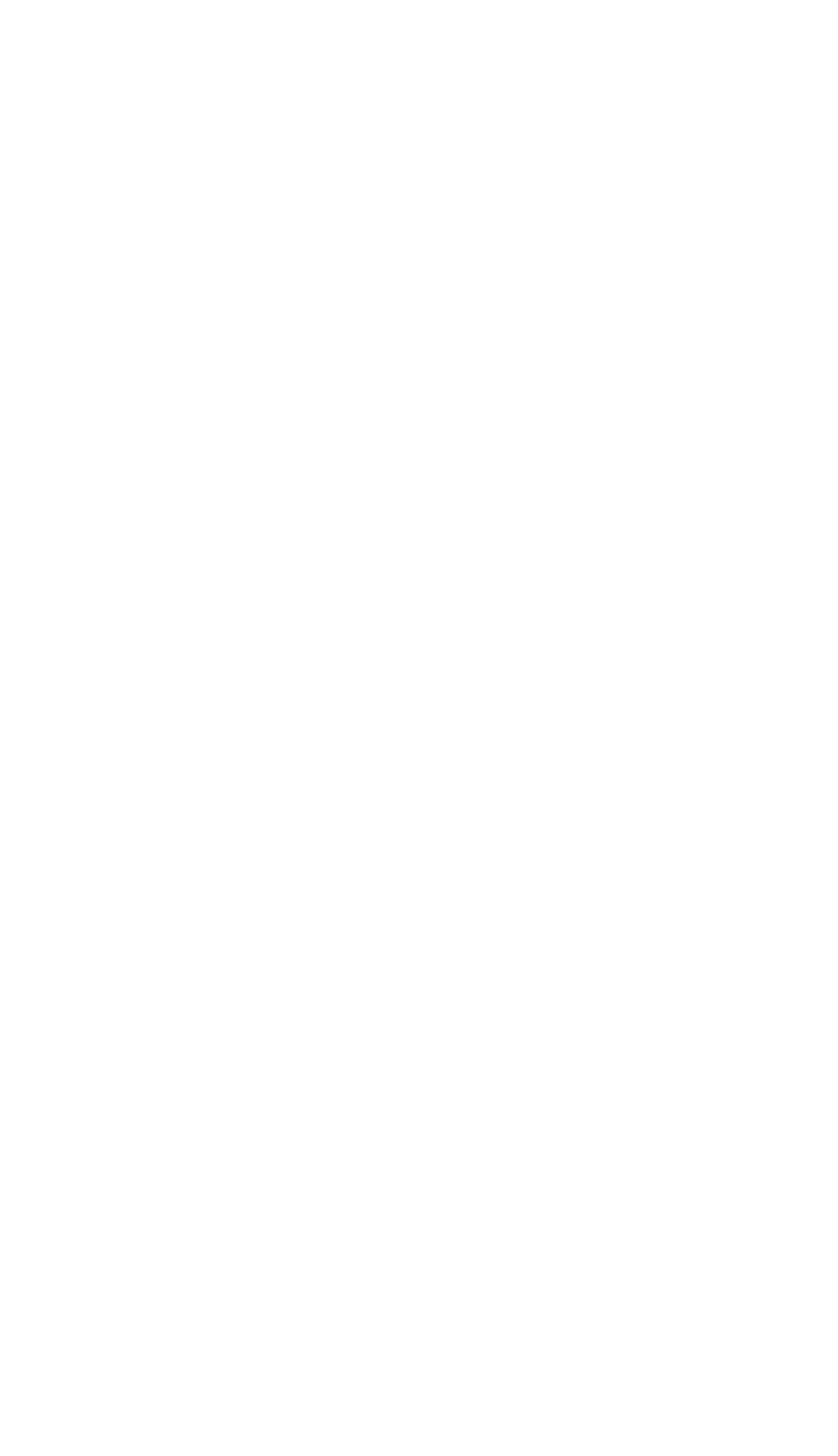




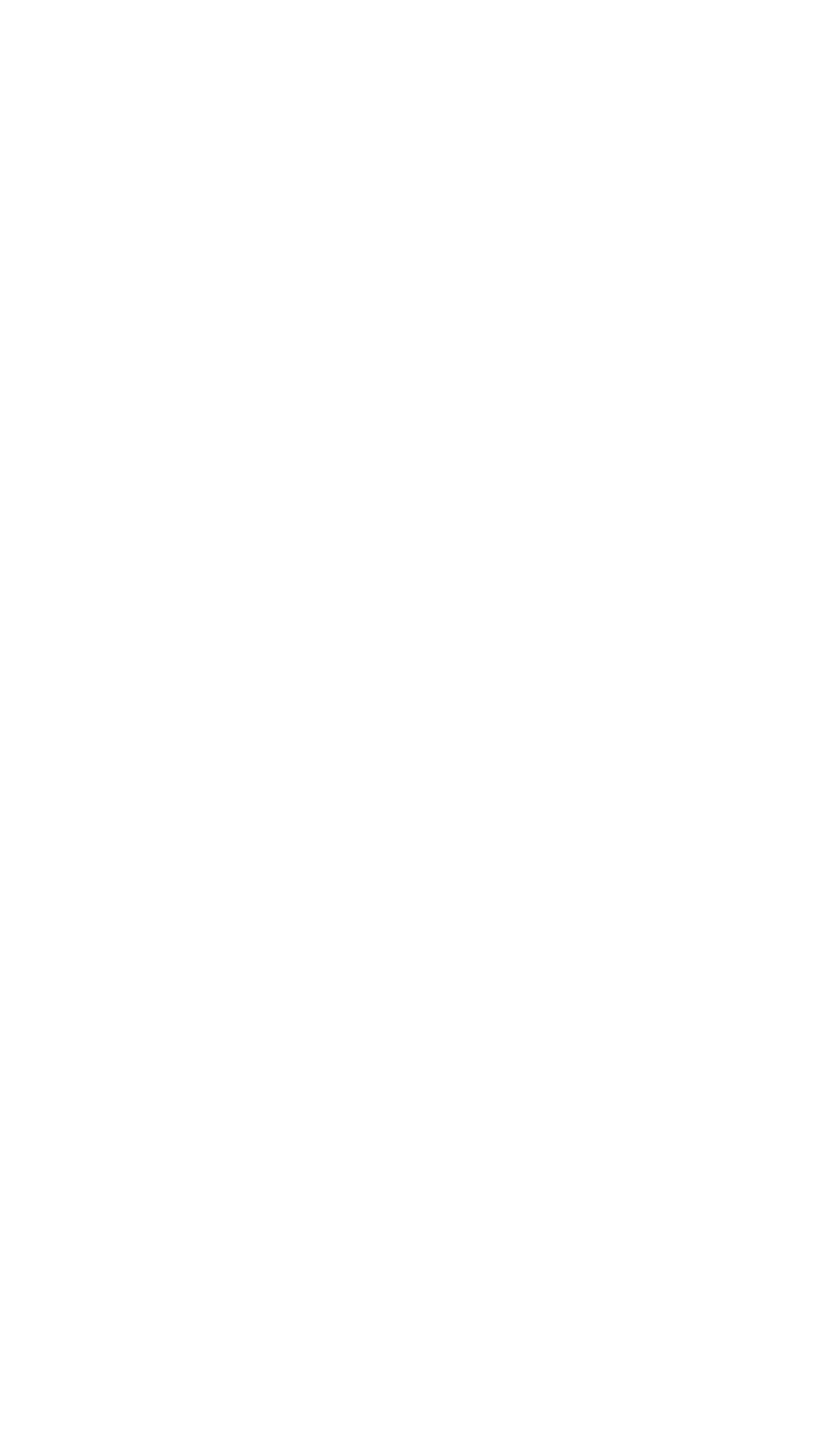




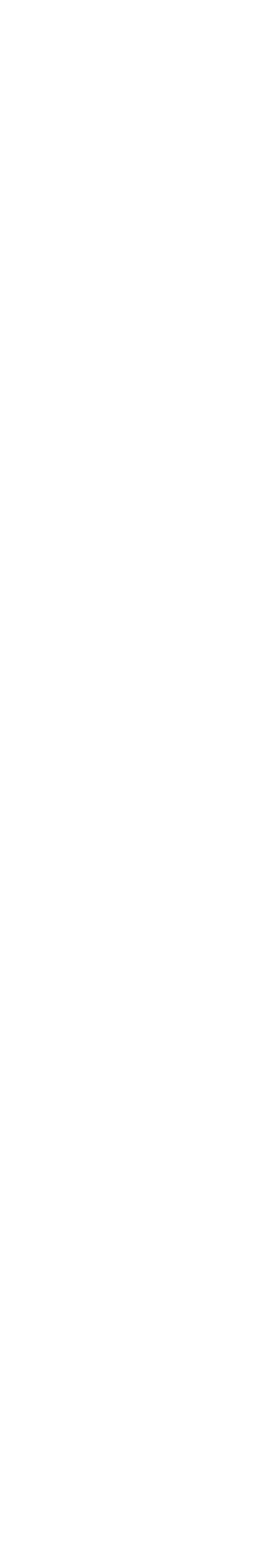




\section{Mineral analyses of ground waters from Monroe County}

(Parts per million. Numbers at heads of columns refer to corresponding well numbers in tablad

\begin{tabular}{|c|c|c|c|c|c|c|c|c|}
\hline & 1 & 6 & 7 & 12 & 13 & 19 & 20 & 24 \\
\hline 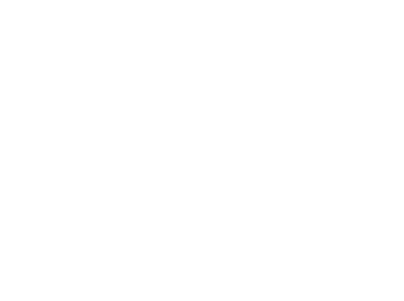 & $\begin{array}{l}16 \\
6.6 \\
11 \\
3.5 \\
.14 \\
77^{.0} \\
3.5 \\
3.1 \\
90^{.38} \\
42 \\
\text { Sept., } \\
1919\end{array}$ & $\begin{array}{r}14 \\
20 \\
5.6 \\
2.5 \\
9.7 \\
4.0 \\
44 \\
6.2 \\
1.9 \\
\text { Trace. } \\
60 \\
24 \\
\text { sept., } \\
1919\end{array}$ & $\begin{array}{l}11 \\
1.0 \\
3.9 \\
1.5 \\
6.9 \\
24.0 \\
5.2 \\
5.5 \\
50.35 \\
16 \\
\text { Dec., } \\
1913\end{array}$ & $\begin{array}{l}13 \\
2.8 \\
8.9 \\
3.1 \\
9.8 \\
57.0 \\
6.1 \\
7.0 \\
76 \\
75 \\
35 \\
\text { Oct., } \\
1914\end{array}$ & $\begin{array}{c}22 \\
1.9 \\
18 \\
3.8 \\
16 \\
3.6 \\
93.6 \\
5.8 \\
4.8 \\
122.25 \\
61 \\
\text { Sept., } \\
1919\end{array}$ & 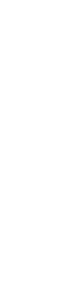 & 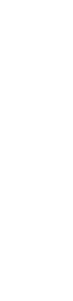 & $\begin{array}{c}29 \\
1.6 \\
24 \\
2.5 \\
82 \\
167.0 \\
4.2 \\
80 \\
314 \\
70 \\
70 \\
\text { Ape, } \\
1914\end{array}$ \\
\hline
\end{tabular}

a Calculated.

Analysts: 1, 6, 7, 13, 19, Margaret D. Foster, U. S. Geological Survey; 7, 12, Mississippi stato Chemical Laboratory; 20, 24, W. F. Hand, Mississippi State Chemical Laboratory.

\section{MONTGOMERY COUNTY}

\section{GENERAL FEATURES}

Area, 398 square miles. Population, 13,805 (census of 1920)

Montgomery County is in the North Central Hills district. The two principal geologic formations that crop out in the county are the Holly Springs sand of the Wilcox group and the Winona sand member of the Lisbon formation of the Claiborne group, both of which are of Eocene age. A wedge-shaped area of the Grenada formation of the Wilcox group enters the northwestern part of the county, and a narrow sinuous band of the Tallahatta formation of the Claiborne group separates the Winona sand from the Grenada or, where that is absent, from the Holly Springs sand. Most of the upland portion of the county north of Big Black River is covered by the eastern attenuated extension of the loess (see pp. 62-63), which is more fully developed farther to the west in Carroll County. Descriptions of the Eocene formations are given on pages 46-52, and their distribution is shown on the geologic map (pl. 2).

\section{GROUND-WATER CONDITIONS}

The Holly Springs sand crops out in an area that covers between three and four townships in the eastern and northeastern parts of the county. The formation, which is 300 or 350 feet thick, dips west by south at a low though somewhat variable angle that perhaps averages about 25 feet to the mile. The Winona sand member of the Lisbon formation crops out throughout most of the remainder of the county and is here 300 or 350 feet thick. The average southwestward dip is estimated to be about 25 feet to the mile, though the dip differs considerably from place to place and in some places appears to be as much as 260 or 270 feet to the mile; Lowe has even 
noted a reverse dip to the east of 68 feet to the mile, at a point on the Southern Railway 2 or 3 miles west of Winona. The Holly Springs sand carries abundant water, and as it underlies not only the area of its outcrop in the eastern and northeastern parts of the county but also the remainder of the county beneath the Winona sand it may be considered the most valuable aquifer. In the western part of the county the top of the Holly Springs sand would be reached at depths of 250 or 300 feet, and the formation should yield flows in the lowland of Black River and perhaps also low in the valley of Batawpan Bogue in the north.

The Winona sand is also water bearing though less abundantly so than the Holly Springs sand, and as the entire county is therefore underlain at depths near the surface by formations that carry water, ample supplies for domestic and farm use can be readily obtained at shallow depths by means of dug and bored wells; springs are also common throughout the area. For these reasons only a few deep wells have been drilled in the county.

In the vicinity of Duck Hill, in the lower slopes of the valley of Batawpan Bogue, beds that are apparently composed in part of water-bearing sand belonging to the Grenada, the uppermost formation of the Wilcox group (see p. 48), intervene between the Holly Springs sand below and the overlying Tallahatta formation above. Some wells at Duck Hill (Nos. 2, 3, 5, 7, 8) appear to have their source in these sands.

\section{LOCAL SUPPLIES}

Duck Hill.-Eight wells in the vicinity of Duck Hill are described in the table of well data (Nos. 1-8). They range in depth from 15 to 296 feet. The shallower wells probably draw their water from the Grenada formation, whereas the deeper wells enter the Holly Springs sand. The following is a log of the 87-foot well (No. 4).

Log of well of D. A. Wilkins at Duck Hill (No. 4)

\begin{tabular}{|c|c|c|}
\hline & Thickness & Depth \\
\hline $\begin{array}{l}\text { Grenada formation(?): } \\
\text { "Soil" }\end{array}$ & \multirow{2}{*}{ 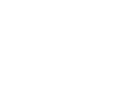 } & \multirow{2}{*}{ 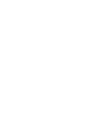 } \\
\hline $\begin{array}{l}\text { Dark clay } \\
\text { Sand and clay }\end{array}$ & & \\
\hline
\end{tabular}

Eskridge.-The 25-foot dug well (No. 9) at Eskridge supplies water for boiler use, probably from the Winona sand.

Winona.-At Winona water is obtained by wells, about 400 feet deep, which completely penetrate the Winona sand and the Tallahatta and Grenada formations and enter the upper part of the $54134-28-23$ 
Holly Springs sand. Water is encountered under artesian pressure sufficient to bring it to a level within 20 to 75 feet of the surface. Data concerning three wells are recorded in the table of well data (Nos. 13-15). Analysis 13 represents water from a 400 (?)-foot well, (No. 13). The municipal waterworks at Winona is owned by the Winona Water, Sewerage, Light \& Ice Co., and is about half a mile northeast of the courthouse. The water supply is obtained from three wells (No. 13; see remarks), each reported to be about 400 feet deep. Two of the wells are actually in use, and the third is held as a reserve supply. The log of the Oil \& Mining Co.'s well (No. 14) is given below:

Log of well of Oil \& Mining Co. at Winona

\begin{tabular}{|c|c|c|c|c|c|}
\hline & $\begin{array}{c}\text { Thick- } \\
\text { ness }\end{array}$ & Depth & & $\begin{array}{c}\text { Thick- } \\
\text { ness }\end{array}$ & Depth \\
\hline $\begin{array}{l}\text { Winona sand member of Lisbon for- } \\
\text { mation and Tallahatta formation: } \\
\text { Sand and clay } \\
\text { Orange-colored sand. } \\
\text { Blue marl } \\
\text { Lignite } \\
\text { Quicksand } \\
\text { Grenada formation: Black clay } \\
\text { Holly Springs sand: } \\
\text { Coarse sand, with fair supply of } \\
\text { water. }\end{array}$ & $\begin{array}{r}\text { Feet } \\
25 \\
10 \\
40 \\
5 \\
15 \\
50\end{array}$ & $\begin{array}{r}\text { Feet } \\
25 \\
35 \\
75 \\
80 \\
95 \\
145\end{array}$ & $\begin{array}{l}\text { Holly Springs sand-Continued. } \\
\text { Lignite } \\
\text { Blue marl } \\
\text { Fine sand } \\
\text { Clay } \\
\text { Quicksand } \\
\text { Clay } \\
\text { Sand, coarse to fine } \\
\text { Brown clay } \\
\text { Coarse sand, with pebbles at } \\
\text { top; water bearing }\end{array}$ & $\begin{array}{r}\text { Feet } \\
10 \\
35 \\
15 \\
10 \\
60 \\
40 \\
25 \\
35 \\
27\end{array}$ & $\begin{array}{r}\text { Feet } \\
165 \\
200 \\
215 \\
225 \\
285 \\
325 \\
350 \\
385 \\
412\end{array}$ \\
\hline
\end{tabular}

A dug well (No. 15) 3 miles south of Winona enters the Winona sand to a depth of 22 feet.

Kilmichael.-In the vicinity of Kilmichael water is obtained chiefly from wells less than 100 feet deep. The shallower wells-that is, wells only 30 or 40 feet deep-may have their source in the alluvial deposits that border Mulberry Creek; the deeper wells enter the Holly Springs sand. One well (No. 10) is 86 feet deep. (See analysis 10.)

Stewart.-At Stewart water is obtained chiefly from shallow wells, but several wells are approximately 100 feet deep. The well of J. A. Staples (No. 11) is 103 feet deep, and its source is the Holly Springs sand. (See analysis 11.) The analysis of a sample of slightly hard water (No. 12) from a 73-foot well, also sunk into the Holly Springs sand, is given in the table of analyses. 


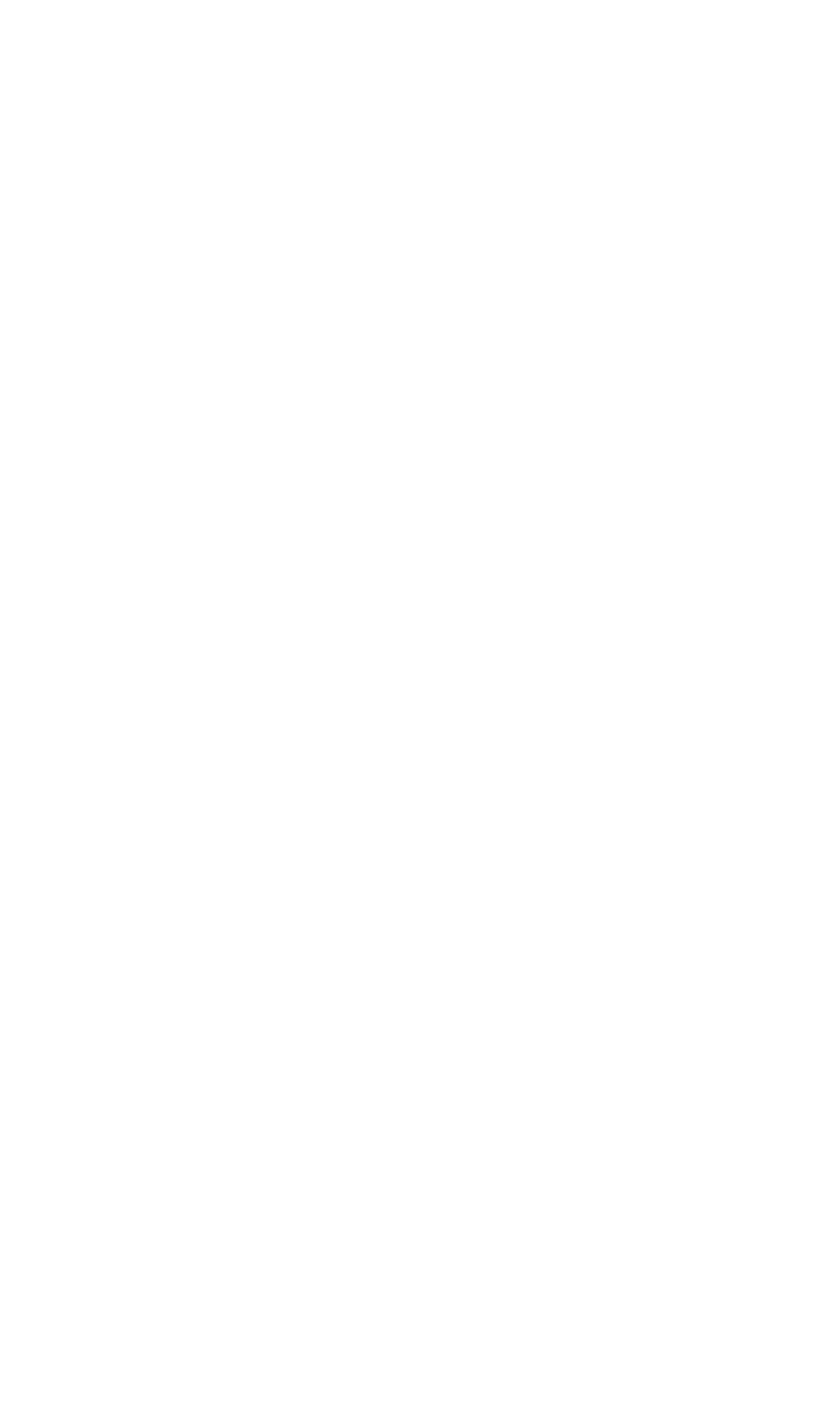


Mineral analyses of ground waters from Montgomery County

[Parts per million. Numbers at heads of columns refer to corresponding well numbers in preceding table]

\begin{tabular}{|c|c|c|c|c|}
\hline & 1 & 10 & 11 & 12 \\
\hline 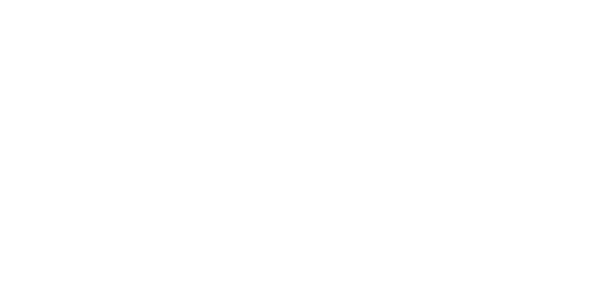 & 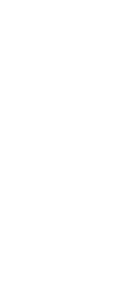 & $\begin{array}{c}29 \\
2.4 \\
10 \\
4.5 \\
7.8 \\
2.0 \\
24 \\
24.0 \\
7.0 \\
99 \\
43 \\
\text { Dec., } 1914\end{array}$ & 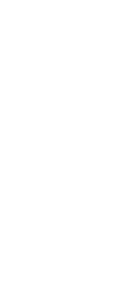 & \begin{tabular}{c}
39 \\
29 \\
22 \\
18 \\
41 \\
${ }^{183}$ \\
28 \\
33 \\
\multicolumn{2}{c}{0} \\
289 \\
129 \\
Aug., 1913
\end{tabular} \\
\hline
\end{tabular}

a Includes iron and aluminum ( $\mathrm{Fe}+\mathrm{Al})$.

- Calculated.

Analysts: 1, 11, W. L. Perdue, University of Mississippi; 10, 12, Mississippi State Chemical Laboratory.

\section{NESHOBA COUNTY}

\section{GENERAL FEATURES}

Area, 561 square miles. Population, 19,303 (census of 1920)

Neshoba County is in the southern part of the North Central Hills district. The strata that immediately underlie the surface are of Eocene age and include the Ackerman formation and the Holly Springs sand of the Wilcox group, and the Tallahatta and Lisbon formations of the Claiborne group. These formations are described on pages 45-52, and their distribution is shown on the geologic map (pl. 2).

\section{GROUND-WATER CONDITIONS}

The Ackerman formation doubtless contains water-bearing beds, but these are not known to have been reached by wells in the county.

The Holly Springs sand is 275 or 300 feet thick and carries abundant water; it is in all respects the most valuable aquifer. The strata that compose this formation crop out throughout approximately the northeast half of the county; their gentle southwestward dip carries them beneath the Tallahatta formation, where throughout the remainder of the county their buried extensions are present at increasing depths toward the southwest; the topmost beds are probably nowhere more than 300 or 400 feet below the surface.

The Tallahatta formation is thin, probably not more than 50 feet thick, and is not a valuable water bearer.

The Winona sand member of the Lisbon formation overlies the Tallahatta formation and is estimated to be 200 feet or more thick. This sand carries large quantities of water.

These formations dip to the southwest at an average rate of 25 or 30 feet to the mile, though local dips of 60 or 70 feet to the mile have been noted. 
Owing to the abundance and excellence of the water that can be obtained at shallow depths or that flows in the form of springs from the exposed edges of the water-bearing sands, few wells in the county have been sunk to depths of more than 100 feet.

\section{LOCAL SUPPLIES}

Stallo.-About 2 miles south of Stallo, a village on the Gulf, Mobile \& Northern Railroad near the northern boundary of the county, the well of Mrs. Anna Whittle, the depth of which is not stated, yields water that is locally used as a mineral water, which presumably comes from a lignitic sandy clay in the Ackerman formation.

Philadelphia.-The municipal waterworks at Philadelphia is located about 500 feet northeast of the Gulf, Mobile \& Northern Railroad station, near the foot of a slope, where the altitude is about 10 feet higher than that of the track at the station. The source of the water is a 6 -inch well,, 300 feet deep, in which the waterbearing bed, a medium-fine sand, lies at a depth of 260 to 280 feet in the Holly Springs sand. A strainer is set in the casing opposite the water-bearing sand, and the water rises within 30 feet of the surface. (See analysis 3.) The old 267-foot well at the courthouse (see analysis 4) was not properly constructed and was abandoned. Analysis 5 represents the water from a 6 -inch well 100 feet deep, owned by A. G. Mayo and located an eighth of a mile west of the courthouse.

Dixon.-Near Dixon water is obtained from the Winona sand at depths of 50 to 90 feet by means of dug or bored wells. The wells of C. C. Roberts, in sec. 1, T. 9 N., R. 10 E., 75 feet deep; F. M. Gardner, a quarter of a mile southwest of the town, 70 feet deep; and Ira Lewis, half a mile west of the town, 89 feet deep, are typical. The water-bearing material is said to be practically all sand and sandy clay, beneath a surface layer of about 10 feet of clay. The water is soft, and the yield of $\cdot 2$-inch wells is ample for domestic and stock uses.

McDonald.-At McDonald F. E. McKee owns a 2-inch nonflowing well, 156 feet deep, located 200 yards northeast of the post office, which taps a water-bearing bed in the Holly Springs sand. The water is used for farm supply and in boilers. An analysis (No. 1) is given below. The dug well of F. M. Banks, a quarter of a mile west of the town, is 48 feet deep and obtains water from a gravel bed in the Winona sand. W. W. Ward owns a 36-foot dug well on a hill $7 \frac{1}{2}$ miles east of $\mathrm{McD}$ onald, in sec. 2, T. 9 N., R. 12 E., which obtains soft water from the upper part of the Holly Springs sand. An analysis of the water is given below (No. 2). 
Mineral analyses of ground waters from Neshoba County

[Parts per million]

\begin{tabular}{|c|c|c|c|c|c|}
\hline & 1 & 2 & 3 & 4 & 5 \\
\hline 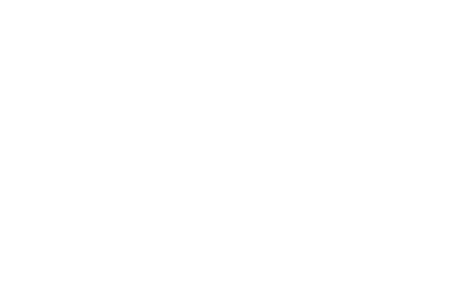 & \begin{tabular}{|l}
38 \\
.42 \\
6.0 \\
2.7 \\
17 \\
40.0 \\
20 \\
9.5 \\
.00 \\
102 \\
26 \\
Sept., 1914
\end{tabular} & 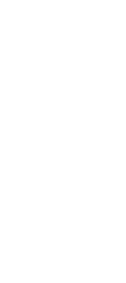 & $\begin{array}{c}56 \\
4.8 \\
9.8 \\
4.0 \\
35 . \\
.0 \\
102 \\
16 \\
5.5 \\
\text { Trace. } \\
183 \\
41 \\
\text { Aug., } 1919\end{array}$ & $\begin{array}{l}54 \\
.56 \\
9.9 \\
1.9 \\
9.8 \\
29^{.0} \\
13 \\
12 \\
116^{.00} \\
32 \\
\text { Sept., } 1916\end{array}$ & $\begin{array}{r}13 \\
1.4 \\
5.7 \\
3.5 \\
14 \\
17^{.0} \\
4.8 \\
14 \\
20 \\
80 \\
29 \\
\text { July, } 1914\end{array}$ \\
\hline
\end{tabular}

A nalysts: 1, 2, Mississippi State Chemical Laboratory; 3, Margaret D. Foster, U. S. Geological Survey; 4, 5 , W. F. Hand, Mississippi State Chemical Laboratory.

1. 156-foot well of F. E. McKee at McDonald.

2. 36-foot well of W. W. Ward at McDonald.

3. 300-foot town weil at Philadelphia.

4. 267-foot well at courthouse at Philadelphia.

5. 100-foot well of A. J. Mayo at Philadelphia.

\section{NEWTON COUNTY}

GENERAL FEATURES

Area, 568 square miles. Papulation, 20,727 (census of 1920).

Newton County is in the southern part of the North Central Hills district but has a small westward extension into the Jackson Prairie Belt. Five geologio formations, all of Eocene age, are exposed in zones of varying width that extend in a northwesterly direction across the county. In succession from northeast to southwest these formations include, in ascending order, the Holly Springs sand of the Wilcox group; the Tallahatta formation, Lisbon formation, and Yegua formation, all of the Claiborne group; and the Jackson formation. These formations are described on pages $46-54$, and their distribution is shown on the geologic map (pl. 2).

\section{GROUND-WATER CONDITIONS}

All the formations carry water in greater or less quantities, but the Tallahatta formation, which is about 100 feet thick, and the Lisbon formation, which is 300 feet or more thick (especially the basal Winona sand member), appear to be the most valuable. The Jackson formation is the least valuable and, except perhaps locally, appears to carry little water. The general dip of the formations is to the southwest at rates between 20 and 30 feet to the mile, though local dips of 60 feet to the mile have been observed. Conditions are therefore favorable for the development of artesian pressure, and flowing wells have been obtained from the Lisbon formation and the Tallahatta formation in the valleys of Chunky Creek and its tributaries in the southeastern part of the county. 
Except in the area in the southwestern part of the county that is underlain by the clays of the Jackson formation, water for domestic. and farm uses can be obtained throughout practically the entire county by wells less than 100 feet deep. In the area underlain by the Jackson formation cisterns for storing rain water are.in common use.

In addition to the geologic formations just described the alluvial deposits of Pleistocene and Recent age in the lowlands that border the large creeks carry water that is readily obtained by means of shallow dug, bored, and driven wells.

Springs that have their source in the sandy layers of the Eocene formations and in the alluvial deposits that border the streams are of common occurrence, except in the area in the southwestern part of the county that is underlain by the essentially nonsandy Jackson formation.

\section{LOCAL SUPPLIES}

Prospect.-At Prospect, near the northwest corner of the county, water is obtained mainly from shallow wells sunk into the Lisbon formation, though the quality of the water from this source is not satisfactory in all places.

Union.-Several nonflowing wells at Union that range in depth from 150 to 350 feet are described in the table of well data (Nos. 18-21). The deeper wells probably completely penetrate the Winona sand and Tallahatta formation and enter the Holly Springs sand. Analysis 19 represents water from one of the 350-foot wells. At Union in a dug well 26 feet deep (No. 20) the water rises to the surface and overflows. Three layers of hard rock (Winona) were penetrated, and the water was found beneath the third layer. This water is hard, as is shown by analysis 20 .

Vance's Springs.-Vance's Springs is a group of about 23 springs, owned by D. F. Vance, 10 miles west-southwest of Union, in secs. 15 and 22, T. 8. N., R. 10 E., within a space of about one-fourth acre. The springs have their source in the Lisbon formation. (See analysis 22.) No improvements have been made.

Conehatta.-At Conehatta, in the area underlain by the Lisbon formation, water is supplied by wells 20 to 60 feet deep, the average depth being about 35 feet.

Lawrence.-At Lawrence, on the northern border of the area in which the Jackson formation crops out, some wells only 15 or 20 feet deep tap water-bearing beds, perhaps in the Yegua formation, but better supplies are afforded by deeper wells that have a maximum depth of 150 feet, drilled through the Yegua formation into waterbearing sands in the Lisbon formation. This deeper water rises under artesian pressure within 30 to 60 feet of the surface. 
Newton.-The municipal waterworks at Newton is about a block northwest of the Alabama \& Vicksburg Railroad station on ground that is about level with the station. The source of the water is a well at the plant that is reported to be 285 feet deep (No. 14). (See analysis 14.) A well (No. 15), 260 feet deep, is believed to obtain its principal water supply from the Lisbon formation at a depth of 200 to 260 feet. (See analysis 15.) On the Day-Fant place, 6 miles south of Newton, water is obtained at a depth of 100 to 180 feet (No. 16). The following log shows the beds penetrated in this well:

Log of Day-Fant well 6 miles south of Newton (No. 16)

[Authority, E. M. Jones]

\begin{tabular}{|c|c|c|}
\hline & Thickness & Depth \\
\hline $\begin{array}{l}\text { Soil (heavy clay loam) } \\
\text { Jackson formation: } \\
\text { Clay } \\
\text { Clay and sand } \\
\text { Black sand, with calcareous water. } \\
\text { Yegua formation(?): Pipe clay. } \\
\text { Lisbon formation(?): Sand; water bearing }\end{array}$ & Feet $11 / 2$ & $\begin{array}{c}\text { Feet } \\
11 / 2 \\
6 \\
26 \\
40 \\
100 \\
180\end{array}$ \\
\hline
\end{tabular}

Hickory.-In the vicinity of Hickory, in the lowlands tributary to Chunky Creek, flowing water is obtained from the Lisbon and Tallahatta formations at depths of 100 to 360 feet. The water of the Gallaspie well (No. 9), 300 feet deep, has its static head 2 feet above the surface and that of the Barber well (No. 11), 150 feet deep, on somewhat lower ground, has its static head 8 feet above the surface. Several other wells are described in the table of well data. Analysis 9 represents water from the Gallaspie well.

Chunky.-Many wells have been drilled in the lowlands along Chunky Creek in the vicinity of Chunky. The wells are commonly drilled into the Tallahatta formation to depths of 100 to 160 feet, and water is encountered under head sufficient to bring it nearly to or above the surface. In a well (No. 1) 6 miles northwest of Chunky the water rises within 8 feet of the surface, and in another well 2 miles southwest of Chunky (No.2) a flow that has a static head of 4 feet above the surface was obtained. A well (No. 3) a quarter of a mile southeast of Chunky is nonflowing, although situated only 12 feet above the creek. (See analysis 3.) Other wells are described in the table of well data, and the log of one of them (No. 7) is given below. 
Log of well of O. L. Chaney, between Chunky and Hickory, near Alabama \& Vicksburg Railroad (No. 7)

[Authority, D. L. Ragland]

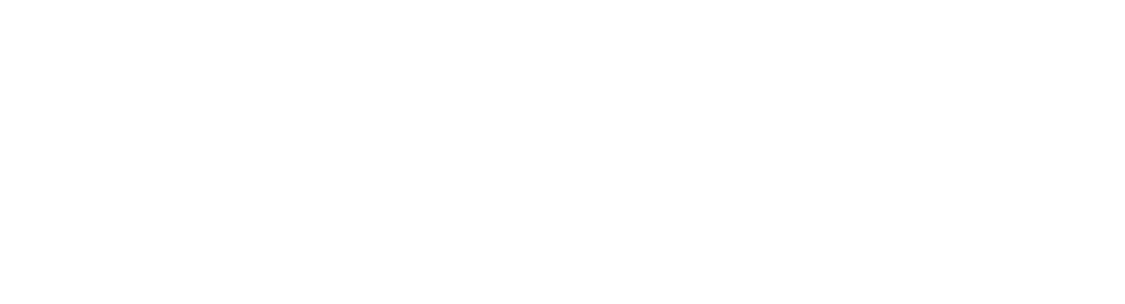

The 131-foot flowing well of D. L. Ragland (No. 5), 6 miles south of Chunky, yields soft water at the rate of 5 gallons a minute. The source of this water is probably the Kosciusko sandstone member of the Lisbon formation. 


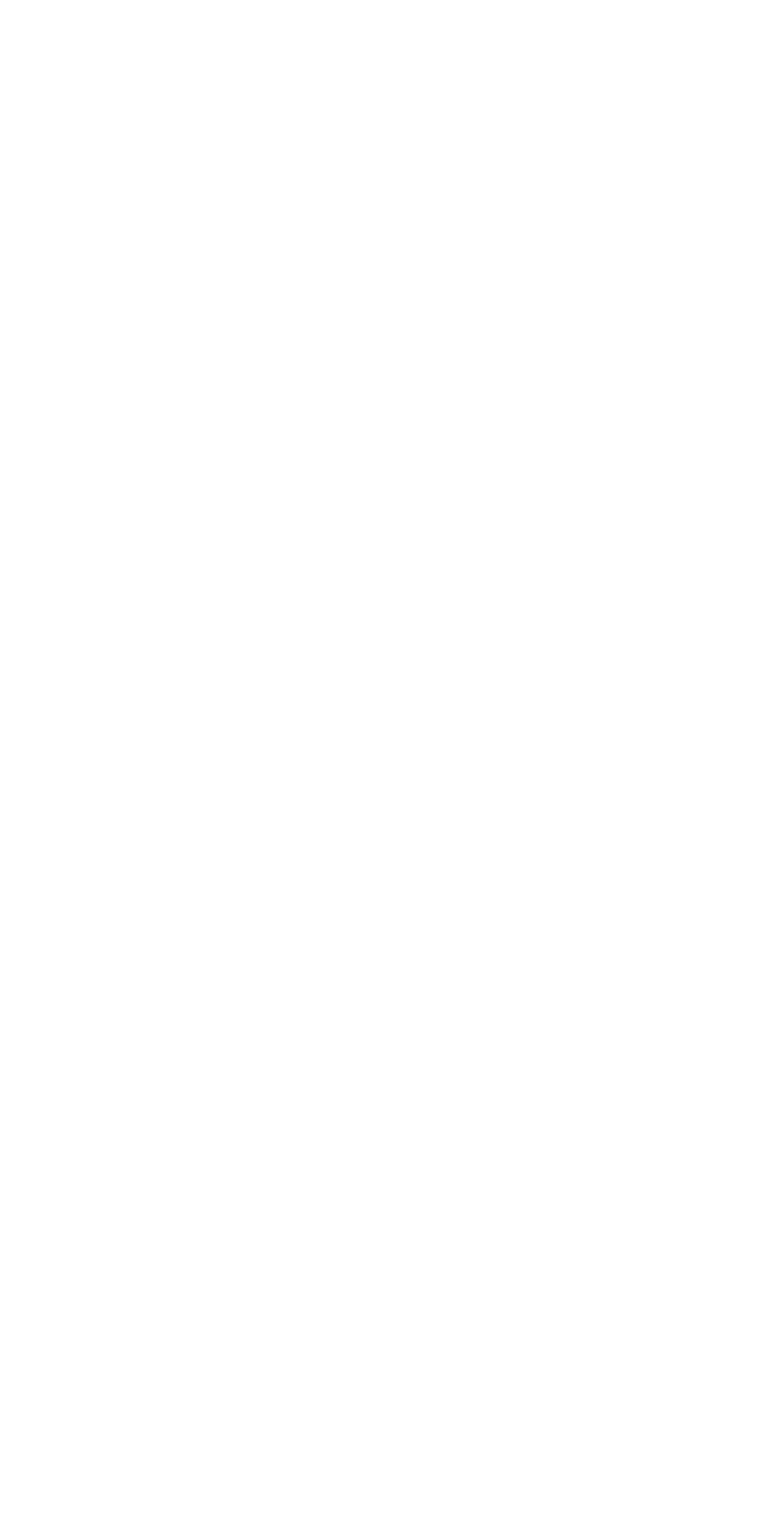




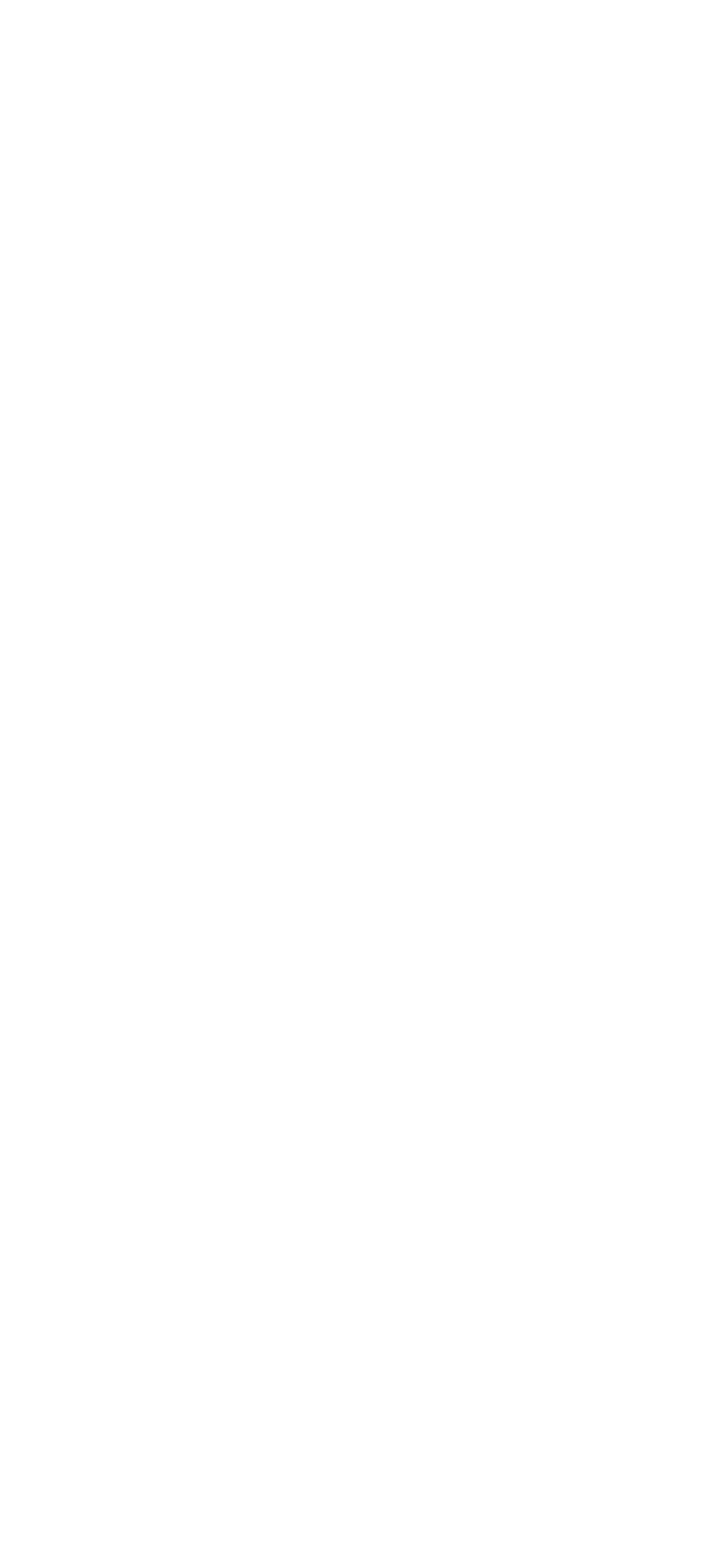




\section{Mineral analyses of ground waters from Newton County}

[Parts per million. Numbers at heads of columns refer to corresponding well and spring numbers in preceding table]

\begin{tabular}{|c|c|c|c|c|c|c|c|}
\hline & 3 & 9 & 14 & 15 & 19 & 20 & a 22 \\
\hline $\begin{array}{l}\text { Silica }\left(\mathrm{SiO}_{2}\right) \\
\text { Iron }(\mathrm{Fe}) \\
\text { Calcium }(\mathrm{Ca}) \\
\text { Magnesium }(\mathrm{Mg})\end{array}$ & $\begin{array}{c}27 \\
1.6 \\
13 \\
1.8\end{array}$ & $\begin{array}{l}32 \\
14.84 \\
4.1\end{array}$ & ${ }_{38}^{37} .72$ & $\begin{array}{c}34 \\
1.8 \\
35 \\
3.9\end{array}$ & $\begin{array}{l}49 \\
1.9 \\
20 \\
6.5\end{array}$ & $\begin{array}{l}48 \\
1.4 \\
68 \\
13\end{array}$ & $\begin{array}{l}32 \\
.24 \\
6.9 \\
1.4\end{array}$ \\
\hline Sodium and potassium $(\mathrm{Na}+\mathrm{K})$ & 50 & $\left\{\begin{array}{l}\mathrm{Na}_{\mathrm{K}} 54 \\
\mathrm{~K} 4.4\end{array}\right.$ & 13 & $\cdot 15$ & c16 & 23 & 8.3 \\
\hline 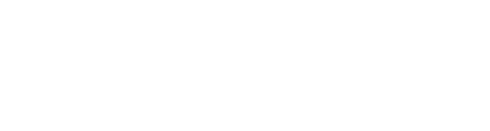 & $\begin{array}{c}4.8 \\
146 \\
17 \\
8.5 \\
.00\end{array}$ & $\begin{array}{r}207^{.0} \\
.5 \\
3.6 \\
.22\end{array}$ & $\begin{array}{l}110^{.0} \\
8.4 \\
6.5 \\
.55\end{array}$ & $\begin{array}{r}142^{.0} \\
9.3 \\
6.1 \\
.46\end{array}$ & $\begin{array}{l}6.0 \\
86 \\
23 \\
5.1 \\
.70\end{array}$ & $\begin{array}{c}256^{\circ} \\
46 \\
5.3 \\
\text { Trace. }\end{array}$ & $\begin{array}{c}21^{\circ} \\
14 \\
8.0 \\
.00\end{array}$ \\
\hline $\begin{array}{l}\text { Total dissolved solids at } 180^{\circ} \mathrm{C} \\
\text { Total hardness as } \mathrm{CaCO}_{3} \text { (calculated) } \\
\text { Date of collection }\end{array}$ & $\begin{array}{l}40 \\
\text { May, } \\
1914\end{array}$ & $\begin{array}{c}216^{\circ} \\
52\end{array}$ & $\begin{array}{c}147 \\
83 \\
\text { Junk, } \\
1914\end{array}$ & $\begin{array}{l}\text { c176 } \\
100 \\
\text { Aug., } \\
1919\end{array}$ & $\begin{array}{l}\mathbf{1 7 0} \\
\mathbf{7 7} \\
\text { Aug., }\end{array}$ & $\begin{array}{c}326 \\
220 \\
\text { Aug., } \\
1919\end{array}$ & $\begin{array}{c}85 \\
23 \\
\text { June, } \\
1914\end{array}$ \\
\hline
\end{tabular}

- Analyses of 5 other springs have similar chemical composition and have total solids 76, 73, 86, 71, and 101 parts per million.

6 Iron and aluminum oxides $\left(\mathrm{Fe}_{2} \mathrm{O}_{3}+\mathrm{Al}_{2} \mathrm{O}_{3}\right)$.

- Calculated.

Analysts: 3, 14, W. F. Hand, Mississippi State Chemical Laboratory; 9, W. R. Perkins (Mississippi Agr. Exper. Sta. Bull. 89, p. 52, 1905); 15, Margaret D. Foster, U. S. Geological Survey; 19, 20, C. H. Kidwell and Margaret D. Foster, U. S. Geological Survey; 22, Mississippi State Chemical Laboratory.

\section{NOXUBEE COUNTY}

\section{GENERAL FEATURES}

Area, 682 square miles. Population, 23,710 (census of 1920)

The northeastern three-fifths of Noxubee County lies within the Black Prairie belt. Most of the western and southwestern part of the county lies in the Flatwoods. A relatively small tract in the southwest corner is in the North Central Hills district. The Black Prairie belt is underlain by the Selma chalk, the maximum thickness of which in the extreme southeast is approximately 900 feet. The Eutaw formation, which underlies the Selma, crops out in an area of a few square miles in the extreme northeastern part of the county, and the southern extremity of the Ripley formation, where it merges into the chalk, forms low hills in a small area in the northwestern part, in the vicinity of Fairport, a village 8 miles northwest of Brookville. These three formations are of Upper Cretaceous age and are overlain by strata of Eocene age, including the Clayton formation, which appears only in small exposures near the Cretaceous contact, and the Porters Creek clay, which underlies the Flatwoods and in places overlaps the Clayton and rests directly on the Selma chalk. The small tract of hilly land in the southwest corner of the county is underlain by beds of sand and clay that belong to the Ackerman formation of the Wilcox group (Eocene). The Eutaw, Selma, and Ripley formations are described on pages $31-43$, and their distribution is shown on the geologic map (pl. 2). 


\section{GROUND-WATER CONDITIONS}

The Selma chalk is economically a non-water-bearing formation but serves as an efficient retaining agent for the waters contained in the predominantly sandy beds of the underlying Eutaw formation. The Eutaw is estimated to be 400 feet thick, and the still deeper Tuscaloosa formation may reach a thickness of 500 feet or more in its buried extension under the county. There are no well records to show the depth to the Paleozoic basement rocks that underlie the Tuscaloosa.

The Eutaw formation is at present the principal source of artesian water, many wells having been drilled to the abundantly waterbearing sands which partly compose it and which form a continuous reservoir under the entire county. Typical wells in different parts of the county are described in the table on pages 363-365. A few wells (Nos. 4, 11, 29) in the northeastern townships are deep enough to reach the Tuscaloosa formation, which is also an abundantly waterbearing terrane. The catchment area of the Eutaw-Tuscaloosa artesian system lies to the northeast, chiefly in Lowndes County, Miss., and in Pickens and Lamar Counties, Ala., where the waterbearing beds of the formations crop out. Flowing wells are obtained in the northeastern part of the county on the terraced lands that border Tombigbee River, and in the valleys of some of the creeks that flow eastward and southeastward to the Tombigbee. Flows are also obtained on the low lands that border Noxubee River and some of its tributary creeks. In the interstream areas the static head of the ground waters ranges from a few feet to 90 feet or more below the surface.

Deep wells were sunk to the water-bearing sands of the Eutaw formation in Noxubee County as early as $1852 .{ }^{45}$ This county was one of the first communities in the United States to discover the valuable asset it possessed in its artesian waters. ${ }^{46}$

Springs are rare and of only slight economic value in most parts of the county. The conditions are also unfarorable for obtaining water by means of shallow wells, so that where deep wells have not been provided cisterns and artificially constructed surface pools are depended upon for supplies.

\section{LOCAL SUPPLIES}

Macon.-In the community of which Macon is the center, the lack of water of satisfactory quality or of adequate quantity at shallow depths compelled an early search for another source of supply, and the records show that deep artesian wells were in use as long ago as the early fifties. Detailed descriptions of six wells at and near

4s Mississippi Agr. Exper. Sta. Bull, 89, pp. 47-49, 1905.

40 Wailes, B. L. C., Report on the agriculture and geology of Mississippi, p. 256, 1854. 
Macon are given in the table (Nos. 17-22). At Macon the waterbearing beds of the Eutaw formation lie at depths of 650 to 750 feet or more, and the static head of the water from this source ranges in different parts of the town from a few feet above the surface to 20 or 25 feet below the surface, depending upon the elevation at the mouth of any given well. The Mobile \& Ohio Railroad owns a well (No. 18), the mouth of which is about 172 feet above sea level, which flowed when drilled in 1898, the static head then being 15 feet above the surface. Subsequently the heavy draft occasioned by the pumping of the well owned by the Arctic Ice \& Coal Co. (No. 19) caused the static head of the water in the railroad well to sink below the surface. Doubtless other wells in the vicinity of the ice factory were similarly affected. The deep-well water is apparently not of satisfactory quality for boiler supplies, and for this reason the municipal waterworks, which provides supplies for the boilers of several manufacturing plants and of the Mobile \& Ohio Railroad, is not equipped with deep wells but obtains its supply from the water of Noxubee River, which flows near the western edge of town. An analysis (No. 17) of water from an 800-foot well indicates that large quantities of sodium and chloride are present in deep waters. The log of one well at Macon is as follows:

Log of well of Mobile \& Ohio Railroad, Macon (No. 18) ${ }^{\circ}$

[Altitude of mouth of well 172 \pm feet above sea level. Adapted from description by Logan and Perkins]

\begin{tabular}{|c|c|c|}
\hline & Thickness & Depth \\
\hline $\begin{array}{l}\text { Clay (residual from Selma chalk) } \\
\text { Selma chalk: Limostone (chalk) }\end{array}$ & $\begin{array}{r}\text { Feet } \\
80 \\
600\end{array}$ & $\begin{array}{r}\text { Feet } 8 \\
608\end{array}$ \\
\hline $\begin{array}{l}\text { Eutaw formation: } \\
\text { Hard sandstone } \\
\text { Soft sandstone } \\
\text { Greensand; water bearing } \\
\text { Soapstone (clay) }\end{array}$ & $\begin{array}{r}3 \\
65 \\
40 \\
53\end{array}$ & $\begin{array}{l}611 \\
676 \\
716 \\
769\end{array}$ \\
\hline
\end{tabular}

- Logan, W. N., and Perkins, W. R., The underground waters of Mississippi: Mississippi Agr. Exper. Sta. Bull. 89 , p. 45,1905 .

Bigbee Valley.-The village of Bigbee Valley, in the northeastern part of the county, about 5 miles east by north of Cliftonville, is in an area of flowing artesian wells, the depths of which as reported range from 400 to 640 feet. (See Nos. 1, 2.) Most of the wells draw upon the waters in the lower part of the Eutaw formation, but wells deeper than 450 or 500 feet enter the underlying Tuscaloosa formation, the waters of which are under somewhat greater hydrostatic pressure and consequently flow more strongly than those of the Eutaw.

Cliftonville.-Many wells that range in depth from 300 to 750 feet have been drilled in the vicinity of Cliftonville. (See wells 8-14.) The source of the water is the Eutaw formation, except possibly a few of the deeper wells, which may reach the Tuscaloosa formation; the 
static head ranges from a few feet to 90 feet below the surface; the deeper wells (600 feet or more) located in the valley of Broken Pumpkin Creek, which flows eastward 2 miles north of Cliftonville, overflow, and flowing wells are common in this valley to the east as far as its junction with Tombigbee River. Logs of two wells at and near Cliftonville are given below:

Log of well of Robertson Bros., a third of a mile northwest of Cliftonville (No. 10)

[Adapted from owner's description]

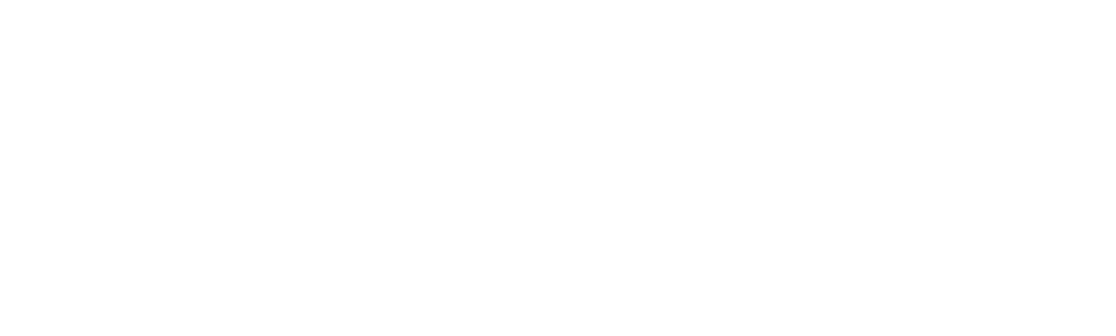

Log of well at Cliftonville (No. 8)a

[Adapted from description by Crider and Johnson]

\begin{tabular}{|c|c|c|}
\hline & Thickness & Depth \\
\hline Selma chalk: Chalk. & \multirow{5}{*}{$\begin{array}{r}\text { Feet } \\
300 \\
20 \\
20 \\
10 \\
40 \\
1 \\
60\end{array}$} & \multirow{5}{*}{$\begin{array}{r}\text { Feet } \\
\mathbf{3 0 0} \\
320 \\
340 \\
350 \\
390 \\
391 \\
\mathbf{4 5 1}\end{array}$} \\
\hline $\begin{array}{l}\text { Eutaw formation: } \\
\text { Greensand. }\end{array}$ & & \\
\hline White sand & & \\
\hline White sand & & \\
\hline $\begin{array}{l}\text { Ferruginous sandstone } \\
\text { Dark-green sand; water bearing. }\end{array}$ & & \\
\hline
\end{tabular}

Crider, A. F., and Johnson, L. C., U. S. Geol. Survey Water-Supply Paper 159, p. 69, 1906.

Deerbrook.-The ground-water conditions at Deerbrook are essentially like those at Cliftonville, except that the westward-dipping water-bearing beds of the Eutaw lie 90 to 100 . feet deeper than at Cliftonville. The static head of the water is reported to be about 70 feet below the surface on the upland, but a few of the deeper wells located low in the creek valleys overflow.

Ravine.-Wells at Ravine, a small village 3 miles south by west of Bigbee Valley, range in depth from 400 to 800 feet. In the creek valleys the wells overflow, but on the upland the static head of the water is 25 to 40 feet below the surface. The source of the water in wells less than 700 feet deep is the Eutaw formation, but in wells more than 700 feet deep it is probably in part the underlying Tuscaloosa formation. (See wells Nos. 29,30.) The following log shows the character of the beds in a well near Ravine: 
Log of well of J.Q. Poindexter, at Ravine (No. 29)*

[Adapted from description by Crider and Johnson]

\begin{tabular}{|c|c|c|}
\hline & Thickness & Depth \\
\hline 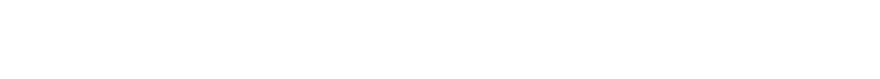 & $\begin{array}{l}\text { Feet } \\
\quad 250 \\
\quad 475\end{array}$ & $\begin{array}{l}F_{\text {eet }} \\
\quad 250 \\
725\end{array}$ \\
\hline
\end{tabular}

c Crider, A. F., and Johnson, L. C., U. S. Geol. Survey Water-Supply Paper 159, p. 70, 1906.

Prairie Point.-Numerous wells that range in depth from 300 to 450 feet and tap the water-bearing sands of the Eutaw formation have been drilled in the vicinity of Prairie Point; the static head ranges from 5 to 40 feet below the surface. A few deeper wells that reach a maximum depth of 800 feet have been reported. Wells 275 to 350 feet deep, located in creek valleys 3 to 4 miles northeast of Prairie Point, overflow at the surface. (See wells 24-28.) The following $\log$ of a well near Prairie Point shows the character of the beds penetrated:

Log of well of D. Creswell, half a mile east of Prairie Point (No. 25)

[Altitude of mouth of well, 20 feet above the level of Bogue Chitto Creek. Adapted from owner's description]

\begin{tabular}{|c|c|c|}
\hline & $\begin{array}{c}\text { Thick- } \\
\text { ness }\end{array}$ & Depth \\
\hline Clay (residual from Selma chalk) & & \\
\hline $\begin{array}{l}\text { Selma chalk: } \\
\text { Soft limerock (chalk) } \\
\text { Eutaw formation: } \\
\text { Sand alternating with layers of rock (sandstone); water bearing in part }\end{array}$ & $\begin{array}{r}260 \\
140\end{array}$ & $\begin{array}{l}300 \\
440\end{array}$ \\
\hline
\end{tabular}

Brookville.-Nonflowing wells 500 to 1,187 feet deep, in which the static head is 50 to 80 feet below the surface, are common in the vicinity of Brookville. The source of the water is the sands of the Eutaw and Tuscaloosa formations. (See wells 3-7.) The logs of two. wells at Brookville are given below. The town owns a waterworks and obtains water from a deep well which was originally drilled to a depth of 1,187 feet. (See $\log$ below.) According to J. T. Wilkins, of Brookville, the principal water-bearing beds are in the Tuscaloosa formation between depths of 1,042 and 1,110 feet, opposite which 70 feet of strainer is set. According to the log two lower water-bearing beds occur in this formation, and one water-bearing sand occurs above in the Eutaw formation at a depth of 650 to 770 feet. Most of the deep wells in the vicinity of Brookville are sunk only to the sand in the Eutaw formation, which, however, is reported to afford a maximum of only about 20 gallons of water a minute, whereas the deeper sand drawn upon for the town supply yields 175 . gallons a minute. 
Log of well of Mobile \& Ohio Railroad, Brookville (No. B)a

[Altitude of mouth of well, about 269 feet above sea level. Adapted from description by Logan and Perkins]

\begin{tabular}{|c|c|c|}
\hline & $\begin{array}{c}\text { Thick- } \\
\text { ness }\end{array}$ & Depth \\
\hline $\begin{array}{l}\text { Clay (residuai from Selma chalk) } \\
\text { Selma chalk, limestone } \\
\text { Eutaw formation: } \\
\text { Hard sand. } \\
\text { Soft sand } \\
\text { Greensand; water bearing }\end{array}$ & $\begin{array}{r}\text { Feet } \\
8 \\
450 \\
4 \\
150 \\
45\end{array}$ & $\begin{array}{r}\text { Feet } \\
8 \\
458 \\
462 \\
612 \\
657\end{array}$ \\
\hline
\end{tabular}

- Logan, W. N., and Perkins, W. R., The underground waters of Mississippi: Mississippi Agr. Exper. Sta. Bull. 89 , p. $45,1905$.

\section{Log of well owned by the town of Brookville (No. 4)}

Altitude of mouth of well, 560 feet above sea level. Adapted from data furnished in part by W. N. Logan)

\begin{tabular}{|c|c|c|}
\hline & $\begin{array}{c}\text { Thick- } \\
\text { ness }\end{array}$ & Depth \\
\hline $\begin{array}{l}\text { Selma chalk and Eutaw formation: } \\
\text { Blue limestone (Selms chalk in part) } \\
\text { Sand, water bearing, and mud (Eutaw) } \\
\text { Hard rock } \\
\text { Sand, with hard layers that have an aggregate thickness of } 60 \text { feet }\end{array}$ & $\begin{array}{r}\text { Feet } \\
650 \\
120 \\
2 \\
173\end{array}$ & $\begin{array}{r}\text { Feet } \\
650 \\
770 \\
772 \\
945\end{array}$ \\
\hline $\begin{array}{l}\text { Tuscaloosa formation: } \\
\text { Blue clay } \\
\text { Red clay } \\
\text { Very fine greenish-gray glauconitic sand, water bearing, and sandstone } \\
\text { Red clay } \\
\text { Very fine greenish-gray glauconitic sand and boulders; water bearing } \\
\text { Hard rock } \\
\text { Sand; water bearing. } \\
\text { Clay } \\
\text { Sand; water bearing }\end{array}$ & $\begin{array}{r}62 \\
35 \\
35 \\
8 \\
25 \\
2 \\
14 \\
19 \\
42\end{array}$ & $\begin{array}{l}1,007 \\
1,042 \\
1,077 \\
1,085 \\
1,110 \\
1,112 \\
1,126 \\
1,145 \\
1,187\end{array}$ \\
\hline
\end{tabular}

The two preceding logs are apparently not in agreement; the Mobile \& Ohio Railroad well shows 450 feet and the town well 650 feet of limestone. According to J. T. Wilkins 450 feet is probably more nearly correct, so that in the second $\log 200$ feet of nonchalky beds of the Eutaw formation must be included under the term "blue limestone." The 1,187-foot well (No. 4) undoubtedly reached the water-bearing sands of the Tuscaloosa formation.

Paulette.-Fifteen wells, which range in depth from 700 to 800 feet and which draw on the water-bearing beds of the Eutaw formation, were drilled within 2 miles of Paulette between the years 1912 and 1915; nine of the wells, which are located in creek valleys, overflow, whereas the other six wells, which are located higher on the slopes or on the uplands, are nonflowing, the static head of the water being 18 feet or less below the surface.

Calyx.-At Calyx, a small village on the upland 5 miles southeast of Shuqualak, water is obtained from the Eutaw formation at a depth of about 800 feet.

Shuqualak.-Shuqualak is located at the western edge of the belt of outcrop of the Cretaceous, near the contact between the Selma $54134-28-24$ 
chalk and the Porters Creek clay of the Eocene. Wells must therefore be drilled through the entire thickness of the Selma, which here amounts to 760 feet. According to the log of the town well, which is given below, water is found in greensand in the underlying Eutaw formation between depths of 860 and 960 feet. The static head is 19 feet below the surface. Several wells have been drilled at and near the town, three of which are described in the table (Nos. 31-33). The town owns a small waterworks, which is located a short distance south of the Mobile \& Ohio Railroad station and obtains water from the 960-foot well described in the table (No 31). The water is soft but is high in sodium and chloride. (See analysis 31.) The following log of the town well is given as it is reported:

\section{Log of well at Shuqualak a}

[Altitude of mouth of well, about 214 feet above sea level. Adapted from description by Logan and Perkins]

\begin{tabular}{l|r|r}
\hline & Thickness & Depth \\
\hline Clay (residual from Selma chalk) & Feet & Feet \\
Selma chalk, limestone (chalk) & 10 \\
Eutaw formation: & 750 & 760 \\
$\quad$ Sandstone.-. & 100 & 860 \\
Greensand; water bearing & 100 & 960 \\
\hline
\end{tabular}

- Logan, W. N., and Perkins, W. R., The underground waters of Mississippi: Mississippi Agr. Exper. Sta. Bull. 89, p. 47,1905 .

Mashulaville.-The water supply at the Noxubee County Agricultural High School, a mile south of Mashulaville, is obtained from a well 1,180 feet deep (No. 23), which taps a water-bearing sand in the Eutaw formation. The water is soft but is high in sodium and chloride, as shown by analysis 23 . 


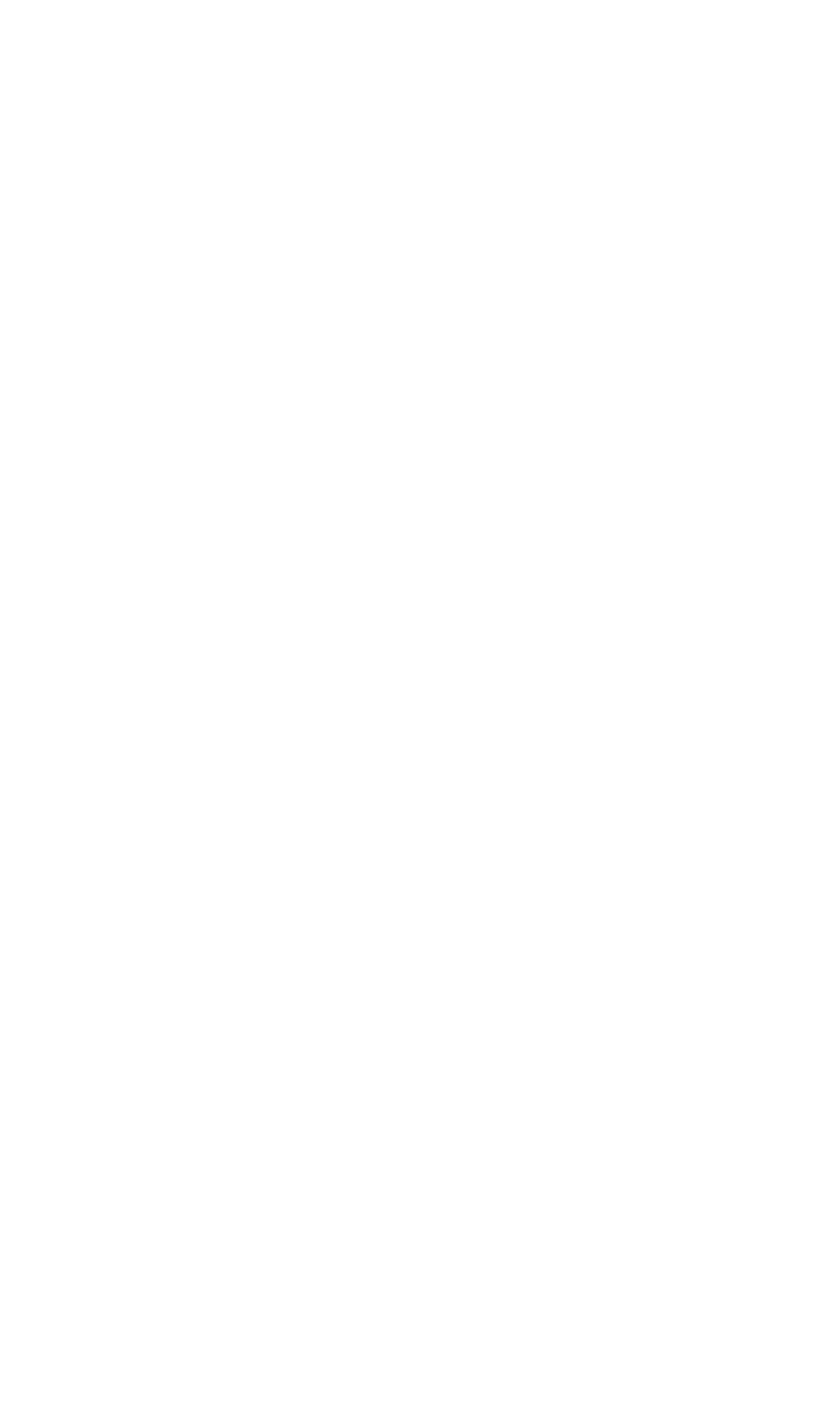




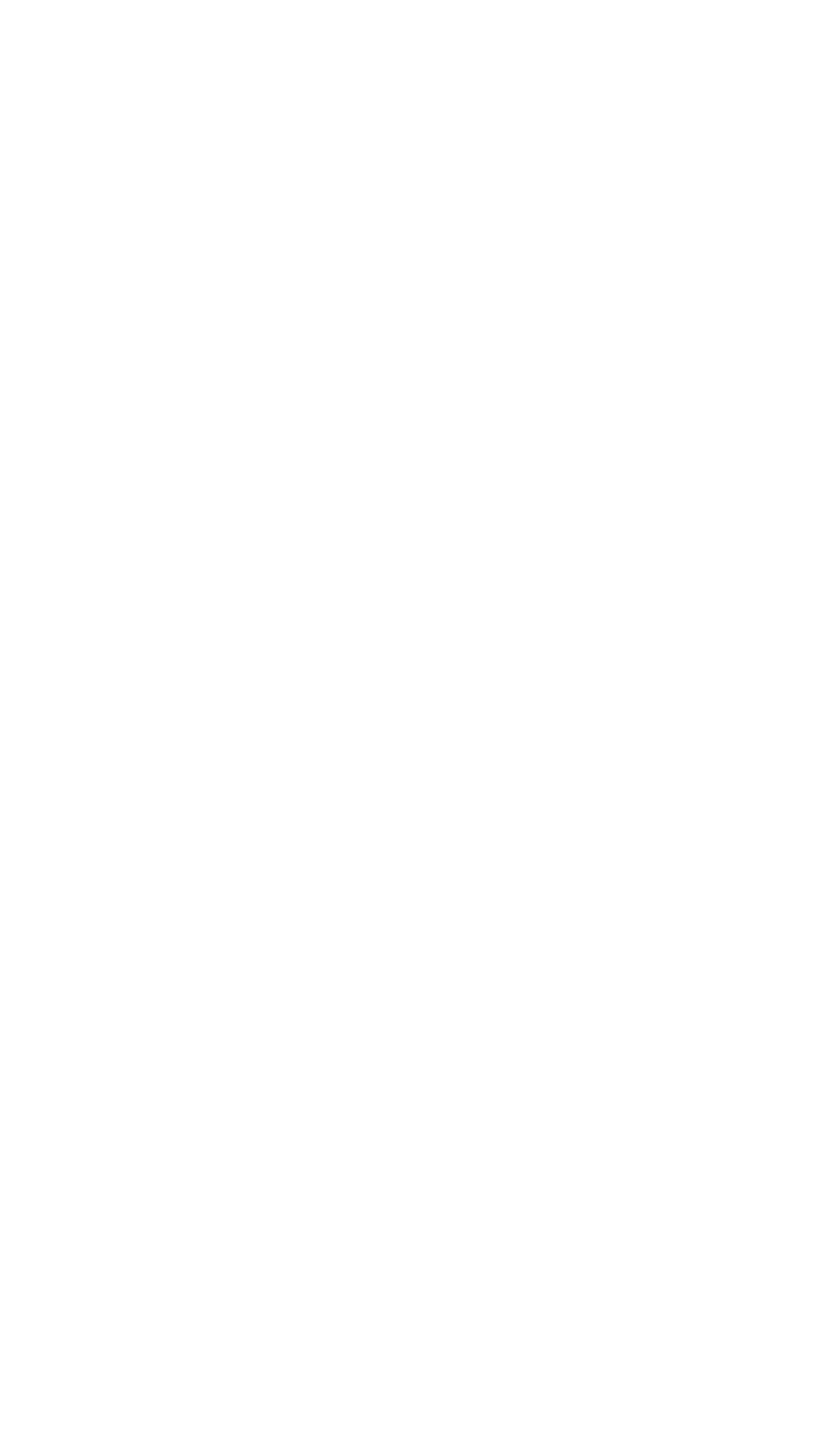


章 巻

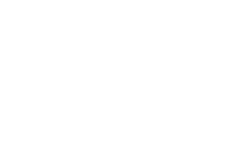

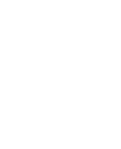

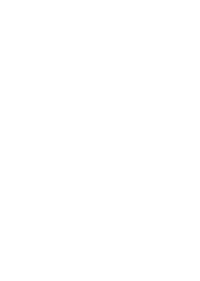

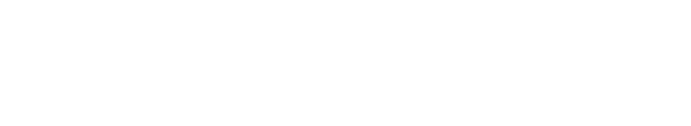

\&

N

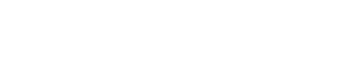

पद

娄

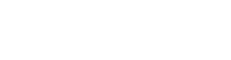

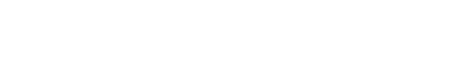

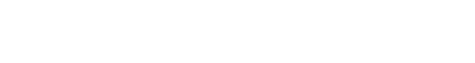

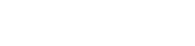

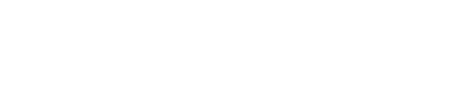

五

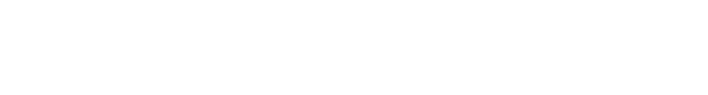

용

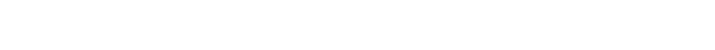

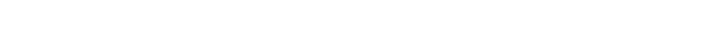

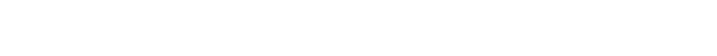

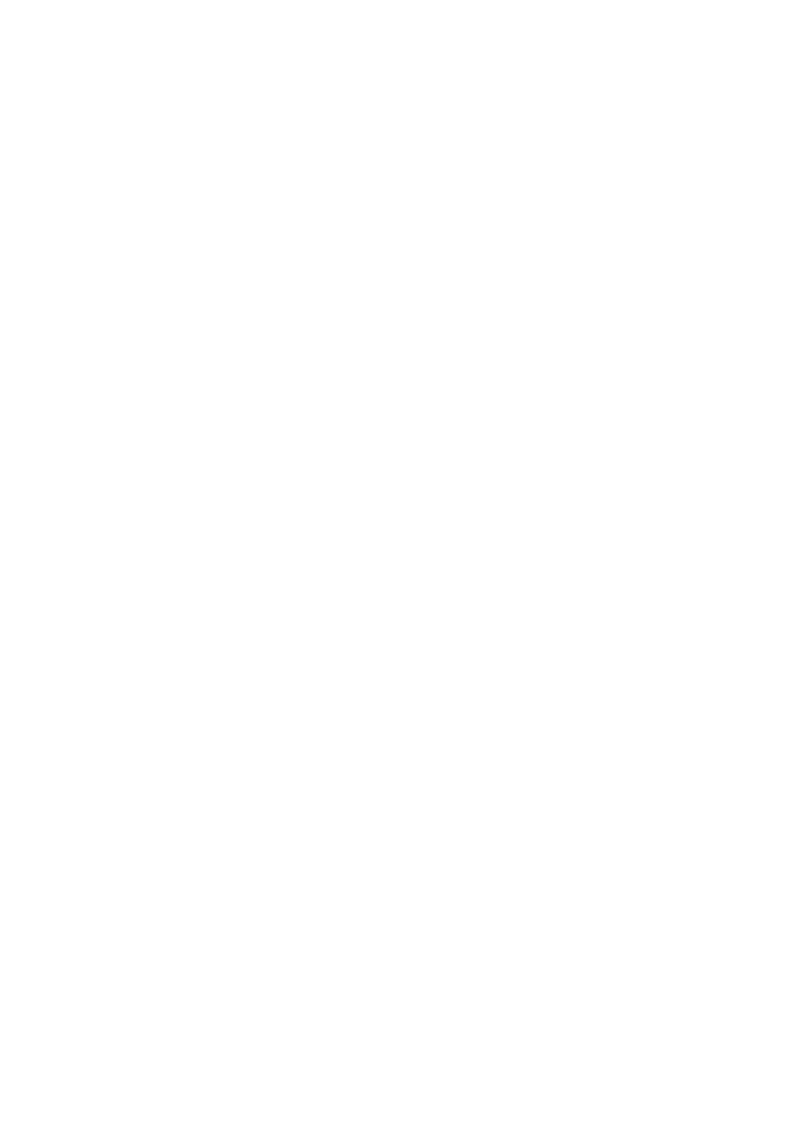




\section{Mineral analyses of ground waters from Noxubee County}

[Parts per million. Numbers at heads of columns refer to corresponding well numbers in preceding table]

\begin{tabular}{|c|c|c|c|c|}
\hline • & 4 & 17 & 23 & 31 \\
\hline $\begin{array}{l}\text { Silice }\left(\mathrm{SiO}_{3}\right) \\
\text { Iron }(\mathrm{Fe}) \\
\text { Calcium }(\mathrm{Ca}) \\
\text { Magnesium }(\mathrm{Mg})\end{array}$ & $\begin{array}{l}27 \\
\quad .35 \\
4.4 \\
4.8\end{array}$ & $\begin{array}{c}12 \\
9.80 \\
9.2 \\
3.5\end{array}$ & $\begin{array}{l}25 \\
1.3 \\
7.7 \\
3.2\end{array}$ & $\begin{array}{r}14 \\
1.2 \\
8.5 \\
\mathbf{2 .}\end{array}$ \\
\hline Sodium and potassium $(\mathrm{Na}+\mathrm{K})$ & 67 & $\begin{cases}\mathrm{Na} & 363 \\
\mathrm{~K} & 32\end{cases}$ & 660 & 611 \\
\hline 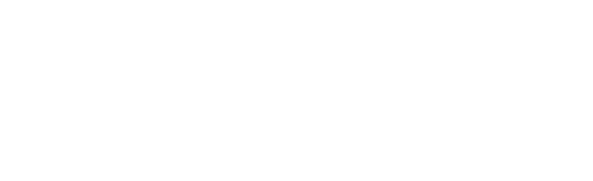 & $\begin{array}{l}9.6 \\
178 \\
16 \\
8.0 \\
227 \\
31 \\
1911\end{array}$ & $\begin{array}{c}365^{.0} \\
1.8 \\
400^{10} \\
31,002 \\
37\end{array}$ & \begin{tabular}{|c|c}
$\mathbf{5 7}$ \\
$\mathbf{5 3 6}$ \\
2.8 \\
649 \\
2.8 \\
$\mathbf{1 , 6 9 0}$ \\
$\mathbf{3 2}$ \\
Aug., 1919
\end{tabular} & $\begin{array}{c}17 \\
537 \\
1.8 \\
629 \\
1,579^{.00} \\
\text { Apr., } \\
1914\end{array}$ \\
\hline
\end{tabular}

- Iron and aluminum oxides $\left(\mathrm{Fe}_{2} \mathrm{O}_{3}+\mathrm{Al}_{2} \mathrm{O}_{3}\right)$.

b Calculated.

Analysts: 4, E. S. Wallace, University of Mississippi; 17, W. R. Perkins (Mississippi Agr. Exper. Sta. Bull. 89, p. 45, 1905); 23, Margaret D. Foster, U. S. Geological Survey; 31, W. F. Hand, Mississippl State Chemical Laboratory.

\section{OKTIBBEHA COUNTY}

\section{GENERAL FEATURES}

Area, 457 square miles. Population, 16,872 (census of 1920)

Oktibbeha County is included in parts of four well-defined physiographic divisions-the Black Prairie belt, the southern extension of the Pontotoc Hills, the Flatwoods, and the North Central Hills. Upper Cretaceous strata, which include from east to west the Selma chalk, the Ripley formation, and the Oktibbeha tongue of the Selma chalk, crop out in the northeastern third of the county, and Eocene strata, which include the Porters Creek clay of the Midway group and the Ackerman formation of the Wilcox group, overlie the westwarddipping Cretaceous strata throughout the remainder of the county. The line between the Cretaceous and Eocene is irregular, owing to stream erosion, but in general trends to the northwest. These formations, together with the deeply buried Eutaw and Tuscaloosa formations (Upper Cretaceous), are more fully described on pages $36-46$, and their distribution is shown on the geologic map (pl. 2).

\section{GROUND-WATER CONDITIONS}

The Eutaw formation, which is about 400 feet thick, is the principal source of artesian water in this county. The formation does not appear at the surface within the county, but in the extreme northeastern part of the county, where the surface is 200 feet or less above sea level, the top of the formation lies at a depth of about 250 feet, and the water-bearing beds are reached at depths of 290 to 350 feet. Many of the wells in the northeastern part of the county overflow, the static head of the water being from a few feet to 10 feet or more above the surface. 
From the northeastern part of the county the Cretaceous strata dip west by south at the rate of 30 to 33 feet to the mile, whereas the land surface gradually rises, so that at Starkville, where the elevation is 362 feet above sea level, the depth to the first water-bearing bed of the Eutaw is about 800 feet. In the intervening area there are many wells that range in depth from a minimum of 290 feet in the northeast to 1,000 feet or more along the Cretaceous-Eocene boundary; a few of the wells are described in the table of well data. The static head of the water is at successively greater depths from east to west owing to the increasing elevation of the surface in that direction. At Starkville, the static head is at a depth of 150 feet, but at the waterworks this has been reduced by pumping to 175 feet. At Longview, 7 miles southwest of Starkville, where the surface lies about 290 feet above sea level, the first water-bearing bed of the Eutaw is reached at a depth of 902 feet and the static head is 85 feet below the surface. The analyses on page 373 represent four rather highly mineralized waters from this formation.

The Tuscaloosa formation is several hundred feet thick and is composed in part of abundantly water-bearing beds, but no wells deep enough to reach these beds have been reported. The formation should, however, be regarded as a future source of supply. In the northeastern part of the county the uppermost beds of the Tuscaloosa should be reached at a depth of 650 to 700 feet and at Starkville at an estimated depth of 1,150 to 1,200 feet. Water from this formation will probably be of better quality than water from the Eutaw formation.

The catchment area of the waters in the Eutaw and Tuscaloosa formations beneath Oktibbeha County lies to the northeast, in Lowndes and Monroe Counties, Miss., and in Lamar County, Ala., where the formations come to the surface. The fact that much of this area stands at a greater altitude above sea level than any part of Oktibbeha County accounts for the hydrostatic pressure, which, as shown above, is sufficient to cause overflows in the northeastern part of the county and to bring the water high enough in the wells in other parts of the county to be within reasonable reach of ordinary force pumps.

A few small springs occur in the hilly area underlain by the sandy strata of the Ripley formation east of the center of the county and also in the hilly tract in the western and southwestern parts of the county that is underlain by the Ackerman formation. In the same areas shallow wells are used to provide domestic supplies. Springs are rare or absent in the Black Prairie belt in the eastern part of the county, which is underlain by the Selma chalk, and in the Flatwoods area, which is underlain by the Porters Creek clay; in these areas the people who do not have deep wells depend for water supplies chiefly on cisterns and surface pools designed for storing rain water. 


\section{LOCAL SUPPLIES}

Starkville.-The municipal waterworks at Starkville is about 100 yards west of the union station on ground 2 or 3 feet lower than the track. The water supply is derived from two wells, one 900 feet deep (No. 32) and the other 910 feet deep; these wells penetrate two water-bearing sands in the Eutaw formation beneath the Selma chalk. A $\log$ of the well taken from the records on file at the waterworks is given below.

Log of well at the waterworks at Starkville (No. 32)

[Altitude of mouth of well, 360 feet above sea level. Adapted from records on flle at the waterworks]

\begin{tabular}{|c|c|c|}
\hline & Thiokness & Depth \\
\hline $\begin{array}{l}\text { Surface soil (residual from Selma chalk) } \\
\text { oktibbeha tongue of Selma chalk: Soft lïmestone } \\
\text { Ripley formation: Compact sand } \\
\text { Selma chalk (main body of formation): "Marl stone" (chalk) }\end{array}$ & $\begin{array}{r}\text { Feet } \\
12 \\
60 \\
26 \\
582\end{array}$ & $\begin{array}{r}\text { Feet } \\
12 \\
72 \\
98 \\
680\end{array}$ \\
\hline $\begin{array}{l}\text { Eutaw formation: } \\
\text { Soft sandstone. } \\
\text { Hard clay } \\
\text { Hard shelly rock } \\
\text { Clay and sand mixed. } \\
\text { Hard shell rock } \\
\text { Sand; water bearing } \\
\text { Hard clay } \\
\text { Sand; water bearing }\end{array}$ & \begin{tabular}{c|}
36 \\
47 \\
4 \\
2416 \\
7 \\
56 \\
10 \\
$351 / 2$
\end{tabular} & $\begin{array}{l}716 \\
763 \\
767 \\
7911 / 2 \\
7981 \\
8541 \\
8641 / 2 \\
900\end{array}$ \\
\hline
\end{tabular}

Several wells within $31 / 2$ miles of Starkville that penetrate to the water-bearing beds of the Eutaw formation are described in the tables (Nos. 32-35).

Agricultural and Mechanical College.-The State Agricultural and Mechanical College, 11/2 miles east by south of Starkville, is equipped with a waterworks and obtains water from the Eutaw formation by means of two wells, respectively 995 and 1,008 feet deep (Nos. 1,2). The log of the deeper of the two wells $(1,008$ feet) is as follows:

.

Log of well No. 2 at the Agricultural and Mechanical College, $11 / 2$ miles east by south of Starkrille (No. 2) a

[Altitude of mouth of well, 390 feet above sea level. Adapted from description by Logan and Perkins]

\begin{tabular}{|c|c|c|}
\hline & Thickness & Depth \\
\hline Soil (residual from the Selma) & ${ }^{\text {Feet }}{ }_{20}$ & Feet ${ }_{20}$ \\
\hline $\begin{array}{l}\text { Selma chalk (chiefiy): Chalk (including tongue of Ripley sand and clay in the } \\
\text { upper portion and perhaps a part of the Eutaw formation in the lower } \\
\text { portiun) }\end{array}$ & 795 & 815 \\
\hline $\begin{array}{l}\text { Eutaw formation: } \\
\text { Sand; water bearing } \\
\text { Hard blue clay }\end{array}$ & $\begin{array}{r}185 \\
8\end{array}$ & $\begin{array}{l}1,000 \\
1,008\end{array}$ \\
\hline
\end{tabular}

a Logan, W. N., and Perkins, W. R., The underground waters of Mississippi: Mississippi Agr. Exper. Sta. Bull. 89, p. 41, 1905 .

The southward-extending tongue of Ripley sand and clay, through which the drill must have passed somewhere in the upper portion of the chalk, is not differentiated in the preceding log. 
Muldrow.-The village of Muldrow and the surrounding district are advantageously situated for obtaining artesian water supplies. Many wells, which range in depth from 290 to 400 feet and nearly all of which flow, are in use. (See wells 10-15.)

Osborn.-The village of Osborn is 25 or 30 feet higher above sea level than Muldrow, and flowing wells are not obtained on this upland. However, the static head of the water is in general less than 40 feet below the surface and therefore easily within the reach of pumps. The wells range in depth from 400 to 700 feet. (See wells 20-24.) The log of one well follows:

Log of well of A. A. Montgomery, Osborn (No. 20) a

[Altitude of mouth of well, 255(?) feet above sea level. Adapted from description by Logan and Perkins

\begin{tabular}{l|r|r}
\hline & Thickness & Depth \\
\hline Soll (residual from the Selma) & Feet & Feet \\
Selma chalk: Limestone (chalk) & $\mathbf{2}$ \\
Eutaw formation: Sand and hard rock; water bearing & 350 & 352 \\
\hline
\end{tabular}

- Logan, W. N., and Perkins, W. R., op. cit., p. 42.

Hickory Grove.-The ground-water conditions at Hickory Grove are essentially like those at Osborn, except that the surface is a little higher above sea level, and consequently the wells average somewhat deeper (450 to 550 feet), and the static head of the water is in general farther below the surface (30 to 70 feet). (See wells 3-6.)

Sessums.-The village of Sessums is near the western edge of the Black Prairie belt, and nearly the full thickness of the Selma chalk must be penetrated in order to reach the water-bearing sands of the Eutaw formation. The wells range in depth from 400 to 750 feet. (See wells 25-31.) One well (No. 29), the mouth of which is said to be 230 feet above sea level, is reported to have flowed a small stream when first drilled; in another well, the altitude of which is not stated, the static head is said to be 17 feet below the surface; in still another, whose altitude is given as 240 feet above sea level, the static head is 60 feet below the surface. The topographic relief is not great enough to account for this apparent discrepancy in the static head of the water in different wells, but the explanation is perhaps to be found in a lack of authenticity in some of the well records. Log of a well at Sessums is given below:

Log of well of Frye \& Frye, Sessums $\left(\right.$ No. 30 ${ }^{a}$

[Adapted from description by Logan and Perkins]

\begin{tabular}{|c|c|c|}
\hline & Thickness & Depth \\
\hline Selma chalk: Limestone (chalk) & Feet $_{450}$ & Feet \\
\hline $\begin{array}{l}\text { Eutaw formation: } \\
\text { Hard rock and sand } \\
\text { Thin hard rock and sand... } \\
\text { Sandstone and sand; water bearing(?) }\end{array}$ & $\begin{array}{r}20 \\
30 \\
153\end{array}$ & $\begin{array}{l}470 \\
500 \\
653\end{array}$ \\
\hline
\end{tabular}

- Logan, W. N., and Perkins, W. R., op. cit., p. 44. 
Oktoc.-A number of wells that range in depth from 750 to 800 feet have been drilled in the vicinity of Oktoc. (See wells 16-19.) Logs of two wells are given below:

Log of well of Kennard \& Self, west of Oktoc, in sec. 18, T.117 N., R. 15 E. (No. 16)

[Adapted from data furnished by W. N. Logan]

Clay (residual from Selma chalk)

Selma chaik: Blue limestone, with shells and sand near bottom

Eutaw formation: Sand; water bearing.

\begin{tabular}{|r|r}
\hline Thickness & Depth \\
\hline Feet & Feet \\
21 & 21 \\
677 & 698 \\
76 & 774 \\
\hline
\end{tabular}

Log of well of A. H. Rice, B(?) miles north by west of Oktoc, in sec. 6, T. 17 N., R. 15 E. (No. 18)

[Adapted from data furnished by R. C. Stone, driller]

\begin{tabular}{l|r|r}
\hline & Thickness & Depth \\
\hline Selma chalk (including Ripley sand and clay in upper part): & Feet & Feet \\
$\quad$ Sand and clay_... & 17 \\
$\quad$ Blue limestone._. & 632 & 649 \\
Eutaw formation: & Sand and shells. \\
$\quad$ Sand, including 6 feet of sandstone; water bearing & 60 & 699 \\
\hline
\end{tabular}

Longview.-Two wells (Nos. 7,8 ) near Longview are the only wells reported west of the Cretaceous-Eocene contact that are deep enough to reach the water-bearing beds of the Eutaw formation; they are 894 and 966 feet deep. The log of the 966 -foot well follows:

Log of the Seitz well, Longview

[Altitude of mouth of well about 290 feet above sea level]

\begin{tabular}{|c|c|c|}
\hline & Thickness & Depth \\
\hline $\begin{array}{l}\text { Surface soil and clay (residual from Porters Creek) } \\
\text { Eocene, Porters Creek clay - dark-brown clay } \\
\text { Upper Cretaceous: } \\
\text { Selma chalk (probably some Ripley sand and clay in upper part) } \\
\text { Blue limestone. } \\
\text { White imestone } \\
\text { Shells and blue rock (probably includes some Eutaw) } \\
\text { Eutaw formation- } \\
\text { Sand; water bearing } \\
\text { Shell rock. } \\
\text { Sand; water bearing }\end{array}$ & $\begin{array}{r}\text { Feet } \\
26 \\
132 \\
\\
500 \\
30 \\
214 \\
12 \\
15 \\
37\end{array}$ & $\begin{array}{r}\text { Feet } \\
26 \\
158 \\
\\
658 \\
688 \\
902\end{array}$ \\
\hline
\end{tabular}

On the assumption that the surface at the mouth of this well is 290 feet above sea level, the base of the Eocene, as indicated in the log, would be 132 feet above sea level. The base of the Eocene at Starkville is about 360 feet above sea level, a difference of 228 feet in 7 miles, which indicates a dip of the Cretaceous-Eocene contact of 32 feet to the mile. 


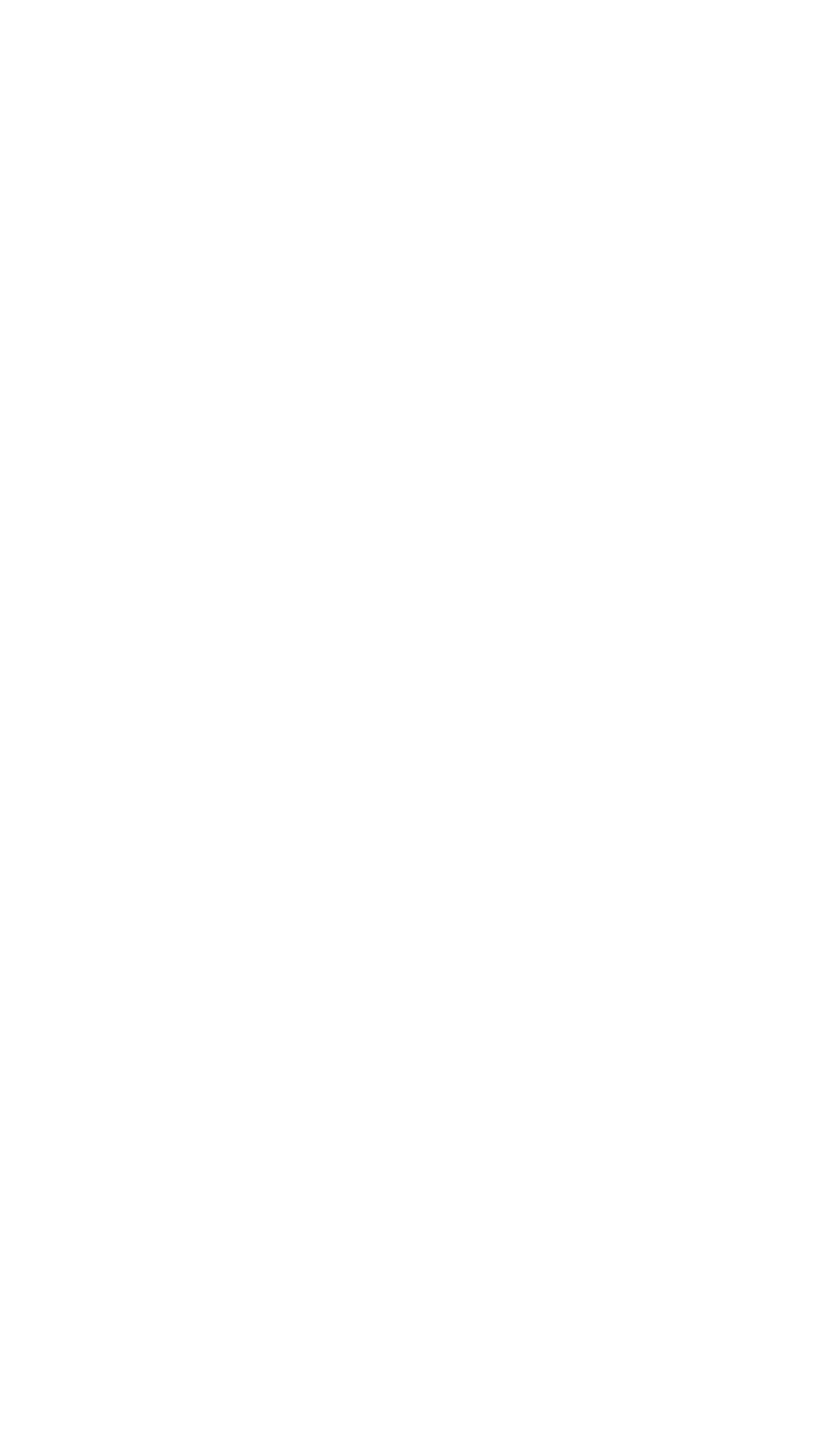




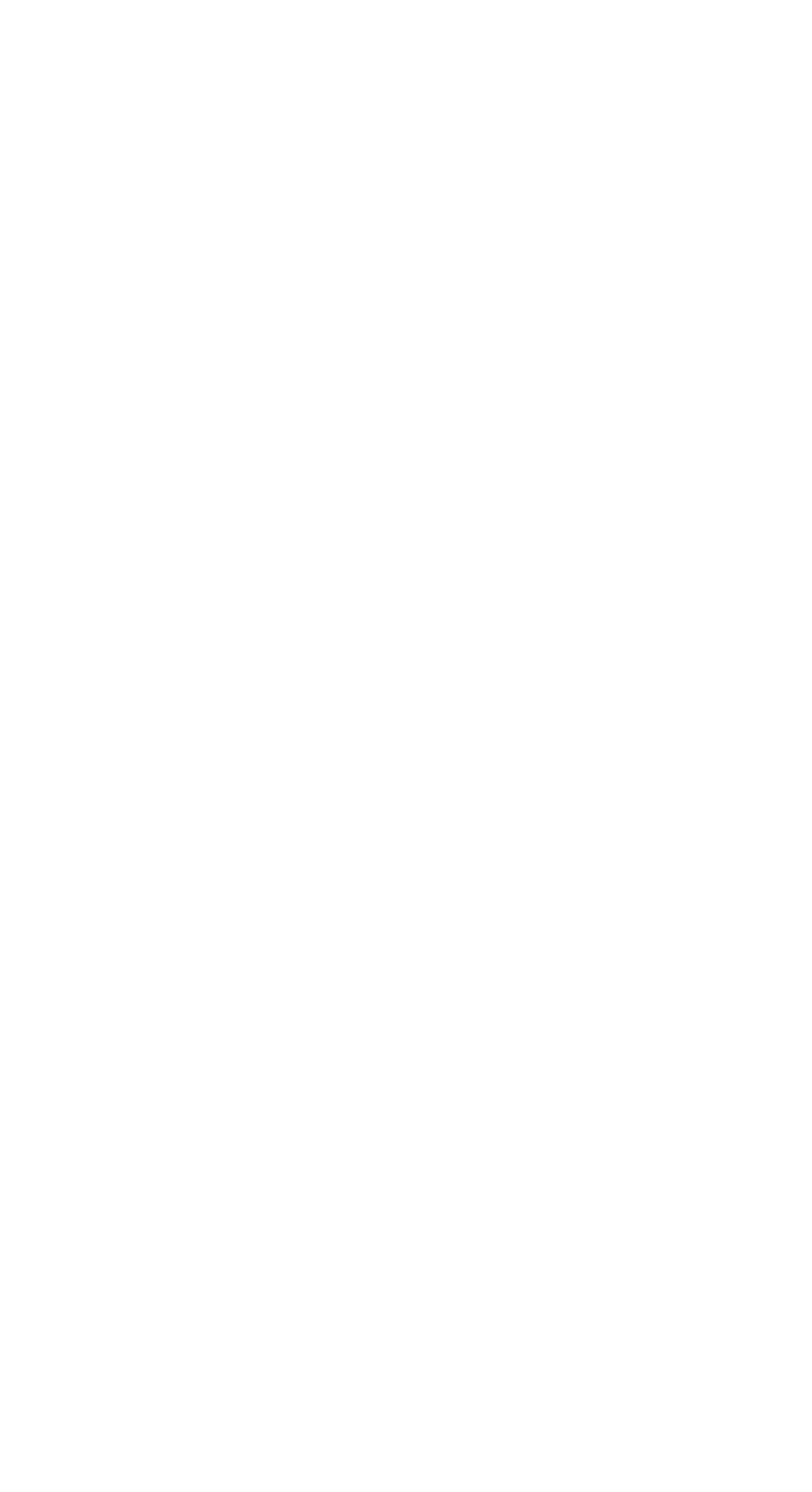


Mineral analyses of ground waters from Oktibbeha County

[Parts per million. Analyzed by W. F. Hand, Mississippi State Chemical Laboratory. Numbers at heads of columns refer to corresponding well numbers in preceding table]

\begin{tabular}{|c|c|c|c|c|}
\hline & 4 & 23 & 24 & 27 \\
\hline 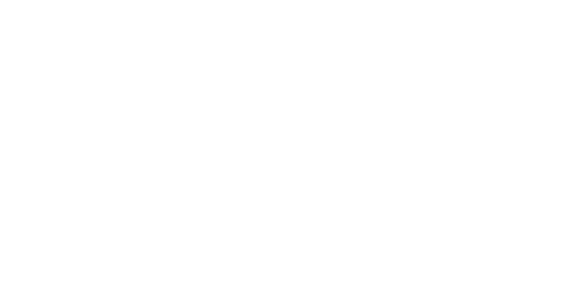 & 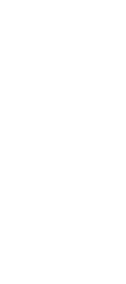 & $\begin{array}{c}7.8 \\
2.0 \\
23 \\
5.6 \\
166 \\
339^{.0} \\
12 \\
120 \\
2.0 \\
578 \\
80 \\
\text { Nov.,1911 }\end{array}$ & $\begin{array}{c}16 \\
.55 \\
8.0 \\
213^{.5} \\
8.4 \\
333.7 \\
3.7 \\
130^{521^{-0}} \\
22 \\
\text { June, } 1914\end{array}$ & $\begin{array}{r}12 \\
1.1 \\
10 \\
3.2 \\
328 \\
\\
478.0 \\
6.4 \\
236 \\
.00 \\
840 \\
\text { Apr., } 1914\end{array}$ \\
\hline
\end{tabular}

PANOLA COUNTY

GENERAL FEATURES

Area, 696 square miles. Population, 27,845 (census of 1920)

About nine-tenths of Panola County lies in the Bluff Hills and the North Central Hills districts, and the remaining tenth lies in the Yazoo Delta. The upland is underlain by beds that belong to the Wilcox group of the Eocene. Two formations of the group, the Holly Springs sand and the Grenada formation, are probably represented in outcrops, but these two formations have not yet been separately mapped. The Wilcox group is almost completely covered with wind-blown deposits of Pleistocene loess, which range in thickness from 40 feet or more near the western border of the upland to only a few feet along the eastern boundary of the county. Only the thicker portions of the loess are represented on the geologic map (pl. 2). Between the thicker body of loess and the underlying Wilcox group lie relatively thin deposits of terrace sand and gravel that are probably of Pliocene age. The Yazoo Delta is underlain by 150 feet or more of alluvial loam, clay, sand, and gravel, which rest upon the westward buried extension of the Wilcox group. Thin surficial deposits of alluvium of Recent and Pleistocene age underlie the lowlands of Tallahatchie and Yocona Rivers. All these formations are described in detail on pages $46-63$.

\section{GROUND-WATER CONDITIONS}

The beds that compose the Wilcox group dip to the west at the rate of 20 or 25 feet to the mile and afford conditions favorable to the development of artesian pressure in their contained waters.

The Ackerman formation, the basal division of the Wilcox group, lies deeply buried in Panola County and is probably not reached by any of the wells recorded in the table of well data. The formation is several hundred feet thick and doubtless includes some water-bearing 
sand layers. The Holly Springs sand, or the middle formation of the Wilcox group, crops out in the eastern part of the county and dips to the west beneath the Grenada formation. The Holly Springs formation is 400 or 500 feet thick, carries large quantities of water, and is the reservoir drawn upon by most of the deeper wells of the county. The water is under sufficient hydrostatic pressure to produce flows in the Yazoo Delta, in the western part of the county, and in the valleys of Tallahatchie and Yocona Rivers and their larger tributary creeks throughout the upland district.

The Grenada, the uppermost formation of the Wilcox group, underlies the loess in an undetermined area in the western part of the upland. Although the formation is dominantly composed of clay, it doubtless contains some interbedded layers of water-bearing sand, which are tapped by wells 200 feet or less in depth. (See table of well data.)

Domestic water supplies are obtained throughout the upland district from springs, and from shallow dug and bored wells, which have their source in the sands of the Holly Springs and Grenada formations, where they lie within 50 or 100 feet of the surface, or in the Pliocene sands and gravels that intervene between the Grenada formation and the thicker portions of the overlying loess, or in the Pleistocene and Recent alluvial deposits that underlie the lowlands of Tallahatchie and Yocona Rivers and their larger tributary creeks.

In the Yazoo Delta, in the west, nonflowing water may be readily obtained from the sandy portions of the underlying alluvial deposits by bored or driven wells, which may range in depth from a few feet to 150 feet or more.

\section{LOCAL SUPPLIES}

Askew.-In the vicinity of Askew, at the base of the bluffs, 2 miles north of Crenshaw, water is afforded by dug or driven wells 10 to 100 feet in depth. The dug well of Y. O. Askew (No. 1) is 12 feet deep and yields soft water from sand entered at a depth of 9 feet. The driven well of J. O. Askew (No. 2) is 80 feet deep and yields hard water from sand entered at a depth of 75 feet; the static head is 30 feet below the surface. A few small springs issue from the more sandy layers of the Grenada formation, which crops out in the bluffs east of Askew. The J. P. Garrett spring, three-quarters of a mile east of Askew, affords a small perennial stream that is used for domestic and stock supply; it probably has its source in terrace sands of Pliocene age.

Crenshaw. - In the vicinity of Crenshaw several water-bearing sands have been penetrated by wells at different depths. One sand lies within 20 or 25 feet of the surface; another is reached at a depth of about 110 feet; a third at a depth of 350 feet, and still others at depths between 650 and 750 feet. The shallow water is said to be colored by vegetable matter and is not of satisfactory quality. Most of the wells are therefore sunk to the second sand (depth 110 feet), which yields nonflowing water. A public flowing well at Crenshaw (No. 12) is 750 feet deep and yields 40 gallons a minute. (See analysis 12. ) 
Como.--In the vicinity of Como water is obtained from wells that range in depth from 74 to 210 feet. The water of nearly all the wells is under considerable artesian head, but none of them flow. In a 76-foot well (No. 9) 11/2 miles west of Como, water was encountered at a depth of 71 feet and rose within 7 feet of the surface. The town of Como owns two wells (Nos. 7, 8), each 210 feet deep, which furnish the municipal water supply. Water was struck in coarse sand at a depth of 206 feet and rose within 98 feet of the surface.

Horatio.-In the vicinity of Horatio, a village about 8 miles west of Sardis, domestic water supplies are obtained chiefly from dug wells (Nos. 14-19), some of which are as much as 150 feet deep. They yield a plentiful supply of soft water from white sand.

Delta.-A flowing well of large yield (No. 13), 2 or 3 miles northeast of Delta, is 650 feet deep; the water is used for household supplies and for stock. (See analysis 13.)

Sardis.-The town of Sardis owns a municipal waterworks located one block north of the Illinois Central Railroad station on a plain level with the track at the station. Two wells (Nos. 20, 21), reported to be 197 and 215 feet deep, afford the water supply. The well of the Illinois Central Railroad (No. 22) at Sardis is 210 feet deep and yields a plentiful supply for the boilers of locomotives. (See analysis 22.)

Batesville.-Flowing wells at and near Batesville range in depth from 300 to 400 feet. Two town wells (Nos. 3, 4), located on the public square, are 302 and 396 feet deep; the 302-foot well has been abandoned but the other flows 10 or 12 gallons a minute into a concrete watering trough for stock (pl. 7, B). (See analyses 3, 4.) A $\log$ of the 302-foot well is given below. The town owns a waterworks located on ground about level with the tracks of the Illinois Central Railroad, a block north of the court house. Water is obtained from two nonflowing wells, each reported to be about 100 feet deep (No. 5).

Log of public well at Batesville (No. 3)

\begin{tabular}{|c|c|c|}
\hline & Thickness & Depth \\
\hline Surface materials & & \\
\hline $\begin{array}{l}\text { Grenada and Holly springs formations: } \\
\text { White sand }\end{array}$ & 10 & \\
\hline Blue clay - sand & 10 & $\begin{aligned} 45 \\
260\end{aligned}$ \\
\hline $\begin{array}{l}\text { Clay and sand } \\
\text { Rock }\end{array}$ & 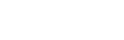 & 260 \\
\hline sand, water bearing & & 302 \\
\hline
\end{tabular}

Courtland.-The municipal water supply at Courtland is obtained from a 700-foot well (No. 10). Although the well yielded a small stream when first drilled, it was necessary to install a pump to raise the desired quantity of water. The dug well of J. C. Pou, a quarter of a mile southwest of the Courtland post office, yields water of fair quality, which is apparently derived from the terrace gravel that underlies the loess. The total depth of this well is not stated, but the water stands within 85 feet of the surface. 


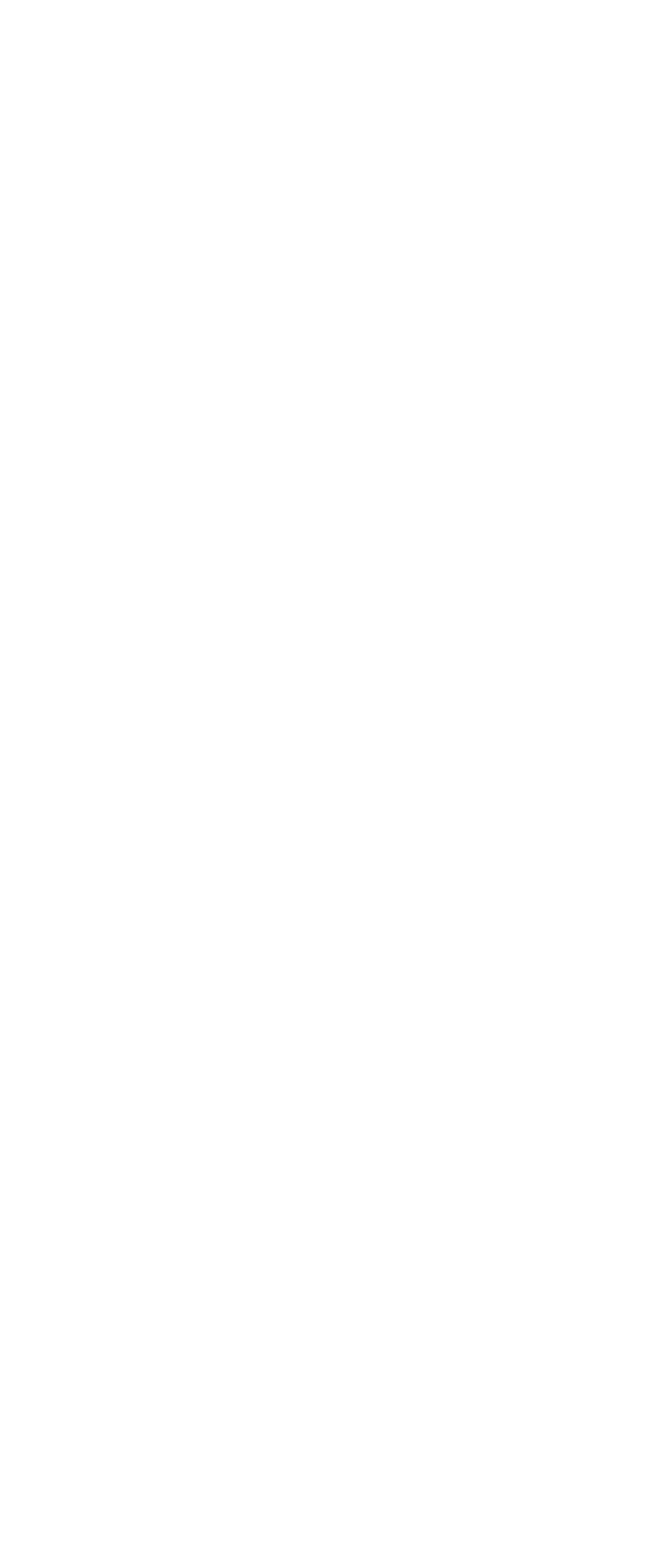




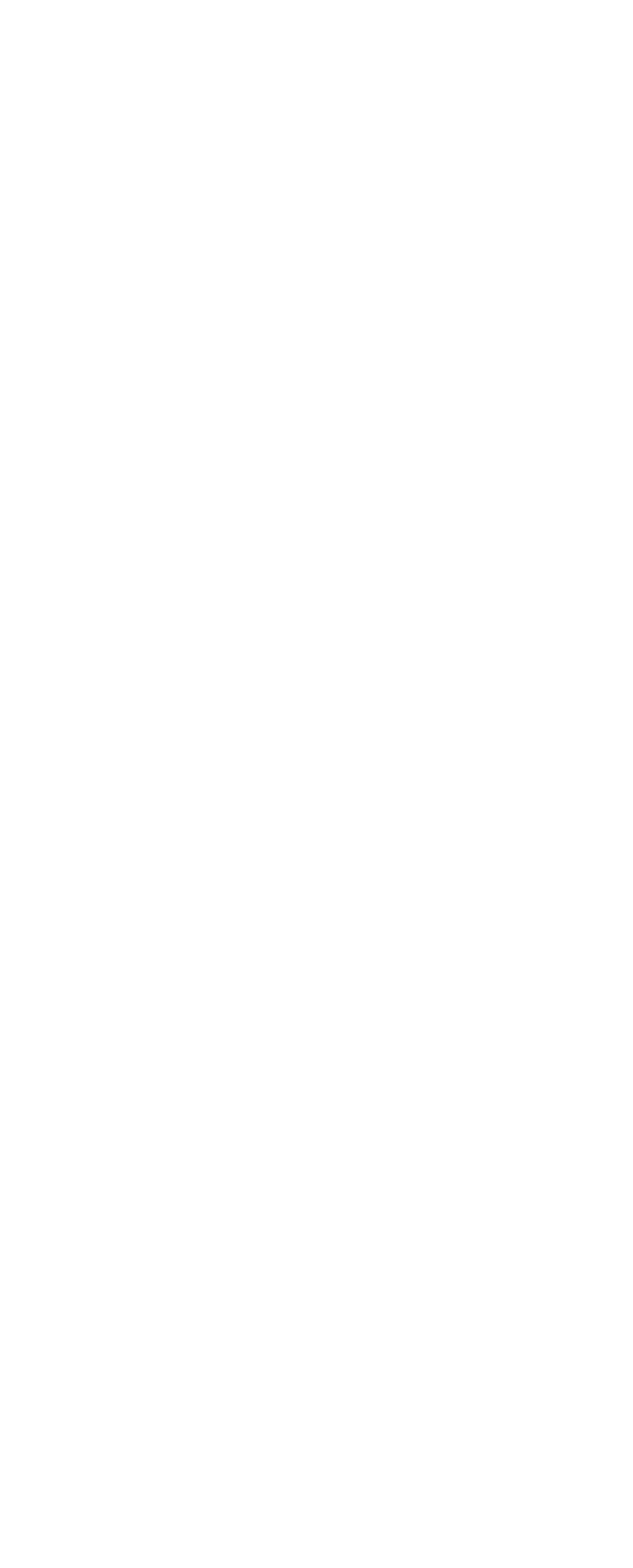


Mineral analyses of ground waters from Panola County

[Parts per million. Numbers at heads of columns refer to corresponding well numbers in preceding table]

\begin{tabular}{|c|c|c|c|c|c|c|c|}
\hline & 3 & 4 & 5 & 12 & 13 & 21 & 22 \\
\hline $\begin{array}{l}\text { Silica }(\mathrm{SiO}) \\
\text { Pron }(\mathrm{Fe}) \\
\text { Calcium }(\mathrm{Ca}) \\
\text { Magnesium }(\mathrm{Mg})\end{array}$ & $\begin{array}{r}30 \\
17 \\
2.7 \\
2.5\end{array}$ & $\stackrel{12}{12} .60$ & $\begin{array}{r}43 \\
2.2 \\
7.1 \\
4.1\end{array}$ & $\begin{array}{l}23 \\
26.60 \\
.3\end{array}$ & $\begin{array}{r}10 \\
1.4 \\
2.7 \\
3.4\end{array}$ & $\begin{array}{l}48 \\
2.5 \\
1.2\end{array}$ & $\begin{array}{r}14.65 \\
4.1 \\
1.4\end{array}$ \\
\hline Sodium and potassium $(\mathrm{Na}+\mathrm{K}) \ldots$ & $\begin{array}{l}\mathrm{Na} 6.0 \\
\mathbf{K} \mathbf{3} .5\end{array}$ & 8.6 & - 24 & 19 & 17 & $\bullet 15$ & $\left\{\begin{array}{l}\mathrm{Na20} \\
\mathrm{K} \\
1.4\end{array}\right.$ \\
\hline 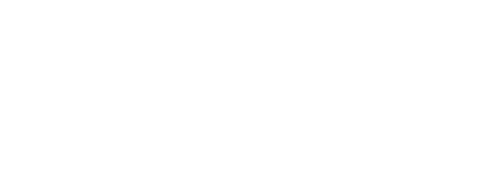 & 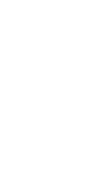 & $\begin{array}{l}47^{\circ} \\
10 \\
4.1 \\
2.0 \\
74 \\
37 \\
\text { Oct. } \\
1911\end{array}$ & $\begin{array}{l}81^{\circ} \\
13 \\
5.3 \\
\text { Trace. } \\
132 \\
35 \\
\text { Aug., } \\
1919\end{array}$ & $\begin{array}{l}122.0 \\
4.5 \\
2.0 \\
4.0 \\
139 \\
66 \\
\text { Oct. } \\
1911\end{array}$ & $\begin{array}{c}49^{.0} \\
6.2 \\
6.0 \\
66 \\
21 \\
\text { Nov. } \\
1915\end{array}$ & $\begin{array}{c}40 \\
30 \\
3.5 \\
4.3 \\
99^{.97} \\
11 \\
\text { Aug., } \\
1919\end{array}$ & \begin{tabular}{c}
$36^{.0}$ \\
3.5 \\
19 \\
\hdashline $82^{3}$ \\
16
\end{tabular} \\
\hline
\end{tabular}

- Iron and aluminum oxides $\left(\mathrm{Fe}_{2} \mathrm{O}_{3}+\mathrm{Al}_{2} \mathrm{O}_{3}\right)$.

- Includes iron and aluminum ( $\mathrm{Fe}+\mathrm{Al})$.

- Calculated.

Analysts: 3, 22, W. R. Perkins (Mississippi Agr. Exper. Sta. Bull. 89, p. 98, 1905); 4, 12, W. L. Perdue, University of Mississippi; 5, 21, Margaret $D$. Foster and Clara M. Forman, U. S. Geological Survey; 13, W. F. Hand, Mississippi State Chemical Laboratory.

\section{PEARI RIVER COUNTY}

\section{GENERAL FEATURES}

Area, 797 square miles. Population, 15,468 (census of 1920)

Pearl River County is in the Long-leaf Pine Hills district. The principal geologic formations that crop out in the county are the Pascagoula clay (Miocene), the Citronelle formation (Pliocene), and surficial Pleistocene terrace deposits, which are in part of stream-laid origin and also probably in part of marine origin. These formations are described on pages $57-61$, and their distribution is approximately shown on the geologic map (pl. 2).

\section{GROUND-WATER CONDITIONS}

In the northern or upland portion of the county the Citronelle formation is the chief source of domestic water supply. The water is obtained from bored wells that range in depth from 15 to 100 feet and from small springs that have their source in the formation. Several typical wells in the vicinity of McNeill are described in the table of well data (Nos. 2-4). The Citronelle formation probably exceeds 200 feet in thickness in the extreme southern part of the county.

The Citronelle formation is underlain by the Pascagoula clay, small outcrops of which appear low in the valley slopes in the northeastern part of the county. In Lamar County on the north, where the main body of the formation comes to the surface, it appears to consist chiefly of nonwater-bearing clay. The thickness there is estimated to be about 300 feet. The formation dips slightly to the south, and doubtless underlies all of Pearl River County beneath 
the Citronelle formation, but the available well logs do not afford sufficient data to permit the exact identification of the formation.

The Pascagoula clay is underlain by the Hattiesburg clay, which in its area of outcrop in the counties to the north (see pl. 2) is also chiefly clay. The formation is known, however, to contain productive water-bearing sands interbedded with the clay, as, for example, at Camp Shelby, in Forrest County. (See p. 159.) The thickness of the Hattiesburg in the northern part of Pearl River County is estimated to be about 375 feet. The water-bearing sand at a depth of 763 to 845 feet in the well of the Goodyear Yellow Pine Co. is probably in the Hattiesburg. Most of the deep wells in the county, including the numerous flowing wells in the vicinity of Picayune (Nos. 9-18) and the nonflowing wells at Carriere and Poplarville (Nos. 1, 19), are believed to have their source in the Hattiesburg. According to the reports received, most of these deep wells yield large quantities of water, the quality of which is excellent for ordinary domestic and industrial uses.

Apparently no wells in Pearl River County have been drilled deep enough to reach the water-bearing beds of the Catahoula sandstone (Miocene), which underlies the Hattiesburg formation. In and for a few miles south of its area of outcrop in Mississippi (see pl. 2) the Catahoula is a highly important aquifer and affords large quantities of good water, as, for example, at Hattiesburg. At Lumberton, in Lamar County just north of the boundary of Pearl River County, the Catahoula is over 300 feet thick and its top is reached at a depth of about 700 feet. The Catahoula dips to the south at a rate between 15 and 20 feet to the mile (probably about 17 feet to the mile), and it is estimated that in the southern part of Pearl River County the water-bearing beds of the formation should be penetrated between depths of 1,100 and 1,600 feet.

\section{LOCAL SUPPLIES}

Poplarville.-The municipal water supply at Poplarville, the county seat, is obtained from a 756-foot well (No. 19), which is located at the pumping station, a quarter of a mile east by north of the courthouse.

Picayune.-The town of Picayune is not provided with a municipal water supply system. Numerous flowing wells have been drilled at and in the vicinity of the town, and typical ones are described in the table of well data (Nos. 9-18). Several of the wells supply groups of families with water for domestic use. For example, one well (No. 9) supplies 16 families, aggregating about 100 people; two other wells (Nos. 11, 12) supply 45 families, aggregating about 225 people; and another well (No. 13) supplies 12 families. 
Nicholson.-The log of a 239-foot well (No. 7) at Nioholson is given below:

Log of well of D. Carver, at Nicholson a

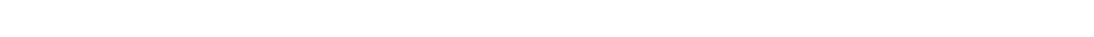

\begin{tabular}{|c|c|c|}
\hline & Thiokness & Depth \\
\hline 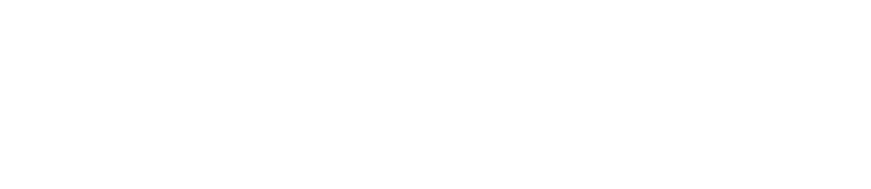 & $\begin{array}{r}65 \\
120 \\
11 \\
10 \\
10 \\
9 \\
14\end{array}$ & 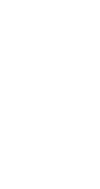 \\
\hline
\end{tabular}

- Missistippi Agr. Bxper, Sta. Bull. 89, p. 69, 1905.

Carriere.-A well at Carriere, owned by Fred Horne and completed in 1919, is 915 feet deep (No. 1). Water obtained in fine gray sand at a depth of 835 to 915 feet rises within 38 feet of the surface. As the purpose of the owner was to obtain an overflow, ishis well was abandoned, though the water could have been raised with a pump and would doubtless have proved to be of satisfactory quality for domestic use. Comparison of the conditions at Carriere, where the altitude of the surface is about 175 feet above sea level, with those at Picayune, where the altitude is only 64 feet, indicates that flowing wells can probably not be obtained at Carriere.

Log of abandoned well of Fred Horne, at Carriere

[Altitude of mouth of well about 175 feet above sea level. Authority, the owner]

\begin{tabular}{|c|c|c|}
\hline & Thickness & Depth \\
\hline $\begin{array}{l}\text { Red clay interbedded with several layers of water-beering sand } \\
\text { Rard blue clay } \\
\text { Fine gray sand; water bearing } \\
\text { Blue clay. } \\
\text { Fine gray sand; water bearing }\end{array}$ & $\begin{array}{r}\text { Feet } \\
100 \\
400 \\
255 \\
80 \\
80\end{array}$ & $\begin{array}{r}\text { Feet } \\
100 \\
500 \\
755 \\
835 \\
915\end{array}$ \\
\hline
\end{tabular}

Orvisburg.-At Orvisburg a domestic water supply is provided for about 25 families by a waterworks owned by the Cecil Lumber Co. The source of the water is a well reported to be about 800 feet deep (No. 8).

Mitlard.-At Millard, a village 5 miles northeast of $\mathrm{McNeill}$, the Batson-McGehee Co. owns a small waterworks and obtains water from two wells-one 163 feet deep, used for drinking and domestic purposes, and the other 490 (?) feet deep, used for boiler supply an $d$ fire protection (Nos. 5, 6). A spring near Millard emerges on a hillslope and yields 6 gallons a minute. It has its source in the Citronelle formation. (See analysis 20.) 


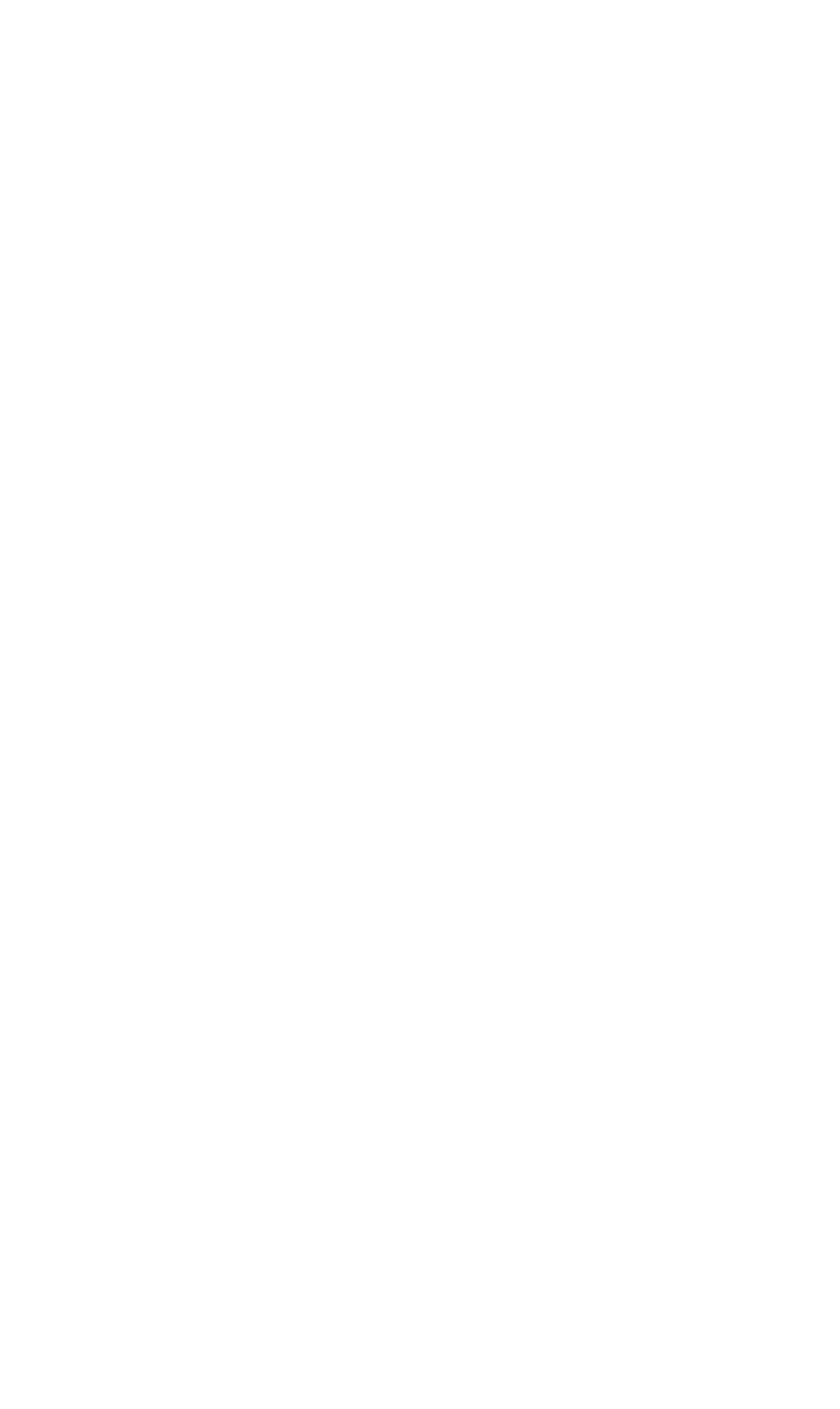




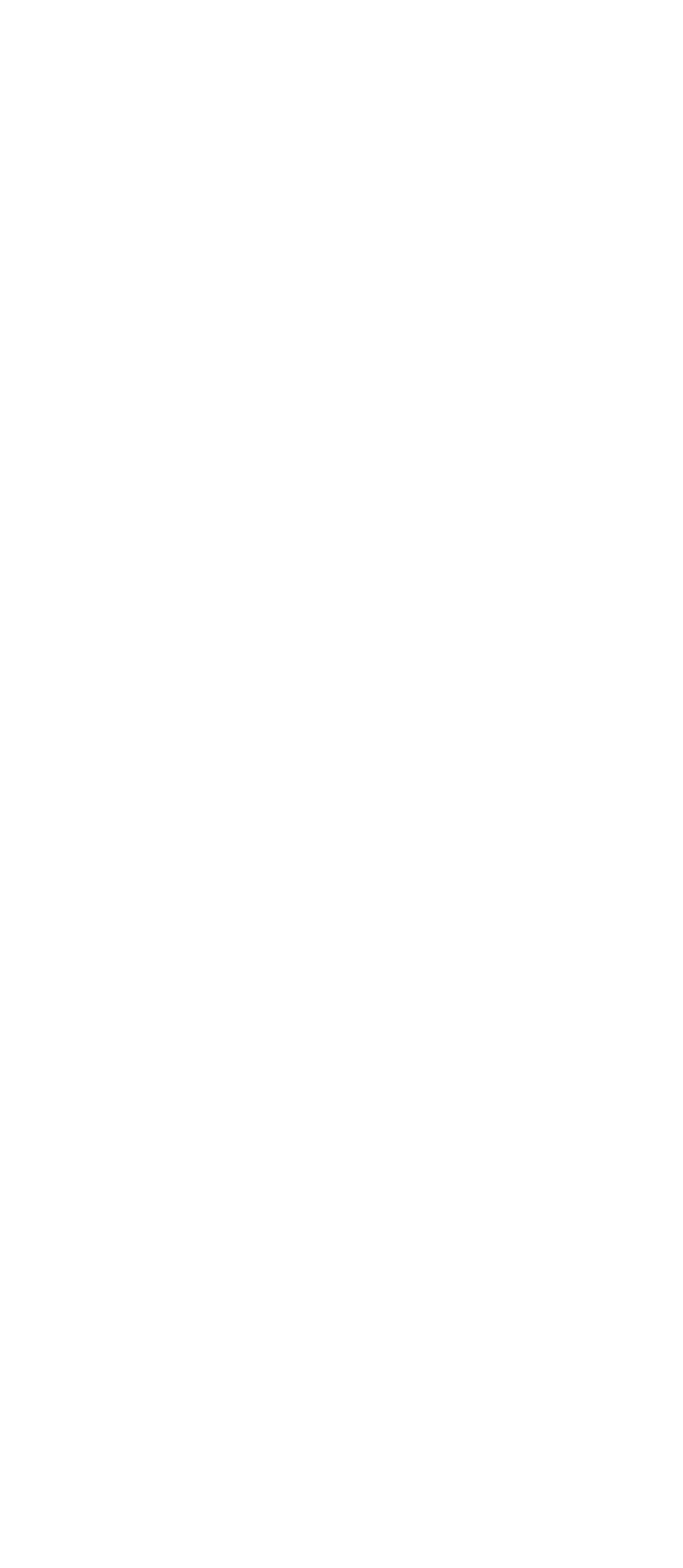




\section{Mineral analyses of ground waters of Pearl River County}

[Parts per million. Numbers at heads of columns refer to corresponding well and spring numbers in preceding table]

\begin{tabular}{|c|c|c|c|c|c|c|c|}
\hline & 6 & 9 & 10 & 15 & 16 & 19 & 20 \\
\hline 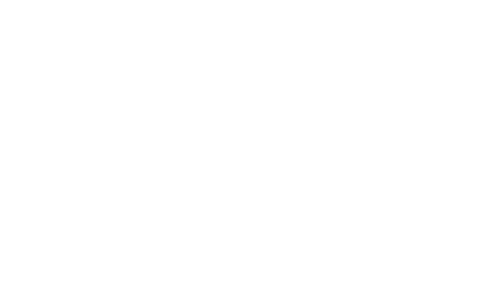 & \begin{tabular}{|c|}
39 \\
.33 \\
5.2 \\
1.7 \\
36 \\
10.0 \\
107.5 \\
6.5 \\
3.0 \\
Trace. \\
152 \\
20 \\
Jan., \\
1921
\end{tabular} & \begin{tabular}{|l}
22 \\
1.00 \\
$84^{.8}$ \\
17 \\
165 \\
15 \\
5.5 \\
1.0 \\
220 \\
6 \\
July, \\
1914
\end{tabular} & \begin{tabular}{|c}
22 \\
1.62 \\
1.4 \\
1.3 \\
90 \\
17 \\
174 \\
16 \\
5.5 \\
$228^{\circ}$ \\
9 \\
July \\
1914
\end{tabular} & $\begin{array}{l}24 \\
1.62 \\
1.1 \\
76 \\
9.6 \\
166 \\
14.0 \\
6.0 \\
205^{\circ} \\
6 \\
\text { Nor. } \\
1914\end{array}$ & $\begin{array}{l}20 \\
.80 \\
.9 \\
86^{-4} \\
12 \\
185 \\
14 \\
4.5 \\
230^{4} \\
4 \\
\text { Apr. } \\
1914\end{array}$ & $\begin{array}{c}35 \\
.55 \\
3.2 \\
1.0 \\
15 \\
.0 \\
37^{.0} \\
7.4 \\
6.0 \\
8^{\circ} \\
12 \\
J_{\text {une }} \\
1914\end{array}$ & $\begin{array}{c}7.4 \\
.42 \\
1.6 \\
.8 \\
5.7 \\
.0 \\
7.3 \\
1.5 \\
6.0 \\
.00 \\
23 \\
7 \\
\text { Maj, } \\
1913\end{array}$ \\
\hline
\end{tabular}

- Calculated.

Analysts: 6, C. S. Howard, U. S. Geological Survey; 9, 10, 15, 20, Mississippi State Chemical Laboratary 16, 19, W. F. Hand, Mississippi State Chemical Laboratory.

\section{PERRY COUNTY}

\section{GENERAL FEATURES}

Area, 644 square miles. Population, 8,987 (census of 1920)

Perry County is in the Long-leaf Pine Hills district. The three principal geologic formations which appear at the surface within the county include, in the ascending order of their age, the Hattiesburg clay (Miocene), the Pascagoula clay (Miocene), and the Citronelle formation (Pliocene). These formations are described on pages $56-60$, and their distribution is shown on the geologic map (pl. 2).

\section{GROUND-WATER CONDITIONS}

As in all the adjoining counties, supplies of water for domestic and farm use are derived chiefly from bored and dug wells that range in depth from 15 to 100 feet or more. Throughout the upland the source of the water is the Citronelle formation, which makes up the 50 to $\mathbf{1 0 0}$ feet or more of the body of the hills in the north and increases to 150 feet or more in the south. In the lowland that borders Leaf River the wells are shallower than on the upland, and the water is obtained principally from the sands and gravels that form the basal portion of the relatively thin Pleistocene terrace deposits. Small springs that have their source in the Citronelle formation or in the Pleistocene terrace deposits are common throughout the county, and some of them are utilized.

The Pascagoula clay, which underlies the Citronelle formation throughout a little more than the southern half of the county, is, so far as known, not water bearing, though it may contain some intercalated water-bearing sands. The thickness of the Pascagoula ranges from a featheredge in the central part of the county to an 
estimated maximum between 300 and 400 feet along the southern boundary.

The Pascagoula clay is underlain by the Hattiesburg clay, which is here between 300 and 400 feet thick and in part is probably water bearing. The formation dips to the south at an estimated rate between 15 and 20 feet to the mile. Although none of the few deep wells reported from Perry County appear to have their source in the Hattiesburg formation, evidence for the occurrence of water in it is afforded by the wells at Camp Shelby, which is only a few miles west of the Perry County line. (See p. 159.) According to this evidence water ought to be obtained from the Hattiesburg in the upland hills immediately south of the Leaf River Valley in Perry County, at depths of 300 to 500 feet. In the valley of Black Creek, in the southern part of the county, the depth, owing to the lower altitude, would probably not be much greater than 300 to 500 feet, and the static head of the water may be high enough there to produce flowing wells. In the Leaf River lowland the same water-bearing beds ought to be reached at depths of 50 to 250 feet, and on some of the lower terrace plains the static head of the water is probably high enough to produce flows. As these water-bearing beds rise to the north at the rate of 15 or 20 feet to the mile, they underlie all the northern part of the county at moderate depths. It is estimated that on the upland along the northern boundary water ought to be found in the Hattiesburg formation at depths of 50 to 200 feet, but flows could not be expected except questionably in some of the deeper creek valleys.

Flowing wells at New Augusta, Richton, Mahned, and Runnelstown are deep enough to completely penetrate the Hattiesburg clay and to enter the underlying Catahoula sandstone (Miocene), which is one of the most extensive and prolific aquifers in southern Mississippi. In Perry County the Catahoula is 450 or 500 feet thick and is completely buried beneath the Hattiesburg clay. The beds of the Catahoula, like those of the Hattiesburg, dip slightly to the south, so that to the north they rise and eventually come to the surface in Jones and Wayne Counties. In the vicinity of New Augusta a water-bearing bed is reached in the Catahoula at depths of 740 to 850 feet and strong flows are obtained (Nos. 4-7). Similar flows can doubtless be obtained throughout the extent of the Leaf River lowland from east to west in the county. At Richton, 10 miles in an air line to the north, water is obtained, probably from the same or approximately the same stratum, at a depth of 600 feet. In the southern part of the county the depth to the formation is several hundred feet greater than at New Augusta, owing to the southward inclination of the strata, so that the water-bearing beds probably lie 800 to 1,000 feet or more below the valley bottoms. However, if the shallower 
strata of the Hattiesburg formation should fail to yield an dequate supply, the prospective strong flows of potable water that might be expected from the Catahoula would probably justify the additional expenditure of money necessary to obtain them.

\section{LOCAI SUPPLIES}

New Augusta.-Several wells 730 to 850 feet deep have been drilled in the vicinity of New Augusta, and four of them are described in the table of well data (Nos. 4-7). The source of the water is the Catahoula formation. The water is under sufficient static head to raise it 20 to 50 feet above the surface of the Leaf River lowland.

Richton. - The 600-foot well of the Richton Lumber Co., at Richton (No. 9), though affording water for drinking and boilers, according to the record, does not flow, but the altitude of the ground at the mouth of the well is not stated. It would seem that water from that depth should be under sufficient head to afford a flow, if the well was located low in the valley of Thompson Creek. The source of this water is believed to be the Catahoula formation. The 22-foot well of Bentley \& Emery at Richton (No. 10), is remarkable for the large amount of water that it affords from so shallow a source. The white sand from which the water is obtained is questionably referred to the Citronelle formation, though data for its accurate identification are not available.

Agness.-A well at Agness, owned by John P. Pearce, failed to obtain an adequate supply of water at a depth of 178 feet. The well was drilled chiefly in the Pascagoula clay, which is not known to contain water in this area. The first water-bearing stratum which, according to the available data, could reasonably be expected at Agness is in the Hattiesburg formation and corresponds to the stratum that is tapped by the wells at Camp Shelby (Forrest County). (See p. 159.) At Agness this water would probably be reached between depths of 350 and 500 feet.

Runnelstown.-Runnelstown is a small village in the northwestern part of the county, 12 miles west of Richton. Several flowing wells have been obtained in the vicinity of the village, and two of them are described in the table of well data (Nos. 11, 12). A $\log$ of J. L. Draughn's well is given below:

Log of well of $J . L$. Draughn, near Runnelstown, in the NW. 1/4 NW. 1/4 sec. 28, T. 5 N., R. 11 W. (No. 11)

[Authority, the owner; from memory]

\begin{tabular}{|c|c|c|}
\hline & Thickness & Depth \\
\hline 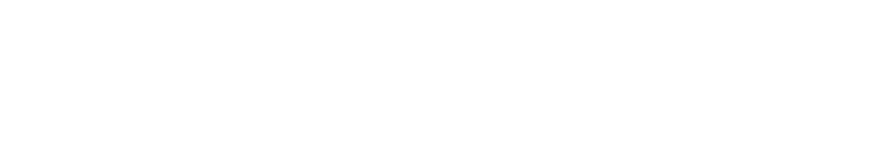 & $\begin{array}{r}\text { Feet } \\
16 \\
169 \\
100\end{array}$ & $\begin{array}{r}\text { Feet } \\
16 \\
185 \\
(?)^{285}\end{array}$ \\
\hline
\end{tabular}




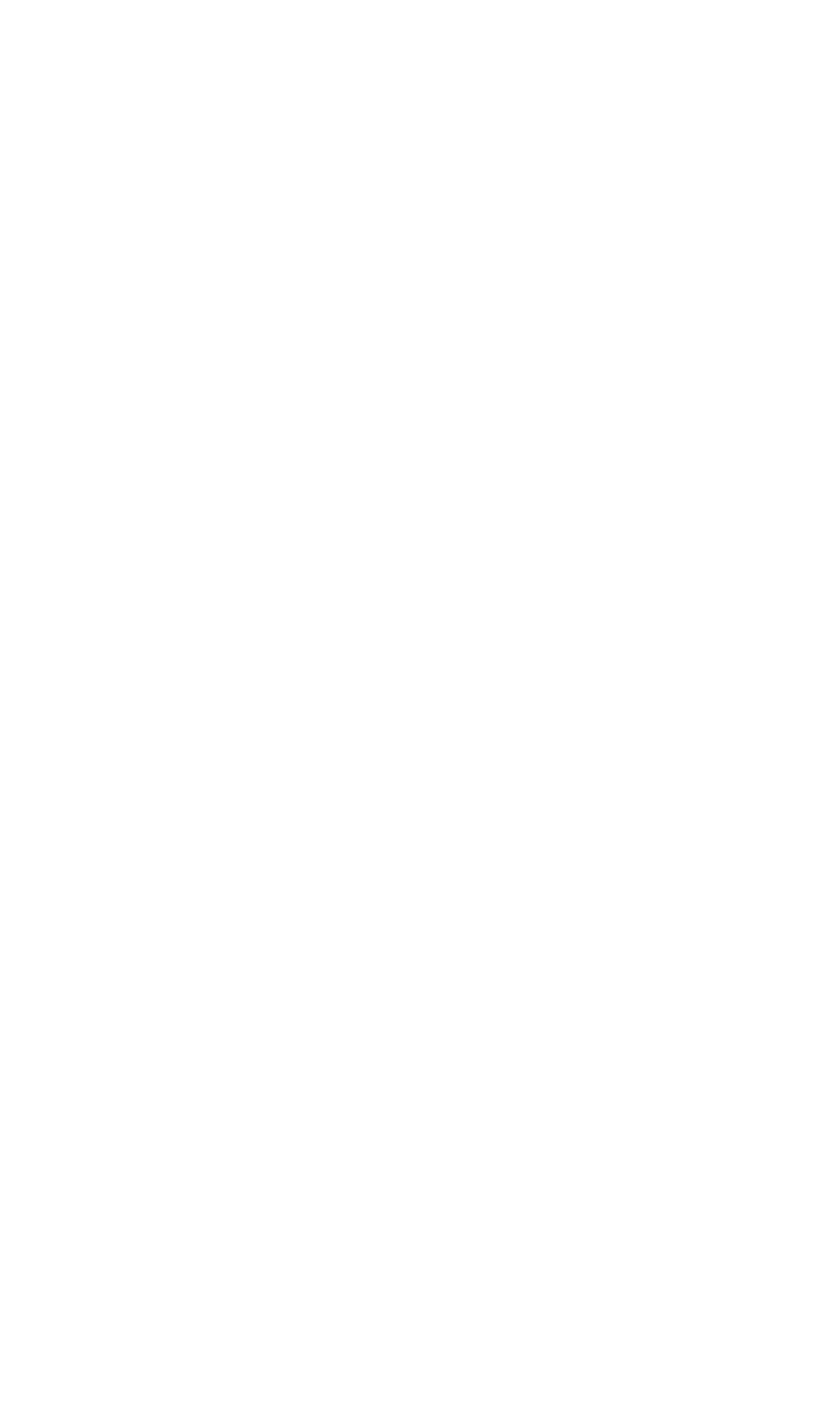




\section{Mineral analyses of ground waters from Perry County}

[Parts per million. Numbers at heads of columns refer to corresponding well numbers in preceding table]

\begin{tabular}{|c|c|c|}
\hline & 4 & 5 \\
\hline 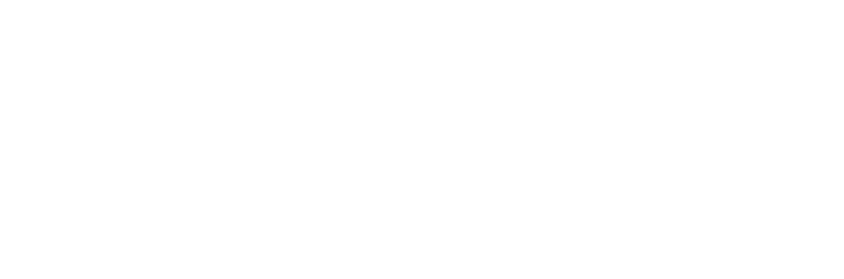 & $\begin{array}{l}13 \\
1.2 \\
3.1 \\
225^{.6} \\
8.4 \\
469^{1.6} \\
49^{5} \\
567^{10} \\
\text { July, } 1913\end{array}$ & $\begin{array}{c}24 \\
.08 \\
.4 \\
2.6 \\
158 \\
9.6 \\
328 \\
6.8 \\
45 \\
\text { Trace } \\
415 \\
12 \\
\text { Apr., } 1918\end{array}$ \\
\hline
\end{tabular}

- Calculated.

Analysts: 4, Mississippi State Chemical Laboratory; 5, A. A. Chambers and C. H. Kidwell, U. S. Geological Survey.

\section{PIKE COUNTY}

\section{GENERAL FEATURES}

Area, 707 square miles. Population, 28,725 (census of 1920)

Pike County is in the Long-leaf Pine Hills district. Two principal geologic formations appear at the surface-the Pascagoula clay (Miocene), which occurs only in small outcrops low on the valley slopes in the northern parts of the county, and the Citronelle formation (Pliocene), which overlies the Pascagoula and determines the principal topographic characteristics of the area. Descriptions of these formations are given on pages $57-60$, and their distribution is shown on the geologic map (pl. 2).

\section{GROUND-WATER CONDITIONS}

Supplies of water for domestic and farm use are derived pricipally from the Citronelle formation, which immediately underlies practically the whole county and ranges in thickness on the divides from about 150 feet in the north to 300 feet or more in the south. The water is obtained by bored and dug wells, chiefly bored, which range in depth from 20 to 100 feet, and from the numerous small springs which flow from the water-bearing sands and gravels where they crop out on the lower slopes of the valleys. Most of the wells are cribbed with wood and are quickly and cheaply constructed, at a cost that ranges from $\$ 15$ to $\$ 40$ a well. The static head of the water in the basal beds of the Citronelle is probably high enough to produce flowing wells low in the valleys of Tangipahoa River, Bogue Chitto, and their principal tributaries in the southern half of the county.

Two so-called blowing wells, similar to those in Amite County on the west (see p. 76), have been reported from Magnolia. Of one of them J. M. Hutson says:

W. C. Lang, of Magnolia, has an 80-foot well that is called the blowing well From it a current of air flows constantly with sufficient force to play a French harp, and the well is a weather sign, the current being stronger just before rain or falling weather. 
Of the other well J. S. Roberts states:

E. F. Cupit, of Magnolia, has a well that has a strong current of air coming from it.

A few wells have been drilled into the Pascagoula clay, which underlies the Citronelle, and some into the still deeper Hattiesburg clay. These two formations, though composed chiefly of clay, have a total thickness of 800 or 900 feet, and contain interbedded sandy layers, some of which have been demonstrated to be water bearing. The static head of these waters is high enough to cause flows from wells located low in the deeper creek and river valleys. The Hattiesburg clay is underlain by the Catahoula sandstone, of Miocene age, which is 350 or 400 feet thick. In some of the counties to the north the more porous beds of this formation constitute a valuable aquifer. In Pike County the Catahoula is estimated to lie at a depth of 900 to 1,400 feet in the north and somewhat deeper in the south; but, so far as reported, no adequate tests have been made to determine the quantity or character of its contrined waters. The static head of these waters would doubtless be high enough to produce flows in the valleys of the larger streams.

\section{LOCAL SUPPLIES}

$M c C o m b$. - The waterworks at McComb is owned by the town and is located 150 yards north of the Illinois Central Railroad station on ground about 10 feet lower than the track at the station. The water supply is obtained from three wells, each about 100 feet deep, one of which is described in the table of well data (No. 7). (See analysis 7.) The log of an abandoned 615-foot well (No. 8) at the waterworks is given below. The source of the water in the 100-foot wells now in use is the sand and gravel layer in the Citronelle formation indicated in the $\log$ at a depth of 28 to 93 feet. A previous attempt to get water by drilling to a depth of 1,509 feet was unsuccessful, and several shallow wells have been abandoned, due to the rusting out of the strainers.

Log of well owned by the town of McComb *

\begin{tabular}{|c|c|c|c|c|c|}
\hline & $\begin{array}{c}\text { Thick- } \\
\text { ness }\end{array}$ & Depth & & $\begin{array}{l}\text { Thick- } \\
\text { ness }\end{array}$ & Depth \\
\hline 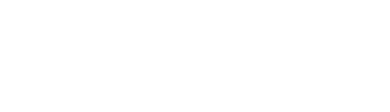 & $\begin{array}{r}\text { Feet } \\
28 \\
65 \\
48 \\
5 \\
5\end{array}$ & $\begin{array}{r}\text { Feet } \\
28 \\
93 \\
141 \\
146\end{array}$ & $\begin{array}{l}\text { Pascagoula clay(?)-Continned. } \\
\text { Gumbo } \\
\text { "Soapstone } \\
\text { White packed sand. } \\
\text { Gumbo }\end{array}$ & $\begin{array}{r}\text { Feet } \\
175 \\
88 \\
4 \\
26\end{array}$ & $\begin{array}{l}\text { Feet } \\
380 \\
468 \\
472 \\
498\end{array}$ \\
\hline $\begin{array}{l}\text { Pascagoula clay }(?): \\
\text { Gumbo }\end{array}$ & 30 & 176 & $\begin{array}{l}\text { Hard gray pocked sand; water } \\
\text { bearing }\end{array}$ & 102 & 600 \\
\hline Hard gumbo and dry gravel & 29 & 205 & Hattiesburg clay (?): Gưmbo........ & 15 & 615 \\
\hline
\end{tabular}

- Adapted from columnar section in U. S. Geol .Survey Prof. Paper 98, pl. 43, column 8, 1926. 
The following lag shows the eharacter of the beds penetrated in a well awned by $R$. E. McInturff, 41/2 miles southeast of McComb, in the SE. $1 / 4$ sec. 34, T. 3 N., R. 8 E.

Log of well of R. E. McInturff, 41/2 miles southeast of McComb (No. g)

[Authority, the owner]

\begin{tabular}{|c|c|c|}
\hline & Thickness & Deptir \\
\hline 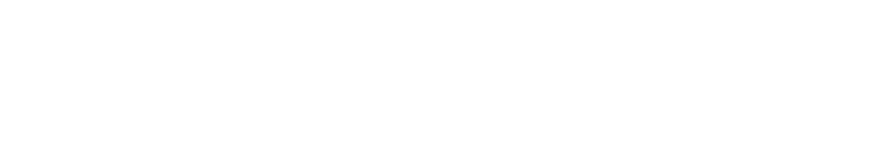 & $\begin{array}{r}\text { Feet } \\
20 \\
26 \\
\mathbf{2} \\
\mathbf{3 2} \\
10 \\
\mathbf{1 4}\end{array}$ & $\begin{array}{r}\text { Feet } \\
20 \\
46 \\
48 \\
80 \\
90 \\
104\end{array}$ \\
\hline
\end{tabular}

Magnolia.-The waterworks at Magnolia, the county geat, is owned by the town and water is obtained from a 324-foot well (No. 11) at the pump station; when first drilled in 1911 this well flowed 50 gallons a minute, 5 feet above the surface, but the head has been lowered until the well no longer flows. A log of the waterworks well is given below.

Log of well at the raterworks at Magnalia (Na. 11)

[Authority, C. I. Brown, driller]

\begin{tabular}{|c|c|c|}
\hline & Thickness & Bepth \\
\hline 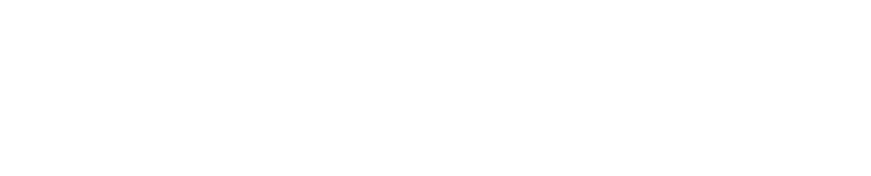 & $\begin{array}{l}\text { Freet } \\
19 \\
19 \\
28.5 \\
9 \\
70 \\
189\end{array}$ & $\begin{array}{l}\text { Feet } \\
27 \\
27 \\
27.5 \\
56 \\
65 \\
135 \\
324\end{array}$ \\
\hline
\end{tabular}

In the 84-foot well of J. S. Roberts (No. 10), a mile south of the post office, the following materials, named in the descending order of their stratigraphic occurrence, are reported to have been penetrated, but their thicknesses are not stated: Blsck sandy loam, soft brown or red elay, hard red clay, very hard deep red sand and chalk [clay], very coarse gravel and irony roek, reachod at a depth of 65 feet, and coarse gravel and yellow sand, water bearing. These materials belong to the Citronelle formation. The log of J. M. Hutson's well, 11/4 miles southwest of Magnolia, a typical well used for domestic supply, is given below.

Log of well of J. M. Hutson, 11/4 miles southwest of Magnolia (No. 12)

[Altitude of mouth of well, about 104 feet above water level in Tanglipahoa River. Authority, the owner]

\begin{tabular}{|c|c|c|}
\hline & Thickness & Depth \\
\hline 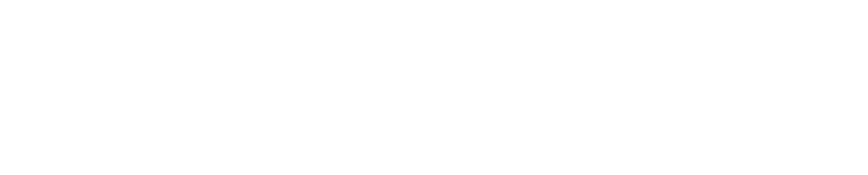 & $\begin{array}{r}75 \\
7 \\
5 \\
3 \\
9 \\
5 \\
4\end{array}$ & $\begin{array}{r}75 \\
82 \\
87 \\
90 \\
99 \\
104 \\
108\end{array}$ \\
\hline
\end{tabular}


Summit.-The municipal water supply at Summit is obtained from two wells, each 110 feet deep (No. 15). The water has its source in typical sand and gravel of the Citronelle formation. The log of a typical shallow well on the upland 7 miles northwest of Summit is given below:

Log of well of C.W. Chisholm in sec. 6,T. 4 N., R. 7 E., 7 miles northwest of Summit (No. 16)

[Authority, W. C. Chisholm]

\begin{tabular}{|c|c|c|}
\hline & Thickness & Depth \\
\hline $\begin{array}{l}\text { Citronelle formation: } \\
\text { Olay } \\
\text { Red sand } \\
\text { Light-colored sand } \\
\text { Quicksand } \\
\text { Light sand and fine gravel; water bearing }\end{array}$ & Feet $\begin{array}{r}20 \\
20 \\
10 \\
10 \\
5\end{array}$ & Feet $\begin{array}{r}20 \\
40 \\
50 \\
60 \\
65\end{array}$ \\
\hline
\end{tabular}

Osyka.-The town of Osyka is provided with a municipal water supply derived from a well which penetrates a water-bearing sand in the Hat tiesburg clay at a depth of 500 to 580 feet (No. 14). The well is loc ated 400 yards southeast of the Illinois Central Railroad station at the edge of Tangipahoa River bottom, at an altitude of about 240 feet above sea level. The well was originally drilled to a depth of 1,310 feet but apparently failed to find an adequate supply below the stratum indicated. The water flows from the well at the rate of 35 or 40 gallons a minute into a ground reservoir that holds 43,000 gallons.

Log of well at the water works, Osyka (No. 14)a

\begin{tabular}{|c|c|c|}
\hline & Thickness & Depth \\
\hline Oitronelle formation: Sand and gravel with some red clay. & Beet ${ }_{150}$ & Feet ${ }_{150}$ \\
\hline $\begin{array}{l}\text { Pascagoula clag: } \\
\text { Blue "muck" clay }\end{array}$ & 200 & \\
\hline $\begin{array}{l}\text { Very coarse sand and gravel, iight gray with reddish tinge; water bearing(?)... } \\
\text { Undifferentiated Hattiesburg clay and Catahoula sandstone: }\end{array}$ & 100 & $\mathbf{4 5 0}$ \\
\hline $\begin{array}{l}\text { Grayish-blue clay } \\
\text { Light-gray sand; water bearing } \\
\text { Gard clay(?) }\end{array}$ & $\begin{array}{r}50 \\
80 \\
680 \\
50\end{array}$ & $\begin{array}{r}500 \\
580 \\
1,260 \\
1,310\end{array}$ \\
\hline
\end{tabular}

- Adapted from section published in U. S. Geol. Survey Prot. Paper 98, pl. 43, column 9, 1916.

Chatawa.-St. Marys Institute at Chatawa is provided with a small waterworks and obtains the water from a spring. The water is reported to be irony.

Fernwood.-At Fernwood the Fernwood Lumber Co. is equipped with a waterworks for boiler supply and fire protection. The water is obtained from Little Tangipahoa River. Three other wells, 97, 325, and 194 feet deep (Nos. 3, 4, and 5), are used for drinking and domestic purposes. The log of one of these wells is given below: 
Log of well of Fernwood Lumber Co. on stock farm (at Hereford barn) a mile southwest of post office at Fernwood

[Altitude of mouth of well about 465 feet above sea level. Log furnished by Sam. L. Olson]

\begin{tabular}{|c|c|c|c|c|c|}
\hline & $\begin{array}{c}\text { Thick- } \\
\text { ness }\end{array}$ & Depth & & $\begin{array}{c}\text { Thick- } \\
\text { ness }\end{array}$ & Depth \\
\hline $\begin{array}{l}\text { Citronelle formation: } \\
\text { Yellow sand } \\
\text { Red sandy clay } \\
\text { Hard sandrock } \\
\text { Hard sand, with a mixture of } \\
\text { white clay...; } \\
\text { Band and gravel; water bearing. } \\
\text { Gumbo }\end{array}$ & $\begin{array}{r}\text { Feet } \\
4 \\
28 \\
2 \\
46 \\
48 \\
4\end{array}$ & $\begin{array}{r}\text { Feet } \\
4 \\
32 \\
34 \\
80 \\
165 \\
169\end{array}$ & $\begin{array}{l}\text { Citronelle formation-Continued. } \\
\text { Sand and gravel; water bearing. } \\
\text { Gumbo } \\
\text { Sand and gravel; water bearing } \\
\text { Chalky clay } \\
\text { Coarse sand and gravel } \\
\text { Pipe clay } \\
\text { Sand and gravel. }\end{array}$ & $\begin{array}{r}\text { Feet } \\
9 \\
\mathbf{9 7} \\
7 \\
\mathbf{5 0} \\
\mathbf{8} \\
\mathbf{1 7} \\
\mathbf{2 8}\end{array}$ & $\begin{array}{r}\text { Feet } \\
178 \\
216 \\
228 \\
272 \\
280 \\
297 \\
328\end{array}$ \\
\hline
\end{tabular}




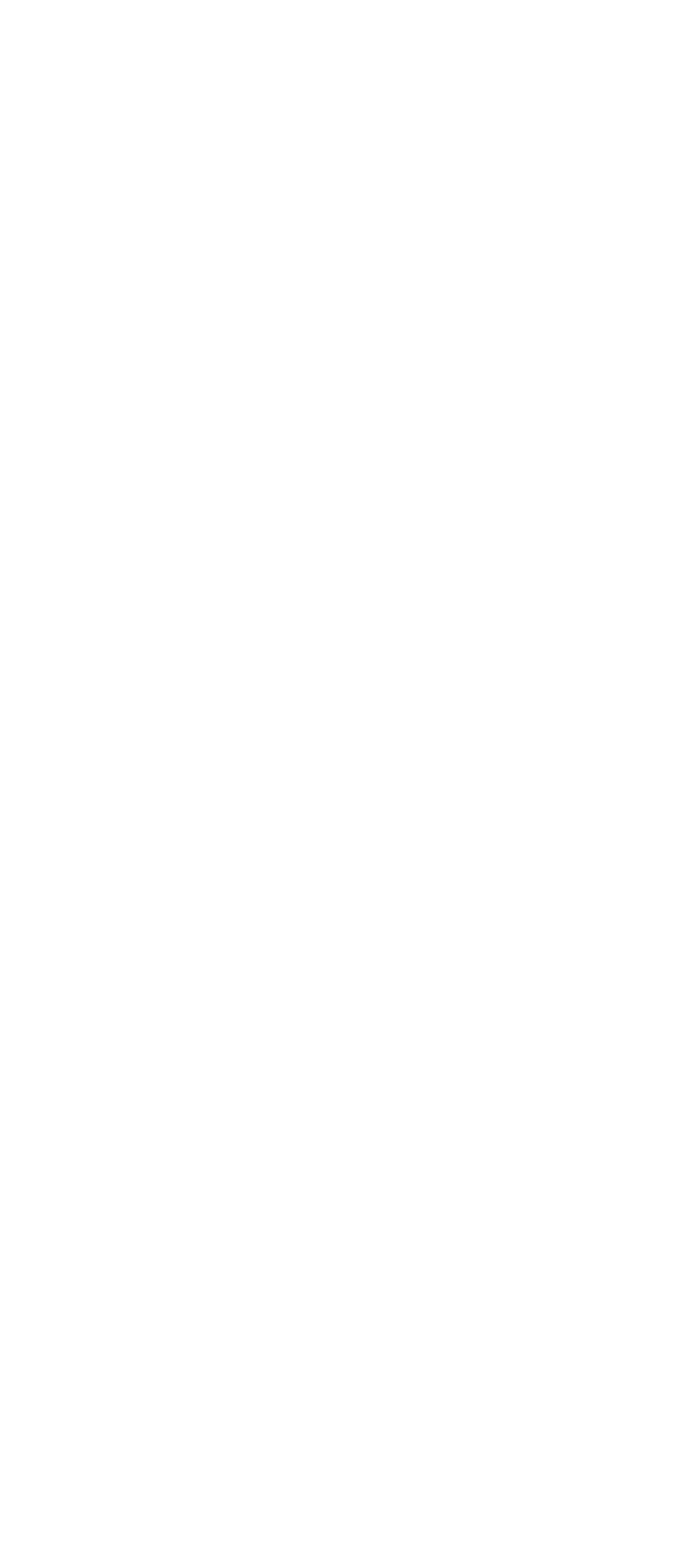




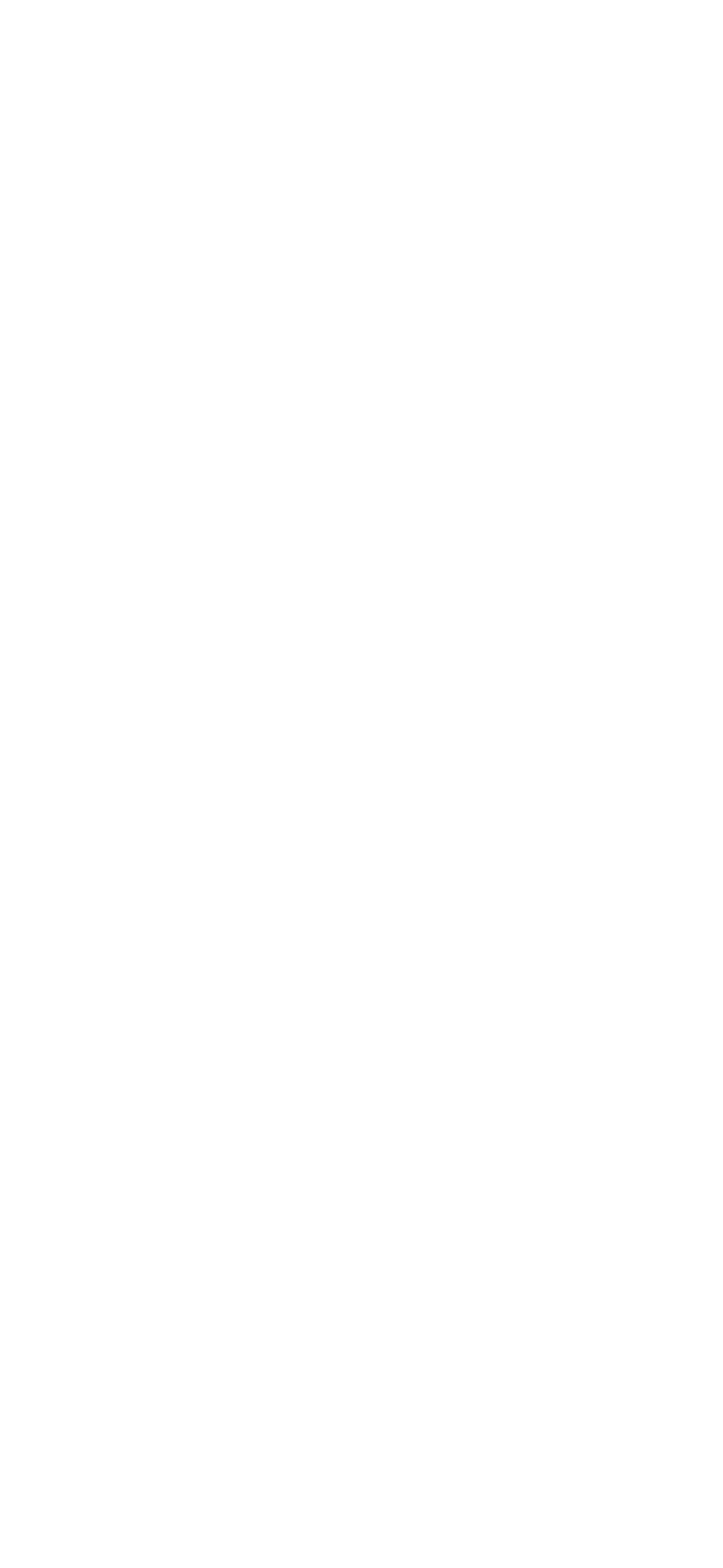




\section{Mineral analyses of ground waters from Pike County}

[Parts per million. Numbers at heads of columns refer to corresponding well numbers in preceding table]

\begin{tabular}{|c|c|c|c|c|c|}
\hline & \& 7 & 9 & 11 & 14 & 15 \\
\hline 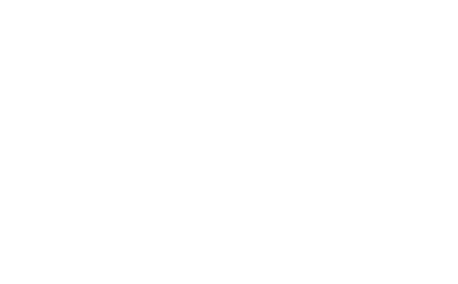 & $\begin{array}{l}36 \\
4.09 \\
2.6 \\
12.6 \\
22.0 \\
2.2 \\
12 \\
4.5 \\
95 \\
21 \\
\text { Sept., } 1919\end{array}$ & $\begin{array}{c}13 \\
3.90 \\
1.5 \\
7.9 \\
12.0 \\
2.9 \\
10 \\
60^{.00} \\
14 \\
\text { Dec., } 1914\end{array}$ & $\begin{array}{c}11 \\
2.05 \\
2.8 \\
12^{.8} \\
30^{.0} \\
3.0 \\
5.6 \\
\text { Trace. }_{49} \\
10 \\
\text { July, } 1919\end{array}$ & $\begin{array}{l}29 \\
1.5 \\
1.9 \\
1.2 \\
9.9 \\
15 \\
12 \\
5.0 \\
64.00 \\
10 \\
1914\end{array}$ & $\begin{array}{l}14.04 \\
2.9 \\
18^{.7} \\
39^{.0} \\
1.6 \\
7.2 \\
7.1 \\
69^{10} \\
\text { July, } 1919\end{array}$ \\
\hline
\end{tabular}

a Composite of three wells, each about 100 feet deep.

$\checkmark$ Calculated.

Analysts: 7, H. B. Riffenburg, U. S. Geological Survey; 9. Mississippi State Chemical Laboratory; 11, 15, Addie T. Geiger, U. S. Geological Survey; 14, W. F. Hand, Mississippi State Chemical Laboratory.

\section{PONTOTOC COUNTY}

\section{GENERAL FEATURES}

Area, 494 square miles. Population, 19,962 (census of 1920)

Pontotoc County may be divided into four more or less clearly defined parts which, in order from east to west, lie in the Black Prairie belt, the Pontotoc Hills, the Flatwoods, and the North Central Hills. The Upper Cretaceous strata crop out in the eastern twofifths of the county and dip to the west unconformably beneath Eocene strata, which immediately underlie the surface throughout the remainder of the county. The Upper Cretaceous strata are separable into two formations - the Selma chalk, which underlies the Black Prairies, and the Ripley formation, which principally composes the Pontotoc Hills. The Eutaw and Tuscaloosa formations do not appear at the surface within the county but lie deeply buried beneath the Selma chalk. The Eocene strata include the Clayton formation and the Porters Creek clay of the Midway group, and the Ackerman formation of the Wilcox group. The Clayton formation, crops out along the western edge of the Pontotoc Hills, the Porters Creek clay underlies the Flatwoods, and the Ackerman formation appears at the surface in the belt of hilly land in the western part of the county. The distribution of these formations is shown on the geologic map (pl. 2). (See also pp. 36-45.)

\section{GROUND-WATER CONDITIONS}

Ground waters are derived from three distinct Upper Cretaceous sources in this county-the main body of the Eutaw formation, the Tupelo tongue of the Coffee sand member of the Eutaw, and the Ripley formation. In the Black Prairie belt, east of the Pontotoc Hills, in the southeastern part of the county, practically the entire 
thickness of the Selnna chalk must be penetrated to reach the main body of the Eutaw formation, whose water-bearing beds lie at a depth of 600 to 700 feet. The catchment area of the water from this source is far to the east, in the hills of Itawamba County, which are composed of the outcropping Eutaw strata and which attain an altitude that produces hydrostatic pressure sufficient to raise the water to a level within 75 or 85 feet of the surface in wells in southeastern Pontotoc County.

In the northeastern part of the county water is obtained from the stratigraphically higher body of sand known as the Tupelo tongue, the catchment area of which is the sand hills of central Lee County, which are typically developed 1 to 5 miles east of Tupelo. (See pl. 2.) At Sherman the Tupelo tongue lies at a depth of approximately 275 to 375 feet and the wells are 250 to 300 feet deep (see wells 11, 12); the static head of the water is 70 feet below the surface.

Throughout the Pontotoc Hills, which mark the outcrop of the Ripley formation, springs of small to moderate yield are numerous. The source of these springs is the beds of sand which, together with interstratified layers of calcareous sandstone, largely compose the formation. Some of the conveniently located springs are utilized, but domestic water supplies in this area are chiefly obtained by dug and bored wells 10 to 100 feet or more in depth. The formation dips to the west at an estimated rate of 30 feet to the mile, and thickens westward until along the line of the Gulf, Mobile \& Northern Railroad the estimated thickness is 300 feet or more. Here the beds consist of porous sand, interstratified with layers of hard sandstone; sand layers at depths of 100 to 300 feet are a valuable source of artesian water. They also constitute a valuable source of artesiau water beneath the Eocene strata throughout the remainder of the county west of the railroad but would be reached at successively greater depths from east to west, the estimated maximum depth of the Ripley formation along the western boundary being 400 to 700 feet. West of Mud Creek, in the southern part of the county, the water-bearing beds of the Ripley are reached at depths of 300 to 500 feet. Flowing wells are obtained from the Ripley in the valleys of some of the headwater creeks of Tallahatchie River in the northern part of the county.

Deep, nonflowing artesian waters can be obtained anywhere in the Pontotoc Hills by drilling through both the Ripley formation and the Selma chalk to the water-bearing beds of the Eitaw formation, which at Pontotoc lie at an estimated depth of 1,000 to 1,400 feet. The Tuscaloosa, also a water-bearing formation, underlies the Eutaw, but no wells deep enough to reach it have been reported from this county. 
Springs occur in the belt of hilly country that is underhain by the Ackerman formation in the westem part of the cenumb, where also water in sufficient quantity for domestic and farm uses can be obtained at most places from sandy beds in the Ackerman formation at depths of 100: feet or lesis.

\section{LOCAL SUPPLIES}

Pontotoc.-On the upland on which Pontotoc is siturated dug and bared wells 25 to 55 feet deep afford the principal means of obtaining domestic water supplies. The water is found above stratum of gray calcareous sandstone that belongs to the Ripley formation. A few wells have been drilled to water-bearing sands in the Hipley formation, at depths of 100 to 300 feet (see wells 8-10), and the static level of the water in these wells lies 40 to 80 feat below the surface. In these walls casing is inserted to the gray sandstone, and thus cuts off the water that is drawn upon by the shallow wells. The log of one of the wells described in the table (No. 8) follows:

Log of well of W. M. Robeson, Pontotoc

[Altitude of mouth of well, 60 feet above the track at the railroad station. Adapted from owner's deseription!

\begin{tabular}{|c|c|c|}
\hline & Thickness & Depth \\
\hline $\begin{array}{l}\text { Eoene (Midway) in upper part, Upper Cretaceeus (Ripley)' in lower part: } \\
\text { Red clay }\end{array}$ & \multirow{5}{*}{$\begin{array}{r}\text { Feet } \\
20 \\
30 \\
3 \\
5 \\
5 \\
20 \\
40 \\
6 \\
59\end{array}$} & \multirow{5}{*}{$\begin{array}{r}\text { Fed } \\
20 \\
50 \\
59 \\
58 \\
60 \\
60 \\
100 \\
100 \\
160\end{array}$} \\
\hline $\begin{array}{l}\text { Dand; water bearing at base- } \\
\text { Uippez Cretaceous (Ripley formation): }\end{array}$ & & \\
\hline $\begin{array}{l}\text { Gray ealcareous sandstente } \\
\text { Blue clay }(?)\end{array}$ & & \\
\hline Rock clay $(?)_{-}$ & & \\
\hline $\begin{array}{l}\text { Rock } \\
\text { Sand: water bearing }\end{array}$ & & \\
\hline
\end{tabular}

Algama.-Domestic water supplies in the neighborhood of Algoma are chiefly obtained from wells 100 to 275 feet deep, which draw upon the water-bearing sands of the Ripley formation. The static head of the water is 50 feet or less below the surface, depending upon the altitude at the mouth of any given well. (See wells 1-4). One well (No. 4), 4 miles southwest of Algoma, is reported to have yielded a small stream when first drilled.

Wallfield.-In the vicinity of Wallfield, a station on the Gulf, Mobile \& Northern Railroad, 41/2 miles south of Algoma, water is obtained chiefly from wells 125 to 160 feet deep which tap a white water-bearing sand of the Ripley formation. (See wells 15, 16.) Nearly all the farms in this community are said to be provided with deep wells. A few wells have been drilled to depths as great as 300 feet.

Ecru.-A well at Ecru (No. 5) only 93 feet deep provides water for the boiler supply of railroad locomotives. A log of this well is given below. 
Log of well of Gulf, Mobile \& Northern Railroad at Ecru (Na. 5) a

[Altitude of mouth of well 350 feet above sea level. Authority, Albert Goldsburg, driller]

\begin{tabular}{|c|c|c|c|c|c|}
\hline & $\begin{array}{l}\text { Thick- } \\
\text { ness }\end{array}$ & Depth & & $\begin{array}{l}\text { Thick- } \\
\text { ness }\end{array}$ & Depth \\
\hline $\begin{array}{l}\text { Eocene (Midway group): } \\
\text { Porters Creek clay-Red } \\
\text { clay and loam } \\
\text { Clayton formation- } \\
\text { Blue clay. } \\
\text { Hard limestono...... }\end{array}$ & $\begin{array}{r}\text { Feet } \\
23 \\
27 \\
4\end{array}$ & $\begin{array}{r}\text { Freet } \\
23 \\
50 \\
54\end{array}$ & $\begin{array}{l}\text { Upper Cretaceous: } \\
\text { Ripley lormation- } \\
\text { Reddish muddy sand... } \\
\text { Shell marl............... } \\
\text { Sand } \\
\text { Reddish sand; water } \\
\text { bearing } \\
\text { Gray clay }\end{array}$ & $\begin{array}{r}\text { Feet } \\
6 \\
1 \\
3 \\
10 \\
10 \\
20\end{array}$ & $\begin{array}{r}\text { Feet } \\
69 \\
60 \\
63 \\
73 \\
03\end{array}$ \\
\hline
\end{tabular}

- U. S. Geol. Surver Water-Supply Paper 159, p. 71, 1806.

Troy.-At Troy, a village on the eastern crest of the Pontotoc Hills in southern Pontotoc County, and in the Black Prairie belt immediately to the east, nonflowing water is obtained from the Eutaw formation beneath the Selma chalk at reported depths of 600 to 700 feet; the water rises within 100 feet or less of the surface. (See well 14.) The water is hard and highly mineralized. (See analysis 14.) Sherman.-In the vicinity of Sherman, in the extreme northeastern part of the county, moderate supplies of water sufficient for domestic supplies are obtained from the Tupelo tongue of the Coffee sand member of the Eutaw formation at depths of 250 to 375 feet (see wells 11,12 ); the static head of the water is about 70 feet below the surface. Greater supplies could be obtained by drilling to the main water-bearing beds of the Eutaw, which lie at estimated depths of 600 to 1,000 feet. 


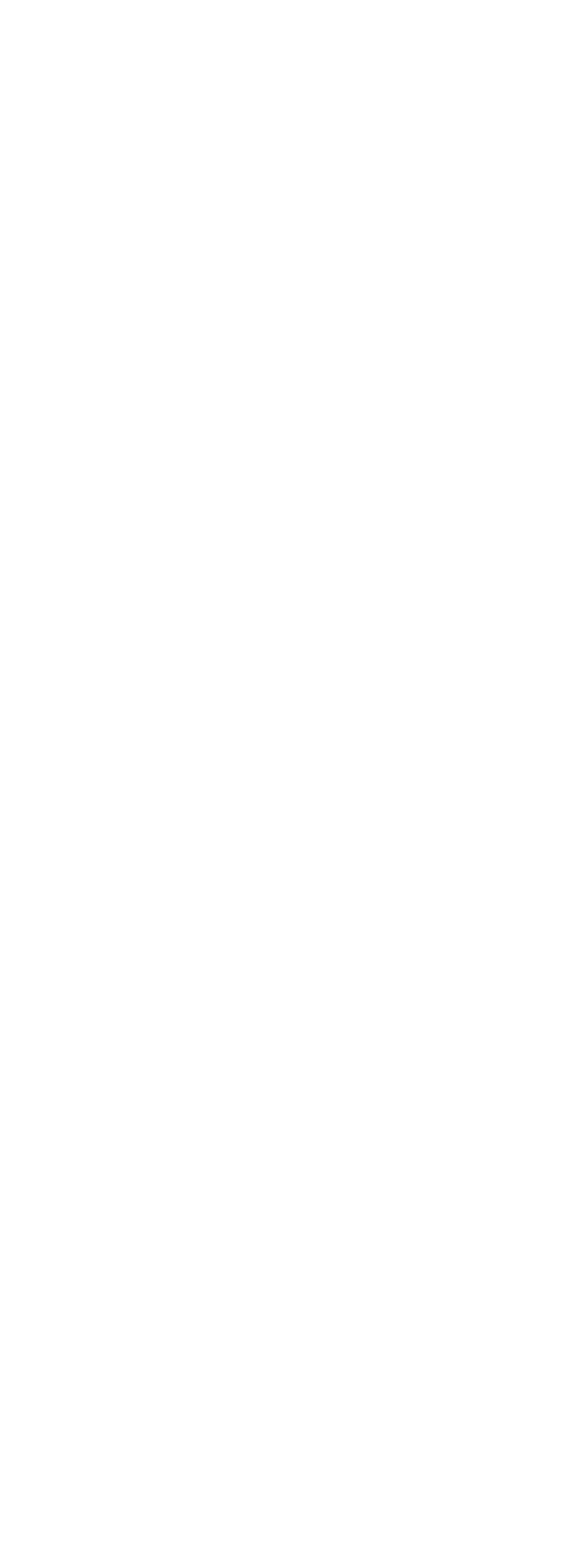




\begin{tabular}{|c|c|c|c|c|c|c|c|}
\hline 苑 & 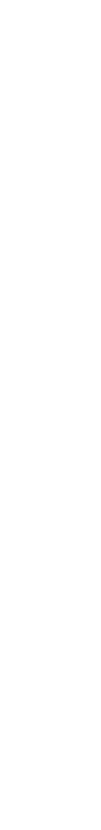 & 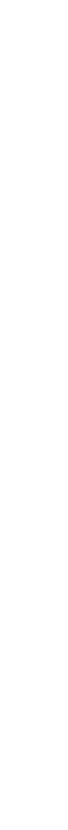 & 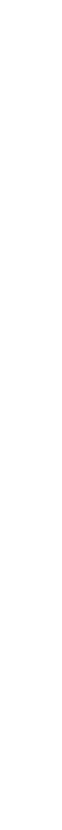 & 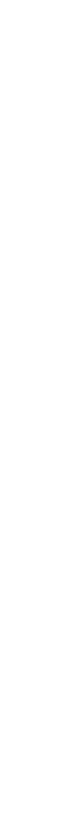 & 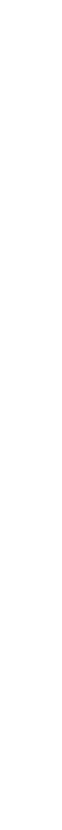 & $\begin{array}{l}8 \\
8 \\
8 \\
8 \\
8\end{array}$ & 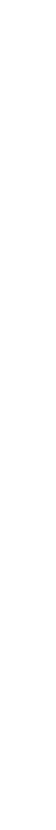 \\
\hline 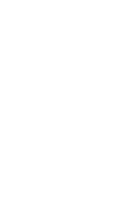 & 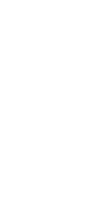 & 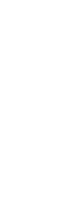 & 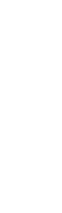 & & 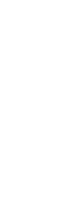 & 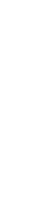 & 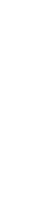 \\
\hline 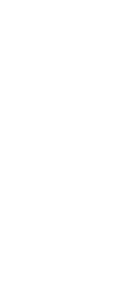 & 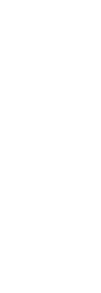 & 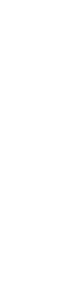 & 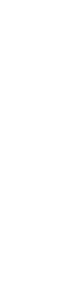 & 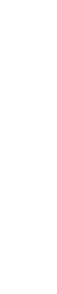 & 虽 & 政 & 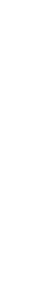 \\
\hline$\stackrel{\mathscr{8}}{\stackrel{8}{0}}$ & 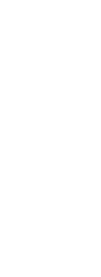 & 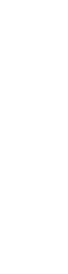 & 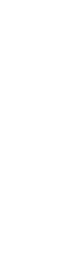 & 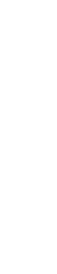 & 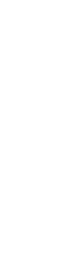 & مُ & 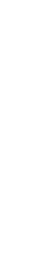 \\
\hline 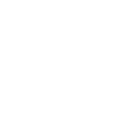 & 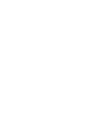 & 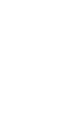 & 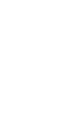 & 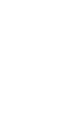 & : & 0 & 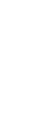 \\
\hline 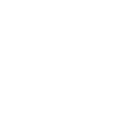 & o & & 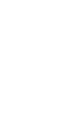 & wo & 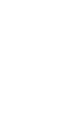 & 9 & \\
\hline$\dot{\mathbf{z}}$ & TNOA & no & $-\infty$ & $9=$ & 욤 & & \\
\hline
\end{tabular}




\section{Mineral analyses of ground waters from Pontotoc County}

[Parts per million. Numbers at heads of columns refer to corresponding well numbers in preceding table]

\begin{tabular}{|c|c|c|}
\hline & 10 & 14 \\
\hline 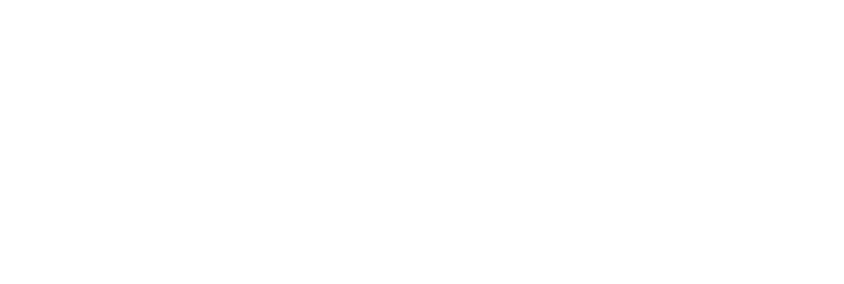 & $\begin{array}{l}14 \\
1.4 \\
57 \\
5.4 \\
17.0 \\
217^{6.0} \\
224^{.00} \\
\text { June, } 1914\end{array}$ & $\begin{array}{l}67 \\
18 \\
70 \\
22 \\
206 \\
220^{\circ} \\
329 \\
128 \\
\text { July, }_{267^{\circ}}^{960} \\
1914\end{array}$ \\
\hline
\end{tabular}

Analysts: 10, W. F. Hand, Mississippi State Chemical Laboratory; 14, Mississippi State Ohemical Laboratory.

\section{PREATTISS COUNTY}

\section{GENERAL FEATURES}

Area, 409 square miles. Population, 17,606 (census of 1920)

Prentiss County lies mostly within the Tombigbee Hills district, but has a westward extension into the Black Prairie belt. The Tuscaloosa, the oldest of the Cretaceous formations of Mississippi, crops out on the lower slopes of Mackys Creek, in the extreme southeastern part of the county. The Eutaw formation, including the Tombigbee and Coffee sand members, appears at the surface throughout the hilly district east of the Mobile \& Ohio Railroad. The Selma chalk immediately underlies the surface of the Black Prairie belt in the western part of the county. In an area in the extreme northwest, about half a township in extent, the Selma is concealed by the overlapping strata of the Ripley formation. These four Cretaceous formations, the Tuscaloosa, Eutaw, Selma, and Ripley are more fully described on pages 29-43 and their distribution is shown on the geologic map (pl. 2). The strata that compose the formations all dip to the west at the rate of approximately 30 feet to the mile.

\section{GROUND-WATER CONDTTIONS}

Throughout the hilly area east of the Mobile \& Ohio Railroad supplies of water sufficient for domestic and farm uses are easily obtainable at shallow depths by dug and bored wells sunk to the water-bearing beds in the Eutaw formation. Hundreds of small springs feed the perennial headwater streams of Tombigbee River, and some of them are utilized by the inhabitants for domestic purposes. No deep wells have been reported from the Eutaw area except near its western margin, as at Baldwyn, Wheeler, and Booneville.

In the valley of Twentymile Creek, in the vicinity of Baldwyn and Wheeler, the waters of the Eutaw are obtained by means of 
wells 190 to 400 feet deep, and some of the wells that are located low on the slopes or in the valleys overflow. At Booneville the static head is 50 to 70 feet below the surface.

In the Black Prairie belt, in the western part of the county, artesian water can be obtained only by drilling through the Selma chalk to the underlying water-bearing sands of the Eutaw. These sands are reached at a depth of 190 feet in the extreme southwestern part of the county. (See well 5.) Along the western border of the Black Prairie belt, in the northwestern part of the county, the thickness of chalk that would have to be penetrated before reaching the Eutaw is estimated to be about 250 feet. Throughout the greater part of this area the static head of the water from the Eutaw is not high enough to cause flows even at the lowest levels in the creek valleys; on the divide west of Booneville the static head is probably 70 to 100 feet below the surface.

The Tuscaloosa formation, which underlies the Eutaw formation, consists of 200 feet or more of water-bearing sands and gravels and subordinate lenses of clay. Although the formation appears at the surface in a small area along Mackys Creek, in the extreme southeastern part of the county, the main belt of outerop (catchment area) lies farther to the esst, in eastern Tishomingo County, Miss., and in Franklin and Colbert Counties, Ala., where the upland reaches elevations above sea level of 600 to 900 feet. The waters of the Tuscaloosa in Prentiss County should therefore be under hydrostatic pressure sufficient to cause flows in the valleys of all the headwater creeks' of Tombigbee River in the county, probably even in such valleys as those of Wolf, Twentymile, and Town Creeks west of the Mobile \& Ohio Railroad. No wells deep enough to reach the Tuscaloosa have been reported within the county.

\section{LOCAL SUPPLIES}

Booneville.-The municipal waterworks at Booneville is located about two blocks north of the Mobile \& Ohia Railroad station east of the track. The water supply is obtained from four wells, each reported to be about 200 feet deep, known as wells Nos. 1 to 4 (Nos. 6-9 in the table). For an analysis of a sample of mixed water from wells Nos. 3 and 4, see analysis 8. An ice plant, which is connected with the waterworks, obtains water for the manufacture of ice from a well about 110 feet deep (No. 10). The water is slightly hard. (See analysis 10.) This well was originally 379 feet deep, but has filled up with sand within 110 feet of the surface. The following $\log$ shows the character of the beds penetrated in one of three wells at the old waterworks, now abandoned, just west of the business part of town: 
Log of well at the old waterworks plant, Booneville *

[ Altitude of mouth of well about 540 feet above sea level. Adapted from description by Crider and Johnson]

\begin{tabular}{|c|c|c|c|c|c|}
\hline & $\begin{array}{c}\text { Thick- } \\
\text { ness }\end{array}$ & Depth & & $\underset{\text { ness }}{\text { Thick- }}$ & Depth \\
\hline $\begin{array}{l}\text { Red clay (residual from the Selma } \\
\text { chalk) } \\
\text { Selma chalk: } \\
\text { Blue rock } \\
\text { Eutaw formation: } \\
\text { Bluish-green sandy clay, with } \\
\text { shells.-. } \\
\text { Blue sand; water bearing.... } \\
\text { Blue rock } \\
\text { Blue sand; water bearing. }\end{array}$ & \begin{tabular}{r|} 
Feet \\
18 \\
52 \\
\\
3 \\
40 \\
1 \\
7
\end{tabular} & $\begin{array}{r}\text { Feet } \\
18 \\
70 \\
\\
73 \\
113 \\
114 \\
121\end{array}$ & $\begin{array}{l}\text { Eutaw formation-Continued. } \\
\text { Blue hard rock. } \\
\text { Clay } \\
\text { Sand } \\
\text { Clay } \\
\text { Sand } \\
\text { Hard rock } \\
\text { Gray sand, with greensand } \\
\text { grains (glauconite) }\end{array}$ & $\begin{array}{c}\text { Feet } \\
11 / 2 \\
188 \\
11 / 2 \\
35\end{array}$ & $\begin{array}{l}\text { Feet } \\
1221 / 2 \\
3101 / 2 \\
312 \\
347\end{array}$ \\
\hline
\end{tabular}

- Crider, A. F., and Johnson, L. C., Mississippi Geol. Survey Bull. 1, p. 45, 1907.

A spring $31 / 2$ miles east of Booneville emerges from the side of a hill and yields less than 1 gallon a minute. It probably has its source in a sand bed in the Coffee sand member of the Eutaw formation. (See analysis 17.)

Baldwyn.-The town of Baldwyn is partly in Prentiss County and partly in Lee County, on the south. Several deep wells on the Prentiss County side are described in the table of well data (Nos. 1-4). The waterworks at Baldwyn is owned by the town and is located on the Prentiss County side. The water supply is obtained from a 410-foot well (No. 2), about 1,200 feet north of the Mobile \& Ohio Railroad station, on ground about level with the track at the station.

\section{Log of well of Baldwyn Brick \& Tile Co., Baldwyn a}

[ Altitude of mouth of well about 360 feet above sea level. Adapted from description by Logan and Perkins]

\begin{tabular}{|c|c|c|}
\hline & Thickness & Depth \\
\hline $\begin{array}{l}\text { Eutaw formation: } \\
\text { Clay and sand. } \\
\text { Material described as himestone, probabiy inaccurately } \\
\text { Clay and sand. } \\
\text { Sand; water bearing }\end{array}$ & $\begin{array}{r}\text { Feet } \\
\pm 40 \\
74 \\
220 \\
46\end{array}$ & $\begin{array}{r}\text { Feet } \\
\quad \pm 40 \\
114 \\
\mathbf{3 3 4} \\
\mathbf{3 8 0}\end{array}$ \\
\hline
\end{tabular}

- Logan, W. N., and Perkins, W. R., The underground waters of Mississippi: Mississippi Agr. Exper: Sta. Bull. 89, p. 24,1915 .

Wheeler.-Many wells which range in depth from 100 to 400 feet and tap water-bearing beds in the Eutaw formation have been drilled in the vicinity of Wheeler. Some of them, in the valley of Twentymile Creek, overflow. Analyses 15 and 16 represent rather hard waters. 


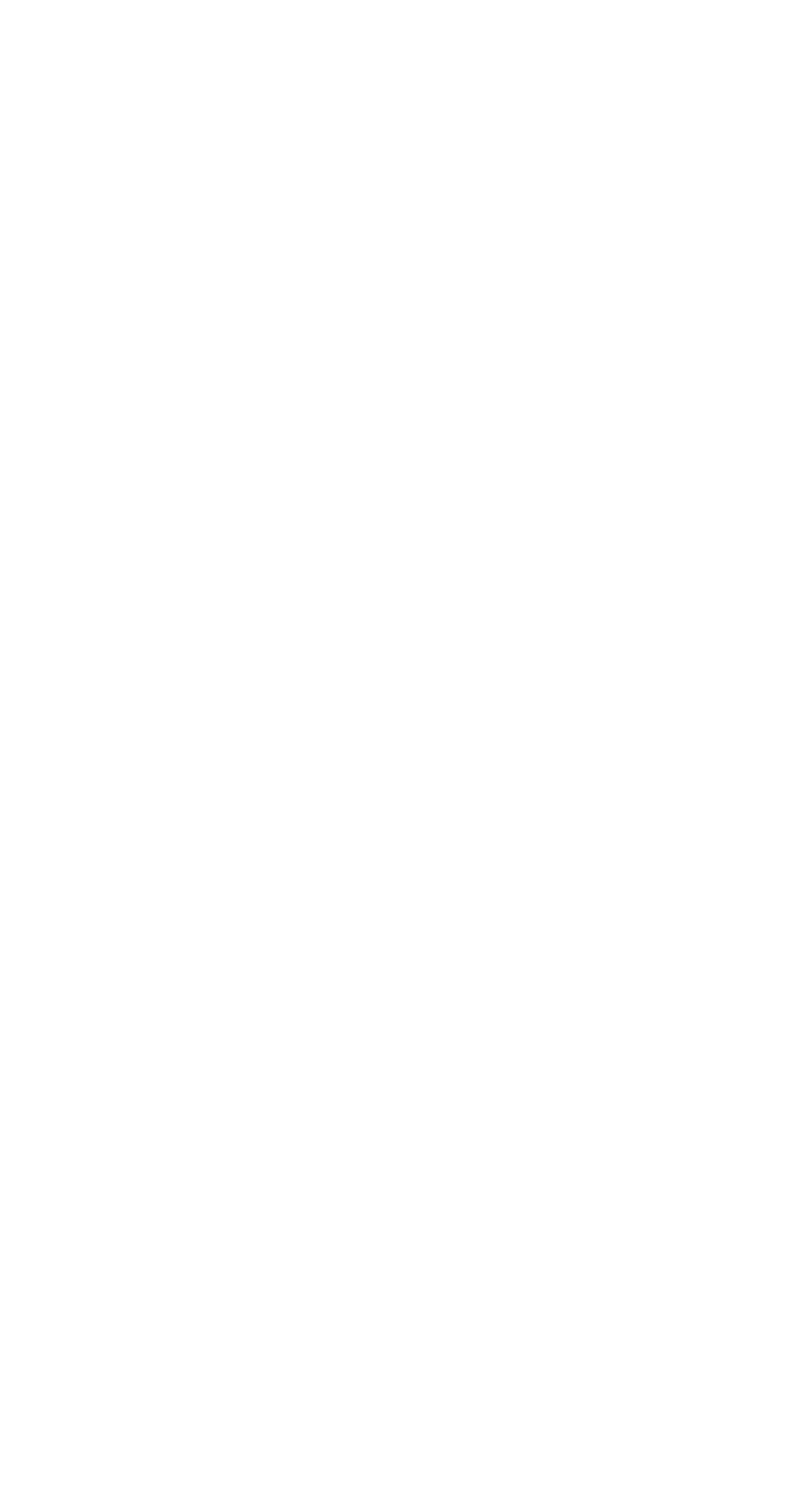




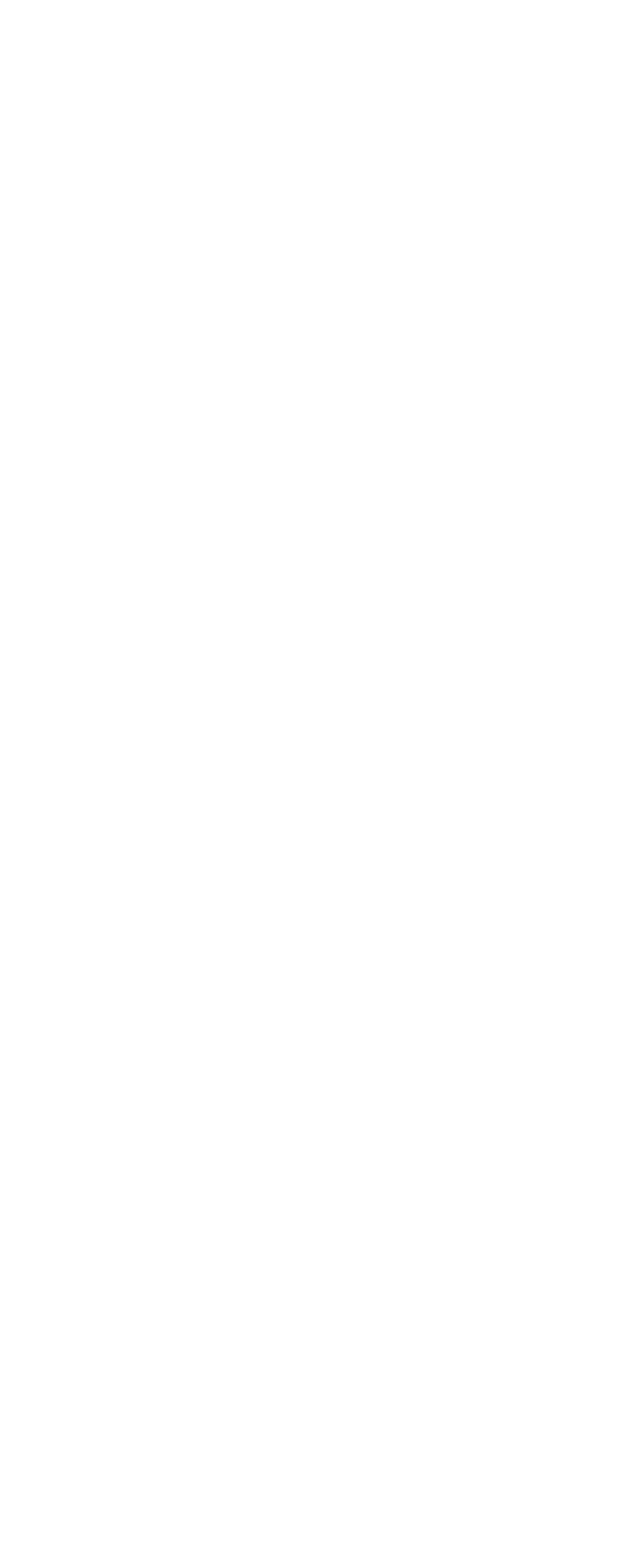




\section{Mincral analyses of ground waters from Prentiss County}

[Parts per million. Numbers at heads of columns refer to corresponding well and spring numbers in preceding table]

\begin{tabular}{|c|c|c|c|c|c|c|c|c|}
\hline & 2 & 3 & .8 & 10 & 13 & 15 & 16 & 17 \\
\hline 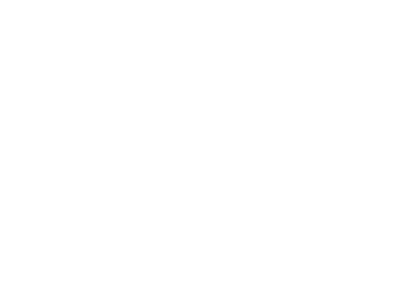 & $\begin{array}{l}15 \\
2.7 \\
29 \\
3.4 \\
26 \\
137^{\circ} \\
7.9 \\
21^{10} \\
170^{\circ} \\
86 \\
190 \\
1914\end{array}$ & $\begin{array}{l}23 \\
24.64 \\
6.6 \\
28 \\
1.9 \\
130 \\
10 \\
20 \\
181.52 \\
87 \\
\text { sept.; } \\
1919\end{array}$ & $\begin{array}{c}45 \\
9.1 \\
14 \\
5.0 \\
26 \\
7.7 \\
92 \\
13 \\
2.4 \\
\text { Trace. } \\
166 \\
56 \\
\text { Sept., } \\
1919\end{array}$ & $\begin{array}{l}36 \\
7.0 \\
35^{4} \\
4.7 \\
20 \\
152^{\circ} \\
22 \\
1.4 \\
\text { Trace. } \\
200 \\
107 \\
80 p t ., \\
1919\end{array}$ & 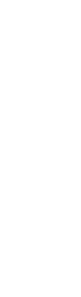 & $\begin{array}{l}18 \\
52 \\
12 \\
12 \\
12 \\
200 \\
37.0 \\
37.2 \\
1.1 \\
232 \\
179 \\
\text { Sept., } \\
1919\end{array}$ & $\begin{array}{c}25 \\
36 \\
6.50 \\
6.8 \\
19^{\circ} \\
145^{\circ} .0 \\
18 \\
15 \\
188^{\circ} .42 \\
118 \\
\text { Sept.. } \\
1919\end{array}$ & $\begin{array}{c}16 \\
13 \\
2.05 \\
2.9 \\
3.8 \\
20 \\
20 \\
5.0 \\
5.7 \\
\text { Trace. } \\
74 \\
44 \\
\text { Bept., } \\
1019\end{array}$ \\
\hline
\end{tabular}

- Composite sample of two wells, Nos. 8 and 9 in precading table.

b Calculated.

Analysts: 2, 13, W. F. Hand, Mississippi State Chemical Laboratory; 3, 10, 16, 17, Margaret D. Foster and Clara M. Forman, U. S. Ceologieal Survey; 8, 15, Margaret D. Foster, U.' S. Geological Survey.

\section{QUTTMAN COUNTY}

\section{GENERAL FEATURES}

Area, 395 square miles. Population, 19,861 (census of 1920)

Quitman County is in the Yazoo Delta, in the northwestern part of Mississippi. The county is underlain by the alluvial deposits of Mississippi River, and beneath the alluvium lies a thick series of sedimentary deposits of Tertiary age. Of these deposits the Grenada, Holly Springs, and Ackerman formations of the Wilcox group, described on pages $45-48$, are of chief interest with respect to the ground-water supplies of the county.

\section{GROUND-WATER CONDITIONS}

The more porous sands and gravels of the alluvial deposits, which underlie the entire county to an estimated depth of 150 to 200 feet, contain an abundance of water that is under little or no artesian head. Bored and driven wells are easily sunk into these deposits, and the water is raised by ropes and buckets or by pumps. At many places the water table is so near the surface that suction pumps can be employed. Locally the shallower waters are rendered more or less objectionable by contact with vegetable matter buried in the alluvium.

The deposits of the Wilcox group of the Eocene underlie the alluvium, and the waters contained in the more porous sands are under artesian pressure. The Wilcox group, which probably has an aggregate thickness of 1,000 feet or more, is divisible in descending order into the Grenada, Holly Springs, and Ackerman formations, but the boundaries between these formations can not as a rule be recognized in well borings. It is believed, however, that most of the wells have their source in the Holly Springs sand, the middle forma- 
tion of the group, which is composed largely of unconsolidated sand that is capable of serving as a reservoir for large quantities of water. The deeper wells range in depth from 600 to 900 feet, and all of them flow; some of them have a head as high as 40 feet above the surface.

\section{LOCAL SUPPLIES}

Sledge.-A 3-inch well at Sledge, owned by J. A. Hanks, is 620 feet deep and flows 8 gallons a minute from sand at a depth of about 600 feet. (See analysis 6 .)

Essex.-At Essex, 8 miles north of Marks, the well of W. D. Conley, the depth of which is not stated, yields a moderate stream of water.

Belen.-Two flowing wells have been reported at Belen. One owned by W. T. Covington, is 880 feet deep and 6 inches in diameter (see analysis 1); the other, owned by M. E. Denton, is 840 feet deep and 2 inches in diameter. The Denton well flows 20 gallons a minute. In each well the flow comes from sand struck 30 or 40 feet above the bottom of the well.

Marks.-The municipal waterworks at Marks is about four blocks southwest of the courthouse. A 41/2-inch well, which is reported to be about 700 feet deep and flows 75 gallons a minute, provides the water supply. (See analysis 3.) There are several privately owned deep flowing wells of large yield in the town, including a 2-inch well owned by W. A. Cox, which is 630 feet deep and yields 70 gallons a minute, and a 3-inch well, owned by L. Marks, which is 636 feet deep and yields 60 gallons a minute. (See analyses 4 and 5.)

The following is the log of the well owned by L. Marks:

Log of well of L. Marks, three-fourths of a mile east of Marks

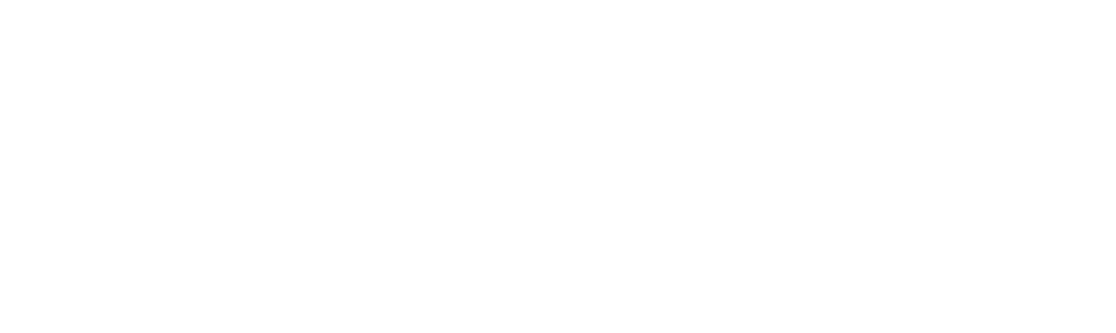

Lambert.-The municipal water supply at Lambert is provided by a well two blocks southwest of the Yazoo \& Mississippi Valley Railroad station, the depth of which is reported somewhat questionably to be about 900 feet. (See analysis 2.) A 700-foot well owned by the Bacon Nolan Co., $11 / 2$ miles southeast of Lambert, flows 100 gallons a minute from a $21 / 2$-inch casing. The water is derived from sand at a depth of 650 to 700 feet, and the static head is reported to be 40 feet above the surface. A 2-inch flowing well owned by J. W. 
Koger, the Delta Gin Co., and others is 690 feet deep and yields 60 gallons a minute, and the 2-inch flowing well of H. L. Hamilton, 720 feet deep, yields 50 gallons a minute from sand in the lower 40 feet.

Longstreet.-At Longstreet water is obtained in part from dug and driven wells 20 to 25 feet in depth and in part from drilled wells 700 feet or more in depth. The flowing well of S. H. Britt is 750 feet deep and yields a strong stream of water that is used for domestic supplies.

Mineral analyses of ground waters from Quitman County

[Parts per million]

\begin{tabular}{|c|c|c|c|c|c|c|}
\hline & 1 & 2 & 3 & 4 & 5 & 6 \\
\hline 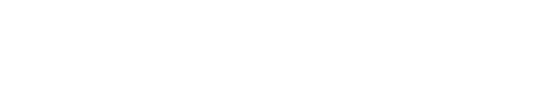 & $\begin{array}{l}40 \\
.60 \\
3.5 \\
4.3\end{array}$ & $\begin{array}{l}26 \\
1.4 \\
6.8 \\
1.7\end{array}$ & $\begin{array}{l}47.26 \\
1.9 \\
1.3\end{array}$ & ${ }_{6.5}^{25} .70$ & $\begin{array}{r}74 \\
1.5 \\
3.2 \\
1.0\end{array}$ & $\begin{array}{r}20 \\
1.5 \\
6.9 \\
3.7\end{array}$ \\
\hline Sodinm and potassium $(\mathrm{Na}+\mathrm{K})$ & b 55 & 651 & 65 & 32 & & 333 \\
\hline 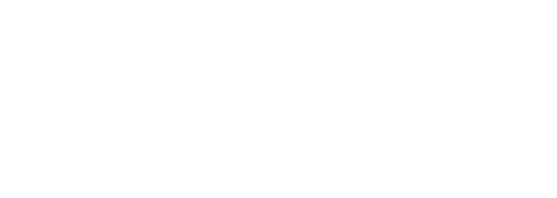 & $\begin{array}{l}161^{.0} \\
4.4 \\
7.0 \\
194.20 \\
26 \\
\text { Aug.; } \\
1911\end{array}$ & $\begin{array}{r}140^{.0} \\
4.3 \\
3.0 \\
16 \\
178 \\
24 \\
\text { Aug.; } \\
1911\end{array}$ & $\begin{array}{l}97^{-23} \\
5.1 \\
3.2 \\
2.4 \\
181 \\
10 \\
\text { Aug., } \\
1911\end{array}$ & $\begin{array}{r}137^{-0} \\
2.2 \\
4.0 \\
5.0 \\
156 \\
54 \\
\text { Aug., } \\
1911\end{array}$ & $\begin{array}{r}134.0 \\
3.4 \\
4.6 \\
\hdashline 205 \\
12 \\
\hdashline-.0\end{array}$ & $\begin{array}{l}105^{\circ} \\
18 \\
1.0 \\
136 \\
32 \\
\text { Aug. }_{1911}\end{array}$ \\
\hline
\end{tabular}

- Iron and aluminum oxides $\left(\mathrm{Fe}_{2} \mathrm{O}_{3}+\mathrm{Al}_{2} \mathrm{O}_{3}\right)$.

- Calculated.

Analysts: 1, 2, 4, 6, W. L. Kennon, University of Mississippi; 3, Margaret D. Foster and Clara M. Forman, U. S. Geological Survey; 5, W. R. Perkins (Mississippi Agr. Exper. Sta. Bull. 89, p. 100, 1905).

1. 880-foot well of $W$. T. Covington, at Belen.

2. $900 \pm$ foot town well at Lambert.

3. 700-foot town well at Marks.

4. 630-foot well of W. A. Cox at Marks.

5. 636-foot well of L. Marks at Marks.

6. 620-foot well of J. A. Hawks at Sledge.

\section{RANKIN COUNTY}

\section{GENERAL FEATURES}

Area, 791 square miles. Population, 20,272 (census of 1920)

Rankin County lies east of Pearl River in the south-central part of the State, about equally divided between the Jackson Prairie belt and the Long-leaf Pine Hills district. The lithologic character and physiographic expression of the Jackson formation, the Vicksburg group, and the Catahoula sandstone, the three geologic divisions that underlie the county, are discussed on pages 53-56, and their approximate distribution in the county is shown on the geologic map (pl. 2).

\section{GROUND-WATER CONDITIONS}

The Jackson formation (Eocene) immediately underlies most of the northern part of the county. The Moodys marl, the basal member of the formation, contains sandy beds that may afford moderate supplies of water suitable for ordinary domestic and farm use. Some of the wells in the northern part of the county (No. 3), 
probably tap water-bearing beds in this member, and emall springs occur in places on the outcrop of the sandy layers. The Yazoo clay, the upper member of the Jackson, is not water bearing, and in the belt in which it crops out in the center of the county cisterns for storing rain water are in common use.

In the Vicksburg group the only formation that appears to be of suitable physical character to contain water is the Forest Hill sand, the basal formation of the group, which crops out in an eastwardtrending belt through the center of the county. The sand is believed to be the source of several springs of small to moderate yield in the vicinity of Pearson and elsewhere in the valley of Richland Creek. One 208-foot well (No. 4), 3 miles east of Johns, probably taps the buried southward extension of the Forest Hill sand.

The area underlain by the Catahoula sandstone in the southern part of the county south of Richland Creek valley is well watered. Small springs are common, and dug, bored, and drilled wells that range in depth from 15 to 100 feet yield adequate supplies of nonflowing water to meet the needs of this agricultural district. Analyses of samples of water from wells and springs in the Catahoula formation are given in the table.

Except in one or two wells the water contained in the more deeply buried formations of Rankin County has not been utilized. One well at Goshen Springs, 152 feet deep, probably draws its supply from the Yegua, the uppermost formation of the Claiborne group (Eocene), as does also the 586-foot well of the Gammill Lumber Co., at Pelahatchee. A dozen or more wells, 600 to 1,200 feet deep, in Hinds, the adjoining county on the west, particularly in the vicinity of Jackson, tap water-bearing beds that are interpreted to belong to the Claiborne group. (See pp. 200-210:) Logs of typical wells are given on pages 202-207. These wells, together with the 1,135-foot well at Taylorsville, in Smith County, on the southeast, afford abundant evidence that water can be obtained from the Claiborne group by deep drilling anywhere in Rankin County. The Yegua, the uppermost formation of the Claiborne, appears at the surface in the extreme northern part of Rankin County and is also exposed to the west in Hinds County at two localities within 3 miles northeast of Jackson. As the beds of both the Claiborne group and the overlying Jackson formation are believed to lie nearly horizontal between the city of Jackson and the northern extremity of Rankin County, ${ }^{47}$ the top of the Yegua formation probably lies less than 200 feet below the surface throughout the northern half of the county. An average dip of 30 feet to the mile would carry the top of the Yegua to a depth of 700 .or 800 feet below sea level along the southern boundary, which would

"Hopkins, O. B., U. 8. Geol. Survey Bull. 641, pp. 109, 110, pl. 8, 1916. 
be 1,000 to 1,300 feet below the surface. The Yegua formation, here about 400 (?) feet thick, is water bearing.

The Yegua formation is underlain by the Lisbon formation of the Claiborne group and this in turn by the Tallahatta, the basal formation of the group in this county. These formations are together 800 or 1,000 feet thick and both contain water-bearing beds. Probably most of the deep wells in the vieinity of Jackson, Hinds County, tap water-bearing beds in the Tallahatta. Some of the deeper wells, the waters of which are rather highly mineralized, may draw from the Wilcox group, which underlies the Claiborne group.

\section{LOCAL SUPPLIES}

Brandon.-Brandon, the county seat, is provided with a small waterworks, which is owned by the Brandon Water \& Light Co. The source of the water is a spring in a branch valley about half a mile north of the public square and about 70 feet lower than the hill on which the main part of the town is built. The yield of the spring is about 5 gallons a minute. (See analysis 13.)

Pelahatchee.-The Gammill Lumber Co., whose mill is half a mile east of Pelahatchee, owns a 586-foot well (No. 6) located at the plant, which provides water for the boilers and for the domestic use of the employees.

Niknar Spring.-Niknar Spring, 2 miles esst of Pearson, in the SW. $1 / 4$ sec. 28 , T. 5 N., R. 2 E., probably has its source in the Forest Hill sand. The spring does not overflow and is in a sense a shallow well. The water is used for domestic purposes.

Piney Woods Country Life School (Belpine).-At Piney Woods Country Life School, a colored industrial school 4 miles southeast of Star, a water supply for the general uses of the school is obtained from three springs which are within a quarter of a mile of the buildings and which have their source in the Catahoula formation. Analysis 14 represents a sample of water from one of the springs. 


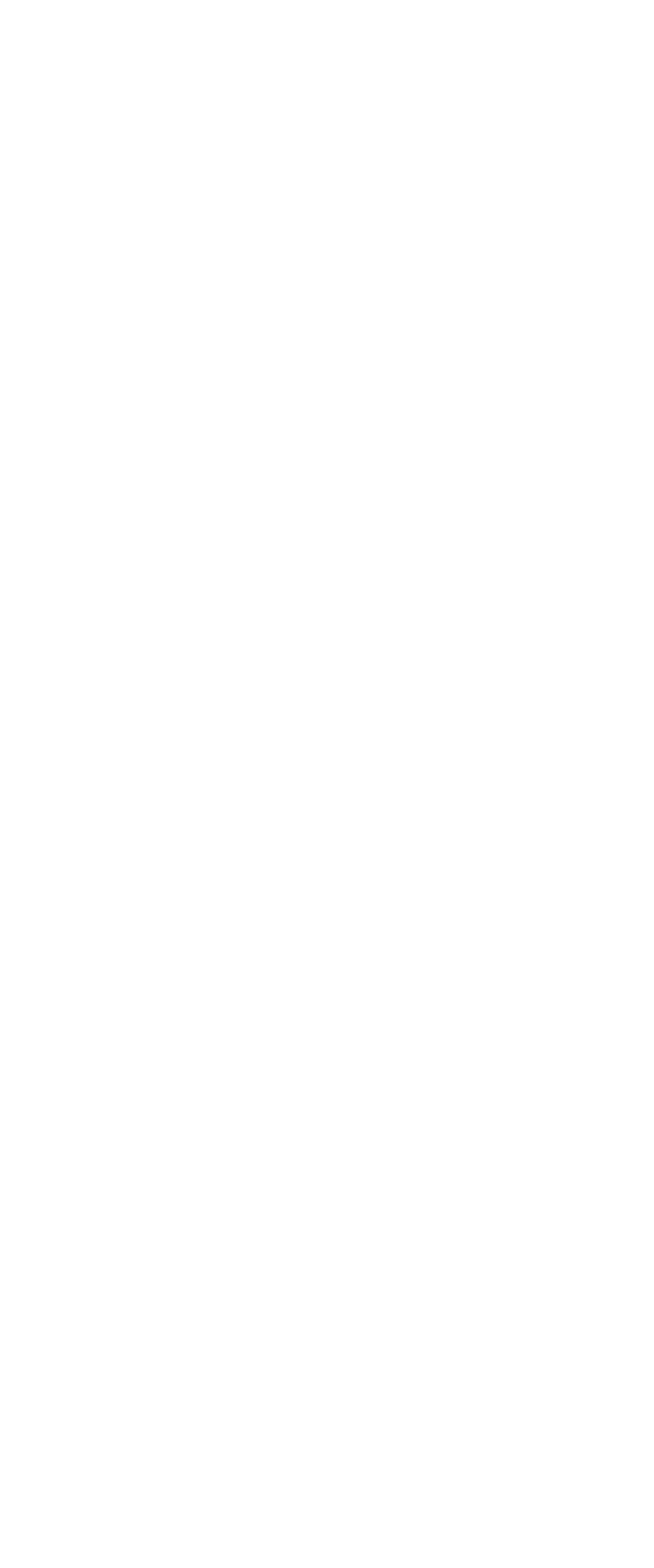




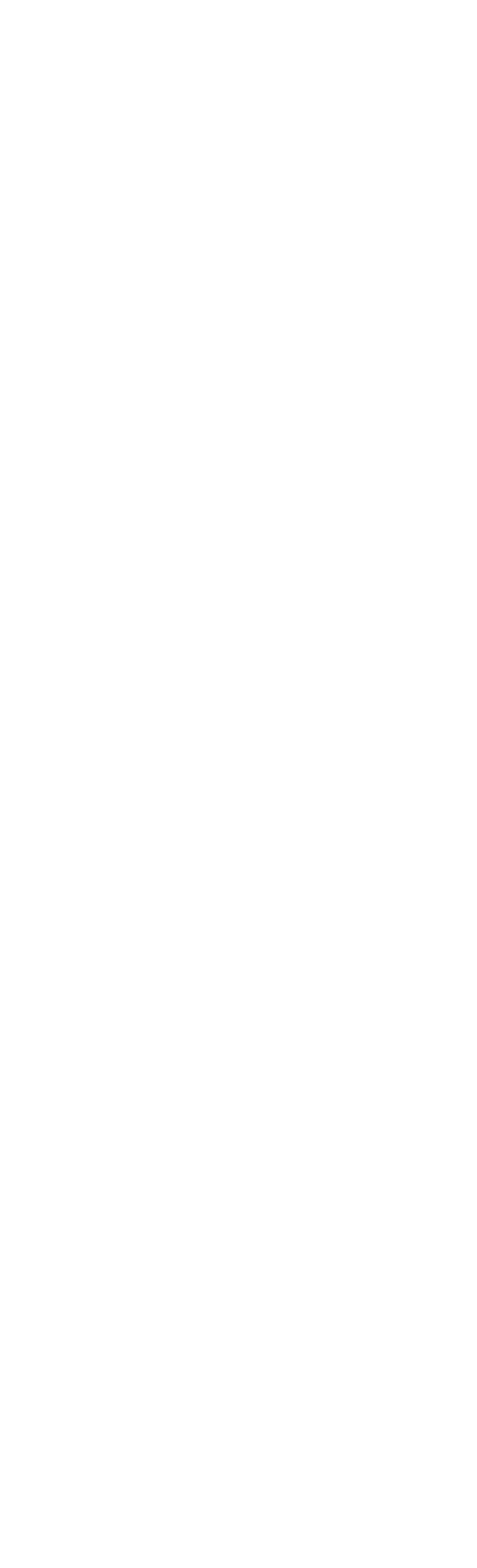


Mineral analyses of ground waters from Rankin County

[Parts per million. Numbers at heads of columns refer to corresponding well and spring numbers in preceding table]

\begin{tabular}{|c|c|c|c|}
\hline & 6 & 13 & 14 \\
\hline 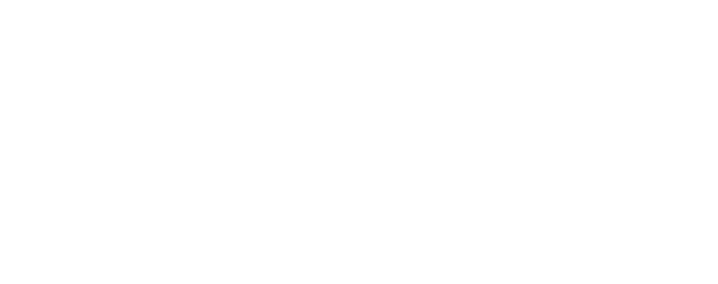 & 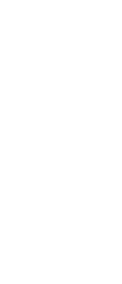 & $\begin{array}{l}{ }_{1.43}^{32} \\
2.7 \\
1.0 \\
28.0 \\
2.1 \\
9.4 \\
9.3 \\
93 \\
13 \\
\text { Aug., } 1919\end{array}$ & $\begin{array}{l}13 \\
.61 \\
.8 \\
6.5 \\
.0 \\
9.8 \\
7.4 \\
8.5 \\
3.4 \\
39 \\
4 \\
\text { Dec., } 1913\end{array}$ \\
\hline
\end{tabular}

a Calculated.

Analysts: 6, 13, Margaret D. Foster, U. 8. Geological Survey; 14, Mississippi State Chemical Laboratory•

\section{SCOTT COUNTY}

\section{GENERAL FEATURES}

Area, 597 square miles. Population, 16,420 (census of 1920)

Scott County, a little southeast of the center of the State, lies mostly within the Jackson Prairie belt, but about one-third of the county extends into the North Central Hills. The geologic formations that underlie the county appear in belts of varying width that belong chiefly to the Eocene and include the Lisbon and Yegua formations of the Claiborne group and the Jackson formation. In addition to these formations the divides in the southern part of the county are covered with surficial sands and gravels that belong in part to the Forest Hill sand of the Vicksburg group (Oligocene) and in part to the Citronelle formation (Pliocene). Descriptions of these formations are given on pages $50-60$, and their distribution is shown on the geologic map (pl. 2).

\section{GROUND-WATER CONDITIONS}

The formations mentioned above probably all contain water-bearing beds of some economic value, though the Jackson is only sparingly water bearing. The principal sources of water appear to be the Lisbon and Yegua formations.

The Eocene formations dip south by west at estimated rates between 20 and 30 feet to the mile, and the waters contained in their deeper portions are under hydrostatic pressure, though in none of the wells thus far reported has the head of the water been high enough to cause flows at the surface. Flowing wells could probably be obtained in some of the deeper valleys, sueh as that of Young Warrior Creek in the north.

Springs of small yield are common throughout the greater part of the county. 
In some parts of the Jackson area the clay of this formation is blanketed with a surficial covering of sand, sandy clay, and gravel, which probably belongs in part to the Forest Hill sand of the Vieksburg group and in part to the Citronelle formation (Pliocene). These materials yield fair supplies of water suitable for domestic ase. Two wellø (Nos. 9, 10) on J. T. Faulkner's place, 5 miles southwest of Forest, the logs of which are given below, probably have their souree in these surfieial materials.

\section{LOCAT SUPPLIES}

Forkville.-Forkville is a small village on Coffee Bogue 8 miles north of Morton. In a 72-foot well owned by J. A. Morgan (No. 11), 4 miles southwest of Forkville, a large supply of soft water is obtained from the Yegua formation, just beneath the Jackson formation. The water is under a head that brings it within 6 feet of the surface. The G. M. Duncan well (No. 12), 11/2 miles southwest of Forkville, also yields a good supply of water from a sandstone in the lisbon formation. The materials penetrated in this well are as follows:

Log of well of G. M. Dumean, 11/2 miles southwest of Forkille (No. 18)

\begin{tabular}{|c|c|c|}
\hline & Thickness & Depth \\
\hline $\begin{array}{l}\text { Yegua formation: } \\
\text { Yenow cilyy } \\
\text { Joint clay }\end{array}$ & Feet $\begin{array}{r}10 \\
30\end{array}$ & Feet $\begin{array}{r}10 \\
40\end{array}$ \\
\hline $\begin{array}{l}\text { J.ibbon formiation: } \\
\text { Bue mud } \\
\text { Limestone; } \\
\text { Blue sand. } \\
\text { Sandstone; with water }\end{array}$ & $\begin{array}{r}10 \\
2 \\
9 \\
4\end{array}$ & $\begin{array}{l}50 \\
52 \\
61 \\
65\end{array}$ \\
\hline
\end{tabular}

Balucta.-The N. F. Duncan well (No. 1), near Balucta, taps a water-bearing blue sand at a depth of 45 feet, perhaps the same stratum as that which was encountered in the G. M. Duncan well at a depth of 52 feet.

Horseshoe and Damascus.-In the northeastern part of the county, at Horseshoe, and at Damascus, a mile east of Horseshoe, water is obtained in part from shallow wells that tap only the first waterbearing bed, but better supplies are furnished by deeper drilled wells. The deepest well at Horseshoe is reported to be 195 feet deep and at Damascus 90 feet; both wells enter the upper water-bearing sands of the Lisbon formation.

Sebastopol.-At Sebastopol, near the northeast corner of the county, the dug well of Dr. W: F. Johnson (No. 22), is only 27 feet deep and taps a water-bearing bed in the Lisbon formation.

Gum Springs.-Near Gum Springs, 4 miles east of Hillsboro, water is obtained by means of relatively shallow wells that enter sandy layers in the Lisbon formation. The G. A. Mellhenny well taps a 
white water-bearing sand at a depth of 55 to 60 feet. The springs from which the place is named are on the property of A. A. Eady, at the base of a hillside; the water emerges at a point 7 feet above the level of Tallabogue Creek.

Morton.-In the vicinity of Morton, in the southwestern part of the county, deep wells which tap water-bearing sands probably in the Lisbon formation, are the chief source of supply. The clays of the Jackson formation do not afford good shallow supplies. The New Lumber Co. at Morton owns an 800-foot well (No. 20), which did not yield a satisfactory supply. The log of one of the two wells owned by the Hall-Legan Lumber Co. is given below:

Log of well No. 1 of the Hall-Legan Lumber Co., at Morton (No. 18)

[Furnished by E. N. Lowe, State geologist; Layne \& Bowler, drillers]

\begin{tabular}{|c|c|c|c|c|c|}
\hline & $\begin{array}{c}\text { Thick- } \\
\text { ness }\end{array}$ & Depth & & $\begin{array}{c}\text { Thick- } \\
\text { ness }\end{array}$ & Depth \\
\hline $\begin{array}{l}\text { Jackson formation and Clai- } \\
\text { borne group: } \\
\text { Red clay } \\
\text { Blue clay. } \\
\text { Gumbo } \\
\text { "Soapstone" (clay) } \\
\text { Fine blue sand } \\
\text { Gumbo } \\
\text { Shells and sand } \\
\text { Gumbo }\end{array}$ & $\begin{array}{rr}\text { Ft. } & \text { in. } \\
39 & 10 \\
95 & 9 \\
94 & 8 \\
69 & 7 \\
7 & 2 \\
19 & 2 \\
15 & 0 \\
4 & 2\end{array}$ & $\begin{array}{rr}\text { Ft. } & \text { in. } \\
39 & 10 \\
135 & 7 \\
200 & 3 \\
299 & 10 \\
307 & 0 \\
326 & 2 \\
341 & 2 \\
345 & 4\end{array}$ & $\begin{array}{l}\text { Jackson formation and Clai- } \\
\text { borne group-Continued. } \\
\text { Mica and silt. } \\
\text { Very fine muddy-brown } \\
\text { packed sand.... } \\
\text { white packed sand; water } \\
\text { bearing (Lisbon forma- } \\
\text { tion ?) } \\
\text { Gumbo }\end{array}$ & $\begin{array}{rr}\text { Ft. } & \text { in. } \\
19 & 1 \\
57 & 2\end{array}$ & $\begin{array}{lr}F t . & \text { in. } \\
364 & 5 \\
421 & 7\end{array}$ \\
\hline
\end{tabular}

Forest.-The town of Forest is equipped with an elevated tank and mains and is furnished with water under contract by the Bienville Lumber Co., whose plant is about half a mile west of the courthouse. The source of the water is a well, reported to be 398 feet deep (No. 5), which is located at the plant. (See analysis 5.) The municipal supply was formerly obtained from two wells, each reported to be about 365 feet deep (Nos. 3, 4), located at a pumping plant near the 50,000-gallon elevated steel tank. These wells and the pumping plant are kept in condition for use in an emergency. The log of an abandoned 683-foot well (No.6) is given below. (See analysis 6.) A 361-foot well (No. 7) is the present source of water for the boilers of locomotives.

Log of well of Alabama \& Vicksburg Railroad, at Forest (No. 6)

[Furnished by E. N. Lowe, State geologist; Layne \& Bowler Co., drillers]

\begin{tabular}{|c|c|c|c|c|c|}
\hline & $\begin{array}{c}\text { Thick- } \\
\text { ness }\end{array}$ & Depth & & $\begin{array}{c}\text { Thick- } \\
\text { ness }\end{array}$ & Depth \\
\hline $\begin{array}{l}\text { Jackson formation and Clai- } \\
\text { borne group: } \\
\text { Clay } \\
\text { Gumbo. } \\
\text { Rock } \\
\text { Gumbo } \\
\text { Dark sand and shelis } \\
\text { Fine, hard white packed } \\
\text { sand (Lisbon formation); } \\
\text { water bearing } \\
\text { Gumbo; in terstratified } \\
\text { with rock in lower } 75 \text { feet. } \\
\text { Rock }\end{array}$ & $\begin{array}{rr}\text { Ft. } & \text { in } \\
30 & 0 \\
20 & 0 \\
15 & 0 \\
119 & 0 \\
24 & 0 \\
& \\
153 & 0 \\
164 & 2 \\
3 & 5\end{array}$ & $\begin{array}{rl}F t & \text { in. } \\
30 & 0 \\
50 & 0 \\
65 & 0 \\
184 & 0 \\
208 & 0 \\
& \\
361 & 0 \\
525 & 2 \\
528 & 7\end{array}$ & 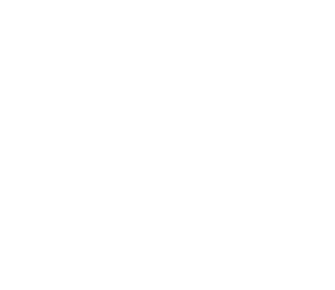 & $\begin{array}{rr}\text { Ft. } & \text { in. } \\
30 & 2 \\
4 & 9 \\
9 & 6 \\
42 & 3 \\
47 & 2 \\
& \\
12 & 0 \\
8 & 9\end{array}$ & $\begin{array}{c}F t, i n \\
558 \\
563 \\
573 \\
615 \\
662\end{array}$ \\
\hline
\end{tabular}


Log of well at home of Z. T. Faulkner, 5 miles southwest of Forest (No. 9)

\begin{tabular}{|c|c|c|}
\hline & Thickness & Depth \\
\hline $\begin{array}{l}\text { Red clay } \\
\text { Gravel and sand. } \\
\text { White sand } \\
\text { Olay and sand. } \\
\text { Sandy clay. } \\
\text { Cravel and sand; to impervious clay }\end{array}$ & $\begin{array}{r}\text { Feet } \\
\\
5 \\
5 \\
4 \\
3 \\
4 \\
1\end{array}$ & $\begin{array}{rr}\text { Feet } & \\
& 5 \\
10 \\
14 \\
17 \\
21 \\
22\end{array}$ \\
\hline
\end{tabular}

Log of public well at Forest

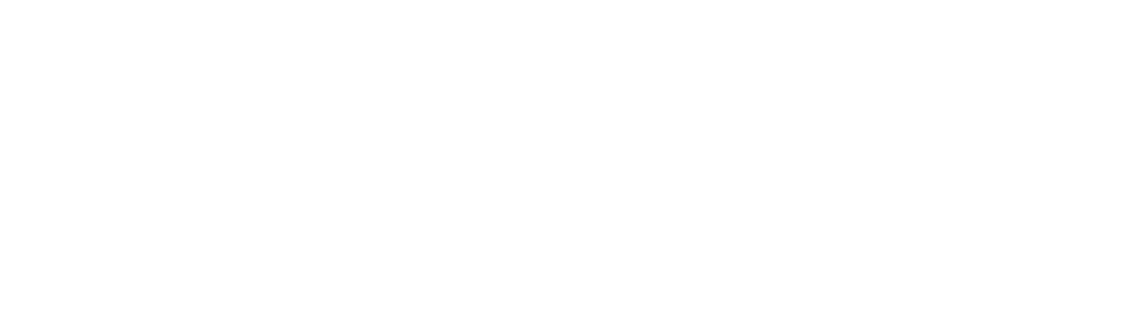

In a 370-foot well (No.8) 2 miles south of Forest water was struck at a depth of 340 feet and rose within 75 feet of the surface. The well furnished water for domestic and stock use and for boilers at the sawmill.

Lake.-The 220-foot drilled well a mile west of Lake (No. 16) penetrated, in descending order, 100 feet of clay, 100 feet of waterbearing sand (Yegua formation?), and 20 feet of clay. The water rose within 30 feet of the surface. (See analysis 16.) In a 40-foot dug well at Lake, owned by W. C. Rush, water-bearing sand was reached at a depth of 30 feet.

Cooperville.-Springs owned by W. A. Palmer, 3 miles north of Cooperville, afford a domestic supply of clear, cool water. The water issues from the base of a bluff on the north bank of a small creek and probably comes from the Citronelle formation. Shallow drilled wells in the vicinity of Cooperville probably also derive their water from the same source. The 28-foot well of Mrs. H. L. Mayo (No. 2) is typical.

Norris.-In the vicinity of Norris in wells such as that of Eliza J. Mathews (No. 21) a sand that probably belongs to the Citronelle formation yields good supplies at depths of less than 60 feet. A number of springs in the vicinity of Norris also furnish domestic supplies from the same source. Springs owned by Eliza J. Mathews, $11 / 2$ miles northwest of Norris; W. A. Gatewood, $11 / 2$ miles southwest of Norris; and Meomard Gatewood, 2 miles southwest of Norris, yield small supplies-ample, however, for domestic use.

Gilbert and Sun.-In the vicinity of Gilbert and Sun, in the southeast corner of the county, the inhabitants obtain their domestic water supplies by means of shallow wells and from springs, in both of which the source of the water is sand that probably belongs to the Citronelle formation. The wells of W. P. Warren (No. 13), William Gaskins (No. 14), and J. W. Daniel (No. 23) are typical. A spring on the property of Mrs. A. Idom, $21 / 2$ miles northeast of Gilbert, also issues from the same sand. 


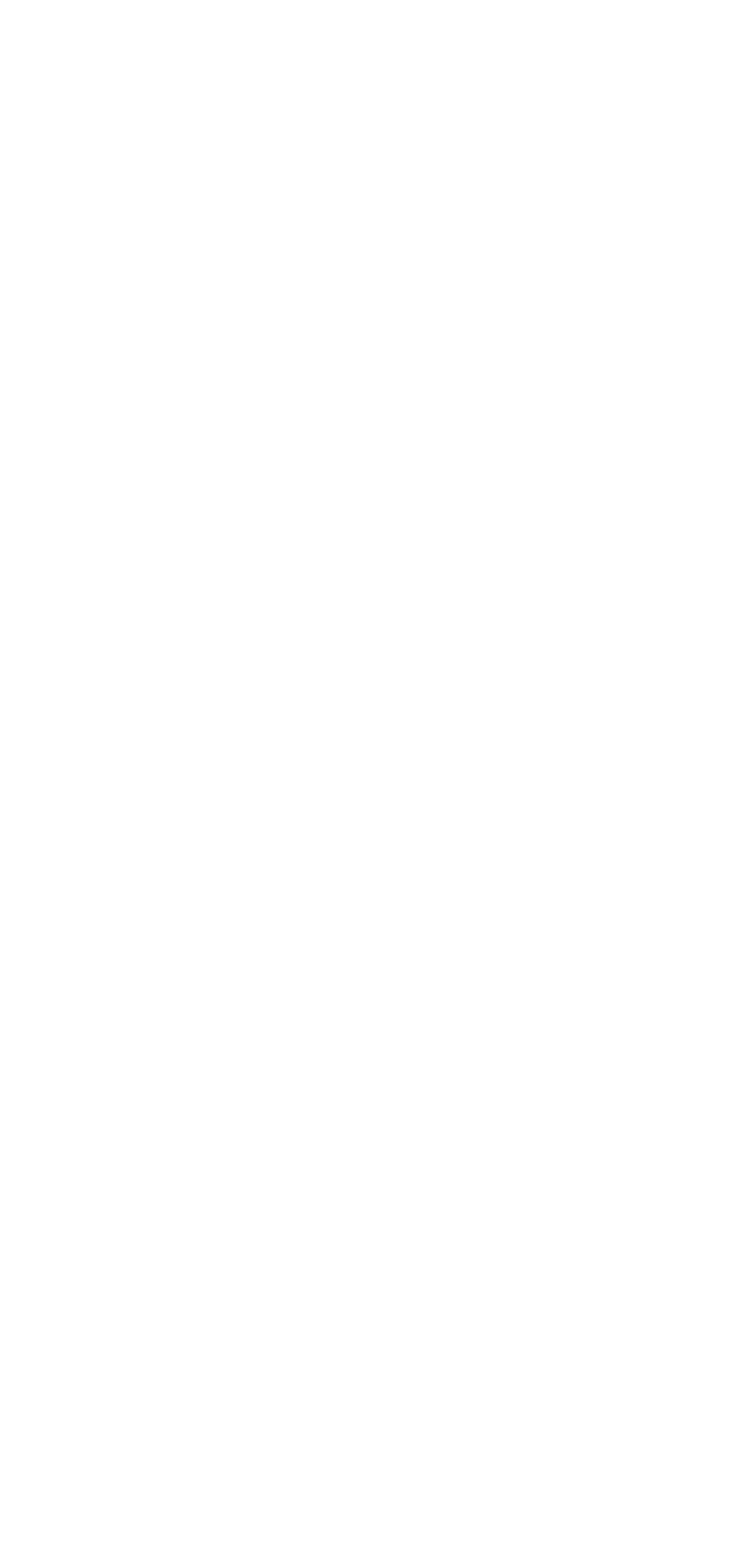




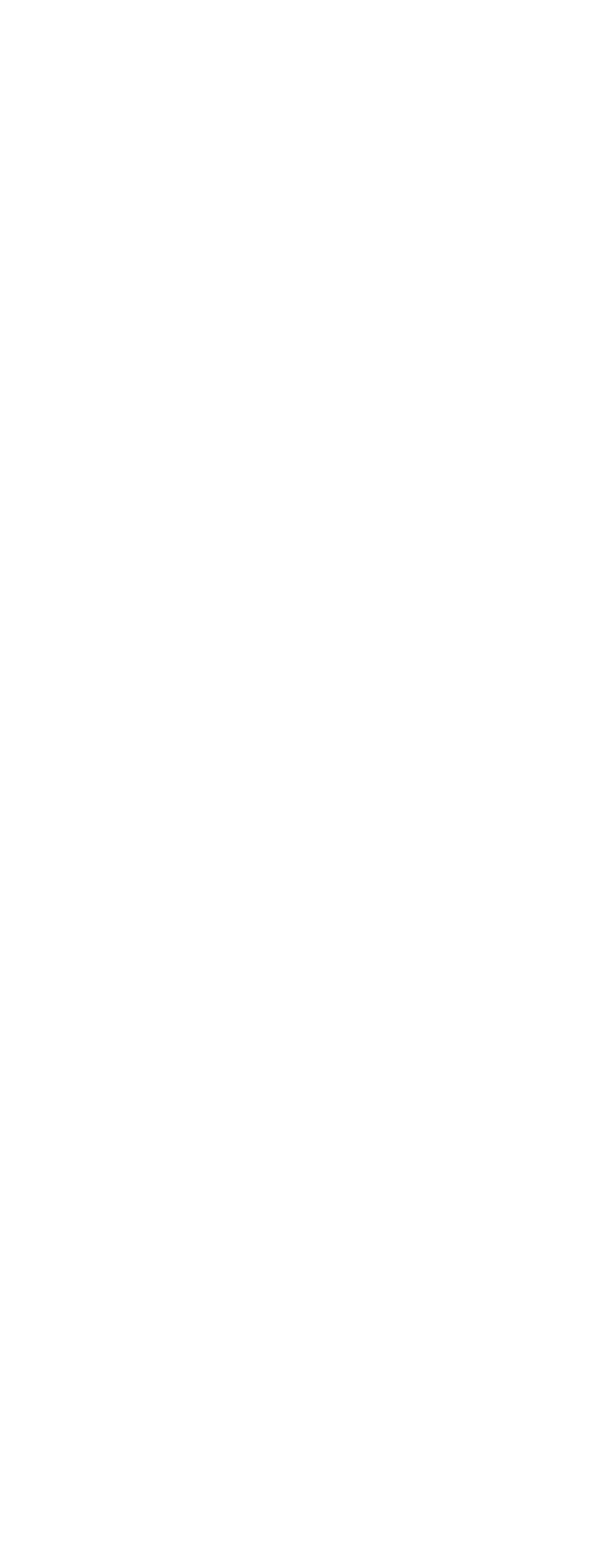




\section{Mineral analyses of ground waters from Scott County}

[Parts per million. Numbers at heads of columns refer to corresponding well numbers in preceding table]

\begin{tabular}{|c|c|c|c|c|}
\hline & 5 & 6 & 16 & 18 \\
\hline 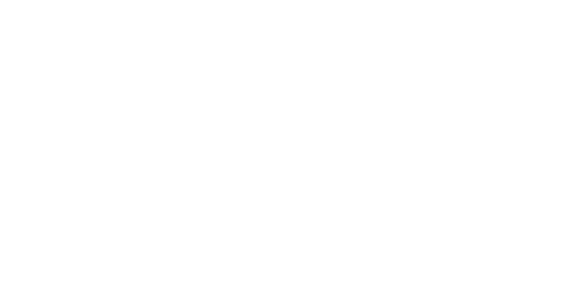 & $\begin{array}{c}53 \\
1.1 \\
19 \\
4.2 \\
621 \\
6.5 \\
68 \\
34 \\
6.1 \\
\text { Trace. } \\
180 \\
65 \\
\text { Aug., } 1919\end{array}$ & 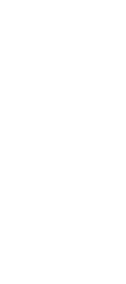 & $\begin{array}{c}38 \\
1.4 \\
15 \\
3.4 \\
12.0 \\
16 \\
53 \\
9.0 \\
144^{.00} \\
51 \\
\text { Apr., } 1914\end{array}$ & $\begin{array}{c}28 \\
21.21 \\
6.7 \\
57^{6} \\
178^{\circ} \\
44 \\
7.7 \\
254 \\
80 \\
\text { Aug., } 1919\end{array}$ \\
\hline
\end{tabular}

- Computed.

Analysts: 5, 18, Margaret D. Foster, U. S. Geological Survey; 6, 16, W. F. Hand, Mississippi State Chemical Laboratory.

\section{SHARKEY COUNTY}

\section{GENERAL FEATURES}

Area, 422 square miles. Population, 14,190 (census of 1920)

Sharkey County embraces an area in the south-central part of the Yazoo Delta. The alluvium of Mississippi River underlies the county. to an estimated depth of 150 or 200 feet, beneath which lies a great series of interbedded sands, clays, and marls that probably includes representatives of all the Eocene formations of central and northern Mississippi. These formations, named in descending order, include the Jackson formation; the Claiborne group, including the Yegua, Lisbon, and Tallahatta formations; the Wilcox group, including the Grenada, Holly Springs, and Ackerman formations; and the Midway group, including the Porters Creek clay and the Clayton formation. (See pp. 44-54.)

\section{GROUND-WATER CONDITIONS}

Large quantities of water under little or no artesian head are contained in the more porous sands and gravels of the alluvial deposits that underlie the delta to estimated depths of 150 to 200 feet. This water is obtained by driven or bored wells equipped with ropes and buckets or with pumps. At most places the water stands near enough to the surface to be within easy reach of suction pumps. In places the water of shallow wells is colored by contact with buried vegetable matter.

The Eocene deposits, which underlie the alluvium, include interbedded layers of sand, the contained waters of which are under an artesian head strong enough to lift them above the surface anywhere in the county. Most of the flowing wells are believed to have their source in sand in the Lisbon formation at depths of 500 to 1,300 feet. 


\section{LOCAL SUPPLIES}

Panther Burn.-A 4-inch well at Panther Burn, 7 miles northwest of Anguilla, in sec. 13, T. 14 N., R. 7 W., owned by Mrs. J. W. Johnson, is 614 feet deep and flows 35 gallons a minute from sand penetrated in the lower 14 feet of the well; the static head is 22 feet above the surface.

Richey.-A well at Richey, owned by the Morton Lumber Co., penetrates water-bearing sand between depths of 545 and 565 feet and yields 50 gallons a minute through a $21 / 2$-inch casing; the static head is 40 feet above the surface.

Rolling Fork.-The municipal water supply at Rolling Fork is obtained from two flowing wells, which were purchased in 1919 from private owners. One well is 785 feet deep and 2 inches in diameter and is about one-fourth mile south of the Yazoo \& Mississippi Valley Railroad station. The other well is $1,200(?)$ feet deep and $21 / 4$ inches in diameter and is about 100 yards west of the station; it flows about 35 gallons a minute, and its static head is 35 feet above the surface. (See analyses 5, 6.) The flowing well of F. B. Graft a mile south of Rolling Fork is 1,100 feet deep, with static head 40 feet above the surface.

Anguilla.-The well of H. G. Fields at Anguilla is 1,136 feet deep, $21 / 4$ inches in diameter, and flows 50 gallons a minute; its static head is 23 feet above the surface. (See analysis 1.)

Blanton.-A 3-inch well at Blanton, owned by $\mathrm{H}$. A. Darden, is 780 feet deep and flows 30 gallons a minute. The temperature of this water as it emerges is $76^{\circ} \mathrm{F}$. (See analysis 2.) The following is the log of a dug well $2 \frac{1}{4}$ miles south of Blanton:

Log of dug well $21 / 2$ miles south of Blanton

\begin{tabular}{|c|c|c|}
\hline . & Thickness & Depth \\
\hline $\begin{array}{l}\text { Alluvium: } \\
\text { Sandy loam. } \\
\text { Dark, sticky clay. } \\
\text { "Buckshot" clay } \\
\text { Fine sandy clay; water bearing }\end{array}$ & $\begin{array}{r}\text { Feet } \\
14 \\
6 \\
10 \\
2\end{array}$ & Feet $\begin{array}{r}14 \\
20 \\
30 \\
32\end{array}$ \\
\hline
\end{tabular}

Issaquena.-The flowing well of the Issaquena Lumber Co. at Issaquena is 1,279 feet deep and yields 60 gallons a minute. The static head is 53 feet above the surface. A 4-inch casing extends to the bottom with strainer set opposite the sands at 1,119 to 1,139 feet and 1,211 to 1,260 feet. A log of the well is given below. 


\section{Log of well of Issaquana Lumber Co., at Issaquena}

[Authority, Charles Wilson, driller for Layne \& Bowler Co.; log furnished by Issaquẹna Lụmber Co.]

\begin{tabular}{|c|c|c|c|c|c|}
\hline & Thick- & Depth & & $\begin{array}{c}\text { Thiok- } \\
\text { ness }\end{array}$ & Depth \\
\hline 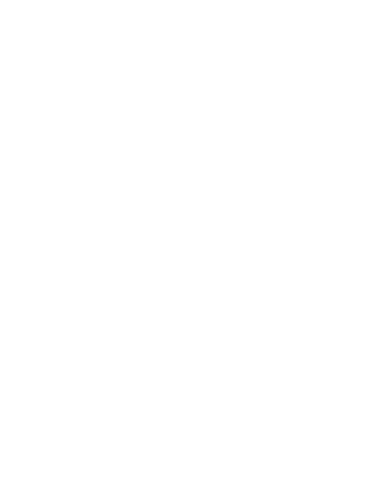 & $\begin{array}{r}\text { Feet } \\
10 \\
31 \\
92 \\
65 \\
12 \\
13 \\
19 \\
96 \\
120 \\
34 \\
58 \\
16 \\
6 \\
15 \\
36 \\
2 \\
22 \\
1 \\
24 \\
18 \\
1\end{array}$ & $\begin{array}{r}\text { Feet } \\
10 \\
41 \\
133 \\
198 \\
210 \\
228 \\
242 \\
338 \\
458 \\
492 \\
550 \\
566 \\
572 \\
587 \\
623 \\
625 \\
647 \\
648 \\
672 \\
690 \\
691\end{array}$ & 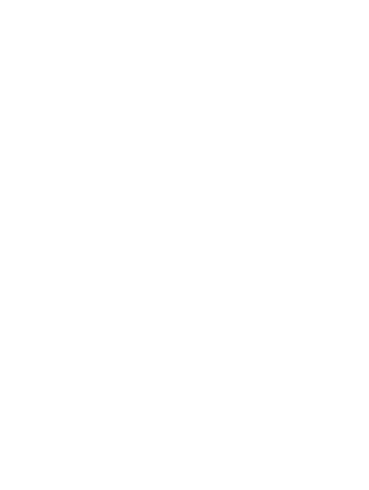 & $\begin{array}{r}\text { Feet } \\
4 \\
23 \\
42 \\
37 \\
37 \\
10 \\
45 \\
1 \\
45 \\
45 \\
24 \\
41 \\
10 \\
16 \\
17 \\
68 \\
20 \\
51 \\
24\end{array}$ & $\begin{array}{r}\text { Feet } \\
605 \\
718 \\
760 \\
797 \\
807 \\
852 \\
853 \\
898 \\
943 \\
967 \\
1,008 \\
1,018 \\
1,034 \\
1,051 \\
1,119 \\
1,139 \\
1,190 \\
1,241 \\
1,260 \\
1,279\end{array}$ \\
\hline
\end{tabular}

Cary.-The town of Cary is provided with a municipal water supply the source of which is a 747-foot flowing well 3 inches in diameter, which flows 25 gallons a minute. The static head is 30 feet above the surface.

\section{Mont Helena.-At Mont Helena, 21/2 miles north of Rolling Fork,} a 1,071-foot flowing well 4 inches in diameter is owned by George C. Harris. The static head is 30 feet above the surface. (See analysis 4.)

\section{Mineral axalyses of ground vaters of Shorkey County}

[Parts per million]

\begin{tabular}{|c|c|c|c|c|c|c|}
\hline & 1 & 2 & 3 & 4 & 5 & 6 \\
\hline 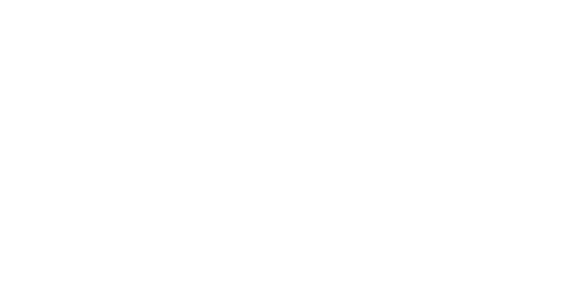 & $\begin{array}{l}16 \\
28.80 \\
1.9 \\
167 \\
31 \\
447 \\
5.2 \\
16 \\
4.0 \\
487 \\
78 \\
\text { Oct. } \\
1911\end{array}$ & $\begin{array}{l}17 \\
4.5 \\
23 \\
2.6 \\
223 \\
34 \\
556 \\
13 \\
20 \\
1.6 \\
608 \\
68 \\
\text { Aug., } \\
1011\end{array}$ & $\begin{array}{c}13 \\
1.0 \\
22.0 \\
1.2 \\
214 \\
34 \\
487 \\
10 \\
33 \\
4.0 \\
590 \\
60 \\
\text { Aug., } \\
1911\end{array}$ & $\begin{array}{c}23 \\
.04 \\
1.2 \\
6185^{.6} \\
45 \\
384 \\
8.0 \\
10 \\
466^{.34} \\
5 \\
\text { July, } \\
1919\end{array}$ & 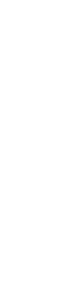 & $\begin{array}{c}33 \\
i .08 \\
1.2 \\
6208 \\
6.8 \\
406 \\
2.8 \\
22 \\
52.16 \\
525 \\
6 \\
\text { July, } \\
1019\end{array}$ \\
\hline
\end{tabular}

- Includes iron and aluminum (Fo+Al).

- Calculated.

Analysts: 1, W. L. Perdue, University of Mississippl; 2, 3, 5, W. L. Konnen, University of Miseissippi; 4, 6, Margaret D. Foster, U. S. Geological Burvex.

1. 1,13e-foot well of $\bar{H}$. $\mathrm{Q}$. Fields, at Anguilla.

2. 780-foot well of H. $\mathrm{A}$. Darden at Blanton.

3. 747-foot town well at Cary.

4. 1,071-foot well of G. C. Harris at Mont Helena.

5. 785-foot town well at Rolling Fork.

6. 1,200土-foot town well at Rolling Fork. 


\section{SIMRSON COUNTT}

\section{GENERAL FEATURES}

Area, 575 square miles. Population, 18,109 (census of 1920)

Simpson County embraces an area in the seuth-central part of Mississippi in the Long-lenf Pine Hills district. Throughout the greater part of the county the Catahoula sandstone (Miocene) is the subsurface formation. The Hattiesburg clay (Miocene) overlaps several miles into the southwestern part of the area, and probably attains a maximum thickness of 200 or 250 feet. Relatively thin remnants of the Citronelle formation (Pliocene), which cap many of the hills, rest on the Hattiesburg clay and on the Catahoula sandstone. Terrace and flood-plain deposits of gravel, sand, clay, and loam occur in thin sheets that rest on the older formations in the lowlands bordering the streams. The geologic formations mentioned are described on pages 55-60, and their distribution is shown on the geologic map (pl. 2).

\section{GROUND-WATER CONDITIONS}

So far as known from the records now on file, no deep wells have been drilled in Simpson County. Water supplies for domestic and farm use are obtained from dug and bored wells that range in depth from 15 to 100 feet. A few bored wells in the vicinity of Falin, a settlement about 3 miles southwest of Braxton, exceed 100 foet in depth, and the greatest depth reported is 130 feet. Springs of small to moderate size are common throughout the county, and some of them are utilized for domestic and farm supplies.

The source of most of the well waters obtained in the hilly uplands is the Catahoula formation, which is composed of irregularly bedded sand, sandstone, and clay. The Catahoula increases in thickness from perhaps 100 feet at the northeast corner of the county, which is within a few miles of the northern featheredge of the formation. to an estimated thickness of approximately 400 feet at the southwest corner of the county. At this place the formation is overlain by 200 or 250 feet of the Hattiesburg clay, so that the total depth to the base of the Catahoula is between 600 and 700 feet. Some of the springs and the waters of some of the shallow wells on the uplands have their source in the sand and gravel of the Citronelle formation, which forms a covering generally less than 50 feet thick on some of the hills. Many of the shallow wells in the lowlands derive water from the sand and gravel that form the base of the flood-plain and terrace deposits. Springs that have the same source occur along the edges of the terraces and at the heads of the branches which originate in the terrace plains. 
The whole series of Tertiary formations older than the Catahoula crops out in a broad northwestward trending belt in central Mississippi, and dips to the south-southwest, passing beneath the Catahoula formation. (See pl. 2.) In Simpson County these formations are completely buried from view, but the Vicksburg group, the uppermost division, is probably not more than 100 feet below the surface in the extreme northeast corner of the county and between 600 and 700 feet below the surface in the southwest corner.

Of these Tertiary formations the ones that may be regarded as the most promising for furnishing supplies of water are the Tallahatta and Lisbon formations of the Claiborne group. Numerous wells in the vicinity of Jackson, Hinds County, which range in depth from 600 to 1,200 feet, tap water-bearing beds in the Claiborne group. Most of these beds are probably in the Tallahatta formation, though some of the shallower ones may be in the overlying Lisbon formation. A well 1,135 feet deep at Taylorsville, Smith County, probably draws its supply from the Lisbon formation. A line drawn from Taylorsville to Jackson crosses the northeast corner of Simpson County, where the Lisbon waters could probably be obtained at depths of 800 to 1,000 feet. On the assumption that the general dip to the south-southwest is 30 feet to the mile, the depth to the Lisbon on the upland in the southwestern part of the county would be 1,600 to 1,800 feet. The actual dip may be either somewhat greater or somewhat less than this assumed dip. The Tallahatta water-bearing beds would lie several hundred feet deeper than the Lisbon throughout the area. The waters of the Claiborne are probably under a sufficiently strong head to produce flowing wells on the lowland that borders Pearl River and in the lower valley of Strong River.

LOCAL DETAILS

Mendenhall.-The water supply at the Agricultural High School at Mendenhall is obtained from the Catahoula formation by a drilled well 220 feet deep and 2 inches in diameter, in the NW. $1 / 4$ NE. $1 / 4$ sec. 34 , T. 2 N., R. 4 E., at an altitude of about 35 feet above the level of the track of the Gulf \& Ship Island Railroad at the station. (See analysis 1.) A 40-foot bored well at the courthouse at Mendenhall is believed to have its source in the Citronelle formation. This well, which was sunk in 1908, is 8 inches in diameter and the water rises within about 30 feet of the surface. (See analysis 2 .)

Dlo.-The lumber mill at Dlo is equipped with a waterworks for boiler supply and fire protection and obtains water from Strong River. 
Mineral analyses of ground waters from Simpson County

[Parts per million. Analysed by C. S. Howard, U. S. Geological Survey. For further data regarding these wells, see text]

\begin{tabular}{|c|c|c|c|c|c|}
\hline & 1 & 2 & & 1 & 2 \\
\hline $\begin{array}{l}\text { Silica }\left(\mathrm{SiO}_{2}\right) \\
\text { Iron }(\mathrm{F} \theta) \\
\text { Calcium }(\mathrm{Ca}) \\
\text { Magnesium }(\mathrm{Mg}) \\
\text { Sodium and potassium }(\mathrm{Na}+\mathrm{K}) \\
\text { Carbonate radicle }\left(\mathrm{CO}_{3}\right) \\
\text { Bicarbonate radicle }\left(\mathrm{HCO}_{3}\right) \\
\text { Sulphate radicle (SO4) }\end{array}$ & $\begin{array}{l}44 \\
.34 \\
4.8 \\
31.1 \\
94^{.0} \\
12\end{array}$ & $\begin{array}{l}11 \\
.07 \\
2.2 \\
1.6 \\
9.4 \\
.0 \\
9.8 \\
3.7\end{array}$ & $\begin{array}{l}\text { Chloride radicle (Cl) } \\
\text { Nitrate radicle (NO } \\
\text { Total dissolved solids at } 180^{\circ} \mathrm{C} . \\
\text { Total hardness as } \mathrm{CaC} \mathrm{g}_{3} \text { (calcu- } \\
\text { lated) } \\
\text { Date of collection. }\end{array}$ & $\begin{array}{l}1.0 \\
\text { Trace. } \\
144 \\
25 \\
\text { Dec., } \\
1920 .\end{array}$ & $\begin{array}{c}11 \\
4.3 \\
56 \\
12 \\
\text { Nov.;. } \\
1920\end{array}$ \\
\hline
\end{tabular}

1. Drilled well, 220 feet deep, of Agricultural High School, Mendenhall.

2. Bored well, 40 feet deep, of county, at Mendenhall.

\section{SMITH COUNTY}

\section{GENERAL FEATURES}

Area, 636 square miles. Population, 16,178 (census of 1920)

Smith County lies in the south-central part of the State, partly within the Jackson Prairie belt and partly within the Long-leaf Pine Hills district. The geologic formations which crop out in the county, named in order from the oldest to the youngest, include the Yazoo clay member of the Jackson formation (Eocene), the Vicksburg group (Oligocene), the Catahoula sandstone (Miocene), and the Citronelle formation (Pliocene). The character, structure, and physiographic expression of these formations are discussed on pages 53-60, and their distribution in Smith County can be approximately ascertained by reference to the geologic map (pl. 2).

\section{GROUND-WATER CONDITIONS}

The available data on which to state the general ground-water conditions of the county are few. Of the geologic divisions named above, the Yazoo clay is the oldest and stratigraphically the lowest bed that reaches the surface in the county.

The Yazoo clay is overlain by the Vicksburg group, which in Smith County is 125 or 150 feet thick. The basal formation of the group, the Forest Hill sand, has an estimated thickness of 50 feet of more or less ferruginous and argillaceous sand and appears to be the only part of the group whose physical character is at all suitable to serve as an aquifer, but little is known of its actual water content. This sand is probably the source of the water afforded by the 100-foot well of Eastman Gardiner \& Co., at Cohay.

The principal water-bearing formation, the one that is drawn upon by hundreds of dug, bored, and drilled wells that range in depth frone 15 to 125 feet, is the Catahoula sandstone, which immediately underlies the surface throughout the hilly district in the central and southern parts of the county, and caps all the hills and ridges in the 
northern part of the county. The formition math reach a maximum thickness of several hundred feet along the southern boundary of the county, from which place it thins to the northward until it decreases to a featheredge on the tops of the hills in the north. In this general area the soils are sandy, owing to the predominantly sandy character of the Catahoula formation from which they are largely derived.

Water occurs in some of the more porous sands and sandstones of the Catahoula, but owing to the irregularity in the bedding it is doubtful if any of the individual water-bearing beds persist over extensive areas. The vertical distribution of these beds is such, however, that adequate supplies of water for domestic and farm supplies can generally be obtained at depths of 25 to 100 feet.

Little is known definitely in regard to the ground-water prospects in the more deeply buried formations that underlie the county. The deep well at Taylorsville taps a water-bearing sand at a depth of 1,130 to 1,135 feet in beds that probably belong to the Lisbon formation of the Claiborne group (Eocene). This sand is probably more or less persistent aquifer beneath the entire county. The Claiborne group crops out in Newton County about 35 miles northeast of Taylorsville, which indicates that the aquifer should rise nearer to the surface from south to north and should be reached in the northern part of Smith County at a shallower depth than at Taylorsville. It is probable that other deeper water-bearing sands would be found in the Claiborne group and also in the still deeper, predominatingly sandy Wilcox group. All these deep aquifers should yield flows low in the valleys of Leaf River, Oakohay Creek, and Strong River.

\section{LOCAL SUPPLIES}

Taylorstitle.-A flowing well at Taylorsville, owned jointly by the town and the Gulf \& Ship Island Railroad Co., is 1,135 deep. and 4 inches in diameter. The original yield was 10 gallons a minute, but the yield has decreased to 6 gallons a intinute or less. A log of the well is given brelow.

Log of well at Taylorsville, owned jointly by the town and the Galf \& Ship Island

[Altitude, about 278 feet above sea level]

\begin{tabular}{|c|c|c|c|c|c|}
\hline & $\begin{array}{c}\text { Thick- } \\
\text { ness }\end{array}$ & Depth & & $\begin{array}{c}\text { Thidk- } \\
\text { ness }\end{array}$ & Depth \\
\hline 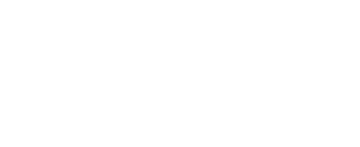 & $\begin{array}{r}\text { Feet } \\
100 \\
200 \\
\\
15 \\
85\end{array}$ & $\begin{array}{r}\text { Feet } \\
100 \\
300 \\
\\
315 \\
400\end{array}$ & 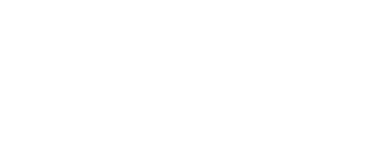 & $\begin{array}{r}\text { Feet } \\
23 \\
3 \\
704 \\
5\end{array}$ & $\begin{array}{r}\text { Feet } \\
423 \\
426 \\
1,130 \\
1,135\end{array}$ \\
\hline
\end{tabular}

- Logan, W. N. and Perkins, W. R., The underground waters of Mississippi: Mississippi Agr. Bxper. Sta. Bull. 89, p. 67, 1905 . Crider, A. F., and Johnson, L. O., U. S. Geol. Survey Water-8upply Paper 169, p. 72, 1906. 
The water-bearing sand at a depth of 1,130 to 1,135 feet probably belongs to the Lisbon formation of the Claiborne group; the hard rock at a depth of 400 to 423 feet is probably the Glendon limestone of the Virksburg group; and the water-bearing sand at a depth of 300 to 315 feet rey represent the basal part of the Catahoula sandstone. These correlations are, however, conjectural.

Mineral analysis of water from town well 1,135 feet deep at Taylorsville, Smith [By W. R. Pérkins, Mississippi Agr. Exper. Sta. Bull. 89, p. 68, 1905]

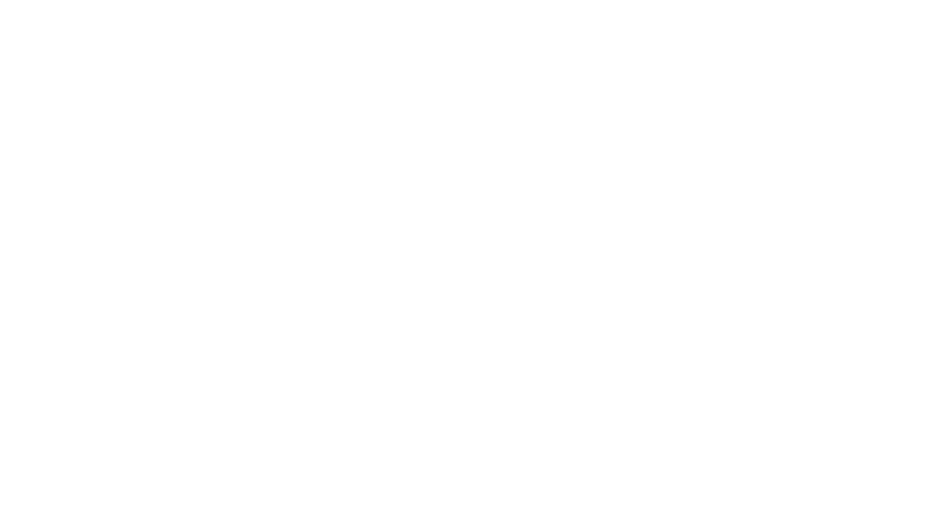

Cohay.-The village of Cohay, 51/2 miles northwest of Mize, is provided with a small waterworks, which is owned by Eastman Gardner \& Co., of Laurel, Miss. Water is obtained from a 4-inch nonflowing well, 100 feet deep, near the center of sec. 17, T. $1 \mathrm{~N}$., R. $7 \mathrm{E}$. The source of the water is the Forest Hill sand, and the yield by pumping is 30 gallons a minute.

Mize.-A well at Mize in sec. 12, T. 10 N., R. 16 W., which is owned by L. D. Hopkins, is 115 feet deep and obtrins water from gravel and white sand, questionably in the Catahoula sandstone, in the lower 15 feet of the well. The water is reported to be hard and is under a slight artesian pressure, as the static head is 95 feet below the surface. The Lumber Mineral Co. owns a 3 -inch well, 83 feet deep, 4 miles southwest of Mize, in the NE. $1 / 4$ SE. 1/4 sec. 27, T. $10 \mathrm{~N}$., R. $16 \mathrm{~W}$. The water, which is derived questionably from the Catahoula sandstone, is reported to be slightly hard and is used for boilers.

Raleigh.-A public well at the courthouse at Raleigh is 245 feet deep and has its source in sand of the Catahoula sandstone at a depth of 183 feet. The well of Mr. Willis, 150 yards east of the courthouse, is 175 feet deep and also enters a water-bearing sand in the Catahoula sandstone.

Summerland.-At Summerland, a typical bored well, owned by J. M. McCall, is 65 feet deep and taps a water-bearing sand, ques$54134-28-28$ 
tionably in the Catahoula sandstone, in the lower 10 feet. The water is under sufficient head to bring it within 12 feet of the surface.

Traxler.-A typical bored well a mile west of Traxler, owned by C. A. Myers, is 75 feet deep and derives its supply from gravel in the lower 5 feet, which is questionably referred to the Catahoula sandstone. The water is under no artesian pressure.

Eunice Everett Spring.-The Eunice Everett Spring is on the slope of a hill in sec. 17, T. 4 N., R. 6 E., a mile east of Polkville. The water emerges from an opening 3 feet in diameter and 4 feet deep, which is probably a solution cavern in limestone or marl of the Marianna limestone (Vicksburg group). Other beds that appear in the slope include clay, lignitic clay, and sand. Several years ago the water was bottled and sold, but it is not now on the market.

\section{STONE COUNTY}

GENERAL FEATURES

Area, 443 square miles. Population, 6,528 (census of 1920)

Stone County, which was organized from the northern part of Harrison County subsequent to the census of 1910, is in the southern part of the Long-leaf Pine Hills district. As shown by the geologic map (pl. 2), the principal geologic formation of the county is the Citronelle (Pliocene), which is more fully described on pages 59-60.

\section{GROUND-WATER CONDITIONS}

Throughout the county domestic water supplies are obtained chiefly from the Citronelle formation by bored and dug wells that range in depth from 15 to 100 feet. A few typical wells are described in the table of well data. The Citronelle here ranges in thickness from nearly 200 feet in the north to 300 feet or more in the south.

The Citronelle formation is underlain in descending order by the Pascagoula clay (Miocene), the Hattiesburg clay (Miocene), and the Catahoula sandstone (Miocene). The Pascagoula and Hattiesburg, though composed chiefly of clay, may, when thoroughly tested, be found to contain interbedded water-bearing sands; in fact, two wells (Nos. 7,9 ) are believed to have their source in the Pascagoula. The most promising source of artesian water is the Catahoula formation, which farther to the north in Mississippi is the source of abundant water supplies. The 1,155 -foot well at Bond is the only well thus far reported in which the Catahoula is believed to have been reached. Here the depth to the top of the formation is interpreted to be about 78 ) feet. The static head of the water in this well is 165 feet below the surface and the mouth of the well is approximately 305 feet above sea level. Wells in the valley of Red Creek, where the altitude is less than 140 feet above sea level, yield flows 
from the Pascagoula formation and would doubtless also yield flows from the deeper Hattiesburg and Catahoula formations, which are regarded as valuable though undeveloped sources of flowing and nonflowing artesian water throughout the county.

\section{LOCAL SUPPLIES}

Bond.-Two deep wells at Bond are described in the table of well data (Nos. 1, 3). The log of the Bond Lumber Co.'s well is given below. Water-bearing sand and gravel believed to be referable to the Catahoula formation was penetrated between depths of 800 and 870 feet, and the water rose within 165 feet of the surface.

Log of well of Bond Lumber Co., 11/4 miles north of Bond post office (No. 1)a

[Altitude of mouth of well about 305 feet above sea level]

\begin{tabular}{|c|c|c|}
\hline & Thickness & Depth \\
\hline 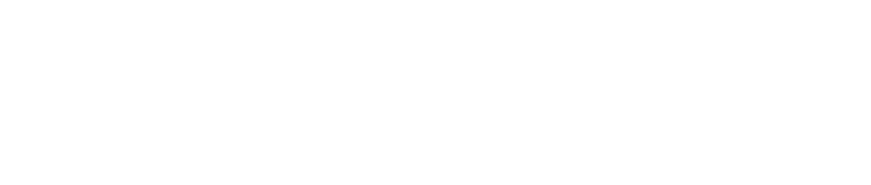 & $\begin{array}{r}\text { Feet } \\
70 \\
120 \\
80 \\
250 \\
265 \\
370\end{array}$ & $\begin{array}{r}\text { Feet } \\
70 \\
190 \\
270 \\
520 \\
785 \\
1,155\end{array}$ \\
\hline
\end{tabular}

- Adapted from U. S. Geol. Survey Prof. Paper 98, pl. 43, columnar section 4.

Wiggins.-The town of Wiggins owns a municipal waterworks located about a quarter of a mile north of the Gulf \& Ship Island Railroad station. The water is furnished by a 152-foot nonflowing well (No. 11), at the pumping plant.

Perkinston.-The village of Perkinston is provided with a small waterworks that is owned by the Harrison-Stone Agricultural High School. Water is obtained from a flowing well 260 feet deep (No. 7), about one-eighth of a mile east of the school buildings, at an altitude of about 120 feet above sea level. (See analysis 7.) The Gulf \& Ship Island Railroad Co. owns a 360-foot flowing well (No. 9) three-quarters of a mile north of the station near Red Creek. The water is used for the boiler supply of locomotives. (See analysis 9.)

McHenry.-The town of McHenry is provided with a small waterworks, which is owned by P. E. Bond. The water is obtained from a spring located four blocks east of the Gulf \& Ship Island Railroad station, at an altitude about 55 feet below the level of the track. The spring yields about 5 gallons a minute. (See analysis 12.)

Log of well of J. F. McCarty, McHenry (No. 5)

[Altitude of mouth of well, about 278 feet above sea level, authority, the owner]

\begin{tabular}{|c|c|c|}
\hline & Thickness & Depth \\
\hline $\begin{array}{l}\text { Citronelle formation: } \\
\text { Coarse sand } \\
\text { Sticky blue mud } \\
\text { Fine white sand; water bearing- }\end{array}$ & $\begin{array}{r}\text { Feet } \\
34 \\
15 \\
6\end{array}$ & Feet $\begin{array}{r}34 \\
49 \\
55\end{array}$ \\
\hline
\end{tabular}


14itloiew.-The log of a deep well at Millview, a villuge on the Gulf \& Ship Istand Railroad just north of the Harrison County line, is given below; no water was obtained.

Log of well at Millview (No. 6) a

[Altitude of mouth of well $200 \pm$ feet above sea level. Authority, W. N. Logan and W. R. Perkins]

\begin{tabular}{|c|c|c|}
\hline & Thickness & Depth \\
\hline $\begin{array}{l}\text { Sand } \\
\text { Blue clay }\end{array}$ & $\begin{array}{l}\text { Feet } \\
150 \\
1000 \\
100\end{array}$ & $\begin{array}{r}\text { Feet } \\
1,0,00 \\
1,700\end{array}$ \\
\hline
\end{tabular}

- Mississippi Agr. Exper. Sta. Bull. 89, p. 76, 1005.

Ramsey Mineral Spring.-Ramsey Mineral Spring, owned by Dr. G. A. McHenry, is located near the head of a small creek 18 or 20 miles east of McHenry and is reported to flow 92 gallons a minute. No analysis is available for publication, but the water is said to possess therapeutic properties. 
STONE CQUNTY

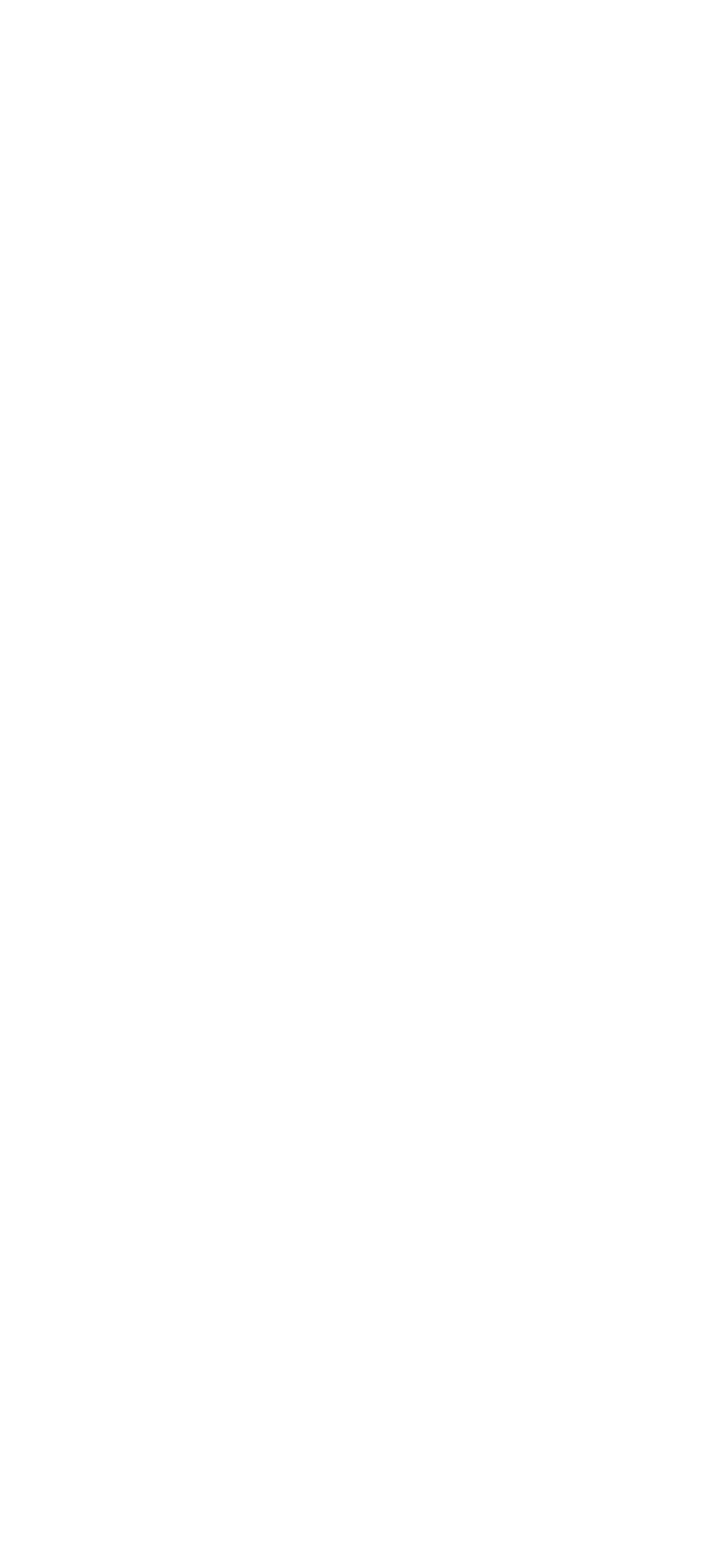




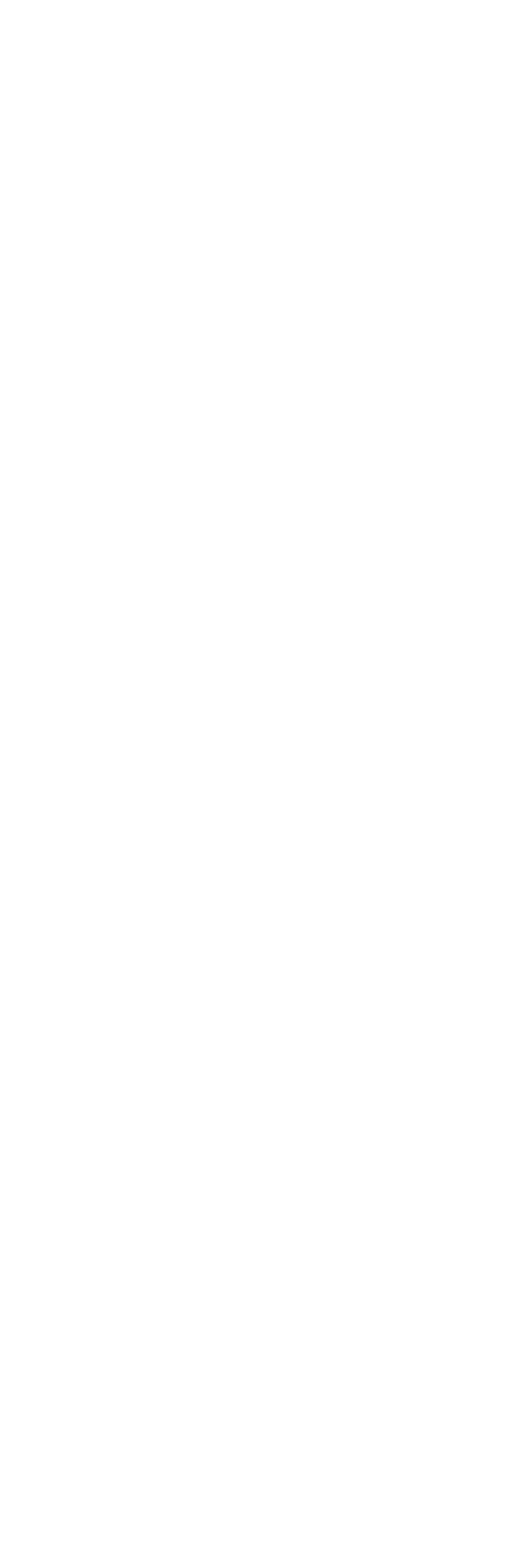


Mineral analyses of ground waters from Stone County

[Parts per million. Numbers at heads of columns refer to corresponding well and spring numbers in preceding table]

\begin{tabular}{|c|c|c|c|c|c|}
\hline - & 1 & 7 & 9 & 11 & 12 \\
\hline 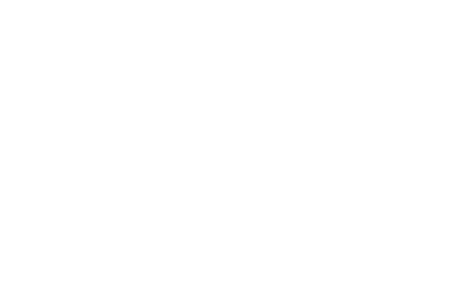 & $\begin{array}{l}54 \\
1.9 \\
7.0 \\
1.8 \\
31.0 \\
92.0 \\
8.4 \\
6.0 \\
152.00 \\
25 \\
1914\end{array}$ & $\begin{array}{c}22 \\
.04 \\
.9 \\
.6 \\
47^{.0} \\
1.6 \\
3.5 \\
\text { Trace. } \\
65 \\
5 \\
\text { Aug., } 1919\end{array}$ & $\begin{array}{c}40 \\
.21 \\
.8 \\
.7 \\
65^{-7} \\
155^{.0} \\
13.9 \\
3.9 \\
198 \\
5^{5} .74 \\
\text { Aug., } 1919\end{array}$ & 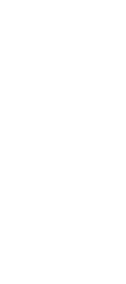 & $\begin{array}{c}8.3 \\
.04 \\
2.8 \\
3.1 \\
.15 \\
24.0 \\
2.0 \\
11 \\
19 \\
79 \\
20 \\
\text { Aug., } 1919\end{array}$ \\
\hline
\end{tabular}

- Calculated.

Analysts: 1, W. F. Hand, Mississippi State Chemical Laboratory; 7, 9, 12, Margaret D. Foster, U. 8. Geological Survey; i1, C. H. Kidwell and Margaret D. Foster, U. S. Geological Survey.

\section{SUNFLOWER COUNTY}

\section{GENERAL FEATURES}

Area, 670 square miles. Population, 46,674 (census of 1920)

Sunflower County embraces an area in the Yazoo Delta in northwestern Mississippi. The alluvial deposits of Mississippi River underlie the surface to an estimated depth of 150 to 200 feet, beneath which lies a thick series of undifferentiated sands and clays that belong to the Claiborne, Wilcox, and Midway groups of the Eocene (p. 43-53).

\section{GROUND-WATER CONDITIONS}

Great quantities of nonflowing water are contained in the more porous sands and gravels of the alluvial deposits that underlie the county to estimated depths of 150 to 200 feet, and this water is easily obtained by bored and driven wells that are equipped with ropes and buckets or with pumps. At many places the water stands near enough to the surface to be raised with suction pumps. In places the shallow well waters are rendered objectionable in color and taste by contact with vegetable matter buried in the alluvium.

The more porous sands of the underlying Eocene deposits carry water under strong artesian head. It is not possible with the available data to distinguish with certainty the different formations penetrated by the deep wells, but it has been roughly estimated that most of the wells between 600 and 1,000 feet in depth have their source in the Lisbon formation and those more than 1,200 feet deep probably penetrate the upper part of the Wilcox group. With the exception of the wells that enter only the alluvium the wells described in the table of well data range in depth from 800 to 1,320 feet and in static head from 30 to 75 feet above the surface. 


\section{LOCAL SUPPIIFS}

Drew.-The town of Drew owns a small waterworks, which obtains water from a flowing well $600(?)$ feet deep (No. 5). The water is forced through the mains to the consumers by the natural artesian pressure, which is 12 to 15 pounds to the square inch. On Sunflower plantation, 6 miles west of Drew, water under strong artesian head is obtained by wells about 960 feet deep (No. 6).

Dockery.-Near Dockery two wells (Nos. 1, 2) owned by William Dockery are 961 and 929 feet deep. (See analyses 1, 2.) A 930-fopt well owned by A. L. Marshall (No. 3), 4 miles northeast of Dockery, yields 100 gallons a minute from sand penetrated hetween depths of 900 and 930 feet.

Ruleville.-In the vicinity of Ruleville wells yield strong flows from depths of 864 to 940 feet (Nos. 18-21). All probably tap waterbearing sands in the Lisbon formation. In the Marlow well waterbearing strata were struck at depths of 800,850 , and 912 feet; the deepest stratum yielded the principal supply. (See analysis 19.)

Halstead.-At Halstead, 6 miles southwest of Ruleville, domestic water supplies are provided in part by cisterns and in part by driven wells, which enter the alluvium to depths of 15 to 65 feet.

Doddsville.-One well (No. 4) at Doddsville is 820 feet deep and yields 80 gallons a minute; the static head of the water is 70 feet above the surface. (See analysis 4 .)

Frazier.-At Frazier, 12 miles west of Sunflower, driven wells 18 to 55 feet deep afford the principal domestic water supply. The water stands within about 15 feet of the surface.

Pentacost.-A flowing well, owner not stated, at Pentacost, 21/2 miles north of Sunflower, is 880 feet deep and yields 40 gallons a minute, presumably from the Lisbon formation.

Sunflower.-A well at Sunflower (No. 22), owned by the town, is 800 feet deep and flows 10 gallons a minute. (See analysis 22.) Another well (No. 23), at Sunflower is 880 feet deep and yields 50 gallons a minute.

Faisonia.-At Faisonia domestic water supplies are derived chiefly from driven wells 20 to 50 feet deep. The quality of this water is reported to be unsatisfactory.

Moorhead.-The municipal water supply at Moorhead is provided by a well that is reported to be about 1,300 feet deep, on the bank of Moorhead Bayou, 300 yards southeast of the Southern Railway station (No. 15). Water from three strata, which are reported to have been penetrated at depths respectively of approximately 900 , 1,050 , and 1,300 feet, is utilized by means of perforations in the pipe. An analysis of the mixed water from these three sources is given in the table (No. 15). The water is distributed to the consumers under the natural pressure from the well, through mains and pipes that 
range in diameter from 6 inches to three-quarters of an ineh. There is no provision for direct fire pressure. A well owned by C. $\mathrm{H}$. Pond (No. 17), three-fourths of a mile west of Moorhead; is 936 feet deep and yields a fairly strong flow. A flowing well owhed by the Bellevue Cotton Mills at Moorhead is 900 feet deep. (See analysis 16.)

Inverness.-In September, 1919, when the senior author visited the town of Inverness, the municipal water supply was obtained from two wells, one, 1,250 feet deep and the other 1,312 feet deep (Nos. 12, 14). In 1920 a third well (No. 13) was drilled, the depth of which is $1,3031 / 3$ feet; a $\log$ of this well is given below.

Log of well at the municipal waterworks at Inverness

[Altitude of mouth of weil 110 teet above sea level. Authoffty, Gray Artesian Well Co.]

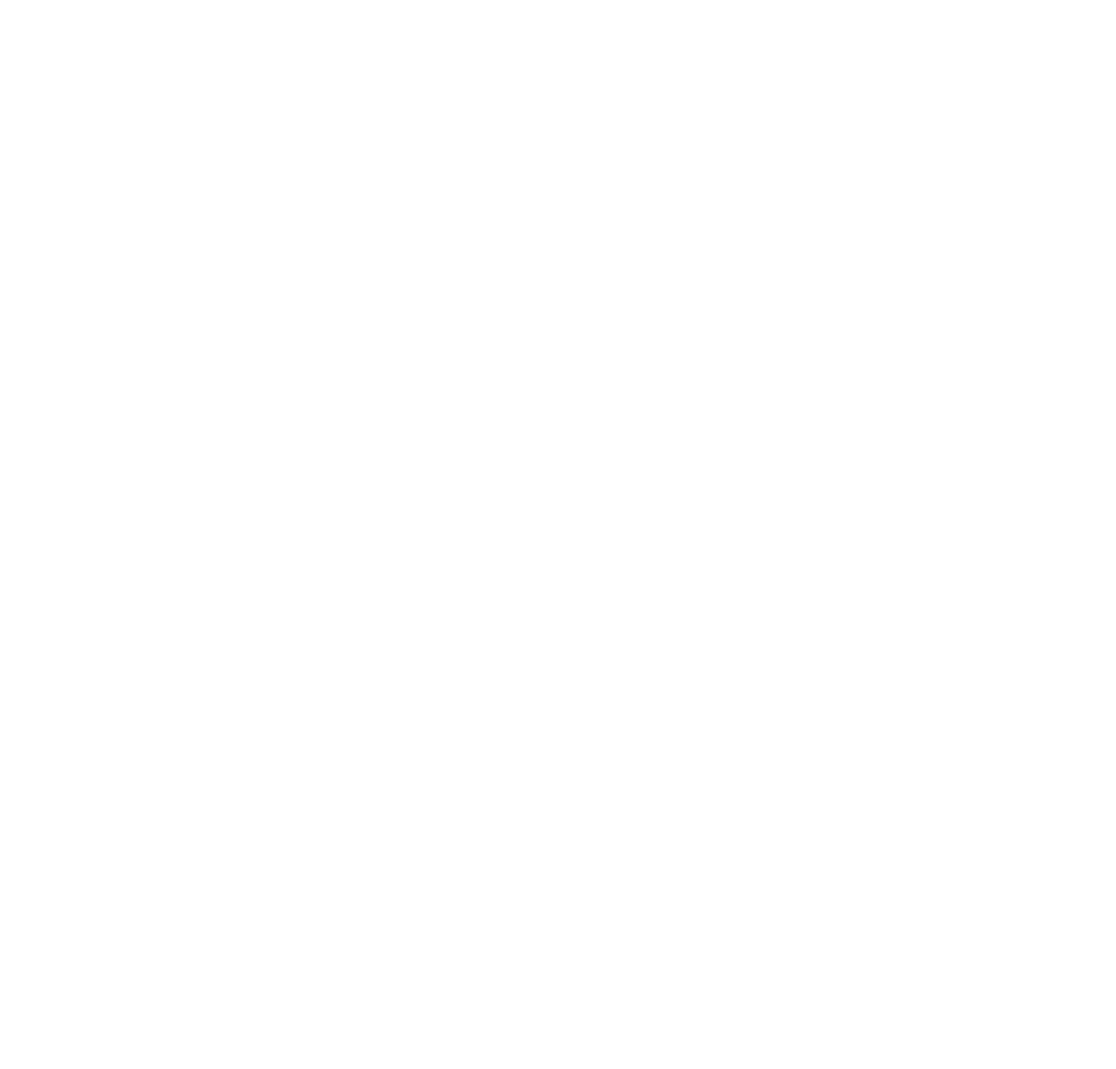

Indianola.-The municipal water supply at Indianola is provided by three flowing wells $1,240,1,320$, and 1,500 feet deep (Nos. 8-10). Water from the two deeper wells is used only for domestic supply. Analysis 8 represents a sample of water from the 1,240-foot well. A well (No. 11) 11/2 miles east of Indirnola is 1,300 feet deep and flows 150 gallons a minute. The temperature of this water as it emerges from the well is $80^{\circ} \mathrm{F}$. This temperature is several degrees higher than that of the shallow well waters. 


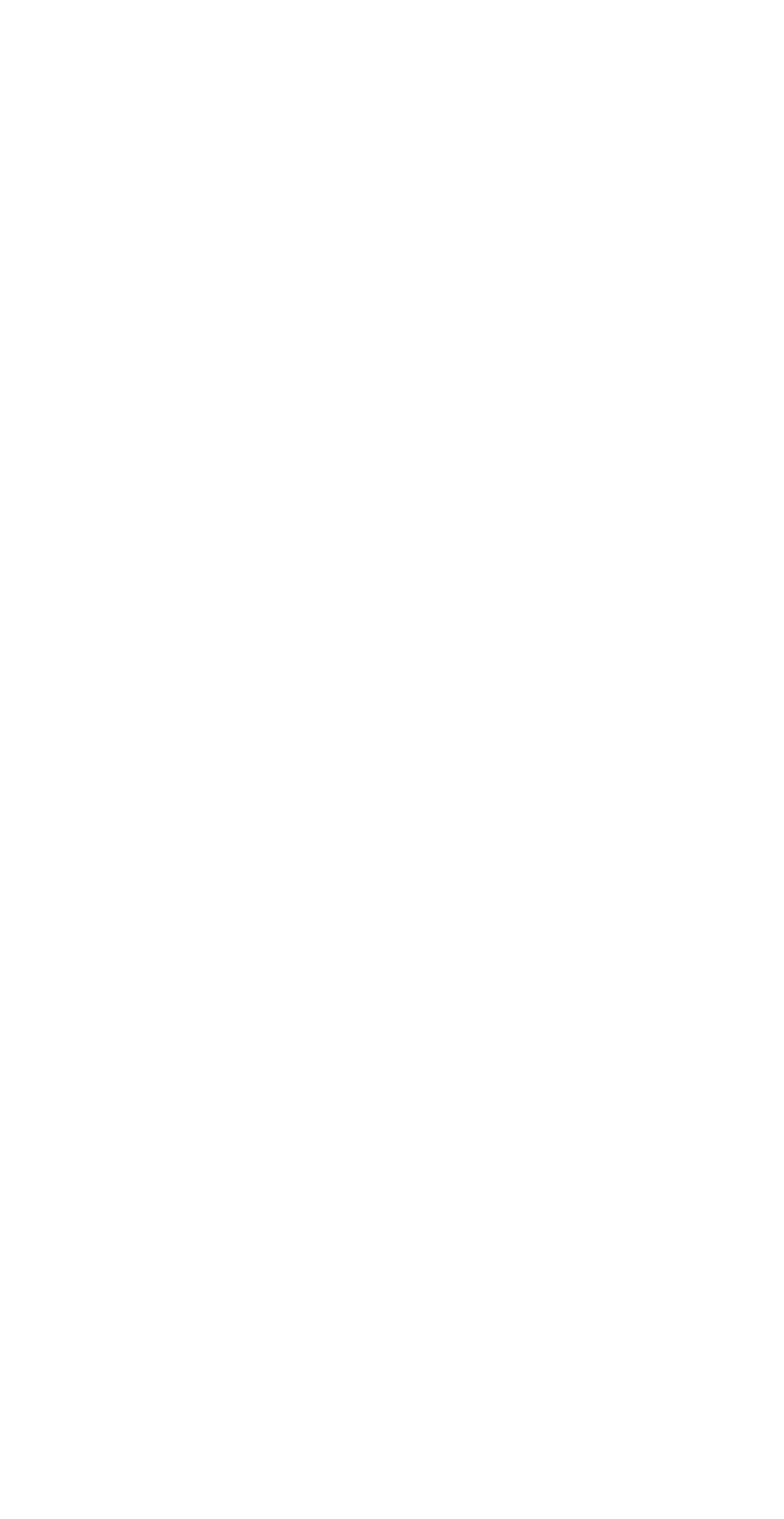




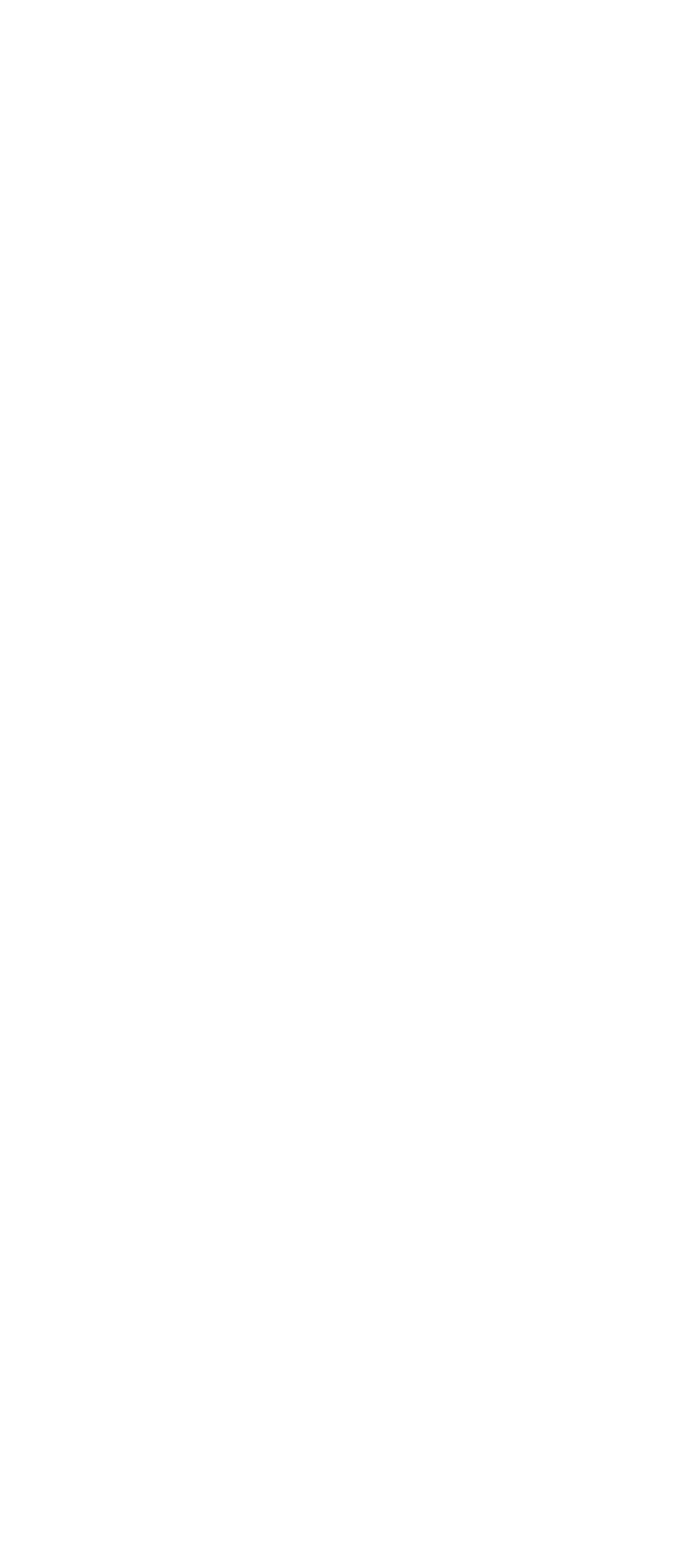


Mineral analyses of ground waters from Sunflower County

[Parts per million. Numbers at heads of columns refer to corresponding well numbers in preceding table]

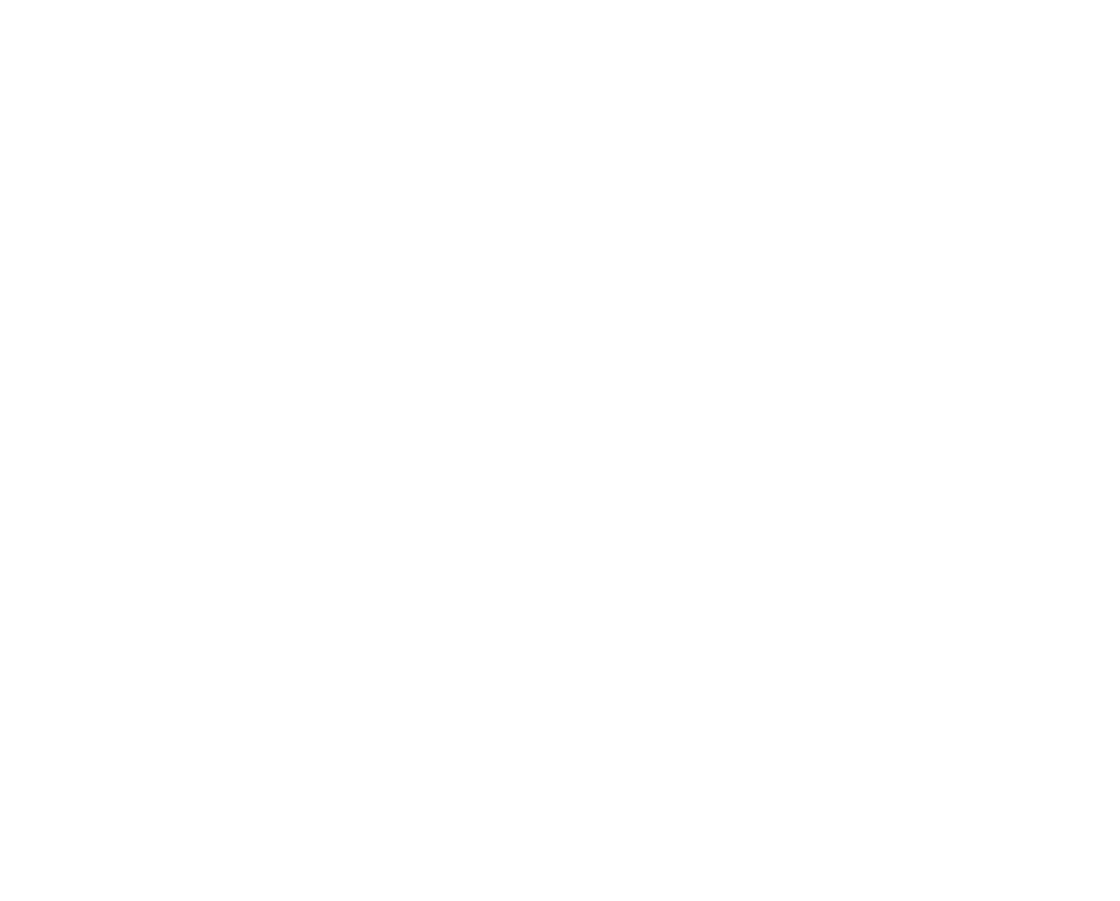

Analysts: 1, 2, 4, 8, 16, 19, 22, W. R. Perkins (Mississippi Agr. Exper. Sto. Bull. 89, p. 85, 1906); 12, W. L. Kennon, University' of Mississippi; 15, Margaret D. Foster and Clara M. Forman, U. S. Geological Survey.

\section{TALLAHATCHIE COUNTY}

\section{GENERAL FEATURES}

Area, 629 square miles. Population, 35,953 (eensus of 1920)

Tallahatchie County extends from the border of the upland or Loess Hills district westward into the Yazoo Delta. The following geologic formations appear in outcrops in the county: Eocene, the Grenada formation of the Wilcox group, and the Tallahatta formation of the Claiborne groups; Pliocene terrace sands and gravels which intervene between the Grenada formation below and the overlying loess; Pleistocene loest, which forms a blanket 30 to 50 feet or more in thickness throughout the eastern or upland portion of the area; and Recent alluvial deposits, which underlie the Yazoo Delta to depths of 150 feet or more. Descriptions of these formations are given on pages 48-63, and their distribution is indicated on the geologic map (pl. 2).

\section{GROUND-WATER CONDITIONS}

The artesian waters of Tallahatchie County are obtained chiefly from the Wilcox group of the Eocene. Of the three formations that compose this group only the uppermost, the Grenada, appears at 
the surface. Its outcrops are confined to the lower slopes of the escarpment of bluff that form the western boundary of the upland and to the lower slopes of some of the deeper creek valleys in the upland. The Grenada formation is probably not an important aquifer.

The Holly Springs sand, or middle formation of the Wilcox group, which is 500 or 600 feet thick, underlies the Grenade formation. The sands that dominantly compose the formation are abundantly water bearing, and their slightly inclined westward extensian out under the alluvial deposits of the Yazoo Delta is the source of many flowing wells in that area.

The Ackerman, or lowermost formation of the Wilcox group, has an aggregate thickness of 500 or 600 feet. The sands are water bearing, and the buried westward extension of the formation in this county is believed to be the source of some of the deepest flowing wells, as at Tutwiler (Nos. 24, 25).

The terrace sands and gravels that intervene between the Grenada formation and the overlying loess in the eastern part of the county are the source of many springs. Many bored or dug wells, generally less than 100 feet deep, have been sunk through the loess to these deposits for domestie and farm water supplies.

The alluvial deposits that underlie the Yazoo Delta to a depth between 150 and 200 feet include large bodies of sand and gravel that carry an abundance of nonflowing water which can be readily procured by bored and driven wells equipped with pumps or buckets.

\section{LOCAL SUPPLIES}

Crevi-Crevi is a village at the base of the bluffe 10 miles north of Charleston. The town well (No. 9) yields flowing water, which comes from a thick bed of sand that is penetrated in the lower half of the well as shown in the following log:

Log of public well at Crevi, 10 miles north of Charleston (No. 9)

\begin{tabular}{|c|c|c|}
\hline & Thickness & Depth \\
\hline $\begin{array}{l}\text { Alluvium: Soll and pipe clay } \\
\text { Greqada formation and Holly Springs sand: } \\
\text { gand } \\
\text { Soapstone (clay) } \\
\text { Rock } \\
\text { Sand (Hilolily springs); water bearing }\end{array}$ & $\begin{array}{rr}\text { Feet } & 50 \\
& 90 \\
0 & 1 \\
200\end{array}$ & $\begin{array}{l}\text { Feet } \\
50 \\
140 \\
\begin{array}{c}100 \\
201 \\
401\end{array}\end{array}$ \\
\hline
\end{tabular}

The C. W. Neilson well (No. 10), 11/2 miles south of Crevi, is 400 feet deep and flows 40 gallons a minute; the source of the water is a sand at the depth of 380 feet.

Enid.-At Enid water is supplied by cisterns and by shallow wells, which range in depth from 25 to 75 feet; the source of the water is the terrace gravel that underlies the loess. 
Vance.-At Vance domestic water supplies are furnished chiefly by a public well (No. 26) 750 feet deep; it yields a strong flow, the source of which is the Holly Springs sand. (See analysis 26.)

Tutwiler.- The waterworks at Tutwiler is about two blocks southeast of the Yazoo \& Mississippi Valley Railroad station. Two flowing wells (Nos. 24, 25) afford the municipal water supply. One well, 1,200 feet deep, is at the waterworks, and the other, 1,180 feet deep, is about four blocks northeast of the waterworks. The source of the water in the two municipal wells is believed to be the Ackerman formation. In well 25 flowing water was also encountered at depths of 810 and 880 feet in the Holly Springs sand. Layers of rock, probably thin beds of sandstone, were encountered at depths of 640 , 800,920 , and 1,140 feet. Analysis 24 represents the water from the 1,200-foot well. There are in all four or five artesian wells in the vicinity of Tutwiler.

Charleston.-The municipal waterworks at Charleston is about a quarter of a mile east of the courthouse, on ground that has an altitude about the same as the track of the Yazoo \& Mississippi Valley Railroad at the station. The source of the water is a well that is reported to be 1,330 feet deep (No. 3); it probably enters water-bearing sand in either the Clayton formation of the Eocene or the Ripley formation of the Upper Cretaceous. The Lamb-Fish Lumber Co., whose plant is about half a mile east of the courthouse, owns and operates a waterworks which provides water for the boilers at the plant and for the domestic water supply for the employees of the plant, who number about 130 families. This waterworks formerly also provided the municipal water supply for the town of Charleston. Water is obtained from two wells, each reported to be 585 feet deep (Nos. 5, 6); they probably tap a water-bearing sand in the Holly Springs formation. The following log shows the character of the beds penetrated in a 362-foot public well at the courthouse, the water of which is used chiefly for drinking:

Log of public well at courthouse, Charleston (No. 4)

\begin{tabular}{|c|c|c|}
\hline & Thickness & Depth \\
\hline Alluvium: Clay and blue mud & & \\
\hline $\begin{array}{l}\text { Grenada formation and Holly Springs sand: } \\
\text { Sand. } \\
\text { Soapstone (clay) } \\
\text { Hard white rock } \\
\text { Sand; water bearing } \\
\text { Soapstone (clay) } \\
\text { Sand (Holly Springs); water bearing. }\end{array}$ & $\begin{array}{r}40 \\
100 \\
2 \\
100 \\
30 \\
40\end{array}$ & $\begin{array}{r}90 \\
190 \\
192 \\
292 \\
322 \\
362\end{array}$ \\
\hline
\end{tabular}

One well (No. 7) is 760 feet deep, but the principal water-bearing sand lies at a depth of 545 feet; the well flows 32 gallons a minute. Another well (No. 8), near the base of the bluffs, 4 miles south of 
Charleston, is 420 feet deep and yields a good flow from the Holly Springs sand. In November, 1920, an oil-prospecting well was being drilled about 8 miles south by east of Charleston. A partial log of this well to a depth of 2,490 feet is given below:

Partial log of oil-prospecting well of Charleston Oil \& Gas Co., known as Newton No. 1 , in sec. 36, T. 24 N., R. 2 E., 8 miles south by east of Charleston

[Furnished by E. N. Lowe, State geologist, October, 1920]

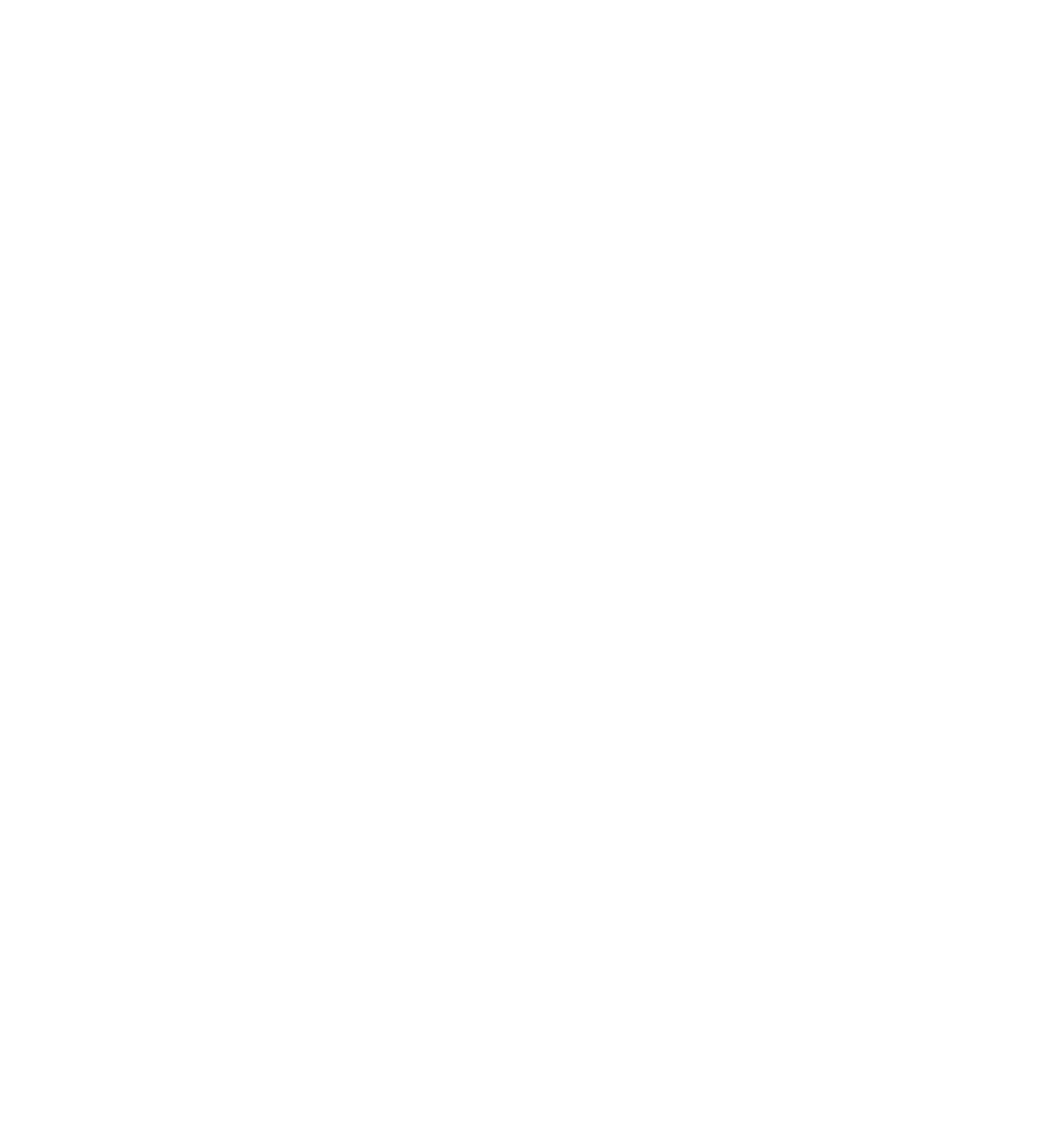

Sumner.-The municipal water supply at Sumner is afforded by a flowing well, depth not stated, at the waterworks, one block southeast of the courthouse. An 800-foot flowing well (No. 19) at the courthouse formerly supplied several residences in its vicinity. The water is now used only for drinking. (See analysis 19.) A 552foot well (No. 20) a mile south of Sumner enters the Holly Springs sand and yields a strong flow; the water is used for domestic and stock supply. 
Sharkey.-Five flowing wells (Nos. 14-18) 2 to 5 miles south of Sharkey range in depth from 450 to 587 feet and discharge 40 to 75 gallons a minute. Wells 14 and 17 tap a white water-baaring sand at a depth of about 400 feet. The other three wells reagh blue sand at a depth of 500 to 550 feet and yield somewhat stronger flows.

Swan Lake.-Several deep flowing wells have been drilled near Swan Lake, all of which tap water-bearing beds in the Holly Springs sand. The three wells described in the table of well data (Nos. 21, 22 , and 23) are 582, 750, and 450 feet deep. A rather hard water from one of these wells is represented by analysis 22 .

Glendora.-A 465-foot flowing well (No. 12) at Glendora entered 2 water-bearing sand at a depth of 420 feet. The 650-foot well (No. 11) at the same place penetrated a productive sand at a depth of 600 feet. (See analysis 11.)

Leverett.-Leverett is a village at the base of the bluffs in the southeastern part of the county. Here water is obtained from the Holly Springs sand by means of deep drilled wells. The log of a typical well (No. 13) 380 feet deep, is given below.

Log of well at Leverett (No. 18)

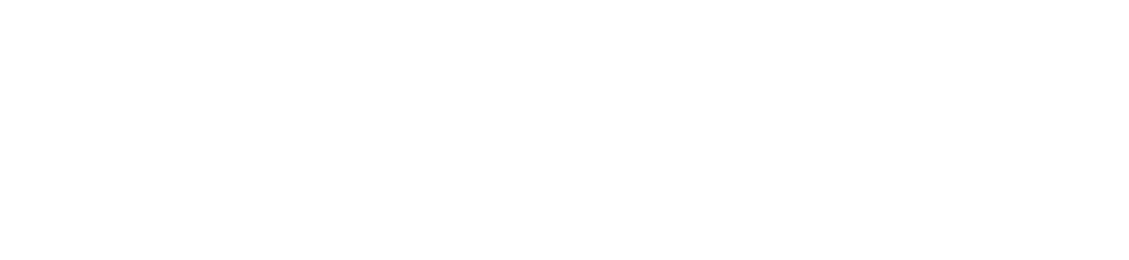

Cascilla.-In the 140-foot well of G. W. Trusty (No. 2), at Cascilla, water was encountered in terrace gravel at the base of the loess at a depth of 120 feet. 


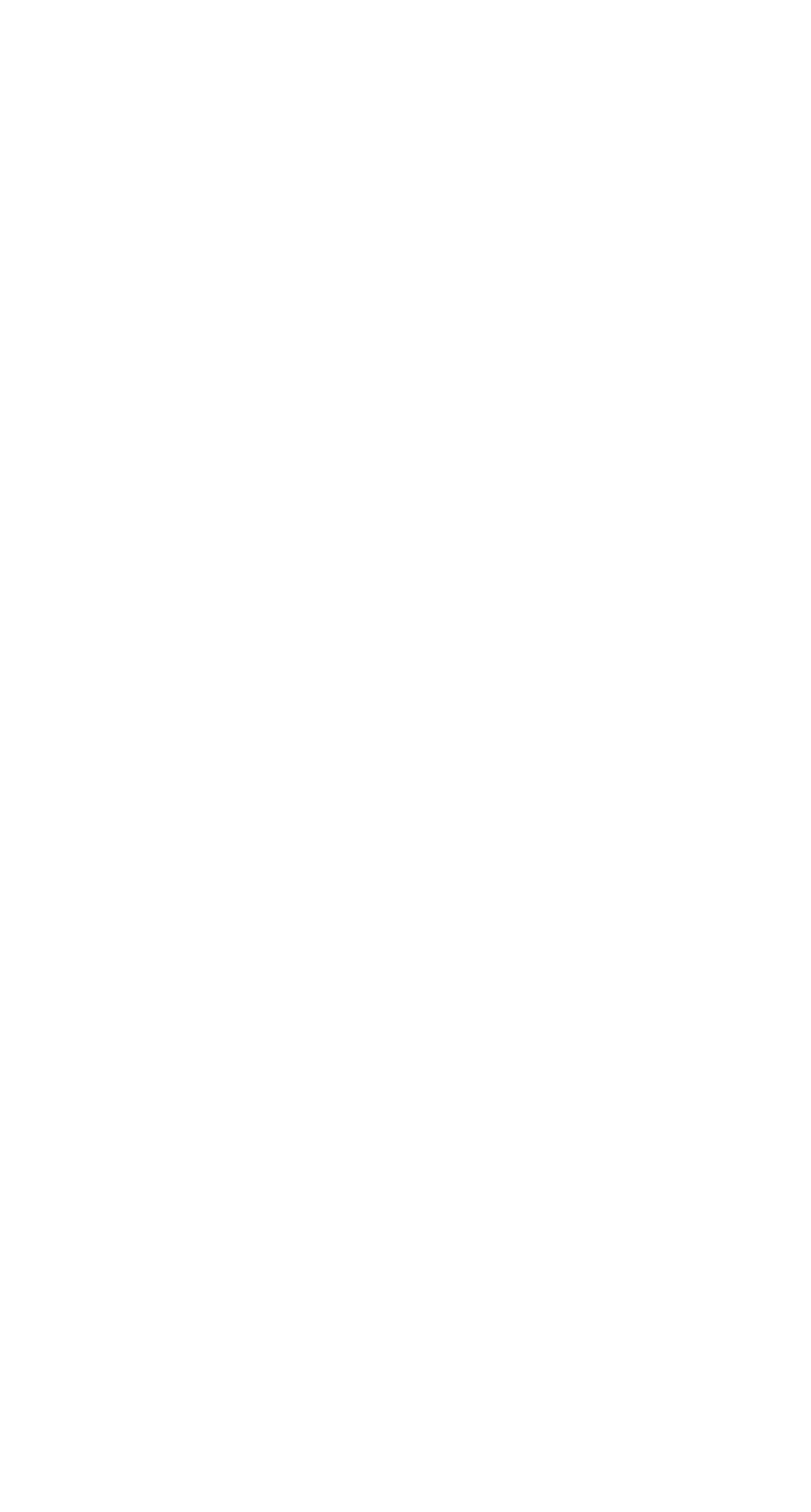




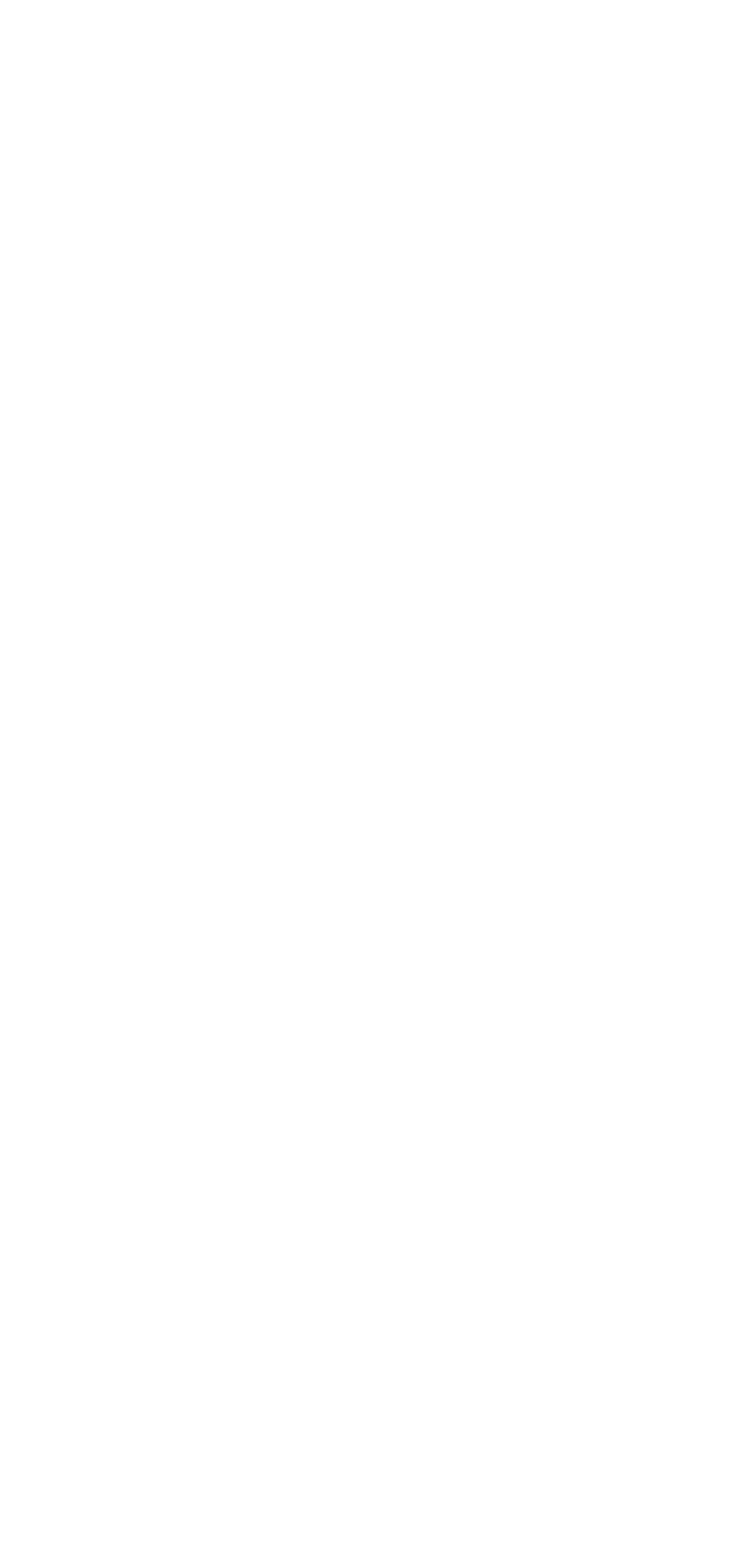


Mineral analyses of ground waters from Tallahatchie County

[Parts per million. Numbers at heads of columns refer to corresponding well numbers in preceding table]

\begin{tabular}{|c|c|c|c|c|c|c|}
\hline & 11 & 17 & 19 & 22 & 24 & 26 \\
\hline $\begin{array}{l}\text { Silica }\left(\mathrm{SiO}_{2}\right) \\
\text { Iron }(\mathrm{Fe}) \\
\text { Calcium }(\mathrm{Ca}) \\
\text { Magnesium }(\mathrm{Mg})\end{array}$ & $\begin{array}{l}30 \\
a .85 \\
1.1 \\
.6\end{array}$ & $\begin{array}{l}28 \\
1.0 \\
3.6 \\
3.6\end{array}$ & ${ }^{20} .60$ & $\begin{array}{l}21 \\
45 \\
8.8\end{array}$ & $\begin{array}{l}40 \\
.53 \\
3.1 \\
.3\end{array}$ & ${ }_{16}^{35} .50$ \\
\hline Sodium and potassium $(\mathrm{Na}+\mathrm{K})$ & $\begin{cases}\mathrm{Na} & 122 \\
\mathrm{~K} & 2.0\end{cases}$ & 93 & 81 & 5.5 & 120 & 120 \\
\hline $\begin{array}{l}\text { Carbonate radicle }\left(\mathrm{CO}_{3}\right) \\
\text { Bicarbonate radicle }\left(\mathrm{HCO}_{3}\right) \\
\text { Sulphate radicle }\left(\mathrm{SO}_{4}\right) \\
\text { Chiloride radicle (CI) } \\
\text { Nitrate radicle ( } \mathrm{NO} \text {. }\end{array}$ & $\begin{array}{l}298.0 \\
2.0 \\
18\end{array}$ & $\begin{array}{l}6.3 \\
247 \\
25 \\
4.5 \\
.00\end{array}$ & $\begin{array}{r}251^{.0} \\
6.4 \\
12.80\end{array}$ & $\begin{array}{c}2.4 \\
290 \\
16 \\
6.0 \\
.00\end{array}$ & $\begin{array}{l}283^{.0} \\
2.4 \\
12.60\end{array}$ & $\begin{array}{l}298^{.0} \\
29 \\
16 \\
.30\end{array}$ \\
\hline $\begin{array}{l}\left.\text { Phosphate radicle (PO } \mathrm{PO}_{4}\right) \\
\text { Total dissolved solids at } 180^{\circ} \mathrm{C}_{-}\end{array}$ & $\begin{array}{r}2.6 \\
\text { b326 }\end{array}$ & & 272 & 296 & 319 & 366 \\
\hline $\begin{array}{l}\text { Total hardness as } \mathrm{CaCO}_{8} \text { (calcu- } \\
\text { lated) } \\
\text { Date of collection }\end{array}$ & 5 & 24 & Aug., 1911 & $\begin{array}{l}149 \\
\text { Nov., } 1911\end{array}$ & June, 9 & Aug., 1911 \\
\hline
\end{tabular}

- Iron and aluminum oxides $\left(\mathrm{Fe}_{2} \mathrm{O}_{3}+\mathrm{Al}_{2} \mathrm{O}_{3}\right)$.

Includes iron and aluminum ( $\mathrm{Fe}+\mathrm{Al})$.

Analysts: 11, W.R. Perkins (Mississippl Agr. Exper. Sta. Bull. 89, p. 90, 1905); 17, E. S. Wallace, University of Mississippi; 19, 26, W. L. Kennon, University of Mississippi; 22, W. L. Perdue, University of Mississippi; 24, Mississippi State Chemical Laboratory.

\section{TATE COUNTY}

\section{GENERAL FEATURES}

Area, 400 square miles. Population, 19,636 (census of 1920)

Tate County is the second county south of the Tennessee State line. The eastern two-thirds of the county lies in the North Central Hills district and the remainder in the Loess or Bluff Hills district. The upland portion of the county is underlain by the Grenada, the uppermost formation of the Wilcox group of the Eocene. The other formations of the group, the Holly Springs sand and the Ackerman formation, lie in succession below the Grenada, but they do not appear in outcrops. In areas of undetermined extent in the western part of the county the Grenada is overlain by terrace sands and gravels of Pliocene age. Above these terrace deposits or, where they are absent, the Grenada formation, lies a nearly universal blanket of loess (Pleistocene), which ranges in thickness from 40 feet or more in the west to only a few feet in the east. The lowland of Coldwater River, on the north, is underlain by a relatively thin alluvial deposit of loam, clay, sand, and gravel of Pleistocene age, and Recent alluvium of similar character underlies the Yazoo Delta to an estimated thickness of 150 feet or more. The formations enumerated are described on pages $46-63$, and their distribution is shown on the geologic map (pl. 2), except that only the thicker portions of the loess are shown on the map.

\section{GROUND-WATER CONDITIONS}

The principal developed sources of domestic water supply in Tate County are the Grenada formation and the Pliocene terrace sands and gravels. Most of the deeper wells in the western part of the upland, and even the shallower wells in the eastern part of the county, have their source in the Grenada. The terrace sands and 
gravels that intervene between the Grenada formation and the overlying loess at most places in the west are porous and make valuable aquifers. Many shallow wells penetrate the loess and enter these sands and gravels, which are.also the source of many springs. The alluvial deposits that underlie the Yazoo Delta and the lowland of Coldwater River contain water that is easily obtained by dug, bored, and driven wells.

Only one well deeper than 120 feet has been reported in the county, and one of the most promising sources of ground water is therefore, for the most part, undeveloped. The Holly Springs sand underlies the Grenada throughout the area and is abundantly water bearing. The water-bearing sands crop out in Marshall County and dip to the west beneath the Grenada formation at a low angle. In the eastern part of Tate County these sands would be reached by wells 100 to 400 or 500 feet deep; in the western part they would probably be penetrated by wells 400 to 800 feet deep; one 500-foot well in the lowland at Savage (No. 11) reaches the Holly Springs sand and yields a flow.

\section{LOCAL SUPPLIES}

Arkabutla.-At Arkabutla the drilled well of J. L. Scott (No. 1) is 30 feet deep and taps water-bearing gravel just beneath the loess. The water becomes roiled easily from the fine particles of loess or clay that are mingled with the gravel. (See analysis 1.)

Coldwater.-Three wells at and near Coldwater (Nos. 2-4) are 63, 63 , and 62 feet in depth, and all of them enter gravel. The water from Mrs. W. H. Eason's well (No. 2) is locally considered to be hard, whereas that from well No. 3 is considered to be soft. All these shallow waters probably contain appreciable amounts of mineral salts, but no waters too strongly mineralized for general use have been reported. A well (No. 5) 3 miles south of Coldwater is 120 feet deep and probably enters the Grenada formation. It yields an ample supply of water which is locally considered to be somewhat better than that from the shallower wells.

Independence.-Two wells at Independence (Nos. 6 and 7) are 70 and 78 feet deep and enter coarse white water-bearing sand probably of the Grenada formation. The water from each well is reported to be rather hard but is utilized for domestic and farm supplies.

Strayhorn.-The dug well of S. T. Clayton (No. 19), a mile north of Strayhorn, is 110 feet deep and penetrates the materials described in the following log:

Log of well of S. T. Clayton, a mile north of Strayhorn (No. 19)

\begin{tabular}{|c|c|c|}
\hline & Thickness & Depth \\
\hline $\begin{array}{l}\text { Loess: Surface clay } \\
\text { Pliocene terrace deposit: Gravel and sand. }\end{array}$ & $\begin{aligned} \text { Feet } & \\
& 20 \\
& 15\end{aligned}$ & $\begin{aligned} \text { Feet } & \\
& 20 \\
& 35\end{aligned}$ \\
\hline $\begin{array}{l}\text { Grenada formation. } \\
\text { Red to white sand } \\
\text { Pipe clay } \\
\text { Sand; water bearing }\end{array}$ & $\begin{array}{r}50 \\
22 \\
3\end{array}$ & $\begin{array}{r}85 \\
107 \\
110\end{array}$ \\
\hline
\end{tabular}


The public well at Strayhorn (No. 18) is only 35 feet deep and doubtless has its source in the Pliocene terrace sand and gravel. (See analysis 18.)

Senatobia.-The municipal waterworks at Senatobia is located on Ward Street about two blocks north of the courthouse. Two wells, each reported to be about 120 feet deep, afford the municipal water supply (No. 12).

Log of well at the waterworks at Senatobia (No. 12)

\begin{tabular}{|c|c|c|}
\hline & Thickness & Depth \\
\hline Loess: Clay & ${ }^{\text {Feet }}{ }_{24}$ & Feet ${ }_{24}$ \\
\hline $\begin{array}{l}\text { Pliocene terrace deposits: Coarse gravel } \\
\text { Grenada formation: }\end{array}$ & 15 & 39 \\
\hline Quicksand & 21 & 60 \\
\hline Sand & 10 & 74 \\
\hline $\begin{array}{l}\text { White clay } \\
\text { Sand }\end{array}$ & $\begin{array}{r}2 \\
14\end{array}$ & $\begin{array}{l}76 \\
90\end{array}$ \\
\hline $\begin{array}{l}\text { Pipe clay } \\
\text { Sand; water bearing (Grenada?) }\end{array}$ & $\begin{array}{r}2 \\
28\end{array}$ & $\begin{array}{r}92 \\
120\end{array}$ \\
\hline
\end{tabular}

Five dug wells at Senatobia are described in the table of well data (Nos. 13-17). They probably enter the upper layers of the Grenada formation. Therapeutic qualities are ascribed to the waters from some of these wells. (See analysis 13.)

Looxahoma.-A dug well (No. 8) 3 miles southwest of Looxahoma is 42 feet deep; water was encountered in white sand, probably of the Grenada formation, near the bottom of the well, and rose under artesian pressure within 18 feet of the surface. (See analysis 8.) Another well (No. 9), half a mile south of Looxahoma, is 109 feet deep and yields a moderately mineralized water from coarse sand near the bottom. The water is hard and is used for medicinal purposes, and for stock. (See analysis 9.)

Sarah.-At Sarah, near the foot of the bluffs, in the extreme southwest corner of the county, water is obtained by means of driven wells 30 to 60 feet deep; the static head is 10 to 20 feet below the surface. This water comes from the alluvial deposits and is of good quality; it is less mineralized and is less stained by vegetation than is the water of some of the shallow wells in the delta lands farther to the west.

Savage.-Savage is a village on the Yazoo \& Mississippi Valley Railroad in the western part of the county. One well (No. 11) at this place yields a flow from the Holly Springs sand at a depth of 500 feet; thin beds of hard sandstone were encountered at depths of 320 and 360 feet. The well supplies several families. (See analysis 11.) Another well (No. 10) at Savage is 191 feet deep and yields rather hard water from a sandy layer, probably in the alluvium. (See analysis 10 .) 


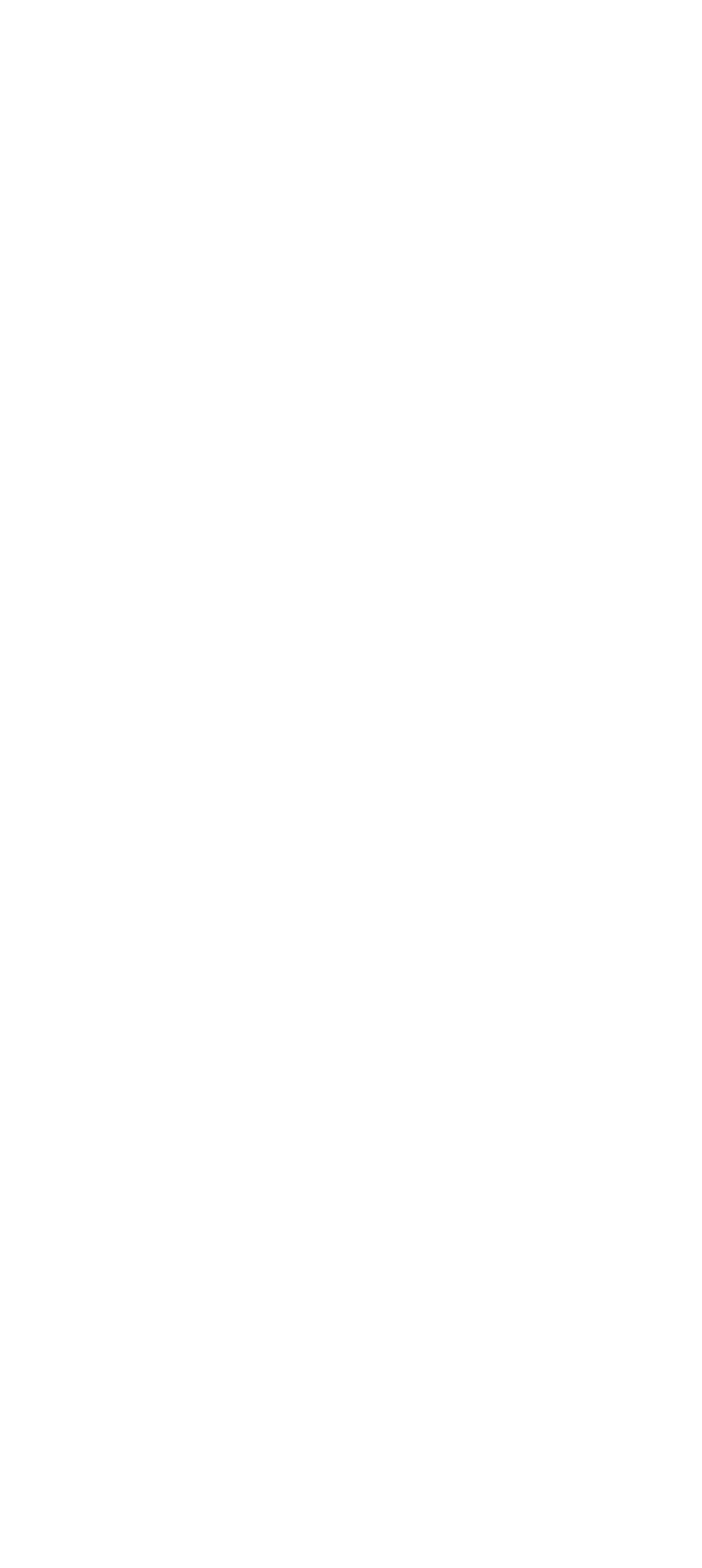




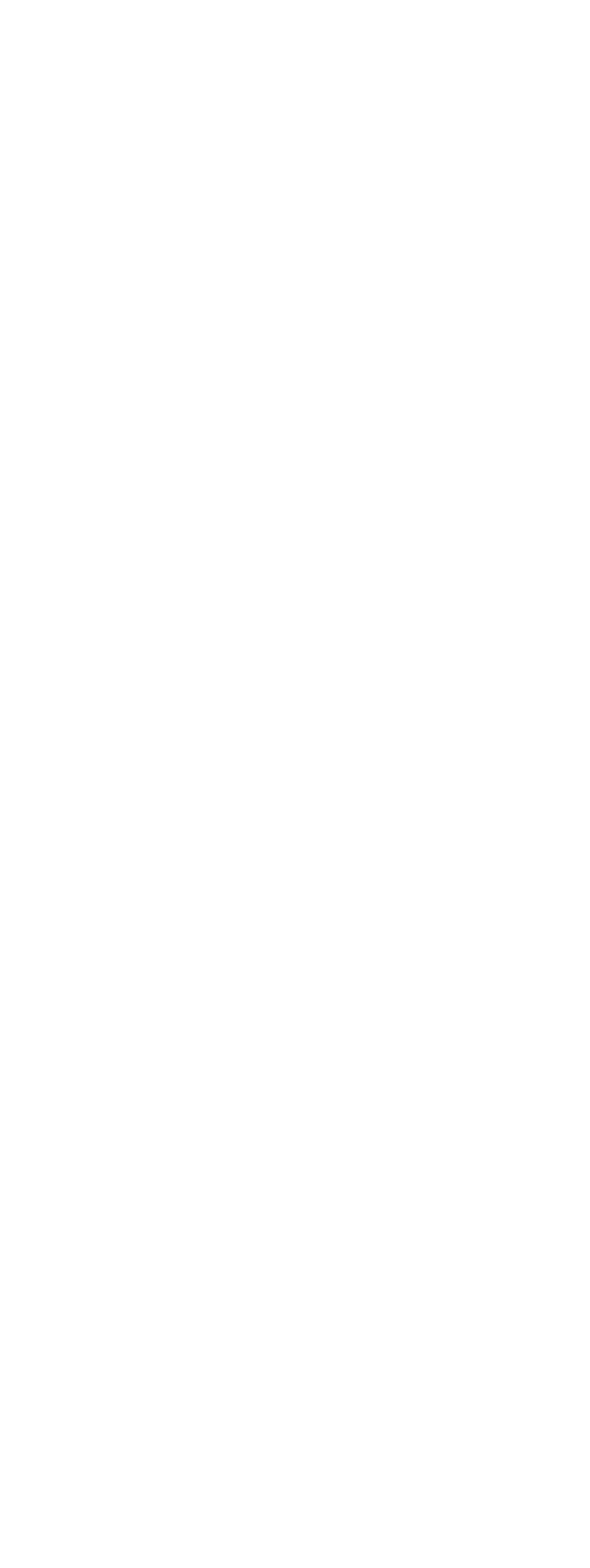




\section{Mineral analyses of ground waters in Tate County}

[Parts per million. Numbers at heads of columns refer to corresponding well numbers in preceding tab]e]

\begin{tabular}{|c|c|c|c|c|c|c|c|}
\hline & 1 & 9 & 10 & 11 & 12 & 13 & 18 \\
\hline 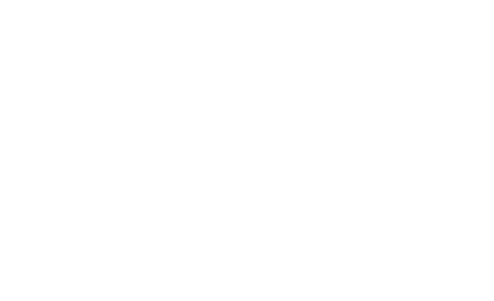 & $\begin{array}{l}46 \\
14^{25} \\
6.5 \\
19.5 \\
78^{.0} \\
11 \\
16 \\
151^{60} \\
62 \\
\text { Dec. } \\
1912\end{array}$ & $\begin{array}{l}14 \\
2.6 \\
64 \\
15 \\
79 \\
71^{.0} \\
3.9 \\
218 \\
28 \\
451 \\
222 \\
\text { Aug., } \\
1914\end{array}$ & $\begin{array}{l}34 \\
03.0 \\
41 \\
16 \\
b 13 \\
197^{.0} \\
24 \\
6.5 \\
230 \\
168 \\
\text { Nov. } \\
1911\end{array}$ & $\begin{array}{l}41 \\
4.9 \\
22 \\
8.7 \\
22.0 \\
142^{.0} \\
14.5 \\
7.5 \\
175^{.00} \\
91 \\
\text { Sept., } \\
1914\end{array}$ & $\begin{array}{l}8.0 \\
20.20 \\
12.9 \\
49^{\circ} \\
18 \\
11 \\
93^{\circ} \\
54 \\
\text { Oct.; } \\
1911\end{array}$ & $\begin{array}{r}17 \\
1.5 \\
5.8 \\
1.3 \\
23 \\
49 \\
49 \\
3.4 \\
24 \\
1.6 \\
105 \\
20 \\
\text { Nov., } \\
1913\end{array}$ & $\begin{array}{c}26 \\
14.80 \\
17 \\
126 \\
126 \\
424^{\circ} .0 \\
4.9 \\
14.9 \\
7.5 \\
408 \\
105 \\
\text { Aug., } \\
1911\end{array}$ \\
\hline
\end{tabular}

- Includes iron and aluminum ( $\mathrm{Fe}+\mathrm{Al})$.

- Calculated.

Analysts: 1, 9, 11, 13, Mississippi State Chemical Laboratory; 10, 12, W. L. Perdue, University of Mississippi; 18, W. L. Kennon, University of Mississippi.

\section{TIPPAH COUNTY}

\section{GENERAL FEATURES}

Area, 446 square miles. Population, 15,419 (census of 1920)

The eastern part of Tippah County, including somewhat less than half of the total area, lies within the belt of country known as the Pontotoc Hills district. Most of the remainder of the county is in the Flatwoods district. The Ripley formation, of the Upper Cretaceous, immediately underlies the surface throughout the Pontotoc Hills, which embrace about the southeastern two-fifths of the county, and include a narrow area that extends to the Tennessee line in the northeast. The Ripley formation is underlain in descending succession by the Selma chalk, the Eutaw formation, and the Tuscaloosa formation, none of which appear at the surface within the county but which crop out successively to the east in Alcorn, Prentiss, and Tishomingo Counties, Miss., and Colbert County, Ala. The Ripley is overlain by Eocene beds, which immediately underlie the surface in approximately the western three-fifths of the county. The Eocene is divisible, in ascending order, into the Clayton formation and the Porters Creek clay of the Midway group and the Ackerman formation of the Wilcox group. These formations are more fully described on pages 39-46, and their distribution is shown on the geologic map (pl. 2).

\section{GROUND-WATER CONDITIONS}

The principal source of domestic water supplies in the Pontotoc Hills consists of the predominantly sandy and in part abundantly waterbearing beds of the Ripley formation, which have an estimated aggregate thickness of about 400 feet. Shallow dug and bored wells, which range in depth from a few feet to 100 feet or more, form the 
chief means of obtaining the water, though some of the many small springs are utilized. The only deep well reported from this area is that of T. L. Randolph at Dumas (No. 13), the depth of which is 210 feet; this well probably penetrates nearly to the base of the Ripley formation.

The Pontotoc Hills of eastern Tippah and western Alcorn Counties constitute the catchment area of the waterbearing sandy beds of the Ripley formation, which dip to the west at an estimated rate of 30 feet to the mile and pass beneath the overlapping Eocene deposits, where in the western part of Tippah County they become a valuable source of artesian water. Many wells 75 to 500 feet deep have been drilled at and in the vicinity of the towns along the Gulf, Mobile \& Northern Railroad, and between this railroad and the western county line. (See table.) As the main creek valleys in this area are lower than the upland level of the Pontotoc Hills - that is, lower than the catchment area-sufficient hydrostatic pressure is developed to raise the water above the surface in wells along Tippah Creek and its tributaries west of Ripley and along the headwater creeks of Tallahatchie River in the vicinity of Cotton Plant and Hickory Flat. At all places, even on the uplands, the static head is near enough the surface to bring the water within comparatively easy reach of force pumps. The water as a rule is obtained from loose, porous sands immediately beneath indurated layers. As indicated in the table, some of the wells are probably not deep enough to reach the Ripley formation but draw from water-bearing sands near the base of the Clayton formation of the Eocene. The Clayton immediately overlies the Ripley and crops out along the western border of the Pontotoc Hills. Many of the wells in northwestern Tippah County, as at Falkner, Tiplersville, and Walnut, tap the water-bearing beds of the McNairy sand member of the Ripley.

The abundantly water-bearing beds of the Eutaw and Tuscaloosa formations, which underlie the county at estimated depths of 300 to 600 feet in the extreme southeast, increasing to 800 to 1,200 feet along the line of the Gulf, Mobile \& Northern Railroad, constitute an as yet entirely undeveloped source of nonflowing artesian water. It is doubtful if flowing wells can be obtained from these formations in Tippah County.

The Pontotoc Hills, which are underlain by the sandy strata of the Ripley formation, and the area immediately to the west, which is underlain by the sandy beds in the lower part of the Midway group of the Eocene, abound in small springs that serve as feeders of the many headwater creeks and branches of Tallahatchie River and Tippah Creek. Some of them are utilized for domestic supplies. 


\section{LOCAL SUPPLIES}

Ripley.-Ripley is provided with a small waterworks, located about two blocks northeast of the Gulf, Mobile \& Northern Railroad station. The source of the water supply is a 220 -foot well (No. 21) from which a gas-driven vertical force pump raises the water to a 10,000 -gallon elevated wooden tank. The log of the well is as follows:

\section{Log of well of M. L. Finger \& Sons, Ripley (No. 21)}

[Estimated altitude of mouth of well 511 feet above sea level. Adapted from description by M. L. Finger]

\begin{tabular}{|c|c|c|}
\hline & Thickness & Depth \\
\hline $\begin{array}{l}\text { Eocene (Midway group): } \\
\text { Sand } \\
\text { Rock (limestone?) }\end{array}$ & Feet $\begin{array}{r}30 \\
30\end{array}$ & Feet $\begin{array}{r}30 \\
60\end{array}$ \\
\hline $\begin{array}{l}\text { Upper Cretaceous (Ripley formation): } \\
\text { Blue marl. } \\
\text { Sand; water bearing at base. }\end{array}$ & $\begin{array}{r}115 \\
45\end{array}$ & $\begin{array}{l}175 \\
220\end{array}$ \\
\hline
\end{tabular}

Several wells in the vicinity of Ripley are described in the table (Nos. 21-26). Many flowing wells have been obtained along the valley of Tippah Creek between Ripley and the western county line.

Blue Mountain.-Many wells 50 to 500 feet deep have been drilled at and near Blue Mountain; most of them are deep enough to reach the water-bearing beds of the Ripley formation, and a few that are located low in creek valleys flow at the surface. (See wells 1-7.) Logs of two wells at Blue Mountain follow:

Log of well of J.E. Brown at Mississippi Heights School, half a mile east of post office, Blue Mountain (No. 2)

[Authority, J. F. Harrington]

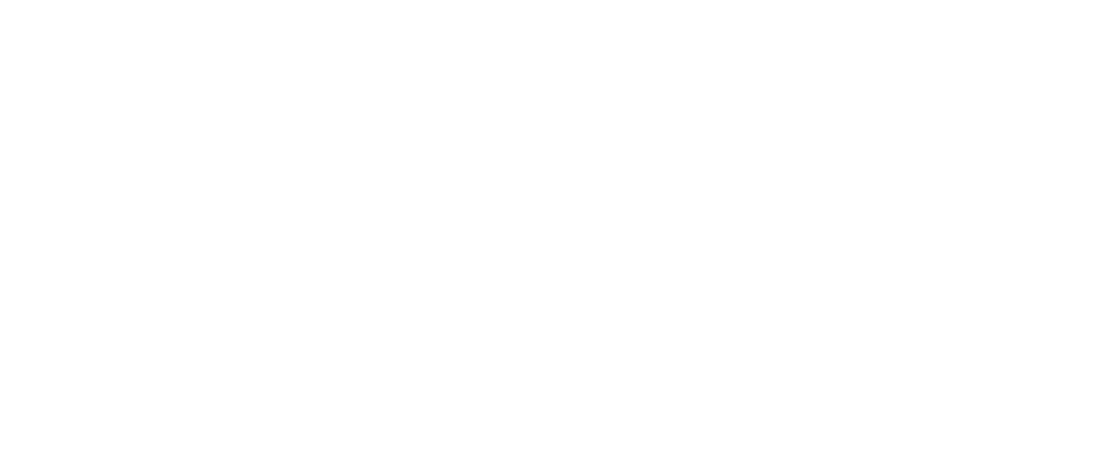

Log of well of Lee Godwin, Blue Mountain

[Altitude of mouth of well 511 feet above sea level. Adapted from data furnished by E. N. Lowe, State geologist]

\begin{tabular}{|c|c|c|}
\hline & Thickness & Depth \\
\hline Clay & Feet 20 & Feet 20 \\
\hline $\begin{array}{l}\text { "Black dirt" (Porters Creek clay) } \\
\text { Rock }\end{array}$ & $\begin{array}{r}140 \\
10\end{array}$ & $\begin{array}{l}160 \\
170\end{array}$ \\
\hline Sand; water bearing (Clayton formation?) & & 179 \\
\hline
\end{tabular}


The water-bearing sand in the lower part of the section is questionably correlated with the Clayton formation of the Eocene.

Small springs, which have their source in sands of the Ackerman formation, are numerous among the hills in the vicinity of Blue Mountain. A group of 12 springs, known as Blue Mountain Springs, within a radius of 50 yards on the campus of Blue Mountain College, in the SW. $1 / 4$ sec. 6 , T. 5 S., R. 3 E., afford a combined yield of 90 gallons a minute of freestone water, an amount ample to supply the general needs of the college. (See analysis 33.) Another group of similar springs, known as Sand Springs, a mile east of Blue Mountain, in the NW. $1 / 4$ sec. 8, T. 5 S., R. 3 E., yields at the rate of 12,000 gallons daily, and by means of a hydraulic ram furnishes the domestic water supply of a residence situated on a hill above the group.

Cotton Plant.-Wells in the vicinity of Cotton Plant, 150 to 500 feet deep, tap water-bearing beds in the Ripley formation. Some of those that are located low in the headwater valleys of Tallahatchie River flow, and in all the others the static head is not far below the surface. (See wells 9-12.) The log of one of Paul J. Rainey's wells (No. 10), near Cotton Plant is given below:

Log of well of Paul J. Rainey, a mile east of post office at Cotton Plant (No. 10)

[Estimated altitude of mouth of well 419 feet above sea level. Adapted from description by A. B. Roach, driller]

\begin{tabular}{|c|c|c|c|c|c|}
\hline & $\begin{array}{c}\text { Thick- } \\
\text { ness }\end{array}$ & Depth & & $\begin{array}{l}\text { Thick- } \\
\text { ness }\end{array}$ & Depth \\
\hline $\begin{array}{l}\text { Soil and clay } \\
\text { Sand; water bearing- } \\
\text { Sandrock } \\
\text { Black clay containing shells } \\
\text { Rock } \\
\text { Black clay } \\
\text { Boulders (concretionary?) } \\
\text { Black clay } \\
\text { Hard black rock }\end{array}$ & $\begin{array}{r}\text { Feet } \\
5 \\
5 \\
30 \\
60 \\
5 \\
5 \\
10 \\
54 \\
6\end{array}$ & $\begin{array}{r}\text { Feet } \\
5 \\
10 \\
40 \\
100 \\
105 \\
110 \\
120 \\
174 \\
180\end{array}$ & $\begin{array}{l}\text { Sand; water bearing } \\
\text { Black clay- } \\
\text { Hard rock } \\
\text { Black clay } \\
\text { Hard rock } \\
\text { Black clay } \\
\text { Rock } \\
\text { Sand water bearing } \\
\text { Black dirt }\end{array}$ & $\begin{array}{r}\text { Feet } \\
30 \\
50 \\
3 \\
15 \\
2 \\
20 \\
2 \\
18 \\
141\end{array}$ & $\begin{array}{l}\text { Feet } \\
210 \\
260 \\
263 \\
278 \\
280 \\
300 \\
302 \\
320 \\
461\end{array}$ \\
\hline
\end{tabular}

This well passed through an undetermined thickness of Eocene strata (Midway group) at the top, probably completely penetrated the Ripley formation, and may have entered the underlying Selma chalk, which would be represented by part or all of the 141 feet of "black dirt" at the base.

The headwater creeks of Tallahatchie River, in the southwestern part of Tippah County, are fed by numerous small springs, of which those on the farm of Paul J. Rainey, described in the following table, may be regarded as typical. 
Springs on farm of Paul J. Rainey, in T. 5 S., R. 3 E., near Cotton Plant

[Compiled by W. N. Logan]

\begin{tabular}{|c|c|c|c|}
\hline \multirow{2}{*}{ No. } & \multicolumn{2}{|c|}{ Location } & \multirow{2}{*}{$\begin{array}{l}\text { Approximate } \\
\text { yield (gallons } \\
\text { per } 24 \text { hours) }\end{array}$} \\
\hline & Quarter & Section & \\
\hline $\begin{array}{l}1 \\
2 \\
3 \\
4 \\
5 \\
5 \\
6 \\
7 \\
8 \\
9 \\
9\end{array}$ & $\begin{array}{c}\text { SE. } \\
\text { SW. } \\
\text { NE. } \\
\text { SE. } \\
\text { SE. } \\
\text { NW. } \\
\text { SE. } \\
\text { NE. } \\
\text { SE. }\end{array}$ & $\begin{array}{l}31 \\
28 \\
28 \\
21 \\
21 \\
22 \\
16 \\
15 \\
11\end{array}$ & $\begin{array}{r}12,000 \\
20,000 \\
14,000 \\
10,000 \\
16,000 \\
8,000 \\
12,000 \\
8,000 \\
10,000\end{array}$ \\
\hline
\end{tabular}

Falkner.-Many wells have been drilled to depths of 150 to 360 feet in the neighborhood of Falkner. Although no flows have been reported the static head is less than 100 feet below the surface in most wells, and in many is less than 50 feet. The Ripley formation is the source of the water. (See wells 14-20.) The log of a typical well near Falkner is given below.

Log of well of W.W.Wright, 1.1 miles northwest of post office at Falkner (No. 20)

[Estimated altitude of mouth of well 525 feet above sea level. Adapted from owner's description]

\begin{tabular}{|c|c|c|}
\hline & Thickness & Depth \\
\hline $\begin{array}{l}\text { Clay and sand } \\
\text { Black slate and soapstone } \\
\text { Sandstone } \\
\text { Blue marl } \\
\text { Fint rock (sandstone?) } \\
\text { Sand; water bearing. }\end{array}$ & $\begin{array}{r}\text { Feet } \\
15 \\
90 \\
40 \\
60 \\
30 \\
5\end{array}$ & $\begin{array}{r}\text { Feet } \\
15 \\
105 \\
145 \\
205 \\
235 \\
240\end{array}$ \\
\hline
\end{tabular}

An undetermined upper portion of this section, perhaps including the three upper layers, is Eocene (Midway group), and the remainder belongs to the Ripley formation of the Cretaceous.

Tiplersville and Walnut.-The ground-water conditions at Tiplersville and Walnut are essentially the same as those at Falkner. Several wells are described in the table (Nos. 27-32). The log of one well near Tiplersville follows:

Log of well of Mrs. N. B. Marsh, half a mile southwest of the post office at Tiplersville (No. 28)

[Altitude of mouth of well about 472 feet above sea level. Adapted from description by N. B. Marsh]

\begin{tabular}{|c|c|c|}
\hline & Thickness & Depth \\
\hline $\begin{array}{l}\text { Clay } \\
\text { Sandrock } \\
\text { Marl } \\
\text { Flint rock (sandstone?) } \\
\text { Sand; water bearing }\end{array}$ & Feet $\begin{array}{r}55 \\
38 \\
22 \\
25 \\
4\end{array}$ & $\begin{array}{r}55 \\
9 \\
115 \\
140 \\
144\end{array}$ \\
\hline
\end{tabular}


The two uppermost layers of this section are thought to represent the basal beds of the Eocene (Midway group), below which only the Ripley formation of the Cretaceous was penetrated.

Dumas.- The log of a 210-foot well (No.13) at Dumas is as follows:

Log of well of T. L. Randolph, on the upland at Dumas (No. 13)

[Adapted from owner's description]

\begin{tabular}{|c|c|c|c|c|c|}
\hline & $\begin{array}{c}\text { Thick- } \\
\text { ness }\end{array}$ & Depth & & $\begin{array}{c}\text { Thick- } \\
\text { ness }\end{array}$ & Depth \\
\hline $\begin{array}{l}\text { Ripley formation: } \\
\text { Hard clay } \\
\text { Yellow sand } \\
\text { Yellow clay } \\
\text { Rock }\end{array}$ & $\begin{array}{r}\text { Feet } \\
25 \\
5 \\
118 \\
2\end{array}$ & $\begin{array}{r}\text { Feet } \\
25 \\
30 \\
148 \\
150\end{array}$ & $\begin{array}{l}\text { Ripley formation-Continued. } \\
\text { White sand; water bearing-. } \\
\text { Bluish clay or shale } \\
\text { Rock } \\
\text { White sand; water bearing-. }\end{array}$ & $\begin{array}{r}\text { Feet } \\
10 \\
37 \\
3 \\
10\end{array}$ & $\begin{array}{r}\text { Feet } \\
160 \\
197 \\
200 \\
210\end{array}$ \\
\hline
\end{tabular}

Chalybeate Springs.-The village of Chalybeate Springs is on a hill east of Muddy Creek, about 2 miles southeast of Walnut. The spring from which the village derives its name is in a ravine just east of the main street and about 50 feet below the top of the hill. The water issues from the contact between the uppermost layer of the Ripley formation (Upper Cretaceous), a tough, micaceous, glauconitic, argillaceous sand, and a layer of hard glauconitic fossiliferous limestone, which forms the base of the Clayton formation (Eocene). The yield is small, and the water is iron bearing. 


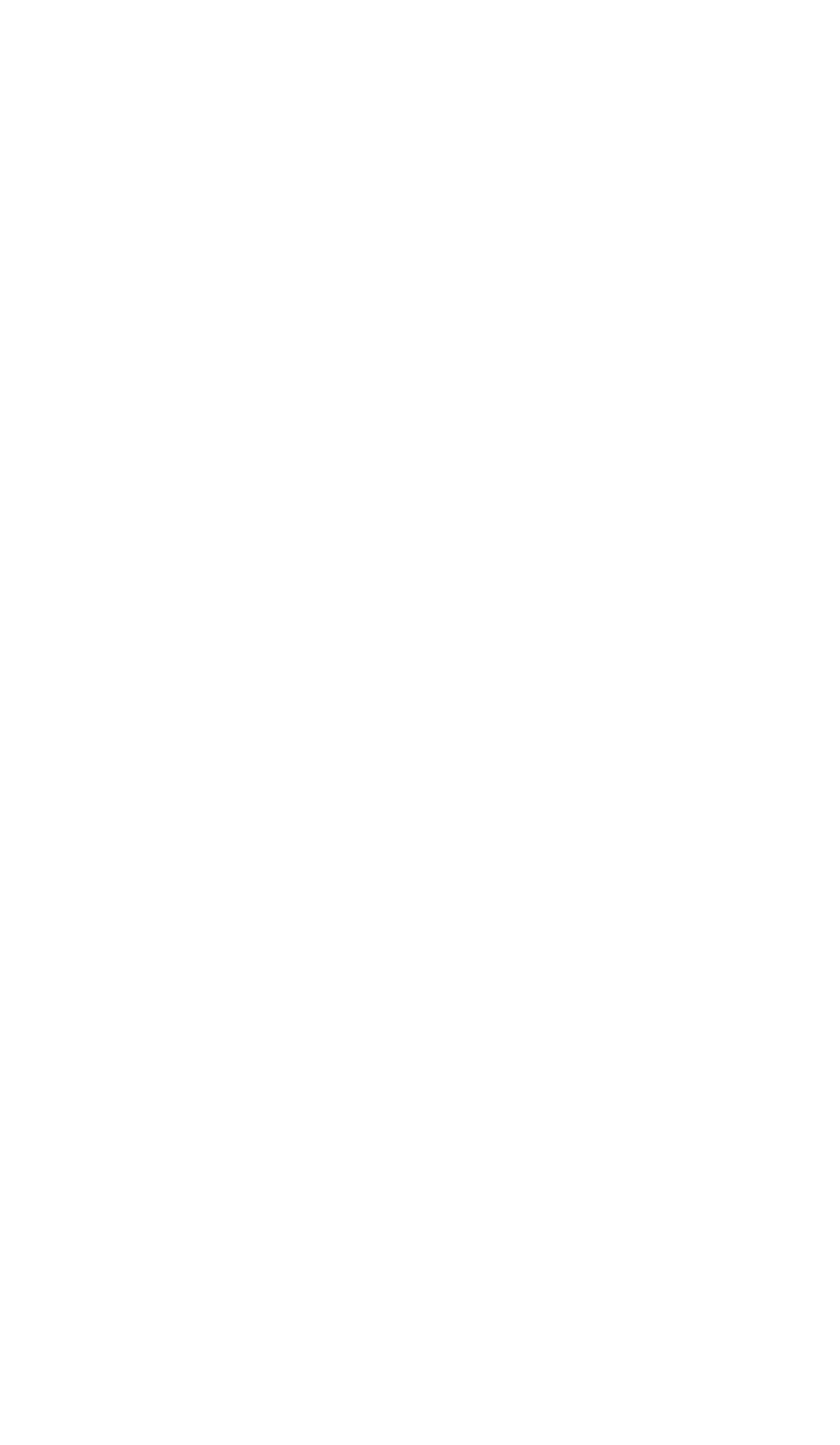




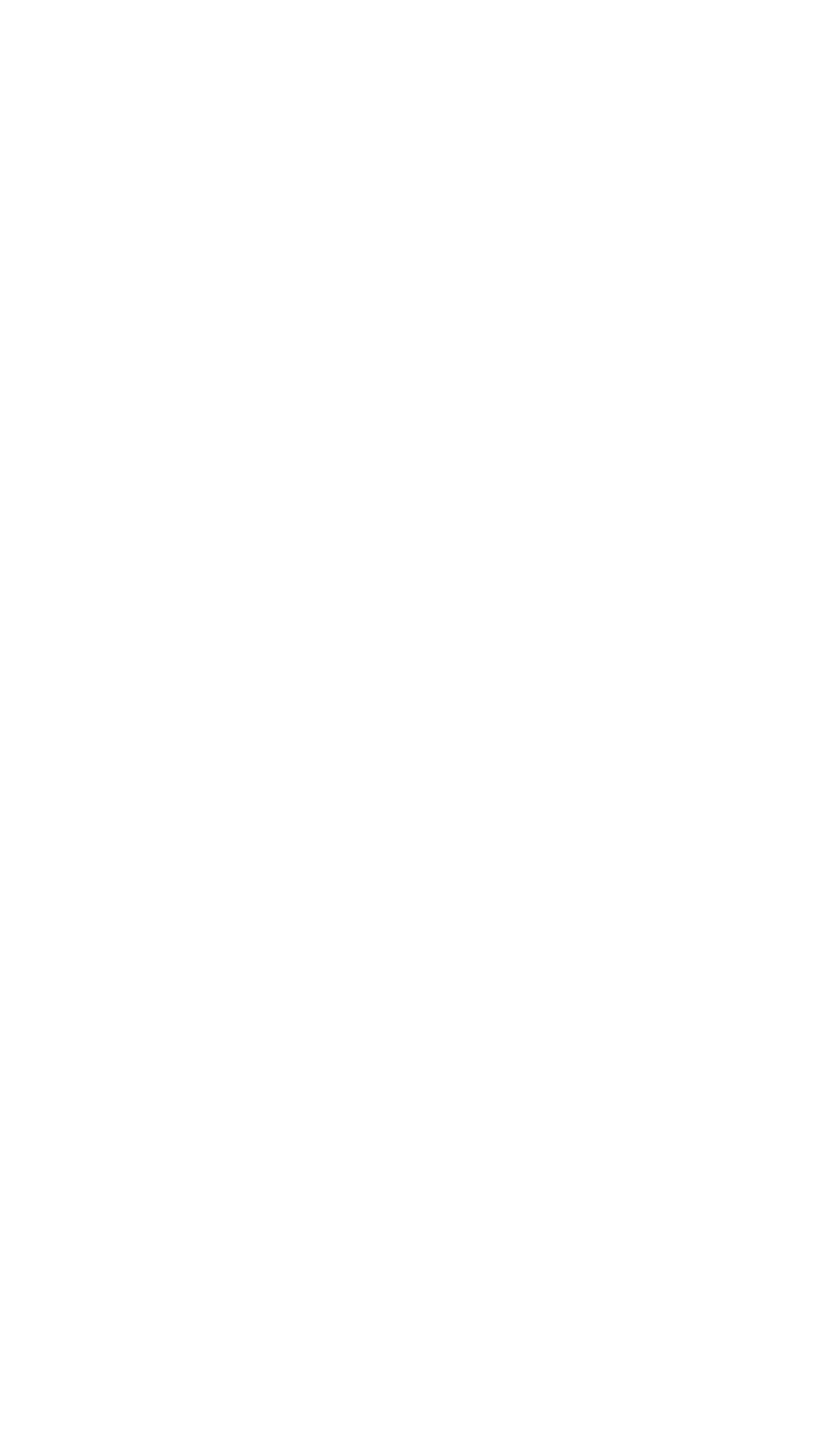




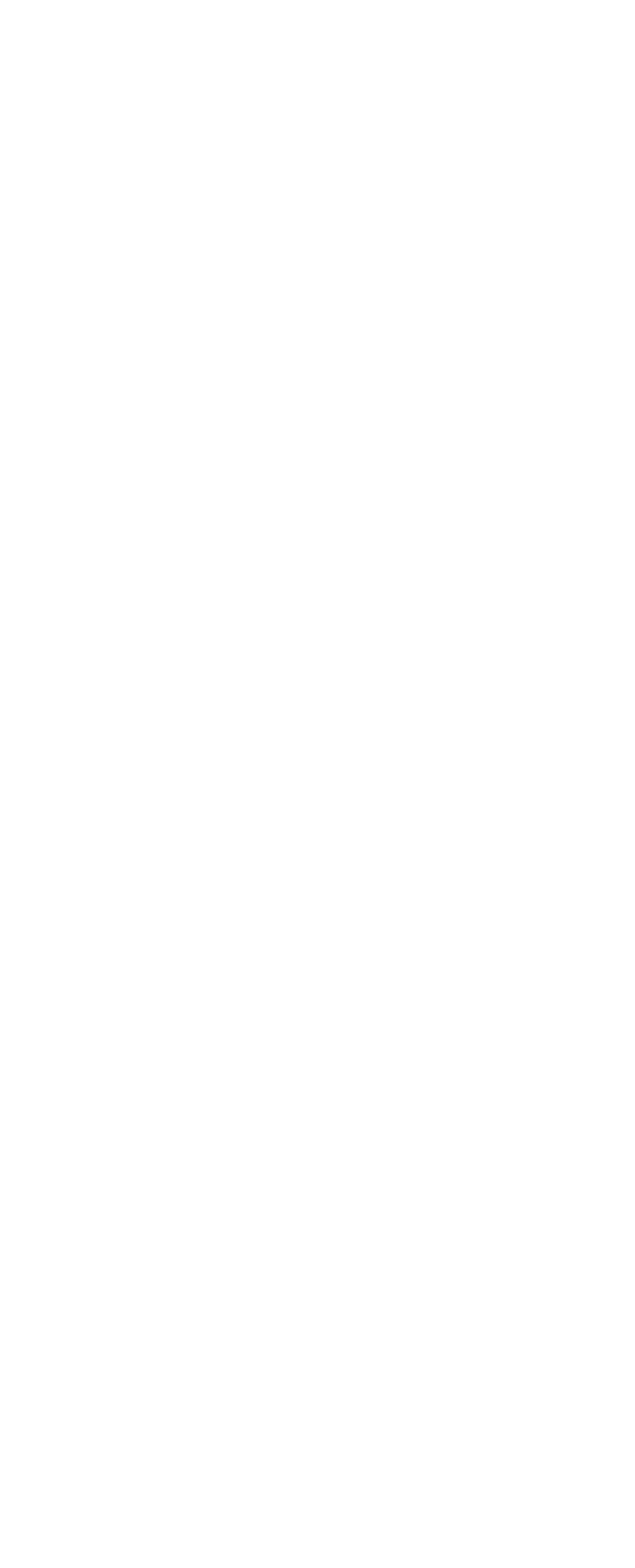


Mineral analyses of ground waters from Tippah County

[Parts per million. Numbers at heads of columns refer to corresponding well numbers in preceding table]

\begin{tabular}{|c|c|c|c|c|c|}
\hline & 2 & 5 & 6 & 7 & 10 \\
\hline \multirow[t]{2}{*}{ 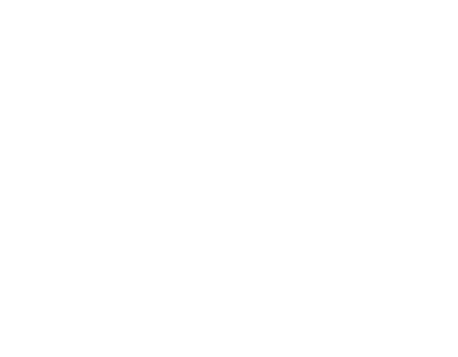 } & $\begin{array}{l}15 \\
\text { Trace. } \\
8.0 \\
5.2 \\
54.0 \\
178^{.0} \\
12 \\
3.0 \\
2.0 \\
188 . \\
41 \\
1911\end{array}$ & $\begin{array}{l}36 \\
2.58 \\
13 \\
25 \\
5.0 \\
153 \\
12 \\
3.0 \\
182^{.21} \\
106 \\
\text { Sept., } 1919\end{array}$ & $\begin{array}{c}29 \\
46.07 \\
9.6 \\
14.8 \\
4.8 \\
179 \\
12 \\
2.0 \\
\text { Trace. } \\
195 \\
154 \\
\text { Sept., } 1919\end{array}$ & $\begin{array}{l}32 \\
7.7 \\
70 \\
31 \\
36 \\
{ }^{318^{-0}} .0 \\
61 \\
24 \\
{ }^{410^{\circ}} .72 \\
302 \\
\text { Sept., } 1919\end{array}$ & $\begin{array}{c}20 \\
6.25 \\
2.4 \\
60 \\
14 \\
135 \\
7.6 \\
4.0 \\
1.2 \\
187 \\
25 \\
\text { Sept., } 1919\end{array}$ \\
\hline & 11 & 21 & 26 & 32 & 33 \\
\hline 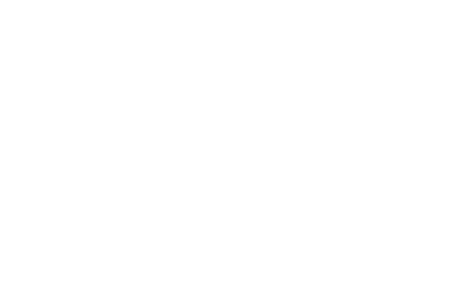 & \begin{tabular}{|c|}
28 \\
67.05 \\
13 \\
17 \\
2.4 \\
284 \\
14 \\
5.0 \\
Trace. \\
274 \\
221 \\
Sept., 1919
\end{tabular} & $\begin{array}{c}31 \\
56.16 \\
8.7 \\
23.7 \\
224.0 \\
10 \\
6.5 \\
2.0 \\
252 \\
176 \\
\text { Sept., } 1919\end{array}$ & \begin{tabular}{|c|}
34 \\
48 \\
7.8 \\
10 \\
2.4 \\
189 \\
6.8 \\
3.0 \\
Trace. \\
201 \\
152 \\
Sept., 1919
\end{tabular} & 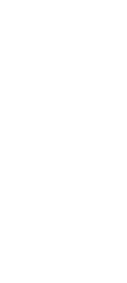 & $\begin{array}{c}22 \\
.06 \\
1.6 \\
14.9 \\
35.0 \\
1.7 \\
3.7 \\
2.3 \\
60 \\
8 \\
\text { Sept., } 1919\end{array}$ \\
\hline
\end{tabular}

Analysts: 2 E, S. Wallace, University of Mississippi; 5, 21, 33, Margaret D. Foster, U. S. Geological Survey; 6, 7, 10, 11, 26, C. S. Howard, U. S. Geological Survey; 32, Mississippi State Chemical Laboratory.

\section{TISHOMINGO COUNTY}

\section{. General FEATURES}

Area, 428 square miles. Population, 15,091 (census of 1920)

Tishomingo County is in the northeast corner of the State, in the section to which the name Tennessee or Tombigbee River Hills has been given. The Tuscaloosa formation of the Upper Cretaceous crops out in a strip 2 to 6 miles wide in the eastern part of the county and is overlain throughout the remainder of the county to the west by the Eutaw formation, also of Upper Cretaceous age. The Tuscaloosa rests unconformably on a basement of Paleozoic rocks that crop out in narrow areas along Tennessee River, Yellow Creek, Indian Creek, Bear Creek, and in places along Mackys Creek and its tributaries; the upper surface of the basement rocks is irregular in detail but in general dips slightly to the west and along the western boundary is estimated to be about 250 feet below the general level of the upland. Decsriptions of the Tuscaloosa and Eutaw formations are given on pages $29-36$, and their distribution is shown on the geologic map (pl. 2). 


\section{GROUND-WATER CONDITIONS}

Springs which flow from the water-bearing gravels and sands of the Tuscaloosa formation and from the sands of the Eutaw formation are common among the hills. The springs of largest yield and softest quality are those that have their source in the gravels of the Tuscaloosa formation in the eastern half of the county; such springs are numerous east of Iuka, in the vicinity of Tishomingo, east of Dennis and Belmont, and in fact throughout the area of outcrop of the gravels between Tennessee River and the southeast corner of the county; one of the springs is shown in Plate 5, $A$. The waters of springs that have their source in the Eutaw formation are in general more highly mineralized than those from the Tuscaloosa.

The area of outcrop of the Tuscaloosa is the catchment area of the abundantly water-bearing sand and gravel beds of the formation, which dip slightly to the west and pass beneath the Eutaw formation. Many shallow wells, mostly of the dug type, tap these beds in the eastern half of the county, but only a few wells in the western half have been sunk deep enough to reach them; three wells at Burnsville, 90, 95, and 127 feet deep, probably penetrate the Eutaw and enter the Tuscaloosa.

The dug wells range in depth from a few feet to a maximum of about 100 feet, and they are the principal means of procuring domestic water supplies, although many of the excellent freestone springs in the eastern part of the county and some of the smaller springs in the western part are utilized.

\section{LOCAL SUPPLIES}

Iuka.-Iuka, the county seat, is well known for the cluster of seven small springs on one of the headwater branches of Indian Creek just south of the business section of the town, where the elevation is about 540 feet above sea level; a small park owned by the town surrounds the springs. Each spring is claimed to possess individual characters and therapeutic qualities, and the town receives considerable local patronage as a health resort. The source of the springs is waterbearing sands near the base of the Eutaw formation. Analysis 1 represents water from the spring nearest to the court house.

There is a 32 -foot dug well 3 by 3 feet in dimensions at the Leatherwood Hotel which probably derives its water from the Tuscaloosa formation. The well was dug in 1912. (See analysis 2.) A spring owned by Mrs. C. W. McKnight yields about half a gallon a minute, and the water is used by some for medicinal purposes. (See analysis 3.) The present domestic supplies of water are obtained chiefly by means of dug wells that range in depth from a few feet to about 90 feet. Those wells located low in the branch valleys enter the gravels of the Tuscaloosa formation, which carry abundant water at depths of 10 to 25 feet; this water is protected by a layer of clay, 6 to 12 feet thick, which overlies the gravel. Wells located on the surrounding hills are not as a rule deep enough to reach the Tuscaloosa, but have 
their source in beds of sand that form the base of the Eutaw formation. The town was formerly equipped with a small waterworks about 300 feet east of the post office, where the surface is about 565 feet above sea level. The source of the water was the basal sands of the Eutaw, and the water was obtained by means of two dug wells, each 37 feet deep. In December, 1915, the plant was destroyed by fire. Crystal Spring, owned by Benjamin Massey, is in a valley three-fourths of a mile northeast of the center of town, on the old Walker place. The spring yields 10 gallons a minute, and the water is notably free from mineral and organic matter.

Burnsvitle.-A public well drilled in 1914 at Burnsville, in the valley of Yellow Creek, is 127 feet deep and 4 inches in diameter, and the water rises within 4 feet of the surface. Four-inch casing is inserted to a depth of 121 feet, and the water is said to come from sand that probably belongs to the Tuscaloosa formation, between depths of 122 and 127 feet. (See analysis 4.) The Bayou Stave Co. owns a 95-foot bored well, drilled in 1905, in the same valley a fourth of a mile east by north of the post office. The diameter of this well is 4 inches and the static head is 7 feet below the surface; the water is raised by steam jet and is used for a boiler supply. The source of the water is probably the Tuscaloosa formation. A 90-foot well owned by J. E. Clement, drilled in 1910, is located in Yellow Creek valley about 400 feet northwest of the post office. A 3-inch casing is inserted to a depth of 75 feet, and the water comes from sand and gravel, which is regarded as belonging to the Tuscaloosa formation, between depths of 85 and 90 feet; the static head is 4 feet below the surface.

Paden.-The dug well of W. S. Stephens, on a hill 100 yards northeast of the Illinois Central Railroad station at Paden, is 52 feet deep and 32 inches in diameter and yields water from white sand in the Tuscaloosa formation at a depth of 50 to 52 feet. (See analysis 5.)

Mineral analyses of ground waters from Tishomingo County

[Parts per million. For further data regarding these wells see pp. 458-459]

\begin{tabular}{|c|c|c|c|c|c|}
\hline & 1 & 2 & 3 & 4 & 5 \\
\hline 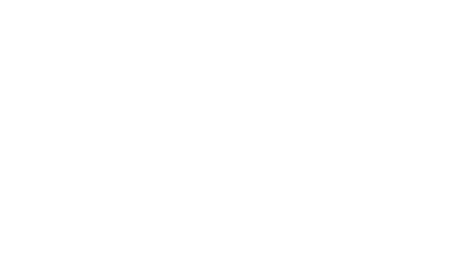 & \begin{tabular}{|c|}
3 \\
19 \\
3.0 \\
2.0 \\
$a 3.9$ \\
14.0 \\
10 \\
1.6 \\
Trace. \\
65 \\
16 \\
Sept., 1919
\end{tabular} & $\begin{array}{l}22 \\
10 \\
6.4 \\
10 \\
15^{.} \\
18 \\
22 \\
20 \\
114 \\
51 \\
1911\end{array}$ & $\begin{array}{c}10 \\
1.5 \\
5.5 \\
1.9 \\
6.2 \\
.0 \\
23 \\
6.5 \\
3.5 \\
43^{.00} \\
22 \\
\text { May, } 1913\end{array}$ & $\begin{array}{r}23 \\
6.6 \\
5.2 \\
2.1 \\
a 3.8 \\
2.0 \\
24.1 \\
8.1 \\
1.3 \\
\text { Trace. } \\
58 \\
22 \\
\text { Sept.,1919 }\end{array}$ & $\begin{array}{c}15 \\
.08 \\
1.4 \\
.7 \\
0.2 \\
11.0 \\
2.5 \\
1.0 \\
30.23 \\
6 \\
\text { Sept., } 1919\end{array}$ \\
\hline
\end{tabular}

- Calculated.

Analysts: 1, 5, Clara M. Forman and Margaret D. Foster, U. S. Geological Survey; 2, E. S. Wallace, University of Mississippi; 3, Mississippi State Chemical Laboratory; 4, Margaret D. Foster, U. S. Geo* logical Survey.

1. Iuka Mineral Springs (nearest to courthouse of five springs), at Iuka.

2. Well, 32 feet deep, of Leatherwood Hotel, at Iuka.

3. Spring of Mrs. C. W. MeKnight, Iuka.

4. Bored town well, 127 feet deep, at Burnsville.

5. Dug well, 52 feet deep, of W. S. Stephens, Paden. 


\section{TUNICA COUNTY}

GENERAL FEATURES

Area, 418 square miles. Population, 20,386 (census of 1920)

Tunica County is in the Yazoo Delta, near the northwest corner of the State. Alluvial deposits of Mississippi River, including irregularly bedded loam, clay, sand, and gravel, underlie the lowland to an estimated depth of 150 to 200 feet. Beneath the alluvium lies a great thickness of sedimentary deposits that belong to the Wilcox and the Midway groups of the Eocene series of the Tertiary. (See pp. 43-49.)

\section{GROUND-WATER CONDITIONS}

The more porous parts of the alluvial deposits that underlie the entire county to depths of 150 to 200 feet carry abundant quantities of water that is under little or no artesian head. This water is obtained by bored and driven wells equipped with ropes and buckets or with pumps. At many places the ground-water level is within easy reach of suction pumps. Locally the shallow-well waters of the alluvium are colored with vegetable matter and thus rendered more or less objectionable in appearance and taste.

The Eocene deposits underlie the alluvium, and some of the sands carry water that is under artesian pressure. The formations that are of practical interest in connection with water supplies are in descending order the Grenada, Holly Springs, and Ackerman formations of the Wilcox group, which probably reach an aggregate thickness of nearly 1,000 feet. Of lesser interest are the still deeper sandy portions of the Clayton formation of the Midway group (Eocene) and of the Ripley formation (Upper Cretaceous). So little is known of the character and thickness of the formations penetrated by the deep wells of Tunica County that but little attempt is made to correlate the water-bearing sands with individual formations. Most of the wells 500 feet or more in depth yield flows, and the highest recorded static head, 10 feet above the surface, is that of the well of F. M. Norfleet, at Dundee, the depth of which is not recorded.

\section{LOCAL SUPPLIES}

Banks.-At Banks, near the northeast corner of the county, domestic water supplies are obtained chiefly by. driven wells that range in depth from 40 to 70 feet.

Commerce.- One of the deepest wells recorded in the county is the 1,650-foot well of Mrs. M. S. Leatherman at Commerce. This well is 3 inches in diameter and when flowing freely yields 42 gallons a minute, with the static head 40 feet above the surface. The well probably taps a water-bearing sand in the Ripley formation of the 
Upper Cretaceous at a depth of 1,650 feet. The natural pressure of the well is utilized to distribute the water to various parts of the plantation for domestic use and for stock. Other water-bearing beds were noted at depths of $400,600,1,000$, and 1,200 feet, but these were cased off. A 6-inch casing extends to a depth of 200 feet; $4 \frac{1}{2}$-inch casing to a depth of 1,220 feet; and 3-inch casing to a depth of 1,500 feet. (See analysis 1.) Mrs. Leatherman also owns a $21 / 2$-inch flowing well 865 feet deep, which taps a water-bearing bed questionably in the Holly Springs sand.

Robinsonville.-A well on the Mary Mack plantation at Robinsonville is 1,000 feet deep and 4 inches in diameter. It does not flow, perhaps because of a leak in the casing, and the static head is about 12 feet below the surface. The water becomes muddy on pumping and is filtered before it is used. This well may reach the Ackerman formation of the Wilcox group. A nonflowing well owned by $A$. Smith is 1,200 feet deep and 8 inches in diameter and probably also has its source in the Ackerman formation. (See analysis 2.)

Tunica.-The municipal water supply at Tunica is provided by a flowing well, reported to be about 1,700 feet deep, which is located at the west end of Edwards Street. The static head of the well is 40 feet above the surface and the yield is 140 (?) gallons a minute; the natural pressure can be utilized to distribute the water to the consumers. About 1,700 feet(?) of 6-inch casing, including 40 feet of strainer, extends to the bottom of the well. The source of the water is believed to be the Ripley formation. (See analysis 4.) An earlier public well at Tunica, 865 feet deep, has ceased to flow, presumably because of poor construction. (See analysis 3.) The following log of the well shows the character of the beds penetrated.

Log of public well at Tunica

\begin{tabular}{l|r|r}
\hline & Thickness & Depth \\
\hline Undifferentiated alluvium and Wilcox group (Grenada formation and Holly & & \\
Springs sand): \\
Sand and clay.
\end{tabular}

Dundee.-A flowing well 6 miles northwest of Dundee, owned by F. M. Norfleet, is 1,200 feet deep and 3 inches in diameter and yields at the rate of 35 gallons a minute. This well supplies the domestic needs of 500 people. The overflow is used to operate a ram which lifts the water to a tank, the top of which is 35 feet above the ground. The water is said to come from white sand and probably has its source in the Ackerman formation. 
Dubbs.-At Dubbs domestic supplies are obtained from shallow wells in the alluvium. The 16-foot driven well of T. H. Gilleland is perhaps typical.

Holly.-At Holly driven wells 22 to 90 feet deep are the principal source of domestic supply. The water stands about 12 feet below the surface and is raised by pitcher pumps.

Near Coldwater River.-A well on a plantation in the southeast corner of the county, on the east side of Coldwater River, 3 miles south of Sarah, in Tate County, is reported to be 521 feet deep and flows 3 gallons a minute. The following $\log$ of the well shows the character of the beds penetrated:

Log of well on a plantation 3 miles south of Sarah, Tate County

\begin{tabular}{|c|c|c|}
\hline & Thickness & Depth \\
\hline $\begin{array}{l}\text { Alluvium: } \\
\text { Soil and clay. }\end{array}$ & $\begin{array}{r}\text { Feet } \\
30 \\
110\end{array}$ & $\begin{array}{r}\text { Feet } \\
30 \\
140\end{array}$ \\
\hline $\begin{array}{l}\text { Wilcox: } \\
\text { Pipe clay } \\
\text { Rock } \\
\text { Sand } \\
\text { Soapstone (clay) } \\
\text { Sand; water bearing (Holly Springs sand) }\end{array}$ & $\begin{array}{r}260 \\
1 \\
10 \\
60 \\
50\end{array}$ & $\begin{array}{l}400 \\
401 \\
411 \\
471 \\
521\end{array}$ \\
\hline
\end{tabular}

Mineral analyses of ground waters from Tunica County

[Parts per million]

\begin{tabular}{|c|c|c|c|c|}
\hline & 1 & 2 & 3 & 4 \\
\hline $\begin{array}{l}\text { Silica }\left(\mathrm{SiO}_{2}\right) \\
\text { Iron }(\mathrm{Fe}) \\
\text { Calcium }(\mathrm{Ca}) \\
\text { Magnesium }(\mathrm{M} \mathrm{g})\end{array}$ & $\begin{array}{l}23 \\
1.10 \\
.7\end{array}$ & $\begin{array}{l}28 \\
8.8 \\
7.9 \\
4.2\end{array}$ & $\begin{array}{r}33 \\
1.7 \\
1.2 \\
.5\end{array}$ & $\begin{array}{l}28 \\
1.5 \\
.8\end{array}$ \\
\hline Sodium and potassium $(\mathrm{Na}+\mathrm{K}) \ldots$ & 64 & 27 & $\mathrm{Na} 38$ & b 99 \\
\hline $\begin{array}{l}\text { Carbonate radicle }\left(\mathrm{CO}_{3}\right) \\
\text { Bicarbonate radicle }\left(\mathrm{H}^{\mathrm{C}} \mathrm{CO} \mathrm{O}_{3}\right) \\
\text { Sulphate radicle }\left(\mathrm{SO}_{4}\right) \\
\text { Chloride radicle }(\mathrm{Cl}) \\
\text { Nitrate radicle }\left(\mathrm{NO}_{3}\right)^{2}\end{array}$ & $\begin{array}{r}32 \\
97 \\
3.2 \\
5.5 \\
.32\end{array}$ & $\begin{array}{l}90.0 \\
7.9 \\
4.0 \\
.60\end{array}$ & $\begin{array}{r}106.0 \\
3.8 \\
3.8 \\
-.0 .0\end{array}$ & $\begin{array}{l}27 \\
170 \\
3.9 \\
24 \\
\quad .57\end{array}$ \\
\hline $\begin{array}{l}\text { Phosphate radicle ( } \mathrm{PO}_{4} \text { ) } \\
\text { Total dissolved solids at } 180^{\circ} \mathrm{C} \\
\text { Total hardness as } \mathrm{CaCO} \text { (calculated) } \\
\text { Date of collection }\end{array}$ & $\begin{array}{c}175 \\
6 \\
\text { Aug., } 1919\end{array}$ & $\begin{array}{l}37 \\
37 \\
\text { Feb., } 1915\end{array}$ & $\frac{135^{.31}}{5}$ & $\begin{array}{c}280 \\
7 \\
\text { Aug., } 1919\end{array}$ \\
\hline
\end{tabular}

- Iron and aluminum oxides $\left(\mathrm{Fe}_{2} \mathrm{O}_{3}+\mathrm{Al}_{2} \mathrm{O}_{3}\right)$.

b Calculated.

Analysts: 1, 4, Margaret D. Foster and Clara M. Forman, U. S. Geological Survey; 2, Mississippi State Chemical Laboratory; 3, W. R. Perkins (Mississippi Agr. Exper. Sta. Bull. 89, p. 81, 1905).

1. 1,650-foot well of Mrs. M. S. Leatherman, at Commerce

2. 1,200-foot well of A. Smith, near oil mill, at Robinsonville.

3. 865-foot town well, at Tunica.

4. 1.700-foot town well, drilled in 1918 , at Tunica. 


\section{UNION COUNTY}

\section{GENERAL FEATURES}

Area, 412 square miles. Population, 20,044 (census of 1920)

The eastern half of Union County lies chiefly in the Pontotoc Hills district. A narrow strip along the eastern border forms the western edge of the Black Prairie belt, which is separated from the hilly upland by a well-defined escarpment. Westward the county extends through the Flatwoods district into the North Central Hills district. The narrow strip of land in the east that forms the western border of the Black Prairie belt is underlain by the Selma chalk (Upper Cretaceous). The Pontotoc Hills are immediately underlain by the Ripley formation (also Upper Cretaceous) and include most of the area between the Black Prairie and the Gulf, Mobile \& Northern Railroad. Strata of Eocene age unconformably overlie the Ripley and compose the material immediately underlying the surface throughout approximately the western half of the county. The Eocene is represented by three formations-the Clayton formation, which crops out along the western border of the Pontotoc Hills; the Porters Creek clay, which underlies the Flatwoods; and the Ackerman formation, which underlies the hilly section in the western part of the county. These formations, together with the deeply buried Eutaw and Tuscaloosa formations, are described on page 29-46, and their surface distribution in Mississippi is shown on the geologic map (pl. 2).

\section{GROUND-WATER CONDITIONS}

The Ripley formation is the principal source of water for both domestic and industrial uses. Surface outcrops throughout the Pontotoc Hills and well logs show the formation to be composed of porous water-bearing sands, interstratified with hard layers of calcareous sandstone and containing subordinate layers of laminated to massive clay. The hard layers serve as retaining agents in the artesian system, as is indicated by the fact that water is nearly always obtained in wells in loose sand immediately beneath the sandstones.

Among the Pontotoc Hills there are many small springs that have their source in the Ripley formation, and some of them are utilized for domestic and farm supplies, but the chief means of obtaining water is dug and bored wells, which range in depth from a few feet to 100 feet or more and tap the Ripley sands.

As the strata that compose the Ripley dip to the west at the approximate rate of 30 feet to the mile, the formation becomes successively thicker from the eastern border of the Pontotoc Hills toward the west. The Pontotoc Hills belt is therefore the catchment 
area of the water-bearing sands that are tapped by many wells in the western two-thirds of the county at depths that range from 25 feet to 400 feet or more. The upland level of the Pontotoc Hills is considerably higher ( 500 to 650 feet above sea level) than the valleys to the west (300 to 350 feet above sea level), so that sufficient hydrostatic pressure is developed to cause flows along Tallahatchie River and many of its tributary creeks and to bring the water within easy reach of pumps on the immediately adjacent uplands. Several wells, which are especially interesting on account of the shallow depth (30 to 35 feet) at which flowing water is obtained (see pl. $8, D$ ), are located at the foot of the northwestward-facing slope of Kings Creek Valley, 3 miles south of New Albany (Nos. 17-19).

The Eutaw formation is a source of artesian water as yet undeveloped, except in the eastern part of the county, where a few wells have been sunk to it. Along the eastern boundary the top of the Eutaw lies at an estimated depth of 250 feet and at New Albany at a depth of about 700 feet. At New Albany the static head would probably not be as high as that of water from the Ripley but would be less than 100 feet below the surface- that is, near enough to be within reasonable reach of force pumps. The deeply buried Tuscaloosa formation, which underlies the Eutaw, is also a possible source of artesian water, but no wells deep enough to reach it have been reported. In the eastern part of the county the top of the Tuscaloosa lies at an estimated depth of about 500 feet, and at New Albany at about 1,100 feet. The catchment area of the waters of the Eutaw and Tuscaloosa formations lies far to the east in Prentiss, Lee, Tishomingo, and Itawamba Counties, Miss., and in Franklin and Colbert Counties, Ala.

\section{LOCAL SUPPLIES}

New Albany.-The first wells drilled to the water-bearing sands in the lower half of the Ripley formation at New Albany yielded flowing water, but owing to the heavy draft subsequently occasioned by the wells of the municipal waterworks and of several manufacturing plants the static head has been locally reduced to 8 feet below the surface. Numerous wells that range in depth from 25 to more than 500 feet have been drilled at New Albany and in the surrounding district. The waterworks at New Albany is owned by the town and is located on Cleveland Street near the Gulf, Mobile \& Northern Railroad station. The water supply is obtained from three wells, each approximately 260 feet deep (Nos. 10-12). The log of one of the wells at the waterworks is given below. A log of another well is given by Crider and Johnson. ${ }^{48}$

${ }^{18}$ Crider, A. F., and Johnson, L. C., Summary of the underground-water resources of Mississippi: U. S. Geol. Survey Water-Supply Paper 159, p. 73, 1906. 
Log of one of the wells at the municipal water and light plant, New Albany

[Altitude of mouth of well about 356 feet above sea level. Adapted from description by A. B. Roach, driller]

\begin{tabular}{|c|c|c|c|c|c|}
\hline & $\begin{array}{c}\text { Thick- } \\
\text { ness }\end{array}$ & Depth & & $\underset{\text { ness }}{\text { Thick- }}$ & Depth \\
\hline $\begin{array}{l}\text { Ripley formation: } \\
\text { Soil and clay- } \\
\text { Red sand; water bearing } \\
\text { Black clay. } \\
\text { Boulders or rock (concretion- } \\
\text { ary?) } \\
\text { Black clay } \\
\text { Limerock } \\
\text { Black clay }\end{array}$ & $\begin{array}{r}\text { Feet } \\
10 \\
40 \\
10 \\
\\
20 \\
10 \\
5 \\
5 \\
2\end{array}$ & $\begin{array}{r}\text { Feet } \\
10 \\
50 \\
60 \\
\\
80 \\
90 \\
95 \\
100 \\
102\end{array}$ & $\begin{array}{l}\text { Ripley formation-Continued. } \\
\text { Black clay or slate } \\
\text { Rock } \\
\text { Black clay. } \\
\text { Loose rocks (concretionary?) } \\
\text { Black clay } \\
\text { Flint rock } \\
\text { White sand; water bearing } \\
\text { Black dirt. }\end{array}$ & $\begin{array}{r}\text { Fcet } \\
28 \\
1 \\
9 \\
10 \\
60 \\
2 \\
38 \\
11\end{array}$ & $\begin{array}{r}\text { Feet } \\
130 \\
131 \\
140 \\
150 \\
210 \\
212 \\
250 \\
261\end{array}$ \\
\hline
\end{tabular}

The following log shows the character of the beds penetrated in a well on the upland 2 miles south of New Albany:

Log of well of E. D. Robbins, on the upland 2 miles south of New Albany, in sec. 20, T. 7 S., R. 3. E. (No. 14)

[Adapted from owner's description]

\begin{tabular}{|c|c|c|}
\hline & Thickness & Depth \\
\hline $\begin{array}{l}\text { Red clay } \\
\text { Black dirt and some gray dirt, with interstratified layers of rock ranging in thick- } \\
\text { ness from } 1 \text { to } 20 \text { feet and aggregating a thickness of } 147 \text { feet; most of the rock } \\
\text { layers occur in the upper } 270 \text { feet of this division; one water-bearing stratum } \\
\text { was found at a depth of } 137 \text { feet; another water-bearing stratum was found at } \\
\text { a depth of } 485 \text { feet in fine gray sand between two layers of rock, each about } 4 \\
\text { feet thick. }\end{array}$ & Feet & $\begin{array}{l}\text { Feet } \\
50\end{array}$ \\
\hline
\end{tabular}

The "red clay" layer at the top of this section is probably in part of Eocene age (Midway group), and the portion below the Eocene probably includes all of the Ripley and perhaps a part of the underlying Selma chalk of the Cretaceous.

Blue Springs.-A 400-foot well at Blue Springs (No. 2) taps a white water-bearing sand in the Coffee sand member of the Eutaw formation at a depth of 380 to 400 feet. The log of this well is as follows:

Log of well of Tupelo Oil \& Ice Co., Blue Springs (No. 2)

[Altitude of mouth of well about 418 feet above sea level. Adapted from owner's description]

\begin{tabular}{l|r|r}
\hline & Thickness & Depth \\
\hline Ripley formation: Sand and clay & Feet & Feet \\
Selma chalk: White limestone with here and there a ledge of sandstone 10 to 12 & \\
inches thick. & 354 & 379 \\
Eutaw formation (Coffee sand member): & 1 & 380 \\
Sea shells and sandstone \\
White quicksand; water bearing
\end{tabular}




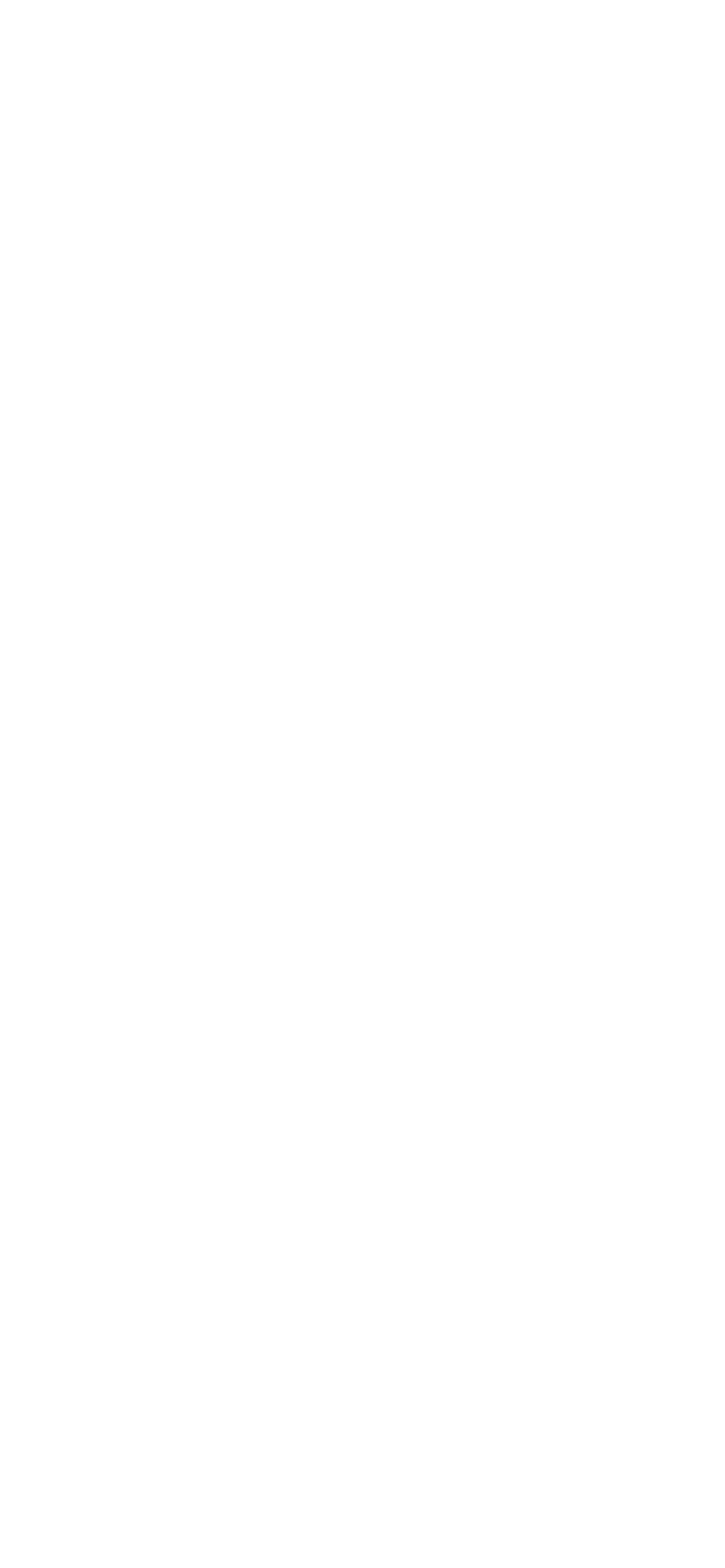




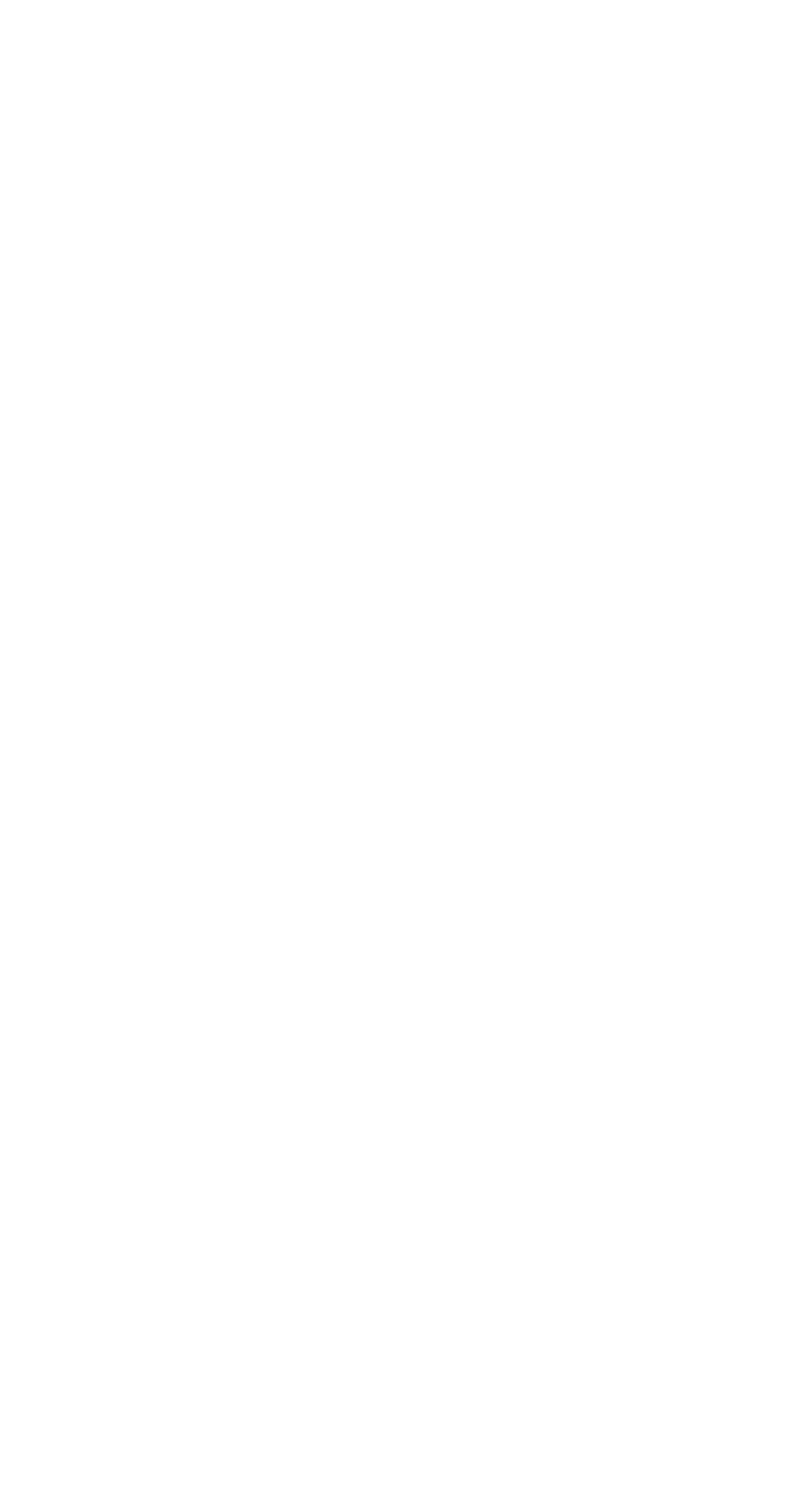


Mineral analyses of ground waters from Union County

[Parts per million. Numbers at heads of columns refer to corresponding well numbers in preceding table]

\begin{tabular}{|c|c|c|c|c|c|c|c|c|}
\hline & 1 & 8 & 9 & 10 & 12 & 14 & 17 & 21 \\
\hline $\begin{array}{l}\text { Silica }\left(\mathrm{SiO}_{2}\right) \\
\text { Iron }(\mathrm{Fe}) \\
\text { Calcium }(\mathrm{Ca}) \\
\text { Magnesium }(\mathrm{Mg}) \\
\text { Sodium and potassium }(\mathrm{Na}+\overline{\mathrm{K}}) \\
\text { Carbonate radicle }\left(\mathrm{CO}_{3}\right) \\
\text { Bicarbonate radicle }\left(\mathrm{HCO}_{3}\right) \\
\text { Sulphate radicle }\left(\mathrm{SO}_{4}\right) \\
\text { Chloride radicle (Cl) } \\
\left.\text { Nitrate radicle ( } \mathrm{NO}_{3}\right) \\
\text { Total dissolved solids at } 180^{\circ} \mathrm{C} \\
\text { Total hardness as } \mathrm{CaCO}{ }_{3} \text { (calculated) } \\
\text { Date of collection }\end{array}$ & $\begin{array}{l}28 \\
79 \\
9.05 \\
9.5 \\
12.0 \\
280^{\circ} \\
29 \\
2.1 \\
304.40 \\
236 \\
\text { Sept., } \\
1919\end{array}$ & $\begin{array}{c}50 \\
1.9 \\
45 \\
4.1 \\
6.3 \\
140 \\
1.0 \\
1.8 \\
2.4 \\
12 \\
202 \\
129 \\
\text { Sept., } \\
1920\end{array}$ & $\begin{array}{l}28 \\
14^{.08} \\
5.5 \\
62 \\
7.2 \\
207 \\
11 \\
2.0 \\
248 \\
58 \\
58 \\
\text { Sept., } \\
1919\end{array}$ & $\begin{array}{c}8.4 \\
2.2 \\
14 \\
5.2 \\
47 \\
173^{.0} \\
18 \\
6.5 \\
1.0 \\
184 \\
56 \\
\text { July, } \\
1911\end{array}$ & $\begin{array}{l}11 \\
1.1 \\
11 \\
2.9 \\
59 \\
171.0 \\
16 \\
6.0 \\
1.9 \\
185 \\
39 \\
\text { Apr., } \\
1914\end{array}$ & $\begin{array}{c}16 \\
15 \\
15 \\
5.5 \\
63 \\
6.0 \\
189 \\
16 \\
3.0 \\
1.8 \\
209 \\
60 \\
\text { Sept., } \\
1919\end{array}$ & $\begin{array}{c}40 \\
17^{.09} \\
4.6 \\
30 \\
9.6 \\
126 \\
7.1 \\
2.0 \\
\text { Trace. } \\
167 \\
61 \\
\text { Sept., } \\
1919\end{array}$ & $\begin{array}{c}22 \\
42 \\
1.05 \\
1.8 \\
11 \\
107^{\circ} \\
8.1 \\
23 \\
5.6 \\
186 \\
112 \\
\text { Sept., } \\
1919\end{array}$ \\
\hline
\end{tabular}

- Calculated.

Analysts: 1, 8, Margaret D. Foster, U. S. Geological Survey; 9, 14, 17, 21, C. S. Howard, U. S. Geological Survey; 10, W. L. Kennon, University of Mississippi; 12, W. F. Hand, Mississippi State Chemical Lahoratory.

\section{WALTHALI COUNTY}

\section{GENERAL FEATURES}

Area, 389 square miles. Population, 13,455 (census of 1920)

Walthall County, recently created from parts of Pike and Marion Counties, chiefly Pike, lies in the Long-leaf Pine Hills district. The materials that immediately underlie the surface are referable chiefly to two geologic formations, one the Pascagoula clay (Miocene), which appears only in small outcrops low on the valley slopes in the central and northern parts of the county, and the other, the Citronelle formation (Pliocene), which overlies the Pascagoula, and which chiefly determines the soils and topographic aspect of the area. These formations are described on pages 57-60, and their distribution is shown on the geologic map (pl. 2).

\section{GROUND-WATER CONDITIONS}

Data in regard to ground-water supplies are meager but are sufficient to justify a few general statements. Most of the inhabitants obtain their domestic supplies from bored wells that range in depth from 20 to 150 feet and from the numerous small springs. The source of the water of both wells and springs is chiefly the Citronelle formation, which ranges in thickness on the divides from about 150 feet in the north to 200 or 250 feet in the south, and the water is found in the more porous beds of gravel and sand of which the formation is largely composed. The water is under little or no artesian head and is raised from the wells either by rope and bucket or by hand or gas-driven force pumps.

Only one deep well has been reported from the county. As this well is situated low in the valley of McGee Creek, it probably started near the top of the Pascagoula clay, penetrated practically the full 
thickness of 350 or 400 feet of that formation, and ended in a bed of sand in the Hattiesburg clay (Miocene) at a depth of 622 feet. The well flows 18 gallons a minute, and the water is used for domestic supplies and in boilers. The Hattiesburg, though composed chiefly of clay, has been demonstrated to contain interbedded layers of water-bearing sand at many places in Mississippi, and doutbless such a layer was found in this well. Similar flowing wells can doubtless be obtained in the valleys of both McGee Creek and Bogue Chitto from the Louisiana line to points several miles north of the latitude of Tylertown.

The Hattiesburg clay is underlain by a still deeper formation, the Catahoula sandstone (Miocene), which is estimated to be about 400 feet thick. The more porous sands are probably water bearing and would doubtless yield flows in the valleys of the larger streams. The depth at which the Catahoula would be penetrated in the northern part of the area is estimated to be 900 to 1,400 feet, and in the southern part it would be several hundred feet deeper, owing to the slight southward dip of the formation.

\section{LOCAL SUPPLIES}

Tylertown.-The 622-foot well of Q. D. Sauls, a quarter of a mile southeast of the post office, is the only deep flowing well reported from the county. The well is 4 inches in diameter, and the water is derived from a bed of sand in the Hattiesburg clay. The static head is $101 / 2$ feet above the surface, and the yield is 18 gallons a minute.

Mineral analysis of water from 622-foot well of Q. D. Sauls, at Tylertown, Walthall County

[Sample collected June 25, 1912; analyzed by Mississippi State Chemical Laboratory]

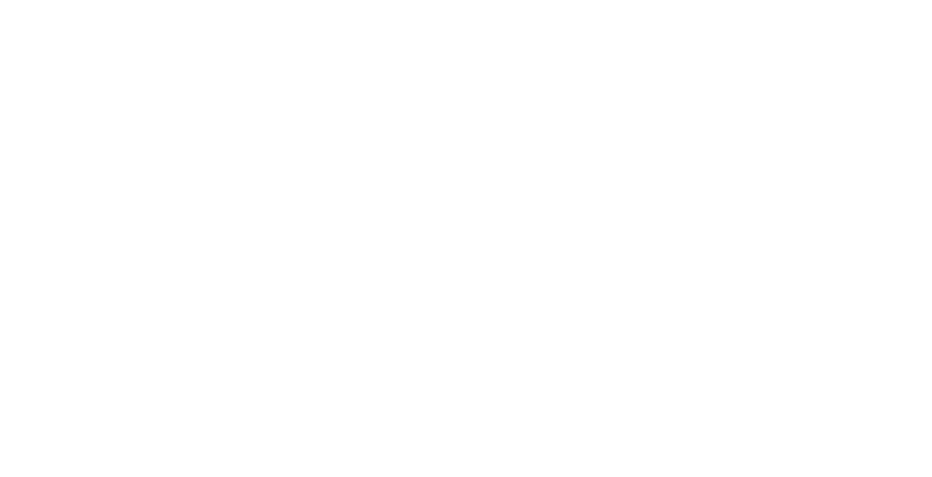

Buncombe.-Bored wells not more than 125 feet deep, which tap water-bearing sand and gravel in the Citronelle formation, are the chief means of obtaining domestic and farm supplies in the vicinity of Buncombe. The water is under no appreciable artesian pressure. 
The 90-foot well of L. L. Dillon, a mile southeast of the town, in the NE. $1 / 4$ SW. $1 / 4$, sec. 20 , T. 2. N., R. 10 E., and the 121-foot well of H. M. Smith, in sec. 28 , T. 2. N., R. 10 E., are typical.

Darbun.-Bored wells are also used at Darbun, in the northeastern part of the county. The well of H. H. Ramsey, 300 yards northwest of the post office, obtains water from the Citronelle formation at a depth of 44 to 50 feet.

\section{WARREN COUNTY}

\section{GENERAL FEATURES}

Area, 572 square miles. Population, 33,362 (census of 1920)

Warren County is sharply divided by a more or less steep westward facing escarpment into an eastern hilly upland and a western alluvial lowland or bottom land of Mississippi and Yazoo Rivers. The upland portion of the county is almost completely covered with loess, a fine silty material that was carried by the wind from mud flats in the Mississippi River bottom to the upland during the Pleistocene epoch of geologic time. The loess ranges in thickness from a few feet to a maximum of perhaps 100 feet, and the greatest accumulations are along the western border of the upland. About the borders of the upland, both in the valley of Big Black River and along the escarpment that borders the upland on the west, lie relatively thin terrace deposits of sandy loam, sand, and gravel, and some of the higher of these deposits are also covered with loess. In the northern part of the county the loess is underlain by the Vicksburg group, which is subdivided into the Forest Hill sand at the base, the Marianna limestone in the middle, and the Byram marl at the top. In the central and southern parts of the county the loess is underlain by the Catahoula sandstone. The bottom lands of Mississippi and Yazoo Rivers are underlain by 100 to 200 feet of alluvium, the unexposed base of which is composed of gravel. Deeply buried beneath the formations already named lie sands, clays, and marls of Eocene age, which include, in descending order, the Jackson formation and the Claiborne, Wilcox, and Midway groups. Still deeper lie formations of Upper Cretaceous age, composed of sands, clays, and chalks. These geologic formations are described on pages $29-63$, and their distribution is shown in Plate 2.

\section{GROUND-WATER CONDITIONS}

The Cretaceous formations, the topmost of which is considered by Lowe ${ }^{49}$ to lie at a depth of a little over 2,600 feet in Warren County, are covered too deeply to be regarded as a practical source of supply, and besides their contained waters are probably too highly mineral-

40 Lowe, E. N., Mississippi Geol. Survey Bull. 15, p. 67, 1919. 
ized for ordinary domestic and industrial uses. The same is probably true of the Midway, the lowermost group of the Eocene. Likewise the water-bearing capacity of the Wilcox group, which overlies the Midway group, is imperfectly known, but the group may perhaps be regarded as a possible source of water supply. According to Lowe's ${ }^{50}$ interpretation the top of the Wilcox lies a little more than 1,500 feet beneath the surface at Vicksburg.

The top of the Claiborne group is reached at Vicksburg, according to Lowe, ${ }^{51}$ at a depth of 1,078 feet; he gives the thickness as less than 500 feet, an amount that seems too small. The Lisbon formation of this group is water-bearing farther to the east, in central Mississippi and may be regarded as a promising source of supply in Warren County, though little is definitely known of its water content in this county. Although there are no available records of wells in the Yazoo Delta in Warren County, which reach this formation, it is estimated that water-bearing sands of the Lisbon should be reached at depths of 1,000 to 1,500 feet. These waters are under strong artesian head that would probably produce flows anywhere in the Yazoo Delta.

The Jackson formation, which overlies the Claiborne group, is generally regarded as an unpromising aquifer because of its predominantly clayey character. In the well of the Delta Ice Co. at Vicksburg (see log. p. 473) 485 feet of non-water-bearing slate-colored clay, which is referred to the Yazoo clay member of the Jackson formation, was penetrated between the depths of 306.5 and 791.5 feet; the clay was followed by 67 feet of black sand with shells, which is referred to the Moodys marl member of the Jackson. Above the main body of clay lies a bed of water-bearing sand 65 feet thick whose position seems to indicate that it belongs to the Jackson formation. This sand may be regarded as a valuable source of ground-water supply throughout the upland portion of Warren County. North of Vicksburg, within the limits of the county, ${ }^{52}$ the sand is nearly horizontal, so that the depth to sand would be about the same as at Vicksburg - that is, 200 to 300 feet. South of Vicksburg the sand dips toward the Gulf at the rate of 18 or 20 feet to the mile, and in the extreme south probably lies 350 to 600 feet below the surface.

In the central and southern parts of the county the Catahoula sandstone, which underlies the surficial covering of loess and terrace sand and gravel, is a source of ground water of considerable value. The formation contains lenses of water-bearing sand. Its base increases in depth fram perhaps 50 feet or less in the central part of the county, where the overlying loess is thin, to 300 or 400 feet in the extreme south. As the records of wells in this section are meager,

so Lowe, E. N., Mississippi Geol. Survey Bull. 15, p. 67, 1919.

b1 Idem, p. 69.

\$2 Hopkins, O. B., U. S. Geol. Survey Bull. 641, pl. 8, 1916. 
the extent to which the inhabitants use the Catahoula waters is not known, but it is to be surmised that there are many shallow wells that tap this source of supply.

The sands and gravels of the terrace deposits in the valley of Big Black River and along the western border of the upland are water bearing and are the source of the waters of many springs and of shallow wells.

At many places along the western border of the upland portion of the county, where the loess is 50 to 100 feet thick, water of satisfactory quality can not be obtained by the usual shallow dug or bored wells. The loess itself is permeable and allows most of the surface water that enters it to drain down through it into underlying formations. Such water as it does contain is hard, owing to the limy character of the loess. In places a bed of water-bearing sand and gravel of terrace origin intervenes between the loess and the older underlying Catahoula sandstone or the Vicksburg group, but this water, due to infiltration from the overlying loess, is also hard. In this region cisterns for storing rainwater have therefore come into general use. An analysis of a sample of water taken from the cistern of R. F. Childs at Bovina station, 101/2 miles east of Vicksburg, is given in the table (No. 2).

In the Mississippi-Yazoo lowland the alluvial deposits, which are estimated to range in thickness from 100 to 200 feet, contain numerous beds of water-bearing sand and gravel. The coarser sand and gravel occurs in the basal third or half of the deposit, and in them the largest quantities of water occur. Owing to the imperfect drainage in this exceedingly flat region and the consequent danger of pollution from surface sources, the waters of shallow wells may perhaps justly be regarded as questionably sanitary, though many such wells are in use. But with properly cased driven or bored wells, 50 to 200 feet in depth, there seems to be no good reason why the deeper waters of the alluvium should not be absolutely pure and safe as regards their sanitary quality. Cisterns are in common use in the lowland.

The alluvial deposits of the Yazoo Delta are probably immediately underlain by the clays of the Jackson formation, whose full thickness is estimated to be 500 to 600 feet. Deep flowing artesian waters can probably be obtained from the Lisbon formation of the Claiborne group, which underlies the Jackson formation.

\section{LOCAL SUPPLIES}

Vicksburg.-The waterworks at Vicksburg, which is owned by the city, is located on Lee Street, on the Mississippi River front 21/2 miles south of the business section. The water supply is obtained from Mississippi River. The principal developed source of artesian water in the vicinity of Vicksburg is a thick bed of sand, whose position appears to indicate that it belongs to the upper part of the 
Jackson formation, though it may represent the Forest Hill sand, the basal formation of the Vicksburg group. In the 10-inch well of the Delta Ice Co., on the upland, the sand just referred to was penetrated between the depths of 241 and 306 feet. The well was originally sunk to a depth of $1,1202 / 3$ feet, but a plug was inserted at a depth of about 360 feet. The water stands at a depth of 120 feet below the surface, is pumped by air at the rate of 200 gallons a minute, and is used in the manufacture of ice. A log of the wetl is given below. (See analysis 1.)

\section{Log of well of Delta Ice Co., Vicksburg}

[Authority, New Orleans Well Drilling Co.]

\begin{tabular}{|c|c|c|c|c|c|}
\hline & $\underset{\text { ness }}{\text { Thiek- }}$ & Depth & & $\underset{\text { ness }}{\text { Thick- }}$ & Depth \\
\hline 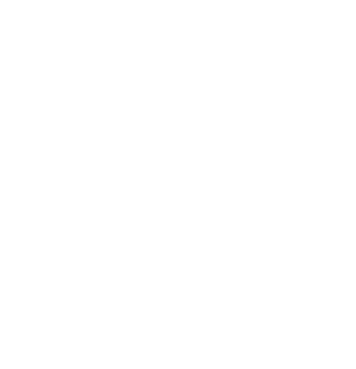 & $\begin{array}{rr}\boldsymbol{F} t . & i n . \\
15 & 0 \\
12 & 0 \\
1 & 6 \\
2 & 3 \\
1 & 6 \\
4 & 0 \\
& 3 \\
12 & 0 \\
1 & 0 \\
22 & 6 \\
3 & 8 \\
122 & 0 \\
5 & 0 \\
12 & 0\end{array}$ & $\begin{array}{rr}\text { Ft. } & \text { in. } \\
15 & 0 \\
27 & 0 \\
28 & 6 \\
30 & 9 \\
32 & 3 \\
36 & 3 \\
& \\
36 & 6 \\
48 & 6 \\
49 & 6 \\
72 & 0 \\
75 & 8 \\
197 & 8 \\
202 & 8 \\
214 & 8\end{array}$ & 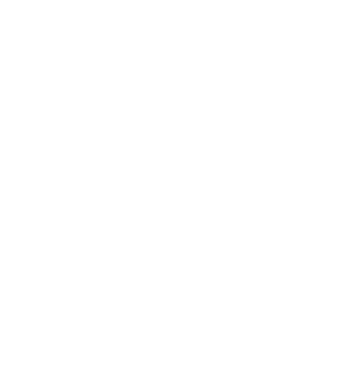 & $\begin{array}{rr}F t . & \text { in. } \\
18 & 0 \\
& 9 \\
8 & 0 \\
65 & 0 \\
485 & 0 \\
& \\
67 & 3 \\
87 & 0 \\
40 & 0 \\
15 & 0 \\
68 & 0 \\
11 & 0 \\
30 & 0 \\
11 & 0\end{array}$ & $\begin{array}{rr}F t . & \text { in. } \\
232 & 8 \\
233 & 5 \\
241 & 5 \\
306 & 5 \\
791 & 5 \\
& \\
858 & 8 \\
945 & 8 \\
985 & 8 \\
1,000 & 8 \\
1,068 & 8 \\
1,079 & 8 \\
1,109 & 8 \\
1,120 & 8\end{array}$ \\
\hline
\end{tabular}

The 4-inch well of the Jones Steam Laundry is 380 feet deep and derives water from the Jackson? sand at a depth of 332 to 380 feet. The water stands 122 feet below the surface. A partial log of the well is given below.

\section{Log of well of Jones Steam Laundry, Vicksburg}

[Authority, William Young, qriller]

\begin{tabular}{|c|c|c|}
\hline & Thickness & Depth \\
\hline $\begin{array}{l}\text { Loess with some gravel. } \\
\text { Not reported: }\end{array}$ & Feet. & Feet ${ }_{150}^{45}$ \\
\hline $\begin{array}{l}\text { Vicksburg group and Jackson formation: } \\
\text { Rock } \\
\text { Shale and gumbouring } \\
\text { Sand; water bearing }\end{array}$ & $\begin{array}{r}40 \\
172 \\
+48\end{array}$ & $\begin{array}{r}160 \\
332 \\
380\end{array}$ \\
\hline
\end{tabular}

Other wells which have their source in the sand questionably referred to the Jackson formation include the 4-inch well of the Vicksburg Steam Laundry, 330 feet deep, in which the water-bearing sand extends from 280 to 330 feet and the static head is 120 feet below the surface; the well of the Vicksburg Sanitarium, 389 feet 
deep; and the well of the Vicksburg Ice Co., 226 feet deep. Two oil-prospecting wells were drilled near Vicksburg in 1916 and 1917 by the Mississippi Oil, Gas \& Investment Co., of Vicksburg.: One on the Kimbal Ferguson farm, in sec. 32, T. 16. N., R. 4 E., reached a depth of 3,462 feet, but the other, on the farm of Mrs. Jennie Henderson, was abandoned at a depth of 2,630 feet. The Ferguson well probably penetrated all the Tertiary formations and entered the Upper Cretaceous, whereas the Henderson well is thought to have ended near the top of the Upper Cretaceous. Logs and other data in regard to these wells were published in $1919 . .^{33}$

Cedars. - The following is the log of a 900 -foot well owned by the Kimberly-Wing Co. at Cedars.

Log of well of Kimberly-Wing Co. at Cedars a

[Layne \& Bowler Co., contractor and driller. Completed Dec. 28, 1910]

\begin{tabular}{|c|c|c|c|c|c|}
\hline & $\begin{array}{c}\text { Thick- } \\
\text { ness }\end{array}$ & Depth & & $\begin{array}{c}\text { Thick- } \\
\text { ness }\end{array}$ & Depth \\
\hline $\begin{array}{l}\text { Topsoil and red clay. } \\
\text { Vicksburg group: } \\
\text { Blue clay } \\
\text { Sands, fine. } \\
\text { Rock (limestone) } \\
\text { Gumbo } \\
\text { Rock } \\
\text { Gumbo } \\
\text { Rock } \\
\text { Gumbo. } \\
\text { Roek } \\
\text { Gumbo } \\
\text { Rock } \\
\text { Gumbo } \\
\text { Rock }\end{array}$ & $\begin{array}{rr}F t . & \text { in. } \\
25 & 0 \\
10 & 0 \\
29 & 0 \\
3 & 3 \\
1 & 3 \\
& 3 \\
1 & 4 \\
1 & 3 \\
2 & 6 \\
1 & 9 \\
11 & 9 \\
1 & 10 \\
1 & 0 \\
2 & 9\end{array}$ & $\begin{array}{rr}F t . & \text { in. } \\
25 & 0 \\
35 & 0 \\
64 & 0 \\
67 & 3 \\
68 & 6 \\
68 & 9 \\
70 & 1 \\
71 & 4 \\
73 & 10 \\
75 & 7 \\
87 & 4 \\
89 & 2 \\
90 & 2 \\
92 & 11\end{array}$ & $\begin{array}{l}\text { Vicksburg group-Continued. } \\
\text { Gumbo } \\
\text { Rock } \\
\text { Gumbo } \\
\text { Rock } \\
\text { Gumbo } \\
\text { Rock } \\
\text { Gumbo } \\
\text { Jackson formation: } \\
\text { Sand, flne. } \\
\text { Gumbo } \\
\text { Claiborne group: } \\
\text { Sand } \\
\text { Gumbo }\end{array}$ & $\begin{array}{rr}\text { Ft. } & \text { in. } \\
1 & 11 \\
& 10 \\
& 5 \\
& 8 \\
10 & 3 \\
& 4 \\
47 & 8 \\
40 & 0 \\
505 & 0 \\
106 & 0 \\
4 & 8\end{array}$ & $\begin{array}{rr}\text { Ft. } & \text { in. } \\
94 & 10 \\
95 . & 8 \\
96 & 1 \\
96 & 8 \\
107 & 0 \\
107 & 4 \\
155 & 0 \\
195 & 0 \\
790 & 0 \\
806 & 0 \\
900 & 8\end{array}$ \\
\hline
\end{tabular}

- Hopkins, O. B., Structure of the Vicksburg-Jackson area, Mississippi: U. S. Geol. Survey Bull. 641, p. $119,1916$.

\section{Mineral analyses of ground waters from Warren County}

[Parts per million. Samples collected Nov. 20, 1920; analyzed by C. S. Howard, U. S. Geological Survey]

\begin{tabular}{|c|c|c|c|c|c|}
\hline & 1 & 2 & & 1 & 2 \\
\hline $\begin{array}{l}\text { Silica }\left(\mathrm{SiO}_{2}\right) \\
\text { Iron }(\mathrm{Fe}) \\
\text { Calcium }(\mathrm{Ca}) \\
\text { Magnesium }(\mathrm{Mg}) \\
\text { Sodium and potassium }(\mathrm{Na}+\overline{\mathrm{K}}) \\
\text { Carbonate radicle }\left(\mathrm{CO}_{3}\right) \\
\text { Bicarbonate radicle }\left(\mathrm{HCO}_{3}\right)\end{array}$ & $\begin{array}{l}32 \\
75 \\
36 \\
88 \\
18 \\
609\end{array}$ & $\begin{array}{l}5.1 \\
22^{.08} \\
1.7 \\
5.9 \\
70^{.0}\end{array}$ & $\begin{array}{l}\text { Sulphate radicle (SOA) } \\
\text { Chloride radicle (Cl) } \\
\text { Nitrate radicle (NOs) } \\
\text { Total dissolved solids } 8 \mathrm{t} 180^{\circ} \mathrm{C} \\
\text { Total hardness as } \mathrm{CaCO} \text { (calcu- } \\
\text { lated) }\end{array}$ & $\begin{array}{r}5.3 \\
6.0 \\
1.1 \\
662 \\
.385\end{array}$ & $\begin{array}{r}7.8 \\
6.0 \\
85^{.80} \\
62\end{array}$ \\
\hline
\end{tabular}

\section{- Calculated.}

1. 1,121-foot well of Delta Ice Co., at Vicksburg.

2. Cistern of R. F. Childs, at Bovina.

33 Lowe, E. N., Oil prospecting in Mississippi: Mississippi Geol. Survey Bull. 15, pp. 65-75, 1919. 


\section{WASEINGTON COUNTY}

\section{GENERAL FEATURES}

Area, 723 square miles. Population, 51,092 (census of 1920 )

Washington County lies in northwestern Mississippi, in the Yazoo Delta district. The "delta" is underlain by alluvial deposits of loam, clay, sand, and gravel that have an estimated thickness of 150 to 200 feet. Beneath the alluvium lies a great series of clays, marls, and sands that probably include representatives of all the Eocene and Upper Cretaceous formations in Mississippi (pp. 29-54).

\section{GROUND-WATER CONDITIONS}

The sandy and gravelly portions of the alluvial deposits that underlie the county to estimated depths of 150 to 200 feet contain large quantities of water, which is under little or no artesian head but which is easily obtained by bored and driven wells that are equipped with ropes and buckets or with pumps. The water table is so near the surface at most places that suction pumps can be successfully operated.

The series of Eocene strata that underlie the alluvium include layers of porous sand in which the contained waters are under artesian pressure sufficient to raise them nearly to or above the surface. These beds have been tapped by numerous wells that range in depth from 375 to 1,850 feet. Few af the wells less than 530 feet deep yield flows, but in most of them the static head is less than 15 feet below the surface; with a few, exceptions wells 540 feet or more in depth yield flows, some of the deeper ones as much as 150 gallons a minute.

Detailed information in regard to the dip, strike, and thickness of the separate formations that compose the buried Eocene deposits is almost totally lacking, but a rough attempt has been made: to der termine the formations or groups to which the principal water-bearing beds penetrated by the different wells belong. These determinations are based on an assumed uniformity in dip, strike, and thickness of the formations from their area of outcrop westward beneath the covering of alluvium. Some of the water-bearing beds are referred to the Lisbon formation, some to the Tallahatta formation, and some to the underlying Wilcox group, but these correlations must be regarded as tentative, pending a more complete knowledge of the facts. 


\section{LOCAL SUPPLIES}

Helm.-At Helm domestic water supplies are obtained in part by means of cisterns, and in part from driven wells, which range in depth from 25 to 70 feet. A few deep wells have also been drilled in the vicinity of Helm, of which the 1,601-foot well (No. 12) is typical.

Greenville.-The municipal waterworks at Greenville is located at the intersection of Carter and Union Streets, near the Yazoo \& Mississippi Valley Railroad. The water supply is obtained from four nonflowing wells $450,480(?), 480$, and 520 feet deep (Nos. 6-9).

Log of abandoned well of Greenville Ice \& Coal Co., Greenville

[Authority, Gray Artesian Well Co.]

\begin{tabular}{|c|c|c|c|c|c|}
\hline & $\begin{array}{l}\text { Thick- } \\
\text { ness }\end{array}$ & Depth & & Thick- & Depth \\
\hline $\begin{array}{l}\text { Mluvhum (ohiefiy): } \\
\text { Cinders } \\
\text { Sandy day } \\
\text { Buckshot clay. } \\
\text { Sand } \\
\text { Sand and gravel } \\
\text { Boulders } \\
\text { Rock } \\
\text { Bouldors } \\
\text { Eocene: } \\
\text { Gumbo } \\
\text { "Soapstone" } \\
\text { Rock }\end{array}$ & $\begin{array}{rr}\text { Ft. } & \text { in. } \\
2 & 0 \\
6 & 0 \\
14 & 0 \\
30 & 0 \\
55 & 0 \\
1 & 0 \\
4 & 7 \\
4 & 0 \\
56 & 6 \\
11 & 0 \\
& 5\end{array}$ & $\begin{array}{rr}\text { Ft. } & \text { in. } \\
2 & 0 \\
8 & 0 \\
22 & 0 \\
52 & 0 \\
107 & 0 \\
108 & 0 \\
108 & 7 \\
112 & 7 \\
169 & 1 \\
180 & 1 \\
180 & 6\end{array}$ & 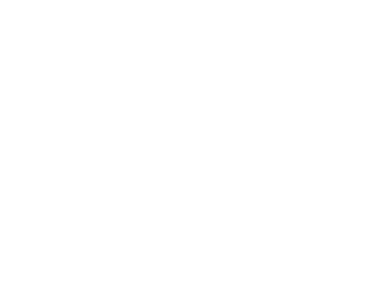 & $\begin{array}{rr}F t . & i n \\
10 & 0 \\
64 & 0 \\
1 & 10 \\
24 & 0 \\
8 & 8 \\
8 & 0 \\
77 & 0 \\
29 & 10 \\
1 & 5 \\
3 & 6 \\
3 & 0 \\
169 & 0\end{array}$ & $\begin{array}{l}\text { Fit. } \\
190 \\
244 \\
246 \\
290 \\
281 \\
989 \\
366 \\
395 \\
397 \\
400 \\
403 \\
572\end{array}$ \\
\hline
\end{tabular}

Stoneville.-Most of the inhabitants of the village of Stoneville, 2 miles northwest of Leland, are supplied with water from a flowing well (No. 21), 1,850 feet deep, owned by E. R. Day and others. The well yields 150 gallons a minute. The water is obtained from numerous layers of sand within 150 feet of the bottom of the well, probably belonging to the Wilcox group of the Eocene. A log of this well is given below. (See analysis 21.) The well of G. B. Walker at this place, depth not recorded, also flows about 150 gallons a minute. (Beo analysis 22.) 
Log of well of E. R. Day and others at Stoneville (No. 21) a

[Altitude of mouth of well, 120 feet above sea level. Authority, T. B. Minyard, drillex]

\begin{tabular}{|c|c|c|c|c|c|}
\hline & $\begin{array}{l}\text { Thick- } \\
\text { ness }\end{array}$ & Depth & . & $\begin{array}{l}\text { Thick- } \\
\text { ness }\end{array}$ & Depth \\
\hline 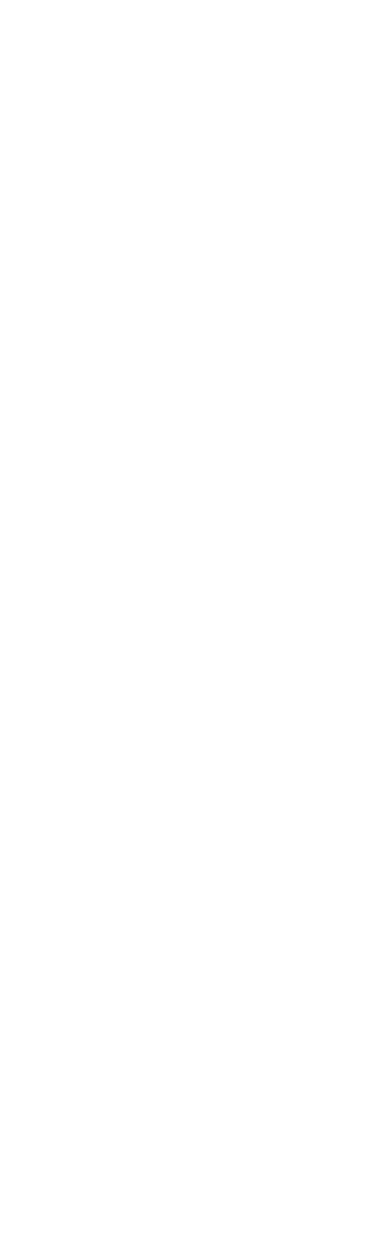 & $\begin{array}{r}\text { Feet } \\
10 \\
23 \\
39 \\
29 \\
44 \\
47 \\
4 \\
7 \\
31 \\
6 \\
2 \\
15 \\
4 \\
76 \\
12 \\
21 \\
1 \\
6 \\
58 \\
47 \\
26 \\
280 \\
10 \\
18 \\
8 \\
16 \\
20 \\
64 \\
20 \\
20 \\
5 \\
25 \\
71 \\
\end{array}$ & $\begin{array}{r}145 \\
192 \\
199 \\
230 \\
236 \\
238 \\
253 \\
257 \\
333 \\
345 \\
366 \\
367 \\
373 \\
431 \\
478 \\
504 \\
784 \\
794 \\
812 \\
820 \\
836 \\
856 \\
\\
920 \\
940 \\
960 \\
965 \\
990 \\
1,061 \\
\end{array}$ & 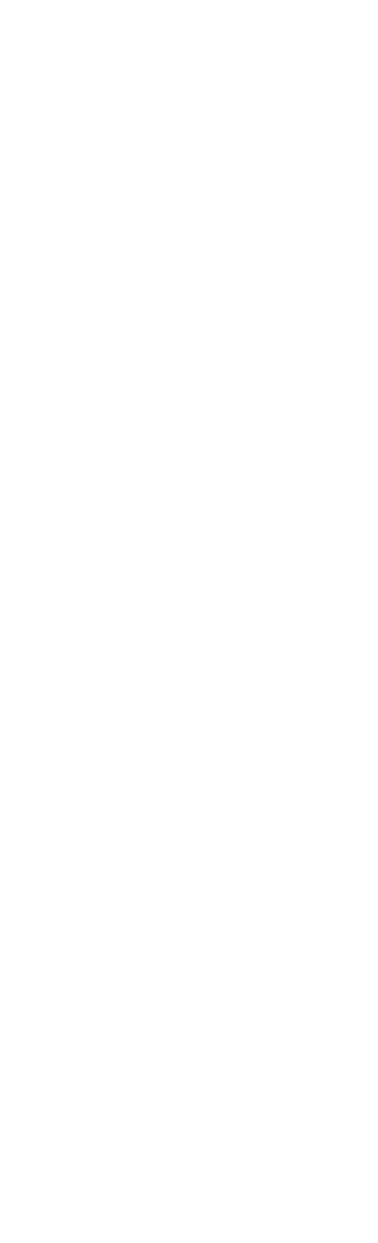 & $\begin{array}{r}\text { Feet } \\
\mathbf{4} \\
\mathbf{1} \\
\mathbf{1 3} \\
\mathbf{3} \\
\mathbf{5} \\
\mathbf{3 1} \\
\mathbf{2} \\
\mathbf{8} \\
8 \\
\mathbf{2} \\
\mathbf{7} \\
\mathbf{3} \\
16 \\
2 \\
\mathbf{5} \\
11 \\
4 \\
6 \\
18 \\
1 \\
3 \\
\mathbf{4}\end{array}$ & $\begin{array}{l}1,632 \\
1,635 \\
1,651 \\
1,653 \\
1,658 \\
1,669 \\
1,673 \\
1,679 \\
1,697 \\
1,698 \\
1,701 \\
1,705 \\
1,708 \\
1,709 \\
1,710 \\
1,719 \\
1,723 \\
1,737 \\
1,760 \\
1,761 \\
1,765 \\
1,768 \\
1,779 \\
1,780 \\
1,799 \\
1,808 \\
1,809 \\
1,811 \\
1,816 \\
1,815 \\
1,816 \\
1,817 \\
1,899 \\
1,850\end{array}$ \\
\hline
\end{tabular}

a Mississippi Geol. Survey Bull. 15, pp. 75-78, 1919. 
Leland.-The waterworks at Leland is owned by the town and is located about 600 feet south of the Yazoo \& Mississippi Valley Railroad station. The present source of the water is two wells; one 527 and the other 516 feet deep (Nos. 16, 17). Analysis 16 represents water from the 527-foot well, and a log of the well is given below:

Log of town well at Leland (No. 16)

\begin{tabular}{|c|c|c|}
\hline : & Thickness & Depth \\
\hline $\begin{array}{l}\text { Alluvium: } \\
\text { Buckshot clay } \\
\text { Fine sandy silt } \\
\text { Gravel } \\
\text { Sand }\end{array}$ & Feet $\begin{array}{r}2 \\
60 \\
-14 \\
64\end{array}$ & $\begin{array}{r}\text { Feet. } \\
2 \\
62 \\
76 \\
140\end{array}$ \\
\hline $\begin{array}{l}\text { Eocene: } \\
\text { Hard rock, } \\
\text { Blue clay, with three strata of hard rock } \\
\text { Fine sand; water bearing (Lisbon formation?) }\end{array}$ & $\begin{array}{r}2 \\
300 \\
85\end{array}$ & $\begin{array}{l}142 \\
442 \\
527\end{array}$ \\
\hline
\end{tabular}

A well at the ice factory at Leland (No. 19) is 530 feet deep; it does not flow, but the water stands within 14 feet of the surface. Another well at the ice factory (No. 20) is only 50 feet deep.

Elizabeth.-At Elizabeth water somewhat colored by contact with vegetable matter is furnished by driven wells 25 to 35 feet deep.

Dunleith.-Water stained with vegetable matter, similar to that at Elizabeth, is found at shallow depths at Dunleith, 6 miles northeast of Leland.

Hollyknowe.-At Hollyknowe two wells (Nos. 14, 15) are respectively 478 and 1,602 feet deep. In the shallower well, the static head is not quite high enough to yield a flow, but the deeper well, which penetrates'to water-bearing sands of the Wilcox group, yields a strong flow. (See analysis 15.)

Swiftwater.-Shallow wells which enter only the alluvium are in use at Swiftwater; the 50-foot well (No. 23) is a typical example. (See analysis 23.)

Burdette.-The well of W. O. Aldridge (No. 2), half a mile northeast of Burdette, is 1,634 feet deep and probably reaches the Wilcox group. Water-bearing beds were encountered at depths of 500 , 1,050, and 1,614 feet, respectively. The well yields a strong flow of water, which emerges at a temperature of $90^{\circ} \mathrm{F}$. (See analysis 2.)

Wayside.-Analysis 24 represents water from the 58-foot driven well of L. L. Lewis, at Wayside.

Arcola.-A well owned by the Arcola Cotton Oil Mill, at. Arcola (No. 1), is 420 feet deep and yields a supply of nonflowing water ample for the domestic use of several families. (See analysis 1.)

Estill.-The 540-foot well of J. T. Atterbury (No. 3), at Estill, 5 miles south of Arcola, flows 50 gallons a minute. 
Longwood.-A well on the Longwood plantation is reported to be several hundred feet deep.

Hollandale.-The municipal water supply at Hollandale is derived from a well (No. 13) 385 feet deep, which does not flow but which yields 200 gallons a minute by pumping. (See analysis 13.)

Leota Landing.-At Leota Landing, on the bank of Mississippi River, domestic water supplies are obtained chiefly from driven wells and from cisterns.

Glen Allen.-The Glen Allen Oil Mill Co., at Glen Allen, owns a drilled well (No. 4) 1,025 feet deep, which yields a strong artesian flow from sand penetrated at a depth of 935 feet; the material penetrated between depths of 935 and 1,025 feet consisted of firm sandstone that required no casing to prevent caving. A 768-foot well (No. 5) on the property of S. M. Spencer, jr., about 5 miles east of Glen Allen, is said to flow 80 gallons a minute. Water was struck at depths of 18 feet (in the alluvium), 300 feet, 500 feet, and 700 feet; only the 700-foot stratum yielded a flow.

Marathon.-At Marathon, 3 miles north of Hampton, the principal source of domestic water supply is driven wells and cisterns. 


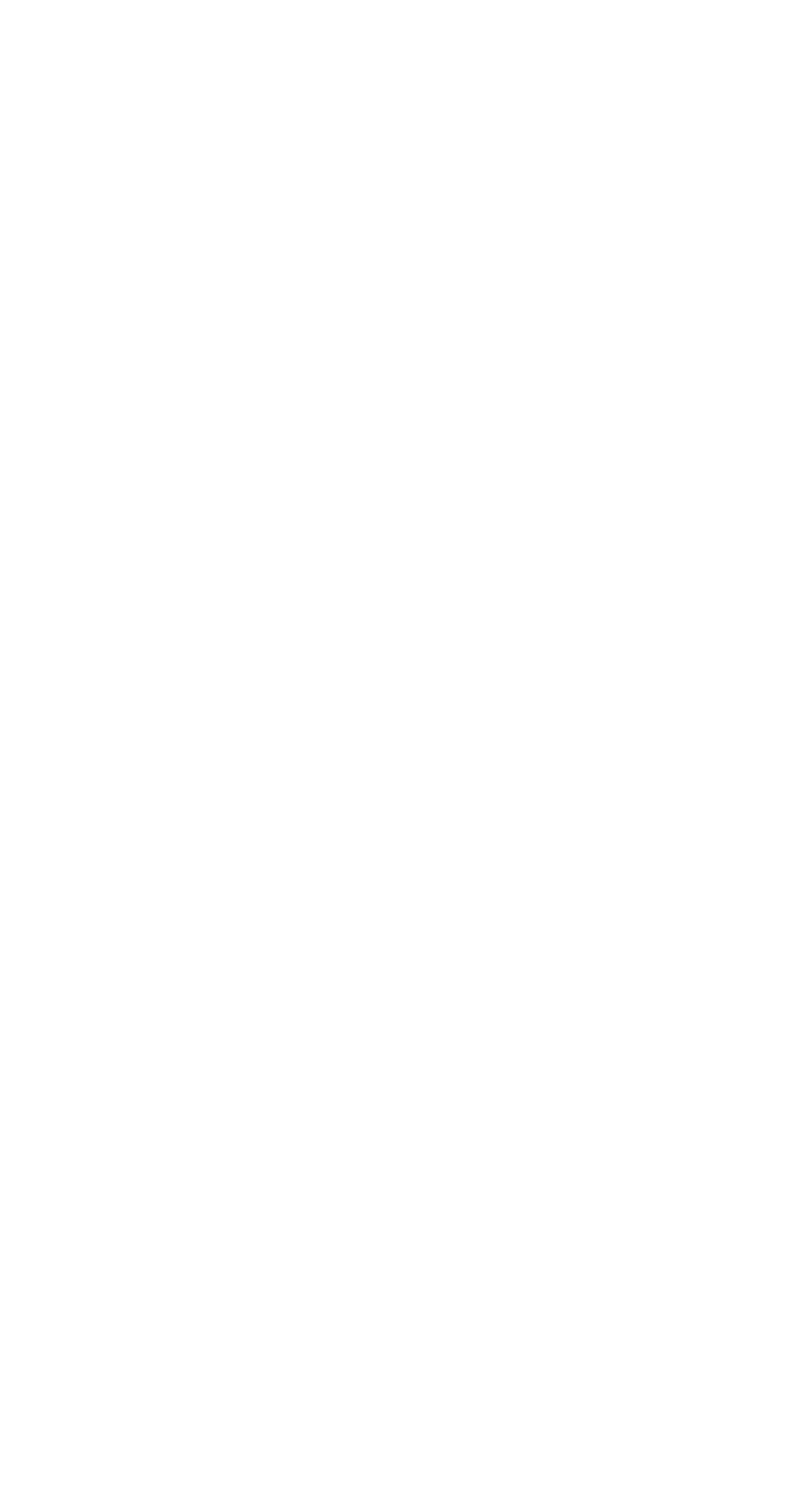




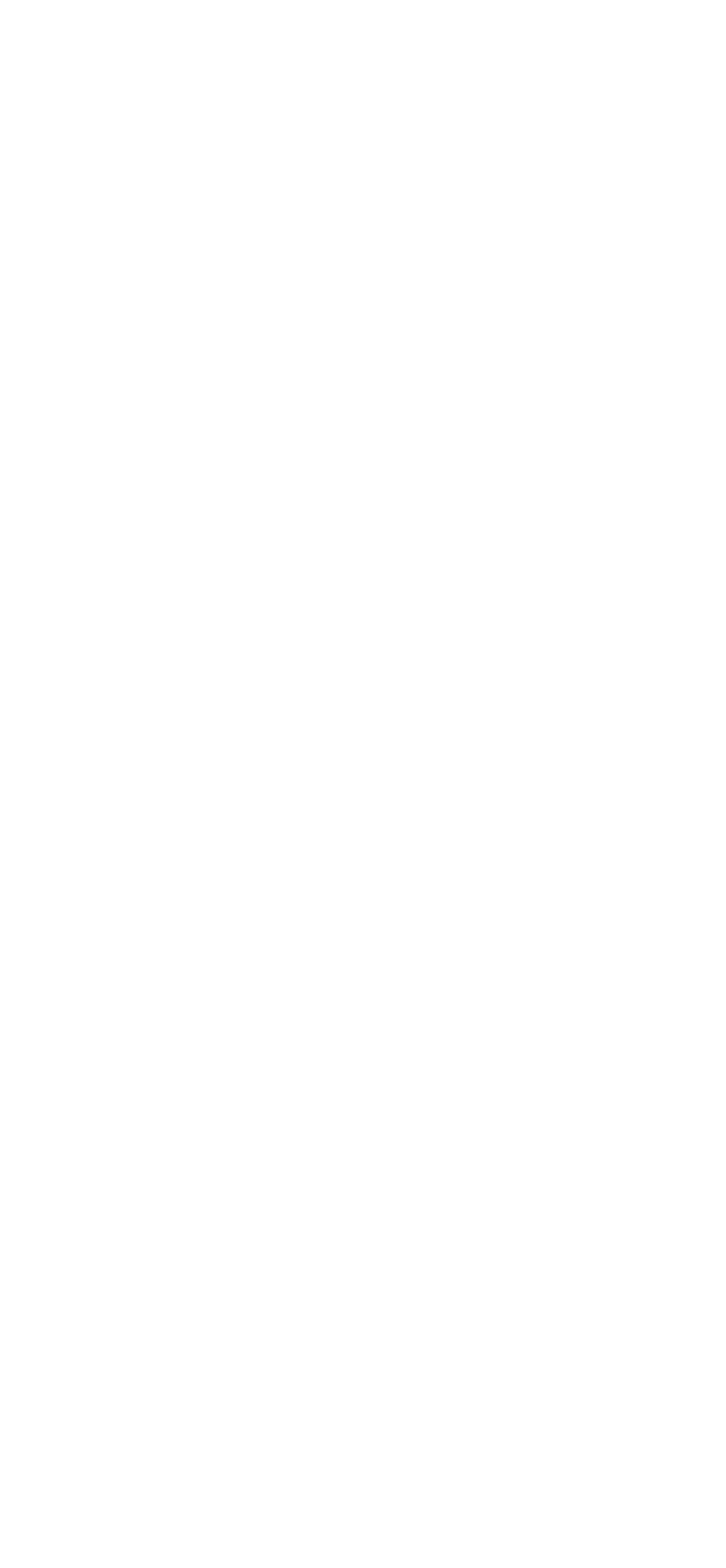




\section{Mineral analyses of ground waters from Washington County}

[Parts per million. Numbers a t hcad of columns refer to corresponding well numbers in preceding table]

\begin{tabular}{|c|c|c|c|c|c|c|c|c|c|}
\hline & & 2 & 8 & 9 & 10 & 11 & 12 & & 13 \\
\hline $\begin{array}{l}\text { Silica }\left(\mathrm{SiO}_{2}\right) \\
\text { Iron }(\mathrm{Fe}) \\
\text { Calcium }(\mathrm{Ca}) \\
\text { Magnesium }(\mathrm{Mg}) \\
\text { Sodium and potassium }(\mathrm{Na}+\mathrm{K}) \\
\text { Carbonate radicle }\left(\mathrm{CO}_{3}\right) \\
\text { Bicarbonate radicle }\left(\mathrm{HCO}_{3}\right) \\
\text { Sulphate radicle }\left(\mathrm{SO}_{4}\right) \\
\text { Chloride radicle (Cl) } \\
\left.\text { Nitrate radicle }(\mathrm{NO})_{3}\right) \\
\text { Total dissolved solids at } 180^{\circ} \\
\text { Total hardness as } \mathrm{CaCO}_{8} \text { (calcul } \\
\text { Date of collection. }\end{array}$ & (ted) & $\begin{array}{c}25 \\
12 \\
12 \\
651 \\
79 \\
1,552 \\
29 \\
12 \\
1,591^{.50} \\
79 \\
\text { Aug., }_{1911} \\
190\end{array}$ & \begin{tabular}{|l}
20 \\
.08 \\
2.4 \\
1.4 \\
.128 \\
26 \\
240 \\
2.0 \\
34.34 \\
.8332 \\
12 \\
Oct., \\
1919
\end{tabular} & $\begin{array}{r}32 \\
2.1 \\
1.2 \\
0173 \\
70 \\
216 \\
2.1 \\
64 \\
466 \\
10 \\
\text { Ott. } \\
1919\end{array}$ & $\begin{array}{c}30 \\
.10 \\
1.8 \\
1.0 \\
a 144 \\
20 \\
267 \\
1.8 \\
48 \\
\text { Trace. } \\
a 878 \\
9 \\
\text { Oat., } \\
1919\end{array}$ & $\begin{array}{l}37 \\
83^{.83} \\
22 \\
51 \\
361^{\circ} \\
92 \\
19 . \\
\text { Trace. } \\
507 \\
298 \\
\text { Oct.; } \\
1913\end{array}$ & $\begin{array}{r}35 \\
2 . \\
1 . \\
\alpha 279 \\
52 \\
631 \\
1 . \\
8 . \\
\text { Trac } \\
6091 \\
12 \\
\text { Oct } \\
191\end{array}$ & & $\begin{array}{c}16 \\
3.5 \\
17 \\
4.4 \\
125 \\
9.6 \\
376 \\
6.0 \\
14 \\
3.0 \\
382 \\
60 \\
\text { July, } \\
1911\end{array}$ \\
\hline & 15 & 16 & 2 & & 22 & 23 & & & 24 \\
\hline $\begin{array}{l}\text { Silica }\left(\mathrm{SiO}_{2}\right) \\
\text { Iron }(\mathrm{Fr}) \\
\text { Calcium }(\mathrm{Ca}) \\
\text { Magnesium }(\mathrm{Mg})\end{array}$ & $\begin{array}{l}40 \\
4.3 \\
4.6 \\
1.4\end{array}$ & $\begin{array}{r}25 \\
61 . \\
1 .\end{array}$ & & $\begin{array}{l}34.14 \\
2.3 \\
1.5\end{array}$ & $\begin{array}{r}26 \\
2.5 \\
3.2 \\
.6\end{array}$ & & & & $\begin{array}{c}50 \\
9.1 \\
174 \\
6.1\end{array}$ \\
\hline Sodium and potassium $(\mathrm{Na}+\mathrm{K})$ & 368 & & 27 & & 309 & $\therefore \quad a 3$ & & & a 143 \\
\hline 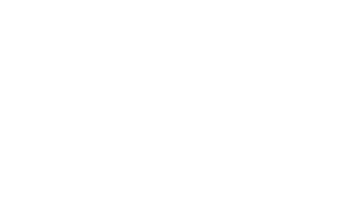 & 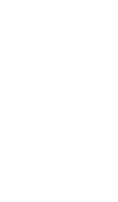 & \begin{tabular}{c}
$299^{\circ}$ \\
1. \\
25 \\
\hdashline $331^{\circ}$
\end{tabular} & Oct., & $\begin{array}{l}39 \\
1.7 \\
6.1 \\
\text { race. } \\
38 \\
12 \\
1919\end{array}$ & $\begin{array}{c}12 \\
740 \\
6.2 \\
13 \\
735^{.0}\end{array}$ & Aug., & & $A u$ & $\begin{array}{c}879^{\circ} \\
46 \\
11 \\
1.0 \\
886 \\
460 \\
8 ., 1911\end{array}$ \\
\hline
\end{tabular}

a Calculated.

3 Iron and aluminum oxides $\left(\mathrm{Fe}_{2} \mathrm{O}_{8}+\mathrm{Al}_{2} \mathrm{O}_{3}\right)$.

Analysts: 2, 13, 23, 24, W. L. Kennon, University of Mississippi; 8, 9, 10, 12, 21, Margaret D. Foster, U. \&. Geological Survey; 11, 15, Mississippi State Chemical Laboratory; 16, W. R. Perkins (Mississippl Agr. Exper. Sta. Bull. 89, p. 91, 1905; 22, W. F. Hand, Míssissippi State Chemical Laboratory.

\section{WAYNE COUNTY}

\section{GENERAL FEATURES}

Area, 812 square miles. Population, 15,467 (census of 1920)

Wayne County lies entirely within the Long-leaf Pine Hills district. The geologic formations which crop out in the county, named in order from the oldest to the youngest, include the Jackson formation (Eocene), which is subdivided into the Moodys marl member and Yazoo clay member; the Vicksburg group (Oligocene), subdivided into the Red Bluff clay, the Marianna limestone, and the Byram marl; the Catahoula sandstone (Miocene); the Citronelle formation (Pliocene); and the terrace deposits that border the streams (Pleistocene and Recent). These formations are described on pages 53-60, and their distribution is shown on Plate 2.

\section{GROUND-WATER CONDITIONS}

The principal developed source of artesian water is the Moodys marl member of the Jackson formation (Eocene), which does not appear at the surface within the county, but which at Waynesboro 
lies at an estimated depth of 250 to more than 500 feet. This buxied member rises to the north and comes to the surface in Clarke County: The water-bearing sand that is tapped by wells at Waynesboro at a depth of about 480 to 500 feet (see log, p. 484), probably belongs to the Moodys marl member. At Hiwannee, 10 miles north of Waynesboro, a water-bearing sand, which is assumed to be the same as that drawn upon by the wells at Waynesboro, is reached at a depth of 265 feet, on which assumption the southward dip of the sand is approximately 25 feet to the mile. If the dip is uniform at this rate this sand should lie at a depth of 900 to 1,100 feet near the southern boundary of the county, its exact depth depending upon the topographic position of any given well. The wells both at Hiwannee and at Waynesboro flow, and the artesian conditions appear to be such that the Moodys marl member would afford flowing water on the lower terraced lands that border Chickasawhay River along its entire course in Wayne County and probably also on the similar terrace lands that border Bucatunna Creek, the principal eastern tributary of the Chickasawhay.

No wells deeper than those at Waynesboro, which are 520 to 580 feet deep, have been reported in the county, but the Lisbon and the Tallahatta formations of the Claiborne group, which should be penetrated at Waynesboro at estimated depths of 550 to 950 feet, and the Wilcox group, whose approximate depth at the same place is believed to be 950 to 1,600 feet or more, doubtless contain water-bearing beds whose waters are under a stronger head than those of the Moodys marl. The character of these waters is, however, unknown, and they may be too highly mineralized for ordinary domestic and industrial purposes, particularly the waters in the Wilcox group. These waters lie at somewhat shallower depths to the north and at increasingly greater depths to the south of Waynesboro.

The Yazoo clay member, which forms the upper part of the Jackson formation, and the Vicksburg group, which lies next above the Jackson, do not appear to afford favorable conditions for the circulation of ground waters in large quantities. The 300 -foot well at the village of Chicora probably taps a water-bearing sand in the Vicksburg group, but the yield by pumping is small, being only 2 gallons a minute.

The formation that is in reality the most extensively developed source of domestic water supply is the Cataboula $a_{s}$, which underlies the southern, central, and western parts of the county. This formation thickens from a featheredge in the northern part of the county to an estimated thickness of 250 or 300 feet in the southern part. These sands are tapped by dug and bored wells that range in depth from 15 to 75 feet or more, and at most places they afford adequate supplies of excellent water for domestic and farm uses. The forma- 
tion is also the source of many small springs, some of which are utilized.

The Catahoula formation is overlain in places by relatively thin surficial remnants of sand and gravel which belong to the Citronelle formation (Pliocene) and which may be the source of some of the small springs and of the water obtained in some shallow wells.

The terrace deposits of loam, sand, and gravel, which occur in the valleys of Chickasawhay River and the larger creeks of the county, are the source of the water obtained in shallow wells located on the terraces and of springs along the edges of the terraces or at the upper ends or along the sides of streams that head in the terraces.

\section{LOCAL SUPPLIES}

Waynesboro.-Six or seven flowing artesian wells have been drilled at Waynesboro. All these wells have their source in sand in the Moodys marl member of the Jackson formation and yield 20 to 40 gallons a minute. The log of a 4-inch well, owned by the town, is given below.

\section{Log of town well, Waynesboro a}

Altitude at mouth of well about 191 feet above sea level. Authority, W. B. Logan and W. R. Perkins]

\begin{tabular}{|c|c|c|}
\hline & Thickness & Depth \\
\hline $\begin{array}{l}\text { Surface clay(?) } \\
\text { Catahoula sandstone(?): Sand; water bearing (importance not stated) } \\
\text { Vicksburg group and Jaokson formation: } \\
\text { Marl and clay with flint "boulders" } \\
\text { Sand; water bearing (Moodys marl member) } \\
\text { Yogua formation(?): } \\
\text { Clay } \\
\text { Not ceported }\end{array}$ & $\begin{array}{r}\text { Feet } \\
30 \\
150 \\
300 \\
20 \\
25 \\
55\end{array}$ & $\begin{array}{r}\text { Feet } \\
30 \\
180 \\
480 \\
500 \\
525 \\
580\end{array}$ \\
\hline
\end{tabular}

1. Mississippi Agr. Exper. Sta. Bull. 89, p. 61, 1905.

The water-bearing sand at a depth of 30 to 180 feet is probably a part of the Catahoula sandstone, although the depth is greater than would be expected from outcrops of the underlying Vicksburg group. The log may be incorrect or the structure may be abnormal. There is evidence of folding near Waynesboro. This water is said to have overflowed at the surface when a depth of 180 feet was reached. The principal water-bearing sand at a depth of 480 to 500 feet is believed to lie at the base of the Jackson formation. This water flows 25 gallons a minute, is highly mineralized, and has a reddish color. (See analysis 1.) A 4-inch well at an ice factory is 520 feet deep and yields 25 gallons a minute. A 4-inch well owned by R. W. Fagan is 525 feet deep and yields 25 gallons a minute. This well supplies a small privately owned waterworks, including an elevated distributing tank. A spring near Waynesboro, owned by Mrs. E. Huggins, probably has its source in a Pleistocene terrace deposit. (See analysis 2.) 
Hiwannee. -The town of Hiwannee owns a $31 / 2$-inch well, 265 , feet deep, which flows 5 gallons a minute. The water is derived frop sand in the Jackson formation and has a slightly reddish color.

Chicora.-The Robinson Land \& Lumber Co.. at Chicora owns a 6-inch well, 300 feet deep, which flows 1 gallon; a minute from sand that is questionably in the Vicksburg group. The well is equipped with a hand pump.

\section{Mineral analyses of ground waters from Wayne County}

[Parts per million]

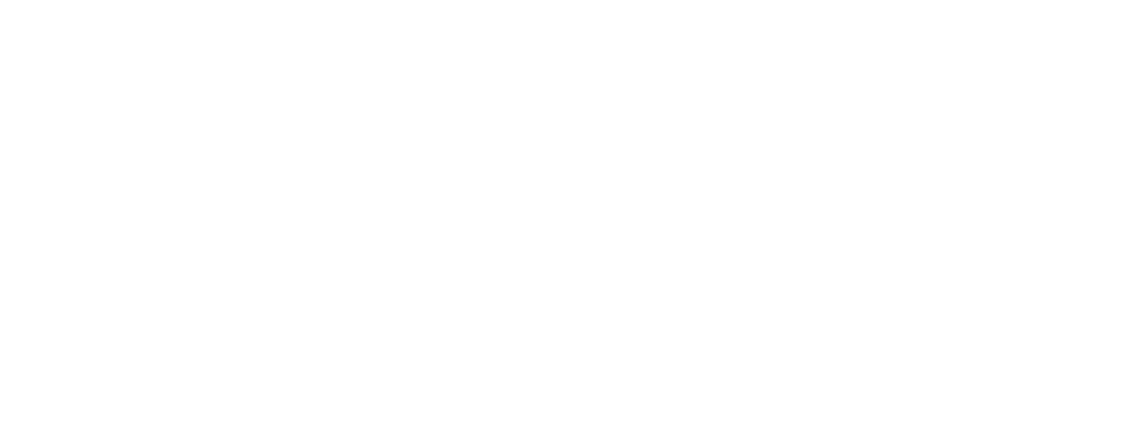

a Iron and aluminum oxides $\left(\mathrm{Fe}_{2} \mathrm{O}_{3}+\mathrm{Al}_{2} \mathrm{O}_{3}\right)$.

Calculated.

Analysts: 1, W. R. Perkins (Mississippi Agr. Exper. Sta. Bull. 89, p. 61, 1905); 2, Mississippi State Chemical Laboratory.

1. 580-foot town well at Waynesboro.

2. Spring owned by Mrs. E. Huggins at Waynesboro.

\section{WEBSTER COUNTY}

\section{GENERAL FEATURES}

Area, 416 square miles. Population, 12,644 (census of 1920)

The greater part of Webster County is in the North Central Hills district, but its eastern end extends into the Flatwoods district. Three geologic formations of Eocene age crop out in broad belts that trend in a direction slightly west of north across the county. These formations are the Porters Creek clay, which is the uppermost formation of the Midway group, and the Ackerman and Holly Springs formations of the Wilcox group. Descriptions of these formations are given on pages 44-49, and their distribution is shown on the geologic map (pl. 2).

\section{GROUND-WATER CONDITIONS}

The Porters Creek clay, 150 or 200 feet thick in Webster County, crops out in the Flatwoods belt, whence it dips to the west at the rate of 20 or 25 feet to the mile and passes out under the remainder of the county beneath the Ackerman formation. The Porters Creek is not an important aquifer.

The Ackerman formation, here 350 or 400 feet thick, crops out west of the Flatwoods in a belt 12 to 20 miles wide. The sandy beds 
of the formation are water bearing and constitute a valuable source of stipply, which is obtained from springs and by wells of shallow to moderite depth.

The Holly Springs sand, which overlies the Ackerman formation, crops out in the southwestern part of the county, where it is 250 or 300 feet thick. The formation is abundantly water bearing and affords domestic and farm supplies that are obtained chiefly from shallow wells and from springs.

Several flowing wells have been reported from creek valleys in the vicinity of Bellefontaine. The water is obtained from the Ackerman formation at depths of 115 to 215 feet. The conditions probably are even more favorable for obtaining flows from the same source in the valley of Big Black River in the southwestern part of the county.

The water-bearing sands of the Eutaw formation (Upper Cretaceous) form a possible though undeveloped source of nonflowing water, especially in the eastern part of the county. These sands lie at depths that range from 1,200 or 1,300 feet in the east to over 2,000 feet in the west. They were reached in a well at Eupora at a depth of 1,900 feet and a milky water of unsatisfactory quality was obtained. A 1,300-foot well at Mathiston failed to reach the Eutaw.

\section{LOCAL SUPPLIES}

Bellefontaine.-The well of W. B. Walker, 200 yards east of the post office at Bellefontaine, is 170 feet deep and flows 3 gallons a minute; a 3-inch casing extends to a depth of 70 feet. The well of E. T. Arnold, 400 yards southeast of the post office, is 215 feet deep and flows $21 / 2$ gallons a minute; a 4 -inch casing extends to a depth of 90 feet. W. E. Lovett's flowing well, a mile east of town, is 117 feet deep and 4 inches in diameter. The source of the water in all three wells is the Ackerman formation. Another well, depth not stated, 3 miles east of Bellefontaine, has a static head of 20 feet above the surface and flows 60 gallons a minute. It probably also taps a water-bearing bed in the basal part of the Ackerman formation.

Dancy.-At Dancy water is supplied by cisterns and shallow wells. Dug and driven wells reach water at depths of 20 to 30 feet in loose materials, probably a sandy facies of the Porters Creek clay.

Eupora.-A nonflowing public well has been drilled in the street in the business part of Eupora, 75 yards north of the Southern Railway station, but no satisfactory information can be obtained in regard to it. According to one report, the total depth of the well is 700 feet, but the principal water probably comes from beds between depths of 250 and 360 feet that are questionably in the Clayton formation. An attempt was made several years ago to obtain a public water supply at Eupora by means of a deep well, which, at a depth of 1,900 feet, struck some water that rose within 80 feet of 
the surface. The water, however, was milky and of unsatisfactory quality for domestic use, and it failed to become clear after considerable pumping. The source of this deep water probably was the Eutaw formation of the Upper Cretaceous. According to Dr. T. O. Douglas sample of water from this well was analyzed, and the analysis given below seems to pertain to this well. According to this authority the water analyzed was probably a mixture from several water-bearing beds but chiefly from beds between depths of 250 and 360 feet.

Mineral analysis of water from public well 700 feet deep at Eupora, Webster County

[Sample collected Aug. 19, 1911; analyzed by W. L. Kennon, University of Mississippi]

\begin{tabular}{|c|c|}
\hline & $\begin{array}{c}\text { Parts per } \\
\text { million }\end{array}$ \\
\hline 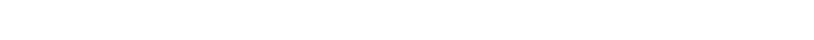 & 33 \\
\hline $\operatorname{Iron}(\mathrm{Fe}) \ldots \ldots$ & 1.4 \\
\hline Calcium (Ca) & 46 \\
\hline Magnesium $(\mathrm{Mg})$ & 10 \\
\hline Sodium and potassium $(\mathrm{Na}+\mathrm{K})$ & 42 \\
\hline Carbonate radicle $\left(\mathrm{CO}_{3}\right)$ & .0 \\
\hline Bicarbonate radicle $\left(\mathrm{HCO}_{3}\right)$ & 215 \\
\hline Sulphate radicle $\left(\mathrm{SO}_{4}\right)$ & 42 \\
\hline Chloride radicle $(\mathrm{Cl})$ & 22 \\
\hline Nitrate radicle $\left(\mathrm{NO}_{3}\right)$ & \\
\hline Total dissolved solids at $180^{\circ} \mathrm{C}$ & 300 \\
\hline Total hardness as $\mathrm{CaCO}_{3}$ (calculated) & 156 \\
\hline
\end{tabular}

Mathiston.--In 1910 an attempt was made by the town authorities of Mathiston to obtain a public water supply by means of a deep boring. Presumably they intended to sink the well through the Eocene formations and the Selma chalk of the Upper Cretaceous to the water-bearing sands of the Eutaw formation, the top of which at Mathiston lies at an estimated depth of 1,400 or 1,500 feet. The well was abandoned in the Selma chalk at a depth of 1,300 feet. According to W. N. Logan the well when it had reached a depth of 900 feet had penetrated 600 feet of clay (Ackerman and Porters Creek), followed by 300 feet of limestone. Springs owned by E. P. Patterson, 13/4 miles north of Mathiston, furnish a good domestic supply of water, presumably from the Ackerman formation. The character of the water in the individual springs, of which there are about 15 , is said to differ considerably.

\section{WILKINSON COUNTY}

\section{GENERAL FEATURES}

Area, 667 square miles. Population, 15,319 (census of 1920)

Wilkinson County is included in three physiographic districts. About 80 square miles along the west side, or approximately 12 per cent of the total area, is included in the Mississippi Alluvial Plain; this is separated by a steep escarpment from the Loess Hills district 
which lies to the east; the Loess Hills pass toward the east into the Long-leaf Pine Hills district which embraces the eastern part of the county. The oldest geologic formation is the Pascagoula clay (Miocene), whose strata is exposed in places in the lower slopes of the deeper valleys and of the escarpment that overlooks the Mississippi lowland on the west, in the central and northern parts of the county. The Pascagoula is nearly completely covered by the Citronelle formation (Pliocene), which is in turn blanketed by the Pleistocene loess. These forma tions are described on pages $47-60$, and their distribution is indicated on the geologic map (pl. 2). The Mississippi lowland is underlain by 150 to 200 feet of alluvial loam, clay, sand, and gravel, which rest upon eroded strata that belong to the Pascagoula formation.

\section{GROUND-WATER CONDITIONS}

The loess, which blankets practically the entire upland portion of the county to depths that range from a maximum of perhaps 50 feet in the west to only a few feet in the east, has not only largely determined the topography and soil conditions in the upland but has also had a marked effect on the ground waters of the area. The loess is underlain by the Citronelle formation, which ranges in thickness from a few feet to 150 feet or more, its maximum thickness being in the southern townships. Where the loess is thickest it is also calcareous, and the surface water that percolates down through the loess dissolves out the lime and carries it down into most of the underlying Citronelle formation, whose waters are thus rendered more or less hard. Although these waters are not too deep to be reached with ordinary wells, their hardness, though by no means everywhere excessive, has led to the construction of many cisterns for storing rain water in the area in which the loess is thick.

The common source of ground water throughout most of the upland is the Citronelle formation, whose waters are obtained by dug and bored wells that range in depth from 20 to 120 feet. As many of the streams have cut their valleys down through the loess into the underlying Citronelle formation, springs that have their source in the water-bearing sands and gravels of the Citronelle are numerous, and many of them are utilized.

Only a few wells have been sunk through the Citronelle formation into the underlying Pascagoula clay or into the older formations that lie beneath the Pascagoula, and little is known of the groundwater supplies that may lie at these greater depths. The deep well at Woodville (see log, p. 489) found water in sand and clay at a depth of 390 to 420 feet in beds that probably belong to the Pascagoula formation. In places in southern Mississippi the Hattiesburg clay (Miocene), about 450 feet thick, which underlies the Pascagoula, contains interbedded layers of water-bearing sand, and the still deeper 
Catehoula sandstone (Miocene) probably 500 feet or more in thickness; is an important aquifer in a broad eastward-trending. belt in the southern part of the State. A well 1,500 feet deep at Woodville would probably reach the base of the Catahoula and serve as a test of these possible sources of supply.

In the Mississippi lowland abundant supplies of water are obtainable from the sands and gravels of the river alluvium at depths that range from 10 to perhaps 200 feet. The shallower wells of this character are subject to pollution from surface sources. Wells in the vicinity of Artonish, 150 to 185 feet deep, are believed to derive their supplies from these alluvial deposits.

\section{LOCAL SUPPLIES}

Woodville.-The town of Woodville is provided with a municipal waterworks, one-fourth mile south of the post office, which obtains water from an 8-inch well 960 feet deep, a partial log of which is given below. The static head of the water is 300 feet below the surface, and the well yields 100 gallons a minute by pumping with air.

Partial log of well owned by the town of Woodville a

[AItitude of mouth of well, 405 feet above sea level. Authority, W. Sperry, driller, through Dr. J. C. Ropert, of Centerville]

\begin{tabular}{|c|c|c|}
\hline & Thickness & Depth \\
\hline $\begin{array}{l}\text { Citronelle formation: } \\
\text { "Alluvial washings" (sand and clay) } \\
\text { Yellow clay, } \\
\text { White sand; water bearing } \\
\text { Red clay }\end{array}$ & Feet $\begin{array}{r}15 \\
15 \\
5 \\
1\end{array}$ & Feet $\begin{array}{r}15 \\
30 \\
35 \\
36\end{array}$ \\
\hline $\begin{array}{l}\text { Pascagoula clay: } \\
\text { Bluish-white pipe clay } \\
\text { Blue clay mixed with pebbles and cobbles } \\
\text { Sand and clay; water bearing (yields } 40 \text { gallons a minute) } \\
\text { Blue clay, with pebbles } \\
\text { Hattiesburg clay: Blue "soapstone," full of grit. } \\
\text { Not reported. }\end{array}$ & $\begin{array}{r}150 \\
204 \\
30 \\
10 \\
185 \\
345\end{array}$ & $\begin{array}{l}186 \\
390 \\
420 \\
430 \\
615 \\
960\end{array}$ \\
\hline
\end{tabular}

- Adapted from columnar section published in U. S. Geol. Survey Prof. Paper 98, pl. 43, column 10, 1916. The log was furnished while drilling was in progress, when the well had reached a depth of 615 feet.

Centerville.-The municipal water supply at Centerville is obtained from the Citronelle formation by means of a well, reported to be 130 feet deep, a quarter of a mile east of the post office. The well is in the bottom of a circular brick-lined pit 52 feet deep (included in the total depth of 130 feet) and 10 feet in diameter. The pumping machinery is installed on the floor of the pit. The source of the water is fine sand in the Citronelle formation. The bored well of J. C. Robert is 90 feet deep and obtains water under no artesian pressure from coarse sand with small pebbles, of the Citronelle formation, in the lower 8 feet. An abandoned well of the Illinois Central Railroad was sưnk to a depth of 150 feet in the Citronelle formation. Before the well was abandoned the water was used in locomotive boilers. 
Turnbull.-The bored well of Jesse Carter, 2 miles northenst of Turnbull, is 89 feet deep and enters water-bearing sand and gravel of the Citronelle formation.

Newtonia.-The bored well of Mrs. A. E. Morgan at Newtonia is 63 feet deep and obtains water under no artesian head from white sand of the Citronelle formation in the lower 4 feet.

Mineral analyses of ground waters from Wilkinson County

[Parts per million]

\begin{tabular}{|c|c|c|}
\hline & 1 & 2 \\
\hline 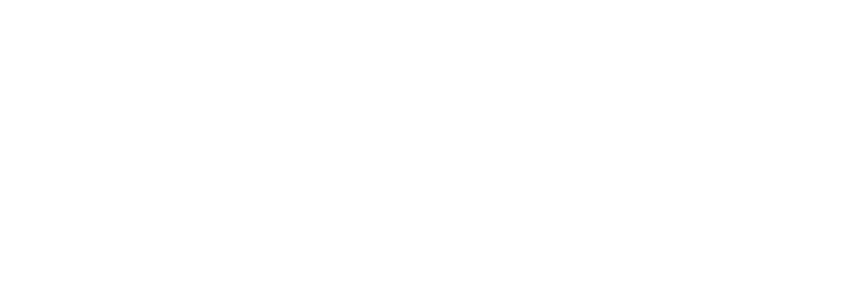 & \begin{tabular}{|l|}
$\mid 20$ \\
2.08 \\
1.4 \\
9.9 \\
$15^{.0}$ \\
1.2 \\
11 \\
3.9 \\
59 \\
11 \\
July, 1919
\end{tabular} & 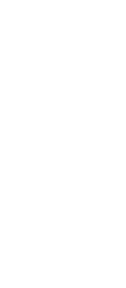 \\
\hline
\end{tabular}

- Calculated.

Analysts: 1, Margaret D. Foster, U. S. Geological Survey; 2, Mississippi State Chemical Laboratory.

1. 130-foot town well one-fourth mile east of post office at Centerville.

2. 60 -foot well of Mrs. S. E. Germany at Centerville.

\section{WINSTON COUNTT}

\section{GENERAL FEATURES}

Area, 597 square miles. Population, 18,139 (census of 1920)

Winston County lies within the North Central Hills district, except a small area in the northeastern part, which grades into the Flatwoods district. The exposed geologic formations, which crop out in successive belts from northeast to southwest in order from the oldest to the youngest, are all of Eocene age and include the Porters Creek clay of the Midway group, the Ackerman and Holly Springs formations of the Wilcox group, and the Tallahatta formation and the Winona sand member of the Lisbon formation of the Claiborne group. These formations are described on pages 44-52, and their distribution is shown on the geologic map (pl. 2).

\section{GROUND-WATER CONDITIONS}

The geologic formations dip to the west-southwest at a rate between 20 and 30 feet to the mile. The Porters Creek clay, which is 200 to 250 feet thick, is generally not water bearing. Some of the more sandy beds in different parts of the Ackerman formation, 
which is 350 or 400 feet thick, carry water in commercially important quantities. The Holly Springs sand, which is 275 or 300 feet thick, carries an abundance of water of excellent quality. The Tallahatta formation and the Winona sand member of the Lisbon formation carry water but crop out only in a relatively small area in the extreme southwestern part of the county.

Of the formations enumerated, the Holly Springs sand is by far the most valuable for its contained waters. Throughout the central and southwestern parts of the county an abundance of water for domestic and farm use is obtained from the sands of this formation by dug and bored wells that range in depth from 20 to 100 feet or more. Water in sufficient quantities for domestic and farm use is also obtained from the more sandy portions of the Ackerman formation throughout its belt of outcrop, which is 10 to 15 miles wide and extends in a northwesterly direction through the eastern half of the county. The municipal water supply at Louisville appears to come from sandy beds near the base of the Ackerman. (See logs, p. 492.)

Springs of small to moderate yield are common throughout most of the hilly parts of the county. In the Flatwoods area in the northeast, however, where the Porters Creek clay is the immediately underlying formation, springs are rare.

In the Flatwoods belt good supplies of nonflowing water could probably be obtained by drilling through the Porters Creek clay, the Clayton formation, if it is present, and the still deeper Selma chalk to the water-bearing sands of the Eutaw formation, the estimated depth of which is 1,200 to 1,400 feet.

The deepest wells reported from the county are the 407 and 488 foot wells at the plant of the Louisville Light \& Power Co., Louisville, and the 392-foot well at the municipal waterworks.

\section{LOCAL SUPPLTES}

Louisville.-Louisville, the county seat, owns a municipal waterworks about 200 feet north of the Gulf, Mobile \& Northern Railroad station, east of the track. A nonflowing well, 3921/3 feet deep, at the waterworks furnishes only a small part of the municipal supply. This well was drilled in 1913 and is in the SE. 1/4 NE. 1/4 sec. 23, T. 15 N., R. 12 E., on ground estimated to be about 554 feet above sea level. The well is 8 inches in diameter and the static head of the water is reported to be about 90 feet below the surface. An analysis of the water is given below. 
Mineral analysis of water from town well about 992 feet deep at Louisville, Winston County

[Sample collected April 24, 1914; analyzed by Mississippi State Chemical Laboratory.]

\begin{tabular}{|c|c|}
\hline & $\underset{\text { marts per }}{\text { milion }}$ \\
\hline Silica $\left(\mathrm{SiO}_{2}\right)_{-}$ & 16 \\
\hline & 3. 2 \\
\hline (Ca) & 4. 2 \\
\hline 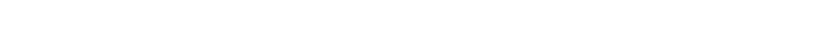 & 1. 4 \\
\hline assium $(\mathrm{Na}+\mathrm{K})$ & 53 \\
\hline$\left(\mathrm{CO}_{3}\right)_{2}$ & .0 \\
\hline ate radicle $\left(\mathrm{HCO}_{3}\right)$ & 146 \\
\hline adicle $\left(\mathrm{SO}_{4}\right)$ & 5. 9 \\
\hline e radicle (Cl) & 6. 0 \\
\hline 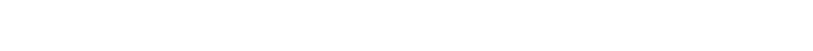 & \\
\hline (1) & 165 \\
\hline iss as $\mathrm{CaCO}_{3}$ (calculated) $\ldots$ & 16 \\
\hline
\end{tabular}

The greater part of the city water is furnished by a well owned by the Louisville Light \& Power Co., whose plant is located near the waterworks. This well, which is $4881 / 4$ feet deep and 6 inches in diameter, has the same source as the municipal well. Its log is given below.

\section{Log of well of Louisville Light \& Power Co.}

[Altitude of mouth of well 554 feet above sea level. Furnished by $\mathbf{E}$. N. Lowe, State geologist, and by T. A. McCreary, superintendent of waterworks; Layne \& Bowler, drillers]

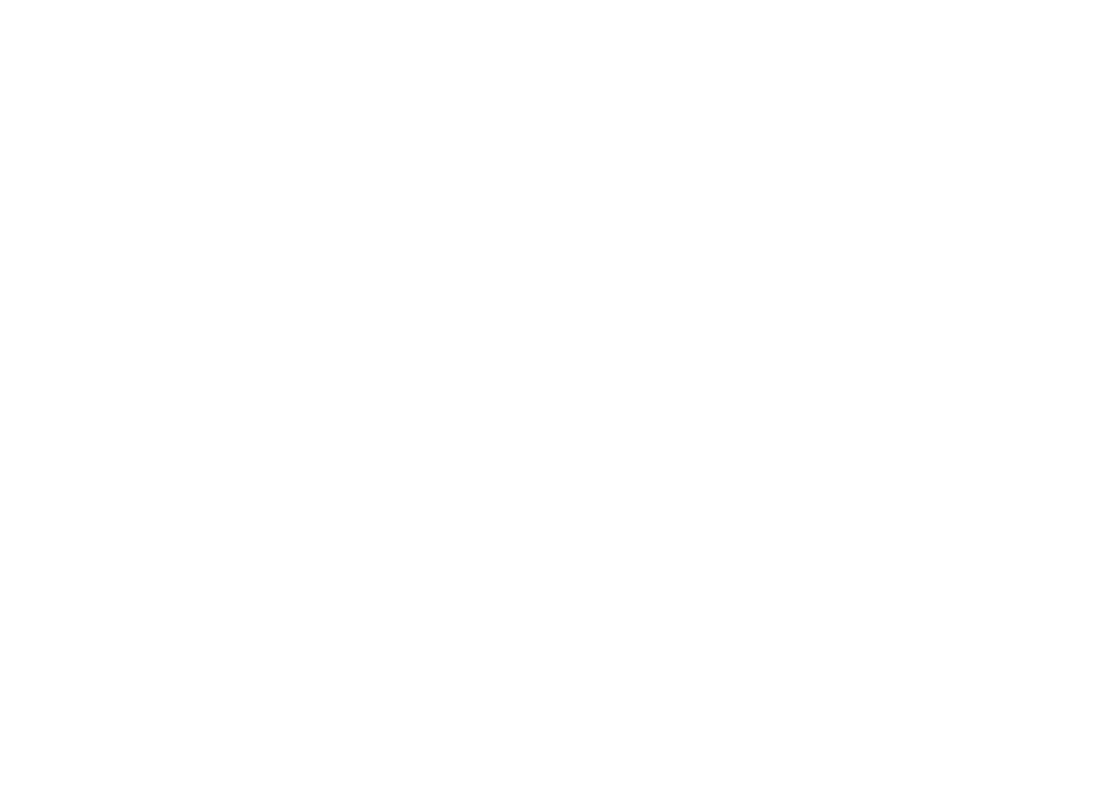

A dug well owned by J. M. Harris at Louisville, is 40 feet deep and has its source in the Holly Springs sand; the static head is 18 feet below the surface. 
Noxapater.-A spring on the W. J. Webb place, 5 miles west of Noxapater, is probably typical of those which commonly issue from the Holly Springs sand. The spring yields about 2 gallons a minute and affords a good domestic supply of soft water. There are said to be seven other small springs within a radius of a few hundred yards from this one.

Estes.-At the village of Estes, $41 / 2$ miles south of Louisville, the Legan \& McClure Lumber Co. owns an 8-inch well 223 feet 7 inches deep, which was drilled in 1920 . Water was obtained in fine blue sand of the Ackerman formation at a depth of 129 to 171 feet. A log of the well is given below.

Log of well of Legan \& McClure Lumber Co. at Estes, 41/2 miles south of Louisville [Authority, Gray Artesian Well Co.]

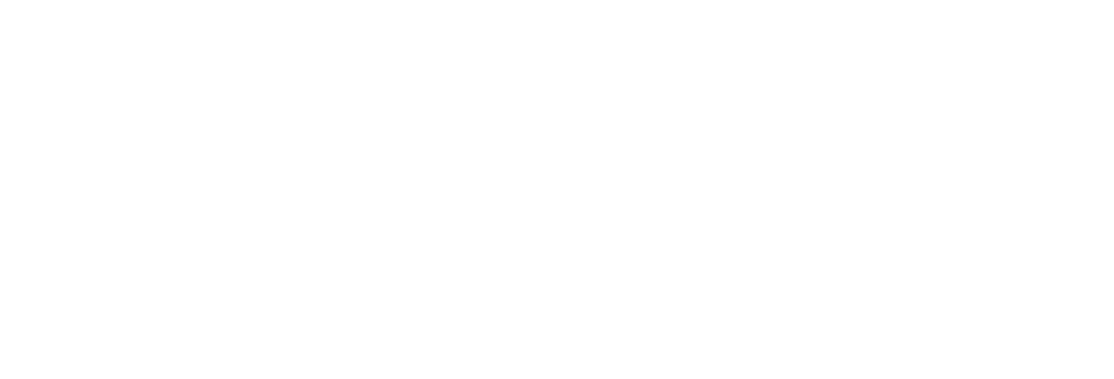

\section{YAIOBUSEA OOUNTY}

\section{GENERAL FEATURES}

Area, 490 square miles. Population, 18,738 (census of 1920)

Yalobusha County is in the North Central Hills district. The geologic formations that underlie the county include, from oldest to youngest, the Ackerman, Holly Springs, and Grenada formations, of the Eocene Wilcox group, and Pleistocene loess, which forms a thin blanket-like covering on the hills throughout the greater part of the county, and the alluvial deposits along Yocona and Shooner Rivers. These formations are described on pages 45-61, and the distribution of the Eocene formations is indicated on the geologic map (pl. 2). Only the thicker part of the loess, whioh lies mainly west of Yalobusha County, is shown on the geologic map.

\section{GROUND-WATER CONDITIONS}

The Eocene formations dip toward the west about 25 feet to the mile, and the conditions are therefore favorable for development of artesian pressure in their contained waters. Flowing wells have been obtained in some of the tributary valleys of Shooner River in the southeast, as at Coffeeville and Bryant, and doubtless flows could be obtained in the Yocona Valley in the northwest. 
The Ackerman formation, which appears at the surface only in a narrow strip along the eastern border of the county, has an estimated aggregate thickness between 500 and 600 feet. Certain of the sandy sitrata are water bearing and are the source of the water obtained in all the deeper wells in the eastern half of the county, as at Coffeeville, Bryant, and Torrance.

The Holly Springs sand, here 400 or 500 feet thick, overlies the Ackerman formation, and its area of outcrop forms a broad northward-trending belt across the eastern and central parts of the county. The sands are abundantly water bearing : and are the source of the water obtained in most of the shallow wells in the eastern and central parts of the area and of the deeper wells in the west.

Springs of small yield are common throughout the area.

In the western part of the county, in the area underlain by the thicker parts of the loess, difficulty is experienced locally in obtaining a satisfactory domestic water. supply from wells, and at such places cisterns are in use for storing rain water.

\section{LOCAL SUPPLIES}

Water Valley.-The municipal waterworks at Water Valley is at the corner of Blount and Railroad Streets, near the Illinois Central Railroad station. Water is obtained from the Holly Springs sand by means of four wells, each 80 feet deep and 8 inches in diameter (No. 18). (See analyses 18,19 .) Twenty-four other 6 -inch wells 60 to 80 feet deep at the plant, drilled from time to time, have been abandoned. The $\log$ of one of the abandoned wells is given below.

Log of city well at Water. Valley

\begin{tabular}{|c|c|c|}
\hline & Thickness & Depth \\
\hline $\begin{array}{l}\text { Holly Springs sand: } \\
\text { Surface clay }\end{array}$ & \multirow{3}{*}{$\begin{array}{ll}\text { Feet } & \\
12 \\
15 \\
18 \\
15\end{array}$} & \multirow{3}{*}{$\begin{array}{r}\text { Feet } \\
12 \\
\quad 27 \\
45 \\
60\end{array}$} \\
\hline $\begin{array}{l}\text { Sand; water bearing. } \\
\text { Stiff pipe clay. }\end{array}$ & & \\
\hline Clay; water bearing & & \\
\hline
\end{tabular}

In the 23-foot bored well (No. 20) at Water Valley the water rises within 15 feet of the surface. This water is distinctly mineralized but is used for domestic supplies. Well No. 21 was drilled to a depth of 1,115 feet in an unsuccessful attempt to obtain flowing water. The deeper strata proved to be less productive than the shallow ones, and in fact the principal supply is derived from coarse sand at a depth of 38 to 48 feet. The well penetrated the Holly Springs sand, the Ackerman formation, and the Porters Creek clay, and questionably entered the Clayton formation. The following is a $\log$ of this well: 
Log of well of O. T. Tarver at Water Valley. (No. 21)

\begin{tabular}{|c|c|c|}
\hline ' & Thickness & Depth \\
\hline $\begin{array}{l}\text { Holly Springs sand: } \\
\text { Yellow clay, } \\
\text { Coarse sand; water bearing } \\
\text { Soft sand and clay } \\
\text { Fard clay } \\
\text { Green sand; slightly water bearing } \\
\text { Ackerman formation, Porters Creek elay, and Clayton(?) formations: Dark lignitic } \\
\text { clay, with a few hard layers between depths of } 800 \text { and } 1,000 \text { feet }\end{array}$ & $\begin{array}{r}\text { Feet } \\
38 \\
10 \\
15 \\
67 \\
35 \\
950\end{array}$ & $\begin{array}{r}\text { Feet } \\
38 \\
48 \\
68 \\
130 \\
165 \\
1,115\end{array}$ \\
\hline
\end{tabular}

Oakland.-Three drilled wells at Oakland (Nos. 13-15) are 440, 472 , and 495 feet deep. They all enter the Holly Springs sand, where ample supplies of water that have a static head of 90 to 100 feet below the surface are found. The water is said to be rather hard and to contain considerable iron. Analysis 13 represents water from the 440-foot well.

Scobey.-The Duke well (No. 16) at Scobey is 304 feet deep and yields an abundant supply of water from sand of the Holly Springs formation near the bottom of the well. The water rises within 80 feet of the surface.

Coffeeville.-At Coffeeville, in the lowland near Turkey Creek, flowing water is obtained by means of wells 100 to 650 feet deep. In the shallower wells the water comes from the Holly Springs sand, and in the deeper wells from the Ackerman and probably from the Clayton formations. Several wells (Nos. 7-12) are described in the table of well data: The 400 -foot flowing well at the courthouse (No. 8) is cased to a depth of 300 feet, and the water comes from consolidated sand between that depth and the bottom of the well. (See analysis 8.)

In the 401-foot county well (No. 9) the principal water-bearing bed is white sand probably of the Clayton formation, which was encountered at a depth of 375 feet. In the 390-foot well (No. 10) flows were struck at approximate depths of 150, 230, and 380 feet. The Hamblett well (No. 11), although only 110 feet deep, emits a small stream from sand penetrated near the bottom of the well. Well No. 12 encountered several water-bearing strata and obtained its largest supply from sand at a depth of 430 to 462 feet in the Ackerman formation. A log of this well is given below.

Log of well of E. Newberger at Coffeeville (No. 12)

\begin{tabular}{|c|c|c|c|c|c|}
\hline & $\begin{array}{l}\text { Thick- } \\
\text { ness }\end{array}$ & Depth & & $\underset{\text { ness }}{\text { Thick- }}$ & Depth \\
\hline $\begin{array}{l}\text { Alluvium: } \\
\text { Sojl } \\
\text { Red ciay. } \\
\text { Holly Springs sand, Ackerman } \\
\text { formation, and Porters Creek } \\
\text { clay: } \\
\text { Ked, yellow, and white sand. } \\
\text { Blue clay } \\
\text { Gray shale.... } \\
\text { Jignite. Black sand; water bearing } \\
\text { Blue clay; sticky gumbo, be- } \\
\text { coming green in some parts. } \\
\text { Gray shale }\end{array}$ & $\begin{array}{l}50 \\
40 \\
20 \\
2 \\
20 \\
70 \\
20\end{array}$ & $\begin{array}{r}59 \\
99 \\
119 \\
121 \\
141 \\
\\
211 \\
231\end{array}$ & $\begin{array}{l}\text { Holly Springs sand, Ackerman } \\
\text { formation, and Porters Creek } \\
\text { clay-Continued. } \\
\text { Black sand; water bearing } \\
\text { (flows) } \\
\text { Lighter drab-colored clay... } \\
\text { Gray shale } \\
\text { Clayton formation(?): } \\
\text { white sand; water bearing; } \\
\text { flows at rate of } 6 \text { gallons a } \\
\text { minute. } \\
\text { Gray shale. } \\
\text { White sand; the principal } \\
\text { water-bearing bed. }\end{array}$ & $\begin{array}{r}30 \\
10 \\
119\end{array}$ & $\begin{array}{l}260 \\
271 \\
391\end{array}$ \\
\hline
\end{tabular}


The town is provided with a municipally owned waterworks on Oak Avenue, on ground about level with the tracks of the Illinois Central Railroad at the station. Water is obtained from a $6531 / 2$ foot well (No. 7).

Bryant.-At Bryant, a village on the second bottom lands along Turkey Creek, W. C. Bryant has drilled three wells (Nos. 1-3), all of which flow small streams. Well No. 1 is 310 feet deep (see log below) and taps a water-bearing sand in the Ackerman formation at a depth of 295 to 310 feet. The other wells penetrate water-bearing sands at shallower depths.

Log of well of W. C. Bryant, at Bryant (No. 1)

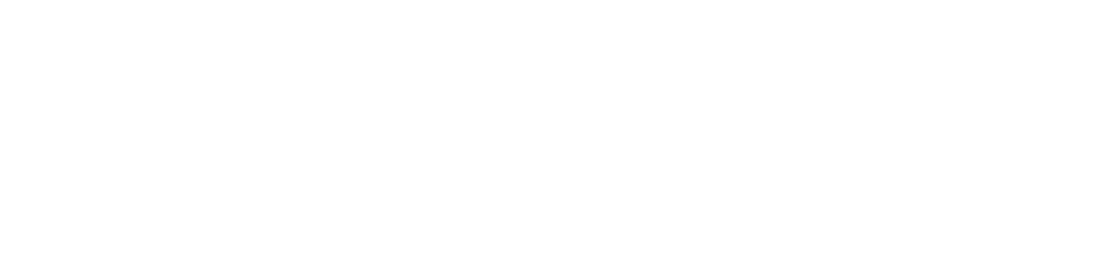

A dug well (No. 4) near a small stream 2 miles southwest of Bryant enters water-bearing alluvial sand at a depth of 25 feet. A flowing well 233 feet deep (No. 5), in the lowland bordering Shooner River 3 miles southeast of Bryant, obtains its main flow from the Ackerman formation at a depth of 210 to 225 feet. A log of the well is given below.

Log of well of W. H. Bailey, 3 miles southeast of Bryant (No. 5)

[Authority, E. P. Webb, driller]

\begin{tabular}{|c|c|c|c|c|c|}
\hline & $\begin{array}{l}\text { Ap- } \\
\text { prox- } \\
\text { imate } \\
\text { thick- } \\
\text { ness }\end{array}$ & $\begin{array}{l}\text { Ap- } \\
\text { prox- } \\
\text { imate } \\
\text { depth }\end{array}$ & & $\begin{array}{l}\text { Ap- } \\
\text { prox- } \\
\text { imate } \\
\text { thick- } \\
\text { ness }\end{array}$ & $\begin{array}{l}\text { Ap- } \\
\text { prox- } \\
\text { imate } \\
\text { depth }\end{array}$ \\
\hline $\begin{array}{l}\text { Wilcox group: } \\
\text { Yellow clay } \\
\text { Red sand, becoming white } \\
\text { Blue clay } \\
\text { Black sand } \\
\text { Lignite } \\
\text { Blue clay } \\
\text { Gray shale }\end{array}$ & $\begin{array}{r}\text { Feet } \\
20 \\
15 \\
65 \\
5 \\
4 \\
40 \\
35\end{array}$ & $\begin{array}{r}\text { Feet } \\
29 \\
35 \\
100 \\
105 \\
109 \\
149 \\
184\end{array}$ & $\begin{array}{l}\text { Wilcox group-Continued. } \\
\text { Black sand; water bearing } \\
\text { Gray shale-... } \\
\text { Alternating layers of hard rock } \\
\text { and water-bearing cavities (?); } \\
\text { probably soft sand. } \\
\text { shalo... }\end{array}$ & $\begin{array}{r}\text { Feet } \\
6 \\
20 \\
15 \\
8\end{array}$ & $\begin{array}{r}\text { Feet } \\
190 \\
210 \\
\\
225 \\
233\end{array}$ \\
\hline
\end{tabular}

Another well (No. 6) in the same vicinity is 238 feet deep and yields a strong flow of mildly sulphureted water, which is used as a domestic supply by several families; the principal water-bearing bed lies at a depth of 175 feet.

Airmont.-At Airmont domestic supplies are obtained by wells sunk to depths of 20 to 100 feet in the Ackerman formation. In most wells the water is encountered beneath clays at depths of 50 to 60 feet.

Torrance.-At Torrance flowing water is obtained from the Ackerman (?) formation by wells several hundred feet deep. One such well (No. 17) is 325 feet deep and flows 35 gallons a minute; the water comes from sand near the bottom of the well. 


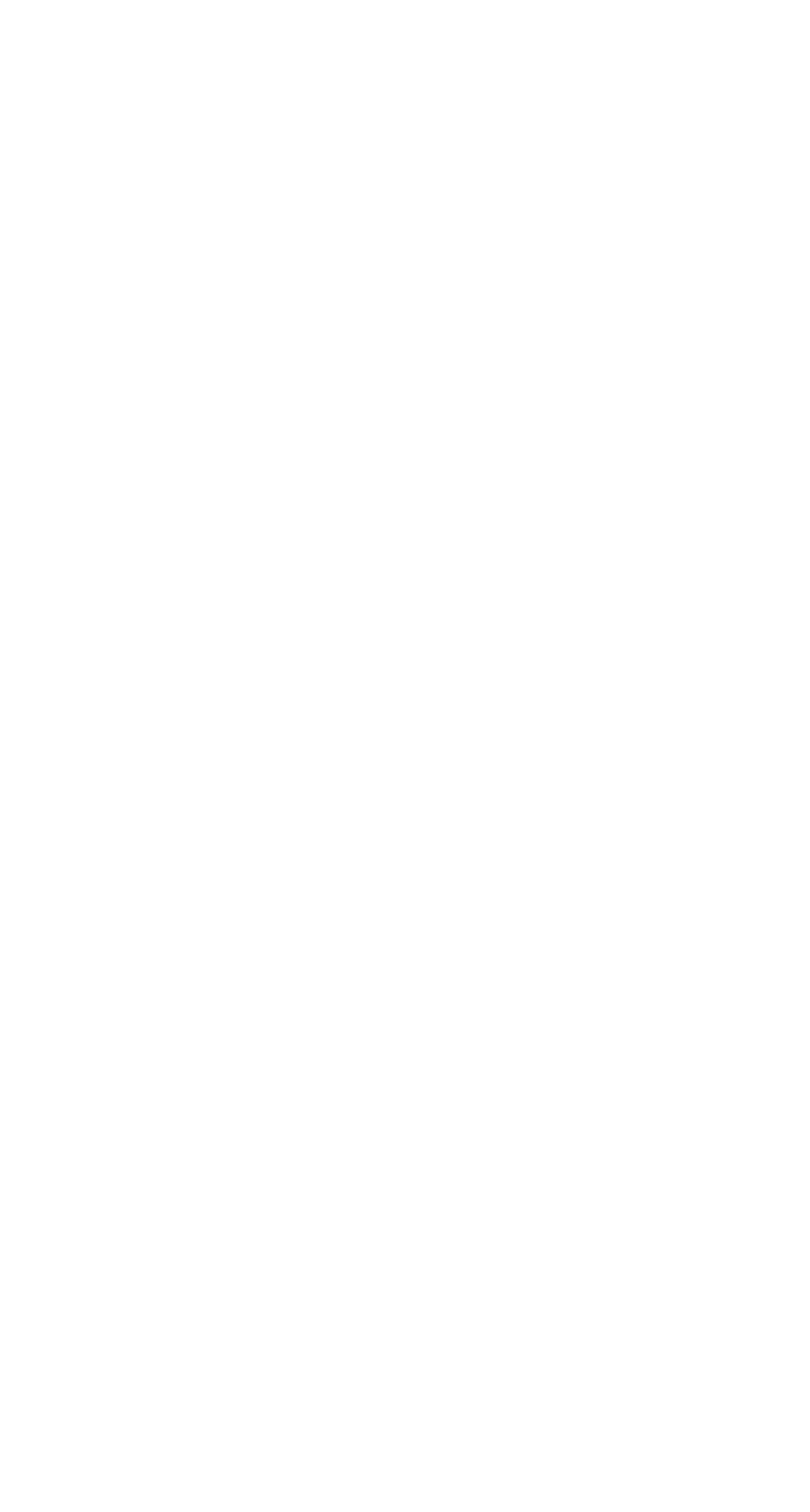




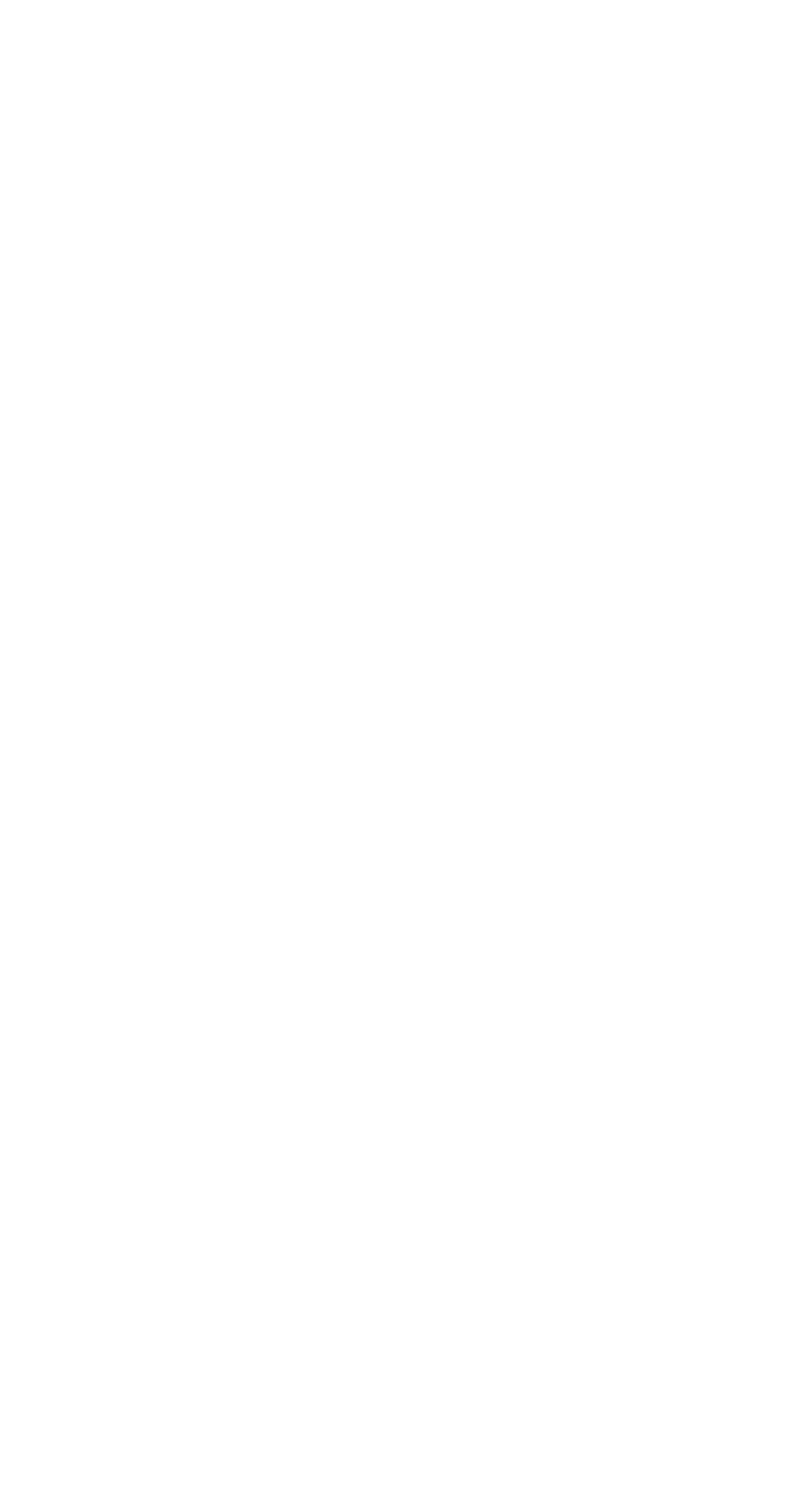


Mineral analyses of ground waters from Y alobusha County

[Parts per million.' Numbers at heads of columns refer to corresponding well numbers in precedfing table]

\begin{tabular}{|c|c|c|c|c|c|}
\hline 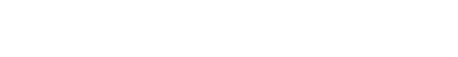 & 1. & 8 & 13 & 18 & 19 \\
\hline $\begin{array}{l}\text { Sillea }\left(\mathrm{SiO}_{2}\right) \\
\text { Iron }(\mathrm{Fe}) \\
\text { Chlum }(\mathrm{Ca}) \\
\text { Magnesinm }(\mathrm{Mg})\end{array}$ & $\stackrel{12}{12} .16$ & $\begin{array}{c}34 \\
12.15 \\
1.2\end{array}$ & $\begin{array}{l}36 \\
10 \\
7.5 \\
3.9\end{array}$ & $\begin{array}{l}21 \\
2.0 \\
1.7\end{array}$ & $\begin{array}{l}12 \\
6.55 \\
1.3 \\
1.7\end{array}$ \\
\hline Sqdium and potassium $(\mathrm{Na}+\mathrm{K})$ & 64 & 48 & - 16 & 23 & \\
\hline 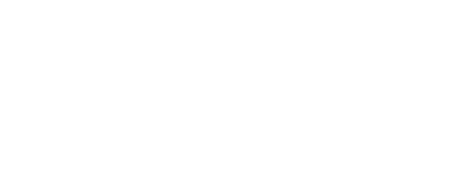 & $\begin{array}{c}195^{.0} \\
1.3 \\
6.5 \\
4.0 \\
195 \\
33 \\
\text { Oct., } 1911\end{array}$ & 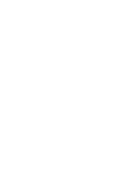 & $\begin{array}{c}60^{.0} \\
16 \\
1.8 \\
\text { Trace. } \\
\text { c121 } \\
35 \\
\text { Aug., } 1919\end{array}$ & $\begin{array}{c}4.8 \\
56 \\
2.6 \\
6.0 \\
1.7 \\
92 \\
12 \\
\text { Bept,, } 1919\end{array}$ & 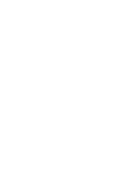 \\
\hline
\end{tabular}

"Ineludes iron and aluminum $(\mathrm{Fe}+\mathrm{Al})$

- Iron and aluminum oxides $\left(\mathrm{Fe}_{2} \mathrm{O}_{3}+\mathrm{Al}_{2} \mathrm{O}_{3}\right)$.

- Calculated.

Analysts: 1, 8, W. L. Perdue, Univensity of Mississippi; 13, Margaret D. Foster, U. S. Geological Survey: 18, C. S. Howard, U. S. Geological Sarvey; 19, W. R. Perkins (Mississippi Agr. Expor. Sta. Bull. 89, p. $106,1905)$.

\section{YAZOO COUNTY}

\section{GENERAL FEATURES}

Area, 905 square miles. Population, 37,149 (census of 1920)

Yazoo County is sharply separable into two physiographic partsthe Yazoo Delta, which includes the northwestern two-fifths, and the Loess or Bluff Hills, which include the southeastern three-fifths. The geologic divisions that appear in outcrops in the county include (1) the Lisbon and Yegua formations of the Claiborne group and the Jackson formation of the Eocene; (2) the Vicksburg group of the Oligocene; (3) Pliocene terrace sands and gravels that overlie the Eocene and Oligocene formations and underlie the loess; (4). Pleistocene loess, which occurs on the upland as a blanket that ranges in thickness from 50 to 75 feet in the west to only a few feet in the east; and (5) the alluvial deposits which underlie the Yazoo Delta to a depth of 150 feet or more, and the thin alluvial deposits that border Big Black River and some of its larger tributary creeks. These geologic divisions are described on pages 50-63, and their distribution is shown on the geologic map (pl. 2); only the thicker parts of the loess are represented on the map.

\section{GROUND-WATER CONDITIONS}

- The strata that compose the Eocene and Oligocene divisions enumerated above, together with the still older deeply buried Eocene strata that underlie them, dip gently south by, west at an estimated rate of 20 to 30 feet to the mile. The conditions are therefore favorable for the development of artesian pressure, and many flowing wells have been obtained in the Yazoo Delta, in the western part of the county. Although no flowing wells have been reported from the valley of Big Black River, the conditions would also seem to be favorable for obtaining flows there. 
The oldest water-bearing formation that can be praetically utilized in Yazoo County is the Holly Springs sand of the Wilcox group, which does not appear in surface outcrops, but its topmost beds in the northern part of the county, at their nearest approach to the surface, lie at an estimated depth of 800 or 900 feet; their southward inclination carries them several hundred feet deeper in the southern part of the county. The coarse sands that largely compose the formation carry an abundance of water under an artesian head strong enough to produce flows throughout the Yazoo Delta. Although the formation is rather deep lying, it is an important though largely undeveloped aquifer for large plantations or industrial concerns that need large quantities of water.

The Lisbon formation of the Claiborne group, which crops out in the eastern corner of the county, contains two valuable waterbearing members, the Winona sand at the base and the Kosciusko sandstone above. Many flowing and some nonflowing wells have their source in it. The aggregate thickness of the Lisbon is estimated at 750 to 850 feet. The depth to the principal water-bearing beds ranges from 600 to 800 feet in the north to perhaps 1,000 feet or more in the south.

The Yegua formation, in its narrow bed of outcrop across the northern part of the county (see geologic map, pl, 2), has an estimated thickness of about 100 feet. The formation increases in thickness toward the south, and its buried extension probably attains a thickness of several hundred feet in the southern part of the county. Some of the more sandy portions of the formation are doubtless water bearing, and the Yegua is thought to be the source of the water yielded by several wells at and near Satartia (Nos. 3-5).

The Jackson formation, which has a thickness of 400 or 500 feet, underlies a broad area in the south-central part of the county. On account of its dominantly clayey character it is not a valuable aquifer.

The Forest Hill sand, the basal formation of the Vicksburg group, which overlies the Jackson formation in the southwestern part of the county, probably yields water to springs and shallow wells.

The terrace sands and gravels of Pliocene age, which throughout most of the upland or Loess Hills belt intervene between the older Tertiary formation below and the loess above, are water bearing, and are tapped by many wells less than 100 feet deep; springs also emerge from these sands and gravels where they crop out on the slopes.

The alluvial deposits that underlie the Yazoo Delta to an estimated depth of 150 to 200 feet include sands and gravels that contain an abundance of nonflowing water, which is easily reached by means of driven and bored wells. 


\section{LOCAL SUPPLIES}

Yazoo City.-Yazoo City is provided with a waterworks system located 1,700 feet southwest of the Yazoo \& Mississippi Valley Railroad station and obtains its municipal water supply from four wells (Nos. 6-9), the depth of each of which, according to J. S. Butler, the superintendent, is about 840 feet, but the exact depth is apparently not known. According to Logan and Perkins ${ }^{54}$ pne well is 800 feet deep, and Logan states in an unpublished manuscript that a second well, drilled in 1906, is 853 feet deep. A third well is reported to be 801 feet deep. The altitude of the surface at the waterworks is about 92 feet above sea level, and the wells flow 100 to 400 gallons a minute. Several other deep wells at and in the vicinity of Yazoo City are described in the table of well data (Nos. 10-16.) The 840-foot flowing well (No. 13) yielded a small flow from sand at a depth of 300 feet, but the main water-bearing sand, which yields 100 gallons a minute, is in the Lisbon formation at a depth of 840 feet. This well supplies the needs of the factory and the domestic needs of 15 or 20 families. The log of a 1,000-foot public well on Main Street is given below.

Log of public well at Yazoo City (No. 10) a

[Authority, W. N. Logan and W. R. Perkins]

\begin{tabular}{|c|c|c|}
\hline & Thickness & Depth \\
\hline $\begin{array}{l}\text { Alluvium(?): Soil and yellow clay } \\
\text { Jackson formation(?): Clay } \\
\text { Yegua and Lisbon formations: }\end{array}$ & $\begin{aligned} \text { Feet } & \\
& 50 \\
& 40\end{aligned}$ & Feet ${ }_{90}^{50}$ \\
\hline $\begin{array}{l}\text { Sand. } \\
\text { Alternate layers of sand, clay, and lignite }\end{array}$ & $\begin{array}{r}50 \\
860\end{array}$ & $\begin{array}{r}140 \\
1,000\end{array}$ \\
\hline
\end{tabular}

- Mississippi Agr. Exper. Sta. Bull. 89, p. 96, 1905.

Analyses of water from two of the Yazoo City waterworks wells (Nos. 6 and 10) and from well 16 are given in the table. Well 16 is reported to be a deep drilled well, though definite information concerning it is wanting. Its water is highly mineralized and unsatisfactory for all purposes. A well (No. 15) 3 miles north of Yazoo City and one (No. 14) 3 miles west of Yazoo City are, respectively, 780 and 743 feet deep and yield strong flows from sand of the Lisbon formation.

Eden.-At Eden a public well (No. 2) 800 feet deep affords a strong artesian flow, which is believed to have its source in the Winona sand member of the Lisbon formation. 
Benton.-Near Benton wells 25 to 90 feet deep enter the waterbearing terrace gravels that underlie the loess deposits. In the 52-foot well of G. T. Hill a quarter of a mile south of Benton these gravels were encountered at a depth of about 45 feet.

Satartia.-In the vicinity of Satartia flowing wells are common. Incomplete descriptions of three wells (Nos. 3-5), which probably have their source in the Yegua formation, are given in the table of well data. The well of C. O. Willis on the Annadale plantation, $11 / 2$ miles northeast of Satartia, yields a flow which may be derived from the Yegua beds, though definite information concerning it is wanting. The well or spring of Miss Inez H: Perry, 5 miles northeast of Satartia, is near the base of the bluffs that border the Yazoo Delta, and the water probably issues from the terrace gravel that intervenes between the Jackson formation and the loess.

Anding.-Well No. 1, at Anding, is reported to be 1,000 feet deep and affords nonflowing water from the Kosciusko sandstone member of the Lisbon formation. 


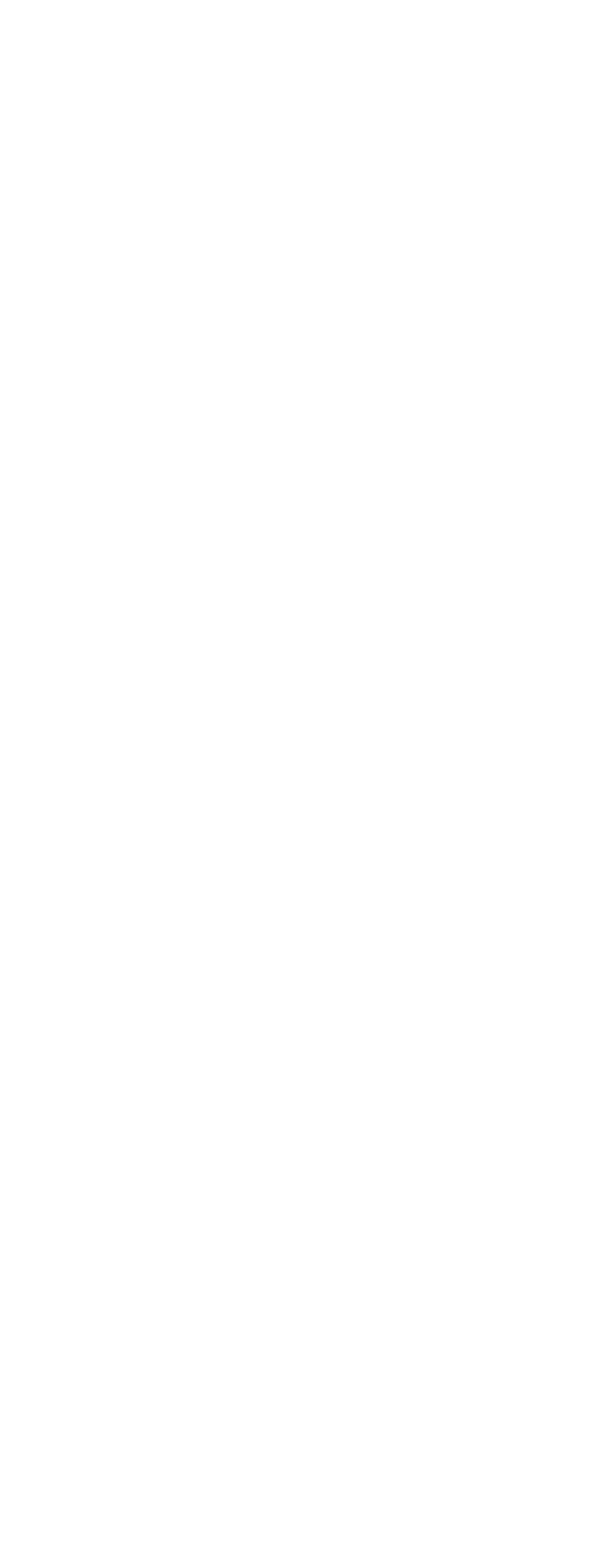


504 GROUND-WATER RESOURCES OF MISSISSIPPI

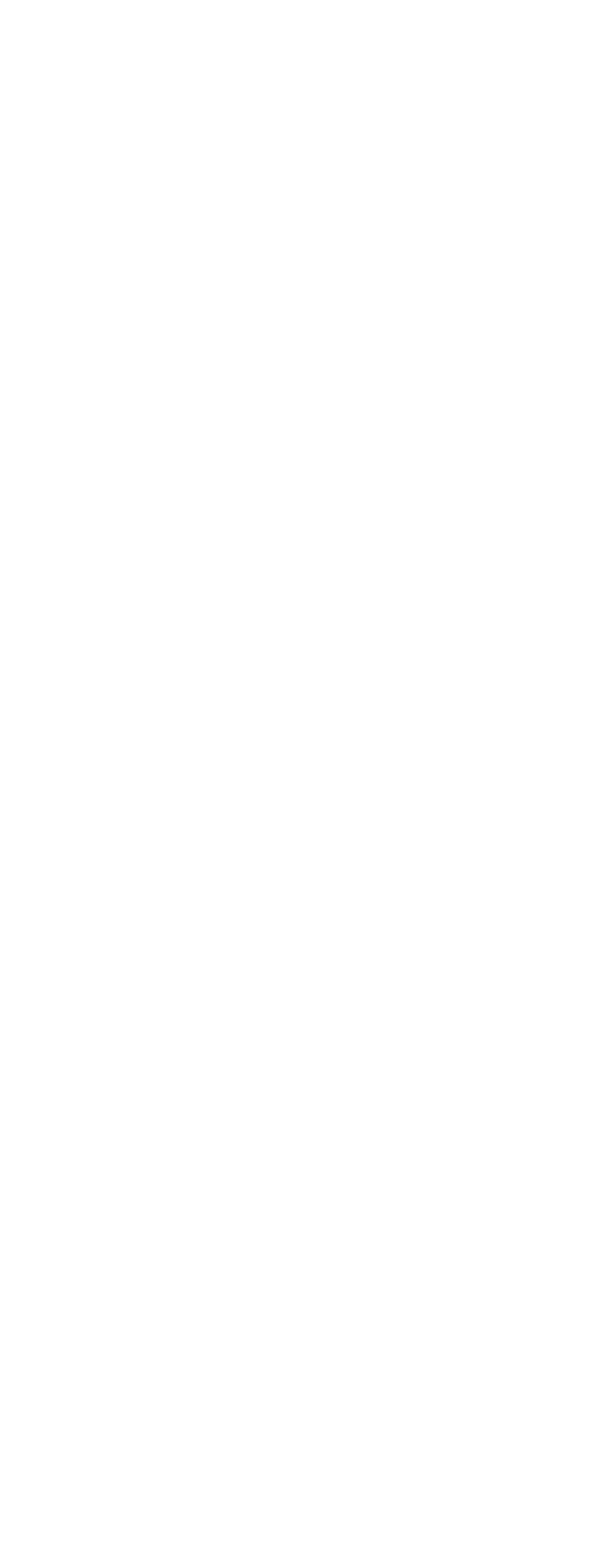




\section{Mineral analyses of ground waters from $Y$ azoo County}

[Parts per million. Numbers at heads of columns refer to corresponding well numbers in preceding table

\begin{tabular}{|c|c|c|c|c|c|}
\hline & 4 & 6 & 10 & 1 & 16 \\
\hline $\begin{array}{l}\text { Bllica (SiOn) } \\
\text { Iron (Fe) } \\
\text { Calcium (Ca) } \\
\text { Magnesium }(\mathrm{Mg}) \\
\text { Sodium and potassium }(\mathrm{Na}+\mathrm{K})\end{array}$ & 116 & 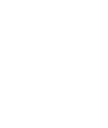 & $\begin{array}{r}19 \\
.2 .4 \\
.8 \\
\mathrm{Na}_{\mathrm{K}} .5 \\
\end{array}$ & $\begin{array}{r}28 \\
1.26 \\
.154\end{array}$ & $\begin{array}{r}24 \\
10 \\
661 \\
459 \\
\mathrm{Na} \\
\mathrm{K} \\
283\end{array}$ \\
\hline 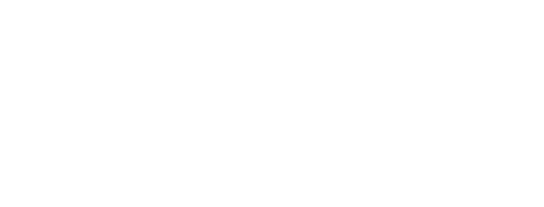 & $\begin{array}{l}261^{\circ} \\
19 \\
20 \\
1925 \\
2011\end{array}$ & $\mid \begin{array}{c}195^{.0} \\
13 \\
7.6 \\
4238^{.83}\end{array}$ & $\begin{array}{r}367^{1.0} \\
1.6 \\
5.9 \\
4.356 \\
4\end{array}$ & 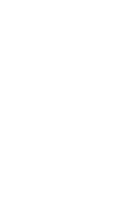 & 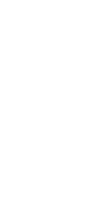 \\
\hline
\end{tabular}

- Iron and aluminum oxddes $\left(\mathrm{Feg}_{3} \mathrm{O}_{3}+\mathrm{Al}_{2} \mathrm{O}_{3}\right)$.

- Calculated.

Analysts, 4, E. S. Wallace, University of Mississippi; 6, 10, 16, W. R. Perkins (Missiesipp iAgr. Exper. Ata. Bull. 89, p. 96, 1905); 11, N. Fuchs, U. S. Geological Survey.

$$
54134-28-33
$$





\section{INDEX}

$\mathbf{A}$

Abbeville, wells in.

Abbott, water supplies in

A berdean water supplies at

Aokerman, water supplies in.

Ackerman formation, distribution'sand waters o

Acknowledgments for aid

Acona, water supplies at

Adams County, analyses of ground waters from

features of

ground water in

wells and springs in

Adelle, water supply at

Agness, ground water at.

Agricola, water supplies at

Agricultural and Mechanical College, log of deep well at

Airmont, ground water at

Alcorn, well of college at.

Alcorn County, anslyses of ground waters from.

features of

ground water in

wells and springs in.

Aldrich, $O, L$., cited

Algoma, water supply at.

Allison's Wells, water of.

Alluvium of Mississippi River, water in.....

Altus, springs and shallow wells at

Amite County, analyses of ground waters from.

features of

ground water in.

wells and springs in

Amory, water supplies at

Analyses of waters, methods followed in.

sources of

Anding, deep well at

Archuss 8prings, teatures of

Arcola, water supply at.......................... 478

Arkabutla, well at_............................. 444

Artesia, water supplies at..................... 311

Artesian waters, conditions affecting.......... 17-19

definition of.................................. 16-17

Arundel Spring, location of.................... $\quad 274$

Ashland, water supplies in

Askew, water supplies at........................ 874

Attals County, analyses of ground waters trom

foatures of

ground water in.

81

wolis in

$81-82$

Avera, flowing wells at
B

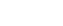

Baldwyn, water supplies in ............. 291-292, 402

Banks, wells at................................. 460

Bankston, water supplies in ................ 111

Barachel Springs, water of.................. 274

Barland, water supplies in................... 116-116

Barnett, water supplies in .................... 120

Bashi formation, occurrence of............... 48

Basic, water supplies in ........................ 117

Batesville, flowing well at, plate showing .... 104 water supplies at............................. $\quad 376$

Baxterville, wells at ................................

Bay St. Louis, flowing wells at and near... 182-184 Bay Springs, spring at.......................... 238

Belden, logs of wells at...................... 292-298

Belen, flowing wells at........................... 406

Bellefontaine, flowing wells at................ 486

Belzoni, water supplies at....................... 220

Ben Lomond, nonflowing well at............. $\quad 228$

Benoit, water supply of ....................... 01

Bentoak, deep wells near........................ $\quad 309$

Benton, wells near ............................... $\quad 502$

Benton County, analyses of ground waters from

features of ................................... 86

ground water in........................... 86-87

Bethany, wells at_................................. 298

Beulah, water supplies in and near.......... $\quad 90$

Bew Springs, spring near...................... 177

Bewelcome, wells in ................. 77-78

Bigbee Valley, water supplies at.............. 358

Biloxi, flowing wells at...................... 101-192

Binnsville, water supplies at.................... 256

Black Prairie belt, description of.............. 4-5

Blackhawk, ground water in.................. 101

Blackmonton, water supplies in................ 101

Blanton, wells at............................... 410

Blodgett, log of well at........................ 252

Blue Mountain, wells and springs at and near............................. 450-45i

Blue Springs, $\log$ of well at .................. 496

Bluff Hills, description of

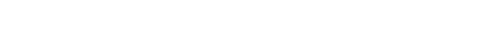

Boiler use of water; requirements for........... ; ;4

Bolivar County, analyses of ground waters from................................. 05

features of .

ground water in.............................. 89

wells in ........................................ 98-94

Bolton, public water sapply at............... 204

Bond, $\log$ of well at........................... 427

Bonita, water supplies at ...................... 274

Booneville, public water supply at.......... 401-402

Bowling Green, wells at....................... 218

Boyle, water supplies in .........................

Brandan, publio water supply at.............. 409 
Bright, water supplies at....... Page

Brookhaven, water supplies at............... 304

Brookville, water supplies at ................ 360-361

Browning, wells at and near..................... 300

Brown's Wells, mineral wells at, plate showing.

water supply of .......................... 140

Bryant, water supplies at_.............. 496

Bude, well of Homochit to Lumber Co. at. 166-167

Wtreha Vista, water supplies in............... 105

Btunckley, water supplies near................ 167

Buncombe, wells at_........................ 469-470

Burdette, deep well at........................ 478

Burnsville, water supplies at................... 460

Butler Springs, water of......................... 262

Byhalla, town well at .............................

\section{c}

Oalcium, eontent of, in ground watere

hardness produced by

21-82

Calhoun City, water supplies in ............. 87

Calhoun County, analyses of ground waters from ...................................

features of

ground water in.

(5)

Calyx, water supply at

Camden, shallow wells at ........................ 317

Camp Shelby, water supply of ............... $\quad 160$

Canaan, water supplies in.................... 87

Canton, loge of wells at.................... $317-318$

Carriere, log of well at......................... $\quad 380$

Carroll County, features of..................... 98

ground water in......................... 98-99

wells in ............................... 102

Carrollton, wells in. . ...................... 99-100

Carthege, analysis of well water from ...... 285-286

Cary, public water supply at................ $\quad 420$

Cascille, well at.............................. 440

Catahoula sandstone, distribution and waters

of . . .

Cedar Bluff, water supplies in................ 180

Cedars, $\mathrm{jog}$ of deep well at.................... 478

Cedarviéw, water supplies in.................. 154

Centerville, water supplies at................ 489

Chalybeate Spring, water of

Chambers, A. A., analyses by ................ 165, 387

Ohandler Springs, water of.................. 292

Charleston; whter supplies at............... $\mathbf{4 3 8 - 4 8 0}$

Chatawa, spring at.......................... 390

Chautauqua Lake, plate showing............ B

souroe end use of water of .

Chester, water supplies in...................... 111

Chickasaw Cutinty, analyos of ground waters trow ........................... 110

features of.................................... 103

ground water in .......................... 108-104

wells in ....................................... 108-109

Ohicore, flowing well at....................... 486

Choctew County, analyses of ground waters frem

features of .............................. 110

ground water in ............................... 110

Chunky, water supplies at ................. 352-858

Citronelle formation, distribution and waters of ............................... $89-6$

City Point, $10 \mathrm{~g}$ of well near.
Claiborne County, analyses of ground waters from - 116

features of

ground water in .............................. 113-114

Claiborne group, formations of............... 50-63

Clarence, well near............................ 171

Clarke County, analyses of ground waters from

features of .................................... 116

tround water in........................... 116-117

wells and springs in

Clarksdale, water supplies in................ 184

Classifieation of waters........................... 28-26

Clay County, unalyzes of ground waters from 132

features of...................................... 125

ground water in .......................... 125-127

wells in ................................... 130-181

Clayton formation, distribution and water of. 43-44 Clermont Harbor, log of deep well at........ 186

Cleveland, water supply of ................. 90

Cliftonville, water supplies at ............... 358-359

Clinton, water supplies at..................... 204

Cloverhill, water supplies at................... 138-134

Coahoma, public water supply of............. 133

Coahoma County, analyses of ground waters from........................... 138

features of .................................... 132

ground water in . . . 132

wells in.................................... 136-137

Coastal Pine Meadows, description of ....... $\quad 7-8$

Cockrum, water supplies at.................. 155

Coffeeville, flowing wells at.................... 495-496

Cohay, water supply of

Cella, water supplies in $\ldots . . . . . . . . . . . . . . . . . . . \quad 101$

Celdwater, wells near........................... 444

Coldwater River, $\log$ of well near............. $\quad 462$

Coles, wells in............................. 77

Coles Creek, well of L. S. Provine near....... 90-97

College Hill station, log of well at........... 260-261

Collins, public water supply of................. 147

Columbia, flowing wells at.................... 824

steel distributing tank at, plate showing - 104

Columbus, flowing wells at and near....... 308-309

Cotnmerce, deep flowing wells at .......... 460-461

Coma, wells at and near........................ $\quad 375$

Composition of ground waters, relations of,

to water-bearing formations

Conehatta, shallow wells at................. 351

Oonway, water supplies at......................... \$ \$5

Coopers Mineral Well, location of

Cooparville, water supplies at................. $\quad 415$

Copiah County, analyses of ground waters from............................... 146 features of .........................twa 198 ground water in.......................... 138-130 wells in .................................... 14145

Corinth, water supplies in and near.........t. $70-72$

Cotton Plant, wells and springe near....... $451-452$ Courtland, wells at............................. 376 Covington County, antyes ground waters from.............................. 152

features of

ground water in .......................... 146-147 wells in

Craig, flowing well at............................ $\quad 922$

Crawford, water supplies at.................. $\quad 312$ 
Creok, intermittent, olate ahowing.

Crenshaw, water supplies at....................

Crevi, flowing wells noar.

Cruger, flowing wells at.........................

Crystal Springs, water supplies in .............

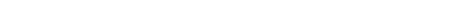

\section{D}

Daleville, spring and shallow wells at

Damaecus, water supply at.

Denoy, water supply at.

Derbun, wells at.

Deer Island, log of well of.

Deerbr6ok, water supply at

Deerfield plantation, springs on and neas.. 16e-16

DeLay, legs of wells at....................... 262-263

Delta, flowing well near ...................... $\quad 375$

Do Soto, water supplies in...................... 122

D. Soto County, features of ................ 152 ground weter in......................... 180-1bs

Dick, wells at.................................. 16t

Dickersen, flowing weil at..................... 188

Disposed of ground waters...................... 14-15

Diron, water-bearing formation under

D10, water from river at.................rrac.... 429

Dockery, wells near.............

Doddsville, flowing well at................... 432

Domestic use of water, requirements for ...m. 23-24

Posswille, $\log$ of R. T. Lo.rerp well at....... 285

Drainage bagins, sketch map showing shapes of.

Drew, flowing wells at

pubard, flowing wells at

Dpbbs, shallow welle at.

opck Hill, water supplies at

Demas, $\log$ of well at..............................

Bumean, wells in.

Duncansby, water from alluvium at...........

Dondee, water supply at

Dunleith, ground water at

Durant, flowing weil at, plate showing ......

water supplies at. 214-21

$\mathbf{E}$

Reclosnest, fowring woll at................er.m 138

Thenezer, Fater supplie at,..................... P10

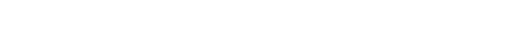

Eden, public flowing well nt....................

Edwarde, water supplies at................... 204-296

Itypt, water supplies in...................... 105

Electric Mills, public water supply at........ 257

Hikzobseth, shallow wells at...................... 478

Ellisville, public wells at....................... $\quad 258$

Bmory, well near.

Rid, shallow wells at............................ 437

Brandals, shallow wells at................... $\quad 257$

anterprise, water supplies in................ 117-119

inpley, log of well at........................... 260

Ashridge, shallow well at..................... 345

musex, flowing well at.......................... $\quad 406$

Estabuehio, water supplies at .............. 251-258

Estes, log of well at............................. 493

Bstesmill, shallow welts at...................... 286

Eatille, flowing well at........................ 478

athad, water supplies In........................ 83

Funice Everett Spring, deseription of.
Eupora, public wells at................... 486-487

Elitaw formation, nature and distribution of $31-35$ Faters of............................. $35-36$

Evanstons, water supplies at.................. 171

Faisonia, shallow wolls at . .................. 432

Falkner, wells near.............................. 452

Farrell, water supplies in ....................... 133

Fayette, oil-prospoeting woll at,............. p42-248

water supplies at.............................

Forawood, water supglies at............... $890-391$

Flatwoods, description of.......................

Flora, water supplias at_........................ \$19

Forest, water supplies at .................. 414-415

Forest Hill sand, water in .............. 54

Forkville, water supplies at._................... $\quad 413$

Forman, Clara M., analyses by............. 95 , $110,297,303,3353,378,407,450,459,402$

Forrest County, analyses of ground water trom

fegtures of............................... 155

ground water in . ......................... 158-157

wells and springs in ...................... 161-164

Toster, Margaret $\mathrm{D}$., analyses by $81,95,100,110,132,146,165,172,181$, $189,199,210,225,236,246,255,259$, 278, 297, 305, 315, 333, 344, 350, 356, $366,378,407,412,418,420,431,436$, $457,459,462,408,482,400$, 499.

Foxworth, shallow flowing well near........... 325

Franktin County, features of ................ 165 ground water in.......................... 168-168

Frazier, water supply at...................... 432 French Camp, water supplies in

Friar Point, public water supply of.......... 133 Fuchs, N., analyses by......... 165, 168, $772,378,505$ Fulton, shallow wells at........................ 227

\section{a}

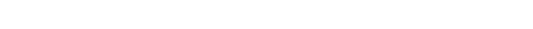

Garden City, water inplies et_..nen......., 10t

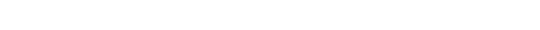

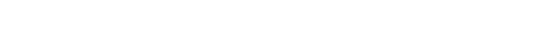

Ceorge County, analyos of gand waten from. 170

features of

ground water in, .............,

Georgetown, wells in.................en...ers 14

Geren, deep wold at_............................ 290

aHbert, ground water at..................... 415

Gten Allen, flowing wells at................. 479

Glondora, flowing wells at....................+m, 440

Gloster, steel distributing tank at, plate ghow.

jng

water supply of ........................... $\quad 7 \pi$

Glover, water supply of....................... 164

Goodmen, watar supplip ot................... 246

Goodwater, water supplies in................ 192

Grace, water supplies at.-..................... 206

Grayspart, weter sapolies at..............e... 197

Greene County, analysis of ground water from

fegtumes of

ground water in................... 172-173

Greenville, public water works at............ 476 
'...... Page

Greenwood, water supplies of. 299-300

Greenwood Springs, water of.................. 338

Grenada, deep wells at. ...................... 177-178 waterworks at, plate showing

Grenada County, analyses of ground waters from

181

features of .............................. 175-176

ground water in......................... 176

wells in .................................. 179-180

Greneda formation, occurrence and water of.. 48

Gulfport, flowing wells in ................... 192

Gum Springs, shallow wells near........... 413-414

Gunnison, water supplies in ................. 89

Guntown, water supplies at................. 291

\section{H}

Halstead, water supplies at.

Hamilton, water supplies at

Hancock County, analyses of ground waters from

features of...

189

ground water in

181

wells in

181-182 187-188

Hand, W. F., analyses by..................... 69, $110,132,146,165,172,181,189,199,210$, $226,240,255,272,278,297,315,323,344$, $350,356,366,373,378,383,394,400,418$, $431,468,482$

Hiandsboro, water supplies at.

Hardy station, water supplies at.............. 177

Harleston, shallow wells at................. 231-232

Harrison County, analyses of ground waters from

features of

ground water in

189

wells in

190-191

Gatchetigbee formation, occurrence and water of ............................... $48-49$

Hawthorn, log of well at.................. 325

Hattiesburg, water supplies in............... 157-158

Fattiesburg elay, distribution and waters of. 56-57

Hazelhurst, public water supply of......... 139-140

Helena, shallow well at........................ 232-233

Felm, water supplies at.......................... 478

Hernando, water supplies at................. 154-155

Hickory, water supplies at.................. 352

Hickory Flat, water supplies in............. 88

Hickory Grove, wells at..................... 369

Fighlandale, flowing well near................ 288

Flinds County, analysis of ground waters from ................................. 210

features of................................ 200

ground water in......................... 200-201

wells in.................................. 208-209

Hiwannee, public well at....................... 485

Hoffman, flowing well at....................... 214

Holcomb, flowing wells at...................... 177

Hollandale, public water supply at........... 479

Holly, shallow wells at........................ 462

Holly Springs, water supplies at......... 322-330

Holly Springs sand, distribution and waters

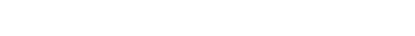

Hollyknowe, wells at.......................... 478

Holmes County, ranalyses of ground waters from

features of 210-211
Page

Holmes County, ground water In......... 211-212 wells in .................................. 216-218

Howison, deep wells at........................ 191, 194

Horatio, water supply at......................... $\quad 375$

Horn Lake, wells at............................. 158

Horseshoe, water supply at.................... 413

Foulka, water supplies in ................ 105-107

Houston, public water supply of ............ 105 steel distributing tank at, plate showing- 104

Howard, C. 8., analyses by................... 86 $98,116,146,181,180,199,210,236,247$, $255,266,272,307,323,333,383,457,468$, $474,499$.

Hudsonville, water supplies at............... . 329

Humphreys County, snalyses of ground waters from......................... 226

leatures of

ground water in ......................... 219-220

wells in................................ 223-204

Furley, shallow wells at........................ 282

Hurricane Creek, ground water at............ 119

Futchison, W. L., analysis by............... 165

Independence, wells at ........... 44

Indianole, deep flowing wells at................ 438

Inverness, log of deep well at ................... 48

Iron, content of, in ground waters............ 29, 24

Isola, flowing wells at ........................ 2.1

Issaquena, $\log$ of deep flowing well at...... $410-120$

Issaquena County, analyses of ground waters from

features of.

Itawambs County, features of

ground water in ........................... 228

Ittabena, water supplies at...................

Iuka, wells and springs at . .................. $458-16 b$

J

Jackson, deep wells lat_.................. 201-201 Jackson County, analyses of ground waters from

features of . . .

ground water in ............................ 228-229

wells in ...................................... 234-236

Jackson formation, distribution and water of. 5 - 4

Jackson Prairie belt, description of._.........

Jackson Spring, location of ....................... 274

Jamestown, flowing wells at ..................... 325

Jasper County, analyse of grounid waters trom

features of ................................ 236

ground water in ........................... 287-2283

Jefferson County, analyses of ground.waters from................................. 246

features of ............................... 240-241

ground water in .................... 241-242, 248

wells in

Jefferson Davis County, features of........... 246

ground water in ........................ 246-247

Jones, R. W., analyses by ..................... 240

Jones County, analyses of ground waters from.

255

features of ................................... 248

ground water in .

wrells and springs in . .................... 258-264

Jonestown, flowing well at.................... 188 
$\therefore 4 ?$ $\mathbf{K}$

Kemper County, analyses of ground waters from

teatures of

ground water in

wells in.

Kennon, W. L, analyses bJ $138,181,210,225,226,266,303,323,407$ $420,436,443,448,468,482,487$.

Kowanee, water supplies at.

Kidweil, $\mathrm{O}$. H., analyses by ............... 13, $166,168,172,259,278,356,387,431$

Krlmichsel, water supplies at:.................. 346

KJln, flowing wells at........................... 185

Kolola Springs, source of ....................... $\quad 312$

Kosciusko, water supplies in.................. 82-83

Kossuth, water supplies in. . ................. 72

L

Tafayette County, analyses of ground waters from

features of

ground water in ...

wells and springs in

259-260

$264-265$

Iafayette Springs, water of ................... $\quad 262$

i aine, fossils trom well at........................ 239

Lake, wells at ................................ $\$ 15$

Lake Cormorant, wells near.................... 154

Takes, features of.................................. 112

Lakeview, water supplies in................... 153

Lamar, water supplies in .................... 87

Lamar County; analyses of ground waters from................................ 272

features of ......................... 266

ground water in ........................ 266-267

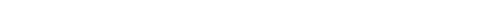

Inmbert, flowing wells at................. 406-407

Inpderdalo; water supplies at ............... 274-275

Lauderdale County, analyses of ground waters from

278

features of

wells and springs in .................. 276-277

Ianrel, water aupplies at...................... 249-251

Iawrence, water supplies at.

Lawrence County, analyses of ground waters from

features of

278

greund water in.......................... 279-280 wells in.

282-283

Leake County, features of..................... 284

ground water in .............................. 284-285

Leakesville, water supplies in................ 173-174

Le County, analyses of graund waters trom . $\quad 297$ features of ............................... 286 ground water in . .......................... 287 wells and springs in................... 294-296

Leedo, logs of wells near....................... $\quad 243$

Leflore, flowing well at........................ 178

Leflore County, analyses of ground waters from

features of........................... 297

ground water in. .

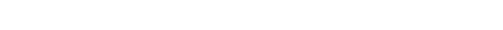

Leland, water supplies at...................... 478

Leota Landing, water supplies at_............. $\quad 479$

Ieverett, water supply at....................... 440

Lewisburg, wells at.
$3 \% 3$

Page

Lexington, water supplies at_................... 218

Liberty, water supplies in .................... 77

Lincoln County, analyses of ground waters from.............................. 807

features of ................................. 208

ground water in . .......................... 303-304

wells in... 305-306

Linton, ground water in....................... 122

Lisbon formation, nature and distribution of. $50-51$ waters of ................................ 51-52

Lockhart, ground water in..................... 274

Loess, nature and distribution of ............. 62-68

Loess Hills, description of....................... : 8

plate showing........................... 8

Logtown, wells at............................ 186

Long Beach, flowing wells at................... 193 well of Long Beach Water Co. at, plate showing ............................ 104

Long-leaf Pine Hills, deseription of ........... 7

Longstreet, wells at_............................ 407

Longriew, wells at ....................... 370

Longwood, well at_....................... $\quad 479$

Looxahoma, wells near...........................

Lotus, ground water at........................ 224

Louin, logs of wells at .................... 288-280

Louise, flowing well at.....................,

Louisville, water supplies at.................. $401-400$

Lowndes County, analyses of ground waters from.......................... 818

fantures of................................... 307

ground water in . ......................... $307-308$

wells and springs in .................... 313-314

Iucedale, water supplies at._................ 170-174

Inacile, water from well at. ....................... 74

Lula, water supplies in ......................... 188

Iumberton, water supplies and jog of well at, $287-298$

Luxapalila River, quality of water of

Lyman, flowing wells at..................... 108

Lyon, water supplies in ................... 135

\section{$\mathbf{M}$}

McCarley, water supplies in . ................ 100-101

MoComb, logs of wells at:_................ $388-889$

McCool, water supplies in

McCondy, water supplies in

McDonald, water supplies in.............. $\$ 49$

McHenry, public water supply of............ 427

McInnis Spring; featurés of

McLain, flowing wells at: $\ldots$

Macon, water supplies at,

Madden, water supply at_.................... " 286

Madison County, analyses of ground waters from

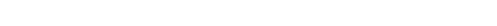

ground water in

wells in

Madison station, wells near ................... 319-820

Magnesium, content of; in ground waters.... 21-22 hardness produced by ..................... 23

Magnolia, logs of wells at_..................... $\quad 889$

Mahon, water supplies near................... 320

Mammoth spring, features of................ 159-160

Mannsdale, spring and deep well at........ 319

Mansfield, N. C., fossils determined by..... 220,2230

Map, geologic; of Mississippi.............. In pooket. of Mississippi, showing areas of flowing wells......................... In poeket. 
Map, of northeastern Mississippi, showing ground-water conditions in Creta-

ceous formation . ............. In pocket. sketch, showing shapes of drainage basins Marathon, water supply at....................

Marion, springs near .

Marion County, analyees of ground waters from

features of $\mathrm{m}$.

ground water in

wells in

Pase

Markette, wells at.

Marks, flowing wells at

Marshall County, analyses of ground water

features $\theta$ from

greand water in

20-327

wolls ond

262

406

212

whrings in........

Marshulaville, deep well near....................

Mathisten, springs and deep boring at........

Maxwell, well at

833

328

828-329

332

862

487

Mayhew, water supplies at................ 300-811

Meehan Junctien, wells near.................. 975

Mendenhall, water supplies ot............... 482

Merlatan, water supplies at........... 12-18, 273-274

Merigeld, water supply of....................... $\quad 90$

Merrm, water supplies at...................... 171

Michigan City, water supplies in............ 87

Mtdnight, water supplies at. ................. 221-222

Midway group, formations of................... 43-45

Mitlard, water supplies at...................... 380

Millview, log ef well at.......................... 428

Mineral Wells, water supplles of.............. 159

Minter City, wells near................... 298

Mississippi alluvial plain, description of......

Mississippi City, publie water supply of....- 193

Mississippi River, analyses of water of ...... 13

Mississippi Itate Ohemieal Laboratory, analyses by

69, $95,138,154,165,175,199,225,255,266$, $272,278,303,315,323,344,348,350,356$, $383,387,394,400,412,443,448,457,459$, $462,469,482,485,490,492$.

Mizt, wells at.

Money, flowing wells at.

Monroe County, ghalyses of ground waters from

features of

ground water in

wells in. $341-343$

Montgomery County, analyses of ground waters from.

features of

ground water in.

344-345

wells in

347

Mont Helena, deep flowing well at.,........ 420

Monticello, water sppplies at ...... 280

flowing well at, plate showing ............ 104

Mpntpeher, water supplies in

Montrose, water supplies at............... $\quad 239$

Mocheville, ground water at.................... 289

Moorhead, fiowing wells at_................ 432-433

Morton, water supplies at..................... 414

Mocolle, water supply at.................. 251

Moss Point, water supplies at................ 230

Mound Bayou, deep well at.
Mound City, well at Pasp

Mount Olive, publie water supply of........ 14t

Mount Plessant, well noer................... 329

Muldon, water supplies at_................... 339

Muldrow, flowing wells near .................. 369

\section{$\mathbb{N}$}

Natchez, water supply of...., ................... 65-66

Natchez formation, occurrence and water of. 61

Neely, well at.................................. 175

Neshoba Copaty, analyos of ground waters from

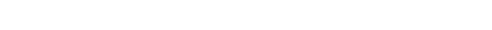

ground water in .................. $348-349$

Nettleton, wells at_.......,

New Albany, fiowing well wouth of, plate showing.............................. 104

water supplies at . . .

New Augusta, wells at...................... $\quad 386$

Newton, water supplies at..................... 352

Newton County, analysis of ground waters

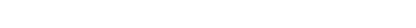

features of .................... 350

ground water in ......................... $350-351$

wells and springs in . ................... $354-\$ 64$

Newtonia, well at. ............................. 490

Nicholson, $\log$ of well at...................... $\$ 80$

Nikpar Spring, description of........,

Nonartesian waters, features of , .............. 16

Norris, water supply at........... 415

North Central Hills, description of - r

Noxapater, springs near.................. 495

Noxubee County, analyses of ground waters from

fagtures of 356

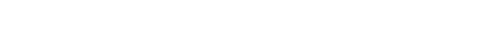

wells in

Nutbank, shallow wells at,

\section{o}

Oakland, wells at. Oakley, well of state penitendiary farm at. . 29 Oakvale, log of Phil R. Polk's well at...... 200-281 Ocean springs, fowing wells at................ 281 Orolane, irator supplies in.................... 104 Oflvo Braneh, ground water at............ 158-154 Oktibbehe County, analyges of ground wraters from........................... 378

features of

ground water in . ......................... 366-367

wells in Oktoc, wells at and newr....................

Orvisburg, water supply at................. 380

Osborn, water supply at....................... 369

Osyka, publie water supply at.................. 390

Orett, flowing wells at. ......................... 251

Owens, water supplies at........................ 24

Oxford, water supplles at....................

Pachuta, water supplies in .................... 120

Paden, well at.................................. 459

Paleozoio rocks, distribution and water ot... Pqnola County, analyses of ground waters from. 
Patiola County, teatures of ground water in.

Page wells in.

376-377

Panther Burn, flowing well at................ 419

Pascagoula, fossils from....................... 220-230 lot of well near . ...........................

Puscagoula clay, distribution and waters of. $57-58$

Pass Christian, flowing wells at.............. 192-193

Fautiaing, well of J. E. Green east of ........ 240

Faulette, wells at................................. 361

Payne A viation Field, water supply of...... 128

Pearl River, plate showing ..................... 104 qualify of water of

Pearl River County, analyses of ground waters from. ...................... 383

features of

ground water in............................. 378

wells and springs in . . .

Pelahatchee, water supply at............... 409

Penn, water supplies at. ...................... 311

Pentacost, flowing well at

Perdue, W. L., analyses by.............. 95, 225, 266 , $286,303,333,348,378,420,443,448,499$

Perkins, W. R., analyses by. $132,138,181,199,210,236,259,297,315$, $356,366,878,407,425,436,443,462,432$, $485,499,505$.

Perkinston, water supplles at...._u............. $\quad 487$

Porry County, analyses of ground waters from

features of

ground water in ............................... 383-385

wells in

Pheba, water supplies in ................tent... 129

Philadelphia, water supplies at............... $\quad 349$

Physiography of the State ................... 2-9

Pisegrune, flowing wells at...................... $\quad 379$

Pitekens, public water supply at ............... 215

Pike County, anelyses of around waters from. 394

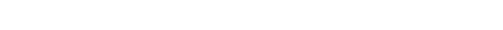
ground water in.......................... 387-388 wells in ...................................... 392-393

Phebur, flowing wells at._..................... 395

Ptney Woods Country Life Sehool, water supply of _._.

Pittsboro, water eupplies in

Plantersville, wells at and near................

Pleistocene formations, distribution and waters of

PHebene terrace deposits, cocurrence and watar of............twect.............. 60-61

Fends, features of ................................ 11-12

Pentotoc, water supplies at...................... 396

Pentotoc County, analyses of ground wators from................................. 400

features of

ground water in........................... 394-396

wells in

Funtotoc Hills, description of.................. 6

Peplarville, public water supply of ........... 370

Port Gibsom, water supplies in ............. 114-115

Port Hudson formation, features of........... 63

Porters Creak clay, distribution and water of. 44-45

Potts Camp, $\log$ of publle well at............ 330-331

Frairie, water supplies at........................ 339

Prairie Point, water supplies at................ $\quad 360$

Precipitation, record of...................... $9-10$
Page

Prentiss, water supplies of

Prentiss County, analyses of ground waters fróm

405

features of.................................. 400

groúnd wătèr in.

wells and springs ln...................... 403-404

Prospect, shallow wells at...................... 351

Publications, earlier............... 1-2

Purvis, water supplies at_................... 269

$\mathbf{Q}$

Quality of ground water.

Quantity of ground water.................... 15

Quitman, water supplies in................ 120-121

wooden distributing tank at, plate showing

Quitman County, analyses of ground waters from.............................. 407

features of............................ 405

ground water in.......................... 405-406

$\mathbf{R}$

Rainfall. See Precipitation.

Raleigh, wells at_._..........................

Ramsey Mineral Spring, water of............ 488

Randall, T. F., $\log$ of well of ................ 78

Rankin County, analyses of ground waters from

features of ................................. 407

ground water in . ........................ 407-409

wells and springs in..................... 410-411

Rateliff, wells at........ 227

Ravine, water supplies at................. 350-360

Rawled Bpring, features of.................... 100

Raymond, public water supply at...........- 205

Reform, spring in............................... 110

Richøy, flowing well at......................... 419

Richton, water supplies at...................... $\quad 385$

Ridgeland, springs near...................... $\quad 320$

Riftonburg, H. B., analyses by .............. 69

116, 146, 18Q, 307, 39

Ripley, water eupplies at.................. 450

Ripley formation, nature and distribution of. $89-42$ waters of.......................................

Robinson Spring, location of................. 207

Robinsonville, deep wells at................... 461

Rocks of Mississippi, character and age of... 27-28

Holling Fork, nowing wells at................. 419

Rosedale, watet supply of...................... $\quad 90$

Rotund Lake, wells near......................... 89

Ruleville, flowing wells near...................... 432

Runnelstown, flowing wells at...n...............

B

St. Anns, shallow wells at.....................

Sállis, water supplies in.......................

Saltillo, wells at and near.........................

Sanford, $\log$ of well at....................... 198-140

Sarah, ground water at.

$\log$ of well south of................... 462

Sardis, wells at_................................. 375

Satartia, flowing wells at...................... 502

Savage, wells at............................... 445

Schlater, wells near.............................. 290-200

Scobey, well at. ............................... 496 
Scooba, water supplies at_................

Scott, well southeast of .

Scott County, analyses of ground waters from.

features of............ 412

ground water in............................. 412-413

wells in.................................... 416-417

Sebastopol, well at...................... 413

Selma chalk, nature and distribution of...... 36-39

water in........ 39

Seminary, wells at.............................. 147-148

Senatobia, water supplies at.................. 445

Sessums, water supply at...................... $\quad 369$

Shannon, wells at and near.................... $\quad 290$

Sharkey, flowing wells near................... 440

Sharkey County, analyses of ground waters trom

features of

ground water in.

Shaw, E. W. acknowredgment to

Shaw, water supply of

Shelby, water supplies in and near............

Shollmound, flowing well at......................

Bherard, wells in.

Sherman, ground water at.......................

Ship Island, flowing wells at..................

Shubuta, water supplies in..................... 122

Shuqualak, water supply at............. 361-362

Sidon, flowing wells at....................... 300

Silver City, water supplies in............... 220-221

Simpson County, analyses of ground waters from................................. 429

features of................ 421

ground water in . ....................... 421-422

Sledge, flowing well at........................ 406

Smith County, analysis of ground water from

features of................................. 423

ground water in .......................... 428-424

Bneve, water from alluvium at............... 220

Sodium, calculation of.......................... 21-22

Boftening of water............................. 26-26

Source of ground waters.......................... 14

8pring, Minnie Portis, plate showing........ 104

- 3 miles east of Iuka, plate showing _....... 104

Springs, features of -

location of ...................

$67,72,73,76,78,79,81,87,86,110,111$, $119,121,123,169,160,168-160,177,198$, $215,238,240,256,262,274,275,312,310$, $320,329,330,331,388,351,374,380,390$, $396,402,409,413-414,426,428,451,452$, $463,458,459,487,483$.

Stafford Mineral Springs, spring at........... 240

Stallo, well near.

Standard, wells at............................ 186

Starkville, water supply at .................... 368

Steens, flowing wells near..................... $\mathbf{3 0 0}$

Stephenson, water supply of................... 77

Btewart, wells at............................. 346

Stone County, analyses of ground waters from.

431

features of ............................... 426

ground water in .

wells and springs in .................... 429-430

Stoneville, log of deep well at.............. 476-477

Stonewall, water supplies in............... 119-120
Strayhorn, wells at. Pact

Streams, features of

Stringer, spring of J. M. Welborne, near..... 240

Strongs, $\log$ of well at....................... 339-340

Suffolk, wells near............................ 168

Summerland, well at........................ 425-426

Summit, publio water supply at............ 390

Sumner, water supplies at.................... 490

Sumrall, water supplies at.................. 208-289

waterworks at, plate showing............. 104

Sun, ground water at............................. 416

Sunflower, flowing wells at...................... 439

Sunflower County, analyses of ground waters from

features of...................................... 431

ground water in. ........................... 483

wells in .................................... 434-435

Sunnyside, flowing wells at.................... 298

Surface waters, features of................... 10-12

quality of ................................... 12-13

Swamps, occurrence of...................... 12

Swan Lake, flowing wells near................. $\quad 440$

Swiftwater, shallow wells at................... 478

Tallahatta formation, distribution and water

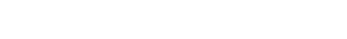

Tallahatchie County, analyses of ground waters from.

features of . .

ground water in.......................... 436-437

wells in .................................. 441-442

Tate County, analyses of ground waters from. $\quad 448$

festures of............................. 448

ground water in. ......................... 443-444

wells in .

Taylorsville, public water supply at....... 424-426

Tchula, flowing wells at........................ 213

Tennessee River Hills. Sec Tombigbee Hills.

Terrace deposits, Pleistocene, occurrence and waters of ....................... 61-62

Pliocene, oceurrence and water of....... 60-61

Terry, deep well at........................... 208

Thornton, flowing wells at_................... 214

Tiplersville, log of well near. ................. 452-458

Tippah County, analyses of ground waters from

features of................................. 448

ground water in. ........................ 448-449

wells and springs in..................... 464-46B

Tishomingo County, analyses of ground waters from .

features of ...................... 457

ground water ín............................. 458

Tombigbee Hills, description of .............. 2-4

Tombigbee River, quality of water of......... 13

Torrance, flowing wells at_....................... 496

Traxler, well near.

Troy, water supply at........................... 899

Tunica, deep wells at............................ 461

Tunica County, analyses of ground waters trom.

teatures of ..... 460

ground water in............................ $\quad 400$

Tupelo, depth and logs of wells at.......... 287-289

Turnbull, well at:.......................... 
Truscalocs a tormation, distribution of........ 20-30 waters of

Tutwller, public water supply at.............. 498

Tylertown, deep flowing well at.............. 469

U

Union, ground water at.

Union Church, log of well st

Union County, analyses of ground waters from.

$\checkmark$ features of.

$469-464$

wells in

$466-467$

Utica, public water supply at 205-206

$\mathbf{v}$

Vaiden, water supplies in

Vance, public water supply at

Vanco's Springs, lccation of.

Vanclesve, deep wells at.

Vanvleet, water supplies in

Vardaman, water supply of

Verona, deep wells at and near

Vicksburg, water supplies in.

Vicksburg group, distributicn and water of.- 54

\section{W}

Wahalak, water supplies at

Walker Springs, features cf

256

Wallace, E. S., analyses by $175,181,240,266,278,333,366,443,457,459,505$

Wallfield, water supply at...................... 396

Walnut, ground water at....................... 452

Walnut Grove, shallow well at................. 286

Walthall County, analysis of ground water from

469

features of

ground water in......................... 468-469

Warren County, analyses of ground water from

features of .............................. 470

ground water in.......................... $470-472$

Washington, water supplies in................ 66

Washington County, analyses of ground waters from

features of

482

475

ground water in........................... 475

wells in

Water Valley, water supplies at............. 494-495

Waterford, shallow wells at.................... $\quad \mathbf{3 3 0}$

Waveland, water supplies at and near...... 184-185

Way, shallow wells at.

Wayne County, analyses of ground waters from
Wayne County, 'features of

ground water in............................. $488-48$

Waynesboro, water supplies at__._........... 484

Wayside, ground water at....................... 478

Webste County, analysis of ground water

trom................................ 487

fentures of ................................... 486

ground water in ............................ 485-486

Weems, springs near.......... 240

Wells, decrease of static level and yield in.... 19

Wells, blowing, explanation of............... 10-20

blowing, featares of .......... 76, 100, 283, 387-388

flowing, plates showing...................... 104

oll-prospecting, logs of...... 118, 148, 149, 810, 438

Wenasoga, water supplies in.................. 72

Wesson, wells at._._............................ 140

West, water supplies at....................... 218-214

West Pcint, water supplies in.............. 127-128

Wheeler, wells at.............................. 402

Whiteapple, well near............................. 168

Wiggins, public water supply of.............. 427

Wilcox group, formations of................... 45-48

waters from undifferentiated deposits of.. $\quad 49$

Wildwrood Springs, description of.............. 168

Wilkinson County, arialyses of ground waters

from-1............................... 490

features of ................................. 487-488

ground water in.............................. 488-489

Wilson, W. T., $\log$ cf well of............... 71

Winona, water supplies at..................... 345-346

Winston Ccunty, analysis of ground water from 492

features of

ground water in............................. 490-491

Woodlend, water supplies in .................... 107

Woodmen Springs, features of................. $\quad 78$

Woodville, $\log$ of public well at............... $\quad 489$

Wortham, log of well at..................... 198-194

$\mathbf{Y}$

Yalobusha County, analysis of ground waters from

features of...................................... 493

ground water in............................ 493-494

wells in

Yaz0o City, water supplies at................. 501

Yazoo County, analyses of ground waters from

features of

ground water in ............................. 499-500

wells in..................................... 503-504

Yazoo Delta, description of..................... 9

485 Yegua formation, distribution, and water of.- 62-58 


